\title{
EL NACIMIENTO DE LA LITERATURA ARGENTINA EN LAS REVISTAS \\ LITERARIAS 1896-1913
}

\section{TESIS DE DOCTORADO}

Director: Dr. Miguel A. Dalmaroni

Codirector: Dr. José Amícola

Doctoranda: Lic. Verónica Delgado

Carrera: Doctorado en Letras/ Facultad de Humanidades y Ciencias de la Educación/ Universidad Nacional de La Plata Septiembre de 2006 


\section{Índice general}

\section{Introducción pp. 2-16}

\section{Capítulo I: La Biblioteca, El Mercurio de América y La Montaña. Las formas de una demanda compartida}

1. Presentación pp. 17-19

1.1. La Biblioteca: las limitaciones de la voluntad autonómica pp. 19-31

2. El mundo intelectual: entre el Estado y la política pp. 31-36

2.1. Los intelectuales de la cultura letrada y el progreso: ganancias y pérdidas pp. $37-40$

2.2. Miguel Cané y Carlos Rodríguez Larreta: defensa de la propiedad en cuestión pp. 41-48

2.3. Las condenas selectivas de Groussac pp. 49-61

2.4. Políticos, literatos, poetas, escritores-periodistas pp. 61-77

3. La lección de Groussac: la organización cultural pp. 78-84

3.1. La discusión con el modernismo pp. 84-91

3.2. La construcción de la literatura argentina pp. 91-92

3.2.1 En contra del criollismo pp. 92-96

3.3. Joaquín V. González y Recuerdos de la tierra. La tradición inventada pp. 97-105

4. El Mercurio de América y La Biblioteca: la continuidad en la diferencia pp. 105-108

4.1. Alianza institucional y afiliación estética: lazos con $L a$ Biblioteca y con $L a$ Revista de América pp. 108-118

4.2. El Mercurio y las revistas. La ejemplaridad del caso francés pp. 118-127

4.3. Las ideologías de artistas: el sacerdocio del arte pp. 127-137

5. Entre La Biblioteca y El Mercurio, La Montaña. Un episodio de política literaria pp. 138-140

5.1. Intelectuales y artistas en La Montaña pp. 140-141

5.1.2. Ingenieros: la crisis del 90 como conspiración moral pp. 141-145

5.1.3. Lugones: el poeta anarquista salvador pp. 145-148

Anexos correspondientes a este capítulo: índice general e índice onomástico de $L a$ Biblioteca (LB), transcripciones de El Mercurio de América, sumarios de La Montaña

\section{Capítulo 2: Ideas: juventud, mercado, novela y cultura nacional}

1. Presentación pp. 149-150

1.1. Ideas: una acción cultural 'necesaria' pp. 151-163

2. Retratos de los jóvenes de Ideas: literatura, calidad moral y profesionalización pp. $163-182$ 
3. Con los mercuriales y contra el ateneísmo. Crítica, legitimidad y polémica en 'Letras argentinas' pp. 182-205

4. Las paradojas del espiritualismo: un mercado ejemplar pp. 206-210

4.1. Novela, mercado, nación pp. 210-211

4.1.1. Con la novela hacia el mercado pp. 211-222

4.1.2. Hacia una tradición nacional de mercado pp. 223-233

4.1.3. Casos patológicos, herencia, medio: las huellas del naturalismo pp. 233-238

5. De las representaciones criollistas hacia el teatro nacional pp. 238-240

5.1. Los públicos del teatro. Ultraje y educación pp. 240-246

5.2. En contra del criollismo: el gaucho se va pp. 246-253

5.3. La sociedad de bombos mutuos: la encuesta a propósito de Sobre las ruinas pp. 253-258

Anexos correspondiente a este capítulo: índice general y de las secciones particulares de Letras argentinas (LA), Letras francesas (LF), Letras Hispanoamericanas y Españolas (LHE) y Teatros (TE) de la revista Ideas

\section{Capítulo 3: Nosotros: el amplio espejo de la cultura nacional}

1. Presentación pp. 259-261

1.1 Nosotros en el comienzo: inconclusión y continuidad pp. 262-271

2. Nosotros y la posta intelectual: la construcción de la autonomía pp. 271-284

3. La crítica y la edificación de la literatura argentina pp. 285-289

3.1. Lugones: ese simpático enemigo de Giusti pp. 289-298

4. Por un teatro nacional: "nobles emociones" y "sanas alegrías" pp. 298-300

4.1. Entre civilización y barbarie pp. 301-307

4.2. Los géneros malsanos pp. 308-313

5. La inflexión nacionalista p. 313

5.1. Una lección de socialismo: el buen nacionalismo pp. 313-318

5.2. Desde el americanismo hacia el nacionalismo pp. 318-330

5.3. Nuevos sujetos, temáticas recurrentes: Nosotros, los argentinos pp. 331-336

5.4. Martiniano Leguizamón: hacia la construcción de la historia nacional pp. 337-349

5.5. La discusión con los pares: el caso Rojas pp. 349-367

5.6. El valor de una encuesta pp. 368- 375

Anexo correspondiente a este capítulo: índice de Nosotros 1907-1913 (NOS)

Conclusiones pp. 376-383

Bibliografía pp. 384-394. 


\section{Introducción}

Esta investigación se inscribe en el campo de estudios sobre publicaciones, cuyos resultados han sido hasta hora más que relevantes. El corpus de esta tesis está compuesto por las revistas La Biblioteca (1896-1898), El Mercurio de América (1898-1900), La Montaña (1897), Ideas (1903-1905), y Nosotros (período 1907-1913) en las cuales se propone indagar el proceso de emergencia y constitución del primer campo literario argentino, atendiendo especialmente a las diversas formulaciones y soluciones que cada uno de estos órganos imaginó con mayor o menor grado de voluntarismo. ${ }^{1}$ En ese sentido, y teniendo en cuenta el carácter necesariamente histórico del objeto, el estudio de las revistas en tanto formaciones culturales y, específicamente, las modalidades de sus relaciones externas e internas deben pensarse en el marco del cambio histórico. De ese modo, sin dejar de advertir que este concepto ha sido pensado para estudiar las prácticas especializadas en sociedades desarrolladas, el mismo será de utilidad para mostrar cómo las publicaciones que conforman nuestro corpus escenificaron en el espacio más específico de su enunciación cultural o literaria, los modos particulares de un proceso más amplio, como lo fue el de la modernización que se venía produciendo no solo en la Argentina, desde las últimas décadas del siglo XIX. Este proceso fue condición de posibilidad de una modernización cultural y literaria, que las publicaciones tematizaron y contribuyeron a forjar. Así, el aumento poblacional a partir de un fuerte componente inmigratorio, el desarrollo creciente de los centros urbanos, la implementación de políticas eficaces de alfabetización y la conformación de sectores sociales medios fueron decisivos en la emergencia de un público lector y en la aparición de un mercado de bienes simbólicos, propiciado por el auge de la prensa periódica.

En relación con el problema de la constitución de un campo intelectual y literario autorregulado y relativamente autónomo, proceso sinuoso y siempre desafiante de cualquier teleología, Pierre Bourdieu ha señalado que la realidad designada por vocablos de uso

\footnotetext{
${ }^{1}$ El concepto de campo intelectual acuñado por Bourdieu en 1966 define, para las sociedades modernas, el área social diferenciada en cuyo seno se inscriben los productores culturales y sus producciones simbólicas, y funciona con arreglo a una lógica específica, marcada por la lucha y la competencia por la legitimidad cultural. Según Carlos Altamirano este concepto "permite pensar los condicionamientos sociales que obran en el universo de la producción cultural, sin ignorar lo que ésta tiene de específico". Cf. Altamirano, 2002: 9-10.
} 
corriente como escritor, artista o intelectual, fue creada por los productores culturales que trabajaron para producirla a través de enunciados normativos por medio de cuyas descripciones fueron haciendo ver el mundo social conforme a sus propias creencias. De ese modo, el funcionamiento del mundo literario en calidad de campo debe considerarse como resultado de un complejo y dificultoso proceso histórico de diferenciación. Desde una perspectiva como ésta, el estudio de las relaciones de sus miembros potenciales con el poder, el mercado y el dinero resulta ineludible. ${ }^{2}$ Así, y para el caso de la cultura francesa, Bourdieu ha definido en términos de "subordinación estructural" la colocación dominada de los escritores e intelectuales en función de sus vínculos con los poderes externos, en el momento que describe como "fase crítica de la emergencia del campo". 3 Esta nueva forma de dominación se instituye, según Bourdieu, a través de las mediaciones del mercado -fundamentalmente la prensa- y de instituciones en las que se intersectan el mundo político con el mundo literario y artístico. Estas instituciones constituirían eficaces articulaciones entre ambos campos y funcionarían como instancias de una legitimación inespecífica o bastarda. ${ }^{4}$ En ese sentido, la lógica confrontativa inherente al funcionamiento de un mundo literario autorregulado, será el resultado histórico de la ardua conquista de los principios de la autonomía literaria. Sin dejar de tener en cuenta el "francocentrismo de los análisis empíricos en los que se asienta su modelo teórico del campo literario" (Gramuglio, 1993: 39) y prestando especial atención a la forma particular en que la autonomización tuvo lugar en nuestro país, las proposiciones de Bourdieu permiten pensar algunos términos generales de ese proceso, legible en el corpus propuesto para esta investigación. En las revistas se estudiará el desarrollo de un movimiento por el cual escritores, críticos, intelectuales y artistas reflexionaron acerca de sus propias prácticas y afirmaron la necesidad y el derecho a su reconocimiento en tanto tales, procurando determinar las singularidades que ese desarrollo adquirió en un contexto político, social y cultural diverso del europeo. Así, por 2

${ }^{3}$ En la historia de la conquista de la autonomía de la literatura francesa que Pierre Bourdieu realiza en Las reglas del arte, es bajo el Segundo Imperio, alrededor de 1840, cuando el campo literario se separa del poder político. Cf. Bourdieu, 1995: 79-174. María Teresa Gramuglio ha señalado las consecuencias metodológicas que suponen las definiciones de campo intelectual en Las reglas del arte. Se trata ya de "una red de relaciones objetivas entre posiciones y ya no agentes del campo (...) la corrección tiene largos alcances metodológicos pues subraya las exigencias de analizar la inserción del campo intelectual en el campo del poder y la estructura interna del campo, antes de comenzar por algún agente individual”. (Gramuglio,1993: 38-42).

${ }^{4}$ Este es el calificativo que utiliza en Las reglas del arte para nombrar dichas instituciones, que en el caso francés, son principalmente los salones. (Bourdieu, 1995: 85). 
ejemplo, para el caso argentino, incluso las posiciones más extremas de los intelectuales en favor de la autonomía no supusieron de manera uniforme edificar la independencia a partir de un divorcio absoluto con respecto al orden estatal. Prueba de esta situación es el pacto con el Estado que imaginó Paul Groussac desde La Biblioteca o el sistema de suscripciones oficiales previamente solicitado por Vicente Quesada y Miguel Navarro Viola desde la Revista de Buenos Aires. En Argentina, además, las revistas han ocupado un lugar central, variando su inserción entre lo institucional y lo no institucional. El funcionamiento de esa variable, institucionalización - no institucionalización, debe pensarse en relación con los circuitos culturales en los cuales se insertaron o se insertan, pero también se liga con las distintas fases del campo intelectual y literario argentino. Asimismo, no es posible establecer una relación fija e invariablemente oposicional entre la novedad y el carácter institucional de las publicaciones.

Las investigaciones de historia literaria y cultural focalizadas en el análisis de publicaciones periódicas argentinas han venido multiplicándose desde hace algunos años. Así lo atestigua la labor continuada de especialistas entre los que se cuentan Jorge B. Rivera, María Teresa Gramuglio, Beatriz Sarlo, Susana Zanetti, John King, Jorge Panesi, Roxana Patiño, Leticia Prislei, Silvia Saítta, Jorge Warley, Carlos Mangone, Geraldine Rogers, Claudia Román, Noemí Girbal. A esto debe sumarse la edición facsimilar tanto de revistas de alta cultura letrada como de semanarios y folletines, ${ }^{5}$ los intentos de intelectuales como Horacio Tarcus y la creación de centros de publicaciones, ${ }^{6}$ la creciente presencia de mesas sobre revistas en los congresos recientes o los simposios específicamente dedicados a ellas. $^{7}$

Desde una perspectiva que las coloca en el centro del análisis de un objeto más vasto -la historia literaria y cultural-, estudiar revistas supone considerarlas como un material básicamente heterogéneo, polifónico, casi siempre contradictorio, e implica necesariamente

\footnotetext{
${ }^{5}$ Oscar Terán en la colección La ideología argentina ha editado La Montaña, la Revista de Filosofía, La voz de la mujer; Margarita Pierini, La novela semanal; el CeDInCl ha publicado en la serie Facsimilares, el Certamen Internacional de La Protesta, Contorno, Cristianismo y Revolución y la edición digital facsimilar completa de Pasado y Presente de los años 1963 a 1965 y 1973.

${ }^{6}$ Centro de documentación e Investigación de la cultura de Izquierdas en la Argentina (CeDInCl).

${ }^{7}$ Un caso paradigmático fue el encuentro organizado por Saúl Sosnowski, para conmemorar los 20 años de la revista Hispamérica que dirige. El resultado de ese encuentro fue el libro que el mismo Sosnowski editó, La cultura de un siglo. América Latina en sus revistas (Madrid - Buenos Aires, Alianza, 1999). Otro, las Primeras Jornadas de Historia de Revistas y Publicaciones Periódicas (Rosario, 2001).
} 
pensar la relación que las publicaciones establecen desde su enunciación política, ética, estética, literaria, con el campo cultural. Estudiar revistas supone dar cuenta de la relación (deseada, efectiva, posible) de una cultura o, específicamente de una literatura, con la sociedad en la que se inscribe. De manera particular, puede decirse que las revistas culturales y literarias conforman el lugar donde los intelectuales (escritores, críticos, artistas, etc.) discuten y redefinen las características, las funciones y la legitimidad de sus propias prácticas. Pensadas como formaciones culturales ${ }^{8}$ las revistas vehiculizan la ideología estética de un grupo, marcan los movimientos y las tendencias artísticos e intelectuales de un momento dado, y esta intervención detenta un carácter determinante y formativo, un papel central en el proceso social y en la cultura en la que se inscriben. Las revistas constituyen así un espacio privilegiado para la construcción de una historia cultural, que las atraviesa y en cuyo curso actúan de diferentes maneras y con grados de eficacia diversos.

2. El problema de la modernización en América Latina ha sido abordado por la crítica literaria y cultural. Ángel Rama afirma que el proceso democratizador que había entrado al continente desde 1870 conjuntamente con la expansión económica imperial cuestionó y puso en crisis el carácter aristocrático, elitista y clasista de la labor de los intelectuales. Ese carácter sirve para comprender la 'conmoción' que se produjo en el seno de las elites tradicionales con respecto a los efectos no deseados de un proceso marcado por la llegada aluvional de extranjeros (Rama, 1985). Así, gran parte de los intelectuales de la fracción intelectual de la elite argentina expresaron sus alarmas frente los peligros de la democracia

\footnotetext{
${ }^{8}$ Raymond Williams utiliza el concepto de formación cultural para dar cuenta especialmente del modo en que funciona la vida cultural y artística, es decir, prácticas especializadas en las sociedades modernas. En ese sentido, identifica las formaciones con los movimientos o tendencias -literarios, filosóficos, científicos, artísticos-, a los que Williams considera articulaciones de formaciones efectivas más amplias, las cuales, a su vez, no siempre guardan una relación afirmativa con los significados de las instituciones formales. (Williams, 1988: 141-142). Posteriormente, en su análisis histórico de las formaciones, Williams va desgranando un modelo de análisis sociológico de este tipo de agrupamiento de los productores culturales entre cuyas premisas pueden mencionarse la necesidad de analizar la composición interna del grupo, sus cambios, sus autodefiniciones, el tipo de actividades que los aglutina así como también sus relaciones externas. Williams afirma que, en la cultura europea, desde mediados del siglo XIX se registra un crecimiento marcado de las formaciones culturales independientes, en particular de grupos de especialización, hecho que para el autor se vincula, entre otras cosas, con las crecientes organización y especialización del mercado y con el desarrollo de una idea liberal de la sociedad y de su cultura en función de la cual podrían aceptarse distintos tipos de obras. (Williams, 1988: 58-67)
} 
como sistema social y respondieron con sus discursos las cuestiones que planteaba esa sociedad aluvional y magmática que tendía a igualar la fuerza del número con la de la calidad (Terán 2000). Parte su parte, en el marco de la modernización y especialmente de las relaciones entre literatura y poder, Julio Ramos ha estudiado los vínculos problemáticos entre la literatura y el Estado, para ver en ese carácter problemático la condición de posibilidad de la autonomización y la modernización literarias. (Ramos, 1989: 8). Asimismo, ha leído en los abundantes prólogos literarios del período, una función decisiva en la diferenciación de subjetividad del escritor moderno y advierte en ellos la configuración de un discurso autorreflexivo que reorganizaba los límites del territorio literario según los criterios de la literatura emergente. (Ramos, 1989: 10) Estudios más próximos inscriptos en esta problemática sostienen que algunos escritores e intelectuales durante la modernización de la literatura argentina en torno a 1910, imaginaron como misión principal de las nuevas letras la planificación del Estado, de la que se seguía la justificación del lugar del escritor moderno en la sociedad. En ese sentido y contrariamente a una diferenciación ya modélica de los escritores centrada en la oposición, la negación o la impugnación del Estado, se plantea que es posible leer en la alianza entre intelectuales o escritores y el Estado, uno de los modos característicos de la modernización literaria argentina. (Dalmaroni 2006)

Por otro lado, el estudio de la conformación de un campo literario autónomo en la Argentina no puede dejar de atender a los procesos de formación y ampliación del público y, particularmente, a los efectos significativos de la explosión de la prensa. Así, Adolfo Prieto observa que el nuevo tipo de lector -producto de las campañas de alfabetización propendió a circunscribir un espacio cultural nuevo respecto del "cual el modelo tradicional de la cultura letrada continuó jugando un papel preponderante aunque ya no exclusivo ni excluyente" (Prieto, 1988). Los vínculos entre esos dos espacios de cultura mostraron zonas de fricción y de contacto, puntos de rechazo y vías de impregnación. Espacio característico y novedoso de la intersección entre ambos circuitos culturales fue la prensa periódica, cuyo desarrollo vertiginoso más entrado el siglo XX, contrastaba con las dimensiones del espacio de la cultura letrada que eran casi las mismas desde hacía veinte años (Prieto, 1988). En América Latina y en comparación con Europa, la inexistencia de un mercado editorial estable y de una institución educativa específica que albergara la literatura indicaba la ausencia de bases institucionales. De ese modo, la literatura estuvo asociada y dependió de 
otras instituciones, y tuvo un desarrollo desigual ligado, en muchos casos, a los deseos de autonomía de quines aspiraban y demandaban la independencia. (Ramos, 1989: 84). Más allá de la posición que tomaron con respecto al mercado y al público, los nuevos escritores los convirtieron en preocupaciones centrales. El hecho de que el público generara en los escritores la necesidad de pronunciarse frente a él es un fenómeno propio del 20, basado en el aumento cuantitativo del público, dos de cuyos resultados fueron el rebajamiento del gusto y la explotación comercial de esa necesidad de lectura, principalmente por los periódicos y los editores, seducidos por los réditos fáciles e inmediatos (Auerbach, 1979). Asimismo, en sintonía con lo que Eric Hobsbawm denominó el sentimiento de incomodidad del arte en los últimos años del siglo XIX europeo algunos de los escritores modernos desde una mirada elitista y aristocrática definieron su arte como lucha contra la mediocridad que identificaron con las formas mercantiles de la cultura (Hobsbawm, 1999). Este pronunciamiento fue pensado para el caso de los modernistas latinoamericanos como una postura generalizada de denostación del proceso capitalista, que exhibía el malestar de "formarse dentro de espacios sociales sometidos a un rápido curso de reificación" y se reconoció en la explicitación del gusto por lo selecto, delicado, exquisito, raro (Real de Azúa, 1977).

La aparición de una incipiente industria cultural promovió el desarrollo de una actitud profesionalista de la que dieron cuenta la crítica y el comentario de libros en periódicos y revistas -a partir de los cuales interesar a los lectores en el consumo de la literatura-, la colaboración literaria en magazines como Caras y caretas, o la inserción en el teatro nacional. (Rivera: 2000). En torno al Centenario Sarlo y Altamirano visualizan una autoimplicación entre la profesionalización del escritor y el desarrollo del nacionalismo cultural, y correlacionan esa temática con el ascenso de la figura del escritor profesional y la construcción de ideologías de artistas. En el campo intelectual emergente, caracterizado por la presencia de elementos arcaicos y novedosos, se ocupan de un conjunto variado de cuestiones, entre otras, los modos de autorización e ingreso a la vida literaria, los criterios de evaluación de las obras, los posicionamientos frente al elogio y el éxito comercial, los vínculos entre las promociones consagradas y las nuevas, las formas de la sociabilidad literaria, las características del nuevo mercado de literatura que comienza a constituirse. (Altamirano-Sarlo, 1983). 
3. Entre fines de siglo XIX y los primeros años del XX, las revistas La Biblioteca (1896-1898), El Mercurio de América (1898-1900), Ideas (1903-1905), Nosotros (1907-1913), y en menor medida La Montaña (1897), resultaron fundamentales como espacios de circulación de la producción artística e intelectual argentina de esos años. Estas revistas culturales y a la vez literarias funcionaron como lugares en los que se concentró e impulsó aquella producción cultural, y, al mismo tiempo, contribuyeron de un modo particular a la formación del emergente campo literario argentino. En ese sentido la bibliografía que se ha ocupado de “el 900” señala esta época, de la cual las revistas forman parte, como el momento de emergencia del primer "campo intelectual", lo cual implica pensar en la sustitución de la figura del político letrado por la del escritor profesional. Nuestra investigación pretende mostrar cómo se actualiza en estas revistas el problema de la constitución de un área específicamente literaria, tratando de dar cuenta de las tensiones y asimetrías de esa emergencia. El carácter incipiente del campo literario argentino -un campo más deseado que efectivamente dado- se corresponde, en estas publicaciones, con el registro de una identificación aún no diferenciada de las prácticas simbólicas. Como revistas culturales y a la vez literarias, estas publicaciones albergan en sus páginas la participación diversa -sobre todo en La Biblioteca- del historiador, del crítico de arte, del artista, del novelista, del publicista, del poeta, del médico, del político, del "literato", del doctor en leyes.

En este marco, las revistas La Biblioteca, La Montaña, El Mercurio de América, Ideas y Nosotros son estudiadas en esta tesis en relación con la manera propia y específica de inscribir sus intervenciones, en función de la autoconciencia por parte de quienes colaboran en ellas, acerca de la urgencia explícita de contar con aquella área delimitada. En nuestro caso el concepto de Pierre Bourdieu exhibe no ya la existencia de ese espacio, sino, por contraste, el hecho de que estas revistas no forman parte ni de un campo intelectual ni de un campo literario consolidados, y al mismo tiempo, insisten en demandar su construcción dirigiendo sus acciones hacia ese fin. Si, como ya se dijo, las revistas pueden ser pensadas como espacios de definición y discusión de las propias prácticas intelectuales, también puede afirmarse que tales intervenciones ponen en escena una actualidad fechada: la del mundo cultural que les es contemporáneo, configurado y enjuiciado desde la 
perspectiva propia. Así, estas publicaciones se ofrecen como material privilegiado para leer en ellas no sólo las modulaciones diversas de aquella demanda, sino también, sus efectos y los cambios ciertos que marcan el camino, siempre desigual, nunca teleológico ni necesariamente ascendente, del dominio más o menos inespecífico de las letras, hacia el campo de la literatura.

Desde una perspectiva que pone su acento en el aspecto institucional de la literatura, sostenemos que la revista Ideas con El Mercurio de América, lo mismo que El Mercurio con La Biblioteca, y Nosotros con Ideas, se suceden a través de un mecanismo de posta intelectual, en virtud del cual funcionan como relevo y ocupación del espacio público que la revista que las antecede deja vacante; las revistas son a la vez registro e instrumento de la estrategia de construcción del campo intelectual argentino todavía en ciernes. Esta lógica pone de manifiesto la necesidad de establecer una continuidad que haga posible el reconocimiento de un mundo literario que se pretende autorregulado; tal continuidad entre las revistas es una estrategia para demostrar que existe en la Argentina de esos años una comunidad de escritores que intentan y que merecen profesionalizarse. El análisis toma los comienzos y los cierres de las publicaciones como ocasiones principalísimas de actualización, planteamiento y reformulación de la idea de continuidad que organiza la dinámica de relevos. Conservación y variación, afiliación y marca particular, continuidad y modificación, intersección y diferencia, son conceptos que cobran utilidad para definir la dinámica que organiza la aspiración compartida de la continuidad institucional. El signo que caracteriza a estas sucesiones hereditarias es contrario de las disputas, y es por ello que la polémica -un género que no deja de practicarse- modifica las reglas de participación. La crítica asume por lo general un carácter estratégico y se atemperan, entonces, las discrepancias -estéticas, ideológicas, literarias- propias entre las generaciones de escritores ya consagrados y los nuevos que aspiran a la legitimidad en un campo literario ya reconocido, cuyas fronteras y regulaciones son definidas y específicas.

A partir de la descripción de cada una de las publicaciones, mostraremos cómo se registra y pone en escena en las revistas, con grados diversos, una orientación temática que proviene también de la política y del Estado, y que se presenta como signo de la inestabilidad y permeabilidad de las fronteras respecto del campo del poder. Al mismo tiempo, se verá cómo se van diseñando nuevas funciones más autónomas para las acciones 
intelectuales y la literatura, a través del análisis de algunas secciones cuyos escritos adquieren carácter programático. Este proceso se actualiza incluso en aquellas que como $\mathrm{La}$ Biblioteca o La Montaña, establecen vínculos estrechos con el orden estatal o con la política, respectivamente, en el intento de distanciarse de las funciones hegemónicas asignadas en sus propios contextos de enunciación. En la brecha que separa las aspiraciones de los directores, redactores y colaboradores de las revistas, y el contexto cultural efectivamente dado en el que intervienen, se registra la serie de acciones particulares, que funcionan como respuestas a un conjunto de cuestiones más o menos recurrentes: las relaciones entre cultura (y literatura) y Estado, entre política y literatura; la construcción de una literatura y una cultura nacional y americana; la discusión sobre la centralidad y legitimidad de las intervenciones de los miembros de la cultura letrada en el marco de los debates sobre la identidad nacional; las obligaciones y atribuciones de los críticos y de la crítica; la construcción de figuras y representaciones de intelectuales en su relación con los procesos históricosociales en los que se inscriben; las evaluaciones de los efectos sociales y culturales de modernización; las funciones dominantes que en cada caso se asignan a la literatura y al arte; la difusión de las obras y de los escritores; la construcción de tradiciones y cánones literario-políticos; las vinculaciones con el mercado y el público.

En el capítulo I, La Biblioteca. Historia, Ciencias, Letras de Paul Groussac atiende especialmente a las relaciones posibles y deseables entre la cultura y el orden político estatal y muestra en la imaginación de un pacto novedoso con el Estado, las prescripciones de una voluntad autonómica indeclinable. La revista, publicada mensualmente bajo el sello editor Félix Lajouane, apareció por primera vez en junio de 1896, y su última entrega correspondió a los meses de mayo y junio de 1898. Las colaboraciones exhiben su diversidad temática y su variedad genérica, las cuales hemos leído en relación con el perfil de sus autores para señalar un carácter general cultural, antes que estrictamente literario de la revista. La Biblioteca incluyó tres secciones fijas: 'Redactores' (al final de cada tomo), 'Documentos históricos' (desde la segunda entrega, julio, 1896), y 'Boletín bibliográfico' (a partir de la entrega de noviembre de 1896). Aunque amplia, la nómina de los incluidos en 'Redactores' permite identificar al grueso de los colaboradores con aquellos integrantes de la elite nacidos en las décadas de 1850 y 1860. Entre ellos: Adolfo Saldías, Miguel Cané, Roque Sáenz Peña, José María Ramos Mejía, Clemente Fregeiro, Jorge Duclout, Diego T. Davison, Alberto B. 
Martínez, Ernesto Quesada, Eduardo Schiaffino, Luis M. Drago, Samuel Gache, Carlos Aldao, Ramón J. Cárcano, Juan A. Martínez, Francisco P. Súnico, Juan A. Argerich, Eduardo L. Bidau, Martín García Mérou, Juan Agustín García (h), Joaquín V. González, Adolfo F. Orma, Alberto Williams, Antonio Dellepiane, Manuel Montes de Oca, Enrique Kubly, Carlos Rodríguez Larreta. Miembro conspicuo de la fracción intelectual de esa elite, y funcionario del Estado en su cargo de director de la Biblioteca Nacional y director de la revista, Groussac imagina, desde la perspectiva ideológica del liberalismo, un vínculo con el campo del poder marcado por la independencia. Así, una empresa cultural como la que él dirige, se distingue de la prensa política, reivindicando la imparcialidad como criterio de juicio, y a su vez, coadyuva en la tarea civilizatoria, propia del Estado. La voluntad autonómica de Groussac se completa en el anhelo de construcción de un público distinto del que consume únicamente diarios. La “desaparición" prematura de la revista en respuesta a la censura de un artículo de su director, por parte del Ministro de Justicia, Culto e Instrucción Pública, señala su dependencia y subordinación respecto del campo del poder. En segundo término La Biblioteca registra una presencia fuerte de colaboraciones cuyas temáticas se ligan claramente con conflictos políticos y con la gestión de gobierno. Esta situación es también indicativa de las relaciones entre intelectuales y Estado en la revista, y remite a una de las formas vigentes de intervención intelectual, y a la centralidad que aún tienen figuras como el literato, el estadista, el publicista, el abogado, por sobre los escritores. Nos ocupamos así de algunas intervenciones de Miguel Cané, Carlos Rodríguez Larreta, y el mismo Groussac frente a los efectos culturales y sociales de la modernización, considerándolos como respuestas específicamente culturales, y por lo tanto, indicativas de la diferenciación creciente entre cultura y Estado. Paralelamente y en contraste con esto, observamos en las siluetas que conforman la sección "Redactores" y en algunas entregas de "Boletín bibliográfico", la existencia de otras figuras de productores culturales más modernas, como el crítico literario, el poeta, el escritor. En tercer lugar, desde un punto de vista más específicamente literario, se analizan las discusiones de Groussac con el modernismo (Rubén Darío) y con el criollismo (tomando como pretexto los Recuerdos de la tierra de Martiniano Leguizamón) en favor de una literatura de tema nacional en lengua culta. Los dos últimos apartados se centran en la relación de La Biblioteca con otras dos publicaciones editadas por esos años, El Mercurio de América (1898-1900) y La Montaña (1897). 
El primer número de El Mercurio de América se publicó en julio de 1898, el último, en mayo-junio de 1900. Eugenio Díaz Romero dirigió las diecisiete entregas que forman la colección completa. Estaba dividida en dos partes. Una, en la que se publicaban artículos, poemas, ensayos, relatos, fragmentos, inéditos. Otra, llamada 'Notas del mes' que incluía, a su vez, secciones de 'letras'. Luis Berisso fue responsable de 'Letras americanas', Leopoldo Lugones de 'Letras francesas', José Ingenieros de 'Letras italianas', José Pardo de 'Letras españolas'. Además, en esta segunda parte, Díaz Romero redactaba 'Las revistas', y Mercurio 'Ecos'. Además, contó entre sus colaboradores a: Juan B. Ambrosetti, Arturo Ambrogio, Víctor Arreguine, Carlos Baires, Luis Berisso, Alberto del Solar, Leopoldo Díaz, Julio V. Díaz, Miguel Escalada, Ángel Della Valle, Ángel Estrada (hijo), Eduardo Ezcurra, Macedonio Fernández, Carlos Guido Spano, Alberto Ghiraldo, Darío Herrera, José Ingenieros, Julio L. Jaimes, Ricardo Jaimes Freyre, Leopoldo Lugones, Américo Llanos, Martín García Mérou, Carlos Malagarriga, Belisario J. Montero, Mauricio Nirestein, Rafael Obligado, Carlos Ortiz, José Pardo, Pedro B. Palacios, José Pagano, Víctor Pérez Petit, Roberto J. Payró, Carlos Ripamonti, José Enrique Rodó, Eduardo Schiaffino, Eduardo Sívori, Charles Soussens, Juan B. Terán, Carlos Vega Belgrano, Alberto Williams. Consideramos El Mercurio como heredera joven de la revista de Groussac en quien intentó aprender las lecciones de un magisterio crítico no siempre promovido por el director de La Biblioteca. En el apartado correspondiente precisamos el tipo de alianza institucional que ese órgano juvenil estableció con su predecesora estatal y referimos brevemente su vínculo con La Revista de América (1894) de Rubén Darío y Ricardo Jaimes Freyre. Analizamos, además, el modo en que El Mercurio propuso una figura de artista marcada por su divorcio del contorno materialista y utilitario, en franca oposición a la reificación inherente al proceso capitalista. Por su parte, La Montaña, contemporánea de La Biblioteca durante sus doce números quincenales, fue también como más tarde lo fueron $E l$ Mercurio, Ideas y Nosotros, un órgano juvenil. Como secciones fijas se publicaron 'Estudios sociológicos', 'Arte, Filosofía, Variedades', 'Actualidad', y dentro de esta última, 'Bibliografía' y 'Movimiento Socialista'. A diferencia de todas las publicaciones del corpus inscribió sus acciones en el campo de la discusión política, no obstante lo cual también constituyó un episodio destacado de la demanda de independencia. Porque las notas firmadas por sus redactores pusieron en escena una diferenciación evaluada como necesaria entre el poeta y el mundo burgués, y entre los intelectuales y la política. El análisis hace evidente que 
las publicaciones de Díaz Romero y del periódico de Ingenieros y Lugones se presentan como extremos opuestos, entre sí y con la revista de Groussac: la primera en su vocación esteticista, modernista y antipedagógica, acuñando en el oxímoron del "desconocido ilustre" la figura de artista privilegiada; la segunda, como periódico que propicia la discusión política y propone la esfera de lo político como dadora de sentido a toda acción intelectual. Sin embargo, planteamos que es posible establecer algunos lazos, desde lo institucional (El Mercurio), o, desde un criterio amplio de reconocimiento del lugar que ocupa el director de La Biblioteca en el medio cultural de la época ( La Montaña), en un gesto que implica desatender las diferencias políticas evidentes entre liberales y anarcosocialistas. Es el carácter precario del mundo intelectual el que hace posibles estas vinculaciones.

Los veinticuatro números de la revista Ideas aparecieron en Buenos Aires entre mayo de 1903 y abril de 1905. Manuel Gálvez y Ricardo Olivera dirigieron conjuntamente la publicación hasta el $\mathrm{n}^{\circ} 2$. Desde la tercera entrega, Olivera se desvinculó del cargo que desempeñaba -aunque luego colaborara esporádicamente. ${ }^{9}$ A partir del $\mathrm{n}^{\mathrm{o}} 3$ el rosarino Emilio Ortiz Grognet, acompañó a Gálvez como 'redactor en jefe', no como director. Ideas tuvo secciones fijas: 'Letras argentinas', 'Letras francesas', 'Letras españolas', 'Letras Hispanoamericanas', 'Teatros', 'Revista de revistas', 'Crónica del mes', 'Música', 'Pintura y escultura', 'Libros del mes'. No todas aparecieron siempre y en todos los números. Así pasó con las secciones de 'Música' (a cargo de Julián Aguirre) y de 'Pintura y escultura' (a cargo de Martín Malharro) que tuvieron una presencia más corta y errática en la revista, o 'Crónica del mes' que, escrita por Gálvez, salió por primera vez en el $\mathrm{n}^{\mathrm{o}} 13$, y llegó solo hasta el $\mathrm{n}^{0}$ 18. Ideas publicó textos inéditos tanto críticos como literario-artísticos, y, también comentó, en "Crónica del mes" sucesos políticos relevantes. Ideas definió un colectivo intelectual (la juventud) en el intento de legitimarse, y lo hizo presentando sus acciones como moralmente necesarias desde dos problemáticas distintas: la de la identidad nacional, y en ese sentido puede pensarse como la aspirante a nueva elite, en el intento de la conformación y realización definitivas de un 'alma nacional'; y la de la construcción de la crítica, la literatura y el teatro argentinos. Ideas reconoció en el Mercurio de América su antecedente inmediato anterior, en la vocación de instituir nuevos y más específicos criterios de consagración y en el costado profesionalista que desarrollaron colaborando con su ${ }^{9}$ Este hecho ocasionó el disgusto del escritor y de Olivera. Los detalles del episodio se encuentran en Gálvez, 1961a. 
escritura en diarios prestigiosos y también en magazines. De este modo, en varias ocasiones realizó una lectura del pasado literario inmediato para autoinstituirse como sucesora afortunada de ese grupo de maestros jóvenes e innovadores. Contraria de la crítica subordinada a intereses exclusivamente mercantiles, y a favor de un discurso especializado que dejara de lado "la camaradería sin escrúpulos", Ideas propuso su práctica crítica como una tarea desmitificadora. Al mismo tiempo, y sin dejar de reconocer un sello propio en los jóvenes de Ideas que se dicen antimaterialistas y espiritualistas, hemos señalado algunas continuidades que acercan a los futuros nacionalistas con los liberales patricios del 80, con los cuales establecerán una oposición selectiva. Consideramos el carácter modélico de la crítica de García Mérou como indicio fuerte de un vínculo ideológico, que no se prolonga en otros aspectos específicos y nodales de la intervención de Ideas. Subrayamos que términos como antimaterialismo y espiritualismo se vuelven paradójicos cuando se revisa la manera en que la revista plantea un vínculo necesario y selectivo con un posible mercado literario, teatral o editorial e incluye en sus páginas propagandas de artículos suntuarios o caricaturas. Este vínculo que definimos como vocación de mercado encontrará en la Biblioteca de La Nación y en las empresas editoriales españolas dos realizaciones de un programa de legitimación de la literatura, la cultura y los escritores en los que podían combinarse éxito y calidad.

El tercer capítulo estudia hasta 1913 la revista Nosotros, dirigida por Roberto Giusti y Alfredo Bianchi, entre 1907 y 1943. Este recorte cronológico obedece a razones vinculadas con la lógica interna del mundo cultural en función de las cuales consideramos significativa la intervención de la revista. El año de 1913 constituye el momento en el que Nosotros ocupa un lugar hegemónico y de máxima visibilidad liderando el debate sobre la identidad nacional a partir de la publicación de "A campo y cielo", segunda de las lecturas que Lugones pronunciara ese año en el teatro Odeón, de la conferencia de Ricardo Rojas "La literatura argentina” y de los resultados de su segunda encuesta (“Cuál es el valor del Martín Fierro?"), en la que se exhibe su poder de interpelación en los nombres de quienes responden. Creemos que más allá de su larga vida, este es el momento más eficaz (y adelantado) de Nosotros, en el cual se concentran, además, los problemas centrales de nuestra investigación. El subtítulo de la publicación a lo largo de los cincuenta y seis números estudiados, Revista mensual de literatura, historia, arte, filosofia, señala el interés 
por un conjunto de prácticas en gran medida coincidente con las disciplinas de la Facultad de Filosofía y Letras, en cuyas aulas comenzaron su amistad los directores. Nosotros tuvo un conjunto de secciones fijas que no fueron siempre las mismas. Entre 1907 y 1913, se destacaron 'Letras argentinas' y 'Teatro nacional' en las que no solo Bianchi y Giusti colaboraron activamente. El análisis de Nosotros mostrará, en primer término, las formas de ingreso en el mundo cultural del grupo de jóvenes que llevan adelante la revista. Si como sostiene Gálvez, la aparición de Nosotros de Roberto Giusti y Alfredo Bianchi, "representa el advenimiento de los descendientes de italianos a las letras argentinas", sus estrategias de autorización e ingreso en la cultura deben pensarse en este contexto, en el que las ventajas del capital social, continúan funcionando como criterios de autorización intelectual. Este sujeto social y cultural encarnado en las figuras de los directores de Nosotros, reivindica para sí las prerrogativas de la formación universitaria, como uno de los modos de transformación de aquel vacío de autoridad social, en un pleno de autoridad intelectual. A diferencia de Ideas, su antecesora, se verá que Nosotros efectivizó la amplitud de su convocatoria en la colaboración intergeneracional y en la promoción sostenida de formas de sociabilidad literaria de tipo incluyente, que ella misma define como afán de "comunión". En el caso de Nosotros el análisis hace evidente que la demanda de autonomía -y como lo había hecho Ideas- se llevó a cabo en el ejercicio de la crítica, que reflexionaba sobre sí misma, y en esa acción, formulaba sus obligaciones. Se trataba de una crítica que sin dejar de polemizar mostraba su carácter estratégico, augurando porvenires literarios 'fecundos' cifrados en la correcciones de las deficiencias del presente. En el final del capítulo nos detenemos en el examen de las condiciones de participación de la revista respecto del problema de la nacionalidad. Nosotros registra e interviene en el fenómeno del llamado "nacionalismo cultural" que, por esos años, se tornó dominante en los debates intelectuales. El análisis demuestra que la discusión acerca de la construcción de una identidad cultural nacional, formó parte de las preocupaciones iniciales de Nosotros. Este tipo de intervenciones adquirieron en Nosotros un carácter central y su presencia es indicativa de una inflexión nacionalista mucho más pronunciada de la que la crítica ha señalado, que además es contemporánea de una valoración positiva la figura de José E. Rodó y de la insistencia en reconectar culturalmente a la Argentina con España. Martiniano Leguizamón y Ricardo Rojas son las figuras a cuyo alrededor la revista va construyendo y precisando los 
términos y matices de su posición. Esta inflexión nacionalista no se registra únicamente en el terreno y en los géneros propios del debate de ideas como lo son en ese momento el ensayo de corte sociológico o las intervenciones provenientes del campo historiográfico, sino que contamina la discusión acerca de la literatura y el teatro nacionales, de los que Nosotros se ocupa puntual y sistemáticamente.

Por último, una breve referencia a los anexos de la investigación. Su redacción constituye un momento decisivo de nuestro trabajo y obedece a razones metodológicas vinculadas con la naturaleza del objeto de estudio. En principio, estudiar revistas, consideradas no ya como materiales de referencia, sino como corpus central, supone, necesariamente, la confección de índices y reseñas razonadas de los textos a partir de los cuales relevar, sistematizar y dar una idea de conjunto de las publicaciones. En ese sentido, y en relación con la investigación misma, estos anexos fueron el punto de partida ineludible para la descripción de las revistas y la formulación más definitiva de las hipótesis iniciales del plan de tesis y de otras, surgidas luego de la lectura detallada de esos materiales. Los anexos relevan los números particulares siguiendo el orden cronológico de su aparición. En ese sentido, el criterio que los preside es crítico no ya meramente documental, y difieren por lo tanto de los excelentes índices existentes sobre algunas de las revistas del corpus. La descripción que surge permite realzar la revistas en sí mismas, determinar sus cambios, dar cuenta de sus preferencias estéticas o posicionamientos ideológicos, señalar las temáticas vigentes en ciertos momentos. De esta manera, los anexos fundamentan y ejemplifican de manera más extensa las tesis desarrolladas en los capítulos. Así, por ejemplo, permiten constatar, en la crítica de Ideas, la magnitud de la impronta naturalista; en Nosotros, precisan el carácter hegemónico de la problemática de la identidad nacional; en el caso de La Biblioteca patentizan sus vínculos con las preocupaciones de la elite estatal. Desde las notas al pie se reenvía a los anexos correspondientes a cada capítulo para la transcripción más extensa de los textos citados o se indican otros también pertinentes con respecto a las cuestiones tratadas. Asimismo, el valor de estos anexos excede nuestra investigación en tanto su contenidos informativo-documentales podrán ser el punto de partida para el análisis de las revistas por parte de otros investigadores.

Los anexos se presentan en tomo aparte y cada capítulo tiene el suyo. En las notas al pie son citados según la abreviatura que consignamos entre paréntesis.

Anexo del capítulo 1: 
-Índice general razonado (LB) e índice onomástico de La Biblioteca

-Transcripciones de El Mercurio de América

-Índice descriptivo de los doce sumarios de La Montaña.

Anexo del capítulo 2

-Índice general de la colección completa de Ideas

-Índices razonados de las secciones particulares de Letras argentinas (LA), Letras francesas (LF), Letras Hispanoamericanas y Españolas (LHE) y Teatros (TE).

Anexo del capítulo 3

-Índice razonado de los números 1 a 56 de Nosotros (NOS)

-"El doctor Imbele”, capítulo de la novela Nosotros de Roberto Payró publicado en Buenos Aires. Revista semanal ilustrada ( $\left.n^{\circ} 62,14 / 06 / 1896\right)$ 


\section{Capítulo I: La Biblioteca, El Mercurio de América y La Montaña. Las formas de una demanda compartida}

\section{Presentación}

En el campo literario argentino en ciernes de fines del siglo XIX, caracterizado, entre otras cosas, por la ausencia de instituciones propias, la consecuente inestabilidad de los emprendimientos culturales, la imbricación todavía fuerte en el circuito de la alta cultura letrada, entre el mundo de la política y el mundo cultural, y un crecimiento vertiginoso de la prensa periódica (Prieto, 1988: 14) en la que ejercitaban sus recientemente adquiridas competencias los nuevos lectores, la revista La Biblioteca escenificó en la figura de Paul Groussac, su director, aunque no solo en ella, la demanda de autonomía con respecto al orden estatal como parte constitutiva de su intervención. Analizar los modos que adquiere dicha demanda implica dar cuenta de los momentos más significativos en que desde la revista se construyeron los enunciados normativos y performativos en que aquella aspiración se hacía ver y se realizaba. ${ }^{1}$ Así este capítulo intenta mostrar cómo La Biblioteca representó, desde la pertinencia que guía nuestro trabajo, un hito tanto desde la mirada diacrónica como sincrónica. Los juicios de sus contemporáneos y miembros de la fracción intelectual de la elite liberal que Groussac a su vez integró, así como aquellos de la promoción de los modernistas nucleados en torno a El Mercurio de América, daban cuenta de su relevancia en tanto producto intelectual moderno. Dicho carácter moderno apuntaba al menos a dos aspectos. El primero remitía a la afirmación indeclinable -y no siempre realizada- de la independencia de la cultura con respecto a las regulaciones del orden estatal y las de la política, en una formulación imaginaria de su vínculo con el Estado, según la cual este último debía patrocinar y proteger los productos intelectuales; el segundo rasgo de modernidad consistió en la construcción por parte de Groussac, principalmente, de la figura del crítico literario experto a la vez que la del estratega

${ }^{1}$ En "La conquista de la autonomía" Bourdieu explica que la "realidad designada por términos de uso corriente como escritor, artista, intelectual, fue creada por los productores culturales que trabajaron para producirla a través de enunciados normativos, o, mejor aún, performativos" que "bajo la apariencia de decir lo que es (...) aspiran a hacer ver y a hacer creer, hacer ver el mundo social conforme a las creencias de un grupo social que tiene la particularidad de poseer un cuasimonopolio del discurso sobre el mundo social". (Bourdieu, 1995: 92) 
cultural. $^{2}$ Las reseñas sobre Los raros y Prosas profanas de Rubén Darío, sobre Recuerdos de la tierra de Martiniano Leguizamón o los perfiles de escritores que incluía en la sección 'Redactores', recortaban, más claramente, al crítico experto; escritos como los de apertura y cierre de la publicación muestran los anhelos del organizador y del ordenador del mundo cultural; en otros escritos -y vinculada con lo anterior- se podía leer la vocación de forjar los postulados estéticos de una literatura nacional argentina. La clausura de esta publicación cuyos efectos fueron evaluados en términos de la percepción de un vacío, inauguró la dinámica de relevos que caracterizaría la sucesión de las publicaciones del corpus, además de afirmar una función modélica o rectora por parte de la revista de Groussac. Esta lógica de reemplazos estratégicos, haría posible el acercamiento entre posiciones estéticas y políticas distantes e incluso contrarias. De ese modo proponemos mostrar el contacto entre la vanguardia literaria y estética de El Mercurio de América y su predecesora a partir del deseo común de contribuir a la construcción de un discurso crítico basado en el conocimiento cierto y profundo de la materia tratada, y en la desvinculación entre arte y política. En función de estos acuerdos algunos de los jóvenes modernistas de $E l$ Mercurio, como Luis Berisso, antepondrían la admiración al recuerdo de las críticas lapidarias que Groussac había descargado sobre ellos. ${ }^{3}$ Asimismo, se analiza la forma en que desde La Montaña los jóvenes José Ingenieros y Leopoldo Lugones, enrolados en el anarcosocialismo, organizaron una forma específica de participación intelectual y artística enmarcada en la discusión sobre teoría política, reconociendo en Groussac al intelectual, más allá de las evidentes diferencias ideológicas que los separan. La solidaridad intelectual, en tanto valor y actitud tributaria de las características de un

\footnotetext{
2 Tomamos estos dos conceptos de Terry Eagleton en su The Function of Criticism. From The Spectator to Post-Structuralism, London, Verso, 1992. Para Eagleton, la función del crítico como estratega cultural en la Inglaterra del siglo XVIII es la de comentarista, informador, mediador, intérprete y popularizador y su deber es consolidar y reflejar la opinión pública, al mismo tiempo que conducir la discusión general frente a su público. [capítulo I] El crítico como experto literario, se define, por contraposición, como el exponente de una competencia intelectual especializada.[capítulo III]. He desarrollado una versión preliminar de estas hipótesis en un artículo "La lección de Groussac en La Biblioteca: la organización cultural", aparecido en 1999 en la revista Tramas para leer la literatura, vol. v, $\mathrm{n}^{\circ}$ 10, pp. 97-105. El libro de reciente publicación Paul Groussac un estratega intelectual (2005) de Paula Bruno retoma -sin citarlas- estas hipótesis de lectura y estas vinculaciones, aunque solo consigna mi trabajo, al final, en la bibliografía.

${ }^{3}$ El caso de Luis Berisso es el más relevante. En el apartado sobre la sección 'Redactores' nos detendremos en él específicamente.
} 
mundo cultural que todavía funcionaba de modo parasitario ${ }^{4}$ era la que hacía posible estas intersecciones.

\subsection{La Biblioteca: las limitaciones de la voluntad autonómica}

En Desencuentros de la modernidad en América Latina Julio Ramos ha abordado, en el marco del proceso de modernización desigual que se dio en el continente, el problema de las relaciones entre literatura y poder, y particularmente entre literatura y Estado. Ramos sostiene que la reflexión acerca de este vínculo problemático, legible en los abundantes prólogos escritos en el último cuarto del siglo XIX, configura la emergencia de una nueva autoridad social de la literatura -que se diferencia de las anteriores ficciones estatales-, y constituye en sí misma la condición de la autonomización literaria (Ramos, 1989: 7-10). Como se verá, la revista de Groussac tematizó este vínculo como clave de la autonomización en dos momentos fundamentales, su comienzo y su final, y lo hizo a través de una serie de escritos cuya función es homologable a la de los prólogos ya citados, escritos que revistieron un carácter programático. La exigencia de protección o patrocinio estatal por parte del director de la revista era signo de una ubicación inicial subordinada y dependiente; una común función civilizatoria que, según Groussac, ligaba a la revista con la institución estatal, hacía de $L a$ Biblioteca un factor de peso en la cuestión nacional, por lo que sus acciones debían ser promovidas y preservadas. Aunque este servicio hablaba también de la heteronomía de la publicación, la exigencia de criterios especializados, de un juicio imparcial no contaminado por cuestiones políticas en materias intelectuales y de una organización mercantil, haría presente un tipo de autoridad y de autorización fundamentalmente propio. En el seno mismo de la institución estatal, las acciones de La Biblioteca podían ser definidas como intencionalidad, gesto voluntarista que pretendía y promovía la creación de un área autónoma y diferenciada para la circulación de la producción simbólica. Así, la revista autodefinida como espacio de ejercicio de "propaganda intelectual", lugar de construcción de una tradición de pensamiento y de literatura nacionales,

\footnotetext{
${ }^{4}$ En "El dinero en la literatura", Émile Zola se refiere al escritor como "parásito" para mostrar la dependencia económica y simbólica de ciertos autores en relación con el Estado (Zola, 1972: 147-180).
} 
alentaba la convergencia del pensamiento crítico y artístico e intentaba dinamizar el mundo intelectual. ${ }^{5}$ De este modo, Groussac escenificaba desde una revista estatal la demanda de autonomía intelectual con respecto al Estado, lo que constituye, para Ramos, la marca diferencial de la literatura moderna; aunque como se verá, sería el mismo Estado el que, según el director de la revista, debía garantizar y preservar el ejercicio de una función intelectual independiente, y de la cual obtenía por su parte, el beneficio civilizatorio de construcción de la nación.

Cuando en el n ${ }^{\mathrm{o}} 1$ de La Biblioteca de junio de $1896,{ }^{6}$ su director Paul Groussac señalaba los propósitos y el criterio editorial de su revista, se apartaba de lo que, en términos estrictos, correspondía a una publicación que desde la perspectiva del Ministerio de Justicia, Culto e Instrucción Pública debía cumplir, según palabras de Luis Beláustegui, “con los propósitos y fines de una publicación costeada por el Tesoro público".7 En ese sentido, el producto era anómalo con respecto a las reglas institucionales fuertes que condicionaban su campo de enunciación. Fundaba así uno de los hitos para la delimitación y el reconocimiento de un mundo intelectual y especí-

\footnotetext{
${ }^{5}$ Más adelante explicaremos qué sentido le asignamos y con qué prácticas identificamos este mundo.

${ }^{6}$ La revista La Biblioteca, apareció por primera vez en junio de 1896, y dejó de salir en mayo de 1898. Se publicó mensualmente bajo el sello editor Félix Lajouane; la colección completa está compuesta de 24 números. En La cólera de la inteligencia. Una vida de Paul Groussac, Carlos Páez de la Torre (h) señala que poco tiempo antes de la aparición del primer número de la revista, el Congreso había concedido a la Biblioteca un subsidio para editar. Este subsidio fue el que empleó Groussac para pagar los costos de imprenta de La Biblioteca "ya que publicará en su revista -según han autorizado, a su pedido- documentos inéditos del fondo de manuscritos". Cf., Páez de la Torre (h), 2005. La revista se vendía por suscripción anual (\$20), o número suelto (\$2); en el extranjero el precio de la suscripción ascendía a \$8 oro; cada entrega tenía generalmente alrededor de 160 páginas. Cf. Navarro Viola, 1897: 227-228.

La Biblioteca Nacional de Buenos Aires, por iniciativa de algunos de sus directores tuvo una serie de publicaciones que fueron sus órganos: Manuel Trelles entre 1879 y 1882 editó la Revista de la Biblioteca de Buenos Aires; Paul Groussac entre 1896 y 1898 editó La Biblioteca y entre 1900 y 1915, Los Anales de la Biblioteca; Gustavo Martínez Zuviría (Hugo Wast), publicó la Revista de la Biblioteca desde 1937 hasta 1955; Jorge L. Borges, en 1957, editó, La Biblioteca ( $2^{a}$ época), que consta sólo de dos números. La colección completa de la revista de Groussac está compilada en ocho tomos, la de Borges, corresponde al Tomo IX. Tomamos estos datos de Maeder, 1962: 3. Actualmente la Biblioteca Nacional publica una revista de edición cuatrimestral, también llamada La Biblioteca, cuya colección hasta la fecha es de tres números $(1,2-3)$.

${ }^{7}$ Estas palabras correspondían a la carta del 19/3/1898 que Luis Beláustegui -ministro de Justicia, Culto e Instrucción Pública- le envió a Groussac y en la que censuraba y apercibía a la publicación. Tomado de "La desaparición de 'La Biblioteca' ", texto de P. Groussac donde explicaba los motivos del cierre de la revista. La Biblioteca, Año II, Tomo VII, mayo, 1898, pp. 244-48.
} 
ficamente literario. Groussac se instalaba en el terreno estatal para abrir un espacio a la difusión de la producción cultural y literaria de esos años, inscribiéndose explícitamente en el camino iniciado por Vicente Quesada y Miguel Navarro Viola con La Revista de Buenos Aires (1863-1871), ${ }^{8}$ la Revista Argentina (primera época: 1868-1872; segunda época, 1880-1883) de José Manuel Estrada, publicaciones que junto con la Revista del Río de la Plata (1871-1877) mostraban un carácter ejemplar. Esas revistas nacidas de la iniciativa individual de sus directores, todos ellos destacados publicistas y polígrafos, representaban para el director de La Biblioteca un paradigma de publicación a realizar. En primer lugar, porque en ellas se conjugaban rasgos propios del libro y del diario: del libro, la utilidad, en función de los temas y su tratamiento; de los periódicos, la actualidad y el interés como criterio de captación de sus lectores. En segundo término, y particularmente en relación con la Revista de Buenos Aires, uno de cuyos directores, Vicente Quesada había sido, como Groussac, director de la Biblioteca de Buenos Aires, ${ }^{9}$ dicho carácter ejemplar se relacionaba de modo evidente con tres cuestiones. Una de ellas, la importancia otorgada a las bibliotecas en tanto instituciones que contribuían al progreso intelectual y por lo tanto nacional. ${ }^{10}$ Otra, fundamental, remitía a la voluntad explícita de sus directores de distinguir la cultura de la política, que se presentaba en $L a$ Biblioteca como aspiración, realizable en un órgano de difusión como el que Groussac imaginaba. En el prospecto que iniciaba la Revista de Buenos Aires, los directores

\footnotetext{
${ }^{8}$ La Revista de Buenos Aires y la Revista Argentina eran consideradas por Groussac como las "tentativa(s) más seria(s) hecha(s) en el país", "La Biblioteca de Buenos-Aires", La Biblioteca, Año I, Tomo I, julio, 1896, p. 185. En el Anuario ya citado, Jorge Navarro Viola reivindicaba estas filiaciones. "El éxito de La Biblioteca es el éxito que solo alcanza entre nosotros lo que es genuinamente literario: esta revista ha recogido con gloria la tradición que le legaron aquellas célebres publicaciones, del río de la Plata, de Buenos Aires, de la Biblioteca Pública, Argentina y alguna otra, cuya importancia no fue quizá plenamente reconocida sino una vez que desaparecieron", p. 228.

9 Vicente Quesada fue director de la Biblioteca Nacional entre septiembre de 1871 y marzo de 1879.

10 La Revista de Buenos Aires insistía en la construción de confraternidades intelectuales entre la Argentina y otras naciones americanas. Es elocuente, al respecto, el título completo de la publicación: Revista de Buenos Aires. Historia americana, Literatura y Derecho. Periódico destinado a la República Argentina, la Oriental del Uruguay y del Paraguay. Además, esta cuestión se observaba claramente en la convocatoria a colaboradores americanos: "Popularizar las producciones de los ingenios americanos por todos los medios, ha sido en nosotros un pensamiento que nos ha preocupado siempre, y por cuya realización hemos hecho y hacemos esfuerzos", Revista de Buenos Aires, Año I, n 3, julio, 1863, pp. 422-425. Por su parte, Groussac aunque declaraba su interés por contar con la colaboración de "muchos hombres de pensamiento y escritores de valía, residentes en otras repúblicas sudamericanas", privilegiaba, sobre todo, lo nacional.
} 
declaraban la intención de crear un tipo de revista que reputaban inexistente, juzgada a la luz de la relación deseada entre la prensa y la política. La metáfora geográfica del vacío, entendida como la obligación de "llenar lo que no existe", y que en Groussac mutaría en otra de tipo biológica, refería a la falta, a nivel nacional, de "periódicos completamente ajenos a la política" y que ya circulaban en otros países americanos, entre los que se contaban la Revista del Pacífico o La Revista de Lima. ${ }^{11}$ Finalmente, la obligación del estado de proteger a las "nacientes" letras, funcionaría como un punto fuerte de coincidencia entre la Revista de Buenos Aires y la que Groussac presentaba entonces. Según un escrito de la entrega de julio de 1863 de la Revista de Buenos Aires, esta protección que los gobiernos americanos deberían garantizar, tendría por forma la suscripción oficial. Ésta no solamente actuaría como estímulo sino que contribuiría a "generalizar en América, las producciones de americanos". ${ }^{12}$ En ese sentido, y para el caso de La Biblioteca, aunque la revista dependiera del apoyo del Estado, esta condición podía ser compensada por el mismo contexto político ideológico, que traducido en la publicación como el espíritu “de la crítica más imparcial y amplia, del bien entendido liberalismo", garantizaría, al menos en teoría, la libertad de decir.

Como declaraba en el segundo número de La Biblioteca, Groussac consideraba central la función desempeñada por las revistas dentro del movimiento intelectual europeo moderno y, por tal motivo, se lamentaba de la suerte que habían corrido hasta entonces las publicaciones argentinas:

Desgracia ha sido el que ninguna publicación análoga [a las europeas y a las de Quesada y Estrada] pudiera implantarse sólidamente en esta tierra movediza y fofa. Todas han sucumbido, a pesar de las condiciones económicas de su elaboración. $^{13}$

${ }^{11}$ En el prospecto con que se abría la revista de Vicente Quesada y Miguel Navarro Viola este deseo era bien claro: "(...) hemos creído que se encontrará menos temeridad en el designio de establecer una Revista mensual, por el estilo de la "Revista del Pacífico", "La Revista de Lima", etc. periódicos enteramente ajenos a la política" [cursivas nuestras] Revista de Buenos Aires, "Prospecto", Año I, n 1, mayo, 1863, p. 5.

12 "Suscripciones oficiales", Año1, n 3 julio, 1863, pp. 422-425. La Biblioteca y la Revista de Buenos Aires coinciden también en la publicación de documentos históricos. Miguel Navarro Viola redactaba la sección 'Efemérides' para la Revista.

${ }^{13}$ Groussac. P. "La Biblioteca de Buenos-Aires”, La Biblioteca, Año I, Tomo I, julio, 1896, p. 185. 
Más tarde, en 1901, y también en su calidad de Director de la Biblioteca Nacional, cargo que había desempeñado desde principios de 1885, Groussac habría de publicar una Noticia histórica sobre la Biblioteca Nacional de Buenos Aires y en 1902, el discurso ${ }^{14}$ que pronunciara en 1901 en la inauguración del entonces nuevo edificio de la institución. ${ }^{15}$ Parte de la Noticia, que había sido escrita en 1893, había aparecido en 1896, en las entregas iniciales de la revista La Biblioteca, ${ }^{16}$ y tanto en ella como en el discurso Groussac destacaba y reiteraba la importancia de las publicaciones periódicas en la producción y divulgación del saber. Groussac las definía sistemáticamente como el otro del periodismo, y las consideraba como el modo más activo de expansión de la información general o especializada, por lo que su rol aparecía fundamental en la concreción de "la solidaridad de la labor universal". ${ }^{17}$ De esa forma, las bibliotecas definidas como "emporios históricos", según Groussac, debían, como política institucional, promover la adquisición de revistas. ${ }^{18}$

En aquel mismo escrito de la segunda entrega de La Biblioteca trataba de dilucidar los motivos de la muerte prematura de las publicaciones, en función de lo cual

\footnotetext{
${ }^{14}$ La Noticia fue publicada en 1901 por la Imprenta y Casa Editora de Coni Hermanos; se trata de la "Edición conmemorativa de su instalación en el nuevo edificio inaugurado el 27 de diciembre de 1901", y consta de 63 páginas; en 1902 la casa Coni editó en 24 páginas el discurso que aquel 27 de diciembre había pronunciado Groussac; la edición de 1938 a cargo de la Librería y casa editora Jesús Menéndez, reúne Noticia y discurso; tiene 111 páginas. Las citas de ambos textos corresponden a la edición de 1938.

${ }^{15}$ El nuevo edificio, ubicado en México 564, había estado destinado, en principio, a la Lotería Nacional.

16 "La Biblioteca de Buenos Aires", Año I, Tomo I, junio, 1896, pp. 9-33; "La Biblioteca de Buenos Aires", Año I, Tomo I, julio, 1896, pp. 161-193.

17 "Fuera de los diarios propiamente dichos, y que representan la faz desgraciadamente más extensa y animada de nuestra intelectualidad, he atribuido importancia excepcional al enriquecimiento de esta sección [publicaciones periódicas]. Sabemos todos que, en la actualidad, las revistas generales o especiales constituyen la forma más activa de expansión y propaganda intelectual. El libro mismo no espera su terminación para salir a luz: se secciona y aparece por fragmentos sucesivos en el periódico. La revista es como el hilo telegráfico que vincula los laboratorios, museos, y academias del mundo entero, patentizando la solidaridad de la labor universal." Groussac, 1938: 70-71

${ }_{18}$ Desde las páginas de la revista, Martín García Mérou se refería, de manera menos optimista, al medio intelectual americano, donde las bibliotecas estaban muy lejos de cumplir el papel que Groussac imaginaba: "Sin ser un caso común, a veces un nombre dotado de mayor resonancia, rompe la indiferencia reinante y vence la incomunicación intelectual que separa las secciones de nuestro continente. (...). El grueso de la producción científica o literaria, la historia, la crítica, los estudios jurídicos, están destinados a reposar, como en una muda necrópolis, en las bibliotecas públicas o en medio de las colecciones valiosas de los eruditos de raza, que sólo muy raras veces hojean sus páginas polvorosas". La Biblioteca, Año I, Tomo II, octubre, 1896, pp. 168-200. Cursivas nuestras.
} 
describía su modus operandi. Esta descripción constituía una evaluación de las condiciones de la producción y difusión del pensamiento intelectual argentino:

La Revue des Deux-Mondes, como todas las publicaciones similares que han alcanzado éxito, tiene una base industrial: quiero decir que su director ante todo la considera como una empresa; él gobierna pero no colabora (...) No es el objeto de una revista dar salida á las lucubraciones del fundador o de sus amigos, sino satisfacer al público, que se interesa muy poco por conocer las relaciones de la dirección con la colaboración. (...)

En nuestros países hidalgos se ignora lo que sea remuneración del escritor. Las revistas se alimentan con la prosa de sus directores o colaboración gratuita: de ahí ciertas condiciones casi inevitables de monotonía é inferioridad: pues, a la larga, el promedio de lo que se da de balde no vale mucho más. (185)

La cita era elocuente porque enunciaba la voluntad de independencia fundándola y ejemplificándola en una organización de tipo mercantil, y por varios motivos que eran del orden de las diferencias: porque exhibía el modelo que Groussac tenía presente para su revista, aunque no le fuera posible realizarlo y se viera constreñido a adaptar su publicación a la forma de la revista de una repartición estatal y esforzarse por desplazarla parcialmente, al menos en algunas secciones, al tono y contenido de una revista literariocultural de mercado; porque pensaba en la existencia de un público adiestrado y ávido consumidor de productos culturales, responsable del éxito de las revistas, aspecto que revestía un carácter programático reconocible en el escrito de apertura de la publicación; y sobre todo, porque señalaba el atraso y la desigualdad con respecto a Europa en las condiciones de producción intelectual y artística argentina, reclamando para ella un sitio del lado de las profesiones remuneradas.

La revista, a pesar de estar subvencionada por el Estado, reivindicaba y de hecho ejercía, hasta donde le resultaba posible, su naturaleza independiente y no oficial, la cual provenía del modelo mercantil francés en el que Groussac declaraba inspirarse. En ese sentido, si bien el campo del poder político daba origen a la revista y era el espacio en que inscribía y fomentaba la producción vernácula, podía admitir dentro de sí una zona 
circunscripta a los asuntos intelectuales, o al menos, tal como imaginaba Groussac, no debía legislar en las cuestiones estéticas, "científicas y literarias, como en otras que atañen a la política y a la filosofía". ${ }^{19}$ En ese hecho se cifraba la diferencia entre la parcialidad inherente a la prensa de partido y el funcionamiento de una empresa cultural del estilo de la Revue des deux Mondes. Según la perspectiva de Groussac, el acto de liberalidad que constituía el financiamiento de La Biblioteca por parte del Estado, era la confirmación de aquel liberalismo político encarnado en un poder político que lejos de controlar, alentara y promoviera una publicación en la que la imparcialidad se erigía en criterio del juicio, por sobre las restricciones de la autoridad política.

El texto de apertura de La Biblioteca anunciaba las características ideológicoestéticas de la empresa "en cuanto a material y ejecución". ${ }^{20} \mathrm{El}$ acento estaría puesto no tanto en la novedad y la originalidad de los trabajos, "que de nadie se pueden exigir, y mucho menos a plazo fijo y en tan apurado momento de nuestra evolución", ${ }^{21}$ sino en la corrección formal y la información sólida. Estimular las formas de la sociabilidad propias del mundo intelectual aparecía como uno de los propósitos básicos de la publicación en el "intercambio de ideas y comunes aspiraciones" con el fin de crear, entre sus miembros, relaciones de solidaridad y fraternidad, aspiración recurrente aunque todavía irrealizada. ${ }^{22}$

Groussac se refería a La Biblioteca, apelando al repertorio biológico, en términos de "organismo", y señalaba su imperativo fundamental de "hacerla vivir", para dar por tierra con las dos objeciones que pesaban sobre ella. Con respecto a la primera, -la ausencia de una tradición crítica de colaboradores para una revista especializada- Groussac observaba: "Se nos ha dicho, por una parte, que no hallaríamos en la Argentina la suma de una colaboración bastante a llenar mensualmente las páginas de una gran revista, faltando a la par entre nosotros la preparación y el vagar indispensable"; 23 en ese sentido, se ponía de manifiesto que Groussac percibía su propia acción como un comienzo, e intentaba agrupar en las páginas de la revista la producción de aquellos que pudieran formar parte de una elite intelectual y artística, de modo que La Biblioteca funcionara como espacio del ejercicio de "propaganda intelectual" a la vez que como lugar de

\footnotetext{
${ }^{19}$ Groussac, Paul, "La Biblioteca”, La Biblioteca, Año I, Tomo I, junio, 1896, p. 5

${ }^{20}$ Ibid., pp. 5-8.

${ }^{21}$ Ibid., p. 5.

22 Ibid., p. 7.

${ }^{23}$ Ibid., p. 6.
} 
construcción de una tradición intelectual nacional, de convergencia y reclutamiento del pensamiento crítico y artístico. Para ello la revista contaría con un "núcleo resistente" de colaboración nacional. A sus ojos, esto resultaba impostergable dado que, como se observaría en las sucesivas entregas de la La Biblioteca, y como remarcaría unos años después, reconocía y asignaba a las elites, esa “minoría intelectual necesaria a la nación”, la responsabilidad de realización de la grandeza de los países. Como señalaría en 1901 “(e)l único progreso eficaz descansa en el perfeccionamiento de lo que existe, y este perfeccionamiento nadie lo realiza tan bien como el [que] lo ha ideado; brazos y cerebros son solidarios". ${ }^{24}$ La segunda objeción se relacionaba con la falta de "lectores de este linaje de producciones", y se traducía directamente en el ambicioso programa de creación de un público que se distinguiera del que leía periódicos casi con exclusividad. ${ }^{25}$ De ese modo, al mismo tiempo que señalaba la ausencia, afirmaba una plenitud. Existía un público lector de diarios, productos en relación con los cuales, "las ciencias y las letras [eran], parientes pobres", y eso se oponía a "la dignidad y la cultura del país" (Groussac, 1938: 93). Consciente de este objetivo y confiado en la eficacia de la revista, Groussac aseveraba categórico: "Es muy sabido que, por lo regular, la necesidad crea el instrumento; pero lo contrario acontece también, y no es raro que la presencia inesperada de un órgano nuevo determine y estimule la función". ${ }^{26}$ Estas palabras describían y contrastaban dos estatutos antagónicos de la literatura y la cultura: por una parte, el que remitía a una lógica aceitada identificable con aquella que gobernaba la producción literaria europea, en la que existía un público que la demandaba, consumía y promovía;

\footnotetext{
${ }^{24}$ En 1901 afirmaba: "Las naciones que saben son las que producen: las que tienen artistas originales, filósofos profundos, literatos de biblioteca y sabios de laboratorio, son también las inundan los mercados del universo con sus artefactos, sin que formen excepción a la regla los Estados Unidos de Longfellow y Emerson, de Edison y Motley. Y la razón es obvia, señores, -tan evidente que no merece discutirse. Todo progreso material arranca del espíritu" (107). Más adelante proseguía: "los que siembran son los que cosechan; y no recuerdo guerra moderna en que los pueblos que compran su armamento hayan vencido a los que lo fabrican" (Groussac, 1938: 109-110).

${ }^{25}$ En 1882, en "El movimiento intelectual argentino", Ernesto Quesada había explicado la situación en términos semejantes, aunque menos indignados: "Entre nosotros se lee enormemente los diarios, pero estos -salvo honrosas excepciones- buscan más bien el lucro que la propaganda" (121); y luego: "La prensa diaria, por su naturaleza misma, por su pronunciadísima tendencia actual, es más bien el receptáculo de las noticias del momento, de la vida fugitiva del instante. No se le puede pedir que lleve a cabo una empresa que no entra evidentemente en sus fines" (125) [la de llevar adelante una labor crítica -la "sana crítica"- que inculque en el público el gusto por las letras]. (Quesada, 1895: 119-141).

${ }^{26}$ Ibid., p. 7.
} 
por otra parte, una situación opuesta en que el gesto voluntarista e intencional, confiaba en su propia potencia para generar una función y delimitar un espacio específico, dentro y a partir del cual podía empezar a pensarse en acciones reconocibles como más estrictamente intelectuales.

En el $n^{\circ} 1$ de la revista, en un artículo que se continuaba en la entrega de julio de 1896 acerca de la historia de la Biblioteca pública de Buenos Aires -ahora Biblioteca Nacional-, Groussac insistía en la vinculación $a b$ origine entre la biblioteca y la patria. Creada en 1810 por decreto de la Primera Junta, y "a inspiración de su ilustre secretario" Mariano Moreno, reconocía en ella una función civilizatoria, tarea que compartía con otras instituciones a las que Groussac juzgaba indispensables para combatir la ignorancia, uno de los enemigos de la "cuestión nacional". ${ }^{27}$ En una matriz que retomaba la oposición sarmientina civilización / barbarie, Groussac realizaba una historia de la institución, a la luz de los avatares de la historia argentina. En el escrito se construía un paralelo entre Groussac y Moreno en función de un conjunto de rasgos que el director de la Biblioteca asignaba al joven intelectual revolucionario. Definido como una “inteligencia flexible puesta al servicio de una inflexible voluntad", redactor casi único de la Gaceta de Buenos Aires, dotado de una "razón luminosa", Moreno aparecía, según esta caracterización, como el antecesor natural de Groussac, encarnando lo mejor de la tradición iluminista que este último reconocía en los hombres de Mayo. ${ }^{28}$ En esta tradición se inscribía Groussac para insistir en la función civilizatoria de la biblioteca y de otras instituciones que como la escuela, la prensa y la universidad, tenían un "destino popular" ${ }^{29}$ como el que Moreno había pensado en 1810, y contribuían a la construcción de la sociedad civil. Este destino popular se realizaba en el carácter público de tales

${ }_{27}$ Ibid., p. 16. El perfil de Amadeo Jacques en la sección Redactores insiste en la cuestión educativa como central.

${ }^{28}$ Alejandro Eujanián ha analizado en "Intelectuales, políticos y profetas. Paul Groussac en la construcción de una imagen del intelectual a fines del siglo XIX" los atributos de una figura de intelectual que pueden desprenderse de la Historia de la Biblioteca Nacional de Paul Groussac; ha señalado también, el carácter rector de la figura de Moreno en tal construcción: "Moreno se constituye de esta manera en el espejo en el que Groussac se mira a sí mismo y a partir del cual construye su autoimagen" (2) [mimeo]

${ }_{29}$ Groussac explicaba que "Nuevo en absoluto, no lo era sin duda el proyecto de tan benéfica institución. (...) La idea propia de Moreno, es el destino popular de la institución, independiente de todo vínculo universitario" [entre los edificios educativos que se estaban construyendo por iniciativa de Vértiz estaba el de una biblioteca anexa al colegio de San Carlos, en lo era el "apreciable sitio que servía de huerta al Colegio de San Ignacio". Ibid., p. 10. 
instituciones, que pueden pensarse, en términos de Luis Alberto Romero y Leandro Gutiérrez, como verdaderas "empresas culturales" ${ }^{30}$ en las que se concentra la intervención de los intelectuales. Así, en el caso de La Biblioteca la producción intelectual y artística subsumida y administrada por una institución estatal, revestía una función que la vinculaba directamente con el campo del poder, del que dependía y con el cual cooperaba en el cumplimiento de una obligación propia del Estado liberal, cual era la construcción de la nación. De este modo, la historia de la Biblioteca escrita por Groussac exponía las tensiones propias de la fase temprana en la formación del campo intelectual, donde la literatura era funcional con respecto a la política. Sin embargo, este relato se leía también como estrategia de compensación en relación con el desvío que la revista representaba, reponiendo así su relación con la institución estatal. Groussac no publicaba una revista del estilo de lo que bien podría ser el 'boletín oficial' de difusión de las actividades y catálogos de la Biblioteca Nacional, pero para hacer menos perceptible el desplazamiento, daba a conocer documentos inéditos tomados del fondo manuscrito de la Biblioteca y escribía, además, la historia de la institución de la cual su revista era deudora.

Aquella deuda le fue recordada a Groussac en 1898 por el ya mencionado Ministro de Justicia, Culto e Instrucción Pública de la Nación, en una carta del 19 de marzo de 1898, en la cual el funcionario comunicaba al director de la revista su disgusto por las injurias proferidas, en un artículo de su autoría, al representante diplomático de Argentina en Chile, Norberto Piñero:

En el citado artículo se exceden los justos límites de la crítica literaria, para llegar hasta la injuria al doctor Piñero. Esto, y las convenientes apreciaciones que consigna con respecto á la representación diplomática que el Gobierno le ha confiado en la República de Chile, no encuadra, en

${ }^{30}$ En Sectores populares, cultura y política. Buenos Aires en la entreguerra Luis Alberto Romero y Leandro Gutiérrez consideran las ediciones de libros baratos y las bibliotecas populares de la entreguerra, como las formas en que los agentes "más moderados de la contestación política e intelectual" transmiten los mensajes, que van modelando la emergente cultura popular y barrial. Como "empresas culturales", las bibliotecas populares y las ediciones económicas de libros, se constituyen en zonas de intersección entre circuitos culturales $\mathrm{y}$, los intelectuales y militantes políticos, en transmisores y mediadores. (Gutiérrez- Romero,1995: 45-67) 
manera alguna, con los propósitos y los fines de una publicación costeada por el Tesoro público, y que ha reemplazado, hasta ahora, la 'Revista de la Biblioteca' sancionada en la Ley de Presupuesto. [cursivas nuestras] $]^{31}$

Si bien el ministro exageraba, también ponía en evidencia la sustitución que realizaba Groussac con su revista al expresar la incongruencia de una publicación como La Biblioteca en tanto órgano de la institución pública. Al mismo tiempo utilizaba para ello un argumento -el de sobrepasar los límites de la crítica literaria- que funcionaba como registro de la existencia -aunque en un espacio inapropiado-, de las atribuciones pero también de las fronteras de algo que percibía como crítica literaria. La respuesta de Groussac tenía como base el mismo argumento: se trataba de crítica literaria, y respondió a la censura contra "la forma de un artículo literario" con la decisión, que se haría efectiva a partir de mayo de 1898 , de cerrar la revista. ${ }^{32}$

Liberado de las presiones oficiales, Groussac no vaciló en su descargo y en el artículo publicado en la entrega de mayo de 1898, puso de manifiesto los motivos reales de la censura, que "se dirige a la substancia misma del periódico" y se sinceraba con respecto a sus intenciones con la revista, que en la cita que transcribimos, aparecía directamente ligada a la literatura:

Cuando se trató de dar forma á la iniciativa del Congreso, el ilustrado doctor Bermejo, con una confianza que me honra, se dignó dejar á mi albedrío todo lo concerniente á la futura publicación. Plan o índole de la revista, periodicidad ó reparto de sus ejemplares, conjunto de detalles de su ejecución material: en nada quiso intervenir; no intentó regimentar las Musas [cursivas nuestras] ${ }^{33}$

${ }^{31}$ Groussac, Paul. "La desaparición de 'La Biblioteca”, Año II, Tomo VIII, abril-mayo, 1898, pp. 244-245.

${ }^{32}$ Groussac argumentaba: "Ese acto de dudoso liberalismo parece apoyarse en la hipótesis de que, para un verdadero hombre de letras, existen bienes más preciosos que el ejercicio del pensamiento y la satisfacción de la conciencia". Además hacía presente una omisión del ministro, a su juicio inexplicable: el hecho de que el artículo suyo en La Biblioteca era la respuesta directa a "un folleto redactado en una legación argentina, repartido y reproducido en Buenos Aires, con desprecio de las mismas consideraciones que se invocan para censurarme, y cuyo objeto es falsear la historia, deslustrando la más brillante figura civil de la revolución. (...) ostenta mi nombre en su cubierta y no contiene un párrafo que no tienda á denigrar embozadamente mi carácter o amenguar mi personalidad" Ibid., p. 246.

${ }^{33}$ Ibid., p. 247. 
El artículo reafirmaba con carácter indeclinable la independencia de la revista, la definía como espacio para la crítica y consideraba positivamente su "éxito creciente en un público selecto". ${ }^{34}$ Pero al mismo tiempo exhibía el costo que debía pagar por esa libertad si no aceptaba las censuras provenientes del campo del poder político. Las últimas palabras del artículo de Groussac remarcaban el carácter inicial y trunco de la acción de la revista y la seguridad de que "la colección de La Biblioteca deja la idea de una tentativa que pudo ser viable y no indigna de este país". ${ }^{35}$ Asimismo el escrito de Groussac se cerraba haciendo explícitas las relaciones necesarias y viables entre una empresa cultural civilizatoria y el Estado, que imaginariamente Groussac había diseñado en el ejercicio de su voluntad autonómica.

Lo cierto es que la publicación necesitaba aún [cursivas nuestras] del doble concurso público y oficial para tener su existencia asegurada y llegar a su completo desarrollo. Este sin duda se hubiera conseguido con un esfuerzo más prolongado; y sin exagerado optimismo podía preverse la hora en que la revista del todo emancipada, lograse integrar su organismo y extender su influencia a toda América Latina.

De esta manera, era evidente que para Groussac la posibilidad de existencia del mundo intelectual en la Argentina de fines del siglo XIX, implicaba, al menos en esta etapa de comienzo, la contribución del Estado (coincidiendo en ello con los directores de la Revista de Buenos Aires), y también de un mercado, entendido éste en la forma de un público propio que con el tiempo sustituyera el apoyo estatal. El episodio mostraba la subordinación y la dominación de la producción intelectual por el poder político y exhibía su estado de precariedad tanto económica como simbólica. Exponía así la ineficacia y los límites efectivos de una voluntad autonómica que debía replegarse y cuyo último gesto no hacía sino amplificar el carácter dependiente de los intelectuales y de la cultura. ${ }^{36}$ Esta precariedad, como se verá en el apartado siguiente (2.4) no se manifestaba

\footnotetext{
${ }^{34}$ Ibid., p. 247.
}

${ }^{35}$ Ibid., p. 248.

${ }^{36}$ En relación con la posibilidad de existencia de un campo literario autónomo, señala Bourdieu: "Unas prácticas regular y perdurablemente libres de las imposiciones y de las presiones directas e indirectas de los poderes temporales sólo son posibles si son capaces de basarse no sólo en las tendencias fluctuantes del estado de ánimo o en resoluciones 
únicamente de ese modo; se podía leer también en la oscilación de los usos y la extensión de los términos literario / literato / letras, los que con frecuencia calificaban y definían ámbitos y prácticas diversos, en los que todavía se desempeñaban sujetos estrechamente ligados con el ejercicio mismo del poder.

\section{El mundo intelectual: entre el Estado y la política}

La diversidad temática de los trabajos publicados así como su variedad genérica y el perfil de sus autores, eran los signos más visibles de un carácter general cultural, antes que estrictamente literario de La Biblioteca. ${ }^{37} \mathrm{El}$ hecho de que abogados, juristas, médicos, políticos, publicistas, escritores, higienistas y poetas convergieran en un mismo espacio, trazaba los límites relativamente laxos del territorio del mundo cultural, y apuntaba, además, a una aún no estrictamente diferenciada identificación de las prácticas simbólicas, distintiva de esta fase del campo intelectual. En la revista de Groussac se actualizan el carácter inicial del campo intelectual y su imbricación con el campo del poder político, en función de los cuales se encontraban en las páginas de La Biblioteca toda una serie de artículos cuya temática provenía del ámbito político-estatal. Así, junto a trabajos de índole más disciplinar y cultural, y por momentos dominando el espacio de la publicación, se hallaban escritos relativos a temáticas y tópicos provenientes de y ligados más estrechamente con cuestiones de Estado. El arco era amplio e iba desde la evaluación de los efectos de la modernización, hasta las campañas de instrucción pública, la discusión de un proyecto constitucional, cuestiones de salud o de gasto públicos. Algunas de las colaboraciones, en función del modo en que eran presentadas por sus autores, asignaban a La Biblioteca una función adicional, como prolongación del espacio parlamentario. Otros escritos mostraban además algo del "valor institucional" de la prensa del siglo XIX a la que según Beatriz Sarlo puede considerarse como "instancia pública de debate" (Sarlo, 1984, IX-XLIV). Así, por ejemplo, se discutía la factibilidad y pertinencia de la modificación de un determinado artículo de la constitución ${ }^{38}$ o la

voluntaristas de la moralidad, sino en la necesidad de un universo social que tiene como ley fundamental, como nomos, la independencia de los poderes económicos y políticos". (Bourdieu, 1995: 98)

${ }^{37}$ El subtítulo de la revista (Historia, Ciencias, Letras), anunciaba también su diversidad.

${ }^{38}$ Orma, E. "El Ministerio nacional”, Año II, Tomo VII, enero, 1898, pp. 32-51. 
sanción por el congreso del proyecto de construcción de un sanatorio para tuberculosos en Córdoba. ${ }^{39}$

El repaso detallado de los trabajos publicados en La Biblioteca permite distinguir tres ámbitos más o menos característicos en los cuales es posible agrupar las colaboraciones, que salvo aclaración explícita, fueron siempre inéditas:

\section{a) Estatal}

En esta caracterización es posible incluir aquellos trabajos vinculados con temas de gestión estatal, discusiones parlamentarias, proyectos edilicios, cuestiones de salud e higiene, de derecho constitucional, etc. Entre otros, se pueden mencionar: "La Basílica de Luján" ( $\left.n^{\circ} 2\right)$; "El dique de San Roque" ( $\left.n^{\circ} 3\right)$; "Supresión de las aduanas" ( $\left.n^{\circ} 4\right)$; "El Puente del Inca y sus termas" (n 9); "Higiene pública. Saneamiento de Mendoza" ( $\left.n^{\circ} 11\right)$; “Constituciones y partidos" ( $\left.n^{\circ} 12\right)$; "Derecho constitucional" ( $n^{\circ} 14$ y n 16$)$; "Sanatorio en las sierras de Córdoba" (n $\left.\mathrm{n}^{\mathrm{o}} 17\right)$; "Acrecentamiento de los gastos nacionales en la República Argentina" ( $\left.n^{\circ} 18\right)$; "El censo y la constitución" ( $\left.n^{\circ} 19\right)$; “El ministerio nacional" ( $\left.\mathrm{n}^{\mathrm{o}} 20\right)$; "Límites con Chile" ( $\left.\mathrm{n}^{\mathrm{o}} 22\right)$; "El presupuesto de recursos. Su duración" (n $\left.n^{\mathrm{o}} 22\right)$; “La ley del año. Distribución de los ministerios" (n⿳ 23-24).

\section{b) Cultural, intelectual, literario}

Los trabajos que pueden nuclearse bajo esta denominación cubren amplias zonas de intereses, y en ese sentido, puede decirse que la revista mostraba una preocupación enciclopédica y una vocación ilustrada. Al mismo tiempo, muchos de estos escritos funcionaron como los espacios más fuertes de intervención intelectual sobre problemáticas vinculadas con los efectos culturales del programa modernizador del liberalismo, o de cuestiones insoslayables de la actualidad política americana. ${ }^{40}$ Es relevante, en ese sentido, el trabajo de Roque Sáenz Peña "Los Estados Unidos en SudAmérica. La doctrina Monroe y su evolución”, vinculado con la intervención de Estados Unidos en Cuba en 1898. Además, bajo la inespecífica denominación de letras o la

${ }^{39}$ Gache, S. "Sanatorio en la Sierra de Córdoba", Año II, Tomo VI, octubre, 1897, pp. 43-54. Dice Gache: “(...) quiero proseguir hoy aquella iniciativa, a cuyo efecto ampliaré mi pensamiento, en la esperanza de que el Congreso se servirá considerar el asunto y resolverlo favorablemente" (43).

${ }^{40}$ Fue publicado en las entregas de junio, julio y octubre de 1897. 
calificación de literarios, se incorporaban en las páginas medulares de La Biblioteca textos sobre literatura, derecho, actualidad científica (medicina, química, meteorología, telegrafía) crítica literaria, historia política nacional (se analizan hechos del pasado, se publica la correspondencia de diversos hombres públicos, etc.), y además, se transcribían discursos. La sección 'Boletín Bibliográfico', que ocupa las páginas finales de la revista, daba a conocer libros recientes, nacionales o extranjeros. Se trata también de obras literarias, históricas, científicas, sociológicas o tesis universitarias. ${ }^{41}$

A modo de ilustración consignamos los siguientes: "El arte en Buenos Aires. La evolución del gusto", por Eduardo Schiaffino ( $\mathrm{n}^{\mathrm{o}} 1$ y $\mathrm{n}^{\mathrm{o}} 2$ ), “Observaciones críticas acerca de unos manuscritos de Tadeo Haenke existentes en la Biblioteca Nacional, por Pedro N. Arata ( $\mathrm{n}^{\mathrm{o}}$ 1), Autobiografia, por Vicente Fidel López ( $\mathrm{n}^{\mathrm{o}}$ 3), "Sarmiento polemista. La campaña en el ejército Grande" y las siete entregas "El Brasil intelectual. Impresiones y notas literarias" de Martín García Mérou (números 5, 6, 8, 9, 17, 18, 19); "La predicción del tiempo", por Francisco Beuf $\left(n^{\circ} 1\right)$; las tres entregas de los relatos de viaje "Marinas y paisajes americanos" de Groussac (números 5, 6, 7, 14); "Lenguas americanas. El tupy egipciaco", de Bartolomé Mitre ( $\left.n^{\circ} 6\right)$; el relato "Un estreno" de Leopoldo Lugones (n 21); "El hombre de oro" (números 12, 13, 16) o "Tutecotzimí" (no 10) de Rubén Darío; "Estética musical y conciertos sinfónicos" de Alberto Williams (n 4), "Sarmiento en París", por Miguel Cané (n $\left.n^{0} 7\right)$; "Artemis" de Enrique Rodríguez Larreta ( $n^{\circ}$ 6); el "Fragmento del poema 'La Magdalena"” de Ricardo Gutiérrez ( $\left.n^{\circ} 8\right)$; las narraciones "La rueda loca" ( $\left.n^{\circ} 2\right)$, "La pesquisa" ( $\left.n^{\circ} 10\right)$ o "La herencia" (n 20) de Groussac; el discurso de Carlos Pellegrini en el tercer aniversario de la muerte de Lucio López (nº 19).

\section{c) Histórico - documental}

La revista dedicaba una sección específica y fija a la publicación de documentos históricos pertenecientes al fondo manuscrito de la Biblioteca y en esta actividad acata una "imposición gubernativa" con la que se declara coincidente y que motu propio ha

\footnotetext{
${ }^{41}$ La sección 'Boletín bibliográfico' estuvo a cargo de Groussac. Las entregas en las que se publicó fueron: noviembre y diciembre de 1896; enero, marzo, abril, mayo, julio, agosto de 1897; enero, febrero, abril - mayo de 1897.
} 
sugerido ${ }^{42}$ En ocasiones, los documentos provenían también de los depositarios de los manuscritos a quienes Groussac conocía personalmente. Es importante destacar la relevancia de esta sección para los historiadores e intelectuales contemporáneos de Groussac ya que representaba la posibilidad de acceder a documentos hasta el momento desconocidos, a partir de los cuales organizar el pasado nacional. Groussac ejercía en este terreno la labor de publicista, término con el que frecuentemente se lo ha definido, haciendo públicos documentos en poder del Estado y de particulares. El modo en que esos documentos podían utilizarse se exhibía en la revista, tempranamente, en el artículo sobre la historia de la Biblioteca de Buenos Aires escrito por Groussac, con que se abría la primera entrega de la publicación. Allí, historiar era realizar el análisis minucioso de los documentos, memorias e informes escritos por directores y bibliotecarios de la institución, y al mismo tiempo, ocuparse "de la vida pública de sus más ilustres directores", quienes eran juzgados desde la perspectiva civilizatoria ya mencionada. ${ }^{43}$ Como pertenecientes a este ámbito pueden citarse: "El congreso americano de Lima. Correspondencia confidencial entre el Presidente B. Mitre y el Ministro en el Perú, don Domingo F. Sarmiento" ( $\mathrm{n}^{\mathrm{o}}$ 1); "Proyecto de Constitución de la Sociedad Patriótica Argentina para las Provincias Unidas del Río de La Plata en la América del Sud” (nº 3); "Representación al rey nuestro señor por el capitán de nabio de la real armada Dn. Santiago de Liniers! Sobre las misiones tapes y guaraníes de las que se hallava governador interino en 28 de junio de 1804" ( $\mathrm{n}^{\circ}$ 6); "Política electoral. Correspondencia confidencial entre el General Mitre y el Doctor Yrigoyen" ( $\left.n^{\circ} 7\right)$; “Carta del Alcalde de

${ }^{42}$ En el texto de apertura de la revista Groussac lo expresaba en los siguientes términos: "También debemos agregar que esta muestra de confianza en la sinceridad y la honradez de nuestro esfuerzo, se ha producido sin condición; -puesto que la autorización de enriquecer cada número de la revista con la publicación de documentos inéditos, extraídos del fondo manuscrito de la Biblioteca Nacional, más que imposición gubernativa, significa aquiescencia a nuestra propia solicitud" (7).

${ }_{43}$ La sección especifica en la que se publicaban estos documentos era "Documentos históricos". Aparece por primera vez en el segundo número, y se publica en los números 2 , $3,4,6,7,9,10,12,13,15,19,20$. [como indicamos en el índice de La Biblioteca, la revista no asigna número a sus entregas; por una cuestión de utilidad, los agregamos, y citamos tal como aparecen en el anexo]

En cuanto al trabajo de Groussac en el campo historiográfico, Alejandro Eujanián sostiene que la "producción intelectual y su labor institucional, que llevó a cabo desde la dirección de la Biblioteca Nacional y de la revista La Biblioteca" constituyen un momento central del "proceso de consolidación de la historiografía como una disciplina profesional en el país" y por lo tanto, de una imagen del historiador opuesta a la del amateur. Las citas corresponden a (Eujanián, 2003: 43-67). 
primer voto del cabildo de Buenos Aires, para S. M. Acompaña documentos que explican episodios anteriores a la toma de aquella ciudad y de Montevideo por los ingleses $\mathrm{y}$ en que intervinieron personas que se significaron más tarde en la independencia del virreynato" ( $\left.\mathrm{n}^{\mathrm{o}} 10\right)$; “Oficio del Comandante General de la Expedición Reconquistadora Don Santiago de Liniers, al excelentísimo Señor Príncipe de la Paz, Generalísimo de los reales Ejércitos y armadas"; y otros documentos, entre los cuales se cuentan una "Carta de Liniers a la princesa Carlota J. de Borbon", una "Representación del Señor Liniers pidiendo al rey tenga a bien el no nombrarlo virrey" ( $\left.n^{0} 12\right)$; y escritos de Santiago de Liniers ( $\left.n^{\circ} 13\right)$.

El análisis de algunos trabajos del ámbito intelectual, cultural y literario sirve para señalar y exponer, en primera instancia, las evaluaciones y tomas de posición de algunos de los miembros de la alta cultura letrada con respecto a las consecuencias del progreso y de la relación de los intelectuales con el Estado; y en un segundo momento, para apuntar la percepción de una diferencia entre el "mundo intelectual" y el campo político. Nos ocuparemos de revisar los episodios más sobresalientes en que en la revista se juzgan los efectos culturales y sociales de la modernización. Así se intentará mostrar que, contrariamente a lo que se ha sostenido, ${ }^{44}$ existió en La Biblioteca una presencia fuerte de escritos cuya temática se ligaba con aquellas cuestiones $\mathrm{y}$, en algunos casos, estuvo dictada por conflictos que se plantearon en el orden político-estatal. En ocasiones, dicha temática se vinculaba, en parte, con la discusión sobre teoría política que tenía lugar en Argentina de acuerdo a los temas de esa discusión en los países europeos, a partir de cuyo examen algunos de los intelectuales forjaron su intervención con respecto a las preocupaciones centrales de la elite dirigente. De ese modo, la revista muestra un fuerte rasgo de heteronomía, propio de ese mundo intelectual en vías de constitución. Abordaremos primero las colaboraciones de Miguel Cané y Carlos Rodríguez Larreta, y luego las de Groussac. Dar cuenta de estos escritos permite asignar a La Biblioteca una

${ }^{44}$ Paula Bruno afirma que la sección que hubiera albergado este tipo de cuestiones, habría sido la anunciada y nunca realizada sección 'Crónica del mes'. Sostiene que "quedaron absolutamente fuera de la publicación los temas vinculados con los sucesos coyunturales del mundo político y los de orden social y económico" (Bruno; 2005, 76). Consideramos, sin embargo, que los análisis de las colaboraciones correspondientes a los parágrafos 2.1 y 2.2 de la presente tesis no permiten sostener tal interpretación ya que coinciden con aquello que Bruno define como político y social. 
dimensión algo más colectiva que la que generalmente, y a primera vista, puede atribuírsele, en función de la presencia constante e innegable, aunque no exclusiva, de trabajos cuya autoría corresponde a Groussac, ya sea que lleven o no su firma. Además, resulta útil para remarcar un grado todavía alto de identificación y superposición entre las prácticas políticas y culturales, característica que se ve reforzada por la nómina de los autores cuyos trabajos se inscriben en el ámbito intelectual, cultural y literario ya mencionado. ${ }^{45} \mathrm{Al}$ mismo tiempo, el análisis de estos trabajos permite ver que la cultura es el espacio donde se registran y discuten problemas y conflictos relativos al orden social, en relación con los cuales se plantean respuestas culturales específicas. En esa especificidad de tales respuestas es posible leer las marcas del ya iniciado proceso de separación entre las letras y el Estado.

Por último, el estudio de la sección 'Redactores' permite reconstruir el modo en que se formula aquella diferenciación entre cultura y política, a partir de la presentación y tipificación de productores y prácticas intelectuales. El repaso de esta sección de la revista hace presente el carácter no lineal y heterogéneo del proceso de autonomización literaria, y señala la emergencia de subjetividades más modernas como la del escritor, el poeta y el crítico, si se las considera en relación con otras como la del literato, el doctor en leyes, el publicista, el estadista o el doctor en medicina que, en términos generales, son dominantes en La Biblioteca, y a los que se sigue incluyendo en el ámbito de las letras.

\subsection{Los intelectuales de la cultura letrada y el progreso: ganancias y pérdidas}

La crítica ha dado cuenta de las tempranas impugnaciones a los efectos no deseados del programa modernizador del liberalismo, realizadas desde el interior mismo de las elites intelectuales y políticas que lo habían alentado y promovido. José Luis Romero caracteriza las reacciones de la elite dirigente en el período que nos ocupa, en

${ }^{45}$ Cf. el "Índice onomástico" de la revista en los Anexos de este capítulo. 
términos de un "liberalismo conservador" de signo marcadamente antipopular. Sostiene que a diferencia del cruzamiento producido entre los inmigrantes y la población criolla, tanto en las capas inferiores como medias (producto de la movilidad social que trajo consigo el éxito económico del inmigrante), la elite aunque prácticamente no modificó su concepción social "acusó categóricamente su reacción ante las nuevas condiciones de la realidad". Este reposicionamiento se tradujo según Romero, en la afirmación de una superioridad social con respecto al conjunto heterogéneo al que observan desde su ubicación central, afirmando su propia condición diferencial de "auténticos hijos del país y amos del suelo". Aquel carácter conservador de la política liberal se mostró en la direccionalidad impresa a las transformaciones, implementadas "desde arriba" para frustrar la eventual pérdida del poder por parte de aquella que -desde el punto de vista de Romero- ha dejado de ser elite republicana y se ha convertido en oligarquía (Romero, 1997: 173-188, 189-209). ${ }^{46}$

Desde la crítica literaria y cultural, Ángel Rama ha analizado en su ya clásico Las máscaras democráticas del modernismo, las respuestas de intelectuales y escritores en los cincuenta años que recortan el período de modernización (1870-1920), con especial énfasis en los momentos de las culturas ilustrada, democratizada y prenacionalista. (1870-1910). ${ }^{47}$ Rama subraya que para comprender la "conmoción" y la "subversión" que aquellas respuestas y "alarmas" intentaron escenificar, es imprescindible "reconocer la cualidad aristocrática, elitista y clasista en que durante siglos se había desarrollado la tarea de los intelectuales americanos, la cual había sobrevivido al cataclismo de la revolución" (Rama, 1985: 16-17).

Más recientemente, Oscar Terán ha revisado desde la perspectiva de la historia intelectual los discursos producidos entre 1880 y el Centenario por la fracción intelectual de la elite dirigente argentina. Afirma que una gran parte de esos discursos de fines de siglo XIX y principios del siglo XX “organizaron una problemática frente al proceso de

${ }^{46}$ Por su parte, Oscar Terán localiza simbólicamente la mutación de la elite liberal en el entierro de Sarmiento, en 1888. Afirma: “(...) cuando a fines de siglo [XIX] cierto pesimismo corroe la autoimagen de la clase gobernante, se percibe que el entierro de Sarmiento por Juárez Celman ha resultado altamente simbólico: según el modelo clásico, se ha pasado de la aristocracia a la oligarquía". (Terán, 1994: 28-31).

${ }^{47}$ Dentro de lo que llama modernización, Rama plantea la existencia de un macroperíodo al que denomina de la cultura modernizada internacionalista, y dentro de él, los momentos consignados en el cuerpo del trabajo. Su análisis llega hasta 1910, en que se inicia otro macroperíodo, el de la cultura modernizada nacionalista. (Rama, 1985: 36-50). 
modernización experimentado en esos años y frente a la tarea de consumar la construcción de la nación”. De cara a la modernización estas intervenciones manifiestan los "fenómenos indeseados e incomprensibles" que ella acarrea y deben ser pensadas como "correctivos que desearían cumplir el papel de lanza mítica capaz de curar las heridas que ella misma produce" (Terán, 2000: 13-20). En el capítulo dedicado a Miguel Cané, Terán sostiene que las objeciones de la clase letrada con respecto a algunos de aquellos fenómenos se localizan en “diversas esferas de representación”, entre ellas la apelación del tema ubi sunt, el rechazo del igualitarismo, la preocupación ante los efectos de las modificaciones tecnológicas y las transformaciones urbanas (Terán, 2000: 20 y Ss). ${ }^{48}$ Asimismo observa que estas cuestiones estudiadas en detalle en Cané están presentes parcialmente en Groussac y se refiere a Del Plata al Niágara. Es importante precisar que varios fragmentos inéditos de ese libro fueron publicados en La Biblioteca bajo el nombre de "Marinas y paisajes americanos", y en ellos es posible leer algunas de las evaluaciones más negativas sobre la democracia y sobre la cultura norteamericana. ${ }^{49}$

De modo general puede decirse que aquellas alarmas alternadas con un cierto optimismo estaban presentes en la revista de Groussac. Lo estuvieron desde su comienzo y quien inauguró el tratamiento de esta problemática fue justamente Miguel Cané con "Nuevos rumbos humanos", publicado en el primer número de La Biblioteca en junio de 1896. Cabe aclarar que la fechación precisa de este escrito bien conocido no es ociosa, puesto que la crítica generalmente se refiere a su edición posterior en volumen, en Prosa ligera, de 1903, lo cual produce una homogeneización incómoda de dos contextos

${ }_{48}$ Josefina Ludmer también ha señalado en su "Introducción" a Juvenilia que "Cané, López y Wilde tienen una posición ambivalente frente al cambio del 80: por un lado, no dejan de representarlo y de participar de la modernidad política, por otro rechazan cierta modernidad cultural" (Ludmer, 1993: 18).

${ }^{49}$ Del Plata al Niágara, cuya edición princeps data de 1897 y por lo tanto, es contemporáneo de La Biblioteca, está dedicado a Carlos Pellegrini; se compone de artículos previamente publicados, algunos en La Nación y La Biblioteca; otros -los menos- en Le Courrier de la Plata, diario dirigido por Groussac; otros son trabajos inéditos. Según aclaraba Groussac en el prefacio a la edición de 1925, todos los trabajos habían sido escritos a partir de las notas que tomara durante el mismo viaje, realizado entre marzo de 1893 y enero de 1894. Bajo ese título se publicaron cuatro entregas: 1. "Marinas y paisajes americanos. I De Valparaíso a Lima", Año I, Tomo II, octubre, 1896, pp. 233-260. 2. "Marinas y paisajes americanos. II De Lima a Colón", Año I, Tomo II, noviembre, 1896, pp. 430-455; continúa el anterior 3. "Marinas y paisajes americanos. De Yucatán a México", Año I, Tomo II, diciembre, 1896, pp. 584-603. 4. "Marinas y paisajes americanos. California", Año II, Tomo V, julio, 1897, pp. 122-148.

Para una visión de conjunto de los tópicos presentes en Del Plata al Niágara, véanse Irazusta, Julio, 1978:57-77 y Colombi, 2004a: 71-94. 
ideológicos, culturales y políticos diferentes. ${ }^{50}$ Por otra parte, y en relación con la revista, el hecho es doblemente significativo. En primera instancia, y más allá de La Biblioteca, porque permite recuperar la utilización de imágenes comunes, acuñadas contemporáneamente por parte de Cané y de Groussac para evaluar el igualitarismo. Se trataba de la identificación del igualitarismo con la barbarie de Atila y los hunos, bajo la que sucumbía la civilización romana. ${ }^{51}$ Asimismo, devuelve al texto de Cané, resituado en el contexto de enunciación original, su carácter de intervención polémica, no ya como mero antecedente o como parte del clima de ideas de lo que Payá y Cárdenas denominaron el "primer nacionalismo argentino". ${ }^{52}$ En segundo término, porque en el interior de la publicación, encuentra en la colaboración de Carlos Rodríguez Larreta, "El socialismo y el derecho civil", y desde la especificidad de una disciplina institucionalizada universitaria, el tratamiento de los problemas que involucran a los militantes de la "revolución social". De ese modo, los dos artículos ameritan ser leídos de manera conjunta, como textos contemporáneos y complementarios.

"Nuevos rumbos humanos" de Cané (no 1), El socialismo y el derecho civil" de Carlos Rodríguez Larreta ( $\left.\mathrm{n}^{\circ} 7\right)$; "Génesis del héroe" $\left(\mathrm{n}^{\mathrm{o}} 8\right)$, "El Centenario" ( $\left.\mathrm{n}^{\mathrm{o}} 15\right)$, "La educación por el folletín" ( $\left.\mathrm{n}^{\circ} 18\right)$ y en menor medida "Alphonse Daudet" (n 19) cuatro colaboraciones de Groussac- conforman en La Biblioteca un conjunto privilegiado en el cual leer las prevenciones de la fracción intelectual de la elite principalmente en relación con los efectos culturales y sociales del igualitarismo, y para precisar el tipo de relación propuesta entre los intelectuales y la política, entre los intelectuales y el Estado. Este vínculo, como se observará, caracterizó un momento de la vida intelectual argentina en el que las acciones de intelectuales y escritores encontraron su motivación en

\footnotetext{
${ }^{50}$ Payá y Cárdenas, en la nota 5 del capítulo I, "La generación del Centenario", remiten a la edición de 1919 de Prosa ligera. En ese capítulo sostienen que algunos de los mismos dirigentes del 80 y del 90 que se pronuncian "contra el materialismo y el desarraigo que amenazaba la nación" y comenzaban a enjuiciar con severidad algunas de consecuencias del progreso". (Cárdenas - Payá, 1978: 17). Por su parte, Terán consigna la edición de 1903 (Terán, 2000).

${ }^{51}$ Cané señalaba: "Atila marchaba ciegamente sobre el mundo romano, como la piedra de una honda lanzada con mano providencial”, La Biblioteca, Año I, junio, 1896, p. 49.

52 El título del libro de Cárdenas y Payá es El primer nacionalismo argentino en Manuel Gálvez y Ricardo Rojas. Oscar Terán y María Teresa Gramuglio, se han ocupado en precisar el uso del término nacionalismo para la cultura argentina. De esas precisiones se sigue el desacuerdo de la consideración por parte de Cárdenas y Payá, de las obras de Gálvez y Rojas como "primer nacionalismo argentino". Cf. Gramuglio, 1994: 23-27; Terán, 1999: 279-287.
} 
cuestiones que excedían en mucho las preocupaciones estéticas o culturales, y de tal modo, indicaban el alto grado de legitimidad de figuras tales como las del literato, el publicista o el catedrático en el medio intelectual, a la vez que señalaban su funcionalidad con respecto a la política del Estado. Asimismo, la consideración conjunta de estos escritos permite construir una visión de La Biblioteca en la que se muestra más cohesionada ideológicamente de lo que pudiera pensarse, y a la vez, hace posible reconocer en ella un carácter más orgánico en lo concerniente al mundo de las ideas de la elite.

\subsection{Miguel Cané y Carlos Rodríguez Larreta: defensa de la propiedad en cuestión}

Como ya observamos, "Nuevos rumbos humanos" era el título del primer escrito de Miguel Cané ${ }^{53}$ en La Biblioteca. La colaboración, que había sido solicitada por Groussac, tenía un signo inaugural doble, dado que se publicaba en la entrega inicial de la revista, y porque se trataba de la primera de una serie de intervenciones cuya problemática nodal la constituían los avances de una era democratizada sobre la hegemonía cultural y social de las elites. Esos textos, entendidos como respuestas a dichos efectos, tenían grados diversos de especificidad cultural. "Nuevos rumbos humanos" caracterizaba de manera general tanto la posición propia de su autor como la que algunos meses más tarde sostendría el joven abogado Carlos Rodríguez Larreta en "El socialismo y el derecho civil", con respecto a las que se mencionaban como "las nuevas teorías" -socialismo, anarquismo, comunismo- y con respecto a la problemática central ya señalada, de la cual dichas teorías eran un aspecto. Ambos textos se conectaban a partir del tratamiento de la "cuestión social", ${ }^{54}$ que por esos años y para

\footnotetext{
${ }^{53}$ Además de "Nuevos rumbos humanos" Cané publicó en La Biblioteca: "Sarmiento en París", "La diplomacia de la Revolución" (en cinco entregas), "El Falstaff de Shakespeare"; para las referencias bibliográficas completas, véase el anexo sobre La Biblioteca. Todas las citas del artículo de Cané corresponden a La Biblioteca, Año I, Tomo I, junio, 1896, pp. 40-55. En adelante sólo consignaremos entre paréntesis el número de página.

${ }^{54}$ En la "Introducción" a Los liberales reformistas. La cuestión social en la Argentina 1880-1916, Eduardo A. Zimmermann, sostiene: "Los orígenes de la llamada 'cuestión social' argentina se remontan a la última década del siglo diecinueve. Este término describe $-y$ describía durante el período- el conjunto de consecuencias sociales del proceso de inmigración masiva, urbanización e industrialización que transformó al país, entre las que se contaron problemas en áreas de vivienda, sanidad y salud pública, el aumento de la 
estos dos autores, se definía cada vez más como "cuestión obrera”, y por el lugar preponderante que otorgaban en sus argumentaciones a la idea de propiedad. De tal forma, estas intervenciones podían considerarse como realizaciones genéricas diferentes del mismo problema. Ambos se ocupaban de responder fundamentalmente al socialismo, al que, con mayor o menor grado de preocupación consideraban peligroso, y guardaban semejanzas en su diagnóstico inicial, puesto que se referían a él como amenaza contra un orden político social vigente. Las críticas de Cané que -como las de Rodríguez Larretase realizaban en un momento en que aún no se había completado el programa modernizador, se planteaban como ejemplo concreto de lo podría suceder en la Argentina, ${ }^{55}$ en la proximidad establecida con la situación político social europea. El artículo era la constatación de una amenaza, registraba un cambio y enunciaba el temor de la pérdida.

El parágrafo inicial, ${ }^{56}$ escrito en una primera persona autobiográfica, se presentaba como la revisión de una crisis ideológica personal del autor con respecto a su antigua -y hasta no mucho tiempo atrás- incuestionada convicción sobre la legitimidad de la forma republicana y representativa para el gobierno de las sociedades humanas (40). Cané se refería a esa época juvenil en términos de "Absolutismo democrático", y en un gesto que otorgaba a su artículo un fuerte carácter de intervención política e intelectual, auguraba a sus "jóvenes lectores argentinos" y pares sociales, una idéntica crisis, en un intento por generalizar ese itinerario ideológico personal presentado como natural e inevitable, propio de un ciclo evolutivo. ${ }^{57}$ Esta idea de evolución funcionaba a lo largo del artículo criminalidad urbana, la protesta obrera y el surgimiento de nuevas corrientes ideológicas que desafiaban la validez de las instituciones políticas y económicas vigentes" y, luego aclara que "la protesta obrera y las relaciones entre el Estado y las organizaciones sindicales se irían afirmando como el tema central de esa 'cuestión social'" (Zimmermann, 1994: 13-15).

${ }^{55}$ Se hace referencia, por ejemplo, a la muerte de Carnot como hecho que ha conmocionado al mundo entero (51).

${ }^{56}$ El artículo se organizaba en ocho apartados. En el segundo, además de la presencia rectora de Tocqueville, Cané citaba a Stuart Mill; la referencia a este último se leía como admiración del "andar pausado de la historia inglesa, ese respeto profundo a lo pasado" (43), y por lo tanto, como contraria de los cambios. En el tercer apartado, se dedicaba a desarrollar la tesis de que las instituciones políticas no garantizaban el mejoramiento de las condiciones de vida. En el parágrafo IV, la figura de Renan funcionaba como sustento teórico de la hipótesis del apartado III. En V y VI, condenaba la revolución social cuestionadora de la idea de propiedad. En la séptima parte continuaba la prédica adversa a las luchas obreras e introducía la cuestión nacional. El parágrafo VIII planteaba la repercusión de los acontecimientos europeos en la Argentina, y proponía una solución.

${ }^{57}$ Así lo explicaba: "Ocúrreseme, pues, ya que Groussac me invita a llenar algunas páginas del primer número de su Revista, exponer sinceramente las fases de su crisis, augurando a 
como contrapartida positiva y conservadora de la "revolución social". La argumentación ponía en el centro a Tocqueville con su definición de democracia y las previsiones negativas con respecto a ella. Así, en tanto la democracia era un hecho social y no legal, un "organismo político" cuyo advenimiento se explicaba por razones o determinaciones culturales específicas de una sociedad dada, ${ }^{58}$ Cané argumentaba que no era la institución política la que garantizaba el progreso y el mejoramiento en las condiciones de vida. De tal forma, sostenía que "la fuerza del sentimiento democrático no radica en su incorporación a leyes positivas, sino en su mayor o menor difusión en un pueblo y en su imperio en las costumbres" (45). El autor de Juvenilia recuperaba el carácter augural y certero de las palabras de Tocqueville en las que se prevenía acerca de "la ley de la ascensión del número sobre las clases", hecho que para Cané era desgraciadamente una realidad, y señalaba la necesidad de mantener las diferencias sociales en sus correlatos legales, como lo era el voto restringido. ${ }^{59}$

En un organización que privilegiaba el orden por sobre la libertad, cuestionaba, desde la idea de armonía planteada por Renan, la finalidad de las luchas políticas de los anarquistas franceses, socialistas alemanes, nihilistas rusos "el movimiento de reacción que se observa en el mundo actual" (47), y por extensión, de quienes en Argentina participaban de tales luchas -aunque esto último no fuera explícito. ${ }^{60}$ Cané materializaba verbalmente la transformación social apelando a un repertorio de imágenes catastróficas de la naturaleza (cataclismos, mareas, rugir de olas), de guerras entre ordenamientos sociales irreconciliables y causantes de defunciones culturales (Atila y el mundo

mis jóvenes lectores argentinos que, cual más, cual menos, pasarán todos por la misma, por poco que la proyección de su pensamiento alcance a la región de las ideas generales", pp. 41-42.

${ }_{58}$ Terán explica que esta concepción de la democracia "configuraba un fantasma que amenaza a las sociedades con un proceso homogeneizador que solo puede nivelar hacia abajo, y para el cual se reserva el término mediocridad" (Terán, 2000: 23).

${ }^{59}$ A los efectos de demostrar que la "felicidad humana" no dependía de regímenes políticos, Cané comparaba los destinos de España y de Inglaterra. En la primera está disponible toda la legislación democrática: sufragio universal, matrimonio civil, juicio por jurados, códigos civil y penal reconocidos internacionalmente; en la segunda las legislaciones política, civil y criminal estaban completamente desorganizadas, sin embargo, sugería Cané, el voto restringido (antidemocrático) actuaba como fuerza de control que contrarrestaba aquella ausencia legal.

${ }^{60}$ Se preguntaba: “(...) si no es para la conquista de regímenes determinados, ¿qué causas y qué fin tiene ese sacudimiento pavoroso, extendido hoy por todo el mundo civilizado, esta protesta violenta contra el orden existente, que empieza a cubrir de sombras el porvenir?" (47). 


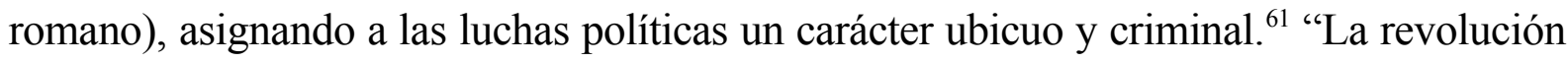
social está en todas partes" (47) afirmaba y, condenaba las nuevas tendencias políticas, vinculadas a una violencia que el escritor experimentaba como la pérdida de la gran aldea transformada ahora en una ciudad enferma, y a la vez, como la difuminación de una patria que se volvía extraña. Según el autor de En viaje, las acciones de ese tiempo -que era definido básicamente como un momento de acción-, se dirigían contra la idea de propiedad, "piedra angular de nuestro organismo social, (...) la idea madre sobre la que hemos levantado este palacio maravilloso de las convenciones humanas". ${ }^{2}$ En ese sentido, el hecho de recurrir a tal argumento para hablar de acontecimientos políticos y culturales era significativo porque indicaba que este principio de orden económico y legal era el que organizaba "la entera estructura jerárquica de la cultura" ${ }^{63}$ Desde su perspectiva, el problema de la transformación social se volvía más abiertamente, hacia el final de su razonamiento, una oposición a la cuestión nacional:

Un país será próspero y grande, no porque se desenvuelva bajo tal o cual régimen de gobierno, sino porque sus hijos conciban bien sus deberes de patriotismo y los cumplan como buenos. El patriotismo no está solo en pelear en los combates al son del himno y a la sombra de la bandera, no está solo en cantar las glorias patrias; está también y sobre todo en la prudencia, la fuerza de voluntad para contener las indignaciones violentas, la fe en la evolución que cura, $\mathrm{y}$ no en el prurito de la revolución que mata (50-51).

\footnotetext{
Zimmermann observa que "El anarquismo fue interpretado como un fenómeno caracterizado por superposición de la cuestión obrera y la criminalidad, y existió una fuerte tendencia a desplazarlo del primero al segundo de estos términos" (Zimmermann, 1994: 17) ${ }^{62} \mathrm{Ibid}$., p. 47. Se interrogaba: “¿Qué significado pueden tener esas palabras mismas: qué puede entenderse por gobierno, libertad, orden, familia, derecho, patria, el día que desaparezca el suelo que les da vida: esa idea de propiedad, que sustenta y sostiene todo nuestro mecanismo social?" (49).

${ }^{63}$ Ángel Rama ha señalado que el siglo XIX fue, además del siglo de la ciencia, el de la democracia "con su masificación y su vulgaridad, su materialismo y su igualitarismo, los que ponían en peligro la entera estructura jerárquica de la cultura, agrediendo a sus más conspicuos oficiantes. No solo los intereses económicos estaban en juego, sino también los culturales, pues esta arremetida afectaba el principio mismo de la propiedad, se tratara de tierras o de conocimientos, de acciones de la bolsa o de exclusivas degustaciones del arte" (Rama, 1985: 15-16).
} 
Si desde su mirada, marcada por una retórica biologicista, las sociedades evolucionaban como cualquier otro organismo, desde esa misma retórica la revolución podía ser pensada en términos de degeneración y muerte; es así que Cané la denominaba “patología actual”. El 'yo' con que se había iniciado la exposición se transformaba en un nosotros de clase que señalaba a su enemigo, nombrado como "nuestros adversarios, los obreros ciegos del porvenir". ${ }^{4}$ De cara a la cuestión nacional, que era entonces la pregunta con que se respondía la cuestión social, la "raza" -un espíritu especial de razase presentaba para Cané como el elemento sobre el que se fundaría la posibilidad futura de cohesión política de la nación, una vez que el suelo hubiera asimilado y homogeneizado los elementos diversos. ${ }^{65}$

La intervención de los intelectuales encontraba su sentido con respecto a este problema. Así, el escrito se cerraba con la propuesta de un "remedio" para aquella enfermedad propia de las sociedades "nuevas y en formación" como la argentina, y consistía en la recuperación de la diferencia y de la calidad individual, a través de lo que Cané denominaba "la cultura moral del individuo" de la que se seguiría, desde arriba hacia abajo, "la cultura y la inteligencia de la masa"

El átomo caracteriza al cuerpo, y si el átomo es susceptible de perfeccionamiento, ahí está el remedio supremo. La esperanza y el honor de la raza humana, está[n] en la noción innata del deber; ese es el átomo que hay que cultivar y perfeccionar. Su desenvolvimiento sano y vigoroso dará vida a las virtudes necesarias para la armonía y el progreso social.

(...) cultivemos siempre la inteligencia: al resplandor de esas luces, es difícil errar el buen camino. (55) [cursivas nuestras]

${ }_{64}$ Ibid., p. 50. Cané resaltaba la semejanza entre los obreros y la barbarie: "Atila marchaba ciegamente sobre el mundo romano, como la piedra de una honda lanzada por una mano providencial" "Nuevos rumbos humanos" (49).

${ }^{65}$ Se interrogaba: ¿¿Propenderá con el tiempo algún espíritu especial de raza entre nosotros? ¿Los grandes e irresistibles medios de asimilación que posee el suelo americano, y en él el nuestro principalmente, concluirán por hacer del pueblo que habita la vasta región argentina, una sociedad homogénea, con caracteres étnicos propios?" (54) 
La respuesta de Cané, en la forma de discurso correctivo, ${ }^{66}$ se actualizaba en una concepción de la cultura de signo patriarcal y familiar, aquella que se proponía preservar y ejercitar en el cultivo de la inteligencia y de una moral individual por parte de la elite, ${ }^{67}$ basada en el deber, cuyos resultados "determinará[n] la cultura y la inteligencia de la masa" (Terán, 2000: 55). En ese movimiento que afirmaba como necesaria una direccionalidad típicamente conservadora ${ }^{68}$ reproducía y escenificaba aquel carácter elitista y aristocrático que Ángel Rama asigna a la labor intelectual en América, y cuyo auge teórico en la Europa de la segunda mitad del siglo XIX fue típico de las elites, ante los avances de la prédica revolucionaria y de la democracia como sistema social (Terán, 2000: 39). ${ }^{69}$ "Hijo del 80, demócrata liberal, en aquel tránsito crucial entre el siglo XIX y el XX”, Cané actualizó en su concepción de la cultura las abjuraciones y conversiones típicas de ese fin de siglo. ${ }^{70}$

\footnotetext{
${ }_{66}^{6}$ Terán define como "discursos complejos y correctivos", a aquellos producidos por quienes aunque apuestan al progreso, avizoran sus consecuencias negativas. Tales discursos "desearían cumplir el papel de la lanza mítica capaz de curar las heridas que ella misma produce" (Terán, 2000: 20).

${ }^{67}$ Terán sostiene que "Cané parece obsesionado por dos preguntas básicas: cómo definir la noción de aristocracia en un país republicano, y cómo marcar de ese modo el límite entre quienes tienen derecho a pertenecer a ella y aquellos otros ante quienes debe erigirse un muro de diferencias" (Terán, 2000: 39).

${ }^{68} \mathrm{Si}$ en "Nuevos rumbos humanos" se dirigía a la juventud, esta apelación también se observaba -y con un sentido similar- en un trabajo posterior de Cané "Sarmiento en París", aparecido en La Biblioteca en la entrega de diciembre de 1896. Allí llamaba a leer los Viajes de Sarmiento, texto y género en los que cifraba la cuestión nacional y su respuesta en clave estética, insistiendo en el ejercicio de una cultura individual: "Y vosotros, jóvenes, los que os quejáis dolientes de que no hay atmósfera intelectual en nuestro país, hacedla revivir, volviendo a las fuentes puras e incomparables del pasado. Leed esos libros admirables, escritos hace más de medio siglo y que, como los de los más grandes maestros conservan en sus líneas y en su color una frescura jamás igualada en el correr de los tiempos (...) Leed, leed esos libros, jóvenes, y veréis con qué orgullo sentiréis el alma de nuestra raza palpitar en sus páginas. Son libros genuinamente nuestros, que no han podido ser escritos en otra parte y que constituyen, hoy por hoy, la nota más clara y luminosa para ayudarnos a comprender la gestación caótica de nuestra nacionalidad. No os hablo de moral, no os hablo de patriotismo, no os hablo de que esa lectura pueda determinaros pequeños Sarmientos (...): os hablo de arte, os hablo de la única manera posible de resucitar entre nosotros esa atmósfera intelectual por la que lloráis" (158). Cursivas nuestras.

${ }^{69}$ Nuevamente la figura de referencia es Ernest Renan.

${ }^{70}$ Giusti, Roberto. "Miguel Cané. El escritor y el político", Comentario, Año III, n 11 , abriljunio, 1956, pp. 25-37. Giusti reconoce en Cané la "fe idealista en el valor de la cultura" como "uno de los rasgos permanentes de su espíritu (...) sus escritos abundan en sugestiones sobre los medios de estimular en la demasiado materialista factoría que era Buenos Aires, el arte, las letras, el teatro, la música, de la cual era un apasionado" (26)
} 
En la entrega de diciembre de 1896, se publicaba en La Biblioteca "El socialismo y el derecho civil" de Carlos Rodríguez Larreta. Este joven abogado de 28 años, procedía de una familia acomodada de clase alta, y era el hermano mayor del aún más joven Enrique Rodríguez Larreta. Según hacía constar Groussac en 'Redactores', había sido el mejor estudiante de su promoción, y su "tesis inaugural" Derechos hereditarios de la mujer casada había recibido la medalla de oro; se destacaba además, por sus colaboraciones políticas y especializadas en temas jurídicos y sociales. ${ }^{71} \mathrm{El}$ artículo publicado era la "lección" que su autor pronunciara como clausura del curso de Derecho Civil de la Facultad de Buenos Aires, del que era profesor suplente, y versaba sobre las consecuencias específicas del socialismo en la disciplina que era objeto de la cátedra. El trabajo de Larreta se distinguía del de Cané por sus condiciones de enunciación: ya no se trataba de las reflexiones personales de un sujeto adulto y sumamente prestigioso de la elite que se dirigía a la juventud previniéndola, sino precisamente de una clase, que como respuesta y en continuidad con "Nuevos rumbos humanos", dictaba uno de aquellos jóvenes y pares sociales a quienes había hablado Cané, ${ }^{72}$ pero que, a diferencia de él, intervenía desde la función docente de la institución estatal, instruyendo a otros, aún más jóvenes. ${ }^{73}$ Advertía sobre la necesidad de las universidades -a las que definía como instituciones "de índole conservadora"- de incorporar las nuevas teorías políticas, en función de una obligación de actualidad $\mathrm{y}$, sobre todo, porque estas cuestiones se vinculaban con el presente e involucraban el porvenir.

En un tono similar al de Cané y desde la defensa de una "ciencia" a la que definía como "tradicional", Rodríguez Larreta atacaba y polemizaba con las nuevas doctrinas que identificaba con el socialismo, enemigo por excelencia del Estado liberal. La revolución social omnipresente y temida por Cané, amenazaba también el derecho civil y las instituciones en que éste se fundaba. Larreta afirmaba la existencia probable de un

\footnotetext{
${ }^{71}$ Rodríguez Larreta fue más tarde canciller durante los gobiernos de Quintana (octubre de 1904 - marzo de 1906) y de Figueroa Alcorta (agosto - octubre de 1910). Además, fue miembro del Tribunal Permanente de Arbitraje de La Haya y de la comisión encargada de la cuestión de límites entre Bolivia y Perú, y convencional en 1898. Editó sus discursos en libro, en 1913.

${ }^{72}$ En 1896 Cané tiene 45 años y Carlos Rodríguez Larreta, 28.

${ }^{73}$ El trabajo está dividido en: "Consideraciones generales", "I. Las doctrinas socialistas y sus teóricos contemporáneos", "II. El socialismo y la propiedad", "III. El socialismo y la familia", "IV. El socialismo y la herencia", "Conclusiones". La Biblioteca, Año I, Tomo I, n 7, diciembre, 1896, pp. 559-583.
} 
vínculo negativo entre la reforma social y el positivismo, en el hecho "de que ambas tendencias están aliadas para demoler esta organización moderna que se ha levantado sobre las bases de la filosofía individualista y liberal" (263). Estas nuevas doctrinas representaban una amenaza a todos los pilares de la sociedad civil que el Estado modernizador argentino había construido y a través de los cuales se había organizado: fundamentalmente, la propiedad (y su calidad hereditaria) ${ }^{74}$ y la familia organizada legalmente en el matrimonio. ${ }^{75} \mathrm{Y}$ si en ello coincidía con Cané, agregaba, en un gesto que lo distinguía de aquél, aunque no lo separaba:

la experiencia de la historia nos enseña que algo debe haber de verdadero y de justo en el fondo de una aspiración [así define al socialismo] que tiene en sí misma la fuerza bastante para marchar contra la corriente de las persecuciones, que apasiona a los hombres hasta el delirio, que ha suscitado fanatismos y ya cuenta mártires $(583)$.

Si Cané proponía no reformar la constitución y avanzar al ritmo lento y necesario de la evolución, Larreta concebía la posibilidad de "rectificar el límite entre libertad y poder, y trazarlo por donde van la misericordia y la solidaridad humanas", sin por eso dejar de augurar el triunfo seguro de las "instituciones seculares del derecho privado" por sobre las "impetuosas" y "violentas" "agitaciones socialistas", 76

${ }_{74}$ "Qué podría, en efecto, subsistir de toda la armazón presente en las relaciones de familia si, en vez de ser el matrimonio la base ineludible, viviesen los hombres y las mujeres en una promiscuidad confusa? ¿Qué quedaría de la patria-potestad y de la tutela, si los padres hubieran de entregar sus hijos al Estado? Sin el dominio perpetuo y exclusivo qué sería de los contratos, ni cuál derecho sobreviviría a la propiedad, que es la madre de todos los derechos? $\mathrm{Y}$ sobre qué fundamento, en fin, se podría entonces apoyar un sistema hereditario?" (561).

${ }^{75}$ Eduardo Zimmermann afirma que la cuestión social planteó nuevos problemas en el ámbito del derecho no solo criminal. Así, en derecho civil, por ejemplo, "temas como la responsabilidad de los empleadores por los accidentes de trabajo, o la sustitución de la noción tradicional del contrato por mecanismos de negociación colectiva, promovieron un activo debate sobre la forma en que las instituciones jurídicas debían adaptarse a los nuevos fenómenos sociales". (91) Entre los testimonios de dicha situación cita "El socialismo y el derecho civil". Consigna, además, que entre 1898 y 1916 se presentaron más de ochenta tesis doctorales sobre temas vinculados con la cuestión social -sin contar las que trataban sobre inmigración. Cf. Zimmermann, 1994: 83-100.

${ }^{76}$ Sostiene "Sobre ellas [las instituciones del derecho privado] se romperán, por más impetuosas y violentas que sean, las agitaciones socialistas, como se quiebran, cuando las levanta la tempestad, las olas del mar en las rocas eternas". p. 583. Como se ve, Larreta retoma el repertorio de imágenes usadas por Cané para caracterizar los movimientos 
Desde la perspectiva de nuestro trabajo la importancia de las colaboraciones de Cané y de Rodríguez Larreta radica en que ambas pueden ser leídas como ocasiones para la intervención de corte intelectual, aunque no tengan el mismo grado de relevancia. En el caso de Cané, se trataba de una solución cultural para el problema social, en la que sus posicionamientos ideológicos implicaban una concepción de la cultura que determinaba el modo de pensar las relaciones entre dicha esfera y el cambio social, entre cultura y nacionalidad, asignando a la cultura una función determinante. Por su parte Rodríguez Larreta, anclado en el universo disciplinar del derecho civil, coincidía con Cané en el diagnóstico, pero el análisis daba cuenta de las consecuencias de los cambios en su campo específico de enunciación disciplinar y lo conducía a proponer una estrategia de negociación con tales cambios.

\subsection{Las condenas selectivas de Groussac}

Groussac escribió en su revista un conjunto de artículos que, como ya observamos, no podían ser leídos sino en relación con otros por la problemática que abordaban, y también, fundamentalmente por el tipo de intervención intelectual que constituían. El análisis de "Génesis del héroe" ( $\mathrm{n}^{\circ}$ 8), "El Centenario" ( $\mathrm{n}^{\circ}$ 15), "La educación por el folletín" ( $\left.n^{\circ} 18\right)$ y "Alphonse Daudet" ( $\left.n^{\circ} 19\right)$ ponía en evidencia evaluaciones de carácter divergente frente a la modernización por parte de su autor. Lo importante de estas intervenciones, que en este y otros sentidos eran equiparables a la de Cané, se vinculaba con el hecho de ser ellas mismas soluciones culturales a conflictos que no tenían un origen específicamente cultural pero cuyos efectos eran perceptibles no solo en el terreno amplio de lo social sino también dentro del dominio más acotado de la producción y el consumo culturales. De ese modo, hacía de sus intervenciones un modo de participación propio. La contrastación de las perspectivas expuestas en dichos trabajos indicaba el carácter selectivo, y no ambiguo del director de

sociales como fenómenos naturales (relativos al mar) violentos. 
La Biblioteca en relación con aspectos determinados de aquel proceso, ${ }^{77}$ mientras iba mostrando un tipo de ejercicio de la función intelectual, a la vez que relacionaba sus preocupaciones políticas con la formulación de una concepción más o menos explícita de los vínculos entre cultura y política, acuñados en la relación particular de los intelectuales con el poder.

"El Centenario" subrayaba un costado favorable del progreso en el diseño imaginario de una alianza deseable de los intelectuales con el Estado, y preanunciaba el año de 1910 como su momento histórico más eficaz. Contrariamente, el examen de "La educación por el folletín", algunas zonas de "Génesis del héroe" y de "Alphonse Daudet", organizaban una visión condenatoria de la modernización, particularmente de las formas mercantiles de la cultura democratizada, a las que se reconocía como instrumentos poderosos de una dudosa "pedagogía" moral y estética.

"El Centenario" se distinguía de los artículos de Cané, Rodríguez Larreta y de los restantes del autor, por tratarse de un texto que se proponía como ficcional. En este "juguete" -así se lo definía- ${ }^{78}$ Groussac imaginaba los festejos del Centenario de la revolución de $1810 .^{79}$ El recurso a lo fantástico era doblemente útil: por un lado, le servía para inscribir su relato dentro de un repertorio ocultista / esoterista, en el marco del cual construía un narrador que anticipaba el tipo de narrador que, más tarde, por ejemplo, diseñaría Lugones en los tres primeros relatos de sus Cuentos fatales ("El vaso de alabastro", “ Los ojos de la reina" y "El puñal"); por otro lado, dicho recurso permitía proponer y representar -aunque de manera ambigua- la posibilidad de un futuro, que contaminado de la clave narrativa, y como realización de los ideales del

7 Transcribimos las referencias completas de los artículos y en adelante consignamos solamente números de página. "Génesis del héroe", Año II, Tomo III, n 8, enero, 1897, pp. 137-151; "El Centenario" Año II, Tomo V, no 15, agosto, 1897, pp. 287-305; "La educación por el folletín", Año II, Tomo VI, n 18, noviembre, 1897, pp. 312-324; "Alphonse Daudet", Año II, Tomo VI, diciembre, 1897, pp. 428-453.

${ }^{78}$ En nota al pie, decía Groussac: "En lugar de este juguete debía aparecer hoy la continuación de Santiago de Liniers. Me obliga a diferir su publicación la doble circunstancia de tener que esperar la llegada de varios documentos esenciales pedidos a Europa y no haber podido realizar aún un viaje indispensable a varios puntos de la provincia de Córdoba, donde el exvirrey pasó el último año de su vida. Pido disculpa a mis lectores, si es necesario pedirla por una demora que tiene su causa en mi escrupulosa preocupación de la exactitud histórica" (287). Es interesante señalar la diferencia sugerida entre las lógicas diversas de la literatura y la historia.

${ }^{79}$ Vale la pena recordar que para Groussac 1810 era el punto desde el cual construía la historia argentina y era el comienzo -luego interrumpido- de la Argentina civilizada e ilustrada, cuya figura central encarnaba Mariano Moreno. 
progreso, se presentaba como visión fantástica. El narrador y protagonista, Paul Groussac, relataba un "singular experimento" que había tenido lugar en el domicilio del sabio Blagowicz, ubicado en un barrio "entonces muy frecuentado por psiquiatras lombrosianos, neurópatas y demás gente de incierta atornilladura" (290), ${ }^{80}$ cuyo objetivo era comprobar lo que de cierto había en el fenómeno de previsión hipnótica que Blagowicz sostenía. Al principio descreído y burlón en cuanto a la posibilidad de la sugestión mental, había accedido luego a la visión del futuro -después de beber un elixir que sabía a chartreuse, y de aspirar de la boquilla de un narguilé, a instancias del profesor Blagowicz. La voz del narrador era la del escritor que profetizaba la utopía nacional del futuro, y en su relato desfilaban todos los tópicos urbanos modernos. Buenos Aires encarnaba su realización y en ella tenían lugar conjuntamente la Exposición universal de 1910 y las fiestas del Centenario de la Revolución de mayo. ${ }^{81}$ La ciudad, como sinécdoque de la nación, era el escenario en el que se habían concretado armoniosamente los ideales del progreso. Transformada de una extensión “casi desierta salpicada de quintas y casitas perdidas entre los árboles", Buenos Aires se había expandido hacia el oeste y hacia el norte, ${ }^{82}$ estaba plagada de "bulliciosos ${ }^{80}$ Groussac también llama al lugar antro de Trofonio, en referencia a uno de los arquitectos del templo de Delfos, y en alusión al valor predictivo de la visión que posteriormente narra.

${ }_{81}$ Es importante señalar el valor que tienen las exposiciones industriales, universales, nacionales, americanas, desde una perspectiva que pone el acento en la construcción de la nacionalidad. En ese sentido, Laura Malosetti observa que tanto en los países europeos como americanos estas "grandes ferias" se multiplicaron durante toda la segunda mitad del siglo XIX y hasta inmediatamente antes de la Primera Guerra mundial (117). Sostiene que para "las naciones industriales como Inglaterra y los Estados Unidos, significó la construcción de 'universos simbólicos' que articulaban las ideas de raza, nacionalidad y progreso de los sectores burgueses: fueron escenificaciones de las relaciones hegemónicas de poder, microcosmos celebratorios en los que cada visitante podía encontrar la explicación y el sentido de su lugar en el mundo" (117). Cf. Malosetti 2001: 115-157. En este escrito Groussac, además de situar la acción durante los festejos del Centenario, establecía semejanzas entre Buenos Aires y la ciudad de Chicago, a cuya exposición universal había asistido en 1893 y sobre la cual había escrito. De ese modo, ubicaba y consideraba a la Argentina como una nación en el concierto de las naciones civilizadas.

${ }^{82}$ Groussac describía: "Es la vasta plaza de una ciudad populosa y activa, con soberbios edificios por todos lados; se abren delante de mí, hacia el oeste, norte y sud, tres anchas avenidas divergentes, cuajadas de transeúntes, cruzadas por alambres, ferrocarriles elevados, coches, automóviles... todo ello nuevo para mí" (295), y más adelante: "la ciudad enorme, con su millón y medio de habitantes, ha invadido y absorbido el oeste hasta Flores, el norte hasta Belgrano: el antiguo parque es hoy el gran paseo urbano de Palermo, los campos Elíseos de Buenos Aires, - y es allí, en el histórico sitio de Rosas, de quien quizá conserven todavía memoria algunos octogenarios, donde se levanta el palacio central de la Exposición" p. 297. Como se veía, la civilización había derrotado a la barbarie, encarnada en Rosas, de quien solo algunos viejos se acordaban. Unas páginas después Groussac mencionaba otros avances tecnológicos con los que se sentía fascinado: "la invisible energía eléctrica, por doquiera 
hoteles y tiendas brillantes", fábricas, maquinarias, y aparecía convertida en sitio de la multitud, "colmena ciclópea", que "trae encontrados y vagos recuerdos de Chicago y de París". Decía el narrador:

Estoy en él [el palacio central de la exposición universal de 1910, en la que se acumulan lo mejor del arte y todos los avances científico-técnicos], sacudido $\mathrm{y}$ traqueado, entre la muchedumbre como una astilla en el océano, un hormigueo de quinientos mil cuerpos de todos aspectos y nacionalidades que ruedan lentamente por calles y plazoletas, entran y salen, se estrechan en los pintorescos pabellones de los cien pueblos del orbe.

Encima del entrelazamiento de las banderas y arcos de triunfo multicolores se alza un gigantesco Adamastor sobre las ondas, el faro metálico de doscientos metros, con sus seis pisos de balcones y sus enormes focos eléctricos que alcanzan a iluminar de noche la gigantesca estatua de América en la isla Martín García... (297)

Ese futuro mostraba una Argentina unificada, en paz, formando parte de la comunidad mundial de los "cien pueblos del orbe" (297). Las multitudes se presentaban como un grupo anónimo y homogéneo que no se ofrecía a los ojos del "visionario" como un peligro, sino que se desplazaban por la ciudad como por un espacio que les era propio; de estas multitudes, se separaría y distinguiría el narrador, puesto que aunque compartiera la ciudad como espacio físico no se igualaba socialmente con ellas.

El palco oficial, en que se situaba el narrador como uno de los notables, remitía a la ubicación imaginaria que Groussac se autoasignaba y deseaba en el ámbito público, y desde donde contemplaba los resultados de la tarea civilizatoria conjunta. ${ }^{83}$ Desde allí escuchaba el repaso de la historia argentina a cargo del presidente:

esparcida, llega por esos finísimos alambres que cruzan el espacio y la traen de las cataratas del lejano Iguazú, o bien se levanta de los caños metálicos hundidos en el suelo y que van a captar a millares de metros de la superficie la fuerza transformada del calor central. los trenes y vehículos siguen derramando el gentío por las bullentes avenidas; cruzan la atmósfera naves extrañas cargadas de pasajeros, aves monstruosas, cometas y aeroplanos que describen curvas sinuosas hasta rasar el suelo y detenerse un momento para volver a subir..." (298).

${ }^{83} \mathrm{En}$ la frase directamente anterior con la que comenzaba el párrafo que transcribimos, decía Groussac: "Sin saber cómo ni sorprenderme por ello, está mi deseo realizado" (298). 
me encuentro en el estrado oficial cerca del grupo de magnates, ministros, generales, diplomáticos, congresales, funcionarios $(\ldots)$

Pero el Presidente ha dado principio a su solemne discurso inaugural: con voz sonora y grandioso ademán evoca ante las gentes las glorias y zozobras del siglo transcurrido: todas las victorias $\mathrm{y}$ retrocesos luctuosos de la sangrienta y luminosa historia, todos los mojones erigidos en las etapas decenales de esa jornada secular, que alboreó en el pobre cabildo de 1810 y termina hoy, a la luz de este mismo sol de mayo, a la vista de ocho millones de argentinos, en presencia de los delegados del mundo civilizado (299)

La ubicación de Groussac en el estrado escenificaba y hacía explícita la alianza entre intelectuales y Estado en la tarea de construcción de la nación, la cual había comenzado en Mayo de 1810 y alcanzaba su punto culminante cien años más tarde. En esta escena se reforzaba la convicción del director de la revista sobre la importancia y utilidad de los intelectuales con respecto al Estado y se ponía en el punto más alto de visibilidad aquella alianza beneficiosa y necesaria entre ambos, que era la misma que ya había enunciado Groussac en el artículo de apertura de La Biblioteca, y que refrendaría en ocasión del cierre. El logro mayor de ese vínculo se hallaba no solo en el reconocimiento que el mundo prodigaba a una nación civilizada sino también en la participación misma de los intelectuales en una modernización eficaz. Asimismo, el hecho de que el narrador ocupara esa posición en el palco y que hubiera llegado hasta allí en un automóvil cubierto de banderas, hacía pensar que seguía siendo, aún en 1910, un intelectual-funcionario; y si bien la escena podía implicar el reconocimiento anhelado de su labor como director de la Biblioteca, la visión futura estaba impregnada de su propia y heterónoma condición intelectual en 1897.

En el final del escrito la certeza de la visión era puesta en duda por la forma en que se había accedido a ella. La ambigüedad se restauraba y era así como había comenzado el escrito de Groussac: "Ni aun después del singular experimento que voy a referir, me atrevo a calificar crudamente al célebre doctor Blagowicz (de la universidad de Cracovia) de taumaturgo vulgar o diestrísimo embaucador" (287). El epígrafe de Byron reforzaba ese sentido, pero al mismo tiempo marcaba el valor profético de las 
palabras del intelectual que las pronunciaba: "I had a dream, which was not all a dream" (287.)

Si en "El centenario" Groussac desplegaba una utopía positiva del futuro de la nación, en función de los logros del progreso, las evaluaciones que se enunciaban en ciertos pasajes de "La educación por el folletín" y de "Génesis del héroe" podían pensarse como su contracara. Mientras en aquella ficción esotérica las multitudes eran vistas como las masas anónimas que transitaban cómodamente la ciudad, y cuya presencia en la urbe no se identificaba con el conflicto social ya que seguía vigente su diferenciación de la elite en la distancia (en la altura) que la separaba de los miembros selectos del palco, en "Génesis del héroe" eran objeto de sus ataques indirectos a través de la crítica a la democracia como "estructura social". ${ }^{84}$ La prensa periódica, representada por diarios, semanarios y revistas de periodicidad e información diversa, hacia la que mayoritariamente se inclinaba el grueso de los lectores producto de las campañas de alfabetización, constituía, a juicio de Groussac, el medio principal y la puesta en escena democratizadora en el terreno del conocimiento, y aparecía, a sus ojos, como un peligro 'intelectual': ${ }^{85}$

La democracia conquistará la alta civilización, como los Hunos el mundo latino: teste David cum Sibylla. Posee el sufragio universal que es su fórmula, la

\footnotetext{
${ }^{84}$ Precisaba Groussac en la nota al pie de la página 139: "Claro está que aquí se trata de una estructura social, no de una forma política". Aquí, coincide con la línea trazada por Cané entre las consideraciones de Tocqueville y de Renan.

${ }^{85}$ Las diatribas respecto de la prensa periódica desde el ámbito de la alta cultura letrada constituyen un fenómeno relativamente común. Nos interesa señalar la coincidencia de las opiniones de Groussac y Joaquín V. González en esta cuestión. Dice González: "Nada más apropiado a la época presente que el periódico, ese libro diario donde se escribe cada palpitación del sentimiento público bajo todos sus aspectos. En el vértigo de la vida comercial, y cuando todos corremos a tomar nuestro puesto de labor, apenas si tenemos tiempo necesario para la lectura, la que, por otra parte, no puede, en manera alguna ser profunda ni seria. Y el diario con su lenguaje insinuante y apasionado, ocupándose de las cuestiones del momento, sintetizando el movimiento del espíritu humano en pocas líneas, satisface la escasa necesidad de las inteligencias, nos suministra las noticias que han de marcar el rumbo de nuestros negocios, y nuestras vidas" y luego: "La prensa es un monstruo que devora en un día enormes cantidades de ideas, que luego arroja revestidas de formas multicolores al seno de la sociedad". Tomo estos datos del escrito de González publicado en la antología de Jorge. B. Rivera, 1993: 67-73. Estas diatribas estuvieron también presentes en los escritores modernistas. En su caso, Rubén Darío se refirió en "La joven literatura" a "la tiranía de la información" con la que tenían que lidiar los escritores que trabajaban como periodistas. Cf. España contemporánea (1901) que reúne los escritos de Darío como corresponsal del diario La Nación en Madrid, entre fines de 1898 y 1900.
} 
instrucción gratuita y obligatoria que es su molde, la prensa que es su órgano. Su triunfo es inevitable. Será el más completo y pesado de los despotismos: el despotismo de la mediocridad. La forma de su instrumento omnipotente tiene todo la belleza de un símbolo: es un laminador, la máquina que aplasta para mejor informar, y realiza el ideal de la igualdad por el perfecto achatamiento. De esos cilindros de acero se escapa en hojas sueltas, toma su vuelo a las aceras polvorientas o fangosas, la biblia de los nuevos tiempos que nadie se ocupará de encuadernar" ${ }^{86}$ (139)

En su evaluación Groussac identificaba la democracia con el triunfo de la barbarie y señalaba los peligros de la igualación social como igualación cultural, cuyo efecto inmediato no era la elevación estética o moral, sino la mediocridad. Groussac consideraba esta igualación como una falacia producto de una guerra, en la que la alta cultura era decapitada por la desjerarquización que difundía, promovía y multiplicaba la prensa periódica, leída masivamente por quienes vivían en el fango. Frente a una cultura cuyos consumo y prácticas se modificaban, en este caso por efecto de las incorporaciones tecnológicas de la prensa, tales modificaciones eran experimentadas como embates certeros a la hegemonía cultural de los intelectuales de la elite. Dichos embates se materializaban en un modo de producción, que introducía nuevas variedades genéricas en la escritura como el despacho, la interview telegráfica o el reportage, y en una forma de circulación de los bienes culturales que, desde la mirada alarmista de Groussac, no solo alteraba la relación de los productores con sus escritos y con el conocimiento que en éstos podía construirse y transmitirse, sino también el lugar dominante de los intelectuales de la elite ya que la prensa plasmaba el acceso a la escritura de un número

${ }^{86} Y$ continuaba: "es la curiosidad instantánea, superficial, inconsistente, que alumbra con humo y llena con oquedad; la actividad en el vacío; la información pasiva sin el esfuerzo de la investigación; el sucedáneo actual de la sabiduría; la moneda falsa de la verdad esterlina; el asignado que dice: valgo, y no tiene valor; el derecho a no meditar; la coartada de este delito: pensar por cuenta propia! -Santa Teresa, no Malenbranche, llamaba a la imaginación: la loca de la casa. Esa loca ya no está en casa: está en la calle, en el paseo, en la bolsa, en el tranvía, engullendo su escudilla de rancho 'igualitario', su ración de sopa boba intelectual. ¡Salud al gran educador de la democracia! Su Majestad el Diario, -en latín, Ephemeris. Nace, circula y muere en un mismo día; lo recogen a la tarde las barrederas mecánicas, en una nube de polvo que simboliza la mentira, la ignorancia, la fatuidad. Pero renacerá de sus barreduras, a manera del fénix aquél. Es infatigable, inacabable, innumerable, como el microbio" (139). 
cada vez más amplio de sujetos. La imagen de la conquista del mundo latino a manos de los Hunos, a partir de cuyo uso Groussac anclaba su pensamiento en el denominado "latinismo finisecular", ${ }^{87}$ señalaba además la imbricación entre cultura y política. El discurso pronunciado por Groussac el 2 de mayo de 1898, con motivo de la intervención a la isla de Cuba por Estados Unidos, publicado en la última entrega de La Biblioteca junto con el de Roque Sáenz Peña, se organizaba también en base a la defensa de la “civilización latina”, y en él se reiteraban con énfasis el ataque al igualitarismo encarnado ahora en el "yankismo democrático, ateo de todo ideal", considerado, en ese contexto de enunciación, un enemigo más temible que el de las hordas bárbaras. ${ }^{88}$

Por otra parte, había en la cita un dato relevante en relación con uno de los objetivos centrales de La Biblioteca, el de crear un público distinto de aquel consumidor de diarios y revistas, un público especializado en los productos de la alta cultura. Los lectores de la revista se recortarían como los de la cultura impresa en libro, y no aquello que "nadie se ocupará de encuadernar". Se hacía explícita entonces, una diferenciación necesaria entre circuitos culturales que para Groussac debían permanecer bien separados y distinguibles. Cabe aclarar que "Génesis del héroe" era un fragmento de El problema del genio en la ciencia y en la historia, obra que Groussac preparaba por ese tiempo. En

${ }^{87}$ Carlos Jáuregui define el panlatinismo como un discurso cuya posición "en la segunda mitad del siglo [XIX] estaba ligado a los intereses de la política exterior francesa que quería colocarse al frente de los países latinos y hacer contrapeso a las 'naciones anglosajonas'. Desde la década de 1850 esa idea tuvo defensores como Michel Chevalier (1806-1879) y Ernest Renan (1823-1892) que habían impulsado un modelo geoideológico que legitimaba la expansión económica de Francia y su patronazgo cultural. En Suramérica la idea resurge a partir de la década 1880 y es usada por los modernistas contra los Estados Unidos (Phelan 5-21)". Cf. "Calibán ícono del 98. A propósito de un artículo de Rubén Darío" [edición digital, p. 8, nota 15.], que lleva la siguiente nota de su autor: "Este artículo 'Calibán: ícono del 98. A propósito de un artículo de Rubén Darío' y "El triunfo de Calibán" de Rubén Darío (Edición y notas) fueron publicados en Balance de un siglo (1898-1998). Número Especial, Coordinación de Aníbal González. Revista Iberoamericana 184-185 (1998)" (9); véase Colombi 2004a, 95-104.

${ }^{88}$ Los discursos fueron publicados bajo el título "Por España. Discursos pronunciados en el teatro Victoria el 2 de mayo de 1898, pp. 213-240. Incluye los discursos de Roque Sáenz Peña y de Paul Groussac con motivo de la intervención de EE.UU en Cuba", Año II, Tomo VIII, abrilmayo, 1898, pp. 213-240. En su condena de la intervención, Groussac reiteraba sus invectivas contra la cultura de origen democrático, sin tradiciones, ni ideales: "Esta civilización, embrionaria e incompleta en su deformidad, quiere sustituir la razón con la fuerza, la aspiración generosa con la satisfacción egoísta, la calidad con la cantidad, el sentimiento de lo bello y de lo bueno con la sensación del lujo plebeyo, el derecho y la justicia con la legislación ocasional de sus asambleas; confunde el progreso histórico con su desarrollo material; cree que la democracia consiste en la igualdad de todos por la común vulgaridad, y aplica a su modo el principio darwinista de la selección, eliminando de su seno las aristocracias de la moralidad y del talento" p. 237. 
ella polemizaba con las teorías de los alienistas y lombrosianos ${ }^{89}$ sobre el problema del genio, "vasta cuestión de psicología histórica" a la que Groussac había intentado “aplicar” el método científico, cuyo modelo decía encontrar, en este caso, en los Principios de geología de Sir Charles Lyell. En ese sentido el contexto de enunciación de sus críticas a la democracia era el de la formulación de una teoría de la diferencia cultural como diferencia absoluta, en tanto el genio se definía como "un poder aislado y exclusivo", "dotado de extraordinaria energía" y "voluntad" "cuyas manifestaciones e impulsos casi instintivos se apartan singularmente de los del talento habitual". ${ }^{90}$ De este modo, el interés por el problema del genio y su desarrollo teórico, a la vez que planteaba la cuestión del método en la disciplina histórica, ${ }^{91}$ se presentaba como otra forma de expresar el disgusto hacia la homogeneización democrática o igualitaria, cuyo carácter ideológico se difuminaba en la pretensión científica.

La crítica ha señalado la semejanza de la matriz teórico-ideológica entre los planteamientos de Cané y Groussac en relación con las prevenciones de ambos con respecto al igualitarismo (Terán, 2000: 24 y ss). En la entrega de diciembre de 1897, Groussac publicó una colaboración sobre Alphonse Daudet, recientemente fallecido, en la que se explicitaban las referencias intelectuales comunes. Tal como lo había hecho Cané en "Nuevos rumbos humanos", Groussac, en un relato de carácter autobiográfico (“impresiones"), exponía una crisis personal, ${ }^{92}$ marcada intelectualmente por las muertes de Renan y Taine, ${ }^{93}$ y en medio de la cual retomaba aspectos de su militancia

\footnotetext{
${ }^{89}$ La obra de Lombroso a la que se refiere es L'Uomo di genio.

${ }^{90}$ En "Génesis del héroe" Groussac distinguía al genio de los grandes hombres. Mientras que el genio legaba a sus contemporáneos y a la posteridad una obra "inmutable e imperecedera", que era la que lo hace glorioso, los grandes hombres "personificación[es] histórica[s], humana[s] o nacional[es]" (141), cuya grandeza derivaba "de la opinión colectiva de las generaciones" (143). Aquí Groussac recurría a "Heroes and Hero-worship" en la que Carlyle sostenía que la historia universal era la historia de los grandes hombres que habían obrado en ella. De 1843 es Pasado y presente, en la cual el autor escocés expresaba sus temores y su aversión por la democracia.

91 En ese sentido, Groussac afirmaba: "La dificultad, lo repito, para el historiador" está "en extraer de una leyenda heroica la parte de realidad que contenga, y depurar el núcleo de historia de la ganga de ficción en que se envuelve" (149)

${ }_{92}$ Explicaba: "Había perdido la fe; sentíame muy viejo para criar nuevos entusiasmos, muy escéptico para recalentar los antiguos que se apagaron ya." (430). "Alphonse Daudet", Año II, Tomo VI, diciembre, 1897, pp. 428-453.

${ }_{93}$ Afirmaba: "Me encontraba con que Renan y Taine habían desaparecido: un año antes [1892] el primero; el segundo, en los días de mi cabotaje en el Pacífico [1893], -y es muy cierto que esta noticia me enlutó el alma como un último duelo de familia, mostrándome al pronto [sic] tan 
antiigualitaria. Así, extendía y preveía la amenaza de igualación al terreno del juicio estético y, afirmaba, para los asuntos de arte, la rección de un criterio organizado jerárquicamente y por lo tanto, basado en la calidad, no en el número: "es cantidad despreciable, estéticamente hablando, el voto de la mayoría democrática o cosmopolita" (448). ${ }^{94}$ El artículo se refería a las que, según un punto de vista, podían considerarse situaciones típicas de la condición del escritor moderno en Francia, -incluso de los consagrados- en una sociedad en que las masas ocupaban un lugar cada vez mayor, a saber: la sujeción a las exigencias de la producción vertiginosa del diario, y la dependencia del Estado, denominada por Groussac como "parasitismo burocrático" (431). Si bien no constituían el problema central de este escrito, las críticas a la prensa volvían a aparecer y apuntaban a los perjuicios que provocaban en la práctica literaria, encarnados en el que definía como "periodismo maquinal", y al que concebía como la negación de una cultura y de un conocimiento profundos y duraderos. Aquí también, el saber no podía alojarse en otro soporte que no fuera el libro o la revista especializada. ${ }^{95}$

Si como señalamos, la diferenciación entre circuitos culturales era requisito sine qua non para la conservación impoluta del espacio de la alta cultura letrada, el diario $L a$ Nación había transgredido ese límite al publicar en sus páginas un folletín naturalista. La ira de Groussac en "La educación por el folletín" encontraba su motivo precisamente en el hecho del entrecruzamiento de aquellos dos circuitos culturales, y más específicamente, en que fuera un diario como La Nación que funcionaba, entre otras cosas, como el espacio de reconocimiento público de la 'aristocracia intelectual', el que

despoblada la patria del espíritu, que súbitamente miré casi con indiferencia la perspectiva de mi vuelta a Europa. Esta impresión sobrevivió a todos los incidentes ulteriores; y cuando más tarde llegué a París, sentíme tan extraño y desterrado como en ese Nuevo Mundo que acababa de recorrer [se trata del viaje de 1893 cuyo resultado es Del Plata al Niágara] "Alphonse Daudet", pp. 431-432.

${ }^{94}$ Estas mismas ideas estaban presentes en Cané en las citas de Tocqueville.

${ }_{95}$ Sostiene que los escritores entregados a tal práctica "cubren sendas columnas de papel con palabreo pululante y efímero que representa las colonias de bacterias del pensamiento" (431). Esta identificación de los productos culturales de la elite con el formato libro se observaba, por citar un ejemplo entre otros, en las apreciaciones de Groussac sobre La gran aldea de Lucio V. López, obra que había aparecido como folletín en el diario SudAmérica: "allí [en el diario Sud-América] publicó La gran aldea, que tuvo en volumen [cursivas nuestras] mucho éxito de lectura, si bien fue diversamente apreciada", Groussac, Paul. "Lucio Vicente López", "Redactores", La Biblioteca, Año III, Tomo VIII, abril, 1898, pp. 264-265. 
generara el contacto. El escrito era relevante porque, a diferencia de los anteriores, ponía en el centro la función política de la literatura y de la cultura.

La escena con que se abría el artículo mostraba doblemente el cruce de espacios culturales. Contaba Groussac que algunos días atrás, en hall suntuoso de la casa de un amigo suyo "uno de los más distinguidos clubmen de Buenos Aires", su llegada había interrumpido a la esposa de este caballero, quien leía el diario La Nación. En la tercera página en la que había quedado abierto el periódico aparecía un aviso de la revista $L a$ Biblioteca y junto a él, el toque "vergonzante", otro aviso de cerveza Bitter Gaillard (primer cruce). En la parte inferior del diario se publicaba un folletín de Zola, con el que a juicio de Groussac, en función del carácter pornográfico del contenido, la señora de su amigo "se intoxicaba" (segundo cruce). Groussac acusaba al diario de Mitre de comportamiento perturbador e improcedente. Al publicar ese material, La Nación se colocaba al mismo nivel que la peor prensa francesa -como el Journal parisiense- , y consecuentemente, se mostraba inescrupuloso en un pacto con el mercado que para Groussac también resultaba impropio, y sobre todo, injusto para la calificada clientela de la que formaban parte sujetos como él. Adolfo Prieto ha analizado el caso de la prensa periódica alrededor del 900 y sostiene que en tanto su crecimiento explosivo "incorporó como variante propia el registro de todos los consumidores regulares de la alta cultura letrada, anteriores o coetáneos, pero no familiares con las prácticas masivas de alfabetización", constituyó un "novedoso espacio de lectura potencialmente compartible" en el que se hacía presente una "tendencia a la nivelación de los códigos expresivos con que concurrían los distintos segmentos de la articulación social" (Prieto, 1988: 14). La cita que transcribimos a continuación mostraba el signo negativo de la potencialidad de ese espacio en el cual para Groussac se producía el efecto contaminante:

Con razón o sin ella, es muy otra aquí la función o la figuración de la prensa. Desde luego, casi no existe diferencia social entre sus principales órganos; si es cierto que el más difundido de todos prospera industrialmente merced a la masa popular, ello no importa decir que falte la otra clientela: agrega a la propia la de todos los demás. Y, sin duda, obedeciendo al menos confesable de los móviles, es como, de algún tiempo a esta parte, el antes más 
solemne y almidonado de los diarios bonaerenses viene corriendo tras la popularidad de mala ley que, por tales medios al menos, esperamos no alcanzará. ${ }^{96}$

Esas líneas enunciaban además el sentimiento de propiedad del espacio del diario por el que esa "clientela propia" se distinguía de "los demás" y remarcaba los efectos de la industrialización en la esfera de la cultura. Señalaba también una identificación entre circuitos culturales y pactos deseables. Así -parecía sugerir-, a la alta cultura de la clientela propia de La Nación le correspondía asociarse a propósitos civilizatorios que se atribuían a la vez a una clase y al Estado, mientras que el circuito popular se distinguía por su casi excluyente condición mercantil. Como se ve en el símil policial de las elecciones retóricas de la cita, lo decisivo residía en que la prensa culta no reemplazase propósitos o ideales por "móviles" poco "confesable[s]".

Por otra parte, Groussac consideraba al diario como un espacio aprovechable no sólo para la educación "estética" sino también como instrumento de pedagogía moral, y por el cual, como explicaba la cita anterior, la prensa argentina tenía una "figuración muy distinta" de la francesa. En ese sentido se leían sus preocupaciones por la circulación libre “en nuestras casas, como 'triunfo periodístico' de La Nación [que]: es un manual completo de corrupción y significa un verdadero ultraje al pudor doméstico" (316). Resultaba así escandaloso que una de las damas de "nuestras familias" pudiera tomar como modelo moral esa literatura inconveniente que publicaba La Nación por razones económicas. Asimismo, estos juicios debían enmarcarse en la denuncia de Groussac como crítico especializado de la estética naturalista: "una escuela que ya no tiene discípulos, y que por no saber renovar su fórmula invariable y tediosa, recurre, para alcanzar un éxito a cualquier ley, a la exageración creciente de sus viejos procedimientos" $(316){ }^{97}$

Por último, debemos mencionar que en la revista se publicaron igualmente otras colaboraciones del director bajo el título "Marinas y paisajes americanos" ${ }^{98}$ Se trataba de "simples sensaciones del trayecto, apuntes de cartera, sin plan ni compostura", ${ }^{99}$ producto

96 "La educación por el folletín", Año II, Tomo VI, noviembre, 1897, p. 315.

${ }^{7}$ Más adelante nos referiremos a la cuestión de lo estrictamente estético.

${ }^{98}$ Cf. nota 49 en el parágrafo 2.1 .

99 "Marinas y paisajes americanos. De Valparaíso a Lima", Año I, Tomo II, octubre, 1896, p. 233. 
del viaje que Groussac realizara entre marzo de 1893 y enero de 1894 por Santiago de Chile, la costa del Pacífico, Lima, Colón, Belice, California, Utah, Chicago (en la que se celebra la Exposición Internacional) y las cataratas del Niágara. En ellas estaban presentes las críticas a la democracia pero también, y en menor medida, la fascinación que provocaban en Groussac los paisajes en que eran visibles huellas humanas como el túnel de Chiquihuite, al que calificaba de "prodigio realizado". ${ }^{100}$ La entrega dedicada a California conjugaba ambos elementos, describiendo a las ciudades norteamericanas como copias vaciadas en un solo molde, regidas por la ley del número, y exponiendo un deslumbramiento innegable ante lo que denominó la "potencia plástica" de la civilización americana. $^{101}$

\subsection{Políticos, literatos, poetas, escritores-periodistas.}

La crítica ha dado cuenta de la relación existente entre el tipo de figuras o imágenes construidas en el interior del campo intelectual y sus contextos históricos y culturales. Dicha relación, que desde la perspectiva metodológica implicada en el concepto de campo (intelectual o literario), nunca es directa, sino mediada por la estructura del campo, varía históricamente. En ese sentido, Beatriz Sarlo y Carlos Altamirano sostienen que "las características del campo intelectual tienen consecuencias sobre las ideologías de artista”, y señalan que esos efectos se registran también en el modo en que son procesadas las ideologías de carácter más general” (Sarlo -

100 "Marinas y paisajes americanos. De Yucatán a México", Año I, Tomo II, diciembre, 1896, pp. 584-603.

${ }_{101}$ Así lo expresaba: "La California actual es el triunfo de la civilización americana y la prueba más acabada de su incomparable potencia plástica. El organismo social que ha podido en tan breve lapso asimilarse el salvaje campamento de Yerba Buena, que muchos vecinos de Market street recuerdan aún, y convertirlo en el San Francisco de hoy, no solo deslumbrante de lujo y magnificencia, sino civilizado, tranquilo, lleno de bibliotecas y colegios - de moralidad igual, si no superior, a la de las ciudades del este, fundadas por puritanos y cuákeros - merece la admiración y el respeto del mundo" (142). "Marinas y paisajes americanos. California", Año II, Tomo V, julio, 1897, pp. 122-148. Beatriz Colombi ha observado que la metáfora favorita para referirse a EE.UU. es la del mamut (Mammoth). Explica que dado que "en Groussac importa más la magnitud que la analogía zoológica" el tópico del gigantismo será el que articule todas las percepciones. (Colombi 2004 a: 85). Las mayores críticas a la democracia estaban en otro escrito que pertenecía a Del Plata al Niágara que no fue publicado en la revista La Biblioteca. El texto, capítulo IX del libro, se llamaba "Democracias latinoamericanas" (Groussac, 1925: 206-223) 
Altamirano, 1983: 83.) Asimismo, Christophe Charle en su análisis del "intelectual" en tanto figura social y cultural nueva a lo largo de los años de 1890 en Francia, sostiene que es necesario resituar tal figura en el contexto histórico y social de ese fin de siglo y afirma la existencia de una determinación cultural en relación con el contenido y la función del intelectual por la serie de representaciones anteriores de las figuras dominantes de la cultura. ${ }^{102}$

Analizar la sección 'Redactores', escrita generalmente por el director de La Biblioteca y conformada por un conjunto de perfiles sobre los autores de las colaboraciones, permite mostrar una transición y simultáneamente la emergencia de una figura de escritor nueva y de otras concomitantes, en las que se va precisando básicamente la diferenciación entre cultura y política, literatura y política. De este modo, junto a las presencias dominantes del político, el literato, el publicista, el estadista, la del doctor en leyes o el doctor en medicina a quienes, en términos generales, se seguía incluyendo en el ámbito de las letras, se encontraban, además de la del escritor antes señalada, otras subjetividades más modernas como las del poeta y el crítico, al tiempo que se delimitaba un universo literario más acotado a la escritura, al ejercicio más moderno de las profesiones ligadas a ella y a nuevos criterios de autorización. Julio Ramos afirma que en el análisis del proceso de autonomización no debe confundirse la multiplicidad de roles desempeñados por los sujetos que, en América Latina, desde los últimos veinticinco años del siglo XIX, demandaban una nueva autoridad social de la escritura, con el signo de un campo intelectual premoderno (Ramos, 1989: 15). En el caso de la revista La Biblioteca, dados su pertenencia a una institución estatal y el alto

${ }^{102}$ En una hipótesis de carácter general afirma que "Al menos desde el siglo XVIII, a cada período le corresponde un ideal de productor cultural". Charle vincula el surgimiento del intelectual con razones internas del funcionamiento del mundo cultural: "El 'intelectual' emerge de hecho en el término de una nueva fase de la vida cultural. El período a lo largo del cual aparece no está marcado exclusivamente por una crisis ideológica o política, como del reemplazo de las figuras precedentes unas por otras. Está también marcado por un cuestionamiento de las dimensiones mismas del campo intelectual, de sus estructuras y sus reglas de funcionamiento. El elitismo de las figuras anteriores corresponde a un campo intelectual estrecho muy ligado a privilegios sociales. La figura del "intelectual" se impone después de una fase de expansión de las profesiones intelectuales, un crecimiento de los públicos interesados y una puesta en cuestión de las jerarquías culturales más antiguas (principalmente el sistema académico tradicional). Muchas veces este neologismo ["intelectual"] entra por los márgenes en el vocabulario social. La figura del sabio, que adquiría la mayor de las legitimidades, no pudo jugar ese rol, puesto que su elitismo se oponía al nuevo estado 'democrático' de la vida intelectual” (Charle, 1990: 20) [la traducción es nuestra] 
número de escritores e intelectuales funcionarios que se contaron entre sus colaboradores, esta prevención de Ramos es de utilidad en el estudio de las pequeñas biografías de la sección 'Redactores' porque permite poner en primer plano aquella transición desde un tipo de subjetividad, como la que podrían representar Miguel Cané, Lucio V. López, hacia otro, legible principalmente en los itinerarios vitales de los jóvenes que aparecían decididamente recortados como escritores, tales los casos de Rubén Darío, Luis Berisso, Enrique Rodríguez Larreta, o Leopoldo Lugones. Nacidos a partir de mediados de 1860, todos, a excepción de Darío, realizaban sus primeras incursiones en la escena literaria porteña de fines de siglo XIX. Se trataba, entonces, por un lado, de miembros de la fracción intelectual de la elite del ochenta, e incluso de promociones intelectuales previas, en quienes la multiplicidad podía ser leída como indicio de un campo intelectual premoderno y para los cuales el ejercicio de la literatura era, en muchos casos, funcional, y en otros subalterno con respecto a la práctica política; por otro, se encontraban los jóvenes ligados al modernismo para quienes la variedad de roles (traductor, periodista, e incluso el empleo estatal) no sería un signo de heteronomía, en tanto la voluntad autonómica, la aspiración a vivir de la literatura, la reivindicación de especificidad del juicio crítico, la vocación estética aparecen en primer plano, ya sea en el interior mismo de lo que publican en La Biblioteca, en las numerosas revistas que muchos de ellos fundaron por esos años, en los diarios, o como reverso, en el proyecto escriturario propio. ${ }^{103}$

Las biografías sumarias de la sección "Redactores" eran publicadas en el final de cada tomo, y fueron una innovación en el periodismo argentino. ${ }^{104}$ Groussac, responsable de casi todas estas noticias, decidió reeditarlas como conjunto, en ocasión del cierre de La Biblioteca, para documentar, con los nombres allí congregados, el valor de su revista en tanto órgano nacional de cultura, para refrendar su poder de convocatoria y su propia colocación destacada en el interior de la elite. ${ }^{105}$ El número total de colaboradores según

${ }^{103}$ Para un análisis de la relación entre literatura y periodismo, Cf. Ramos, 1989: 84-111. 104 Jorge Navarro Viola se refiere a esta sección como una "innovación feliz entre nosotros", la de "publicar en cada número siluetas de los colaboradores". Cf. Anuario de la prensa argentina 1896 (229). Todas las citas de la sección corresponden al tomo VIII, a la entrega de abril de 1898. En adelante solo consignamos número de página. El índice de la revista confeccionado como anexo permite ubicar estos perfiles en los tomos en que originalmente aparecieron.

${ }^{105}$ Explica: "Reproduzco, además de un índice general, las noticias biográficas de todos los colaboradores con que se ha honrado durante sus dos años de vida, como un documento 
'Redactores' ${ }^{106}$ ascendía a 70 y casi todos ellos eran argentinos. ${ }^{107}$ Se trataba en su mayoría de sujetos que habían pasado por una educación universitaria, principalmente abogados (36), médicos (8), y en menor medida, ingenieros -éstos últimos, en general de origen francés-; además de militares de carrera, también estaban presentes profesores (de colegios y de la universidad), escritores ${ }^{108} \mathrm{y}$ en escasa medida, artistas (pintores y músicos). ${ }^{109}$ La mitad de los colaboradores (35) correspondía a aquellos nacidos en las décadas del $50 \mathrm{y}$ del $60,{ }^{110}$ considerados por el director de la revista como "la generación que va llegando a la madurez" $" 111$ en el momento en que se publicaba La Biblioteca; solamente seis habían nacido en la década del 70; ${ }^{112}$ los nacidos entre 1727 y 1839

justificativo de su aceptación entre los elementos cultos de la República" [cursivas nuestras]. (248)

106 'Redactores' no incluye los nombres de Ambrosio Morante, Santiago de Liniers y Damián Menéndez, que aparecen en el índice general, publicado por Groussac al final del tomo 8. Como señalamos en el Índice razonado que presentamos como anexo, el Índice general es, fundamentalmente, una nómina de autores en la que se consignan tomo, título de la colaboración y página de inicio de la misma. Además de autores, las secciones de aparición regular forman parte de esa lista, y también, de modo anómalo, algunos de los artículos del propio Groussac, resaltando así la presencia del director. Esto sucede con "La educación por el folletín", y con el relato "La pesquisa" que había aparecido sin firmar. En el "Índice general” no figuran Juan A. Martínez, ni Rómulo Martini.

${ }_{107}$ Además de Groussac, son franceses Francisco Beuf, Ulric Courtois, Amadeo Jacques, Carlos Doynell; Jorge Duclout, alsaciano; Matías Calandrelli, italiano; Rubén Darío (nicaragüense); Enrique Kubly, Abel J. Pérez, Agustín de Vedia, Clemente Fregeiro, uruguayos; Matías Romero, mejicano; Francisco P. Súnico, de Canarias. En algunos casos, el carácter extranjero se desdibuja ya que la educación y la inserción cultural es decididamente argentina.

${ }_{108}$ Usamos el término escritor en un sentido abarcador que incluye a críticos, poetas, autores teatrales.

${ }^{109}$ Como pintor y crítico de arte colaboró Eduardo Schiaffino, del que Groussac señalaba sería Director del Museo Bellas Artes próximo a inaugurarse en el momento en que colabora en la revista, en 1896. Como músico, Alberto Williams, también a cargo de una institución especializada, como lo era el Conservatorio de Buenos Aires. Al brindar esta información, el director de La Biblioteca mostraba el valor que asignaba a las instituciones formales en el reconocimiento de las prácticas artísticas.

${ }_{110}$ De la década del 50: Adolfo Saldías, Miguel Cané, Roque Sáenz Peña, José María Ramos Mejía, Clemente Fregeiro, Jorge Duclout, Pedro B. Palacios, Diego T. Dávison, Abel Pérez, Alberto B. Martínez, Ernesto Quesada, Eduardo Schiaffino, Luis M. Drago, Samuel Gache, Miguel Romero; de la década del 60: Carlos Aldao, Ramón J. Cárcano, Juan A. Martínez, Francisco P. Súnico, Juan A. Argerich, Eduardo L. Bidau, Carlos Doynel, Martín García Mérou, Juan Agustín García (h), Joaquín V. González, Adolfo F. Orma, Alberto Williams, Antonio Dellepiane, Manuel Montes de Oca, Enrique Kubly, Luis Berisso, Rubén Darío, Carlos Rodríguez Larreta.

${ }^{111}$ Perfil de Eduardo L. Bidau (255)

${ }^{112}$ Fermín Rodríguez (h) (1871), Rómulo Martini (1873), Enrique Rodríguez Larreta (1873), Leopoldo Lugones (1874), Horacio Beccar Varela (1875). 
sumaban 18, y muchos de ellos habían estado o estaban ligados a la historia y a la política argentina de modo protagónico; ${ }^{113}$ los de la década del 40, eran $12 .{ }^{114}$

Gran parte de los abogados, se consignaba, ejercían la docencia universitaria y, en ese sentido, se hacía visible la especialización de los estudios de derecho no solo en la existencia de la institución misma sino también, a partir de los nombres de las asignaturas dictadas y los de aquellos que sucesivamente estuvieron a su cargo, algunas de cuyas lecciones aparecieron en la páginas de la revista, como la de Carlos Rodríguez Larreta sobre Derecho civil o, la lección inaugural de Antonio Dellepiane en la cátedra de Filosofía del derecho. Así, por ejemplo, se consignaba que Lucio V. López “ocupó [en 1884] la cátedra de Derecho constitucional en la Facultad, sucediendo a Estrada, y precediendo, no menos dignamente, a Del Valle en tan alta enseñanza” (265), que Juan Agustín García (h) dictaba Introducción al derecho (259), que Pedro Goyena había sido “profesor de Derecho romano en la Facultad, desde 1874, desempeñando esta enseñanza con ciencia y autoridad creciente hasta su muerte" (260), o que Juan A. Martínez era profesor de Filosofía general en La Plata (267). Asociado a la especialización de los estudios de derecho, aparecía siempre el género tesis como punto inicial de una trayectoria en el ámbito jurídico; las tesis otorgaban el grado de doctor en leyes, y casi todas las noticias biográficas informaban sobre su temática particular. De este modo se marcaba el punto de origen de un recorrido intelectual con el signo de la institucionalidad como su rasgo más relevante. Algunas de aquellas tesis mencionadas fueron Las causas del delito de Dellepiane, Obligaciones divisibles e indivisibles de Lucio V. López, la de Joaquín V. González sobre derecho político, Los hechos y los actos jurídicos de Juan Agustín García (h), Represión de Manuel Montes de Oca, Divorcio de Carlos Aldao, Hijos naturales, adulterinos y sacrílegos de Ramón J. Cárcano. En muchos de los casos, tanto los abogados, como los médicos e ingenieros que por ese entonces tenían entre cuarenta o cincuenta años, ocupaban cargos en la administración del Estado en función de sus propias competencias disciplinares. Así, se trazaba un corte en la identificación del

\footnotetext{
${ }_{113}$ Tales los casos de Bartolomé Mitre, Domingo F. Sarmiento, Juan Bautista Alberdi, Nicolás Avellaneda.

${ }^{114}$ Ernesto Maeder agrupa a los colaboradores en: hombres de la organización nacional, hombres del ochenta, y de la generación del centenario. Como se ve, pasa por alto a los menos numerosos jóvenes, representantes del modernismo. De los últimos, solo cita a Lugones.
} 
político con el abogado de cuño más antiguo, y se perfilaba el funcionario más decididamente especializado. Entre los médicos, Pedro N. Arata, también farmacéutico, se decía, era miembro de academias científicas extranjeras, y fundador del Laboratorio Municipal de Buenos Aires; Samuel Gache, había ocupado "sucesiva o simultáneamente" (258) los cargos de Secretario de la Asistencia pública, del Patronato de la infancia y del Instituto Pasteur de Buenos Aires; Francisco P. Súnico, se había desempañado como Inspector general sanitario de Buenos Aires y trabajaba como médico del Colegio militar; José María Ramos Mejía, además de profesor universitario, presidía, en 1896, el Departamento Nacional de Higiene. Por el lado de los abogados, Carlos Aldao, había sido secretario de la misión especial argentina en Washington para el arbitraje de Misiones. Casi todos los políticos viejos y jóvenes eran abogados, y aunque esto seguía siendo una norma, al mismo tiempo, las colaboraciones de los abogados más jóvenes versaban sobre materias jurídicas. ${ }^{115}$ Cabe mencionar, en ese sentido, “Constituciones y partidos”de Juan A. Argerich, "La propiedad raíz en Buenos Aires” de Juan A. García (h), "Derecho constitucional” de José M. Guastavino, "El ministerio nacional" de Adolfo F. Orma, entre otras.

En cuanto a los escritores y al espacio más específico de la literatura, si la presencia de una institución universitaria podía considerarse, como lo era en el caso del derecho, índice de un reconocimiento disciplinar y por lo tanto de una práctica especializada y más autónoma, es importante señalar que 1896, año en que se inició $L a$ Biblioteca, fue también el año en que se fundó la Facultad de Filosofía y Letras de Buenos Aires, de cuyo Consejo Académico Groussac fue miembro titular durante cuatro meses. Tulio Halperín Donghi ha observado en su Historia de la Universidad de Buenos Aires la tardía fundación de dicha facultad, estableciendo una relación directa entre su creación y la que denomina una "actitud nueva", fuertemente reticente y crítica del

115 El campo de los estudios históricos también está presente en la revista y son los abogados y los políticos \ abogados los que escriben sobre historia en La Biblioteca -además de Groussac mismo que, como ya señalamos va proponiendo en sus trabajos un método de análisis propiamente histórico. La cuestión metodológica, especialmente el problema de la "inducción" aparece problematizada en "La paradoja de las ciencias sociales", Año I, Tomo II, octubre, 1896, pp. 309-320. Este artículo es importante además porque sostiene el carácter determinante de las "ideas" en relación con los hechos económicos: "Los hechos económicos son subalternos y viene después. El más culminante de este fin de siglo, el imperio creciente del proteccionismo, es la resultante de guerras colosales que no fueron a su vez, en Estados Unidos y en Alemania, sino el estallido de un sentimiento latente y de un aspiración histórica: la nacionalidad" (314) 
positivismo triunfante en los claustros universitarios. ${ }^{116}$ Esa actitud, según Halperín Donghi, manifestada en un "conjunto de objeciones sin duda fundadas pero no sistematizadas", y la representatividad que la misma adquirió en relación con un momento de la conciencia nacional que el historiador califica de crepuscular, explicaría su "eco" en la Universidad de Buenos Aires, cuyo "homenaje" sería justamente, la apertura de Filosofía y Letras. Definida como el espacio del cultivo de las altas actividades intelectuales, inscripta en un medio al que se reputaba hostil, esta facultad significó la sistematización del estudio de materias hasta el momento llevados a cabo por aficionados (Halperín Donghi, 1962: 100-101). En relación con la posibilidad misma de existencia de Filosofía y Letras, como una de las bases institucionales necesarias para la efectivización de una práctica literaria autónoma, Julio Ramos ha observado que se debe por un lado a la especialización de los estudios de Derecho, reorganizados en 1895, que expulsaron "a las letras de su dominio", deslindando lo estrictamente legal del saber decir o la elocuencia, y por otro, a la defensa de una especificidad en el seno de las nuevas humanidades, que irían avanzando sobre el positivismo. ${ }^{117}$ Dada la reciente creación de la Facultad de Filosofía y Letras, 'Redactores' no hacía de la referencia a ella el signo más visible de la especialización disciplinar como sucedía con los estudios de derecho. Las menciones a la facultad se limitaban a señalar que tal o cual personaje se desempeñaba en ella como académico. En cuanto al dominio impreciso de las letras, las denominaciones con que Groussac o Enrique Rodríguez Larreta se referían a los colaboradores revelaba una pluralidad terminológica, indicativa de la coexistencia de diferentes figuras identificables como dominantes, transicionales y emergentes: publicistas, literatos, abogados, políticos, juristas, profesores, críticos literarios, escritores, poetas. Correlativamente con esto se utilizaban las fórmulas "mundo literario", "vida ${ }_{116}$ La Facultad de Filosofía y Humanidades, fundada en 1882, cuando era rector de la Universidad Nicolás Avellaneda, había tenido una existencia nominal de un año, y en 1883, la eliminación de las partidas presupuestarias que le correspondían, determinó su fin. Halperín explica que además de la "formación de estudiosos en las disciplinas humanísticas" la institución tuvo como objetivo primordial "la preparación de los futuros profesores de enseñanza media en esas asignaturas". Fue este último propósito, el que aseguró su existencia, más allá de la de la reticencia del gobierno "a admitir que la docencia exigía, en efecto, una formación profesional especializada". (Halperín, 1962: 101).

En el 13 de febrero de 1896, se fundó por decreto del presidente de la Nación, José E. Uriburu.

${ }^{117}$ Ramos remite a la definición posterior de Rojas en La restauración nacionalista (1909), fundamentalmente a la historia y a la literatura como discursos rectores en relación con el nacionalismo del Centenario (Ramos, 1989: 61). 
literaria" y "las letras' y a veces 'literatura'. En la nota referente a Vicente Fidel López (1815) Groussac sostenía: "López cultivó las letras con eficacia y fervor, no dejando -fuera de la poesía-, género literario en que no se aplicara con éxito su talento flexible y rápida asimilación. Periodista, profesor, crítico, historiador, novelista y hasta filólogo, ha cruzado infatigablemente el campo del pensamiento" (264). ${ }^{118}$ La cita era elocuente porque señalaba las incumbencias de las letras, y las identificaba con la totalidad del campo del conocimiento, al que también pertenecía la poesía. La "reputación literaria" de Luis L. Domínguez (1819), definido como "concienzudo historiador", se fundaba principalmente, según Groussac, en "su Historia Argentina, obra de exacta información e insuperable claridad de estilo, de todo punto excelente" (257). Del joven Rómulo Martini (1873) se comentaba "ha tomado inscripción [sic] en el departamento de Ciencias sociales [de la Facultad de Florencia] para completar su alta educación literaria" (267). ${ }^{119}$ Enrique Rodríguez Larreta se refería al ininterrumpido trabajo de historiador de Adolfo Saldías en términos de su "vida literaria". También estaba presente en otros usos del término una concepción de lo literario (usado como adjetivo) que lo vinculaba con lo formal y con la idea de retórica. El perfil de José M. Ramos Mejía mostraba esta cuestión de manera clara, en tanto definía Las neurosis de los hombres célebres en la historia argentina" (1878-1882), Estudios clínicos sobre las enfermedades nerviosas y mentales (1893) o La locura en la historia (1875) como obras "en que la ciencia revist[e] forma literaria" (12). El mismo sentido se deslizaba en la descripción de los textos de Cané, que hacía el director de La Biblioteca: "notables por la finura francesa del gusto y la elegante espontaneidad del estilo, son las siguientes: Ensayos, Juvenilia, En viaje, Charlas literarias, A la distancia. Casi todas ellas, como lo indican sus títulos, son impresiones de viaje y de arte" (254). Como veremos, también se hacían presentes ya algunas de las mismas ideas que para Groussac definían a los jóvenes escritores, fuese en calidad de posesiones o como carencias: una altísima educación del gusto y la creación y preocupación por un estilo personal. La noticia sobre Nicolás Avellaneda, figura política por excelencia -junto con las de Carlos Pellegrini, Roque Sáenz Peña, o Julio A. Roca- remitía a un modo de participación escrituraria pública ligada a la prensa política. Hombre polifacético, su

${ }^{118}$ Cursivas nuestras.

${ }^{119}$ Cursivas nuestras. 
perfil manifestaba un cruce habitual entre literatura y política y recuperaba también aquella idea de elocuencia asociada a la figura del tribuno y, por lo tanto, a un carácter político-estatal del ejercicio de la palabra: "Orador en la prensa y literato fortuito en la tribuna, tuvo que engañar su sed artística mojando sus labios en el hueco de la mano, al pasar el río, como el guerrero bíblico.” $(253)^{120}$

En la revista, más allá de la sección 'Redactores”, abundaban usos similares del término literario. Así, Adolfo Saldías, al responder a José María Ramos Mejía las críticas que éste había realizado a su estudio sobre Rosas ${ }^{121}$ afirmaba que Ramos Mejía, conocido por ensayos como La locura en la historia, Las neurosis de los hombres célebres en la historia argentina, y los Estudios clínicos sobre las enfermedades nerviosas y mentales, estaba obligado a responder dado que se trataba de "un contemporáneo que por su talento goza de justa reputación en nuestro pequeño mundo literario"; ${ }^{22}$ Bartolomé Novaro, por su parte, se refería con el mismo sentido a las 'profesiones literarias'. ${ }^{123}$ Es así que muchas veces se identificaba mundo literario con mundo intelectual, entendiendo por éste, el espacio en el que confluían prácticas diversas como la medicina, la psicología, la historia, el derecho, y también la literatura en sentido más estricto. Algo de esta pluralidad se actualizaba también en la denominación ya casi residual de publicista, con que se designaba a aquel que escribía sobre materias diferentes, no solo a los especialistas en derecho público. Publicistas eran o habían sido Vicente y Ernesto Quesada, Agustín de Vedia, Abel J. Pérez, Valentín Alsina, Florencio Varela y Juan Bautista Alberdi. ${ }^{124}$ Por su parte, un uso del término literato empleado para definir el

\footnotetext{
${ }^{120}$ El joven escritor Enrique Rodríguez Larreta, en la nota sobre Julio A. Roca, desarticulaba la unión de la política con las letras y sostenía: "En cuanto a su faz literaria, observamos que sería injusto juzgarle por una aptitud que no ha buscado. En este sentido, solo es exigible a los hombres políticos el civilizado respeto por la más alta cultura. Sin embargo, sus adversarios le imputan un desdén burgués por el talento y las virtudes más severas del estudio. Esto sería demasiado triste y nos tranquiliza, en parte, recordar que su más sentido discurso fue pronunciado en la tumba de un poeta, y que el pueblo de Córdoba acaba de oír su voz junto a la estatua de Vélez" p. 276. La cita es importante además porque remite a la oposición extrema entre arte y mundo burgués que se hará visible en el modernismo pero también en los discursos de José Ingenieros y Leopoldo Lugones en La Montaña de que nos ocupamos más adelante en este mismo capítulo.

${ }^{121}$ Ensayo sobre la Historia de la confederación Argentina.

${ }^{122}$ Año II, Tomo VII, marzo, 1898, p. 450. Cursivas nuestras.

123 "Inacción y ejercicio", Año I, Tomo II, diciembre, 1896, pp. 543-558.

${ }^{124}$ Según la Real Academia Española, el término publicista además de designar a quien conoce en profundidad y escribe sobre el campo específico del derecho público, nombra a aquel que escribe para el público sobre temas diversos y a quien ejerce la publicidad.
} 
estilo escriturario de sujetos como Sarmiento, Alberdi, Avellaneda, Pedro Goyena, designaba preferentemente en las noticias de 'Redactores' a aquellos dedicados a la lucha política y al debate de ideas, quienes, a su vez, se diferenciaban claramente del escritordiplomático representado por Martín García Mérou o de los escritores funcionarios como Miguel Cané. ${ }^{125}$ Otro empleo del vocablo en los perfiles de Juan Antonio Argerich ${ }^{126}$ y Joaquín V. González, nacidos ambos en la década 1860, distinguía la función política de la práctica de la escritura. ${ }^{127}$ La nota sobre González, que comenzaba con el repaso sumario de los cargos políticos desempeñados hasta ese momento por el riojano ${ }^{128}$ inmediatamente después de haberse graduado como doctor en leyes en Córdoba, exponía esta diferenciación, precisando además los géneros comprendidos en las letras y aquellos que claramente respondían a un objetivo pedagógico:

Para concluir con lo didáctico, digamos que tiene en preparación un Manual de la Constitución, y es

${ }^{125}$ Estos escritores pueden pensarse bajo el concepto de J. Ludmer de "coalición cultural del nuevo Estado" dentro de la cual se ubicarían aquellos que como Miguel Cané, Lucio López, Eugenio Cambaceres, Martín García Mérou "no son literatos profesionales, sino los primeros escritores universitarios y a la vez funcionarios estatales en la cultura argentina." (9). Y más adelante: "Esta cultura rica de 1880 (...) produjo una escritura fragmentaria y conversada, novelera y elegante, sustancialmente culta y refinada: 'aristocrática'" (9-10). Las citas corresponden a Ludmer, 1993: 9-37. Este mismo concepto es desarrollado por Ludmer in extenso en Ludmer, 1999: 23-139.

Desde el punto de vista de Groussac, en 'Redactores', las figuras de García Mérou y de Miguel Cané no son homologables, como podrían serlo para Ludmer. El autor de Ley social, once años menor que Cané, era considerado, por el director de La Biblioteca, antes como escritor que como funcionario. Así, Groussac afirmaba que "Todo el mundo celebra al poeta fluido e inspirado, al crítico sagaz en su benevolencia, al galano prosista de las Impresiones, al pensador de los ensayos históricos: es menos conocida la labor paralela del diplomático" (260). Se trataba de un "joven escritor (...) cuyo nombre resuena en América latina" (259.) respaldado por una obra vasta producto de "un talento precoz" (260). Por otra parte, su tarea como crítico literario, analista y conocedor de la literatura y las historias literarias brasileñas, lo situaba en un sitio preferencial. En ese sentido, García Mérou examinaba y reflexionaba críticamente sobre un género hasta el momento vacante en la cultura argentina, como lo era, la historia literaria. La trayectoria de Cané, en cambio tenía, más allá de las valoraciones de Groussac, una impronta fuertemente política: "Arrastrado a la agitación política más por sus antecedentes que por sus gustos, fue redactor de la Tribuna y del Nacional"; sus escritos correspondían sobre todo al género "impresiones de viaje y de arte". (255), y eran consignados, no el en principio, sino al final de la noticia.

${ }^{126}$ Sobre Argerich, se mencionaba su "talento de literato y pensador" (252)

127 También y con un sentido que remite estrictamente al estilo propio, Groussac usó el término literato en relación el joven Leopoldo Lugones: "Y cuando amanezca ese día, [el día en que deje de imitar] el señor Lugones no será algo, sino alguien; (...) y la América Latina tendrá quizá otro literato de talento robusto y personal." (265-266)

${ }^{128}$ González había sido diputado nacional entre 1886 y 1889 , en que fue electo gobernador de La Rioja, cargo al que renunció para volver a ser diputado hasta 1896. 
académico de la Facultad de Letras. Como literato, Joaquín V. González ha publicado: La tradición nacional (1888), Mis montañas (1892), y, más recientemente, un volumen de Cuentos, obras todas que han merecido excelente acogida. Talento sincero y espontáneo en su región deliberadamente circunscripta, el autor de Mis Montañas es uno de los escritores más francamente argentinos de su generación. $^{129}$

Tal como quedaba consignado se incluían dentro del mismo ámbito de las letras $L a$ tradición nacional en que se exponía un programa de política cultural con respecto al pasado, Mis Montañas, que podría considerarse como autobiografía, y los Cuentos, más netamente ficcional.

Si como ya observamos la institución universitaria no aparecía en 'Redactores' como signo más visible de la creciente autonomización de la literatura o al menos de una especialización en ciernes, esta sección remitía a la modernización literaria en otro tipo de referencias que se reiteraban en los perfiles de aquellos recortados como escritores modernos. En ese sentido, las notas sobre los escasos escritores jóvenes presentes en La Biblioteca exhibían un comienzo literario que los vinculaba al fenómeno de expansión y auge de la prensa periódica, y a la consiguiente ampliación de las profesiones literarias (de las que eran tributarias la necesidad de un público y la existencia de un mercado); la prensa funcionaría para estos jóvenes como forma de subsistencia constituyendo, por lo tanto, uno de los modos de profesionalización de la escritura, y a la vez, en ausencia de bases institucionales propias de la literatura, espacio alternativo de legitimación y circulación, más o menos prestigioso según el medio de que se tratara. ${ }^{130}$

129 'Redactores' (260). Cursivas nuestras.

${ }^{130}$ La ausencia de instituciones que nuclearan a prácticas artísticas especializadas no significaba la inexistencia de otro tipo de asociación de los aspirantes a miembros de un mundo cultural más autorregulado. En ese sentido, el Ateneo de Buenos Aires (1893-1900) en el que se dieron cita escritores, pintores, músicos e intelectuales en general, pertenecientes a distintas generaciones y tendencias estéticas, constituía el tipo de agrupamiento amplio e inespecífico cuyo objetivo estaba centralmente relacionado con la posibilidad misma de existencia de un ámbito para los productos culturales (en sentido amplio). Fue, sin duda, importante en el camino de profesionalización de los escritores, cuestión que estuvo planteada desde los inicios del Ateneo por Ricardo Gutiérrez. Para un análisis detallado de lo relativo a las artes plásticas en el Ateneo, Cf. Malosetti Costa, 2001: 327-390. Una descripción detallada de la fundación, autoridades, actividades, miembros, 
El escrito sobre Luis Berisso, quien había colaborado en La Biblioteca en abril de 1897, con un artículo acerca de Manuel Gutiérrez Nájera, escenificaba aquella función de la prensa, señalando a diarios y revistas como territorios de una colaboración especializada, y trazando las notas fundamentales de una diferencia nunca antes enunciada con tanta enjundia e ironía:

Nació en Buenos Aires el 8 de mayo de 1866, y se educó en el colegio del Salvador. En 1884 publicó en el diario Sudamérica su primer artículo, ${ }^{131}$ que decidió de (sic) su vocación literaria y artística. El señor Berisso no ha estudiado derecho ni medicina, no ha sido empleado ni perteneció jamás a otra corporación que el Ateneo: ha sido, es y será colaborador literario de diarios y revistas: es su característica. En 1888 recorrió parte de Europa, estuvo en contacto con los hombres y las cosas de arte; desarrolló sus conocimientos literarios, cultivó su gusto - y siguió escribiendo correspondencias como antes artículos. Acaso sea el único argentino que, después de los treinta años, cifre en las puras letras su mayor delicia y única ambición. Culto tan noble merecía y ha recibido su recompensa: el señor Berisso está en vísperas de tener talento. Tiene en prensa un volumen titulado $E l$ pensamiento de América, y ha terminado la traducción de Belkiss, [de] de Castro una de tantas imitaciones de Flaubert, que se parecen a la tentación como la luna se parece al sol. ${ }^{132}$

conflictos, y personajes más relevantes se encuentra en Giusti, 1954: 53-89. Jorge B. Rivera publicó en El escritor y la industria cultural el discurso de apertura de Calixto Oyuela. Véase también, Suárez Wilson, 1968; Pastormerlo, 2005, mimeo. En el capítulo 2 se retoman algunas cuestiones vinculadas con el Ateneo. Cf. Parágrafo 3.

${ }_{131}$ Muchos años más tarde, Luis Berisso, en la nota que escribiera a propósito de la muerte de Groussac, explicaba que lo había conocido en la redacción del diario y unas líneas más adelante, consignaba que por ese tiempo "(h)acía mis primeras armas en el periodismo metropolitano al margen de la crónica teatral, en busca de cómodas butacas y fáciles conquistas", Nosotros, Año XXIII, n² 242, julio, 1929, pp. 26-29. Debe destacarse que la crónica teatral no se presentaba para Groussac como un punto importante de comienzo, y por lo tanto era dejada de lado.

${ }^{132}$ Groussac, Paul. "Redactores de La Biblioteca", Año II, Tomo IV, abril-junio, 1897, p. 491, cursivas nuestras. Como ya observamos en el cuerpo de este parágrafo, en el último tomo de la revista Groussac compiló la sección 'Redactores' de cada tomo en una sola, ordenada alfabéticamente. Es interesante señalar que en 1898, Groussac modificó el escrito sobre Berisso, despojándolo de la nota injuriosa. En lugar de "el señor Berisso está en vísperas de tener talento", el crítico escribió: "Culto tan noble merecía y ha recibido su recompensa: Berisso es hoy uno de nuestros buenos ensayistas" (p. XVIII). [cursivas del original]. Cabe 
Aunque su estreno literario hubiera tenido lugar en un diario netamente político como Sudamérica, del cual el mismo Groussac había sido redactor y director gerente, se remarcaba la relación entre la literatura ("puras letras") y el periódico, que era presentado como su medio natural; ${ }^{133}$ el relato de su educación era valorado como contrastación negativa del camino habitual de los escritores funcionarios, que no intentaban vivir exclusivamente de su pluma; el viaje a Europa, consabido rito iniciático de la juventud liberal y patricia del ochenta, había sido, en este caso, de sociabilidad y educación estéticas e intelectuales; los resultados de ese periplo no se habían traducido en ningún informe de utilidad para el gobierno, sino en colaboraciones periodísticas, y su vuelta no había sido coronada con empleo alguno en ninguna repartición estatal. La noticia era relevante porque mostraba en la construcción de ese comienzo el modo en que la literatura y el escritor se iban distinguiendo de la "buena sociedad", como lo era este nuevo vínculo con el periodismo, en cuyas redacciones se iban edificando relaciones laborales y más horizontales. ${ }^{134}$ La nota sobre Rubén Darío, al que se definía como poeta y escritor fecundo, ${ }^{135}$ reforzaba su inserción en el campo periodístico como redactor de diarios, tanto en su país como en otros de América Central y colaborador prolífico en medios de

aclarar que la edición de El pensamiento de América de Luis Berisso, aparecida en 1898 bajo la misma casa editora de la revista La Biblioteca (Félix Lajouane), llevaba, además del prólogo de Víctor Pérez Petit, la misma noticia biográfica modificada por Groussac para el tomo VIII. El trabajo sobre Gutiérrez Nájera formaba parte de ese libro.

${ }^{133}$ En el escrito sobre Gutiérrez Nájera, era el mismo Berisso quien enfatizaba ese mismo vínculo entre periodismo y literatura $-y$ que Groussac observaba para él-, señalando los quince años ininterrumpidos del trabajo del mexicano en la prensa, labor a la que asignaba un sentido bien alejado de la pedagogía ideológica y del debate político. Dicho sentido se concentraba, sobre todo, en el hecho de presentar "bajo nuevos prismas" un libro, un cuadro, una calle, un aspecto de la naturaleza y, a la vez, en llevar adelante una función de mediador ("familiarizó") entre el mundo del arte y el lector del diario. Cf. "Manuel Gutiérrez Nájera", Año II, T4, abril, 1897, pp. 104-118.

${ }^{134}$ Cf. Sarlo - Altamirano, 1983: 83 -84.

135 "(...) este joven y fecundo escritor ha dado a luz varios tomos de versos y prosa, entre los cuales mencionaremos las obras siguientes: Primeras notas, Abrojos (poesía), Azul (prosa y verso), Rimas, Ensayo sobre Calderón, etc. Tiene actualmente en prensa un volumen de crítica: Los raros. Darío es un poeta de imaginación exótica con extrañas magnificencias, y de factura novedosa y exquisita: un cincelador a lo Moréas y Régnier" (256) 
España y de América. ${ }^{136}$ El escrito acerca de Leopoldo Lugones, ${ }^{137}$ quien por esa época tenía veintitrés años y era redactor de La Montaña junto con el joven José Ingenieros, llamaba la atención porque volvía presente la relación problemática del escritor con el dinero e ironizaba sobre el valor determinante del mismo en la construcción de las posiciones ideológicas y estéticas del cordobés. ${ }^{138}$ La cuestión material, que hasta entonces no se había planteado en esos mismos términos en el resto de los perfiles, constituía una preocupación vital, no solo para alguien como el autor de Las montañas del oro (1897), cuya situación podía calificarse de precaria, debido a la incompletud de sus estudios, ${ }^{139}$ la ausencia de vinculaciones sociales, y a que solo contaba con los ingresos provenientes del periodismo. ${ }^{140}$ La relación entre la literatura y el dinero

${ }^{136}$ Rubén Darío, quien había sido incorporado como corresponsal de La Nación el 28 de noviembre de 1892, llegó a Buenos Aires el 13 de agosto de 1893, como Cónsul General de Colombia. Compañeros de La Nación fueron Roberto Payró y Julián Martel. A los pocos días de su arribo, estuvo presente en la reunión del Ateneo en la que se despedía a Federico Gamboa. En el Ateneo, el 29 de septiembre de 1896, dictó una conferencia sobre Eugenio de Castro, que sería incluida luego en Los raros. Recordemos que Berisso, por esa época, estaba traduciendo a de Castro. Cf. Zanetti, 2004: 9-59. Sobre la residencia de Darío en Argentina, véanse también Carilla, 1967; Matamoro, 2002; Barcia, 1968. (Advertencia de Juan Carlos Ghiano; Estudio preliminar, recopilación y notas de Pedro L. Barcia); García, 2002.

${ }^{137}$ En La Biblioteca aparecieron tres colaboraciones de Lugones: "La voz contra la roca" (agosto de 1897), "Un estreno" (febrero de 1898) y "Táctica" (abril de 1898) relatos que pertenecerían al volumen de La Guerra gaucha (1905).

${ }^{138}$ Así se decía: "fáltale un poco de sosiego material para ser todo un burgués como sus maestros" (265)

${ }^{139}$ En su relato Groussac afirmaba: "Antes de concluir sus estudios preparatorios, abandonó el colegio y echó a vagar por esos montes y valles provinciales, leyendo, borrajeando papel, cantando a la ventura sus primeros versos, como el Transeúnte de Coppée. Así preparado llegó a Buenos Aires y escribió en algunos diarios, lanzando rayos y centellas contra burgueses, pelucones, eunucos clásicos y cuanto no fuera socialismo y decadencia... Alguien hubo que, sin escandalizarse por la algazara juvenil y sólo atento a lo vibrante de la voz, quiso ver de cerca al monstruo: encontróse con un joven modesto, respetuoso, ingenuo admirador de Hugo y Leconte de Lisle, a quienes imita, y de Michelet, a quien acaba de descubrir... A esto se reduce el dossier criminal del joven Lugones: fáltale un poco de sosiego material para ser todo un burgués como sus maestros; y un gusto literario más cultivado, para ser un poeta y un escritor a secas" (265)

${ }^{140}$ María Teresa Gramuglio ha definido la situación de los comienzos de Lugones como la de "una precariedad múltiple", que tiene una contrapartida (compensación) en ciertas estrategias escriturales de autorización, como por ejemplo, la elección de la continuidad estética con modelos literarios dominantes, en el poema "Los mundos". En el mismo poema Gramuglio advierte y analiza el contraste entre la voz que enuncia y "la condición real del poeta que escribe: un joven provinciano de dieciocho años, sin fortuna, sin educación sistemática completa, sin fuertes apoyos familiares ni sociales en un medio que le es hostil por su socialismo furiosamente proclamado; un aprendiz de escritor que no logra editar su primer libro; alguien desprovisto, en suma, de todos aquellos capitales, sean sociales, materiales o simbólicos, que facilitan un acceso sin conflictos a la vida literaria" (52). Esta precariedad se prolonga desde su llegada a Buenos Aires en 1896 hasta 1898, año en que 
representaría una de las cuestiones más importantes para los escritores noveles de fines de siglo XIX y ya entrado el siglo XX, al tiempo que constituiría uno de los aspectos fundamentales de la modernización literaria. En ese sentido, sería Manuel Gálvez, un escritor tempranamente preocupado por la profesionalización de la literatura, quien al referirse a la "generación de Ideas", pondría el acento en la "pobreza" de algunos de los miembros de la revista (Gálvez, 1961: 46). Dado que quienes colaboraban en La Biblioteca eran en su mayoría -tal como indicaba su 'Indice general'- miembros de la elite, mantenían fluidas relaciones con ella, o bien tenían un vínculo institucional fuerte con el Estado, desempeñando cargos políticos en el poder ejecutivo a nivel nacional y provincial, o en el parlamento, trabajando en algunas de sus dependencias a las que ellos mismos habían fundado u organizado, o ejerciendo como médicos, abogados, incluso, ingenieros, ${ }^{141}$ la preocupación por los medios de subsistencia no se presentaba como algo relevante en sus noticias biográficas.

El repaso de algunas de las notas de 'Redactores' permitía ver además la intención de construir un linaje intelectual entendido para Groussac como grupo de notables, aristocracia intelectual, que como ya analizamos, configuró un tópico de los discursos de cierta zona de la fracción intelectual de la elite frente a los efectos indeseados del programa modernizador. En ese sentido, los textos mostraban la coexistencia de dos formas de entrada en el mundo cultural y en la literatura que daban la pauta del cambio que se estaba produciendo en la esfera literaria. Uno de esos modos de entrada en el mundo literario, era el que se sostenía en la condición de la literatura como herencia familiar y como signo de distinción. Los dos casos paradigmáticos eran los de Miguel Cané y Lucio López, ambos hijos de escritores. Del primero de ellos decía Groussac: "Hijo de un escritor distinguido, heredó el talento y el amor a las letras" (255). El talento y el cultivo de las letras eran una marca de clase, y aparecían como bienes heredables, al igual que las prerrogativas sociales de las gentes distinguidas. Cuando se refería a Lucio López, Groussac completaba la forma en que se tramaba este modo de ingreso y legitimación en "las letras": "Hijo y nieto de escritores, alumno predilecto de Don Juan

comenzó a relacionarse con figuras del roquismo, fruto de lo cual obtuvo cargos y misiones oficiales (Gramuglio, 1996: 49-64). El perfil de Groussac en 'Redactores' también pone en escena el contraste entre la voz vibrante del monstruo irreverente y la modestia del joven respetuoso.

${ }^{141}$ En general, los ingenieros no eran argentinos: Carlos Doynel, Jorge Duclout. 
M. Gutiérrez, íntimo amigo de Cané: todas las influencias atávicas y ambientes le destinaban a la literatura" (264). A los lazos de parentesco se agregaba la sociabilidad de la clase, que también tributaria de los lazos familiares, permitiría concretar un destino literario que les era propio, en la forma de un ingreso no problemático ni dificultoso en la vida literaria. La segunda forma era aquella que traía a un primer plano el talento como el capital más visible y único objeto a valorar. Este criterio estaba presente en las notas sobre aquellos colaboradores jóvenes, que planteaban su actividad como excluyente, y venían respaldados por un inicio promisorio, una colaboración regular en la prensa, o como en el caso de Darío, por el hecho de haber editado unas cuantas de sus obras. Estos eran los casos de Darío, Lugones, Berisso, Enrique Rodríguez Larreta, ${ }^{142}$ Delio Miranda seudónimo de Groussac como autor de "Lo que se ama"- o de la figura que Groussac perfilaba como el autor anónimo del cuento "La pesquisa", que no era otro que él mismo. ${ }^{143}$ En las siluetas de los jóvenes el director de la revista, en tanto crítico especializado, vaticinaba, pronosticando triunfos, y prodigaba consejos nunca exentos de aristas filosas. El caso de Enrique Rodríguez Larreta, quien gozaba de las prerrogativas de la cuna y del talento, y al cual Groussac definía como "príncipe de la generación entrante" augurándole un futuro innegable como escritor, representaba una situación que se tornaría cada vez más excepcional.

Como antítesis de la figura del poeta joven, se leía en 'Redactores' el caso de Rafael Obligado, nacido en 1851. Aunque coincidía con Berisso, Lugones o Darío en el hecho de no haberse graduado en la universidad, ${ }^{144} \mathrm{y}$ en hacer de la literatura su actividad principal, era distinto por varios motivos. En primer lugar, Obligado era un poeta consagrado, cuya obra gozaba de reconocimiento tanto en América como en España; ${ }^{145}$ en segundo término, y ésta era una diferencia fundamental, su dedicación exclusiva a la literatura, fundada en la fortuna familiar, se había construido, según Groussac, de

${ }^{142}$ Enrique Rodríguez Larreta, un año mayor que Lugones, constituía un caso distinto. Había cursado y concluido sus estudios de derecho y provenía de una familia rica.

${ }^{143}$ En nota al pie, Groussac afirmaba: "La persona respetable que nos comunicó el manuscrito nos lo dio como el estreno literario de un joven argentino." Según León Benarós, algunos otros seudónimos de Groussac fueron: Candide, X, (Le Courrier français), Junius, Dilettante, Fiacre, Graphis, Grafus, Graindorge, Petit-Jean, Puck, Tom Pastell, Witness, Nichette, Misogyne. Cf. Benarós, 1998: 14.

${ }^{144}$ La nota de Groussac aclara que estudió en la universidad "sin seguir carrera facultativa".

${ }^{145}$ Era miembro correspondiente de la Academia española y "académico de la Facultad de letras" (271) 
espaldas al mercado de las profesiones: Obligado había logrado "preservar el gusto y el ejercicio de la literatura, de la compulsión profesional fomentada por la onda expansiva del periodismo y de las luchas políticas" (Prieto, 1988:113). Por otra parte, Obligado era en 'Redactores' el poeta de Poesías (1875) Héroes y tradiciones -en ese momento en preparación- y si bien la temática de este "poeta argentino" (271) al igual que el tipo de alejamiento del mercado y de la política que lo caracterizaba, eran de orden más residual comparado con el que por esos mismos años propondrían algunos miembros de $E l$ Mercurio de América, se apuntaba ya una definición de la literatura como aquel espacio de la imaginación no contaminado de cuestiones prosaicas. ${ }^{146}$

Por último, en la sección 'Redactores' Groussac construía una gama de imágenes públicas reconocibles vinculadas con el mundo intelectual en la que se evidenciaba la ambigüedad de ese término literario y su extensión. Así aparecían en esa galería el héroe nacional (Mitre, quien además aparece frecuentemente en la revista), el militar (Iriarte), el profesor (Matías Calandrelli, Amadeo Jacques) $)^{147}$, el orador (N. Avellaneda, Pellegrini), el jurista (Dellepiane, Vélez Sarsfield), el político (Roca), el publicista (Alberdi), el poeta (Darío). Este amplio colectivo y su variedad de tipos constituía un canon político-intelectual marcado por una participación intergeneracional; la misma, característica de esta fase de la vida intelectual, se encontraría aún a comienzos de siglo $\mathrm{XX}$, en la revista Ideas y en los primeros ocho años Nosotros, dos publicaciones llevadas adelante por grupos de jóvenes que a diferencia de La Biblioteca revistieron, aún en su

\footnotetext{
${ }^{146}$ En este sentido se trata de que lo señala Terry Eagleton en el capítulo I, "Ascenso de las letras inglesas", de su Una introducción a la teoría literaria. Si bien es cierto que no puede trasladarse la forma en se produce la autonomización de la literatura en Inglaterra a la forma en que se produce en Argentina, creemos que lo señala Eagleton puede servir para reconocer puntos de coincidencia. Afirma Eagleton: "ya se comienza a advertir en el seno de ese radicalismo literario [está hablando del romanticismo] otro énfasis que para nosotros resulta más familiar: la insistencia en la soberanía y en la autonomía de la imaginación, en su espléndido alejamiento de cuestiones exclusivamente prosaicas tales como alimentar a la propia prole o luchar por la justicia social" (32). Recordemos lo que unos párrafos más atrás observaba respecto del término prosaico: "Es un hecho que durante el período romántico el término descriptivo 'prosaico' (escrito en prosa) comenzó a adquirir la acepción negativa de 'prosaico' como sinónimo de insulso, vulgar, carente de inspiración" (31). (Eagleton, 1983: 29-70).

${ }^{147}$ Groussac dedica a Amadeo Jacques una de las notas más extensas de 'Redactores. Lo recuerda, además de en su propia versión de connacional francés, en la de Cané: "De la autoridad paternal que ejercía sobre la juventud porteña, se encuentra un eco vibrante en las Juvenilia de Cané..." (264)
} 
amplitud estética, rasgos decididamente formacionales, y por lo tanto más cercanos a la dinámica de un mundo literario regido por sus propias normas.

\section{La lección de Groussac: la organización cultural}

En 1929, año de la muerte de Paul Groussac, la revista Nosotros publicó un número de homenaje. En el artículo "Reflexiones sobre Pablo Groussac", Alberto Gerchunoff observaba dos cuestiones de carácter general que servían, sin embargo, para pensar la significación de la tarea de Groussac desde las páginas de La Biblioteca y su condición diferencial con respecto a otros escritores que le eran contemporáneos. Afirmaba Gerchunoff: “(...) en un país mentalmente desorganizado, realizó como el humanista del siglo $\mathrm{XV}$, una misión pedagógica de ordenamiento y regulación" (Gerchunoff, 1929: 67). ${ }^{148}$ Por otra parte explicaba: "En una época en que la literatura era un desdoblamiento de la acción política, o un empeño fugaz de aficionados, Pablo Groussac pudo consagrarse, en casi todas las circunstancias de su vida, a la tarea de escritor. El destino le fue favorable" (Gerchunoff, 1929: 63). Algunas otras notas publicadas en ese volumen de Nosotros fueron coincidentes en pensar a Groussac bajo esta imagen del organizador que ellas mismas contribuyeron a forjar, principalmente en ámbito de los estudios históricos. ${ }^{149}$ En ese campo se lo reconocía como maestro y verdadero iniciador de una forma de hacer historia fundada en el análisis riguroso de los

\footnotetext{
${ }^{148}$ Cursivas nuestras.

${ }^{149}$ Cf. en el tomo de homenaje de Nosotros, "Paul Groussac" de Ramón J. Cárcano (22-25),"Groussac historiador y crítico" de Enrique Ruiz Guiñazú (57-62), "Reflexiones sobre Pablo Groussac" de Alberto Gerchunoff (63-67),"Dos lecciones de Pablo Groussac" de José María Monner Sans (75-78), "Los hombres y la historia en Groussac" de José Luis Romero (107-112). Es importante señalar que también había críticas a la perspectiva elitista con que encaró la historia. José Luis Romero observaba: "Groussac, aunque él mismo se contradiga en la teoría, aunque él mismo niegue en parte la posibilidad de medir con igual medida alas masa y a las personalidades aisladas, ha conseguido encontrar la relación y el sentido en que los individuos se mueven en el devenir histórico y ha orientado su historia en sentido manifiestamente minoritario: una historia general hubiera sido para él una serie de pequeños renunciamientos" (Romero, 1929: 110).
} 
documentos que se distinguía de la impresión y del mero acopio de datos. José Bianco, quien se quejaba de la condición argentina de "pueblo remolcado" y consideraba a Groussac como actor extremo de tal situación, sostenía que "le ha incumbido a un extranjero la tarea de organizar nuestra vida intelectual e iniciar una revisión amplia y minuciosa de nuestros valores, comenzando por los históricos" (Bianco, 1929: 81-89). Bianco señalaba además la labor de "terrible fiscalización" que en tanto crítico había desarrollado Groussac, ${ }^{150}$ para destacar así el invariable carácter polémico y no condescendiente de sus escritos. Esta misma figura del organizador tuvo su descendencia en estudios críticos posteriores. Entre ellos, Luis Alberto Romero en el prólogo a la edición de Los que pasaban, se refiere a Groussac como "organizador de la cultura y verdadero mentor y maestro de varias generaciones intelectuales argentinas" (Romero, Luis Alberto, 1980: I-VI); Alejandro Eujanián, por su parte, le asigna un "rol de guía intelectual de una nación que consideraba culturalmente atrasada" (Eujanián, 2003); Paula Bruno, en la "Introducción" de su libro, sostiene para Groussac la función de "articulador del espacio cultural argentino durante el cambio de siglo" [pasado] (Bruno, 2005: 18).

“Ordenamiento y regulación”, dos ideas a partir de las cuales interpretar y describir las acciones de Groussac a finales del siglo XIX y que remitían, por una parte al reconocimiento objetivo de la necesidad de encauzar los esfuerzos de la intelectualidad de Buenos Aires, y por otra, al gesto voluntarista que caracterizaba sus intervenciones desde La Biblioteca. Groussac se imaginaba a sí mismo como legislador y organizador de la forma de la política cultural y en ese sentido debía pensarse el pacto entre empresas culturales y Estado, así como las relaciones entre intelectuales y Estado, tal como aparecen en "El Centenario". ${ }^{151}$ Verdaderas consignas para la acción intelectual, dichas ideas se actualizaban en la diferenciación clara que, en tanto desideratum, prescribía Groussac entre los intelectuales y los escritores con respecto a los políticos, y en la atribución de una serie de obligaciones para la crítica, que resultaban novedosas. A partir de la construcción de su figura como la de un crítico experto, se leía la intención del reconocimiento de la literatura como la posesión de un saber específico, de una

\footnotetext{
${ }^{150}$ Beatriz Colombi retoma y desarrolla esta idea de Bianco. Cf. Colombi, 2004: 71 y ss.

${ }^{151}$ La Biblioteca, Año II, Tomo V, agosto, 1897, pp. 287-305.
} 
técnica. Para Groussac los escritores se distinguían por una parte, por una cierta especificidad de saberes y formaciones, y por otra, junto con los intelectuales, por el modo de participación que ambas figuras sociales deberían tener en el campo político. Los políticos aparecían como la contracara negativa de intelectuales y escritores y se recortaban de ellos en función de su oportunismo. El político era definido como hombre que "piensa y obra al día", y comparable con el hombre de negocios, en la medida en que "no es otra cosa que un especulador de hombres, para quien la ley de la oferta y la demanda rige también esta mercancía" (173). El campo político no debía ser para Groussac la arena en que se consagraran y se realizaran los intelectuales. Sus reclamos en ese sentido se volvieron explícitos, por ejemplo, en la segunda entrega de "La Biblioteca de Buenos Aires", ${ }^{152}$ en la cual describía la trayectoria de aquellos a quienes él considera miembros de la "superioridad intelectual". El escrito enunciaba la relación presente y dominante de los intelectuales, -y también de algunos escritores-, con respecto a la política. Decía Groussac, explicando la renuncia de Tejedor a la dirección de la Biblioteca Nacional.

En estas repúblicas, es imposible que cualquiera superioridad intelectual no remate en la política, como en la encrucijada central a la que conducen todas las avenidas. No vivirían aquí impunemente Pasteur o Darwin, sin habérselas con algún ministerio o presidencia de cámara, como el poeta Mármol, que era estadista como un zorzal. Nuestra máquina política es tan perfecta, que contiene en sí misma su principio y su fin. (173).

También y en el mismo artículo, Groussac señalaba la aberración de que un poeta, Mármol, ocupara otras funciones para las que, desde su mirada de erudito y especialista, no estaba preparado. Pero lo disculpaba: dado que era la "situación social", traducida en un ordenamiento sociopolítico embrionario, defectuoso, e incompleto la que producía esa colocación desajustada en virtud de la cual los intelectuales invariablemente desempeñaban cargos políticos.

${ }_{152}$ "La biblioteca de Buenos Aires", Año I, Tomo I, julio, 1896, pp. 161-193. 
La culpa mayor en sus dislates críticos y oratorios pertenece a la organización social, incompleta $\mathrm{y}$ provisoria, de que antes hablé, y según la cual la vida pública es el fin y la consagración de todas las notoriedades. Mármol fue escritor y orador político, diputado, senador, casi ministro, lanzándose a las discusiones más especiales y técnicas, tendiéndose a fondo en el asunto más extraño a sus aficiones, con admirable intrepidez. Su falta de preparación era enciclopédica! (179)

Más allá de la descalificación de Mármol en tanto poeta y más aún, poeta puesto a político, se subrayaba el lugar desviado de la consagración en ausencia de un espacio propio de circulación para la producción literaria, dentro de la lógica de funcionamiento de ese enmarañado espacio. Así, Mármol se consagraba en su tiempo como escritor -aunque para Groussac fuera un pésimo novelista y peor poeta- en el espacio del ejercicio de un mandato político. Contra ese estatuto de los intelectuales asentado en la diversificación de funciones en dominios diferentes, Groussac esgrimió la necesidad del conocimiento especializado y la demanda de autonomía para los productos intelectuales.

El director de La Biblioteca asumió para el circuito de la alta cultura letrada funciones similares a las de un "estratega cultural" y a la vez las de un "experto literario". ${ }^{153}$ Como estratega cultural consideraba central la función de cierta prensa y de las revistas para la construcción y consolidación de un público culto, se encargaba del comentario bibliográfico de las novedades que consideraba relevantes del "mundo literario" de Buenos Aires, y como mediador de la cultura europea, fundamentalmente francesa, reseñaba también libros de interés diverso. Como experto literario, desde $L a$ Biblioteca, su figura se proyectaba en la vida cultural de Buenos Aires de fin del siglo XIX, como la del casi único crítico especializado, ${ }^{154}$ y los casos en que esta práctica se

${ }^{153}$ Tomo estos dos conceptos de Terry Eagleton en su The Function of Criticism. From The Spectator to Post-Structuralism, London, Verso, 1992. Para Eagleton, la función del crítico como estratega cultural en la Inglaterra del siglo XVIII es la de comentarista, informador, mediador, intérprete y popularizador y su deber es consolidar y reflejar la opinión pública, al mismo tiempo que conducir la discusión general frente a su público El crítico como experto literario, se define, por contraposición, como el exponente de una competencia intelectual especializada (Eagleton, 1992).

${ }^{154}$ A excepción de Martín García Mérou, quien, sin embargo, no había intervenido en el mismo sentido y de la misma forma que el director de La Biblioteca. 
ejercitaba, constituían un episodio en el que se ostentaban las características observables en un campo literario constituido. ${ }^{155}$ En ese sentido, si la revista mostraba una intención inclusiva en relación con lo nuevo en general, ${ }^{156}$ cuando se diera la ocasión de emitir un juicio, Groussac no escatimaría las más feroces y certeras observaciones, a la vez que prodigaría consejos útiles a los jóvenes y no tan jóvenes, construyendo para sí mismo el lugar del maestro. Groussac 'olvidaba' en estos casos la precariedad del mundo literario argentino, para enseñar con el ejemplo, en qué debía consistir y cuáles debían ser las reglas del debate estético, y al exigir su observancia, era también su juez. ${ }^{157}$

La sección en que este tipo de crítica se localizaba era 'Boletín bibliográfico'. Si bien como ya observamos, en esta sección se publicaron notas sobre libros de distinta clase, nos detendremos en el análisis de aquellas que consideramos significativas en relación con las posturas de Groussac en cuanto al modernismo y al criollismo, para señalar su vinculación con la posibilidad de construir una literatura nacional tal como ésta se formulaba en la revista, con mayor o menor grado de explicitación. Dar cuenta de estas intervenciones permite mostrar las afiliaciones de su lectura con una poética determinada, pero, sobre todo, los criterios generales del juicio estético en los que se basaría una crítica que se quiere especializada. Escritos como el dedicado a Los raros de Rubén Darío promovieron la admiración de los jóvenes escritores de fin de siglo y abrieron el espacio a réplicas no menos contundentes, ${ }^{158}$ en un juego que oscilaba entre el reconocimiento de la autoridad intelectual de unos y la proclamación del talento de

${ }_{155}$ Sonia Contardi, a partir de su consideración del circuito de la cultura letrada de Buenos Aires entre 1880 y 1910, como un espacio más cerrado y menos permeable, sostiene que el mismo podría ser pensado como "una biblioteca o recinto, administrado culturalmente por el General Mitre, el periódico La Nación y por Paul Groussac" al que califica como guardián del sector más ilustrado y cuyo órgano reconoce en la revista La Biblioteca. Contardi afirma que el ingreso (irrupción) de Darío en ese circuito produce una alteración, cuya respuesta debe ser leída en la nota de Groussac sobre Los raros. [en cursivas en el original] Cf. Contardi, 1994: 7-36. Creemos, sin embargo, que las nociones de estratega cultural y crítico experto son preferibles a la de guardián, dado que aunque ésta última sirve para dar cuenta de la oposición que la nueva sensibilidad despertaba en no pocos miembros de aquel circuito, desdibuja el interés cierto y la amplitud -de Groussac, entre otros-, por las nuevas figuras, con las cuales compartieron espacios de sociabilidad literaria.

${ }^{156}$ En la nota referida a Prosas profanas de Darío, se leía este deseo de inclusión en la amplitud de criterios, aunque fundada en su condición de superioridad intelectual: "yo soy un griego de Focea, amante de la luz y bebedor de vino; de ningún modo un fumador de opio 'podeoroso y sutil': pero mi cabaña tiene galería abierta hacia los cuatro vientos y está construida ante un vasto horizonte, sobre un promontorio que domina el mar", Año II, Tomo III, enero, 1897, pp. 152-158. Cursivas nuestras.

${ }^{157}$ Rodolfo Borello califica a Groussac de "juez por excelencia en cuestiones literarias" dentro de un variante de la crítica la que denomina dogmática o magistral. (Borello,1967) 
otros, y en el que desde la prensa como sitio privilegiado se cuestionaba fuertemente el control oligárquico del aparato cultural. Como se sabe, el autor de Azul respondió los ataques del director de la revista a Los raros con un artículo, "Los colores del estandarte", que era además parte de su campaña a favor del movimiento modernista en Buenos Aires. ${ }^{159}$

Por otro lado, y como parte de aquella función de ordenamiento del mundo cultural, es posible leer en La Biblioteca el esbozo de una programa de literatura nacional en el que adquiría una importancia efectiva la función de la crítica, en tanto modo de discriminar las obras genuinas de las carentes de valor, seleccionando aquellas que podrían ingresar en una tradición que ella misma propondría y construiría. En un contexto de especialización e institucionalización de la literatura, de la que era una prueba la creación de la Facultad de Filosofía y Letras, una crítica como la que Groussac ejerció puede ser pensada también desde el punto de vista de la organización de una literatura argentina, como afirmación de un concepto más especializado de literatura, en tanto sus prescripciones apuntaron, además del asunto, aspectos relativos

\footnotetext{
${ }^{158}$ Además de la polémica que ocasionó el cierre de la revista, en La Biblioteca se dio otra, con Mitre, también vinculada con la labor de Groussac como historiador, sobre las invasiones inglesas a Buenos Aires. Mitre había publicado en La Nación ciertas críticas a las notas de Groussac sobre Liniers que habían aparecido en la revista, en las entregas de septiembre de 1896, enero, febrero y marzo de 1897. Groussac le respondió con un artículo "Liniers. Digresión polémica, por Paul Groussac", en el que además, para que el lector tuviera presentes los argumentos que intentaba rebatir, aparecían las objeciones de Mitre. Cf. La Biblioteca, Año II, Tomo IV, junio, 1897, pp. 436-480. Así lo explicaba: "El señor Mitre, cuya Historia de Belgrano necesita consultar muy a menudo todo aquel que de estas materias argentinas se ocupe, ha dignádose prestar atención a ciertas críticas menudas que de pasada hemos creído útil apuntar. A decir verdad, hubiéramos preferido que el ilustre historiador se diese espera hasta la conclusión de este trabajo antes de salir, a la defensa de sus opiniones. A no haberse abierto el ingrato paréntesis, esta sería la hora en que, sin duda para solaz de nuestros lectores, terminaríamos nuestro bosquejo del virreynato de Liniers y el trágico alborear de la Independencia. Pero, iniciado el debate en la forma que más reproducimos, y dada la calidad excepcional de su autor, nadie extrañará que, nuestra costumbre de guardar silencio ante objeciones casi siempre superficiales y desinteresadas, interrumpamos el relato para acudir a la brecha.

La forma de esta réplica habrá de ser forzosamente minuciosa y pedestre, teniendo que seguir paso a paso el itinerario marcado por nuestro respetable impugnador. Para no acrecentar lo árido de la discusión, -y también evitar las citas truncas que sirven de pretexto para eternizar las polémicas, -juzgamos conveniente transcribir in extenso el interesante trabajo del Señor Mitre (el cual, digámoslo entre paréntesis, tenía en la Revista que se honra con tan valiosa y asidua colaboración). Así el lector tendrá a la vista todo el expediente y podrá sin esfuerzo escoger entre las dos versiones contradictorias" (236-237).

${ }^{159}$ Los colores del estandarte apareció en el La Nación el 27 de noviembre de 1896.
} 
a los recursos y la lengua utilizados. ${ }^{160}$ En ese sentido, y sin dejar de tener presente que el cumplimiento de la tarea asignada a los escritores, críticos e intelectuales puede inscribirse en términos de Eric Hobsbawm como una "necesidad" de los Estados, ${ }^{161}$-lo que impide olvidar el carácter heterónomo de la escritura-, revisaremos una intervención como la de Joaquín V. González publicada en la sexta entrega de la revista; su lectura permite ver que el servicio de construcción de la nación como comunidad imaginaria y la especialización, como una forma de la autonomía, no necesariamente fueron pensados, desde la perspectiva de un funcionario estatal, como condiciones de enunciación excluyentes para los escritores, en tanto estos últimos eran considerados expertos, conocedores y sistematizadores de la materia de la futura tradición nacional. $^{162}$

\subsection{La discusión con el modernismo}

En La Biblioteca la presencia del modernismo como poética epocal, ${ }^{163}$ la de Rubén Darío, su más alto exponente, así como las de Leopoldo Lugones, Leopoldo

\footnotetext{
160 Raymond Williams, en Marxismo y literatura, repasa la historia europea del concepto literatura, y señala que durante el proceso de su especialización en el sentido de trabajos creativos e imaginativos la crítica tomó una nueva y efectiva importancia en tanto era la que podía validar dicho concepto especializado, discriminando las obras auténticas de las menores. Observa a su vez que este desarrollo del término dependía de una elaboración del concepto de tradición al que se asociaba, desde el Renacimiento, la idea de una literatura nacional. Esta, por su parte -explica Williams- "dejó de ser historia para convertirse en tradición", en tanto se trataba de una "selección que culminó, de un modo circular definido, en los 'valores literarios' que estaba afirmando la 'crítica' " (Williams, 1980: 66-67)

${ }^{161}$ Eric Hobsbawm ha observado que entre 1880 y 1914 la declinación de las comunidades reales -como la familia, la aldea, la parroquia, el barrio, o los gremios, entre otras- se produjo porque las mismas ya no podían abarcar como anteriormente lo habían hecho, la "mayor parte de los acontecimientos de la vida de la gente [y] sus miembros sintieron la necesidad de algo que ocupara su lugar". Para Hobsbawm fue la nación, entendida como comunidad imaginaria, la que colmó ese vacío y se vinculó inherentemente con el estadonación, fenómeno típico del siglo XIX. Afirma que "El estado no solo creaba la nación, sino que necesitaba crear la nación (...) [que] era la nueva religión cívica de los estados. Constituía un nexo que unía a todos los ciudadanos con el estado, una forma de conseguir que el estado-nación llegara directamente a cada ciudadano, y era al mismo tiempo un contrapeso frente a todos aquellos que apelaban a otras lealtades por encima de la lealtad del estado: a la religión, la nacionalidad o a un elemento étnico no identificado con el estado, tal vez sobre todo a la clase". (158-159). Cf. Hobsbawm 1991: 152-174.

${ }^{162}$ En cuanto a la relación de los intelectuales -no solo escritores- con el Estado, Leticia Prislei ha observado cómo Joaquín V. González "habilita" a los intelectuales para solucionar la cuestión social y reconoce en ese gesto la convicción del poder político acerca de la necesidad de crear una esfera pública vinculada al pensamiento, las artes y las ciencias. (Prislei, 1999)
} 
Díaz, ${ }^{164}$ Luis Berisso -y a través de este último, la de Manuel Gutiérrez Nájera-, es relevante porque funciona como uno de los conectores principales con las revistas que componen el corpus de la investigación. En ese sentido, prefigura y habilita el mecanismo que definimos como posta intelectual en tanto el modernismo y el conjunto de problemáticas y tópicos asociados a él se harán presentes, con modulaciones distintas, en El Mercurio de América, La Montaña, Ideas y Nosotros. Así, por ejemplo, la definición del artista o del intelectual como aristos, en un contexto social marcado por una masificación creciente y la consecuente demanda de autonomía para el arte, serán puntos de coincidencia; igualmente, la ambición de construir un público de pares o ampliado, según el caso, aparecería también como punto de articulación entre estos órganos. La figura de Darío, constituiría para los jóvenes de El Mercurio de América la referencia más fuerte de su inscripción en la escena literaria: a él y al boliviano Ricardo Jaimes Freyre pedirían prestadas sus palabras de apertura. La Montaña publicará "Metempsicosis", alabaría la calidad moral de su autor, y tendría por momentos, en las colaboraciones de Lugones, una impronta de filiación fuertemente decadentista; algunas notas de Alberto Gerchunoff en Ideas pensarían la literatura argentina a partir de la experiencia modernista; Nosotros se abriría con la publicación conjunta de un fragmento de una obra de Payró y la crítica que Darío escribiera para La Nación. En lo que sigue veremos cómo la inclusión del modernismo en la revista de Groussac ameritó un debate estético más específico a partir de las reseñas de Los raros y Prosas profanas, y casi por contraposición, dio pie para formular los lineamientos de un programa de literatura nacional.

La publicación de La Biblioteca entre 1896 y 1898 coincidió con tres de los cinco años durante los que Rubén Darío vivió en la Argentina. ${ }^{165}$ Desde mediados de agosto de

\footnotetext{
${ }^{163}$ Rama sostiene que en Darío la palabra "modernismo", desde Azul (1888) hasta El canto errante (1907), no definió una estética sino una poética epocal en la que podían incluirse distintas poéticas individuales (Rama, 1985: 64)

${ }^{164}$ En la última parte de la entrega de mayo de 1897 de 'Boletín Bibliográfico', Groussac se ocupó de las Traducciones de Leopoldo Díaz (327-328), atacando no solo las traducciones sino el ejercicio mismo de la traducción: "La traducción en verso, como todos los géneros literarios, tiene sus leyes propias: la primera de todas es que no se debe intentar." Año II, Tomo IV, mayo de 1897. Los autores vertidos al español, eran, entre otros, Horacio, Leconte de Lisle, Poe. (327)

${ }^{165}$ Como ya observamos en nota, en el parágrafo 2.4 de este capítulo, Rubén Darío llegó a nuestro país el 13 de agosto de 1893, en el vapor francés Diolibah y dejó la Argentina el 8 de diciembre de 1898.
} 
1893 hasta principios de diciembre de 1898, el escritor nicaragüense desarrolló una intensa actividad literaria que se desplegó en la edición de dos de los libros más importantes de su campaña de legitimación del modernismo, a saber, Los raros y Prosas profanas; en la frecuentación de variados espacios donde se encontraban escritores e intelectuales, como lo fueron cafés, restaurantes, redacciones de diarios; en su múltiple colaboración en el periódico de Mitre; luego en La Tribuna dirigida por Mariano de Vedia y El Tiempo de Carlos Vega Belgrano; como partícipe de las reuniones y actividades que llevaba adelante el Ateneo de Buenos Aires, en el cual dictó una conferencia sobre Eugenio de Castro, y donde trabó alianzas con los artistas plásticos de entonces. ${ }^{166}$ Desde su llegada a Buenos Aires funcionó como el poeta faro de los escritores jóvenes modernistas, no solo desde el punto de vista escriturario, sino también, por su experiencia de 1894 con La Revista de América, que había dirigido junto a Jaimes Freyre, otra de las figuras centrales del movimiento literario hispanoamericano.

Si bien La Biblioteca no fue una publicación estrictamente literaria, y su director no fue nunca partidario de la nueva estética promovida por Darío y sus adeptos, sus páginas dieron a conocer, y en ese sentido, respaldaron a aquellos jóvenes en quienes el director reconocía la presencia de talento y originalidad. Esto era posible no solo por una búsqueda indeclinable y tenaz de lo nuevo por parte Groussac, ${ }^{167}$ que lo definía como crítico moderno, sino también porque la sociabilidad literaria de entonces, aún en el disenso, priorizaba el establecimiento y fomento de vínculos con representantes de posiciones estéticas divergentes y antagónicas, incluso en el caso de los que aspiraban a la renovación. Las reuniones del Ateneo en las que se dieron cita escritores, intelectuales y artistas de procedencia y edades variadas, eran prueba de ello. Si bien el Ateneo mantenía un efectivo carácter elitista, era un tipo de institución que con sus propios cambios, dejaba atrás la práctica de las reuniones privadas, para abrirse a una participación más amplia, aunque no popular. ${ }^{168}$ Además, el prestigio intelectual de

\footnotetext{
${ }^{166}$ Cf. Malosetti Costa, 2001.

${ }^{167}$ Así lo expresaba: "Pido a la Justicia -que espero sea la suprema Lógica-, que, al llegar alguna vez la inevitable decadencia, me ahorre el dolor de verla producirse, en lo físico por la sordera, en lo intelectual, por el odio a la novedad" (...) me doy el testimonio , en mi esfera limitada, de no haber dejado pasar hasta ahora una innovación artística, desde Wagner hasta Ruskin y Moréas, una tentativa científica" La Biblioteca, Año I, T2, noviembre, 1896, p. 476.

${ }^{168}$ Para ver el cambio en las formas de relación entre escritores, cf. Rama, 1985: 41.
} 
Groussac en el mundo cultural de entonces, que José Bianco identificó con la "posición de Summus Magister que aquí espontáneamente se le acordó” (Bianco, 1929: 84), hacía de la revista un espacio de difusión y consagración altamente valorado. En ella se publicaron "El coloquio de los centauros", "Folklore de la América Central. Representaciones sus bailes populares de Nicaragua"; bajo el título "Poemas de América", un poema sin nombre y "Tutecotzimi"; "El hombre de oro" (en tres entregas) de Darío; de Lugones, "La voz contra la roca", "Táctica” y "Un estreno; de Berisso, "Manuel Gutiérrez Nájera"; de Enrique Rodríguez Larreta, “Artemis". 169

La sección 'Boletín bibliográfico' estuvo a cargo de Groussac y apareció en once de las veinticuatro entregas de la revista. ${ }^{170}$ En general, no se reseñaron obras literarias en el sentido estricto del término, ${ }^{171}$ salvo en cuatro ocasiones; dos de ellas estuvieron dedicadas a las obras de Darío ya citadas, otra, a Recuerdos de la tierra de Martiniano Leguizamón; la última, se ocupaba brevemente de Traducciones de Leopoldo Díaz. La nota con que se inauguró la sección fue la crítica a Los raros; se publicó en la entrega de noviembre de $1896,{ }^{172}$ y doce días más tarde, traspasaría las páginas de la revista, para ser publicada en el diario La Nación, el 27 de ese mismo mes. Este dato, no era ocioso, dado que mostraba la percepción clara de Groussac en reconocer al periódico, y no a su revista estatal, como el espacio más adecuado para un debate, cuya repercusión podría tener un alcance público más amplio y una respuesta polémica del autor del libro, que era colaborador principal del diario. Además, terciaba en una disputa que, anticipada en el suelto del diario de Mitre para promocionar la inminente salida del libro a la venta, se había producido, en efecto, a través de una

\footnotetext{
${ }^{169}$ Es importante observar que Rodríguez Larreta reemplazaría brevemente a Groussac en la dirección de la revista, unos meses antes de su cierre. Éste era un gesto de confianza que obedecía a la posición del joven en tanto hijo de una familia de la elite pero, también al respaldo de su talento por el director. El 'Boletín bibliográfico' de febrero de 1898, se explicaba: "Habiendo el director de La Biblioteca resuelto tomar algunas semanas de descanso, el doctor Enrique Rodríguez Larreta ha aceptado gentilmente la dirección interina de la revista." Año II, Tomo VII, febrero, 1898, p. 320.

170 'Boletín bibliográfico' se publicó en: noviembre y diciembre de 1896, enero, marzo, abril, mayo, julio, agosto de 1897, enero, febrero, abril - mayo de 1897 (esta última entrega corresponde al número doble 23-24, que constituye el octavo tomo, con que se cierra la revista; en el recuento de las apariciones de la sección, es contada como una sola).

${ }^{171}$ Cf. el anexo LB.

${ }^{172}$ La Biblioteca, Año I, Tomo II, noviembre, 1896, 474- 480. La revista se publicaba el 15 de cada mes.
} 
serie de intervenciones, algunas muy favorables y otras no tanto. ${ }^{173}$ En efecto, "Los colores del estandarte", salió en el mismo medio, dos días después de que Groussac publicara su nota.

Aunque apenas empezada la reseña de Los raros, su autor expresaba el reconocimiento por el "talento tan indiscutible" del escritor, alababa su modestia y la dedicación exclusiva al arte, inmediatamente después condenaba la obra por considerarla un despilfarro de las dotes artísticas del poeta. La objeción fundamental, que en Groussac alcanzaba no solo al nicaragüense sino prácticamente a toda Latinoamérica, apuntaba al peligro de la imitación. Ese enunciado remitía a la visión particularmente europea del literato francés en la cual, a su vez, era posible leer las propias determinaciones del proceso de modernización en Argentina y el resto del continente, marcadas por la dependencia de las metrópolis como lo fue principalmente París para el caso de los modernistas. ${ }^{174}$ Con un tono ostensiblemente irónico, se refería a Darío como "heraldo de pseudotalentos decantes, simbólicos, estetas", importador e imitador del decadentismo francés en Buenos Aires. ${ }^{175}$ Este derroche de talento que tenía su motivo, según Groussac, en una posición desventajosa del poeta frente a la lectura de Verlaine, hacía de Los Raros un intento fallido. Tal situación desfavorable -dominada- se originaba en dos carencias, a saber: Darío era ante todo un poeta, no un crítico, y no era francés. ${ }^{176}$ Estas faltas de Darío constituían posesiones para Groussac, haciendo del

${ }^{173}$ El libro salió el 12 octubre. Luis Berisso escribió a los pocos días un artículo para La Nación (16/10/1896); Miguel Escalada, redactó una biobibliográfica sobre Darío que apareció en ese mismo periódico el 29 de octubre; Paul Corti, en La Nación intervino con "El movimiento literario. Fenómeno raro originado en Los raros" (6/11/1896). Lugones en El Tiempo, y a favor de Léon Bloy, que había sido calificado de raté por Groussac, publicó "Desagravio de un raté" (25/11/1896), y ya había escrito sobre Los raros en el periódico de Vega Belgrano (26/10/1896). Manuel Ugarte, en su Revista Literaria sacó una breve nota. Cf. Colombi, 2004; Barcia, 1965; Contardi, 1994:7-36.

174 Miguel Dalmaroni ha señalado que: "Cuando hablamos de la modernización de la literatura argentina estamos, así, frente a un problema de relaciones de subordinación respecto de la metrópoli europea (para el período que nos interesa, sobre todo París y Madrid). El estudio de esas relaciones deberían conducirnos, por supuesto, no a describir los procesos latinoamericanos como cumplimientos defectuosos de los modelos adoptados, sino a notar cómo aquella subordinación se cuenta entre las determinaciones de las formas históricamente específicas que tuvo el proceso de modernización en América Latina". (Dalmaroni, 2006: 29)

${ }^{175}$ Decía Groussac: "El autor de esta hagiografía literaria es un joven poeta hace tres años (...), trayéndonos, viâ Panamá, la buena nueva del 'decadentismo francés' (474)

${ }_{176}$ Groussac, en la noticia biográfica de 'Redactores' correspondiente a la entrega de julio de 1896, que era la segunda, había anunciado que el poeta tenía en prensa un libro de crítica llamado Los raros. 
crítico un mediador necesario entre la literatura francesa y la americana, es decir, colocándolo en un lugar privilegiado. En la descripción de Groussac, el "autor de esta hagiografía", en la que se emparentaba a artistas consumados con verdaderos ratés, mostraba los signos de extravío en una lengua y en una cultura que no conocía ni le eran propias:

\begin{abstract}
Vagaba, pues, el señor Darío por esas libres veredas del arte, cuando por mala fortuna vínole a las manos un tomo de Verlaine, probablemente el más peligroso, el más exquisito: Sagesse. Mordió en esa fruta prohibida, que por cierto, tiene en su parte buena el sabor delicioso y único de esos pocos granos de uva que se conservan sanos, en medio de un racimo podrido. El filtro operó plenamente, en quien no tenía la inmunidad relativa de la raza ni la vacuna de la crítica [cursivas nuestras] (475)
\end{abstract}

Groussac insistía en la calidad y especificidad del saber literario que poseía, y que autorizaban su palabra, para fundar un discurso crítico de carácter polémico. "No me meto de rondón en estas teologías" (479), decía, para advertir a Darío sobre los peligros de la adaptación al castellano del metro francés usado por los decadentes. Groussac definía la crítica como una vacuna y la ubicaba, entonces, en el mismo rango que otros discursos, si no científicos, al menos especializados. Además, en su mirada eurocéntrica, exhibía y machacaba la condición de superioridad de Francia, frente a una cultura joven como la de Latinoamérica, donde la inexperiencia y el desconocimiento resultaban inevitablemente en la "remedada cavatina de un histrión" (480).

Groussac analizaba y atacaba el simbolismo y el decadentismo franceses y los consideraba renovaciones incompletas por "no tener los jóvenes escritores franceses ideas exactas acerca de la rítmica" (478); a su vez, la prosa decadente no tenía, a sus ojos, ningún valor estético: "no existe como manifestación perceptible para los contemporáneos y admiradores de Flaubert y Taine, de Renan y Veuillot (...) de France y Maupassant, y hasta de Barrès" (480). Así, en tanto el modernismo era considerado por Groussac como una "inoculación" del decadentismo y del simbolismo en la poesía americana, resultaba entonces, como innovación también incompleta, una "mezquina reacción de estilo y sobre todo métrica" contra el naturalismo y el parnaso. Aunque estas 
observaciones literarias fueran atinadas o pasibles de rectificación, lo cierto era que el director de La Biblioteca mostraba que el volumen, más allá de presentarse como un obra de crítica, implicaba básicamente una estrategia de autolegitimación por parte de Darío mismo y a favor de la renovación del arte americano, capitalizando la experiencia de la poesía gala. En ese sentido, atacaba, por superfluos, los recursos que el nicaragüense usaba para distinguirse, convertido en anunciante de la buena nueva del decadentismo francés, y principalmente, criticaba el libro en su factura material. ${ }^{177}$ Con respecto a la misma, el retrato del autor, obra de Eduardo Schiaffino, mostraba un nuevo tipo de alianza estética, entre literatura y bellas artes cuyo objetivo básico era promocionar y legitimar ambas prácticas, y que reaparecería en El Mercurio de América y en $L a$ Montaña bajo la formulación común en el colectivo "artistas". El autor de la nota apuntaba también uno de los problemas que, como ya observamos, sería básico en ese contexto social, cual es el de la separación del artista de la vulgaridad de las muchedumbres, y que llevaría a la enunciación de situaciones paradójicas y extremas, como las que en ocasiones se dieron en El Mercurio de América. ${ }^{178}$

Para sobresalir entre la muchedumbre, al gigante le basta erguirse; los enanos han menester abigarrarse y prodigar gestos estrepitosos. Por eso ostentan la originalidad ausente de la idea, en las tapas de sus delgados libritos, procurando efectos de iluminación y tipografia, a manera de los cigarreros y perfumistas, y que bastarían a caracterizar lo frívolo e infantil de la pretendida evolución. - A este propósito, séame lícito reprochar al señor Darío las pequeñas 'rarezas' tipográficas de su volumen, indignas de su inteligencia. Aquel rebuscamiento en el tipo y la carátula es tanto más displicente, cuanto que contrasta con el abandono real de la impresión: abundan las incorrecciones, las citas cojas, -hasta del caro Verlaine- las erratas chocantes, sobre todo en francés. Créame el distinguido escritor: lo raro de un libro americano no es estar impreso en

${ }^{177}$ La primera edición del libro había sido impresa en los talleres gráficos de la Tipografía La Vasconia. Barcia señala que su publicación había sido anunciada en un suelto de La Nación el 6 de octubre de 1896, y que en la misma se lo describía como un "elegante volumen de 200 páginas impreso en rico papel satinado y llevará al frente un retrato del autor, hecho por el pintor Schiaffino" [tomado de la nota 61 de la "Segunda parte. Darío en la Argentina (1893-1898) del estudio preliminar de Barcia a Escritos dispersos de Rubén Darío)" (53)

${ }^{178}$ Damos cuenta de esto en el parágrafo 4.2. de este capítulo. 
bastardilla, sino traer un texto irreprochable $(475-476)^{179}$

Groussac calificaba de vano el intento de Darío en Los Raros por tres motivos: por su tema, por la lengua en que estaba escrito, y por el público al que apuntaba. Los reproches del final de la reseña indicaban la posibilidad de un arte americano cuya originalidad debía pensarse en relación con el mundo virgen que América constituía. ${ }^{180}$ Esta poética de lo propio es la que para el caso de la literatura argentina defendería Groussac, al referirse a Recuerdos de la tierra.

Como se dijo en el apartado anterior, Groussac construyó su figura como la de un crítico experto, esto es que ejercía su práctica en base a un determinado saber especializado. Si es cierto que la revista mostraba una intención inclusiva en relación con lo nuevo en general y, privilegiaba las relaciones de fraternidad entre los nuevos y los que pertenecían a generaciones anteriores, señalando la necesidad de aunar los esfuerzos de todos aquellos posibles miembros de un campo intelectual, también lo era el hecho de que en la sección ‘Boletín Bibliográfico' Groussac suspendiera esos criterios dominantes de inclusión y ejerciera una crítica belicosa. En ese sentido, se adelantaba comportándose como miembro de un campo literario constituido donde campearan el "espíritu de secta" 181 y la polémica como modalidades definitorias de participación. De este modo, las opiniones de Groussac en tanto crítico postulaban la existencia de un campo literario que juzgaba las obras según valores y criterios estéticos. Estos criterios específicos se manifestaban como una poética crítica, entre cuyos puntos centrales se hallaban el combate contra la imitación, el estudio riguroso, la capacidad de reconocer la calidad y el talento, la búsqueda de lo nuevo entendido como valor estético.

\subsection{La construcción de la literatura argentina}

${ }^{179}$ Groussac, veía en esto una imitación de publicaciones francesas como la Revue Blanche, el Mercure de France, La Plume.

${ }^{180}$ Decía Groussac: "El arte americano será original -o no será. ¿Piensa el señor Darío que su literatura alcanzará dicha virtud con ser el eco servil de rapsodias parisienses, y tomar por divisa la pregunta ingenua de un personaje de Coppée: Qui pourrais-je imiter pour être original?", p. 480.

${ }^{181}$ La frase corresponde a Eugenio Díaz Romero, poeta y director de El Mercurio de América. Más adelante nos referimos a la sección "Las revistas" del $\mathrm{n}^{\circ} 1$ de El Mercurio, en que aparece. 
En la entrega de enero de 1897 de 'Boletín Bibliográfico' Groussac reseñaba dos libros cuya aparición podía ser tomada como motivo de festejo en el panorama casi desierto del circuito de la cultura letrada. El hecho de que en la sección solo se trataran cuatro obras literarias confirmaba dicha escasez. ${ }^{182}$ Estas obras fueron Recuerdos de la tierra de Martiniano Leguizamón y Prosas profanas de Rubén Darío, y los juicios sobre ellas deben pensarse de manera conjunta. A partir de las afirmaciones de Groussac se podía leer la declaración más explícita del programa de literatura nacional que se insinuaba en La Biblioteca. En este programa, basado en una determinada elección de lengua y de tema, se inscribían otros textos literarios publicados en la revista como "El cacui” de Rafael Obligado (en la primera entrega), "Un estreno" y “Táctica” de Leopoldo Lugones, más tarde incluidos en La guerra gaucha ${ }^{183}$ Los tres textos respondían a ese doble requerimiento temático y de lengua literaria. "El cacui" que formaba parte de Héroes y tradiciones, contaba la leyenda de una mujer que no había sido buena hermana y que se convertía en un pájaro que lloraba esa culpa. ${ }^{184}$ "Un estreno" y “Táctica” eran relatos de tema histórico en los que Lugones construía una épica nacional. Este programa de literatura argentina era otra de las ocasiones en que se exponía la tensión entre una funcionalidad de la literatura con relación a las políticas estatales y su necesidad de autonomía.

\subsubsection{En contra del criollismo}

\footnotetext{
${ }^{182}$ Adolfo Prieto, en la introducción de su libro sobre el criollismo, señala esta escasez, que era percibida casi como una queja por los miembros de la alta cultura letrada: "Desde las punzantes citas de Navarro Viola en el Anuario Bibliográfico a las quejosas memorias de Manuel Gálvez; desde las referencias más o menos casuales de Cané, Groussac y Darío hasta los más ponderados informes de Alberto Martínez y Roberto F. Giusti, un único tema obsesiona a los observadores y testigos del circuito de la cultura letrada: la escasez de títulos provistos por los miembros de ese circuito y la limitación del consumo" (Prieto, 1988: 15)

183"Un estreno" fue publicado en la entrega de febrero de 1898, "Táctica", en la última entrega de la revista, en abril de 1898.

${ }^{184}$ En el poema, se compara esos hermanos con el nosotros argentino, fruto de cuya nohermandad, es el sufrimiento de la patria: "Y mientras sufra la patria/ tanto martirio, paisanos, / y nuestros ranchos no sean/ algo más que pobres ranchos, / ¡Ay! porque nunca supimos, / a nuestra vez, ser hermanos, / se oirá ese grito, ese lloro, / Ese clamor desgarrado!" pp. 119-20.
} 
En el comienzo de la crítica de Recuerdos de la tierra Groussac exponía un estado de la cuestión estética. Por una parte, festejaba la aparición del libro porque podía proponerlo como una alternativa viable al decadentismo, y por otra, desconfiaba del éxito que la obra había tenido entre aquellos a quienes apodaba "amantes del argentinismo de circo". Así, el modernismo/decadentismo y el criollismo aparecían como las dos vertientes para una polémica; de ellas el director de la revista rescataría algo para su propuesta de programa de literatura nacional: ${ }^{185}$

La han saboreado, sobre todo, los amantes del argentinismo de circo, que respiran en Juan Moreira o Calandria la infinita melancolía de la pampa y el sano perfume del monte virgen! El señor Leguizamón triunfa sin esfuerzo: no hay exageración en decir que llega a la raya revoleando el talero y golpeando la boca al decadentismo. Puede descansar satisfecho el vencedor y desatarse el pañuelo de la frente

De la cita se desprendía la aprobación del intento de Leguizamón, e inmediatamente se aclaraba los motivos de ese triunfo: Leguizamón se imponía por haber elegido una materia apropiada para su literatura. Sin embargo, Groussac circunscribía la validez de esos recuerdos, porque la restringía a la elección de la materia narrativa, y dejaba de lado su resolución defectuosa. Condenaba, del mismo modo, al público que había valorado o valoraría positivamente la obra, identificándolo con la concurrencia de las representaciones del circo y del teatro criollista. El desprecio hacia los "amantes del argentinismo de circo", leído desde otro ángulo, no era otra cosa que la preocupación por el éxito de que gozaba esa corriente de la literatura y la cultura nacionales, en el fecundo circuito del consumo más popular. ${ }^{186}$ Para el crítico los relatos del entrerriano eran ${ }^{185} \mathrm{El}$ otro enemigo estético para Groussac es el naturalismo, y lo crítica en "La educación por el folletín".

${ }^{186}$ Cabe aclarar que Calandria. Costumbres camperas, también de Leguizamón no era, en realidad, equiparable con Juan Moreira de Eduardo Gutiérrez. La pieza, estrenada en mayo de 1896, en el teatro de la Victoria por la compañía Podestá-Scotti, presentaba un personaje bastante distinto del de Gutiérrez. Puede decirse que se trataba de la reescritura correctiva de la vida de Moreira. Juan Carlos Ghiano ha señalado e insistido en las diferencias entre ambos personajes: "El prontuario policial que fue el origen del folletín de Gutiérrez se había acomodado a la condena de injusticias policiales que ensuciaban al país, y al respeto a los hombres de campo unidos por la hombría rebelde del héroe. En sus líneas fundamentales era la misma suerte de Servando Cardoso, aunque Leguizamón -atento a las modulaciones de su leyenda- evitase el robo de chinas y la matanza de comisarios, como escamoteó el final trágico del matrero, salvándolo para el progreso que se asentaba en campos ayer 
simples "bocetos criollos", ${ }^{187}$ a los que no vacilaba en vincular, por los detalles de edición, con los textos de las colecciones criollistas.

El análisis de la "ejecución" se concentraba en el problema de la lengua literaria de esas narraciones. Contrario de la artificiosidad en el arte y, a su vez, enemigo de la transcripción llana de "las incorrecciones y giros gauchescos que, desde Hidalgo y Ascasubi, se repite servilmente" (153), se oponía así a la lengua literaria de los “criollizantes" que, a su entender, era centralmente imitativa. Afirmaba: "El arte es la dificultad: jóvenes, desconfiad de los recursos fáciles!” (153) Las reflexiones de Groussac se organizaban en torno de una frase que aludía al atuendo estrafalario de una lengua marcada por la impertinencia de la mezcla, en la que la variante culta se usaba de manera ridícula y artificiosa ("la pompa gerundiana”): "(P)odríamos pedirle que su estilo no vistiera el smoking arriba del chiripá”, se quejaba (154). La lengua cimarrona de Recuerdos de la tierra era producto del artificio que convertía a la lengua culta de pacotilla en criollizante, dando por resultado una hibridez que para Groussac resultaba imposible, y que no debía ser la norma de una literatura nacional. Sin embargo, al mismo tiempo, se trataba de un movimiento inverso, por el cual se sobreimprimía -se tatuaba- la referencia hiperculta sobre una "locución de la tierra", de la que derivaba un efecto ridículo, remedo del "lloriqueo en falsete de nuestros payadores de arrabal" (153). Explicaba Groussac:

No esperábamos que el señor Leguizamón resolviese de entrada un problema tan superior a sus fuerzas, pero podíamos pedirle que su estilo no vistiera el smoking arriba del chiripá, y no hiciera codearse en la misma página las pompas gerundianas, con las agachadas rastreras de un tabear que de tan criollo resulta cimarrón. Citaré un ejemplo de ese tatuaje, entre ciento que tengo señalados (154)

escenario de luchas cerriles. Los subtítulos de los diversos cuadros de la comedia señalan el itinerario esperanzado que habrá de redimir al simpático matrero, en evolución que parece el contrapunto de los puestos por Gutiérrez a los capítulos de su novela. Si Leguizamón comienza por la prisión de Calandria, termina con la redención" p. 19 Cf. Ghiano, 1961:7-25. La obra fue publicada por Ivaldi \& Checchi, con ilustraciones de A. Del Nido, en Buenos Aires, en 1898.

${ }^{187}$ En ese sentido, Leguizamón aparecería, en el final de la reseña, como un mal escritor, "aprendiz de pintor [que] borronea zurdamente su ensayo" (155). 
El uso de las cursivas que hacía Groussac era significativo, puesto que si bien se trataba de tres casos distintos, el tipo de error era el mismo. Smoking, tabear y tatuaje eran para Groussac palabras extrañas o extranjeras en relación con la lengua en que era necesario escribir, y por eso en la reseña se marcaba la distancia.

En el final de la crítica, mientras reforzaba el acierto de la elección del tema, Groussac insistía también en la constatación alarmada con que había comenzado la reseña: el éxito seguro y "plausible" del libro de Leguizamón. De esta forma reintroducía la advertencia inicial de no equiparar el éxito con la calidad de las obras, y por lo tanto retomaba el imperativo de trazar líneas divisorias entre los públicos, que ya había aparecido en otras colaboraciones suyas, como "La educación por el folletín". Así, reiteraba sus críticas al circuito de consumo popular perseverando en su diferencia con el de la alta cultura letrada, e insistía en la identificación entre mercado, cultura popular y mala realización estética. En la misma línea, el crítico sugería que Leguizamón había triunfado en esa franja de público, por el tema elegido, pero también por la "ejecución deficiente" del libro. La fórmula propuesta por Groussac para una literatura argentina sería entonces la doble obligación del tema (nacional) y de la lengua (culta). En el párrafo final de la reseña de Recuerdos de la tierra, Groussac resumía las prescripciones en que debía fundarse dicha literatura, anticipando en ello su juicio a Prosas profanas, pero también poniendo en primer plano la cuestión de la realización y del talento del poeta nicaragüense:

Vamos a ver el ejemplo contrario de un escritor cuyo talento se malogra en gran parte por lo inconsistente de su materia. El señor Leguizamón labra monigotes en el oro nativo de la substancia nacional; el señor Darío cincela ninfas en un bloque de hielo artificial, bajo los trópicos, sin oír el gotear siniestro que llora la destrucción de la obra apenas concluida:

Lequel vaut mieux, Seigneur?...(160)

De esta manera, la sustancia de la literatura debería asentarse en la exploración y explotación del mundo virgen de la vida rural argentina. Es importante remarcar que 
Groussac centraba su lectura en el problema de la lengua y relacionaba este aspecto con la capacidad de la literatura de poner en escena, modelar y finalmente representar una identidad colectiva. De ese modo, el programa de literatura nacional que el crítico esbozaba en ese punto y como contraejemplo de Recuerdos de la tierra, se emparentaba directamente con una operación de construcción o invención de la nación, entendida como totalidad imaginaria. En un contexto cultural en el que "el espacio de la cultura letrada aparecía como replegado en sí mismo" (Prieto, 1988:19) y en una sociedad urbana en proceso de modernización creciente y marcada por la presencia de extranjeros -problema este último con respecto al cual Cané ya había intervenido en la revista-, la literatura pudo ser pensada como el instrumento de una política cultural entre cuyos objetivos se encontraba la construcción imaginaria de la nación, o, al menos, de una lengua entendida como lengua común. María Teresa Gramuglio ha observado que, si como sostiene Ernest Gellner, es posible considerar el nacionalismo como un principio político basado en la congruencia entre la unidad política y la unidad nacional, en "situaciones de malestar o de alarma en que se supone la desarticulación de una congruencia antes existente" se presentan, incluso por fuera del aparato estatal, movimientos y sentimientos nacionalistas (Gramuglio, 1994: 23-27). En ese sentido, la nota de Groussac, se ocupaba de un texto cuyo título exponía una de las respuestas a la alarma que provocaban los cambios acarreados por la modernización social, cultural y política. La nación de los recuerdos de Leguizamón se localizaba en el pasado y un espacio rural no siempre calmo, cuyo suelo, según el narrador, era desgarrado por el paso del tren. Esta perspectiva en que se enrolaban con motivaciones distintas tanto la reseña como el libro reseñado, implicaba para la literatura una tensión entre su autonomía y una funcionalidad con respecto a las necesidades imaginarias del Estado. En el parágrafo siguiente nos detendremos en una lectura particular de Recuerdos... a cargo de Joaquín V. González, un letrado perteneciente a la dirigencia política; la misma, publicada en $L a$ Biblioteca algunos meses antes de la reseña de Groussac, puede ser pensada como una intervención intelectual de signo incorporador ${ }^{188}$ ante la desarticulación del nacionalismo entendido como aquella congruencia entre el ordenamiento político y la nación, a la vez

${ }_{188}$ En el contexto de descontento que expresaron algunos miembros de la fracción intelectual de la elite frente a las nuevas teorías y movimientos sociales y a la presencia de extranjeros, la propuesta de González revestía un carácter progresista para incluir a todos y alinearlos imaginariamente como los ciudadanos del estado-nación. 
que recorta a la literatura como una práctica especializada, más allá de la función o servicio que se le asigna.

\subsection{Joaquín V. González y Recuerdos de la tierra. La tradición inventada}

El libro de Leguizamón fue criticado dos veces en La Biblioteca. Antes de la nota de Groussac en 'Boletín bibliográfico" se había publicado un escrito de González en la entrega de la revista de noviembre $1896,{ }^{189}$ que más tarde aparecería como “Introducción" a la edición de los Recuerdos de $1957 .{ }^{190}$ Esta lectura se vinculaba con la de Groussac, en virtud de ciertas elecciones compartidas cuales eran la necesidad del mismo tema y el mismo registro de lengua literaria. Sin embargo, exponía la mirada de un funcionario ${ }^{191} \mathrm{y}$ de un diseñador de políticas culturales sesgadas por las urgencias del Estado, no de un crítico literario. De este modo, si Groussac anteponía aspectos literarios tales como la técnica, el asunto, la ejecución, y se trataba ante todo de un programa estético, en este caso se pensaba en una tarea que el autor de La Tradición nacional asignaba a la literatura, en el marco de una operación típica de lo que autores como Benedict Anderson entienden por nacionalismo. ${ }^{192}$ Es así que la literatura se presentaba en la lectura de González como un discurso inclusivo, capaz de convocar aquellos elementos del pasado que afirmaran no solo una temática sino principalmente un conjunto de valores y creencias potencial y efectivamente compartibles. Asimismo el texto debe leerse como el deseo (la necesidad imaginaria) de una institucionalización determinada de la literatura, es decir, de la función que se prescribía para ella, ${ }^{193}$ direc-

\footnotetext{
${ }^{189}$ Año II, Tomo II, noviembre, 1896, pp. 384-400.

${ }^{190}$ La primera edición del libro fue realizada por Félix Lajouane, editor también de la revista de Groussac. La segunda edición, sesenta y un años más tarde, estuvo a cargo de Mar Océano.

${ }^{191}$ En la noticia de 'Redactores' Groussac refiere que ese año de 1896 Joaquín V. González es diputado.

${ }^{192}$ En su libro Comunidades imaginadas, Benedict Anderson sostiene que la nacionalidad o la calidad de nación, lo mismo que el nacionalismo, son artefactos culturales de una clase particular. No clasifica al nacionalismo como una ideología. Para Anderson la creación de estos artefactos fue la destilación espontánea de un 'cruce' complejo de fuerzas históricas discretas. Una vez creados, se volvieron 'modulares', capaces de ser transplantados. Anderson define luego a la Nación: comunidad política imaginada como inherente limitada y como soberana. (1993: 17-26)

${ }^{193}$ Tomamos el concepto de 'institución' de Peter Bürger quien entiende por tal no establecimientos como editoriales, comercio de libros, el teatro, los museos, todos mediadores entre la obra y el público, sino las definiciones de la función del arte en su 
tamente relacionada con el interés de fundar un pasado común, que podía transmitirse a través de una "narrativa de la nación" (Dalmaroni, 2006: 34). ${ }^{194}$ En el contexto de descontento que expresaron algunos miembros de la fracción intelectual de la elite frente a las nuevas teorías y movimientos sociales y a la presencia de extranjeros, la propuesta de González revestía un carácter progresista para incluir a todos y alinearlos imaginariamente como los ciudadanos del estado-nación.

En el comienzo de su artículo y bajo el pretexto de una explicación autorreferencial, González colocaba en el centro la temática de la memoria y del pasado que ésta convocaba. Se refería a sí mismo como un sujeto atento a la "memoria y sus evocaciones de tiempos felices" [cursivas nuestras], ya fueran personales, de su región o de la patria común, y manifestaba su sorpresa ante la aparición de un libro como el del entrerriano "en esta época en la cual creyérase que nadie se ocupara de cosas pasadas." ${ }^{195}$ Al margen de la premeditación de su autor, el libro tenía, según el articulista, la cualidad de sobrepasar la dimensión pretérita de los recuerdos, para dejar entrever la existencia de un conjunto de elementos del pasado situados a una distancia precisa por la cual eran accesibles al narrador y revestían un carácter legendario para el lector:

más allá de esos 'recuerdos' viven, como mal ocultos tras de un velo transparente y movible, sucesos, personajes, leyendas, panoramas y cuadros, ni tan remotos que escapen a la impresión personal del narrador, ni tan cercanos que pierdan para nosotros ese dulce y fantástico prestigio de los días que pasaron (384-385).

El rasgo casi mitológico de esa constelación de elementos que la literatura desocultaría y traería a un presente atemporal ("viven"), resultaba decisivo para la

contingencia social y los cambios de dicha función de período en período". (Bürger, 1985-1986: 5-33)

${ }^{194}$ Es interesante apuntar el contraste entre las respuestas de González y Cané a la cuestión nacional escritas contemporáneamente y publicadas en la revista con diferencia de pocos meses.

${ }^{195}$ Todas las citas corresponden al texto de González aparecido en La Biblioteca con el título de la obra de Leguizamón en la entrega de noviembre de 1896. Año I, Tomo II, noviembre, 1896, pp. 384-400. 
dimensión incorporadora que guiaba la posición del literato riojano. En ese mismo sentido, era relevante que, si bien el libro se ocupaba de una región, podía ser considerado como la "expresión del alma y la fisonomía de sociedades hermanas"; éstas eran las diversas zonas geográficas, cuyas agrupaciones humanas estarían vinculadas por una "marcha histórica común" antes que por el componente étnico, que, en muchos casos, era idéntico. Es por esto que González no vacilaba en considerar Recuerdos de la tierra como representativo de la grandeza de la patria, al ver en el libro la misma cualidad que en ella, esto es, la de "no permitir que por un solo signo se retrate o califique toda su extensión" (386) para asentar dicho carácter representativo en la diversidad regional. A su entender, la obra daba cuenta de tres elementos fundamentales, como lo eran el descriptivo de lugares, costumbres y tipos de la Mesopotamia; el tradicional e histórico que comprendía "tiempos de heroísmo y miserias comunes"; el folklore que aparecía, en cierto modo, como una amalgama de la que participaban los dos primeros, ${ }^{196}$ y que constituía la "exposición de esas creencias y usos locales, que dan a conocer los caracteres ingénitos de las agrupaciones humanas" propias de aquellos espacios descriptos. De esos tres elementos, González privilegiaría el histórico, al que redefiniría en otro tramo del escrito, en dos "divisiones" mezclando el ordenamiento anterior. Una de ellas se relacionaba con "los episodios relativos a acciones o impulsos patrióticos, a personajes y sucesos de la vida política"; la otra, remitía a lo tradicional renombrado como "folklórico". Este último y nuevo sentido de "tradicional" por el que si inclinaba, se distinguía de la primera acepción porque despojado de su anterior dimensión heroica, aludía a las creencias y costumbres de los pobladores, las que también tenían su historia.

La preocupación por organizar el pasado en una historia futura conectaba la literatura con la fundación misma de la nación, en tanto funcionaba -y este libro era el ejemplo- como discurso preparatorio y gestador de "los elementos de la futura historia nacional, la historia verdadera, la que sigue a una Nación como organismo fisiológico y como personalidad humana, sin desprenderla de sus orígenes, de sus adherencias fatales hacia la tierra que habita" (386). La nación se presentaba como algo natural y

${ }^{196}$ Reunía a los primeros elementos en tanto incluía a las creencias como propias de lugares y comunidades humanas particulares. 
recién engendrado en la elaboración de cuya historia era indispensable el trabajo de una "literatura nacional folklórica" que debería iluminar y dar a conocer a cada una de las provincias del país, y que se desempeñaría como factor de cohesión de los elementos dispersos de la historia literaria y geográfica. La literatura, desde esta perspectiva que la ligaba directamente con el espacio, era una forma de cartografiar el alma nacional, en sus aspectos físico (territorial) e histórico (folklórico), a través de un discurso escrito sobre la base de un rescate arqueológico. ${ }^{197}$ Como la de los relatos de Leguizamón, la lengua de este discurso debía pertenecer al registro culto, y a diferencia de aquella -parece sugerir González- debía evadir la tendencia a mezclar "las graves enseñanzas de la biblioteca con la sencillez conmovedora" de lo narrado. Esta caracterización era similar a la posterior descripción descalificadora de Groussac: la biblioteca y el smoking eran los modos de nombrar a la cultura letrada y urbana; la sencillez y el chiripá hacían referencia a la materia del relato en su procedencia regional y a la experiencia de la vida rural que las dos lecturas aprobaban. Tanto el riojano como el francés indicaban que la obra de esta literatura nacional debía ser realizada por los letrados/ escritores, y el propio González ya había desplegado este programa casi diez años antes, en La tradición nacional (1888) y lo prolongaría en Ideales y caracteres (1903). El que esa responsabilidad estuviera en manos de los intelectuales, quienes de ese modo venían a cumplir con una demanda imaginaria del Estado, era un dato relevante en tanto los señalaba como especialistas o conocedores de los elementos diversos "del espíritu y cualidades de la nación” y por tanto capaces de sistematizarlos. Así, los relatos de la tierra se ofrecían para González no solo como obras "de experiencia directa", sino también como forma de exhumación del pasado, por parte de un sujeto que a la manera de un sabio positivista debía "deducir" (...) "leyes permanentes para incorporarlas al caudal de la historia común" (388) en la

${ }_{197}$ González considera que "puede construirse un sistema o un mapa de las cualidades y costumbres, creencias, supersticiones, modismos, variantes de lenguaje, y que las diferencias constitutivas de cada zona se hallan determinadas por los caracteres del suelo correspondiente y de su historia, comprendidas en ésta la de las razas primitivas y la del establecimiento y desarrollo de la nación conquistadora". Esta literatura deberá ser regional, en tanto pretenda expresar correctamente "el espíritu y cualidades de la nación que la habita", La Biblioteca, Año I, Tomo II, noviembre, 1896, p. 388 
observación y descripción de las cosas pretéritas de la naturaleza patria, "tesoro todavía oculto, reservado a los tiempos venideros". 198

González hacía explícita la historicidad de la nación como forma de organización de las sociedades, y enunciaba a la vez una de las paradojas que Benedict Anderson señala en relación con el nacionalismo: ${ }^{199}$

No hemos nacido viejos, ciertamente, como quisiéramos creerlo a veces en nuestra vanidad, cuando en el dominio de la vida intelectual, de las labores del espíritu, sólo contemplamos un inmenso vacío y la vasta soledad inexplorada." (387)

Llenar ese vacío recogiendo y seleccionando las tradiciones, leyendas, personajes o costumbres constituía el modo de forjar un pasado nacional portador de valores compartidos. A sus ojos, los personajes del libro de Leguizamón eran tipos y como tales comunicaban el mensaje de fraternidad entre las regiones distintas, a través de los cuales se cumpliría en este libro con la función cohesiva que González asignaba a la literatura. Si la nación podía ser definida, a su juicio, como el sentimiento de fraternidad por el cual "vendrían a confundir sus almas [las regiones], a comunicarse sus fantasías del pasado y sus ensueños informes aún del futuro" (391), la literatura ejecutaba por escrito esa "fantasía".

Debemos señalar que Joaquín V. González leía el libro de Leguizamón alineándolo junto a la literatura de Rafael Obligado, autor de Santos Vega, obra considerada como modelo deseable tanto por el tema como por la realización. En ese sentido, y en términos de Raymond Williams se trataba de operar con el pasado de manera selectiva, priorizando algunas de sus zonas y descartando otras, en el intento de construir una versión del pasado intencionalmente seleccionado a través de la cual incorporar y ratificar una serie de valores y significaciones centrales para la

${ }^{198} \mathrm{Al}$ referirse a la naturaleza en esos términos, González trasladaba a ella un rasgo cultural, esto es, su calidad de nación, La Biblioteca, Año I, Tomo II, noviembre, 1896, p. 392.

${ }^{199}$ Anderson observa tres paradojas respecto de la nación, a las que se enfrentan sus teóricos y críticos: a) Modernidad objetiva de las naciones ante el historiador vs. la antigüedad subjetiva de las mismas a la vista de los nacionalistas. b) Universalidad formal de la nacionalidad -tener una es como tener un sexo- vs. la particularidad inevitable de sus manifestaciones concretas. Se es argentino, persa o francés y c) Poder político de los nacionalismos frente a su pobreza y aun incoherencia filosófica (Anderson, 1993: 22-25). 
organización social y cultural contemporánea (Williams, 1980: 137-142). En su análisis de Recuerdos... el futuro ministro de Roca generalizaba el sentimiento sobre las cosas pretéritas e indicaba que la exhumación era el procedimiento habitual por el que los pueblos habían fundado las religiones y epopeyas que los singularizaban. Asimismo y como ya había explicado, dicha exhumación debía centrarse de modo particular en los elementos del pasado que definía dentro de lo histórico, como folklóricos, y excluyendo aquellos relacionados con las miserias comunes, en favor de la memoria de "los tiempos felices". En efecto, había para González una epopeya de las cosas de la tierra argentina, de la que Leguizamón y él mismo habían escrito una parte, y a la cual había contribuido Obligado reestableciendo en la leyenda del payador un linaje poético que tenía su origen en los incas. ${ }^{200} \mathrm{El}$ interés por la obra de Obligado radicaba en la preferencia de su autor, al menos durante casi todo el texto, por la versión sobrenatural de la leyenda despojada de alusiones a un presente evaluado como negativo. ${ }^{201}$ También Mis Montañas de González se inscribía en el mismo género y así lo proclamaba Groussac en la nota de 'Redactores' dedicada a su autor:

Con mayor abundancia y menos preocupación de la forma, González casi representa en prosa lo que Obligado en poesía. Es un gran elogio para ambos (260)

De esta forma se trazaba en La Biblioteca un circuito de literatura de tema nacional en lengua culta constituido en prosa por Leguizamón, González y Lugones (con su epopeya de los relatos de La Guerra Gaucha) y en poesía por Rafael Obligado (con el rescate de héroes y tradiciones también relacionadas con la tierra). Esta línea se distinguía doblemente de la gauchesca y del criollismo, para asegurar una lengua

${ }^{200}$ Cf. Obligado, R. "Independencia literaria" (publicado 9/7/1876, La Ondina del Plata). (Obligado, 1976: 64).

${ }^{201}$ En relación con esta cuestión Prieto señala que esta preferencia bien marcada del comienzo, cambia en final: "Pero con últimos versos de Vega, el poema deja de ser, bruscamente tributario de la tradición. El diablo [Juan sin Ropa, el payador con quien Vega compite]

deja de ser el diablo de la cosmovisión cristiana para presentarse como expresión del progreso y la ciencia que construyen ciudades en el desierto" (Prieto, 1988: 119). 
nacional y un conjunto de tradiciones en la afirmación de una porción del pasado exenta de conflictos, capaz de generar una continuidad imaginaria con el presente. ${ }^{202}$

Por último, la cuestión de la nacionalidad y de la participación de los intelectuales y escritores en la construcción de una identidad nacional atravesó la cultura y la literatura argentinas de los siglos XIX y XX. En La Biblioteca la temática estuvo presente desde el comienzo en las funciones civilizatorias asignadas a las instituciones estatales, en la lectura de Groussac sobre la historia nacional, en el diseño imaginario de las relaciones entre intelectuales y Estado, en el esbozo de un programa de literatura argentina, así como también en las respuestas de miembros de la fracción intelectual de la elite liberal (Cané, el propio Groussac, C. Rodríguez Larreta) y en funcionarios representantes más progresistas de la dirigencia política (González) ante los efectos culturales y sociales de la modernización. Así en La Biblioteca, se organiza y a la vez se abren los términos de un debate que constituirá uno de los tópicos más relevantes en algunas otras revistas del corpus. En Ideas, por ejemplo, a través de la formulación de una tradición para la novela inscripta en la línea iniciada por Martín García Mérou en Libros y autores, en el intento de construir un teatro con preocupaciones "sociológicas", y en la afirmación de la juventud como reserva espiritual necesaria a la nación; en Nosotros y con una hegemonía ascendente entre 1908 y alrededor del Centenario de la Revolución de mayo, esta problemática hará de la revista un escenario de disputas entre ficciones identitarias divergentes, y será fundamental en secciones como 'Letras argentinas' y 'Teatro nacional'. En ambos casos el tema mismo formará parte de las estrategias de autorización de los colectivos intelectuales y artísticos que llevarán adelante estas publicaciones juvenilistas, en un medio al que declaraban casi invariablemente hostil frente al arte y a los productos intelectuales.

Desde una mirada histórica que intenta precisar las formas que adquirieron los reclamos de independencia de intelectuales y escritores, en un mundo en el que las

\footnotetext{
${ }^{202}$ Fabio Espósito ha observado que a diferencia de las historias de Bartolomé Mitre $Y$ Vicente F. López, La tradición nacional, construye en el pasado tradicional "un lugar donde los conflictos políticos se desvanecen, o mejor dicho, una zona propicia para que desde el poder político se instrumente una operación fundada en la ficción de la mezcla cultural" (28) Cf. Elite letrada, estado y mercado (tesina de licenciatura), Biblioteca de la Facultad de Humanidades y Ciencias de la Educación, UNLP.
} 
intersecciones entre la política y la práctica de la escritura seguían siendo dominantes, La Biblioteca desempeñó un papel fundamental. En primer término, y atendiendo justamente a esa imbricación todavía importante entre el orden político y el orden cultural, su director imaginó un pacto con el Estado basado en una estrategia de compensación, por el cual aquél debía alentar y proteger las empresas culturales que, como La Biblioteca, contribuían en la tarea civilizatoria e inherente al Estado de construcción de la nación. Más allá del episodio del cierre, que indicaba la condición subordinada de los intelectuales y de la cultura, Paul Groussac pudo mostrarse, a lo largo de las veinticuatro entregas, como ejemplo del ejercicio de una función intelectual independiente, tanto en el terreno de la literatura como en la práctica de la disciplina histórica. Compartieron ese ejemplo otros colaboradores de la revista quienes como Miguel Cané, Carlos Rodríguez Larreta o Joaquín V. González, mostraron modos específicos de la acción intelectual, algunos de los cuales señalaron a la cultura como una práctica ("cultivo") en el que cimentar la identidad patria. Sin pasar por alto el carácter orgánico con respecto a las ideas de la elite, reconocible en las problemáticas presentes en sus páginas, La Biblioteca se ocupó de la literatura, mostrando una amplitud únicamente condicionada por los valores de la calidad y la novedad. Ese espíritu amplio y liberal se ratificó con la publicación de los textos de los miembros más representativos de la juventud modernista en Buenos Aires, y mediante la defensa de criterios de valoración literaria fundados en la posesión de saberes particulares. En la inclusión de los poetas y escritores más jóvenes, la revista puso en escena la emergencia de una subjetividad que no era posible deslindar de las nuevas profesiones literarias asociadas al periodismo y que apuntaba una diferencia fundamental con otras figuras, tales la del literato o el doctor en leyes. Como se verá, la lección de Groussac sería retomada casi reverencialmente por El Mercurio de América -en especial por los críticos- , órgano juvenil que insistiría en el lazo productivo entre publicaciones y conocimiento, y que inauguraba el mecanismo de sucesiones que definimos como posta intelectual. Desde una esfera de participación más acotada, El Mercurio abundaría en el discurso de un espiritualismo antiburgués que, en contraste con el que estaría presente más tarde tanto en Ideas como en Nosotros, no pondría su acento en la salud y en la normalidad, y establecería algunos lazos con ciertos rasgos del decadentismo francés, también 
reconocibles en ciertos textos de La Montaña. Asimismo, las páginas de El Mercurio sumarían a la figura del crítico experto encarnada por Groussac, la del crítico artista, y antepondrían, a la edificación de la literatura nacional, la de una hermandad o comunidad artística hispanoamericana.

\section{El Mercurio de América y La Biblioteca: la continuidad en la diferencia}

En contraste con La Biblioteca, órgano de carácter estatal y subvencionado con fondos públicos, El Mercurio de América ${ }^{203}$ fue como toda una gran cantidad de revistas de fin de siglo argentino y latinoamericano, ${ }^{204}$ una publicación que vehiculizó principalmente los intereses de un grupo de jóvenes, y junto con la fugaz aunque fundamental Revista de América que la precedió, ${ }^{205}$ funcionó como el espacio privilegiado de promoción de los escritores del modernismo. De ese modo, sus

${ }^{203}$ El primer número de la revista se publicó en julio de 1898, el último, en mayo-junio de 1900. La colección completa es de diecisiete entregas. Su director fue Eugenio Díaz Romero y los demás, recibieron el nombre de redactores. Estaba organizada en dos partes. Una en la que se publicaban artículos, poemas, ensayos, relatos, fragmentos, etc., inéditos. Otra, llamada 'Notas del mes' en la que generalmente un mismo crítico se encargaba de una sección de 'letras'. Luis Berisso era responsable de 'Letras americanas', Leopoldo Lugones de 'Letras francesas', José Ingenieros de 'Letras italianas', José Pardo de 'Letras españolas'. Además, en esta segunda parte, el director escribía la sección 'Las revistas' y Mercurio asumía colectivamente la responsabilidad de 'Ecos'. En las primeras páginas se consignaban, por orden alfabético, los principales colaboradores. La lista era la siguiente: Juan B. Ambrosetti, Arturo Ambrogio, Víctor Arreguine, Carlos Baires, Luis Berisso, Carlos Alfredo Becú, Ernesto de la Cárcova, Ramón J. Cárcano, Alberto del Solar, Leopoldo Díaz, Julio V. Díaz, Miguel Escalada, Ángel Della Valle, Ángel Estrada (hijo), Eduardo Ezcurra, Macedonio Fernández, Carlos Guido Spano, Alberto Ghiraldo, Darío Herrera, José Ingegnieros, Julio L. Jaimes, Ricardo Jaimes Freyre, Michel Kaplan, Joaquín Lemoine, Leopoldo Lugones, Américo Llanos, Martín García Mérou, Carlos Malagarriga, Gerardo Maya, Belisario J. Montero, Alberto B. Martínez, Mauricio Nirestein, Rafael Obligado, Carlos Ortiz, José Pardo, Pedro B. Palacios, José Pagano, Víctor Pérez Petit, Roberto J. Payró, Ernesto Quesada, José M. Ramos Mejía, Carlos Ripamonti, José Enrique Rodó, Francisco Sicardi, Eduardo Schiaffino, Eduardo Sívori, Charles Soussens, Juan B. Terán, Carlos Vega Belgrano, Francisco de Veyga, Eduardo Wilde, Alberto Williams, Carlos Zuberbühler.

${ }^{204}$ Entre ellas, la mexicana Revista Azul dirigida por Manuel Gutiérrez Nájera y Carlos Díaz Dufóo; la venezolana Cosmópolis bajo la responsabilidad de Pedro Emilio Coll, Pedro César Dominici y Ubarneja Archepohl; El Iris de Ricardo Palma; la Revista Nacional de Literatura y ciencias Sociales de José Enrique Rodó, Víctor Pérez Petit y los hermanos Martínez. Datos tomados de Zanetti, 2004: 19-20.

${ }^{205}$ Según consta en la edición facsimilar realizada por Boyd G. Carter, de 1967, la colección completa es de tres números, todos de 1894. El primero, el 19 de agosto, el segundo el 5 de septiembre y el tercero y último, el $1^{\circ}$ de octubre. Lafleur, Alonso y Provenzano, dan como fecha de cierre de la publicación, el mes de septiembre. 
acciones se circunscribieron a un terreno más estrictamente literario, si bien ello no implicó el desinterés por otras prácticas e incluso por la actualidad política. ${ }^{206}$ Calificada por Lafleur, Alonso y Provenzano como la revista más valiosa del modernismo (Lafleur, Provenzano, Alonso, 1962: 28), en ella colaboraron además de escritores, poetas, críticos y traductores literarios, músicos y pintores. Esta variedad, como ya se señaló, es indicativa del valor que adquirieron las alianzas como formas de promoción conjunta de prácticas que se consideraban parte de un dominio no ya exclusivamente literario sino artístico $\mathrm{y}$, en tanto modo de volver visibles las vinculaciones efectivas entre quienes intentaban definir su arte como autónomo y como verdadera innovación. Como se verá en la nota de apertura, dicho afán de innovación, trazaría los límites de su enunciación, en la declarada búsqueda de un equilibrio entre la tradición y lo nuevo. En efecto, la revista no tuvo sino un carácter alternativo, ${ }^{207}$ si se piensa en la relación enunciada con la tradición y en el énfasis con que hizo explícito su deseo de una colaboración plural y no sectaria, basado en una definición amplia del arte, cuyas escasas restricciones estarían dadas, como en La Biblioteca, por la forma en que fueran vertidas las opiniones y la "belleza" de los textos. $^{208}$ Sin descuidar que este planteo pudiera vincularse con el momento de emergencia del mundo literario, es pertinente señalar que dicho carácter alternativo se manifestó claramente en una crítica a ciertos modos de institucionalización de la literatura, considerados anacrónicos, y en la postulación de la figura social del artista distinguible de algunas otras previas. En ese sentido, El Mercurio articuló estratégicamente ambos impulsos, que en principio podrían excluirse. De ese modo, y en términos institucionales, rubricó su comienzo construyendo para sí la imagen de

\footnotetext{
${ }^{206}$ Artículos como "Por la paz internacional", "Problemas sociales contemporáneos" de José Ingenieros, o la existencia misma de la subsección 'Sociología' en 'Notas del mes', son prueba de ello.

${ }^{207}$ En su análisis histórico de las formaciones culturales, Raymond Williams tipifica sus relaciones externas en relaciones de especialización, alternativas, y de oposición. En el primer caso, se trata de promover un trabajo en un medio artístico específico; en el segundo, "se aportan medios para la producción, exposición o publicación de algunos tipos de obras, cuando se considera que las instituciones existentes las excluyen o tienden a excluirlas"; en el tercero, se da cuando el carácter alternativo se transforma en una oposición y cuestionamiento decididos frente a las instituciones establecidas, o de modo general, las condiciones en las que se inscriben. Cf. Williams, 1988: 65.

${ }^{208}$ Groussac se refería a esta cuestión como "corrección y compostura en la forma"; los jóvenes hablarían de "Todas las tendencias y opiniones bellamente vertidas". Cursivas nuestras.
} 
heredera joven de la revista de Groussac, haciendo efectivo el mecanismo de posta intelectual. Éste, como se verá, no debe pensarse como traspaso inmodificado sino como forma de ratificar una demanda compartida y como oportunidad de una intervención propia, en este caso, marcada por la presencia de un conjunto de problemas relativos a la modernización literaria y por una estética particular, en función de los cuales se leen respuestas culturalmente más nuevas si se las compara con algunas de las analizadas en La Biblioteca. Los puntos que conectan a la revista de Díaz Romero con su predecesora se patentizaron también en la presencia de ciertos escritores como Darío, Leopoldo Lugones, Luis Berisso, Leopoldo Díaz que representaron algunos de los ejes fundamentales de las acciones de El Mercurio, a saber: la poesía, la crítica, la traducción. En relación con figuras de la pintura y de la música, los nombres de Eduardo Schiaffino o de Alberto Williams apuntan una coincidencia por demás relevante. ${ }^{209}$ Asimismo, la condición de maestro del director de La Biblioteca en el ejercicio de la función crítica para esta promoción intelectual constituye otro punto de enlace. Sin embargo, el ejemplo de ese magisterio que, dicho sea de paso, no tuvo en Groussac un promotor y se dio casi unidireccionalmente en las reivindicaciones que los nuevos hacían de sus juicios muchas veces retomados, ${ }^{210}$ produjo como resultado una crítica no siempre pensada y vertida como confrontación polémica o como admonición. Estudiar el modo en que se construye la relación entre El Mercurio y La Biblioteca, y entre esta última y La Montaña, sirve para mostrar que esas posibilidades de contacto fueron, en realidad, necesidades comunes entre aquellos que se pensaban como miembros de un mundo cultural más sólidamente organizado y todavía en emergencia, y que fueron justamente estas condiciones de enunciación las que promovieron tales vínculos. En los parágrafos siguientes (4 y 5) se expondrán la forma y las ocasiones en que se construyen esos lazos, y a la vez, se hará especial

\footnotetext{
${ }^{209}$ Ambos fueron los representantes exclusivos de dichas prácticas tanto en La Biblioteca como en El Mercurio. Schiaffino, defensor de la vanguardia estética y director del Museo Bellas Artes, había colaborado como crítico de arte en las entregas primera, tercera y cuarta de La Biblioteca; en alguna se refería a la ausencia de instituciones específicas (museos, exposiciones), a partir de las cuales el arte pudiera estar en contacto con el público. Como crítico musical Alberto Williams, participó en tres oportunidades en la revista de Groussac, en las cuarta, sexta y novena entregas; los trabajos llevaron por título "Estética musical y conciertos sinfónicos".

${ }^{210}$ Rubén Darío da a entender algo de eso cuando se refería a Groussac en los términos de "autoridad magistral". Cf. "Los colores del estandarte", La Nación, 27/11/1896.
} 
énfasis en ciertas subjetividades emergentes, para señalar la modificación que a partir de ellas se opera en la relación de los escritores e intelectuales con el público y con la política.

\subsection{Alianza institucional y afiliación estética: lazos con La Biblioteca y con La Revista de América.}

Con el número doble de abril-mayo de 1898 quedaba cerrada la publicación de La Biblioteca y el 20 de julio de ese mismo año aparecía, también en Buenos Aires, el primer número de El Mercurio de América, dirigido por Eugenio Díaz Romero. En las páginas que seguían al sumario ${ }^{211}$ con que se abría, en una nota de la dirección, se proclamaba el reconocimiento a la labor realizada por La Biblioteca, y de este modo el nuevo órgano se sumaba al conjunto de voces que, tanto durante la vida de la revista como luego de su cierre, le habían asignado el más alto valor intelectual. ${ }^{212} \mathrm{El}$ Mercurio, según se explicaba, venía a cubrir el espacio vacante dejado por la revista de Groussac, y con ello contribuiría desde su especificidad, a consolidar una empresa altruista cuyos efectos benéficos se derramarían, al parecer, no solo en el terreno de la

\footnotetext{
${ }^{211}$ Sumario del $n^{\circ} 1$

La dirección ..................... El Mercurio de América

Eduardo Schiaffino ..........En las Sierras de Córdoba

Rubén Darío................... Las ánforas de Epicuro

Víctor Pérez Petit ..............os modernistas [sobre D'Annuzio]

Ricardo Jaimes Freyre... Castalia Bárbara

José Ingenieros .............. Psicología colectiva

J.V.D. ..........................Cuestiones de actualidad

Gabriel D'Annunzio..............La ciudad muerta

Notas del mes

Carlos Baires................... Sociología y Filosofía

E. S. [Eduardo Schiaffino] ....Notas artísticas

Eugenio Díaz Romero .........Las revistas

Adolfo del Mármol .............. Los teatros

Luis Berisso........................ Letras americanas

L.L. [Leopoldo Lugones] ... Letras francesas

${ }^{212}$ En el Anuario de la prensa argentina 1896 Jorge Navarro Viola calificaba la aparición de La Biblioteca como "el acontecimiento culminante del periodismo argentino durante el corriente año (...) la mejor [revista] que se publica en lengua española" (Navarro Viola, 1896: 228.); Rubén Darío en "Los colores del estandarte" opinaba que se trataba de "la revista más seria y aristocrática que hoy tenga la lengua castellana" y se refería a ella como "nuestra Revue des deux Mondes"; luego del cierre, Carlos Pellegrini en una carta a Groussac fechada el 9 de junio 1898 y escrita desde París, afirmaba: "Era la única solución elevada [dar por terminada La Biblioteca] después de la gran necedad oficial. Pierde el país, pero Ud. gana." Tomado de Benarós, 1998: 144-145.
} 
literatura. De este modo, se inauguraba la dinámica de sucesiones hereditarias o relevos entre las publicaciones del corpus, en función de la cual las revistas que actuaban como reemplazos, se pensaban como garantías de una institucionalidad precaria de las prácticas que promocionaban:

Desaparecida La Biblioteca, creemos hacer una obra de bien dando á la luz una nueva publicación literaria. La Biblioteca ha sido, hasta hace algunos días, el órgano artístico social que más se ha leído en Buenos Aires y en todas las provincias de la República. ${ }^{213}$

El escrito concentraba algunos de los tópicos que organizarían la intervención de la revista; varios de ellos se ligaban con problemáticas que no eran nuevas, aunque sí lo fueron las posiciones que en relación con ellas se dieron en el terreno de lo estrictamente literario o artístico. Así, y en una línea que ya habían enunciado otros con bastante anterioridad, como Ernesto Quesada en "El movimiento intelectual argentino", Martín García Mérou, dos años antes y desde las páginas de La Biblioteca; ${ }^{214}$ o como más tarde se leería en el escrito inaugural de Nosotros, ${ }^{215}$ ${ }^{213}$ El Mercurio de América, Año I, Tomo I, pp. 3-5. Cursivas nuestras.

${ }^{214}$ En 1882 Ernesto Quesada se refería a esta situación y a la función que les cabía a las revistas, en los siguientes términos: "He ahí, pues, la misión patriótica de las 'revistas' argentinas: estrechar los vínculos de solidaridad nacional, creando una verdadera vida intelectual en toda la República; hacer cesar el aislamiento pernicioso con que, respecto a los otros países de América vivimos." (Quesada, 1895: 140-141). El final del artículo era elocuente porque enunciaba una de las pautas que hasta entrado el siglo XX funcionarían, al menos en el espacio de la alta cultura letrada, como acuerdos más o menos explícitos sobre la necesidad entre las publicaciones de suspender las contiendas: "La tarea [de estrechar vínculos] es demasiado ardua y demasiado difícil, para que la competencia entre las 'revistas' sea posible: las pocas que hay deberían aunar sus esfuerzos para lograr ese resultado, actuando cada una en su esfera, en su especialidad, y en su público. Ninguna se estorba: todas están llamadas a prestarse mutuo apoyo: la rivalidad es imposible" (Quesada, 1895: 141). Por su parte, Martín García Mérou, en la primera entrega de "El Brasil intelectual" afirmaba: "Sin ser un caso común, a veces un nombre dotado de mayor resonancia, rompe la indiferencia reinante y vence la incomunicación intelectual que separa las secciones de nuestro continente. Sólo por una rara excepción, una obra nacida bajo una estrella propicia, adquiere entre nosotros carta de ciudadanía, como acontece con ese tierno idilio que Estrada tuvo el mal gusto de comparar con Graziela; y la María de Jorge Isaacs se convierte en el breviario amoroso de las cándidas imaginaciones de quince años. El grueso de la producción científica o literaria, la historia, la crítica, los estudios jurídicos, están destinados a reposar, como en una muda necrópolis, en las bibliotecas públicas o en medio de las colecciones valiosas de los eruditos de raza, que sólo muy raras veces hojean sus páginas polvorosas." La Biblioteca, Año I, Tomo II, octubre, 1896, pp. 168-200. Cursivas nuestras.

${ }^{215}$ La dirección de Nosotros señalaba: "Nada de más urgente necesidad que la creación de sólidos vínculos entre los aislados centros intelectuales sudamericanos", Nosotros, Año I, Tomo I, n 1, p. 6. 
insistían en la situación de "aislamiento"con respecto a las "naciones de América". ${ }^{216}$ La definición de su iniciativa por oposición al utilitarismo y a la vulgaridad que este mismo acarreaba, al igual que la afirmación del individualismo estético que el manifiesto ponía en primer plano, se vinculaban con las determinaciones materiales y sociales de su enunciación, mostrando una de las paradojas más características de los escritores del modernismo no solo latinoamericano. Como se verá, la revista promocionó una figura de artista, uno de cuyos casos paradigmáticos fue el pintor francés Gustave Moreau, en la que puso de manifiesto los problemas a los que se enfrentaron los jóvenes en una sociedad crecientemente mercantilizada y en la que el arte y la literatura se vieron, desde la mirada de sus productores, en la necesidad de distinguirse.

El Mercurio a diferencia del Mercure de France ${ }^{217}$ en el que claramente se inspiraba, enfatizó desde su nombre mismo un anhelo continental, no ya nacional, de difundir el mensaje del arte americano. La nueva publicación se haría cargo de trascender, con su difusión, las fronteras de la Argentina, uno de los propósitos que $L a$ Biblioteca no había podido realizar, y que debía cristalizar en la existencia efectiva de un público no solo nacional sino continental. Groussac, en el artículo sobre el cierre de su revista, había afirmado la confianza en el alcance de su empresa en toda América latina, una vez que ésta se hubiera emancipado de la dependencia estatal (248) por su inserción en un mercado. Se trataba de otra forma de continuidad, que en el marco del mecanismo de posta, implicaba retomar objetivos de corte institucional inconclusos, que hilvanarían a las revistas, unas con otras, aunque con matices e inflexiones específicos. De este modo afirmaban:

No obstante, La Biblioteca fue poco conocida en los países del Nuevo Mundo. EL MERCURIO DE AMERICA en una esfera menos brillante y no tan estrecha, tendrá Dios y el tiempo mediante, la amenidad y la vibración juvenil de que carecía $\mathrm{La}$ Biblioteca. $^{218}$

\footnotetext{
${ }^{216}$ El Mercurio de América, Año I, Tomo I, p. 5.

${ }^{217}$ Cf. en el Anexo de la revista Nosotros la transcripción del artículo de Remy de Gourmont sobre Le Mercure de France. (NOS: 88-89)

${ }^{218}$ El Mercurio de América, Año I, Tomo I, p. 3.
} 
Como se dijo, el tipo de vínculos que caracteriza la lógica de reemplazos entre las revistas de ningún modo supone el pasaje inalterado de un conjunto de problemáticas sino que debe pensarse como persistencia y a la vez como modificación, como presencia necesaria en el espacio público y, al mismo tiempo, como plus y rasgo particular. Si el periódico de Groussac había cumplido a los ojos de esta nueva publicación, uno de sus propósitos, -cual era el de crear en Buenos Aires un público consumidor de los productos de la intelectualidad culta-, la singularidad de El Mercurio de América radicaría sobre todo en el carácter juvenilista, que las sucesivas entregas actualizarían en la promoción de los escritores jóvenes. La amenidad, que se sumaba al rasgo juvenilista, podía pensarse como un valor asociado al modernismo, y a la vez como modo de captar el interés de los lectores. El Mercurio veía en La Biblioteca una publicación literaria y artística, y ambas revistas sostuvieron la originalidad, la novedad y la pluralidad ideológica como sus valores y criterios constitutivos. Aunque ponía su acento en la innovación y se presentaba principalmente como el lugar de difusión de la juventud artística, El Mercurio propició la solidaridad y la amplitud, cuando tomando prestadas las palabras de Darío y Jaimes Freyre, declaraba "el respeto á las tradiciones y la jerarquía de los Maestros". ${ }^{219}$ Este gesto inclusivo se había registrado en La Biblioteca con respecto a los jóvenes modernistas y a la figura de Darío. A pesar de que era evidente que Groussac no aceptaba a Darío y al modernismo al que éste lideraba sin prevenciones, ${ }^{220}$ varios textos modernistas fueron criticados y publicados en La Biblioteca. Por su parte, la juventud modernista de El Mercurio no polemizaría con Groussac sino que, dejando de lado ese cuestionamiento, privilegiaría los lazos de unión, antes que las diferencias estéticas con La Biblioteca.

Al igual que Groussac, El Mercurio consideraba que ante la inexistencia de un público, las revistas funcionaban como los órganos más apropiados para su construcción. En tal sentido y en el comienzo de La Biblioteca Groussac había observado que “(...) no es raro que la presencia inesperada de un órgano nuevo determine

\footnotetext{
${ }^{219}$ Ibid., p. 5.

${ }^{220}$ En la entrega de enero de 1897 de La Biblioteca Groussac, a propósito de Prosas profanas separaba a Darío del modernismo "El señor Darío es muy joven; sobrevivirá al movimiento perecedero y fugaz al que ha adherido" (158)
} 
y estimule la función", 221 Para El Mercurio, una vez creada la función por el órgano que había sido su antecesor, la misma aparecía entonces como necesidad: Buenos Aires, en tanto ciudad culta y pensante, debía tener su "periódico". Si las revistas eran consideradas como productos culturales propios de una fase del desarrollo de la vida intelectual, y Buenos Aires una ciudad que albergaba a hombres de pensamiento, $E l$ Mercurio era la publicación destinada a ese público culto, que a la vez -y por su obrase consolidaría. ${ }^{222}$ Preocupados por todas las cuestiones relativas a la producción del pensamiento, los lectores cultos de Buenos Aires tendrían que sostener la revista en retribución de lo que ésta les proporcionaría en materia artística y cultural. De ese modo, ya no se trataba, como en el caso de La Biblioteca, de la protección del Estado como reaseguro indispensable para la supervivencia de la revista, sino de un pacto imaginario con el estrato más distinguido de un público al que se interpelaba como suscriptor natural.

La nota de Luis Berisso del no 1, "El Mercurio de América y la desaparición de La Biblioteca” de la sección 'Letras americanas' a su cargo, era otro de los artículos fundamentales en los que se registraba la intención de continuidad como relevo directo, así como también la conciencia y el reconocimiento de la condición endeble de las empresas culturales. ${ }^{223}$ Este escrito, como otros que se publicarían también en Ideas, tuvo además un carácter estratégico manifestado en el hecho de que el crítico no se ocupaba de reseñar ningún libro, sino que se dedicaba a exponer la condición desventajosa de la producción literaria, e insistía en señalar a las revistas como los vehículos propios de la cultura y el pensamiento además de considerarlas como los modos de intervención y publicidad intelectuales. La retórica con que definía a la juventud como colectivo cultural responsable de El Mercurio, establecía evidentes contactos con la actitud antipositivista y antimaterialista que tenía uno de sus focos de irradiación no sistematizada, en la Facultad de Filosofía y Letras, y que de modo

\footnotetext{
${ }^{221}$ La Biblioteca, Año I, Tomo 1, p. 7.

${ }^{222}$ Decían: "Si Buenos Aires es una ciudad culta, está en la obligación de sostener un periódico de la índole del nuestro. Aún más. Si en Buenos Aires hay seres que piensen, EL MERCURIO DE AMERICA viene a llenar esa necesidad", Año I, Tomo I, p 3.

${ }^{223}$ En la misma nota Berisso exagera o construye un ficción deseable sobre las dimensiones de la actividad intelectual en la Argentina de esos años, la cual de hecho se restringía casi a Buenos Aires. De esta forma sostiene: "La Biblioteca tenía pues vida arraigada y autoridad incontestable en los centros intelectuales de la República" (72)
} 
general se hacía presente en la mayoría de las intervenciones de los propios productores relativas al estatuto del arte en el contexto de la modernización. Este discurso que valoraba el esfuerzo desinteresado de los jóvenes inmersos en un medio indiferente a la "Belleza", y donde, según Berisso "cualquier especulador en tierras o invernador de puercos, es estimado socialmente, más que todos los talentos juntos" (72), ${ }^{224}$ constituyó uno de los modos de diferenciación a los que apelaron los escritores para definir su nueva autoridad social. En relación con este problema Julio Ramos ha observado que la autonomía del arte con respecto a la razón práctica, plasmada en este discurso del desinterés, funcionó como garantía de una autoridad social entendida como "nuevo recinto de la moral" y que contrarrestaba el dominio del materialismo en la experiencia de la 'Belleza' por una minoría selecta (Ramos, 1989: 60). Esta impugnación del público como burgués formaría parte de las formulaciones de las 'ideologías de artista' de El Mercurio. Aunque este mismo escrito, y en términos generales, achacaba al público definido en su apatía como "práctico", la responsabilidad de los fracasos de estas "nobles" empresas, para el caso de La Biblioteca, no había sido el factor más determinante de su final. Éste se hallaba, según Berisso, en la intromisión del poder político en los asuntos intelectuales, que denunciada como "ineptitud proverbial de los gobernantes", señalaba una colocación dominada o subordinada para el arte. ${ }^{225}$ La nueva revista, a su juicio, debía asumir el riesgo de su muerte temprana, pero se financiaría con el concurso económico exclusivo de aquellos que la hicieran y este altruismo funcionaría como condición de diferenciación del materialismo del "público apático" y fundaría su independencia del campo del poder:

El director de esta nueva revista, número mil de las que se han fundado y fundido en Buenos Aires, me ha confiado a mí esta importante sección, en la cual

\footnotetext{
${ }^{224}$ A esa misma imagen recurrió también la revista Nosotros cuando su nuevo editor, Francisco Albasio insistía que entre los fines básicos de la publicación estaba el de "luchar por elevar el espíritu en poco más allá de los cálculos ganaderos". Nosotros, Año V, Tomo VI, n 32 , septiembre, 1911, p. 256.

${ }^{225}$ Explicaba y argumentaba: "Pero cuando no es la proverbial apatía del público la que mata estas empresas altruistas, que representan verdaderos sacrificios de mente y de dinero, es la ineptitud de los gobernantes, que se permiten amonestar en forma descomedida a un escritor, cuyo mayor error ha sido tener la franqueza y el valor de decir la verdad a todos sin excepción, El Mercurio de América, Año, I, Tomo 1, p. 72
} 
daré cuenta de los libros y folletos que me sean enviados, en forma de pequeñas noticias bibliográficas, reservándome hacerlo más extensamente, cuando la importancia o trascendencia del asunto lo demanden [en cursiva en el original]

En un tono bastante menos optimista que el de las palabras de presentación, Berisso hacía referencia a la multiplicidad de intentos fallidos que habían tenido lugar en la capital y al destino, hasta ahora predecible para las revistas. Éstas se fundaban y se fundían, y esta dinámica señalaba un movimiento de comienzo iterativo, que aparentemente nunca dejaba de comenzar, y que tenía en el factor económico, y específicamente en la ausencia de un mercado, uno de los problemas fundamentales. Por otra parte, aunque el crítico pensaba a El Mercurio y a las demás publicaciones de su mismo circuito, como productos de un esfuerzo altruista, el criterio con el que medía los resultados era mercantil, como también lo eran el género y la extensión de las notas pequeñas noticias bibliográficas- que escribiría para 'Letras americanas'.

El Mercurio puso en primer plano su vínculo con otra publicación, La Revista de América que habían dirigido Darío y Ricardo Jaimes Freyre en Buenos Aires en 1894. ${ }^{226}$ A diferencia del que construyó con la revista de Groussac, en el que lo institucional pesaba de manera evidente, éste fue de corte más estrictamente estético. Las páginas iniciales firmadas por la dirección hicieron de este reconocimiento un gesto de afiliación estética, lo cual implicaba también la asunción de una política literaria. El Mercurio hacía suyos, transcribiéndolos, los propósitos de La Revista de América, y en ese acto mismo acuñaba su matriz retórica de intervención pública, la cual se trasladaría, de forma más o menos explícita según los casos, a textos en los que se perfilaban imágenes de artista. Así demostraban su coincidencia y la apropiación:

Nuestros propósitos como los de los fundadores de La Revista de América, son: "Levantar oficialmente la bandera de la peregrinación estética, que hoy hace con visible esfuerzo la juventud de América Latina, a los Santos Lugares del Arte y a los desconocidos Orientes de ensueño; mantener al propio tiempo que el pensamiento de

\footnotetext{
${ }^{226}$ Sobre la Revista de América, cf. Pineda Franco, 2006.
} 
la innovación, el respeto a las tradiciones y la jerarquía de los Maestros;

Trabajar por el brillo de la lengua española en América, y al par que por el tesoro de sus riquezas antiguas, por el engrandecimiento de esas mismas riquezas en vocabulario, rítmica, plasticidad $\mathrm{y}$ matiz:

Luchar por que prevalezca el amor a la divina belleza, tan combatida hoy por invasoras tendencias utilitarias;

Servir en el Nuevo Mundo y en la ciudad más grande y práctica de América latina, á la aristocracia intelectual de las repúblicas en lengua española"

Esta identificación con La Revista de América implicaba, además de la adscripción estética, asumir una axiología que tenía en el elitismo, encarnado en la idea de aristocracia intelectual o artística, y en la "pulcritud y escrúpulo creativos", algunas de sus bases más firmes. ${ }^{227}$ El manifiesto de 1894 presentaba una mezcla de elementos nuevos y viejos, indicaba su preferencia por geografías imaginarias exóticas y desconocidas, poniendo énfasis en la intención de renovar la lengua española en cuanto a la métrica, los ritmos, el vocabulario. Asimismo significaba la definición del arte como un lugar separado del mundo, una patria que se reconocía como tal en la posesión de una bandera, ${ }^{228} \mathrm{y}$ en cuya definición era central su divorcio del contorno materialista y utilitario. Con respecto a esta forma de diferenciación, y para el caso de la literatura y el arte franceses, cuya autonomización localiza hacia 1850, Pierre Bourdieu ha observado que el campo literario y artístico se construyó en tanto tal en y por oposición a un mundo "burgués". Dicha oposición tenía su origen en el rechazo de una burguesía que como nunca antes afirmaba sus valores e imponía a través de la prensa una definición "degradada y degradante" del arte. ${ }^{229}$ En el contexto

${ }^{227}$ Carlos Real de Azúa identifica y recorta un "lote modernista, cuyas obras juveniles más definitorias, más o menos entre 1885 y 1905, asumieron con más nitidez que otras determinados arbitrios técnicos, determinadas reiteraciones temáticas, determinadas tonalidades expresivas, dentro de una corriente más amplia de cosmopolitización y variadas fertilizaciones formales y doctrinarias; dentro también de un nuevo clima de deliberación, pulcritud y escrúpulo creativos." (Real de Azúa, 1977: 43).

${ }^{228}$ Es interesante señalar como una forma frecuente en las ideologías de artista que se acuñan por esos años, la de de definir el arte apelando a una retórica de la patria. Así por ejemplo, el artículo con que Darío responde a Groussac su crítica a Los Raros en La Biblioteca se llama "Los colores del estandarte", La Nación, 27 de noviembre de 1896.

229 Cf. Bourdieu, 1995: 95. 
latinoamericano, y para el modernismo, Carlos Real de Azúa se refiere "a una postura casi oficial de denostación del proceso capitalista, ostentada en su malestar de formarse dentro de espacios sociales sometidos a un rápido curso de reificación" (Real de Azúa, 1977: 45). Esta postura antieconomista, en el texto de Darío y Jaimes Freyre estaba directamente ligada con la condición del artista como peregrino, o como exiliado del mundo, cuya residencia posible se localizaría en un estado del arte en el que la belleza se erigía como el valor exclusivo de esa patria continental vivida con devoción religiosa; se leía también en el contraste entre la práctica y moderna Buenos Aires y la juventud 'desinteresada' que había hecho La Revista de América y que en 1898 inauguraba El Mercurio de América. La condición de peregrino, podía emparentarse con aquello que Eric Hobsbawm definió como el sentimiento de incomodidad del arte en los últimos años del siglo XIX europeo (Hobsbawm, 1999: 229-251), y que se ligaba con los resultados de la sociedad burguesa y del progreso histórico, no solamente en campo de la cultura. Estos, que habían sido concebidos como una "marcha coordinada hacia adelante del espíritu humano", no se presentaban como lo que se había esperado, y el terreno estrictamente cultural se constituía, al menos desde una mirada elitista, como lucha contra la mediocridad, "convalidándose contra el dominio de la multitud y los excéntricos" (Hobsbawm, 1999: 236). ${ }^{230} \mathrm{Se}$ trataba, en efecto, para la juventud de El Mercurio de un gesto de diferenciación, que tramado como malestar o incomodidad, se advertía en la voluntad de afirmar el carácter "oficial” del mundo artístico -en el sentido de Real de Azúa-, o en la percepción del arte como un universo efectivamente autónomo, regido por una serie de valores específicos que entraban en contradicción con los del espacio social urbano en el que se inscribía. Consecuentemente sostenían en aquella misma retórica a medias patriótica, a medias religiosa:

Y en efecto: estamos decididos á luchar. Lejos de todo propósito utilitarista, sabremos mantener bien alto el pabellón artístico. Todas las tendencias y opiniones hallarán abrigo en estas columnas. El arte es uno. La Belleza inmortal es la misma, sea

\footnotetext{
${ }^{230}$ Aquí Hobsbawm cita a F. Nietzsche en Der Wille zur Macht en Sämtlichte Werke, Sttugart, 1965. [La voluntad de poder, en Obras Completas]. Es importante señalar que El Mercurio publicó Humano, demasiado humano en las entregas de septiembre-octubre, noviembre-diciembre de 1899 y de enero-febrero de 1900.
} 
cual fuere la época o la forma en que se encuentre representada.

Confianza de los jóvenes en la fuerza de la lucha, reafirmación del valor que define la frontera entre el arte y el mundo. Y reafirmación también de la estrategia de inclusión en la amplitud de los criterios artísticos. Este impulso que se enunciaba en otro pasaje de la nota de apertura como "nuestro espíritu amplio y liberal" tenía parentescos con "el marco del bien entendido liberalismo" que propugnaba $L a$ Biblioteca, y con la primera colaboración de Eugenio Díaz Romero en la sección 'Las revistas', a su cargo. ${ }^{231}$ Como se verá, en ella parafraseaba las palabras de Groussac, al contraponer el funcionamiento de la cultura europea con lo que sucedía en América Latina, donde el disenso debía ser -y era- atemperado, dados las dimensiones exiguas y el carácter todavía emergente de la organización del mundo intelectual. Así, observaba: "Rara vez campea [en Europa] el bien entendido liberalismo". ${ }^{232} \mathrm{El}$ Mercurio consciente de la necesidad de cohesión hizo explícitos los lazos de camaradería intelectual. Esto podía observarse en la lista de colaboradores en la que estaban presentes sujetos de generaciones previas y que reunía a pintores, ${ }^{233}$ hombres de teatro, músicos, intelectuales, así como poetas y novelistas que cultivaban estéticas distintas e incluso opuestas. ${ }^{234}$ Sin embargo, como lo demostraban su alineamiento con La Revista de América y el núcleo básico de escritores que la llevaban adelante, la revista era un órgano de difusión del modernismo y, en general, de los valores que éste promovió. Entre ellos, la preeminencia otorgada a la "Belleza" que cimentaba en la oposición entre arte y mundo 'burgués' una solución al problema de la autonomía, se presentaba como un 'avance' en relación con la posibilidad de conformar un campo literario entendido como mundo aparte, y con respecto a su predecesora en la cual producción literaria ( $\mathrm{y}$ artística) hallaba su lugar en un espacio dominado por otras prácticas y otras disciplinas intelectuales. $^{235}$

\footnotetext{
${ }^{231}$ Se trata del texto de apertura de la sección 'Las revistas' que está a su cargo, pp. 66-69. 232 Ibid., p. 67.

${ }^{233}$ Sívori, Schiaffino, Della Valle, Ripamonti, Ernesto de la Cárcova. Cf. nota 202 de este apartado.

${ }^{234}$ Por ejemplo, los casos extremos de Roberto Payró y Darío.

${ }^{235}$ Además de esta primacía de la belleza, Real de Azúa señala los que siguen como valores recurrentes en los textos y conductas modernistas: cosmopolitismo, idealismo antieconomista, elitismo, religiosidad, hispanismo, latinoamericanismo, antiyankismo, compasión social, culto del héroe. (Real de Azúa, 1977: 43)
} 


\subsection{El Mercurio y las revistas. La ejemplaridad del caso francés. ${ }^{236}$}

El Mercurio de América, La Revista de América, La Biblioteca y, más adelante, las otras publicaciones del corpus, coincidieron en traer a un primer plano la reflexión sobre las revistas. En ese sentido, se volvía evidente la importancia de estas publicaciones como espacio de configuración de un saber específico sobre la literatura en el contexto de una modernización cultural con respecto a la que las mismas fueron vehículo y encarnación. De esta evidencia dieron cuenta quienes las hacían al considerar que las revistas como productos culturales propios de una fase del desarrollo de la vida intelectual y artística eran su medio inherente de manifestación. Esta apreciación no era nueva y en ella coincidieron miembros de la fracción intelectual de la elite liberal (Ernesto Quesada, en su ya clásico "El movimiento intelectual argentino" de 1882, ${ }^{237}$ Paul Groussac en "La biblioteca de Buenos Aires", 1896), ${ }^{238}$ los modernistas (Rubén Darío, Ricardo Jaimes Freyre, Luis Berisso, etc.) y lo harían también los jóvenes de principio de siglo XX. En algunos casos dentro de los que debe incluirse a La Revista de América de Darío y Jaimes Freyre, El Mercurio de América, Ideas y Nosotros, ${ }^{239}$ el énfasis se concretó en la presencia de secciones destinadas a dar cuenta de las revistas editadas no solo en el país y en el continente americano sino también en las metrópolis de Europa, que funcionaron como modelos indudables para las capitales latinoamericanas. En ese sentido, las revistas como productos culturales modernos llevaron adelante una tarea de importación y difusión de la modernidad cultural europea, de la cual muchos de los escritores latinoamericanos formaron parte en su calidad de viajeros, residentes o cronistas y

\footnotetext{
${ }^{236}$ Más tarde y una vez desaparecido El Mercurio, el sentido de esta ejemplaridad sería tema de la primera colaboración de Eugenio Díaz Romero en Mercure de France como encargado de la sección Lettres Hispano-américaines. Mercure de France, 38, mai, 1901, pp. 567-5671. Tomamos estos datos de Samurovic-Pavlovic, Liliana. Les lettres hispanoaméricaines au Mercure de France 1897-1915, Paris, Centre de Recherche Hispaniques, Institut d'Études Hispaniques, Paris V, 1969.

${ }^{237}$ Reseñas y críticas, Buenos Aires, Félix Lajouane editor, 1895, pp. 119-141.

${ }^{238}$ La Biblioteca, Año I, Tomo I, julio, 1896, pp. 161-193.

${ }^{239}$ La sección en Nosotros se llamó 'Revista de revistas' y su encargado fue Alfredo Costa Rubert. Si bien fue anunciada desde el primer número, su aparición tuvo un carácter errático.
} 
ejercieron la crítica en los géneros asociados a la prensa periódica como los relatos de viaje o las crónicas. ${ }^{240}$ Así, esta labor de difusión se vinculaba, por un lado con la llamada internacionalización del arte, un fenómeno característico, según Hobsbawm, de fines de siglo XIX y principios del XX; dicha internacionalización consistió en el gran florecimiento del arte, no solo en Europa sino además en una zona más amplia de la civilización occidental. Para el historiador británico, en el caso de la cultura en el sentido de elite, este hecho se relaciona con la "mayor posibilidad de movimiento dentro de una amplia zona cultural"; en cuanto a este último aspecto, lo más importante no sería la instalación de artistas extranjeros en los países por cuyas culturas nacionales sentían una gran atracción, sino sobre todo y principalmente, lo que atañe a los lectores occidentales, quienes a través de la traducción descubren nuevas literaturas como la rusa o la escandinava. ${ }^{241} \mathrm{Al}$ mismo tiempo dicho afán de difusión era una prueba efectiva de lo que Ángel Rama denominó "un cierto isocronismo", al que señaló como característico de la transformación de la literatura latinoamericana (Rama, 1985: 36). Definido como el grado de proximidad con que desde Hispanoamérica se siguió la producción de las grandes capitales culturales, tal isocronismo para El Mercurio de América tuvo como referencia a París, a diferencia de lo que ocurriría en los primeros años de Nosotros cuya mirada estaría orientada hacia Madrid. Como partícipes de una modernización marcada por el internacionalismo, ${ }^{242}$ y como hacedores de revistas en las que no solo informaban sobre las obras recientemente publicadas o daban a conocer textos inéditos, sino también en su tarea fundamental de traductores, ${ }^{243}$ los escritores mostraron al público Beatriz Colombi da cuenta de la forma en que viajaron un conjunto de escritores
latinoamericanos, entre fines del siglo XIX y principios del XX, período marcado por los
procesos de modernización económica, social, cultural y los efectos, previstos o indeseados
que ella produce. La importancia del viaje y específicamente la de los relatos que lo tienen
como marca de origen -las llamadas "escrituras o lecturas viajeras" - radica en que serían
puntos de articulación de procesos culturales hispanoamericanos. Cf. Colombi, 2004: $13-24$.
${ }_{241}$ En el caso de la música el fenómeno de internacionalización se había dado previamente.
(Hobsbawm, 1999: 233-235).
${ }_{242}$ Dentro de lo que llama modernización, Rama plantea la existencia de un macroperíodo al
que denomina de la cultura modernizada internacionalista que se extiende desde 1870 a
1910, año en que se inicia otro macroperíodo, el de la cultura modernizada nacionalista.
Dentro del primer macroperíodo 1870 -1910, distingue tres momentos: el de la cultura
ilustrada (1870-1890), el de la cultura democratizada (1890-1900) y el de la cultura pre-
nacionalista (1900-1910) (Rama, 1985)
243 Los modernistas llevaron adelante una importantísima tarea como traductores. Cf.
Gutiérrez, José Ismael. "Traducción y renovación literaria en el modernismo 
literaturas, autores y movimientos hasta entonces escasamente conocidos para el espacio nacional en el que intervenían. ${ }^{244}$

La sección "Las revistas" de El Mercurio de América, presente desde el primer número, estuvo a cargo de su director. Aunque esa entrega inicial prometía ocuparse de revistas de Europa y de América, la elección recaía en las publicaciones europeas y particularmente francesas. Así, se ponía de manifiesto el carácter modélico de París en el plano científico y cultural, que era sopesado en función de la cantidad y variedad de publicaciones con que contaba la ciudad, definida por Díaz Romero como "primer centro intelectual del mundo" y donde cualquier "suceso notable sea cual fuere el género al que pertenezca, es casi seguro que hallará en las revistas de París, detractores y apologistas". ${ }^{245}$ Otra sección, "Ecos", firmada por 'Mercurio', y de la que seguramente se encargara también Díaz Romero, informó en lagunas ocasiones sobre la repercusión de El Mercurio en los medios intelectuales franceses, ${ }^{246}$ hecho que insistía en mostrar dónde ubicaba El Mercurio la unidad de medida temporal de la modernidad estética.

Para el director de la revista esta preferencia podía fundarse no solo en un reconocimiento obvio del lugar hegemónico de Francia en el terreno artístico y

hispanoamericano", Livivs $\mathrm{N}^{\circ} 1,1992$, pp. 69-83.

${ }^{244}$ La internacionalización del arte también está presente en la perspectiva que propone Pascale Casanova en La República mundial de las letras. Para la autora -y ésta es su premisa básica- existe en Occidente un universo literario mundial que se ha constituido progresiva e históricamente. Definido como una estructura compuesta y regida por relaciones de fuerza (producto de una desigualdad estructural) entre los agentes que procuran la legitimidad literaria, y por lo tanto, una disputa por establecer el valor literario, dicho campo literario internacional se organiza en base a un centro y periferias. Desde los inicios del espacio transnacional (momento que Casanova fecha en el siglo XVI, con la emergencia de los estados europeos), las luchas en el interior del espacio internacional se libran entre lenguas rivales. La unificación progresiva de ese espacio está caracterizada por dos procesos: la expansión progresiva de su geografía y la autonomización de la literatura, en función de la que se constituyen instancias específicas de consagración. Para Casanova esta autonomía es también, desigual. En tal sentido, el centro es más autónomo que las periferias y funciona como una unidad de medida temporal de la modernidad estética, como "meridiano de Greenwich" o presente literario. París es el caso paradigmático de la relación centro-periferia para los jóvenes modernistas de El Mercurio. Cf. Casanova, 1999: 19-68.

245 "Las revistas", Año I, Tomo I, no 1, pp. 66-69.

${ }^{246}$ La Plume, Revue des Revues, Mercure de France, Revue d'Art Dramatique, sobre las que Díaz Romero escribía. La Revue des Deux Mondes se menciona, pero no es comentada. En otras entregas se dedican noticias bibliográficas a Revue Rouge, L'Ermitage. El repaso de lo publicado en esas revistas mostraba la selección de valores entre los que se destacaban la delicadeza, el carácter selecto de los materiales y de los sujetos.

La sección Ecos implica también una forma de subrayar la necesidad del reconocimiento de los pares, en este caso, otras publicaciones, y no sólo argentinas. 
literario o en una afiliación de la revista con el simbolismo y el decadentismo, sino sobre todo en el modo con arreglo al que funcionaba y se desarrollaba la producción intelectual en la capital europea, en contraste con lo que ocurría en América Latina. La descripción que hacía Díaz Romero de ese modus operandi lo mostraba como un anhelo de realización aún dudosa para los escritores americanos. En ese sentido, la literatura francesa regida por una lógica de la lucha por la legitimidad cultural se reconocía, en términos de Bourdieu, como un mundo aparte que fijaba sus modos propios de intervención. La existencia social de ese espacio dotado de un alto grado de autonomía relativa de los poderes externos, del que derivaban la independencia material y moral de los escritores y el mayor grado de institucionalización de la literatura y la crítica, era la condición de posibilidad de lo que con envidia llamó Díaz Romero "espíritu de secta", inherente a los grupos. Para los miembros de la revista, dicha autonomía, que en las notas era legible por contraste, por ejemplo, en las impugnaciones a los criterios mercantiles del periodismo o al criterio social dominante en "la sociedad elegante" (en el caso de la ópera), ${ }^{247}$ por considerarlos modos de valoración espurios, funcionaba como un horizonte no siempre realizable de manera completa. En efecto, más allá de una demanda de independencia reiterada desde el interior de muchos órganos, el carácter emergente del campo literario argentino volvía necesario privilegiar, aún en el disenso, un tipo de sociabilidad no generacional y ni exclusivamente artística. Díaz Romero proponía el contraste en los siguientes términos:

La diferencia de tendencias, es tan manifiesta en Europa, que difícilmente llegarían a encontrarse dos opiniones igualmente afirmativas y armónicas. El espíritu de secta está allá más desarrollado que en ninguna otra parte del mundo. Rara vez campea el bien entendido liberalismo. Y no obstante, las publicaciones francesas, son las más leídas sino también las más apreciadas, aún sobre las alemanas e inglesas. (67)

Así, en el caso francés, el de un campo literario constituido, las polémicas y disputas entre los grupos no eran consideradas como factores disrruptores, sino que

${ }_{247}$ Del Mármol, Adolfo. “Los teatros”, Año I, Tomo I, n 1, julio, 1898, pp. 69-71. 
además de presentarse como la forma típica de alcanzar la legitimidad cultural, y de ser el mecanismo de consagración que remitía a instancias específicas, dichas polémicas parecían tener un efecto positivo y multiplicador. Éste se traducía en la existencia efectiva de un público culto que consumía y demandaba los productos intelectuales. En Argentina, como contrapartida negativa de ese "espíritu de secta" y bajo una premisa proveniente del orden político -el bien entendido liberalismo- debía desarrollarse un espíritu de fraternidad. Como ya se dijo, ese bien entendido liberalismo que había sido la petitio principii "de la crítica más imparcial y amplia" en La Biblioteca, había marcado para la revista de Groussac su condición subordinada, en la fijación del límite de lo decible; para Díaz Romero, exhibía los rasgos de una producción que, comparada con la europea, resultaba escasa y ponía de manifiesto, además, la falta de mercado y de un estrato de público. ${ }^{248}$ Centrado en el pacto que más tarde organizaría las acciones de Ideas y Nosotros y entendido como la "promesa de unir y no dividir", aquel espíritu amplio requería de una gesticulación inclusivista y no sectaria. Esta promesa podía pensarse como "marca de la acumulación de capital simbólico" y era propia del carácter incipiente del campo. ${ }^{249}$

En el interior de la revista y como correlato de ese modo de sociabilidad que organizaba la vida literaria, las notas críticas hicieron presente, en ocasiones, un doble movimiento ambiguo y no exento de contradicciones, por el cual al lado del reconocimiento necesario y la crítica favorable, se exhibía una intención efectivamente belicosa. Las situaciones variaban según se tratara de jóvenes recién venidos a la literatura, de pares generacionales con una alta reputación, de mayores consagrados, enrolados en tendencias que los jóvenes consideraban ya perimidas o decididamente contrapuestas. En el primer caso, y si se reconocía algún mérito, el consejo a la manera Groussac-cuyos juicios eran frecuentemente citados- no se hacía esperar; ${ }^{250} \mathrm{en}$

${ }^{248}$ Así lo explicaba: "Y efectivamente, hay razón para ello [el éxito entre el público de las revistas francesas], puesto que su producción es mayor, la competencia más esparcida y su literatura más vasta". "Las Revistas". Año I, Tomo I, p. 67.

${ }^{249}$ Leticia Prislei señala que esta promesa o pacto de sociabilidad, se actualiza en un "inclusivismo por el cual se relativizaría la alteridad sociocultural de los participantes" (Prislei, 1992: 41-59).

${ }^{250}$ A propósito de Poemas helénicos de Martín Goycoechea Menéndez (Córdoba, Bruno y Cía. editores, 1899), Berisso hacía visible, una vez más, la gravitación de Groussac para los críticos: "(...) alcanzó el honor de merecer, hace tres años, por una monografía literaria, una carta alentadora de Groussac, que si peca por algo, es por severo y descontentadizo. Desde entonces, he seguido paso a paso, las huellas del joven cordobés -a quien no conozco ni de 
el segundo, la crítica era más francamente punzante, como sucedió a raíz de ciertas apreciaciones de José Enrique Rodó; ${ }^{251}$ en el último, podía ser violenta y tenía por finalidad establecer un corte claro en materia literaria. Esta modalidad crítica se reiteraría posteriormente, en algunas intervenciones de Manuel Gálvez en Ideas, pero sobre todo en los escritos de Roberto Giusti de los primeros años de Nosotros, aunque desde otra poética crítica, más identificada con una literatura de orientación mimética y de corte realista. Fue en las notas de Luis Berisso principalmente donde el doble movimiento inclusivista y al mismo tiempo polémico llegó al paroxismo.

Ejemplo del primer caso de ambivalencia fue la crítica a La casta de José María Vélez, en la que aparecía la discusión sobre el arte nacional en relación con la cual podía ligarse a El Mercurio con La Biblioteca: ${ }^{252}$

Ni novela, ni cuento; más bien una narración; promesa de algo que bulle y se agita en La casta, y que tomará o no forma $\mathrm{y}$ vuelo definitivos, dependiendo de ello un escritor o borroneador más, agregado a la falange que cubre este hemisferio (...)

El léxico pide a gritos una podadera; el lenguaje no parece castellano: está plagado de barbarismos,

vista- sin hallar justificados más que en parte, los conceptos elogiosos del Maestro. Ahora, después de leer los Poemas helénicos, me convenzo una vez por todas, del superior criterio y la clarovidencia del ilustre escritor, lince en descubrir la veta del talento, hasta en las capas más ocultas a la mirada general" (233)

${ }^{251}$ En la entrega de noviembre de 1898, a propósito del prólogo a Narraciones de Juan C. Blanco (Montevideo, Imprenta Dornabeche y Reyes, 1898), Berisso afirmaba: "El Sr. Rodó nos ha dado esta vez un chasco mayúsculo; su prologado es un discreto prosador, sin ninguna de aquellas cualidades sobresalientes, que harían disculpables los excesos entusiastas" (307). Esto no le impide saludar casi prosternado el libro Rubén Darío. Su personalidad literaria, su última obra, de Rodó, algunos de cuyos fragmentos habían aparecido en El Mercurio. (marzo, 1899, pp. 225-226). Otro caso de crítica entre pares es la referencia de José Ingenieros en 'Letras italianas' a los juicios críticos de Lugones sobre $L a$ Gioconda de D'Annunzio (febrero, 1899, pp.153-154). "Y vamos a mi Leopoldo [había hablado antes de Matías Calandrelli] que va siendo un caso en nuestro movimiento literario. (...) Lugones, tiene actualmente, una desfavorable predisposición contra todo lo que tiene sabor a modernismo. Hay en esto cierta animosidad, de apóstata. Me explico. Lugones tuvo su crisis de modernismo y llegó en sus primeras erupciones, hasta el límite extremo de lo que, con o sin acierto, se dio en llamar decadentismo. (...) ¿Qué pensar? O Lugones no comprende ni siente a D'Annunzio, y esto no es explicable; o no conoce suficientemente el idioma italiano para apreciar la belleza de sus versos que aún no han tenido traductor." (154) ${ }^{252}$ Los nombres representativos de esa vertiente del arte nacional son, como en $L a$ Biblioteca, los de Joaquín V. González, Rafael Obligado, Sarmiento, Martiniano Leguizamón y Roberto J. Payró. Este último era incorporado por La Australia Argentina (1898), reseñada por Berisso en la entrega de enero de 1899 pp. 65-66. En drama, el único autor que se erigía por sobre el criollismo era Leguizamón con Calandria, también de 1898, y de la que se ocupaba Berisso inmediatamente después de La Australia Argentina. 
neologismos y criollismos en cantidad tal que haría irritar la bilis al menos académico de los lectores (...)

Con todo, no confundiré yo al Sr. Vélez con la plaga de plumíferos ignorantes que invade las revistas del interior y maltrata la lengua y el sentido común; porque si bien el vocabulario gauchesco revienta a cada paso entre párrafo y párrafo, logra a veces iluminar cuadros de la naturaleza

(...) ya que quiere hacer arte nacional, hágalo a la manera de Rafael Obligado y Joaquín González, archivando esa terminología primitiva y grotesca que detona en la obra literaria como una mancha de aceite en una pechera de armiño (307-308)

Para terminar con el reconocimiento nuevamente dudoso:

(...) me complazco en reconocer en su autor una inteligencia y una promesa. Encarrile y depure aquella y logrará producir trabajos que seré el primero en celebrar, si acierta. (308) ${ }^{253}$

Para Berisso, Vélez era al mismo tiempo un escritor y un borroneador, una promesa construida a partir de una mala iniciación, una inteligencia que debía ser depurada, y también, un autor digno de alabanza futura aunque cifrada en el azar ("si acierta"), no en su condición de artista. Estos enunciados contradictorios no se animaban del todo a transformarse en una crítica definitivamente negativa, se desdecían para mostrar la diferencia entre el gusto estético del crítico y el del autor criticado, indicar el rumbo correcto dentro de la línea en que se inscribía su autor, y a su vez, hacían evidente la obligación de celebrar el hecho de que se produjeran y publicaran obras que, aunque malas, aspiraban a participar del juego literario.

Muy otro era el sentido de este tipo de ambivalencia en la reseña que Berisso dedicó a España de Calixto Oyuela en enero de 1899. En este caso, se trataba de una disputa con un intelectual consagrado, conservador e intransigente en materia estética,

${ }^{253}$ Todas las citas de la bibliográfica de Berisso corresponden a El Mercurio de América, noviembre, 1898, pp. 307-308. 
${ }^{254}$ que servía para definir por contraposición los valores que organizaban las lecturas de Berisso.

Quizá la América no cuenta actualmente [con] un escritor más erudito en las letras españolas que el doctor Calixto Oyuela. Adorador de los clásicos y del purismo lingüista [sic], de la Academia Española y de Manuel de Cabanyes; enemigo acérrimo de lo moderno en arte, y especialmente de los llamados decadentes, locales e importados, conservador y ortodoxo como su maestro ilustre Marcelino Menéndez y Pelayo, el doctor Calixto Oyuela goza de una sólida reputación en los países del habla castellana. (...)

En castillado en su retórica rancia, hace fuego desde todas las troneras contra los iconoclastas modernos que derrumban viejos ídolos, revolucionando la métrica, reemplazando en la literatura la pesada arquitectura gótica, por la esbelta y hermosa del Renacimiento; resucitando formas de expresión desaparecidas y creando formas nuevas.

Sin embargo, y más allá de ser el enemigo estético obvio de los jóvenes mercuriales y de cuyos versos Berisso podía afirmar que eran "rígido(s), pálido(s), poco armonioso(s)" u "opaco(s)" (67), Oyuela era rescatado, en esta nota, desde la perspectiva general de la religación cultural con España. La misma ya había en aparecido en El Mercurio y tenía en Rubén Darío, un promotor indiscutido, no solo desde las páginas de la revista. ${ }^{255}$ En

${ }^{254}$ En "La cultura porteña a fines del siglo XIX. Vida y empresas del Ateneo", Roberto Giusti hace referencia al rechazo que la figura de Oyuela provocó, sobre todo en los jóvenes a causa de "sus intransigencias estéticas" cuando fue elegido presidente del Ateneo luego de la renuncia de Guido y Spano, en octubre de 1892. Cf. Giusti, 1954: 53-89.

${ }^{255}$ Respecto de las vinculaciones entre España y Argentina, en el marco más general de los lazos entre España e Hispanoamérica, la crítica ha señalado el año de 1898 como un punto de inflexión. En su ya clásico artículo "El modernismo literario y las ideologías", Carlos Real de Azúa ha observado que entre los escritores modernistas existió una "nueva estimación del legado hispánico, en contraste con el desdén tradicional del siglo XIX" y señala entre los motivos de ese cambio la pérdida de las últimas colonias españolas a manos de Estados Unidos. Esta nueva definición se reconoce en lo que Rafael Gutiérrez Giradot en "El 98 tácito: Ariel de José Enrique Rodó" ha denominado, "reacción filial" por parte de Rubén Darío, la figura "más representativa de las aspiraciones de independencia cultural de Hispanoamérica". "El triunfo de Calibán", escrito de Darío que actualiza dicha respuesta, fue publicado en el diario El Tiempo de Buenos Aires el 20 de mayo de 1898; allí se reencauza la construcción de una identidad cultural de Hispanoamérica cimentada en la lengua, que constituye de modo innegable el punto de unión entre España y las jóvenes repúblicas. Esa nueva disposición hacia la "madre patria" es correlativa, en el caso de los modernistas -y el escrito de Darío lo prueba- del rechazo hacia los Estados Unidos, concebidos, en su faz negativa, como encarnación del utilitarismo, el materialismo y la vulgaridad. Para Graciela 
la entrega de noviembre de 1898, se había publicado "El crepúsculo de España", donde el nicaragüense enunciaba que sus "simpatías han estado del lado de esa ilustre monarquía empobrecida y caída; sus antipatías, de parte de esa democracia rubicunda [EE.UU.], que abusa de su cuerpo apoplético y su ciclópeo apetito" (302-303). ${ }^{256} \mathrm{El}$ antiyankismo de estas formulaciones encerraba no solo el reposicionamiento frente a lo hispánico sino también la insistencia en la distinción de los artistas con respecto a la vulgaridad sin tradición, encarnada para Darío como lo había sido para Groussac -en la nueva coyuntura política de la pérdida de las últimas colonias españolas a manos de Estados Unidos- en la figura del cíclope, símbolo de una modernización cuantitativa y no cualitativa. Desde el punto de vista de ese nuevo hispanismo que no necesariamente coincidía con el del autor de España, la reseña de Berisso elogiaba en él a "uno de los más fervientes defensores de España en América, uno de los argentinos que más han luchado por la unidad del 'Gran Imperio artístico castellano' (68). La autonomía del arte que en la caracterización de Oyuela se hacía presente en su definición como espíritu noble y desinteresado, ${ }^{257}$ no impedía, sin embargo, los posicionamientos políticos de la literatura como lo era, en parte, esta nueva mirada hacia España, en palabras de Berisso: "esa nación hidalga y caballeresca, la cual después del momentáneo eclipse por el que acaba de pasar volverá a brillar esplendorosa" (68). Esta evaluación actual del legado hispánico por los modernistas se haría presente en Ideas en la propuesta de una sección específica de 'Letras españolas' y se intensificaría en Nosotros a través de la publicación Montaldo la opción por el hispanoamericanismo puede ser leída como "la alternativa de la clase intelectual frente a los desplazamientos y reacomodos de la esfera de la cultura impactada por los cambios de la industria cultural". El caso que toma es también el de Darío, en sus crónicas. Afirma que el nicaragüense problematiza el "arte que se adapta a los nuevos requerimientos de las industrias culturales y aprende a convivir con sus nuevas exigencias y formatos (...). Rubén Darío hizo la tarea por todos: incorporó el arte al mercado pero al mismo tiempo mantuvo la ilusión de una cierta 'aura'" (6). CiberLetras, ISSN: 1523 $-1720, n^{\circ} 2$, January 2000. Hubo también en Buenos Aires otros intelectuales y escritores que intervinieron y se manifestaron contrarios de la política norteamericana. Entre ellos, Paul Groussac y Roque Sáenz Peña, quienes se sumaron a la convocatoria de la Comisión Directiva del Club Español de Buenos Aires a la intelectualidad culta de la ciudad, como oradores en el acto del Dos de Mayo en el teatro Victoria. Como ya señalamos ambos, textos aparecieron en la última entrega de La Biblioteca de abril-mayo de 1898.

${ }^{256}$ En el texto afirmaba: "Los que vienen, los que hoy son la esperanza de España, deben asentarse sobre las viejas piedras del edificio caído, y sobre él comenzar la reconstrucción, poniendo la idea nacional en contacto con el soplo universal; manteniendo el espíritu español, pero creciendo a la luz del mundo" (303)

${ }^{257}$ En relación con este valor del desinterés, Julio Ramos, sostiene que ni el desinterés, ni el arte por el arte, deben confundirse con una postura asocial sino que dicha autonomía se vincula con su desplazamiento de la esfera de la educación (Ramos, 1989: 60). 
de textos de autores españoles y en el registro de un intercambio intelectual en las secciones que, como 'Notas y comentarios', dieron cuenta de otros aspectos de la vida literaria no estrictamente ligados con la publicación y crítica de las obras.

Como se puede observar, esas oscilaciones del discurso crítico dibujaban un tipo de gesticulación intelectual y literaria que abundaba en definiciones programáticas y enérgicas de la literatura como innovación rupturista, y no vacilaba en señalar las posturas que consideraba arcaicas, y sobre todo, aquellas que ignoraban la renovación poética del simbolismo o las que pretendían el retorno a lo que Berisso llamaba "literatura de facón, chiripá y vidalita", 258 al mismo tiempo, dichas ambigüedades dejaban al descubierto una forma de consentimiento estratégico, tributario de aquel espíritu amplio y liberal, indicativo este último, de una modernización cultural aún incompleta, y según Berisso, insatisfactoria.

\subsection{Las ideologías de artistas: el sacerdocio del arte.}

En su estudio de las formas de asociación o nucleamiento de los productores culturales, Raymond Williams observa que desde la mitad del siglo XIX se registra en la cultura europea un crecimiento notorio de las que llama formaciones culturales independientes, y vincula este hecho con dos factores. Uno, la creciente organización y especialización del mercado y por lo tanto la también creciente división del trabajo; otro, el crecimiento de una idea liberal de la sociedad y su cultura que se corresponde con la tolerancia de los distintos tipos de obras. Igualmente señala que la formación de estos grupos de especialización por estilos o tendencias fue relevante para la organización y la regulación de las relaciones de los productores con el mercado y para la presentación de un conjunto de obras a la opinión pública. Para Williams, no obstante las tensiones y conflictos que se plantean en la formación de estos grupos, no pueden ser explicados únicamente en términos liberales y de mercado. En ese sentido, afirma que hay que tener en cuenta la generalización y el desarrollo progresivo de la idea de que las prácticas artísticas y los valores asociados a ellas son despreciados por los valores dominantes de la modernidad, deben distinguirse de ellos o son pensados como superiores u hostiles

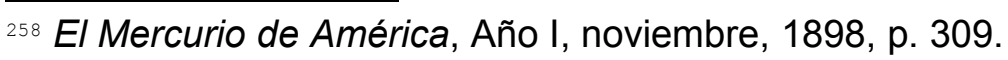


con respecto a los mismos. De este modo, Williams plantea que las relaciones sociales de los artistas constituyen casos diferenciales si se las compara con otras prácticas (Williams, 1988: 67-69). ${ }^{259}$ Por su parte, Erich Auerbach asevera que la polémica y el ultraje contra el público burgués legible en el prólogo de Germinie Lacerteux (1864) de los hermanos Goncourt es un síntoma característico de la relación que, a lo largo del siglo XIX europeo, principalmente francés, se había establecido entre el público y la mayoría de los artistas (poetas, escritores, músicos, pintores, escultores). En una formulación cuyo sentido es similar al que más tarde Bourdieu propondría en su explicación de la economía literaria como un "mundo económico al revés", Auerbach sostiene una relación inversa entre éxito inmediato y valor durable, por la cual los escritores más importantes fueron incomprendidos por un público no habituado a la originalidad de las obras nuevas. En este fenómeno de denostación del público que se dio con especial amplitud y violencia a finales del siglo XIX y principios del XX, se constituiría un modo paradojal en que los escritores burgueses como los Goncourt o Flaubert se diferencian de otras prácticas o esferas de producción. Auerbach observa que el hecho de que el público se hiciera presente como variable positiva o negativa en las intervenciones de los escritores y artistas se liga con la ampliación cuantitativa del público (y el consecuente rebajamiento del gusto) y con la explotación comercial de la necesidad de lectura de ese público, sobre todo por la prensa y los editores que aspiraban, según Auerbach, a la ganancia fácil y por lo tanto publicaban obras del gusto del público e incluso inferiores (Auerbach, 1979: 464-492).

El Mercurio de América como formación cultural de carácter alternativo escenificó de modo particular las relaciones de los escritores y artistas con el mercado y el público, en el contexto de la modernización latinoamericana. En estos vínculos, la tendencia a la profesionalización del ejercicio de la escritura, que encontró en la prensa periódica su espacio de privilegiado, revistió un papel central en la definición de la

${ }^{259}$ Además, Williams sostiene que "producir para el mercado como objetivo que adquiere prioridad sobre cualquier otro, es algo en gran medida evidente en cada fase [artesanado, postartesanado, profesional de mercado], aunque haya muchos ejemplos de productores que luchan contra las tendencias del mercado o incluso las ignoran de forma efectiva. Culturalmente esta interacción es crucial, puesto que define las relaciones sociales de los artistas en un nivel diferente al de muchos otros tipos de producción." Agrega que en la base de estas distinciones se halla un intento de diferenciación entre la producción de tipos de objetos, distinción que puede formularse entre el contraste entre lo "meramente utilitario" y lo "artístico" (Williams, 1988: 45-46). 
literatura y del arte y en la construcción de una figura de artista. En cuanto a este tipo de figuras y para la literatura argentina, Beatriz Sarlo y Carlos Altamirano observan que la prosperidad de las ideologías de 'artista' es correlativa de la tendencia a profesionalización de la función del escritor (Sarlo- Altamirano, 1983: 71). En El Mercurio y también en La Montaña, muchas de las intervenciones tuvieron como eje de sus planteos la caracterización de figuras sociales en relación con las que los jóvenes definieron, a su vez, a aquellas otras pertenecientes a su propio mundo intelectual, literario o artístico. La Montaña tomó distancia de los políticos (Lugones) y de los "reptiles burgueses" (Ingenieros). ${ }^{260}$ Por su parte, la revista de Díaz Romero, distinguió al escritor y al crítico del maestro o pedagogo, y propuso la idea de sacerdocio y la superioridad del arte en un medio que resultaba hostil. El Mercurio encarnó la paradoja entre el anhelo de autonomía del arte y sus nuevos vínculos con las posibilidades de circulación en el mercado, lo cual suponía vender las obras como mercancías, ${ }^{261}$ y lo hizo claramente en el diseño de una subjetividad que intentaba resaltar su inadecuación cierta en relación con los valores del mundo capitalista. En ese sentido, mientras que muchas de las notas exhibían -en un contexto de producción dominado por las urgencias de la colaboración periodística-, un ideal de artista que produjera para sí mismo, o para un público minoritario, desde una sección como "Publicaciones recientes" se señalaba un afán de conocer y difundir los últimos productos del mercado editorial (por más selectos que éstos fueran) y se lamentaba de la ausencia de un público que aunque reducido, no era exactamente de pares, y que como ya se señaló, era interpelado como suscriptor.

Fue un pintor y crítico de arte, Eduardo Schiaffino, encargado de la subsección 'Notas artísticas' quien formuló de manera más extrema y en términos de denegación, los vínculos deseables de los artistas con el mercado. Así como sucedía con las notas

${ }^{260}$ Cf. apartado 5 de este capítulo.

${ }^{261}$ Según Graciela Montaldo, "Los escritores se han profesionalizado y delimitan, para su práctica, un espacio diferenciado que no tardan en convertir en aristocrático. Pero sería difícil entender estos cambios y procesos fuera de los cambios y procesos conjuntos de la cultura del fin de siècle: progresivamente al alcance "de todos". La autonomía estética parece ser, en realidad, el sistema de negociaciones de la estética a los requerimientos de las industrias culturales. Aun cuando esa literatura no es uniforme y sino que se dispara en múltiples direcciones, la relación negociada del arte en el mercado cultural parece marcar casi todas las propuestas del fin de siècle" (Montaldo, 1999: 81). 
iniciales de Berisso y Díaz Romero, la colaboración inicial ${ }^{262}$ de Schiaffino, funcionaba como caso testigo cuya ejemplaridad se focalizaba en dos artistas extranjeros, Gustave Moreau (1826-1989) y Edward Burne Jones (1833-1898), prerrafaelista inglés. ${ }^{263}$ Con respecto a Moreau -cuya "Aparición" fascinaba al decadente Des Esseintes de À rebours-, el crítico valoraba su espíritu aristocrático, su condición "orgánica" (innata) de artista dotado para la percepción de lo "bello", ${ }^{264}$ y destacaba el refinamiento de su arte, asentado en el saber de una técnica manejada con tal destreza que lo elevaba al rango de Maestro. Tal como era presentado, este "dibujante impecable" y "colorista exquisito" de "imaginación delicada", "noble y melancólico", encarnaba la sustracción a la lógica mercantil y realizaba "el ideal del artista de producir para sí mismo" (63). En cuanto a los problemas de los lazos entre artistas y mercado, y para los escritores franceses de mediados del siglo XIX, contemporáneos de Moreau, Pierre Bourdieu afirma que la revolución simbólica por la cual los artistas se liberan de la demanda burguesa, reconociendo como exigencia única la de su propio arte, tiene como consecuencia la anulación o desaparición del mercado y del burgués como cliente potencial. ${ }^{265}$ Ese elemento de orden simbólico determina, para Bourdieu, un hecho material, la creación del propio mercado, donde la ganancia es el reconocimiento social de los pares o de los lectores entendidos. El campo artístico o literario como mundo económico al revés, confiere, paradójicamente, todo su peso a los bienes heredados y particularmente a la renta, que es el reaseguro a falta de mercado. ${ }^{266}$ La descripción de Schiaffino de la situación de ${ }_{262}$ El Mercurio de América, Año I, n 1 , julio, 1898, pp. 63-65. En adelante citamos entre
paréntesis el número de página.
${ }^{263}$ También se refería a Ernest Meissonier (1815-1891) enrolado en el realismo burgués con
motivo de la donación de algunas obras suyas al museo del Louvre por parte de su segunda
esposa.
${ }^{264}$ Este uso que la burguesía hace del arte, y que los artistas sienten como profanación, es
expresado por Lugones en el artículo del no 7 de La Montaña, "A $100^{\circ}$ de infamia". Protesta
Lugones: "Se tomó al Arte como adorno y es moda esto del arte, lo cual quiere decir que
desde ese momento nos vimos sofocados por la más insoportable vulgaridad" (168); más
adelante: "El burgués se ha hecho coleccionista de cuadros y lector de las novelas de Ohnet.
Por lo cual se cree ya pintor, ya literato (...) Naturalmente se decreta la fundación de una
galería de pinturas para educar el gusto, porque parece que el gusto, es decir la facultad de
percibir lo bello, cualidad innata entre todas, es una cosa que se educa" (169) [cursivas
nuestras].
${ }^{265}$ Cf. Bourdieu, $1995: 128-133$.
${ }^{266}$ Bourdieu explica el principio de funcionamiento de la economía artística en relación a su
ruptura con la demanda del público burgués: se trata de un mundo económico al revés, en el
cual el arte en tanto ajeno a la economía corriente, no tiene precio. Dice Bourdieu: "Estamos 
Moreau podía leerse como ejemplo ad hoc del estatuto del artista y de sus vinculaciones con el mercado apuntado por Bourdieu:

ocupaba [Moreau] en el concepto de la crítica una situación artística muy alta y era al mismo tiempo, poco menos que ignorado por el público (...)

(...) su espíritu aristocrático no podía consentir para sus obras, concebidas en el recogimiento de un santuario de arte, en (sic) la promiscuidad bulliciosa de las banales exposiciones públicas

(...) Moreau era rico; su fortuna personal [lo eximió] de la cruel necesidad de vender sus obras para vivir. (63)

La caracterización de Schiaffino respondía a una selección interesada de ciertos aspectos de la vida del artista. En ella, por ejemplo, no se mencionaban los vínculos del pintor con la Academia de Bellas Artes de París, a la que perteneció desde 1888 y en la que había sido profesor entre 1891 y 1898, como tampoco la realización por encargo de una pintura para la iglesia de Notre-Dame-de-Decazeville, ni su participación, en 1870, como soldado en la guerra francoprusiana. Esa selección configuraba la imagen de un aristócrata de la imaginación, sacerdote de su santuario artístico, cuyas obras establecían una distancia subjetiva y objetiva tanto con relación al gran público consumidor de bienes culturales, como a las instituciones y espacios en los que se sostenía ese intercambio. ${ }^{267}$ Así, para la mirada de Schiaffino, el salón y la crítica que se publicaba en los grandes diarios, eran descalificados como agentes de consagración en detrimento del atelier donde pudiera realizarse la crítica de los pares.

De ese modo, en Gustave Moreau se realizaba el oxímoron del desconocido ilustre, en efecto en un mundo económico al revés: el artista sólo puede triunfar ene el ámbito simbólico, perdiendo en el ámbito económico (por lo menos a corto plazo), y al contrario (por lo menos a largo plazo)." (130) Al respecto decía Flaubert: "Cuando uno se dirige a la multitud, es justo que la multitud no le pague. Eso es economía política. Ahora bien, yo mantengo que una obra de arte digna de este nombre y hecha a conciencia no es valorable, carece de valor comercial, no puede pagarse con dinero. Conclusión: si el artista no tiene rentas, tiene que morirse de hambre!" Citado de Bourdieu, 1995: 128.

267 Schiaffino explicaba que salvo tres cuadros ("Orfeo" perteneciente a museo de Luxemburgo y "El joven y la muerte" y "Galatea", que habían formado parte de la exposición del centenario de la Revolución francesa), su producción durante veinte años no había tenido carácter público. Según consta en la biografía sumaria de Moreau realizada por el Museo Gustave Moreau, el artista decidió, en abril de 1895, hacer construir en la calle La Rochefoucauld los ateliers necesarios para presentar sus obras al público. Algunas biografías de Moreau muestran su interés por participar de las instituciones artísticas como la Academia Real de Bellas Artes o su aspiración al premio Roma. La datación de los cuadros que hace Schiaffino no es completamente correcta. 
por lo cual el autor de la nota definía la situación como anómala o excepcional, comparada con la de la mayoría de los artistas. Asimismo, estas afirmaciones de Schiaffino exponían la construcción de una imagen de artista en la que se manifestaba una tensión no resuelta con la crítica, una práctica que aunque se destinara a un público de expertos o pares, no dejaba de ser un discurso público.

El crítico narraba la vida de Moreau en una sucesión de hechos a la que reconocía un encadenamiento necesario basado en las condiciones de su producción pictórica, inmejorables y determinantes de la consagración final.

La existencia de Gustave Moreau ha sido tan completa, se encadena de una manera tan lógica, que le ha permitido asegurar en la mejor forma el destino de su producción intelectual. (...) No conozco destino más admirable, que el de este noble y melancólico artista; viene al mundo entre los privilegiados de la fortuna y estudia, con tal dedicación que llega a ser en el difícil arte de la pintura un técnico de primer orden; (...) cuando el artista se torna maestro, capaz de realizar de un modo insuperable los ensueños de su altiva fantasía, huye el aplauso de los contemporáneos, se encierra solitario en su torre de marfil, y al par que un avaro desgrana lentamente, una por una, las piedras preciosas de sus colores misteriosos que parecen irradiar fulgores de hornalla; atraviesa la vida sigilosamente; ejecuta como un jornalero la labor de cada día y semejante al orfebrero que obra pacientemente en la penumbra del taller modesto una ducal corona, acaricia y pule el fruto de su ingenio (...) prepara la joya deslumbrante, destinada a ornar la frente de la patria amada.

Gustave Moreau ha producido directamente para la posteridad (64)

El conjunto de rasgos que concentra el pasaje citado (privilegio económico, torre de marfil, técnica refinada, fantasía y ensueño como la contracara del mundo filisteo, obras carentes de público y de precio, pinturas únicas y por lo tanto merecedoras de una recepción aurática) definen una posición artepurista. Sin embargo, en medio de esta consagración devota, lo práctico se hacía presente en la igualación semántica deslizada entre los términos jornalero / orfebrero, en una clara referencia al proceso socioeconómico en relación con el cual esta vida de artista se presentaba como 
respuesta y del que intentaba diferenciarse. ${ }^{268} \mathrm{Al}$ mismo tiempo, la diferencia entre los tipos de producción que indicaban ambos términos se veía suavizada por la semejanza que sugería la terminación idéntica de ambas palabras. Por último, la independencia y el apartamiento del mundo de esa existencia infatigable tenían como coronación imprevista y como servicio último, el enaltecimiento de la patria a la que Moreau legaba toda su obra.

El final de la nota hacía evidente la función contrastiva que guiaba la intervención:

(...) No son pues los productores silenciosos que vuelcan su alma en el recogimiento de sus estudios, lejos del mundo, de sus pompas y de sus fútiles querellas los que escasean, Moreau ha demostrado que aparecen en todo tiempo, en cuanto las circunstancias que los rodean son clementes en vez de hostiles.

En tal sentido, la imagen de artista que diseñaba Schiaffino a partir del caso Moreau, y en tanto forma extrema de la enunciación de la autonomía del arte, era pensada como contracara del estado del arte en Buenos Aires y en otras ciudades de América, donde, a diferencia de lo que sucedía en París, ni los gobiernos -carentes de toda previsión en la construcción de un arte nacional- ni la liberalidad de los ciudadanos fomentaban el desarrollo del arte. ${ }^{269}$ La referencia a Edward Burne Jones, en el final de la entrega de

${ }^{268}$ Cuando Erich Auerbach analiza las cartas de Flaubert y el Journal de los hermanos Goncourt refiere esta penetración de lo práctico a pesar de todo: "y mientras el escritor se desvía desdeñosamente del trajín de lo político y lo económico, valorando constantemente la vida nada más que como asunto literario, y se mantiene apartado con amargura y altivez, de los grandes problemas prácticos, conquistando, cada día, y a menudo fatigosamente, el asilamiento estético necesario para su trabajo, lo práctico penetra a pesar de todo en él en mil formas ruines: surgen disgustos con los editores y críticos, odio al público que el escritor quiere conquistar faltándole la base de un sentimiento y pensamiento comunes; a veces existen también preocupaciones monetarias y, casi sin interrupción, irritabilidad nerviosa y temores respecto a la salud" (Auerbach, 1979: 475-476).

${ }^{269}$ Así lo exponía: "La ciudad de París tan rica en obras de arte gracias al genio de la nación, a la solicitud de gobiernos previsores y a la liberalidad de los ciudadanos, acaba de enriquecerse con dos legados valiosísimos efectuados esta vez directamente por artistas o sus deudos inmediatos", p. 63.

Como contraejemplo de la situación de Moreau se pude leer en la sección "Bellas artes" de La Revista de América la nota de Rubén Darío sobre la exposición póstuma del pintor argentino Graciano Mendilaharzu organizada en 1894 por Eduardo Schiaffino, realizada en el Ateneo. Allí Darío elogia la iniciativa de Schiaffino en la "traficante y política Cosmópolis". "Este buen amigo del pobre pintor Mendilaharzu ha sido el autor de la feliz idea de reunir y exponer los cuadros y dibujos del artista argentino que recibió la fatal consagración de la desgracia, antes de entrar en la divina y salvadora de la muerte", Revista de América, Año I, $\mathrm{n}^{\circ} 3,1^{\circ}$ de octubre de 1894 , pp. $56-58$ 
'Notas artísticas', se alineaba con las cuestiones planteadas para Moreau, e insistía en el modo de distanciar el arte "del siglo industrial” (65) que el pintor había propugnado apelando al "portentoso despertar del sentimiento místico".

Las diatribas contra el público, como otra forma de marcar la brecha que debía separar a la literatura del mercado, se podían leer en las críticas de Leopoldo Lugones al drama Le Martyre de Jean Richepin, a quien Darío había incluido en Los raros y al que Lugones valoraba por su fuerza y “entereza varonil”. El autor de Las Montañas del oro criticaba la adecuación de la obra a las fórmulas probadas del éxito teatral marcadas por el efectismo en un escritor "cuyos propósitos anárquicos no alcanzan a borrar los apetitos del éxito", ${ }^{270}$ Este afán de consagración inmediata afectaba el modo en que los temas eran tratados, en una concesión a la vulgaridad, para "bordarse de laureles fáciles las sienes", arrancados a un público que no podía percibir los "ilogicismos de escena" y que solo buscaba "látigo en los nervios". ${ }^{271}$

El rechazo de la vulgaridad del público reaparecía en la oposición entre el arte y la mediocridad que abría "Artistas y pedagogos"272 de Eugenio Díaz Romero. E1 epígrafe de este artículo, que correspondía a un pasaje de "Los mediocres" de Darío, servía para contraponer a la utilidad de la figura del crítico pedagogo o estudioso, la elevación de la subjetividad del crítico como artista y, desconectado, por tanto, de la función docente. Así, arte y pedagogía constituían dos prácticas inconmensurables y el arte, desvinculado del cumplimiento de algún mandato, se alojaba en un dominio propio. Del lado de las "cosas buenas", y no de las "cosas bellas", el profesor Calandrelli expresaba una institucionalización de la literatura cuya tarea era modelar y educar la subjetividad de los niños; desde esta mirada, y como objeto de una pedagogía estatal, la literatura debía ocupar un lugar en los programas escolares, y circular en los 'libros de texto' -que el mismo Calandrelli escribía. La polémica con el

\footnotetext{
${ }_{270}$ El Mercurio de América, Año I, julio, 1898, pp. 80-81.

${ }^{271}$ También Luis Berisso, -además de las consideraciones iniciales de 'Letras Americanas'expresaba sus prevenciones por este anhelo de éxito en sus críticas a Bohemia sentimental de Ramón Gómez Carrillo: "El afán de producción, de que parece estar atacado Enrique Gómez Carrillo, y la precipitación con que viene dando a luz libro tras libro, acabará por dañarle. Cuando como él se ha logrado formar un nombre literario respetado en todo el continente, es preciso que sepa conservarlo", El Mercurio de América, enero, 1899, p. 69.

${ }^{272}$ El Mercurio de América, Año II, enero, 1899, pp. 52-61.
} 
pedagogo tenía su origen ${ }^{273}$ en unos juicios suyos sobre Rubén Darío. Es importante recordar que la nota de la dirección que había iniciado El Mercurio, hacía suyos los propósitos del propio Darío y Jaimes Freyre en La Revista de América, y de tal forma, otorgaba a Rubén Darío un lugar de privilegio. Esos objetivos que, como ya se dijo, contenían la matriz de intervención de la revista, cobraban cuerpo en el diseño de una imagen de artista que se realizaba en la figura de Darío, y en relación con la cual, este escrito podía considerarse como una defensa de su propia revista.

En términos generales, la caracterización del artista (y del crítico) y de su condición era coincidente con la de Schiaffino y enfatizaba el rasgo de "refinamiento psíquico necesario para gustar ciertas cosas", aspecto que aquél había definido para Moreau en términos de condición "orgánica”. De igual modo este artista o crítico artista, ${ }^{274}$ "alma exquisita al par que severa", debía educar su espíritu en todas las esferas estéticas, y al mismo tiempo, ser capaz de valorar y alentar el esfuerzo realizado, sobre todo cuando esa "ascensión” (56) se llevaba adelante en Buenos Aires, ciudad a la que Darío había caracterizado como traficante y política. Para la nueva literatura era también necesaria una crítica nueva que agregara a la preparación intelectual, al "dominio de la belleza y la ductilidad de la idea", la capacidad de juzgar lo nuevo, constituyéndose así en el espacio de su legibilidad.

El texto reiteraba el tópico del medio dominado por el materialismo, hostil e indiferente a las manifestaciones del espíritu superior y aristocrático del arte al que definía como un "sacerdocio". Afirmaba Díaz Romero:

\section{(...) usted ignora que el arte es un sacerdocio y que los que a él se consagran en una época}

\footnotetext{
${ }^{273} \mathrm{La}$ crítica a Calandrelli se reiteró en la entrega siguiente de la revista, de febrero de 1899. En la sección de Letras Italianas, Ingenieros descalificaba sus opiniones sobre La Gioconda de D' Annunzio, en un tono más jocoso que el de Díaz Romero. Decía: "Calandrelli -Oh! señor Matías- ha evacuado un juicio que no debió intentar jamás (...) El señor Matías está imposibilitado para ello; en el cerebro de un hombre y maduro, que ha encanecido entre los clásicos latinos, la pedagogía y las elucubraciones filológicas(...) no pueden haber centros capaces de percibir las armonías sutiles que fluyen de la obra de ese maravilloso mago del estilo" p. 153. Calandrelli había colaborado en La Biblioteca con "Filología americana", y en 'Redactores' Groussac lo presenta como un funcionario educativo y profesor. Fue entre otras cosas rector y profesor del colegio Nacional de La Plata hasta 1888. Escribió "varias obras didácticas y textos escolares relativos a las lenguas clásicas". La Biblioteca, Año II, Tomo VIII, p. 255.

${ }^{274}$ Díaz Romero definía la crítica como una rama de la literatura, El Mercurio de América, Año II, enero, 1899, p. 56.
} 
innoble, en un medio bastardo, lejos de la civilización verdadera, privados de lo indispensable, humillado ante el concepto de los poderosos por ese hecho solo, forzador a arrostrar miserablemente la vida, escarnecidos, apedreados, no son siquiera acreedores de una palabra de aliento (...)

Usted ignora que habitamos un país indiferente, sin ideales, ni tendencias altruistas, dedicado por completo a la ganadería, al cultivo de la caña de azúcar, a la especulación vergonzosa, privado como ningún otro, de centros literarios y artísticos, de ambiente generoso y pensamientos augustos, indigno del progreso y de las ideas que animan el espíritu de otras naciones $(60)^{275}$

Así, el arte se presentaba como una condición y el artista como un átopos, un peregrino, casi mártir, "humillado" ante el poder material -y político-, ocupando un sitio socialmente devaluado, e ignorado en "medio de la desoladora aridez de nuestro ambiente de mercaderes y agiotistas". ${ }^{276}$ Llevado al terreno de lo cultural, estos mercaderes no eran otra cosa que el público, al que aquí también se denostaba al identificarlo con la misma ignorancia de Calandrelli en materia literaria, señalándolos como los lectores del periódico El Nacional en que había aparecido el artículo que diera origen a la disputa.

Este espiritualismo antifilisteo finisecular en el que abrevaban Schiaffino, Díaz Romero o Berisso, era una de las formas en que se tramaba la necesidad de reconocimiento de las prácticas artísticas en tanto universos diferenciados. Esta aspiración de reconocimiento se actualizaba de modo preferencial en los productores y de ese modo, el énfasis mayor se concentraba en promocionar una imagen de artista,

\footnotetext{
${ }^{275}$ Una formulación casi idéntica de esta cuestión aparece en la nota de Berisso "El Mercurio y la desaparición de La Biblioteca". Allí expone sus quejas: " (...) el público no responde a estos esfuerzos desinteresados y nobles de la juventud, que vive todavía de sueños e ideales, en esta época práctica y materialista, donde cualquier especulador de tierras o invernador de puercos, es estimado, socialmente, más que todos los talentos juntos", El Mercurio de América, Año I, nº 1, julio, 1898, p. 72.

${ }^{276}$ Estas palabras no pertenecen a Díaz Romero sino a Berisso, pero consideramos que su inclusión es completamente pertinente, en virtud del tono de las intervenciones de uno y de otro. "De mi diario", El Mercurio de América, Año II, mayo, 1898. Fue justamente sobre Luis Berisso que Víctor Pérez Petit en el prólogo a El pensamiento de América del mismo Berisso afirmó que se trataba de "uno de esos caballeros medievales, esclavos de su lema, completamente extranjeros en nuestras civilizaciones modernas" (Berisso, 1898: XII).
} 
entre cuyos rasgos dominantes se hallaba la voluntad de sustraerse de la reificación que suponía su consumo por un público inexperto. En la medida en que este espiritualismo señalaba al mundo materialista y burgués como su enemigo, presentándose como contrapartida, ponía en escena, desde lo estético-literario, una de las contradicciones de la modernización capitalista. Es así que si en el marco de la división social del trabajo, característica de la modernidad los escritores se veían impulsados a la profesionalización, paradójicamente la forma misma en que la literatura y el arte asumían para distinguirse y profesionalizarse atacaba e impugnaba la modernización económica. 


\section{Entre La Biblioteca y El Mercurio de América, La Montaña. Un episodio de política literaria}

En 1897, un año después de la aparición de La Biblioteca, dos jóvenes argentinos, José Ingegnieros y Leopoldo Lugones publicaron, en Buenos Aires, el $\mathrm{n}^{\mathrm{o}} 1$ de $L a$ Montaña. Periódico socialista revolucionario. ${ }^{277}$ El título ponía en evidencia que el periódico se proponía construir un espacio para la discusión fundamentalmente política. De este modo, a primera vista, privilegiaba una temática divergente de la que los jóvenes del modernismo promovían en sus ideologías de artista. Más allá de esta diferencia obvia, las acciones de La Montaña constituyeron un episodio de política intelectual y literaria. En ese sentido, en el contexto de la emergencia un mundo cultural relativamente autónomo, las intervenciones de este diario pudieron ser pensadas como un intento significativo por instaurar el reconocimiento social de aquel universo, a partir de su distinción del campo de poder y del orden político.

Como lo serían sucesivamente El Mercurio, Ideas y Nosotros, La Montaña fue una publicación juvenil. En ese sentido, la diferencia más ostensible con respecto a las otras revistas del corpus, se establecía con La Biblioteca de Paul Groussac quien, como miembro conspicuo de la elite intelectual liberal gozaba de una legitimidad indiscutida. En efecto, se trataba de órganos de carácter disímil, cultural el de Groussac, político el de Ingenieros y Lugones, y cuyos grados de institucionalización eran diversos -la publicación de Groussac pertenecía a una repartición del Estado, la de los jóvenes se ubicaba claramente en la periferia. No obstante, La Montaña no construía antagonismos absolutos e irreconciliables con La Biblioteca. Del mismo modo, ambas cooperaban y podían ser alineadas en un linaje similar, en función de su demanda coincidente, más allá de las estrategias y las formas en que se relacionaban con el campo del poder. En este punto -pero no en otros- La Montaña invertía el juego de relaciones y demandas planteadas hacia el Estado que leíamos en La Biblioteca. La revista de Groussac, ligada directamente con el Estado en tanto órgano oficial de la Biblioteca Nacional, abría una

${ }^{277}$ La colección completa consta de 12 números, que fueron publicados quincenalmente. EI primer número apareció en abril de 1897 y el último en septiembre de ese mismo año. José Ingegnieros y Leopoldo Lugones figuraban como 'Redactores'. El periódico tuvo secciones fijas: 'Estudios sociológicos', 'Arte', 'Filosofía', 'Variedades'; 'Actualidad'. Actualidad, a su vez, albergaba las subsecciones 'Bibliografía', y 'Movimiento Socialista'. Los números estaban fechados según el calendario de la Comuna de París. 
cuña y se instalaba en el espacio institucional del campo de poder, y desde allí difundía la producción intelectual y artística nacional. Como era evidente, ambas publicaciones discutían sobre el lugar del arte en la República. Según se dijo, desde el seno del liberalismo político y basada en el voluntarismo de su director, La Biblioteca había afirmado la independencia de las empresas culturales con respecto al poder políticoestatal, y a la vez, había señalado al Estado su obligación de promoverlas y protegerlas. A su turno, La Montaña, ubicada en un margen -lejos de cualquier vinculación con el poder estatal- asignaba al arte un lugar revolucionario, colocación derivada de su fe política. Sin embargo, ni esta concepción del arte ni la adscripción ideológica de la publicación impedían que La Montaña resguardara la dinámica basada en el pacto de sociabilidad que era dominante en las acciones intelectuales en ese momento de emergencia. Así, por ejemplo, el artículo de José Ingenieros sobre Groussac -"Pablo Groussac y el Socialismo"- señalaba una cierta proximidad con La Biblioteca, en el reconocimiento por los jóvenes de su figura prestigiosa. Esta evaluación, que no atendía a las discrepancias políticas, permitía establecer una continuidad entre las generaciones de intelectuales y artistas responsables de cada uno de los proyectos. Ingenieros, desde su periódico de carácter juvenilista, precisaba las posiciones que cada uno ocupaba dentro del mismo espacio compartido e incipiente, y reconocía a Groussac como un intelectual de "la guardia pasada" que "tiene el doble privilegio del talento y de la independencia" ( $\mathrm{n}^{\mathrm{o}} 6$, 146). Esta continuidad entre las publicaciones podía ser leída, además, como enlace entre la vanguardia estética modernista a la que La Biblioteca había abierto sus páginas ${ }^{278}$ y la vanguardia política, que al igual que el modernismo estético se dirigía a la juventud de América. Del mismo modo, esta conjunción a primera vista paradójica entre anarcosocialismo y modernismo estético se hacía posible en virtud de "la misma negación inmediata ejercida tanto en una política derrumbista social-anarquizante cuanto en el repliegue hacia la interioridad modernista" y se había manifestado también en los

${ }^{278}$ Como ya señalamos, en La Biblioteca se publicaron de Lugones "La voz contra la roca" (agosto de 1897), "Un estreno" (febrero de 1898), Táctica (abril-mayo, 1898). En la sección 'Boletín bibliográfico', Groussac reseñó Los raros y Prosas profanas de R. Darío (en noviembre de 1896 y en enero de 1897 respectivamente). También aparecieron "Artemis" de Enrique Rodríguez Larreta (noviembre de 1896) y la reseña de Traducciones de Leopoldo Díaz (mayo de 1897). Cf. apartado 3.1 de este capítulo. 
contactos de Lugones e Ingenieros con el sector juvenil y renovador del Ateneo de Buenos Aires. $^{279}$

\section{1. Intelectuales y artistas en La Montaña}

Según ya se anotó, en el fin siglo XIX proliferaron las intervenciones que forjaban y diferenciaban las subjetividades modernas de escritores, intelectuales y artistas, hecho que era correlativo de la autonomía creciente del campo literario. Los redactores de La Montaña no constituyeron una excepción y se avocaron a esta tarea de manera regular construyendo representaciones imaginarias del intelectual y del poeta. La columna 'Los reptiles burgueses', de José Ingenieros, los escritos de Leopoldo Lugones específicamente relacionados con el arte, así como los pasajes significativos de 'Los políticos de este país' -también de Lugones-, constituyen el corpus más relevante en el que se edificaron estas figuras. Tanto en las colaboraciones de Ingenieros como en las de Lugones, los intelectuales fueron definidos por contrapartida y diferenciación de los políticos, quienes encarnaban y sustentaban el orden burgués. Este conjunto de textos recortaba un espacio de enunciación que se pretendía distinguido y distinto del campo del poder. Así, en los artículos de Lugones se observaba principalmente la construcción de la figura del artista en tanto poeta, y en otro orden que consideramos en sistema con las intervenciones de Ingenieros, se ponía en escena y se denunciaba el escándalo político como estrategia para singularizar la figura del intelectual. En los trabajos de Ingenieros se registraba la intención de construir una imagen de intelectual marcada positivamente en términos morales como la contracara de la dirigencia política argentina.

En el marco de la hegemonía obvia de los discursos políticos en el periódico, La Montaña acudió a un repertorio de imágenes provenientes de ciertos mitos políticos del siglo XIX europeo, para tramar la construcción de las figuras de intelectual y de poeta. En este sentido, el hecho de que la revista recurriera a un "archivo de imágenes" provenientes del campo del poder para acuñar esas dos figuras, se explicaba al menos

${ }^{279}$ Cf. Terán, 1986: 26-27. También es importante señalar que esta conjunción también se enuncia en "El noviazgo rojo", un texto de Jean Ajalbert, que la revista hacía suyo y que podía leerse como programático. Cf. La Montaña, n 4, pp. 90-93. 
por dos razones. La primera, porque para debatir problemas específicos, la publicación intervenía desde el espacio de la discusión sobre teoría política. La segunda se relacionaba con una estrategia por la que la actividad de los intelectuales y artistas, considerados desde una cierta especificidad de sus prácticas (a partir de su distinción de la política como término de referencia privilegiado) aparecía resaltada en una dimensión que era también política. Asimismo, en el periódico se registraba un movimiento doble -y que tornaba explícita una tensión- con respecto a las relaciones entre literatura y política. Así, por una parte, en el trayecto de la literatura a la política, se construía la figura del poeta necesario para la nación, cuyo resultado era la elevación social del poeta, incluso por encima de la dirigencia política. Por otra, en el movimiento desde la política hacia la literatura, se incursionaba en la literatura como actividad secundaria, situación todavía común para cierta franja de sujetos de la generación precedente. ${ }^{280}$

En lo que sigue nos ocuparemos fundamentalmente de las cuatro entregas de "Los reptiles burgueses", de algunos aspectos de "Los políticos de este país", y señalaremos sumariamente lo relativo a la imagen del poeta construida por Lugones.

\subsubsection{Ingenieros: la crisis del 90 como conspiración moral}

En su estudio sobre el imaginario político, Mythes et mythologies politiques, Raoul Girardet observa que se "nos presenta con una irreductible evidencia que las agitaciones políticas de los últimos siglos de historia europea no han cesado de estar acompañadas de una asombrosa efervescencia mitológica" (Girardet, 1986: 11). Agrega, además, que los movimientos de ebullición imaginaria deben ser relacionados con algún fenómeno de ruptura, mutación, crisis, o con alguna situación de orden social, político o económico determinada. En ese sentido, y con respecto a los escritos de José Ingenieros de la serie "Los reptiles burgueses" -contemporáneos de ¿Qué es el socialismo?-, Oscar Terán afirma que pueden ser leídos como espacios donde se configura "una primera organización" de la "mirada teórica" de Ingenieros; para

\footnotetext{
${ }^{280}$ Más adelante hacemos referencia al caso concreto de Pellegrini al que se refiere Lugones.
} 
Terán, esa mirada “está mediada por una serie de ideologías contestatarias que impugnan ciertas estructuras del país programado por el liberalismo argentino, y dicha negación se opera sobre la base de la crisis del 90" que es interpretada en clave ética (Terán, 1986: 11). Así, es posible pensar que en esa evaluación crítica de la política liberal se jugaba la existencia de un espacio de enunciación que al propugnar una crítica y al explicar en términos morales la situación presente, reivindicaba el deber y el carácter ético del discurso de los intelectuales. Este discurso sustentado en su condición moral positiva, interpretaba el orden burgués en términos de conspiración. A diferencia de los discursos europeos analizados por Girardet, en el caso de Ingenieros no se trataba de la conspiración de grupos ocultos que pretendían acceder al poder para luego ejercerlo sobre el resto del mundo, sino de un orden estatal corrupto. En ese sentido, los intelectuales autorizaban su discurso en el hecho definitorio de su escisión de las políticas y de la ideología del Estado liberal.

La afinidad, el contagio y el parentesco con este mito político de la conspiración se registraban ya en el título de la sección -'Los reptiles burgueses. Los conspiradores, tal como aparecían en las constelaciones mitológicas del siglo XIX europeo, en las figuras de los judíos, masones o jesuitas, ${ }^{281}$ se caracterizaban por un tipo particular y rastrero de desplazamiento en el espacio, el reptar, que el nombre de la columna de Ingenieros transformaba en epíteto. Afirmaba Ingenieros:

La vida social ha asumido una forma única, concentrándose a esa exclusiva modalidad del movimiento: la reptación. En el estercolero burgués arrastrarse es vivir. (49)

Esta afiliación se confirmaba, no solo en los predicados de la animalidad, ${ }^{282}$ sino también en el acaparamiento total de la riqueza pública, la corrupción, el envilecimiento de las costumbres, la descomposición sistemática de las tradiciones sociales y de los valores morales (Girardet, 1986: 25-69). Los reptiles-conspiradores estaban marcados por una desviación de la normalidad social que, en Ingenieros, aparecería como anormalidad moral criticada, bajo la lupa del paradigma biológico, en términos de patología social.

${ }^{281}$ Girardet analiza estos tres casos de conspiraciones en el siglo XIX europeo, en el capítulo "La Conspiración”. Cf. Girardet, 1986: 25-69.

${ }^{282}$ Ingenieros habla de "bestia humana", "paquidermos burgueses", p. 49. 
La sintaxis de los discursos de Ingenieros tomaba la forma de la descripción injuriosa, lo mismo que algunos pasajes de "Los políticos...". La serie completa constaba de cuatro artículos, cada uno de los cuales daba cuenta de problemas específicos. El primero, "Los que van al santuario", ${ }^{283}$ ponía al descubierto el carácter hipócrita de las prácticas religiosas y señalaba ese momento histórico como el de la "culminación de las mediocridades" (49). En Ingenieros, este estado moral tenía su contrapartida en una meritocracia del talento, que constituía el patrimonio de los intelectuales. El sistema republicano se criticaba en términos de prostitución, sus funcionarios conformaban la "turba rapaz de sus clientes", y eran condenados por la exhibición de un materialismo representado en la "pasión de los inmundos billetes de bancos embrollones y la xantopia desesperada" (49). Esta definición oponía el mérito al clientelismo, el talento a la vulgaridad, presentaba la ética como resultante del mérito y del talento, y por lo tanto como propia de los intelectuales. El paradigma biológico se hacía presente para acusar y poner en escena la patología moral:

El torbellino castra los corazones y las
conciencias; no hay un solo órgano sano, un solo
átomo inmaculado en este cadáver social. No
puede haberlo porque las purulencias burguesas lo
han infectado todo, fecundándolo con sus
gérmenes que pululan en todas las arterias sociales
como savia saturada con una lepra de nuevo
género: una lepra del alma que dobla las cervices y
roe las vértebras dorsales amenazando con hacer
hereditarios los estigmas del servilismo (49)

Se trataba, según Ingenieros, de una sociedad enferma, infectada, purulenta y acomodaticia que empleaba la religión como forma superficial de limpiar sus delitos sociales y sobre todo institucionales: el saqueo del erario, el robo a los bancos, la hipocresía de aquellos que "mercantilizan una patria en la que no creen y cuya adoración pretenden imponer al pueblo" (50). En "Los cerebros de la moral" 284 se recurría a una retórica análoga. Distribuidos en las instituciones públicas, estos reptiles conspiradores inculcaban una "educación malsana, que se impone a los recién venidos

\footnotetext{
${ }^{28}$ La Montaña, Año I, n 2, 15 de abril, 1897, pp. 49-51.

${ }^{284}$ La Montaña, Año I, $n^{\circ} 5,1^{\circ}$ de junio, 1897, pp. 120-122.
} 
a la palestra de la vida en una inoculación de gérmenes pestíferos que hacen más estragos en el espíritu que todos los microbios en el cuerpo" (121). En la entrega tercera, "Intelectuales y bolsistas", definía a ambas figuras como "pedículos del gran pubis social"285 y sugería, desde la conjunción de los términos del título, lo que luego se hacía evidente: el carácter mercantil del vínculo de la burguesía con los productos intelectuales. De ese modo, Ingenieros criticaba el uso de los bienes intelectuales por parte de los burgueses como forma de acrecentar su capital social, y denunciaba la condición dominada de la cultura en un ordenamiento más que precario, tanto simbólica como económicamente:

(...) consigue hacerse rodear por hombres de verdadero talento que verán en él a un generoso editor a precio de una dedicatoria; costeará una revista literaria o científica (...) en cambio de su agradecimiento, que se manifestará con la aplicación del ansiado calificativo: 'Intelectual' (197)

Así, los productos intelectuales, a los que también se accedía por dinero, eran una forma más del prestigio social. Esta formulación coincidía con aquella de Lugones, en la que se refería al "arte de adorno" para señalar la vulgarización del arte a partir de una operación que lo igualaba con la moda; ${ }^{286}$ se emparentaba también con las críticas que posteriormente realizarían los jóvenes de Ideas al público aristocrático al que considerarían tan inculto como el público popular. En ese marco, además, el arte era concebido como objeto pasible de una cierta pedagogía, cuyo fin y efecto era también, como para Ingenieros, el beneficio del prestigio social. A diferencia de los burgueses, los verdaderos artistas, poetas y científicos cuyo único capital era su talento, encontraban en "la ley de la eterna maldición: Talento de rodillas ante Oro", su ubicación subordinada (194). En la última entrega, "Los padres de la patria", ${ }^{287}$ Ingenieros retomaba la idea de la degeneración que había aparecido antes, e inventaba

\footnotetext{
${ }^{285}$ La Montaña, Año I, nº 8, 17 de julio, 1897, pp. 192-194.

${ }^{286}$ Señala Lugones: "Desde que empezó a ser un concepto social y una expresión pedagógica esa portentosa imbecilidad que se llama 'Arte de adorno', todo gabinete de señorita ostentó, junto al indispensable instrumento musical, un caballete", La Montaña, Año I, $\mathrm{n}^{\circ} 7,1^{\circ}$ de julio, 1897, p. 168.

${ }^{287}$ La Montaña, Año I, no 10 , pp. 239-241.
} 
otra, marcada por el evolucionismo, la de "selección servil". A sus ojos, esta selección regía el espacio parlamentario, y había reunido a los más mediocres para el mejor saqueo del tesoro público. El rasgo distintivo de la animalización servía para impugnar las decisiones de los legisladores, reducidas a una "degeneración aprobatoria". Describía Ingenieros: "Una ligera cerviflexión, casi siempre unánime, sanciona con fuerza todos los proyectos equivalentes a una succión lujuriosa en el pezón de esa inagotable glándula mamaria que se llama presupuesto" (240).

En todos los casos la voz que enunciaba, enrolada en el socialismo, construía desde ese espacio ideológico las condiciones de autorización moral de su propio discurso. La referencia, publicación e incluso traducción de autores extranjeros consagrados en los campos científico, artístico o de la discusión política, a la vez que se presentaba como estrategia de acumulación de capital simbólico, indicaba la voluntad de discutir los problemas en los términos del debate teórico especializado. En ese sentido, la demolición de la moral burguesa, que a la manera de un programa orientaba los discursos de Ingenieros, se presentaba como estudio de casos de los tipos de reptación, formulando sus características generales y revelando, en medio de su propósito interpretativo, una vocación analítica.

\subsubsection{Lugones: el poeta anarquista salvador}

En la serie "Los políticos de este país" de los números 1, 4, 11, que ya había sido anunciada por Ingenieros como complemento de sus intervenciones de "Los reptiles...", Lugones descubría los escándalos de la actualidad política, acusando a los responsables con nombre y apellido: Carlos Pellegrini, Luis Sáenz Peña, Uriburu. Aunque el foco de sus acusaciones se vinculaba con cuestiones políticas, las injurias de Lugones versaban fundamentalmente sobre la calidad intelectual de quienes son criticados, no sobre su actuación pública. ${ }^{288}$ En ese sentido, era emblemático el caso de Carlos Pellegrini, que como paradigma del intelectual de su clase, era estigmatizado por su improvisación y su vulgaridad, y en tanto escritor, era condenado por su adscripción a estéticas altamente codificadas como el naturalismo y el romanticismo. Decía Lugones:

\footnotetext{
${ }^{288}$ En el $n^{\circ} 4$ de "Los políticos de este país" Lugones critica a la intelectualidad burguesa y como intelectuales se refiere exclusivamente a los políticos del país: Uriburu, Sáenz Peña, cuyas atributos son los de "imbécil o bribón" (99).
} 
Que me den la obra y entonces podré decir algo al respecto. Cuatro o cinco prosas ranciamente románticas o naturalistas es todo lo que de él conozco, fuera de sus discursos, cuatro o cinco prosas, en que todo lo que se descubre es una infinita bajeza de alma, una desesperante mediocridad 289

Lugones evaluaba moralmente a Pellegrini desde su perspectiva estética. En efecto, Pellegrini resultaba condenado como político porque no era un escritor fecundo y porque no sostenía la novedad como valor estético constitutivo de sus escritos, que dicho sea de paso, como discursos políticos aspiraban a otro tipo de corrección, más relacionada con la oratoria o la corrección estilística, y dejaban de lado la pretensión estética. En virtud de esta crítica, Lugones forjaba para sí un lugar donde la novedad estética funciona como criterio de juicio y como valor. Al mismo tiempo, iba delineando un conjunto de atributos negativos de la burguesía cuyos tópicos concordaban parcialmente con aquellos que unos meses más tarde, esgrimirían los modernistas argentinos nucleados en El Mercurio de América para legitimar la figura del artista como referencia espiritual positiva frente al burgués.

La imagen de poeta que Lugones construía en el periódico era legible en escritos de su propia autoría ("La moral del arte", "A $100^{\circ}$ de la infamia"), a los que se agregaban otros firmados por los Redactores. ${ }^{290}$ Esta imagen participaba de algunos rasgos de otro mito político, el del Salvador. En cuanto a este mito señala Girardet: "el tema del Salvador, del jefe providencial, aparecerá siempre asociado a símbolos de purificación; el héroe redentor es el que libera, corta ataduras, derriba los monstruos, hace retroceder a las fuerzas malvadas. Siempre asociado también a las imágenes de luz, el oro, el sol ascendente, el brillo de la mirada y a imágenes de verticalidad, la espada, el cetro, el árbol centenario, la montaña sagrada" (Girardet,1986) ${ }^{291}$ El poeta de Lugones

\footnotetext{
${ }^{289}$ La Montaña, Año I, $\mathrm{n}^{\circ}$ 1, p. 26.

${ }^{290}$ A veces, refrendando con su firma lo escrito por otros intelectuales, sobre todo franceses ("Colonia socialista de artistas de la redacción de La plume, "La obediencia pasiva" de Ernest Renan, "El noviazgo rojo" de Jean Ajalbert).

${ }^{291} \mathrm{En}$ el $\mathrm{n}^{\circ} 4$, aparece también la misma referencia a la mediocridad intelectual de la burguesía, en los mismos términos que se registran en la primera entrega: la imbecilidad y la bribonería. Cf. La Montaña, p. 99.
} 
mostraba obvios parentescos con algunos de estos rasgos tales como la verticalidad, la montaña, la luz, el oro, y era presentado como la figura social que condensaba todos los signos de un poder superior.

Lugones moldeaba aquí como también en los poemas "La voz contra la roca" y "Los Mundos", en algunos otros de Misal Rojo, y en ciertos artículos de El Pensamiento Libre, la idea de la necesidad de la voz del poeta. Profeta y misionero de Dios, el poeta era definido en La Montaña a partir del campo semántico de la orografía como una 'cumbre', para señalar su carácter elevado y el de su arte. Sujeto potente y viril poseído por una fe tan firme "como la musculatura de un toro", ${ }^{292}$ cuya moral sólo a él le pertenecía y podía cambiarla a su antojo, en tanto el mundo es una objetivación exteriorizada de su yo, ${ }^{293}$ el poeta tenía la obligación de sublevarse contra la moral burguesa, con la cual establecía un contraste radical. Lugones apelaba a las formulaciones provenientes del modernismo y el decadentismo, que como señala Terán sirven para "denunciar un malestar en la cultura" a fines de un siglo XIX en el que predominan "las creencias en un saber y una práctica realmente positivos proyectados hacia un indudable progreso" (Terán, 1986: 13). Asimismo esta caracterización imaginaria del poeta establecía coincidencias claras con algunos de los rasgos que desde el campo político definían la figura del anarquista: su rechazo del materialismo, su filiación idealista, la oposición a todo principio de autoridad, ${ }^{294}$ la sensibilidad estética, la libertad, su posicionamiento frente al orden burgués en general. De esta manera, se pedía prestada para el arte una figura del imaginario político con el fin de construir una determinada imagen de poeta o artista, y esto indicaba que los postulados básicos de la fe política del periódico eran los que servían y de los que se servía La Montaña para pensar las cuestiones relativas al arte.

El repaso de las intervenciones de Ingenieros y Lugones en su revista es útil para mostrar cómo las condiciones precarias e inestables del mundo cultural, características de fines de siglo XIX, hicieron posible la coincidencia entre La Montaña y La Biblioteca. Tal coincidencia, que dejaba de lado las diferencias políticas entre

292"La moral del arte", La Montaña, Año 1, nº 5, p. 118.

${ }^{293} /$ bid., p. 118.

${ }^{294}$ En La Montaña aparece un escrito de Renan, en el $n^{\circ} 2$, en contra del principio de obediencia pasiva. "Forzar a todos a soportar la obediencia es matar el talento y el genio" (44) 
anarcosocialismmo y liberalismo, se dio por parte de los jóvenes en la valoración positiva de Groussac. Más allá de considerarlo como un miembro activo de la intelectualidad de la elite, se alineaban con él en tanto proponía criterios de juicio intelectual basados en la calidad y el mérito de la producción. Estos criterios organizaban el ejercicio de una práctica crítica rigurosa y ejemplar en que se sustentaba la autoridad de Groussac. En ese sentido, los jóvenes de La Montaña, desde su espacio de acción restringido, repitieron la amplitud previa de Groussac hacia la modernidad literaria e incluyeron el escrito del director de La Biblioteca sobre Esteban Echeverría como tema legítimo de debate en su periódico, representante de la vanguardia política. Asimismo, promovieron la construcción de figuras propias de un campo autónomo como las del intelectual y el poeta, a los que otorgaron un sitio privilegiado en la sociedad. 


\section{Capítulo 2: Ideas: juventud, mercado, novela y cultura nacional}

\section{Presentación}

En el campo literario argentino de los primeros años del siglo XX y desde una perspectiva que atiende especialmente a las condiciones materiales y sociales de las distintas fases de la modernización cultural, la revista Ideas adquiere una importancia indiscutible. Considerada por Jorge B. Rivera como "verdadero repositorio de cuanta fórmula intelectual y artística circulaba por la Argentina de comienzos de siglo" (Rivera, 1995: 63), condición ésta que ratificaba la amplitud indispensable que las otras revistas del corpus ya habían señalado para esa fase de la vida literaria y que indicaba la vigencia de la lógica de relevos; Ideas fue, no obstante, el escenario de una transformación. En ese sentido, aunque los nombres de Leopoldo Lugones, Eugenio Díaz Romero, Antonio Monteavaro, Pedro B. Palacios o Alberto Williams y las referencias laudatorias a Darío remitían claramente a El Mercurio de América, igual que la inserción preponderante de sus colaboradores en el mercado de la prensa y su declarado espiritualismo, ${ }^{1}$ se trataba de un colectivo intelectual que plantearía su intervención con características diferentes. Más allá de los nombres que enlazaban la revista con la publicación de Díaz Romero y de aquellos que como Martín García Mérou, Paul Groussac, Godofredo Daireaux o Ernesto Quesada, remitían a La Biblioteca; muchos otros como Emilio Becher, Antonio Monteavaro, Charles de Soussens, Emilio Ortiz Grognet, Benjamín García Torres, Atilio Chiáppori, Alberto Gerchunoff, participaron de la bohemia porteña -según algunos, dudosa-, y a la vez de esta empresa que ponía en su centro la profesionalización del escritor, como una cuestión tributaria de la autonomía a la que aspiraban para la propia práctica. La revista comenzó a producir un cambio decisivo en el modo de pensar las relaciones entre los nuevos escritores y un mercado que imaginaba como posible; así, esa red de instituciones que funcionaba más aceitadamente en el caso de la prensa o del teatro, empezó a ser presentada en la revista como un elemento no siempre denostado, a pesar de que se criticaran severamente sus modalidades más comerciales. La revista otorgó una función primordial a la crítica literaria, cuyo programa fue definiendo a lo largo de

\footnotetext{
${ }^{1}$ Más adelante nos referimos a la diferencia entre el espiritualismo de Ideas y el de El Mercurio.
} 
sus veinticuatro entregas, en el intento por asignarse un pasado literario en la novela, género al que jerarquizó, y por construir un teatro también nacional sustentado en la producción de los autores dramáticos argentinos - no ya en las compañías teatrales. Fue en esa operación en la cual produjo un desplazamiento de la política del desinterés que había caracterizado a El Mercurio de América, hacia una vocación de mercado legitimada en la educación o ilustración de un público más amplio y que otras empresas culturales, como la 'Biblioteca de La Nación', venían ensayando desde 1901. Asimismo, el problema de la independencia de los escritores, que se ligaba directamente con aquella vocación, estuvo presente desde el comienzo en los perfiles sobre los colaboradores que redactaron Ricardo Olivera y Manuel Gálvez, en los cuales se informaban los modos en que éstos se habían estrenado literariamente, la obra que los respaldaba (si la tenían) y sus medios de subsistencia. Como caso extremo de una situación económicamente precaria se presentaban los retratos de Antonio Monteavaro sobre dos miembros de la bohemia porteña de principios de siglo $\mathrm{XX}$, Florencio Sánchez y Charles de Soussens.

Por otra parte, Ideas propuso una relación necesaria entre cultura y nación, en un sentido menos elitista y más amplio con que lo habían hecho, en el pasaje del siglo XIX al XX, algunos miembros de la elite liberal del ochenta -como Cané en "Nuevos rumbos humanos"-; con la cual, sin embargo, no establecería una oposición radical sino selectiva. Esto puede explicarse, en alguna medida, porque aunque quienes llevaban adelante el proyecto no eran sujetos desclasados y carentes de relaciones, no podían igualarse socialmente con aquéllos: no se trataba de escritores patricios sino de clase media; asimismo se vinculaba con una estrategia de legitimación, a través de la cual, esta intelectualidad joven residente en Buenos Aires, se autoinstituía desde su especificidad como reserva espiritual y moral de la nación dentro de una sociedad a la que, otra vez, se calificaría de hostil e indiferente con respecto a la cultura. En ese sentido, y a la luz de los lugares que algunos de sus miembros -como Ricardo Rojas y el propio Gálvez- comenzaron a ocupar a partir del Centenario, Ideas pudo pensarse como aspirante a nueva elite, anhelo que, según informaría el autor de El diario de Gabriel Quiroga en sus detalladas memorias, no estuvo ausente en la revista. 


\section{1. Ideas: una acción cultural 'necesaria'}

En mayo de 1903, apareció por primera vez la revista Ideas que dirigían Manuel Gálvez y Ricardo Olivera, dos jóvenes de 19 años de origen provinciano. Quien primero había tenido la idea de fundar una revista había sido Mariano Antonio Barrenechea secundado por Jorge Eduardo Coll, a los que se sumó Gálvez. Éste comunicó el proyecto a Ricardo Olivera, aunque finalmente, y por cuestiones económicas, quedaron solos los dos últimos. Barrenechea había pensado en una revista modesta y dedicada exclusivamente a la crítica, pero Olivera quería fundar un órgano del estilo de la Revue de deux Mondes (Gálvez, 1961a: 54). "Sinceridades", escrito que abría la revista y que llevaba la firma del segundo, asumía la representación en el espacio público de un grupo de escritores y artistas jóvenes para fundar una política cultural presentada como necesaria. Como lo había hecho Luis Berisso en El Mercurio de América, Buenos Aires estaba en el centro de la argumentación de Olivera. Sin embargo, para Berisso, la ciudad, pensada en el marco de una literatura del continente y en virtud de un innegable movimiento intelectual, se asemejaba más a la Cosmópolis de Darío en Prosas profanas ${ }^{2}$ que a las materialistas ciudades fenicias a que el manifiesto aludía desde un punto de enunciación nacional.

Buenos Aires -expresión sintética de la repúblicanunca ha tenido esa morosa predilección por las cosas del espíritu que es exquisito exponente de las civilizaciones superiores. Llamarlo Atenas ha sido siempre mejor sarcasmo que elogio. (...)

La realidad, que ignora los codos galantes que disfrazan de Cortesano á la Mentira, muestra argentinos que tienen más bien rasgos de fenicios que perfiles de atenienses. (...)

Así se explica el éxodo del Talento. (...)

[Pero]Siempre han existido cerebrales vigorosos que han anhelado la reacción. El ambiente opaco de factoría ha encontrado inadaptables. (...)

IDEAS porque es de la Juventud será entera para verdad. $^{3}$

"Palabras liminares" (Darío, 1977: 179-181).

${ }^{3}$ Olivera, Ricardo, "Sinceridades, Ideas, Año I, n 1, mayo, 1903, pp. 3-10. 
El título de este texto de comienzo que, a principios de 1900, caracterizaba el estado del mundo intelectual argentino, evaluando de forma negativa la condición espiritual de Buenos Aires, exhibía la marca fuerte de un sujeto que se adjudicaba ese valor moral, identificado como el lugar de enunciación de una palabra necesaria. ${ }^{4} \mathrm{Tal}$ sujeto se situaba en el lugar privilegiado de la verdad dado que se presentaba como la voz capaz de enjuiciar, en los términos más apropiados, aquella condición espiritual. La posición que para sí construía Ideas se destacaba por recuperar muchos de los tópicos y oposiciones que a fines de siglo XIX formulaban un lugar para la producción intelectual y artística: materialismo/ espiritualismo, moral utilitaria/ desinterés, artistas cultivados/multitudes bárbaras, arte/política, mediocridad/meritocracia del talento. Sin embargo, en esa recuperación, se operaba un giro retórico, que anticipaba lo que sería luego dominante en algunos discursos nacionalistas del Centenario de corte espiritualista. ${ }^{5}$ El vocabulario que acuñaba el manifiesto armaba un registro al que más tarde se apelaría: sobresalían sintagmas y palabras como "necesidad nacional", “operación salvadora" de la nación, "destino", el 'fermento disolvente', el "ideal” entendido como ideal nacional, la "fe", la "mentira" como "vicio nacional". El término "factoría" que ya había sido utilizado por Calixto Oyuela en su discurso como presidente del Ateneo en 1893 o por Ernesto Quesada para caracterizar a Buenos Aires como "factoría ultramarina", a propósito de la primera exposición de arte en el Ateneo, ${ }^{6}$ y cuyo uso sería también frecuente en discursos nacionalistas posteriores, remarcaba el antagonismo entre los resultados de un progreso exclusivamente

\footnotetext{
En adelante nos referiremos a los pasajes significativos de "Sinceridades"; en anexo presentamos la transcripción del texto completo. Todas las referencias de este texto corresponden a Ideas, Año I, nº 1, mayo, 1903, pp. 3-10.

${ }^{5}$ En "Sinceridades" a diferencia de lo que se observará más tarde, hay una visión más positiva del progreso.

- Oyuela afirmaba: "El grado de civilización que hemos alcanzado y la excepcional importancia de nuestra ciudad principal hacían realmente asombrosa la falta de un centro de esta naturaleza y lo estaban llamando a voces, si ya no era que prefiriésemos al dictado de una ciudad culta el de tosca y aparatosa factoría". Tomado del Discurso inaugural del Ateneo. (Rivera, 1993: 82) Por su parte, Quesada en un artículo de La Prensa de mayo de 1893, "El primer 'salón' argentino", destacaba la existencia misma de la institución y la realización del Salón de arte: "El hecho solo de que en un centro de más de medio millón de almas, que se distingue especialmente por su carácter de factoría ultramarina, haya sido posible formar una agrupación exclusivamente intelectual como es el Ateneo, y éste a su vez se haya sentido bastante autorizado para crear el Salón anula de Bellas Artes, es un signo halagüeño de progreso que no puede tratarse de modo baladí y merece fijar nuestra atención". Cf. Quesada, 1895: 373-406.
} 
económico y el imperativo ineludible por darse una cultura propia en la que asentar la futura hegemonía continental de la Argentina, a la que, se creía, estaba predestinada. Del mismo modo, este manifiesto recurría a otra referencia legítima, al recuperar el símil que ya había empleado Paul Groussac en "La educación por el folletín” con el fin de oponerse al naturalismo de Zola. El director de La Biblioteca había afirmado que "el estado de alma" de Zola "no difiere esencialmente del de un minero de Alaska". Así, Olivera denunciaba el carácter rudimentario de la cultura porteña, recurriendo a los términos de Groussac, para referir la condición elemental de las instituciones universitarias y de los universitarios argentinos: "no es paradoja afirmar que un universitario argentino y un minero de Alaska tienen estados de alma muy semejantes" (6) Nótese que esta apelación al carácter rector de la figura crítica de Groussac, constituyó un rasgo común a Ideas y a la revista de Díaz Romero. Aunque de un modo menos directo, en otros escritos de Ideas se citarían las palabras del director de La Biblioteca. ${ }^{8}$

En "Sinceridades" se concentraban algunas de las marcas que daban el tono de la intervención de Ideas, al menos desde lo declarado. Apelando a un tópico frecuente a fines de siglo XIX en las formulaciones respecto de la vinculación arte/sociedad, en el que se reconocía un parentesco con El Mercurio de América, quienes hacían la revista señalaban, con una modulación propia, la indiferencia del medio por los productos intelectuales. Para un estado espiritual como el que se mostraba desde "Sinceridades", la respuesta de Ideas desde lo estético-intelectual proponía y reivindicaba una acción que desde ese ámbito específico pudiera colaborar en la construcción de una nación 'potente'. Adelantándose a las afirmaciones de Lugones de 1909 en su prólogo a Lunario sentimental, asignaban un lugar central para los productos intelectuales:

\footnotetext{
7 "La educación por el folletín" (320)

${ }^{8}$ Por ejemplo, en la nota de presentación de Ángel de Estrada, en la que se citaba el juicio de 'Redactores' de La Biblioteca; también Atilio Chiáppori, en el $n^{\circ} 13$, se decía admirador de Groussac y reseñaba en 'Letras argentinas', el tomo tercero de los Anales de la Biblioteca. Además, la revista publicaría "El alma francesa", Año II, Tomo 4, no 14, junio, 1904, pp. 107-109.
} 
Todos olvidan que es factor esencial de la potencia de una nación, la robustez de pensamiento y su verdadera riqueza, producto del cultivo simultáneo de campos y cerebros" [cursivas nuestras]. ${ }^{9}$

De esta forma, en la igualación que proponía esa tarea conjunta, se forjaba un lugar deseado por los miembros de la intelectualidad de Buenos Aires entre los que se contaban los jóvenes de Ideas. Los intelectuales aseguraban la centralidad de su intervención sustentándola en la propia capacidad de pronunciar la palabra justa para el "destino" de la nación argentina. Ideas se proponía, entonces, hacer una contribución en lo relacionado con la espiritualidad que sugería el término nación, y que en la revista muchas veces se denominaba alma argentina. ${ }^{10}$ Señalaba Olivera:

Es dolorosa esta exhibición de la cultura argentina en estado rudimentario. Pero San Agustín habla de la utilidad de los sufrimientos perdidistis utilitatem calamitatis et miserrima facta estis. Si la desunión que multiplica las dificultades, y la carencia de estímulos que genera los desalientos, han sido causas del triste estado actual, si la indiferencia ha triunfado de las vocaciones y si la ausencia de fe ha traído la esterilidad, el remedio está señalado. Debemos trabajar, creer y confiar y lo demás nos será dado por añadidura. Es necesidad nacional que grita su urgencia, reunir el esfuerzo de la juventud al de las generaciones anteriores y de polarizar todas las energías hacia la gestación de un ideal para el pueblo argentino. ${ }^{11}$

El carácter "impermeable" del medio social -pensado como una tierra aún infértil- era otra de las formulaciones del tópico de la indiferencia, cuando no de la hostilidad, y servía para describir la relación con el arte tanto del público presentado como "pueblo" y de las clases dirigentes. Tal como lo habían demandado Vicente Quesada y Miguel Navarro Viola, Groussac o Schiaffino, para Olivera correspondía a

\footnotetext{
9 "Sinceridades", p. 4. Para diseñar la función social del poeta, Lugones, en el prólogo a la primera edición de Lunario sentimental, afirmaba: "Los encargados de esta obra [enriquecer y renovar el idioma], tan honorable, por lo menos como la de refinar los ganados o administrar la renta pública, puesto que se trata de una función social, son los poetas." (Lugones, 1995: 32)

${ }^{10}$ En este escrito Olivera hablaba de "alma colectiva" (4)

11 "Sinceridades", p. 6-7.
} 
estas últimas la obligación de proteger las empresas culturales y fomentar la existencia de las instituciones de las que dependía la perdurabilidad de prácticas específicas, y a las que consideraba elementos primordiales para el desarrollo de la cultura. Estas consideraciones registraban así el punto de continuidad entre las publicaciones, en la denuncia común de un vacío institucional. Además, el diagnóstico de Olivera coincidía con el que se hallaba en casi todas las páginas iniciales de las publicaciones del período que focalizaban en la distancia entre intelectuales y pueblo, leída como ausencia de un público especializado, en la escasez de espacios específicos (de producción, difusión, intercambio y consagración), y en la precariedad y la consiguiente vida breve de las empresas culturales, sobre todo de aquellas que como Ideas se presentaban sin lazos institucionales con el Estado:

Ateneos, Sociedades de artistas y de literatos, Escuelas de bellas artes, exposiciones Pintura y escultura, Universidades Populares, cuando logran nacer de las abnegaciones de algún pequeño grupo, arrastran vida precaria y casi siempre efímera, sin lograr nunca echar raíces hondas en esta tierra todavía impermeable. (6) ${ }^{12}$

En ese contexto se escenificaba la batalla por la autorización de la propia voz en relación con dos órdenes reconocibles: el campo político, que se imponía con su voz más fuerte por poderosa y que Olivera señalaba como "el gritar de su [de Buenos Aires] plebe politiquera", y el campo económico, representado en la voz inhumana y metálica del progreso, ${ }^{13}$ que también cercenaba la posibilidad de producción de un discurso intelectual. En Buenos Aires, cuyos ciudadanos tenían "más bien rasgos de fenicios que perfiles de atenienses", urbe en que imperaba la mentira, "gran ciudad que continúa gran aldea", se exhibía un estado de cultura "rudimentario" y "primitivo". ${ }^{14}$

12 "Son instituciones exóticas que nuestras clases dirigentes miran y no protegen y el pueblo en su total ignorancia de analfabeto contempla y no comprende", p. 6.

13 "Llamarlo Atenas ha sido siempre mejor sarcasmo que elogio. Tal vez en cortos períodos, por veleidad caprichosa, ha apaciguado el ruido de sus fábricas o el gritar de su plebe politiquera, para gustar mejor algún raro sonido que no tenía vibraciones de metal: un ático artículo de Goyena, la oratoria tribunicia de Del Valle, el período armonioso de Estrada, un verso de Andrade o una ironía de López", Ibid., p. 3.

${ }^{14}$ Cuando hacía referencia al desarrollo del teatro, y lo consideraba única manifestación intelectual de Buenos Aires, Olivera señalaba: "estudiar el desarrollo argentino de los demás factores que hacen las culturas nacionales es descubrirlos en estado primitivo" Ibid., p. 3. 
Las causas de ese estado había que buscarlas, según Olivera, en la ausencia de fe, de la que, a su vez, se derivaban la improductividad y la apatía no solo del público, sino también de todos aquellos que decían conformar la intelectualidad culta de la ciudad. En un gesto que repetía el de La Biblioteca y que también se encontraría, pocos años después, en otra revista de jóvenes como Nosotros, Ideas convocaba a todas las generaciones intelectuales a esta empresa cuyo éxito futuro tendría como requisito excluyente la creencia en la construcción de un "ideal" -hasta ahora inexistente- para los argentinos. De ese modo, desde un área de intervención que se pretendía específica, se llamaba a cumplir una labor que superaba en mucho ese dominio restringido. Esa obra, entendida como una misión espiritual y presentada como una "gran tarea", implicaba como programa máximo la construcción de una identidad cultural.

Aunque se insistía en mostrar un rasgo de espiritualidad notoria, la retórica del manifiesto mostraba contaminaciones evidentes con el discurso proveniente de la sociología positivista, en el que la sociedad era descripta en términos biológicos como un organismo sobre el cual realizar una "operación salvadora de inocular ideal" que le permitiera "recorrer triunfal el ciclo de su evolución". ${ }^{15}$ Estas contaminaciones, no eran infrecuentes en otros discursos intelectuales de la época y podían vincularse con un rasgo propio de lo que Carlos Real de Azúa define como "medio intelectual novecentista hispanoamericano" en "Ambiente espiritual del 900" (Real de Azúa, 1950: 15-61). Aunque para Real de Azúa no pueda hablarse de una "ideología" novecentista, teniendo en cuenta el rasgo "controversial y caótico" del período que va de fines de siglo XIX a 1910, es posible precisar repertorios de ideas y creencias, marcados por la coexistencia de posturas y corrientes disímiles, hecho directamente relacionado con las políticas culturales y comerciales de las editoriales francesas y españolas. ${ }^{16}$ Esta situación, hacía por ejemplo que una respuesta antimaterialista y ${ }^{15}$ Ibid., p. 7.

${ }^{16}$ Según Real de Azúa, las primeras ejercieron su influencia sobre "el sector creador y protagónico de la cultura", mientras que las españolas lo hicieron sobre "estratos mucho más grandes o profundos". Entre las francesas Alcan y Flammarion en filosofía y sociología, el Mercure de France en literatura, según el crítico, debido a la gran difusión del francés. Entre las españolas las series de la madrileña La España Moderna, a fines de siglo; después la Biblioteca Sociológica Internacional de Henrich, y la selección de Los Grandes Pensadores publicada por Maucci sirvieron como difusión y propaganda del pensamiento anárquico-positivista-ateo de la Escuela Moderna, de Francisco Ferrer. También, la 
espiritualista como la de Ideas, se presentara sobre el telón de fondo todavía vigente, aunque en crisis, del positivismo filosófico spenceriano, y abundara en el uso de términos que la volvían contradictoria. ${ }^{17}$

"Sinceridades" ponía en escena un rasgo de espiritualidad 'crítica' que debía pensarse como forma de diferenciación y marca distintiva que en Ideas asumían aquellos que aspiraban a ser representativos de la figura del intelectual. Además, es necesario destacar que el lazo de las acciones propuestas en el texto con un destino nacional, tenía su motivación en aquello que se percibía como incumplimiento del vaticinio de la hegemonía continental de Buenos Aires. Ese destino, que coincidía en términos generales con lo que había pronosticado Groussac en "El Centenario", era, en realidad, el deseo de quienes lo enunciaban, e insistía en subrayar el año de 1910 como ocasión de "balance y de prospecto". Entre los elementos a ser evaluados y proyectados se encontraba la relación entre intelectuales y Estado. Así, cuando Ideas en tanto grupo "espiritualista", ${ }^{18}$ utilizaba el adjetivo nacional como atributo de “cultura" para plantear su intervención y su vínculo con el campo del poder, exhibía su propósito de dar cuenta de un estado moral para modificarlo:

Es así como la Argentina se encamina con paso tardío y vacilante por las rutas del progreso $\mathrm{y}$ próxima a su primer centenario no es aún capaz de la hegemonía continental a que nació predestinada, porque su aristocracia repugna las severas disciplinas y sus multitudes no saben de la fuerza maravillosa del libro. ${ }^{19}$

valenciana de Sempere -que luego sería Prometeo- publicó muchos de los títulos de las editoriales anteriores "y ejerció en América una importancia global decisiva e incontrastable". Otra editorial madrileña, Daniel Jorro, tuvo gran influencia en Hispanoamérica. (Real de Azúa, 1950: 17)

${ }^{17}$ Así, en un tramo posterior quedaba explicitado el método de análisis proveniente del determinismo de Taine. "Todo ha contribuido -la herencia y el ambiente- a que la audacia encontrara medio propicio y auxiliada por la camaradería sin escrúpulos, pudiera otorgar reputaciones incontrovertidas a mediocres insignificantes". p. 10.

Real de Azúa sostiene que "(c)uando hablamos de positivismo vigente en 1900, englobamos dentro de él, en puridad, una serie de corrientes coludidas con su significación, lateralmente poderosas y de prestigio autónomo. Ejercieron una honda influencia en América el llamado "positivismo penal", el evolucionismo biológico de Darwin y Huxley, las teorías deterministas de Hipólito Taine, el monismo materialista de Buchner y de Haeckel, y la crítica religiosa y la exégesis bíblica protestante, liberal o atea". (Real de Azúa, 1950: 23)

${ }^{18}$ Es Gálvez mismo quien propone esta denominación: "En nuestro grupo literario éramos casi todos espiritualistas". (Gálvez, 1961: 42).

19 "Sinceridades", p. 5. 
Entre la aristocracia social y las multitudes parecía situarse ese grupo de intelectuales, que intentarían hacer del esfuerzo disciplinado y del estudio un signo de su distinción. Goyena, Del Valle, Estrada, Andrade y López, eran algunas excepciones de ese estado espiritual y sus ejemplos servían para formular, por contraste -y desde el principio de este manifiesto-, el tópico de la mediocridad, que aparecía como sustrato de "Sinceridades". ${ }^{20}$ Asimismo, era relevante que los nombres argentinos presentados como referencias positivas pertenecieran a sujetos principalmente dedicados a la política, en la que habían descollado por sus dotes oratorias, y que todos ellos estuvieran muertos. Estas menciones, sumadas a las de Taine y Claude Bernard, mostraban una de las líneas de continuidad con el mundo del ochenta, que no sería la única. Por lo demás, de ello podía deducirse el señalamiento del carácter político del proyecto cultural de Ideas y la afiliación genérica de "Sinceridades" con la oratoria y la elocuencia.

Como se dijo, el tópico de la mediocridad presente tanto en La Montaña como en El Mercurio de América era un modo de reconocer a los artistas e intelectuales como grupo social; ${ }^{21}$ en Ideas podía pensarse, además, como lectura contemporánea de Ariel de José Enrique Rodó, de 1900. La crítica ha señalado que el libro de Rodó fue recibido con entusiasmo en los círculos literarios americanos, y que esa acogida se vinculaba más que con su novedad, con el hecho de que la obra operaba una condensación de una serie de tópicos ya más o menos presentes en cierta sensibilidad que serían luego conocidos bajo el nombre de arielismo. La obra planteaba el ideal de una vida desinteresada, en la que se "conjugan el mensaje moral del cristianismo con el modelo de la cultura griega". (Altamirano - Sarlo, 1983: 74- 75). Florencia Bonfiglio explica que “(e)l modelo que sueña Rodó aúna estética y ética, entrelaza el helenismo y el cristianismo en un sincretismo cristiano-pagano típico del fin de siglo. (...) y apela a la fe en un profeta, un conductor espiritual que, mediante una educación

\footnotetext{
${ }^{20}$ En otras ocasiones se mencionaba esta cuestión: "No hay ambiente para el arte y para las Letras: siempre el mismo gesto de indiferencia o burla". Ibid., p. 4.

${ }^{21}$ Otra formulación del tópico de la mediocridad se observaba en la descripción de Buenos Aires como un espacio hostil al arte cuyos artistas e intelectuales debían buscar su consagración en París. En tanto Buenos Aires constituía la "expresión sintética de la República", podía establecerse, por extensión, un paralelismo entre ella y el país: así como la ciudad no era en términos intelectuales sino una "aldea colosal", la Argentina que aspiraba a ser una nación no era sino una "factoría", puesto que carecía de alma.
} 
"continental"”, propagara su ideal entre los jóvenes. Más adelante observa que Ariel plantea una lucha entre el espiritualismo y el materialismo en el seno de la ciudad modernizada. (Bonfiglio, 2005: 4) 22 Por su parte, Julio Ramos sostiene que el mensaje a la juventud de América de Rodó en Ariel presupone una "esfera específicamente estética" como campo discursivo autónomo de la política y del Estado, en función de la cual Rodó podía pensar, por ejemplo, su idea de América Latina como “esfera de la cultura" (Ramos, 1989: 70)

En efecto, "Sinceridades" participaba como Ariel del anhelo de construcción de una identidad cultural -en el caso de la revista de Gálvez y Olivera, argentina-, y cifraba esta posibilidad en las acciones de una elite intelectual identificada con la juventud. Como en la obra de Rodó, estaba también presente la necesidad de un magisterio espiritual, que los jóvenes parecían reclamar en estas palabras iniciales, y que debía manifestarse como una "prédica" de valores, principalmente, el de la "nobleza de la solidaridad". ${ }^{23}$ Se trataba en ambos casos de una textualidad marcada por la exhortación, a la manera de los sermones laicos de la Francia de la segunda mitad del siglo XIX, en la cual se hacía visible un carácter fuertemente afirmativo y en el que se sustentaban las acciones propuestas como formas de mejorar o corregir la moral presente. ${ }^{24}$ El texto de Olivera se organizaba en base a la utilización de dos

${ }^{22}$ Bonfiglio explica que "El Ariel es también un diseño de ciudad, y Próspero trabaja como un proyectista de modelos culturales, pero mientras la 'ciudad letrada' era un 'parto de la inteligencia (como afirmaba Rama en La ciudad letrada), la ciudad de Próspero pretende ser un parto del espíritu". En cursiva en el original. (Bonfiglio, 2005: 4)

${ }_{23}$ "Es preciso que los Maestros prediquen la nobleza de la solidaridad", p. 8.

${ }^{24}$ En su "Prólogo a Ariel", Carlos Real de Azúa, renuente a considerar esta obra de Rodó como "mera, libre y personal proposición de ideas", esto es un ensayo, señala su inscripción histórica en el género de las "oraciones rectorales de colación de grados y otras piezas de elocuencia académica" que a mediados de siglo XIX contribuyeron a generar "una constelación literario-ideológica de prolongada visibilidad". El significado de estas oraciones sería, según Real de Azúa, el de conformar una especie de "'discursos del trono' de un siempre pretendiente poder cultural, una suerte de presencia expansiva y aun imperativa del sistema educativo superior en la sociedad" (IX). Aunque estos discursos se refirieran básicamente a cuestiones del ámbito académico, Real de Azúa afirma que habitualmente abundaban en opiniones sobre la marcha de la sociedad o "los deberes más acuciantes de la 'intelligentsia' nacional, o muy especialmente, sobre el estado de ánimo juvenil". Advierte, además, que Rodó pudo haber conocido algún texto de esa clase, y que fue seguramente a través de la literatura y la cultura francesas que llegó al medio intelectual latinoamericano esta modalidad discursiva. Sus representantes más destacados fueron Jules Simón -que afirmaba que los profesores de filosofía deben ser "predicadores laicos"-, Ernest Renan -quien según Real de Azúa ejerció una autoridad indiscutida sobre el joven Rodó-, Jules Ferry, Anatole France, Ernest Lavisse, entre otros cultores de un género común a todos los miembros de la universidad laica y radical de la segunda mitad del sigo XIX. Con respecto a 
modelos culturales, el de la metrópolis y el de la polis -encarnados en las referencias a París y a Atenas, respectivamente-, y apelaba asimismo al discurso religioso, explícito en la cita de San Agustín, y en la recurrencia a un vocabulario proveniente de ese campo semántico. Así, "Sinceridades" oponía Buenos Aires tanto a París, a la que se deseaba imitar infructuosamente, como a Atenas, para impugnar en este último caso, la afiliación presente en el uso de la metáfora cristalizada que el texto convocaba -Atenas del Plata; por lo demás, Buenos Aires era el espacio donde tenía lugar aquella batalla entre materialismo y espiritualismo, actualizada en la oposición entre lo fenicio y lo ateniense, entre la capital argentina exclusivamente mercantil y la polis griega. Sin embargo, y más allá de la referencias a lo griego, que no se limitaban a la mención de Atenas, sino que podían observarse en el gusto por "un ático artículo de Goyena", o "el período armonioso de Estrada", ${ }^{25}$ el parentesco más importante con esta obra de Rodó estaba dado en la postulación -para Ideas aún no realizada- de una esfera cultural autónoma en el seno de la ciudad modernizada, desde donde se proponía un mejoramiento espiritual fundado en la cultura como factor determinante.

"Sinceridades" mostraba las fallas que los jóvenes de Ideas observaban en los intentos anteriores por consolidar un área diferenciada para los productos intelectuales y desde la cual contribuir en la tarea nacional. Se establecían acciones a seguir, vinculadas, principalmente con las formas de conducta entre los aspirantes a miembros de ese mundo en su calidad de intelectuales y artistas. La voluntad inicial y declarada de concentrar la totalidad de los esfuerzos para combatir la desunión, se actualizaba en un carácter inclusivo de la convocatoria -no limitada a los jóvenes sino también a los maestros-; así, se llamaba a participar de "una revista mensual, donde la obra acabada de los maestros se reúna a los bocetos de los aprendices, con el provecho recíproco que el docent diximus ya enunciaba". ${ }^{26}$

"IDEAS porque es de la Juventud será entera para verdad", sentenciaba Olivera, $\mathrm{y}$, en una explicación causal que encubría una operación ideológica, se reiteraba el

\footnotetext{
la autoridad de Renan sobre Rodó, el crítico uruguayo afirma que su discurso de 1896 ante la Asociación de Estudiantes de París "pulsaba bastante puntualmente casi todas las que serían las cuerdas del encordado ariélico" (p. X). A esta influencia habría que agregar la de Jean-Marie Guyau (1854 - 1888).

${ }^{25}$ Cursivas nuestras.

${ }^{26}$ Ibid., p. 9.
} 
carácter moral de la intervención, cuyo objetivo amplio era, según el autor del texto, la búsqueda de la verdad. La implicación entre juventud y verdad resaltaba el carácter juvenilista de la empresa, pero, sobre todo, insinuaba otras implicaciones quizá más indirectas, aunque no inadecuadas, en función del proyecto general: igualación entre juventud y futuro, entre identidad y verdad, entre verdad-como destino- y nación. Así, aunque la convocatoria estaba dirigida a todas las generaciones, la juventud se responsabilizaba del llamamiento, y se autoasignaba el lugar central. La tónica de las relaciones propuestas (entre los que pudieran ser considerados "nuestros verdaderos intelectuales", aquellos ya merecidamente consagrados o los nuevos que pudieran surgir), estaría dada por la "hospitalidad afectuosa" 27 y "la nobleza de la solidaridad", formas esperadas para una exhortación aglutinadora como la de Ideas. Por eso mismo, Ideas no se presentaba como conservadora ni como revolucionaria, ni se definía abiertamente -a diferencia de El Mercurio-, como la revista de una escuela estética. Y éstas eran también las formas necesarias del vínculo entre los escritores, los críticos, poetas, y demás intelectuales, en este momento "primitivo" y "rudimentario" de la cultura argentina. Por consiguiente, en contra de los grupos, en contra de las acciones solitarias, promovía la necesidad de unión en una retórica casi militar que acercaba este escrito una arenga:

Las vanidades, las impaciencias, los rencores, -la arcilla humana- puja por encerrar a cada uno, en las torres de marfil que constituyen los egoísmos. Es preciso que los maestros prediquen la nobleza de la solidaridad, y evidencien otro factor de triunfo, mostrando cómo de la sangre mezclada en las batallas, se han compuesto los mágicos elixires que han hecho batallones invencibles. ${ }^{28}$

Dentro de esa intervención específicamente cultural, la revista pondría en el centro de su programa la crítica literaria. En este intento, volvía a jugar su papel aquello de 'ser para la verdad' de los jóvenes, en tanto se proponía ejercer la "verdadera crítica", cuyos representantes, según el texto, eran escasos en el mundo intelectual capitalino. Sus cultores se concentrarían en desmitificar y luchar contra las

\footnotetext{
${ }^{27}$ Ibid., p. 9.

${ }^{28}$ Ibid., p. 8.
} 
falsas consagraciones de la crítica practicada en los diarios, que reproducía opiniones ajenas y que, para juzgar las obras, anteponía "la camaradería sin escrúpulos" a las cuestiones estéticas. ${ }^{29}$ Contrariamente a esto, la crítica en Ideas asentaría la legitimidad de sus afirmaciones en el conocimiento específico de la materia tratada, para dar por tierra con una práctica falsa, superficial, de rastaquoerismo intelectual, que consagrara a los mediocres.

Es así como tenemos oradores tartamudos, historiadores que no alcanzan a cronistas, sociólogos que no sospechan a Comte, novelistas incapaces de comprender la vida; pseudo-críticos, pseudo-filósofos ..... ¿Quién dijo que la mentira es vicio nacional $?^{30}$

Lo que acontecía en el ámbito de la cultura era representativo para Ideas de lo que sucedía en todos los aspectos de la república. Frente a la mentira, la verdad y la sinceridad de la juventud, que denunciaba una condición moral hipócrita, ${ }^{31}$ eran dos requisitos espirituales que constituían, según Olivera, el terreno propicio para el arte. La crítica se pensaba a sí misma como "un pampero agreste y duro"32 que en su tarea sanitaria limpiaría y derribaría falsos ídolos. Tal imagen, podía ligarse con el carácter 'nacionalista' de la intervención de Ideas. Nacida en esta tierra como el pampero, la revista y particularmente la crítica, señalaban su condición de enunciación dominante en lo propio. Ideas propondría la construcción de un canon de literatura nacional, apuntando, sobre todo, a la elección de la novela como género a partir del cual

\footnotetext{
${ }^{29}$ Ibid., p. 8.

30 "Sinceridades", p. 10.

${ }^{31}$ La frase con que cerraba Olivera su "Sinceridades" afirmaba, una vez más, el valor de los miembros de Ideas: "Porque es raro mérito ser sincero en tiempos de hipocresía". p. 10.

32 Como vemos, la naturaleza es un reservorio de metáforas para dar cuenta de las cuestiones intelectuales. Ya consignamos el caso de Lugones y el repertorio de la orografía para referirse al poeta -en tanto cumbre, Himalaya- y al espacio de enunciación que aparece en el título del periódico que redacta junto con Ingenieros. En Ideas domina otro repertorio: el de lo eólico. En un pasaje referido a Carlos $\mathrm{O}$. Bunge, y en la misma línea de defensa del "ideal", Gálvez señala: "Y Bunge (...) es aquí uno de los pocos convencidos que han opuesto al utilitarismo político e industrial de la masa, las fuerzas de sus ideales, que han de triunfar de la indiferencia, e imponerse a la muchedumbre de los necios haciéndole escuchar hasta del sordo, como el turbión que desciende de la montañas, e invade la llanura, trayendo en su ancho seno, salvajes rumores de huracán". Año II, T.3, n.9, enero, 1904, p. 85. Rojas, en una nota de letras españolas sostiene: "un nuevo ideal ha surgido, pasando de la ciencia al arte, como esos vientos que, nacidos de la tempestad, llevan alas distintas flores, gérmenes de vida" Año II, Tomo 3, no 10, febrero, 1904. En "Sinceridades", la crítica se define como "pampero agreste y duro" que se opone a los "venticelos cortesanos", p. 10.
} 
construir una literatura entendida en términos autónomos. ${ }^{33}$ Como es evidente, podía advertirse una contradicción entre ese programa de ruptura y las pautas de comportamiento entre intelectuales en esta fase del campo, en tanto una voz crítica autoproclamada como un viento devastador podía ser contraria al pacto de sociabilidad vigente, ya señalado en el caso de El Mercurio. Sin embargo, esto se explicaba en función del tipo de reglas de legitimación y de los modos de ingreso al mundo intelectual imaginados desde la posición de estos jóvenes. Sus modos se diferenciaban de los que, aún en vigor, eran propios de un universo en el que la literatura constituía un elemento más de capital social de quienes ocupaban lugares centrales en el campo del poder político y económico. En contra de la idea de la literatura como herencia familiar, Ideas apostaba a construir una aristocracia del espíritu, como forma de legitimación cultural de los jóvenes escritores e intelectuales. En ese sentido, el talento y los valores estéticos eran las pautas para "seleccionar" a esa elite. Este darwinismo social, ahora cultural y espiritual, estaba en el tono de la operación del Ariel, con el cual, como señalamos, "Sinceridades" establecía algunos lazos.

\section{Retratos de los jóvenes de Ideas: literatura, calidad moral y profesionalización}

Como ya observamos, El Mercurio de América puso en escena la oposición entre los valores del altruismo y del desinterés, y aquellos que sustentaban e imponían los procesos de modernización, apuntando fundamentalmente a los aspectos que señalaban el carácter utilitario y materialista de dichos procesos, para definir el terreno del arte como un recinto pretendidamente impoluto, y al artista como sujeto que encarnaba dicho antagonismo. Julio Ramos ha observado que la retórica del desinterés es anticipatoria del arielismo, en cuyo discurso se ubicaría, según el crítico, el desplazamiento del positivismo de su lugar rector en la educación, y la consiguiente institucionalización del margen de la literatura como crítica de la modernización (Ramos, 1989: 60). En "Sinceridades", y como lectura contemporánea de Ariel, esta crítica tomó forma en la disputa entre el espiritualismo y el materialismo, en una versión que debe distinguirse de la de El Mercurio o de La Montaña. En ese sentido y

${ }^{33}$ Más adelante dedicamos un apartado al desarrollo de esta hipótesis. 
para Ideas, el espiritualismo estuvo singularizado por una serie de atributos que desplazaban su eje hacia los valores de la salud y la normalidad, en detrimento de ciertos rasgos decadentistas presentes en los discursos de Lugones en La Montaña, o, por ejemplo, del aislamiento que Schiaffino promovía en la figura de Moreau. ${ }^{34}$ Ese desplazamiento se daría por una parte, en la construcción de una subjetividad juvenil que, aunque se presentara como nueva, articulaba algunos rasgos residuales provenientes de la sociabilidad del ochenta; por otra, en el vertiginoso reemplazo de lo americano por lo nacional, ámbito en el que se ejercería la crítica de la modernización, con el anhelo de consolidar prácticas e instituciones culturales y literarias. En este apartado se analizará a la juventud intelectual, grupo autorrepresentado como la conjunción de calidad moral y talento, para mostrar su carácter transicional: Ideas presenta una articulación de rasgos que le otorgaban un perfil profesionalista con otros que la ligaban indiscutiblemente con formas de una sociabilidad anterior, como la de la fracción intelectual del ochenta.

Cuando en Amigos y maestros de mi juventud Gálvez se refería a su "generación” y repasaba los que, a su juicio, habían sido sus aportes centrales en el incipiente campo literario del 900, utilizaba como subtítulo las fechas de 1903-1905, las cuales correspondían a los años en que se había publicado la revista Ideas ("Mi generación. 1903-1905", “La revista Ideas. 1903-1905”). Este dato era relevante ya que mostraba el rol decisivo que, a su entender, había tenido el periódico en relación con los miembros del grupo, y porque señalaba que era la revista la que cohesionaba y definía como tal a esta formación (o más allá de las fechas de nacimiento e ingreso a la vida pública o de la megalomanía propia de Gálvez en la reconstrucción de sus memorias). ${ }^{35}$ El repaso sumario de las características señaladas por Gálvez servía para completar el perfil del grupo literario esbozado en "Sinceridades"; estos rasgos

${ }^{34}$ Hay que aclarar, sin embargo, que el mismo Lugones en la revista de Díaz Romero, había criticado con rudeza y pacatería, Del amor, del dolor y del vicio de Enrique Gómez Carrillo, calificándolo de pornográfico y señalando que su parentesco con la "literatura de los andenes".

${ }^{35}$ En cuanto a la formación del grupo, Gálvez señala que tuvo su origen y "espina dorsal" en la amistad entre Emilio Ortiz Grognet y Emilio Becher. Todos los miembros de la revista habían nacido entre 1879-1884. (Gálvez, 1961: 38). Se reunían en el cuarto de Ortiz Grognet del Hotel Helder, ubicado en la calle Florida. Entre otros, eran habitués: Alberto Gerchunoff, Ricardo Rojas, Emilio Becher, Benjamín García Torres, Atilio Chiáppori, Alfredo C. López, Gálvez, Felipe Barrantes Abáscal (responsable de las caricaturas de Ideas), el suizo Charles de Soussens. (Chiáppori, 1944) Capítulos primero y último. 
adquirían un alto grado de validez, especialmente, para el mismo Gálvez, Emilio Becher, y Ricardo Rojas. Tanto "Mi generación (1903-1905)" como "La revista Ideas (1903-1905)", eran de utilidad para pensar -en el marco de la construcción de funciones autónomas para la literatura- problemas relativos al proceso de profesionalización del escritor, tales como el reconocimiento de su figura social como subjetividad diferenciada, su situación material, sus empleos o sus relaciones con los medios periodísticos.

En una conjunción a primera vista improbable y que no aseguraba la comunidad de ideas sino la heterogeneidad que el grupo albergaba, Gálvez sostenía que quienes hacían y participaban de la revista, habían sido los primeros en mirar de manera colectiva "hacia las cosas de nuestra tierra", ${ }^{36}$ y eran, a la vez, wagnerianos, anarquizantes, rebeldes, tolstoístas. A pesar de reivindicarse nacionalistas no se identificaban de modo completo con el nacionalismo de los Recuerdos de la tierra de Leguizamón, ni con el de las Poesías de Obligado. En ese sentido, no se proponían cartografiar literariamente el territorio argentino, ni conformaban el grupo de estudiosos que, como lo había pedido Joaquín V. González, organizaran las bases de una "literatura nacional folklórica", sino que concentrándose en la indagación de los males presentes, construirían el alma argentina. Era en función de este rasgo, y de su distanciamiento del positivismo -cuestionado pero aún vigente- que se autoproclamaban espiritualistas. ${ }^{37}$ En otro pasaje de los recuerdos Gálvez reivindicaba a su generación como heredera del simbolismo, aunque aclaraba que no lo era en cuanto a la materia poética, puesto que -como había afirmado previamente- ella estaba constituida por "las imágenes de los seres y de las cosas de nuestra tierra" (Gálvez,

Asimismo Gálvez agrega otros nombres que formaron parte de la generación de ldeas: Juan Pablo Echagüe, Ricardo Olivera, Mariano Antonio Barrenechea, Mario Bravo, Abel Cháneton, Alfredo C. López, Ernesto Mario Barreda, Luis María Jordán, Mario Sáenz, Guillermo E. Leguizamón, Joaquín Rubianes, Alberto Rougés, Salvador Oría, Emilio Alonso Criado. Gálvez incluye a Horacio Quiroga y a Florencio Sánchez. (Gálvez, 1961: 40-41)

${ }^{36}$ Esto no implicaba desconocer los que calificaba de trabajos "aislados" de quienes como Sarmiento, López, Martel, Payró o Lugones, habían hecho "obra argentina" (Gálvez, 1961: 37). El hecho de colocar a Payró y a Lugones, escritor vivos y en plena producción, en el pasado y junto a todos muertos, mostraba la intención de revelarse como la generación del presente.

${ }_{37}$ Gálvez consigna como exponentes nacionalistas su Diario de Gabriel Quiroga (1909), a Ricardo Rojas con La Restauración nacionalista (1909), y a Emilio Becher, en varias de sus colaboraciones de La Nación. (Gálvez, 1961a: 37) 
1961: 41). Menos cosmopolitas que los modernistas de El Mercurio de América, menos internacionalistas que los jóvenes anarco-socialistas de La Montaña, los miembros de Ideas, casi todos ellos provincianos, ${ }^{38}$ eran para Gálvez quienes habían luchado como héroes "contra el ambiente materialista y descreído, extranjerizante y despreciador de lo argentino, indiferente hacia los valores intelectuales y sociales"; esa batalla los había convertido en los "pioneers desinteresados" de lo que, para la época en que Gálvez escribía sus recuerdos, consideraba un "sorprendente movimiento cultural y espiritual" (Gálvez, 1961: 43)

En otro orden de cosas, el director de Ideas sostenía que la suya era la primera generación de escritores. ${ }^{39}$ Para mostrar lo que esto significaba acudía, como prueba, al caso de los hombres del ochenta quienes como Miguel Cané, Carlos Pellegrini, Lucio V. López, representaban la subjetividad social del literato o la del hombre de letras más que la del escritor; más allá de que hubieran producido obras importantes, para casi todos ellos la literatura era una función de la política o se ejercía como una práctica no exclusiva. Estos doctores producían de modo irregular, "escribían -según Gálvez- algo allá las cansadas, aunque no faltara entre ellos algún escritor de talento”. En ello coincidía con las apreciaciones de Roberto Giusti, quien señalaba la dispersión como la marca de la "generación mundana" a la que habían pertenecido los hombres del $80 .{ }^{40}$ En el mismo sentido, David Viñas observa que

el tránsito visible entre el apogeo de la oligarquía y el período posterior de repliegue de la elite liberal hasta el advenimiento del radicalismo al gobierno en 1916, se va subrayando significativamente por el fin del liderazgo de los gentlemen-escritores hacia una profesionalización del oficio de escribir, por un desplazamiento del predominio de los escritores con apellidos tradicionales hacia la aparición masiva y la preeminencia de escritores

\footnotetext{
${ }_{38}$ Gálvez había vivido en Santa Fe; Juan Julián Lastra y Carlos A. Leumann eran santafecinos; Rojas, santiagueño; Echagüe, sanjuanino; Becher y Ortiz Grognet, rosarinos; Mario Bravo, tucumano; Gerchunoff venía de Entre Ríos; Alfredo López Prieto, de Río Cuarto. Entre los porteños estaban: Atilio Chiáppori, Mariano Antonio Barrenechea, Abel Cháneton, Ernesto Mario Barreda, Luis María Jordán. (Gálvez,1961: 39)

${ }^{39}$ Dice Gálvez: "Antes de nosotros (...), no existió en la Argentina una verdadera generación de escritores" (Gálvez, 1961: 35)

40 Giusti afirmaba: "Cané se dispersó, como los demás escritores de su generación mundana, todos de ilimitada curiosidad intelectual, en el ensayo breve, el artículo, la crónica, la relación de viajes, las memorias, la filosofía ingrávida" (Giusti, 1956b: 27).
} 
provenientes de la clase media y, en algunos casos, de hijos de inmigrantes. (1996:10)

La mención, por parte de Gálvez, de Juvenilia o La gran aldea como ejemplos claros de aquel talento, agregaba a la dedicación incompleta y a la consiguiente aparición errática de las obras, la cuestión genérica de esos textos, que debe ser pensada también históricamente. En ese sentido, y como se plantearía desde las páginas de la revista, si había que construir un futuro y un pasado literarios y esto debía hacerse en la novela, los textos citados de Cané y López ${ }^{41}$ podían considerarse, en 1903, intentos inaugurales e imperfectos. En primer lugar, porque en virtud del pacto de lectura que implicaban en tanto memorias, recuerdos o autobiografías -variantes practicadas por los escritores universitarios del ochenta- encontraban su sentido más legítimo en el mundo público y político que recreaban, donde era posible reconocer, sin mayores problemas, a personas y sucesos reales. Por el contrario, en la revista se hacía hincapié en la demanda de géneros, pactos de lectura y públicos deseables que no desatendieran el contexto de modernización cultural y social en que eran producidos. Una de las ocasiones más visibles de este reclamo fue la bibliográfica firmada por Atilio Chiáppori sobre el primer volumen de las Memorias de Lucio Mansilla, en la sección de 'Letras argentinas'.

Indudablemente, esta primera parte debe carecer de interés para la mayoría de los lectores. Salvo las anécdotas chispeantes de tal o cual personaje sonado, y que como no todas pertenecen a la infancia o adolescencia del general pudieron incluirse en cualquiera de ellas, los recuerdos exclusivamente familiares de este volumen, solo pueden gustarlos un reducido círculo: el que deriva del núcleo social en el que el autor se actuara. El general Mansilla parece que ha olvidado que escribe para una ciudad transformada, cosmopolita y de casi un millón de habitantes a cuya enorme mayoría no puede llamarle la atención, por ejemplo, que su tía Hermenegilda permaneciese

${ }^{41}$ Josefina Ludmer sostiene que la modernización de 1880 obliga al Estado a adoptar una cultura nacional, en tanto la nacionalidad se presenta como condición para funcionar en el nuevo orden mundial moderno. Para Ludmer son los escritores patricios los que "inventan una cultura nacional que es agente de cohesionar el estado". Miguel Cané en Juvenilia es el "funcionario memorialista" y a Lucio López con La gran aldea, el "cronista social". (Ludmer, 1999:42) 
soltera o que tuviese la cara deformada, circunstancias las dos que, por otra parte, no influyen en la leyenda ni pueden rectificar la historia. Por eso, en mi entender, en vez de citar tanto nombre propio y particularidades de personas que no tuvieron más actuación que la familiar, algunas de las cuales no han dejado, siquiera, descendencia, pudo el autor extenderse en pinturas de cuadros sociales, de escenas de la época, de barrios de la ciudad antigua, los únicos susceptibles de participar de la verdadera tradición. 42

Chiáppori percibía con agudeza la dificultad de Lucio V. Mansilla para interpelar a un público anónimo e impugnaba desde el comienzo las condiciones de recepción impuestas por el género memorias, a la vez que señalaba la inadecuación y el desfasaje de su autor con respecto al mundo cultural y social en que publicaba; de ese modo, atacaba también el tipo de subjetividad en que se sustentaba la obra y el público de pares sociales -constituido por el círculo de relaciones políticas y familiares- que la obra circunscribía como propio. En ese sentido, este volumen de Mansilla, que correspondía a su infancia y adolescencia, era juzgado por Chiáppori como una supervivencia del pasado, y Mansilla mismo como un sujeto anacrónico, incapaz de registrar las transformaciones sociales, entre ellas, la existencia de un público ampliado, ${ }^{43}$ al que los escritores pudieran interesar con obras no tramadas en su propia historia familiar, y por lo cual pudieran ser ellos mismos percibidos exclusivamente como autores. Asimismo, la cita condensaba la demanda de una poética de la ficción

\footnotetext{
${ }^{42}$ Ideas, Año II, $\mathrm{n}^{\circ} 16$, agosto, 1904, pp. 422-423. Por su parte, Gerchunoff, en $\mathrm{n}^{\circ} 3$ de la sección también había criticado a Mansilla, a propósito de En vísperas, "por el general Lucio V. Mansilla" (hermanos Garnier editores, París, 1903). A propósito del lugar que fueron ocupando los intelectuales del 80 en los primeros años del siglo XX, señala el mundo de la diplomacia (sus "inocuos y dorados puestos") como el espacio en que se desarrollan los últimos años de estos gentlemen-escritores -Cané, Wilde, Mansilla. (Viñas, 1996: 11)

${ }^{43}$ Algo de eso también estaba presente en la reseña de Emilio Becher sobre Vibraciones fugaces de Carlos Romagosa en la que cuestionaba la validez de la autobiografía: "Ante los ojos del lector desapasionado, los hechos que el Sr. Romagosa ha querido narrarnos, parecen excesivamente personales -desprovistos de todo interés general- y por más profunda e intensa que haya sido en el ánimo del autor, la vibración [en cursiva en el original] de estos acontecimientos, resulta siempre demasiado 'fugaz' para que pueda interesar a un público extraño" [cursivas nuestras]. Más adelante, y en relación con los capítulos referidos a cuestiones políticas sostenía que no eran la "materia más apta para el libro". Ideas, Año I, Tomo 2, nº 6, octubre, 1903, pp. 223-224. Cf. LA: 5-6.
} 
-repetida en muchas otras reseñas de Ideas- señalando, además, el principio que debía organizar la literatura argentina moderna: una poética realista -y en ocasiones de corte naturalista- que Gálvez encontraba en un determinado corpus de la literatura y del teatro argentinos, y que Rojas resaltaba en novelistas como Blasco Ibáñez y otros autores de los que se ocupaba en 'Letras españolas' y 'Letras hispanoamericanas'. Este escrito de Chiáppori actualizaba dos temporalidades distintas en relación con la literatura que se correspondían, por un lado, con una situación deseada, percibida como emergente; y por otro, con otra situación presentada con un carácter más residual del que tenía en realidad. Estas temporalidades se singularizaban en función de las elecciones particulares respecto de tres elementos: sujeto escritor, géneros y público.

La construcción de una literatura nacional en Ideas, que como ya se dijo sería uno de los objetivos que la revista llevaría adelante, estaba directamente asociada con la subjetividad social del escritor profesional. Ese intento tomaría como géneros principales a la novela y al teatro, objetos de los que daría cuenta desde las secciones específicas dedicadas a las letras argentinas y extranjeras, y al teatro. Esa voluntad profesionalista tuvo en Gálvez un militante consecuente, no solo desde las páginas de Ideas. ${ }^{44}$ Así se explicaba que, a la hora de construir continuidades, Gálvez optara, en estos recuerdos literarios, no por los liberales del 80 sino por el grupo nucleado alrededor de la revista de Díaz Romero, la "generación" de El Mercurio de América, aunque ésta, a su juicio, no hubiera tenido ni la homogeneidad ni la duración suficientes para adquirir un carácter tan compacto como la suya. Una primera diferencia era obvia: la revista pensada como órgano de grupo, remitía a una práctica que, según la pertinencia con que Gálvez ponía en perspectiva el pasado -la del camino de las letras a la literatura- promovía un reclutamiento principalmente literario. Mansilla, Cané, López, aunque habían participado profusamente en la prensa política, no habían ideado revistas literarias - no obstante, haber colaborado en ellas y también en diarios prestigiosos del Buenos Aires de esa época. ${ }^{45}$ Además y sobre todo, en los

\footnotetext{
${ }_{44}$ Me refiero, por ejemplo, a su experiencia posterior en la Cooperativa Editorial Buenos Aires, fundada en 1917.

${ }^{45}$ Cané colaboró en Buenos Aires (1895-1899), La Biblioteca (1896-1898), Juventud (1897), La quincena (1893-1900), Mansilla publicó en La Biblioteca, Revista Sarmiento (1894-1899), López también publicó en la revista de Groussac. En cambio, participaron de la prensa política.
} 
jóvenes de El Mercurio de América, la literatura era -de entre otras prácticas artísticas que la revista incluyó y con las que construyó alianzas estratégicas- la que los constituía como grupo, en la afiliación declarada a la estética modernista; la demanda de autonomía y la dedicación exclusiva a la escritura, valores dominante entre los mercuriales, podían contarse como factores decisivos en la elección de Gálvez. Así para quien fuera por esos años de 1900, el fracasado autor teatral de La conjuración de Maza, Mansilla, López, Cané y otros tantos no habían sido verdaderos escritores sino abogados, funcionarios, oradores, dentro de una sociabilidad básicamente política. Para Gálvez la profesión literaria podía definirse en términos relativos como sigue:

No quiero decir del escritor que vive sólo de las letras, porque este fenómeno es desconocido aquí, salvo entre los autores de teatro, sino del hombre que se dedica principalmente al trabajo literario, que publica con regularidad y que, aunque no intente vivir con sus ganancias de escritor, no de periodista, trata de ayudarse con ellas (Gálvez, 1961: 36)

En ese sentido Gálvez se consideraba un escritor aunque, para ganarse la vida, tuviera que trabajar como ujier en la Cámara en lo Criminal, Comercial y Correccional. La cita, más allá de lamentar la imposibilidad efectiva de la literatura como profesión única -y aunque más no fuera, parcialmente remunerada- mencionaba otro aspecto del mismo problema, que sería una constante en Gálvez y que, como se verá, se hacía presente en las noticias biobibliográficas de Ricardo Olivera sobre los colaboradores: eran considerados autores aquellos que publicaban regularmente y en el formato de libro. ${ }^{46}$

En otro pasaje de "Mi generación" Gálvez retrataba a los miembros de Ideas entre los que se contaban: Emilio Becher, Juan Pablo Echagüe, Emilio Ortiz Grognet, Ricardo Rojas, Alfredo López Prieto, Abel Cháneton, Ernesto Mario Barreda, Carlos Alberto Leumann, Mario Bravo, Luis María Jordán, Horacio Quiroga, Florencio ${ }^{46}$ María Teresa Gramuglio ha observado esta cuestión, a propósito de la figura de escritor que construye Gálvez en el personaje de Gabriel Quiroga, en el Diario de Gabriel Quiroga: "Pero este escritor no es, en la concepción de Gálvez, un escritor, pues se trata de alguien que no publica [cursivas de Gramuglio] alguien a quien este texto le ha sido arrancado y que no escribirá un segundo libro: no llegará, por lo tanto, a constituirse en autor, esto es en alguien que confiere unidad a un conjunto de textos" (Gramuglio, 1992: 48). Véase también Gramuglio, 2001: 9-55. 
Sánchez, Alberto Gerchunoff. Estos retratos eran verdaderas figuras o imágenes de escritor, tal como las entiende y analiza María Teresa Gramuglio (Gramuglio, 1992: $35-64)$

estas figuras de escritor remiten inexorablemente, por una lado a la construcción de una subjetividad fechada, y por el otro, al estado del campo literario a que pertenece el escritor, a los conflictos presentes en ese campo, a las formas de acceso posible, y al conjunto de condiciones cambiantes que regulan la práctica literaria (Gramuglio, 1992: 39-40)

Gramuglio agrega que, en tanto ideologemas, "construyen soluciones simbólicas a conflictos históricos concretos" (Gramuglio, 1992: 40) De esta manera, los retratos que presentaba Gálvez eran significativos porque acumulaban un conjunto de rasgos ligados con las problemáticas vigentes para ese estado del campo literario. En primer término y de modo general, Gálvez diferenciaba a aquellos que se habían dedicado definitivamente a la literatura de quienes habían tomado otros rumbos, en función de los cuales la escritura era leída como una veleidad de la juventud. Cuando se refería a los que habían continuado en la literatura, la utilización de vocablos como crítico, novelista, cuentista, poeta o dramaturgo daban cuenta de proyectos literarios específicos; de tal modo la profesión elegida resultaba determinada por algún género literario moderno, no por la colocación social de cada individuo. En casi todos los casos se planteaba una relación problemática con el dinero. Así, por ejemplo, Gerchunoff había estado, en ocasiones, en la verdadera miseria; ${ }^{47}$ Juan Pablo Echagüe, aunque verdaderamente pobre, siempre había cuidado su forma de vestir; Alfredo López Prieto, era pobre pero "altivo y digno" (50); Juan Julián Lastra, además de poeta fue "un empleado sin más recursos que su sueldo" (51); Gálvez mismo se mostraba como una persona que debía trabajar en su profesión de abogado, y para quien, cierta vez, el robo de la recaudación de la revista por parte del cobrador había significado

\footnotetext{
${ }_{47} 7$ "En esos años de 1902 a 1905, en que por su escasez de dinero llegó a veces a la verdadera miseria, jamás nos pidió dinero, salvo en dos o tres ocasiones en que necesita veinte centavos para ir en tranvía a Flores, en cuya plaza tenía que dar una conferencia" (Gálvez, 1961a: 46)
} 
una pérdida "catastrófica" equivalente a la de su sueldo. ${ }^{48}$ En estos recuerdos, y con respecto a la oposición espiritualismo / materialismo, la pobreza del escritor se transformaba en su capital simbólico. Es decir, la pobreza era aquí riqueza y en esta juventud pobre se atesoraba la reserva espiritual de la nación. Este atributo esencial de necesidad siempre estaba acompañado de la calidad moral del sujeto: se era pobre, pero digno, inteligente, desinteresado, ingenioso. Además, este énfasis en la falta de recursos materiales servía para pensar la condición inestable de la práctica literaria, cuyo valor económico se definía, igual que en algunas formulaciones previas de $E l$ Mercurio, como inversamente proporcional a su calidad, siendo esta última equivalente de la condición moral e intelectual de los sujetos. Frente a este cuadro desesperante, en otro pasaje de las memorias, se leía que muchos de los miembros de Ideas eran colaboradores de La Nación, y por lo tanto cobraban algún dinero:

Hubo un momento, año más, año menos, en que la alta crítica, en todas las ramas del arte, estaba en manos de hombres de nuestro grupo. Fue cuando en La Nación, el diario de la gente culta del país, Echagüe hacía la crítica de teatros, Barrenechea la de música, y Chiáppori la de pintura y escultura. (Gálvez: 1961:60)

De esta forma, Gálvez atenuaba ese rasgo de pobreza absoluta y angustiosa con que caracterizaba a estos escritores y críticos, en tanto sugería el carácter hegemónico del grupo en virtud de sus intervenciones en el diario de Mitre. Así, la necesidad de subsistencia llevaba a estos jóvenes a ganarse la vida con su escritura y los convertía en escritores profesionales -cobraban sus artículos-; prueba de ello, como señalaba Gálvez, era su condición de colaboradores especializados, en un periódico que como La Nación combinaba el interés por el mercado con un altísimo grado de prestigio cultural. Por consiguiente, es posible pensar que estos retratos se tramaban en un exceso que adquiría un carácter estratégico: se recalcaba una situación angustiosa que

\footnotetext{
${ }^{48}$ Este es uno de los que Gálvez señala como "tropiezos" graves de la revista. En el mismo sentido, juzgaba la partida de Olivera de la dirección, porque lo dejaba sin la mitad del capital necesario para la empresa. Otros son de origen distinto, aunque Gálvez pensaba sus consecuencias en términos económicos (disminución de suscriptores): la publicación, sin el permiso correspondiente de un escrito de Lugones a una joven, los que ocasionaron las críticas de Gerchunoff respecto de algunos escritores y publicistas, el asunto escabroso de un relato de Ingenieros. Ibid., p. 63.
} 
era necesario cambiar, y era esa insistencia en lo desesperado del caso lo que se utiliza como réclame. ${ }^{49}$ No obstante estos énfasis y atenuaciones, es preciso señalar otros datos que los materiales de las memorias de Gálvez, tal como lo han indicado Sarlo y Altamirano, obliteraban. Así sucedía, por ejemplo, con el peso que seguían teniendo las relaciones familiares para el ingreso en un diario como La Nación, "meca cultural y profesional de esos años" (Altamirano - Sarlo, 1983: 84). En ese sentido, la revista recuperaba el valor de los lazos familiares en la forma en que Gálvez firmaba sus artículos, poniendo entre paréntesis la palabra 'hijo', lo mismo que sucedía con las colaboraciones de Ángel de Estrada, a través de lo cual esbozaba una similitud mediante los signos de una tradición familiar. De esta manera, Manuel Gálvez no era un provinciano advenedizo, sino que, como se indicaba, había en la figura de su padre, un sujeto socialmente distinguido, y cuya mención funcionaba para ese hijo como marca de capital social. Igualmente, esas relaciones se evidenciaban, de modo retrospectivo, en detalles que Gálvez iba mechando en su relato. Así por ejemplo, narraba la noche en que él y Olivera habían presentado a Gerchunoff al diplomático argentino Belisario Montero, en el Club del Progreso, del que, aclaraba, "yo era socio", lo mismo que Olivera (Gálvez, 1961: 46). De ese modo, se trataba de la juventud argentina, un sujeto que siendo de transición se declaraba totalmente nuevo. Ese carácter transicional se exhibía en la incorporación de rasgos residuales, i.e. la apelación a los vínculos sociales provenientes de la política como formas de

\footnotetext{
${ }_{49}$ Dos críticos nos sugieren esta observación. Primero, Jorge B. Rivera cuando se refiere a la condición de los escritores del 900 y describe la situación cultural señalando la existencia de "un aparato cultural ciertamente permeable y liberal que no oponía exagerados reparos al punto de vista ideológico y metabolizaba por igual a 'decadentes', 'contestatarios' e 'integrados'" [volvemos a usar esta cita porque creemos que es totalmente pertinente]. (Rivera, 1993: III). También Miguel Dalmaroni lo que se refiere a El triunfo de los otros y las estrategias de autovictimización (Dalmaroni, 2006:141-152). Es otra vez Gálvez el que se contradice y vuelve a dar un dato que coincide con lo que las observaciones de Rivera y Dalmaroni tienen en común. Dice Gálvez: "Cuando yo tenía veinte años, había menos motivo que ahora para la guerra de las generaciones. Ninguno de nosotros encontró cerradas las puertas de los diarios y de las revistas. Es cierto que al principio, en general, no nos pagaban las colaboraciones; pero esto era costumbre de la época. Los escritores viejos no pasaban de la docena y no dejaron de mostrar interés por nosotros, cuando, terminado el tiempo de los proyectos y de las tenidas inacabables en los cafés nos pusimos a trabajar seriamente" [cursivas nuestras] (Gálvez, 1961: 72) En relación con el concepto de réclame, funciona de modo similar al escándalo. Con respecto a este último Christopher Charle, ha señalado, cuando analiza la significación del caso Dreyfus en relación a los intelectuales como grupo, que el escándalo, voluntario o involuntario, es un proceso clásico de conquista de la notoriedad en el campo intelectual y en el campo político. (Charle,1990: 7-15)
} 
autorización, la frecuentación de los mismos espacios de sociabilidad que los hombres del ochenta.

Algunas de las cuestiones a las que apuntaban las memorias de Gálvez estuvieron presentes en las noticias sobre los colaboradores, que la revista incluyó en sus dos primeros números, escritas casi en su totalidad por Ricardo Olivera. ${ }^{50} \mathrm{Su}$ lectura confirmaba como testimonio contemporáneo, la centralidad efectiva los problemas abordados por Gálvez en Amigos y maestros de mi juventud. Estas noticias, a la manera de los medallones de Groussac en La Biblioteca, señalaban el modo en que cada uno de ellos participaba del mundo intelectual, daban cuenta de la obra que lo respaldaba -si la tenía-, describían su relación con las instituciones del Estado y con la política, precisaban trayectorias personales y grupales, vaticinaban éxitos, apuntaban recorridos. Estos perfiles fueron decisivos para presentar el tipo de sujeto intelectual que Ideas intentaba construir y legitimar, y en ellos se exponía una serie de rasgos comunes a los jóvenes escritores - artistas, y, al mismo tiempo, se ensayaba una periodización de generaciones literarias, que era a la vez un modo de singularizar el propio grupo. De esa forma, de la lectura global de las notas surgían tres lotes netamente distinguibles. El de los "consagrados" en el cual se ubicaba a Cané, Mansilla, Wilde, Guido Spano, Groussac; el de los modernistas o los nucleados en torno a El Mercurio de América, dentro del cual se incluían a Leopoldo Lugones, Darío, José Ingenieros, Ricardo Jaimes Freyre, Eugenio Díaz Romero y Ángel de Estrada, y, por último, el de los directores de Ideas. El corte entre los últimos dos grupos casi contemporáneos remitía a cuestiones que podemos considerar de orden formacional; este hecho hacía posible que, más allá de los posicionamientos estéticos particulares, ambos grupos necesariamente compartieran aspectos vinculados con los procesos de modernización cultural, por ejemplo, una inserción preferencial en el campo periodístico, su experiencia en la creación de revistas, su participación en un mismo tipo de sociabilidad -la de las redacciones de diarios o de cafés- o, incluso, su

\footnotetext{
${ }^{50}$ Tuvieron su noticia biobibliográfica: Alberto del Solar, Ángel de Estrada, Martín Gil, Eugenio Díaz Romero, Guillermo E. Leguizamón, Emilio Ortiz Grognet, Martín A. Malharro, Julián Aguirre, Juan Pablo Echagüe, Emilio Becher, Leopoldo Lugones, Juan Ángel Martínez, David Peña, Alberto Ghiraldo, Mario Sáenz, Ricardo Rojas. Gálvez escribió las correspondientes a Lugones, Juan A. Martínez
} 
aspiración a vivir, al menos parcialmente, de la literatura. Muchas revistas literarias del período informaron sobre quienes colaboraban en ellas y, generalmente, esas pequeñas biografías aparecían al final del número o del tomo, en secciones como 'Los redactores', “nuestros colaboradores", como lo había hecho La Biblioteca. El hecho de que Ideas los publicara en el cuerpo de la revista, inmediatamente después del artículo firmado, indicaba una intención clara por enlazar al sujeto con su obra, en tanto propietario y autor de ésa y otras producciones intelectuales, construyendo así un criterio de autorización basado en ese vínculo. Al mismo tiempo, mostraba el propósito de presentarlo al público, legitimándolo por lo ya realizado y en el caso de los más jóvenes, desplazando hacia el futuro el cumplimiento de lo que en esa circunstancia era una promesa. ${ }^{51}$

En general, aunque muchos de los jóvenes repetían el comienzo de la formación de los escritores universitarios de la coalición del 80, ingresando en la Facultad de Derecho, este paso por la universidad se presentaba como mero expediente en la educación de sujetos que, se decía, iban a dedicarse de lleno a la literatura, y no solo en sus ocios diplomáticos. Varios de ellos dejarían trunca su carrera universitaria para reivindicar los beneficios de la autoformación literaria / intelectual, como contrapartida al desprestigio de la institución académica a la que consideraban "improvisadora de doctores". Este aspecto se distanciaba de lo que ocurriría, cuatro años después, con los miembros de Nosotros -incluidos los directores-, quienes estudiarían afanosamente y se graduarían en la Facultad de Filosofía y Letras, espacio que no dejaría de modelar sus vínculos y su acción intelectual. Así resultaba para Emilio Becher y Emilio Ortiz Grognet, quienes rápidamente dejaron sus carreras de derecho; Atilio Chiáppori se alejó tempranamente de la medicina. ${ }^{52}$ Otros, como Juan Pablo Echagüe, ni siquiera habían terminado su bachillerato. Casi todos ellos, como se dijo, colaboraban en diarios y revistas más o menos prestigiosos y ésta era una de las formas que asumía la profesionalización a la que aspiraban. A diferencia de los recuerdos de Gálvez -quien había ejemplificado únicamente con el diario de Mitre como caso más relevante-, las notas de Olivera apuntaban la inscripción fuerte de estos

\footnotetext{
${ }^{51}$ De Rojas, dice Olivera: "porque es esperanza fundada, será realidad". Año I, Tomo 1, no 2, junio, 1903, p.179

${ }^{52}$ Cf. Giusti, Roberto 1956c: 118.
} 
escritores en otros diarios y, de modo menos visible, indicaban un vínculo efectivo con revistas semanales, cuyo paradigma exitoso era Caras y Caretas. ${ }^{53}$ De tal modo, esos textos incorporaban también la relación de estos jóvenes profesionales con publicaciones del género misceláneo, orientadas hacia el público y al mercado, y que colocaban en primer plano dichos aspectos. ${ }^{54}$ Frente a ellos se elevaba la figura social del "escritor heredero", 55 encarnada en Ángel de Estrada quien "honra la tradición del apellido -trabajando en silencio - con limas flaubertianas- formas armoniosas". Así, el autor de "Sinceridades" podía definir con justeza -y admiración- a este joven que gozaba de los privilegios del nacimiento y la fortuna, como un "marqués del viejo régimen" cuya obra podía ser calificada de "anacronismo delicioso". 56 Aunque los

${ }^{53}$ Como se verá, Ideas tomaría algunos elementos característicos de estos semanarios como la inclusión de dibujos en la serie "Galería de intelectuales". Cf. apartado 5.1.

${ }^{54}$ Con respecto a Juan Pablo Echagüe, Olivera informaba que había colaborado en Caras y Caretas, El Gladiador, además de hacerlo en Revista Nacional, La Nación, El País o El Tiempo; de Ortiz Grognet comunicaba que escribía o había escrito para El Tiempo, El Diario, La Nación, La Capital, El Municipio; Ricardo Rojas, aparecía como parte de la redacción de El País.

Por otra parte, las cartas escritas por esos años por Emilio Becher a Emilio Ortiz Grognet, recuperan esta tendencia al mercado. Becher comenta a su amigo los inconvenientes de $\mathrm{El}$ Heraldo, periódico dirigido por Olivera, del que era secretario de redacción y del cual también participaban Gerchunoff, de Soussens y Gálvez. Además de los problemas internos con el dueño, Gregorio Lastra, observaba que "parece difícil que muerda en el público este diario. No le llevan el apunte. Es un heraldo afónico" Carta del 27 de febrero de 1904 publicada en Nosotros, Segunda época, tomo 4, n ${ }^{\circ} 15$, junio, 1937, p. 177. Manuel Gálvez, observaba que para 1903, Becher ya había publicado en varios diarios, y que luego de abandonar El Heraldo, pasó al Buenos Aires Herald, a principios de 1905 entró como reemplazo de Ricardo Rojas en El País y en 1906, ingresó en La Nación, que "sería para él un hogar espiritual" (Gálvez, 1961a: 80). También fue redactor de Libre Palabra y Diario Nuevo. Según Giusti, David Peña, director del Diario Nuevo, había juntado a "muchos jóvenes periodistas volanderos con talento de escritores", entre los que estaban Monteavaro, Gerchunoff, Chiáppori, Mario Bravo y Becher, que escribía reportajes políticos. (Giusti 1939: 14-15).

${ }_{55}$ Jorge B. Rivera, en "La forja del escritor profesional (1900-1930). Los escritores y los nuevos medios masivos", señala para el momento crítico de la profesionalización, situado a principios de siglo $\mathrm{XX}$, dos tipos de escritores, en los que se muestra la polarización existente en ese momento. Uno, el "escritor heredero", descendiente directo del gentlemanescritor del 80, y el "escritor profesional". Para el primer caso Rivera reconoce a Ángel de Estrada (1872-1923), para el segundo a Horacio Quiroga (1878-1937), quien ha reflexionado sistemáticamente acerca de su oficio y sobre las cuestiones materiales relacionadas con él. Cf. Rivera, 1981- 2000. En Ideas la figura de Estrada aparecía exactamente de ese modo en el perfil que escribe Olivera: "(P)ertenece a una familia de intelectuales que mucho ha hecho por el progreso de la Literatura Nacional”. Ideas, Año, I, n 1, mayo, 1903, pp. 25-26. Más adelante nos referimos a estas cuestiones.

${ }^{56}$ Olivera indicaba: "Ángel de Estrada (hijo) pertenece a una familia de intelectuales que mucho ha hecho por el progreso de la Literatura Nacional. (...) Todos nuestros escritores consagrados ha tenido para con él, primero los consejos cariñosos que iluminan el camino, después las frases de elogio que recompensan las fatigas de la jornada, gustándolas en el 
jóvenes de Ideas no podían identificarse con Ángel de Estrada (hijo), quien constituía el caso del escritor dedicado de lleno a la literatura gracias a las prerrogativas de la fortuna, el talento y tradición intelectual familiar, tampoco lo hacían con la figura del "polígrafo" que representaba David Peña en las notas de Olivera. En efecto, casi quince años mayor que los directores de Ideas, y contemporáneo de Roberto Payró, este rosarino, al igual que otros de su generación, no había dado, según Olivera, lo que se esperaba de él, por haberse dedicado conjuntamente a la política, al periodismo como colaborador y fundador-, al teatro, a la docencia. ${ }^{57} \mathrm{Si}$ la multiplicidad de intereses de Peña era el motivo por el cual éste no había realizado todo lo que prometía, la aspiración de alguien también mayor -como Martín Malharro- de concentrarse en la pintura, se presentaba para Olivera como un aspecto compartido al que debían agregarse las dificultades económicas, su inserción en el mercado de la prensa como dibujante, ${ }^{58}$ y su condición de trabajador infatigable. Asimismo, su figura servía para poner en primer plano la potencia, la energía y la virilidad, como cualidades necesarias para los artistas en un contexto social y cultural como el de principio de siglo. ${ }^{59}$

Para algunos de ellos, la literatura se ubicaba en el espacio de lo privado, en franca distinción con respecto al periodismo y para casi todos, también contraria de la política y "las glorificaciones del éxito" (Echagüe). La nota sobre Mario Sáenz exhibía, de manera contundente, la voluntad de Olivera por distinguir la literatura con

reposo de la etapa. Cané, Mansilla, Wilde, Guido Spano... lo han reconocido escritor y aunque el sustantivo ha perdido mucho de su antigua nobleza en su vulgarización moderna, realza esta vez su significado el venir de tan alto. Hasta Groussac -el imparcial y el severolo ha saludado 'príncipe de la generación entrante con Enrique Rodríguez Larreta y algún otro' (...) Lo certifican trabajador, tres libros hechos en casi su totalidad con notas de viaje e impresiones de arte; elaborados con primores de filigrana tienen los tres -la misma gracia tenue de esas blondas princesitas que sutilizan el amor en Versalles y en Trainon". Ideas, Año I, tomo I, $n^{\circ} 1$, p. 26. Como se ve, Estrada representaba un anacronismo tanto por la figura de escritor que encarnaba como por la materia estética de sus obras.

${ }^{57}$ Ideas, Año I, nº 2, p. 128.

${ }^{58}$ En la nota sobre el chileno Alberto del Solar, Olivera consignaba que la novela El faro, había sido publicada "en volumen artísticamente ilustrado por Malharro", Ideas, Año I, tomo $1, n^{\circ} 1$, p. 20. Anticipos de El faro habían aparecido en El Mercurio de América en la entrega de mayo de 1899.

${ }^{59}$ Olivera afirmaba que lo que más admiraba en Malharro era "su potencia de querer y de llegar: estos hombres que triunfan por la única virtud de su energía". Se refería a Malharro como "raro ejemplar argentino del self made man". Ideas, Año I, Tomo 1, n² 2, p. 63. 
respecto a ambos órdenes. ${ }^{60}$ En otros casos, aunque se tratara de sujetos que provenían de familias con un pasado político relativamente reconocido, como acontecía con Ricardo Rojas, su perfil rescataba el hecho mismo de apartarse de aquella herencia familiar del "exclusivismo político", subrayando la intención de hacerse un nombre, no en la política, sino en la literatura, con la publicación de La victoria del hombre, algunos de cuyos poemas aparecieron en Ideas en el n 7 de $1903 .{ }^{61}$

Por último, dos colaboraciones de Antonio Monteavaro insistían, desde el cuerpo de Ideas, en los aspectos materiales de la vida de los escritores. Desde la perspectiva que nos ocupa, ambos escritos eran relevantes porque escenificaban en una forma de sociabilidad, como lo fue la llamada bohemia porteña de principios de siglo $\mathrm{XX},{ }^{62}$ las dificultades económicas por las que atravesaban los escritores. Mientras que en los casos previos de Gálvez y Olivera, estas cuestiones habían sido retratadas atendiendo, sobre todo, a los aspectos vinculados con los aprietos monetarios de un lapso vital cuya proyección, más allá del presente dudoso, apuntaba a una realización futura tanto material como literaria, los textos de Monteavaro se focalizaban en la cuestión del dinero como constitutiva de esa vida bohemia. El primero de ellos, "Un retrato al pastel”, que se ocupaba de Florencio Sánchez, apareció en la quinta entrega de la revista, y, aunque en el inicio hubiera señalado la consagración reciente del

${ }^{60}$ Más allá del caso particular de Saénz, el texto proponía la dedicación exclusiva a la literatura, en la crítica al mercado -en su versión más denostada- y a la política: "Esperemos. Y esperemos, deseando que la actividad política no ocupe todas sus horas. [es presidente del comité universitario del Partido Republicano] (...) sería lástima grande que su inteligencia se esterilizara haciendo artículos de diarios que viven veinte y cuatro horas, y discursos de club que encuentran su postrera repercusión, confundidos con el eco del último viva aguardentoso de los comparsas que remedan al pueblo ausente, en la eterna farsa de nuestra Política." Año I, n 2, junio, 1903, p. 154. Además, en la identificación de la literatura con el espacio privado, se observaba: “(...) afirman sus íntimos, que conserva muy cuidadosamente velados a miradas indiscretas, poesías, cuentos, hasta libros. Hablan de las "Hojas del Misal"- colección de versos, de un ensayo histórico sobre Moreno, de un estudio crítico "Los Epicúreos Argentinos", de alguna novela ya esbozada, de cierta obra teatral concluida, de toda una germinación silenciosa que florecerá en su hora." p. 154.

${ }^{61}$ El libro de Rojas fue criticado por Becher en el $n^{\circ} 8$, de diciembre de 1903, y fue tema de la sección "Redacción" del nº 13 de 1904.

${ }^{62}$ Jorge B. Rivera afirma que "La bohemia fue, para muchos, una suerte de noviciado jocundo y desaprensivo que precedía la incorporación al universo solemne de las grandes redacciones, los empleos oficiales, la enseñanza y la 'carrera de escritor', como puede decirse que lo fue para el joven Lugones, para Gerchunoff y para Rojas. Para otros, por el contrario, fue primero una luminosa réplica de la bohemia francesa o madrileña, con sus "raros' y sus 'malditos', con sus Verlaine y sus Alejandro Sawa (...) para concluir luego en la deserción, el alcohol, la página periodística nómina, la cama del hospital" (Rivera, 19812000: 358-359) 
uruguayo con $M^{\prime}$ hijo el dotor, se enfocaba en el tema económico de los años previos. Así, afirmaba Monteavaro en su primera frase: "El título de la obra La novela de un joven pobre escrita por Feuillet, rotularía admirablemente un artículo sobre Florencio Sánchez". El valor de esta nota radicaba en que ponía en primer plano la necesidad de analizar la vida del autor, antes que su obra porque ésta ya había sido discutida y estudiada, y porque aquélla era "fecunda en hechos y emociones". De ese modo, se remarcaba que la literatura se trataba también y principalmente de autores como sujetos históricos, en cuyas figuras se encarnaban y debían ser leídos problemas que, como los allí planteados, también eran literarios. Así, era uno de los bohemios quien señalaba la relevancia de la invención de la vida de $\operatorname{artista},{ }^{63}$ y en ese sentido, mostraba nítidamente su propia figura social. El escrito, puntualizaba un trayecto de la vida de Sánchez centrado en su relación - y la de otros bohemios- con el dinero, definida en términos de derroche y marcada por las urgencias del presente. Las penurias económicas encontraban su compensación en las emociones múltiples de la vida bohemia. ${ }^{64}$ En el segundo artículo, Monteavaro se refería a Charles de Soussens, escritor suizo, "penúltimo bohemio del quartier latin trasplantado a Buenos Aires", y en un pasaje subrayaba "las miserias de su existencia". El crítico contaba, en tono jocoso, que su habitual escasez de dinero obligaba a de Soussens a vestir trajes que heredaba de otros, que invariablemente le quedaban holgados o chicos. Su historia podía leerse como la contracara de la de Sánchez, dado que si éste había comenzado en la bohemia para, de algún modo, estabilizarse tanto económica como socialmente a

${ }^{63}$ La novela de las horas y de los días de Manuel Ugarte, reseñada por Gerchunoff en el nº 6 , también apuntaba a este tema.

${ }_{64}$ Año I, Tomo 2, n 5 , septiembre, 1903, pp. 28-33. Monteavaro, integrante él mismo de la bohemia porteña, luego -en palabras de Giusti- "envilecido por el alcohol", refería: "Yo lo conocí en plena bohemia. ¡Qué diferentes a las nuestras son las amables escenas de los encantadores Musset y Murger! Sánchez tenía pocos amigos. Tres o cuatro desharrapados como él, solían frecuentarlo en los momentos de aguda miseria, no para aportarle consuelo sino para disminuir la propia infelicidad en la egoísta contemplación de la desdicha ajena. Relaciones no le faltaban, y algunas poderosas. Pero la altivez del mísero supera a la del pudiente. (...) Desaliñado en el vestir, modesto, desgarbado, mal causeur, le faltaban todas las exterioridades brillantes que provocaban la simpatía o la admiración [aunque aclara que, en privado, ostentaba el don de la ironía]. Más adelante contaba su modo "delicioso" de gastar el dinero cuando lo tenía: "Repartía la plata en todos los bolsillos y se lanzaba en busca de conocidos a quienes convidar. Exhibía el total de un bolsillo ( 3 pesos) y prevenía que los gastos debían limitarse porque necesitaba esa suma para cortarse el pelo. Al rato derrochaba los 3 pesos y brotaban 5 de otro bolsillo, los cuales sufrían la suerte de sus predecesores y así sucesivamente, retirándose, al fin, sin blanca y con el pelo largo". (30-32). 
partir del éxito teatral y del matrimonio, el recorrido de Soussens marcaba una curva descendente. Así, Monteavaro informaba que había sido un "talentoso y sabio joven”, "galán encantador e iluso", profesor en un importante colegio londinense para transformarse, finalmente, en "el bohemio que se anega hoy en un gris crepúsculo, sin ensueños, sin ambiciones, víctima de tedios incurables", cuyos sentimientos habían sido burlados. Sin embargo, el tono risueño del escrito ponía en duda la posibilidad de una caída definitiva; además, el artículo se cerraba con un dato significativo que reponía y leía el contexto de la profesionalización por vía de la prensa -lo mismo que en las memorias de Gálvez- como atenuante de esa situación angustiosa frente a la que funcionaba como un reaseguro:

Y a pesar de sus hábitos desarreglados y fantásticos, nunca le falta un periódico para ubicar sus vivaces y originales lucubraciones.

En esta tierra nadie se muere de hambre, digan lo que quieran los atorrantes. Siempre se abre una puerta al talento. ${ }^{65}$

El colectivo cultural descripto en las páginas precedentes hizo del juvenilismo al igual que El Mercurio y abrevando en el tono del mensaje arielista - una marca propia. A diferencia de la revista de Díaz Romero, e inaugurando una orientación que sería clave en los primeros años de Nosotros, más allá de la amplitud desplegada en la publicación de novedades estéticas, las preocupaciones de Ideas tuvieron el signo de lo nacional, ancladas, no obstante, en el conocimiento efectivo de la internacionalización del arte. Estos escritores, críticos y artistas noveles intentaron legitimarse en una

\footnotetext{
${ }^{65}$ Ideas, Año II, Tomo 5, no 17, septiembre, 1904, pp. 69-78. Cursivas nuestras. Esta misma visión de una bohemia "laboriosa" está también en la crítica de Jorge B. Rivera quien sostiene que ese grupo de escritores "concluyó por servir, asidua y activamente, a la exigente fragua del periodismo de comienzos de siglo [XX]". (Rivera, 1981-2000: 359). El artículo abundaba en detalles tales como la relación entre el suizo y José Ingenieros (que le pasaba los jaquets que ya no usaba), sus intentos de batirse a duelo, la enemistad con el francés Michel Dumas, residente en Buenos Aires por esos años. También explicaba que en su segundo retorno a París, de Soussens debió ganarse la vida escribiendo réclames en verso para un fabricante de zapatos. (76). En Amigos y maestros... al referirse a las colaboraciones de la revista, Gálvez observaba que de Soussens le había entregado un cuento "El crimen de la calle Florida" que, "raro fenómeno", había sido pagado. (58). El relato se publicó en el $n^{\circ} 4$, agosto, 1903, pp. 324-336. Además, una colaboración de Carlos Ortiz, "Vagando y divagando", tiene a Soussens como interlocutor de Ortiz, en un bar y luego en las calles de Buenos Aires, $\mathrm{n}^{\circ}$ 8, diciembre, 1903, pp. 327-332. La nota está dedicada a Gando, dueño del bar en el que se desarrollaba la conversación.
} 
apelación a rasgos modernos y otros más residuales, en virtud de lo cual su figura fue, antes que completamente nueva, de transición. Como se verá, algunas de las problemáticas que los definieron, como una pronunciada orientación sociológica demandada para el arte, particularmente para el teatro -pero también para la novelalos ligaba con el $80 .{ }^{66}$ En la subjetividad que promovían hicieron coincidir positivamente valores estéticos y morales, a los que consideraban imprescindibles para la grandeza nacional, o como la denominó Olivera, para "una nación potente". Ese anhelo por participar en la construcción de una cultura nacional junto con la asignación de esta tarea a las elites intelectuales, también los vinculaba claramente con la generación de López, Cané y Groussac. El vitalismo actualizado en el talento, el esfuerzo, el trabajo, la potencia, o la virilidad, se alineaban junto a una muy evidente y declarada aspiración "de querer y de llegar", ${ }^{67}$ con respecto a la cual algunos se presentaban como promesas seguras. ${ }^{68}$ Como correlato de la profesionalización de la que participaban y contribuían a forjar, y cuyos aspectos económicos también fueron tematizados, la revista enfatizó la necesidad de una crítica literaria especializada como institución central para el funcionamiento del mundo literario en calidad de campo relativamente autónomo. En ese sentido, Ideas intentaría desarrollar una labor que desde su inicio vinculó con una tarea desmitificadora, rasgo que estuvo presente en sus autodefiniciones, donde insistió en erigirse como "crítica verdadera" frente a las falsas consagraciones provenientes de un periodismo carente de escrúpulos.

\section{Con los mercuriales y contra el ateneísmo. Crítica, legitimidad y polémica en 'Letras argentinas'}

${ }^{66}$ Giusti observaba que "Todas o casi todas las novelas de esa década [80] y aun de la siguiente, anunciaban desde el subtítulo ser estudios de costumbres. Era la época positivista con el triunfo de la sociología" (Giusti, 1956b: 27).

${ }^{67}$ Ideas, Año I, nº 1, p. 63.

${ }^{68}$ Carlos Real de Azúa, sostiene que el vitalismo muestra el impacto de la filosofía de Nietzsche, no limitado al reclamo del superhombre: "Su voluntad de poderío, su conmovido énfasis sobre la vida, desencadenaron una difundida reacción contra el intelectualismo idealista que afirmó fervorosamente las nociones de voluntad, energía, fuerza, trabajo y salud". (1950: 32). Ideas publicó "Nietzschismo" y "Una visión de Zarathustra" de José Ingenieros, "Federico Nietzsche" de José León Pagano, "Nietzsche, las mujeres y Rémi de Gourmont" de Mariano Antonio Barrenechea. Cf. Índice de Ideas. 
La revista Ideas asignó a la crítica un lugar central y este interés se tradujo en la existencia de secciones de reseñas dedicadas a literaturas nacionales -argentina, francesa, española- ${ }^{69}$ al teatro, a la literatura hispanoamericana, y se hizo visible, también, en las colaboraciones realizadas por fuera de esas secciones específicas. En ellas los escritores fueron definiendo su propia práctica como tarea de desmitificación, con un énfasis que, en ocasiones, fue decididamente reiterativo. Esta tarea develadora tuvo como correlato evidente el deseo de autorización de una voz crítica que intentaba distanciarse tanto de las formas espurias de consagración, en las que algunos veían reproducidos los comportamientos de la clase política, a la que consideraban "prostituída", ${ }^{70}$ como de los elogios o denostaciones automáticos y superficiales de la prensa diaria, motivados en muchos casos, en el interés comercial. En este apartado se observará una tensión constitutiva de la revista entre el programa crítico que se declaraba polémico y sus realizaciones efectivas, que, como se verá, no se dieron sin concesiones. En ese sentido, Ideas continuaba, a su manera, con una modalidad crítica que tenía su antecedente inmediato en algunas notas de El Mercurio de América, en las cuales a la vez que, por ejemplo, se objetaba con dureza una mala realización, los defectos se atenuaban realzando algún aspecto valorable de la obra o del autor tratados. En las reseñas bibliográficas los jóvenes críticos de Ideas no dejaron de ejercer un discurso autorreflexivo y valorativo de una práctica cuyos criterios de juicio se proponían renovar, cambio que necesariamente promovía -y se basaba en- una concepción de la literatura marcada por el signo de la modernización. Para hacer perceptible su propia diferencia, definieron como enemigos de una disputa, más necesaria que real, a los representantes del que entendieron como el espíritu del Ateneo, tratando de exponer el desfasaje de los mayores consagrados con respecto al ordenamiento del mundo literario al que aspiraban los nuevos escritores y críticos. Del mismo modo, señalaron su vinculación innegable con el grupo de El Mercurio de América, en una lectura del pasado literario inmediato que los identificaba como la continuidad natural de ese grupo de maestros jóvenes e iniciadores del cambio que ellos mismos, en los primeros años del nuevo siglo, representaban y estaban en

\footnotetext{
69 "Letras francesas" estuvo a cargo de Emilio Becher; 'Letras españolas" y "Letras hispanoamericanas", de Ricardo Rojas. Cf. Anexos LF: 1, LHE: 1.

${ }^{70} \mathrm{En}$ el $\mathrm{n}^{\circ} 3$ de 'Letras argentinas' Gerchunoff afirmaba: "Diríase la república de las letras copiando la oligarquía fraudulenta de nuestro sistema gubernamental..." p. 277.
} 
condiciones de realizar. En la misma línea que la revista de Díaz Romero, Ideas insistiría, además, en enarbolar su distancia con respecto a un público amplio en formación, al que sin embargo algunos miembros de la revista no dejaron de imaginar como objeto de una pedagogía estética; al mismo tiempo se distinguirían de otro público, aristocrático, también ignorante en materia artística. Nos detendremos aquí especialmente, en aquellas intervenciones que escenificaron de manera clara los cuestionamientos de los modos de legitimación vigentes en el campo literario en formación de principios del siglo; en el diseño selectivo del pasado literario se intentará mostrar, en términos de profesionalización, la disputa de estos jóvenes con figuras como los escritores diplomáticos, cuyo carácter residual leerían como arcaico.

La sección de 'Letras argentinas' estuvo presente desde el comienzo de Ideas. En ella escribieron, simultánea y/o sucesivamente, los miembros más representativos de la "generación de Ideas": Juan Pablo Echagüe, Lorenzo Fernández Duque, Roberto J. Bunge, Alberto Gerchunoff, Emilio Becher, Alfredo C. López, Manuel Gálvez, Atilio Chiáppori, Abel Cháneton. La sección dejó de aparecer con ese nombre en el n ${ }^{\circ}$ 17, y fue reemplazada por otra, 'Libros del mes', a cargo del Roberto J. Bunge; paralelamente, hubo también otra sección, 'Libros recibidos', de la que se ocuparon Gálvez y Cháneton. (LA: 1) La denominación letras, lo mismo que la de libros, mostraba la extensión de los términos en que se incorporaban obras no sólo literarias. Así, por ejemplo, en 'Libros del mes' Roberto Bunge se refería a El imperio jesuítico (Lugones), Los simuladores de talento (José María Ramos Mejía), El caudillismo y la anarquía argentina (Lucas Ayarragaray), Estudios sociales, de Belisario Montero, Don Juan de Garay, de José Luis Cantilo. Lo mismo sucedía en 'Letras argentinas' que, aunque abordó con mayor énfasis que las otras dos secciones problemas literarios en sentido estricto, incorporó también todas aquellas obras impresas que se consideraban intelectualmente relevantes. Finalmente, la denominación 'Libros' insistía en la relación de la cultura con ese formato, al que se ligaba con la posibilidad de los autores de construir una obra en sentido general. ${ }^{71}$

\footnotetext{
${ }^{71}$ La lista que surgía de los 24 números de ldeas mostraba, para el circuito del que participaba la revista, la presencia fuerte de figuras y obras de la generación anterior. Algo más de la mitad de los libros reseñados -y por tanto publicados- en las tres secciones ya nombradas, correspondían a memorias, informes, ensayos de corte sociológico, relatos de
} 
Además, la revista daba cuenta de la literatura argentina en colaboraciones no incorporadas a aquellas secciones, para ocuparse de modo especial y más extensamente de determinados obras y autores. Tales eran los casos de, entre otros, la nota de Ernesto L. O’dena ( $\left.n^{\circ} 8\right)$ sobre Florencio Sánchez, el trabajo de Olivera sobre La novela de la sangre de Carlos O. Bunge ( $\mathrm{n}^{\mathrm{o}} 11$ - 12), o las colaboraciones de Antonio Monteavaro sobre Florencio Sánchez ( $\left.n^{\circ} 5\right)$, sobre Charles de Soussens ( $n^{\circ}$ 17) y Triunfador de Roberto Payró ( $\left.n^{\circ} 18\right)$. Desde una perspectiva de conjunto, Ideas indicaba su preferencia por la producción de autores nacionales, y en ese sentido, la intención de mostrar la existencia de tal producción y de difundirla, legitimándola a través de una crítica especializada. En 'Letras argentinas' principalmente, pero también en las otras secciones de reseñas, los críticos registraban cuestiones relacionadas con las dificultades concretas de los escritores en un medio intelectual cuya precariedad se medía por la ausencia de instituciones específicas, tal como lo había señalado Olivera en "Sinceridades". Así, se referían a la posibilidad de construir una tradición literaria; tematizaban los vínculos entre los jóvenes intelectuales y los viejos, insistiendo en la necesidad de formas de legitimación y de consagración, asociadas, por ejemplo, a los nuevos modos de agrupamiento intelectual, como lo eran estas revistas juveniles que promocionaban; y daban a conocer las obras noveles, o apuntaban aspectos de las relaciones deseables o indeseadas entre literatura y mercado. Todos estos problemas eran tratados en el contexto del ejercicio de la llamada "crítica verdadera", cuyo programa era enunciado y se precisaba con la colaboración primera de cada crítico.

El sanjuanino Juan Pablo Echagüe inauguró la sección con una nota cuyo carácter programático era evidente, ya que no se refería a ningún libro sino que criticaba y discutía los principios negativos, que según su parecer, organizaban la vida literaria nacional. ${ }^{72}$ En efecto, el crítico impugnaba el modo en que se construían las reputaciones intelectuales, leía allí las huellas de una práctica política pretérita e

\footnotetext{
viajes. Sin embargo, esta situación era indicativa, de la dificultad que encontraban los escritores -jóvenes y no tan jóvenes- para publicar, antes que de la ausencia absoluta de producción. En ese sentido, la revista funcionaba como medio de publicación de obras en preparación, pero también de otras que no encontraban editor.

${ }_{72}$ Ideas, Año I, $\mathrm{n}^{\circ} 1$, Letras argentinas pp. 68-71. Echagüe fue crítico teatral y firmaba sus notas con el seudónimo de Jean Paul.
} 
incivilizada, que imponía sus juicios a un público pasivo definido como 'grey'. Echagüe mostraba como consecuencias de esta situación desventajosa de las letras, la falta de "autonomía mental", el "servilismo mental"73 y un marcado "atraso literario", cuyo término de referencia, omitido, eran las culturas europeas centrales, sobre todo la francesa. ${ }^{74}$ De ese modo, los restos de una sociabilidad política, nombrados bajo el término caudillaje, indicaban el cruzamiento de dos órdenes cuyas regulaciones debían mantenerse separadas. Frente a tales circunstancias, esbozaba el programa de corrosión y derrumbe que guiaría la sección, planteada como espacio de lucha:

Impera en las letras argentinas cierta especie de caudillaje, resto atávico del político que antes aplastara al país bajo su bota. Ha erigido su autoridad sobre un pasivo concensus omnium deprimente para nuestra autonomía mental. E invocando la usurpada consagración que debe a manejos de chicana electoral aplicados a la literatura, pontifica de Sumo Artista distribuidor de indulgencias y anatemas inapelables, que la grey tolera, peor aún, acata sumisamente.

Esos tiranuelos -entre los cuales no faltan Anatoles Frances de caricatura, para uso doméstico, que reflejan el original exactamente como un espejo convexo- son los responsables de nuestro relativo atraso literario. Ellos han enseñado a la juventud que pueden levantarse cátedras de maestro sobre la base del indolente laisser faire criollo, utilizando recursos de orfeón carnavalesco: exhibición y ruido. Ellos han demostrado prácticamente que para vencer, requiérese más audacia y bambolla que meditación y estudio. Ellos han extraviado por sugestiones de ejemplo la buena orientación intelectual, torciéndosela hacia el éxito inmediato y fugaz, en vez de dirigirla al único fecundo: el que se alcanza al fin de recias bregas forjadoras de cerebros y de músculos. Ellos, en fin, son los que hacen triunfar esa escuela de papagayos donde tan admirablemente aprenden los discípulos de la

\footnotetext{
${ }^{73}$ Es importante destacar que, más adelante en la misma nota, la cuestión de los límites entre lo cultural y lo político y de los propios límites del campo intelectual, era enunciada con una palabra que, como soberanía, remitía a lo político estatal, y sugería la idea un estado literario o república literaria independiente.

${ }^{74}$ Echagüe conoció en profundidad esta cultura y escribió sobre ella: Los métodos históricos en Francia en el siglo XIX, Buenos Aires, L. J. Rosso, 1931; Letras francesas, Buenos Aires, M. Gleizer, 1930.
} 
ciencia de los preceptores: repetir en tono

sentencioso, frases clichés y juicios elaborados. ${ }^{75}$

Se trataba de demoler ${ }^{76}$ las formas que, provenientes de un estadío pasado y anacrónico de la política, la política criolla, ${ }^{77}$ continuaban organizando, según Echagüe, la circulación y producción de los bienes culturales. Asimismo parecía sugerir que a ese momento de la historia política argentina, que implicaba la existencia consolidada y ordenada de un Estado nacional, le correspondía -como efecto de esa modernización estatal-, una cultura autónoma. Así, se objetaba las formas propias de un accionar político corrupto ("laisser faire criollo"), que sobreimpresas a las letras daban por resultado, antes que un juicio crítico meditado, un conjunto de clisés más propios de la oratoria; a la vez, proponía una alternativa específica de formación, estudio, meditación, originalidad de ideas, y criterios de consagración basados en la calidad de la obra, es decir, en cuestiones estéticas y también de calidad de pensamiento, no en las ventajas que ofrecían las relaciones con el poder. Echagüe insistía también - y con una frase que retomaba lo dicho por Olivera en "Sinceridades"- en el lugar que debía ocupar el arte en la sociedad, como corresponsable y determinante, junto con el progreso material, del "éxito" de la nación: "el que se alcanza al fin de recias bregas forjadoras de cerebros y músculos" (69). Directamente vinculada con los modos de consagración "usurpadores" denunciados en la nota, Echagüe construía irónicamente la figura del Sumo Artista que, en otros críticos de Ideas sería equivalente a la del pontífice. Asimismo, es relevante observar que la metáfora religiosa que en El Mercurio de América y La Revista de América ${ }^{78}$ designara con signo positivo el arte nuevo, aquí era utilizada para referir la condición obsoleta y sectaria de aquellos que no podían ser considerados maestros, mientras que el arte o la crítica nuevos, definidos como una "planta joven",

\footnotetext{
${ }^{5}$ Ibid., p. 69-70

Echagüe se refería a esta tarea intelectual como "demolición futura".

Fue Carlos Octavio Bunge quien definió el sintagma, como "los tejemanejes de los caciques hispanoamericanos entre sí y para con sus camarillas. Su objeto es siempre conservar el poder, no para conquistar los laureles de la historia sino por el placer de mandar". (Romero, 1983:63)

${ }^{78}$ Los "Santos lugares del arte".
} 
se asociaban a la ciencia o la patria. ${ }^{79}$ Además, en la nota, y como otra faceta de estos administradores fraudulentos de autoridad intelectual, Echagüe modelaba un personaje colectivo y anónimo, los 'tiranuelos', a medias caricaturesco, a quienes responsabilizaba de ese estado del mundo literario. De esta forma, fraguaba una modalidad crítica en la que la demanda de autonomía se realizaba, en términos teóricos generales, como confrontación o rebelión, aunque a la hora de criticar autores concretos -y salvo excepciones como Cané- esta retórica beligerante podía dar paso a una camaradería más indulgente, aun en el disenso. ${ }^{80} \mathrm{El}$ valor programático inaugural de este escrito se ratificaba en el hecho de que ésta sería la única participación del crítico en la sección. ${ }^{81}$

El gesto belicoso de esta crítica destinada a "voltear el gigantesco ídolo", estaba dirigido hacia afuera del grupo juvenil y funcionaba como recurso para hacer público

\footnotetext{
${ }^{79}$ Afirmaba: "Urge combatir este mal, del mismo modo que apremia extirpar los parásitos en la planta joven, facilitándole un libre y sano crecimiento. Precisamos reivindicar nuestra lesionada soberanía del espíritu, porque sin ella caeremos en el servilismo mental, la más humillante de las esclavitudes en razón de la pasividad del sometimiento. (...) hay que rebelarse virilmente contra los supremos sacerdotes del viejo templo polvoriento sobre cuyos altares enguirnalados de telarañas, ofícianse a puertas cerradas glorificaciones al Éxito". Y luego proseguía: "[Hay que] romper los vidrios aunque sea á pedradas si las ventanas están muy altas, dando paso á la luz de un pensamiento nuevo. (...) Y hay que colocar después otro símbolo en el ara: el del trabajo lento y silencioso como la germinación de la semilla, cuyo fruto solo ha de cosecharse más tarde, cuando cumplido su natural proceso de desarrollo, la granada espiga se abra dorada por el sol....He aquí la causa a la cual servirá esta sección de la Revista luchando enérgicamente, de frente.

Es verdad que no hemos de exterminar ni acaso conmover ese fetichismo que esteriliza tantas juveniles inteligencias. Para voltear el gigantesco ídolo, fuera necesario un formidable batir de arietes. Pero acaso algunos certeros golpes de piqueta, abran en el basamento una brecha que sirva de partida a la demolición futura ..... No olvidemos, entre tanto, el decir de Hugo: "el coloso se derrumba al fin, roído por la persistencia del insecto". Ibid.. p. 70-71. Las cursivas son nuestras y resaltan el uso de términos provenientes de la biología y la medicina.

${ }^{80}$ Como ejemplo de esta crítica más benevolente, véase la nota de Roberto Bunge sobre Modos de ver de Martín Gil, $n^{\circ} 4$, agosto, 1903, pp. 273-380 (LA: 4-5), en la que alterna le enunciación de los defectos con los consejos y cierto reconocimiento. Baste este fragmento como anticipo: "No le faltan condiciones, sin embargo. Menos desprecio por 'S. M. la frase', menos empeño en aparecer irónico y original, menos abuso de las complicaciones imaginativas, tan difíciles como peligrosas, lo convertirían en un escritor sano y agradable, para ciertos temperamentos. Si se dedicara franca y decididamente a cultivar la literatura campestre, estaría en su puesto, y llegaría alguna vez, no lo dudo, a justificar su renombre de autor nacional" p. 379 También el ya citado ejemplo de Mansilla. Cf. apartado 2.

${ }^{81}$ Echagüe escribió en Ideas dos veces más, pero ninguna en 'Letras argentinas'. En el $n^{\circ} 2$ lo hizo en la sección 'Teatros' donde se refirió a la obra Don Gil de las calzas verdes de Tirso de Molina y a El doctor Morris de Alberto del Solar, cuyo primer acto había sido publicado en el $n^{\circ} 1$ de la revista. (TE: 3 ). En el $n^{\circ} 6$ publicó los fragmentos de una nota de Rufino Blanco Fombona sobre Cané, que a su vez, comentó. Más adelante nos detenemos en esta nota.
} 
su anhelo y lograr el reconocimiento. De este modo, la tensión entre pacto de sociabilidad y ejercicio de la crítica con carácter polémico se resolvía, en la medida en que se aclarara que la batalla por la autonomía no implicaba romper las formas del consenso intelectual sino que se focalizaba en aquella "camaradería sin escrúpulos" promotora de mediocres, atacada por Olivera en "Sinceridades". El carácter selectivo de la confrontación hacía posible, por ejemplo, la inclusión no problemática de intelectuales como Ernesto Quesada o Groussac como colaboradores de la revista, en quienes era posible reconocer los frutos de una labor intelectual seria basada en el estudio y en la continuidad, más allá de sus vínculos con la elite política. Asimismo, esa sociabilidad denigrada y erigida sobre un tipo de consagración que reproducía las relaciones de poder, no era válida para el grupo de Ideas porque, por un lado, no hacía de la producción un valor central; por el otro, porque el capital social de los jóvenes no era parangonable con el de los literatos del 80, en virtud de lo cual debían sostener como principio y estrategia de autorización el par escritor-obra.

Un testimonio de la modalidad crítica más benevolente se hallaba en la nota de Roberto J. Bunge sobre Modos de ver de Martín Gil; en ella, acto seguido de la enumeración de los defectos que podían parecer insalvables (como el carácter inconexo de los relatos, la excesiva diversidad de temas "vaciados todos en el mismo molde antiestético", la abundancia de lugares comunes, e incluso, la "mediocridad" de las ideas), se hacían presentes los consejos y cierto reconocimiento. Entonces, Bunge alentaba y descubría las condiciones del escritor, y aun vaticinaba para él un sitio destacado como "autor nacional", "sano y agradable", en la tradición de la "literatura campestre". También Atilio Chiáppori, en la ya citada reseña sobre las memorias de Lucio Mansilla, a la vez que cuestionaba su impericia literaria para captar el interés de un público más amplio y anónimo, nunca llegaba al punto de desconocer las virtudes escriturarias del autor y cerraba su escrito destacando la "amenidad" y la "viveza" de los relatos cuyos forma y estilo, afirmaba, "son los mismos que conocimos en las Causeries". ${ }^{82}$ Algo parecido sucedía con la crítica indecisa de Gálvez a la Novela de la sangre de Carlos Octavio Bunge, en que ensalzaba su poder de transmitir "la

${ }^{82}$ Chiáppori lo planteaba así: “¿Es necesario que me refiera a la amenidad, a la viveza, de los relatos del general Mansilla? Sería inoficioso." Ideas, Año II, n 16, agosto, 1904, pp. 422-423. 
impresión de lo trágico" a la vez que señalaba el trazado defectuoso de los personajes principales e indicaba las incorrecciones estilísticas originadas en el desconocimiento de "la técnica del idioma", para otra vez destacar "su [de Bunge] amplio saber, su conciencia del arte, la pureza de su intención". ${ }^{83}$

Si la exhortación inicial de Echagüe -en la que no se ocupaba de obras sino de problemas generales- se mostraba fuertemente programática y polémica, las notas de Alberto Gerchunoff no abandonaban ese tono. ${ }^{84} \mathrm{El}$ primer artículo ${ }^{85}$ comenzaba con la ficcionalización de su propia tarea como miembro de redacción de una revista literaria, ${ }^{86}$ para retomar el desafío implicado en el programa ya enunciado por Echagüe y Olivera dando cuenta de los problemas que debían sortear los nuevos críticos. Dichos problemas se relacionaban con dos aspectos de una misma cuestión. El primero, el de la escasa calidad de las obras y, el segundo -y fundamental- el de la institucionalización de una crítica "prostituida por la hipocresía desvergonzada", que labraba reputaciones falsas, procedimiento por el cual, según Gerchunoff, se copiaban las formas de acción política de la oligarquía (LA: 3). Con ello Gerchunoff insistía en la necesidad de renovación de criterios promovida por Ideas y señalaba en la figura del burgués -que aparecía como fuente de legitimidad de tales aseveraciones- la

${ }_{83}$ Año II, Tomo 3, no 9, enero, 1904, pp. 75-89. A estos casos pueden agregarse el de Gálvez sobre Xarcas silenciario de Carlos O. Bunge (LA: 12-13); las notas de Roberto Bunge sobre El imperio jesuítico (LA: 19-20), Los simuladores de talento (LA: 20-21); el artículo de Rojas sobre Odio por Alfonso Danvilla; la bibliográfica de Becher sobre Vibraciones fugaces de Carlos Romagosa (LA: 5-6).

${ }^{84}$ Gerchunoff colaboró en los números 3, 6 y 7 de 'Letras Argentinas'. (LA: 3-4; 5-7) En general, las notas de Gerchunoff exhibían una virulencia -y en ocasiones una perspicaciamayor que las de otros escritores de la sección, proveniente, tal vez, de una inteligencia fraguada al calor de las intervenciones políticas. Emilio Becher daba cuenta de ese carácter enfático de Gerchunoff, en una carta a Ortiz Grognet, cuando le anunciaba a éste último: "Uno de estos días voy a visitar a Gerchunoff a fin de que me brame su artículo". Se refería a un "La alegría de ser joven" que refutaba un artículo de Becher "El dolor de ser joven". Carta correspondiente al 15 de febrero de 1903.

${ }^{85}$ Año I, n 3, julio, 1903, pp. 276-284.

${ }^{86}$ Sostenía: "Es de lamentar que en la Argentina no exista un psicólogo de la talla de monsieur Bourget, pues tendría ocasión para inmortalizarse en una obra cuyo asunto le propondríamos nosotros ...

El argumento, nuestro novedosísimo argumento, consiste en desarrollar la psicología de un solo personaje, miembro de la redacción de una revista literaria, que se consume de angustia al no poder elogiar -como honradamente quisiera- las obras cuya crítica está a su cargo.

Tal es el asunto que no debería desperdiciarse, o tal es, mejor dicho -personalizando el caso- la situación desagradable y violenta del redactor de esta sección”. p. 277. 
procedencia social de quienes ejercían aquellos modos de consagración, en que se enlazaban la autoridad cultural con la idea de propiedad.

Juzgar una obra mediocre o combatir un ídolo falso con la virulencia y la severidad que imponen las circunstancias, es cosa que no se practica frecuentemente entre nosotros, donde la crítica está prostituida por la hipocresía más desvergonzada. Diríase la república de las letras copiando la oligarquía fraudulenta de nuestro sistema gubernamental... (...)

Bien sabemos que en el ambiente social en que vivimos, el prejuicio obstaculiza toda intención sincera, exigiendo patente de autoridad al que pretende hablar en voz alta.

Y desgraciadamente, contra este mal, toda protesta es prematura aún. Es menester resignarse un tanto. Son usos lógicos mientras presida todas las funciones de la vida ese venerable rinoceronte que se llama Burgués! (277-278)

El desarrollo de la sección ilustraba esos objetivos claramente ya que intentaba desarticular la implicación necesaria entre sello editorial, ubicación social o empleo estatal del sujeto, y calidad estética o de pensamiento de los textos, para dar lugar un discurso crítico cuyo interés se concentrara en las obras, no en sus autores, no en los signos de distinción de las ediciones. ${ }^{87}$ En ese desplazamiento de los criterios legítimos de valoración hacia la obra y las cuestiones estéticas e intelectuales, podía verse el deseo colectivo de los nuevos de constituirse en sujetos intelectualmente autorizados. En los juicios negativos sobre algunos de los propietarios 'ilustres' de esos textos, Gerchunoff pretendía mostrar la asociación entre el alto grado de envejecimiento de una figura socialmente relevante y su intrascendencia desde el punto de vista literario, a la luz del valor de la laboriosidad profesionalista que Ideas intentaba consolidar. De los siete libros que Gerchunoff reseñaba, cinco habían sido publicados por sellos renombrados. De esos cinco, tres (Ensayos y notas por Juan Agustín García -hijo-,

Sergio Pastormerlo observa que: "En los ochenta, los lectores de la elite letrada aprendieron a contemplar con intensidad erudita la materialidad de los libros. El arte de la tipografía se transformó en un saber de alta legitimidad cultural, capaz de significar elocuentemente el grado de civilización (civilité) alcanzado por una sociedad, y comenzó a ser materia de certámenes que atraían la curiosidad del público lector más distinguido." (Pastormerlo, 2006: 26). 
Horas lejanas, de Darío Herrera; El cadete del año 13, de Rodolfo Díaz de Olazábal), habían sido realizados en Argentina por el prestigioso librero-editor Arnoldo Moen; los otros dos, se habían editado en París y Ginebra: En vísperas de Mansilla por Garnier y Las sombras de Hellas de Leopoldo Díaz por Floury y Eggimann. ${ }^{88}$ Sobre los dos restantes, Tradiciones argentinas de Pastor Obligado y Fantasías y leyendas del joven Gustavo A. Martínez Zuviría, no se consignaba editorial. La ruptura de ese prestigio automatizado ponía de manifiesto los aspectos que, a juicio de Gerchunoff, debían valorarse en las obras. Así, por ejemplo, se objetaba el criterio organizador del libro -y no la figura- del autor de La ciudad indiana (1900), ${ }^{89}$ de quien cabía esperar una obra "más completa y útil", no esas notas "verdaderamente chocantes, dignas de figurar en una recopilación de obras póstumas de cualquier periodista rural..." y cuya publicación sólo era explicable por el "vicio de la libromanía, tan general en los escritores americanos" (279). Del mismo modo, el crítico impugnaba la vaciedad de pensamiento de En vísperas, obra que a su juicio, no aportaba nada a la solución del tema tratado; definía el "lujoso volumen" de Mansilla como "pseudo-libro" cuyo asunto permitía al funcionario estatal "llenar varios capítulos con digresiones de filosofía gelatinosa, cuajada de humorismos de cocina que en boca del insigne diplomático adquieren cierto matiz de lunfardismo elegante" (382, cursivas nuestras). En el mismo sentido, atacaba por la insipidez de su contenido, los cuentos del panameño Herrera, autor a quien definía como "un verdadero adorno en nuestra sociedad elegante" (280). ${ }^{90}$ La inquina de Gerchunoff contra Herrera podía explicarse ${ }^{88}$ Díaz era por ese tiempo cónsul argentino en Suiza. El libro, traducido al francés por Frédéric Raisin, tenía prólogo de Rémy de Gourmont y había salido en 1902. Se trataba de una edición bilingüe.

${ }^{89}$ Según Gerchunoff, "(s)u Ciudad indiana nos lo reveló como un fuerte argumentador, y sobre todo como un estudioso, consagrado a documentar con acertado criterio a veces, los acontecimientos históricos de una época compleja, cuya interpretación científica daría motivo a una obra importantísima de sociología argentina". LA: 3.

${ }_{90}$ Darío Herrera, modernista panameño, colaborador de La Nación, había publicado en la entrega de julio-agosto de 1899 de El Mercurio de América con texto titulado "Luminea". Horas lejanas según consta en el prólogo de Rodrigo Miró a la edición de la Lotería Nacional de Beneficencia (impresora Panamá S.A., 1970), había sido impreso por los hermanos Coni sin que Moen arriesgara un peso. Moen mismo contaba cómo había sido la edición: "Me preocupaban los originales de su libro, del cual solía siempre hablarme, pero no estaba en condiciones de soportar la pérdida que seguramente produciría la publicación de una obra escrita por un autor desconocido fuera del ambiente literario. Con el deseo de ayudarlo trataba yo de encontrar una solución, cuando, por fin, se me ocurrió una idea. Hablando con uno de los literatos más pudientes, le propuse que si conseguíamos diez interesados en adquirir igual cantidad de ejemplares cada uno, a razón de dos con cincuenta centavos, y 
como distanciamiento de las estilizaciones de la estética modernista en favor de una literatura un poco menos preocupada por la técnica y más atenta a la originalidad del pensamiento. ${ }^{91}$ El caso de Leopoldo Díaz, cuyo libro sumaba al prestigio de la edición franco-suiza, el prólogo de Rémi de Gourmont, exponía claramente las facilidades que brindaban los empleos estatales a la hora de publicar una obra. ${ }^{92}$ Más allá de la reconocida perfección formal de los sonetos, el rasgo dominante, según Gerchunoff, era la falta de originalidad en las ideas, que podía leerse en contraste con el estilo de la impresión, el prestigio de las editoriales involucradas, y el renombre del prologuista. En relación con este último, el crítico destacaba, burlonamente, "los malabarismos del escritor francés por hablar lo menos posible de los poemas que prologa[ba]" (LA:4). En resumen, Gerchunoff establecía diferencias precisas entre el ejercicio de la literatura por los escritores modernos, que eran solo escritores, y los funcionariosescritores, para impugnar la fórmula que definía, en el marco de la clase, la institucionalización del arte como adorno o lujo; del mismo modo, criticaba como negativa la preocupación excluyente de los poetas por la forma, en tanto consideraba que la literatura era, además de una forma, idea, y en ese sentido, desestimaba las proezas estilísticas acercándolas, por su carácter superfluo, al arte de adorno.

Si en la primera nota Alberto Gerchunoff se había referido a varios escritorespolíticos o escritores-funcionarios, su colaboración del $\mathrm{n}^{\circ} 7$ estaría dedicada casi íntegramente a la obra de un escritor, Ángel de Estrada, a partir de cuya figura con el compromiso de no vender ni regalar éstos, hasta tanto no se agotara el resto de la edición, cuya venta sería a beneficio de Herrera, yo me animaba a editar la obra. Rápidamente fueron cubiertas las diez acciones, y poco después apareció Horas lejanas, así se titulaba, nítidamente impreso por la casa Coni, causando gran regocijo a su autor, y un murmullo de despecho a los alacranes". Según Moen quien lideraba a los alacranes era José Ingenieros. p. 5.

${ }^{91}$ En ese sentido podían leerse las siguientes afirmaciones de Gerchunoff:

"Se nos asegura que el autor se ha desvelado para que sus cuentos contengan la menor cantidad de quées y otros detalles.

En nuestra humilde opinión, creemos que el Sr. Herrera hubiera hecho obra más virtuosa desvelándose por llenar ese elegante y vacío volumen con un par de gramos de sentido común, en vez de hacer de Horas lejanas una risible orgía de inocentadas. Nuestro pésame". p. 281

${ }^{92}$ Se refería a Díaz con la frase de un poeta: "Misterios de los hombres de prebenda, diría Heine", para señalar el carácter inadecuado de la unión entre funcionariado y poesía. Tanto en el caso de Díaz como de Herrera, dos colaboradores de El Mercurio de América, Gerchunoff parecía oponerse a los empleos estatales como modo de subsistencia de los escritores.

Díaz había publicado "Sonets" en mayo de 1899 y en mayo de ese mismo año, "El arrecife de las sombras". 
abordaba un conjunto de problemas específicamente literarios, principalmente el de la construcción de una tradición literaria en la cual insertar la propia intervención colectiva. Como lo haría Gálvez en el $n^{\circ}$ 9, Gerchunoff ponía en el centro de su nota una lectura selectiva del pasado literario, organizado alrededor de la modernidad del grupo de "los raros" de El Mercurio con el que afiliaba a los jóvenes de Ideas. Dentro un protocampo literario -cuya existencia se demostraba con la selección previa de los mercuriales- y frente a este grupo, el crítico erigía como enemigos a los representantes del espíritu de Ateneo: quien lo había inaugurado, Calixto Oyuela y un miembro adherente, Miguel Cané. ${ }^{93}$

De aquel grupo de raros (hay que subrayar siempre esta palabra), entonces simples arlequines de las frases, forjadores de originalidades absurdas, según el criterio general, resultaron algunas cabezas que hoy resplandecen en toda América; -Rubén Darío, el decadente de los "aires suaves y pausados giros", se erigió una estatua con sus Prosas profanas; Leopoldo Lugones, el tempestuoso gigante de Las Montañas del oro, es ahora el más original y profundo escritor de Sud América; José Ingegnieros el eterno humorista que entre ocurrencia y ocurrencia se ha hecho célebre en el mundo científico, y por último Ángel de Estrada, que es un literato exquisito, cuya labor representa un esfuerzo audaz y considerable.

Y el círculo de los clásicos y sus adeptos espirituales zozobraron - ¡oh destino cruel!- en su propia solemnidad. El eminente Oyuela ya tiene canas y aún sigue medrando a la sombra de Fray Luis de León y Francisco Cobanyes, y asombrando de tiempo en tiempo a la gente desprevenida con sonetos filosóficos, dedicados a caballos que se debocan, o bien elegías, llenas de cristiana inocencia, en el homenaje al cadáver de León XIII... Miguel Cané, el más solemne de todos, ateneísta, si no de hecho, por lo menos de espíritu, grande y resonante como una bordaleza (sic) vacía (...) (301-302)

\footnotetext{
${ }_{93}$ Según Giusti (1954:54-57) Miguel Cané, lo mismo que Estanislao Zeballos y Manuel Podestá, no fueron a la reunión en casa de Obligado, sino que mandaron sus cartas de adhesión. Cané formó parte como vicepresidente, de la primea comisión. Dejó su cargo cuando fue elegido intendente de Buenos Aires.
} 
La denominación raros, procedente de la obra homónima de Darío, ${ }^{94}$ indicaba por extensión a los escritores jóvenes que a fines de siglo XIX se habían contado en las filas del modernismo, pero también apuntaba a las ideas de trabajo constante y de una dedicación exclusiva a la literatura, como marcas distintivas de estos sujetos. Desde una perspectiva focalizada en precisar las características de la subjetividad del escritor profesional, Ángel de Estrada ilustraba en parte esa definición, en tanto personificaba la anhelada regularidad de producción y edición de sus obras, más allá de las distancias que lo separaban de los jóvenes de Ideas. El autor de La voz del Nilo, a quien se incluía en el grupo de los raros, era "uno de nuestros escritores más laboriosos", y la prueba estaba en que cada año publicaba un libro. Al ejemplo de Estrada, Gerchunoff oponía dos modalidades de autorización de la literatura. En primer término, Gerchunoff se refería a las ya citadas formas de consagración ligadas al prestigio proveniente de los órdenes social y político, ratificadas en la alusión clara a Prosa ligera de Cané, editado ese mismo año por Moen; $;{ }^{95}$ en segundo lugar, y para la poesía, mencionaba, para impugnarla, una legitimidad fundada en la reunión impropia de tipo mercantil entre versos y tarjetas postales, quejándose de que "para merecer patente de poeta, suficiente es dar a luz un opúsculo de versos de tarjetas postales". ${ }^{96}$ De este modo, la poesía se convertía en 'adorno' o ilustración escrita de un material gráfico considerado más importante que el poema (se trataba de "versos para tarjetas postales [cursivas nuestras]); en cuanto a la prosa, además, la objeción apuntaba al carácter inorgánico y aleatorio de los artículos que componían el volumen, escritos sin un plan previo, y en el caso de Cané, durante la función diplomática ${ }^{97}$ Asimismo, la frase con que el crítico explicaba el vínculo entre la condición material de Estrada y su vocación literaria, mostraba una forma de profesionalización que distinguía a este

\footnotetext{
${ }_{94}$ El panteón de escritores que Darío armaba en Los raros daba cuenta de sus propias afiliaciones estéticas; los raros podían identificarse, en general, por sus vínculos problemáticos con las normas sociales. Entre otras significaciones, la palabra condensaba las de locura, degeneración, pesimismo, neurastenia.

${ }^{95}$ La alusión era concreta: "basta para adquirir renombre, uno que otro volumen de prosas ligeras, apenas tolerables o las más de las veces intolerables del todo". p. 330 (LA:6)

${ }_{96}$ Ideas, Año I, nº 7, noviembre, 1903, pp. 300-305.

${ }_{97}$ Los escritores jóvenes también organizaron sus libros como recopilaciones de lo que escribían para los periódicos; sin embargo la diferencia radicaba en la aspiración de tener una obra literaria o crítica de carácter orgánico.
} 
escritor heredero de los miembros de Ideas: "Empezó a dedicarse a la literatura, a pesar de ser rico". A pesar de señalaba que la literatura era pensada como un oficio con el cual ganar dinero, y en ese sentido, estos jóvenes escritores profesionales de la revista encontraban en la escritura un modo de subsistencia. Sin embargo, Estrada era también un profesional en tanto había elegido desde siempre el de las letras como dominio de su intervención, sin relegar la literatura a una función intermediaria. ${ }^{98}$

Casi como una réplica o duplicación del escrito de Gerchunoff, Gálvez retomaba en el $n^{\circ} 9$ de 'Letras argentinas ${ }^{99}$ los tópicos que aquél había planteado en el $\mathrm{n}^{\mathrm{o}}$ 7. En esta ocasión, el director de la revista se ocupaba de La novela de la sangre y mostraba a su autor, Carlos Octavio Bunge, como modelo del intelectual estudioso y a su obra como respuesta antiutilitaria. Mucho más moralizante y por eso menos irónico, coincidía con Gerchunoff en el reconocimiento de la labor pionera de los jóvenes de El Mercurio, grupo al cual ambos críticos situaban en la lejanía de un pasado más imaginario que real; el diagnóstico de las dificultades que enfrentaban las nuevas generaciones que trataban de abrirse paso en un medio intelectual dominado, según el crítico, por un conjunto dudoso de firmas indiscutidas, era otro punto de contacto; a ello también debía sumarse la mención despectiva de los escritores diplomáticos y sus libros de viajes. No obstante, a diferencia de Gerchunoff, Gálvez evaluaba los intentos de los modernistas como un relativo fracaso y depositaba en la juventud de principio de siglo XX a la que pertenecía, la responsabilidad de construir la obra de una futura tradición literaria, todavía ausente en un medio intelectual que insistía en definir como vacío o indiferente, porque no concordaba con el propio deseo:

Faltos en absoluto de todo ideal, incapaces de una labor continuada, absorbidos en las luchas de una política de chisme, fraguando revoluciones o acometiendo presupuestos, los escritores argentinos, en su mayoría, no han hecho obra, y apenas si los más constantes pueden presentar al cabo de años, uno que otro libro de viaje o algún

\footnotetext{
${ }_{98}$ En relación con la posibilidad de vivir de la literatura, Gerchunoff refiriéndose a la época de Ideas, afirmaría en Argentina país de advenimiento, que había sido en ese momento cuando empezó a tomar cuerpo un medio artístico nuevo en el que los escritores pensaban su literatura como una actividad permanente que podía ser cultivada "sin relegarla a la categoría de una función intermediaria" (Gerchunoff, 1952: 49).

${ }_{99}$ Lo retoma en la reseña sobre La novela de la sangre de Carlos Octavio Bunge, en el apartado IV.
} 
opúsculo de comentarios sobre cualquier artículo probablemente el 5 o 6 de la Constitución Nacional.

Las nuevas generaciones que llevan una fe como lema y la lucha por un ideal como bandera, fueron desoídas y hasta vilipendiadas por el montón predominante e ineducado de los que habían recibido consagraciones como firmas indiscutibles. Darío, Lugones, Jaimes Freyre, Ingegnieros y otros más -el grupo de El Mercurio de América si es lícito clasificarlos bajo esa denominación- no encontraron eco, y sus voces predicando nobles principios perdiéronse, como hambrientas de desierto y se hizo alrededor de sus obras un desolador vacío.

Son raros los que, no aleccionados por los fracasos anteriores, arremeten contra la indiferencia en una furiosa lucha a muerte. ${ }^{100}$

El carácter excepcional de los jóvenes implicado en esta nueva mención de la palabra raros, diferenciaba a estos héroes juveniles por su formación, y sobre todo por el basamento ético de sus acciones, movidas por la creencia en un 'ideal' y la 'fe', del "montón ineducado" -reconocido, en este caso, en los consagrados - y del "utilitarismo político e industrial de la masa" (86). ${ }^{101}$ Los mismos jóvenes de Ideas, los nuevos raros, continuadores de aquellos pioneros, estaban dispuestos a realizar un anhelo que había quedado trunco.

Gerchunoff y Gálvez no fueron los únicos en ver a la generación de Darío, Lugones, Ingenieros o Berisso como un punto nodal en la breve tradición literaria, en construirla como su predecesora natural y asignarle la función de un magisterio juvenil. En el no 1 , en el retrato de Eugenio Díaz Romero, Olivera había elogiado este aspecto y enfatizado el valor de El Mercurio de América pero, a diferencia de los otros críticos, se había permitido juzgar deceptiva y severamente las trayectorias posteriores de algunos de los integrantes de aquel grupo, respecto de las cuales habían jugado un papel más que relevante las condiciones materiales de los escritores y, una vez más, la "indiferencia" del medio social. Desde su mirada juvenilista, Olivera se quejaba e ${ }_{100}$ Ideas, Año II, nº 9, 1904, pp. 86-87.

${ }^{101}$ Gálvez aplicaba los atributos generalmente utilizados calificar al público sobre las firmas consagradas, y mezclaba la crítica al filisteísmo social general con la impugnación de los criterios de autorización. 
ironizaba sobre los efectos que los empleos estatales aceptados, por ejemplo, por Lugones o el mismo Díaz Romero, habían tenido en su producción literaria; en cuanto al primero, que se desempeñaba como inspector de escuelas, mostraba su colocación dominada con respecto al orden político en el tono bajo de sus críticas a un ministro contrapuesto a la voz del poeta de Las Montañas del oro-; en relación con Díaz Romero, la consecuencia había sido, directamente, según Olivera, la ausencia de producción. ${ }^{102}$ A su turno, Becher ordenaba el pasado literario mundial reciente para leerlo como capitalización de la experiencia de la poesía francesa por los escritores americanos y nacionales, a propósito de La victoria del hombre, de su amigo Ricardo Rojas Emilio. ${ }^{103}$ El escrito era fundamental porque fijaba un corte entre los modernistas y la generación anterior, cuya divisoria se establecía en la consideración de la literatura como una práctica culturalmente reconocida y acrededora del sitio más elevado en el ordenamiento social, diferenciación de la que provenía, precisamente, la conciencia del propio oficio; como tal se había diferenciado del "cuarto de hora del aburrimiento" y había erigido sus propios criterios de valoración, en el armado de una jerarquía estética (373). De este modo, inscribía a Rojas y a su grupo como continuadores de esa primera tarea de renovación técnica y de ideas, reconociéndolo como sucesor de Darío y de Lugones. ${ }^{104}$

${ }_{102}$ Olivera sostenía: "Lugones descendió de Las Montañas del oro para efectuar simples inspecciones escolares, y en los últimos tiempos aquella Voz que habló contra las rocas, debió disminuir mucho el tono para criticar un pobre mortal aunque ministro, y la 'gran columna de silencio y de ideas en marcha' que es su genio, es ahora silencio e inmovilidad. Darío que se hizo perdonar sus primeros periodismos por haberlos hecho servir en la fábrica de su España contemporánea, escribe ahora vagas correspondencias de prosa amorfa, que no es por cierto hermana ni de las Prosas profanas ni de Azul. Aquel agitador socialista que fue Ingegnieros, se ha metamorfoseado en un médico muy sabio con consultorio frecuentado, que cuando escribe es sobre psiquiatría, ciencia penal, antropología y otras cosas igualmente graves y solemnes. Jaimes Freyre peregrina aislamientos en capitales de provincia, y la tarea estéril de diarismo hace abortar al hermano de Castalia Bárbara cada vez que lo concibe su talento. $Y$ este mismo Díaz Romero, ubicado en un rincón del Presupuesto, ha dejado sus Harpas en el Silencio..." p. 37.

${ }^{103}$ Año I, Tomo 2, n 8, diciembre, 1903, pp. 372-384.

${ }^{104}$ Afirmaba: "(...) esos decadentes, a quienes se acusaba de todos los extravíos dieron, por primera vez, a nuestro arte, una conciencia [en cursiva en original]. Ellos refutaron la idea, tan errónea como inmoral, proclamada por los escritores de la generación anterior, de que la literatura era una tarea agradable y frívola, buena para el cuarto de hora del aburrimiento; y demostraron la ignominia de esta conducta que ponía el Ideal al nivel de las más bajas profesiones y reservaba para el alma excelsa de Beatriz la posición subalterna y equívoca de una concubina. Establecieron también una jerarquía más noble, y Los Raros propusieron a la admiración de la juventud, en vez del arte precario de las Academias, la sólida y poderosa escultura de Leconte de Lisle y la resplandeciente maravilla de Villiers. En suma, 
Como se dijo en el comienzo del apartado, la revista definió algunos de sus rasgos propios en la crítica reiterada a las actitudes intransigentes de determinados miembros del Ateneo de Buenos Aires con respecto a la modernidad literaria, reunida alrededor de Rubén Darío. Esta oposición entre ateneístas, vistos como arcaicos, y los raros, ofrecía un juicio parcial acerca de dicha institución, o al menos relativo a un momento de su historia. En ese sentido, aquellos mismos raros habían encontrado en la institución su lugar a partir de la llegada de Darío a Buenos Aires, quien había servido “de catalizador nucleando a los 'jóvenes y los 'revoltosos' alrededor de sus banderas estéticas y su bohemia moderna". ${ }^{105}$ En relación con este aspecto, y sin desconocer las distintas posiciones que pugnaban en el Ateneo, ${ }^{106}$ Laura Malosetti Costa ha destacado que éste constituyó una "formación peculiar en la que se estableció una alianza entre 'nuevos' y 'viejos', entre artistas e intelectuales modernos y renovadores y figuras prestigiosas, sólidamente reconocidas y con poder (tanto en el plano intelectual como económico y político)" (Malosetti, 2002: 347-352). De ese modo, la revista ponía en evidencia y enfatizaba su oposición particular hacia las concepciones de la literatura promovidas por aquellos a los que Gerchunoff nombraba como el sector "histórico" de la institución, los clásicos e hispanizantes. ${ }^{107}$ En la misma nota sobre Estrada, Gerchunoff acuñaba la figura despreciada del fracasado ilustre, ${ }^{108}$ cuyos exponentes más destacados volvían a ser Oyuela y Cané. Representante conspicuo de la posición

\footnotetext{
la obra de los llamados decadentes consistió en aplicar a la literatura española las doctrinas parnasianas y simbolistas, por la reforma de la técnica y la renovación de los pensamientos." Ibid., p. 373-374

${ }^{105}$ En el mismo sentido, Ingenieros (1915) contaba que "gustando de las letras, frecuentaba el 'Ateneo' donde Rubén Darío concentraba el interés de los jóvenes. En 1898 el poeta Eugenio Díaz Romero editó la revista "El Mercurio de América", que fue auspiciada por Darío y en la que colaboramos casi todos los ateneístas del último tiempo".

${ }_{106}$ Podían reconocerse: nacionalistas cultos y románticos a la manera Rafael Obligado; clásicos e hispanistas cuyo representante más emblemático fue Oyuela; naturalistas Como Argerich; modernistas aglutinados por la figura de Darío Jaimes Freyre, Lugones, Leopoldo Díaz, Luis Berisso. (Malosetti, 2002: 350; Giusti, 1954: 52-59)

${ }^{107}$ Explicaba Gerchunoff: "Data su iniciación [de Estrada] de la época en que recién nacían aquí las modernas corrientes literarias y comenzaba a tener más boga el cenáculo de los raros, encabezado por Rubén Darío y Leopoldo Lugones, en oposición al histórico Ateneo, cuyas ruinas aún existen, acaudillado por el distinguido Dr. Calixto Oyuela, autor de la célebre Oda a España". Ideas, Año I, n 7, noviembre, 1903, p. 301.

108 Gerchunoff se refería a Cané y a Oyuela como parte del núcleo integrado por "otros muchos fracasados ilustres que no sigo nombrando por pura higiene artística..." Ibid., p. 302.
} 
antiprofesionalista en el Ateneo, ${ }^{109}$ Calixto Oyuela había mostrado su rigidez en materia estética frente a los 'decadentes' y, para Gerchunoff, era el emblema de un cerrado casticismo. A Cané se lo descalificaba por escribir una literatura "almaceneril"; en este calificativo podía leerse, junto a la idea de un agrupamiento azaroso de los textos sobre cuestiones dispares, el rechazo hacia las figuras de estos hombres de Estado, gentlemen escritores, y hacia la mediocridad de sus obras. En ese sentido, utilizaba el término Roberto J. Bunge como prueba de la calidad de $E l$ imperio jesuítico, y rescataba el valor del silencio con que habían recibido la obra de Lugones los "panegiristas de profesión" que prodigaban elogios incondicionales "a cuanto libro mediocre publica tal cual almacenero de Letras". ${ }^{110}$ Esta figura del fracasado ilustre que los dos ateneístas ejemplificaban de modo cabal, funcionaba como la cara inversa de los retratos de los jóvenes de Ideas, quienes confiaban en el carácter promisorio de su generación pensada como la elite intelectual futura. ${ }^{11}$

Además de Gerchunoff, otros redactores importantes de la revista desautorizaron al autor de Juvenilia. Ricardo Rojas, en 'Letras hispanoamericanas' se refería con las figuras del "pontífice"112 y de "celoso director de almas" al carácter rector de sus opiniones en el seno de la alta sociedad, para ridiculizarlo por haber elevado la moralidad como variable del juicio en asuntos de arte, al mismo tiempo que

${ }^{109}$ Roberto Giusti refiere que en la reunión en casa de Obligado, Ricardo Gutiérrez planteó como preocupación central las cuestiones de la propiedad literaria y el salario del escritor, afirmación que según Giusti "tuvo la virtud de escandalizar particularmente a Oyuela". (1954:55). Respecto de esta cuestión Jorge B. Rivera señala: "El Ateneo de Buenos Aires, fundado en 1893, fue una de las tentativas más ambiciosas en la larga y tesonera lucha por agrupar a escritores y artistas en una entidad que expresara sus intereses específicos. Frente a quienes desean convertir el Ateneo en una sociedad de tipo gremial, Oyuela representa fundamentalmente la línea que lo de fine y defiende como tribuna de la 'actividad intelectual pura y desinteresada'. Oyuela (...) es uno de los defensores más irreductibles de la línea 'antiprofesionalista'”. (Rivera, 1993: 81).

110 Ideas, Año II, no 17, septiembre de 1904, p. 79. Cursivas nuestras.

${ }^{111}$ El repaso de Gálvez sobre los puestos que los miembros de su generación fueron ocupando, más tarde, en la política, en el Estado y en la cultura, pude servir como prueba de esta percepción. (Gálvez, 1961)

${ }^{112}$ Gálvez en el $n^{\circ} 9$ retomaba exactamente este término: "entonces [alrededor de 1884, año de publicación de Fruto vedado de Groussac] Cané no era pontífice ni había soñado con escribir Martín Gil”, p. 89. Cursivas de Gálvez. En el n 11-12, trataba de explicar el fracaso de Nebulosa de Carlos M. Ocantos y recurría nuevamente al poder consagratorio de esa figura: "Es que le han faltado las cartas consagradoras de los pontífices y la venia de los maestros árbitros de la crítica.

De otra manera, Ocantos habría sentido en su propia tierra -como tanto aborigen tarambana- la huraña realización del éxito." (333) (LA: 12) También en Amigos y maestros recordaba su desprecio juvenil por Cané pp. 72-75. 
señalaba la distinción efectiva entre arte y buena sociedad e indicaba el alcance acotado a la elite de la directivas culturales del autor de En viaje. ${ }^{113}$ En esa misma entrega, la publicación incluía a Cané en 'Galería de intelectuales contemporáneos'; la definición del breve texto que acompañaba al dibujo mostraba en el empleo estatal (fuese en el parlamento o como diplomático, en la función docente o en el rasgo de “conversador ameno"), al hombre del 80 que como un "picaflor" mojaba su pluma en el terreno del arte, y encarnaba la multiplicidad de empleos que Julio Ramos liga con un funcionamiento heterónomo de la literatura. Aunque esta inclusión hablaba del reconocimiento cierto, éste era matizado tanto con el dibujo como con el breve texto que definía al autor de Juvenilia. ${ }^{114}$ Texto e ilustración repetían la anécdota referida por Rojas subrayando la evidente pacatería moral como un criterio atrasado de juicio estético. ${ }^{115}$ De todos los golpes que Ideas propinó a la figura de Cané, la intervención de Juan Pablo Echagüe en octubre de 1903 fue la más punzante, ${ }^{116}$ no integró ninguna de las secciones fijas de la revista sino que se publicó como uno de los artículos centrales de esa entrega. A diferencia de las opiniones de los otros redactores, que se referían al autor de En viaje a propósito de obras de otros escritores, el texto le estaba

${ }^{113}$ Esta anécdota con la que los jóvenes de Ideas hostigaban la figura de Cané ya había sido consignada en 'Varias' -en julio de 1903-, una sección miscelánea a cargo de Héctor J. Delmonte, que apareció solo dos veces, en los números 3 y 4 de la revista. En esa entrega de julio se leía: "Al fin salió de su ostracismo inmerecido la hermosa producción de Mascagni [Iris].

Esta vez el público no ha tomado en cuenta la rígida crítica del año pasado, vertida por el Dr. Cané.

Están de parabienes los amantes de la música y el buen sentido" (294)

A propósito del público de Buenos Aires Rojas contaba que -Los abonados de la Opera habían asistido más de una vez a las representaciones de Iris, sin escandalizarse de la obra, -acaso porque no la comprendieron, - hasta que cierto pontífice [Cané] denunció la inmoralidad del libreto y anunció la perdición de las almas...Las damas desesperaron entonces de contrición (sic), boicotearon la pieza y, desde aquel día, no asistir a las audiciones de Iris fue un acto de buen tono [cursivas de Rojas], según aquel celoso director espiritual... p. 243.

114 "Estadista y diplomático. Picaflor en el gran bosque del Arte y escritor delicado, fino armonioso y sutil. Traductor de Shakespeare Conversador ameno [cursivas mías] y catedrático distinguido (...) Periodista y crítico (...) Cierta vez del año antepasado, -alguien lo ha dicho- su cerebro claro y enérgico tuvo un mal pensamiento': jinculpó al libreto de Iris de licencioso!... Toda su obra de artista fecundo, bien vale el perdón de este desliz". p. 261.

${ }^{115}$ En el dibujo Cané saliendo del teatro Ópera se lleva en brazos a una mujer pequeña, que, suponemos, es la actriz que encarna a Iris - vestida y peinada como geisha. La mujer está haciendo "pito catalán" y riéndose; Cané tiene la mano en alto y parece preparado a escarmentar a la joven; también parece contestar a quienes, desde adentro del teatro, aplauden el libreto inmoral. Año I, $n^{\circ} 3$, Tomo 1, julio, 1903, pp. 258-261.

${ }^{116}$ Cané "vu du dehors", Ideas, Año I, Tomo 2, n 6, octubre, 1903 pp. 177-179. 
íntegramente dedicado, y ya desde su título apuntaba a las formas de reconocimiento como tema central. "Cané vu dehors", formuló una teoría sobre la gloria literaria para poner en duda el carácter pontificial de su figura, basándose en la autoridad internacionalmente indiscutida de una publicación francesa como La Revue y en el prestigio de Rufino Blanco Fombona. Echagüe afirmaba que "La posteridad -se ha dicho- comienza en el extranjero", y tomaba esa frase para sacar partido de los juicios negativos del venezolano sobre Cané, con motivo de la publicación de Prosa ligera. Estas evaluaciones externas apuntaban a los aspectos que la revista tematizaba con especial interés, y los objetivaba en la apelación a una mirada exterior, y como se sabe, afín en el terreno estético. De este modo, Echagüe oponía a la parcialidad de cierta franja cultural de Buenos Aires, que juzgaba como provinciana, la "resonancia mundial", y por lo tanto moderna, de La Revue. ${ }^{117}$

...'Un rastaquoère insoportable, una mediocridad grisonnante afectado de cierto sans façon petulante, es el argentino al cual se debe un volumen reciente titulado Prosa ligera. Este libro de vejez, flor tardía, literatura de empleado de administración pública, es la corona que ha tejido para su frente, en el otoño de su vida, un diplomático de ultramar. Colección de prosas triviales, artículos de diario, tarea de pacotilla, este opúsculo sin unidad, sin plan, sin trascendencia, escrito en estilo notario, se parece más al ensayo zurdo e inhábil de un adolescente grafómano que a la obra de la madurez de un hombre envejecido en la ociosidad de las oficinas públicas. Es una colección abundante de frases hechas. En ese jardín de lugares comunes florecen con igual exhuberancia las banalidades de pensamiento y las de estilo. La memoria sustituye en el autor a la imaginación",

Como se puede observar, Blanco Fombona no solo criticaba el tipo de literatura nacida en el espacio estatal y de la función pública -pensada más para la prensa que para el

${ }^{117}$ Decía “Uno de nuestros 'varones ilustres', el señor Dr. Miguel Cané, ha sido juzgado en cierta publicación francesa de resonancia mundial, a propósito de su último libro, Prosa ligera. La autoridad de la revista que inserta ese juicio, la nombradía del crítico que lo firma, la fama del escritor que lo motiva, son razones que me deciden a transcribirlo. Conviene mostrar a la opinión de adentro cómo dictamina la opinión de afuera. Multiplicar los puntos de vista, es procurar el conocimiento completo del punto observado", p. 177. 
libro orgánico y configurada como un “fragmentarismo ameno" (Viñas 1996: 11). También objetaba la subjetividad que la sostenía y trazaba una demarcación entre los géneros de los escritores universitarios del 80 (autobiografía, memoria, conversación) y la ficción destinada a un público moderno. Estas observaciones negativas reenviaban a un conjunto de rasgos positivos no marcados, que conformaban una axiología que debía orientar la valoración y la producción de los textos, y entre los que se contaban -como en los casos de otros críticos- el estudio y el talento, la construcción de obras y no de recopilaciones, la originalidad de pensamiento y la consideración de la literatura como trabajo. Asimismo, como rasgo fundamental y ligado con la modernización literaria, estaba el hecho mismo de apelar a la voz autorizada de un propulsor de la estética modernista para afirmar una concepción de la literatura y de los escritores. A través de este recurso, se insistía en el vínculo con la generación de El Mercurio de América y en la vigencia de criterios internacionalizados, no meramente nacionales con que medir y avalar la calidad de las obras.

Por último, el enfrentamiento estratégico con el Ateneo, reaparecería en "Juicios de afuera", ${ }^{118}$ sección que Ideas dedicaba a transcribir las repercusiones que pudieran tener la revista, sus miembros o escritores afines en los medios intelectuales argentino o extranjeros. En el $n^{\circ} 18$ Manuel Gálvez insistía en esa oposición, a propósito de los juegos florales organizados en 1904 por el Ateneo, al que consideraba una institución arcaica, y por lo tanto incapaz de juzgar a los escritores modernistas ya consagrados y menos aún a los más jóvenes, quienes por tal motivo no habían enviado sus obras. La figura de Calixto Oyuela, nombrado como "profesor", recuperaba la diferencia entre artistas y pedagogos, que llevaba el sello de El Mercurio y de la crítica a la institución universitaria, donde Oyuela enseñaba literatura castellana y francesa. 119. Coincidente con la impugnación a los ateneístas históricos debía leerse la queja de

${ }^{118}$ La sección apareció en los números 11-12, 13, 14, 16, 18, 21, 22.

119 Gálvez afirmaba: "Esos juegos florales realizados para conmemorar creo que el Descubrimiento de América, no han tenido otros prestigios que el encanto de una incomparable corte de amor y la elocuencia frondosa de Belisario Roldán.

Quizá porque el jurado no autorizaba a confiar lo suficiente en un fallo certero, quizá por la resistencia a ser juzgados por dilentanttis y escritores en general de una inferioridad reconocida, los poetas argentinos no han realzado con su concurso la fiesta, que debió por tal causa de resultar opaca.

Y estas ausencias son el fracaso de la institución. 
algunos de los colaboradores de Ideas respecto a la ausencia de un verdadero magisterio intelectual por parte de la generación anterior, ${ }^{120}$ basado en el "altruismo" y en el estímulo de los nuevos. Aunque en esa declarada orfandad construyeron sus vínculos con los maestros jóvenes y con figuras como Almafuerte y Sicardi, los nombres de algunos liberales del 80 tampoco estuvieron ausentes. ${ }^{121}$

Como se pudo observar, los jóvenes críticos de Ideas bregaron por establecer un discurso fundado en el valor positivista y a la vez moral de la verdad, y concebido como una práctica ejercida por sujetos especialistas y profesionalizados, a través de su inserción creciente en el mercado de las profesiones literarias que ofrecían tanto diarios como magazines. En la afirmación de la necesidad de tal discurso incluyeron como marca distintiva de su propia autoridad intelectual, un conjunto de diferenciaciones que a su vez fueron claves para delimitar no solo los criterios legítimos de juzgamiento de las obras sino también la distinción entre las letras y la literatura. En ese sentido, procuraron expulsar de ese dominio a la figura residual pero aún vigente del escritor funcionario oponiéndose, sobre todo, al desempeño de los cargos diplomáticos, identificados con el ocio, y del que era tributaria una concepción de la literatura entendida antes como pasatiempo que como trabajo. De este modo, atacaron sistemáticamente a Miguel Cané, representante más conspicuo de esa subjetividad y "director" del gusto y la moral de la alta sociedad a la que, en su mayoría, no pertenecieron estos nuevos escritores y críticos. Sin embargo, esta

No ha podido concurrir, por ejemplo, Leopoldo Lugones, cuyo ideal artístico, noble y elevado, dista mucho del concepto que tiene de la literatura el profesor Oyuela. Y porque no podía ser ponderado con el señor Gabriel y Galán, este magnífico, que ha dicho en su verso la armonía de los orbes, el ritmo de los astros, el canto de las mareas, el himno de la naturaleza; poeta de imaginación poderosa, artista exquisito, que tiene en alguna estrofa la delicadeza de Samain, y la sutilidad imprevista de un espíritu moderno.

Ni Almafuerte, voz de bronce, cantor de la chusma poeta de un vigor extraordinario, poseedor del estilo más propio entre los escritores de América, alma de bondad, donde todas las protestas hallan un eco y todos los desheredados un consuelo.

$\mathrm{Ni}$ Jaimes Freyre, un griego de la decadencia en quien se ha cumplido prodigiosamente lea estética del maestro - de la musique avant toute chose,- cuya riqueza rítmica es su característica y "Castalia" su gloria.

Ni tampoco los jóvenes." Ideas, Año II, n 18, octubre de 1904, pp. 236-237.

120 Era Rojas quien se quejaba de que "los jóvenes de América, aunque vivamos en 'la Atenas del Plata'... aquí la juventud intelectual entra en la vida, sola, vacilante, y librada a sus propias fuerzas. Los que la precedieron en la jornada, no le ofrecen ejemplos, ni le señalan rumbos." Año I, nº 2, junio, 1903, pp. 169-175. (LHE: 1-2)

${ }^{121}$ Por su parte, Gálvez que reivindicaba la independencia, nombraba a un conjunto de maestros en el que aparecían mezclados Darío, Lugones, Wilde, Sicardi Joaquín González y Groussac. Año II, Tomo 3, no 10, febrero, 1904, pp. 181-186. (LA: 10-11) 
exégesis no sopló siempre y sin matices como aquel pampero agreste y duro, declarado en "Sinceridades", y sus embates se vieron, en ocasiones, alternados con el reconocimiento o el consejo. Por último, la selección y respaldo de un pasado literario identificado con las figuras nucleadas en torno a Darío, Jaimes Freyre, Lugones, Ángel de Estrada y a El Mercurio de América, al que ubicaban en un pretérito casi mediato, trazaron una separación entre los géneros correspondientes a la sociedad patricia y una literatura capaz de interpelar a un público ampliado. En ese sentido, se intentará exponer de qué manera la revista mostró un interés por participar en un mercado posible, cuyo funcionamiento ejemplar se encontraba en el circuito de consumo 'masivo' de los diarios, magazines y semanarios plebeyos. ${ }^{122}$

${ }^{122}$ En el contexto de modernización y ampliación de la esfera pública y Con respecto al semanario Caras y Caretas, Geraldine Rogers ha descripto su modus operandi como "lógica de integración". En ese sentido afirma que el semanario reunió componentes de campos diversos de la cultura e integró elementos que en otros ámbitos eran incompatibles. (...) En ella agentes y modos de producción antagónicos se ordenaban en un sistema de interdependencia mutua, absorbiendo las diferencias estéticas e ideológicas que eran evidentes en otros contextos". (Rogers, 2006). 


\section{Las paradojas del espiritualismo: un mercado ejemplar}

Si hubiera que señalar las marcas más explícitas de la intervención de la revista Ideas, la elección recaería en los términos antimaterialismo y espiritualismo. Así lo confirmaban su nota de apertura y muchos otros escritos de las secciones de la publicación en los que, como ya se vio, se tematizaba para enjuiciarlo críticamente, un estado del mundo intelectual contemporáneo, frente al cual estos dos términos constituían, respectivamente, una respuesta como denegación de una situación actual y como prescripción regeneradora del futuro. Antimaterialismo y espiritualismo, dos conceptos cuya potencia ideológica, resultaba, sin embargo, atenuada si se reparaba en la forma en que Ideas intervino y a la vez imaginó su participación en un mercado para la zona de la cultura letrada a la que pertenecía. El mercado se presentaba en la revista como tema y como problema al que se enfrentaban algunos de los intelectuales jóvenes de la alta cultura que participaban de Ideas, quienes percibían la necesidad de orientar sus estrategias hacia la empresa de construir un público para el teatro y la literatura nacionales en vías de autonomización. En ese sentido, la inserción en el mercado, tanto de la revista como de los escritores que colaboraban en ella, se presentaba no tanto como una realización ${ }^{123}$ sino como aquello a que se aspira pero que también se postulaba como imprescindible, y cuya forma y funcionamiento deseables se iban delineando. Novela y teatro fueron los dos géneros que la revista eligió casi desde sus inicios, y en relación con los cuales se planteó la construcción de una identidad nacional y de una tradición literaria, operación en la cual se produjo un desplazamiento hacia una lógica de mercado, más propia del circuito de consumo amplio de la cultura popular.

Un aviso del $\mathrm{n}^{\mathrm{o}} 5$, particularmente llamativo por su tono jocoso, parece un momento clave en el que la revista exhibía su deseo de inserción en un mercado de bienes simbólicos, tomando como modelo el mercado de bienes económicos. El aviso que ocupaba una página entera, promocionaba bebidas: Eremita, Pelinkovac, Altvater y Slivovitz. Entre los nombres Eremita y Pelinkovac, en la parte superior del aviso, se leía el nombre de la revista, y debajo, el siguiente eslogan: "Una idea puede conmover

${ }^{123}$ Como veremos más adelante hay una apelación al mercado con la inclusión de propagandas. 
el mundo y si es buena inmortalizar a su autor". A continuación, un texto descriptivo de los productos informaba y promocionaba:

El Pelinkovac y el Eremita produjeron un movimiento en la humanidad, cuando ideó el Sr. P. Pokoray su fabricación el año 1862 en la ciudad de Agram, capital de la Croacia (AustriaHungría). El Pelinkovac es un aperitivo compuesto por salvia, cura el hígado y estómago y puede asegurarse que no tiene igual ni semejante. El Eremita es mejor que el mejor fernet. No podemos ni debemos exagerar la bondad del Pelinkovac y el Eremita; pero si se unieran todos los nombres de las personas que los conocen y alaban, podría darse la vuelta al mundo varias veces. Todos los redactores de Ideas, sus lectores y amigos de ambos, que se cuentan por millones, pueden testificar lo expuesto. Altvater [otro producto incluido junto con Slivovitz] es un licor tan fino, que causa admiración entusiasma e inspira y Slivovitz es un cognac de ciruelas de consumo notable en mucha parte (sic) del universo: aquí se ha principiado a apreciar. Invitamos a probar estos productos." [la negrita es del original $]^{124}$

El aviso interesaba además porque explicitaba en clave burlona una visión optimista del mercado y de las aspiraciones megalómanas de Ideas. Así, se ironizaba respecto del anhelo de inmortalidad y notoriedad pública, a escala internacional, de los intelectuales de la revista (las ideas conmueven el mundo) y sobre sus posibilidades efectivas de la revista de intervenir en un mercado para beneficiarse con un número de lectores que resultaba figuradamente equiparado a una cadena de consumidores, de la misma manera en que lo haría cualquier mercancía. Además, la cita sugería cómo se componía ese público restringido de la revista, más allá del recurso a la exageración: se trataba de un número apenas superior al de los amigos de los redactores, y casi tan reducido como el de los bebedores de Altvater y Slivovitz, igualmente nuevos en el mercado argentino como lo eran los intelectuales jóvenes de la revista en el mundo literario. De este modo la valoración positiva del mercado, que venía dada por el prestigio de un producto europeo, y que igualaba éxito comercial y legitimidad, ${ }^{124}$ Año I, Tomo 2, nº 5, septiembre, 1903, páginas no numeradas. 
reforzaba la imagen del público como una utopía, como un espacio a construir. Por otra parte, el tono cómico permitía exponer la convicción acerca de la necesidad de apertura hacia formas mercantiles de financiamiento, hasta ahora consideradas impropias, y que la ideología de Ideas expulsaba de su cuerpo antimaterialista. El hecho de que aunque formaran parte de la revista, las páginas dedicadas a la publicidad no estuvieran numeradas, señalaba la distancia deseable entre cultura y mercado, contraria al vínculo que el anuncio promovía. Asimismo, las diatribas contra la crítica de la prensa diaria presentes en el interior de la revista, y que el airado pasaje del $n^{\text {o }} 15$ que citamos a continuación atestiguaba, ponían de manifiesto las contradicciones de aquella ficción de continuidad entre mercados imaginada en el aviso de licores, que el tono humorístico desdibujaba:

Reaccionar contra el mercantilismo de la prensa, es obra santa. Porque en los actuales periódicos, sus páginas son prospectos de avisos, y chismes de beatonas, sus noticias. Todo lo ha invadido el negocio. Un reclamo de fajas eléctricas, como una crítica teatral, se pagan por centímetros. ${ }^{125}$

Gálvez se presentaba entonces como un cruzado contra la mercantilización extrema de la cultura en la prensa diaria. Pero, su revista incluía avisos publicitarios y ponía de manifiesto el movimiento necesario hacia el mercado; lo hacía apelando a estrategias que, provenientes de la prensa periódica, tenían distintos grados de relevancia.

En primer lugar, la inclusión de publicidades de los objetos más variados aparecía como un procedimiento inédito para una revista de la alta cultura letrada, y como forma directa de participar de la lógica del consumo. ${ }^{126} \mathrm{Al}$ comienzo y al final de la revista, además de propagandas de librerías, se incluían avisos publicitarios de ${ }^{125}$ Ideas, Año II, no 15, p. 316.

${ }^{126} \mathrm{Al}$ menos desde el segundo número, la revista incorpora publicidades. La colección de la que consultamos el primer número es una encuadernación, de modo tal que en dicho proceso pueden haber sido eliminados los avisos correspondientes a esa primera entrega. De todas maneras, es evidente que desde el comienzo se había pensado en la publicidad. En ocasiones, los espacios destinados a los avisos no se cubrían y en la revista aparecía una nueva forma de publicidad, la de Ideas promocionando tales espacios con el título de "Disponible". Por supuesto, los avisos no otorgaron a la revista ningún otro beneficio que el de reducir las pérdidas. En sus memorias Gálvez quien constantemente hace referencia al dinero, solo se refiere a las propagandas en una frase "Algunos avisos se consiguieron" (Gálvez, 1961a: 65). 
objetos de consumo absolutamente ajenos al arte como zapatos, bebidas, propiedades, ropa, brebajes para la anemia, aceite, cigarros, muebles, carruajes y animales. La revista, al modo de Caras y Caretas, se rodeaba de objetos de consumo asociados a los signos visibles del lujo de sujetos pretendidamente importantes. Así un aviso de ropa o de zapatos remitía directamente a la elegancia, el fumar cigarros se vinculaba con hombres de negocios; del mismo modo la compra de un caballo señalaba a aquellos que tenían carruaje. ${ }^{127}$ Esta inclusión de publicidad hubiera aparecido como algo impensable para intelectuales como Paul Groussac, Joaquín V. González, o Calixto Oyuela, ${ }^{128}$ y este hecho daba cuenta del cambio en la valoración respecto de ciertos procedimientos típicos de la prensa periódica (semanarios y periódicos diarios), regidos con criterios decididamente empresariales.

En segundo término, se trataba del registro de un modo probado de la profesionalización, en términos del mercado de las profesiones literarias. En los perfiles de los colaboradores de los dos primeros números se describía la inserción de los sujetos en el mercado de la prensa, tanto del circuito culto como del popular. De esta manera, aparecían tanto La Nación, El País, El Diario, El Tiempo como El Gladiador o Caras y Caretas como espacios de publicación entre los cuales se transitaba sin demasiado conflicto. Esta situación se explicaba por el hecho mismo de tratarse de escritores jóvenes, quienes, si bien se reconocían como miembros de una cultura alta, buscaban abrirse paso en el mundo literario aprovechando el espacio más hospitalario y menos exclusivo de los semanarios plebeyos. Como ya se observó, estos perfiles ponían de relieve la participación bien activa de estos sujetos en el mercado de profesiones literarias, provisto por las numerosas publicaciones existentes. El mercado de la prensa aparecía además en los géneros que, según indican estos perfiles, cultivan los jóvenes: crónicas, novelas cortas, tradiciones, leyendas, artículos. Los diarios y revistas funcionaban como primera edición de lo que no siempre se convertiría en

${ }^{127}$ Esto se ve además en el texto de David Peña "Fomento del teatro nacional" en el que nos detenemos en el apartado 5 de este capítulo. Uno de los sujetos que participa de la conversación es un gran señor que fuma su Chesterfield.

${ }^{128}$ Recordemos la consternación de Paul Groussac cuando descubre en el diario La Nación un aviso de cerveza Bitter Gaillard junto a una propaganda de su revista. Cf. "La educación por el folletín", La Biblioteca, Año II, T6, noviembre, 1897, pp. 313-324. 
libro. ${ }^{129}$ Además, y como rasgo común de una publicación preocupada por informar de las novedades literarias y artísticas, sus secciones permanentes eran las de reseñas, género que por su brevedad, remitía a la prensa.

Por último, durante un corto tiempo, en Ideas apareció la sección 'Galería de intelectuales contemporáneos', ${ }^{130}$ en la que se publicaron, en una inclusión característica de los semanarios ilustrados, dibujos de corte caricaturesco de José Ingenieros, Carlos Octavio Bunge, Miguel Cané, Bartolomé Mitre, Ángel de Estrada (hijo). Estas siluetas firmadas estaban acompañadas por un breve texto, también con firma, en el que se trazaba el perfil de ese intelectual apelando a una imagen pública consensuada, y en general, laudatoria. ${ }^{131}$

\subsection{Novela, mercado, nación}

En sus secciones de reseñas, Ideas dio cuenta de obras de variado tipo tales como recopilaciones de artículos críticos, previamente publicados en diarios y revistas, tesis y folletos; también incluyó libros de actualidad política y social, de historia argentina, libros de poemas, y obras pertenecientes al género narrativo. De éstas últimas, 15 fueron novelas y 8 volúmenes de cuentos. En ese sentido, la revista mostró su preferencia por el género novela, tanto en 'Letras francesas' como en 'Letras argentinas' y 'Letras españolas'. En esa elección hizo explícita una concepción acerca del género relativamente compartida por los colaboradores, a la vez que fue organizando los lineamientos de una tradición novelística nacional, cuyo diseño más claro estuvo a cargo de Gálvez. ${ }^{132}$ Esas reseñas mostraban el trazado de afiliaciones y líneas, señalaban la preferencia por determinados autores -argentinos y extranjeros- e indicaban la tensión autonomía - heteronomía, doble aspecto, no necesariamente contradictorio, bajo el cual

\footnotetext{
${ }^{129}$ La sección 'Revista de revistas' apuntaba a una propaganda de tipo intelectual: da a conocer las publicaciones europeas, y se puede pensar como un gesto de y hacia el interior de la cultura letrada. En ese sentido es diferente del tipo de avisos que antes mencionamos. ${ }^{130}$ En la sección 'Varias' del $n^{\circ} 3$-a cargo de Héctor J. Delmonte- se anunciaba el comienzo de estas ilustraciones.

${ }^{131}$ Las caricaturas fueron realizadas por Barrantes Abáscal, y los textos que las acompañan firmados por "E.", del cual no se ofrecen más datos.

${ }^{132}$ Más adelante daremos cuenta de esto, en relación con la nota a propósito de dos novelas de Manuel Podestá. Estas funciones asignadas a la novela eran también postuladas para el teatro. Cf. apartado 5.
} 
aparecía la novela. Esta tensión remitía a dos posiciones respecto del género, que aunque divergentes, se sostenían en la revista. Una de ellas, la que relacionaba el género con el estado del campo; así, la novela - a la luz de la experiencia europea- era considerada como el género correspondiente a un campo literario autónomo, en el que se cifraba la posibilidad de inserción en un mercado intentando captar el interés del público lector de diarios, magazines, o distinto tipo de folletería popular, para reorientarlo al consumo de literatura argentina de calidad. En este punto se planteaba la novela como el género apropiado para dar comienzo a una literatura nacional autónoma. Desde otra perspectiva, la novela era considerada como el género que imaginariamente afirmaba la comunidad nacional, entendida para muchos de los miembros de Ideas como comunidad espiritual y cultural. Desde este punto de vista se acentuaba su carácter heterónomo en virtud de su funcionalidad en tanto suministro de una ficción identitaria.

En lo que sigue se verá cómo los jóvenes escritores de Ideas dieron muestras de una preocupación compartida por insertar su propia producción intelectual en circuitos más amplios de los que, aunque no siempre a su alcance, constituían las formas de edición a principios de siglo XX en Buenos Aires. En ese sentido, se observará cómo estos nuevos intelectuales pensaron para sus libros alternativas que no los asimilaran sin más a la mera 'intención industrial' y les permitieran, al mismo tiempo, alcanzar un carácter efectivamente público. Asimismo, en relación con la novela, se mostrará su condición de vehículo apropiado para un "ideal” de signo nacional; a su vez, se intentará probar en qué medida para la revista, y en especial para su director, la sociedad productiva entre novela - entendida como representativa y condensadora de una identidad cultural- y nación, solo se sustentaría por el armado de una tradición literaria, que para ser efectiva debía reorganizar y pensar sus vínculos con un mercado posible.

\subsubsection{Hacia un mercado posible}

En relación con el concepto de ampliación del público lector, Sergio Pastormerlo, en la línea señalada por Adolfo Prieto, ha observado que puede designar indistintamente un proceso histórico de larga duración, por el que sucesivamente se incorporaron a la cultura letrada nuevos sectores sociales, como también al fenómeno más puntual que 
tuvo lugar en las décadas de 1870 y 1880, cuando el proceso se inició con las reconfiguraciones decisivas propias de una emergencia. En este último sentido, dicha ampliación implicó una transformación global y radical de la cultura letrada, por la que ésta dejó de identificarse con el ámbito reservado a una minoría social, para convertirse en un espacio plural y escindido donde debieron convivir, no sin conflictos, dos circuitos de producción y consumo culturales: un circuito culto y un circuito popular. En ese sentido, a partir de dicho cambio, comenzó la separación de la cultura letrada y clase dominante, en función de la cual los textos no se adecuarían o representarían con exclusividad los gustos e intereses de la elite (Pastormerlo, 2006: 1-2). Desde la perspectiva de larga duración, el concepto es útil en nuestro caso para precisar los modos en que a principios de siglo $\mathrm{XX}$, la revista Ideas registró las modificaciones que en términos culturales produjeron las políticas estatales alfabetizadoras, cuyo efecto más evidente fue una nueva distribución de la lectura $-y$ de la escritura. En ese sentido, la preocupación por el público asociada a la novela reveló el interés de la revista por dirigirse a un nuevo estrato que constituía una base social diferente para la literatura, en la que algunos, como Gálvez o Payró, empezaban a cifrar sus posibilidades de independencia, y en la que otros, representantes de una posición más claramente elitista, como Becher, no dejaron de percibir una creciente e inevitable condición mercantil de la literatura.

Emilio Becher, considerado por sus compañeros de la revista y sus contemporáneos como el crítico más importante, fue el único redactor de 'Letras francesas' y en la primera entrega de la sección se ocupaba de Verité de Zola. ${ }^{133}$ A partir de su lectura era posible discernir un aspecto del funcionamiento de cierta porción del mercado editorial de Buenos Aires en una alianza entre prensa y edición de literatura. Así, este rosarino, que consignaba en francés el título de la novela de Zola, y por lo tanto mostraba su diferencia cultural, se refería, sin embargo, a la versión en español de El Diario de Láinez, ilustrada por otro colaborador de Ideas, Martín Malharro, cuyo trabajo juzgaba magnífico. Aunque como conocedor ${ }^{134}$ criticaba la $^{2}$

${ }_{133}$ También se ocupaba de L'Oblat de Huysmans, considerándola como reverso de Verité.

${ }^{134}$ Becher mismo era traductor. Por ese tiempo había publicado en la Revista Argentina una versión de un cuento de Rosny. Carta con fecha 3 de enero de 1903. 
traducción de la novela, que a su juicio no debía haber sido realizada por periodistas "inferiores", no objetaba el hecho mismo de la divulgación mercantil de la obra a través del periódico sino que reclamaba una realización acorde con el prestigio y la calidad del autor francés. De este modo, la nota era relevante porque no expresaba un desdén por esta alianza comercial que, como se verá, sería cada vez más frecuente, sino que ponía en primer plano una preocupación por criterios o decisiones editoriales, como la traducción de los textos, en las que los escritores debían ser incluidos como expertos. $^{135}$

Por su parte, Gálvez también escandía sus reseñas con cuestiones relacionadas a emprendimientos editoriales de la prensa en los que estaba involucrada la literatura y con aspectos generales sobre el público. Así, su primera colaboración en 'Letras argentinas', en la entrega de enero de 1904 -lo mismo que la nota del $\mathrm{n}^{\mathrm{o}} 1$ en 'Teatros'-, en la que iba a ocuparse de tres novelas y un volumen de cuentos, indicaban el interés por esta temática. ${ }^{136} \mathrm{Al}$ considerar La novela de la sangre de Carlos O. Bunge y Alma de niña e Irresponsable de Manuel Podestá, Gálvez mostraba además la intención de construir una tradición literaria nacional apelando a esa especie genérica, e indicaba cómo esa tradición debía difundirse. ${ }^{137}$ Cuando se refería a la obra de Bunge, Gálvez señalaba los efectos negativos en la producción literaria del modo de publicación por entregas, del que La novela de la sangre se diferenciaba; dichos efectos suponían la necesidad de captar a los lectores con abundancia de observaciones o descripciones del período histórico tratado -la época de Rosas- regidas exclusivamente por un criterio de fidelidad histórica con respecto a ese tiempo pretérito. En ese sentido, porque la obra apelaba a un recurso literario -la explicación

\footnotetext{
${ }^{135}$ Becher se quejaba: "Hace tres meses, terminamos la lectura del último evangelio de Zola en la desagradable versión que, ilustrada magníficamente por Malharro, divulgó entre nosotros El Diario. La carencia de unidad, la innominable penuria del estilo, la absoluta ignorancia de todo idioma, son cualidades que no nos han sorprendido; pero hemos de deplorar la falta de respeto evidente, el espíritu de chacota y de blague con que periodistas inferiores se han permitido traducir esta obra, que la proximidad de la Muerte había hecho doblemente sagrada". Año I, $n^{\circ} 1$, mayo, 1903, pp. 72-85. (LF: 1-2). Por otra parte, en el $n^{\circ}$ 4 , se refería a las "agradables ediciones Lotus" que habían divulgado, Une volupté nouvelle. De ese modo se confirma que Becher no objetaba ese tipo de proyecto editorial. Ideas, Año I, n 4 , agosto, 1903, p. 366.

${ }^{136}$ El volumen de cuentos era Espigas sueltas Leopoldo Basa. (LA: 8-10) Las novelas La novela de la sangre, Lama de niña e Irresponsable.

${ }^{137}$ En el apartado siguiente nos ocupamos de esta cuestión.
} 
psicopatológica, y no meramente referencial en relación con personajes históricos- se oponía al propósito industrial, identificado únicamente con un tipo de escritura destinada al consumo por un público al que se pensaba como comprador y al que no se consideraba como sujeto de una experiencia que también podía ser estética. ${ }^{138}$ En el desdén de Gálvez hacia la novela por entregas, podía leerse también su insistencia en el formato libro como aquel en que debían circular y divulgarse las obras.

Nótase sin mayor examen, la tendencia del autor a salvar su obra, de la abrumadora y despreciativa calificación de "novela por entregas" a que el argumento le hubiera, irremediablemente, llevado. Bunge ha salvado su obra sin dificultad visible, con su amplio saber, su conciencia del arte, la pureza de su intención, alejada de todo propósito industrial.

Es por esto que, a falta de observaciones cuya imposibilidad es evidente, tratándose de una época no vívida, ha recurrido al elemento psicopatológico, para dar una base de robustez al libro. ${ }^{139}$

Si a propósito de La novela de la sangre el director de la revista criticaba la variante mercantil de la novela por entregas, la nota sobre los textos de Manuel Podestá implicaba el señalamiento de un vínculo deseable, en especial de la novela, con una franja de lectores que venían ejercitando sus competencias en la "Biblioteca de $L a$ Nación". ${ }^{140}$ En el escrito de Gálvez la mención del vínculo entre la novela y un mercado

Gálvez acentuaba la condición de autor como artista -refiriéndose a él en un tono romántico o gótico- y así lo caracterizaba: "artista, enamorado de aquel luchar heroico, de esas pasiones brutales, de lo sombrío del cuadro, de ese rojo intenso que reclamaba un moderno pintor de alma, inspiróse en la época y puso en ella los personajes de su novela, altas figuras de un drama siniestro, perdido, feliz, en las lúgubres lejanías de aquel tiempo muerto". Año II, Tomo 3, n 9, enero, 1904, p. 77

Por su parte, Ricardo Olivera al ocuparse de esta obra de Bunge, señalaba lo contrario que Gálvez.

${ }_{139}$ Ideas, Año II, n 11-12, marzo-abril, 1904, pp. 82-83.

${ }^{140}$ En relación con la edición de libros en Argentina, Fernando Degiovanni observa que "La Biblioteca Popular de Buenos Aires" de Miguel Navarro Viola, aparecida entre 1878 y 1880 , lo mismo que "Biblioteca de La Nación" (1901-1920), a cargo de Emilio Mitre y Roberto J. Payró -considerados ambos los proyectos más exitosos hasta la segunda década del siglo XX- habían difundido básicamente la novela contemporánea europea en traducción. (Degiovanni 2001: 42; 45-48). Sergio Pastormerlo señala que "La Biblioteca Popular" preveía la publicación de 12 volúmenes anuales, aunque esto se pudo hacer durante los dos primeros años. La frecuencia de publicación era mensual; cada volumen mensual de alrededor de 260 páginas en octavo, se componía de una serie de escritos misceláneos, 
posible, aunque escueta, era significativa. En ese sentido, era relevante que Gálvez no reseñara las novelas de Podestá que, se suponía, motivaban la nota. Así, argumentaba que no se veía en la necesidad de hacer la crítica de Alma de niña e Irresponsable, porque era suficiente para recomendar su lectura o para señalarlas como novelas valiosas, el hecho mismo de su publicación por el diario La Nación, que seguía siendo el más prestigioso de Buenos Aires, y porque no se trataba de obras inéditas, sino de reediciones en la biblioteca del periódico. ${ }^{141}$ En esta colección, el director de la revista percibía en términos más certeros la posibilidad de reunir éxito comercial con calidad estética como medio de acceder a una masa más amplia de lectores, a los que había que formar en términos estéticos, pero también en los valores de una cultura nacional.

La Biblioteca estuvo a cargo de Emilio Mitre, director del diario entre 1894 y 1909, y principalmente de Roberto J. Payró -quien abandonaría el proyecto en 1907, con motivo de su viaje a Bruselas- y del administrador del diario, José María Drago. Según Margarita Merbilhaá, la colección se basaba en una necesidad de la alianza entre el libro y el periódico fundada en la identificación de las dos formas de lectura, alianza cuyos efectos beneficiosos para la circulación del libro, contribuirían a su democratización. (Merbilhaá, 2006: 32-33). El proyecto, a pesar de estar inspirado en los exitosos modelos franceses y norteamericanos que habían popularizado la literatura, tenía la pretensión de ser un "medio de cultura" y "uno de los más sinceros elementos de difusión intelectual de la República". Por su parte, Jorge B. Rivera observa que aunque pudo cumplir con los objetivos de editar obras interesantes y de lectura fácil, ofrecer ediciones cuidadas y

principalmente de novelas, cuentos y ensayos de corte moralizante. Entre los colaboradores argentinos se contaban Vicente Quesada, Santiago Estrada, Avellaneda, García Mérou y Eduarda Mansilla figuraban. Los escritores extranjeros más presentes en la colección fueron De Amicis, Poe, Dumas hijo, Hawthorne, Gautier, Paul de Kock y Levin Schucking; lo principales traductores eran Carlos Olivera -quien tradujo a Poe-, S. N. V., Alejandro Korn y E. L. Negri. (Pastormerlo, 2006: 12-13)

${ }^{141}$ Según Rivera: "La Biblioteca en líneas generales tendía a consolidar entre las capas medias el proyecto cultural y la concepción literaria del grupo de referencia que leía en idioma original las novedades que aparecían traducidas en la colección. El catálogo de la "Biblioteca de La Nación" a la vez informa sobre los contenidos posibles de las lecturas que emprendía el sector "ilustrado" de la clase media: algunos clásicos, mucha literatura francesa de segunda línea, del tipo sentimental y folletinesco-, algunos pocos autores argentinos como Enrique Vedia y Carlos María Ocantos". La Biblioteca publicó 875 títulos. (Rivera, 1981-2000: 337-360). Por otra parte, Luis Alberto Romero, señala que el emprendimiento surgió, en parte, para tratar de"encontrar una ocupación para los tipógrafos, desplazados por las nueva linotipos", (Romero, 2000: 19) 
buenas traducciones, todo ello a un costo bajo, ${ }^{142}$ no ayudó demasiado al desarrollo de la "naciente industria nacional", ya que se privilegió la línea traductora y, en especial, de entretenimiento. (Rivera, 1981, 2000: 34-35). El caso debía ser atrayente para Gálvez porque quien estaba al frente del proyecto era un escritor-periodista y traductor como Payró, siempre preocupado por los aspectos materiales y gremiales de la literatura -como lo mostrarían algunas de sus crónicas de 1906 y algunas de sus obras teatrales. ${ }^{143}$ El que Gálvez se ocupara de esa edición de los textos de Podestá ponía en primer plano un cambio de signo, es decir, una nueva valoración de las posibilidades comerciales de la escritura -que históricamente distinguimos como el problema del mercado- que se estaba produciendo para la zona de la cultura letrada a la que él mismo y su revista pertenecían. 144 Tal alternativa comercial que intentaba combinar difusión y calidad se presentaba como viable y ejemplar en tanto esa conjunción nueva y económicamente exitosa, podía significar para los escritores la posibilidad de ganar dinero con la escritura sin someterse a los gustos de un público todavía 'inculto' y sin sacrificar la composición a los requerimientos de los formatos como el de las novelas por entregas, pensados para la franja más netamente popular del consumo de literatura. A esto se sumaba la legitimidad fundada en el prestigio de un diario como La Nación, que además confiaba a un escritor la dirección del proyecto editorial, y en ese sentido, depositaba en los intelectuales la tarea de educación del gusto de un público surgido de la nueva distribución de la lectura

\footnotetext{
${ }^{142}$ La edición rústica costaba 40 centavos para los suscriptores de La Nación y 50 centavos para los que no lo eran. La edición encuadernada valía 1 peso. Los lectores podían adquirir los cuatro libros que se publicaban mensualmente pagando una suscripción idéntica a la del diario, que ascendía a $\$ 1,80$.

${ }_{143}$ Por ejemplo, El triunfo de los otros (1907). Las crónicas de 1906 fueron compiladas en 1909.

144 Gálvez conocía a Payró a través de Gerchunoff, quien profesaba una profunda admiración por el director de la colección; además, por la misma época de la aparición de las novelas de Podestá en "La biblioteca de La Nación", y dos entregas después de la nota sobre ambos textos en la revista, Ideas editaría Sobre las ruinas de Payró como parte de la publicación ( $\left.n^{\circ} 11-12\right)$ y en folleto. Gálvez contaba que había conocido a Payró en casa de Martín Malharro de quien Payró era amigo, y allí había surgido la idea de publicar Sobre las ruinas. El escritor, pretendía que el director de la revista le pagara derechos de autor. Finalmente, el joven propuso "publicar el drama en la revista y hacer luego una tirada especial, repartiéndose, después de cobrados los gastos, 'las ganancias', ilusión en que, a pesar de los tiempos, ambos caímos, pues Payró aceptó la propuesta” (Gálvez, 1961: 186). El dato no es ocioso porque mostraba en el proyecto, la intención de Gálvez de promover una obra de calidad y a la vez de ganar dinero. Aunque en una escala reducidísima, era un ensayo de lo que intentaría más tarde y con más éxito en la Cooperativa Editorial Buenos Aires. Cf. Gálvez, 1961b: 87-99.
} 
y la escritura, como resultado de las eficaces políticas estatales de alfabetización. Afirmaba Gálvez:

Es innegable que La Nación ha hecho obra meritoria, sacando del olvido libros como éste que debieron ser inolvidables, no solamente por su valor actual, sino porque marcaron el comienzo de la novela argentina. ${ }^{145}$

La vinculación con un mercado posible avizorada en el ejemplo de la "Biblioteca de La Nación", vista además como provechosa en relación a la novela, no resultaba autocontradictoria con el espiritualismo y antimaterialismo declarados por la revista. Más bien, ese emprendimiento editorial aparecía asociado a la idea de una empresa cultural, cuyos criterios declarados de selección de las obras eran el valor literario y la actualidad; asimismo, más allá de la pretensión explícita de alcanzar un público amplio, los anuncios que habían promocionado la biblioteca inmediatamente antes de su lanzamiento, no incurrían en concesiones mercantiles como podrían serlo la referencia al carácter ameno de las obras o el entretenimiento que podían reportar (Merbilhaá, 2006: 36-37). De ese modo, Ideas no realizaba, en este caso, una evaluación demonizada de las empresas comerciales que propagandizaban el consumo de la letra escrita y de la cultura, como sucedía por ejemplo con algunas de las intervenciones más virulentas de Gálvez sobre el teatro de signo criollista. ${ }^{146}$ Esta valoración formaba parte de una vocación de mercado, propia de un conjunto de escritores que empezaban a ver en ese terreno posible una sanción que, a futuro, no estaría necesariamente exenta de calidad. La explicación había que buscarla en el hecho de que, para Gálvez, serían los escritores los que modelarían con sus obras no solo el gusto literario sino también -como se verá en el apartado siguiente-, una identidad cultural nacional. Algunos meses después de la nota a propósito de Alma de niña e Irresponsable, las palabras del mismo director de la revista en la sección 'Crónica del mes', de mayo de 1904, cuando se cumplía el primer aniversario de Ideas, serían prueba de esta aspiración de educar y formar un público en materia artística y a la vez en valores elevados:

\footnotetext{
${ }^{145}$ Manuel Gálvez, Año II, Tomo 3, nº 9, enero, 1904, p. 89.

${ }^{146}$ Más adelante analizamos esta cuestión. Cf. apartado 5.
} 
Nuestra misión, en su humildad, ha sido educadora, porque se ha inculcado al lector (perdonad, si exagero) una idea noble y serena del arte. ${ }^{147}$

Mientras que Gálvez leía en "La Biblioteca de La Nación" la ejemplaridad de una empresa cultural y comercial e imaginaba como posible un mercado para los productos de la pluma de los nuevos escritores, en la sección de 'Letras españolas' del número de febrero de 1904, Ricardo Rojas ubicaba ese modelo comercialmente exitoso e intelectualmente eficaz, en la experiencia de ciertas editoriales españolas que desde hacía ya tiempo venían difundiendo el pensamiento y la literatura modernas a través de ediciones populares. Cuando se ocupaba de la novela La catedral de Vicente Blasco Ibáñez y consignaba los datos de la edición, reunía, lo mismo que Gálvez y Payró, el deseo de difusión con el servicio intelectual que ofrecía la elección de una obra que había sido publicada en una edición popular y económica. Rojas encomiaba la labor de la editorial valenciana Sempere de tendencia anarquista, que había tenido la iniciativa de hacer ediciones baratas de las obras del pensamiento renovador del siglo XIX, y también, de vez en cuando, había sacado algunas novelas. Entre estas últimas se contaban, para 1904, Flor de Mayo, La barraca y La catedral ${ }^{148}$ del escritor castellano. Cuando en esta misma nota, Rojas refería su propia experiencia a la hora de elegir un libro, que dicho sea de paso, no seleccionaba en la biblioteca familiar sino que se hallaba en una librería, contaba que, de las obras presentes en los catálogos y escaparates de la editorial, las que más le habían atraído eran las obras de filosofía, crítica, ensayo, a pesar de "sus peligros de traducción" (162-163). ${ }^{149}$ Sin embargo, reseñaba una novela cuyo ejemplar leía en la edición de una actualizada biblioteca con fines difusores. De este modo, en términos intelectuales, Rojas se definía como crítico literario y optaba por el género novelístico en el cual podía leer los frutos del pensamiento renovador del siglo XIX, que editoriales como Sempere habían

\footnotetext{
${ }_{147}$ Ideas, Año II, nº 13, mayo, 1904, p. 92.

${ }^{148}$ Rojas afirmaba: "La casa valenciana de Sempere, ha prestado a los pueblos de habla española, el beneficio inapreciable de popularizar, al exiguo precio de sus ediciones económicas, el pensamiento renovador del siglo XIX. Alternando con volúmenes de filosofía y de crítica, ha publicado varias novelas, entre ellas Flor de Mayo y La Barraca, del escritor castellano V. Blasco Ibáñez." Ideas, Año II, n 10, febrero, 1904, pp. 162-180.

${ }_{149}$ Entre los autores seleccionados se contaban Kropotkine, Vandervelde, Schopenhauer, Renan. p. 163.
} 
distribuido en los países de habla española. ${ }^{150}$ Así, quedaba otra vez expuesto el diseño que desde Ideas se proponía para la relación de los escritores jóvenes de la alta cultura letrada en modernización con un mercado posible, sustentado en su alianza ineludible y beneficiosa con los proyectos culturales populares y divulgadores de calidad, que a su vez proveyeran a los nuevos escritores argentinos formas de publicación alternativas -en el formato libro- y ya no las inaccesibles de los libreros-editores. Esta última figura tenía en Arnoldo y Balder Moen su encarnación más representativa; ${ }^{151}$ de

${ }^{150}$ Ya en el $n^{\circ} 2$ de la revista, en su primera colaboración, Rojas había hecho referencia indirecta a estas cuestiones, relativas a la edición y circulación de libros. Así, se podía leer, a propósito de El Superhombre de Juan Valera, que dos obras de Pompeyo Gener, Amigos y Maestros : Contribución al estudio del espíritu humano a finales del siglo XIX (1897) e Inducciones (1901) eran conocidos y difundidos en Buenos Aires. El título completo del primero de esos dos libros -y que Rojas no consignaba-, era El superhombre y otras novedades : artículos críticos sobre producciones literarias de fines del siglo XIX y principios del $X X$, publicado en Gerona por Fernando Fé (Madrid) y Juan Llordachs (Barcelona). Inducciones Ensayos de filosofía y de crítica, Barcelona, Imp. Tobella y Costa, 1901. $8^{\circ}$. En el $n^{\circ} 5$ Rojas se ocuparía de Cosas de España de Gener, dando detalles de la edición que comentaba; así, explicaba que se trataba de una reedición del libro Herejías publicado en 1887 en Madrid, al que ahora la edición de catalana de Llordachs de 1903, agregaba cuatro capítulos sobre 'La cuestión catalana'. pp. 138 y 145.

${ }^{151}$ Roberto Giusti, en Visto y vivido, su libro de recuerdos de la vida literaria y cultural, se refiere al problema y la excepcionalidad que constituía la publicación de un libro en Buenos Aires, en el período que él llama el primer novecientos. En ese contexto informa sobre las características del emprendimiento editorial de los hermanos Moen: "Los libreros Moen, Arnoldo y Balder, de origen dinamarqués, establecidos desde el Año 1885 en la calle Florida (...) autorizaban con su nombre prestigioso, sin comprometer un centavo, las obras de los escritores que lograban tanto honor. Cuando un poeta o un novelista decía: 'Moen me hace una vidriera', lo contemplábamos con la misma envidiosa admiración con que hubiéramos mirado a quien nos dijese: 'El emperador Guillermo me invitó en su yate', o: 'Estuve en una cacería con Eduardo VII'. Hacer una vidriera significaba llenarla durante una semana con libros que llevaban al pie el nombre de los supuestos editores, coronada la artística pila por el retrato del feliz autor flanqueado por los recortes de algún suelto periodístico elogioso. Había grados en el honor. Aquélla era la máxima jerarquía. Inmediatamente por debajo estaba la muy apetecida de merecer todo el primer plano de la vidriera, y ya era bastante favor conseguir de los hermanos Moen, no siendo ellos los editores responsables, que exhibieran un libro argentino entre los franceses que formaban la habitual población de su vidriera" (Giusti, 1965:100-101). Como se ve, la cita muestra una funcionalidad muy distinta que la de la publicación por parte de estos pseudoeditores. Los hermanos Moen, a diferencia de otros editores, nunca asumen riesgos económicos, que van todos a cuenta de los mismos autores o de 'mecenas' que los financian. Gálvez por su parte, también da cuenta de la ausencia de editores en Argentina, no ya en el primer novecientos sino en 1915: "Los que así se llamaban [editores] eran simples libreros, y publicaban tres o cuatro libros por año, generalmente de Historia o Derecho, y harto raras veces, de literatura. Los libros argentinos de carácter literario eran pagados por sus autores. El librero, aunque figurase como editor, era nada más que administrador, y un administrador poco propenso a rendir cuentas...", (Gálvez,1961 b: 87) 
ella se distinguiría la figura del editor moderno que empezaría a aparecer en Buenos Aires desde mediados de la década del 10 en adelante. ${ }^{152}$

Como se vio, en su nota sobre La novela de la sangre, Gálvez diferenciaba esta obra de Carlos O. Bunge de la modalidad de novela por entregas, debido a que utilizaba lo psicopatológico como recurso estético capaz de generar el interés de los posibles lectores. En ese sentido, condenaba dicha modalidad mercantil, puesto que debía abundar en descripciones inocuas. A su turno, Ricardo Olivera reprobaba el mismo texto de Bunge, justamente, porque abundaba en recursos folletinescos que lo volvían inverosímil. ${ }^{153}$ No obstante las críticas negativas a Bunge como novelista, Olivera daba cuenta del prestigio intelectual de su autor, conseguido a través de las ediciones económicas, principalmente de origen español. Entre ellas, La España Moderna -"vulgarizadora peninsular de Spencer, Taine y Stuart Mill”- había publicado, en 1902, La Educación, que llevaba un prólogo de Unamuno; Rafael Altamira había editado Nuestra América y, los Principios de Psicología, traducidos por Augusto Dietrich -traductor de Nordau y Nietzsche- tenían un lugar en la

${ }^{152}$ Esta nueva figura, definida como un agente cultural moderno, controla financieramente las publicaciones, y a la vez define las características de los productos impresos según el gusto y los intereses del nuevo público; dispone la edición de libros como bienes culturales organizados en series y colecciones que funcionan como verdaderas guías de lecturas; orienta su intervención hacia el mercado y planifica y estimula líneas de producción literaria contribuyendo a su consolidación como profesión remunerada. Es con estos nuevos editores que la literatura alcanza una dimensión efectivamente más pública y se convierte en un objeto democratizado. Este hecho no comprende solo a las obras difundidas masivamente a través de las nuevas colecciones destinadas a los sectores populares, sino que también incide en la producción literaria e intelectual más identificable con un consumo restringido. (Delgado y Espósito, 2006: 64-66)

${ }^{153}$ Así, por ejemplo, indicaba como folletinesca, la inverosimilitud de la pelea de Blanca con un mazorquero, al que logra ahuyentar. Afirmaba: "Ponson du Terrail y Montepin reconoceríanle discípulo". No obstante, la crítica central de Olivera, se refería a la perspectiva político-ideológica antirrosista de la obra. El crítico señalaba la deuda que por tratarse de una novela histórica, contraía este relato con la verdad; ésta debía buscarse y construirse en diálogo con la disciplina histórica, en una alusión clara a la nueva evaluación de la figura de Rosas en el campo de la historia, al que Olivera llamaba "crítica científica". Además de señalar los errores históricos, Olivera se burlaba del modo en que hablaba uno de los personajes: "Pero es indudablemente [el] traspiés más divertido el fogoso discurso con que en una reunión familiar. Silvio, condiscípulo de Echeverría, defiende las Facultades extraordinarias en una jerigonza pseudo-sociológica que envidiaríale cualquier pedante universitario de 1903" (302). 
colección francesa de Félix Alcan. ${ }^{154}$ Por su parte, la novela objeto de la nota, también había sido editada en España:

'Nadie es profeta en su tierra', y el doctor Bunge, por compensación feliz, empieza a serlo en la extraña. La novela de la Sangre ha sido impresa también allá, en los hospitalarios países consagradores: Daniel Jorro, Madrid, leeréis en el pie de imprenta, libres -una vez siquiera- del inevitable Moen, pseudoeditor de eminencias caseras.

De esta manera, el artículo volvía sobre el carácter problemático de la publicación de libros en Argentina y la descripción de los avatares editoriales de la abundante producción de Bunge mostraba, por contraste con su fecundidad, la ausencia de emprendimientos como los peninsulares, que difundieran más ampliamente la producción vernácula. El hecho de que La novela de la sangre hubiera sido editada casi simultáneamente por dos editoriales de España -Henrich y Daniel Jorro- era un dato confirmatorio. Así la edición por medio de estas casas españolas, con vasta experiencia en el comercio y distribución de libros, en colecciones especialmente organizadas, evitaba la opción habitual de la publicación costosa; a su vez, implicaba una compensación simbólica en la posibilidad de consagrarse en medios intelectuales más prestigiosos e internacionales, que como Madrid y Barcelona, empezarían a funcionar para algunos escritores -entre ellos, Rojas y Gálvez-, en calidad de meridiano cultural antes que París. Pocos años después, la relación de otros jóvenes de Ideas con las editoriales españolas, en la lectura de cuyas obras se habían formado intelectualmente, sería efectiva para sus propias carreras. Así, por ejemplo, Juan Pablo Echagüe editaría su Prosa de combate en 1906 en el sello Sempere y con prólogo de Manuel Ugarte; Rojas, en 1907 y también con Sempere, publicaría El alma española: ensayo sobre la moderna literatura castellana, en la

\footnotetext{
${ }^{154} \mathrm{~A}$ los datos que consignaba Olivera sobre la edición de las obras de Bunge, se puede agregar que por ese tiempo Principios de psicología individual y social, también había sido editada en Madrid por D. Jorro Editor en 1903; Nuestra América en la Imprenta de Henrich de Barcelona, en 1903, y posteriormente en 1905, en Buenos Aires por Valerio Abeledo. Xarcas silenciario, novela de la que se ocuparía Gálvez en el $n^{\circ} 11-12$ de Ideas, se editó en 1903 en Henrich. La novela de la sangre: novela histórica argentina, se editó también en la Imprenta de la Casa Editorial F. Sempere y Cía (Valencia - Madrid), colección Arte y Libertad. Cf. LA: 15-16 para la transcripción de este pasaje de Olivera.
} 
colección 'Arte y libertad' y, en 1908, Cartas de Europa en la casa Sopena de Barcelona; ${ }^{155}$ Visiones de América: apuntes de un viajero argentino y Visiones de España: apuntes de un viajero argentino de Manuel Ugarte aparecerían también en Sempere, mientras sus Cuentos de La Pampa se habían editado en 1903 en Madrid, en la colección ‘Mignon’ de Rodríguez Serra.

Según ya anotamos, la revista tuvo una percepción clara de los problemas y soluciones viables que los escritores atravesaban en un proceso de profesionalización de la literatura que no era posible disociar del sesgo mercantil creciente que iba tomando la cultura, sobre todo en el circuito popular. ${ }^{156}$ De ese modo, Ideas exhibió su interés por aspectos ligados a un mercado de bienes culturales posible como lo eran la edición, la traducción, la selección y la distribución de las obras, y el éxito, que recubierto de propósitos más elevados, como renovar el pensamiento y el arte o llevar adelante la educación literaria e intelectual de un público amplio, podía presentarse ahora como un objetivo a conquistar. Al mismo tiempo, estas preocupaciones funcionaban como demanda de una autonomía que ya no se cifraba en la diferencia irreductible entre los escritores y los lectores hipotéticos, y que por lo tanto, desandaba o modificaba los términos de la oposición activa entre arte y mundo burgués. Desde la revista la situación de los primeros no podía ser calificada más que como precaria puesto que, no había verdaderos editores que habilitaran al anhelado pasaje del diario al libro, o porque no existía un público que consumiera regularmente y permitiera financiar los productos culturales más especializados como lo eran las publicaciones juveniles. ${ }^{157}$

${ }^{155}$ Cartas de Europa también había sido editada en Buenos Aires, por Rodríguez Giles; en 1907, la parisina Garnier Hnos., editó El país de la selva y en 1908 Cosmópolis.

${ }^{156}$ Nos ocupamos de esta cuestión en el apartado 5.

${ }^{157}$ Gálvez explicaba que Ideas se financiaba con su sueldo de ujier. (Gálvez, 1961a: 62-65) 


\subsubsection{Hacia una tradición nacional de mercado}

Según ya consignamos, la revista mostró su interés por un mercado posible para los productos de la franja de la alta cultura letrada en modernización de la que participaba. Ese interés se concentró de modo particular en el género novelístico, que fue, más allá de las escasas realizaciones nacionales, la especie privilegiada por los críticos de las diversas secciones de reseñas. Tal énfasis en la novela, asociado a los deberes más altos que desde las páginas de Ideas se asignaban a la literatura, supuso llevar a cabo una serie de precisiones y distinciones, cuyo resultado fue la elevación del género a una jerarquía tal que lo habilitara en el desempeño de altos servicios para la cultura argentina. Así Becher señalaría la vinculación indisociable de la novela con la historia social y política, y lo consideraría equivalente de la epopeya homérica; Gálvez haría hincapié en la incorporación de los saberes de la ciencia moderna, y en ello coincidiría, en parte, con Rojas para quien, además, la novela servía, a principios de siglo XX -según lo mostraban algunos autores españoles-, para escenificar el 'nuevo ideal' cuyos predicadores laicos debían ser los escritores. Finalmente, luego de esta revaloración, el director de Ideas, organizaría su tradición novelística, en la que incluiría obras de los literatos del 80, y cuya continuidad tendría su clave en una poética mimética de signo realista y naturalista, como proveedoras de recursos literarios capaces de interpelar a un público lector de periódicos y folletines, y que asistía a las representaciones de los géneros populares sainete, zarzuela o teatro criollista.

A propósito de L' eau profonde de Paul Bourget, Emilio Becher constataba la hegemonía de la novela en la literatura occidental: 158 "La novela ha dejado de ser en nuestros días un género, pues ha invadido toda la literatura" (72). Para el crítico novela e historia social moderna presentaban una relación de implicación, por la cual este género había constituido en el siglo XIX el equivalente de la epopeya de los tiempos "heroicos", como los que había representado Homero en sus textos. ${ }^{159}$ Becher

${ }_{158}$ Ideas, Año n 9, enero, 1904, pp. 72-74 (LF: 7-8).

${ }^{159}$ Becher afirma: "Durante el siglo XIX, la novela creció en importancia, aspiró a condensar la suma de actividades, a ser la expresión de toda la vida, como lo fue en tiempos heroicos, 
organizaba una tradición novelística -preferentemente francesa- cuya plenitud localizaba en Flaubert y Villiers de L'Isle Adam. La clasificación posterior en ‘especies' reposaba en aquella implicación entre el género y la historia social, política y cultural francesa. De ese modo, observaba en Zola y los "naturalistas rusos" el estudio de lo social; en Pierre Loti la novela era relato de viajes; con Paul Adam, las tradiciones, los símbolos eran el objeto privilegiado; con los Rosny, la ciencia había ingresado como modo de explicación y como forma de tramar las fícciones; finalmente, las novelas de Bourget marcaban la entrada de la psicología moderna (72). En esa misma la línea de relación de la literatura con la historia, dichas obras eran consideradas como "la confesión de toda una casta" (74).

Si la reseña de Becher sobre Bourget condenaba al escritor francés por repetirse en la fórmula exitosa de una temática que, como la literatura de alcoba, era juzgada intrascendente en términos estéticos y espirituales, la nota de Rojas sobre La catedral de Vicente Blasco Ibáñez, mostraba la utilidad de un texto que actualizaba las innovaciones tanto estéticas como del pensamiento científico, filosófico, histórico. ${ }^{160}$ La novela, ubicada a continuación de la ciencia era, según Rojas, el medio que comunicaba y manifestaba la existencia de una nueva fe, y La catedral encarnaba ese ideal "que necesitan los pueblos en lo presente, el valor de la sinceridad que desafía las iras de la plebe para regenerarla" (166). De tal forma, la literatura novelesca parecía destinada a cumplir una función curativa, en tanto exponente de valores sociales positivos y regeneradores; por su parte, la figura del escritor investida de "altos deberes" "161 adquiría, en el ejercicio de esa función, un alto grado de legitimidad social. Serían los escritores, definidos por Rojas como "predicadores laicos”, quienes erigirían una tradición nacional de ilustres, en la que debía apoyarse la fortaleza de las naciones. Esta tarea estaba asociada con la revalorización de novela en tanto Rojas sostenía que ese "apostolado novísimo" debía ser realizado dentro o fuera de los géneros literarios con Walnicky, después, con Homero, y entre los bárbaros, la epopeya", Ibid., p. 72. 160 Ideas, Año II, nº 10, febrero, 1904. (LHE: 5-6)

161 Afirmaba: "He constatado, antes de ahora, una actitud análoga, por parte de otros escritores españoles, que parecen convencidos de los altos deberes que les impone esta ola de crisis en su país. Es claro que resulta más propicia para su destino inmediato, la actitud de quienes prefieren halagar las miserias del chauvinisme, agravado en España por las miserias de la superstición", Ibid., 166. La reseña es importante también porque intenta rescatar una España que deja atrás dicho pasado y lucha por un nuevo 'ideal', que para Blasco está en el socialismo. 
clásicos, y específicamente en la novela realista- naturalista. Así, el género en su variante realista y de corte social, a la manera de Blasco Ibáñez, era recuperado para esta obligación y elevado por el talento, ${ }^{162}$ y estaba destinado -como el drama- "a ser, dado su carácter, el más proficuo surco de la nueva cosecha" (163). Esta cosecha era la de un pensamiento nuevo que profetizaba una época mejor, es decir, un espacio para la formulación de utopías, que en el caso de Rojas, se proponía como progreso espiritual (“profecía generosa de una época mejor”) cimentado en lo que él llamaba "un nuevo ideal”, que llevaba el signo de la nación: ${ }^{163}$

(...) entre la polvareda de las torres que caen, un nuevo ideal ha surgido, pasando de la ciencia al arte, como esos vientos que, nacidos de la tempestad, llevan a las distintas flores, gérmenes de vida. El drama y la novela estaban destinados a ser, dado su carácter, el más proficuo surco de la nueva cosecha, y en él ha nacido La catedral (...) [cursivas nuestras] (163).

Rojas y Becher coincidían en legitimar a los escritores por esta función social de la literatura. Becher enunciaba en una retórica más cercana a El Mercurio de América, la autorización de los artistas basada en una superioridad moral y social, así como en cierta "vocación del Ideal"; este rasgo los distinguía de la mediocridad burguesa e implicaba para la literatura moderna una funcionalidad, definida como "la necesidad de que el escritor sea, delante de los pueblos humanos, una especie de columna de fuego" (162-163). ${ }^{164}$

En la sección 'Letras argentinas' de la misma entrega en que Becher constataba la hegemonía de la novela en Francia, el director de la revista diseñaba una tradición

${ }^{162}$ Comentaba: "El talento ha demostrado ya qué tendencia semejante es, en la novela, por lo menos, compatible con la más pura belleza del arte", p. 166.

${ }^{163}$ El ideal que surgía de la obra era un ideal nacional: "Los rasgos apuntados bastan para presentar a un escritor vigoroso. La obra resulta así personal y nacional, profundamente nacional", p.178.

${ }^{164}$ Año I, Tomo 2, n 6, octubre, 1903, pp. 217-225. Por ese tiempo, Becher escribía un texto cuyo título provisorio era Rol mesiánico de Buenos Aires en el que sostenía que la ciudad tendría "en el porvenir, un destino de ciudad mesiánica, madre del Salvador futuro, matriz de Cristos. Será la gran metrópoli, la capital de las nuevas razas latinas" Carta a Ortiz Grognet con fecha 15 de enero de 1903. En ese rol, podemos suponer que los escritores tendrían una participación central, en virtud de la idea de conducción que sugería la metáfora citada de ser delante de los pueblos una columna de fuego. 
para la novela vernácula, al parecer motivado por la reedición de Alma de niña e Irresponsable de Manuel T. Podestá, obras que, aparecidas por primera vez en 1889 y 1891, había reeditado en 1903, 'La Biblioteca de La Nación', y a las cuales ubicaba en el comienzo del género. ${ }^{165}$ Esta intervención, a diferencia de aquellas en que la revista había ordenado el pasado literario más inmediato estableciendo un corte entre los maestros jóvenes identificados con El Mercurio de América y los representantes del espíritu del Ateneo, tendía un puente con los escritores del ochenta, a través de una serie de nombres consagrados en la que se seguía excluyendo a Cané. Gálvez afirmaba que "Toda la historia de la novela argentina cabe en los últimos 30 años del pasado siglo" (87), historia en la que, como mostraba la cita, era posible distinguir modelos literarios distintos, entre otros costumbristas, naturalistas, policiales, médicos:

A las novelas policiales de Gutiérrez, nuestro exacto equivalente de Fernández y González, sucedió una serie de obras, ya olvidadas por desgracia, que vinieron a fundar, si es que esta palabra puede usarse, la verdadera novela nacional. El talento observador de Groussac había dado un bello fruto; una novela argentina "inspirada por nuestra naturaleza, nuestras costumbres, nuestra vida política y social, novela sana en el fondo" según la frase de García Mérou, y cuyo título, era Fruto vedado. López hacía el proceso de la

${ }^{165}$ Con respecto al surgimiento de la novela nacional en el ámbito de la alta cultura, Fabio Espósito, siguiendo a Adolfo Prieto, observa que generalmente ha sido asociado con la circulación de libros entre un público acotado que se mantiene más o menos sin alteraciones hasta la época del Centenario, mientras que la emergencia de la novela popular ha sido vinculada con la difusión de los "folletines criollistas" en el diario La Patria Argentina. Sin embargo, aclara que "esta brecha entre los diarios y los libros de autores nacionales parece más un espejismo que una realidad, puesto que la división tajante entre una cultura selecta articulada en torno del libro, y la cultura popular en torno de la prensa, no contempla el hecho de que el núcleo más importante de las novelas de la alta cultura aparezca conformado por obras que fueron publicadas sobre todo en los folletines de los diarios porteños y luego promocionadas, criticadas y difundidas por estos órganos de prensa". El diario Sud-América aparece, según Espósito como "el medio periodístico que impulsa con mayor energía el desarrollo de la novela culta nacional, puesto que allí se publicaron a lo largo de cuatro años los denominados "folletines del Sud-América", esto es, la única serie de novelas nacionales de la alta cultura de la época". Es relevante señalar que el 'éxito' de las novelas de la que Gálvez llamaba más adelante y en esta nota, "nuestra intelectualidad", se había debido a la difusión en el diario. Aunque Ideas promovía la publicación de ficción en el formato libro, la valoración de la "Biblioteca de La Nación" señalaba como deseables las modalidades y la amplitud de circulación del diario, e indicaba esa relación primera entre novela y periódico en la prensa política del 80. Cf. La Emergencia de la novela en la Argentina (1880-1890). 
sociedad en La gran aldea, con su fina ironía y sus rasgos de Dickens, Cambaceres, después de Silbidos de un vago y Música sentimental, publicaba Sin rumbo, un éxito grandioso como los anteriores y que causaría indignaciones y aplausos. Luego hubo una paralización casi absoluta, sólo interrumpida por algunas obras de Ocantos, hasta que, en la última década, el poderoso Sicardi, vino a encerrar definitivamente en sus cinco tomos del Libro extraño, toda la sociabilidad argentina en sus fases más diversas; la política, el hogar, el suburbio. En aquella época anterior fue cuando Podestá dio a conocer sus novelas Alma de niña e Irresponsable, dos libros olvidados, y que tal vez, pasaran desapercibidos, en ese tiempo de incertidumbres y politiquerías. (87-88)

Esta tradición que, parecía decir Gálvez, recién entonces podía ser enunciada, una vez que la literatura y la política se habían constituido en órdenes separados y una vez superadas las crisis, reunía figuras de escritor diferentes e históricamente situadas. En algunos casos, esas figuras señalaban un vínculo con la escritura propio de un mundo cultural que a principios de siglo XX los jóvenes de la revista consideraban anacrónico. Sin embargo, en esa disposición del pasado novelístico eran otras las pertinencias que lo organizaban. Una de ellas era el éxito efectivo, leído como tal, o deseado por Gálvez para esas obras; otra, su calidad, directamente vinculada con la condición sociocultural de los sujetos que las habían producido. Como ya se vio, el vínculo con un mercado posible, se presentaba como un elemento central para Ideas; según Gálvez, en la Argentina, dicho lazo había encontrado su realización pretérita en un escritor como Eduardo Gutiérrez, cuyos folletines habían contribuido a desarrollar un perfil profesionalista de la escritura, más allá de su dudosa moral. Asimismo, el hecho de que las dos obras naturalistas de Podestá hubieran sido reeditadas por la 'Biblioteca de La Nación', destacaba el carácter fundacional de los textos, y sobre todo, apuntaba al modo selectivo en que se construían las tradiciones; al mismo tiempo, subrayaba que el carácter efectivo de las mismas se efectuaba y dependía de la difusión que pudieran tener. Así estas dos obras valiosas, sacadas "del olvido" por una 
empresa de prestigio, se aseguraban un lugar en la literatura nacional. ${ }^{166} \mathrm{La}$ conexión que Gálvez establecía con el ochenta no era solo novelística sino también crítica, dado que, para forjar su propia intervención, recurría al antecedente altamente legitimado del crítico de la coalición cultural, Martín García Mérou. En efecto, el director de Ideas retomaba los artículos reunidos en "La novela en el río de la Plata", ${ }^{167}$ y ésta era otra de las formas de continuidad con los miembros de un mundo cultural al que la revista no dejaba de impugnar.

Aunque las referencias resultaban obvias, la lectura de Gálvez no era un remedo exacto de las observaciones de García Mérou. En principio, era significativo que Gálvez no incorporara a Cané a quien sí incluía García Mérou, cuyas obras junto con las de Paul Groussac y Lucio López anunciaban, a juicio del crítico del ochenta, "una época fecunda para nuestra naciente literatura" (García Mérou, 1886: 56). Por otra parte, para García Mérou, el éxito de Gutiérrez, su "popularidad", aparecía como un dato para reflexionar sobre la calidad estética y los peligros morales de una pedagogía literaria encarnada en sus novelas como formadoras de ciudadanos, y dicho éxito no estaba necesariamente vinculado con las relaciones entre la literatura y un mercado posible, entendido como un comprador anónimo de obras; en Gálvez tal "popularidad" se convertía en la clave a partir de la cual leer el pasado, y a la vez, darse una estrategia tendiente a construir un público amplio para la novela culta, con una voluntad más democratizadora.

Esta lectura legítima de García Mérou habilitaba a Gálvez para incluir las "novelas policiales de Gutiérrez", en el mismo terreno que Fruto vedado de Groussac, La gran aldea de Lucio López, y Silbidos de un vago, Música sentimental, Sin rumbo, de Cambaceres. Sin embargo, la inclusión de Gutiérrez suponía, en el caso de Gálvez, dejar de lado la valoración moral negativa de García Mérou (como lectura perniciosa para las "masas"), ${ }^{168}$ y recuperar en cambio esos títulos como novelas de aventuras y considerarlas a partir de la ejemplaridad de su consumo por un público amplio, es decir,

${ }^{166}$ Ese mismo año de 1903, que se cerró con la publicación de los textos de Podestá, "La Biblioteca de La Nación" había sacado La gran aldea de Lucio López.

${ }^{167}$ Los artículos aparecieron recopilados en Libros y autores, Buenos Aires, Félix Lajouane, 1886.

${ }^{168}$ Explicaba García Mérou: "Ciertamente no es este el alimento que necesitan las masas, y, aunque no hubiera en ello un deber moral, el simple buen gusto debía proscribir este género de literatura" Ibid., p. 18. 
como obras de éxito comercial y de asuntos y personajes locales. Desde esta misma perspectiva, Gálvez incluía al autor de Potpourri: suponía una lectura distorsionada de los datos reales de la venta y de la recepción de las tres primeras novelas de Cambaceres -lectura exagerada, que pensaba a los lectores del 80 como público ampliado y veía a las obras en su éxito de venta relativo casi como bestsellers. Por esta razón definía aquellos textos como "éxitos grandiosos", e instituía ese parámetro como valor central. Por otro lado, Gálvez ligaba la novela con el sujeto que la producía, y en ese sentido, el género se prestigiaba puesto que, decía el director de Ideas, era el "exponente de nuestra intelectualidad". 169

Por contraste, en 1904, -cuando, según su opinión, no se escribían libros como los mencionados-, aquella tradición novelística parecía no tener una continuación. La excepción era Francisco A. Sicardi, a quien Gálvez reconocería como uno de sus maestros, ${ }^{170}$ y cuyo Libro extraño guardaba similitudes con Nosotros, proyecto inconcluso de Payró de $1896,{ }^{171}$ y se asemejaba también, al plan que, en 1912, trazaría Gálvez para sus novelas. ${ }^{172}$ A la manera de una comedia humana nacional, el director de Ideas ambicionaba “describir, a volumen por año, la sociedad argentina de mi tiempo". ${ }^{173}$

169 Dice Gálvez: "En aquella época Fruto vedado y las obras de Cambaceres, constituían el exponente de nuestra intelectualidad", p. 89.

170 Para Gálvez, Sicardi, “como Almafuerte, era 'un raro', y hubiera podido figurar en el libro de Rubén Darío. La rareza de Sicardi estaba en su literatura y en su espíritu". Más adelante: "Las novelas y los versos de Sicardi son la obra de un alma atormentada, violenta y a la vez misericordiosa" (1961a:108-109). Prosigue: "No hablaba de cosas inútiles ni de vulgaridades. Su alma estaba llena de grandes preocupaciones. Amaba con pasión a la Patria, a sus hijos, a sus libros, al arte.

Había sufrido mucho. Sus primeros libros parecieron a alguna gente la obra de un loco. Era de origen modesto, hijo del capitán de un pequeño barco mercante, pero estaba casado con una dama de la más distinguida sociedad y del más ilustre abolengo. Ciertas personas de su parentela política, y que acaso no olvidaban aquel origen, creyeron de buena fe, o simularon creer, en la chifladura de aquel hombre que escribía cosas tan raras.

Habíale amargado también la indiferencia del público y de la crítica", p. 111. Como se ve los atributos de esta imagen coinciden con la forma más básica en que se presentaban, en El Mercurio como en La Montaña, los intelectuales y artistas. Aquí además hay que señalar el "amor a las cosas de la patria" como marca de afiliación -personal y de grupo- que construye Gálvez con Sicardi. La revista publicó un texto de Sicardi, "El genio y la multitud". Año I, Tomo 1, n 4, agosto, 1903, pp. 305-307.

${ }_{171}$ Cf. Capítulo 3.

172 Dicho plan solo apareció comentado en el Amigos y maestros de mi juventud.

${ }^{173}$ Gálvez explicaba que "(e)l plan abarcaba unas veinte novelas, agrupadas en trilogías. Debían evocar la vida provinciana, la vida porteña y el campo; el mundo político, intelectual y social; los negocios, las oficinas y la existencia obrera en la urbe; el heroísmo, tanto en la guerra con el extranjero, como en la lucha contra el indio y la naturaleza; y algo más. Ciertos títulos de las trilogías no se fundaban en similitudes geográficas ni de otro carácter más o menos material del ambiente de las novelas sino en semejanzas espirituales o morales". 
Esos tres proyectos eran imaginados como totalidades en las que se pretendía encerrar la sociabilidad argentina del presente que les era contemporáneo, y por consiguiente, se asociaban con la edificación y representación de una identidad cultural nacional; se asentaban además en una poética fuertemente mimética, ${ }^{174}$ de signo realista cuyos procedimientos podían interpelar mejor a lectores no entrenados en literatura pero sí en folletines criollistas con los que compartían "la seducción del referente", localizable de manera clara en la prensa. ${ }^{175}$ De ese modo el vínculo con el proyecto inconcluso de Payró era evidente porque aunaba periodismo y literatura para crear la lengua literaria en que debían ser escritas las ficciones destinadas a un público amplio. ${ }^{176}$ En ese sentido, la nota

Gálvez sostenía que de haber alguna influencia en el trazado del plan, podía ser principalmente la de Zola. También nombra a Balzac y a Pérez Galdós. Cf. Gálvez, 1961b: 10-11.

${ }^{174}$ En relación con la obra de Sicardi, Graciela Salto señala que tiene una doble afiliación, que además, el mismo autor señaló. Una de ellas, remite a las sagas narrativas del realismo y el naturalismo francés, visible en la apelación a la genealogía familiar; otra lo vincula con el conjunto de saberes científicos y pseudocientíficos sobre las enfermedades hereditarias, actualizadas en las psicopatías hereditarias presentes en ciertas ficciones médicas argentinas. (Salto, 2002: 44). Un ejemplo de incorporación de esas patologías a la ficción se encontraba en el relato de Groussac "La herencia", publicado en La Biblioteca, "La herencia", Año II, T7, enero, 1898, pp. 94-107.

${ }^{175}$ María Teresa Gramuglio, en la línea iniciada por Adolfo Prieto, afirma que el nuevo público lector, producto de las campañas tendientes a formar a los ciudadanos alfabetizados que demandaba el proceso modernizador, en términos generales, permaneció ajeno al espacio tradicional de la cultura letrada, y se volcó a la lectura de periódicos, folletos, y folletines, principalmente criollistas, dando origen al circuito de la cultura popular. Observa asimismo que en los primeros años del siglo, el fenómeno de lectura del criollismo empezó a declinar y fue reemplazado por los folletines sentimentales. Al mismo tiempo que se producía este cambio, se podían advertir "los signos de un desplazamiento que dará a la literatura en formas cultas un espacio que, sin llegar a ser comparable en magnitud con el que disfrutaron aquellas expresiones populares, fue, sin embargo lo suficientemente consistente para que en él la novela y el teatro encontraran un público capaz de sostener una producción regular". A su juicio, el realismo literario resultó inseparable de ese desplazamiento porque sus procedimientos tradicionales junto con las intersecciones entre sus ficciones y las del folletín fueron funcionales a las expectativas y disposiciones de los lectores que ingresaban a la cultura letrada. Además Gramuglio subraya como otro aspecto relevante en la elección de un poética mimética como lo es el realismo, su carácter apropiado para "tramitar las necesidades de reconocimiento y autoconciencia que se agudizan en los momentos en que el cambio social hace de la sociedad un problema para sus integrantes" (Gramuglio 2002: 7-8)

${ }^{176}$ Rubén Darío, en un artículo publicado en La Nación en 1896, sostenía que el plan que Payró -al que definía como periodista- había pensado para Nosotros abarcaba diversos aspectos de la vida argentina. Así comentaba: "Para este libro has hecho, según entiendo, varios planos; al par del plano urbano, has puesto un plano moral, un plano intelectual y un plano político y administrativo. $Y$ en ellos has ido estudiando parte por parte, acumulando observaciones, marcando detalles. Te sabes tu Buenos Aires de memoria. Lo has auscultado: le conoces cerebro, ojos, lengua, corazón, vientre y sexo, vigores y enfermedades." Además, Darío emparentaba Nosotros con una serie de obras anteriores. Algunas de ellas -las de Cambaceres o de Sicardi-, coincidían con las que Gálvez reunía en 
de Gálvez sobre Nebulosa ${ }^{177}$ de Carlos M. Ocantos, era significativa porque permitía identificar una poética sobre el género, más allá de que la obra de Ocantos no se adecuara completamente a ella. Así, uno de los postulados básicos, sostenía que la novela argentina debía estar de acuerdo con "nuestro espíritu" nacional. Para el crítico, dicho espíritu nacional se encontraba en la lengua literaria, en los personajes propios del medio ficcionalizado, y en el tono con que debían referirse los acontecimientos. Así, podía objetar, por ejemplo, la amenidad con que Ocantos narraba escenas trágicas, en un texto en el que sin embargo, apreciaba una innegable impronta galdosiana. Por otra parte, el autor de Nebulosa encarnaba el ideal de producción que Gálvez anunciaría en 1912. El director de Ideas no ocultaba su admiración por la fecundidad y regularidad de publicación de Ocantos. Así, afirmaba: "Con una insistencia digna de aplauso grafomanía o fe, no importa la causa- sus novelas han sucedídose con breves lapsos de tiempo, casi anuales, nutridas de lectura, de asunto argentino siempre" (324). No obstante, desde la mirada con que había analizado la tradición novelística nacional, Ocantos cometía el error de desentenderse del éxito, ${ }^{178}$ y ésta era una de las causas por las que sus novelas habían sido olvidadas. Para Gálvez, preocupado por los modos de captar y construir un lectorado para una novela culta, que pudiera continuar -revitalizándola- la línea iniciada en los folletines populares y elevada con las obras realistas- naturalistas de los intelectuales patricios, la clave se hallaba en la escritura de ficciones en las que los lectores pudieran reconocer ciertos elementos y también encontraran otros nuevos. De esta forma si era posible elogiar a Ocantos por una "acción en verdad interesante" o por el trazado de una variedad de personajes típicos -jugadores, vividores, señoritas sin escrúpulos, borrachos, maridos engañados, políticos, etc.-, también podía desaprobárselo porque esos mismos personajes eran "extraños a nuestro medio" -la alta sociedad porteña- y hablaban en un lenguaje plagado de españolismos, cuyo resultado era una

su tradición novelística. Como se podía ver en las referencias de Darío al plan de Payró, Buenos Aires asumía la representación de la república. En Gálvez, por contraste, no solo se atendería a la vida urbana de la capital moderna.

177 Ideas, Año II, Tomo 3, no 11 y 12, marzo-abril, 1904, pp. 324-347. La obra correspondía al tomo IX de las Novelas argentinas de Ocantos.

${ }_{178}$ Cuando se preguntaba por el fracaso de las novelas de Ocantos, Gálvez sostenía: "Venían sin réclame, sin ruido, como revelando una total despreocupación del éxito. No aplaudo tal sistema. Simplemente lo constato. Por eso, Ocantos no ha triunfado? Por eso solamente? No, hay algo más." Ibid., p. 324. 
"literatura anodina, que no es argentina, ni creo que sea española". ${ }^{179}$ Como se podía observar, el reaseguro contra esa literatura anodina podía encontrarse además en la inclusión de nuevos materiales, que Gálvez verificaba en la literatura de Sicardi, tales como el suburbio, las transformaciones urbanas, los personajes marginales, o el hogar (Salto, 2002: 55). Esos tópicos guardaban una relación fundamental con el presente, y debían aunarse con la capacidad del novelista para construir "la visión del conjunto de los vastos panoramas sociales" (Gálvez, 1961: 112). De esta forma, Gálvez proponía tempranamente en Ideas, una relación provechosa entre la cultura letrada y un mercado posible, en la que acentuaba el vínculo entre novela e identidad cultural. Esta alianza que implicaba un cambio de valoración de palabras tales como éxito y público anónimo y ampliado, encontraba en las estéticas de signo realista los recursos eficaces y "funcionales a las expectativas y disposiciones de los lectores que ingresaban a la cultura letrada" (Gramuglio, 2002: 8). Individualmente y más entrado el siglo XX, ese vínculo coronaría al director de Ideas con la venta de sucesivas ediciones de sus novelas.

Por último, un tipo de novela de signo realista, como el que se proponía en Ideas, necesitaba de la legitimación de la crítica. Mientras tanto, y dada su inexistencia, encontró la manifestación del modelo de literatura proyectado en la producción del teatro nacional que se iba consolidando, a la vez que fue afirmando su crítica (fundada en dicha concepción de la literatura nacional) en las notas sobre teatro y sobre las escasas obras narrativas -cuentos y novelas- que se reseñaron en las secciones específicas. En ese sentido, y como se verá en el apartado 5, fue en el teatro, cuyos desarrollo y autonomía se dieron previamente a los de la novela argentina, que esta poética se consagró casi en el comienzo de siglo XX, y tuvo en Sánchez y en Payró, autores que también constituirían referentes insoslayables para la revista Nosotros, dos de sus exponentes más relevantes. Como ya se dijo, aparece en el discurso crítico de Ideas una impronta realista naturalista que merece un examen particular. En efecto, no solo sirvió para forjar y promover una estética literaria deseable para las obras, sino también para señalar indirectamente las atribuciones de la crítica, de la literatura y de los escritores, en un

${ }^{179}$ Gálvez conjeturaba que ese carácter anodino tal vez se vinculaba con el hecho de que el autor viviera en España. Como prueba, citaba una frase de Casuso, el protagonista de Nebulosa: "-¡Nada, Teles, que estoy cada día más flamante! ni una pata de gallo, ni barriga siquiera. ¡Qué me echen a mí pollos de veinte años”, p. 329. Por lo demás, la crítica presentaba un carácter ambivalente, que iba y venía del elogio a la desaprobación. 
momento marcado por el cambio social. Los escritores de Ideas buscaron autorizarse y ser reconocidos también a partir de esas atribuciones.

\subsubsection{Casos patológicos, herencia, medio: las huellas del naturalismo}

Como observa Carlos Real de Azúa, el medio intelectual del 900, moldeado por las políticas de las editoriales españolas y francesas para América Latina, se caracterizó por la convivencia de corrientes y posturas disímiles e incluso antagónicas. ${ }^{180}$ Esta situación se registró en Ideas en la presencia de concepciones heterogéneas que otorgaban a las intervenciones intelectuales del grupo un aspecto, por momentos contradictorio. Pudo observarse, por ejemplo, en la coexistencia de una vocación espiritualista (que demandaba la construcción de un 'ideal' para el pueblo argentino, abría sus páginas a la filosofía nietzscheana, ${ }^{181} \mathrm{o}$ declaraba la bancarrota de la filosofía positivista) ${ }^{182} \mathrm{y}$ de un repertorio semántico directamente ligado con la poética naturalista $-\mathrm{y}$ por consiguiente, con el materialismo y con el positivismo. Tal circunstancia se actualizó en la crítica de Ideas como un efecto rezagado de ciertos rasgos de la poética naturalista, que emparentados con la vigencia del positivismo en una amplia zona del mundo intelectual, se ponían de manifiesto en una perspectiva sociológica para el análisis de las obras. ${ }^{183}$ Por lo demás, esta impronta naturalista

\footnotetext{
${ }^{180}$ Real de Azúa afirma que en el medio intelectual del 900 coexisten corrientes y posturas y que "(n)o es difícil sorprender la tonalidad romántica en los sentimientos, en la ideología política y en la filosofía de la historia, conviviendo con el positivismo ortodoxo y sus derivaciones, o con lo tradicional en las costumbres - y a veces en las creencias religiosas - , y a todos y cada uno de estos temperamentos con las reacciones o superaciones del positivismo, sin que la noción de su múltiple conflicto inquiete largamente" (Real de Azúa, 1950: 18).

${ }^{181}$ Cf. apartado 3, nota 69.

${ }^{182}$ Becher afirmaba esta cuestión en el $\mathrm{n}^{\circ} 1$ de Ideas en su nota sobre Verité de Zola, cuya mirada sobre la lucha entre el positivismo y la fe le resultaba parcial: "hay una profunda corriente de ideas hacia el catolicismo, provocada por la bancarrota de la filosofía positiva y el anhelo de una fe superior. Zola no ha querido o no ha podido ver esta faz del problema", p. 77.

${ }^{183}$ José Luis Romero sostiene que las distintas intervenciones de los grupos intelectuales de comienzos del siglo XX en Argentina, fueron el resultado de un mismo método y una misma doctrina: "la lectura de Taine, Renan, Fustel de Coulanges, confluía con la de los sociólogos positivistas en una imagen del contorno espiritual y material de las sociedades que se expresaba generalmente bajo la frase 'mundo moral'”. (Romero, 1983: 65). Por su parte, Carlos Real de Azúa, señala que "(f)ue el positivismo filosófico —en su versión spenceriana
} 
encontraba su motivación en un contexto ideológico, en el que como señala Real de Azúa, el positivismo ocupaba un plano intermedio sobre el que se percibían un conjunto de influencias renovadoras, que lo cuestionaban de modo profundo. Desde el terreno de la crítica, recurrir a las teorías contemporáneas vigentes con las cuales el naturalismo se emparentaba, podía servir como un modo de legitimar la propia práctica en relación con las atribuciones que le eran reservadas. De esta forma, podía rastrearse en Ideas un conjunto de postulados presentes en algunos textos programáticos de Zola de la década del 1880. Así, las reseñas exhibían marcas fuertes de afiliación con la teoría de los milieux y la importancia de lo hereditario para la construcción de personajes (determinismos del medio y de la herencia); y la necesidad de incorporar la descripción detallada y precisa como forma de individualización de espacios y personajes, considerados no como abstracciones sino como sujetos particulares (reales). ${ }^{184}$ Asimismo, la centralidad de la figura de los intelectuales en relación con el perfeccionamiento social ${ }^{185}$ constituía otro punto de contacto con el naturalismo. A esto debían sumarse la presentación de escritores o críticos como trabajadores, estudiosos, marcados, en algunos casos, por una pretensión fuertemente cientificista. A su vez, la preferencia de Zola por la novela y el teatro ${ }^{186}$ como géneros

- el ingrediente de más volumen de ese ambiente intelectual de fin de siglo. Las casas editoriales españolas dieron a la obra del filósofo inglés una difusión que posiblemente, ni antes ni después, haya tenido entre nosotros pensador alguno" Más adelante observa que la doctrina forjada por Hipólito Taine para dar cuenta del arte, basada en los tres factores de raza, medio y momento, convirtió en dogma "el modo de pensar asociacionista, determinista y mesológico" (...) "con detrimento de la libertad humana y de la acción misteriosa del espíritu" (1950: 21; 24).

${ }_{184}$ Zola considera la descripción como "un estado del medio que determina y completa al hombre" (Zola, 1972: 203).

${ }^{185}$ Rojas, en la nota sobre La catedral de Blasco Ibáñez, hablaba de "regeneramiento".

${ }_{186}$ Zola en "El naturalismo en el teatro" sostiene: "[el naturalismo] da nuevo vigor a las artes, a la escultura, a la pintura sobre todo; ensancha el campo de la crítica y de la historia, se posesiona de la novela y triunfa por fin con Balzac y Stendhal, afirmando el movimiento iniciado en el siglo XVIII" (Zola, 1945: 245). Con respecto al teatro, y en este mismo artículo, Zola espera el mismo camino naturalista que viene recorriendo la novela: "Espero que aparezcan al fin en nuestro teatro hombres de carne y hueso tomados de la realidad y analizados científicamente sin recurrir a la mentira. Espero que se nos libre de personajes ficticios, de estos símbolos convencionales de la virtud y el vicio que no tienen ningún valor como documentos humanos. Espero que el medio ambiente determine a los personajes, y que los personajes sean el producto de la lógica de los hechos combinada con la lógica del propio temperamento (...) Espero, por último, que la evolución verificada en la novela llegue también al teatro, que éste se inspire en las fuentes de la ciencia y el arte moderno, en el estudio de la naturaleza, en la anatomía del hombre, en la pintura de la vida, en un proceso verbal exacto, tan original y poderoso, que nadie hasta ahora se ha atrevido a llevarlo a escena" (Zola, 1945: 262-263) 
en los que se realizaba el carácter sociológico del arte moderno, encontraba su eco en Ideas cuyas apuestas críticas más fuertes se realizaban con respecto a esos dos géneros. El gusto declarado de algunos redactores por obras "de tesis", de "fino criterio sociológico", ${ }^{187}$ en detrimento de obras más imaginativas, ${ }^{188}$ así como el acento en una lengua literaria no artificiosa ni convencional para dar cuenta de la vida moderna en todos sus aspectos, podían leerse en el sentido de esa afiliación estética. En Ideas estos postulados aparecían convertidos en los enunciados que sustentaban la práctica crítica, y a partir de los cuales se leían obras no necesariamente inscriptas en el naturalismo. De este modo, el naturalismo se presentaba como huella de lectura y no como reedición de un episodio de la historia y de la crítica literarias argentinas.

La vinculación con los postulados naturalistas se volvía explícita en el énfasis que las reseñas ponían en las determinaciones del medio y de la herencia, en la importancia de la observación y la necesidad de las descripciones. Además, se manifestaba un interés por el detalle como forma más eficaz para la individualización de los personajes que no debía dejar de lado el criterio de verdad psicológica. Las obras y representaciones teatrales eran valoradas en función de un vínculo deseable y promovido con lo social contemporáneo. Así, podían legitimarse como relatos históricos o en tanto modos de representar las transformaciones producidas por la modernización y los conflictos que este proceso conllevaba. De ello se seguía la posibilidad de considerar la literatura como una protociencia de lo social, un saber que exhibía y escenificaba "vicios" y virtudes con una finalidad regeneradora y ejemplar. El escritor aparecía entonces como un apóstol laico -según Rojas, y apelando a una

\footnotetext{
${ }^{187}$ La revista realizó una encuesta a propósito de Sobre las ruinas de Roberto Payró, obra que se había publicado en Ideas en el $n^{\circ} 11-12$ de marzo-abril de 1904. Algunas de las respuestas insistían en este carácter sociológico de la literatura, en este caso teatral. Salvador Oria sentenciaba que era la mejor obra del teatro nacional porque "es un estudio sociológico oportuno del ambiente 'nacional' hecho con amor y, en cierto modo, con arte dramático" (206); Abel Cháneton explicaba: "Payró, con admirable criterio sociológico, ha sorprendido un momento de nuestra evolución y con habilidad de maestro ha concebido y ejecutado su obra". Ideas, Año 2, n 14, junio, 1904, 207. Cf. apartado 5.3. de este capítulo. ${ }^{188}$ Aunque no se publicó en Ideas la crónica de Juan Pablo Echagüe sobre Inútil de David Peña -obra que criticó Gálvez en la revista-, indicaba esa tendencia: "El señor Peña es un imaginativo. Al igual de (sic) ciertos pintores impresionistas citados por Nordau, retrata las cosas como él las ve; solo que su ojo es defectuoso y las ve mal (...) Es la modalidad fantaseadora del autor de Inútil (...) la que ha desnaturalizado la acción, acaso verídica en su origen." (Echagüe, 1919: 36)
} 
fórmula que era ya un lugar común- que tenía a cargo la tarea de regeneración social en momentos de crisis nacional y siempre al servicio del progreso. A nivel del discurso, la vinculación con el naturalismo se realizaba en las elecciones léxicas que funcionaban como las huellas de la lectura naturalista. De esta manera sintagmas y términos tales como "trozos de vida" (tranche de vie), "caso patológico bien observado", "tara", "debacle", "regenerar", "estudio" (para referirse a cierto carácter científico de la literatura), "sencillez" (para valorar la lengua literaria de los autores), "herencia", "tesis", "lucha por la vida", etc. reenviaban directamente a la matriz léxica positivista, cientificista y evolucionista del naturalismo.

Cuando las obras eran criticadas, las hipótesis de lectura de filiación naturalista funcionaban como pertinencia de lectura y como parámetro de realización exitosa. De este modo, una obra como Espigas sueltas de Leopoldo Basa -libro que recopilaba trabajos "breves y ligeros" de distinta clase, cuentos y narraciones- , era juzgada por su falta de observación, el conocimiento inexacto del ambiente, y la ineficacia de su lengua para "expresar la vida moderna". ${ }^{89}$ Con respecto a Danvilla, autor de los cuentos de Odio, Rojas sostenía que no se podía calificar como perteneciente a una escuela literaria; y era el mismo Rojas quien insistía en marcar la desobediencia respecto del modelo de Zola, sobreimprimiendo su propia poética crítica a la elección estética de Danvilla. En ese sentido, si bien reconocía en el escritor "facultades de observación", esto se veía opacado por la ausencia casi completa de "las descripciones del ambiente, sobre todo las descripciones de cosas inanimadas, que son tan frecuentes en Zola, por ejemplo". ${ }^{190}$ Por su parte, Roberto Bunge esgrimía a Pereda como modelo literario inalcanzable para Martín Gil, autor de Modos de ver, ${ }^{191}$ cuando Gálvez se

${ }^{189}$ Gálvez comentaba: "De estilo, español, ya se sabe con esto lo que quiero decir, no es su idioma un instrumento que pueda expresar la vida moderna en toda su amplitud. Carece de concisión y elegancia, dos elementos indispensables en un libro contemporáneo, que debe llenar gustos refinados y vertir el pensamiento sin derroche de palabras" Ideas, Año II, $\mathrm{n}^{\circ} 9$, enero, 1904, p. 86.

${ }^{190}$ Entre los argumentos elegidos para elogiar los relatos del autor Rojas cuenta la presencia de psicología, "mucha observación", la "fina crítica social que constituye su mérito [del cuento "A la puerta de la Iglesia"]. Los personajes van pasando por distintos medios y su armado y caracterización se juega en ese pasaje.

191 Bunge afirmaba: "No llegará a escribir obras desbordantes de verdad y de bríos, de sentimientos y de pasiones como Pereda -a quien podría presentarle como su mejor modelo literario- pero llegará, en cambio, a merecer el aplauso de muchos lectores, ávidos de escenas campestres, y hartos de Moreiras y demás 'héroes' bandidos". Ideas, Año I, Tomo $1, n^{\circ} 4$, agosto, 1903, p. 380. 
ocupaba de la novela de Carlos O. Bunge Xarcas Silenciario ${ }^{192}$, hacía referencia a la utilización de teorías consideradas valiosas por su proximidad con la ciencia, y empleaba términos como "explicar" un "caso" y "apariencia psicopatológica". ${ }^{193}$ La ocasión más visible de este uso del naturalismo se hallaba en la reseña del director de la revista sobre La novela de la sangre. El relato era presentado como una novela histórica que exponía una perspectiva antirrosista, posición ideológica con la cual Gálvez acordaba. Aunque los dos primeros apartados de los cuatro que componían la nota, reforzaban el carácter histórico del relato, el tercero, que se ocupaba de la construcción de los personajes, no enfatizaba el criterio de verdad histórica, sino que apelaba al argumento cientificista para recurrir nuevamente al repertorio del naturalismo. Así, en sus observaciones sobre Wagner, afirmaba que tal "como Wagner, según Nordau, recurre al leit motiv, para caracterizar un personaje, de un modo análogo y con objeto idéntico, Bunge afecta a los suyos con una tara o con una obsesión" (81). ${ }^{194}$ Finalmente, y tras el seudónimo de Georges Dorée, Gálvez había explicitado su adscripción al teatro naturalista en una defensa de los postulados del Teatro Libre de André Antoine. ${ }^{195}$

Por otro lado, la huella del naturalismo en la crítica de Ideas se vinculaba con el problema de la lengua literaria que debía emplearse y con la definición de una temática

\footnotetext{
192 Xarcas Silenciario cuenta la historia del manuscrito que escribió Bocelli, posteriormente internado en el Hospital de Alienados, referida por Juan López, un procurador y amigo de Bocelli. La historia narrada en el manuscrito ("Recuerdos de ultratumba de Xarcas Silentiarius") transcurre en el siglo IV. Año II, Tomo 3, n 11 y 12, marzo-abril, 1904, pp. 324-347.

193 "He aquí lo más interesante del libro, tema del prólogo y del epílogo, donde Bunge recurre a diversas teorías, más o menos científicas para explicar el caso y que dan una base meritoria a la obra, por la originalidad del asunto, su apariencia psicopatológica, el fino humorismo que en sus páginas vive" (334). Gálvez subraya la importancia del prólogo y del epílogo, escritos por Bunge, en los que se revela "un profundo saber sobre psicología" (337). ${ }^{194}$ Cursivas nuestras. Además, Gálvez insistía en el acierto de la pintura de los personajes secundarios, representados en su realidad de hombres vivos: "Silvio, don Valentín Válcena, Amenábar, el mismo Rosas, son seres que parecen vivir, tal es el efecto que sus idiosincrasias producen en la imaginación del lector". Año II, Tomo 3, n 9, enero, 1904, p. 82.

195 "Antoine y el teatro libre", Año I, Tomo 2, no 5, septiembre, 1903, pp. 21-27. En 1887 André Antoine fundó su Teatro Libre en el pasaje L'Elysée-des-Beaux-Arts de Montmatre, en París. Allí se postuló el primer teatro moderno propiamente dicho como un sistema de representación escénica pautada por directores, no por los actores. El Teatro Libre se fundamentó en "la verdad sobre lo verdadero", y privilegió puestas "documentales" y fue un teatro social y de ideas teatro. Cf. Byrón, Silvestre «Iniciación teatral/El Caso Riglos» (EAF/Liber, 2002). $1^{\text {a }}$ Ed. Internet: Iberoamerica-act (25/5/02); Nettime-lat (22/6/02).
} 
para la novela y el teatro nacionales. En ese sentido Gálvez, principalmente, reclamaba la necesidad de una lengua que, pensada para el consumo de un público ampliado, tuviera su ideal en un estándar de corrección al cual debía sumarse un plus estético que la diferenciara de la mera lengua de prensa. ${ }^{196}$ En relación con la temática deseable para ambos géneros, ésta se expondría claramente en la valoración positiva de obras teatrales como Sobre las ruinas de Roberto Payró, La gringa o M'hijo el dotor de Florencio Sánchez, o El gringo de Otto Miguel Cione, que mostraban una preocupación por llevar a escena argumentos ligados con el propio proceso social contemporáneo, y en las que el costumbrismo fue un ingrediente central.

\section{De las representaciones criollistas hacia el teatro nacional}

En su libro sobre el criollismo, Adolfo Prieto observa que contrariamente a lo que sucedía en el circuito de la cultura popular, el espacio de la cultura letrada casi no había cambiado sus dimensiones entre 1880 y 1910, hecho que se convirtió en una obsesión para muchos de sus miembros incluido Gálvez, y que explica que la cultura letrada reaccionara en términos específicamente culturales ante la aparición y desarrollo de la literatura popular de signo criollista. Según el crítico, el espacio de la cultura popular registraba una superabundancia tal de signos criollistas que éstos se expandían de la literatura hacia la vida cotidiana. Aunque el espacio de la cultura letrada, en cambio, se encontraba aparentemente replegado sobre sí mismo en el cultivo del naturalismo, el modernismo de Darío, y de alguna vertiente de poesía "nativa", todos los indicios recogidos de su descripción parecen indicar que, en el interior de ese espacio, "la aparición y el desarrollo de la literatura popular tuvo efectos y exigió respuestas de la más variada intensidad y calibre, señalando orientaciones y produciendo finalmente textos que no pueden leerse correctamente si se los desvincula de su relación de reciprocidad con los textos producidos en el espacio

\footnotetext{
${ }^{196}$ Muchas de las críticas teatrales de Juan Pablo Echagüe que no aparecieron en la revista sirven, sin embargo, para mostrar esta perspectiva de lectura. Más adelante haremos referencia a estos aspectos.
} 
de la cultura popular". ${ }^{197}$ Por su parte, Ricardo Pasolini, indica que entre 1870 y 1910 , la ópera y el circo se transformaron en los polos antagónicos de la oferta teatral de Buenos Aires, y que "a partir del desarrollo de prácticas de consumo específicas y de particulares comunidades de significados asociados a los géneros", fue posible reconocer franjas de un público cada vez más amplio y polarizado. Al circo y a la ópera se sumaban, dentro de la oferta teatral, zarzuelas, comedias y los dramas en italiano o en francés, los sainetes de origen español, y a comienzos del siglo XX, los dramas de autores nacionales. Inscripta en ese contexto, la revista de Gálvez puso en escena una polarización de públicos a los cuales definió, por momentos, como igualmente ignorantes y desplegó una operación crítica, editorial y de sociabilidad respecto del teatro -cuyo punto más alto es la realización de una encuesta a propósito de Sobre las ruinas de Payró- ${ }^{198}$ que pudo leerse como una de esas respuestas de la alta cultura letrada en modernización. Estas acciones representaron un intento sostenido de la revista tanto por promocionar a los autores dramáticos nacionales y constituir un teatro nacional de ideas, sustituto del criollismo, como por "educar el gusto y la sensibilidad” del sector 'aristocrático' que asistía a las representaciones de la ópera y veía en ellas una forma más de acumulación de prestigio social. ${ }^{199}$ Pero también de cooptar para una dramaturgia nacional -cuyos frutos ya eran visibles-, al

${ }^{197}$ Prieto observa que el término "criollismo" no tuvo igual significación para los diversos sectores de la población. Así, para el grupo dirigente de la población nativa significó "el modo de afirmación de su propia legitimidad y el modo de rechazo de la presencia inquietante del extranjero"; para los sectores populares de la población nativa que habían dejado su lugar de origen para asentarse en las ciudades, el criollismo pudo expresar "nostalgia o una forma sustitutiva de rebelión frente a la extrañeza del mundo urbano"; para los extranjeros pudo significar la forma inmediata y visible de asimilación. (Prieto, 1988: 15 y ss.)

${ }^{198}$ Por operación editorial nos referimos a la publicación por parte de la revista de partes de obras teatrales, y en cuanto a la sociabilidad, nos referimos a la encuesta con que se conmemora el primer año de Ideas. Cf. apartado 5.3. de este capítulo.

199 El público de la ópera no era un público homogéneo y podían establecerse diferenciaciones en función de su erudición lírica. Sin embargo, este criterio no era el único según el cual determinaba las jerarquías o el prestigio de las audiencias del teatro lírico porteño. Pasolini afirma que "(e)s posible pensar, que ante la masificación del género, los diferentes públicos encontraran en su asistencia a tal o cual teatro la línea demarcatoria de su identidad social, en un contexto en que la marea inmigratoria amenazaba, al menos en la imaginación de la elite, con socavarla. Según Rosselli, desde el inicio de la ópera moderna en Buenos Aires -aproximadamente desde 1880 en adelante- se definieron dos audiencias claramente diferenciadas: un público a la moda, y en su parte más influyente, no italiano, y otro popular y casi totalmente italiano." También hay que tener en cuenta el precio de las entradas, que generaba, hacia el interior de los teatros, una distribución también particular. Cf. (Pasolini, 1999: 228; 247-248) 
público popular que Ideas consideraba cautivo de la probada y exitosa fórmula de los dramas criollos. Hacia 1903, esta denominación de dramas criollos, era un "residuo taxonómico" tras del cual se ocultaba una variada oferta teatral, y un tipo de drama de temática criollista asociado al desarrollo de compañías teatrales nacionales, cuyas obras se representaban principalmente en los teatros Apolo, Nacional, Rivadavia o Libertad. (Pasolini, 1999: 259-260). ${ }^{200}$

\subsection{Los públicos del teatro. Ultraje y educación.}

La preocupación por el público, y en especial, por el público teatral, estuvo presente desde el comienzo de la revista. Este especial interés se vinculaba con el movimiento hacia un mercado posible que, como se dijo, se registraba en la revista de modos diversos: la inclusión de avisos publicitarios, la importancia dada a los modos de circulación y edición de libros, el elogio de la labor cultural de emprendimientos comerciales como las ediciones económicas de casas españolas o "La Biblioteca de $L a$ Nación". Esa intención de insertarse en un mercado de bienes culturales e incidir en él se confirmaba por el hecho de que la revista tuviera desde el comienzo una sección fija dedicada al teatro: Ideas se propuso dar cuenta de lo que acontecía en las salas donde se representaban obras pertenecientes a un circuito de consumo más generalizado y, por lo tanto, económicamente más accesible que la ópera, al mismo tiempo que desataba su inquina contra el redituable teatro de signo criollista. En ese sentido, Ideas y en especial su director, veían en el mundo del teatro un mercado efectivo, cuyo público no era una quimera sino una realidad. Ese espacio, que funcionaba con arreglo a la lógica comercial de los empresarios del rubro, representó una forma efectiva de profesionalización de los escritores, más allá de los problemas de sus autores con los dueños de las salas o de las compañías. De este modo, desde una perspectiva que

\footnotetext{
${ }^{200}$ José Podestá que había alquilado el teatro Apolo, encargó la dirección a Ezequiel Soria. Éste en 1901, junto con Enrique García Velloso y el actor español Mariano Galé, intentaron organizar una compañía de actores que representara obras de autores nacionales. En 1902 se llevaron a escena Política casera del propio Soria, Jesús Nazareno de García Velloso, Canción trágica de Payró, La piedra de escándalo de Martín Coronado, Al campo de Nicolás Granada. (Ordaz, S/F: 49-50)
} 
afirmaba para los escritores y críticos los derechos del ejercicio de una pedagogía del gusto no exenta de calidad moral, la revista identificó dos estratos de público de los que a su vez se distinguió, y a los que aspiró a reunir como público de un teatro nacional en formación. En efecto, aunque las críticas de los redactores a ambos públicos mantuvieron, en parte, la distinción del arte tanto de la buena sociedad como del público lego, acercándose así a las formulaciones de El Mercurio de América, el imperativo de captar y construir un público para las obras argentinas atenuaría los alcances de aquella separación también necesaria. En ese sentido, mientras que en la revista de Díaz Romero, las denostaciones contra el público habían servido como modo de diferenciar el arte oponiéndolo al materialismo burgués, las invectivas realizadas desde Ideas supusieron la confianza en la propia acción intelectual para modificar las modalidades del consumo de obras teatrales.

En "Sinceridades" Ricardo Olivera, quien dedicaba al teatro parte importante de sus reflexiones y lo definía como "la manifestación más intelectual de esta metrópoli y casi la única". A la vez que reconocía el movimiento de compañías extranjeras en los escenarios porteños y ofrecía una breve sociología del público, se quejaba de la ausencia de condiciones para hacer de aquello que imaginaba como "el buen teatro" un producto cultural de consumo popular:

No llevan a la sala de la Gran Ópera los mismos impulsos que encaminan hacia las aulas de la Sorbona: se asiste a una lección cediendo únicamente a imperativos de la Idea y se concurre a una representación por lujo, por vanidad, porque lo exige la moda o porque conviene á un flirt. Hay todavía otras razones. El teatro y el buen teatro sobre todo, es caro y como consecuencia privilegio de la minoría; en todas partes está aun lejano el advenimiento del Teatro Popular y lo que en París es solo esperanza, en Buenos Aires es quimera. En el pequeño núcleo pudiente que frecuenta los espectáculos por tantas cosas ajenas al Arte, es raro encontrar delicados temperamentos de sensitivos que comulguen con la Belleza en una nota de Tamagno ó en un gesto de Sarah. ${ }^{201}$

${ }^{201}$ Ideas, Año I, nº 1, mayo, 1903, p. 4. 
Estas breves referencias al público servían para identificar la democratización y, por lo tanto, la ampliación del público como líneas programáticas de Ideas en relación con el teatro. Asimismo, Olivera oponía dos formas del consumo estético que se correspondían con teatros y públicos diferentes. La crítica al público del buen teatro [la Gran Ópera], identificado con la elite recuperaba la oposición arte/ mundo burgués en virtud de la cual el teatro se manifestaba como signo de riqueza y funcionaba para esa clase, básicamente como un espacio de construcción de legitimidad social, o, como línea demarcatoria de su identidad. La cita mostraba la aspiración de construir un teatro popular vernáculo, cuyas funciones educativas quedaban sugeridas en la diferencia irreductible entre los deseos de figuración social de la elite y la aspiración de saber como sinónimo de civilización, que organizaba la mirada intelectual y artística de Olivera. De este modo, se delineaba otro público, ampliado, del que se esperaba concurriera al teatro guiado a la vez por cuestiones estéticas y por "los imperativos de la idea", convirtiéndose, así, en objeto de pedagogía. La imagen del público como quimera podía pensarse como la visión optimista de un emprendimiento que no obstante perseguía una finalidad comercial, encontraba su utopía en la construcción de un público cuyo interés genuino en el arte se convertía en signo del estado intelectual y moral nacional.

Semejantes a esas críticas de Olivera fueron las observaciones que Ricardo Rojas realizó al pasar, en nota al pie del artículo dedicado a dos obras teatrales de José Echegaray, El loco dios y Malas herencias: ${ }^{202}$

Bien sabemos lo que Larra decía de la opinión pública con tan amarga verdad y lo que observadores recientes han anotado acerca de la psicología colectiva. Las multitudes en la historia, en el delito, en el aplauso, dondequiera que están, son siempre ilógicas, inconscientes, fácilmente sugestionables. Su mentalidad es más baja cuanto más heterogénea su composición. No creo que en el presente caso pueda argumentarse con 'lo selecto de los públicos', pues todos los días vemos cuál es el ambiente de nuestros 'teatros elegantes'; y una

${ }^{202}$ En la bibliográfica sobre Los modernistas de Víctor Pérez Petit, Ricardo Rojas insistía en el valor didáctico de la crítica, que no hallaba en el libro del uruguayo y que podía pensarse como modo intelectual de resolver el problema del público. Año I, Tomo 1, nº 2, junio, 1903, pp. 175-178; LHE: 2. 
opinión autorizada reveló no ha mucho, a propósito de Wagner, qué gente va a las temporadas líricas de Bayreuth. En tal concepto, dispenso tan poco respeto intelectual, con relación a los elementos que lo componen, a la multitud que gasta frac $y$ seda en las salas decoradas, como a la otra, vestida de andrajo, de los tumultos callejeros". [cursivas nuestras] ${ }^{203}$

Estas impugnaciones situaban la cuestión del público en el marco más amplio de los problemas relativos a la multitud en las sociedades modernas, desde la perspectiva de las contribuciones de la criminología italiana de Lombroso, Ferri, Garófalo y Sighele -entre otros-, difundida en Argentina por La España Moderna y Sempere, para señalar su parentesco con el delito. ${ }^{204}$ Esta nota era importante porque en ella se reiteraban las objeciones de Olivera sobre la elite como público de ópera. En términos culturales este público aparecía como equivalente de la multitud urbana de Buenos Aires cuyo comportamiento Rojas evaluaba a partir de la idea de degeneración. ${ }^{205}$ Así, teniendo en cuenta las funciones que Rojas asignara a la novela y al teatro a propósito de La catedral de Blasco Ibáñez, la crítica podía asumir una tarea regeneradora y formadora de un gusto verdadero.

\footnotetext{
${ }^{203}$ Año I, nº 3, Tomo 1, julio, 1903, pp. 236-249. LHE: 3-4.

${ }^{204}$ La muchedumbre delincuente: ensayo de psicología colectiva de Escipión Sighele ; traducción de P. Dorado, había sido publicada en 1892 por La España Moderna. Una corriente de estudios vinculada a la psicopatología criminal, se inició en el país por la difusión de las doctrinas de Lombroso, Ferri, Garófalo, Marro, Sighele, Colaianni, Tarde, Prins, Dorado, Sommer, encaminadas a renovar el Derecho Penal. Rojas, por su parte, se ocuparía de Cosas de España de Gener en el no 5 de Ideas. Al parecer, el crítico había leído a Nordau en francés y a Sighele en italiano, cuyas referencias bibliográficas citaba en sendos idiomas.

${ }^{205}$ Otro ejemplo del comportamiento inapropiado y vulgar del supuesto público selecto, se hallaba, para Rojas, en los conciertos y conferencias: "Los conciertos de la Biblioteca han degenerado también en reuniones sociales. La gente va allí, como a la Opera, a ver, no a oír ...[cursivas de Rojas] Pues, a tales 'guarangos' he visto cuchichear con el vecino, mientras la orquesta ejecutaba una sinfonía de Beethoven; y mientras Groussac pronunciaba su magistral conferencia sobre Bizet, he visto irritado, a hombres y mujeres, bostezar y suspirar de aburrimiento impaciente! La denuncia es cruel, pero la debo a la verdad, y ella deprime al auditorio tanto cuanto levanta al eminente escritor", pp. 243- 244. Cursivas nuestras.

Por su parte, Becher, apropósito de la conferencia "Las ideas en el siglo" de Manuel Ugarte, también atacaba al público aristocrático y al socialista: "El público socialista ha demostrado, esa noche, que vale tanto como los auditorios aristocráticos, por la grosería del temperamento y la vehemencia de la estupidez", Ideas, Año I, nº 6, octubre, 1903, p. 222.
} 
Por su parte, Gálvez también profirió sus anatemas contra el público, no obstante lo cual abrió una posibilidad para su educación estética, sobre todo, para aquel estrato que identificaba como lector de las críticas teatrales de la prensa. Las afirmaciones del primer número donde el director de Ideas ponía de manifiesto la motivación y el programa que guiarían sus propósitos, expresaban una polémica. Ese programa cuya quejosa enunciación ocupaba casi cinco páginas, se concentraba en la crítica, el público y la desestimación del criollismo, tres elementos cuyas vinculaciones eran más que evidentes. En continuidad con los escritos de Olivera y Echagüe, Gálvez presentaba su intervención en tanto conjuro de la crítica falsa y adulona, frente a la cual reivindicaba la suya, como "verdadera".

No haremos programa. Solo prometemos decir la verdad. ¡Difícil empeño el nuestro, aquí, donde tantas cosas se hacen mal; donde tan pocos son los que tienen el valor suficiente, la independencia necesaria, para decir muy alto sus pensamientos; donde los cerebros raquíticos y adulones que se arrastran ante el falso brillo de los simuladores de talento, abundan por desgracia; donde las ambiciones son inmensas; donde hay tanto mérito prestado, tan poco mérito verdadero! ${ }^{206}$

La verdad de su discurso se autoinstituía como necesaria y se fundaba en el principio de independencia. De este modo la cuestión se planteaba en términos institucionales y la impugnación más fuerte recaía en el vínculo de la crítica con la prensa periódica, un espacio que Gálvez reconocía dominado por un pacto publicitario y comercial, que se

\footnotetext{
${ }^{206}$ Ideas, Año I, n 1, mayo, 1903, p. 86. Esta verdadera crítica ya se había anunciado en el manifiesto escrito por Olivera: "En nuestras secciones permanentes, donde se hará crítica verdadera, no soplarán venticelos cortesanos; será un pampero agreste y rudo. Y a su menor amago, el público percibirá crujidos de ídolos rotos", "Sinceridades", p. 10.
} 
traducía en "las exigencias del noticierismo" $" 207$ y en transacciones dudosas ${ }^{208}$, y por los que se veían comprometidos los valores de "imparcialidad" y especificidad de la crítica. En cuanto al público, Gálvez demarcaba dos estratos, cuyas imágenes eran contrapuestas. El primero de ellos era presentado como una materia maleable, y en ese sentido como víctima de la crítica que, al promocionar determinadas obras en función de acuerdos económicos con las empresas teatrales, no cumplía con la formación del gusto, una de sus tareas pedagógicas básicas. Gálvez se refería entonces al "público, el buen público, al que engañan" (87). Ese buen público podía identificarse con un estrato medio que consumía la crítica de los periódicos como guía cultural. La otra imagen, más negativa, se refería al público inculto del teatro Apolo, asiduo concurrente a las representaciones de la compañía de José Podestá, cuyas tragaderas admirables, deglutían las obras sin importar la calidad de los textos. ${ }^{209}$ Era este exceso del público, considerado como incapacidad de discernir la calidad de las obras, el que fundaba la necesidad de una crítica verdadera como la que la revista intentaba llevar adelante, batallando por legitimar un teatro que no se adaptara a los reclamos de los espectadores. ${ }^{210}$ Esta valoración de la crítica en relación con el público adquirió en

${ }^{207}$ Explica Gálvez: "El crítico, en primer lugar, obligado por las exigencias del noticierismo [cursivas nuestras] escribe su artículo en el más breve tiempo posible después de la representación (...)" (86). Más adelante: "Un crítico reputado exige de las empresas el pago de sus artículos [cursivas nuestras]. $Y$ yo os advierto que no es exigente: con poca cosa queda satisfecho. Otro hay, que juzga del mérito de las obras según la nacionalidad del autor. Otro hay, que es incapaz. Otro hay, que cuando se trata de elogiar al amigo o de adular, agota el diccionario. Otro hay, .... iba a decir mal: ahora es una empresa periodística que recibe varios miles de pesos, por sostener el interés de una temporada, cuyo resultado era dudoso en extremo. Otro..... pero es bastante. (...) Elogia el articulista para conseguir diversos fines: localidades para su familia y sus amigos, los favores de alguna actriz, o la subvención de la empresa [cursivas nuestras]. Ideas, Año I, n 1, p. 87. Las objeciones a la crítica fueron un leit motiv de las notas de Gálvez. Así, se refería a la "crítica prostituida" ( ${ }^{\circ}$ 3, TE: 3), a la mercantilización excesiva de la crónica teatral. Así se quejaba en 'Crónica del mes' del $n^{\circ}$ 15: "Todo lo ha invadido el negocio. Un reclamo de fajas eléctricas, como una crítica teatral, se pagan por centímetros". Ideas, Año II, nº 15, pp. 316-317.

${ }_{208}$ Ideas, Año II, n' 15, p. 316.

209 "Tenemos entendido que no faltan -y menos ahora- obras originales. ¿Por qué no se representan éstas, con absoluta exclusión de esas malas traducciones? El público, cuyas tragaderas son admirables y que es afecto en grado sumo a la compañía, no protesta de estos excesos. A la crítica corresponde hacerlo" p. 90.

${ }^{210}$ A propósito ¡Ya soy viejo! del uruguayo Enrique Crosa, Gálvez se refería al público en términos despectivos, principalmente porque lo asociaba con los géneros bajos pero exitosos: "Pero ya está visto que esta 'bestia enorme' como le llama D’Anunnzio, prefiere lo que adula sus groseros gustos, esos absurdos melodramas, donde se mezcla la dramaticidad más ridícula a la gracia ordinaria del sainete". Año 2, n 10, febrero, 1904, p. 190. TE: 7. 
Ideas un carácter dominante y no se limitó a la literatura y al teatro sino que alcanzó también al ámbito de las artes plásticas, desde el cual Martín Malharro, una de las voces más autorizadas, asignó a la crítica una función "moderadora" de los avances del comercio sobre "la buena fe" de los consumidores y compradores de arte aún inexpertos. $^{211}$

\subsection{En contra del criollismo: el gaucho se va.}

Desde su primera entrega la revista mostró de varias maneras su interés particular por el teatro. El hecho de que el primer escrito que se publicara inmediatamente después de "Sinceridades", fuera un fragmento de una obra teatral, $E l$ doctor Morris del chileno Alberto del Solar, y que hubiera una sección específicamente dedicada al "Teatro", ${ }^{212}$ a cargo de Gálvez, configuraban una insistencia e indicaban su relevancia en la publicación. Dicho énfasis, puede decirse, coincidió con la propia trayectoria escrituraria de Gálvez, quien por esos años, armaba su primer comienzo literario en relación con el teatro, hecho que ratificaría en "Un estreno accidentado", primer capítulo de Amigos y maestros de mi juventud, al afirmar que "Soñaba con ser autor" (Gálvez, 1961: 18). ${ }^{213}$ Como ya observamos, Ideas intentó promover una alternativa al consumo teatral de obras de signo criollista -pero también del sainete y del género chico- y ese anhelo tomó la forma de una diatriba en la que se atacaron tales representaciones, reputándolas anacrónicas en relación con una modernización que transformaba vertiginosamente la ciudad no solo en sus aspectos sociales y materiales sino también en su fisonomía cultural.

\footnotetext{
211 "De la crítica", en la sección "Pintura y escultura", Año I, n 1, mayo, 1903, pp. 56-63.

${ }^{212}$ Para el detalle de la sección, cf. el anexo específico TE.

${ }^{213}$ Las obras teatrales escritas por Gálvez fueron: El Destino (cuyos personajes eran gauchos, escrito en verso y con música de Carlos López Buchardo), La conjuración de Maza (drama en un acto que es el fruto de su lectura de la Historia de la Confederación Argentina de Adolfo Saldías), ambas de 1900, y una comedia, En las redes del amor de 1901. La conjuración de Maza fue adaptada como zarzuela, uno de los géneros denostados por Gálvez.

En cuanto a lo que Gálvez entendía por teatro, esto se aclaraba en la nota misma: no se trataba de literatura dramática sino de un espectáculo.
} 
La nota inaugural de Gálvez en 'Teatro' hizo visible la preocupación por el ascendiente $^{214}$ de los dramas criollos sobre los gustos de una franja de público -al que por eso mismo se descalificaba- y planteó la discusión que animaría las páginas de Ideas, directamente vinculada con la necesidad de los nuevos autores teatrales de legitimar sus obras y la temática que éstas diseñaban como la más apropiada para definir un teatro nacional. En ese sentido, aunque Gálvez concedía, y a disgusto, la relevancia de los actores criollos del Apolo en el origen del teatro nacional, ${ }^{215}$ sostenía que en la formación (ya no la fundación) de la escena nacional debían intervenir múltiples elementos, por lo cual no debía exagerarse el mérito de aquellos a quienes consideraba meros intérpretes. De este modo, Gálvez discutía con la vertiente popular del teatro y con los directores de las salas cuyas decisiones estaban más orientadas e interesadas únicamente en la rentabilidad, e intentaba privilegiar el rol central de los autores dramáticos por sobre las compañías. De esta forma, criticaba la política de representar traducciones y arreglos que, en su mayor parte, se regían por el criterio de la consagración previa y el éxito ante otros públicos y en el extranjero. Explicaba:

En todo caso, el papel de una compañía podría consistir en apoyar la formación del teatro [cursivas del Gálvez], protegiendo a los jóvenes que se inician, representando solamente obras

${ }^{214}$ Para 1903, el consumo de dramas criollos en Buenos Aires representa el $15 \%$ de las asistencias registradas. (Pasolini, 1999: 261) En ese sentido, puede pensarse que lo que preocupa es el éxito, es decir su visibilidad, y no la cantidad de obras representadas.

${ }^{215}$ Gálvez relativizaba: "Una compañía iniciada modestamente, ha atraído la atención de los inteligentes y del público. Su importancia, si bien exagerada por todos, no puede negarse, porque allí el teatro nacional ha tenido su origen. -Hablaremos de ella, pues, algunas pocas palabras.

En el teatro Apolo, se instaló, hace tres años, una compañía de actores criollos. [cursivas en el original] Venían del circo. Habían abandonado las piruetas del payaso y las contorsiones del acróbata, para vestir de chiripá y empuñar el facón, en los dramas primitivos que aún hoy suelen representarse en la pista de los circos, y que tienen casi todos, por argumento, el eterno tema del gaucho perseguido. No tardó mucho tiempo en que se produjese un cambio; con los antiguos dramas alternaron piezas nuevas, y quizá peores. En este tiempo, un director inteligente [Soria], comenzó a mejorar la compañía. Luego, Jesús Nazareno, todo un triunfo. Los intelectuales fijaron en el Apolo su atención y algunos llevaron sus producciones. El buen éxito de la compañía aumentaba extraordinariamente. Se observó que algunos actores no carecían de talento, y que algunas obras eran aceptables como Maula y Al campo.

En estos últimos meses la preocupación general por esta compañía ha sido notoria, habiéndosele asignado una importancia enorme. Se le ha atribuido la fundación del teatro nacional, como si un teatro, en este sentido, fuese algo que pudiera fundarse" [cursivas de Gálvez], pp. 88-89. 
originales y de estas las mejores, y valiéndose de otros muchos medios conducentes a ese fin. ${ }^{216}$

Así, Gálvez no se oponía a una alianza entre esos actores y la autores dramáticos jóvenes, sino que la promovía. De tal modo, reforzaba ese movimiento de la cultura letrada hacia la cultura popular, en un intento por cooptar al público que los Podestá habían venido construyendo en Buenos Aires desde 1900. ${ }^{217}$ Esa cooptación, como anotaba en una entrega posterior, se realizaría lentamente y a través de obras en las que los autores fueran modificando y modelando los gustos y lograran dar forma a un teatro nacional (a la vez universal y moderno), vehículo de "enseñanzas proficuas, tan hondamente intenso".218

Mientras que en la primera nota Gálvez intentaba disputar un lugar para los jóvenes dramaturgos, argumentando y proponiendo una alianza entre actores, empresas teatrales y autores argentinos, en la segunda entrega de la revista indicaba que el teatro nacional debía sustituir al gaucho y su medio social por otros personajes y, sobre todo, escribirse en una lengua estándar, comprensible para todos, es decir, una lengua literaria basada en aquella de la alfabetización estatal:

¡El gaucho en escena! Es el asunto de siempre. Alguien ha dicho que sin él no hay teatro nacional. Y por desgracia, desde hace varios años, vemos desfilar por los escenarios con impasibilidades de resignado, toda una falange de emponchados, con facón al cinto y trabuco en mano. Y hablan en su

\footnotetext{
${ }^{216}$ Recordemos que en 1901 José Podestá rechazó La conjuración de Maza de Gálvez, que finalmente fue representada por la compañía española del teatro Rivadavia.

${ }^{217}$ Es necesario observar que en la reconstrucción que hacía en sus memorias Gálvez otorgaba a los Podestá -de quienes se decía amigo- mayor importancia en relación a la "formación" del teatro argentino que en 1903. Así se ve claramente la índole estratégica de sus afirmaciones respecto de estas compañías de actores, cuyas obras había presenciado muchas veces, y cuya temática y personajes había copiado en El destino. Además, el hecho de que los personajes de esta obra fueran gauchos mostraba claramente su intención de escribir para el público que consumía habitualmente ese tipo obras. Además, en el final de esa misma nota, al referirse a Lo irreparable arreglada por Héctor Quesada para el Apolo, elogiaba al "simpático criollo don Camilo" como lo más interesante de la versión argentina. p. 94

Cuando nos referimos a 1900 como el momento en que los Podestá comienzan a formar un público para su teatro, no ignoramos que estos actores ya contaban con un público para sus representaciones. La fecha indica el momento en que los Podestá se instalan en el teatro Apolo y en la Comedia, con lo cual sus representaciones adquieren regularidad.

${ }^{218}$ Ideas, Año I, nº 4, agosto, 1903, pp. 381-391, TE: 4.
} 
lenguaje peculiar, lleno de modismos, refranes extraños y palabras no usuales; citan plantas exóticas y pájaros raros, conocen el guaraní y hablan mal el español. ${ }^{219}$

Al mismo tiempo que los ataques al criollismo en su versión popular daban cuenta de la importancia que se le asignaba en Ideas, el juicio sobre la representación de Lázaro, drama en verso escrito en 1869 por el doctor Ricardo Gutiérrez, intentaba clausurar un ciclo ubicándolo en el pasado como objeto de evocación y, por lo tanto, expulsándolo del presente teatral; de ese modo, Gálvez habilitaba el cambio de temática, de personajes y medios sociales, fundado en la demanda de adecuación de las obras con su contemporaneidad modernizada. La tentativa de Gutiérrez valía, además, porque este gaucho, que anunciaba su partida, se expresaba en un registro literario y culto del español, y no en la lengua incomprensible de un criollismo bastardo:

Lázaro es, sin duda alguna, el último gaucho cantor que pasa por nuestros escenarios. La Pampa, que evocó tantas veces nuestro espíritu, el sonido doliente de las cuerdas de la guitarra, se va con sus gauchos para siempre, a refugiarse en el olvido de las cosas viejas. Y ese Lázaro, el protagonista de un drama salvaje pero evocador de un mundo nuestro, se aleja del escenario donde vivieron sus hermanos de leyenda, -Martín Fierro, Santos Vega, Calandria,- entre flores, en plena pampa, al gemido de un triste inmensamente poético. Y antes de irse, amargamente, nos dice con los versos del más exquisito poeta en lengua española:

Yo soy el postrer gaucho que parte para siempre/ De nuestra vieja patria llevando el corazón. ${ }^{220}$

En relación con este alejamiento deseado del gaucho, que, dicho sea de paso, se hacía efectivo en las obras representadas, ${ }^{221}$ las notas que Juan Pablo Echagüe,

\footnotetext{
${ }^{219}$ Ideas, Año I, $\mathrm{n}^{\circ} 2$, junio, 1903, p. 196.

${ }^{220}$ Año I, $n^{\circ} 7$, noviembre, 1903, pp. 309-312. TE: 6. Cursivas nuestras.

${ }^{221}$ El doctor Morris de Alberto del Solar; M'hijo el dotor de Sánchez, Canción trágica de Payró, Próspera de Peña, Jetattore de Laferrere, Sacrificio de Méndez Caldeira, Alborada de Enrique García Velloso.
} 
colaborador de Ideas, publicaba por ese tiempo en el diario El País, ${ }^{222}$ precisaban el alcance que en la prensa tenía esta polémica y enunciaban de manera explícita la poética que se intentaba promover. La crónica escrita en ocasión del estreno de Sobre las ruinas de Roberto Payró, en mayo de 1904, era significativa porque a la vez que señalaba para el teatro una orientación sociológica e indicaba, por lo tanto, una intención cognoscitiva respecto del proceso histórico nacional, se hacía eco y respondía al escrito “¡El gaucho se va!” del tucumano Alberto Rougés, aparecido en Ideas, quien lamentaba la desaparición del gaucho, y lo elevaba a una categoría mítica. ${ }^{223}$

Sobre las ruinas, envuelve un hondo pensamiento sociológico. Estudia el problema importantísimo de la evolución del campesino, que es, en cierto modo, toda nuestra historia. Una literatura miope ha venido lamentando en prosa y en verso la lenta pero fatal desaparición del gaucho. 'El gaucho se va -decía- se va el trovador de la pampa, el tipo legendario de la nobleza y el valor criollos, la carne de cañón de nuestras guerras'. Y bien ique se vaya enhorabuena! El gaucho es un personaje anacrónico, encarnación de energías regresivas, el gaucho es rémora, el gaucho es obstáculo que nos barrea el camino hacia el progreso (Echagüe, 1919: 26) [cursivas nuestras]

De este modo, el teatro al que siempre adjetivaba como "nacional", representaba para Echagüe una práctica cultural eficaz en la constitución de una sociedad cuyos valores, costumbres e ideas debían buscarse no ya en el pasado sino en el presente. Aunque se trataba, por supuesto, de un presente depurado también de

\footnotetext{
${ }^{222}$ Algunas de estas crónicas fueron reunidas en Un teatro en formación, editado en Buenos Aires, en 1919, por Tragant.

${ }^{223}$ Alberto Rougés participaría desde julio de 1904 en la Revista de Letras y ciencias sociales de Tucumán, dirigida por Juan B. Terán y Julio López Mañán. En el escrito se decía: "Esfuerzos inútiles ha hecho el payador por encerrar en estrofas aquellas llíadas americanas; para conseguirlo debieron ser pesadas aquellas cárceles de estrofas, hechas con hierro fundido en la inspiración, en la llama abrasadora que da un cerebro genial y gloriosamente incendiado. Por eso lleva su heroica historia el gaucho que se va. Ya sin vuelta, a desembocar en el olvido, dejando solo leves rastros de su paso.

Con el alma errante de los pamperos vivió en la tierra; hoy se va por no escuchar el crujido espantoso que, martirizadas en las máquinas, dan sus hermanas de crianza, las fuerzas antes rayos, tempestades ... antes salvajemente libres, hoy esclavas, hoy torturadas", Ideas, Año II, Tomo 3, no 11 y 12, marzo abril, 1904, pp. 314-316.
} 
nuevos personajes urbanos ligados a formas culturales populares como el tango o la milonga, de los que los llamados "géneros malsanos"224 -sainete, melodrama, género chico $^{225}$ - ya se habían apropiado.

Por su parte, en "Fomento del teatro nacional", publicada en junio de 1903, el autor teatral y periodista David Peña, retomaba en clave ficcional los aspectos que los redactores de la revista habían tematizado en las notas críticas acerca de la posibilidad de formación de un teatro propio. El escrito interesaba porque imaginaba una relación mutuamente beneficiosa entre mercado y cultura, en la cual la cultura, tomando como paradigma la organización empresarial de una sociedad anónima, era considerada como un producto económico y simbólicamente redituable, incluso para aquellos que no pertenecían al ámbito del arte. Se trataba de la conversación entre un "gran señor" miembro del poder económico y político -definido por los espacios que le eran propios (La Bolsa, la Casa de Gobierno)- y un representante del teatro, quien intentaba convencerlo sobre las ventajas de participar como accionista en la sociedad anónima que promoviera el teatro y protegiera a sus miembros, autores y profesores. Según Peña, el teatro nacional debía constituirse a partir del público, el autor y el asunto, elementos que, aunque existentes, se hallaban "dispersos". Cuando se le preguntaba sobre lo que consideraba teatro argentino, el hombre de negocios afirmaba que era el de los hermanos Podestá: los dramas criollos del Apolo o del Rivadavia (cuyos protagonistas son el gaucho, la china o el compadre, la guitarra; en las que hay el pericón o el gato con canciones o estilos de la tierra ${ }^{226}$ y cuyo argumento es casi siempre un suceso de policía)". El interrogado agregaba "el género chico del país que se representa en el Mayo, la Comedia o en el Victoria”. Peña indicaba el carácter limitado de estos dramas, y, además, exhortaba a los autores a incluir otros personajes

${ }^{224}$ La expresión "género malsano" pertenecía a Gálvez. La empleó en el n 4 para referirse al melodrama Cristian de Ezequiel Soria, que se representaba en el teatro de la Comedia. Año I, n 4, agosto, 1903, p. 382.

${ }_{225}$ Según Luis Ordaz, el auténtico iniciador del género chico criollo fue Nemesio Trejo. Inspirado en el género chico español, los tipos peninsulares como las verbenas, el chulo o la chulapa hallaron sus equivalentes en las milongas, el compadrito porteño y la taquera de barrio.

${ }^{226}$ En cursiva el texto de Peña. El autor definía el múltiple servicio social del teatro: para el país en tanto elemento representativo de su cultura, para el dramaturgo al que posicionaba hacedor de una obra útil, para "la niña honesta, inteligente, anónima como para el joven que va por ahí, sin rumbos y aun sin fuerzas, seducido por una vocación no comprendida", era claramente un formador de valores morales. Ideas, Año 1, n² 2, mayo, 1903, pp. 195-199. 
y otros argumentos, porque "ya va para años con esto de los Moreiras, más o menos pendencieros", y desde lo institucional proponía crear espacios específicos conservatorio, escuela de teatro- para la formación de actores nacionales cuyo modelo era europeo (Clara della Guardia, Reiter, Tina, Calvo, etc.). El autor de Próspera comedia en la cual Peña "se atreve a decir al público todas las vergüenzas y las hipocresías de que vive esta aristocrática sociedad criolla"-227 legitimaba la necesidad de un nuevo teatro, asignándole funciones pedagógicas, orientadas a corregir vicios, castigar costumbres, vencer enfermedades. También era el instrumento para impulsar la recuperación de personajes de la historia argentina, a los que estimaba representativos de la nación, a diferencia de "los Moreiras". ${ }^{228}$ Así, Peña, que trazaba un mapa de la escena teatral popular de Buenos Aires, señalaba el imperativo de promover una oferta distinta a través de la creación de una institución específica que combinara los aspectos gremiales con aquellos relativos a la formación de sus profesionales. La sociedad, a la manera de la Sociedad de Autores Dramáticos de París, tendría como fin proteger a sus miembros, y demandaba la contribución del Estado a través de becas para subvencionar a los jóvenes que quisieran dedicarse al teatro. Así, los autores se beneficiarían con la representación y explotación de sus obras, los profesores con una cátedra, y los accionistas con dinero y con el prestigio de figurar "entre los fomentadores de este patriótico anhelo". ${ }^{229}$ Aun teniendo en cuenta un carácter sumamente optimista y por consiguiente, un tanto ingenuo de este escrito y de su autor, como "apóstol un tanto iluso del teatro nacional” (Echagüe, 1919: 37), el intento de Peña no podía ser tildado de irrelevante. Tres años después, encontraría en las crónicas de Roberto Payró en La Nación, su traducción en una campaña activa. Esta militancia tuvo resultado la creación de una primera Sociedad de escritores, a la que adhirieron, además del propio Payró, Becher, Gerchunoff, Gálvez y gran número de autores teatrales. ${ }^{230}$

${ }^{227}$ Gálvez, Año I, nº 6, octubre, 1903, pp. 229-232. TE: 5 .

${ }^{228}$ Se preguntaba: “¿No hay vicios que corregir, costumbres que castigar, enfermedades que vencer como las que agitaron noblemente al genio de Goldoni, Moreto, Lope y Alarcón?", Ideas, Año I, $\mathrm{n}^{\circ}$ 2, junio, 1903, pp. 123-124.

${ }^{229}$ Ideas, Año I, n 2, junio, 1903, p. 127.

${ }^{230}$ Las crónicas de Payró de 1906 fueron: "Crónica del día: la casa de los que no la tienen" (18/09), "Crónica del día: El hogar intelectual" (26/09), "Crónica del día: La Sociedad de escritores" (27/09). Según Payró en la primera de esas crónicas, tal sociedad sería "(u)n círculo literario que participara de los atractivos de un punto de reunión, de un club, si se 


\subsection{La sociedad de bombos mutuos: La encuesta a propósito de Sobre las ruinas}

Las notas sobre teatro hicieron evidente la creencia en la eficacia del género como modelador de conductas y factor determinante en la edificación de valores positivos, a través de obras nutridas en una temática fuertemente marcada por los signos de una modernización socialmente conflictiva, con respecto a la cual piezas dramáticas eran imaginadas, desde su especificidad cultural, como soluciones posibles. De esa poética surgieron personajes que, como los estratos de público, fueron también polarizados y remitieron al enfrentamiento entre lo rural en retroceso y lo urbano en ascenso; se propiciaron obras en las que "vibraba" el trabajo o la idea de reconstrucción sobre los fundamentos mismos de un pasado ruinoso (Viñas, 1986: XII) galvanizada en el matrimonio entre los hijos de los criollos y de los inmigrantes. En efecto, Ideas impulsó y acompañó un teatro de ideas, por medio de una crítica también anclada en un realismo costumbrista y naturalista, que postulaba -y exigía- el ejercicio de la mimesis como recurso óptimo para escenificar la modernidad social. En ese sentido, si la literatura dramática nacional se desarrolló apegada a las circunstancias sociopolíticas, en las que encontró los referentes indispensables para configurarse (Cazap, 2002: 92), Ideas, en su limitado espacio de circulación, tuvo un papel que simbólicamente no puede calificarse como desdeñable, en cuanto a la promoción de esa vertiente culta como representativa de la escena nacional. En la revista, tal campaña se ligó directamente con los vínculos problemáticos entre autores y mercado teatral -la situación de los dramaturgos, en términos generales, era precaria o de indefensión- y tuvo su momento más alto en la publicación de una encuesta a propósito de Sobre las ruinas de Roberto Payró.

quiere y de las ventajas positivas de una sociedad como la de Gens de Lettres y de Auteurs Dramatiques de París", en la que, al mismo tiempo que se realizara un intercambio de ideas y la sociabilidad intelectual, fuera una sociedad práctica que defendiera los derechos y deberes de los escritores y autores dramáticos, que estaban merced de editores y de empresarios teatrales. En la segunda crónica pasaba revista a los problemas que esta sociedad intentaría paliar entre los que se contaban la propiedad literaria indefensa, "la injustificada carestía del libro argentino", "la imposibilidad de escribir, fuera de los diarios, sin tener rentas, un empleo en el gobierno y quien publique", el "yugo que las empresas teatrales ponen al cuello a los autores". Crónicas reunidas en Rivera, 1993: 95-102. Finalmente, la Sociedad Argentina de Escritores fue creada en 1928. 
Ideas espectacularizó la intención de disputar un espacio en la escena teatral, que juzgaba dominada por las representaciones de los dramas criollos, para lo cual la figura de la que se sirvió fue, como en el caso de la 'Biblioteca de La Nación', Roberto Payró, cuyo drama había sido publicado en el $\mathrm{n}^{\circ}$ 11-12. Con motivo del primer año de vida de la revista tuvo lugar un banquete, que los organizadores calificaron como "fiesta de arte", y que más allá de su carácter autocelebratorio, constituía uno de los modos en que se corporizaba la hermandad intelectual como la sociabilidad literaria típica entre escritores. ${ }^{231}$ En ese banquete, "en lugar de los discursos de práctica" se distribuyó, por iniciativa de Juan Pablo Echagüe y de Antonio Monteavaro, una encuesta sobre esa obra de Payró, motivada por la negativa de los empresarios teatrales Pepe y Pablo Podestá a representarla en la Comedia y en el Apolo. Como forma específica de intervención literario-artística, puso de manifiesto las relaciones conflictivas entre los escritores y el mercado de bienes simbólicos. Las preguntas que componían la encuesta eran ya una evaluación y orientaban las respuestas:

1. ¿Qué opinión le merece la obra de Payró, rechazada por las empresas teatrales: Sobre las ruinas?

2. ¿Cree usted que debe ser representada?

3. En caso afirmativo ¿qué medio cree oportuno para conseguir su representación? . ${ }^{232}$

Como contrapartida de la forma en que se tomaban las decisiones en dichas empresas, las preguntas apuntaban hacia un criterio de evaluación fundado en la calidad estética y propio de escritores e intelectuales, a la vez que retomaban las cuestiones que tanto la causerie de Peña como las notas de Gálvez y de Abel Cháneton habían juzgado capitales para el teatro nacional. La mayoría de las respuestas, publicadas en el ${ }^{\circ} 14$, coincidían en que Sobre las ruinas era un hito del teatro argentino, y un caso que

${ }^{231}$ Estuvieron presentes José Ingegnieros, David Peña, Osvaldo Saavedra, Carlos Octavio Bunge, Félix Lima, Lorenzo Fernández Duque, Ricardo Rojas, Julián Aguirre, Abel Cháneton, Atilio M. Chiappori, José Ojeda, Antonio Monteavaro, Manuel Gálvez (hijo), Roberto J. Payró, Alberto Gerchunoff, Emilio Becher, Juan Pablo Echagüe, Justo Solsona Jofre, Alfredo Arteaga, Salvador Oria y Ángel M. Novillo Linares. Se excusaron Francisco Sicardi, Alberto Williams, Mario Saénz, Ricardo Olivera, Roberto J. Bunge, Carlos Vega Belgrano, Eugenio Díaz Romero, Héctor Muñoz, Carlos de Soussens, Julio A. Rojas." Ideas, Año II, $n^{\circ}$ 14, junio, 1904, p.203.

${ }^{232}$ Ideas, Año II, no 14, p. 204. 
actualizaba las consecuencias de una actitud no condescendiente con los condicionamientos de 'representabilidad' que el mercado imponía a las obras. En casi todas las opiniones se registraba un desacuerdo programático y maniqueo frente a las decisiones del mercado teatral, que condujo a situaciones ridículas como la respuesta de Ricardo Rojas: aunque manifestaba no haber leído el drama, lo consideraba como tal, representable. Para David Peña se trataba de una obra de calidad con "grandezas de Shakespeare aunque poco apta para el público de compañías como la de José. J. Podestá; Carlos Octavio Bunge aprobaba su representación y proponía formar una “compañía seleccionada de artistas argentinos", punto en el que acordaban Novillo Linares, Gálvez, Lorenzo Fernández Duque y Alfredo Arteaga. Por su parte, Antonio Monteavaro, siguiendo el ejemplo de la Comédie Française, pretendía que el Estado con su protección, fomentara la existencia de un "teatro de artistas" encargado de decidir qué obras destinar al conocimiento del público. Otras respuestas, como la de Echagüe, ponían en primer plano el valor ideológico de Sobre las ruinas, al margen de su escasa "plasticidad escénica"; Becher la elogiaba como "obra de 'ideas"”; Solsona Jofre destacaba la tesis desarrollada; Salvador Oria la consideraba como un "estudio sociológico oportuno del ambiente 'nacional' hecho con amor y, en cierto modo, con arte dramático"; según Osvaldo Saavedra debía representarse "porque envuelve una idea sociológica que satiriza la barbarie campesina"; a su turno, Gálvez sentenciaba que no existía en la Argentina "nada que pueda compararse con Sobre las ruinas".

Por último, un reclamo subyacente en la mayor parte de las respuestas, y que Monteavaro había hecho explícito, era la posibilidad de que el teatro nacional fuera más que un mero emprendimiento comercial, y que por consiguiente, las empresas particulares no tuvieran el poder absoluto en la selección de las obras que el público debía conocer y consumir. La encuesta significó una intervención directa sobre las decisiones empresariales y la obra de Payró finalmente fue representada por la compañía de Jerónimo Podestá en la Comedia. Ideas interpretó esto como una victoria del arte verdadero por sobre el mercado teatral, y en ese mismo sentido, como triunfo parcial en favor de la autonomía de los escritores. También lo vio como mérito de la revista, que entonces ganó notoriedad y reconocimiento en tanto grupo intelectual, 
fundado en el peso de la palabra colectiva y de su autoridad específica. ${ }^{233}$ Como logro grupal constituyó, además, un programa de acciones por parte de los representantes jóvenes de la alta cultura en modernización, para quienes la crítica especializada debía ser el modo propio en el que se consagraran las obras; tal crítica encontraba su sede en las revistas especialmente creadas para ese fin, y perseveraba en diferenciar este tipo de publicación del resto de la prensa. En la sección 'Teatros' del nº 17, Abel Cháneton reconocería esta misma significación e insistiría en el valor y en la efectividad de la acción común de los intelectuales, frente a las pretensiones del mundo mercantil. En una estrategia de autoconsagración, Cháneton sobredimensionaba el resultado, la obra y la labor de los miembros de Ideas:

El triunfo de "Sobre las ruinas..." es un triunfo colectivo. Los honores de la jornada corresponden por igual a Payró, glorioso autor, a Ideas y a toda la intelectualidad argentina. Como que importa la primera batalla ganada contra el mercantilismo miope y tiránico de empresarios torpes. El drama que el público consagró la noche de su estreno, con la ovación más grande que a autor nacional se haya hecho nunca, fue rechazado en dos teatros (...) Se ha escrito tanto acerca de "Sobre las ruinas" que resultaría pesado insistir. ${ }^{234}$

${ }^{233}$ En cuanto a este punto es significativa la lectura retrospectiva de Gálvez sobre la encuesta, cuyos resultados generales reseñaba, y al hacerlo exhibía el carácter estratégico de casi todas las opiniones, sobre la primera pregunta. Gálvez ironiza: "A algunos se les fue la mano en el elogio del drama: Peña encontró en él 'grandezas de Shakespeare' y Gerchunoff declaró que 'haría honor a cualquier teatro extranjero' y que Sudermann podría firmarlo." (Gálvez, 1961a:187)

Cuando en Visto y vivido Roberto Giusti se ocupaba de Payró en el contexto de las reuniones y encuentros en cafés literarios del "primer novecientos", refirió en estos términos la significación de la encuesta. Giusti sugería que la operación tuvo por objeto la legitimación del grupo de Ideas como grupo crítico que logra imponer su palabra, que la de la obra Payró, en tanto este último, aunque aún no hubiera publicado El casamiento de Laucha, ni Divertidas aventuras del nieto de Juan Moreira, era ya un escritor conocido como autor de los cuentos de Pago chico y La Australia Argentina" (Giusti, 1965:102). Ideas, Año II, n 17, pp.98-99.

${ }^{234}$ Finalmente, la confrontación con el mercado teatral, volvió a hacerse presente en la pluma de Monteavaro en "Otra obra de Payró", nota que escribiera sobre Triunfador (1897) también de Payró. Se supone que la obra era una versión primigenia de El triunfo de los otros (1907) pieza que, precisamente, tematizaría en la figura de Julián, las condiciones del escritor-periodista explotado que, escribiendo para otros no lograría jamás el reconocimiento público. La importancia del escrito residía en colocar en el centro la disputa por la legitimidad de la representación de la comunidad nacional, a través un teatro que, como el de Payró o el de Sánchez, abrevara en una temática lo suficientemente amplia como para condensar "los múltiples caracteres de la idiosincrasia nacional". Decía Monteavaro: "Los pipiolos de Talía, todos unilaterales en su concepción, salvo contadas y plausibles excepciones, solo 
En el marco de un discurso espiritualista explícito, Ideas desarrolló un movimiento hacia el mercado que debe leerse como respuesta de los intelectuales jóvenes que percibían la necesidad imperiosa de construir un público para el teatro y la literatura nacionales en vías de autonomización. De esta manera, la revista construyó más allá de ciertas contradicciones- una visión positiva de un mercado posible en relación con el cual imaginó las condiciones y las formas de su propia intervención. Esa visión optimista se manifestó en la incorporación de una serie de marcas del espacio de la prensa periódica, que la revista tomó como modelo, y que aparecieron tematizadas en la puesta en ficción de la publicidad de bebidas y de la causerie de David Peña. Para el caso del teatro, se trató de asignar un rol central a los autores por sobre las compañías y los empresarios, y favorecer una alianza entre los autores nacionales y las compañías, en la cual se privilegiara la representación de obras originales por sobre las traducciones. El teatro se mostraba, además como el espacio particularmente apropiado para la interpelación de un público más amplio, cuya existencia efectiva se verificaba en el consumo de los dramas criollistas, un público cuyo gusto debería depurarse por medio de los dramas nacionales de ideas. Para la novela, Ideas enunció una propuesta precisando un tipo de relación con el mercado en función de la cual se piensa la posibilidad efectiva de una existencia pública y más autónoma de la literatura. A partir de este trato efectivo con el mercado a primera vista inesperado, que se diferenciaba de los propósitos industriales que según Ideas eran inherentes a ciertos productos de la cultura popular, la novela fue considerada como un género adecuado para la construcción del público, sin que eso significara dejar de lado propósitos más espirituales y elevados. Novela realista moderna, que diera cuenta de las transformaciones del mundo contemporáneo de sus lectores, escrita en una lengua literaria legible -cuyos parámetros fueran claridad, precisión y sencillez-, y vendida a precios económicos, tal el ejemplo aprendido con la Biblioteca de La Nación. ${ }^{235}$

deleitaban su pluma en el corral de la estancia, empapando, la producción obtenida, a guisa de desinfectante, en una chirle solución de romanticismo hemorroico. (...)

Hay en el ambiente otros sentimientos, otras ideas, otras tendencias e individuos, que merecen destacarse a fin de constituir, con elementos complejos, un todo homogéneo cuya resultancia sea el alma argentina". Ideas, Año II, n 18, octubre, 1904, pp. 218-219.

${ }^{235}$ María Teresa Gramuglio ha observado que Gálvez fue el novelista adecuado para el momento adecuado. En ese sentido, sostiene que aunque sus novelas incorporaban muchas de las convenciones de la literatura trivial de los folletines como podían serlo las 
tramas lineales, los personajes estereotipados o las moralejas, "por el mayor cuidado de la composición por el uso de un lenguaje culto pero que no desafiaba la competencia de los lectores, e incluso por la mayor extensión y el formato de libro" fueron aptas para interesar a un público nuevo. (Gramuglio, 2002b: 151). 


\section{Capítulo 3: Nosotros: el amplio espejo de la cultura nacional}

\section{Presentación}

La revista Nosotros, a diferencia de las otras publicaciones del corpus, y más allá de las dificultades efectivas que debió salvar durante sus primeros años, tuvo una vida extensa. Este rasgo remite, por una parte, a la existencia de un colectivo cultural al que pertenecía el núcleo de quienes la realizaban, directamente vinculado con el espacio universitario. Se trataba de egresados o estudiantes de La Facultad de Filosofía y Letras quienes en su intento de ingresar en la literatura, hicieron de la inserción institucional una característica propia ${ }^{1}$, invirtiendo así una valoración negativa de la universidad inmediatamente anterior como la manifestada por de Ideas. ${ }^{2}$ La existencia misma de la academia marcó una fase en el proceso de diferenciación de la literatura y convirtió al estudioso, al crítico y al profesor en figuras de referencia, y a obras y autores en objeto de un estudio detallado y necesario. Por otra parte, Nosotros se vinculaba con la existencia de un público relativamente más amplio, de clase media, social y culturalmente equiparable con los directores y colaboradores. Además, mientras que para los jóvenes de Ideas habían seguido funcionando como formas de legitimidad y autorización literarias, las inherentes al capital social, en el caso de los miembros de Nosotros, se forjaron y demandaron otros criterios dado que muchos de ellos eran sujetos hijos de inmigrantes, carecían de relaciones sociales y su vínculo con la cultura no podía sustentarse en el pasado familiar. ${ }^{3}$ Como parte de sus estrategias de

\footnotetext{
${ }^{1}$ En ese sentido, Gálvez señalaba la Facultad como el punto de procedencia novedoso de escritores e intelectuales: "Estos muchachos, en su mayoría, eran o estudiantes o egresados de la Facultad de Filosofía y Letras. Su entrada en la literatura significaba una curiosa novedad, pues hasta entonces habíase considerado a la Facultad de Filosofía y Letras como casi inexistente. El haber echado al mundo una docena de escritores era una razón de existir para esa cenicienta casa de estudios, que más de una vez hubo de ser suprimida de un mandoble por la disimulada barbarie de nuestros políticos", (Gálvez, 1961a: 288). [cursivas nuestras]

${ }^{2}$ En 1903 Ricardo Olivera sentenciaba: "No hay universidades ni universitarios. La grave y solemne escolástica desterrada de todas las escuelas europeas, hace vid en nuestros claustros todavía coloniales. Las facultades son siempre escuelas profesionales donde todos corren detrás del diploma, sin querer saber si fuera de los textos que proporcionan las nociones necesarias para balbucear exámenes y aprobar cursos, hay algo digno de ser leído y meditado. Y los ya graduados no estudian porque ignoran lo suficiente para creer que saben demasiado". Ideas, Año I, nº 1, mayo, 1903, pp. 5-6.

${ }^{3}$ Gálvez los calificaba de "desconocidos", a excepción de Álvaro Melián Lafinur y Hugo de Achával "de vieja estirpe intelectual y social argentina". Más adelante aclara que eran desconocidos porque eran "unos chiquilines". (Gálvez, 1961a: 289)
} 
autorización en un mundo cultural en que los miembros de la revista no dejaron de ser considerados como advenedizos por algún joven observador contemporáneo, Nosotros cultivó, con una constancia insuperada, diversas formas de una sociabilidad literaria marcada por la horizontalidad y la hermandad, que funcionaron además, como modos de cohesionar no solo a los jóvenes, sino también a individuos de otras promociones intelectuales, como sucedió con Rafael Obligado o Martiniano Leguizamón.

El análisis de la publicación entre 1907 y 1913 muestra cómo, desde sus páginas, se fueron definiendo y también volviéndose más efectivas, nuevas formas de ingreso en el mundo intelectual y literario, ligadas con una política de democratización cultural; además, permite observar el ascenso temprano y la posterior centralidad de las temáticas relativas a la identidad nacional, y en ese proceso, enfatizar el carácter definitivamente nacionalista de Nosotros en su conjunto -no ya atendiendo exclusivamente a un recorrido crítico centrado en las inflexiones más visibles de ese proceso. ${ }^{4}$ Asimismo, este análisis da cuenta de un modo de intervención de los intelectuales marcado por una relación no orgánica con las políticas del Estado sino principalmente mediado por el lugar que ocupaban en el campo literario en emergencia (Gramuglio, 2002 c: 37-50). ${ }^{5}$ Desde la perspectiva del nuevo tipo de intelectual universitario que la revista contribuyó a forjar, que en sintonía con algunas intervenciones de Ideas combinaba el estudio riguroso con los atributos de la salud, la potencia y la virilidad, el desarrollo de la investigación puede proporcionar, a su vez, una mirada sobre las respuestas culturales de las elites intelectuales y políticas de cara a las concreciones de la "masificación" y a la declinación de su propia eficacia. En ese sentido, es cierto, como señala Oscar Terán, que la crisis de legitimidad que el sector liberal afrontó desde el 90 se intentaría salvar recurriendo a "la transferencia de esa crisis hacia otra de identidad nacional, y [a] la implementación del reformismo político" (Terán, 1994: 28-31), en razón de lo cual, las intervenciones de los miembros de la revista en ese debate sobre la identidad nacional pueden leerse como parte de la

\footnotetext{
${ }^{4}$ Nos referimos especialmente a la reseña de La restauración nacionalista de Ricardo Rojas por Roberto Giusti, a la encuesta sobre Martín Fierro, y a la publicación del discurso inaugural de Rojas de la cátedra de literatura argentina. Cf. Anexo NOS para estas referencias.

${ }^{5}$ Así puede pensarse la figura de Ricardo Rojas en el apartado 5.5. "La discusión con los pares: el caso Rojas".
} 
lógica incorporadora propia de un proceso hegemónico. Sin embargo, no es menos cierto que esas intervenciones que discutieron las soluciones ideológicas más decididamente conservadoras imaginadas por esos años, hicieron de Nosotros un espacio cultural claramente progresista y democrático. De este modo, la revista no puede ser pensada como mero testigo, aunque lúcido, del proceso cultural argentino sino como un participante activo. ${ }^{6}$ En el terreno más circunscrito de la literatura, la revista, igual que Ideas, realizó una intervención fuerte en favor de las poéticas de orientación mimética tanto para la narrativa como para el teatro. Esta preferencia como veremos, despuntaría desde el inicio de Nosotros, y lo mismo que en Ideas tendría en Roberto Payró ${ }^{7}$ y en Florencio Sánchez, sus referentes ineludibles a los que homenajearían en diversas ocasiones. En evidente continuidad con la revista de Gálvez, el teatro ocupó un espacio privilegiado en la publicación, que intentó precisar y legitimar, a través de la sección 'Teatro nacional', las temáticas y géneros apropiados para las funciones morales que se le asignaba. Nosotros fue sede de una crítica literaria que se profesionalizaba en el contacto fluido con la academia, y a la que instaba a constituirse como estudio de largo aliento que debía alojarse indefectiblemente en el libro. En las secciones específicas, y en el ejercicio de una crítica que intentaba dar cuenta y fomentar una literatura nacional casi inexistente comparada con las literaturas europeas-, la revista explicitaría las atribuciones necesarias de una práctica que en el contexto de constitución de un campo autónomo, atemperaba y modificaba según el caso, las formas de la disputa intelectual, aunque no dejara de practicarla.

\section{1. Nosotros en el comienzo: inconclusión y continuidad}

\footnotetext{
${ }^{6}$ Aurora Ravina define a Nosotros como "testigo lúcido de la vida del país" e intenta dar cuenta, a partir de ese carácter testimonial, de las tradiciones políticas argentinas (Ravina, 1999: 58-60).

${ }^{7}$ La figura de Payró había sido en el terreno del teatro, central para ldeas. Nosotros reconocería a Payró como periodista y dramaturgo, y fundamentalmente promocionaría su obra narrativa.
} 
En agosto de 1907 dos jóvenes universitarios, italiano uno y descendiente directo de italianos el otro, Roberto Giusti y Alfredo Bianchi, ${ }^{8}$ publicaron en Buenos Aires el primer número de la revista Nosotros. En esa entrega inicial se anunciaban como secciones permanentes 9 'Opiniones' por Emilio Becher, 'Crónica extranjera' al cuidado de Joaquín de Vedia; Emilio Ortiz Grognet se ocuparía de 'Bellas Artes', Miguel Mastrogianni, de 'Música', y Benjamín García Torres de 'Cuestiones pedagógicas'; de 'Letras Francesas' se encargaría Atilio Chiáppori, de 'Letras Italianas’ Leopoldo Longhi, y Gerchunoff sería el redactor de ‘Letras Españolas’; Juan Más y Pí escribiría sobre 'Letras Portuguesas y Brasileñas', José M. Rizzi daría cuenta de 'Letras Hispanoamericanas'. Roberto Giusti llevaría adelante 'Letras Argentinas' y 'Teatro Nacional'; la responsabilidad de 'Revista de revistas' recaería en Alfredo A. Bianchi, y 'Notas y comentarios' en ambos directores. La breve nota ${ }^{10}$ que inauguraba esa entrega declaraba la aspiración de intervenir en el espacio de la cultura nacional pero también y más allá de ella, en la cultura sudamericana, como forma de conjurar el aislamiento que según los directores era el signo que la caracterizaba. El tópico no era nuevo, y ligaba a Nosotros con El Mercurio de América en esta vocación inicial

\footnotetext{
${ }^{8}$ La idea de fundar la revista pertenecía a Bianchi, quien ya tenía alguna experiencia como administrador de Rinconete y Cortadillo (1900; 6 números) junto con Enrique Rúas, que luego llegaría a ser director de de P.B.T; inmediatamente después, dirigió Preludios (1901-1902; 41 números). En sus recuerdos literarios Giusti citaba un pasaje del cuaderno personal de Bianchi, quien ya albergaba la idea de fundar otra revista: "A decir verdad, yo no fui el primer candidato a acompañarlo en la empresa, porque en un anotador conservado entre sus papeles, donde figuraban prolijamente escritas (...) las lecturas por él efectuadas de enero a julio de 1907, descubro al pie del nombre Vida que ocupa la primera página en grandes caracteres, la siguiente anotación, posterior después de veintiún años: 'Título que debió tener una revista que pensé fundar con Enrique Banchs a principios de 1907'” (Giusti,1965: 319-120).

La revista tuvo dos épocas. La primera va de 1907 a 1934 y se publican 300 números; la segunda, de abril de 1936 a septiembre de 1943 y se publican 90 números. Salvo el período que va de septiembre de 1920 a marzo de 1924, en que Julio Noé codirige con Bianchi la revista, los directores son siempre Giusti y Bianchi. Para una descripción más detallada de la publicación, véase el anexo correspondiente.

Roberto F. Giusti -quien se nacionalizó argentino- había nacido en Lucca, Italia, en 1887; Alfredo Bianchi, había nacido en 1883 en Rosario, de padre italiano y madre entrerriana.

${ }^{9}$ En el primer número Bianchi y Giusti figuraban como directores, y Alfredo Costa Rubert como administrador. Los responsables de las secciones formaban el 'Cuerpo de redacción'. No todas esas secciones se realizaron ni tuvieron el carácter permanente con que se las presentó. En el desarrollo del capítulo y en el anexo NOS se precisan estas cuestiones.

${ }^{10}$ Para la transcripción de la nota completa, Cf. NOS: 1. En adelante se citarán, para la argumentación, los pasajes significativos.
} 
continental. Esta introducción sirve para ver cómo tematizaba Nosotros el estado del mundo cultural, cuestión que a lo largo de los primeros años sería central:

Ningún otro anhelo anima a los directores que el de poner en comunión en sus páginas, las viejas firmas consagradas, con las nuevas ya conocidas y con aquellas de los que surgen o han de surgir (...) Nada de más urgente necesidad que la creación de sólidos vínculos entre los aislados centros intelectuales sudamericanos ${ }^{11}$

Este afán de "comunión" de Nosotros implicaba dos ideas al mismo tiempo, que eran pautas de conducta entre intelectuales: reunión y camaradería, y se relacionaba con lo que desde el modernismo y desde las otras revistas del corpus (La Biblioteca, El Mercurio de América, Ideas) y se había venido enunciando como necesidad en toda América hispana. Este afán surgía de la evaluación de un estado de cosas, que era presentado en la idea de vacio cultural, intelectual y literario. La respuesta de Nosotros consideraba el vacío como inconclusión y evaluaba su propia acción como continuidad. La carencia que señalaba la presentación de la coyuntura cultural enunciada como "vacío" se relacionaba con la dispersión, el aislamiento o la desunión, que se manifestaban en términos institucionales. De este modo, el afán totalizador de la revista se exhibía, justamente, en el tipo de sociabilidad postulada para los miembros del incipiente campo intelectual, y en el alcance de su participación dentro de ese espacio. En el mismo sentido debía leerse la sostenida voluntad incluyente que caracterizó a Nosotros, promocionada por Bianchi y por Giusti hasta la exasperación y que funcionó como programa, obstinada en construir solidaridades intelectuales entre los miembros de una misma promoción pero también entre quienes pertenecieran a generaciones diferentes. El pacto intergeneracional que proponía esta publicación de jóvenes, basado en la continuidad y en la no exclusión, se rubricaba en las colaboraciones presentes en la revista. Así, junto a los nombres de muchos redactores de Ideas o los de los directores, fue posible encontrar los de Martiniano Leguizamón, Antonio Dellepiane, Ernesto Quesada o Roberto Payró. En ese sentido, Nosotros no quiso ser la revista de una "formación" ni de una generación, hecho que hubiera

${ }^{11}$ Nosotros, Año I, Tomo I, agosto, 1907, n 1, p. 6. 
evidenciado el dominio de la diferencia y la ruptura por sobre la hermandad intelectual en que se fundaban las continuidades que pretendía construir. ${ }^{12}$ La continuidad era una estrategia de acumulación de capital simbólico, se regía por la idea de "sumar y no dividir" y explicaba el anhelo abarcativo de comunión intergeneracional y la relación fraternal entre todos, jóvenes y no tanto. Cuando se refiere a esta fase del campo, Leticia Prislei describe los vínculos entre intelectuales como un "pacto de sociabilidad" que sustenta aquella promesa de unión (Prislei, 1992: 41-59). ${ }^{13}$ Así, la cohesión grupal, que como la totalidad a que aspira puede ser improbable, se reasegura en esa intención de continuidad entre generaciones. La ausencia de capital social de los jóvenes que constituyen el núcleo central de Nosotros determinó el modo de su intervención en el intento de transformar ese vacío de autoridad social en un pleno de autoridad cultural. A la vez, esa estrategia fue funcional a la emergencia de un campo literario que venía demandado por la modernización. En ese sentido, sujetos como Giusti o Bianchi, marcados en su origen por el signo de la inmigración, fueron, al mismo tiempo, un exponente de los resultados de la modernización social y cultural, y la voz del reclamo por un espacio de circulación para la producción intelectual y artística.

La revista expuso su pronunciado afán totalizador en otro pasaje de la nota introductoria, al declarar la pretensión excesiva de ser el lugar de la afirmación y confluencia no sólo del presente ${ }^{14}$ sino también del pasado y del futuro, como

12 Las palabras de Gerchunoff en ocasión del cuarto año de vida de la revista lo confirmaban: "No funda ninguna tendencia, no es el órgano de cenáculo alguno. Acoge con generosidad tentativas juveniles y fomenta la labor mental con invariable energía. Su programa consiste en no tenerlo, lo cual hay que elogiar, pues esto excluye todo límite perjudicial y toda estrechez, todo prejuicio equívoco", Año V, Tomo VI, $n^{\circ} 32$, septiembre, 1911. (NOS: 93).

${ }^{13}$ Esa idea está presente en la retrospectiva de Giusti "La revista Nosotros y sus vicisitudes", al recordar el comienzo de la revista y evaluar sus relaciones tanto con los miembros del grupo que frecuentaba la oficina de Becher en La Nación, como con quienes se reunían en el café de Los Inmortales, y en la función de reconciliación que la revista cumplió entre ambos grupos. Así lo expone: "Se incubó la revista contemporáneamente en el ya dicho saloncito de Becher y en las mesas del café de Los Inmortales, dos zonas más o menos bohemias, recelosas una de la otra, sino en guerra declarada. Puesto entre las encontradas ojerizas, nosotros los reconciliamos en las páginas impresas y al cabo en la vida. Porque nuestro propósito fue unir y no dividir" (Giusti, 1957: 21-37).

${ }^{14}$ La revista se presentaba e insistía en afirmarse como vocación de presente, y eso hacía en cada uno de sus aniversarios. En 1911, y con motivo de su reaparición decía Giusti: "Nuestra aspiración no es la de dormir gloriosamente en las bibliotecas del futuro; es la de vivir, y muy despiertos, la vida del día, con todos sus afanes, sus contratiempos, sus 
dimensiones intelectuales y culturales. Nosotros, porque se pensaba a sí misma como el lugar de una afirmación, actualizaba dicho gesto en su nombre y en la primera frase de la "Presentación": "La revista ya lleva en su título una rotunda afirmación de sí misma" 15 . El "nosotros" del título podía leerse entonces como el sustituto de la cultura argentina (o de "nuestra vida intelectual" como la llamaba Giusti): la revista quería ser su "espejo", el sitio privilegiado de su representación. De esta manera, no definía $a$ priori -es decir, no excluía- un nosotros estético, político o ético. En esa intención de representarla, la cultura era recortada como una práctica necesaria y, de este modo, la revista autoproclamaba su acción como legítima, en una continuidad evidente con la publicación de Gálvez.

Ese primer número escenificaba la construcción del espacio y la función con que Nosotros se autodefinía. A la nota de apertura de la dirección le seguían dos escritos. El primero era un artículo de Rubén Darío sobre el relato de Roberto Payró que se publicaba inmediatamente después. Según aclaraban los directores en nota al pie, el relato de Payró era un fragmento del primer capítulo de una novela sobre Buenos Aires. La obra titulada Nosotros, ${ }^{16}$ había sido anunciada años atrás, y aunque no se había publicado era conocida en el círculo intelectual que rodeaba al escritor. ${ }^{17}$

satisfacciones morales." Nosotros, Año V, n 32, septiembre, 1911, p. 254.

${ }^{15}$ Nosotros, Año 1, no 1, p. 5.

${ }^{16}$ Con motivo de la celebración de los veinticinco años de Hispamérica, su director, Saúl Sosnowski, organizó un encuentro realizado en Buenos Aires entre el 27 y el 29 de septiembre de 1997, cuyos trabajos se reunieron en un libro, que es material de consulta ineludible para los estudiosos de revistas. Sin embargo, el trabajo sobre Nosotros consigna datos erróneos, con respecto a la revista Nosotros y de la obra homónima de Payró. Nicolas Shumway, autor del artículo, doctor en Literatura Hispanoamericana, quien fuera Profesor titular de Literatura Latinoamericana de Yale, señala que el capítulo de la novela inconclusa de Payró es un ensayo que se publica en las dos primeras entregas de la revista. Basta leer la nota de la dirección y hojear completo lo que cree ensayo para aclarar tales errores. Cf. Sosnowski, 1999: 165-180

${ }^{17}$ Estos datos se consignaban en la revista en nota al pie, con la primera parte del capítulo. Giusti, en la "Introducción" de la publicación especial del Fondo Nacional de las Artes, refiere que algunos fragmentos de la novela de Payró habían sido publicados también en La Nación, once años antes de 1907 (Giusti, 1971: I-XXXIX). Por otra parte, el domingo 14 de julio de 1896, en el $n^{\circ} 62$ de Buenos Aires. Revista semanal, se publicó otro capítulo de Nosotros titulado "El doctor Imbele". Allí reaparecía Teófilo Lové, el periodista del primer capítulo y se mencionaba como conocidos de Imbele a Holmberg y Guido Spano. Este doctor de cuarenta y dos años, quien nunca había ejercido la profesión, vivía de la fortuna que había heredado de su padre. Llevaba una vida dedicada al ocio y encarnaba un conjunto de valores negativos. Así, era desconfiando, avaro, egoísta, indiferente al arte y a la literatura; se burlaba de los que trabajaban y sentía desprecio por la humanidad. Más allá de su creencia en la debilidad de su salud, era fuerte y practicaba todo tipo de deportes. Debo el conocimiento de este capítulo al vasto conocimiento hemerográfico de Federico 
En la coincidencia entre el título de la novela y el nombre de la revista, estaba según Bianchi y Giusti, el origen de una transacción que convenía a Nosotros: ${ }^{18}$ usar el nombre de la novela a cambio de la publicación de su primer capítulo. La crítica de Darío, que ya había sido publicada en La Nación en 1896, resultaba significativa pues sugería un acuerdo básico entre el programa de la revista y el de la novela de Payró. Anotaba Darío: "meter la Argentina en un libro tarea es de dar temor. No hay un libro que contenga la Argentina"19. El plan de la novela de Payró, que el poeta nicaragüense refería y en el que se intentaba consignar las "cosas que los demás desdeñan, pero que constituyen nuestra originalidad", ${ }^{20}$ confluía con el proyecto de la revista en una misma idea abarcadora y representativa de la identidad cultural argentina. Como dijimos, la obra de Payró aún no había sido terminada, y este dato se tornaba relevante porque se relacionaba con aquella percepción inicial de vacío como incompletud, el cual ahora se presentaba en la forma de una novela inconclusa. Publicar en el comienzo de la revista una novela inacabada significaba definir la propia acción como vocación de continuidad. Si el género elegido para representar a la Argentina era la novela, y la novela en cuestión está todavía por escribirse, de manera análoga el colectivo cultural que encerraba el nombre de la revista se mostraba también como algo a construir, y era allí donde se volvía imprescindible la existencia de un espacio que, como esta revista, intentara condensarlo y representarlo.

La opinión de los directores sobre la obra de Payró -consignada en la nota al pie del texto de Darío- insistía en el anhelo de continuidad, presentado ahora en la forma de una tradición de literatura nacional. Y la tarea era puesta en manos de una crítica (la de los directores) cuya operación consistía en un trabajo sobre el pasado (que diera la

Bibbó. Beatriz Sarlo, en su cronología de Obras de Payró de editorial Ayacucho, consigna que en el $n^{\circ} 41$ de junio de 1912, la revista publicó otro capítulo de la novela. Sin embargo, el contenido del escrito, cuyo título es "Del lado de afuera" al igual que la nota al pie que solo consignaba que se trataba de un fragmento de un libro en preparación, no permiten considerarlo así. El relato, que es una conversación entre Jeohvah y Satanás, versa sobre la disputa entre la razón y la fe. Nosotros, Año VI, nº 41, junio, 1912, pp. 89-94. En NOS, se adjunta el capítulo del semanario Buenos Aires.

${ }^{18}$ En la "Introducción" a la Bibliografía, Giusti aclaraba que había sido Alberto Gerchunoff el que sugirió el nombre para la revista. (Giusti, 1971: I-XXXIX).

${ }^{19}$ Darío, Rubén, "Presentación a 'Nosotros' por Roberto J. Payró" Nosotros, Año I, nº 1, p. 11.

${ }^{20}$ Esta frase pertenece al periodista Lové, uno de los personajes de ese primer capítulo, quien declaraba, para luego abandonarla, la idea de escribir "un libro nuevo e interesante lleno de cosas que los demás desdeñan...” Año I, n 1, agosto, 1907, p. 16. 
propia versión acerca de ese pasado), pero sobre todo, en la posibilidad misma de prescribir esa tradición señalándola como necesaria. Aunque comenzara publicando dos escritos que ya contaban casi con diez años, la revista apostaba a la incorporación de los nuevos nombres de escritores e intelectuales, anunciando y designando a futuro los elementos que llegarían a conformarla. Así, el peso volvía a colocarse sobre el porvenir:

Como toda la obra de Payró - obra genuinamente nacional [cursivas nuestras] como lo atestiguan $L a$ Australia Argentina, y los cuentos de Pago Chico, y Sobre las ruinas, y El casamiento de Laucha- es una novela fuerte, sincera, que suple los vanos aristocratismos de forma por un concepto vigoroso y fecundo. Por eso, por lo que ha de representar en nuestras letras esta novela en cuanto aparezca, no hemos titubeado -apartándonos algo de nuestro propósito de no publicar sino páginas inéditas- de hacer preceder este fragmento que de ella insertamos, por un artículo que a su respecto escribiera Darío en 1896 en La Nación. $^{21}$

La crítica de Nosotros construiría su tradición nacional en la elección de una poética de representación realista de la sociabilidad argentina cuya figura paradigmática y más apropiada para la narrativa era Roberto Payró. La novela Nosotros cuyo tema era la Argentina, transcurría en la ciudad de Buenos Aires, a la que se consideraba como expresión de la República. José Inciente, hacendado y representante de los patricios de Buenos Aires $^{22}$ registraba la modernización de la ciudad, a la que regresaba después de catorce años de ausencia, y testimoniaba, no sin nostalgia idílica por el pasado, el pasaje de la gran aldea a la gran ciudad. La

${ }^{21}$ Nosotros, Año I, Tomo I, no 1, agosto, 1907, pp. 6-7.

${ }^{22}$ La llegada de Inciente a Buenos Aires se publicaba en la sección 'Vida social' de un diario de la capital, en el que trabajaba un amigo suyo, Gargol, quien ha escrito el suelto que sigue: "Tenemos el gusto de saber que ha llegado a esta capital, después de catorce años de ausencia y de paso para Europa, adonde va en viaje de placer, el distinguido hacendado don José Inciente, que tan estrechamente ligado está a nuestras viejas familias patricias" [cursivas nuestras], Nosotros, Año 1, $\mathrm{n}^{\circ} 1$, p. 14. Es interesante señalar que Inciente había pasado este tiempo de 'retiro' en su estancia, lo que reforzaba su posición conservadora y refractaria hacia la ciudad como espacio de la transformación descripta en el relato, y señalaba la propiedad de la tierra como definición y demarcación de los antiguos sujetos patricios. También, daba cuenta del viraje en la significación del término criollo, que como ya observamos -siguiendo a Adolfo Prieto- fue para los sectores dirigentes de la población nativa el modo de afirmación de su propia legitimidad y el rechazo de la presencia "inquietante" de los extranjeros. (Prieto, 1988: 18) 
conversación entre Inciente y su amigo de infancia Lové, permitía vehiculizar también otra visión del progreso, optimista y positiva, en la que se cifraba, como resultado y como fin, la constitución de la nacionalidad argentina, respecto de la cual la inmigración adquiría un rol definitorio. En este punto la novela de 1896, se mostraba, otra vez, asociada a las características del nuevo sujeto social y cultural (los inmigrantes y su descendencia) que la aparición de Nosotros, nueve años más tarde, ponía en circulación e intentaba legitimar, y que la novela de Payró mostraba como sujeto característico de un futuro más o menos inmediato. Así, desde la mirada de los directores, el valor de esta novela y del resto de la obra de Payró, se fundaba en su componente nacional porque lo representaba, y en la estética que adoptaba. La estética realista en la que se inscribía era útil para dar testimonio de lo genuinamente argentino ("nuestra originalidad") que la novela misma construía e identificaba con lo nuevo sociocultural. ${ }^{23}$ De este modo, la mezcla de las "razas" y de las costumbres diversas funcionaba como nutriente substratum de lo propio. ${ }^{24}$ La literatura de Payró democratizaba lo nacional, a través de la elección estética realista para poner en escena cuestiones relativas a la política estatal ${ }^{25} \mathrm{y}$ a otras formas de sociabilidad y costumbres producto de los cambios. Así, el periodismo como profesión y en particular el escritorreporter ${ }^{26}$ constituían la mediación y vehículo por excelencia de esas transformaciones.

${ }^{23}$ Darío ensayaba una tradición posible en la que se inscribiría el texto de Payró: "Intentas encerrar en tu libro a Buenos Aires. Tarea es. No conozco tampoco libro que la contenga. No cuento con lo antiguo. No me refiero sino a este Buenos Aires modernísimo, cosmopolita y enorme, en grandeza creciente, lleno de fuerzas, vicios y virtudes, culto y políglota, mitad trabajador, mitad muelle y sibarita, más europeo que americano, por no decir todo europeo. A mi memoria vienen a este respecto algunos nombres: Cambaceres, Juan Argerich, el autor de ¿Inocentes o culpables?, Miró con su Bolsa, y Sicardi con sus libros extraños. ¿Citaré al celebérrimo López Bago?" Nosotros, Año 1, no 1, p. 11.

${ }^{24}$ Lové actualizaba a su amigo:

“(...) Hace tanto tiempo que no ves esto! Hay que ponerte al corriente.

Buenos Aires, que despertaba, lanzábase a una vida múltiple y complicada, impelida por las fuerzas más diversas, en plena modificación del medio, de la raza, de las costumbres. Nada en ella era definitivo: de un día para otro todo variaba, desde el tipo de ciudad hasta sus habitantes. Cada raza nos traía algo de sus cualidades y defectos, y poco a poco esas razas iban confundiéndose, haciéndose una sola, cuya evolución estaría completa dentro de un tiempo relativamente corto. La mezcla de sangre traía la mezcla de costumbres, y la creación de un carácter propio.

-Nuestro cosmopolitismo va a ser nuestra nacionalidad". Nosotros, Año 1, n² 2, p. 66. Luego insiste en los efectos beneficiosos de mantener abierta la inmigración.

${ }^{25}$ En ese sentido pueden pensarse también Sobre las ruinas, Pago chico, El casamiento de Laucha.

${ }^{26}$ En la nota sobre "Nosotros" Darío definía a Payró como un escritor-reporter y lo comparaba con Zola, a quien el mismo Payró traducía por entonces para La Nación. 
De tal manera, el procedimiento literario no era una marca de "aristocratismo" sino que se subordinaba a la idea que presidía la novela, y a la lengua literaria que Payró utilizaba, forjada en el periodismo. ${ }^{27}$ De esta forma, la revista exponía una aspiración programática por democratizar la cultura -las ideas-, aspiración que tenía su correlato en un modelo de lengua literaria, que la revista empezaba a definir en este comienzo, y que precisaría en varias oportunidades-, como un idioma de la salud, reconocible ya en los atributos de vigor y fecundidad de Payró. ${ }^{28}$ Esta novela 'democrática' era colocada como hito en la futura literatura argentina, y en ese sentido, la revista de Bianchi y Giusti, ejemplos de la cultura democratizadora, recibía algo del carácter fundacional que parece asignarse a la novela.

Desde el comienzo, la publicación manifestó la alianza necesaria entre la literatura y el ejercicio de la crítica al publicar, junto con el fragmento de la obra de Payró el artículo de Rubén Darío. En efecto, ese escrito funciona como modelo de la propia práctica de los directores puesto que, presentado en conjunto con el capítulo de Payró, realizaba el programa crítico al que aspiraban Bianchi y Giusti. Así, la crítica se presentaba como un discurso que ponía en su centro la cuestión de la autonomía y por tanto, debía acompañar en una misión estratégica las obras de valor a la vez que debe establecer criterios específicos para su legitimación, y realizar el "ideal de cultura y difusión literaria y artística". ${ }^{29}$ Además, el texto del nicaragüense podía ser útil para indicar la condición emergente y endeble de la literatura y de los escritores no solo en 1896, circunstancia en virtud de la cual la necesidad de comunión hacía posible la defensa y el encomio por parte de Darío de un escritor como Payró, cuya estética presentaba francos antagonismos con la suya.

\footnotetext{
${ }^{27}$ La crítica de Rubén Darío define a Payró como el escritor formado en el periodismo: "has tenido un buen campo de experiencia y ese es el diario. ¡El diario! Yo le oigo maldecir y sé que se le pinta como la galera de los intelectuales, como el presidio de los literatos, como la tumba de los poetas. Y es a mi ver injusto de toda injusticia ese cargo. (...) Sin esas gimnasias de la prensa, tu idea no habría tenido nunca músculos. (...) sí, eres un periodista; ¿pero quita eso ser un escritor? No es obra de un inmenso, de un colosal repórter esa Roma de Zola que estás aún traduciendo para La Nación? Nosotros, Año 1, n 1, pp. 10-11. ${ }^{28}$ Esta caracterización corresponde sobre todo a Giusti quien no pierde oportunidad de abogar por una prosa "sana" y "robusta".

${ }^{29}$ Melián Lafinur, Álvaro. Nosotros, Año V, n 41, pp. 153-154. Con estas palabras establecía la continuidad entre su labor y la de Giusti, a quien reemplazaba en la sección de "Letras argentinas".
} 
En un movimiento que debía pensarse como autorreferencial, los directores se mostraban como aquellos que, detentando un conocimiento específico sobre la literatura propio de una minoría ("los menos"), podían rescatarlo del pasado y de la condición efímera del periódico para ofrecerlo a los lectores de la nueva revista: ${ }^{30}$

una página que, desconocida para los más y olvidada seguramente por los que tuvieron ocasión de leerla, bien merece, como todo lo de Darío, retener por un instante la atención del lector. Además contiene enseñanzas que si bien ya dichas en 1896, nadie negará que es conveniente repetirlas en 1907 (8)

Asimismo, el hecho de que la nota al pie de la Dirección se encontrara, no en el anticipo de la novela sino en el texto de Darío, se volvía significativo porque apuntalaba aquella alianza entre crítica y literatura que los textos como conjunto constituían. Por último, la presencia de estos dos textos, que contrariaban la voluntad de la revista de publicar solo inéditos, establecía otra vez su carácter modélico e indicaba la inscripción de la revista en esa doble tradición crítica y literaria.

Por otra parte, la presencia de Payró, a quien los jóvenes veían como un maestro, ${ }^{31}$ y la de Darío, cuyo prestigio era indiscutible, señalaban en la apelación a nombres prestigiosos, una de las estrategias de la que se serviría la publicación cuando se tratara de autorizar su voz en un campo intelectual en emergencia, táctica a la que principalmente echó mano para intervenir en asuntos que involucraron lo nacional. Este recurso debía pensarse como otra de las formas de acumulación de capital simbólico por parte de sujetos recién llegados al mundo de la cultura y que no habían conquistado aún una reputación.

${ }^{30}$ Recordemos que tanto Giusti como Bianchi tendrían a su cargo secciones de crítica, "Letras argentinas" y "Teatro nacional" respectivamente.

${ }^{31}$ Giusti recuerda en Visto y vivido a Payró y se refiere al lugar que para ellos y otros de su época ocupaba el escritor: "Payró era el de más años, y cuando venía [al café "La Brasileña"], el centro de la tertulia. No publicaría El casamiento de Laucha su breve novela picaresca, llena de gracia e intención, hasta el año siguiente [1905], y solamente en 1911 conoceríamos su novela más sólida, las Divertidas aventuras del nieto de Juan Moreira; pero ya era el autor de La Australia Argentina, los cuentos de Pago Chico y otros libros celebrados; tenía un nombre en el periodismo y ese mismo año [1904] Jerónimo Podestá había estrenado en el teatro de la Comedia Sobre las ruinas, la primera obra de ideas de nuestro teatro" (p. 102); y más adelante: "Era aquel a quien los jóvenes ya consideraban el maestro" (Giusti, 1965:103). 


\section{Nosotros y la posta intelectual: la construcción de la autonomía}

Como ya señalamos en relación con el modo en que El Mercurio de América se vinculaba con su predecesora La Biblioteca, y a propósito de la relación de Ideas con El Mercurio, la posta intelectual puede definirse como el mecanismo por el cual las publicaciones del corpus funcionan como relevo y ocupación del espacio público que la revista que las antecede deja vacante. En este sentido, la posta es una forma que intenta consolidar las bases institucionales de funcionamiento del campo intelectual en ciernes, en relación con el cual las revistas son, a la vez, registro e instrumento de la estrategia de su construcción. El tipo de conexión que supone la idea de posta o relevo, en términos metodológicos, implica atender a los elementos que vinculan unas revistas con otras y, necesariamente, obliga a precisar la singularidad de cada una, incluso cuando se retoman propósitos de corte institucional pendientes, o se repiten elecciones estéticas, dado que su significación no puede ser pensada en términos aislados sino en el interior mismo de cada revista y en relación con el momento, cada vez diferente, en que circulan.

Al igual que los escritos con que se abrían las otras revistas del corpus, la presentación de Nosotros, puede se pensada como manifiesto que tematizaba un estado del mundo cultural; este manifiesto, que constituía un juicio crítico, recurría a una retórica y una formulación de sesgo modernista para enunciar los términos de su "programa": "tenerse apartada de todo lo burdo, lo vulgar, de todo lo manoseado", ${ }^{32} \mathrm{y}$ legitimarse en el cumplimiento de "altos fines". ${ }^{33}$ Nosotros conjugaba dichos postulados, además, con una concepción espiritualista del arte, en clara referencia al carácter arielista de Ideas. Los nombres de Emilio Becher, Atilio Chiáppori, Alberto Gerchunoff y Emilio Ortiz Grognet, como miembros del cuerpo de su redacción,

\footnotetext{
${ }^{32}$ Nosotros, Año I, n 1, p. 5.

${ }^{33}$ La Dirección legitimaba el arte y afirmaba su superioridad social, a través de las oposiciones de lo alto con lo bajo, y de luz y la oscuridad:

"Sonrían los descreídos. Salmodien una vez más su repetida pregunta: "¿para qué sirve éso?" El arte, en toda su aparente inutilidad, pasa sencillo, sonriente, en marcha hacia el cumplimiento de los altos fines que persigue, sin cuidarse de aquellos que desde las tinieblas le arrojan piedras". [cursivas nuestras] Nosotros, Año I, nº 1, p. 6.
} 
señalaban una continuidad que no se limitaba meramente a su presencia, sino que indicaba un mismo interés por la crítica. Así, secciones como 'Letras argentinas', 'Letras francesas', 'Música', 'Letras Hispanoamericanas', 'Revista de revistas', 'Bellas Artes' o 'Teatro nacional', expresaban una coincidencia temática relevante.

La vinculación de Nosotros con El Mercurio de América y con Ideas se hizo explícita en el discurso de Giusti para la celebración del segundo año de Nosotros, transcripto en el final de ese número de septiembre de 1909, junto con las palabras de Florencio C. González ${ }^{34}$ (quien codirigía Renacimiento, a la que Nosotros consideraría su "hermana"). ${ }^{35}$ En esa "demostración", forma de sociabilidad intelectual cuyo motivo generalmente era el de celebrar la aparición de un libro, el regreso o la partida de algún escritor, ${ }^{36}$ y en la que la cordialidad reemplazaba la "fría solemnidad de las fiestas 'distinguidas", Giusti planteaba la necesidad de recuperar la breve aunque fructífera "serie" de las publicaciones juveniles nacionales, haciendo hincapié en la importancia de un espíritu contemporizador antes que rebelde. ${ }^{37}$

La simiente por lo demás caía en terreno propicio. Un órgano de la índole de Nosotros era necesario para continuar la serie de aquellas gallardas, entusiastas y juveniles revistas, puntos de

\footnotetext{
${ }^{34}$ El discurso de Florencio C. González va también en el sentido del de Giusti. Se refiere a quienes hacen Renacimiento como "el grupo de hermanos en propósitos" de Nosotros y haciendo referencia a la condición relegada de la producción intelectual, sostiene: " $Y$ vosotros, señores de Nosotros, disonáis en este concierto de la materialidad, porque tenéis en el cerebro una llama que ilumina con intensos resplandores el horizonte siempre azul de vuestros ideales. (...) por ello lo que en otras partes no pasaría de ser un feliz suceso, entre nosotros adquiere todas las proporciones de un acontecimiento: señalar dos años de vida a una publicación que enseña desinteresadamente, es ya aquí un fenómeno social". Nosotros, Año II, n 24, p. 464.

En la celebración, que se realizó en el Restaurante Luzio, hablaron también Alfredo L. Palacios, Carlos de Soussens y Atilio Chiappori.

${ }^{35}$ Cuando Nosotros reapareció, en abril de 1911, después de un año, la dirección en su nota de apertura calificaba a Renacimiento (1909-1913, dirigida por Juan Más y Pí, Horacio P. Areco, Juan L. Ferrarotti) y a Atlántida (1911-1914, dirigida por David Peña) de "aguerridas compañeras" y "las dos [publicaciones] más semejantes por su carácter". "A nuestros lectores", Año IV, Tomo 5, n² 27, abril, 1911, pp. 161-162. (NOS: 66-67)

${ }^{36}$ La primera demostración fue la que Nosotros tributó a Ricardo Rojas.

${ }^{37}$ Giusti volvería a señalar esta afiliación al explicar que quienes habían fundado Nosotros -"sus componentes más significativos"- se habían iniciado en "publicaciones inmediatamente precedentes, con especial significación El Mercurio de América e Ideas" (Giusti, 1971: III). Por su parte, Lafleur, Alonso y Provenzano afirman las revistas de Gálvez y Díaz Romero, junto con Juvenalia, Rinconete y Cortadillo, Preludios y Horizontes, son "eslabones que conducen a Nosotros" (1962: 41).
} 
concentración de energías espirituales dispersas, cuyos dos últimos exponentes fueran El Mercurio de América e Ideas, que todos conocéis bien y recordáis con afecto, pues las circundasteis entonces con la misma efusiva simpatía con que ahora circundáis a Nosotros. Órganos de jóvenes sí, pero de jóvenes que no olvidan a quienes les han precedido, sin servidumbre espiritual por cierto, mas tampoco sin irrazonadas rebeldías, por el exclusivo placer de rebelarse. Órganos, en suma, en los cuales, como tuve ocasión de escribirlo hace dos años en la presentación de la revista, se encontraran en comunión con sus páginas las viejas firmas consagradas con las nuevas ya conocidas y con aquellas de los que surgen o han de surgir" ${ }^{\prime 38}$

Nosotros compartía con ambas revistas el rasgo juvenilista y sobre todo el "arielismo" de algunos textos programáticos de Ideas, en la consideración de la juventud intelectual como depositaria de las "energías" espirituales en las que se cifraba el "progreso" intelectual de la nación. En ese sentido, la revista de Bianchi y Giusti marcaba una diferencia porque se establecía preferentemente como relevo y por tanto como continuadora de las revistas de jóvenes escritores, no ya de La Biblioteca de Groussac, a la que sin embargo, en otro momento, calificó como "la mejor revista aparecida" ${ }^{39}$ El Mercurio e Ideas eran consideradas pioneras en el esfuerzo institucional común por concentrar los empeños aislados, y por lo tanto necesarias en su momento como entonces lo era Nosotros. Por otra parte, en este discurso se reiteraban las dificultades y la falta de apoyo económico por parte del Estado. ${ }^{40}$ Esta protección estatal se juzgaba indispensable para la supervivencia de la publicación en ausencia de un público y de un mercado que la sostuvieran. No obstante, el director de la revista se distanciaba del consuetudinario lamento de los intelectuales frente a la

\footnotetext{
${ }^{38}$ Y continúa: "Conviene lamentarlo, pero debemos explicárnoslo y darnos cuenta de que es lógico que para la mayoría de nuestros congresales un órgano que es exponente del pensamiento joven argentino no merezca la pena de ser ayudado, mientras sí se han ganado con justicia una pensión las revistas para uso de los bufetes de abogados." Nosotros, Año III, n² 24, pp. 461-464.

39 'Notas y Comentarios', Año III, Tomo IV, nº 20-21, mayo-junio, 1909, pp. 263-264.

40 "Ya sé que nos ha faltado la estimación de los que no son de nuestro mundo, ya sé que el Congreso Nacional nos ha negado una pequeña subvención que para la revista hubiera sido un gran auxilio...", Nosotros, Año III, n² 25, p. 463.
} 
hostilidad o indiferencia del medio. En especial, se alejaba de la imagen de Buenos Aires como ciudad fenicia que incumplía su papel hegemónico continental, presente en el manifiesto de Ideas. A esto debía agregarse el reconocimiento "franco, unánime y constante" que, según Giusti, la prensa había tributado a Nosotros:

Hay que considerar que ciertamente el público intelectual aquí es escaso, pero que del mismo modo lo es, donde más, donde menos, en todas partes. También en Atenas las sutiles disputas de Protágoras con Sócrates tenían sin cuidado al portero de la casa. Naturalmente esta ciudad no es Atenas. Solo una desmedida vanidad patriótica pudo hacerlo creer a alguien por un instante. Pero si no es Atenas, tampoco creo que sea Cartago, como yo alguna vez he oído decirlo. Ni tanto ni tan poco. Roma, si os place, la Roma republicana, manteniéndonos en el campo intelectual, saltando por encima de todas las enormes diferencias, y no dándole al paralelo más valor que el de un símil literario. (463)

Como lo probaba la nota previa a la demostración, aparecida en el $n^{0} 22-23$ cuando se cumplía ese tercer aniversario, el optimismo no siempre constituyó la tónica. En efecto, la revista se abría con un texto, en el cual la Dirección protestaba con fuerza y se refería al triunfo restringido de Nosotros entre un público lector poco numeroso. De tal modo, el hecho de que los lamentos se ubicaran en el comienzo de la publicación y los agradecimientos optimistas se hallaran en el final relativizando el carácter adverso de las condiciones de producción intelectual, ponía de manifiesto, una vez más, el rasgo táctico y consensuado en la discursividad de la queja. Estos reclamos de corte institucional vinculados con el mecanismo de relevo o posta, apuntaban a lo estratégico retomando los tópicos con que habitualmente se los formulaba. Así, el desprecio de la sociedad por los productos del pensamiento, la inexistencia de un público especializado y de verdaderos intelectuales, presentes en este pasaje, conectaban a todas las publicaciones del corpus, más allá de su enunciación particular y del carácter más o menos repetitivo que adquirieran:

(...) Los progresos por Nosotros realizados los atestiguan plenamente los últimos números, en que 
la abundancia y selección del material le han ganado así los elogios repetidos de la prensa argentina y extranjera como el favor unánime del público lector.

Entendámonos: del público lector de estas cosas, que, por desgracia, es bien escaso. Algunos centenares de personas y pare $\mathrm{Ud}$. de contar. No nos engañemos: los estudios serios y extensos, si tienen entre nosotros pocos cultivadores, encuentran igualmente pocos lectores. Se les prefiere a (sic) las poesías ligeras y los cuentos breves.

Y más adelante y en coincidencia con el discurso ya citado, agregaba:

De ahí deriva la falta de medios con que comúnmente deben luchar las publicaciones de esta índole, cuando como Nosotros han sido lanzadas sin capital, contando con el solo esfuerzo de sus directores y la buena voluntad de los simpatizantes con ellas. Falta de medios que en el caso presente hubiera podido ser subsanada por los poderes públicos -aquí donde el dinero se despilfarra a manos llenas estérilmente- si una indiferencia deplorable, menos por lo que nos toca que por lo que significa, no hubiera siempre contestado con silencio a nuestros modestos pedidos de ayuda. ${ }^{41}$ [cursivas nuestras]

De esta manera, la solución se presentaba, como para Groussac en $L a$ Biblioteca, bajo la forma de la ayuda proveniente del Estado, aunque desde una perspectiva distinta y principalmente, por la colocación de los sujetos por fuera del poder político estatal. Si en el caso de Groussac se trataba del órgano de una

${ }^{41}$ Nosotros, Año III, $\mathrm{n}^{\circ}$ 22-23, julio-agosto, 1909, pp. 265-266. Juan Antonio Argerich fue quien había presentado en el Congreso Nacional el pedido de subsidio para la revista. Más tarde, en 1913 la Dirección se quejaba en 'Notas y comentarios' acerca de la misma desprotección que sufría por entonces la Biblioteca Nacional, dirigida por Groussac: "Únicamente 1.000 \$ mensuales se consagran a la compra de obras, partida mezquina que hace decir al señor Groussac con manifiesto sarcasmo, que esperaba que el honorable congreso 'se dignaría, para el año 1913, mejorar un tanto nuestras módicas donaciones, demostrando así que para él también figuran las riquezas del pensamiento en la escala de los valores sociales'. (...) Tiempo es ya, nos parece, de que los poderes públicos se preocupen por la suerte de nuestra Biblioteca, la cual es, en fin de cuentas, la primera institución de la índole de la segunda ciudad latina del mundo." pp. 109-110, Nosotros, Año VII, n 47, marzo, 1913. 
repartición pública, y por lo tanto completamente subvencionado, para el caso de Nosotros se pedía, a cambio de la obra "benéfica" intelectual y cultural que la publicación realizaba -de reclutamiento de las elites intelectuales y artísticas encauzadas en la construcción de la cultura nacional-, el subsidio con que pudieran cubrirse los gastos básicos de armado, publicación y distribución. Esta solución era común a la que reclamaban otros escritores hispanoamericanos, como por ejemplo, Manuel Gutiérrez Nájera, quien solicitaba la protección del gobierno de Porfirio Díaz para la literatura, ${ }^{42}$ o se emparentaba con aquello que Vicente Quesada había explicitado como modo de sostener su Revista de Buenos Aires. ${ }^{43}$ Es dable observar que las diferencias con que las publicaciones abordaban la temática de la autonomía permitían identificar la construcción de los sujetos intelectuales que las revistas propagandizaban: para El Mercurio y asociada a una de las formas de la profesionalización (el periodismo), se trataba del artista que construía su literatura o su arte como el otro del trabajo, planteando así una relación dominante de divorcio con el mercado ${ }^{44}$; para Ideas la cuestión se concentraba en la inserción de los escritores profesionalizados o en vías de hacerlo, en un mercado posible al que aportarían su calidad y por lo tanto instruirían moral y estéticamente. Para Nosotros, la imagen era la del intelectual-escritor que construía su independencia por la imparcialidad del juicio y el conocimiento disciplinar, pero sobre todo, pensada como la posibilidad de desarrollar, de manera constante, una labor específica imaginada como obra extensa. ${ }^{45}$ Es según esa imagen como Giusti iría construyendo los que Jitrik denominó mitos "del universitario completo y cabal" y del "intelectual argentino" (Jitrik, 1998: 102). Esa figura se forjaría en órganos que como Nosotros, se autoinstituían como espacios de reunión y reclutamiento intelectual.

En la "Introducción" a la Bibliografía de la revista Nosotros del Fondo Nacional de las Artes, Giusti corroboraba lo acertado del esfuerzo, y el lugar

\footnotetext{
${ }^{42}$ Gutiérrez Nájera, Manuel. "La protección de la literatura”, tomado de Ramos, 1989: 87.

${ }^{43}$ Cf. Capítulo 1, apartado 1. La Biblioteca: las limitaciones de la voluntad autonómica.

${ }^{44}$ Cf. el análisis de Julio Ramos sobre la poesía de Martí como el interior, lo opuesto absoluto del trabajo, incluso en el mercado de la escritura (periodismo) en el que Martí interviene con un género como la crónica, cuyo estudio sirve para recuperar el afuera que se oblitera en la poesía (Ramos, 1989: 82-110).

${ }^{45}$ Cf. el pasaje citado del discurso de Giusti del n $22-23$.
} 
hegemónico al que aspiró y que efectivamente tuvo la publicación, y defendía una vez más la solidaridad como valor necesario para la construcción del espacio de la cultura:

(...) se lee la extensa respuesta de Bianchi [a la
encuesta del no $279-280$, "Una generación se juzga
a sí misma", de 1932 y en ocasión de los 25 años
de Nosotros], exposición rica de noticias sobre los
antecedentes de la revista y la obra por ella
cumplida en procura de ser el espejo de un anhelo
de solidaridad extendido a todos los ámbitos de la
cultura [cursivas nuestras] (Giusti, 1971: I-
XXXIX)

En casi todos sus aniversarios, que fueron tomados siempre como motivo de celebración, la revista se juzgaba a sí misma, y evaluando "el camino recorrido", utilizaba una operación común a otras publicaciones, que podemos llamar -parafraseando algunas palabras de Giusti- la de 'darse ánimos para proseguir la marcha'. En su primer aniversario la dirección había señalado obstáculos pero sobre todo "el benévolo apoyo de todos - público, escritores y prensa-"46. Nosotros desarrolló y multiplicó toda una serie de eventos que como gestos y prácticas específicas, al igual que la autocelebración, apuntaban a la edificación de una comunidad intelectual y literaria. Se trataba de un conjunto de acciones o convocatorias aglutinantes, que Giusti mismo definió como "medio activo de vinculación intelectual y personal, tan eficaz como la letra impresa": reconocimientos, números de homenaje (generalmente con motivo de la muerte de alguien, pero también de algún éxito literario), premios, 'demostraciones' a escritores argentinos y extranjeros, almuerzos, ${ }^{47}$ cenas, reuniones en cafés literarios o en redacciones de ${ }^{46}$ Nosotros, Año II, no 13-14, agosto-septiembre, 1908, pp. 5-6.

${ }^{47}$ En la palabra almorzáculo, debe leerse una oposición a la idea de cenáculo y a su impronta aristocrática, y a la vez, una forma de relación horizontal entre pares; todas estas prácticas se caracterizaron por el gran número de participantes. Además la revista se encargó de registrarlas en 'Notas y comentarios'.

Giusti recuerda los almuerzos a los que llamaban almorzáculo: "Por esa época, mensualmente, los domingos, en el popular restaurante Ferrari, situado en la esquina de Sarmiento y Uruguay, empezó a tenderse una larga mesa alrededor de la cual nos sentábamos a almorzar un grupo de colaboradores de Nosotros, casi todos literatos, casi todos todavía en agraz. Me sería difícil recordarlos uno por uno, pero citaré a los más asiduos. Entre los muertos Evaristo Carriego, Juan Mas y Pí, Alfredo Bianchi, Carlos de Soussens, Macedonio Fernández, Carlos Alberto Leumann, Juan José de Soiza Reilly, Emilio Ravignani, Federico Mertens, Álvaro Melián Lafinur; de los por fortuna vivientes, Enrique Banchs, Rafael Alberto Arrieta, Marcelo del Mazo [también F. Sánchez y Salvador 
diarios. Todas estas prácticas señalaban los espacios en que tenían lugar y se gestaban no solo los vínculos intelectuales sino también proyectos colectivos, como Nosotros, modo de sociabilidad que ya tenía su historia como se vio a propósito de El Mercurio y de Ideas. ${ }^{48}$ De ese modo, años después, Giusti indicaba que en el "saloncito" de Becher en La Nación surgió y fue bautizada la revista, y Gálvez refería que los miembros de Ideas se reunían en el cuarto de Ortiz Grognet del Hotel Helder, ubicado en la calle Florida.

Al menos desde su título -Nosotros. Revista mensual de letras, arte, filosofia y ciencias sociales-, se presentaba como una publicación cultural no ya estrictamente literaria o artística. En ese sentido, en función del itinerario trazado en la posta, se mostraba una formulación que apuntaba también a la intervención en el campo mucho más extenso de lo que Giusti llamaba "cultura argentina". Es por eso que desde el primer número la revista contuvo, además de las secciones de letras, una dedicada a las representaciones teatrales; otras dos, dedicadas a la música ${ }^{49}$ y a las artes plásticas respectivamente; “Notas y comentarios”, en parte similar a 'Crónica del mes' de Ideas, repasaba hechos de diversa índole que consideraba dignos de señalar y comentar. El anhelo de totalidad por el que la revista intentaba abarcar todos los ámbitos de la cultura, se observaba en la variedad de sus secciones; esta presencia podía ser pensada

Boucau] (...) La barata, copiosa y sabrosa ración de ravioles y de pollo 'allo spiedo' que nos servía el gordo Ferrari, rociada, y aun bañada y sumergida por el legítimo Chianti...." (Giusti, 1965: 119-120).

De los cafés literarios frecuentados por la llamada "bohemia porteña" de los primeros años del siglo XX se destacan "La Brasileña", "Los Inmortales" (llamado antes "Brasil"). Cf. Martínez Cuitiño, 1954 y Bossio, 1995.

${ }^{48}$ En el "saloncito" de Becher en La Nación surgió y fue bautizada la revista. Giusti evoca la tertulia que se reunía por las noches en el café "La Brasileña" a la que lo llevó Bianchi: "Allí trabé relación con Roberto Payró, Joaquín de Vedia, Florencio Sánchez, Emilio Becher, Carlos de Soussens, Atilio Chiáppori, Alberto Gerchunoff, Ricardo Rojas, el escultor Arturo Dresco, y algún otro." (Giusti, 1965: 102).

${ }^{49}$ La sección Música apareció una sola vez, en el $n^{\circ} 2$ de la revista. Su redactor, Miguel Mastrogiani, se refirió en ella a los estrenos y representaciones vinculados con la ópera. En ese única entrega, y en sintonía con las reflexiones sobre el público aristocrático de algunos redactores de Ideas, señaló la importancia de la moda como determinante en el consumo de la música, y relacionó el carácter heterogéneo del público porteño con el eclecticismo de la oferta musical. Las notas de Mariano Antonio Barrenechea, que más tarde aparecieron en Nosotros, no repasaban los repertorios de los teatros líricos sino versaban sobre aspectos específicos de la práctica musical. En alguna medida, estas notas cubrieron esa área de interés. También hubo otra sección, 'Crónica musical' en la que escribieron Barrenechea (20-21), T. A. Y ( $i ? 27)$, Mastrogiani (32, 33), Juan Pedro Calou (35, 39, 41, $42,43,45,48,51,52,53,55,56)$ y se encargaron de repasar los conciertos. 
en conjunto como el intento de constituir redes o alianzas que respondían también a la vocación autonómica e institucional de la literatura y las artes. Así, 'Música' o 'Bellas Artes ${ }^{50}$ además de las secciones dedicadas a las letras, se convertían en los espacios de inscripción de los reclamos colectivos, relacionados con la demanda de instituciones específicas, el enjuiciamiento del poder político en su indiferencia por los productos intelectuales, la necesidad de difundir a los artistas argentinos, la intención de promover eventos relacionados con prácticas específicas. Prueba de ello fue la nota de Emilio Ortiz Grognet que ilustraba este tipo de alianzas en la sección de 'Bellas Artes' del n ${ }^{o} 2 .^{51}$ Quien escribía señalaba el acuerdo básico entre los miembros de la esfera de la cultura, afirmaba que privilegiaría el análisis de lo propio por sobre lo extranjero, y definía las obligaciones de la crítica de arte, en primer lugar, como discurso dirigido a los artistas en calidad de estímulo; en segundo término, con respecto a sí misma en su capacidad de distinguir el valor de las obras e incluso anticiparlo; por último, investida de una finalidad patriótica, afirmaba su misión de publicidad, paso primero para el reconocimiento:

Alentar a nuestros artistas, predicarles fe para la lucha y el cultivo de la propia personalidad; hacerles conocer del público, sacarles de la sombra, donde la incuria nacional injustamente les ha relegado hacerles apreciar en lo que realmente valen y prometen valer, será el alto y patriótico fin que con todo tesón perseguiremos." ${ }^{2}$

\footnotetext{
${ }^{50}$ Daba cuenta de las exposiciones más relevantes del mes en Buenos Aires, la llegada de artistas, etc.

${ }^{51}$ Nosotros, Año I, n 2, septiembre, 1907, pp. 125-128.

${ }^{52} \mathrm{Ibid}$., p. 128. En otro pasaje enfatizaba su divorcio con los mercaderes de arte, que hacian de éste un simple negocio, y sostenía que en su "propaganda" éste sería tema de discusión:

"De las aisladas exposiciones que con explicable rubro, dado el medio, se organizaban en los años pasados, queda sólo la tradición; hoy las exposiciones se suceden unas a otras y algunas, las malas especialmente, se propagan por generación espontánea. El snobismo rumboso hizo medrar a los mercaderes, la fama de nuestra largueza y minuficencia, limpió de telarañas la infinidad de cuadros, grandes brochazos de barniz rejuvenecedor se extendieron sobre la pátina de olvido de muchas telas de valor subalterno que han sido negociadas aquí a precios altos y hoy gozamos la justa fama de constituir uno de los mercados artísticos más importantes del mundo.

Más importantes sí, pero menos considerados; somos excelentes pagadores y apreciadores de una gran deficiencia; esto es lo lamentable y esto dará también tema continuo a nuestra propaganda." Ibid. pp. 125-126
} 
Más adelante, y a modo de síntesis, citaba un párrafo de Martín Malharro aparecido en la sección 'Pintura y escultura' de Ideas. ${ }^{53}$ La mención de esta figura insoslayable en la renovación de la plástica argentina, servía para organizar la sección teniendo como eje la posibilidad de un arte nacional, ${ }^{54}$ debate que unos años antes había tenido lugar en el Ateneo de Buenos en la disputa de Eduardo Schiaffino -cuya posición suscribía Malharro- ${ }^{55}$ con Rafael Obligado y Calixto Oyuela.

Creemos, dice en un arte nacional, en un arte original como nuestra naturaleza; en un arte con carácter propio, netamente definido, sincero, con medios de expresión nuestro [s], en un arte lozano, valiente y original como original es el Facundo de Sarmiento.

La razón primera y fundamental de la originalidad de Facundo es la independencia y originalidad del espíritu del autor. ${ }^{56}$

La cita importaba porque por un lado, mostraba la continuidad temática con la revista de Gálvez de la que Ortiz Grognet había sido redactor, y por otro, porque indicaba la forma en que se legitimaban, unos a otros, los discursos programáticos; también lo era porque señalaba explícitamente a Sarmiento como origen de un modelo de construcción de tradición nacional cultural, cuyo programa la revista suscribía al menos en la apelación a la metáfora del vacío, que debía llenarse a través de una labor intelectual y cultural sostenida. La autonomía se presentaba como especialización del discurso de la crítica literaria y artística, y se observaba también en otras disciplinas, que como la literatura atravesaban un proceso de constitución y consolidación, como por ejemplo, la historia, la sociología. ${ }^{57}$ Esto era visible en las tentativas de

53 "Pintura y Escultura", Ideas, Año I, n 1, mayo, 1903, pp. 56-63.

${ }^{54}$ Es importante consignar que Malharro había ilustrado Recuerdos de la tierra de Martiniano Leguizamón, uno de los iniciadores en literatura del nacionalismo de las "cosas de la tierra", con el cual coincidía en la temática de representar el paisaje nacional, aunque bajo la perspectiva de los impresionistas y postimpresionistas franceses. Además, en "La estética en la escuela", Malharro promovió la necesidad de una reforma de la enseñanza artística. Ideas, Año III, Tomo 6, n 23-24, marzo-abril, 1905, pp. 310-327.

${ }_{55}$ Para esta cuestión, Cf. "La querella del paisaje y el arte nacional" (Malosetti Costa, 2001: 337-346).

${ }^{56}$ Nosotros, Año I, nº 2, septiembre, 1907, p. 128.

${ }^{57}$ Un ejemplo de esto lo constituye el artículo de Ricardo Levene "El espíritu de la historia". Se trataba en realidad de la transcripción de la conferencia de apertura del curso de ese año de 'Revista de la Historia Moderna y Contemporánea' de la Facultad de Derecho y Ciencias 
sistematizar la producción vernácula construyendo un corpus -ya fuera de poesía, narrativa o teatro- por medio de antologías o por la recolección de materiales preparatorios, como pudo serlo el libro de Vicente Rossi sobre el teatro rioplatense. ${ }^{58}$ En el caso de la historia se actualizaba en la preocupación por un estudio riguroso de las fuentes y en una información detallada y completa, como método que debía organizar las obras históricas. ${ }^{59}$ En 1913, en la sección 'Notas y comentarios' ese deseo de construcción de un corpus se plasmaba en el proyecto de una Antología Argentina de prosistas y poetas en dos volúmenes, que llevarían adelante la Sociedad Cooperativa Limitada Nosotros y la casa editora Mendesky y Cía. Esta última que se haría cargo de los gastos, imprimiría la obra en Barcelona o en París. La misma, se decía, "está sin duda destinada a tener resonancia dentro y fuera del país, por cuanto se trata de una antología ideada sobre un vasto plan, como que hasta ahora no contamos con otra similar". Sin embargo, no se trataba de una historia literaria como la que propondría Rojas en la conferencia de inauguración de la cátedra de literatura argentina, cinco meses después, ya que el criterio de selección de las obras, por el que se incluirían tanto autores fallecidos como vivos, sería el de "la belleza literaria de los

Sociales. Está dedicada al Dr. Manuel Derqui. Levene se refería a la historia como nueva ciencia y hacía un repaso de los métodos y procedimientos de investigación histórica y sociológica. En contra del estudio de los detalles, señala: "Las grandes causas históricas y sociales, gestadoras de los grandes acontecimientos hacen su obra silenciosa y lentamente, pero sólida y definitiva, como la obra de la estalactita sobre las rocas. A veces, por momentos parece como si esos factores desaparecieran, y es que se han sumergido en el fondo mismo del alma social y allí continúan actuando, ocultos por los pequeños factores que hacen ruido sonoro en la superficie", Nosotros, Año II, $\mathrm{n}^{\circ}$ 13-14, agosto-septiembre, 1907, p. 102. Para el caso de la literatura se trataba de libros en que los autores reunían en volumen sus artículos críticos aparecidos en diarios, o de obras como la de Giusti o Ugarte sobre poesía. También se observaba este tipo de empresa en otros países hispanoamericanos y se las consigna en la sección 'Bibliografía', como los Ensayos críticos de Manuel F. Cestero en el $n^{\circ} 40$.

${ }^{58}$ Teatro Nacional Rioplatense. Contribución a su análisis y a su historia, Río de la Plata, 1910. Fue reseñado por Giusti en la sección 'Bibiografía', Año IV, Tomo 5, n² 29, junio, 1911, pp. 393-394.

${ }_{59}$ Cf. la crítica de Emilio Ravignani a Los orígenes argentinos de Roberto Levillier, y los diversos artículos que se publican en la revista sobre la enseñanza de la historia, como por ejemplo la nota de Coroliano Alberini sobre Teoría y práctica de la historia de Juan B. Justo, en el $n^{\circ} 24 ;$ Metodología y enseñanza de la Historia de Victorio M. Delfino, que con prólogo de Víctor Mercante, se comenta en el $n^{\circ} 40$; el artículo de Coroliano Alberini sobre La enseñanza de la historia en las universidades alemanas de Ernesto Quesada, en el $n^{\circ} 41$. 
trabajos seleccionados", en detrimento de "razones cronológicas", “de veneración o de respeto". 60

Como ya observamos a propósito de la revista de Gálvez, uno de los problemas principales que encontraron los escritores y, en particular los jóvenes, fue la ausencia de editores o empresas editoriales para sus obras. A comienzos del siglo XX la mayoría de los libros en castellano que se vendían en Buenos Aires eran editados en París, Roma, Leipzig y, en menor medida, en Madrid y Barcelona. Incluso las contadas ediciones nacionales a menudo se mandaban a imprimir en Europa, cuyos talleres superaban a las imprentas locales en precio y calidad. En este sentido, eran las editoriales francesas y alemanas las que dominaban el mercado hispanoamericano del libro, pues gozaban de enormes ventajas competitivas no sólo en el campo de la producción, sino también en el de la comercialización de los bienes producidos. Estas empresas, de vasta experiencia en la gestión editorial, contaban con una amplia red de promoción, distribución y comercialización del libro a lo largo de Hispanoamérica, frente a la cual la pobre organización de los editores nacionales resultaba insuficiente a la hora de competir en un mercado interno de proporciones reducidas. ${ }^{61}$ En tal sentido, las páginas de las revistas constituían una forma intermedia de publicidad entre el periódico y el libro, formato al que no muchos accedían y marcado siempre con el signo de la dificultad. Ideas, cuyo ejemplo continuaría Nosotros, había publicado otras obras teatrales completas, nacionales y extranjeras, además de Sobre las ruinas de Payró, aparecida en la revista y en folleto. ${ }^{62}$ La revista convirtió ese impulso en una editorial también llamada Nosotros, que funcionaba como alternativa a la consabida y onerosa publicación costeada por los autores (mediante el pago, por ejemplo, a los escandinavos Arnoldo y Balder Moen). Prueba de esa dificultad de los autores para editar sus libros fueron las expresiones irónicas de Giusti sobre la aparición de Ideaciones de Juan Más y Pí, colaborador de Nosotros: "No es finísimo, sino modesto, el papel en que está impreso; no lo han editado los hermanos Moen, y se vende baratísimo; pero es un muy buen libro". ${ }^{63}$ Podía leerse allí la huella de las intervenciones de Gerchunoff en Ideas, o un eco de las opiniones de Rojas sobre los

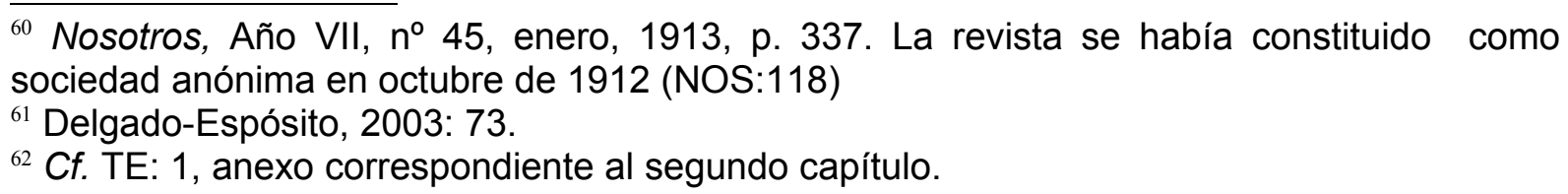


beneficios de difundir y democratizar las obras en ediciones de bajo costo. ${ }^{64}$ Para mediados de 1912, la editorial de la revista Nosotros ya había sacado veintitrés libros, doce de los cuales eran obras dramáticas, cinco poéticas y el resto correspondía principalmente a textos críticos. Las obras teatrales fueron Los derechos de la salud de Florencio Sánchez; Presente griego y El Arlequín de Otto M. Cione; Los colegas de Carlos O. Bunge; Las Erinnias de Leconte de Lisle; ${ }^{65}$ Por cuatro garabatos de Alfredo Duhau; Fuego fatuo de Enrique García Velloso; Ganador y placé de Arturo Giménez Pastor; El dolor del rosal de Alejandro Marcó; Comedia de pequeños burgueses de Gerchunoff; Salomé de Oscar Wilde y El retorno de José Fabio Garnier. Enrique Banchs era el autor de cuatro libros de poemas: Las barcas, El libro de los elogios, El cascabel del Halcón, La urna; de Ernesto Mario Barreda era La canción del hombre que pasa. Los volúmenes que el aviso de la contratapa reunía bajo la denominación 'Otras obras' fueron Ecce Hommo, Los fragmentarios de Pedro Sonderéguer, Remy de Gourmont de Mariano Antonio Barrenechea, El teatro de Florencio Sánchez de Ricardo Rojas, ${ }^{66}$ y Nuestros poetas jóvenes de Giusti. ${ }^{67}$

${ }^{63}$ Nosotros, Año II, T4, no 18-19, enero-febrero, 1909, pp. 130-132. La misma Nosotros fue editada, al comienzo, por los hermanos Moen.

64 Ideaciones había sido editado en Barcelona en el sello F. Granada y cía. editores, en 1909. Según explicaba la nota de la dirección, en 'Notas y comentarios' del $n^{\circ} 18-19$, en la reunión mensual en lo de Ferrari (el "almorzáculo"), se celebraba la aparición del libro. Año II, T4, no 18-19, enero-febrero, 1909, pp. 136-139.

Juan Más y Pí asiduo colaborador de Nosotros tuvo a su cargo 'Letras catalanas',

${ }^{65}$ La traducción era de Enrique Banchs.

${ }^{66}$ Se trataba de una conferencia pronunciada en el teatro Odeón en homenaje a Sánchez, recientemente fallecido que la revista había publicado en abril de 1911. (Año IV, Tomo V, $\mathrm{n}^{\circ}$ 27, abril, 1911, pp. 163-180). (NOS: 67-68)

${ }^{67}$ Según constaba en un ejemplar suelto del $n^{\circ} 24$ de julio de 1909, Nosotros entregaba gratis cualquiera de esos libros a los suscriptores que pagaran por adelantado un año entero. Los libros valían entre 0,50 y 2 pesos. Los derechos de la salud y Presente griego se habían agotado, lo cual indicaba por una parte, el favor de los compradores por el teatro, y por otra, el éxito y la importancia de estos uruguayos en la escena nacional. Los libros se vendían en las librerías de la Administración de la revista (sitas primero en Florida 512 y Esmeralda 483, después en Bernardo de Irigoyen 946) donde también podían adquirirse otros, no editados por Nosotros, como por ejemplo De mi jardín y los trigales de Alberto Escudero; Las naves de oro de Arturo Vázquez, Los poemas sentimentales de Richard Lavalle. Como se pude ver, además de difundir a los autores, la editorial funcionaba como modo de financiación de la revista. Además, otra forma en que se promovieron las suscripciones fue el trato con la administración del diario La Nación por el cual los suscriptores de la revista que abonaran por adelantado un año o un semestre, serían obsequiados con un volumen o dos de las obras de la 'Biblioteca de La Nación', para lo cual se adjuntaba una lista de los que no estaban agotados. Por si eso fuera poco, la Administración de la revista correría con los gastos de envío. Es importante observar la relevancia y el éxito que tuvo esta colección, muchos de cuyos títulos eran reseñados en 
Por otro lado, la continuidad con Ideas podía leerse también a partir de la inclusión de publicidades como forma de financiar los gastos que implicaban la factura y distribución de la revista -según sus directores, equivalentes a los de un libro-; como en la revista de Gálvez, dicha incorporación era evaluada, a veces, de modo ambivalente. En ese sentido, se interpretaba la negativa de Francisco Albasio uno de los administradores a publicar avisos "recomendando al consumo cualquier excelente aceite de oliva". ${ }^{68}$ Esas palabras serían desmentidas seis meses después, cuando en el mismo número en que se anunciaba la reorganización de Nosotros como una sociedad anónima, aparecían publicidades de pianos, aseguradoras y bancos. ${ }^{69}$

\section{La crítica y la edificación de la literatura argentina}

Nosotros dramatizó la voluntad autonómica de la literatura y sus condiciones a través del ejercicio de una crítica que, autorreflexiva, remarcaba sus atribuciones adecuadas para el momento y de ese modo, señalaba el carácter necesariamente relativo de los juicios respecto de una literatura en emergencia. Así, las secciones de letras, teatros y 'Notas y comentarios' se convirtieron en espacios de propaganda intelectual. Los escritos de Giusti, Melián Lafinur, Mas y Pi, Gerchunoff, entre otros, resultaban relevantes cuando se trataba de pautar la propia práctica crítica, uno de cuyos imperativos era la difusión intelectual y artística. A partir de un consenso tácito y declarado por los redactores, Álvaro Melián Lafinur, por ejemplo, pregonó una poética de "amplitud y tolerancia". En continuidad con las observaciones de Ideas, pudo pensar la eficacia inmediata de su discurso en términos de la educación del gusto

Nosotros. Este éxito, fue anotado, al pasar y con tono despectivo por Manuel Lugones, uno de los críticos teatrales de la revista, que se refería a la falta de originalidad del argumento de La echarpe de miss Silvia (comedia en tres actos de Camilo Muniagurria), señalando que "La menos perspicaz de las lectoras de la biblioteca de La Nación podría citarnos inmediatamente muchos argumentos similares". Nosotros, Año VI, Tomo IX, $\mathrm{n}^{\circ} 44$, diciembre, 1912, pp. 214-216. Por otra parte, debemos aclarar que en general, hemos trabajado con colecciones encuadernadas de Nosotros, por lo que no nos es posible saber la duración y el alcance de estos modos de promocionar la revista.

${ }^{68}$ Año V, Tomo VI, nº 32, septiembre, 1911 p. 256.

${ }^{69}$ Año VI, Tomo VIII, $\mathrm{n}^{\circ}$ 42, julio, 1912, p. 246. Allí se anunciaron una serie de cambios. Cf. NOS: 118. 
y como modo de encaminar el criterio de los lectores, eficacia fundada en una tarea develadora del sentido estético y del valor moral de las obras. Como consejo para el autor tratado, la crítica debía operar un efecto "saludable" en la corrección de los defectos observados por una inteligencia noble y sincera, ${ }^{70}$ con respecto a su propio sistema de producción, la crítica debía superar las habituales recopilaciones de artículos previamente publicados en diarios y proponerse -al menos en su intencióncomo estudio riguroso y extenso. ${ }^{71}$ En el marco de lo que se consideraba como un mundo cultural precario, la crítica practicada por Nosotros, que proclamaba siempre la libertad de opinión -y por ello Jorge Rivera pudo definirla como "tribuna libre" (Rivera, 1995: 60), privilegiaba, en especial desde la perspectiva de sus directores, la construcción de continuidades. Así, los números de homenaje no eran pensados como simple alabanza de aquellos a quienes estaban dedicados, sino que tenían una intención también programática de revisar la obra, para diseñar un lugar posible de ese sujeto en la 'cultura argentina', o el valor que podía tener para la vida intelectual nacional cuando se trataba de extranjeros. No obstante, Giusti recordaba el homenaje a Florencio Sánchez con motivo del estreno de Los derechos de la salud en Buenos

70 Transcribimos la nota de Melián Lafinur en el momento en que reemplazó a Giusti en 'Letras argentinas':

"La Dirección de Nosotros me ha hecho el honor de encomendarme la crítica de literatura argentina en esta sección bibliográfica. La he aceptado consecuentemente con mi propósito de servir en cuanto me sea posible el ideal de cultura y difusión literaria y artística que esta revista importa.[cursivas nuestras] (...) Si no estoy seguro de dar lucimiento a mis crónicas, puedo en cambio estarlo en lo que respecta a la serenidad, amplitud y tolerancia de mis juicios, jamás turbados por apasionamiento que conduce a la injusticia, ni regidos por fórmulas estrechas [cursivas nuestras] La crítica requiere para ser ejercida con nobleza, esa virtud de simpatía y facultad de admirar, que capacitan a quien la realiza para compenetrarse con la obra examinada, y desentrañar su significación moral y su valor estético [cursivas nuestras] Como dice Renan, "el progreso de la crítica no es posible sino a condición de una rigurosa buena fe".

Describe, luego, las atribuciones y utilidad de la crítica: "La eficacia virtual de la crítica, en cuanto a su finalidad inmediata, ha sido muy discutida. Creo no obstante que un dictamen sincero, en que la serenidad se transparente, juicioso en sus observaciones y expresado con altura y buena fe, no puede menos de operar en los autores una acción saludable a la vez que concurre a formar el gusto y encaminar el criterio de los que leen.

El concepto de tolerancia antes enunciado, no implica desde luego una benevolencia incompatible con la dignidad del arte, hacia obras falsas y deleznables". Nosotros, Año $\mathrm{V}, \mathrm{n}^{\circ}$ 41, pp. 153-154. Para la transcripción más extensa, Cf. NOS: 115-116.

71 Respecto de Almafuerte de Juan Mas y Pí, Giusti sostiene: "Siempre han sido descuidados en el país los estudios de aliento sobre tal o cual escritor, sobre éste o aquel aspecto de nuestras letras. Bien sé que en general ellas valen muy poco, mas no a tal punto de no presentar lados interesantes para la curiosa mirada de los que a tales estudios gustan de aplicarse." Giusti Año I, Tomo 1, n 5, diciembre, 1907, p. 333. 
Aires y en Montevideo, y hacía referencia a un tópico frecuente a fines de siglo pasado en las formulaciones respecto de la vinculación arte/sociedad, tópico con el cual también se había iniciado la revista Ideas en 1903: ${ }^{72}$

El homenaje lo justificábamos por la necesidad que obligaba a los escritores, de unirse y apoyarse reciprocamente y para afirmarse y defenderse en un medio, cuando no hostil, indiferente [cursivas nuestras] (Giusti, 1971: XXIV)

La crítica, sobre todo en los comienzos, debía adecuarse según Giusti al momento y al espacio intelectual en que se practicaba. Así lo señalaba en la cuarta entrega de la sección 'Letras argentinas' que durante muchos años llevó su firma:

Por más que el mérito de tal o cual libro sólo sea escaso, sin embargo se impone en estas notas bibliográficas el elogio, la frase de aliento para su autor, si es que el libro, en su valor meramente relativo, revela un digno esfuerzo o una sana aspiración de arte. Y la razón es obvia.

Nuestra literatura -si es que existe- no tiene sino un valor relativo. Por lo tanto no se puede usar a su respecto el mismo criterio que se emplearía al juzgar la literatura europea. Es de desear, naturalmente, que la producción artística argentina sea de verdadero mérito, mas no han de exigirse imposibles. Por algo hay que empezar. Al lado de un Obligado, de un Groussac, de un Lugones, de un Ramos Mejía y de algunos otros hombres de letras que honrarían a cualquier país ¿cuántos, entre nosotros, cuya labor, que es considerada y es justo considerar con respeto, quedaría borrosa en otro medio ${ }^{73}$

La claridad de las palabras de Giusti reforzaba la necesaria fraternidad entre los miembros de un mundo intelectual en los comienzos de su existencia e indicaba que el problema de la literatura nacional, en tanto actividad social efectivamente diferenciada, seguía siendo el de su casi inexistencia, y sumado a esto, el de su valor estético escaso. Esta cita exponía, además, una primera y reducida serie de escritores,

${ }^{72}$ Cf. Capítulo 2, parágrafo 1. Ideas: una acción cultural necesaria.

${ }^{73}$ Año I, n 4, noviembre, 1907, p. 264. 
quienes formaban parte del pasado literario que merecía ser rescatado para construir una tradición de literatura argentina, y cuyo dominio, como lo probaba la inclusión de Ramos Mejía, se ampliaba hacia lo intelectual. En otro pasaje del número dedicado a Sánchez, aunque en un tono mucho más belicoso, el director de Nosotros descalificaba y condenaba a quienes veían en este tipo de crítica una cuestión exclusiva de elogios personales -no de talentos reales. Giusti afirmaba que la función del discurso crítico no solo consistía en legitimar la literatura, los escritores, y en autoinstituir su propia autoridad entendida como modo específico de construcción de prestigio y consagración, sino también en promover de las conductas modeladoras de una vida literaria marcada por la camaradería: ${ }^{74}$

Los puritanos de la literatura suelen clamar sobre estos impulsos sinceros que califican de "mutuo elogio". Bien sea: mutuo elogio, sí; pero ¿acaso fuera preferible un ideal de vida literaria en el que cada escritor se encastillase en sí mismo, envolviendo en profundo desprecio a los demás? ¿cómo han de surgir las buenas, las nobles, las fecundas ideas; cómo han de formarse las sólidas reputaciones sino al calor de los círculos literarios, sino mediante el mutuo apoyo, el mutuo estímulo, exteriorizados por el artículo, la carta, el consejo ${ }^{75}$

Los buenos modales de esta crítica en los que era evidente la familiaridad con El Mercurio y con Ideas, insistían en su carácter estratégico inherente, en virtud del cual la crítica tomaría, en ocasiones, una forma más cercana al consejo o la reconvención, otras al elogio reticente o la disputa atemperada, otras a la confrontación directa. Así, se podía explicar la ambigüedad de un discurso crítico que combinaba el elogio con el consejo y el juicio inflexible. Por ese motivo, sus dictámenes siempre contemporizaban: el mecanismo consistía en referir algunos errores o defectos de la obra en cuestión para luego minimizarlos o atenuarlos, cambiando el argumento que de estético pasaba a ser ético; se valoraba entonces la calidad espiritual de los sujetos,

\footnotetext{
${ }^{74}$ Pierre Bourdieu, siguiendo a Schücking, define las acciones similares a estas como pertenecientes a "sociedades de bombos mutuos", que aparecen contemporáneamente con los "signos de una nueva solidaridad entre el artista, y el crítico o el periodista". (Bourdieu:1980: 143).

${ }^{75}$ Año II, nº 6-7, enero-febrero, 1908, pp. 5-6
} 
se los alentaba en la tarea que habían emprendido, se les daba consejos para superar los errores del presente, se apostaba a la calidad de la obra futura. Así, en la necesaria relatividad de sus afirmaciones y en su afán de rescatar aquello que de valorable tenían los escritores y obras en los que se percibía algún talento, la crítica se volvía, en ocasiones, indecisa. ${ }^{76}$

\title{
3.1. Lugones: ese simpático enemigo de Giusti
}

En la "Introducción" ya citada de Giusti a la Bibliografía de la revista Nosotros, se contaba una anécdota que sirve para precisar y a la vez reforzar el carácter problemático y táctico de una relación intelectual, la de Giusti, en tanto crítico, con Lugones. En el repaso detallado de la labor de Nosotros en el espacio de "la cultura argentina" Giusti afirmaba:

\begin{abstract}
El mismo escritor ilustre a quien colaboradores de la revista juzgaban con severidad crítica, había sido o sería más adelante objeto de expresiones de adhesión y simpatía intelectual, promovidas en algunas ocasiones -valgan los ejemplos de Lugones y Groussac- por la propia dirección. (...) No era infrecuente que resentimientos de ayer se convirtieran en afectuosas adhesiones. El retrato de Lugones que ostentábamos en la galería que cubría las paredes de la redacción, galería hoy dispersa, llevaba esta dedicatoria: "A Nosotros, mi simpática enemiga”. (Giusti, 1971: XIII-XIV)
\end{abstract}

La dedicatoria de Lugones en su retrato, que era casi un oxímoron, aparecía como una broma de Lugones a su crítico, en tanto acertaba en una definición implícita del carácter ambivalente de las intervenciones críticas de Giusti en Nosotros con respecto a la obra del autor de Las montañas del oro. Estos juicios constituían, al mismo tiempo, la ostentación de un desacuerdo tanto estético como de protocolo y

\footnotetext{
${ }^{76}$ A propósito de la crítica de fines de siglo XIX, y en especial en relación con las operaciones vinculadas con la construcción de una historia de la literatura, Oscar Blanco ha observado tres tipos de operaciones: se relata lo incipiente y lo malogrado, se intenta una genealogía a partir de una lista de nombres, y a falta de obras se recuerdan escenas, fisonomías, inteligencias. (Blanco, 1997:57)
} 
sociabilidad literarios; dichos desajustes implicaban la toma de distancia en relación con una imagen de escritor que cultivaba Lugones, y se traducían no tanto en cuestionamientos de ética literaria sino más bien en ataques a la estética de Lugones, con la cual Giusti, tampoco acordaba. El pasaje ya citado del número dedicado a Sánchez encubría una referencia a Lugones cuando Giusti opinaba sobre la forma necesaria que debían asumir las relaciones entre escritores, y se refería al caso no deseado del escritor que se 'encastilla en sí mismo'. Lugones se presentaba ante Giusti como aquel que no participaba de la comunión intelectual que Nosotros intentaba diseñar. En ese sentido, la cumbre o la montaña, metáforas pertenecientes al repertorio de la orografía, con que el poeta se había pensado a sí mismo, implicaban una forma de relación con el público y un modo vinculación del escritor, intelectual o crítico con la cultura nacional, divorciado de las ideas de magisterio, de horizontalidad, de apertura y de hermandad intelectual, propiciadas desde la revista. Por lo demás, debemos dejar en claro que las expresiones de adhesión y simpatía intelectual por parte Giusti, llegaron conjuntamente con la muerte de Lugones. Más allá de su trabajo en Nuestros poetas jóvenes, donde encomiaba al poeta (se refería a su "compleja personalidad literaria"), ${ }^{77}$ Giusti no le dedicó ningún artículo especial ni en Visto $y$ Vivido ${ }^{78}$ ni en Crítica y polémica ni en Momentos y aspectos de la cultura argentina, ${ }^{79}$ libros en que hacía un balance y una historia de la cultura nacional.

\footnotetext{
${ }^{77}$ En esta obra Giusti se ocupa de Lugones más que de ningún otro poeta, dedicándole un capítulo entero "Leopoldo Lugones" y un "Apéndice" final (Giusti, 1911:157-190): El apéndice está compuesto por dos artículos aparecidos en Nosotros "Leopoldo Lugones. A propósito de Lunario sentimental", ( ${ }^{\circ} 22-23$, julio-agosto de 1909) y "Leopoldo Lugones y su obra" a propósito del libro de Juan Más y Pí (n²7, abril, 1911, pp. 226-231).

${ }^{78}$ Afirmaba: "Entre los nuestros no reconocíamos sino a un gran poeta: Leopoldo Lugones (...) En Lugones, el vigor del prosista, que había hecho proezas verbales en la conmemoración de Emilio Zola, se imponía como un puño macizo. Las Montañas del oro eran recitadas con voz cavernosa en las pláticas de café; el Himno a la luna, defendido agresivamente contra los incomprensivos; los sonetos samenianos de Los crepúsculos del jardín, paladeados sensualmente aún antes de ser reunidos en libro en 1905" (Giusti, 1965: 94). Tal vez sea éste el comentario más elogioso de Giusti sobre Lugones y su reconocimiento más claro. En otro pasaje del mismo libro, se refiere a Lugones para señalarlo como escritor consagrado y sus libros como caso anómalo de venta: "Escasa venta tenían los libros argentinos. Si Lugones vendía en pocas semanas unos cuantos centenares de ejemplares, por ejemplo, de Los crepúsculos del jardín o de La guerra gaucha, la salida se juzgaba considerable" (Giusti, 1965: 101).

${ }^{79} \mathrm{~A}$ diferencia de Lugones, Ingenieros, Becher, de Soussens, Payró y Carriego -entre otrosaparecen en el índice con capítulos especiales. Giusti dedica un parágrafo 'Aparece Leopoldo Lugones' dentro del capítulo "La cultura porteña a fines del siglo XIX". Allí Giusti para hablar de Lugones cede su voz a Darío en "Un poeta socialista", y la retoma para
} 
Esta relación intelectual podía leerse en las referencias de la sección 'Letras argentinas' de dos formas. Una directa, en artículos que trataban específicamente alguna obra de Lugones, y otra más ocasional, pero igualmente significativa, como en las reseñas de libros de otros autores. Revisar esas ocasiones permite ver cómo se fue tramando ese lazo intelectual oscilante. En 1907, en el comentario dedicado a Las Barcas de Enrique Banchs, Lugones era presentado como uno de los dos grandes poetas argentinos junto a Almafuerte, y funcionaba como parámetro a partir del cual elevar al autor del libro reseñado. Pero en la nota a propósito de El enigma interior, libro de versos de Manuel Gálvez, ${ }^{80}$ el director de Nosotros condenaba en sordina Los crepúsculos del jardín y abiertamente el intento de Gálvez en el empleo del verso libre. Giusti veía en la originalidad un valor, que asociaba con la novedad, de modo que señalaba, precisamente, la falta de originalidad como punto de igualación entre Lugones y Gálvez. Así, mientras los poemas Gálvez, quien desconocía las cuestiones del verso libre y abusaba de él, eran considerados defectuosos, la obra de Lugones aparecía como una buena aplicación de ese recurso y su autor como un imitador - en la medida en que ya existía una tradición en ese asunto. Dos números después, en la breve nota introductoria a 'Letras argentinas' del n 4 -previa a la crítica de Joyeles de J. Aymerich-, Giusti incluía a Lugones como uno de los nombres indiscutidos de la casi inexistente literatura nacional, dentro de la que reconocía una tradición de cosas de la tierra. ${ }^{81}$ No obstante el carácter laudatorio de la mención, era posible registrar allí una operación intencionada del crítico quien, aunque consagraba a Lugones colocándolo junto a Rafael Obligado, Ramos Mejía y Groussac, en cierto modo negaba su literatura como valor estético del presente. En ese sentido, importa observar que esta valoración de Lugones se realizaba en 1907 cuando el escritor, reconocido como autor de Las Montañas del oro, El imperio jesuítico, Los crepúsculos del jardín, La guerra gaucha, Las fuerzas extrañas, aún estaba en plena producción.

\footnotetext{
recordar el episodio de la exclusión de Los raros. (Giusti, 1954: 77-79)

${ }^{80}$ Año I, n 2, Tomo I, septiembre, 1907, pp. 119-120.

${ }^{81}$ Ya había señalado esta tradición a propósito de Voz del desierto de Eduardo Talero, en el $\mathrm{n}^{\circ} 1$ de la revista: "Ya forman número en nuestras letras aquellas obras que deben su justa fama a su característica de ser el fiel reflejo del ambiente físico y social en que nacieron, y a ese sabor inconfundible del terruño que sus autores supieron infundirle" p. 53.
} 
Del modo semejante, dos reseñas sobre obras de Ricardo Rojas elogiaban a Rojas para mejor criticar, implícita y explícitamente, a Lugones. En ellas se iba organizando el diseño de una oposición entre Lugones y Rojas basada en cuestiones estéticas pero también de política cultural, que culminaría en la elección temporaria del segundo en torno al debate de la identidad nacional. ${ }^{82}$ En efecto, en la primera reseña, sobre El país de la selva de Ricardo Rojas, ${ }^{83}$ Lugones era nombrado como representante consagrado de un nacionalismo literario de tema nacional en lengua culta que incluía a Echeverría, Obligado, Leguizamón y González. Giusti enunciaba esta tradición en términos similares a los había empleado González para fundamentar la invención de un pasado que cohesionara imaginariamente a la Argentina:

Hasta la saciedad se ha escrito sobre la
conveniencia que existe para todo el país, de que,
palmo a palmo, región por región, vayan sus hijos
conquistándolo para las letras. Al nuestro, desde
tal punto de vista, le ha cabido buena suerte
Obligado y Leguizamón -en verso y prosa,
respectivamente- han clavado sus estandartes
victoriosos en esa riente tierra de Entre Río cuyo
Paraná se ha vuelto el río proverbial del poeta de
"El hogar paterno". González ha unido para
siempre su nombre a sus montañas, con aquella
clásica obra de una arquitectura maciza como la de
esas mismas montañas. Por allá Lugones se ha
apoderado con La guerra gaucha de las mesetas
salteñas y jujeñas, convirtiéndolas en materia de
arte en su prosa ruda, abrupta, que bien condice
con la épica lucha que "canta".

Al momento de tratar el lenguaje empleado por Rojas, Giusti destacaba la simplicidad, la sencillez, su carácter llano, la espontaneidad vigorosa, a los que debían agregarse las reflexiones "sesudas", como valores de la obra del joven intelectual que encarnaba la figura encomiable del "hombre de estudio y de pensamiento", característica del nuevo espacio institucional universitario al que ambos pertenecían. De esta forma, quedaba si no desmentida, al menos sospechada la valoración positiva anterior de La guerra gaucha cuya lengua literaria abigarrada se contraponía al ideal de sencillez y llaneza, y no podía equipararse, salvo por los materiales que

\footnotetext{
${ }^{82}$ Cf. parágrafo 5.5 de este capítulo.

${ }^{83}$ Nosotros, $n^{\circ} 8$, mayo, pp. 150-152
} 
incorporaba, por ejemplo, con Recuerdos de la tierra de Leguizamón. La cita que transcribimos mostraba ese cambio de signo de manera más clara:

El libro se desliza con el tono de una narración, casi siempre sencilla, llana, que nos pone en contacto directo con las cosas y seres que el autor se propone pintar. Por eso repruebo el primer capítulo, en el que un cierto aparato épico -propio, comprendo, de la materia tratada- y algunas formas estilísticas lugonianas que el asunto involuntariamente sugiere, le hurtan al relato sencillez y naturalidad ${ }^{84}$ [cursivas nuestras]

Así lo que antes había aparecido para el crítico como virtud en Lugones -la concordancia entre estilo y asunto, entre épica y prosa ruda-, se presentaba entonces en Rojas como defecto, cuyo origen debía buscarse no en Rojas mismo, ni en lo que su estilo tenía de personal, sino en la filiación lugoniana de ciertas formas de su escritura. De este modo, cuando Rojas se distanciaba de los procedimientos lugonianos era merecedor de los elogios de Giusti. Nótese al mismo tiempo que el crítico cifraba las cualidades estilísticas de Rojas en su formación, que no podía identificarse con el autodidactismo de los mercuriales ni de Lugones:

El lenguaje que Rojas emplea no es desmirriado ni pobre: tiene nervio y es rico y jugoso, como era de esperar de quien ama darles a sus altas cualidades de artista el sólido substrato de una ilustración literaria severa ${ }^{85}$

Inmediatamente después, en 'Letras argentinas' de la entrega siguiente, Giusti se ocupaba de El alma española de Ricardo Rojas, que figuraba en 'Libros recibidos' de ese mismo número, junto con la reedición de El imperio jesuítico de Lugones, de la cual, según anotaban los directores, la revista se ocuparía en la entrega posterior. ${ }^{86}$ Esta vez, para afirmar la reputación literaria de Rojas, Giusti utilizaba el argumento de la continuidad $^{87}$ estética entre todas sus obras, que en el artículo de 1909 dedicado a

\footnotetext{
${ }^{84}$ Ibid., p. 151.

${ }^{85}$ Ibid., p. 151.

${ }^{86}$ Nosotros, Año II, Tomo II, n 9, abril, 1908, pp. 223-225

${ }^{87}$ La continuidad parece ser una idea rectora del pensamiento crítico de Giusti, privilegiada por sobre la innovación o la ruptura. Giusti, en el final de la reseña a El país de la selva muestra cómo lo persigue esta idea, que llega hasta el ridículo: "Concretando en una
} 
Lunario sentimental, se aplicaría como patrón de juicio negativo de los textos de Lugones, ${ }^{88} \mathrm{y}$, de ese modo, seguía trazando la oposición entre ambos escritores:

No hay en ella discontinuidad como en la de otros escritores: ciertas características comunes de los tres libros que la constituyen, son testimonio de la unidad de pensamiento de su autor. ${ }^{89}$

El intento de Rojas era elogiable, según Giusti, por dos razones: el talento y el espíritu que "tiene mucho de castizo, que me sabe a bien". ${ }^{90}$ Es importante observar que esta preferencia de Giusti por lo español en la que coincidía con el santiagueño no respondía a un interés individual sino que se extendía a la revista en su conjunto; en este escrito, dicha inclinación hacia la cultura peninsular se hacía presente cuando el crítico se lamentaba del divorcio presente entre los argentinos y el alma peninsular. ${ }^{91}$ Inmediatamente después, criticaba la influencia francesa, ${ }^{92}$ que constituía una referencia indirecta - pero clara- a Lugones, y que enlazaba con aquella primera, a propósito de El enigma interior donde Lugones había aparecido como un aplicador del verso libre francés. Sin embargo, unas líneas más adelante la mención era directa y Giusti expresaba, entonces, su gusto por la prosa de Lugones en El imperio jesuítico, por encerrar el mismo valor castizo que había hallado en Rojas. Así, Lugones era apreciado por su similitud con el autor de El alma española, en cuyo libro el director de la revista percibía -y respiraba- "una atmósfera sana":

\footnotetext{
imagen una impresión puramente personal, hallo una rara relación entre esta obra y el aspecto físico de su autor: admiro en ella toda esa arrogante fiereza, esa noble austeridad que respira la cabeza del poeta, coronada por la melena bravía. Diríase que él ha comunicado su vitalidad juvenil "p. 152.

${ }^{88}$ En Nuestros poetas jóvenes también aparecía este argumento, solo que, en 1911, Giusti podía empezar a ver cierta continuidad estética: "Por fin Lugones nos ha dado las lecciones de Belleza y Energía que yo le pedía para poder llamarlo Maestro. No sólo en las Odas seculares, sino en toda su producción del centenario" (Giusti, 1911: 51). Según Giusti los nuevos textos desvanecían "la orgía de Las montañas del oro", "la afeminación de Los crepúsculos del jardín" y "la locura de Lunario sentimental".

${ }^{89}$ Nosotros, Año II, Tomo II, n 9, abril, 1908, p. 223.

${ }^{90}$ Ibid., p. 223.

${ }^{91}$ Cf. parágrafo 5.2. de este capítulo.

${ }_{92}$ Por supuesto, se suavizaba el ataque: "Pues ciertamente, ninguna cosa más provechosa para nuestras letras que esa influencia francesa, sólo reprobable por los rancios pedantes, que ha venido a airearlas, que les ha abierto horizontes, que las ha puesto en el buen camino; únanse a ella enhorabuena, si es posible, otras influencias, sobre todo italianas; pero manténgase en nuestras letras el espíritu español" p. 224.
} 
Téngase efectivamente en cuenta que es el castellano nuestro idioma y que, si algo nos conviene, es ahondarlo y espurgarlo (sic) y conocerlo mejor, para usarlo con provecho, más bien que dar a nuestra lengua un colorido gris que va adquiriendo por el calco que de ella hacemos sobre la francesa. Léase si no El imperio jesuítico de Lugones -justamente me refiero a un libro de actualidad- y dígase si no vale más esa prosa gallarda que sabe a castizo, que esa jerga mestiza e incolora en la que todos solemos nadar. ${ }^{93}$

La prometida reseña a propósito de la segunda edición de El imperio jesuítico, a cargo Giusti, se publicó un mes después, en la entrega doble correspondiente a mayo y junio de $1908 .{ }^{94}$ El director de Nosotros reconocía la calidad estilística de la prosa de Lugones, su posición de escritor de referencia para los más jóvenes y sus condiciones de historiador. Sin embargo, cada uno de estos reconocimientos aparecía atenuado. Así, aunque declaraba que su prosa "era francamente admirable" al mismo tiempo la adjetivaba como "desigual" "adoleciente" y "falta de flexibilidad", para manifestar su disenso con la opinión general que consagraba a Lugones como "quien mejor maneja hoy día el idioma castellano". Asimismo, mientras reconocía la "dilatada influencia" de la prosa lugoniana, le auguraba un ascendiente improbable y poco duradero, e instaba a los escritores a desecharla como ejemplo. Por último, se detenía morosamente en las imprecisiones e incongruencias en relación con la verdad histórica, no obstante considerarlas marginales.

Aun cuando esta nota sobre El imperio jesuítico mostraba el carácter reticente y controlado de los elogios que en apariencia tributaba a su autor, la reseña sobre Lunario sentimental atacaba sin ambages la reputación literaria de Lugones, y por lo tanto todas sus obras. Giusti construía en este artículo la figura de Lugones como la del escritor para la juventud ${ }^{95}$ que deslumbraba por su potencia verbal. El director de Nosotros se rebelaba contra un consenso crítico mayoritario e incuestionado, que veía

\footnotetext{
${ }_{93}$ Nosotros, Año II, Tomo II, nº 9, abril, 1908, p. 224.

${ }^{94}$ Nosotros, Año II, no 10-11, mayo-junio, 1908, pp. 327-332.

${ }^{95}$ Decía Giusti: "Habiéndome también yo contado entre los más, sugestionados mis veinte años, la edad lugoniana por excelencia, por la rebelde gallardía, por la potencia verbal del poeta (...)", Año II, n²2-23, julio-agosto, 1909, pp. 290-306.
} 
en la figura de Lugones a un pontífice literario. De tal modo, se colocaba en un sitio, si bien marginal para "los más", innovador para "los menos", en el que se delineaba como crítico especializado:

Los años empero van pasando, y en el acatamiento incondicional de los más comienza a abrir brecha la discusión sensata de los menos, alimentada invariablemente por cada una de las nuevas obras que Lugones de mano en mano agrega a su ya copiosa producción. ${ }^{96}$

La "personalidad literaria" de Lugones, que se manifestaba escriturariamente en la ausencia de unidad entre sus obras, y públicamente en la "pose" de "erudito", orgulloso y pedante que alardeaba cuanto le era posible, provocaba el encono de Giusti, quien oponía a ésta la figura del "maestro". La preferencia del crítico se vinculaba con cierta idea de pedagogía pero remitía también a una inclinación hacia lo colectivo y hacia la generosidad intelectual. De ese modo, se insinuaba, una vez más, la contraposición con Rojas: frente a la pedantería de Lugones y su "rastacuerismo intelectual", resonaba aquella severidad de la educación literaria del autor de El país de la selva, con quien Giusti compartía la formación y la sociabilidad universitaria. Frente al eclecticismo estético de Lugones quedaba reforzado aquel valor de la continuidad en la obra de Rojas. ${ }^{97}$ Por último, en 1911 y a propósito del libro de Juan Mas y Pí Leopoldo Lugones y su obra, ${ }^{98}$ Giusti ratificaba sus juicios contra La guerra gaucha, Lunario sentimental, y reiteraba su preferencia por la prosa de El imperio jesuítico. Como en la reseña del Lunario sentimental, esta intervención tendía a legitimar y reafirmar su trabajo crítico pionero y sostenido sobre la obra de Lugones, junto con los de Monteavaro, Nervo, Gerchunoff y Berisso, entre otros. ${ }^{99}$

\footnotetext{
${ }^{96}$ Ibid., p. 290.

${ }^{97}$ En el mismo sentido de esas valoraciones funciona la figura de José Ingenieros, quien es recordado por su generosidad con los jóvenes, por su perseverancia en el estudio y por su labor de editor en La Cultura Argentina y en Revista de Filosofía. (Giusti, 1965: 104-111)

${ }^{98}$ Nosotros, Año IV, $n^{\circ} 27$, abril, 1911, pp. 226-231.

${ }^{99} \mathrm{En}$ la sección "Bibliografía"del siguiente a la nota sobre Leopoldo Lugones y su obra, Giusti reiteraba sus opiniones adversas y pronosticaba el pasaje a la posteridad del autor con Historia de Sarmiento: "Tengo para mí que hasta ahora éste es el libro [cursivas de Giusti]. Vez pasada empeñárame en la molesta tarea de intentar probar lo deleznable de la deslumbradora obra lugoniana. Vi en ella mucho talento, sí pero poca vida, pocas condiciones para durar. Quienes me interpretaron en el sentido de que yo lo juzgaba a Lugones inferior a cualquier fulano de tantos que raquíticamente vegetan en estos arenales
} 
Como ya se observó, los juicios de Giusti sobre Lugones en Nosotros deben pensarse como la ostentación de desacuerdos de ética y estética literarias. En ese sentido, los valores que la poética crítica de Giusti consideraba positivos para la literatura argentina, se oponían a los que hallaba en las obras de Lugones. Valores como el efecto de espontaneidad, la belleza sin alambicamiento, la claridad de los conceptos, la eticidad puesta en primer plano, señalaban una elección clara por la estética realista. Esta preferencia se había manifestado en Nosotros desde primer número, con la publicación del texto de Payró, cuya literatura, junto con la de Sánchez fue celebrada por la revista. Si, como anotaba Giusti, el castellano era nuestra lengua y la literatura era el espacio en que se afirmaba el idioma nacional, y si un modelo de lengua literaria como el que promovía Giusti podía sustentarse desde un proyecto novelístico como el de Payró, entonces se patentizaba y se explicaba su desacuerdo de Giusti con Lugones. Por último, si es posible construir y leer figuras de escritor en los textos ${ }^{100}$ pero también en las formas de la sociabilidad literaria, el disenso de Giusti con Lugones revestía un carácter más que evidente: la imagen que Lugones erigía para sí resultaba contraria a la horizontalidad y la comunión en que debían basarse, según Giusti, las vinculaciones entre los miembros de la cultura argentina, sobre todo a principios de siglo. En todas estas intervenciones era posible leer, además, la construcción del conjunto de valores en los que Giusti fundamenta su práctica y proyectaba sobre la figura del escritor, el lenguaje de la obra y el discurso del crítico. Naturalidad, belleza, serenidad, sencillez, concisión, fuerza, originalidad, sabor castizo y riqueza del léxico, claridad, rasgos todos ellos contrarios de "la afectación y la

de las letras, no me entendieron o yo no me expliqué. Negarlo a Lugones solo es factible desde un punto de vista superior, solo con esta pregunta: ¿qué quedará de él? Su fuerte y complejo talento se debe al Tiempo, a la historia literaria de nuestra lengua: yo planteé la cuestión de si había respondido a esa esperanza y la resolví negativamente. Y bien; permítaseme ahora volver sobre aquel severo juicio, lo que hago muy gustoso. Pienso ahora que cuando La guerra gaucha esté arrumbada como un malogrado esfuerzo retórico, y El imperio jesuítico haya sido arrastrado por la corriente del olvido, junto a la nula producción histórica, que nada agrega y nada quita a lo sabio, y en cambio estorba; cuando Las fuerzas extrañas se recuerde como brillante dechado de una moda que pasó; cuando todos esos títulos ya no sean sino restos flotantes de un gran naufragio -y por consiguiente, restos muy dignos de respeto-, probablemente la Historia de Sarmiento seguirá leyéndose todavía.

El escritor al fin ha encontrado su tema." Año IV, Tomo V, n² 28, mayo, 1911, pp. 299-301. Para la transcripción ampliada, Cf. NOS: 70-71.

${ }^{100}$ Cf. Gramuglio, 1992: 35-64. 
retórica", ${ }^{101}$ se constituyeron en evaluaciones recurrentes y positivas, casi cristalizadas, que Giusti tomaba como cualidades deseables y que prescribía para la literatura y los escritores.

Finalmente, la preferencia por una literatura de corte realista como la de Payró y por el tipo de sujeto que éste representaba -con su "vida de trabajo" y con su vasta obra "inspirad(a) en la realidad", destinada a "exponer, criticar y remediar"- (Giusti, 1924: 9-36), ${ }^{102}$ se erigía en parámetro de juicio tanto para la obra como para el autor elegidos. Así, en las notas críticas tendían a la construcción de una imagen autoral marcada por los rasgos de la salud, la fuerza, el esfuerzo continuado, la serenidad. De esa manera, se establecía una distancia explícita de los atributos de cierta imagen estereotipada y residual del escritor tardomodernista y decadente, sobre todo aquel que Giusti caracterizó como el caso del que se "encasti(lla) en sí mismo", pero también del erudito pedante que reconocía en Lugones. Del mismo modo, las reseñas daban cuenta de la figura del crítico como especialista - más semejante al docente que al escritor o poeta con lo cuales no establecía una identificación. Una figura distinta del crítico-artista, más ligado a ciertos modernistas argentinos, uno de cuyos casos paradigmáticos fue Luis Berisso.

\section{Por un teatro nacional: "nobles emociones" y "sanas alegrías"}

Desde su aparición, en agosto de 1907, Nosotros hizo del teatro una preocupación central. Le dedicó una sección específica, publicó en sus páginas y también bajo su sello editorial obras inéditas de autores nacionales, dio cuenta de concursos, premios y diversas actividades relacionadas con el teatro. También lo promovió en el ejercicio puntilloso de géneros diversos de sociabilidad literaria e intelectual ya aludida como los homenajes, las demostraciones, las despedidas, los recibimientos, de los que de modo sistemático sus lectores fueron enterados. A esto sumaba la información sobre aspectos vinculados con la organización no solo institucional sino gremial del teatro, como lo fue, por ejemplo, la creación la Sociedad

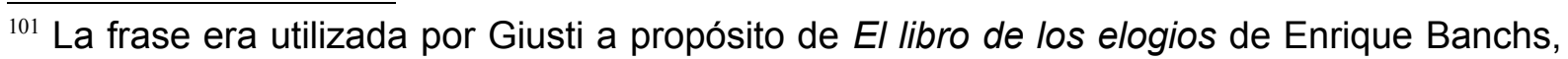
Nosotros, Año I, n 15, p. 102.

${ }^{102}$ El artículo se publicó por primera vez en La Nación en octubre de 1917. 
de Autores Dramáticos, a principios de $1908,{ }^{103}$ y el interés demostrado por los concursos teatrales de mayor resonancia como el del conservatorio Labardén fundado en 1906 por Gregorio de Laferrère, o el del teatro Nacional de Pablo Podestá. Inscribiéndose en una línea que la conectaba con Ideas en el intento de construir un teatro argentino, Nosotros aparecía en ese terreno como su relevo directo, para ejercer la crítica en un ámbito donde ya el gaucho, según indicaba la nómina de obras teatrales juzgadas, no hegemonizaba las representaciones. No obstante, era posible reconocer los ecos a veces asordinados, otras precisos, de la disputa frontal que se había entablado desde Ideas con respecto al teatro popular, en especial de signo criollista. El nombre de la sección destinada a estos asuntos fue, 'Teatro nacional'. Por tal denominación se entendía, desde la perspectiva de los directores y críticos, una práctica que nucleaba a autores, obras, temáticas, compañías de actores y salas donde las obras se representaban, todos los cuales las sucesivas entregas de la revista irían definiendo y evaluando a través de un discurso crítico especializado. Era allí donde se volvía relevante la función de la revista que, desde el circuito de la cultura letrada prescribía y seleccionaba la serie de elementos deseables y necesarios para la escena nacional. Es importante advertir que la crítica no se refería solo a la obras sino que incorporaba muchas veces la opinión del público que las había consagrado. De esta forma la revista daba cuenta de la necesidad de posicionarse frente a un fenómeno cultural que revestía un carácter más masivo que la literatura. Y lo hacía en las evaluaciones respecto de dramas que, como Sobre las ruinas de Payró, pertenecían al llamado "teatro de ideas" o de tesis ${ }^{104}$ que Nosotros reivindicaba, y explicitando, a veces, una relación conflictiva con el mercado y los autores teatrales en su crítica negativa hacia los emprendimientos simplemente comerciales. A esto debía agregarse la publicación, en la revista o como libros, de obras teatrales pertenecientes al género

${ }^{103}$ En 'Notas y comentarios' del número doble dedicado a Florencio Sánchez, deja constancia de la creación de esta sociedad, cuya 'mesa directiva' estaba formada por Otto Miguel Cione (presidente), V. di Napoli Vita (vicepresidente), Félix Alberto de Zabalía (secretario); Raúl Casariego (secretario de Actas); Alberto Ghiraldo (tesorero); Enrique García Velloso, José de Maturana, Vicente Nicolau Roig, Fernando Navarrete (vocales). enero-febrero de 1908.

${ }^{104}$ Esta denominación era usada por los intelectuales de la alta cultura como oposición a las representaciones del circo criollista, no meramente como marca afiliatoria con el llamado "teatro de ideas" cultivado en Francia, a fines de siglo XIX . Cf. la opinión de Giusti sobre Payró en nota al pie del $n^{\circ} 1$, y las opiniones de quienes responden a la encuesta del $n^{\circ} 14$ (junio, 1904) de Ideas a propósito de Sobre las ruinas de Payró. Capítulo 2, parágrafo 5.3. 
comedia -con acento costumbrista-, una alternativa específica frente al sainete o la zarzuela.

Por momentos más beligerante, por momentos más conciliadora, la discusión acerca de la conformación de un teatro nacional, aparecía como un interés explícito de Nosotros. El repaso de la sección específica, de la serie de obras que se publicaban y de los autores promocionados, indica las preferencias temáticas, lingüísticas y fundamentalmente genéricas en torno de las cuales debían pensarse, según Nosotros, las líneas centrales de la escena nacional, y al mismo tiempo, sirve para exhibir los desacuerdos que con los llamados "género(s) ínfimo(s)"105 como la zarzuela, el género chico el sainete o la revista. Reaccionar era la palabra utilizada positivamente en diversas ocasiones para demandar y plantear la necesidad de un cambio que proviniera de las intervenciones de los autores teatrales, para poner otra vez en movimiento una 'evolución' cuyas figuras de referencia inmediata más relevantes seguían siendo Florencio Sánchez y Roberto J. Payró. Si como los críticos de la revista reconocían, algunos más a su pesar que otros, el teatro nacional había tenido su origen -su pasadoen las representaciones itinerantes de una pantomima protagonizada por un gaucho malo, a cargo de un grupo de actores provenientes del circo, su futuro debía quedar ligado a la labor de los autores y críticos pertenecientes a la zona de la cultura letrada en la que se inscribe Nosotros. Este pleito debe leerse, también, e igual que en Ideas, como una de las reacciones o reacomodamientos de la alta cultura letrada democratizada con respecto a lo que ha venido sucediendo en el circuito de la cultura popular. Así, a la crítica periodística se le demandaba el ejercicio de una "verdadera misión de control" destinada a contrarrestar el mercantilismo dominante en las salas porteñas; al mismo tiempo, se interpelaba al público como espectador pensante, instándolo a que "reaccione y analice antes de aplaudir". ${ }^{106}$ Por último, Nosotros adjudicó al teatro funciones morales y educativas y vio en él, como lo había hecho Ideas, un modo y un signo de civilización

\footnotetext{
${ }^{105}$ Manuel Lugones, Año VII, Tomo IX, n 45, enero, 1913, p. 301.

${ }^{106}$ Nicolás Barros, 'Teatro nacional', Nosotros, Año V, Tomo VI, n 33, octubre, 1911, p. 332. NOS: 95-96.
} 


\subsection{Entre civilización y barbarie}

En la sección 'Teatro Nacional' escribieron, entre 1907 y 1913, en momentos distintos y con regularidad, Ricardo Bianchi, Nicolás Barros, Manuel Lugones, Samuel Linnig $^{107}$ y más esporádicamente Roberto Giusti ${ }^{108}$ y Evar Méndez. La sección daba cuenta de las obras representadas en diversos teatros porteños, principalmente Nacional, Marconi, Nuevo, Apolo, Nacional Norte, Moderno, casi todos ellos vinculados con las diversas ramas de los Podestá. ${ }^{109}$ Según la sección, en el Marconi subieron a escena La eterna ciega de Otto Miguel Cione, Juan Facundo Quiroga de Alejandro Gancedo (hijo), Parientes pobres de Coronado; entre sus reprises estuvieron Los Muertos y En familia de Florencio Sánchez, El Arlequín de Otto Miguel Cione; en el Apolo, se representaron, por ese tiempo, La conferencia de La Haya de Nicolás Granada, La eterna prosa de Cayol, Tucumán, La cruz de Alberto Ghiraldo, Canción de primavera, "poema rústico en tres actos" de José Maturana; en el Nacional, Para vencer de Leopoldo Longhi, El mejor tesoro de Ortiz Grognet, Otras músicas, El buen dolor y En el cepo de Félix Alberto de Zabalía, Las dos fuerzas de Julio Sánchez Gardel, La rondalla de Víctor Pérez Petit, La tía Brígida de Alberto Novión, Jaula de locos y La suerte negra de José de Maturana; en el Nacional Norte, Por cuatro garabatos (comedia en un acto) de A. Duhau; en el Moderno inaugurado por Pablo Podestá en 1911 se estrenó Los mirasoles de Julio Sánchez Gardel, Los colegas de Carlos Octavio Bunge.

107 Linnig, Samuel Guillermo Eduardo, firmó sus notas como Samuel Linnig. Nació en Montevideo (1888) y murió en Adrogué (1925). Fue artista de circo, poeta y autor teatral. Con la troupe, The Rampony, recorrió el país. En Nosotros comenzó su carrera de ensayista. "Voten por la mujer" fue su primera obra, y se estrenó en 1915 en el teatro Apolo. Su inclusión era relevante porque mostraba la fluidez y el contacto entre los miembros de la revista y los autores populares. Linnig fue autor de tangos, entre otros, "Melenita de oro".

${ }^{108} \mathrm{Si}$ bien Giusti estuvo directamente vinculado con el mundo del teatro, entre 1908 y 1910, en 'Teatro Nacional' colaboró una sola vez, en el primer número de la revista. En Visto y vivido refiere que en 1908 escribía las notas teatrales para El País, sección que hasta ese momento había llevado adelante Juan Pablo Echagüe; luego, en 1909, sucede a Joaquín de Vedia en la secretaría del Odeón; en 1910 vuelve a trabajar como crítico para El País. Giusti, 1965: 60-78.

${ }^{109}$ En 1902 en el Apolo de José Podestá se llevaron a escena Política casera de Soria, Jesús Nazareno de García Velloso, Canción trágica de Payró, La piedra de escándalo de Martín Coronado, Al campo de Nicolás Granada. 
En su revista de estrenos y reprises, la sección ponía en primer plano y alternadamente diversas cuestiones relativas al teatro, que las notas de Alfredo Bianchi correspondientes a los números 2, 3, 4, 5, 6,7 y 9 presentaron como aquellos problemas a los cuales volverían una y otra vez los demás críticos, con énfasis diversos. Así, por ejemplo, la relación de los autores con el público, que interrogaba si era legítimo o no recurrir a las fórmulas ya probadamente eficaces y complacientes con el gusto de los espectadores. En un medio cultural en que los aspectos comerciales determinaban la representación de las obras, el caso de Piedra de escándalo de Coronado podía funcionar como argumento en favor de un tipo de obra "sana y moral" que, a la vez, incluyera los elementos efectistas que aseguraran su éxito. ${ }^{110}$ De eso se seguía, además, la valoración que desde la crítica podía hacerse sobre las actitudes particulares de los autores respecto del mercado y del éxito de las obras como su forma más tangible, en relación con lo cual Florencio Sánchez volvía a consignarse como caso testigo, según lo certificaban las opiniones Joaquín de Vedia y Ambrosio Pardal, resaltando su despreocupación por el éxito inmediato de sus obras de aliento. ${ }^{111}$ Del mismo modo, la preferencia por ciertos géneros y estéticas se presentaba como aspecto central de esas crónicas, y se ligaba de modo indisociable con la función y el lugar -centrales- que se asignaba al teatro en la sociedad. En ese sentido, la revista transcribía los juicios elogiosos de Juan Pablo Echagüe sobre El arlequín de Cione, obra en la que el crítico veía "un trabajo fuerte, serio, bueno" que "(r)evela estudio y sanos propósitos artísticos en su autor", y "tiende hacia un fin de moral social combatiendo esa plaga terrible del alcoholismo que carcome y envenena colectividades e individuos". ${ }^{112}$ O ensalzaba en Los colegas de Bunge, la capacidad para hacer pensar y sentir al público, “compenetrándose de la original idea, nervio de la obra, que aparte sus méritos artísticos, es también de una encomiable eficacia ética". ${ }^{113}$ Estas y otras cuestiones, como la objeción a las formas espurias de la crítica teatral, ${ }^{110}$ Bianchi observaba: "En pleno medio popular ha triunfado, tanto por los golpes escénicos que en ella se hallan, cuanto por ser una obra sana y moral", Nosotros, Año I, $n^{\circ} 5$, diciembre, 1907, p. 338.

${ }^{111}$ En ese sentido, Pardal distinguía dichas obras de las que Sánchez escribía o había escrito "pane lucrando".

${ }^{112}$ Notas y comentarios, Año II, Tomo II, agosto, no 13 -14, 1908, 128- 134.

${ }^{113}$ No obstante esta afirmación, Nosotros aclaraba que esa constatación sobre la obra de Bunge no implicaba "una especial inclinación nuestra por las piezas moralizadoras", Nosotros, Año II, Tomo II, mayo-junio, n 10-11, 1908, pp. 233.234. 
fueron tematizadas en Nosotros en un discurso que no dejaba de insistir sobre la mediocridad y la indiferencia del público, constituyeron las problemáticas privilegiadas. Las quejas de Nosotros frente a la indiferencia del público por el tipo de obras que la revista intentaba legitimar debían pensarse como respuestas al éxito alcnazado por géneros menores como el sainete cómico-lírico o la zarzuela, y por consiguiente, como estrategia que escenificaba la disputa por el público. Esta contienda se ponía de manifiesto como exhortación de los críticos a los autores a quienes instaban a escribir obras que lejos de ponerse a tono con el gusto del público, lo modelaran. ${ }^{114}$

Dos intervenciones de Bianchi resultaron sintomáticas del malestar que provocaba en el director de la revista la situación del teatro nacional, en que los verdaderos autores se entregaban a la escritura de piezas que desestimaban el valor del teatro en la sociedad. En el número de noviembre de 1907, luego de repasar los estrenos del teatro Nacional y con motivo de La conferencia de La Haya de Nicolás Granada estrenada en el Apolo, a la que definía como "sátira grosera e inconveniente", Bianchi exponía un estado crítico del mundo teatral. ${ }^{115}$ La crisis de la escena nacional tomaba cuerpo, según Bianchi, en un rumbo no previsto de las producciones contemporáneas, en contraste con el comienzo "vigoroso" al que ubicaba cinco años antes. Estas obras indeseadas e imprevistas eran sainetes y zarzuelas, géneros que para Bianchi estaban fuera de la literatura, lo mismo que el vaudeville. El caso de esta pieza, representativo de la tendencia "antiartística" y moralmente cuestionable, pero exitosa, exasperaba al director de Nosotros porque revelaba que los autores se inclinaban hacia especies dramáticas estética y moralmente incompatibles. En ese sentido, Bianchi se quejaba porque no se trataba de un "sainetero" sino de un escritor reputado que, traicionando sus obras previas ;Al campo! y La gaviota, "dos tentativas sanas y serias", desciende estética y moralmente. Si piezas como La piedra de

\footnotetext{
114 Bianchi afirmaba: "cuando como en el caso actual [El buen dolor] no se premia con justicia una tentativa seria, se niega el derecho del desaliento al autor y que en vista de la inutilidad del esfuerzo, se entregue éste a la composición de sainetes cómico-líricos, más al alcance del gusto del público. De este gran error, son culpables y responsables, ante todo, los auditores inteligentes". Nosotros, Año I, n² 2, septiembre, 1907, pp. 134-136.

115 "Nuestro teatro se halla indudablemente en un período de crisis. Surgió vigorosamente hará unos cinco años, casi como un movimiento de reacción contra el malhadado género chico que tan estragado tenía nuestro gusto", Año I, Tomo 1, n 4, noviembre, 1907, p. 269.
} 
escándalo (Martín Coronado), Canción trágica (Payró), iAl campo! (Nicolás Granada), Jesús Nazareno (García Velloso), habían constituido en 1902, junto con $M^{\text {' }}$ hijo el dotor inmediatamente posterior de Sánchez, ese momento inicial fecundo, marcado por la estética realista (costumbrista y de trama sentimental), entonces, obras como La conferencia de La Haya, debían impugnarse como desvíos.

La "crisis" antes enunciada se transformó en "período de plena barbarie" en la nota del número de diciembre. Según Bianchi no debíamos olvidar que "el teatro influía singularmente sobre la marcha y la calidad de los hechos ambientes", ${ }^{116}$ y que se vinculaba eficaz y productivamente con el presente y determinaba el gusto del público. El teatro venía a cumplir así una función civilizatoria, en virtud de la cual Bianchi anudaba educación, estética y moralidad en una tríada provechosa y benéfica. Esta responsabilidad se vía reforzada por la contraposición con el "embrutecimiento popular" producto de sainetes y zarzuelas, que ya explicitara en la nota del número 4. ${ }^{117}$

A pesar de que en el transcurso de estos años, se dieron muchas obras malas, casi todas eran tentativas más o menos serias y por lo tanto dignas de estima. Pero, de un tiempo a esta parte, se nota en nuestros autores una evolución alarmante. La mayoría tiende a la fácil composición de sainetes y zarzuelas de fácil aplauso, pero con el agravante de ser estas piezas lo más antiartísticas y groseras.

Para Bianchi, las razones de la barbarie asociaban con los géneros más populares, especialmente con sus tonos (sobre todo sentimentaloides), contenidos, estéticas, estereotipos, estilizaciones, opuestos a aquel ideal de "arte natural" y verdadero que no dañaba las costumbres. Así, ni la construcción de sanos valores morales ni la educación familiar, sobre todo de las mujeres, podían ser llevadas a cabo por estos géneros 'inconvenientes'. Bianchi se preguntaba:

¿dónde poder conducir [a] una hija o [a] una hermana. Verdaderamente no se sabe. De vez en cuando, se ven en los carteles algunas de las buenas obras de épocas anteriores, pero, con todo, no hay un buen teatro, un teatro donde, después de nobles

116 Nosotros, Año I, Tomo 1, n 5, diciembre, 1907, pp. 337-338.

${ }_{117}$ Año I, Tomo 1, nº 4, noviembre, 1907, p. 269. 
emociones, después de sanas alegrías, se está al abrigo de alguna pieza grosera presentada brutalmente. ${ }^{118}$ [cursivas nuestras]

Casi como conjuro de aquella barbarie, el número doble de enero-febrero de 1908, dedicado a Florencio Sánchez con motivo del estreno en Montevideo de Los derechos de la salud, exhibía de modo contundente las preferencias estéticas de Nosotros por un teatro naturalista de tesis, y constituía una intervención ejemplarizadora, que excedía la calidad de la obra. Por un lado, porque mostraba el tipo de obra reclamada para el teatro nacional, y por otro, porque preconizaba las obligaciones de la crítica, en un contexto calificado de "indiferente". Además de la reproducción completa de este drama, y de una serie de escritos sobre Sánchez y su obra, la revista publicaba una "Explicación" en la que estas cuestiones se explicitaban y enfatizaban. ${ }^{119}$ La publicación de este número de homenaje se vinculaba también con la reacción adversa que la obra había despertado en la crítica y era una forma de solidaridad intelectual con Sánchez. Como se sabe, el tema de la pieza despertaba rispideces; uno de los personajes, Roberto, lo sintetizaba así: "Sí, amo a Renata, con todas las fuerzas del alma y del instinto y con todos los derechos de mi salud". Algunas notas con que Nosotros acompañaba el texto del drama daban cuenta de la cuestión, cuando señalaban la filiación nietzscheana del autor. Así, el uruguayo Samuel Blixen advertía esta situación:

\footnotetext{
${ }_{118}$ Nosotros, Año I, Tomo 1, no 5, diciembre, 1907, p. 337

${ }^{119}$ El texto de la "Explicación" es el que sigue y ya ha sido citado para tratar estas cuestiones relativas a la crítica:

"El homenaje es sencillo: no supone una trascendencia de ninguna especie, ni pretende ser una consagración. (...)

Los puritanos de la literatura suelen clamar sobre estos impulsos sinceros que califican de "mutuo elogio". Bien sea: mutuo elogio, sí; pero (...) ¿cómo han de surgir las buenas, las nobles, las fecundas ideas; cómo han de formarse las sólidas reputaciones sino al calor de los círculos literarios, sino mediante el mutuo apoyo, el mutuo estímulo, exteriorizados por el artículo, la carta, el consejo?", Año II, Tomo II, n 6-7, enero-febrero, 1908 , p. 6.

Cf.. el parágrafo 4.3. La crítica y la construcción de la literatura argentina en el que nos referimos a este contexto calificado de indiferente.

Además, en la nota de Bianchi sobre Los derechos de la salud, publicada en ese número, se insistía, una vez más, en la ausencia de un público calificado que pudiera hacer de esta obra un éxito: "Los derechos de la salud, escrito en francés y estrenado en París, hubiera obtenido uno de esos éxitos que consagran [a] un autor y hacen que su obra dé triunfalmente la vuelta al mundo. Entre nosotros, se ha dado solo diez noches, y ocho de ellas estaba el teatro vacío" Ibid., p. 90.
} 
Idea fundamental novedosa, clara y exacta; argumento sobrio y lleno de interés; originalidad en las situaciones; riqueza de observación psicológica; caracteres lógicos y bien trazados; acción rápida y segura; diálogo admirable por la naturalidad, el colorido, y la elocuencia... todo eso hay en Los derechos de la salud. Producción modernísima por su tendencia doctrinaria, casi clásica, resulta por la sencillez de sus recursos y la sobriedad de su belleza. Está impregnada de ese optimismo sano y cruel que Nietzsche ha inculcado en las almas contemporáneas, y que da razón hasta a las mismas perversidades de la vida $^{120}$

Las críticas que seguían al texto de la obra de Sánchez pertenecían a Juan Cancio, Samuel Blixen, V. di Napoli Vita, Joaquín de Vedia, Carlos Octavio Bunge, Raúl Montero Bustamante, Antonio Monteavaro, Arturo Giménez Pastor, Luis Doello Jurado, Ambrosio Pardal y Alfredo Bianchi. En ellas se realizaba la promoción de la figura del dramaturgo al que se elevaba a pilar de un teatro americano (Di Napoli Vita), se lo consideraba "nuestro Bracco" (Ambrosio Pardal) o "prueba real de gran teatro verdadero", "inteligencia bien nuestra" (Juan Cancio, seudónimo de Mariano de Vedia). Bianchi veía en él al "más poderoso removedor de ideas de nuestro tiempo"; la dirección de la revista se refería a Sánchez como "pilar necesario, indispensable (...) de nuestro naciente teatro", cuyos logros -afirmaba de Vedia- se amplificaban en un medio aún hostil e indiferente a los productos intelectuales. Las notas permitían leer también el consenso con respecto a la poética de corte realista - naturalista y que las intervenciones de Cancio, Bianchi y Joaquín de Vedia ${ }^{121}$ expresaban claramente. Inscriptos en esa poética los autores debían avanzar analizando nuevos medios y

\footnotetext{
${ }^{120} /$ bid., p. 62.

${ }^{121}$ Bianchi lo expresaba en los siguientes términos: "Creemos que, como todo buen autor naturalista, el señor Sánchez piensa que en el teatro, el autor debe abstenerse de toda intervención. Por lo tanto, no desea que tal o cual personaje de sus obras resulte simpático. Tomados de la vida real, con sus teorías, con sus sentimientos, su estilo propio, su acento y sus tics, los traslada a la escena y allí los hace actuar, indiferente a todo cuidado que el de anotar los hechos. [cursivas de Bianchi]. Pero para arribar a esta exactitud, que es la perfección, a la desaparición completa del autor detrás de sus creaciones, es necesario conocerlas a fondo, identificarse con ellas, entrar, como se dice, en su piel: en fin, es preciso un riguroso análisis psicológico." p. 90

Por su parte de Vedia destacaba el "talento poderosamente objetivo", el "acento espontáneo de la vida y el matiz pintoresco del color local", pp. 285-286.
} 
temáticas sociales. En números posteriores, la revista cosecharía los frutos de esta línea en la que veía una posibilidad de renovación de la escena nacional. En ese sentido, Nosotros podría enorgullecerse de la publicación de piezas tales como Los colegas (Carlos O. Bunge), El arlequín (Otto M. Cione), Por cuatro garabatos (Alfredo Duhau), El dolor del rosal (Alejandro Marcó), Ganador y placé (Arturo Giménez Pastor), Fuego fatuo (Enrique García Velloso), Comedia de pequeños burgueses (Alberto Gerchunoff). ${ }^{122}$

Como se ve, el homenaje a Florencio Sánchez significó no solo el apoyo de la revista al dramaturgo uruguayo y a Los derechos de la salud en particular, sino también y más en general, el señalamiento de una estética que se consideraba apta para escenificar otros medios sociales o para construir nuevos tipos como el "inmigrante próspero", el "propietarios benévolo", o el "hijo positivo" (Viñas, 1986: XI): el teatro debía escenificar respuestas a una realidad que se presentaba como conflictiva (Cazap -Massa, 2002: 92), y de la que los directores de Nosotros eran parte. Asimismo, en cuanto a los vínculos entre intelectuales y escritores, pudo leerse como el perfeccionamiento de una práctica que Ideas había planteado tempranamente en relación con Sobre las ruinas de Payró. Así, en un campo literario en vías de constitución, la revista celebraba la solidaridad intelectual como forma de cohesionar ese mundo a través de acciones específicas como lo eran la edición de la obra y la crítica de un autor apreciado por lo que significaba como renovación para la escena nacional, tal como lo señalara Rojas.

\subsection{Los géneros malsanos}

\footnotetext{
${ }^{122}$ Para la reseña de los argumentos de estas obras y las fechas de su publicación en la revista, véase NOS. Las obras también fueron publicadas como libros por la editorial Nosotros.
} 
La crítica literaria reciente afirma que las vertientes culta y popular del teatro argentino estuvieron estrechamente vinculadas y que esto se debió tanto a la gran circulación de las obras como al hecho de que autores de la vertiente culta ensayaban también los géneros populares (Cazap-Massa, 2002: 91-109). En Nosotros esta situación tuvo sus manifestaciones explícitas, por ejemplo, con el caso de Nicolás Granada ya citado, y se registraba, además, en la evaluación negativa de las incursiones de autores más populares en las variantes genéricas elevadas, mostrando una relación que a la luz de los escritos sobre teatro publicados en la revista es bastante menos armónica de lo que podría pensarse. ${ }^{123}$ El desprecio por el sainete y la zarzuela, iban junto con una inflexión nacionalista presente en Nosotros desde sus inicios. Más allá de la revista, esa inflexión fue propia del tono de los debates culturales alrededor del Centenario. De acuerdo con ese impulso, también se asignaban al teatro las funciones imaginarias similares a las que Ideas prescribía para la novela futura, las mismas que Nosotros había propuesto desde su primera entrega con la reedición del relato inconcluso de Payró del que la revista tomaba su propio nombre. En ese sentido, el carácter representativo y condensador del teatro con respecto a una identidad cultural de signo nacional, no debía realizarse sino a través de su vertiente culta. Así, la impugnación de las especies genéricas plebeyas tenía su correlato en una diferenciación progresiva entre el teatro criollo y el teatro nacional. En la brecha que abría ese ajuste semántico, Nosotros marcaba una distancia, y proponía su poética como la más legítima para el teatro nacional. Ésta se definía, en términos estéticos y según los críticos, como realista costumbrista o naturalista, pero siempre presidida por un imperativo mimético cuya realización más acabada se actualizaba en dramas, comedias, comedias dramáticas. De este modo se demandaba o se valoraba positivamente en las obras -como sucedía en la revista Ideas-, la observación y el conocimiento exacto de los medios sociales, la pintura de costumbres y descripción de

${ }^{123}$ Además, esto estaba motivado por el hecho de que el teatro se consolidaba cada vez más como un modo de vida en el que autores literariamente inexpertos o sin talento veían en él un medio de subsistencia. Así, podía leerse por ejemplo, las observaciones de Nicolás Barros, en la sección 'Teatro nacional': "el mercantilismo de los pseudoautores, va convirtiendo el teatro nuestro en modus vivendi, vulgar y fácil, para los que se hallan vinculados por alguna circunstancia personal a las empresas" y estimulados por "una idea más burguesa y positiva de la vida: la eterna razón del estómago". Año $\mathrm{V}$, Tomo VI, $\mathrm{n}^{\circ} 33$, octubre, 1911, p. 331-332. 
caracteres, el uso de una lengua literaria no artificiosa ni convencional para dar cuenta de la vida moderna y representarla en todos sus aspectos; la relación indisoluble con el presente donde el drama se situaba y sobre el cual operaba y por lo tanto, el énfasis en lo particular y en la capacidad del arte de representar "los hechos actuales", ${ }^{124}$ el criterio de verdad psicológica en la construcción de los personajes; la sencillez, la objetividad.

En homenaje a Sánchez, algunos meses después de su muerte en noviembre de 1910, la revista decidió publicar una serie de cuatro conferencias tributadas en su honor, aunque finalmente solo se reprodujeron la de Rojas en el Odeón ( $n^{\circ} 27$, abril 1911) y la de Joaquín de Vedia, en el teatro Nacional Norte ( $\mathrm{n}^{\mathrm{o}} 28$ ). ${ }^{125}$ Ambas conferencias junto con el discurso que pronunció también de Vedia en el homenaje de Pablo Podestá a Sánchez, conmemorando el primer aniversario de su desaparición ( $\mathrm{n}^{\mathrm{o}}$ 34), constituyeron intervenciones significativas en el trazado de esa poética, porque precisaban el ajuste semántico que ya señalamos y exhibían la perspectiva nacional desde la que eran pensadas. Así Rojas, en el marco de su autoproclamación como "pregonero de una argentinidad más intensa, y heraldo ilusionado de un arte propio", ${ }^{26}$ señalaba como precursores de Sánchez los sainetes de 1890 y la literatura criolla del XIX, asignando a la obra del dramaturgo un valor testimonial de la "formación de la conciencia argentina" (172), y por lo tanto portador de lo nacional, que ya no se definía exclusivamente como criollo. ${ }^{127}$ Sánchez aparecía, entonces, en la mirada de

${ }^{124}$ Rojas se refiere a la "poderosa capacidad representativa de los hechos actuales" que "permanecen en los límites del particularismo y la realidad", Nosotros, Año IV, Tomo V, 5, $n^{\circ}$ 27, abril, 1911, p. 169.

${ }^{125}$ Las otras dos son las de Vicente Martínez Cuitiño y Enrique García Velloso.

${ }^{126}$ Nosotros, año IV, $\mathrm{n}^{\circ} 27$, abril 1911, p. 164.

${ }^{127}$ Rojas reconocía en las obras de Sánchez una "poderosa capacidad representativa de los hechos actuales" y en ese sentido son realistas (p. 169), "permanecen en los límites del particularismo y la realidad" ya que no realizan generalizaciones filosóficas. (p. 169) Entre todos los rasgos que señalaba como característicos del autor ("la simpatía humana", "la prodigiosa capacidad auditiva y visual", "las memorias específicas que son subsiguientes a toda sensación de gestos y sonidos", que daban a su teatro "el acento espontáneo de la vida y el matiz pintoresco del color local) destacaba la inclusión de personajes e historias nuevos en el teatro culto: "Fábulas desconocidas y sin prestigio, tipos de gauchos, de gringos, de compadres; lenguaje de orilleros y gurisas, de canillitas y lunfardos; escenarios de leonera de conventillo y de galpón, he ahí lo que Sánchez nos ofrecía en su teatro, desafiando la tradición culterana y el snobismo rioplatense; (...) Su victoria es la victoria del Teatro Nacional [en mayúscula en el original] en el Río de la Plata, y recíprocamente. Sus tipos, sus lenguajes, sus escenas, venían elaborándose desde muchos años atrás, y ha contribuido a 
Rojas, como una especie de sociólogo de esa nueva fórmula ampliada de lo nacional, a partir de su "poderosa capacidad representativa de los hechos actuales":

Había elaborado ya las escenas de nuestra clase media y de nuestras clases rurales, donde sus antecesores y colaboradores son tan numerosos, y preparábase a obrar con nuestra burguesía, donde su labor hubiera sido tan personal, que habría dado a nuestro teatro una nueva era, a nuestra literatura una nueva conquista; y puesto que no solo el gaucho es argentino, a nuestra conciencia civica una nueva revelación. (173) [cursivas nuestras]

La misma operación con respecto a lo criollo se registraba en los escritos de Joaquín de Vedia. Cuando se refería a los orígenes del "teatro argentino" ( $\left.\mathrm{n}^{\mathrm{o}} 34\right)$, destacaba el carácter original del período marcado por la figura de Juan Moreira, lo valoraba por su capacidad de aglutinar a un público heterogéneo, y lo ubicaba definitivamente en el pasado ${ }^{128}$ a partir del momento en que esa capacidad convocante había declinado, en virtud de lo cual quedaba relegado a aquellos no "favorecidos del rango y la fortuna":

Esa abandonada escena criolla quiere seguir la transformación, rompe para siempre con la pista,

realizarla, esa pléyade numerosa constituida en Sociedad Argentina de Autores dramáticos que con sobrados títulos patrocina también esta ceremonia", Ibid., p. 173

Y continuaba: "Raro es el tipo de Sánchez cuyo antepasado no esté en los sainetes de hace veinte años o en la literatura criolla del siglo anterior. La escena del matadero descripta por Echeverría le preludia, el argumento gaucho contado por Hernández le anuncia, los tipos criollos creados por Gutiérrez le hacen presentir, los diálogos cosmopolitas referidos por Fray Mocho le dan el instrumento elaborado -todo esto sin contar a todos sus predecesores del teatro-, de tal modo que escenas, argumentos, tipos y coloquios, vienen a confluir en él, cristalizándose en una obra cíclica y un talento sintético que a todos los resume.", Ibid., p. 173.

128 Sostenía: "Nace éste [el teatro argentino] con Juan Moreira, pantomima primero, alternada con diálogos después y convertida por último en drama; es un poco el proceso de formación de lo que ha venido a llamarse en Francia la ópera cómica. Su escenario es en un comienzo la pista del circo, que se complica más tarde con un escenario verdadero. Es original y bárbaro, aquel producto de la ciudad que vive en íntimo consorcio con la vida y las costumbres del campo, pero es tan propio del medio, que nadie, aún en las clases sociales que ya empiezan a sacudir sus vínculos tradicionales y a vivir en la nación fuera de la nación; nadie, ni los remilgados, ni los que dan principio a la tarabilla parisién, dejan de ir a verlo, y no una, sino muchas veces. Muy pronto, la ciudad, multiplicados sus elementos de comunicación con el exterior, al tiempo que se aflojan los vínculos con el interior, relega aquel teatro al público constituido por factores ajenos al interés que congrega a los favorecidos del rango y la fortuna en esas salas donde grandes actrices y actores extranjeros evocan, con lo precipitado y desmantelado de sus representaciones, reminiscencias de la misa en el campamento". Año V, Tomo VI, nº 34, noviembre, 1911 
su cuna, y renunciando a su nombre de bautismo, se hace llamar nacional. Al perder su personalidad, sufre la crisis determinada por las nuevas orientaciones generales, cae en la imitación servil, imitación de la barbarie originaria por un lado, imitación del populacherismo de la zarzuela española por otro, imitación, en fin, de las pretensiones filosofistas de cierto drama moderno. La retahíla inagotable de las metáforas gauchas, el accidental 'cocoliche', y el episódico 'lunfardo', proveen su lenguaje, sus asuntos o sus caracteres, y cuando sale de ahí, es para caer en tal lecho de lirios y crisantemos de contrabando que se envenena el aire de las salas miserablemente sórdidas. Todo es falso, el gringo y el compadre, el paisano inculto y el pueblero hipócrita y cruel.

Si como puede observarse, el cambio de nombre ocasionaba la crisis del teatro criollo, la obra de Sánchez, presentada por de Vedia como continuidad y articulación con aquel pasado criollo, se erigía ahora en teatro nacional, encontraba "un público" y “actores que lo interpreten”, una temática, reflejaba las costumbres, el temperamento, el espíritu de la raza. ${ }^{129}$

129 "Entonces aparece Florencio Sánchez, que tiene el instinto, una genial preciencia del teatro, y sin volver al punto de partida, porque ya no es necesario, trae a la escena, con la misma ingenua sinceridad que dio vigor al primitivo género criollo, los hombres del país, con los cuales ha vivido y ha peleado también, y hace esa serie de dramas y comedias, como Barranca Abajo, como La gringa, rápidos en la forma que los sintetiza, lentos en el fondo que desarrollan, donde el estallido solo viene con el hartazgo del sufrimiento, donde la lucha no es tumultuosa, donde no hay abismos, sino declives, donde se siente la monótona tranquilidad de la naturaleza, donde el amor o el odio hacen pausadamente su camino a través de largas distancias, el teatro de la pampa argentina y de las cuchillas uruguayas, que saltando sobre el gaucho del folletín va a buscarlo en la leyenda para unirlo con su última realidad viviente en tipos tan bellos, tan nobles, tan consoladores, como don Zoilo, don Cantalicio, o el viejo de M'hijo el dotor. Así como encuentra un público que, a pesar de su cosmopolitismo, le comprenda, le estimule, le aplauda, encuentra actores que le interpreten. Hay teatro, donde el intérprete se siente ancho en su papel, y donde el pueblo ve reflejarse las costumbres, el temperamento, el espíritu de la raza.(...) Dentro de la campaña misma, realiza la conjunción de ese crepúsculo con la nueva aurora, y entre don Nicola el colono y don Cantalicio el criollo despojado, que plantean el conflicto, está Próspero, el tipo joven en quien se suma el esfuerzo positivo del trabajo y el idealismo altanero de la aventura; y entre el paisano don Zoilo y el pueblero Juan Luis, está el pobre Aniceto, que desaparece, más apto y más libre que aquél, mejor y más bueno que éste, con rumbo a quién sabe qué desquites o venganzas. $Y$ no se crea tampoco que es unilateralmente campesina la visión del autor: así como supo ver y sobre todo sentir ese aspecto principalísimo de la existencia nacional, supo considerar y comprender, en sus calles en sus casas, en sus tugurios, en las salas de los palacios y en los patios de los conventillos, en las guaridas del crimen y en el honesto hogar obrero, en todas sus fases, la metrópoli frenética de opulencia y miseria, de ansias y dolores, de virtud y vicio", Ibid., pp. 
Más o menos contemporáneas de los escritos de Rojas y de de Vedia, las notas de la sección específica denunciaban aquellos elementos considerados enemigos de un verdadero teatro nacional. El "sainetismo", ${ }^{130} \mathrm{y}$ sus autores son denostados, y en estas críticas se condenaba también el carácter meramente empresarial y mercantil que había adquirido el teatro, y su consiguiente conversión en un modus vivendi aprovechado por pseudoautores. Los críticos de la revista asignaban a las obras teatrales una función docente que según ellos no podía realizarse en piezas artísticamente mediocres, enroladas en un género "guarango y soez", "gestero", escritas en "lunfardos inverosímiles", con “afanes de efectismo melodramático". Era por esto que instaban a los autores de la vertiente culta a "reaccionar", buscando nuevos argumentos, y demandaban una urgente conversión a los saineteros, amonestando a quienes como Carlos M. Pacheco, incursionan en el drama o en la comedia con obras faltas de ideas y de acción dramática. Cuando los autores defraudaban la poética relativamente compartida desde la que eran juzgados, las amonestaciones y consejos se multiplicaban.

La intervención de Nosotros en relación con el teatro no puede desvincularse de la experiencia anterior de Ideas en su pretensión de señalar los elementos indispensables para la construcción de un teatro nacional y su demanda no solo de nuevas temáticas, sino también del requerimiento de un mayor grado de profesionalización por parte de actores y autores. Nosotros, que fue contemporánea de la llamada época de oro del teatro argentino, paradójicamente se refirió a ese momento en términos de crisis y de barbarie; esta evaluación negativa de la escena teatral que le era contemporánea podía explicarse como evaluación del éxito más generalizado de los géneros populares, comparado con el del teatro culto. En ese sentido, Nosotros propuso una empresa de nacionalización del teatro que suponía que los autores debían transformarse en escritores, por medio del cultivo de géneros más elaborados y jerarquizados como la comedia o el drama. Para los actores, por su parte, tal nacionalización implicaba el abandono de la gestualidad propia del circo y del teatro de signo criollista, para dar paso 387-390.

${ }^{130}$ La expresión corresponde a Nicolás Barros, en la nota del $n^{\circ} 33$ sobre Carlos. M. Pacheco. Barros había definido a Nemesio Trejo como "popularizado sainetero" que fracasa en el intento por cultivar géneros más trabajosos, Nosotros, $n^{\circ} 30$, julio, 1911, p. 64. 
a un teatro en el que la idea y el pensamiento pudieran conjugarse con la emoción. Así, la revista promovió una estética realista (costumbrista o naturalista) como modo eficaz de representar problemáticas que fueron tema de las piezas teatrales: la inmigración, el trabajo, y específicamente la condición de los intelectuales. ${ }^{131}$ Por otra parte, la cuestión del público teatral, al que percibían como heterogéneo, fue una preocupación directamente vinculada con las posibilidades de nacionalización del teatro. Así, desde las páginas de su revista, Alfredo Bianchi pudo pedir a Pablo Podestá que "contuviera un poco sus ímpetus rugidores que, si bien pueden agradar al público de las galerías altas, solo consiguen, ante el público culto, hacer antipático y hasta odioso al personaje que precisamente debiera serlo menos". ${ }^{132}$

\section{La inflexión nacionalista.}

\subsection{Una lección de socialismo: el buen nacionalismo}

Jorge B. Rivera ha caracterizado el proyecto de Nosotros como el de "satisfacer las expectativas de consumo y producción suscitadas por la pedagogía normalista y por la incipiente Facultad de Filosofía y Letras" (Rivera, 1995:60). Así, el nosotros de Nosotros podía definirse fundamentalmente como un grupo de jóvenes formados en esa Facultad creada en Buenos Aires, hacía poco más de diez años. La colocación a que aspiraban escritores e intelectuales que participaban de la revista tuvo un signo institucional fuerte. La institución funcionaba como garantía de horizontalidad democrática convirtiéndose en sede de una forma más moderna del intercambio

\footnotetext{
${ }^{131}$ La comedia Ganador y placé de Arturo Giménez Pastor, trata de los problemas que enfrenta un autor teatral para escribir sobre el tema que le tocó en suerte en el concurso, tema del que no sabe nada. El título a partir del cual debe imaginar su obra es Ganador y placé. En nota del autor se aclara: "Esta comedia fue la consecuencia de una humorada de autores dramáticos que se convirtió en concurso o certamen público sometido a las condiciones que se enuncian en el diálogo [se refiere al diálogo entre Aurelio y su mujer en el que Aurelio explica su desgracia por haberle tocado tal título]. Esto explica la naturaleza de la obra, y el apasionado interés que esa justa despertó y el favor que hasta ahora otorga el público a Ganador y placé explican su publicación". Año V, Tomo VI, n 32 , septiembre, 1911, p. 191. También Fuego fatuo de Enrique García Velloso. La obra trata de un artista (Lucero) a quien su mujer -Eloísa, que ha renunciado a un mejor pasar por estar con él- no comprende. Lucero es el artista que se niega a seguir los imperativos del mercado. Argüello es un amigo que también es artista y a su regreso de Europa decide dedicarse a la industria agropecuaria. Año $\mathrm{V}$, Tomo $\mathrm{VI}, \mathrm{n}^{\circ}$ 34, noviembre, 1911.

${ }^{132}$ Las palabras corresponde a Bianchi, en su comentario sobre la representación de La eterna ciega de Otto Miguel Cione, Año I, Tomo 1, n² 2, septiembre, 1907, p. 136.
} 
literario en la que se construyen afinidades no solo estéticas. ${ }^{133}$ Los directores ubicaron la escena de comienzo de su amistad en la Facultad de Filosofía y Letras -en ese momento Giusti tenía, 17 años y Bianchi 21-, hecho que se traduciría en la presencia de colaboradores pertenecientes a ese espacio institucional, ${ }^{134}$ y en el intento de construcción de un público especializado y también universitario. ${ }^{135}$ Esto no quería decir que la revista dejara de lado la idea de un público culto ampliado, conformado por "estudiantes, profesionales e intelectuales de clase media al que es necesario satisfacer desde miras ideológicas, estéticas, político-culturales comparativamente heterogéneas". La publicación tampoco abandonó la idea de ejercer sobre tal público una cierta pedagogía, reciclando para él la hegemonía de los ideales de la 'alta cultura' (Rivera, 1995: 62.) Giusti reconstruyó el comienzo de la relación con Bianchi en los siguientes términos:

Me conocí con Alfredo Bianchi en el atrio de la facultad de Filosofía y Letras, hasta podría decir qué día del mes de junio, pues guardo en mi poder un folleto - la Defensa de los criminales de Edward Carpenter!- el cual me fue dedicado en memoria de la iniciada amistad. (Giusti, 1965: 319)

A diferencia de la norma de la revista de no publicar, salvo en contadas oportunidades, artículos en los que hiciera explícitas sus ideas políticas, ${ }^{136}$ la escena reconstruida por Giusti en sus memorias condensaba, en la lectura del libro de Carpenter, una significación y una afiliación marcadas políticamente, las cuales sirven

\footnotetext{
${ }^{133}$ Beatriz Sarlo y Carlos Altamirano definen la facultad como: "lugar de contactos, fuente de trabajo, acceso a los libros (muchos de los jóvenes escritores carecían de bibliotecas familiares), comunicación con los consagrados" (1983: 87).

${ }^{134}$ Cuando en 1912 Julio Noé quien colaboraba en la revista desde tiempo atrás ocupa el cargo de secretario de redacción, ese carácter universitario es colocado en el centro por los directores en la presentación que hacen de Noé en 'Notas y comentarios': "uno de los buenos representantes de la generación universitaria del momento actual", Nosotros, Año VI, Tomo IX, $\mathrm{n}^{\circ} 44$, diciembre, 1912 p. 223. [cursivas nuestras]

${ }^{135} \mathrm{~L}$. Eduardo Brizuela sostiene que en Visto y vivido "hay un fuerte predominio de hombres ligados a la Facultad" (Brizuela, 1987: 25-31).

${ }^{136} \mathrm{El}$ hecho de que Giusti abandonara la dirección de la revista confirma este norma general. Leticia Prislei que a principios del año 1920 "Giusti, que adscribió fugazmente al tercerismo, decidió renunciar a Nosotros porque los estatutos de la misma la declaraban apolítica. Este alejamiento parcial se mantuvo entre 1920-1924. Se desempeñó como concejal, por el Partido Socialista, en la municipalidad porteña (1921-1926)" Fue electo diputado por el Partido Socialista Independiente (1932-1934). Cf. Prislei, 1998: 3397-3400.
} 
para caracterizar la tarea intelectual que ambos encaran desde Nosotros. De ese modo, podía decirse que el fundamento político de la amistad que sustentaba la revista, se transfería a las acciones que Nosotros pretendía desplegar en la cultura argentina. En "Conversaciones de actualidad. Elogio de la democracia", un escrito aparecido en la revista en 1909, Alberto Gerchunoff escenificaba este carácter político. El escrito estaba dedicado a Joaquín de Vedia y se trataba de la ficcionalización de las opiniones sobre la democracia que circulaban entre los miembros de la alta cultura. En él se refería una reunión de amigos en casa de uno de ellos, músico y anarquista. Del encuentro participaba también la hermana del músico, de quien el protagonista Leonardo Cruz, un socialista confeso, estaba enamorado. "Sentados en el patio, los contertulios del café Garibaldi discutían asuntos diversos": de arte y de política. El texto era importante porque sellaba la unión entre ambos órdenes o, al menos, la necesidad de imaginar un lugar para el arte en relación con la política y así, una función que lo legitimara. Leonardo Cruz anotaba:

La democracia es, por otra parte, un sistema que solo por singulares enredos de sofismas, puede oponerse a la existencia honda y alta de los espíritus superiores.

Los artistas ganan con la democracia porque en ella la belleza se exalta y difunde. La teoría, no sé si original, es por lo menos exacta. Las obras de arte de otras épocas permanecían enclaustradas en las galerías del Vaticano, en los templos, en las cámaras de los reyes y los palacios de los grandes señores. (...) El pueblo al ilustrarse se hace sensible a la belleza y ésta aumenta a medida que se agranda el por ciento de los que saben gozarla. (...)

La estrofa recitada en la asamblea es más bella que dicha en el círculo íntimo de los selectos, porque su belleza mece gran número de almas y las satura con su perfume. De este modo, la poesía de estéril se convierte en fecunda y cumple con amplitud sus designios augustos.

(...) Ahora se sabe que la democracia no es la igualdad. No se pretende eso. Se busca simplemente dar a todos los hombres los mismos derechos e imponerles deberes idénticos. El 
zapatero de la república bien gobernada, no es igual, desde luego a Domingo Faustino Sarmiento, pero a ambos señala el estado de obligaciones parecidas que las realizan según sus capacidades. Uno escribe libros y otro clavetea zapatos.

De esta manera, instruido el mayor número de gente en la administración de los negocios públicos, se llega a un orden de cosas agradables, en el cual la vida se desliza tranquila. La justicia, equilibrada por la ausencia de odios y parcialidades siniestras, cobra prestigio y hace venerables las leyes. La justicia, en pro de cuya organización quiso fundar un partido Roberto Payró, observada de este modo, contribuirá a reformar muchos conflictos de carácter diverso. Y reformándose las leyes a medida que se vive, se llega a la democracia plena y armoniosa. ${ }^{137}$

El escrito es relevante porque hace explícita la opinión política compartida por algunos miembros de la revista, entre los que se contaban los directores, pero sobre todo, porque enunciaba una perspectiva en relación con la democracia, vinculada directamente con la posición, no sólo estética, sino también ciudadana de quienes hacían Nosotros como intelectuales democratizadores de la cultura. ${ }^{138}$ La evaluación favorable de la democracia en tanto sistema político exhibía su diferencia con respecto a valoraciones previas que, como las de Groussac en "La educación por el folletín", Cané en "Nuevos rumbos humanos", ${ }^{139}$ Becher en "La tradición y el patriotismo" 140 Rodó en Ariel, la habían impugnado porque, considerada como sistema social, daba por tierra con las jerarquías, equiparando la calidad con la cantidad. El cambio que representaba Nosotros al respecto provenía del pensamiento socialista, cuyas ideas compartían -estuvieran o no afiliados al Partido- Gerchunoff, Giusti, Ingenieros, Bianchi, Mario Bravo, Payró. ${ }^{141}$

\footnotetext{
${ }^{137}$ Año II, T4, n 18-19, enero-febrero, 1909, pp. 70-71.

${ }^{138}$ Jorge Rivera caracteriza la labor de Nosotros como "difusionista y socializador[a]". (Rivera, 1995: 60).

${ }^{139}$ Cf. Capítulo 1, parágrafos $2.1,2.2$ y 2.3 .

${ }^{140}$ La Nación, Buenos Aires, 28/06/1906, publicado con seudónimo. Tomamos estos datos de Rivera, 1992: 29-33.

${ }^{141}$ Giusti recuerda en Visto y vivido la simpatía extendida en los miembros de su generación por las ideas socialistas: "Los anarquistas convictos y confesos eran raros en nuestras filas (...) General era en cambio la adhesión a las ideas socialistas. Nadie había leído, en verdad, El capital, a lo más, hojeado en un compendio. No nos arriesgamos siquiera a leerlo cuando en 1907 seguimos en la cátedra de Sociología de la Facultad, el curso que dictó nuestro
} 
Respecto de la acepción de la palabra socialista en ese momento, Noé Jitrik señala que:

Los socialistas eran, en realidad, como Giusti, liberales; tan solo habían hecho una síntesis entre una tradición nacional no muy vieja y ciertas ideas de transformación social y cultural. (...) aquellos social-liberales, en cambio, se movían por otros impulsos, eran antiautoritarios, pensaban que el Estado -así como lo había imaginado Sarmiento-, podía a través de leyes justas dar forma a una suerte de rosada utopía. Payró, sin duda, encarnaba a la perfección todos esos cruces: la literatura debía [en cursiva en el original] constituirse en y desde el nuevo y gran escenario, en la turbia mezcla con la que se podía amasar el nuevo país. (Jitrik, 1998:101-110)

Como se ve, la crítica de Jitrik concuerda con las intenciones y la formulación del narrador del escrito de Gerchunoff. Éste funcionaba como su alter ego y resaltaba la relación, que habíamos apuntado, con el modelo sarmientino, acerca de la creencia en el poder efectivo y real de la labor parlamentaria, y de la pedagogía intelectual, en función de la cual la literatura coadyuvaba en la construcción de la nacionalidad. Si estas afirmaciones son pertinentes en términos generales, el análisis detallado de Nosotros entre 1908 y 1913 revela, no obstante una inflexión de corte nacionalista, que "Elogio de la democracia" resumía en las siguientes frases: "Sí, contestó Leonardo. Como socialista verdadero soy republicano y patriota. Mi amigo, el sabio doctor Justo ya lo ha dicho: El socialismo es el buen nacionalismo". ${ }^{142}$

El nacionalismo cultural practicado por la revista presentaría dos caras: una que miraba hacia el pasado, en la vertiente nostálgica y rural representada principalmente por Martiniano Leguizamón; otra tendiente al futuro, marcada por el espiritualismo y

maestro Ernesto Quesada sobre las doctrinas filosóficas y sociales de Carlos Marx.(...) Vagamente se creía que el fruto [la transformación del orden social], sazonado por el irresistible calor de los movimientos populares, caería maduro del árbol. (...) Se preguntará el lector si pensando así estábamos todos afiliados al pequeño partido que en 1904 llevó a Alfredo Palacios al Congreso. De ningún modo." Más adelante se refería a esta simpatía ideológica como "sarampión socialista" que "prendió en muchos aprendices de escritores y jóvenes universitarios en formas más o menos esporádicas e irregulares", por ejemplo en Becher (Giusti, 1965: 86-87).

${ }^{142}$ Nosotros, Año III, n 19, 1909. 
el idealismo por momentos excesivo. La presencia fuerte Rodó (no sólo como colaborador sino también como autor estudiado, y reverenciado en calidad de maestro por distintos críticos de Nosotros, sobre todo a partir de Motivos de Proteo) certificaba ese rasgo espiritualista. Por su parte, Ricardo Rojas quien llevaría adelante una posición fuertemente idealista, funcionaría como el par con quien Nosotros discutiría la construcción de una identidad cultural nacional. Asimismo, algunas de las intervenciones de Julio Noé, secretario de redacción desde diciembre de 1912, se inscribieron en esa misma línea.

\subsection{Desde el americanismo hacia el nacionalismo}

Nosotros exhibió su intención de construir o participar de una comunidad intelectual latinoamericana, ${ }^{143}$ desde los primeros números, en su declaración explícita de la nota de apertura y en el anuncio de secciones como 'Letras Hispanoamericanas', 'Letras Brasileñas y Portuguesas'. ${ }^{144}$ La retórica en que enunciaba este afán americanista recuperaba su afiliación con ciertas formulaciones modernistas relativas al arte, que empezaban a mostrar un signo residual y cuya función era diseñar un lugar para la producción simbólica, definiéndola como el otro del materialismo y la vulgaridad. Al mismo tiempo, se diferenciaba de Ideas, que ya desde "Sinceridades" había señalado lo nacional como espacio de su intervención. En la tapa del primer número -que se mantuvo idéntica a lo largo de período que estudiamos (1907-1913)-, un atleta coronado de laureles llevaba en su mano izquierda una trompeta y en la derecha sostenía el globo terráqueo hacia el que miraba y en el que se veían "las tres Américas": aquel propósito de aproximar culturalmente a las naciones

\footnotetext{
${ }^{143}$ En la presentación se hablaba de "salvar las fronteras de la patria y extenderse a toda América latina" [en minúscula en el original] p.6. NOS: 1.

${ }^{144}$ Estas secciones a veces fueron solo propuestas y nunca se realizaron. Así, por ejemplo, la prometida sección 'Letras Hispanoamericanas' no apareció nunca entre 1907 y 1913; Más y Pí, quien era presentado como encargado de 'Letras Brasileñas y Portuguesas', escribió sobre Letras Brasileñas -no ya portuguesas- una sola vez. Allí se refería a la "verdadera y la más digna obra de confraternización americana" p. 114. Nosotros, Año I, $n^{\circ} 2$, septiembre, 1907, pp. 112-114. En el $n^{\circ} 5$, en 'Notas y comentarios', se mencionaba la incorporación de Elysio de Carvalho como encargado de 'Letras Brasileñas', sin que luego se concretara esta participación (NOS: 21)
} 
latinoamericanas era evidente. Asimismo, la nómina de colaboradores que se dieron cita durante los dos primeros años y una insistente proclamación de su benéfica labor en tal sentido, confirman la voluntad de intercambio. ${ }^{145}$ Aunque el afán latinoamericanista no desapareciera, las sucesivas entregas perfilaron la acentuación progresiva de una tendencia espiritualista antes presente, la cual coincidió con una puesta en primer plano de la figura y la obra de José Enrique Rodó, entre octubre de 1908 y enero de 1910, y con la incorporación explícita de las relaciones culturales con España, como parte del programa de la revista. Este énfasis también sirvió como entrada y acompañó los discursos nacionalistas, que se irían tornando hegemónicos en la revista -ascenso que comienza en 1908 y culmina en 1913, año de la publicación de la encuesta sobre Martín Fierro, luego de las conferencias de Lugones, cuando Nosotros alcanzó su punto máximo de visibilidad en el campo literario.

Con respecto al "éxito" de Ariel, Carlos Real de Azúa observa que solo tuvo lugar recién cuando "las grandes editoriales de alcance euroamericano, es decir, dotadas de una adecuada distribución en todo el continente tomaron a su cargo la tarea", para el caso la editorial valenciana Sempere. (Real de Azúa, 1976: IX-XXXV). De ese modo, el hecho de que Nosotros se ocupara por ese tiempo del ensayista uruguayo, tenía su motivación en un suceso del mercado editorial. Igualmente, fue contemporáneo del éxito editorial más modesto de la primera edición de Motivos de Proteo (1909), que se había publicado en Montevideo en abril de 1909, en la imprenta "El Siglo Ilustrado", para la "Librería de la Universidad". ${ }^{146}$ Sin embargo, es pertinente

${ }^{145}$ Entre los nombres de este bienio se contaron: Manuel Pichardo, Márquez Sterling, Arturo R. de Carricarte (cubanos); Samuel Blixen, Raúl Montero Bustamante, Carlos Vaz Ferreyra, José Enrique Rodó (uruguayos no residentes en Argentina); Amado Nervo (mexicano); José Santos Chocano (peruano); Rubén Darío (nicaragüense); Max Grillo, Antonio Gómez Restrepo, Manuel Cervera, Samuel López, Guillermo Valencia (colombianos); Rufino Blanco Fombona, Felipe Valderrama (venezolanos). Entre los latinoamericanos residentes por ese tiempo en Buenos Aires participaron de la revista entre 1907-1909: Florencio Sánchez, Víctor Arreguine, Horario Quiroga, Otto Miguel Cione (uruguayos); Arturo Pinto Escalier, Luis Ipiña (bolivianos); Eloy Fariña Núñez (paraguayo); Pedro Sonderéguer (colombiano). Cf. Giusti, 1957: 21-37.

${ }^{146}$ Agotada esta primera edición de dos mil ejemplares, Rodó resolvió hacer una segunda. En un comienzo intentó -como lo había proyectado para la primera, prevista para 1905 y en Barcelona- con una casa europea, pero, las condiciones del contrato eran absolutamente inconvenientes. Finalmente, la obra fue publicada (y mejorada) por Berro y Regules, en 1910. Tomamos estos datos del citado prólogo de Real de Azúa. 
señalar que la revista mostraba un interés por Motivos de Proteo que no podía explicarse únicamente en función de un afán de actualidad. En ese sentido, Nosotros no solo había dado cuenta de esta última obra en dos entregas consecutivas, sino que en octubre de 1909 había publicado un capítulo -“El espíritu de Goethe”-, y en el número de enero de 1910, Motivos de Proteo volvió a ser objeto de crítica, con lo cual el énfasis era claro. Por otra parte, la respuesta de Rodó, publicada por la dirección en 'Notas y comentarios' de la entrega de diciembre de 1907, ${ }^{147}$ mostraba el interés temprano de Giusti y Bianchi por contarlo entre sus colaboradores.

El primer artículo dedicado a Rodó, firmado por el prestigioso colombiano Antonio Gómez Restrepo, se abocaba fundamentalmente a Ariel y a la figura del autor. Como ya observamos, Motivos de Proteo fue reseñado dos veces en Nosotros; la primera por Álvaro Melián Lafinur (en dos entregas sucesivas), la segunda por Alberto Gerchunoff, ambos pertenecientes al grupo central de la revista. Más tarde, el número de enero de 1913, se abría con un artículo de Pedro Henríquez Ureña, tomado de Mes literario de Venezuela, en el cual se ensayaba un análisis sobre toda la obra del escritor uruguayo, y se lo ubicaba como el presente de una tradición americana entre cuyos nombres están Bello, Sarmiento, Luz y Caballero, Juan Montalvo. ${ }^{148}$ En todos estos artículos se valoraba positivamente al autor y su obra. En adelante nos detenemos en las notas de Gómez Restrepo, Melián Lafinur y Gerchunoff porque son útiles para mostrar cómo se colocaba en primer plano el espiritualismo antes mencionado, y porque marcan el comienzo del ascenso de Rodó en Nosotros. Este ascendiente de Rodó, que no era privativo de la revista, se relacionaba también, con la influencia de la

147 'Notas y comentarios' Año I, Tomo I, n 5, diciembre, 1907, p. 339-340. Cf. NOS: 21-22. Rodó había empezado en 1907 sus colaboraciones en La Nación de Buenos Aires.

148 Las referencias completas de los trabajos son: "José Enrique Rodó" por Antonio Gómez Restrepo, Año II, T3, n 15, octubre, 1908, pp. 137-147; "Motivos de Proteo" por Alvaro Melián Lafinur, Año III, T.4, n 22-23, octubre, 1909, pp. 351-356; "Motivos de Proteo" por Alvaro Melián Lafinur, Año III, T4, n 24, noviembre, 1909, 445-454; "Un Maestro . Motivos de Proteo", por Alberto Gerchunoff, Año IV, T.5, n² 25, enero, 1910, pp. 56-62; "La obra de Rodó" por Pedro Enríquez Ureña, Año VII, T.9, enero, 1913, n 45, pp. 225-238. Además se publican "El espíritu de Goethe", anticipo de Proteo, Año III, T4., n 18-19, octubre , 1909, pp. 30-32; "Introducción al estudio sobre Montalvo", anticipo de El Mirador de Próspero, Año VII, T.10, marzo, 1913, n 47, pp. 5-18. Cuando muere en 1917, Nosotros le dedica un tomo de homenaje.

El trabajo de Pedro Henríquez Ureña junto con el de Gómez Restrepo proponen análisis que van más allá del carácter laudatorio, la transcripción y la glosa, que se observa en los de Melián y Gerchunoff. 
prédica de Ariel cuyo contenido, como se observó a propósito de Ideas, exaltaba la función de la inteligencia y afirmaba el principio de la aristocracia del espíritu (Romero, 1983: 57).

En octubre de 1908, Gómez Restrepo destacaba en "José Enrique Rodó” el criterio "amplio y hospitalario" - más allá de sus desacuerdos con puntos centrales de la doctrina del autor estudiado-, subrayaba "su entusiasmo por las más desinteresadas manifestaciones del arte" y remarcaba su oposición a la "filosofía utilitaria". Para el crítico, se trataba ante todo de un ensayista, que ofrecía una mirada del arte desde el punto de vista sociológico, y en función de su evaluación no adversa a la democracia, se colocaba más del lado de Guyau que de Renan, en tanto aquélla no era considerada como un peligro para el arte. ${ }^{149}$ Hacía hincapié, además, en la ligazón entre el culto de la moral y el de la estética, y en la aversión de Rodó hacia "ciertos héroes de la literatura modernísima, enfermos de la voluntad y el corazón". ${ }^{150}$ Un año más tarde, la crítica de Melián Lafinur insistía en el lugar central de Rodó dentro del pensamiento y la literatura latinoamericanos, ${ }^{151}$ y en la misma línea de Gómez Restrepo, definía al escritor como "maestro de voluntad", señalando la exaltación de tal facultad como factor de perfeccionamiento tanto individual como colectivo. En ese sentido, Melián retomaba la observación de Rodó según la cual los pueblos (la voluntad colectiva, la personalidad, el genio nacional) debían cambiar sin descaracterizarse. Así, para el crítico, Motivos de Proteo constituía la obra de un moralista, ${ }^{152}$ sus lecciones de energía servían para sugerir vocaciones verdaderas a los jóvenes y para fortalecer espíritus enfermizos. ${ }^{153}$ Era lo que Gerchunoff llamaba el "destino sacerdotal” de

${ }^{149}$ Más allá de la evidente filiación con Renan, en las figuras de Calibán y Ariel, el crítico quiere ver en Ariel, al que juzga como condensación ( ese momento, 10/1908) del "espíritu" de su autor, una consideración de la modernización social menos negativa que la que efectivamente entraña.

${ }^{150}$ Cf. Motivos de Proteo, LXXXIII y LXXXIV, sobre el dilettante y el dilettantismo, pp. 194-197 de la edición de la Biblioteca Ayacucho.

${ }^{151}$ Melián, hiperbólico, deseaba que: "el veredicto de todos los que piensan le consagre unánimemente el primer escritor de la América Latina, entre todos los de su índole" p. 351.

${ }^{152}$ Es interesante observar que Giusti definiría con estos términos a Payró, en la conferencia leída en la Universidad Libre de Buenos Aires, en octubre 1917; la misma se publicó en La Nación y después como prólogo a Divertidas aventuras del nieto de Juan Moreira de la colección Escritores americanos (Maucci, Barcelona), y en 1924, en la segunda serie de Crítica y polémica. (Giusti, 1924: 24).

${ }^{153}$ Gerchunoff destacaba la virtud de "robustecer voluntades enfermizas". 
Rodó, que indicaba "rumbos" de pensamiento y de acción. ${ }^{154}$ De ese modo, Rodó venía a llenar la función de un magisterio intelectual que Ideas había invocado sin resultados, y que Rojas localizaba en la figura de Valera para los jóvenes españoles, en contraposición con lo que sucedía a la juventud argentina porque "los que la precedieron en la jornada, no le ofrecen ejemplos, ni le señalan rumbos". ${ }^{155}$ Esta misma función de un magisterio espiritual le sería reconocida por Giusti en su ensayo “José Enrique Rodó” de 1917, año de la muerte del autor de Ariel, y en el contexto de desasosiego que había provocado la Gran Guerra (Giusti, 1917: 31-47).

El carácter augural que Gerchunoff asignaba en la nota a Motivos de Proteo estaba relacionado con el contexto social de la Argentina inmigratoria ${ }^{156}$ y servía a la revista para construir una tradición cultural nacional de corte incluyente, que ponía su acento en la persistencia de la educación personal y colectiva. La propuesta de Rodó que no precisaba un hic et $n u n c-{ }^{157}$ era compatible con quienes hacían la revista puesto que los miembros de esa futura tradición intelectual argentina eran los nuevos intelectuales, en su mayoría hijos de inmigrantes, jóvenes que realizarían "la cultura perfeccionada, la simetría y el brillo, que se alcanza tras prolijos refinamientos de crisol."158 Esa metáfora, a su vez, se emparentaba con las opiniones vertidas en la novela inconclusa de Payró: la mezcla de sangre implicaba la mezcla de las

${ }^{154}$ Gerchunoff dedicaba este artículo a Becher. Se quejaba de la ausencia de crítica para un libro tan importante. El escrito era muy elogioso. Rodó aparecía en él bajo distintas figuras: "maestro docto" que hablaba de cosas bellas con palabras bellas, "predicador de una suave religión de belleza y verdad", "Un maestro. Motivos de Proteo" p. 60.

${ }_{155}$ Ideas, Año I, Tomo I, nº 2, junio, 1903, pp. 174-175.

156 "Si ha podido florecer un D. Juan María Gutiérrez en época de sangrientas luchas, y elaborarse después en pleno fundente étnico, tipos como Payró y Lugones, después del esfuerzo de nuestros primitivos, que dejaron labor de epopeya -Sarmiento y HernándezRodó, digo, confirma la razón de los que esperan frutos opulentos de las generaciones mezcladas bajo el cielo americano. Su obra, repito, anuncia la cultura perfeccionada, la simetría y el brillo, que se alcanza tras prolijos refinamientos de crisol." Ibid., pp. 60-61 [cursivas nuestras] Es importante señalar que es el cielo y no el suelo (es decir, la procedencia) el que ampara la mezcla de dichas generaciones.

${ }^{157}$ Real de Azúa se refiere a este aspecto en términos de "ucronismo y utopismo". (Real de Azúa, 1976: LX).

158 "Un maestro. Motivos de Proteo", Nosotros, Año IV, Tomo V, n 25, enero, 1910, p. 61. La lectura de Gerchunoff era la que imprimía un carácter nacional a la tradición, y esto se observaba claramente en los nombres que aparecían como representativos de cada una de las fases de la historia literaria que esboza. Así, para cada una de ellas hay un tipo de productor cultural. Figuras como Sarmiento y Hernández realizaban la epopeya; Payró y Lugones (este último prácticamente contemporáneo de Gerchunoff) eran los escritores de la Argentina modernizada. 
costumbres, y la creación de un carácter propio. Además, también era compatible con el sujeto sociocultural de la revista porque proponía la posibilidad de un ingreso en la cultura no determinado por "la fatalidad de la condición social y del ejemplo paterno", en tanto postulaba la anulación de las diferencias sociales. ${ }^{159}$ Finalmente, para Gerchunoff la obra encarnaba la condición de un advenimiento que complementaba aquel sesgo profético:

Hoy día, en que las ideas sufren extraño desvío, las personas de talento se orientan hacia el pasado en ilógico afán de retroceso; hoy día en que las aspiraciones de mejora social son admiradas con desprecio, hoy que los poetas se acercan a Paul Deroulede, acabada encarnación de lo vacuo (si es que lo vacuo puede tener encarnación) y olvidan a los esplendorosos sembradores, a los obstinados renovadores de la sociedad, Rodó aparece como indicando el verdadero camino. Agradezcámosle tan generosa tarea, hagamos votos para que continúe trabajando siempre con tan armoniosa energía por el bien y la verdad. (62) [cursivas nuestras]

De este modo, las reseñas de los argentinos, que subrayaban el magisterio espiritual de la figura y la obra de Rodó, destacaban el culto del idealismo, ensalzaban su visión optimista de la vida y del hombre futuros, encomiaban la función de los escritores como "renovadores de la sociedad" y celebraban el ensayo como portador de valores éticos y estéticos. En el caso de Gerchunoff, se dotaba de contenido y se nacionalizaban las condiciones de enunciación de Motivos de Proteo, leído como una apuesta necesaria para el mejoramiento individual y colectivo, en un contexto intelectual y social de signo reaccionario. Por otra parte, las notas de Melián y Gómez Restrepo enfatizaban el descrédito del tipo de subjetividad dilettante, también impugnada por Rodó, y señalaban así la preferencia de Nosotros por otra figura marcada por los atributos de la salud, la fuerza, la continuidad en el esfuerzo, la serenidad. Los ejemplos al respecto fueron abundantes. Cabe destacar, el escrito de Giusti sobre Misas herejes de Evaristo Carriego, en el que exhortaba a los poetas

${ }^{159}$ Motivos de Proteo, p. 195. Recordemos que Rodó perdió tempranamente a su padre. 
americanos "proponerse el apostolado de una poesía sencilla, honda y, no de enfermizos credos, flores de un día regadas con ajenjo. Lo cual no significa que hayan de cantar eternamente la patria, la bandera, los Andes o Manco-Capac"; ${ }^{160}$ o el pedido del mismo Giusti a Chiáppori, luego de la lectura de los relatos de Borderland, para que se apartara de la "atmósfera malsana", de esa "literatura anormal, y nos diera con su estilo tan propio, tan inconfundible, algún otro libro, -cómo decirlo?- más sano, más humano........" ${ }^{161}$

Finalmente, estas lecturas mostraban, por parte de la revista, la adscripción a ciertos rasgos del juvenilismo, discurso que si bien todavía estaba vigente, no era en absoluto novedoso. En ese sentido, el acento en la juventud como colectivo cultural y social ya había sido proclamado desde Ideas -con sus marcas diferenciales- y antes, en 1900, por Ariel como condensación de una serie de elementos que constituían el "ethos prospectivo" de la juventud latinoamericana y española. ${ }^{162}$

Como señalamos, la lectura de Motivos de Proteo y la elevación de la figura de Rodó al rango de maestro coincidió con la acentuación del espiritualismo - idealismo y con la incorporación explícita de las relaciones culturales con España, como parte del programa de la revista, que se enunciaba en el texto de conmemoración de primer aniversario. Aunque 'Letras españolas', a cargo de Gerchunoff, solamente apareció con ese nombre en tres de las doce entregas del primer año (números 2, 4 y 8), estuvo desde el comienzo entre las secciones permanentes de Nosotros. Además, por fuera de la sección y con la firma de otros críticos, se publicaron, con una frecuencia creciente a partir de diciembre de 1907, colaboraciones sobre literatura española, hecho que ratificaba el deseo de construcción de un vínculo intelectual con la Península.

Esta conexión con España no se agotaba en la publicación de textos literarios y críticos vinculados con lo que allí se producía. Se podía rastrear también en otras

\footnotetext{
${ }^{160}$ Cursivas nuestras. Nosotros, Año II, Tomo III, agosto-septiembre, no 13-14, 1908, pp. 114-116. Es interesante observar la infinidad de veces que en la crítica de Nosotros se utilizaba la palabra "sana": "Obra de tendencia sana", "una obra robusta y sana", "sana aspiración de arte", "obra sana y moral", "la idea justa y sana", "una atmósfera sana”, etc..

${ }^{161}$ Nosotros, Año I, Tomo I, n 5 , diciembre, 1907, p. 333.

${ }^{162}$ Cf. Altamirano - Sarlo,1983; Real de Azúa1976: XXIII. Es evidente que Ariel constituye la impugnación del utilitarismo y del materialismo, encarnados en los Estados Unidos; también lo es el hecho de que en él se advierte sobre los peligros del cosmopolitismo y la democracia, prevenciones estas últimas, con las cuales, de modo general, la revista no acuerda, más allá de su adopción de un discurso juvenilista e idealista.
} 
secciones de la revista. Así, 'Notas y comentarios' siempre firmada por la dirección, ${ }^{163}$ constituía un espacio en que Giusti y Bianchi daban cuenta de todo un conjunto de hechos relativos a la sociabilidad cultural: partidas, regresos, estrenos, llegadas de artistas, conciertos, conferencias, cartas recibidas, datos sobre la repercusión de Nosotros en diversos ámbitos intelectuales, la actualidad política. De tal modo, los directores hacían visibles las otras formas de construcción de la "hermandad espiritual" "164 entre la Argentina y España. En el mismo sentido, secciones como 'Libros recibidos' o 'Bibliografía', informaban sobre la circulación de impresos provenientes de España y testimoniaron la importancia de las editoriales españolas en la difusión de la cultura latinoamericana; por otra parte, las más esporádicas 'Revista de revistas' o 'Revistas recibidas', indicaban el carácter fluido y la inmediatez de los intercambios intelectuales con la llamada "madre patria". ${ }^{165}$ Así, por ejemplo, Gerchunoff escribía sobre Carmen de Francisco Villaespesa $\left(n^{\circ} 2\right)$, se ocupaba de Museo y Cantares de Manuel Machado ( $\left.\mathrm{n}^{\circ} 4\right)$, o La casa de la primavera de Gregorio Martínez Sierra (no 8). Por su parte, Juan Más y Pí, dedicaba sendos ensayos a Azorín $\left(n^{\circ} 5\right)$ y Juan Maragall ( $\left.n^{\circ} 8\right)$, y Carlos Octavio Bunge hacía lo propio con las novelas de Manuel Hoyos y Vinent ( ${ }^{\circ}$ 9). Entre otros se publicaron, poemas de Fernando Fortún ( $\left.n^{\circ} 9\right)$, Leonardo Shérif ( $n^{\circ}$ 9), Martínez Sierra $\left(n^{\circ} 5\right)$, y relatos de Hoyos y Vinent $\left(n^{\circ} 5\right)$. Según constaba en 'Notas y comentarios', las colaboraciones de estos dos últimos autores, habían sido solicitadas por la dirección de la revista.

Según anotamos, la voluntad por establecer esos vínculos culturales se patentizaba en una serie de datos provenientes de las secciones de carácter informativo ya mencionadas. Entre ellos puede destacarse la transcripción de la carta de Luis Mandrés a la dirección de Nosotros, en la que explicaba la finalidad del recientemente constituido Salón Sud-Americano de Barcelona: "facilitar con todos los medios

${ }^{163}$ Esta sección se publicó en cincuenta y tres de los cincuenta y seis números de la revista que conforman nuestro corpus de estudio. No apareció en los números 30,35 , 42; en la sección 'Bibliografía' del $n^{\circ} 30$, se aclara los motivos por los cuales 'Notas y comentarios' no aparece.

164 Unamuno, Miguel. "Algunas consideraciones sobre literatura hispanoamericana", La Lectura, septiembre-octubre, 1906.

${ }^{165}$ En el final del anexo NOS se adjunta la descripción realizada a partir de los números 2 a 22-23 [de septiembre de 1907 a julio-agosto de 1909] que muestra la presencia de la cultura española en la revista, principalmente observable en las temáticas, los autores, la procedencia de las colaboraciones, $o$ las editoriales que difunden las letras hispanoamericanas. En el cuerpo del trabajo solo consignamos algunos de esos datos. 
posibles las comunicaciones de la América del Sur con España” y “cooperar al (sic) desarrollo general de toda iniciativa plausible entre los países Sudamericanos y la Península". ${ }^{166}$ Igual valor tenía la edición de la revista española El Cuento Semanal especialmente realizada para Argentina, con el objetivo de "hermanar lo más posible la literatura hispana y la bonaerense, ofreciendo a sus representantes una tribuna selecta y propicia a todas las inquietudes del espíritu moderno". ${ }^{167}$

Precisamente, la cuarta entrega de 'Notas y comentarios', transcribía una carta de agradecimiento de Miguel Unamuno a quien Giusti había enviado los dos primeros números de la revista, y que el rector de Salamanca, explicaba, no había tenido tiempo de leer. En la carta, Unamuno, prometía una colaboración que finalmente no realizó en el período del que nos ocupamos (1907-1913), y caracterizaba la función que debía cumplir Nosotros en relación con la cultura nacional en un contexto como el argentino; ${ }^{168}$ se manifestaba "en espíritu y en anhelos" acompañando a la publicación. También realzaba la doble significación de la revista de acrecentar la cultura propia y de hermanar a las naciones de lengua castellana, entre las que se contaba España, por supuesto. La figura de Unamuno ya había aparecido en el artículo del crítico colombiano Max Grillo del número anterior de Nosotros. ${ }^{169}$ Allí y desde una posición adversa a "la civilización moderna" que "todo lo ha gastado", Grillo destacaba el idealismo de Unamuno y afirmaba la centralidad cada vez mayor del escritor español en la cultura hispanoamericana. Esta centralidad se basada en la labor crítica de Unamuno quien entre 1901 y 1906, se había ocupado de dar a conocer la producción intelectual, principalmente rioplatense, en la sección "De literatura hispanoamericana", de revista madrileña La Lectura ${ }^{170}$ La primera de esas entregas tuvo un carácter programático en

${ }^{166}$ Nosotros, Año II, n 16-17, noviembre-diciembre, 1908, p. 322.

${ }^{167}$ Nosotros, Año I, nº 8, marzo, 1908, p. 158.

${ }^{168}$ Cf. el apartado 5.3. Nuevos sujetos, temáticas recurrentes: Nosotros, los argentinos, en el cual analizamos la carta con más detalle.

${ }^{169}$ Grillo, Max. "Don Miguel de Unamuno (Breves apuntes. Acerca de D. Miguel de Unamuno y de su influencia en las letras hispanoamericanas)", Nosotros, Año 1, no 3, octubre, 1907, pp. 149-161. En la edición de la obra completa de Unamuno se consigna que este artículo apareció en Bogotá en la revista Trofeos, en 1907.

170 Unamuno ya se había ocupado de la producción intelectual hispanoamericana, aunque de un modo menos sistemático. Su primer ensayo, "El gaucho Martín Fierro. Poema popular gauchesco de don José Hernández", data de 1894. Dedicado a Juan Valera. se publicó en la Revista Española, Año I, n 1, marzo, 1984, pp. 5-22 . A partir de 1899, y gracias a Rubén Darío, Unamuno colaboró en el diario La Nación. La primera de las notas, del 19 de mayo de 1899, "Sobre la literatura hispanoamericana", está dedicada a Darío. 
el que explicitaba el objetivo de acercar a "la América española" y a España, a través de la lengua, como "el único enlace sólido". ${ }^{171}$ En ese escrito al que denominaba "Preámbulo", Unamuno abogaba por un casticismo no estrecho ni limitado geográficamente; instaba a los escritores hispanoamericanos a dejar a un lado la influencia francesa, cuyos resultados eran los "abismos de afectación" y el "artificio", y promovía el tratamiento de temas propios. ${ }^{172}$ El artículo de Max Grillo, considerado pionero por la crítica posterior, se publicó también, y por ese mismo tiempo, en la revista colombiana Trofeos. Grillo destacaba el reconocimiento que hacía Unamuno de la influencia del modernismo hispanoamericano en las letras españolas y recalcaba el carácter no sectario del escritor español. ${ }^{173} \mathrm{El}$ hecho de que Grillo transcribiera algunos párrafos de las notas de Unamuno de La Lectura ${ }^{174}$ constituía la adscripción al programa de un hispanismo, planteado como el deseo y la necesidad de una interacción cultural de España con sus ex colonias. ${ }^{175}$ Grillo ponía en primer plano la cuestión identitaria de los

171 De Torre, Guillermo: "Unamuno y la literatura Hispanoamericana”, Cuadernos de la Cátedra Miguel de Unamuno, XI, Salamanca, 1961, pp. 5-25. En el artículo de Torre repasa las vinculaciones con escritores latinoamericanos.

${ }^{172}$ La Lectura, Año I, n 1, 1901, pp. 58-63. Tomado de la edición de la obra completa. En ese número, después de las consideraciones generales, se ocupa de Ariel de José E. Rodó y de Montaraz de Martiniano Leguizamón. Ya en "Sobre la literatura Hispanoamericana" y en referencia a su nota sobre La Maldonada de F. de Grandmontagne, Unamuno recordaba y recomendaba a Darío en 1899 "que no solo del gaucho pedía yo que ustedes, los hispanoamericanos, nos hablasen, sino también de los afanes del estanciero, de los trabajos del colono, de las luchas civiles, de la eflorescencia industrial, de todo, en fin, lo que constituye la vida americana, y no de delicuescencias traducidas del francés, a que no me negará usted que son por allá no pocos jóvenes en exceso aficionados." Agregaba, además, que "Buenos Aires está tan lejos de la guitarra pampera como del morbo gallico barriolatinesco, y a descubrirnos ese potente Buenos Aires usted más que nadie debe contribuir" Para un estudio detallado de las cuestiones relativas a la literatura latinoamericana, véanse principalmente las más de treinta notas que entre 1901 y 1906 publicó el autor en La Lectura de Madrid, y otras, aparecidas en diversas revistas y diarios, argentinos y españoles, y recopilados en la Obra completa. Cf. el trabajo ya citado de G. de Torre, y "Unamuno, Rubén Darío y el modernismo" de Elke Meier, Cuadernos de la Cátedra Miguel Unamuno, XXVII-XXVIII, Salamanca, 1983, pp. 135-148.

${ }^{173}$ Esta descripción es del orden de la estrategia, ya que es sabido que Unamuno no acepta a los autores modernistas, salvo algunas excepciones como José Asunción Silva o Amado Nervo. Respecto de Rubén Darío su opinión es "evasivo". Cf. el ya citado "Unamuno y la literatura Hispanoamericana".

${ }^{174}$ Las notas de La Lectura correspondían a septiembre y octubre de 1906.

${ }^{175}$ Entre esas citas se cuenta la siguiente: "La necia y torpe política metropolitana nos hizo perder las colonias, y una no menos necia ni menos torpe conducta en cuestión de lengua y de literatura podría hacernos perder -si estas cosas se rigieran por procedimientos de escritores y literatos -la hermandad espiritual. Tenemos que acabar de perder los españoles todo lo que encierra en eso de madre patria, y comprender que para salvar la cultura hispánica nos es preciso entrar a trabajarla de par con los pueblos americanos, recibiendo de ellos, no solo dándoles". 
países latinoamericanos, que se manifestaba como un aspecto del idealismo unamuniano, destacando aquella idea del "patriotismo lingüístico" asentado en la posesión de una lengua común. ${ }^{176}$ En ese sentido, observaba que "No pasa inadvertido para Unamuno de [sic] lo que interesa al desarrollo de las unidades nacionales, a las relaciones de los países de un mismo origen hispánico, a la producción literaria o científica de los grupos sociales", ${ }^{177}$ afirmando, de esta manera, una incidencia fuerte de lo español en los procesos de construcción de las identidades culturales de los jóvenes países latinoamericanos. Así señala la creciente fluidez de los lazos culturales entre España y América Latina, una tendencia que se muestra en Nosotros como algo cada vez más efectivo. El hecho de que el texto del colombiano se publique casi simultáneamente en Bogotá y en Buenos Aires ratifica esta tendencia. ${ }^{178}$

Como puede verse, la revista comenzó a construir desde su inicio un vínculo con la cultura española que si bien no se declaraba entre los objetivos de la nota de apertura en 1907, adquirió una centralidad creciente, como lo muestran, en ocasiones, algunas entregas de la publicación. Tal carácter central no se manifestaba necesariamente, ni todos los casos, en la presencia de autores o de temas objeto de las colaboraciones sino que se recuperaba, como ya observamos, en secciones que atendían a las formas de sociabilidad cultural: cartas, bienvenidas (a Vicente Medina), demostraciones (a Blasco Ibáñez). Allí se iba modelando y definiendo aquel vínculo, y la función que Nosotros pretendía cumplir en tanto "un medio más, acaso insignificante pero de todos modos eficaz, para robustecer los débiles lazos intelectuales que unen esta república con las restantes de América Latina y con la madre patria". ${ }^{179}$ Asimismo, las frecuentes menciones a las grandes casas editoriales -tal el caso de la valenciana Sempere-

176 "A [la] manera de los conductores de pueblos, Miguel Unamuno entra en la pelea (...) desconoce el recinto de la torre de marfil; prefiere vivir en un castillo almenado que tiene fosos, vigías y mesnada que lo defienda.

Defiende lo que debe defenderse: la patria en lid abierta, sin patrioterías [cursivas nuestras], orientando su espíritu a los todos vientos; defiende la libertad (...) defiende la religión, mejor dicho el sentimiento religioso, porque es aquella elevación de las almas en presencia de lo desconocido; defiende la tradición castiza, no la que aspira a conservarse por vieja, sino la que debe perdurar por generosa; defiende a su pueblo del prosaísmo enervador, y le grita, jadelante!, señalándole el camino de la nueva jornada", Nosotros, Año I, $\mathrm{n}^{\circ} 3$, octubre, 1907, p. 159.

177 Nosotros, Año I, n 3, octubre, 1907, pp. 159-160.

${ }^{178}$ Podemos suponer que efectivamente el autor, a pedido de la revista, envió su trabajo, ya que cuando Nosotros levanta trabajos de otras publicaciones lo aclara.

179 'Notas y comentarios', Año I, nº 5, diciembre, 1907, p. 339. 
informaba sobre una relación bien concreta ya que estas empresas funcionaban como alternativas viables de edición y difusión de la obra de los jóvenes latinoamericanos (Rodó, Ugarte o Rojas, por ejemplo).

Aquellos vínculos promovidos entre 1907 y julio de 1908, se institucionalizaron en la nota que abría el número del primer aniversario de Nosotros. No es casual que allí, además, el recuerdo pretendidamente fidedigno del programa enunciado en agosto de 1907 registrara las marcas del pasaje del americanismo al nacionalismo:

Nosotros no se ha adscripto a ninguna tendencia literaria, política o filosófica. El momento es de indecisión y sus directores han preferido la tolerancia por todas las opiniones a un exclusivismo sin sólidas bases.

Un espíritu definido la animó, sin embargo, desde sus primeros pasos: su espíritu francamente americano, fundado sobre un amplio y bien entendido nacionalismo. Toda su propaganda ha tenido por objeto estrechar vínculos entre las diferentes naciones latinas de América y entre éstas y la madre patria. Más vale marchar en la ruta de la tradición con la mirada fija hacia adelante, que desviarse de ella, extraviándose. ${ }^{180}$ [cursivas nuestras]

El agregado era evidente y el socialismo, el buen nacionalismo de Gerchunoff, o el bien entendido nacionalismo de los directores, conformaban, junto con la reposición de la continuidad cultural con España, lo nuevo de aquel programa que quería presentarse idéntico a sí mismo. Como se puede ver, una postura como la que en este contexto de principios del siglo enunciaba Nosotros no guardaba relación con el amplio y bien entendido liberalismo de la nota de apertura de La Biblioteca, aunque la explicación de Jitrik pudiera mostrarlas como expresiones sinónimas. Groussac era un liberal, pero conservador, que en reiteradas ocasiones miraba con recelo los efectos socioculturales de la modernización, las nuevas teorías político-sociales a las que adscribían muchos de los inmigrantes, identificando la democracia con el triunfo de la barbarie y señalando los peligros de la igualación social como igualación cultural. El bien entendido liberalismo se circunscribía en La Biblioteca a la construcción de elites ${ }_{180}$ Para la transcripción de la nota completa, Cf. NOS: 36-37. "Un año de vida", Nosotros, Año II, Tomo III, 3, n 13-14, agosto-septiembre, 1908, pp. 5-6. 
intelectuales y culturales e impugnaba la democratización de la cultura que en el texto de Gerchunoff aparecía como utopía a la que podía aspirar el arte.

Por otra parte, esta continuidad cultural con España que ahora era presentada como un anhelo, se vinculaba con el problema de la lengua literaria nacional. Esta cuestión escandía las intervenciones de Giusti en 'Letras argentinas', y su paradigma, como veremos, estaría representado por las escrituras de Rojas o Payró; sería, además, uno de los puntos de debate a propósito de la segunda encuesta de Nosotros sobre el "valor del Martín Fierro". ${ }^{181}$

\subsection{Nuevos sujetos, temáticas recurrentes: Nosotros, los argentinos}

La intervención de los intelectuales y escritores en la labor de construcción de una identidad nacional como el anhelo mismo de forjarse una ficción identitaria, definen procesos ligados directamente con la modernidad. ${ }^{182}$ En ese sentido, Oscar Terán revisa las diversas modulaciones de la "idea nacional" en nuestro país y observa que las elites político-intelectuales de la Argentina como las de otros países latinoamericanos, participaron tempranamente en esta tarea "cosmopolita". En un arco

${ }^{181}$ Cf. el apartado 5.6 de este capítulo.

${ }^{182}$ Eric Hobsbawm en Naciones y nacionalismo desde 1870 afirma que la cuestión acerca de la nación se ubica en el "punto de intersección de la política, la tecnología y la transformación social" de modo que la existencia de las naciones no se reduce a lo territorial o a la voluntad de crearlas, sino que tal existencia se vincula con una etapa del desarrollo económico y tecnológico (p. 18). Hobsbawm sostiene que no pueden darse definiciones esenciales de la nación, ya que se trata de un concepto históricamente situable y variable. En ese sentido realiza una historia del concepto que se organiza a partir de tres perspectivas: a) revolucionaria, y aquí la nación tenía un significado político; la nación se definía como el "conjunto de los ciudadanos cuya soberanía colectiva los constituía en un estado que era su expresión política" (p. 27) y como el estado se definía como territorial, la nación se vincula con un territorio; b) liberal - burguesa (1830-1880), en la que la nación se define como viable en términos económicos en función de un tamaño mínimo y aparece, desde la óptica del liberalismo, como una "fase de la evolución o del progreso humano desde el grupo pequeño hacia el grupo mayor, de la familia a la tribu y la región, a la nación y finalmente, al mundo unificado del futuro" (p. 47); c) desde 1880 la lengua y la etnicidad se erigen en criterios fundamentales para definir la nación; surge el nacionalismo como ideología (de corte reaccionario) que según Hobsbawm se hizo cada vez central en la "era de la democratización y de la política de masas de Europa" (p. 53). (Hobsbawm, 1991) 
que va desde el análisis de lo que llama “el legado problemático de la Generación del 37" hasta 1999, cuando escribe su artículo, Terán señala algunas realizaciones centrales de aquella idea. Se refiere así a Mitre y a Sarmiento, apunta la discusión de Mitre con Joaquín V. González, y se detiene en la etapa posterior a la organización del estado nacional. ${ }^{183}$ En relación con ese momento Terán propone que la "elite concibe entonces que desde el Estado se debe construir una identidad que refiera a la cultura y diseñe un 'sujeto nacional"', y reconoce en este deber así concebido, el comienzo del nacionalismo culturalista que cristalizó en el Centenario de la Revolución de Mayo (Terán, 1999: 281). Asimismo y tomando como objeto los avatares del liberalismo político argentino Terán sostiene que la crisis de legitimidad que el sector liberal afronta desde 1890 se intentará salvar "apelando a dos mecanismos: la transferencia de esa crisis hacia otra de identidad nacional, y la implementación del reformismo político" (Terán, 1994: 28-31). Por su parte, en "Pluralismo y nación” Hilda Sábato señala que para la elite política argentina, y desde un modelo de nación que por ese entonces se propugnaba, los inmigrantes aparecían como el elemento necesario a partir del cual se constituiría la nueva nacionalidad, cimentada en los ideales de progreso y libertad que postulados desde arriba, eran considerados comunes. ${ }^{184}$ De cara a una transformación social que cargada de conflictos sociales y marginalidad urbana no resultó tal como la elite liberal había imaginado, Sábato reconoce como respuesta a tales situaciones, el surgimiento de un nuevo nacionalismo, que integraba y a la vez segregaba todo aquello que le era adverso. La inmigración se convirtió entonces en la preocupación central de un programa nacionalizador de carácter autoritario. ${ }^{185}$

En su análisis del "novecientos" Sarlo y Altamirano coinciden con Terán en que el tema de la nacionalidad no se piensa para ese entonces como novedoso, si se tiene en cuenta la circulación desde veinte años antes "de un conjunto de significaciones ideológicas, una suerte de legado intelectual y literario”. Según ambos autores lo que

${ }_{183}$ El recorrido de Terán continúa con la política yrigoyenista, el peronismo, la última dictadura militar, la postdictadura, el menemismo. (Terán, 1999: 279-287).

${ }^{184}$ El artículo discute el pluralismo cultural como perspectiva de análisis del proceso de formación nacional en Argentina, no en sus cuestionamientos a la disolución de identidades parciales y de las diferencias como requisito imprescindible para la integración de la nación ni en su hipótesis del mosaico plural como opuesta al crisol de razas, sino en aquello de lo que no puede dar cuenta. En ese sentido, el trabajo ensaya una propuesta de análisis a la que denomina "Pluralismo sin esencias" (Sábato,1989: 2-5).

${ }^{185}$ Ibid., p. 3. 
resulta más nuevo es la resignificación de muchos elementos, que en algunos casos invierte las valoraciones previas, como sucede con la evaluación ahora negativa de factores que como la inmigración habían estado asociados al progreso, o los nuevos sentidos de palabras como "criollo" (Altamirano - Sarlo, 1983: 93). ${ }^{186}$ Desde una perspectiva centrada no ya en la historia de las ideas sino en la literatura, y particularmente en el proceso de su autonomización, ${ }^{187}$ visualizan una autoimplicación entre ese conjunto de temas ideológicos y la profesionalización de los escritores, que iniciada con el modernismo, cristaliza por primera vez alrededor del Centenario. El análisis de María Teresa Gramuglio de los ensayos de interpretación del Centenario ${ }^{188}$ destaca como cualidad distintiva de esos textos el hecho de que "el presente funciona como una solicitación fuerte e inequívoca" y considera que, más allá de la celebración, 1910 se presenta como la “ocasión clásica para realizar un balance sobre lo conseguido en los cien años de vida independiente, interrogarse sobre el presente de la nación, que muchos veían inquietante y formular algunos pronósticos sobre el provenir". Gramuglio sostiene que para pensar estos ensayos es necesario tener en cuenta "las posiciones que sus autores ocupaban en el campo literario en función de sus relaciones con el poder". Así Gramuglio distingue al "letrado tradicional" que pertenece a la dirigencia política (Joaquín V. González), a los intelectuales de nuevo cuño cuya

${ }^{186}$ En relación con "criollo" explican: "Un nuevo sentido (...) irá cristalizando poco a poco en torno a esta palabra, un sentido que evocará valores y virtudes positivas y cuyo término contrapuesto será el de 'gringo' o 'inmigrante'. En el espacio de significación que circunscribían estas palabras, generosidad, desinterés e, incluso, cierta disposición para la vida heroica, se contraponían a la imagen de una laboriosidad sin elevación de miras, afán de lucro y mezquindad". (Altamirano- Sarlo, 1983: 94-95)

${ }^{187}$ Los autores incluyen el proceso de autonomización de la literatura en el más amplio de la modernización, cuyo momento más alto es el de la primera presidencia de Julio A. Roca (1880-1886). "El ciclo político y económico iniciado bajo la primera presidencia del general Roca había comportado una modificación profunda de las relaciones económicas y de la estructura social, así como un acelerado proceso de urbanización en Buenos aires y en el área litoral. El régimen político que había cristalizado bajo la llamada generación del ochenta -liberal en sus formas institucionales y oligárquico en su funcionamiento efectivo- fue el requisito de ese proceso y el custodio de sus componentes básicos: la gran propiedad terrateniente y su aliado, el imperialismo británico" (Altamirano- Sarlo, 1983: 72)

${ }_{188}$ Gramuglio trabaja en especial con tres obras publicadas en 1910: El juicio del siglo de Joaquín V. González, Blasón de plata de Ricardo Rojas y El diario de Gabriel Quiroga de Manuel Gálvez. A este corpus central agrega otros textos que, por su temática o por el carácter ensayístico, participan de la reflexión en torno a una serie de motivos comunes que tienen resoluciones diferentes en cada caso. Esos otros textos son los escritos por Leopoldo Lugones: Odas seculares, Didáctica, Piedras liminares, Prometeo y las reflexiones sobre Martín Fierro (1913 en conferencias, 1916 en libro). (Gramuglio, 2002c: 37-50). 
relación con el poder no es tan orgánica aunque lleven adelante sus iniciativas (Lugones y Rojas) ${ }^{189}$, y a aquel que intenta ser un escritor profesional (Manuel Gálvez). La cuestión de la nacionalidad aparece en estos ensayos como aspecto en el que se concentran los problemas relativos a la organización política y al conflicto social, respecto de los cuales la inmigración se constituye como cuestión fundamental.

En un contexto de pérdida y construcción de nuevas legitimidades, tanto por parte de los sectores oligárquicos como de los nuevos sujetos sociales, y de efectivización de los cambios que la modernización y las transformaciones sociales acarrean en el mundo cultural, Nosotros armó una posición nacionalista fuerte en torno a la cuestión de la identidad colectiva. Lo nacional se postulaba como forma de autorización de los miembros de la revista, en tanto intelectuales de la cultura democratizada y universitaria, y a la vez descendientes directos de inmigrantes italianos, así como también -aunque en sordina, puesto que Nosotros no lo hacía explícito- como legitimación del ideario político al que adherían. La revista mostró su vocación por insertarse en esa serie de lo nacional e intervino activamente antes, durante y después del Centenario, en relación con las formulaciones imaginarias construidas al respecto, y lo hizo en el ejercicio de la crítica desde las reseñas de sus secciones específicas de 'Letras argentinas', 'Teatro nacional', 'Bibliografía', y también en las "demostraciones". Si pensamos ese período como un momento de pugna por la legitimidad entre las versiones de la nacionalidad vertidas tanto en obras literarias como no literarias y en trabajos de corte histórico o ensayístico, y tenemos en cuenta la percepción que de Nosotros como colectivo cultural propuso Manuel Gálvez en sus memorias, los términos de la intención de la revista y del debate se vuelven, entonces, más evidentes. Para el director de Ideas la aparición de la revista de Bianchi y Giusti

representa el advenimiento de los descendientes de italianos a las letras argentinas. Véase, sino, los apellidos de los más frecuentes colaboradores del periódico: Giusti, Bianchi, Alberini, Ravignani, Ferrarotti... Aparte de estos muchachos, sorprende el número de colaboradores de nombre italiano, entre viejos y jóvenes, ignorados y prestigiosos,

${ }^{189}$ Con respecto a las relaciones de los escritores e intelectuales con el Estado en la época que nos ocupa, Cf. Dalmaroni, 2006. 
que tuvo la revista: Capello, Magnasco, Albasio, Pandolfo, Dellepiane, Corti, Della Costa, Mazzoni, Robatto, Muzzilli... Era del caso de exclamar “iL'Italia al Plata!”, como suele hacerse entre nosotros cuando en algún lugar o institución abundan los italianos o sus descendientes." (Gálvez, 1961: 289)

En esta cita Gálvez reconocía y sobre todo evaluaba a un sujeto extranjero y no demasiado autorizado culturalmente, calificándolo como advenedizo y nuevo, dentro de un campo en el que las prerrogativas del capital social continuaban vigentes como criterios de legitimación; un espacio en el que Gálvez mismo, intentaba también ocupar un lugar. La condición de parvenus quedaba reforzada si recordamos, además, que en la descripción del autor del Diario de Gabriel Quiroga el calificativo de "desconocidos" se aplicaba a la mayoría de quienes que hacían Nosotros, a excepción de Álvaro Melián Lafinur y Hugo de Achával, a quienes reconocía una "estirpe" intelectual y social de larga data en nuestro país. ${ }^{190}$

Nosotros entendió la construcción de una identidad nacional, como ya se dijo, básicamente en términos culturales. Así lo testimoniaba el acuerdo con los conceptos de Unamuno en la carta ya citada que se publicó en el número 4 de 1907. Afirmaba Unamuno:

Creo que ahí, en la Argentina, lo mismo que aquí, en España, es necesidad crear un núcleo de jóvenes atentos a las formas más elevadas, más puras, menos pragmáticas -aunque no por eso menos prácticas - de la cultura, a todo lo que siendo hoy un nuevo lujo espiritual para la colectividad en conjunto, llegará a ser mañana sustancia de la patria. Una nación necesita alma y alma duradera y fuerte (...) la labor de ustedes tiene que ser dar personalidad espiritual a la patria argentina, y que tenga un signo y sello y un valor para los demás pueblos. Y esto es más necesario donde la avenida de gentes extrañas, de emigrantes, tienden a romper la unidad de carácter

\footnotetext{
${ }^{190}$ El desprecio por Bianchi y Giusti, a los que no deja de ver como advenedizos, se observa también en el relato de la presentación de los responsables de Nosotros al director de la Comisión Protectora de Bibliotecas Populares, Miguel F. Rodríguez, en la reunión de los sábados en casa de Rafael Obligado. Rodríguez preguntó a Bianchi y Giusti -que acababan de serle presentados por Obligado- si Nosotros es una revista de agricultura. "Y en cuanto a Bianchi y a Giusti, a quienes el bibliógrafo debió encontrarles aspecto de agricultores 0 chacareros, debieron sufrir una especie de conmoción cerebral" (Gálvez, 1961:298).
} 
espiritual. La unidad de ustedes habrá de ser unidad de integración, no de homogeneidad, y por eso es más difícil. ${ }^{191}$ [cursivas nuestras]

Así la idea renaniana de nación como alma, principio espiritual y conciencia moral, ${ }^{192}$ sería parte de este "programa" nacionalista de Nosotros basado en la integración, que los intelectuales jóvenes harían suyo e intentarían moldear como "reacción" necesaria, mediante una retórica que anudaba espiritualismo -entendido como elevación moral- y nación. Se trataba de armar una cultura nacional que convertida en tradición, valiera como rasgo diferencial frente a las otras naciones, siendo su signo y su sello. ${ }^{193}$ A diferencia de Renan, y tal como las palabras de Unamuno lo indicaban, la "personalidad espiritual" de la Argentina posinmigratoria no podía ser un legado del pasado, sino que debía construirse.

Unamuno señalaba de forma más explícita que los directores, la posición que, inmediatamente después y cerca del Centenario, se tornó bien evidente respecto de la construcción de la nación como identidad cultural, que suponía previamente la presencia de extranjeros entre cuya descendencia se contaban Giusti o Bianchi. ${ }^{194}$ El pasaje importaba además una definición de los sujetos que debían estar a cargo de esta operación cultural de signo incluyente, que coincidía con la imagen y el rol que para sí pretendían los miembros de Nosotros: eran los intelectuales argentinos jóvenes quienes debían ocupar la vanguardia en esa construcción de la cultura nacional, como

\footnotetext{
${ }_{191}$ Nosotros, Año I, Tomo I, nº 4, p. 271.

${ }^{192}$ Recordemos que en “¿Qué es una nación?" Renan negaba la posibilidad de definirla en función de la raza, la lengua, el territorio, la religión. Afirmaba que "Una nación es un alma, un principio moral. Dos cosas que no forman sino una, a decir verdad, constituyen esta alma, este principio espiritual. Una está en el pasado, la otra en el presente. Una es la posesión en común de un rico legado de recuerdos; la otra es el consentimiento actual, el deseo de vivir juntos, la voluntad de continuar haciendo valer la herencia que se ha recibido indivisa". Edición digital.

${ }^{193}$ Unamuno, en su primera colaboración en el diario La Nación, en 1899, ya había afirmado la necesidad de una elite intelectual nueva que llevara adelante la tarea de forjar un arte nacional.: "Pocas cosas me interesan más que esa vida ascendente, que llegará a tener un arte que la eternice. Llegará a tenerlo cuando el poderoso progreso que hoy impulsa a la Argentina se haya hecho tradición, cuando brotando del seno de esa inmigración abigarrada surja una aristocracia, sea la que fuere, que pueda pasar de la posesión a la contemplación [cursivas nuestras] (77). Obra completa "Sobre la literatura Hispanoamericana".

${ }^{194}$ Noé Jitrik, en el artículo ya citado, define a Nosotros como un "mito de una continuidad", y observa que esa continuidad "sugería otros mitos, los del intelectual argentino, los del universitario completo y cabal (...)" (Jitrik, 1998: 102).
} 
respuesta al presente que los interpelaba y en el que intervenían desde su ámbito específico.

Dos figuras, cuyas procedencia y significación fueron diferentes, resultaron claves para describir la forma en que la revista se colocó respecto del problema: Martiniano Leguizamón y Ricardo Rojas. Ambos imaginaron una concepción propia, en relación con las cuales Nosotros precisaría la suya. En adelante nos proponemos analizar algunas de esas intervenciones para ver de qué manera, la revista construyó las condiciones para su participación legítima en ese debate, participación que le otorgaba una posición más notable en el campo intelectual emergente.

\subsection{Martiniano Leguizamón: hacia la construcción de la historia nacional}

Martiniano Leguizamón apareció de modo recurrente en la revista, y representó en ella una concepción de nacionalismo literario y cultural, que junto con el de Rafael Obligado $^{195}$ se centraban en la representación de la vida rural -a la que los unía el legado familiar de la posesión de la tierra-, y de la guerra de la independencia. A ellos se agregaba, desde Uruguay, Eduardo Acevedo Díaz, manifiesto admirador de Leguizamón y cuya labor literaria era similar. Desde 1908 hasta 1913, pero de modo especial entre 1909 y 1911, las apariciones de Martiniano Leguizamón fueron constantes en la revista. El relevamiento de las ocasiones en que Nosotros se ocupó de su figura, de sus obras o publicó algunos de sus escritos, sugiere el carácter

\footnotetext{
${ }^{195}$ En la revista se publican dos poemas significativos de Obligado: "Rosa" en el $\mathrm{n}^{\circ} 30$ de 1911, y "Protesta" en el $n^{\circ} 43$ de 1912. Es importante observar la oposición que se plantea entre ambos. Mientras que "Rosa" recrea el trabajo rural de Luciano y sus "isleros" en las orillas del Paraná, deteniéndose en los detalles de vestimenta, paisaje y las bromas, "Protesta" se presenta como una intervención marcada por la nostalgia de la pérdida. El primer verso así lo registra: "La pampa de mis cantos ya no existe" (p. 20), para concluir luego en las dos últimas estrofas: "Porque llamáis al derribar, progreso, / Progreso al golpe de esa garra fría, / por cuanto muere cuanto amé, por eso, / Os digo a todos la protesta mía. // ¡Salud!... La patria, de un glorioso abismo/ Surge, y pide a sus bardos nuevo canto.../ Pero yo, en lo más hondo de mí mismo, /siento la honrada ingenuidad del llanto." p. 21. Además también en 1911 se publica un artículo a la obra de Rafael Obligado, cuyo autor, Gregorio Uriarte, previene sobre la posibilidad de interpretar la obra de Obligado como contraria al cosmopolitismo, que dicho sea de paso, constituye uno de los ejes de los debates acerca de la identidad nacional. ( $n^{\circ} 33$, pp. 261-277) Recordemos la amistad que une a Nosotros con Obligado, quien promueve la iniciativa de publicar una antología literaria de prosistas argentinos que beneficiará económicamente a la revista, y presidió la Sociedad cooperativa que pasa a constituir Nosotros desde noviembre de 1912.
} 
significativo de su presencia entre 1908 y $1913,{ }^{196}$ y hace posible reconstruir su perfil en la publicación. El hecho de que Giusti, Julio Noé (quien tiempo después reemplazaría a Banchs en la secretaría de redacción), y Juan Más y Pí, tres miembros centrales de Nosotros le dedicaran varias de sus notas, reforzaba su importancia.

Desde la mirada de Giusti, Leguizamón era un sujeto de referencia como escritor destacado y como historiador o estudioso del pasado argentino. Esta doble condición tornaba más eficaz el interés por las tradiciones y la prédica del autor de

${ }^{196}$ Cronológicamente las oportunidades en que aparece son: 1908:

- Giusti, Roberto F. Letras argentinas, "El país de la selva, por Ricardo Rojas", Año II, Tomo II, n 8, marzo, 1908, pp. 150-154.

-Se consigna el título de esta obra de Leguizamón en 'Libros recibidos', Martiniano Leguizamón, El colegio del Uruguay, Buenos Aires, Año II, Tomo III, agosto-septiembre, $\mathrm{n}^{\circ}$ 13-14.

- Carricarte, Arturo R. de. De crítica; alrededor de Alma nativa, Año II, Tomo III, n 16-17, pp. 247-251, noviembre-diciembre.

1909

- Giusti, Roberto. De cepa criolla por M. Leguizamón, Año II, Tomo III, nº 16-17, pp. 308-310, noviembre- diciembre.

- En 'Libros recibidos', Martiniano Leguizamón, De cepa criolla, La Plata, Talleres gráficos Sesé, 1908.

1909

- Leguizamón, Martiniano, "Aclaración”, Año III, Tomo IV, n 18-19, pp. 33-35, enero-febrero.

- Explica una cuestión que Carricarte señala respecto de un cuento suyo que tiene igual argumento que otro de Nervo.

- En 'Notas y comentarios' se lo menciona como prologuista de Los gauchos judíos de Alberto Gerchunoff, Año III, Tomo IV, $\mathrm{n}^{\circ} 22-23$, julio-agosto.

-Leguizamón, Martiniano, Urquiza y la Casa del Acuerdo; advertencia preliminar, Año III, tomo $4, n^{\circ} 24$, pp. 396-400, septiembre [aunque se publica en noviembre]

-En este mismo número 24 se lo menciona primero en la lista de los participantes de la demostración a Nosotros, con motivo del segundo aniversario, y en 'Bibliografía' se señala que han recibido el libro (al que definen como "contribución histórica") Urquiza y la casa del acuerdo de Leguizamón.

1910

Giusti, Roberto, Urquiza y la Casa del Acuerdo, por M. Leguizamón, Año IV, Tomo V, n 25, pp. 66-69, enero.

1911

-Leguizamón, Martiniano, "Nuestros orígenes literarios", Año IV, Tomo V, n² 29, pp. 321-329, junio.

-Acevedo Díaz, Eduardo, “A Martiniano Leguizamón”, Año IV, Tomo VI, n 30, pp. 28-29.

-Más y Pi, Juan, "Sobre unas críticas",[respuesta a Martiniano Leguizamón], Año IV, Tomo VI, n 30, julio, 1911, pp. 23-27.

-Leguizamón, Martiniano. "Coplas de la tierra; petenera y vidalita"[sobre Tras los mares de Juan Antonio Cavestany], Año V, Tomo VI, n 31, pp. 85-95, agosto.

-Giusti, Roberto, reseña en la sección 'Bibliografía' de Tras los mares de Juan Antonio Cavestany, que había criticado Leguizamón, y la nota tiene como referencia las observaciones de Leguizamón. Año V, n 32, Tomo VI, septiembre, pp. 241-244.

-Leguizamón, Martiniano, "La demostración a Roberto Payró", Año $V$, tomo 6, n 34, pp. 417-419, noviembre. 
Calandria, en el contexto de una "reacción" de "sistemático nacionalismo" -términos que Giusti tomaba del discurso de Rojas en la demostración que Nosotros le tributara-, que debía involucrar, principalmente, a los artistas y los "literatos". Si tal reacción se encarnaba en la construcción de monumentos intelectuales que conectaran el pasado con el presente atendiendo a las necesidades del momento actual, los estudios sobre "lo que fue" adquirían centralidad. ${ }^{197}$ La eficacia imaginaria del autor de De cepa criolla se plasmaba en la conversión ideológica a la que sus lectores se veían inducidos:

Leguizamón es algo más que un escritor; es también un estudioso que con cariño filial gusta de escudriñar las cosas de nuestro pasado; y así como en el campo de nuestras letras ocupa un lugar preeminente, merecidísimo tiene el que la Junta de historia y numismática americana le ha cedido, incorporándolo a su seno.

"De cepa criolla" con ser una recopilación de artículos ya aparecidos, me ha cautivado. El cariñoso interés que Leguizamón tiene por las cosas de la tierra y el sentimiento sincero que le guía de contribuir con su granito de arena a la obra de constituir una compacta nacionalidad, tienen en el libro tan sincero acento de verdad que conquistan en el acto y son acicate para que el cerebro del lector se ponga inmediatamente al unísono con las ideas que inspiran a su autor. ${ }^{198}$

-Noé, Julio, Páginas argentinas, por M. Leguizamón, Año V, Tomo VI, n³ 34, pp. 410-411, noviembre1911.

-Leguizamón, Martiniano, “El escudo de armas de Buenos Aires", Año V, Tomo VI, n 35, pp. 439-441, diciembre. Se trata de un artículo de Leguizamón, que ha sido requerido por el consejo deliberante a discutir este tema, en su calidad de miembro de la Junta de Historia y Numismática americana.

1913

-Segunda encuesta de Nosotros "¿Cuál es el valor del Martín Fierro?, Año VII, Tomo X, $\mathrm{n}^{\circ}$ 50, junio, 1913, pp. 425-433. Su respuesta es la primera que publicó la revista.

-Leguizamón, Martiniano. "Marcos Sastre", Año VII, Tomo XII, n 56, pp. 253-258, diciembre.

${ }^{197}$ Giusti enuncia el programa en los siguientes términos: “(...) levantar en nuestros libros otros tantos monumentos a nuestros grandes hombres, inundar en una palabra, el país de estudios sobre lo que fue, o lo que aun conserva sabor criollo, no con absurdas ambiciones de crear un híbrido idioma argentino, sino al contrario valiéndose de la fresca, bella, robusta lengua castellana, remozándola de acuerdo con nuestras necesidades, tal ha de ser el punto de mira de todos, arqueólogos, historiadores, críticos, novelistas, hombres de teatro" Cf.. Año II, Tomo III, n 16-17, noviembre-diciembre, 1908, pp. 308-310. (NOS: 45-46).

${ }^{198}$ Nosotros, Año II, Tomo III, n 16-17, noviembre-diciembre, 1908, p. 309. 
Sin embargo, desde la mirada de Nosotros, el programa histórico y especialmente literario (que en Leguizamón privilegiaba la mirada hacia el pasado, para rescatar de una campaña no modernizada al tipo social del gaucho y las costumbres rurales), resultaría incompleto sin la incorporación de las ciudades y de las nuevas formas de sociabilidad resultado de la política inmigratoria de los programas modernizadores. De este modo, para prevenir cualquier malentendido que pudiera derivarse de sus palabras previas, Giusti se explicaba:

No es esta de ningún modo una indicación de limitar nuestros horizontes al gaucho, como algunos lo pretenden, con un cerrado criollismo. La República Argentina tiene su campaña y sus ciudades; su pasado y su porvenir; no es por lo tanto solo con la mirada puesta en el campo y en el pasado que ha de estar el artista; pero sí ha de dirigirse a ellos con frecuencia, y no, como ahora, rimar versos en que nieva en Diciembre, porque así sucede en París. (309)

En un sentido similar, en "De crítica", un escrito publicado en el mismo número que la reseña de De cepa criolla de Giusti, Arturo Carricarte intervenía identificando el pasado con la campaña, y el presente y el porvenir con la vida urbana. El crítico constataba en la literatura argentina la existencia de "un sello de común amor al pasado" que elevaba al gaucho a mito y leyenda, señalando, como era obvio, a Leguizamón como representante de esta tendencia. Asimismo, Carricarte reconocía en la dinámica del progreso la inevitable sustitución del nacionalismo literario que Leguizamón proponía, cuya función básica, asociada a una práctica institucional de signo estatal ("levantar acta"), consistía en documentar y dar testimonio del pasado, y así, aproximarlo al presente. De este modo, el progreso tendría también sus bardos:

Esa 'visión' retrospectiva no puede ser tendencia definitiva; no solamente porque ello se opone a la ineludible ley de progreso que impele hacia adelante y solo permite accionar en torno, no hacia atrás, sino, porque en la alternidad de la función humana, individual o colectiva, otras necesidades vendrán pronto a sustituir a la actual que consiste en levantar acta, precisa y fiel de una situación a 
medias desvanecida y cada vez más remota. De ahí que lo 'actual' en la Argentina, su cultura, su riqueza, su sólida organización política y su prosperidad administrativa, que no son transitorias ni están en peligro, tendrán a su vez, sus cantores como el pasado los tiene hoy, tan entusiastas y brillantes. ${ }^{199}$

Casi un año después, en noviembre de 1909, la revista publicaba la "Advertencia preliminar" que Leguizamón escribía a su libro Urquiza y la casa del Acuerdo, un texto cuya relevancia radicaba en la construcción que de sí mismo hacía el autor, quien se mostraba como un sujeto fuertemente autorizado y legitimado. Esa legitimidad encontraba en la propiedad un punto nodal, aspecto que como se confirmaría más adelante, articulaba la argumentación de otros de sus escritos. Así, Leguizamón era un poseedor de documentos y también miembro de la Junta de Historia y Numismática Americana, institución encargada de construir el pasado nacional, siguiendo una tradición iniciada por Tácito en sus Anales. De esta manera el autor de Recuerdos de la tierra era quien tenía en sus manos, en germen, la edificación de una versión del pasado argentino, necesaria y preferible a la de una tradición historiográfica acusada de parcialidad y ejemplificada en la historia de Mitre. Como muchos otros, detentaba una misión, derivada de su condición de sujeto propietario de la letra escrita en que debía cimentarse esa nueva interpretación del relato de la historia nacional. ${ }^{200}$ En la sección de 'Letras argentinas' del número siguiente (25) Roberto Giusti, dedicaba al libro y a la figura del autor una reseña en la que elogiaba su erudición, su propósito y la "aplastadora documentación" en que basaba sus análisis. ${ }^{201}$ Esta imagen que forjaba Giusti de Leguizamón al ocuparse de Urquiza y la casa del acuerdo, le otorgaba un sitio de tal relevancia, que entre los números 29 y 35 la revista haría de su figura un centro y un pivote para procesar la cuestión nacional.

\footnotetext{
199 Nosotros, Año II, Tomo III, n 16-17, noviembre-diciembre, 1908, p. 249.

${ }^{200}$ Esta reseña también se relacionaba con el intento de construcción de la historia como disciplina, como dominio de investigación, y por lo tanto como contribución al recorte del objeto y del método. En ese sentido, en esta misma entrega de la revista se publica una nota sobre Teoría y práctica de la historia de Juan B. Justo.

${ }^{201}$ Giusti, Roberto, Urquiza y la Casa del Acuerdo, por M. Leguizamón, Año IV, Tomo V, nº 25, pp. 66-69, enero, 1910.
} 
Así, en "Nuestros orígenes literarios" del n $\mathrm{n}^{\mathrm{0}} 29,{ }^{202}$ Leguizamón polemizaba con Más y Pí, a propósito de Leopoldo Lugones y su obra, y negaba a Lugones el lugar de iniciador que el crítico destinaba en la temática -no en la técnica ni en la calidad estética- "de las cosas nuestras". Esa inexactitud lo impelía a

rectificar algunas de sus rotundas conclusiones, porque revelan, o un desconocimiento completo de nuestros orígenes literarios, o un injustificado menosprecio hacia otros escritores de esta tierra, iniciadores cabalmente de esa reacción con tendencia nacionalista que el crítico pretende atribuir a las obras del autor elogiado. ${ }^{203}$

Esos otros escritores eran, principalmente, los argentinos Rafael Obligado ("cantando episodios de la guerra de la independencia y la leyenda del payador argentino en décimas fluentes"), Joaquín V. González (Mis Montañas y Cuentos), el uruguayo Eduardo Acevedo Díaz (Ismael), ${ }^{204}$ y por supuesto, el mismo Martiniano Leguizamón quien antes de La guerra gaucha ya había escrito Recuerdos de la tierra (1896), Calandria (1898), Montaraz (1900), y los relatos de Alma nativa -casi todos ellos anteriores a 1906, fecha de su edición en volumen. ${ }^{205}$ De este modo su "papel", según su visión personal, no podía limitarse al de "paladín de las huestes lugonianas":
(...) no renuncio a mi humilde papel de montonero en la brega para abrir una picada en la selva densa de las cosas nuestras, y no necesito recordar aquí que, ese afán siempre alerta para salvar del olvido el rico acervo de las tradiciones y costumbres nativas, fue el tema predilecto que orientó mi producción $(\ldots)^{206}$

\footnotetext{
${ }^{202}$ Leguizamón, Martiniano, "Nuestros orígenes literarios", Año IV, Tomo V, $n^{\circ} 29$, junio, 1911, pp. 321-329. (NOS: 73-74).

${ }^{203}$ Año IV, Tomo V, n 29, junio, 1911, p. 321.

${ }^{204}$ Señalaba a Mas y Pi la tarea de Eduardo Acevedo Díaz, escritor uruguayo autor de Ismael (1888, que inicia la trilogía de romances históricos) cuyo personaje es el gaucho con su caballo en el escenario agreste.

${ }^{205}$ Incluía en la misma tendencia nacional a Sánchez y a Payró, contrariamente a lo que pensaba Mas y $\mathrm{Pi}$ : "Tampoco puede calificarse "teatro bajo" el meritísimo esfuerzo de los escritores que como el malogrado Florencio Sánchez en Barranca abajo y La gringa y Roberto J. Payró con Sobre las ruinas, llevaron a la escena estudios serios y bien interesantes del problema social planteado por la inmigración que va desalojando al antiguo morador de nuestros campos". pp. 325-326.

${ }^{206}$ Nosotros, Año IV, Tomo V, nº 29, junio, 1911, p. 323.
} 
De este modo, a la vez que Nosotros prodigaba su hospitalidad a Leguizamón abriéndole sus páginas con una frecuencia más que notoria, también lo hacía a través de escritos de otros autores, referidos al autor de Calandria. Así, en el número siguiente, de julio de $1911,{ }^{207}$ la revista publicó la carta-dedicatoria de Eduardo Acevedo Díaz, que acompañaba el ejemplar del libro de su autoría - Épocas militares de los países del Plata-, que enviaba a Leguizamón. El que la revista diera a conocer esta carta personal, y que además explicara en nota al pie, que "por referirse a un debate de actualidad y venir de tan autorizada pluma, hemos juzgado oportuno darla a la publicidad en estas páginas"208, indicaba la importancia otorgada a Leguizamón y, al mismo tiempo, ratificaba la voluntad de intervenir en un tema insoslayable de debate. Acevedo Díaz expresaba su coincidencia con el escritor argentino ${ }^{209}$ y señalaba la necesidad de estudiar al gaucho, en el que veía un agente de la depuración del ambiente hispano colonial, y el origen de la nacionalidad. ${ }^{\mathbf{2 1 0}}$

Finalmente, en la reseña sobre Tras los mares de Juan A. Cavestany, ${ }^{211}$ que llevaba por título "Coplas de la tierra; petenera y vidalita", Leguizamón centraba su extenso análisis (y sus objeciones) en la hipótesis incomprobada de Cavestany en función de la cual

la poesía y la música argentina es [sic] la herencia dejada por los conquistadores, producto de la alegría burbujeante del andaluz mezclada a las recónditas tristezas de la Pampa, siendo el gaucho

\footnotetext{
${ }^{207}$ El número 30, como conjunto, representa la apuesta más compacta de la participación de la revista en el debate acerca de la nacionalidad. En él se publican -y en este orden: "Rosa" de Rafael Obligado (pp. 9-13); la reseña sobre Los lises del Blasón de Rojas escrita por Gerchunoff (pp. 14-22); "Sobre unas críticas", respuesta de Mas y Pi al artículo de "Nuestros orígenes literarios" de Leguizamón (pp. 23-27); la carta de Acevedo Díaz "A Martiniano Leguizamón"(pp. 28-29); "Oda a los padres de la patria", E. Banchs, pp. 30-42; en Bibliografía Coriolano Alberini reseña Las transformaciones de la sociedad argentina de Horacio G. Rivarola (70-72) y Alfonso de Laferrère analiza también Los lises del blasón (72-74)

${ }^{208}$ Acevedo Díaz, Eduardo, “A Martiniano Leguizamón”, Año IV, Tomo VI, n 30, julio, 1911, pp. 28-29.

${ }^{209}$ Sostiene: "He leído sus libros y sus críticas, y pienso como usted. Su estética nativa habla al corazón y al pensamiento" p. 28. En ese mismo número 30 , Julio Noé se ocupa, en 'Bibliografía', del libro que Acevedo Díaz le enviara a Leguizamón -Épocas militares de los países del Plata-, y la similitud con Leguizamón se acentúa, ya que Acevedo es también un poseedor de documentos, aunque su método histórico es calificado de antiguo. Cf. Nosotros, Año IV, Tomo VI, n 30, julio, 1911 p. 80. (NOS: 86).

${ }^{210}$ Para la transcripción completa del texto Cf. NOS: 82.

${ }^{211}$ Nosotros, Año V, Tomo VI, n 31, agosto, 1911, pp. 85-95.
} 
su encarnación que la perpetuó con áspera vida de penurias en el desamparo del desierto. ${ }^{212}$

La estrategia de Leguizamón consistía en establecer una separación entre el folklore argentino y el de España, para ligar al primero con la cultura indígena americana más elevada. En efecto, trataba de otorgar a la música popular (canto y baile), y a los sujetos a ella asociados, el valor de la nacionalidad verdadera, para lo cual debía trazar una oposición con lo español. En contra de los que denominaba "abolengos exóticos" y del carácter incorrecto de la filiación entre la petenera y la vidalita, reputaba escasas las pruebas de Cavestany, para emparentar ambas composiciones. ${ }^{213}$

Por otra parte, la idea de propiedad -y la imagen de Leguizamón como sujeto propietario- se presentaba de diversos modos y organizaba un tramo significativo de sus argumentos. En primer término, aparecía como propiedad de la tierra en tanto representación imaginaria situada dentro una tradición en la que se inscribía como autor. En segundo lugar, como propiedad de la letra escrita en su capacidad de organizar y modelar -apropiándose de ella-, una porción de la cultura popular. Finalmente, esa idea remitía a la posesión de la tierra como temática de su escritura y sobre la que pretendía ejercer entonces, por un desplazamiento, la propiedad de representación nacional. En ese sentido, la presencia del sello con que marcaba su ganado en la contratapa de Recuerdos de la tierra (1896), hacía explícita esta relación entre cultura y propiedad, reforzando el lugar y las características de su participación. $^{214}$

En el no 34 Nosotros organizó, conjuntamente con la revista Renacimiento, una “demostración” a Roberto Payró para celebrar el éxito de Divertidas aventuras del nieto de Juan Moreira. En esa oportunidad Leguizamón pronunció el discurso "a ${ }^{212}$ Ibid., p. 89.

${ }^{213}$ Para la transcripción más extensa Cf. NOS: 86-87.

${ }^{214}$ La reseña concluía con una cita propietaria y con la marca de lo aborigen como componente central de lo propio, ya que su autor utilizaba una voz de la tierra para contestar o reclamar el derecho a la cultura de signo americano: "Y con la misma pasión con que él exalta el inconfundible abolengo de la copla de su nativa tierra sevillana, ha de concederme que defienda yo el origen americano de la vidalita; y que empleando una voz del tosco lenguaje aborigen que aún la entona allá bajo la sombra de nuestros bosques mediterráneos, le diga: -Kayca noccapa,- esto es mío." p. 95. [cursivas nuestras]. Debo a Facundo Vázquez el conocimiento del sello del ganado en la contratapa de Recuerdos de la tierra. 
nombre de ambas publicaciones". El discurso afirmaba la hermandad literaria entre Payró y el disertante, en virtud de la elección de una temática común que cultivaba "los veneros de belleza y emoción que nos brindan los asuntos de la tierra". ${ }^{215}$ En ese mismo número Julio Noé en 'Bibliografía' escribe sobre Páginas argentinas de Leguizamón postulando al autor como el iniciador de una campaña prolongada "a favor del nacionalismo literario" -la que por esto mismo, podía considerarse contraria de la obra ya citada de Mas y Pi-, ubicando a Leguizamón como pionero y antecedente de la obra de Lugones en La guerra gaucha. Decía Noé:

La campaña iniciada hace ya varios años a favor del nacionalismo literarios, ha tenido en don Martiniano Leguizamón el más constante $\mathrm{y}$ convencido de sus defensores. Si la semilla no ha fructificado como era dable esperar, no es culpa de quienes la ofrecieron. París sigue siendo para los escritores americanos la Meca de sus mejores sueños, y los volúmenes a 3,50 francos la fuente de sus inspiraciones y sabidurías. ${ }^{216}$

En contra del "francesismo literario" que consideraba dominante en las letras hispanoamericanas, afirmaba:

(...) Por fortuna la ansiada reacción ha comenzado, y ella nos promete los mejores resultados, a pesar de la insistencia enfermiza con que muchos de nuestros escritores, nacidos en la última aldea provinciana, lloran su Versalles y su duquesita de blanca peluca.

Contra esta tendencia ha luchado siempre Martiniano Leguizamón. (...)

Su predicación idealista no es menos estimable.(...)

${ }^{215}$ Leguizamón se presentaba como 'hermano en las letras' y como 'amigo' de Payró. Nosotros, Año V, Tomo VI, n⿳ 34, noviembre, 1911, pp. 418-419. NOS: 100. (recordemos que Payró sería el prologuista de Montaraz de Leguizamón). En realidad, este discurso caracterizaba más a Leguizamón que a Payró, en tanto es evidente, al menos con respecto a Divertidas aventuras, la diferencia entre la literatura de ambos: la de Leguizamón más nostálgica y mirando al pasado, intentaba fijarlo para siempre en la escritura, para conjurar el olvido que como amenaza pesa sobre él, y polemizando con los seguidores del modernismo. Por su parte, la literatura de Payró aspiraba a intervenir en el presente a través de la crítica de los aspectos perniciosos de la política criolla y cultivaba una forma moderna como la novela.

${ }^{216}$ Nosotros, Año V, Tomo VI, n 34, noviembre, 1911, pp. 410-411. 
Siente que el cosmopolitismo invasor nos está llevando todo (...)

Al fin y al cabo, Leguizamón completa la obra que iniciara Sarmiento, que continuaran Gutiérrez, González, Groussac, Obligado, y que Ricardo Rojas propiciara últimamente en dos libros de envidiable fortuna ${ }^{217}$

La omisión de La guerra gaucha y de su autor en esta tradición de nacionalismo literario reforzaba la postura de Noé con respecto al juicio de Más y Pí sobre Lugones. La oposición al cosmopolitismo que amenazaba con disolver lo verdaderamente argentino tal como lo representaban Noé y Leguizamón, revelaba el sentimiento de pérdida, pero también la respuesta compartida por cierta porción de la cultura letrada modernizada en la empresa de nacionalización de los inmigrantes. ${ }^{218}$

A primera vista, y teniendo en cuenta las filiaciones de la revista vinculadas con la construcción de una tradición nacional de signo incluyente, un sujeto como Leguizamón podía presentar varios problemas. El tipo de figuras que pretendía erigir en paradigmas del pasado nacional, condensadoras y representantes de la cultura argentina -la tradición indígena americana incásica y el gaucho respectivamente-, no coincidían con la posición de Nosotros. Desde la perspectiva de Giusti tampoco podía haber acuerdo en la impugnación del cosmopolitismo, evaluado por Leguizamón como responsable de la "rápida transformación a que asistimos en la que el perfil, la fisonomía peculiar de las cosas de antaño se borran o se pervierten, sustituidas por un nuevo tipo". ${ }^{219}$ Sin embargo, su presencia servía a la revista para introducirse en el debate de la mano de una voz legitimada, para dar su posición, y discutir con los pares generacionales (por ejemplo con Rojas a propósito de La restauración nacionalista) lo que no se discutía con Leguizamón. Y no obstante, se otorgaba un lugar privilegiado a esa voz con la que se pretendía establecer una relación horizontal -puesto que se compartía el mismo espacio público de enunciación-, y de este modo la revista se

\footnotetext{
${ }^{217}$ Nosotros, Año V, Tomo VI, n 34, noviembre, 1911, pp. 411.

${ }^{218}$ Oscar Terán señala, en relación con la crisis de legitimidad del sector liberal, "la empresa de nacionalización de las masas fundada en la enseñanza patriótica que José María Ramos Mejía impulsó desde la dirección del Consejo Nacional de Educación." Señala también que la apelación al positivismo en Las multitudes argentinas, revela la crisis del sujeto liberal. (Terán, 1994: 29).

${ }^{219}$ Leguizamón, Prólogo a Alma nativa.
} 
autorizaba. En ese punto, el gesto enlaza con la inclusión del relato de Payró en la entrega inicial de la revista, que señalaba su intención de continuidad con un escritor culto de las generaciones anteriores, aunque se tratase en aquel caso de una novela urbana inconclusa. ${ }^{220}$

Asimismo algunos escritos de Leguizamón en Nosotros mostraban un aspecto que podría considerarse conflictivo en relación con los directores de la revista, atendiendo a la imagen que de sí construía el autor de Recuerdos de la tierra y al eje que organizaba esos escritos, bien diferente del tipo de figura que se iba perfilando en Giusti y Bianchi. Así, "Coplas de la tierra”, colaboración que reseñaba el libro de un extranjero sobre la Argentina, presentaba a su autor fundamentalmente como un propietario legítimo de la tierra y de la cultura nacional. Sin embargo, desde otras notas publicadas en la revista, inscriptas en el terreno de los estudios históricos, Leguizamón proponía aquella misma idea de inconclusión encarnada en la novela Nosotros de Payró sobre la cual la revista edificaba la legitimidad de sus acciones. Observaba:

${ }^{220}$ En Nosotros, más adelante, estas diferencias se harían bien explícitas. En 1916 Julio Noé, quien antes defendía fervorosamente a Leguizamón, afirmaría, en su reseña de La cinta colorada: "He leído las páginas de este libro en parecido estado espiritual al que recorro, de tanto en tanto, los museos que guardan viejas cosas argentinas. Lo he leído con inquietud y con cierta tristeza; con la misma tristeza y la misma inquietud con que miro el rostro de un criollo u observo estampas y objetos de otrora. (...)

El señor Leguizamón, como muchos argentinos de su época y otros de ulteriores, ha oído de niño leyendas e historias de la patria vieja, el relato de escenas que los suyos han vivido o contemplado, y su imaginación ha sentido, así, todo el encanto de lo primitivo, de lo autóctono, de lo puro. Artista, ha sabido más tarde destilar en buenas páginas sus primeras impresiones y decir de sus amores más hondos. De este modo, su pasión artística y su fervor nacional se armonizan en una obra simpática y sincera.

Yo no he oído en mi hogar lo que el señor Leguizamón ha oído en el suyo. Soy argentino de la nueva estirpe, a quien sus padres en el recuerdo de sus Pirineos y de sus Alpes originarios, no pueden dar, sino escasa, la visión del pasado argentino. La cinta colorada no lució en ninguno de los míos, ni tampoco conocieron el exilio de los unitarios; gente de mi estirpe no corrió la pampa primitiva, ni anduvo con sus hombres, ni supo sus leyendas. Así, no puedo sentir como un argentino tradicional las cosas de antaño. Comprenderá, pues, el lector, por qué he leído con inquietud y tristeza el libro reciente del señor Leguizamón. O su autor da la pauta de lo que un argentino debe ser y, en tal caso, yo lo fuera pobremente, -o bien es posible que un hombre pueda sentir intensamente su patria sin necesidad de imágenes para su culto: recuerdo histórico o memoria guardada- y en tal caso la pedagogía de los museos y el valor de la historia disminuyen notablemente. Quisiera creer lo segundo. De lo contrario, las pobres criaturas que no nos satisfacemos de un patriotismo de afirmaciones hipócritas o ligeras, nos veríamos irremisiblemente condenados a una nacionalidad parcial”. Nosotros, Año X, nº 88, agosto, 1916, pp. 209-210. 
La historia argentina tiene que rehacerse para despojarla de la parcialidad con que fue escrita; estimo, pues, un deber de los poseedores de documentos el darlos a conocer para facilitar el trabajo al historiador del futuro, ahorrándole la tarea engorrosa de la busca del documento necesario que no siempre se encuentra en los archivos públicos.

Releo de nuevo esos documentos y las conclusiones que de ellos deduje antes de lanzarlos a la publicidad para que cumplan su destino, y siento arraigarse en mi espíritu la convicción profunda de que cumplí, como miembro de la Junta de Historia y Numismática Americana dentro de las limitaciones del tema y la cortedad de mis medios de expresión- con la desinteresada obligación impuesta por la divisa que sirve de guía a nuestras investigaciones históricas: "lucem quaerimus". 221

Así, la historia argentina, lo mismo que la novela nacional, no era para Leguizamón algo hecho, sino una tarea por realizar. Debía fundarse como disciplina que recuperara el pasado, a partir del análisis de los archivos y situarse en una institución pública. Era por esa razón que, a pesar de ser un poseedor de documentos, realizaba una exhortación en su carácter de miembro de la Junta de Historia y Numismática Americana. De esa manera, para Leguizamón, el relato de la historia debía abandonar la parcialidad de la memoria como género y como forma de transmisión de un legado familiar, para convertirse en un discurso acerca del pasado, construido desde las instituciones del Estado y desde la sociedad civil. La figura de Leguizamón significaba para estos intelectuales jóvenes la confirmación de sus aspiraciones de intervenir en el diseño del pasado argentino insertándose en las instituciones específicas y en el armado de una historia futura en la cual la inmigración de la que ellos descendían desempeñaba en un rol central.

En coincidencia con Leguizamón y a propósito de Urquiza y la casa del acuerdo Giusti declaraba: 221 “Advertencia preliminar” que Leguizamón escribe a su libro Urquiza y la casa del Acuerdo
por M. Leguizamón, Nosotros, Año III, Tomo IV, n 24 , noviembre, 1909, p. 400 . 
Vale la pena meditar sobre cuál será el concepto histórico que dentro de cincuenta años tendrán las generaciones argentinas respecto de este primer siglo de vida independiente, cuya iniciación gloriosa vamos a conmemorar en breve, ¡ay!, acaso con más ridículo relumbrón y escandaloso despilfarro, que alto $y$ sincero entusiasmo patriótico.

Tenemos una historia ya, y cuan noble y respetable; pero no es la definitiva, la que cristalizará en el futuro (...)

La época constitucional, como más vecina a nosotros, es todavía, naturalmente, la más confusa y discutida. Diariamente aumenta a su respecto la bibliografía. (...) La última obra de la índole [documentos de rehabilitación, polémicas] que nos llega es la de don Martiniano Leguizamón, Urquiza y la casa del Acuerdo. Es también un libro de polémica. Su autor lo tituló modestamente "Contribución histórica". Lo es, en efecto, y valiosísima. ${ }^{222}$

La historia argentina aparecía como algo doblemente inconcluso: en tanto disciplina (había que convertirla en un campo específico del saber con un método de investigación, y debía practicarse en instituciones) y como relato de la nación. En ese sentido, los miembros de la revista, casi todos descendientes de italianos, y autolegitimados como intelectuales, construían su lugar social y cultural. Las historias de Mitre y López, parciales, no daban cuenta de esta porción reciente de la Argentina moderna. Eran los jóvenes historiadores de este grupo -entre otros, Ravignani, Levene, Alberini- los encargados de construirla.

\subsection{La discusión con los pares: el caso Rojas}

En sus intervenciones, Nosotros construyó figuras de escritor que, tendientes a asociar una estética a un tipo de subjetividad, definían, además, formas deseables del vínculo entre los intelectuales. A partir de la distancia explícita entre este tipo de subjetividad y los atributos de cierta imagen estereotipada del poeta decadente, algunos de cuyos rasgos compartían los modernistas de El Mercurio de América o el

${ }^{222}$ Nosotros, Año IV, Tomo V, n 25, enero, 1910, p. 66. 
Lugones de los escritos sobre arte de La Montaña, Nosotros fue elaborando el perfil de un sujeto que en tanto intelectual hizo de la relación con el presente algo fundamental, y como escritor, se enrolaba en una estética de corte realista. ${ }^{223}$ Sus directores se convirtieron en modelo de las formas de la sociabilidad a que se aspiraba en el mundo literario, dentro del cual Roberto J. Payró, como lo establecía Gerchunoff en "Elogio de la democracia", y lo rubricaba la demostración ofrecida por Nosotros, ${ }^{224}$ aparecía como representante indiscutido. Inclusión, camaradería, comunión, fraternidad, hermandad, solidaridad, son términos definitorios de estos lazos, cuya crónica Nosotros jamás pasó por alto, afanándose en consignar los detalles de los encuentros, almuerzos, homenajes, festejos, aniversarios, partidas, regresos, muertes, publicaciones, premios. Ricardo Rojas, como ya señalamos al referirnos a la relación crítica de Giusti con Lugones, encarnó durante un tramo de Nosotros al intelectual, quien iba dejando de ser el joven promisorio para consolidarse como la realización más positiva de las virtudes de una formación disciplinada, sostenida y rigurosa. El hecho de que Rojas participara activamente de la vida universitaria era, como ya se dijo, un punto de contacto fuerte, teniendo en cuenta la vocación institucional que promovía la revista, y su fluida relación con la Facultad de Filosofía y Letras. Asimismo, tanto Rojas como Giusti consideraban la enseñanza como la posibilidad excluyente del progreso intelectual y general de la nación. De este modo Rojas era la figura del par -aunque tuviera cinco años más que Giusti- con quien la revista discutía el tema de la identidad cultural. Aunque no participó como colaborador sino hasta junio de 1908, ${ }^{225}$ sus libros fueron criticados por Giusti en la sección 'Letras argentinas'.

La presencia del autor de El país de la selva funcionó en la revista como el gozne que articulaba la discusión sobre la identidad cultural. ${ }^{226}$ A través de la relación

\footnotetext{
${ }^{223}$ En relación con esta cuestión es ilustrativo el consejo de Giusti a Chiappori, en la reseña de Borderland: "gustaríame que el señor Chiappori se apartara desde ya de esta literatura anormal, y nos diera con su estilo tan propio, tan inconfundible, algún otro libro, -cómo decirlo?- más sano, más humano....." , Año I, Tomo I, nº 5, diciembre, 1907, p. 333. NOS: 20. ${ }^{224}$ Año V, Tomo VI, $n^{\circ}$ 34, noviembre, 1911.

225 "La hoja de parra", Año II, junio, 1908.

${ }^{226}$ El listado que sigue muestra las apariciones de más importantes de Rojas entre 1907 y 1913:

-Reseña de Giusti de El país de la selva, Año II, Tomo II, nº 8, marzo de 1908, pp. 150-154. -Reseña de Giusti de El alma española, Año II, Tomo II, nº 9, abril, 1908, pp. 223-224.
} 
intelectual con Rojas, cuya obra gozaba de prestigio no sólo entre sus antiguos amigos de Ideas como Chiappori, Gerchunoff, Ortiz Grognet o Becher, sino también entre muchos de los miembros de Nosotros, la publicación configuró y definió su concepción respecto de lo nacional. Alrededor de las intervenciones de Rojas, acompañándolas en el comienzo (en 1908), y en un gesto fuerte de adhesión a su ideario, la revista compartió la idea de una reacción nacionalista, que como veremos después, no concebiría en términos de la "restauración" que sostuvo Rojas. Nosotros -Primera colaboración de Rojas en la revista: "La hoja de parra”, Año II, Tomo II, mayo-junio, $n^{\circ}$ 10-11, 1908, pp. 300-305.

-Demostración de Nosotros a Rojas, Año II, Tomo III, agosto-septiembre, n 13-14, 1908, pp. 122-127

-Reseña de Giusti de Cartas de Europa, Año II, Tomo III, agosto-septiembre, n 13-14, 1908, pp. 116-117.

- Se publica "Rapsodia póstuma", por Ricardo Rojas. En el poema se realiza la exaltación de un héroe ["varón en rostro y alma formidable/ (rostro de tigre y alma de león)-"; "épico y lírico varón"], Año II, T III, nº 15, octubre, 1908, p. 178.

-Reseña de De cepa criolla por Giusti, Año II, Tomo III, n 16-17 noviembre- diciembre,1908, pp. 308-310.

- Es mencionado en la reseña de Alma nativa de Leguizamón, por Arturo Carricarte, Año II, Tomo III, $\mathrm{n}^{\circ}$ 16-17 noviembre- diciembre, 908, pp. 247-251.

-Rojas es nombrado como uno de los asistentes a la demostración que celebra el primer aniversario de la revista, Año III, Tomo IV, n² 24, noviembre, 1909, p. 460.

-En la sección 'Bibliografía', la dirección consigna los libros recibidos y explica: "A esta producción de índole histórica puede agregarse el notable informe sobre educación, La restauración nacionalista, presentado al Ministerio de Instrucción Pública por el conocido hombre de letras D. Ricardo Rojas, respecto del cual debemos postergar la publicación del artículo que le dedicábamos, por ser incompatible, debido a los puntos que en él se tocan, con la situación anormal que a la prensa ha creado el estado de sitio últimamente dictado." Año III, Tomo IV, n² 24, noviembre, 1909, p. 465.

- Giusti en nota al pie de 'Letras argentinas', se refiere a la continuidad del estado de sitio y a cómo éste afecta su libertad de expresión: "Como quiero decir a mi gusto una infinidad de cosas vedadas, esperaré a que concluya el estado de sitio para ocuparme de La restauración nacionalista, el bello trabajo de Ricardo Rojas. Hay que respetar las leyes....", Año IV, Tomo V, $n^{\circ}$ 25, enero, 1910.

-Reseña de Giusti de La restauración nacionalista, Año IV, Tomo V, n² 26, febrero, 1910, pp. 139-154.

-Se publica "El teatro de Florencio Sánchez", Conferencia dada en el teatro Odeón en homenaje a Sánchez, recientemente fallecido, Año IV, tomo V, $\mathrm{n}^{\circ}$ 27, abril, 1911, pp. 163-180.

- Aparece nombrado en la nota de A. L. P. sobre Historia de la América Latina de Manuel Ugarte, 'Bibliografía', Año IV, Tomo V, n² 28, mayo, 1911, p. 302.

-Como orador en la conmemoración del centenario de Sarmiento que realiza la Sociedad de Psicología, 'Notas y comentarios', Año IV, Tomo V, n² 28, mayo, 1911.

- Alberto Gerchunoff se ocupa de Los lises del blasón de Rojas, Año IV, Tomo VI, $n^{\circ} 30$, julio, 1911, pp. 14-22. En ese mismo número, la obra es criticada en la sección 'Bibliografía' por Alfonso de Laferrere, y también en la misma sección de ese número, Julio Noé se refiere al prólogo de Rojas a la Bibliografía sobre Sarmiento realizada por los alumnos de Rojas de UNLP.

-Juan Luis Ferrarotti incluye a Rojas en una galería de intelectuales y escritores argentinos entre los cuales están Lugones, Sicardi, R. Payró, E. Larreta, Ameghino, 'Bibliografía' ( a 
adscribió al nacionalismo culturalista de Rojas, al espiritualismo que concentraba en la intelectualidad joven la condición moral necesaria para llevar a cabo la construcción de la nacionalidad. Sin embargo, se distanciaría de lo que consideró una mirada excluyente, que en última instancia, dejaba lado la injerencia de los nuevos sujetos sociales en la construcción de la cultura nacional.

Las críticas de El país de la selva, El alma española, y Cartas de Europa, todas ellas firmadas por Giusti y publicadas en la sección 'Letras argentinas' en 1908, mostraban cómo el director de Nosotros organizaba y planteaba el problema de la lengua, que era uno de los puntos básicos del nacionalismo de signo cultural en el que abrevaba la revista. En esos tres escritos Giusti iba posicionando a Rojas como el escritor laborioso cuyos esfuerzos se veían, uno tras otro, coronados con una reputación intelectual, que derivaría, más tarde, en la consideración de su figura por parte de Nosotros como "acaso el más representativo de la joven intelectualidad argentina", 227 valoración que será ampliamente consensuada en 1913. Así, Giusti se ocupaba del primero de los tres libros mencionados, situándolo en una tradición a la propósito de Casos de derecho penal de Carlos O. Bunge") Año V, Tomo VI, $\mathrm{n}^{\circ} 35$, diciembre, 1911.

- Entre los folletos recibidos, en la sección 'Bibliografía', aparece Sarmiento evocado ante la juventud universitaria de La Plata de Ricardo Rojas, Año VI, tomo VII, n 36, enero, 1912.

-En 'Notas y comentarios', consignan, la aparición de Blasón de plata de Ricardo Rojas, que será criticada en el número siguiente, Año VI, Tomo VIII, nº 41, junio 1912.

-Álvaro Melián Lafinur publica una crítica sobre Blasón de plata, que anticipa algunas de las objeciones de Giusti en sus memorias, Año VI, Tomo VIII, nº 42, julio 1912, pp. 228-235.

-Se anuncia la creación de la cátedra de literatura argentina a cargo de Rojas en la Facultad de Filosofía y Letras, Año VI, Tomo IX, n 44, diciembre, 1912.

-Álvaro Melián Lafinur, en "El año literario", nombra entre los libros más destacados a Blasón de plata, Año VII, Tomo IX, n 45, enero, 1913, pp. 295-297.

- Se publica "La literatura argentina", conferencia leída por Rojas el 7/6/1913 con motivo de la inauguración de la cátedra de Literatura argentina en la Facultad de Filosofía y Letras; de Año VII, Tomo X, n 50, junio, 1913, pp. 337-365. En ese mismo número, se lo nombra en la introducción al texto de la segunda encuesta de Nosotros [sobre Martín Fierro]; en 'Notas y comentarios' el discurso de Rafael Obligado en la inauguración de la cátedra de Literatura argentina, lo señala como "don Ricardo Rojas, al autor de la Restauración Nacionalista, precisamente porque se trata de restaurar el alma argentina en su amplia vibración; al evocador del Blasón de Plata, que así descendió a las tumbas del Inca, conmovidas por el himno patrio, como vio resurgir la vida trasvasada del conquistador a "las carnes terreñas de las madres indias"; y también al poeta de los Lises del Blasón, porque el dominio de la rima y el ritmo prueba la microfonía del oído para todas las audiciones, inclusive la delicadísima del latir de los pueblos", p. 425.

227 Noé, Julio. Comentario a la Bibliografía de Sarmiento con prólogo de Ricardo Rojas (UNLP, trabajo realizado por alumnos de letras), Nosotros, Año IV, Tomo VI, $n^{\circ} 30$, julio, 1911, pp. 77-79. 
cual definía en tanto forma de asignar un sentido a una geografía que, de ese modo, era 'ganada' imaginariamente para las letras. El lenguaje "rico y jugoso" de estos textos, representativos de una porción de territorio nacional, era estimado como producto de la "ilustración literaria severa" de su autor. ${ }^{228}$ En la elogiosa reseña de El alma española ${ }^{229}$ del número siguiente, de abril de ese año, Giusti insistía en el ascenso gradual pero ininterrumpido de la reputación literaria de Rojas, quien ahora y sólo un mes después, aparecía como poseedor de una "obra, ya bastante vasta y sin nada de deleznable”. La crítica anudaba lengua, tradición y raza: en Rojas, el conocimiento o la “comprensión” del alma peninsular se vinculaba, según Giusti, con un lenguaje en que reverberaba lo español. De este modo, la lengua se constituía como "transcripción acumulada de la experiencia de pasadas generaciones" (Anderson, Perry, 2002: 9), en una concepción que era propia de los nacionalismos culturales. En la descripción de ese lenguaje que conservaba "algo de la buena prosa castellana", en el gusto del articulista por el espíritu general de la obra "que tiene mucho de castizo que [le] sabe a bien", en el tono de lamento con que, a veces, Giusti reconocía una desvinculación respecto de lo español que no era la más deseable, se exponía el momento en que la revista formulaba más claramente una voluntad de reconexión con la Península. Oponiéndose a la exclusividad de la influencia francesa en las letras argentinas, el director de la revista fomentaba el carácter fructífero y beneficioso de otras influencias, "sobre todo la italiana" -algo que sería retomado en la reseña de $L a$ restauración nacionalista, ya en polémica con su autor- manteniendo siempre el espíritu español que parecía ser, para Giusti, el garante de aquella integración de la que hablaba Unamuno en su carta a lo jóvenes de Nosotros. Sostenía: “(...) ese espíritu que es su lastre, (...) da el nervio, el colorido, el modo de ser propios del sentir de la raza". ${ }^{230}$ En la edición de agosto-septiembre, Giusti daba cuenta de Cartas de Europa, ${ }^{231}$ volumen que reunía los artículos que Rojas había enviado como colaborador a La Nación, desde los diversos destinos de su viaje. Entonces volvía a

\footnotetext{
${ }^{228}$ Año II, Tomo II, no 8, marzo de 1908, pp. 150-154. Rojas es presentado como autor de una "obra robusta y lozana, que no ha de morir porque la atan múltiples lazos al terruño de cuyos jugos se ha nutrido", 152.

${ }^{229}$ Nosotros, Año II, n 9, abril, 1908, pp. 223-224

${ }^{230}$ Cursivas nuestras. Nosotros, Año II, Tomo II, n 9 , abril, 1908, p. 224.

${ }^{231}$ Año II, agosto-septiembre, n 13-14, 1908, pp. 116-117.
} 
insistir en la conexión cultural con España, en este caso a partir de la afinidad de Rojas con el escritor Francisco Navarro Ledesma, del cual el santiagueño era admirador. El "espíritu de la raza" que la tradición intelectual española vehiculizaría, debería ser elemento constitutivo de una tradición argentina de sello propio y original, plasmada en un idioma de sabor castizo. ${ }^{232}$

Con motivo del regreso de Ricardo Rojas de Europa, Nosotros le ofreció un banquete de bienvenida. La crónica detallada de ese encuentro, que incluía los discursos de Atilio Chiáppori y del homenajeado, y una poesía de Charles de Soussens, fue publicada en el número doble de agosto-septiembre de 1908. Además, en 'Letras argentinas' de ese mismo número, Giusti se ocupaba, como se dijo, de Cartas de Europa. Esta misma entrega en la que la revista conmemoraba su primer aniversario, constituyó el momento en que una serie de elementos ya presentes, como lo eran la relación cultural con España previamente mencionada y los relativos a su nacionalismo, adquirieron una configuración discursiva explícita y un sesgo más programático.

Antes de la transcripción de las palabras de los oradores, la dirección escribió un breve texto en el que puntualizaba el sentido de esta "demostración", que dicho sea de paso, y como práctica recurrente, era una forma más en la que la legitimidad de la revista se ponía a prueba, como evaluación de su poder de convocatoria. Era por eso que cada vez que Nosotros informaba sobre alguna de estas manifestaciones públicas, consignaba no solo los nombres de los asistentes, sino también los de aquellos que firmaban las cartas de adhesión. Así, la importancia de ese encuentro, del cual los diarios se habían ocupado, se demostraba tanto por "el número como por la representación intelectual y social de los adherentes", en virtud de lo cual se demandaban como urgentes la valoración y reconocimiento del "esfuerzo de la ${ }^{232}$ Así lo explica: "A mi ver existe un cierto parentesco espiritual entre el malogrado escritor español, cuya fama ha de ir acreciéndose con el tiempo, y nuestro compatriota. Ambos son frutos jugosos del espíritu de la raza: eminentemente castizo el español, cual árbol robusto que arraigó profundamente en las entrañas de la tradición de su pueblo; castizo también el argentino, en quien empero en el viejo tronco de la tradición se han insertado los ramajes vírgenes y audaces de sus selvas de América" pp. 117-118. Nótese la recurrencia de la palabra "jugoso" cada vez que se habla del espíritu de la raza o del lenguaje que lo actualiza.

Al final de su crítica, Giusti afirma que los libros anteriores de Rojas le han provocado la misma "impresión" - la citada inmediatamente antes sobre Cartas de Europaque el libro último confirma. 
inteligencia productiva y la obra desinteresada del espíritu". Este reconocimiento que Nosotros reactualizaba y reclamaba en Buenos Aires, era el que Rojas había conseguido en su periplo europeo, en sus lecturas en el Ateneo de Madrid, en los artículos publicados en la prensa extranjera, en las universidades inglesas, o en la colonia de artistas sudamericanos del Barrio Latino. ${ }^{233}$ En una mirada que evaluaba el presente como el tiempo de la disgregación de una supuesta, pretérita y anhelada "unidad espiritual del pueblo argentino", ${ }^{234}$ Nosotros proclamaba el advenimiento necesario de una "era nacionalista", que combatiera las fuerzas "destructoras del cosmopolitismo". Esa unidad nacional solo podría lograrse en la labor colectiva -y no sectaria- de la generación joven, una faena que la revista nombraba bajo el concepto de "reintegración" del alma nacional. El homenaje a Rojas ofrecía una significación doble. Desde una perspectiva que atendiera a los modos de funcionamiento propios del mundo intelectual, este tributo podía considerarse como una forma de alcanzar notoriedad no ya por parte de un sujeto en particular, sino por todo un grupo cultural. Este reconocimiento implicaba, como lo había sido para los jóvenes de Ideas, una autoproclamación de artistas e intelectuales como agentes civilizadores y por lo tanto forjadores de una verdadera cultura nacional. ${ }^{235}$ En términos ideológicos, homenajear a Rojas presentándolo como delegado y motor de esa "reacción", suponía, además de asociarse con el discurso espiritualista y antimaterialista del desinterés, adherir a su objeción del cosmopolitismo, adscripción que la revista abandonaría con el correr del tiempo, al menos desde la pluma de la dirección. Sin embargo, a mediados de 1908 sostienen:

Hubiera debido temerse que esta palabra de 'nacionalismo', la cual por otra parte solo significa la convicción de que es necesario conservar la integridad moral de la patria, sorprendiese el sentimentalismo cosmopolizante que se enternece

\footnotetext{
${ }^{233}$ El país de la selva y Cosmópolis fueron publicados en París por Garnier, El alma española por la valenciana Sempere.

${ }^{234}$ Así lo señala Nosotros anotando su coincidencia con el discurso de Chiappori.

${ }^{235}$ La antinomia civilización barbarie está presente en el discurso de Rojas: “(...) puede decirse que en nuestro país la antigua lucha entre la civilización y la barbarie no ha terminado: ha cambiado simplemente de escenario y de forma: su teatro es la ciudad ya no es el campo, y los montoneros ya no emplean el caballo sino la electricidad: Facundo viaja en tranvía. (...)" p. 126
} 
en confraternidades internacionales y desdeña lo que constituye nuestro verdadero patrimonio. Pero esa palabra responde a ideas y sentimientos por suerte más difundidos de lo que se cree. Por eso este banquete ha sido significativo por más de un concepto. Ha sido una afirmación elocuente en favor del culto desinteresado del arte y de la patria. Ha sido al mismo tiempo una manifestación de simpatía sincera por la obra de una de las personalidades más representativas de nuestra juventud. [cursivas nuestras] $]^{236}$

Si como sostiene Perry Anderson, existe una correspondencia histórica entre las formas de nacionalismo dominantes en distintos períodos -desde el siglo XVIII en que surge la primera formulación de la idea nación- y las versiones del internacionalismo que les son contemporáneos, ${ }^{237}$ la cita además de indicar un costado chauvinista, señalaba una oposición al internacionalismo propia de las formulaciones de un tipo de nacionalismo, dominante desde 1860 y hasta la Primera Guerra Mundial. Comparada con los argumentos que posteriormente sostendría Giusti en la discusión con Rojas a propósito de La restauración nacionalista, la postura aquí construida presentaba ostensibles diferencias.

\footnotetext{
${ }^{236}$ Nosotros, Año II, Tomo III, agosto-septiembre, no 13-14, 1908, pp. 122-123.

${ }^{237}$ Perry Anderson sostiene que el patriotismo y el cosmopolitismo de sello ilustrado, primera formulación de la idea de nación como colectividad popular, surgido con las revoluciones norteamericana y francesa del siglo XVIII, y cuyo vocabulario filosófico provenía del racionalismo característico de la llustración, hacia 1830 ya no existía. Afirma que por ese tiempo se dio una nueva configuración, a la que denomina nacionalismo, cuyo lenguaje retórico provenía del romanticismo europeo, que no era cosmopolita, aunque valoraba la diversidad cultural. Desde fines de 1860 Anderson registra un cambio abrupto en la forma dominante del nacionalismo en Occidente. Entonces el chauvinismo fue la atmósfera y el discurso generalizado de los estados industriales más importantes de corte expansionista. Para el momento, la forma de internacionalismo era directamente opuesta al tipo predominante de nacionalismo señalado. El internacionalismo del período, que tiene su "sede simbólica" en la Segunda Internacional de los partidos socialistas, abarcaba a más países y por tanto a más trabajadores industriales reales. "El chovinismo que acompañaba y aseguraba este nuevo expansionismo tomaba por lo general, del darwinismo social. Su lenguaje intelectual era, en esencia, positivista y su definición de la nación cada vez más étnica: es decir, una mezcla de elementos culturales y físicos, de registro notablemente menos ideal que el de sus predecesores. Declarando que lo que regía las relaciones entre los pueblos era la 'ley del más fuerte', este tipo de nacionalismo de las grandes potencias -o de los países aspirantes a serlo-, del que no hubo pocos reflejos incluso fuera del centro del sistema, en el porfiriato en México o en el gobierno de Roca en Argentina, predicaba por primera vez la hostilidad directa hacia otras naciones o pueblos". (Anderson, Perry, 2002: 11)
} 
A su turno, el joven Rojas, definido por Chiáppori como un escritor, en quien se adivinaba al gran político, proclamaba la función de los intelectuales como un servicio de regeneración moral. ${ }^{238}$ Tramado en las categorías propias del espiritualismo antipositivista se organizaba así un contexto discursivo de crisis moral y en un marco de ataques al liberalismo, común en otros autores, ${ }^{239}$ y ante el cual las reacciones de esta generación de escritores se presentaban imprescindibles. De esta forma, frente a un pueblo que Rojas juzgaba "podrido de escepticismo", los triunfos del esfuerzo de quienes (como él mismo) se consagraban "al culto de la belleza y de la patria", constituirían una ocasión inmejorable para avivar el ideal heroico, base del sentimiento nacional. Idealismo, desinterés, antiutilitarismo, perfeccionamiento moral, eran conceptos en torno de los cuales se organizaba ideológicamente el programa de "sistemático nacionalismo" proclamado por Rojas, en el que la retórica de la guerra y de la religión no estuvieron ausentes. ${ }^{240}$ A su juicio, la moral utilitaria debía combatirse con un idealismo que tenía en la cultura un resorte fundamental para "restaurar" la "idea de continuidad en la obra de generaciones"; el ejercicio de aquel "sistemático nacionalismo", aparecería, desde su perspectiva, como forma de reponer la "cohesión espiritual con la raza". Autonomía e identificación colectiva con un territorio, por parte de un pueblo espiritualmente homogéneo, funcionaban como modo de equilibrar un progreso meramente material, y por lo tanto, necesariamente incompleto. La cultura, como se dijo, estaría destinada a cumplir un papel fundamental, pues el progreso material debía ser una resultante del desarrollo cultural. De este modo, y como lo

\footnotetext{
${ }^{238}$ En el sentido de esa función política del intelectual, Chiappori sostiene que: "En efecto; de los hombres de nuestra generación que se preocupan del porvenir espiritual de la raza, Ricardo Rojas es el mejor dotado para agitar ideas y congregar almas afines en un inminente movimiento de regeneración. A la solidez de su cultura, a su gesto categórico y su probidad antigua une la más ardiente fe en los destinos de la Patria, entusiasmo que le hace esperar, en oposición al pesimismo ambiente, un supremo resurgimiento del alma nacional." Nosotros, Año II, Tomo III, agosto-septiembre, $\mathrm{n}^{\circ}$ 13-14, 1908, pp. 123-124. Cursivas nuestras.

${ }^{239}$ Julio A. Rojas publica más tarde "Pellegrini", se refiere al momento también como crítico. Así afirma: "El país atraviesa por uno de los momentos más difíciles de su historia; no peligra por cuestiones internacionales ni por la violencia de sus luchas internas; peligra porque se ha disuelto el espíritu nacional, porque nadie apasiona a la opinión pública, porque comienza a perderse la fe en los partidos y a tenerse fe en círculos y antesalas", Nosotros, Año III, Tomo IV, nº 20-21, mayo-junio, 1909, pp. 233-236.

${ }^{240} \mathrm{El}$ siguiente pasaje es un ejemplo claro: "Proclamemos el desinterés de la sabiduría; mostremos a los hombres la belleza mística y militar que hay en ciertos renunciamientos. Tengamos todos algo de monjes en nuestra condición de soldados" p. 125
} 
propondría más tarde en La restauración nacionalista, aquella comunidad homogénea $^{241}$ encontraría uno de sus modos de realización en la enseñanza de la historia, a través de la cual, confiaba, podrían construirse "el sentimiento de solidaridad social y el de perpetuidad histórica". ${ }^{242}$

La realización de tan vasto plan, que será la condición de una democracia más sana, de una economía más estable, y de un arte duradero y original, no podrá realizarse sino con el concurso de todos los hombres de pensamiento, persuadidos de que si hace cincuenta años pudo ser el ideal de la nación que surgía una política de cosmopolitismo, ésta al realizarse ha comportado nuevos problemas que nos obligan a modificar la fórmula originaria y adoptar otra de sistemático nacionalismo. Entre un pueblo heterogéneo de diez millones de habitantes, y otro de cinco, pero dotado de cohesión espiritual e ideales nacionales, éste será el que venza en la guerra y el que prospere en la paz [cursivas nuestras] $]^{243}$

En el marco de una propuesta incluyente y democrática en la que, sin embargo, las elites seguían desempeñando una función preponderante respecto del futuro de la nación, se juzgaba necesario cambiar el contenido político e ideológico del Estado liberal ante los efectos problemáticos de una política inmigratoria pretérita. Así, correspondería a los intelectuales resolver la cuestión argentina, a través de una acción cultural homogeneizadora de signo nacional.

Como si la transcripción de las palabras de Rojas junto con las de la dirección hubiera sido insuficiente para exhibir el acuerdo con la prédica nacionalista de aquél, en la nota de 'Letras argentinas' de noviembre-diciembre de $1908,{ }^{244}$ dedicada a De cepa criolla, Giusti insistía: citaba el discurso de Rojas, que funcionaba como marco

\footnotetext{
${ }^{241}$ Cf. Anderson, 1994.

${ }^{242}$ Nosotros, Año II, Tomo III, agosto-septiembre, n 13-14, 1908, p. 126.

${ }^{243}$ Ibid., p. 127.

${ }^{244}$ En el $n^{\circ} 15$, la revista publica un artículo de Arturo de Carricarte, dedicado a ensalzar la tarea de Nosotros como difusora de cultura y promotora de un arte nacional: "Además de eso - gran factor de cultura- alientan y estimulan la labor nacional (...) exponiendo el error de tendencias malsanas, ora aplaudiendo aciertos y despertando la atención de reacia de nuestros públicos sobre la posibilidad de crear y mantener un arte propio, noble y grande en cada porción de nuestra América", Nosotros, Año II, Tomo III, n 15, octubre, 1908, p. 198.
} 
ideológico de su lectura sobre la obra de Leguizamón y se convertía en otra ocasión para señalar las obligaciones de los artistas, sobre todo de los literatos, como recreadores de lo nacional, en un movimiento que era así, contrario de la extranjerización. $^{245}$ En esta oportunidad, el término 'literatos' incluía a sujetos identificados en un espacio disciplinar. A diferencia de aquellos definidos en un uso anterior del vocablo, o comprendidos en una figura como la del "letrado tradicional" cuya relación con el poder era orgánica-, ${ }^{246}$ éstos podían ser considerados como miembros de un mundo cultural bastante más autorregulado. Esta situación no impedía que desde esa especificidad intervinieran activamente en cuestiones que involucraban problemas de orden estatal, como éste de la nacionalidad. De ese modo, para el director de la revista, los arqueólogos, historiadores, críticos, novelistas, estudiosos de la literatura, dramaturgos debían contribuir a recuperar ("revivir") el pasado, para volverlo presente en sus tradiciones, sus costumbres, sus tipos sociales (todos ellos vinculados con lo criollo rural), construir la historia nacional y dejar de lado, la perspectiva facciosa. Si como Giusti afirmaba, la sociabilidad argentina de 1908 no se identificaba con el campo sino con las ciudades, entonces éstas debían incluirse en la aún incompleta literatura nacional. Se trataba, además, a su juicio, de volver efectiva esa cultura, y particularmente la literatura, a través de la escuela como agente privilegiado. Había que reformar para ello los planes de enseñanza, en ese momento sellados por el enciclopedismo, y proponer una lista de autores y títulos, que Facundo, a su juicio, debía encabezar. ${ }^{247}$

${ }^{245}$ Giusti critica en términos morales la extranjerización de los intelectuales, y reivindica el carácter político de la cultura. Sostiene: "Extranjerizarnos hasta la saturación; irnos a París (París es Europa) apenas podamos; ubicarnos lo mejor posible en el presupuesto; reírnos de la política como de cosa que hay que tomar en broma para no hacerse mala sangre, es todo aquello de que somos capaces. Conservar una característica nacional mantener una tradición, cultivar una interesante peculiaridad de nuestras costumbres, ni por sueño! Todo eso el cosmopolitismo lo ha borrado" p. 308.

${ }^{246}$ Cf. Gramuglio, 2002c: 37-50.

247 Giusti interpela: "¿Cuándo haremos conocer de verdad la literatura argentina en los colegios nacionales, poniendo a los alumnos en contacto con las mejores páginas de nuestros prosistas y poetas, vivos o muertos, y no como ahora, haciéndoles aprender de memoria una lista de veinte o treinta nombres, como apéndice a un curso que se iniciara con el Ramayana y El libro de Job? ¿Cuándo será obligatoria la lectura de Facundo en las escuelas como lo es la de I promessi sposi en Italia?" Nosotros, Año II, Tomo III, n 16-17, noviembre-diciembre, 1908, p. 310. NOS: 45-46. 
Si como se pudo observar, hasta ese momento la revista había intervenido en la discusión sobre lo nacional en una adscripción a los postulados de la campaña de Ricardo Rojas que dejaba pocos resquicios para la crítica, la reseña de La restauración nacionalista a cargo de Giusti, de febrero de 1910 marcaba un punto de inflexión. Era el comienzo de un distanciamiento que implicaría la revisión de algunos aspectos de las propias posiciones previas, para llegar a una discrepancia irreconciliable en 1912 . En esa ocasión, Giusti afirmaría, más allá de la alta consideración en mantuviera a Rojas, que "no [le] es dado seguirlo en su personal prédica nacionalista". ${ }^{248}$ Se trataba de una polémica que, sin embargo, no atacaba el acuerdo básico de orden general en relación con la funcionalidad de los intelectuales. Desde la perspectiva de este acuerdo, y en el marco de una clara estrategia de construcción de la propia legitimidad, tanto para Rojas como para Giusti, los intelectuales se convertían en agentes privilegiados en la solución de la cuestión nacional, en tanto "proveedores discursivos espirituales de las políticas del Estado" (Dalmaroni, 2006). En tal sentido, es importante recordar que La restauración nacionalista era el producto de un encargo del Ministerio de Instrucción Pública para estudiar la enseñanza de la historia en Europa, y de esta forma, un caso representativo de una intervención intelectual directamente determinada por el tipo de relación entre establecida y buscada con el campo del poder. ${ }^{249}$

Como la crítica ha señalado, los reparos principales del director de Nosotros a la propuesta de La restauración nacionalista de Rojas se centraban por un lado, en los argumentos del autor, que contrarios al cosmopolitismo como "cualidad esencial del perfil argentino", proponían la idea de una síntesis o fusión en la que las diferencias inherentes a aquel, se disolvieran; por el otro, y por parte de Giusti, en una valoración de la tradición cultural, que privilegiando el futuro, no se circunscribiese al pasado local o hispanoamericano, y redunda en la "adopción de una tradición humanísticodemocrática universal" (Altamirano-Sarlo, 1983: 96). En lo relativo al cosmopolitismo, aquel acuerdo inicial con Rojas, que para el intelectual "gringo"

\footnotetext{
${ }^{248}$ Año VI, Tomo VII, $\mathrm{n}^{\circ}$ 36, enero, 1912, p. 71. [cursivas nuestras]

${ }^{249}$ Cf. Gramuglio, 2002c: 45; Gramuglio, 2001:9-55. En relación con la forma de sustento de los escritores, este viaje de Rojas combinaba el empleo estatal y la colaboración periodística en distintos medios. Como ya se mencionó, Cartas de Europa es la compilación de los artículos escritos para La Nación.
} 
también se ligaba más con un aspecto "sentimental" o "espiritual" que étnico, se desvanece ahora ante una propuesta que busca la "unidad" en la adquisición de un sentido histórico que, vinculado principalmente con el pasado, debe realizar la escuela a través de la enseñanza de la historia. Dicho sentido histórico debía construirse además y según Rojas, en el conocimiento de los nombres "tradicionales" de lugares, a través de los museos que albergan restos de ese tiempo pretérito, y por medio de una "pedagogía de las estatuas" de héroes nacionales, algo que también había señalado en la revista Julio A. Rojas en su discurso sobre Pellegrini. ${ }^{250}$ Como señalamos a propósito de la funcionalidad de la figura de Martiniano Leguizamón, y como lo ratificaba esta reseña del ensayo de Rojas, la historia más gloriosa de la Argentina se hallaba para Giusti, en los siglos venideros y por lo tanto, comparados con ella, los cien años de vida independiente de la Argentina (1810-1910) conformaban una porción mínima, "un punto".

Por otra parte, los motivos del cambio de opinión del director de Nosotros podían ligarse además, con el lugar de joven consagrado que ahora ocupaba Rojas, no solo entre sus pares generacionales. En el año del Centenario, el debate acerca de la nacionalidad estaba en su momento más efervescente, y por lo tanto, resultaba imprescindible esclarecer los alcances de un programa nacionalista compartido, en un comienzo, de modo general, dentro del cual se jugaba una estrategia de legitimación de los intelectuales jóvenes y de su labor cultural. Compartido de modo general en un comienzo, ese programa mostraba, sin embargo, en el presente, aristas problemáticas para los escritores hijos de inmigrantes, que también eran "gringos". Los términos que años más tarde utilizaría Giusti en Visto y vivido para marcar su origen italiano -“procedencia gringa”-, estaban presentes en esta polémica con Rojas:.251

\footnotetext{
${ }^{250}$ Julio A. Rojas afirmaba la función cohesiva de los monumentos: "Al pie de las estatuas, desde la más remota antigüedad, hubo siempre una conjunción de ideales colectivos: Grecia, dando forma plástica a las divinidades olímpicas, inmortalizaba en el pentélico famoso las fuerza directrices del organismo social y entregaba al culto severo de las generaciones futuras las cosas inmateriales de su tradición, como si quisiera refrenar el curso de las horas fugaces y darles perennidad terrena." Nosotros, Año III, Tomo IV, $\mathrm{n}^{\circ}$ 20-21, mayo-junio, 1909, p. 233.

${ }^{251}$ En Visto vivido Giusti explicaba: “(...) pero siempre tuve la impresión de que entre el apologista de la indianidad, de antigua estirpe hispanoamericana, y el argentino de la primera generación, de procedencia 'gringa', existía una desinteligencia espiritual de fondo. Esta desinteligencia temperamental quizá la ahondé yo, sin que se quebrara nuestra amistosa relación, cuando hice razonados reparos a su libro $L a$ argentinidad. Digno
} 
Imagínome que eso de las miserias espirituales solo puede referirse aquí a nuestra condición de pueblo cosmopolita. ¿Lo ocultaremos, pues, avergonzados? Los letreros políglotas son simplemente una resultante lógica de un hecho social. Y yo pregunto: ¿cómo se logrará que el alumno constate estas miserias espirituales en la misma escuela en que aprende el idioma del país, el castellano, en unión del gringuito que dice aún voy del médico, o el hijo de franceses que arrastra lamentablemente las erres ${ }^{252}$

Hacia el final de la nota, y retomando la idea de inconclusión que ya señalamos en relación con la nacionalidad y con la historia, Giusti asignaba a "la enorme masa de extranjeros" la función de plasmar la nueva nacionalidad. ${ }^{253}$ Impugnando el concepto mismo de restauración nacional, proponía la edificación de la nacionalidad con la mirada hacia el futuro y con el acogimiento de todos los elementos que la conformaban, habitantes del mismo territorio, en el ejercicio de una política de conciliación, que culturalmente se organizara en base a la civilización latina y tuviera como ejemplos a "España, la madre; Italia la nodriza, la más conservadora del espíritu clásico; y Francia, la maestra eterna de la libertad". ${ }^{254}$ Mientras que en agosto de 1908, la palabra nacionalismo remitía, para Giusti, al privilegio exclusivo de lo propio por sobre lo foráneo, distante de las "confraternidades internacionales" y contrario al cosmopolitismo en tanto exhibición de la diferencia, a fines de 1909 y principios de $1910,{ }^{255}$ el término debía garantizar una faz más incorporadora.

heredero de su estirpe y de su tierra santiagueña, pisada antes de la conquista por la civilización incaica, Rojas, animado por una especie de fatalismo radical y telúrico, veía la historia de su patria desarrollarse teleológicamente hacia fines como señalados providencialmente por el dedo de Dios. La Idea hegeliana, en este caso "la argentinidad, la conciencia y la idea de un pueblo nuevo", se realizaba en nuestra historia, era su Deus exmachina. De tal idea él era el profeta, el augur, el vate. Todas las cosas parecían hacerle signos misteriosos" (Giusti, 1965:166).

${ }^{252}$ Nosotros, Año IV, n 26, febrero, 1910, p. 147.

${ }^{253}$ lbid., p. 151.

${ }^{254}$ Ibid., p. 154.

${ }^{255}$ El ensayo de Rojas es de 1909. Es reseñado unos meses más tarde por la vigencia del estado de sitio. Esta situación es consignada por Giusti en números anteriores ( $n^{\circ} 22-23$, julio-agosto, 1909; $n^{\circ} 24$, noviembre, 1909; $n^{\circ} 25$, enero, 1910). 
Por último, el crítico abordaba más abiertamente la cuestión social, en la que los extranjeros en tanto trabajadores urbanos y militantes anarquistas estaban implicados. En ese sentido, y en una actitud claramente progresista y opositora, criticaba con severidad la solución represiva que la cuestión social había venido recibiendo desde el Estado y la mirada xenófoba que a comienzos del siglo XX, identificaba a obreros extranjeros con "elementos de corrupción y desorden", ${ }^{256}$ y más ampliamente, como cuestionadores de los fundamentos del orden político, económico y social de la Argentina (Zimmermann, 1994: 11-20) ${ }^{257}$ En términos discursivos, la oposición entre criollos y gringos organizaba la argumentación de Giusti y ponía en evidencia -las cursivas de la palabra gringo eran signo de ello- aquella valoración negativa del nuevo sujeto social y la dificultad de imaginarlo como connacional. Desde una posición que lo acercaba en términos generales al reformismo, Giusti abogaba por la sanción de leyes de selección de inmigrantes. Estas leyes, a diferencia de algunos proyectos presentados en la Cámara de Diputados, no debían promover, según sostenía, el exterminio de los "partidos extremos", socialista y anarquista. ${ }^{258}$

\footnotetext{
${ }^{256}$ Nosotros, Año IV, tomo V, n 26, febrero, 1910 p. 153.

${ }^{257}$ Recordemos además que en noviembre de 1909 el anarquista ruso Simón Radowitzky había asesinado al jefe de la Policía Ramón L. Falcón y a su secretario, como respuesta a la represión en los festejos del Día del Trabajo de ese año, de la que las organizaciones obreras consideraban a Falcón responsable. (Zimmermann, 1994:150-172) Nosotros en el $\mathrm{n}^{\circ} 24$ consignó este asesinato junto con el de Francisco Ferrer, educador y militante anarquista, en Barcelona. La revista hizo saber a sus lectores que la nota sobre el tema no se publicaba en dicho número por la vigencia del estado de sitio. Como artículo no se publicó después, pero Giusti, a título personal, opinó sobre la cuestión en la reseña de La restauración nacionalista.

${ }^{258}$ Giusti explicaba -sin promoverlo- el uso de la violencia por los militantes anarquistas: "Incomodan a los criollos de pura cepa las nuevas ideas, incomoda la preponderancia del elemento obrero, extranjero o de estirpe extranjera, pero ya argentino de alma, toma en la vida pública. Me atrevería a sostener que la muerte del coronel Falcón ha sido un resultado lógico de este mal. Siempre ha sido de muy malos ojos toda manifestación obrera, que significa extranjera [en cursiva en el original], y los luctuosos sucesos del primero de Mayo del año último no fueron otra cosa que una paliza dada a esos gringos...Los gringos se han vengado por medio del brazo de un 'loco rojo'. Lamentable muerte desde el punto de vista sentimental; explicabilísima desde el punto de vista sociológico. Explicabilísima y útil, porque es de esperar que haya abierto los ojos y enseñado dos cosas: la primera de ellas que ya ha terminado la era en que contra el gringo se enviaba en son de guerra a su irreconciliable enemigo, ese tape a caballo que se llama guardia de seguridad; la segunda, que se imponen leyes de selección de los inmigrantes y en eso también estamos de acuerdo-, porque explicar un delito no significa desear su multiplicación. (...) Es doloroso, pero la violencia no engendra más que violencia. $Y$ ésta, a veces es buena. El crimen de Bresci regeneró a Italia". Nosotros, Año IV, tomo V, n² 26, febrero, 1910, pp. 153-154.
} 
En 1911, luego de un año de ausencia y ya reintegrada a la vida literaria, Nosotros publicaba dos notas sobre Los lises del blasón, cuyo rasgo común consistía en reconocer en el autor a un intelectual de talento probado, y a la vez, marcar sin ambages el desacuerdo ideológico con Rojas a partir de la impugnación estética, o señalando la distancia en ambas dimensiones. Aparecidas en el n $n^{\circ} 30$, las notas estaban firmadas por Alberto Gerchunoff y Alfonso de Laferrere, respectivamente. El escrito de Gerchunoff, en 'Letras argentinas', que llevaba un epígrafe de Cosmópolis de Rojas, ${ }^{259}$ explicitaba una institucionalización de la literatura que sería contrastada una y otra vez con las composiciones de Los lises del blasón. Si la continuidad reconocible de una a otra obra del autor de Cosmópolis había sido un aspecto relevante y altamente estimado por Giusti -en contraste con Lugones-, parecía serlo también para Gerchunoff. Según éste, las poesías de Los lises... "no guardan relación con los propósitos" que Rojas venía enunciando, es decir, con su prédica idealista. Esa discontinuidad, que se presentaba como la falta de fidelidad a un programa, en el que la literatura cumplía una función, era apreciada, también, como una realización estética fallida. Y lo era, a juicio de Gerchunoff, en dos aspectos, que en realidad, se presentaban de manera conjunta. Primero, porque si los escritores, y tal como Rojas y Gerchunoff consideraban apropiado, aspiraban a legitimar su práctica en virtud de una acción de elevado carácter moral (la "civilización de la república”), tal propósito no podía sustentarse en un puro juego verbal. De ese modo, y en segundo término, Rojas fracasaba porque era imposible reconocer en sus poemas vínculos fuertes con la tradición y con el territorio. Ese "volumen de versos inusitados" ofrecía, a juicio de Gerchunoff, poemas inaccesibles a la "multitud", carentes de "tendencia espiritual", inútiles a los efectos de condensar y plasmar los paisajes nativos, y por lo tanto, ineficaces para plasmar lo nacional en imágenes que apelaran a la emoción, no al intelecto. Casi como un detalle, y en medio de un elogio -tal como lo había hecho Giusti-, la nota señalaba su desacuerdo con el núcleo ideológico de La restauración nacionalista y confirmaba el alejamiento progresivo entre Nosotros y Rojas. Por otro lado, como actualización del anhelo de reconocimiento por parte de los escritores e ${ }^{259}$ La frase que funcionaba como epígrafe era “...la literatura es cosa abominable. El arte que se universaliza es el que vive por el aliento de la tradición y por la emoción del paisaje nativo, como los poemas homéricos ó el romancero del Cid."(Ricardo Rojas, Cosmópolis, p. X.). Nosotros, Año IV, Tomo VI, nº 30, julio, 1911, p. 15. 
intelectuales jóvenes, este escrito de Gerchunoff era significativo, porque indicaba claramente una estrategia colectiva. De tal modo, si la literatura pretendía autorizarse autoasignándose una función política que Gerchunoff definía como una "particip[ación] en la civilización de la república", entonces, nada más apropiado y conveniente que una concepción como la del Rojas, que en ocasiones y obras anteriores a ésta, había dicho, por ejemplo, que "un cuento de Leguizamón vale para nosotros más que una tragedia helénica". ${ }^{260}$ Este poder de la ficción para forjar mitos identitarios que conectaran el presente con el pasado se actualizaría en el libro posterior de Rojas, Blasón de plata. Meditaciones sobre el abolengo de los argentinos, del que Nosotros también daría cuenta.

Para Alfonso de Laferrere, y casi como una reiteración de las opiniones de Gerchunoff, Los lises del blasón representaba una "mancha" en la carrera literaria de su autor, una obra "puramente intelectual", "puramente artística", en la que ni la emoción ni la poesía estaban presentes. Ambos críticos censuraban el carácter superfluo de la poesía del libro y la calificaban de "extraño aljamiado" (Gerchunoff) o de "esfuerzos ineficaces por lo artificiales"(de Laferrere). Pero la nota sobre Blasón de Plata de Álvaro Melián Lafinur, del no 42 de julio de 1912, se presentaba además como una impugnación más fuerte de la figura de Rojas. Sin dejar de reconocer sus méritos observaba:

Una confianza ilimitada en sí mismo, lleva al señor Rojas a exagerar la seguridad en su palabra y en su gesto que resultan a veces demasiado categóricos. Su manera de afirmar es una característica defectuosa en un talento que precisamente por su educación, debiera reconocer que hay cosas que no pueden ser objeto de aserciones rotundas, y que es conveniente dudar un poco a veces de nuestras representaciones. Mi verdad es la verdad, parece ser el postulado que fluye de la obra y la persona de Rojas. Suele asumir en sus libros posturas vatídicas y ademanes de hierofante y todo ello es producto de su

\footnotetext{
${ }^{260}$ Gerchunoff explica: "Aconseja [Rojas] amar los paisajes nativos, saturarse con el humus de la tierra materna. Es sin duda el credo artístico que nos conviene y es el que debemos pregonar si aspiramos a que la literatura participe de la civilización de la república". Nosotros, Año IV, Tomo VI, nº 30, julio, 1911, p. 15.
} 
individualidad apasionada, impetuosa y llena de fe en sus creencias y en su esfuerzo. ${ }^{261}$

El hecho de que se censurara el libro de un intelectual como Rojas indicaba que, a diferencia de lo que sucedía en el comienzo, las opiniones adquirían un carácter menos contemporizador, más definido, y las polémicas se mostraban más directas. ${ }^{262}$ A la vez, sin embargo, no era menos cierto que el autor de Blasón de plata, un intelectual cuya legitimidad estaba en ascenso, continuaba siendo elegido por Nosotros para debatir el tema de la identidad cultural, y por eso en 1912 decidían ocuparse de la reedición de un libro que ya había sido publicado en $1910{ }^{263}$ En ese sentido, Melián discutía, por ejemplo, el concepto de "indianismo" en continuidad con las críticas de Giusti sobre La restauración, para afirmar el carácter limitado de ese concepto a la hora de pensar y probar "la perpetuación indígena en los argentinos contemporáneos". ${ }^{264}$

El $\mathrm{n}^{\mathrm{o}} 44$ de Nosotros apareció en diciembre de $1912^{265}$ y en 'Notas y comentarios" se anunciaba la creación de la cátedra de literatura argentina en la Facultad de Filosofía y Letras, de la que se haría cargo Rojas, luego de "haber rendido las pruebas de práctica". Meses después, en la entrega de junio de 1913, además de publicar la conferencia inaugural de la cátedra, Nosotros transcribió el discurso de Rafael Obligado en el que Rojas era presentado como el sujeto conveniente para desempeñar ese cargo, en virtud de una trayectoria intelectual marcada por el ejercicio programático de su nacionalismo, del que obras como La restauración nacionalista o Blasón de Plata daban cuenta. En ese sentido, y a pesar de las diferencias ideológicas con el programa nacionalista de Rojas, Nosotros celebraba la institucionalización de la

${ }^{261}$ Nosotros, Año VI, Tomo VIII, n 42, julio, 1912, p. 229.

${ }^{262}$ Sobre la disputa de Enrique Larreta con quien escribiera un libro en contra de La gloria de don Ramiro. Nosotros critica que Larreta, utilizando su condición de diplomático haya movilizado a la policía francesa para encontrar al autor de El caso de la gloria de don Ramiro.

${ }^{263}$ La primera edición de Blasón de plata salió en 1910 en La Biblioteca de La Nación; la segunda apareció bajo el sello Martín García, en 1912. La nota de Lafinur se ocupa de esta última.

${ }^{264}$ Nosotros, Año VI, $\mathrm{n}^{\circ} 42$, Tomo VIII, julio, 1912, p. 233. No obstante sus objeciones, el crítico "la original visión global o sincrética del autor", "su interpretación mística de los acontecimientos y de las leyendas que los deforman o magnifican". (230-231). Cursivas de Melián Lafinur. Para la transcripción más extensa, Cf. NOS: 116-117.

${ }^{265}$ El n ${ }^{\circ} 42$ salió en julio de 1912, el 43 y el 44, en noviembre y diciembre de ese mismo año, respectivamente. 
literatura argentina, cuya existencia efectiva podría probarse a través del armado de una historia literaria como la que Rojas describía en la apertura de la cátedra. ${ }^{266}$

Como ya observamos, la figura de Rojas fue central en este período de Nosotros para organizar la intervención de la revista en el debate sobre la cuestión de la identidad nacional. El repaso de los escritos principales que, entre 1908 y 1913, se ocuparon de Rojas y de su obra describe un movimiento de ascenso y progresiva legitimación de este intelectual con cuya prédica nacionalista-espiritualista Nosotros acordaba. Este acuerdo, en principio casi acrítico y marcado por el tono laudatorio, empezó a resquebrajarse a partir del momento en que la revista reivindicó la aceptación y asunción de las diferencias propias del cosmopolitismo como bases de una integración todavía no realizada. El punto más álgido de esta disputa ideológica se dio, en 1910, con la reseña de Giusti sobre La restauración nacionalista, y marcó un viraje no registrado exclusivamente en las notas de Giusti o en aquellas firmadas por la dirección. Sin embargo, esa distancia ideológica, no impidió que Nosotros celebrara la inauguración de la primera cátedra de literatura argentina, con la publicación de la conferencia inaugural. Ese hecho mostraba la vigencia del pacto de sociabilidad que organizaba la revista e indicaba que, bajo el signo de la imparcialidad y de lo que Giusti denominó libertad polémica (Giusti, 1971: XIII), Nosotros entraba en el punto más alto de su visibilidad en el mundo cultural y literario con la publicación de su segunda encuesta. Los resultados de esta interpelación, que se preguntaba sobre el valor de Martín Fierro de Hernández, se publicaron en el mismo número que la conferencia de Rojas, con la que directamente se relacionaba, sometiendo a discusión algunas de sus afirmaciones.

\subsection{EI valor de una encuesta}

En 1913 Nosotros publicó los resultados de su segunda encuesta. ${ }^{267}$ La misma llevaba por título la pregunta “¿Cuál es el valor de Martín Fierro?” y el texto que

\footnotetext{
${ }^{266}$ Para un análisis de estas cuestiones, Cf. Altamirano, 1983: 107-115.

${ }^{267}$ Entre 1907 y 1913 la revista realizó dos encuestas. La primera, publicada en el no 43 de 1912, había sido sugerida por Carlos Octavio Bunge, se preguntaba “¿Es más culta la mujer que le hombre en nuestra sociedad?"; la segunda es la analizamos en este apartado. Los resultados salieron en los números $50,51,52,54$.
} 
había circulado entre un conjunto de intelectuales que la dirección calificaba de "distinguido núcleo de hombres de letras" -indicando, por tanto, su elevado poder de convocatoria en el medio cultural porteño-, establecía las condiciones y motivaciones que habían decidido a Nosotros a repartir la circular. La consulta se originaba ${ }^{268}$ en las lecturas de Leopoldo Lugones en el teatro Odeón, a propósito de Martín Fierro de José Hernández; la segunda de estas lecturas, "A campo y cielo"269 había sido publicada por Nosotros en el $n^{\circ} 49$, inmediatamente anterior al de la publicación de las primeras contestaciones de la compulsa; al mismo tiempo, el texto de la presentación señalaba como otro acicate para realizar la consulta, la conferencia de Rojas, "La literatura argentina", que como se observó, aparecía en el n ${ }^{0} 50$ de Nosotros, junto con los primeros resultados de la encuesta. En ese sentido, la revista ampliaba el debate o, más precisamente, ponía en cuestión las afirmaciones de ambos escritores que consideraban al poema de Hernández como el poema nacional argentino (Lugones) o lo definían como "nuestra Chanson de Roland" (Rojas). Así lo planteaba Nosotros:

El problema literario que plantean estas rotundas afirmaciones es de una importancia que nadie puede desconocer. ¿Poseemos en efecto un poema nacional, en cuyas estrofas resuena la voz de la raza? El acercamiento establecido por los críticos entre los varios poemas gauchescos, recogido oficialmente en los programas de literatura de los estudios secundarios, ¿importa acaso un enorme error de apreciación sobre el diverso valor estético de aquellos poemas? ¿Es el poema de Hernández una obra genial, de las que desafían los siglos, o

\footnotetext{
${ }^{268}$ Con anterioridad, la revista publicó la respuesta de Enrique Banchs a una encuesta realizada por Juan Más y Pí, que había aparecido en el diario La Razón de Montevideo. El texto de la encuesta era el siguiente:

"¿Cree usted en la existencia de una literatura verdaderamente nacional?

¿Qué tendencia guía a la generación actual y qué perspectivas ve usted a su actividad artística"

¿Cuál es su opinión sobre la novela y el teatro en el Río de La Plata?

¿Qué concepto le merecen los esfuerzos realizados hasta hoy?". Nosotros, Año VI, tomo IX, $\mathrm{n}^{\circ}$ 44, diciembre, 1912, pp. 217-222. Puede pensarse que también encontró su motivación en esta encuesta, realizada por un colaborador suyo, aunque los propósitos de ambas fueran diferentes.

${ }^{269}$ Se trataba del capítulo III de El payador, capítulo que en 1913 fue la segunda de las conferencias leídas por Lugones en el Odeón, tal como se consignaba en 'Notas y comentarios' de ese número de la revista (225-236); el texto presenta diferencias léxicas con la edición en libro.
} 
estamos por ventura creando una bella ficción, para satisfacción de nuestro patriotismo ${ }^{270}$

Entre quienes respondieron se contaron Martiniano Leguizamón, Carlos Octavio Bunge, bajo el seudónimo de Maestro Palmeta, Calixto Oyuela -que no dio su nombre y cuya opinión la revista refirió como procedente de un "ilustre escritor"- Enrique de Vedia, Rodolfo Rivarola, Manuel Gálvez -quien desde 1912 y por ese tiempo publicaba en Nosotros anticipos de El solar de la raza-, ${ }^{271}$ Manuel Ugarte, Carlos Baires, Alejandro Korn, Hugo de Achával, Edmundo Montagne, Emilio Lascano Tegui, Antonio de Tomaso, Emilio Alonso Criado. Como ha señalado Carlos Altamirano, la encuesta anudaba varias significaciones y tanto su contenido como las respuestas evidenciaron una problemática intelectual que excedía las fronteras del campo literario y cuyo "centro de gravedad estaba" fuera de él. En ese sentido, Altamirano señala el proceso de fundación de la literatura argentina a través del trazado de las líneas de una tradición literaria nacional como parte de esa problemática, basada en una concepción de la historia literaria y de la épica propias del historicismo romántico, que aunque impregnada de un repertorio de motivos provenientes del positivismo, conservaba, según el crítico algunas de sus premisas. Las palabras del crítico catalán y colaborador asiduo de la revista, Juan Más y Pí, colocaron en primer plano el problema de la fundación de una literatura propia, y de tal forma advertían que "levantar el poema de Hernández al rango de poema nacional equivale a querer fundar una literatura que se diversifique de la española, tan digna de respeto". ${ }^{272}$ Así, la pregunta por la pertenencia de la obra de Hernández a la épica, organizaba la encuesta, y se vinculaba directamente con el problema de la identidad

\footnotetext{
${ }^{270}$ Nosotros, Año VII, Tomo X, nº 50, junio, 1913, p. 425

${ }^{271}$ Gálvez colaboraba en Nosotros en la sección 'Pintura y escultura' desde 1912; escribió también artículos sobre el Salón Nacional de 1913 y ese mismo año, otros titulados 'Arte argentino'. En el $n^{\circ} 56$, Nosotros realizó una demostración en su honor, con motivo de la aparición en libro de El solar de la raza, que fue criticado en dos ocasiones, una por Julio Noé, otra por Melián Lafinur.

${ }^{272}$ Más y Pí, se oponía a las consideraciones de Rojas y Lugones porque negaban a España un lugar en la tradición que proponían. Así Observaba: "Llevar ciertas tendencias sociológicas al campo de la literatura es peligroso e impropio de la sana ecuanimidad espiritual. El nacionalismo predicado por Rojas ofrece sus defectos y la tendencia archicriolla de Lugones no es aceptable en su totalidad, pues continúa el error histórico que da como base de todo el vivir argentino la fecha de 1810, dejando de lado una sociedad fuerte y constituida, como lo demuestra su mismo triunfo en esa fecha, sin arraigo ni base en la historia". Nosotros, Año VII, tomo X, nº 50, junio, 1913, p. 432.
} 
nacional, en tanto para el historicismo romántico la épica revelaba la esencia histórica de una comunidad (Altamirano, 1983: 110-111). De este modo, y como era obvio, ésta era otra de las intervenciones en que la revista participaba en los debates intelectuales del momento a través de la discusión en torno de una temática que, aunque aglutinante, distaba de ser novedosa. Como lo señaló la propia revista, indicando que le había correspondido a Lugones "con todo el prestigio de su talento" el afirmar lo que muchos otros pensaban y no habían puesto por escrito, podía decirse que se trataba de una encuesta ya hecha (lo mismo señalaría posteriormente, en su contestación, Emilio Alonso Criado). De tal manera, por parte de Nosotros, la encuesta tenía un valor performativo que se medía también en el éxito de su convocatoria en el seno de la intelectualidad culta y universitaria de Buenos Aires, y a partir de ella la revista se revestía de un autoridad mayor.

La temática tenía una historia que podía corroborarse en una nutrida bibliografía que desde fines de siglo XIX la había tomado como objeto. En el principio de esa lista, consignada por Alonso Criado en su respuesta, se mezclaban los nombres de estudiosos españoles (Marcelino Méndez y Pelayo, Blanco García, Miguel de Unamuno, Ciro Bayo) con los de los argentinos que, hacia el presente de 1913 ejercían un dominio casi exclusivo de la temática, multiplicado en distintos artículos. De 1913 eran las conferencias de Lugones y Rojas, a las que debía sumarse la disertación "El derecho en la literatura gauchesca" de Carlos O. Bunge, y la conferencia de Juan Agustín García, en respuesta a Bunge. ${ }^{273}$ De ese modo, y considerando que el foco del debate se hallaba no en una cuestión de la historia literaria sino en la significación conflictiva que desde hacía tiempo y principalmente a partir fines de siglo XIX había adquirido la presencia de una gran masa de inmigrantes, la revista había convocado, a

273 Entre los españoles, Antología de Poetas Hispano-Americanos (1895) de Marcelino Menéndez y Pelayo; La literatura española en el siglo XIX de Blanco García (1896); "La literatura gauchesca" (1899) de Unamuno; "El romancerillo en el Plata" (1913) de Ciro Bayo. De los trabajos producidos en Argentina, Criado consignaba: "Apreciaciones sobre Martín Fierro" (1873) de Luis María Torres, las cartas a José Hernández escritas por Mariano Pelliza (1873) y Adolfo Saldías (1878), "El gaucho Martín Fierro" (1878) de Miguel Navarro Viola, "El gaucho Martín Fierro" de Santiago de Estrada (1879, en la revista La América del Sud), "Juicio sobre Martín Fierro de Hernández" (1881) de Andrés González del Solar, "La literatura argentina" de Juan A. Argerich (1890), "La poesía gauchesca" (1899) de Mario Sáenz, "El criollismo en la literatura argentina" (1902) de Ernesto Quesada, De cepa criolla (1909) y Páginas argentinas (1911) de Martiniano Leguizamón, Historia de la literatura argentina (1910) de Enrique García Velloso. 
intelectuales ("hombres de letras") en general, no solo a escritores. En efecto, también participaron sociólogos, militantes socialistas, profesores de derecho, quienes imprimieron a sus intervenciones un carácter decididamente sociológico, en sintonía con el tono intelectual general del momento. En virtud de la adhesión o el rechazo de ese grupo a las tesis de Lugones o Rojas, era posible distinguir una disputa entre positivismo cientificista y antipositivismo espiritualista. El primero se manifestaba en los términos del análisis sociológico; enrolados en el segundo, los escritores promovían la invención de un pasado prestigioso, cuyos modelos se encontraban en la literaturas nacionales europeas. Ambas posiciones se presentaban como perspectivas para pensar la edificación de la nacionalidad, que la encuesta, tributaria de las conferencias ya citadas, hacía girar conflictivamente alrededor del término raza.

Así, del lado de los escritores, Leguizamón, que reivindicaba para sí un sitio destacado en el interés por las cuestiones nacionales, afirmaba que, en efecto Martín Fierro era "nuestro poema nacional (...) porque en sus toscos octosílabos (...) se condensan las más nobles aspiraciones, los ideales más hondos y generosos”; Manuel Gálvez anotaba que el libro sintetizaba "el espíritu de la raza americana, en lo que ésta tiene de hondo y permanente", considerándolo además, como "el momento más elevado de las letras castellanas" en el que era posible encontrar imágenes dignas de Esquilo o sentencias que podía firmar Epicteto. ${ }^{274}$ Manuel Ugarte coincidía con Rojas, y además, consideraba la obra como "la primera semilla de arte que echó raíces" y aunque rudimentario, era el precursor y "padre indiscutible de la naciente literatura" que no podía ser sino nacional. ${ }^{275}$ En su brevísima respuesta, Enrique de Vedia, negaba al Martín Fierro su función de piedra angular de la literatura argentina y sostenía que era la "crónica rimada (...) de una época de la evolución sociológica de nuestro país argentina". ${ }^{276}$ Por su parte, Rodolfo Rivarola argumentaba que no era posible considerar la obra de Hernández como poema de la raza, en tanto la raza criolla en la que se había originado y sobre la que trataba había sido sustituida por otra; esta última no podía ver en el Martín Fierro la condensación de una esencia que la representara. Los argumentos de Rivarola se colocaban del lado contrario a las $\overline{274}$ En realidad, y como anotaba el propio Gálvez, esas frases pertenecían a El diario de Gabriel Quiroga, de 1910.

${ }^{275}$ Nosotros, Año VII, tomo XI, n 51 , julio, 1913, pp. 81-82.

${ }^{276}$ Nosotros, Año VII, tomo X, nº 50, junio, 1913, p. 428. 
ficciones de la nacionalidad de los escritores y se fundaban en los criterios cuantitativos de las estadísticas poblacionales. Así, el Censo de 1895 era prueba contundente de esa sustitución de la sociabilidad argentina, y por lo tanto del carácter arbitrario de la operación imaginaria de Rojas y Lugones. ${ }^{277}$ Hugo de Achával -que decía no haber leído el poema de Hernández y afirmaba que se podía discutir el clasicismo de ciertas obras sin haberlas leído-, suscribía la idea de Rivarola de la sustitución -no evolución- de la raza criolla y limitaba las lecturas de Lugones a un elemento de la personalidad literaria: "En cuanto a que Lugones, después de explicar los mitos griegos haya querido forjarnos el mito estético de Martín Fierro, no es cosa que deba desconcertarnos a sus admiradores. Todos sabemos que tiene un talento tan grande que es capaz de hacerlo todo". ${ }^{278}$ Asimismo, de Achával criticó la posición exagerada de Gálvez -a quien aludía y no nombraba-, aprovechando la ocasión para volver presente de manera indirecta, lo que la encuesta ponía en discusión en cuanto al componente inmigratorio. Lo hizo desestimando la opinión del autor de El diario de Gabriel Quiroga con respecto al lugar que éste otorgaba Hernández en la literatura castellana, pero fundamentalmente citando una frase de Gálvez de La Revista de América de París, en la que el escritor declaraba el carácter pernicioso de la influencia de la literatura italiana en la argentina. Achával explicaba que había conocido el artículo de Gálvez por intermedio de "Ingegnieros"; éste se había referido al caso como una "curiosidad". Esta calificación y los términos de "cursi pretexto de nacionalismo e ideas afines", con que de Achával definía las motivaciones de las palabras de Gálvez, mostraban que ése era el centro de gravedad la encuesta. ${ }^{279}$ Otros interpelados, como Carlos Baires y Antonio de Tomaso, también indicaron la representación parcial de la sociabilidad argentina por parte de Martín Fierro y remarcaron la idea de la discontinuidad de la raza, cuyo tipo definitivo se elaboraría lentamente; otros, como Lascano Tegui, designaron la operación de Rojas, al que consideraba "aquejado de nacionalismo", como propia de una concepción que se

\footnotetext{
${ }^{277}$ Ibid., pp. 428-429.

${ }^{278}$ Nosotros, Año VII, tomo XI, n 51, julio, 1913, p. 83.

${ }^{279}$ Nosotros, Año VII, tomo XI, nº 51, julio, 1913, p. 84.
} 
empeñaba en buscar la construcción de continuidades imaginarias con el pasado cultural. $^{280}$

Por último, si hasta ese momento las respuestas habían señalado en términos más o menos implícitos el contexto de enunciación de la convocatoria, las "Consideraciones generales" de Emilio Alonso Criado en el n 54, las exponían abiertamente, más allá de las evaluaciones que implicaban, señalando la necesidad de un nacionalismo incluyente como respuesta a la crisis moral:

La falta de luchas con elementos extranjeros durante medio siglo y la llegada al país, en ese mismo período, de "Cuatro millones y medio" de inmigrantes, produjeron en la masa de su población (escasamente el doble de aquella cifra) una verdadera apatía por todo lo que, entro de la nacionalidad argentina, era o significaba "Patria".

A cambio de las violencias de una guerra, productora siempre de esos sagrados espasmos de energías nacionales, y siendo necesario contrarrestar la deflojisticación realizada en el espíritu público por las oleadas inmigratorias, los estadistas, dándose cuneta de las graves consecuencias que podría producir la acentuación de este fenómeno, que con justicia llegó a llamarse "El problema nacional" por excelencia, decidieron nacionalizar razonadamente al pueblo. ${ }^{281}$ [cursivas nuestras]

La encuesta significó un modo de intervención intelectual en relación con el que, como en tantos otros, Nosotros fue pionera. Al mismo tiempo, y desde una perspectiva que atiende a los modos propios de la legitimación en el mundo literario y en particular, del sujeto social cuyo ingreso en la vida cultural estaba directamente vinculado con la aparición de la revista, esta consulta constituyó una participación que, desde lo específico se abrió al debate de una cuestión que podía denominarse estatal. En ese sentido, la encuesta se repartió entre distintas personalidades de la comunidad

${ }^{280}$ Lascano Tegui diferenciaba Martín Fierro de la epopeya francesa y polemizaba con Rojas: "La Chanson de Roland y la Gesta del Mío Cid, son los umbrales de hermosa piedra bruta puestos a la entrada de dos literaturas. Las producciones literarias que le siguen en el orden del tiempo, señalan la perfecta evolución del arte y de las épocas (...) Martín Fierro, en cambio, es un jalón aislado en medio de la pampa." Nosotros, Año VII, tomo XI, $n^{\circ} 51$, julio, 1913, p. 85.

${ }^{281}$ Nosotros, Año VII, tomo XII, n 54, octubre, 1913, pp. 60-61. 
intelectual y política, y teniendo en cuenta las contestaciones, pudo pensarse, en un punto como un triunfo parcial de la posición de la revista con respecto a las formas de cohesionar imaginariamente la nación. De tal modo, muchas de las respuestas pusieron en evidencia, recurriendo a una perspectiva marcada por la sociología positivista, que la 'raza' no era, en la Argentina, un elemento ya cristalizado sino que se asistía al proceso de su conformación. Por lo tanto, algunos afirmaban que los monumentos intelectuales que la condensaran también presentaban un carácter inconcluso que no podía ser llenado, según las opiniones más adversas, con la “intención de los profesores de nacionalismo". ${ }^{282}$ Sus resultados sirvieron para confirmar la relevancia alcanzada por Nosotros luego de siete años de existencia. Una importancia que los nombres de los encuestados no hacían más que confirmar.

La aparición de la revista Nosotros significó el ingreso a la cultura de un lote de escritores jóvenes fuertemente ligados con la institución universitaria en la que encontraron gran parte de sus lectores. No obstante, la revista no fue académica e intentó conquistar un público amplio en los sectores medios en ascenso, de los que provenían sus directores. Desde una mirada que enfoca especialmente los modos de autorización en el mundo cultural, los jóvenes de la revista carentes de vinculaciones sociales hicieron de ciertas formas de la sociabilidad literaria un modo de acumulación de capital simbólico. En ese sentido, en la promoción y en la práctica de un conjunto de valores que debían orientar sus acciones pudieron encontrar también las estrategias que los legitimaran. La comunión, la horizontalidad, la fraternidad, la camaradería o la solidaridad se actualizaron no solo en la frecuentación asidua de cafés y redacciones de diarios sino en intervenciones literarias específicas, como lo prueban el homenaje a Florencio Sánchez, la demostración a Ricardo Rojas o la insistencia autocelebratoria de la publicación en cada uno de sus aniversarios. Del mismo modo, un espíritu contemporizador antes que rebelde favoreció los vínculos de Nosotros con miembros de generaciones precedentes e hizo posible que Rafael Obligado presidiera el primer directorio de la Sociedad Cooperativa en que la revista se constituyó en 1912. La promesa de unir y no dividir, no solo funcionó como medio de ganar notoriedad y

${ }^{282}$ Lascano Tegui, Emilio. Nosotros, Año VII, n 51, julio, 1913, p. 88. 
estuvo motivada por el carácter emergente de un mundo literario. Sin embargo, en ocasiones Nosotros matizó la retórica del lamento usada con que los escritores definieron habitualmente el estatuto del arte en el fin de siglo XIX.

La publicación desarrolló una labor intelectual en la que pueden identificarse puntos de contacto con la revista de Gálvez. En ese sentido, la crítica tuvo un lugar central y como en Ideas también promovió las poéticas literarias de orientación mimética a las que tanto para la literatura como para el teatro consideraron apropiadas para la representar una modernidad cultural cuyos contenidos ya no fueron los mismos que los de la generación finisecular de El Mercurio de América. Asimismo, el afán de construir un teatro nacional Nosotros marcó su afiliación con Ideas y también lo hizo en una misma concepción cultural de la nacionalidad. Con respecto al debate de la identidad nacional cuyo carácter dominante fue evidente en la Argentina de esos años, la revista, además de asignarle un lugar clave en sus páginas lo abrió al conjunto de los intelectuales, y a través de su segunda encuesta los interpeló para discutir cuestiones que excedían la literatura. 


\section{Conclusiones}

Las revistas La Biblioteca, El Mercurio de América, La Montaña, Ideas y Nosotros, promocionaron y difundieron la producción intelectual, literaria y artística, entre los últimos años del sigo XIX y la primera década del XX y contribuyeron de modo decisivo en la construcción de un campo autónomo. Participantes de una modernización literaria que ellas iban forjando, estas publicaciones modularon en términos propios la necesidad de independencia autoinstuyéndose como espacios y vehículos de esa demanda. Con diversos grados de un voluntarismo característico de ese momento de emergencia de la literatura como práctica socialmente diferenciada, los directores, redactores y colaboradores de estas revistas escenificaron las intervenciones normativas y performativas de su reclamo. A través del mecanismo de relevos que denominamos posta intelectual hemos estudiado la dinámica por la que estos órganos se sucedieron unos a otros y privilegiaron aquello que Roberto Giusti definió como propósito "de unir y no dividir". Contrario al "espíritu de secta" que el director de El Mercurio de América reconociera como rasgo típico de un campo literario maduro, este "pacto de sociabilidad" (Prislei, 1992) organizó, con un impulso fuertemente cohesivo, los lazos entre escritores. Estudiar esa lógica de reemplazos estratégicos supuso dar cuenta de las continuidades y de las diferencias, que respectivamente hilvanaron y distinguieron unas revistas de otras en el tratamiento de un conjunto de problemas relativos a la modernización literaria. Cada revista enfatizó algunas de esas cuestiones centrales, cuya nómina fue amplia y variada.

En el primer capítulo precisamos cómo, desde La Biblioteca, Paul Groussac imaginó la forma posible de la autonomía intelectual en la formulación de un pacto entre empresas culturales y Estado, según la cual éste debía patrocinar y proteger los productos intelectuales. En ese sentido, al mismo tiempo que debía garantizar y preservar el ejercicio de una función intelectual independiente, el Estado era retribuido con el beneficio civilizatorio de construcción de la nación. Característico de un mundo cultural todavía imbricado con el mundo político, ese pacto realzaba los anhelos voluntaristas en el marco de una colocación subordinada y dependiente de la institución 
estatal a la que la revista pertenecía. De este modo, ese pacto podría inscribirse en la serie de casos en que la alianza entre intelectuales o escritores y el Estado, constituye uno de los modos característicos de la modernización literaria argentina (Dalmaroni, 2006). Por otra parte, el análisis de algunos escritos de los miembros de la elite liberal aparecidos en la revista ha permitido reconocer en ellos un modo específico de participación. Así, estos discursos se propusieron como soluciones o respuestas culturales a problemas vinculados con los efectos sociales de la modernización. Al mismo tiempo, a partir de reponer una contemporaneidad que la crítica no había señalado, hemos determinado la utilización de metáforas comunes por parte de Cané y Groussac para evaluar los efectos culturales de ese proceso. Así, ambos intelectuales se refirieron a la democracia como sistema social antijerárquico con la imagen de la decapitación de la cultura latina a manos de los hunos. "La educación por el folletín" atacaba los pactos impropios entre la alta cultura y el mercado de la prensa; "El Centenario" ratificaba la alianza entre intelectuales y Estado en la tarea civilizatoria, presente desde el comienzo de la publicación. Aunque el núcleo de colaboradores de $L a$ Biblioteca se halló entre los integrantes de la fracción intelectual de la elite, y por lo tanto, las figuras dominantes fueron las del abogado, el literato, o el político o el funcionario estatal, en las que seguían intersectándose los dominios de la cultura y la política, la sección 'Redactores' muestra también la presencia de subjetividades más modernas. Éstas eran las del poeta, el crítico, el escritor que a la vez que delimitaban un universo literario más acotado a la escritura y ponían en primer plano nuevos criterios de autorización, hacían visibles algunos aspectos de la vida literaria, que como las relaciones entre dinero y literatura o entre periodismo y literatura, cobrarían una importancia central poco tiempo después. De cara al problema de construcción de una literatura argentina, Groussac polemizó tanto con la vertiente criollista como con el modernismo proponiendo una tradición de tema nacional en lengua culta. Desde las páginas de $L a$ Biblioteca Joaquín V. González terció en esta disputa, y en su lectura de Recuerdos de la tierra fue posible observar que autonomización y servicio pudieron funcionar como condiciones no excluyentes de enunciación para los escritores, quienes convocados como expertos deberían sistematizar la materia de la futura tradición nacional. 
Como observamos, La Biblioteca tuvo un carácter modélico no solo para los jóvenes modernistas de El Mercurio de América. Su ejemplaridad se vinculaba con las funciones similares a las de un "estratega cultural" y a la vez las de un "experto literario" que Groussac ostentó en el circuito de la cultura letrada. Como crítico experto fue visto por los jóvenes como un maestro, aunque los mercuriales atemperaron, en ocasiones, el carácter franco y polémico de sus notas dando paso a una forma de camaradería intelectual que Groussac nunca practicó. Como estratega cultural insistía, como lo había hecho Ernesto Quesada, en la función central de las revistas para la construcción y consolidación de un público culto, y como mediador de la cultura europea, fundamentalmente francesa, Groussac se ocupaba de libros de materias diversas. La revista de Díaz Romero se definió construyendo una afiliación doble. La primera, de carácter institucional, hizo posible, el vínculo necesario con $L a$ Biblioteca, en virtud de la precariedad de las empresas culturales y de su condición subordinada con relación al campo del poder. La segunda y más moderna, consistió en decirse heredera de la Revista de América (1894) de Darío y Jaimes Freyre, de la cual absorbió su carácter alternativo antes que oposicional. El Mercurio mostró el valor de las alianzas como formas de promoción conjunta de las prácticas artísticas -no ya solo literarias- que hacía evidentes las vinculaciones efectivas entre quienes intentaban definir su arte como autónomo y como verdadera innovación. Signados por la contradicción típica de los artistas en las sociedades que se modernizaban y masificaban a un ritmo a sus ojos vertiginoso, los colaboradores de El Mercurio buscaron nuevos signos de distinción, que edificaron, por ejemplo en figuras como la del "desconocido ilustre", cuyo caso paradigmático encontró Eduardo Schiaffino en el pintor francés Gustave Moreau. En La Montaña, Lugones e Ingenieros propusieron también sus propias imágenes de poeta y de intelectual, respectivamente, mediante una publicación inscripta en el campo de la discusión sobre teoría política. Ingenieros lo hizo recurriendo al mito político de la conspiración procedente del siglo XIX europeo. Así, el redactor de 'Los reptiles burgueses' propuso diferenciar moralmente al intelectual del burgués, cuyo uso de los bienes culturales, en tanto forma del prestigio social, impugnó. Lugones, por su parte, abrevó en el mito político del Salvador, presentando al poeta como la figura social que condensaba todos los signos de un 
poder superior. Desde el repertorio semántico de la orografía presente en otros textos suyos contemporáneos elevaba la voz del poeta al rango de palabra necesaria. Más allá de las diferencias con La Biblioteca y en función del pacto de sociabilidad, Ingenieros y Lugones dejaron a un lado las distancias ideológicas entre vanguardia política y liberalismo y aún en ese disenso, elogiaron la figura de Groussac.

Los miembros de Ideas hicieron del juvenilismo -abrevando en el tono del mensaje arielista- una marca propia. A ello debe sumarse el signo nacional que tuvieron sus preocupaciones, principalmente la contribuir a la constitución de una cultura argentina. No obstante, participaron como los jóvenes de El Mercurio, de una efectiva internacionalización del arte e incorporaron las novedades estéticas nacionales y extranjeras. Vieron en la generación de Darío, Lugones, Ingenieros o Berisso el punto de inflexión de una breve tradición literaria, y como su predecesora natural le asignaron la función de un magisterio juvenil. Al mismo tiempo, establecieron una oposición selectiva con los miembros de la generación 80 , algunas de cuyas figuras -como Cané- fueron blanco de sus ataques sistemáticos contra los llamados ateneístas. Porque para legitimarse apelaron a rasgos modernos y otros más residuales la figura que construyeron fue, antes que completamente nueva, de transición. Como críticos literarios batallaron a favor de criterios específicos de legitimación de las obras y los autores y en algunos casos intentaron desarticular la implicación necesaria entre ubicación social o empleo estatal del sujeto y calidad estética o de pensamiento de los textos.

Las reflexiones sobre Ideas ponen en primer plano la figura social del escritor y el tema de la profesionalización. Tanto los perfiles de Olivera como los que retrospectivamente escribió Gálvez exhibieron la constitución de figuras marcadas por su inserción en el incipiente mercado de bienes culturales. El análisis de las colaboraciones de Antonio Monteavaro centrado en los participantes de cierta sociabilidad bohemia muestra el carácter problemático aunque nunca extremo de las relaciones entre la literatura y el dinero, fundado en las posibilidades laborales ofrecidas por la prensa y el teatro. La revista mostró una vocación de mercado entendida como una necesidad de orientar sus acciones hacia la construcción de un público para la novela y el teatro, que volvía paradójicos sus declarados espiritualismo 
y antimaterialismo. Para Gálvez una empresa cultural y comercial como 'La Biblioteca de La Nación', hacía posible pensar en la conquista de un mercado para los nuevos escritores. Por su parte, Ricardo Rojas hallaba dicha ejemplaridad en la experiencia de ciertas editoriales españolas que como la valenciana Sempere habían venido difundiendo el pensamiento y la literatura modernos a través de ediciones populares. Del mismo modo, aquella vocación de mercado alcanzó al teatro, un terreno en que aspiraron intervenir legitimando a los autores por sobre los actores y cuya temática criollista evaluaron anacrónica dentro de una sociedad aluvional.

Por otra parte, como han mostrado varios estudios entre los que se cuentan los de María Teresa Gramuglio, la carrera y la obra de Manuel Gálvez son centrales para una historia social de la literatura y por lo tanto para una historia de los intelectuales latinoamericanos, interesada especialmente en los aspectos materiales y sociales de las fases distintas de la modernización cultural. En ese contexto la investigación sobre Ideas mostraría que la importancia de Gálvez no podría ser descripta acabadamente sin conceder especial atención a su revista, proyecto en el que, como señalamos, el escritor concentró gran parte de sus energías juveniles y en el que delineó algunos de los principales rasgos de su proyecto creador. En ese sentido, el señalamiento de la inexistencia de una novela argentina en los primeros años del siglo pasado anticiparía ése como el espacio privilegiado de su intervención literaria; asimismo, la construcción de una tradición novelística nacional anclada en la estética realista o en su variante naturalista sería central en la formulación posterior del plan de sus novelas y como poética a partir de la cual interpelar y conquistar a un público ampliado. La combinación entre calidad y éxito comercial que Gálvez leía en la 'Biblioteca de $L a$ Nación' constituiría otro episodio relevante en la definición del proyecto escriturario y mercantil del director de Ideas. Por otro lado, en el caso de Rojas, su interés en la tarea cultural benéfica de difusión realizada por las editoriales españolas puede, en parte, considerarse como motivadora del emprendimiento de La Biblioteca Argentina (1915).

Los resultados de la investigación de Nosotros entre 1907 y 1913 muestran el carácter más efectivo de los nuevos modos de autorización intelectual que algunos miembros de Ideas no dejaron de proponer. Sus directores, inmigrante uno e hijo de inmigrantes el otro, sellaron su amistad en las aulas de la Facultad de Filosofía y 
Letras, institución con cuyos miembros la revista mantuvo relaciones fluidas. En un mundo cultural en el que la metáfora del vacío funcionaba como una descripción casi tópica, la revista respondió considerando el vacío como inconclusión y evaluando su propia acción intelectual como continuidad. Esta idea alrededor de la cual es posible agrupar otras como comunión, camaradería u horizontalidad se actualizó en la imagen de inconclusión vehiculizada en el capítulo de la novela de Payró con que se abría, también llamada Nosotros. El afán totalizador y la sostenida voluntad incluyente que caracterizaron a Nosotros, señalan un deseo de constituirse en el sitio privilegiado de representación de la cultura argentina. La insistencia en el anhelo de continuidad se actualizó en el intento de construir una tradición de literatura nacional, que la crítica de Nosotros construiría en la elección de una poética de representación realista de la sociabilidad argentina, cuya figura paradigmática para la narrativa fue Roberto Payró, y para el teatro, Florencio Sánchez. Con respecto a la crítica y repitiendo una modalidad ya practicada tanto en El Mercurio como en Ideas, se registró una ambivalencia por la cual la crítica se aproximaba en ocasiones a una forma del consejo o la reconvención, en otras, escatimaba sus elogios, en otras confrontaba abiertamente. La tarea de una crítica que se modernizaba a través de sus fluidos vínculos con la institución universitaria, fue realizada desde las secciones de reseñas en las que los colaboradores pensaron su práctica como el desarrollo constante de una labor específica imaginada como obra extensa y de estudio riguroso.

La temática de la nacionalidad organizó gran parte de las acciones de la revista. Los discursos nacionalistas se fueron tornado hegemónicos en la revista y ese ascenso culminó en 1913, año de la publicación de la encuesta sobre Martín Fierro. La revista imaginó los modos legítimos de su participación en el debate de la nacionalidad a partir de una estrategia que consistió en ingresar en la discusión de la mano de una figura prestigiada y socialmente relevante (Leguizamón) a la vez que discutía con un par generacional (Rojas) las aristas más agudas de ese problema. En tal sentido, la publicación se sumó y acordó, en un comienzo, con el programa de sistemático nacionalismo de Rojas. Este acuerdo caducó cuando la revista reivindicó la aceptación $\mathrm{y}$ asunción de las diferencias propias del cosmopolitismo como bases de una integración todavía no realizada y discutió las posturas de Rojas en La restauración 
nacionalista de 1909. No obstante, y resguardando las formas de sociabilidad en las que Nosotros fundara sus intervenciones, esa distancia ideológica, no fue un obstáculo para que la revista celebrara la inauguración de la primera cátedra de Literatura Argentina de la que se haría cargo Rojas.

La investigación realizada ha realzado el carácter central de las cuestiones relativas al mercado, el dinero y el público en escritores e intelectuales jóvenes como signo de una autonomización creciente del campo literario. En ese sentido, los resultados de este trabajo podrían prolongarse en el estudio detallado de las relaciones entre literatura y dinero, por ejemplo, en el caso de Emilio Becher y otros 'bohemios'que participaron en Ideas. En el camino abierto por Jorge B. Rivera en Los bohemios, el estudio de la correspondencia entre Becher y su amigo Emilio Ortiz Grognet, publicada en 1937 por la revista Nosotros, podría iluminar aspectos de una sociabilidad literaria decisiva y propia de la modernización literaria. Como aspecto fundamental de ese proceso la investigación podría continuarse en el análisis del campo editorial nacional, terreno aún no demasiado explorado y sobre cuyo papel central reflexionó Carlos Real de Azúa en 1950, al señalar la importancia fundamental de las políticas de las casas editoras peninsulares y francesas en la conformación del medio intelectual novecentista hispanoamericano.

Por otro lado, en el marco más general de los lazos entre España e Hispanoamérica con respecto a los cuales 1898 aparece como un punto de inflexión, podrían profundizarse en Nosotros las vinculaciones entre España y Argentina, en la línea desarrollada por un conjunto de investigadores entre los que puede citarse a Emilia de Zuleta (1983). De tal modo, sería posible rastrear tales vínculos en la presencia de libros, autores, revistas, temáticas, instituciones y tendencias estéticas así como en las visitas de españoles a la Argentina y de argentinos a España. El relevamiento de la publicación realizado en el anexo correspondiente podría funcionar como punto de partida de esa temática.

Asimismo en el contexto de las vinculaciones entre intelectuales y Estado éstas podrían ser indagadas más avanzado el siglo en los años de la 'Gran Guerra', en las páginas de La Nota (1915-1921), una publicación semanal de la que participaron 
intelectuales, políticos y escritores de distintas generaciones. En el semanario la guerra funciona como tema insoslayable del campo intelectual y literario y se transforma en una ocasión inmejorable para debatir, por ejemplo, sobre el nacionalismo cultural. Las sucesivas entregas en las que Rojas publica su "Definición de nacionalismo" forman parte de un material abundante y valioso en relación con el tema.

Tanto en la identificación provisional de estas proyecciones como, sobre todo, en el desarrollo de la tesis hemos procurado desplegar algunas de las posibilidades de un modo de revisar la historia literaria que, lejos de haberla perdido, mantendría una vigencia creciente. Una historiografía literaria que atienda a las particularidades de un campo de prácticas, a las formas y estrategias que se despliegan en ese terreno; pero que, al mismo tiempo, estudie las determinaciones culturales, sociales y políticas que permiten comprender tales prácticas a la vez como resultados y motores de un proceso de cambios, reacciones y respuestas. 


\section{Bibliografía}

\section{Fuentes}

La Biblioteca Historia, Ciencias, Letras (1896 - 1898) Revista dirigida por Paul Groussac

La Montaña. Periódico socialista revolucionario (1897). Redactores: José Ingegnieros y Leopoldo Lugones, Edición facsimilar de la UNQUI, 1997.

El Mercurio de América (1898-1900). Revista dirigida por Eugenio Díaz Romero.

Ideas (1903-1905). Revista dirigida por Manuel Gálvez.

Nosotros. Revista mensual de Letras, Arte, Historia, Filosofia (1907-1913). Revista dirigida por Roberto F. Giusti y Alfredo A. Bianchi.

Nosotros, Año XXIII, tomo 65, n 242, julio, 1929 [número de homenaje a Paul Groussac, con motivo de su muerte]

Ardissone, Elena - Salvador, Nélida (1971) Bibliografía argentina de artes y letras: Bibliografia de la revista Nosotros [1907-1943], Buenos Aires, Fondo Nacional de las Artes.

Becher, Emilio (1937). Correspondencia con Emilio Ortiz Grognet. Nosotros segunda época, Año II, Tomo IV, mayo, junio, julio, agosto, pp. 3-27, 160-178, 280-296, 413-429.

Chiáppori, Atilio (1944) Recuerdos de la vida literaria, Buenos Aires, Emecé.

De Vedia, Joaquín (1954) Cómo los vi yo, Buenos Aires, Manuel Gleizer editor.

Echagüe, Juan Pablo (1918) Un época del teatro argentino 1904-1918, vol. I, Buenos Aires, editorial América Unida.

Echagüe, Juan Pablo (1919) Un teatro en formación, Buenos Aires, Imprenta Tragant.

Echagüe, Juan Pablo (1928). "El teatro de ideas", Hombres e ideas, Buenos Aires, Manuel Gleizer editor, pp. 159-197.

Gálvez, Manuel (1961a) Amigos y maestros de mi juventud. T1 de Recuerdos de la vida Literaria, 4 tomos. Buenos Aires, Hachette.

Gálvez, Manuel, (1961b) Recuerdos de la vida literaria, T. II, En el mundo de los seres ficticios, Buenos Aires, Hachette.

García Mérou, Martín (1886) Libros y autores, Buenos Aires, Félix Lajouane.

García Velloso, Enrique (1960) Memorias de un hombre de teatro [selección], Buenos Aires, Eudeba.

Giusti, Roberto (1911) Nuestros poetas jóvenes. Revista crítica del actual movimiento poético argentino, Buenos Aires, Nosotros. 
Giusti, Roberto F. (1917) Crítica y polémica (primera serie), Buenos Aires, Edición de Nosotros.

Giusti, Roberto F. (1924) Crítica y polémica (segunda serie), Buenos Aires, Cooperativa Editorial Buenos Aires.

Giusti, Roberto F. (1927) .Crítica y polémica (tercera serie), Buenos Aires, Cooperativa Editorial Buenos Aires.

Giusti, Roberto F. (1930) Crítica y polémica (cuarta serie), Buenos Aires, Cooperativa Editorial Buenos Aires.

Giusti, Roberto F. (1939) Rosarinos que yo conocí. Quid novis? Suplemento. Pedagogía Literatura-Ciencias-Artes- Notas varias, Tomo VII, $\mathrm{n}^{\mathrm{o}} 35$, Escuela Normal $\mathrm{n}^{\mathrm{o}} 2$ 2, J. M. Gutiérrez, Rosario.

Giusti, Roberto F. (1946) "Una generación juvenil hace cuarenta años”, Siglos, escuelas, autores, Buenos Aires, editorial Problemas, pp. 345-369.

Giusti, Roberto F. (1956a) "El teatro de Payró", Payró, Roberto J., Teatro completo, Buenos Aires, Hachette, pp. 7-28.

Giusti, Roberto F. (1956c). “Atilio Chiáppori y su generación”, Poetas de América y otros ensayos, Buenos Aires, Losada.

Giusti, Roberto F. (1957) “La revista Nosotros y sus vicisitudes”, Dávar, n 71, julioagosto, pp. 21-37.

Giusti, Roberto F. (1965) Visto y vivido, Buenos Aires, Losada.

Giusti, Roberto F. (1971) “Introducción”, en Ardissone, Elena (comp.), Bibliografía de la revista Nosotros 1907-1943, Buenos Aires, Fondo Nacional de las Artes, pp. I-XXXIX.

Giusti, Roberto, F. (1956 b) "Miguel Cané. El escritor y el político”, Comentario, Año III, $\mathrm{n}^{\mathrm{o}}$ 11, abril-junio, pp. 25-37.

González, Joaquín (1896) "Recuerdos de la tierra", La Biblioteca, Año I, Tomo II, noviembre, pp. 384, 400.

Groussac, Paul (1938). Noticia histórica sobre la Biblioteca Nacional de Buenos Aires (1810-1901) y discurso pronunciado en la inauguración del actual edificio, Buenos Aires, Librería y casa editora Jesús Menéndez.

Groussac, Paul (1980) Los que pasaban. Buenos Aires, CEdAL, [selección, prólogo y notas por Luis Alberto Romero]

Groussac, Paul (2001) Los que pasaban. Buenos Aires, Taurus [selección y estudio preliminar de Alejandro Eujanián]

Groussac, Paul (2005) El viaje intelectual, primera y segunda series, Buenos Aires, Simurg.

Groussac, Paul. (1925) “Democracias latinoamericanas”, Del Plata al Niágara, Buenos Aires, Jesús Menéndez editor, pp. 206-223.

Ingenieros, José (1915). "La personalidad intelectual de Ramos Mejía (1849 - 1914)" Conferencia pronunciada en el Ateneo de Estudiantes Universitarios. Publicada en Revista de Filosofía, Año I, Vol. II, Buenos Aires, $2^{\circ}$ Semestre. 
Maeder, Ernesto, J. A. (1962) Índice general de La Biblioteca (1896-1898), Resistencia, Universidad Nacional del Nordeste.

Martínez Cuitiño, Vicente (1954) El café de Los Inmortales, Buenos Aires, Kraft.

Navarro Viola, Jorge (1897). Anuario de la prensa argentina 1896, Buenos Aires, Coni.

Oyuela, Calixto (1980). “Asociaciones literarias", en Estudios Literarios, El escritor y la industria cultural, Buenos Aires, CEdAL.

Oyuela, Calixto. (1980) "Discurso de inauguración del Ateneo", El escritor y la industria cultural (Jorge Rivera comp.), Buenos Aires, CEdAL.

Payró, Roberto J. (1909) Crónicas, Buenos Aires, Minerva.

Payró, Roberto J. (1968) Al azar de las lecturas. La Plata, Facultad de Humanidades y Ciencias de la Educación, U.N.L.P.

Quesada, Ernesto (1895a) "El movimiento intelectual argentino", Reseñas y críticas, Buenos Aires, Félix Lajouane editor, pp. 119-141.

Quesada, Ernesto. (1895b) “El primer 'salón' argentino”, Reseñas y críticas, Buenos Aires, Félix Lajouane editor, pp. 119-141.

Quesada, Vicente y Navarro Viola, Miguel. (1863) "Prospecto", Revista de Buenos Aires, Año I, $n^{\circ} 1$, mayo, p. 5-8

Rojas, Ricardo (1938). "Evocación de Emilio Becher”, en Emilio Becher, Diálogo de las sombras y otras páginas, Buenos Aires, Facultad de Filosofía y Letras, Instituto de Literatura Argentina, pp. III-XLVII.

Zola, Émile (1945) "El naturalismo en el teatro", La escuela naturalista. Estudios literarios, Buenos Aires, Editorial Futuro, (traducción revisada, anotada y prologada por Alvaro Yunque), pp. 239-272.

Zola, Émile (1972) El naturalismo, selección, introducción y notas de Laureano Bonet, Barcelona, Península, pp. 201-206.

Zola, Émile "La República y la Literatura" (1945) La escuela naturalista. Estudios literarios, Buenos Aires, Editorial Futuro, (traducción revisada, anotada y prologada por Alvaro Yunque), pp. 51-79.

\section{Bibliografía teórica}

Altamirano Carlos, director (2002). Términos críticos de sociología de la cultura, Buenos Aires - Barcelona - México

Altamirano, Carlos (1981) "Proposiciones para una teoría social de la cultura", Punto de vista, IV, 11, marzo-junio, p. 20-23.

Altamirano, Carlos (1988)."Raymond Williams, 1921-1988", en Punto de vista, XI, 33, setiembre-diciembre, pp. 1-2.

Altamirano, Carlos y Sarlo, Beatriz (1983b). Literatura/sociedad, Buenos Aires, Hachette. 
Anderson, Benedict. (1993) Comunidades imaginadas. Reflexiones sobre el origen y la difusión del nacionalismo, México, FCE.

Anderson Perry (2002). "Internacionalismo: un breviario", $N L R, \mathrm{n}^{\mathrm{o}}$ 14, 2002, pp. 5-24.

Bourdieu, Pierre (1967) "Campo intelectual y proyecto creador", en AA.VV., Problemas del estructuralismo, México, Siglo XXI.

Bourdieu, Pierre (1995) Las reglas del arte. Génesis y estructura del campo literario, Barcelona, Anagrama.

Bürger, Peter. (1992) "Literary Institution and Modernization", The Decline of Modernism, Pennsylvania, Pennsylvania State University Press, pp. 3 -18.

Casanova, Pascale (1999) La Republique mondiale des Lettres, Seuil.

Charle, Christophe (1990) Naissance des “intellectuels" 1890-1900, Paris, Les éditions de Minuit, pp. 1-8.

Eagleton, Terry (1983). Una introducción a la teoría literaria, México, FCE, pp. 29-70.

Eagleton, Terry (1984). The Function of Cristicism. From The Spectator to PostStructuralism, London, Verso.

Gramuglio, María Teresa (1992) “La construcción de la imagen”, en Tizón, H., Rabanal, R. y Gramuglio, M. T., La escritura argentina, Santa Fe, UNL, Ediciones de la Cortada, pp. 35-64.

Gramuglio, María Teresa (1993) "La summa de Bourdieu", Punto de vista, año XVI, n 47, diciembre de, pp. 38-42.

Girardet, Raoul (1986) Mythes et mythologies politiques Paris, Éditions du Seuil.

\section{Bibliografía crítica y sobre el período}

Aira, César (2001). Diccionario de autores latinoamericanos, Buenos Aires, Emecé-Ada Korn.

Altamirano, Carlos (editor). (1999). La Argentina en el siglo XX, Buenos Aires, ArielUniversidad de Quilmes.

Altamirano, Carlos y Sarlo, Beatriz (1980). Conceptos de sociología literaria, Buenos Aires, CEdAL.

Altamirano, Carlos y Sarlo, Beatriz (1983a). Ensayos argentinos. De Sarmiento a la vanguardia, Buenos Aires, CEdAL.

Altamirano, Carlos. (1979) "La fundación de la literatura argentina", Punto de vista, Buenos Aires, II, 7, noviembre

Arrieta, Rafael A. (1956) Introducción al modernismo literario, Buenos Aires, Columba, pp. 23-30. 
Auerbach, Erich (1979) Mimesis. La representación de la realidad en la literatura occidental, México, FCE.

Benarós, León (1998) Paul Groussac en el Archivo General de la Nación, Buenos Aires, Archivo General de la Nación.

Blanco, Oscar (1999) "Final de siglo. Memorias, fragmento. La conformación de una crítica literaria”, en Rosa, Nicolás (editor), Políticas de la crítica. Historia de la crítica literaria en la Argentina, Buenos Aires, Biblos, pp. 43-57.

Bonfiglio (2005) "José Enrique Rodó: el espíritu de Ariel en la ciudad modernizada", mimeo.

Bossio, Jorge, A. (1995) Los cafés de Buenos Aires. Reportaje a la nostalgia, Buenos Aires, Editorial Plus Ultra.

Botana, Natalio (1979). El orden conservador. La política argentina entre 1880-1916, Buenos Aires, Sudamericana.

Brizuela L. Eduardo. (1987) "Giusti en la Universidad", Boletín de la Academia Argentina de Letras, Tomo LII, enero-junio, no 203-204, pp. 25-31.

Bruno, Paula. (2005) Paul Groussac un estratega intelectual, Buenos Aires, Universidad de San Andrés - FCE.

Carilla, Emilio (1967) Una etapa decisiva de Darío. Rubén Dario en la Argentina, Madrid, Gredos.

Cazap, Susana y Massa, María Cristina (2002) "Teatro nacional y realidad social", Gramuglio, María Teresa (directora), El imperio realista, Buenos Aires, Emecé, pp. 91-109.

Cazap, Susana y Massa, María Cristina (2002). "El sainete criollo. Mímesis y caricatura", Gramuglio, María Teresa (directora), El imperio realista, Buenos Aires, Emecé, pp. 129-144.

Colombi, Beatriz (2004a) "El relato como epigrama. Del Plata al Niágara de Paul Groussac" Viaje intelectual. Migraciones y desplazamientos en América Latina (1880-1915), Rosario, Beatriz Viterbo, pp.

Colombi, Beatriz (2004b) "En torno de Los raros. Darío y su campaña en Buenos Aires", Rubén Dario en La Nación de Buenos Aires, Buenos Aires, Eudeba, pp. 61-82.

Contardi, Sonia (1994) “Los raros y otras crónicas literarias de Rubén Darío en los periódicos de Buenos Aires. Linaje y pensamiento literarios hispanoamericanos”, Buenos Aires, Losada., pp. 7-36

Croce, Marcela. (1994) La montaña. Jacobinismo y orografia, Buenos Aires, Fac. de Filosofía y Letras.

Cymerman, Claude (1993) Diez estudios cambacerianos, Rouen, Universidad de Rouen, capítulos 4 y 9 .

Dalmaroni, Miguel (2006) Una república de las letras. Lugones, Rojas, Payró. Escritores argentino y Estado, Rosario, Beatriz Viterbo. 
Dalmaroni, Miguel. "Literatos y Estado (Payró, Groussac, Lugones), en Jitrik, Noé (compilador), Las maravillas de lo real. Literatura latinoamericana, Buenos Aires, Instituto de Literatura Hispanoamericana, 2000, pp. 123-132.

Darío, Rubén (1968). Escritos dispersos de Rubén Darío. (Recogidos en periódicos de Buenos Aires), La Plata, UNLP, Facultad de Humanidades y Ciencias de la Educación, (Advertencia de Juan Carlos Ghiano; Estudio preliminar, recopilación y notas de Pedro L. Barcia),

De Torre, Guillermo. (1961) "Unamuno y la literatura Hispanoamericana", Cuadernos de la Cátedra Miguel de Unamuno, XI, Salamanca, pp. 5-25.

Espósito, Fabio (1998) Elite letrada, estado y mercado (tesina de licenciatura), Biblioteca de la Facultad de Humanidades y Ciencias de la Educación.

Espósito, Fabio. La Emergencia de la novela en la Argentina (1880-1890), mimeo. Tesis doctoral, Facultad de Humanidades, UNLP.

Eujanian, Alejandro (2001). Estudio preliminar a Paul Groussac, Los que pasaban, Buenos Aires, Taurus, pp. 9-35.

Eujanián, Alejandro (2003). "Paul Groussac y la crítica historiográfica", en Cattaruzza, Alejandro y y Eujanian, Alejandro. Políticas de la historia. Argentina 1860-1960, Buenos Aires, Alianza editorial, pp. 43-67.

Eujanian, Alejandro. "Intelectuales, políticos y profetas. Paul Groussac en la construcción de una imagen del intelectual a fines del siglo XIX", mimeo.

Fernández, Javier. (1987). "Roberto F. Giusti y la generación de la revista Nosotros", Boletín de la Academia Argentina de Letras, Tomo LII, enero-junio, no 203-204, pp. 33-43.

Frugoni de Fritzsche, Teresita (1966) El naturalismo en Buenos Aires, Buenos Aires, Instituto de Literatura Argentina "Ricardo Rojas", Facultad de Filosofía y Letras.

García, Ignacio (2002) "Rubén Darío y Francisco Grandmontagne en Buenos Aires de 1898", Revista Iberoamericana $\mathrm{n}^{\mathrm{o}} 198$, enero-marzo.

Generani, Gustavo (2002) "Roberto Payró. El realismo como política", Gramuglio, María Teresa (directora), El imperio realista, Buenos Aires, Emecé, pp. 61-89.

Gerchunoff, Alberto (1952) Argentina, país de advenimiento, Buenos Aires, Editorial Losada, Cristal del Tiempo.

Gerchunoff, Alberto (1929) "Reflexiones sobre Pablo Groussac", Nosotros, Año XXIII, n 242, julio, pp. 63-67.

Bianco, José (1929). Paul Groussac, Año XXIII, nº 242, julio, pp. 81-89.

Ghiano, Juan Carlos (1961). "Martiniano Leguizamón y el teatro”, Buenos Aires, Ediciones Solar Hachette, pp. 7-25.

Ghiano, Juan Carlos (1987) "Giusti en la crítica iberoamericana", Boletín de la Academia Argentina de Letras, Tomo LII, enero-junio, n 203-204, pp. 15-23.

Girbal Blacha, Noemí y Quatrocchi-Woisson, Diana (directoras) (1999). Cuando opinar es actuar. Revistas argentinas del siglo XX, Buenos Aires, Academia Argentina de la Historia. 
Gnutzmann, Rita (1998) "La batalla del naturalismo en Buenos Aires", La novela naturalista en Argentina 1880 - 1900, Amsterdam - Atlanta, Rodopi.

Goldchluk, Graciela. (1996) Manuel Gálvez en el campo en el campo cultural argentino, Tesina de Licenciatura, Facultad de Humanidades, UNLP, inédito.

Gramuglio, María Teresa (1996) "Comienzos en el fin de siglo: Leopoldo Lugones”, Orbis Tertius, Año I, 2/3, La Plata, Centro de Estudios de Teoría y Crítica Literaria, Humanidades, UNLP, segundo semestre, pp. 49-64.

Gramuglio, María Teresa (2001) "Estudio preliminar", El Diario de Gabriel Quiroga. Opiniones de la vida argentina, Buenos Aires, Taurus, pp. 9-56.

Gramuglio, María Teresa. (2002a) "El realismo y sus destiempos en la literatura argentina", Gramuglio, María Teresa (directora), El imperio realista, Buenos Aires, Emecé, pp.15-38

Gramuglio, María Teresa (directora) (2002b), Gálvez El imperio realista, Buenos Aires, Emecé, pp. 145-176 Gramuglio,

María Teresa (2002c) "Momentos del ensayo de interpretación nacional. 1910, 1930", Boletín del Centro de teoría y Crítica Literaria $n^{\circ} 10$, Rosario, Facultad de Humanidades y Artes, UNR, pp. 37-50

Gutiérrez, Leandro -Romero, Luis Alberto (1995), Sectores populares, Buenos Aires, Sudamericana.

Halperín Donghi, Tulio (1962). Historia de la Universidad de Buenos Aires, Buenos Aires, Eudeba.

Halperín Donghi, Tulio. (1980). "Un nuevo clima de ideas”. En Ferrari, Gustavo y Ezequiel Gallo (comp.). La Argentina del Ochenta al Centenario. Buenos Aires, Sudamericana.

Hauser, Arnold. Historia social de la literatura y el arte, Madrid, Guadarrama, 1974.

Historia de la literatura argentina, tomo 3, Buenos Aires, CEdAL, 1981.

Hobsbawm, Eric, J. (1991) Naciones y nacionalismo desde 1870, Barcelona, editorial Crítica, 1991.

Hobsbawm, Eric. (1999) La era del Imperio 1875-1914, Buenos Aires, Crítica, Grijalbo Mondadori.

Irazusta, Julio (1978). "Paul Groussac y su carrera literaria en argentina", Gobernantes, caudillos y escritores, Biblioteca Dictio.

Jitrik, Noé (1998) "Roberto F. Giusti (En la consolidación de la literatura argentina)", El ejemplo de la familia. Ensayos y trabajos sobre literatura argentina, Buenos Aires, Eudeba, pp. 101-110.

Lafleur, H., Provenzano, S., Alonso, F. (1960-1968) Las revistas literarias argentinas 1893-1960, Buenos Aires, Ediciones Culturales Argentinas.

Lafleur, H., Provenzano, S., Alonso, F. Las revistas literarias, Buenos Aires, CEDAL, 1980.

Levin, Harry (1974) El realismo francés, Barcelona, Laia.

Loprete, Carlos A. (1955) La literatura modernista en la Argentina, Buenos Aires, Editorial Poseidón. 
Ludmer, Josefina (Comp.). Las culturas de fin de siglo en América Latina. Rosario, Beatriz Viterbo, 1994.

Ludmer, Josefina (1999) El cuerpo del delito. Un manual, Buenos Aires, Perfil libros.

Ludmer, Josefina (1993) "Introducción" a: Cané, Miguel. Juvenilia y otras páginas argentinas. Buenos Aires, Espasa Calpe.

Malosetti Costa, Laura (2001) "Pintores y poetas II. El Ateneo", Los primeros modernos. Arte y sociedad en Buenos Aires a fines del siglo XIX, Buenos Aires, FCE, pp. 327-390.

Mangone, C. - Warley, J. (1994) El manifiesto. Un género entre el arte y la política, Buenos Aires, Biblos.

Matamoro, Blas (2002) Rubén Darío, Madrid, Espasa.

Meier, Elke (1983) "Unamuno, Rubén Darío y el modernismo”, Cuadernos de la Cátedra Miguel Unamuno, XXVII-XXVIII, Salamanca, pp. 135-148.

Montaldo Graciela. De pronto el campo. Literatura argentina y tradición rural, Rosario, Beatriz Viterbo Editora, 1993.

Montaldo, Graciela. (1994) La sensibilidad amenazada. Fin de siglo y modernismo. Rosario, Beatriz Viterbo.

Montaldo, Graciela (1999) "La cultura invisible: los hispanoamericanos y el problema de América Latina" Ficciones culturales y fábulas de identidad en América Latina, Rosario, Beatriz Viterbo, pp. 81-139.

Onega, Gladys (1969) "El Centenario", La inmigración en la literatura argentina, Buenos Aires, Galerna, (ed. posterior en CEdAL).

Ordaz, Luis (1981) "Tres comediógrafos sobresalientes", Capítulo. Historia de la literatura argentina, tomo 3, Buenos Aires, CEdAL, pp. 169-192.

Ordaz, Luis. El teatro en el Río de La Plata desde sus orígenes hasta nuestros días, Buenos Aires, ediciones Leviatán. S/F.

Páez de la Torre, Carlos (h). (2005) La cólera de la inteligencia. Una vida de Paul Groussac, Buenos Aires, Emecé.

Pasolini, Ricardo O. (1999). "La ópera y el circo en el Buenos Aires de fin de siglo. Consumos teatrales y lugares sociales", Historia de la vida privada en Argentina, Tomo 2, Buenos Aires, Taurus, pp. 227-273.

Pastormerlo, Sergio (2005) Diccionario de autores, publicaciones periódicas e instituciones culturales en Argentina, 1880-1890", mimeo.

Payá, Carlos y Cárdenas, Eduardo (1978) El primer nacionalismo argentino. Buenos Aires, Peña Lillo.

Pereyra, Washington L. (1993) La prensa literaria argentina 1890 - 1974, Buenos Aires, librería colonial.

Pineda Franco, Adela. (2006) Geopoliticas de la cultura finisecular en Buenos Aires, París y México: las revistas literarias y el modernismo, Pittsburgh, Instituto Internacional de Literatura Iberoamericana, Universidad de Pittsburgh. 
Prieto, Adolfo (1988) El discurso criollista en la formación de la Argentina moderna. Buenos Aires, Sudamericana.

Prislei, Leticia. (1998) "Nosotros. Revista de Letras, Arte, Filosofía, Historia y Ciencias Sociales" en Diccionario Enciclopédico de las Letras de América Latina (Fundación Biblioteca Ayacucho, pp. 3395-3400.

Prislei, Leticia. (1999) “Tres ensayos y una encuesta en busca de la nación”, Prismas. Revista de Historia intelectual, 3.

Prislei, Leticia (1992) "Itinerario intelectual y político de los Maestros-ciudadanos. (Del fin del siglo a la década del '20), Entrepasados, Año II, nº 2, pp. 41-59.

Unamuno, Miguel (1961) Letras de América y otras lecturas, Tomo 8 de las Obras completas, Barcelona, Vergara.

Rama, Ángel. (1985a) Las máscaras democráticas del modernismo, Montevideo, Fundación Internacional Ángel Rama.

Rama, Ángel. (1985b) Rubén Dario y el modernismo. Alfadil ediciones, Caracas -Barcelona.

Ramos, Julio (1989). Desencuentros de la Modernidad en América Latina. Literatura y política en el siglo $X X$, México, FCE.

Ravina, Aurora. "Profesar el plural. Nosotros 1907-1934/1936-1943”. (1999) En Girbal Blacha, Noemí y Quatrocchi-Woisson, Diana (directoras). Cuando opinar es actuar. Revistas argentinas del siglo $X X$, Buenos Aires, Academia Argentina de la Historia, pp. 57-91.

Real de Azúa, Carlos (1950). Ambiente espiritual del 900. Número, Montevideo, año 2, $\mathrm{n}^{\circ}$ 6-7-8, enero-junio de, pp. 15-61.

Real de Azúa, Carlos (1976) Prólogos a Rodó, José Enrique, Ariel y Motivos de Proteo, Sucre, Biblioteca Ayacucho, pp. IX-XXXV y pp. XXXVII-CVI, respectivamente.

Real de Azúa, Carlos (1977) "El modernismo literario y las ideologías”, Escritura, Año II, $\mathrm{n}^{\mathrm{o}}$ 3, enero-junio, pp. 41-75.

Renan, Ernest (1882) “Qué es una nación?”, edición digital.

Rivera, Jorge B. (comp.) (1993) El escritor y la industria cultural. Buenos Aires, CEAL.

Rivera, Jorge B. (1981) "El ensayo de interpretación. Del Centenario a la década de 1930", en Capítulo. Historia de la literatura argentina, tomo 3, Buenos Aires, CEdAL, pp. 433-456

Rivera, Jorge B. (comp.) (1992) Antología, textos y protagonistas de la bohemia porteña, Buenos Aires, CEdAL, pp. 29-33.

Rivera, Jorge, B. (1981- 2000). "La forja del escritor profesional (1900-1930). Los escritores y los nuevos medios masivos", en Capítulo. Historia de la literatura argentina, tomo 3, Buenos Aires, CEdAL, pp. 361-384.

Rivera, Jorge, B. (1995) El periodismo cultural, Buenos Aires, Paidós.

Roca Martínez, José Luis (1987) “Manuel Gálvez y la generación de Ideas”, Buenos Aires, pp. 985-995. 
Rogers, Geraldine (2006). Caras y Caretas: cultura, política y espectáculo en el cambio de siglo argentino (1898-1904). Tesis doctoral, Facultad de Humanidades, UNLP.

Romero, José Luis (1982) Las ideologías de la cultura nacional y otros ensayos. Buenos Aires, CEAL.

Romero, José Luis (1983) “El espíritu del Centenario", El desarrollo de las ideas en la sociedad argentina del siglo XX, Buenos Aires, Ediciones del Solar, pp. 55-95.

Romero, José Luis (1997) "La conformación de la Argentina aluvial” (pp. 173-188), “La línea del liberalismo conservador" (pp. 189-209), Las ideas políticas en Argentina, Buenos Aires, Fondo de Cultura Económica.

Romero, Luis Alberto (1980) "Prólogo" a Los que pasaban, Buenos Aires, CedAL, pp. IVI.

Romero, Luis Alberto (2000). Argentina. Una crónica total del siglo XX, Buenos Aires, Aguilar.

Samurovic-Pavlovic, Liliana (1969). Les lettres hispano-américaines au Mercure de France 1897-1915, Paris, Centre de Recherches Hispaniques, Institut d'Études Hispaniques, Université de Paris V.

Sarlo, Beatriz (1984) "Prologo" a Payró, Roberto Jorge, Obras, Barcelona, Biblioteca Ayacucho, pp. IX-XLIV.

Sarlo, Beatriz (1993)."Raymond Williams: una relectura", en Punto de vista, XVI, 45, abril, p. 12 y ss.

Sosnowski, Saúl (ed.) (1999). La cultura de un siglo. América Latina en sus revistas, Buenos Aires, Alianza editorial.

Soto, Luis Emilio (1957) "El cincuentenario de la revista Nosotros, Ficción, no 10, Buenos Aires, noviembre-diciembre, pp. 73-78.

Terán, Oscar (1994). "La tradición liberal”, Punto de vista, Año XVII, no 50, noviembre, pp. 28-31.

Terán, Oscar (1999) “Acerca de la idea nacional”, Altamirano, Carlos (ed.), La Argentina en el siglo $X X$, Buenos Aires, Ariel, pp. 279-287.

Terán, Oscar (2000).Vida intelectual en el Buenos Aires fin-de-siglo (1880-1910). Derivas de la "cultura científica”, Buenos Aires, Fondo de Cultura Económica.

Ulla, Noemí (1969) Selección y prólogo a La revista Nosotros, Buenos Aires, Galerna.

Viñas, David (1986). "Prólogo" a AAVV, Teatro Rioplatense, Caracas, Biblioteca Ayacucho, pp. IX-XLIV

Viñas, David (1996). Literatura argentina y realidad politica. De Lugones a Walsh, Buenos Aires, Sudamericana.

Williams, Raymond (1988). Cultura. Sociología de la creación y del arte, Barcelona, Paidós Comunicaciones. 
Williams, Raymond (2000). Palabras clave. Un vocabulario de la cultura y la sociedad, Buenos Aires, Ediciones Nueva Visión.

Williams, Raymond. (1980) Marxismo y literatura, Barcelona, Península.

Zanetti, Susana (2004) “Itinerario de las crónicas de Darío en La Nación”, Zanetti, Susana (coordinadora), Rubén Darío en La Nación de Buenos Aires, Buenos Aires, Eudeba, pp. 9-59.

Zimmermann, Eduardo (1994) Los intelectuales reformistas. La cuestión social en la Argentina 1890-1916, Buenos Aires, Editorial Sudamericana - Universidad de San Andrés. 
ANEXOS 


\section{ANEXOS CORRESPONDIENTES AL CAPÍTULO 1}




\section{Índice razonado de LA BIBLIOTECA. Historia, Ciencias, Letras. Revista dirigida por Paul Groussac. 1896-1898}

Se consigna el índice de cada una de las entregas de la revista, cuya colección completa consta de 24 números en 8 tomos.

La revista La Biblioteca, de periodicidad mensual, apareció por primera vez en junio de 1896, y su último número $\left(\mathrm{n}^{\mathrm{o}} 24\right)$ corresponde a mayo de 1898. Colocamos entre paréntesis el número a cada entrega revista, porque respetamos la forma en las presenta Groussac, que es por entregas que llevan el nombre de cada mes, y no están numeradas. La revista presenta tres secciones fijas: 'Redactores' (aparece en todos los tomos, al final), 'Documentos históricos' (desde la segunda entrega, julio, 1896), y 'Boletín bibliográfico' (a partir de la entrega de noviembre de 1896). Paul Groussac es quien redacta todas las notas biográficas de la sección 'Redactores' salvo las que corresponden a Horacio Beccar Varela, Julio A. Roca, Miguel Romero y Adolfo Saldías, de quienes se ocupa Enrique Rodríguez Larreta. También Groussac se encarga de la sección 'Boletín bibliográfico' con la excepción que se consigna en este índice.

En este índice se comentan y transcriben pasajes de aquellos artículos considerados más relevantes, y que registran una serie de temas característicos de la atmósfera de esa época. Aquellos que llevan ** son considerados y analizados con detalle en el desarrollo de las hipótesis en el cuerpo del trabajo.

\footnotetext{
Año I, Tomo 1, junio-agosto, 1896.

Año I, Tomo 1, junio de 1896 (1) [Buenos Aires, imprenta de Pablo E. Coni e Hijos, 680 de la calle Perú]. -"La Biblioteca" pp. 5-8, por Paul Groussac. Este artículo es el que abre la publicación y en él se determinan propósitos, políticas culturales -la relación necesaria con el Estado liberal- y el marco ideológico del bien entendido liberalismo que está en la base de la empresa de Groussac. **

-“La Biblioteca de Buenos Aires”, pp. 9-33, por Paul Groussac. Se trata de la historia de la institución surgida por iniciativa de M. Moreno junto con el nacimiento de la patria y que Groussac analiza a través de la sucesión de los distintos directores. Esta entrega es la primera. **

-“Arqueología americana", pp. 34-39, por Bartolomé Mitre. [sobre la obra del abate Brasseur de Bourbourg)] Señala Mitre: "Dirigido por su imaginación más que por su ciencia, se extravió persiguiendo ilusiones etimológicas que le condujeron a conclusiones incompletas o arbitrarias en un palabreo exuberante. Su método no es científico, su criterio es escaso, su estilo difuso, su sistema carece de base racional y sus investigaciones son, en gran parte, fruto del trabajo ajeno, que en gran parte trató de obscurecer. En definitiva, su obra carece de originalidad, aún en lo que tiene de extravagante, $y$, adelantando muy poco los buenos estudios americanos, ha contribuido a desnaturalizarlos, dando origen a una escuela filológica, semi-científica, semi-fantástica, que por medio de etimologías y analogías que se contradicen entre sí, lo mismo prueba que los americanas son escépticos o turanios, o griegos o chinos, o egipcios o escandinavos, volviendo así a la confusión de las razas y las lenguas de la vieja escuela americano-judía, de que Kingsborough fue el último propagador.” p. 38.

-"Nuevos rumbos humanos", pp. 40-55, por Miguel Cané.** Este artículo constituye una de las manifestaciones más enfáticas de la reacción de la elite intelectual ante los efectos de la modernización y una respuesta en términos culturales.

-La predicción del tiempo, pp. 56-68, por Francisco Beuf.

"La masa popular de hoy, sometida al régimen de regenerador de la enseñanza obligatoria, con sus flamantes programas y su novísima pedagogía, no es menos crédulas y refractaria al criterio racional que la de ayer, tan extraña como fuera a toda enseñanza escolar." p. 56

"El saber a medias fomenta esa tendencia incurable, lejos de combatirla, como se alimenta casi exclusivamente con la lectura de periódicos, irresponsables por esencia y superficiales por definición" p. 56.

El artículo se declara contrario del progreso encarnado en el saber que proporciona la prensa periódica. Critica y se burla de las predicciones del tiempo y sobre todo de las que transmite la prensa, puesto que no tienen base científica alguna. A cada ejemplo de la literatura 'popular' acerca del clima (la tormenta de Santa Rosa, por ejemplo) Beuf, repone la explicación científica.

-La tentación del suicidio, pp. 69-87, por José María Ramos Mejía.
} 
Resume su libro en preparación sobre el suicidio. El concepto que organiza su exposición es el de selección darwiniana. "El cerebro, sometido a una presión demasiado violenta para los seres de estructura ingénita débil, o conmovidos por causas adquiridas que una ligera predisposición hereditaria pone en condiciones propicias de recepción mórbida, se rompe, diremos así, como el ánfora del desesperado poeta del Génie funèbre" p. 71-87.

-"El arte en Buenos Aires. La evolución del gusto" [nombre del capítulo: 'El limbo'], por Eduardo Schiaffino, pp. 88-96. Trata de dar cuenta de "cuál era el estado del gusto público, allá en la época de Rozas" y sostiene que ese estado "lo establece claramente y en forma asaz pintoresca, una frase de Don Juan Manuel al Señor Guerrico, que regresaba de Europa trayendo consigo algunos cuadros: 'Ya vino éste con cosas de gringo"' $p$. 88. Analiza la arquitectura, la pintura, los peinados, la decoración, los oficios [platería, herrería, etc.] En una identificación de la evaluación del gusto con la de la autoridad política en términos de "barbarie' señala haber "reseñado desde el punto de vista plástico el escenario visible de la vida bonaerense anterior a la influencia europea." p. 96.

-Observaciones críticas acerca de unos manuscritos de Tadeo Haenke existentes en la Biblioteca Nacional, por Pedro N. Arata, pp. 97-110.

-El cacui (del libro inédito Héroes y Tradiciones), por Rafael Obligado, pp. 111- 120.

Toma la leyenda del cacui, mujer que no sabe ser buena hermana y que se convierte en pájaro que llora esa culpa. En el poema, se compara esos hermanos con el nosotros argentinos, fruto de cuya no-hermandad, es el sufrimiento de la patria: "Y mientras sufra la patria/ tanto martirio, paisanos, / y nuestros ranchos no sean/ algo más que pobres ranchos, / ¡Ay! porque nunca supimos, / a nuestra vez, ser hermanos, / se oirá ese grito, ese lloro, / Ese clamor desgarrado!” pp. 119-120.

-Escritos de Mariano Moreno, por Paul Groussac, pp. 121-160.

\section{Año I, Tomo I, julio, 1896. (2)}

-"La Biblioteca de Buenos Aires", por Paul Groussac, pp. 161-193. Continúa y concluye la historia de la institución que él mismo dirige. **

-Federalización de Buenos Aires, por Pedro Goyena (escrito en 1891), pp. 194-212.

-La Basílica de Luján, por Ulric Courtois, pp. 213-230. Se discute sobre el estilo arquitectónico de la Basílica será gótico- y sobre los motivos por los cuales erigirla. Señala Courtois: "Una basílica gótica brotando del suelo de la campaña de Buenos Aires, ayer pampa todavía, es un fenómeno que el filósofo debe de interpretar como uno de los tantos signos de la evolución actual, la cual, como es muy sabido, significa una regresión invencible hacia el espiritualismo. Aun los más escépticos, estamos hartos de ese estrecho materialismo o positivismo, que pretendió resolver el gran problema con suprimirlo; los que piensan y los que sienten buscan rumbos nuevos o retroceden a los antiguos. Volveremos algún día a ver correr la savia de lo ideal, como en el siglo de las Cruzadas?" p. 213.

-Los cosméticos. Historia e higiene, por Pedro N. Arata, pp. 231-257. Hace una historia del uso de cosméticos por los mujeres de Occidente y de Oriente, desde la Antigüedad hasta el Renacimiento.

-Coloquio de los centauros, por Rubén Darío, pp. 258-267.

-Documentos históricos [Sección]. El congreso americano de Lima. Correspondencia confidencial entre el Presidente B. Mitre y el Ministro en el Perú, don Domingo F. Sarmiento, pp. 268-290

-La rueda loca, por Paul Groussac, pp. 291-324 (relato).

\section{Año I, Tomo I, agosto, 1896. (3)}

-Autobiografía, por Vicente Fidel López, pp. 325-355.

-El arte en Buenos Aires- La evolución del gusto, por Eduardo Schiaffino, pp. 356-368. Este capítulo se denomina 'Iniciación'. Schiaffino reseña aquí la labor individual de una serie de artistas, dedicados fundamentalmente al retrato, quienes habían ido llegando a Buenos Aires des de 1826. Entre ellos: J. P. Goulu, Carlos E. Pellegrini, Fiorini, Raymond Monvoisin, D’Hastrel de Rivedoy, Ignacio Manzoni, Verazzi, Noel, Palliere, Novarese, Marcel, Duteil, Epaminonda Chiama, J. Agújari, Ernest Charton, C. Samsom, etc. Refiere Schiaffino la escasa circulación de las obras de estos pintores: "A pesar de que algunos tienen talento, y de que 
su obra en ciertos casos llega a ser numerosa, su influencia es lenta sobre la masa del público, por falta de exposiciones y de museos; tan sólo determinadas personas, contadas familias, se ponen en contacto con ellos, e introducen la vida misteriosa del retrato en los parcos interiores, animando así la parquedad de los muros" p. 358.

-Primera constitución argentina, por Clemente L. Fregeiro, pp. 369-385.

-El dique de San Roque, por Carlos Doynel, pp. 386-402.

-Folklore de la América Central. Representaciones sus bailes populares de Nicaragua, por Rubén Darío, pp. 403-409.

-Los cosméticos. Historia e higiene, por Pedro N. Arata, pp. 410-433.

-Documentos históricos:

Proyecto de Constitución de la Sociedad Patriótica Argentina para las Provincias Unidas del Río de La Plata en la América del Sud, pp. 434-451.

-El litigio anglo-venezolano, por Paul Groussac, pp. 452-487.

-Redactores de Biblioteca [Sección; aparece al final de cada tomo; incluye una reseña biobibliográfica acerca de los colaboradores] pp. 488-491.

Año I, Tomo II, septiembre - diciembre, 1896. [Buenos Aires, Librería de Félix Lajouane, Editor, 85 de la calle Perú]

Año I, Tomo II, septiembre, 1896. (4)

-Treinta años después, por Carlos Pellegrini, pp. 5-19 (escrito en julio de 1896) (a 30 años de la guerra del Paraguay)

-Sarmiento polemista. La campaña en el ejército Grande, por Martín García Mérou, pp. 20-38 (escrito en Petrópolis, en septiembre de 1895)

-Supresión de las aduanas, por Francisco Seeber, pp. 39-51.

-Orígenes de la imprenta argentina, por Bartolomé Mitre, pp. 52-77.

-El arte en Buenos Aires. La evolución del gusto. II Iniciación, por Eduardo Schiaffino, pp. 78-93. Continúa con el análisis de las obras de los pintores de los cuales no se ocupó en la primera parte de la que esta entrega es la continuación. ['Iniciación'].

-Tratados de comercio, por José A. Terry, pp. 93-110, escrito el 4/9/1896.

-Estética musical y conciertos sinfónicos, por Alberto Williams, pp. 111-118.

-Proceso histórico de la moral, por Enrique Kubly, pp. 119-133.

-Documentos históricos:

Un Liniers desconocido, pp. 134-143.

Se trata de documentos escritos por el conde Liniers, hermano de Santiago de Liniers, "mezclado en el teje y maneje de la política brasilera [sic] en el Plata, a raíz del movimiento de independencia." (p. 134). Aclara Groussac, en una nota al pie, que "parte de estos documentos se publicaron en la Revista de Buenos Aires, en 1864, pero tan desfigurado su texto, que podría dudarse fuera copia del mismo original. El nuestro es transcripción literal del manuscrito" p. 134. En esta entrega se transcribe la información sobre el conde, personaje según Groussac poco conocido, solamente mencionado por el general Bartolomé Mitre.

-El litigio anglo-venezolano, por Paul Groussac, pp. 144-160. (incluye un mapa político de 'South America' publicado por la compañía Arrowsmith en 1811)

\section{Año I, Tomo II, octubre, 1896. (5)}

-Mendoza en 1829 (fragmentos de memorias póstumas de Sarmiento), pp. 161-167.

-El Brasil intelectual. Impresiones y notas literarias, por Martín García Mérou, pp. 168-200.

"De las literaturas sud-americanas, ninguna es tan poco conocida entre nosotros como la de Brasil. De tarde en tarde con mayor o menor dificultad, jadeante y fatigado por la larga travesía, recibimos uno que otro libro de nuestros hermanos del Perú, de Méjico, de Venezuela o Colombia. Sin ser un caso común, a veces un nombre dotado de mayor resonancia, rompe la indiferencia reinante y vence la incomunicación intelectual que separa las secciones de nuestro continente. Sólo por una rara excepción, una obra nacida bajo una estrella propicia, 
adquiere entre nosotros carta de ciudadanía, como acontece con ese tierno idilio que Estrada tuvo el mal gusto de comparar con Graziela; y la María de Jorge Isaacs se convierte en el breviario amoroso de las cándidas imaginaciones de quince años. El grueso de la producción científica o literaria, la historia, la crítica, los estudios jurídicos, están destinados a reposar, como en una muda necrópolis, en las bibliotecas públicas o en medio de las colecciones valiosas de los eruditos de raza, que sólo muy raras veces hojean sus páginas polvorosas. Este triste destino, es el lote general de toda la labor intelectual del nuevo mundo. En cuanto respecta a nosotros, los únicos nombres literarios que han salvado las fronteras de la patria son los de Guido Spano y Andrade, para no referirme al de Mármol, algo envejecido, pero cuyas imprecaciones frente a Rosas despiertan todavía el entusiasmo de una parte de la juventud sudamericana. Las huellas de Sarmiento y Alberdi quedan grabadas en Chile, aunque menos vivientes que las de Andrés Bello; pero sería excusado buscar fuera de aquel país y del escaso número de iniciados a que acabo de referirme, quienes conozcan los Recuerdos de provincia o la Peregrinación de Luz del Día." pp. 168-169.

Señala las similitudes entre Brasil y EE.UU. respecto de "la influencia de las nuevas gentes, la facilidad del contacto con los pueblos del viejo mundo, las corrientes inmigratorias ... son otras tantas causas que en el Brasil concurren para que la acción del medio se debilite, en detrimento de la originalidad individual. Consecuencia de estos hechos, es el espíritu de imitación que estraga la cultura intelectual de aquella nación, como estraga la república del Norte" p. 172.

-El acetileno, por Ulric Courtois, pp. 201-218.

-Bibliografía americana. Libro de Bernal Díaz del Castillo. Solución de un problema bibliográfico, por Bartolomé Mitre, pp. 219-232.

-Marinas y paisajes americanos, por Paul Groussac, pp. 233-260.

Artículo que posee una nota al pie en la que su autor señala: "Si algún memorioso lector hubiera conservado de otras 'impresiones de viaje', publicadas en el diario La Nación, conviene advertirle que, ni por las regiones descritas ni por la forma adoptada, se confunden unas y otras. Con las primeras se procuró condensar, alrededor de la capital o ciudad significativa de cada región, sus rasgos sociológicos más importantes; las presentes son simples sensaciones del trayecto, apuntes de cartera, sin plan ni compostura, pero que, en cierto modo, forman en su espontaneidad el complemento de aquéllas. Por lo demás, unas y otras se encontrarán en un volumen en preparación." p. 233. El volumen fue Del Plata al Niágara.

-Filología americana. Lule y Tonocoté, por el "Prof." Matías Calandrelli, pp. 261-276.

-Lourdes y Rome de Emilio Zola, por Abel S. Pérez, pp. 277-298 (escrito en Montevideo, en agosto de 1896)

-Antecedentes institucionales. A propósito del libro Introducción al derecho argentino, por el Dr. J. A. García, Hijo, por Luis M. Drago, pp. 299-308.

-La paradoja de las ciencias sociales, por Paul Groussac, pp. 309-320.

"La comparación de una sociedad humana con un organismo es más antigua que Spencer, Bacon y el mismo Aristóteles: es anterior a toda enseñanza didáctica; ya se encuentra en Homero, casi al principio de la Ilíada, la analogía verbal de démas (cuerpo) con dêmos (pueblo), que parece revelar el parentesco y origen común. De ahí, en política, el cúmulo de imágenes y locuciones tomadas de las ciencias médicas. Puede que los sociólogos modernos se excedan en su cotejo de la circulación comercial con la vascular, o de la administración nacional con el sistema nervioso: en términos latos, el procedimiento es legítimo y guarda más ventajas que inconvenientes. Encuentro utilidad en estudiar, por ejemplo, el estado reciente de que convalece la República Argentina, como una enfermedad generalizada, una distrofia constitucional cuyo pronóstico depende de sus causas primitivas, y cuyo tratamiento, parecido al de la anemia globular, habría de ser muy prolongado, para alcanzar plena eficacia." p. 309. Y más adelante: "En estas páginas arriesgadas bajo mi sola responsabilidad, lo que critico, pues, no es tanto la clásica asimilación que he mencionado, cuanto su abuso peligroso en cuanto afecta a métodos y conclusiones" p. 310

"En mi sentir, la flagrante esterilidad de las 'ciencias políticas y sociales' -sobre todo de la economía- proviene de un fundamental error de método: se ha generalizado antes de tiempo." p. 310.

Año I, Tomo II, noviembre, 1896. (6)

-Notas y fragmentos inéditos, por Nicolás Avellaneda, pp. 321-348. 
-Lenguas americanas. El tupy egipciaco, por Bartolomé Mitre, pp. 349-363.

-Artemis, por Enrique Rodríguez Larreta, pp. 365-383.[relato]

-Recuerdos de la tierra [de M. Leguizamón], por Joaquín V. González, pp. 384-400. (octubre de 1896). Este mismo artículo es el que aparece como prólogo en la edición en libro. ${ }^{* *}$

-El Brasil intelectual, por Martín García Mérou, pp. 401-430.

-Marinas y paisajes americanos, por Paul Groussac, pp. 431-455.

-Estética musical y conciertos sinfónicos, por Alberto Williams, pp. 456-465.

-Documentos históricos: "Representación al rey nuestro señor por el capitán de nabio de la real armada Dn. Santiago de Liniers! Sobre las misiones tapes y guaraníes de las que se hallava governador interino en 28 de junio de 1804", pp. 366-473.

-Boletín bibliográfico [es la primera vez que aparece], por Paul Groussac, pp. 474-480. Está dedicado a Los raros de Rubén Darío.

\section{Año I, Tomo II, diciembre, 1896. (7)}

-El salto de Azcochinga, por Lucio V. López, pp. 481-492. Lleva una nota al pie en la que se explican los motivos de la publicación del escrito de López: "Deseosos de honrar la memoria del malogrado escritor, en este número de La Biblioteca, cuya aparición casi coincide con el segundo aniversario de su muerte, no hemos vacilado en reproducir el último escrito de Lucio López, -ya publicado en La Nación el 2 de noviembre de 1894 -dando la preferencia, sobre otros esbozos del todo inéditos, a este cuadro de costumbres, lleno de vida y colorido, en que se muestra el talento cabal del autor de La Gran Aldea. A tales páginas, no basta la publicidad efímera del diario. No dudamos que las vuelvan a leer con interés y admiración los mismos que las conocían; y es el caso de repetir aquel famoso verso Henault, atribuido a Horacio: Indocti discant et ament meminisse periti" p. 481.

-Filosofía de las revoluciones mexicanas, por Matías Romero, pp. 493-516.

-Sarmiento en París, por Miguel Cané, pp. 517-542. (París, octubre, 1896).

Alaba la figura de Sarmiento al que define como: "El soberbio viejo, que fue uno de los raros cultos individuales de mi vida" p. 517 Apostrofa a los lectores de la elite, especialmente a los jóvenes: "Vosotros los que tenéis en vuestras bibliotecas sin vida los ocho o diez tomos publicados de las obras de Sarmiento, haced un esfuerzo sobre vuestro horror de la letra de molde y abrid, por cinco minutos el volumen de Viajes. Y vosotros, jóvenes, los que os quejáis dolientes de que no hay atmósfera intelectual en nuestro país, hacedla revivir, volviendo a las fuentes puras e incomparables del pasado. Leed esos libros admirables, escritos hace más de medio siglo y que, como los de los más grandes maestros conservan en sus líneas y en su color una frescura jamás igualada en el correr de los tiempos (...) Leed, leed esos libros, jóvenes, y veréis con qué orgullo sentiréis el alma de nuestra raza palpitar en sus páginas. Son libros genuinamente nuestros, que no han podido ser escritos en otra parte y que constituyen, hoy por hoy, la nota más clara y luminosa para ayudarnos a comprender la gestación caótica de nuestra nacionalidad. No os hablo de moral, no os hablo de patriotismo, no os hablo de que esa lectura pueda determinaros pequeños Sarmientos (...): os hablo de arte, os hablo de la única manera posible de resucitar entre nosotros esa atmósfera intelectual por la que lloráis; os insto a entrar en esos libros, como empujo a todos los jóvenes argentinos que hay en París, a ir al Louvre, al Colegio de Francia o a la Facultad de Letras, para que se den cuenta que hay otras cosas en el mundo que el oficio de abogado, la chicana política, la operación de bolsa o el casamiento ventajoso" p. 158.

-Inacción y ejercicio, por Bartolomé Novaro, pp. 543-558. Este escrito es interesante porque señala -en una forma sui generis- el furor educativo que por esos años constituye una de las políticas centrales del Estado argentino.

"La República Argentina se preocupa mucho del cultivo de la inteligencia de sus habitantes. Los palacios que más hermosean su capital, y las principales ciudades de las provincias, son monumentos levantados por ellas a la instrucción primaria. Están llenos de niños que van a adquirir las primeras nociones del saber humano; a que se les encienda en la frente la luz que ha de disipar las nieblas naturales de la ignorancia.

Al ver la obra realizada en esta clase de instrucción, se siente deseo de evocar con gratitud las sombras de Sarmiento y de Zorrilla, que descansan en la eternidad; de estrechar la mano a Carlos Guido Spano, a José 
María Gutiérrez y a sus inteligentes colaboradores, por lo que hicieron ya y continúan haciendo en favor de la educación primaria nacional.

La instrucción secundaria, aunque no tan lujosamente instalada, cuenta con numerosos Colegios nacionales, con los colegios incorporados a ellos, y los institutos libres, que también están repletos de jóvenes que profundizan los conocimientos adquiridos en las escuelas. En estos colegios el cultivo de la inteligencia empieza a forzarse demasiado. El cerebro de los jóvenes, incompletamente desarrollado, es casi torturado para saturarlo con el vasto saber que exigen los tremendos programas de los cursos secundarios. Se estudia mucho en los Colegios nacionales, y tanto, que el último mes del año los alumnos presentan todos los signos del sistema nervioso muy fatigado, y a veces enfermo, por los esfuerzos intelectuales exagerados, las vigilias, los insomnios, y las emociones profundamente depresivas de los exámenes anuales, que suelen ser excesiva y hasta cruelmente rigurosos.

La instrucción superior tiene dos grandes universidades: la de Buenos Aires y la de Córdoba, con sus facultades bien organizadas, con cátedras numerosas. Allí los jóvenes tienen generalmente que estudiar más que en los Colegios nacionales, más que si siguieran los cursos de las universidades más afamadas de la Europa y la América. (...)

Las escuelas normales de profesores y de maestros, las escuelas de comercio, etc., muy concurridas también, son instituciones de la mayor utilidad, donde se hace trabajar mucho al cerebro, para ponerlo en condiciones de dirigir la enseñanza de las nuevas generaciones, o de tomar parte en el mundo de los negocios y de la fortuna.

Los éxitos notables obtenidos en el ejercicio de las profesiones científicas y literarias, así como la vasta enseñanza de las escuelas, los colegios y las universidades; las frecuentes sesiones de las sociedades que se ocupan de letras y de ciencias; todo lo que se imprime, y que se lee, demuestran que se ejercitan bastante, si no en demasía, las facultades intelectuales de los argentinos.

Esta observación no daría lugar a ninguna crítica, y hasta podría se motivo de nuestro legítimo orgullo, si este afán de perfeccionar el pensamiento y el cerebro fuese acompañado de algún conato oficial para perfeccionar también las otras funciones y los otros órganos del cuerpo." pp. 543-545.

-El socialismo y el derecho civil, por Carlos Rodríguez Larreta, pp. 559-583.**

-Marinas y paisajes americanos, por Paul Groussac, pp. 584-603.

-Documentos históricos:

Política electoral. Correspondencia confidencial entre el General Mitre y el Doctor Irigoyen, pp. 604-617.

-Boletín bibliográfico:

Dedicado a Lecciones de filosofía general de E. J. Weigel Muñoz, pp. 618-629. Groussac sentencia a Weigel Muñoz por el libro que ha dado a publicidad: "Se atribuye a Richelieu aquel chiste fúnebre: 'Me bastarían seis renglones del hombre más honrado, para hacerle ahorcar'. Muy lejos estamos d perseguir el 'ahorcamiento del señor Weigel Muñoz -aunque sólo fuera en efigie universitaria- pero no es dudoso que bastaría la lectura de su dedicatoria al doctor Eduardo Costa, ante una junta de Sorbona, para hacerle condenar a la última pena filosófica." p. 618 Señala que parte de un error el de suponer que la filosofía puede no ser general; dice Groussac: "la filosofía es general por definición, siendo 'la ciencia de las ciencias', y entonces la presente redundancia equivale a decir: álgebra matemática v.g., o cosa por el estilo” p. 619. Luego pasa a desguazar las cuatro primeras lecciones del libro.

Redactores de La Biblioteca, pp. 631-638.

Año II, Tomo III, enero-marzo, 1897. [Buenos Aires, Librería de Félix Lajouane, Editor, 85 de la calle Perú; se sigue imprimiendo por Coni]

Año II, Tomo III, enero, 1897. (8)

-Ricardo Gutiérrez, por Juan A. Argerich, pp. 5-22.

-La Batalla de Angaco. Episodio de la guerra civil de 1841, por Ernesto Quesada, pp. 23-53.

-Inacción y ejercicio, por Bartolomé Novaro, pp. 54-67.

-El Brasil intelectual, por Martín García Mérou, pp. 68-95.

-La música y las distintas escuelas, por Francisco Seeber, pp. 96-111 (Bayreuth, 19/81894). 
-Santiago de Liniers, por Paul Groussac, pp. 112-126.

-Fragmento del poema "La Magdalena" de Ricardo Gutiérrez, pp. 127-136. (París, 1874).

-Génesis del héroe, por Paul Groussac, pp. 137-151. Este es un capítulo de El problema del genio en la ciencia y en la historia que Groussac preparaba por ese tiempo. Siempre preocupado por el método, Groussac señala que se ha puesto especial esfuerzo en separar "netamente al hombre de genio, propiamente dicho, de esas colosales personificaciones populares -fundadores, profetas, conquistadores- a quienes el epíteto flotante de 'grandes hombres' se adhiere comúnmente" p. 137. En ese mismo sentido metodológico agrega inmediatamente después: "he procurado aplicar a esta vasta cuestión de psicología histórica el método científico, de que el ilustre Luell ha dado el ejemplo y el modelo más acabado en sus Principios de geología: la hipótesis fecunda de las causas actuales" p. 137. Para Groussac el genio es una facultad, un "poder aislado y exclusivo, que se distinguen del talento habitual" (p. 138), "propiedad, distinta y una verdadera 'forma' intelectual" (p. 140), "entraña quizá la ley secreta de la vida -la voluntad de Schopenhauer: -pues es él quien crea sin descanso y encuentra en la obra maestra realizada su sanción inmortal" (p. 140). Por su parte el 'grande hombre' que Groussac identifica con el 'héroe' de Carlyle, los "los hombres inmensos y fulgurantes de la historia y de la poesía" (p. 142), aquellos cuya existencia -en términos de Carlyle- condensa la de la humanidad. (p. 142). A falta de una obra maestra personal, la "grandeza representativa de los 'héroes' es del todo extrínseca y convencional" y se cifra en "la opinión colectiva de las generaciones, prolongada y desbordante" (p. 143).

Este escrito de Groussac es muy significativo por lo que se refiere a sus opiniones sobre la democracia. **

-Boletín bibliográfico:

Dedicado a Recuerdos de la tierra de Martiniano Leguizamón y Prosas profanas de Rubén Darío, por Paul Groussac, pp. 152-160.**

\author{
Año II, Tomo III, febrero, 1897. (9) \\ -Juan María Gutiérrez, por Juan B. Alberdi, pp. 161-192. \\ -El régimen colonial, por Juan A. García, (h), pp. 193-209. \\ -El Puente del Inca y sus termas, por Pedro N. Arata, pp. 210-232. \\ -El Brasil intelectual, por Martín García Mérou, pp. 233-260. \\ -Estética musical y conciertos sinfónicos, por Alberto Williams, pp. 261-270. \\ -Santiago de Liniers, por Paul Groussac, pp. 271-312. \\ -Documentos históricos: \\ Diario inédito por Don Pedro A. Cerviño, del ataque de los ingleses desde el 17 hasta el 30 de junio de 1806, \\ pp. 313-324.
}

Año II, Tomo III, marzo, 1897. (10)

-Sistemas de filosofía, por Adolfo Alsina, pp. 325-343 (Montevideo, 7/01/1850).

Nota al pie: "Este discurso, que no figura en la edición de las obras de don Adolfo Alsina, presenta bajo una faz imprevista al ilustre caudillo y orador popular. Cierto que es su primera producción, como que lo pronunció, en Montevideo, el 8 de enero de 1850, en los exámenes generales de filosofía del Colegio Nacional que allí dirigía el benemérito don Luis J. de la Peña. Nadie esperará, pues, encontrar en estas páginas ideas originales; pero acaso sorprenda a algunos la firmeza de la convicción y la claridad precisa de la forma. Por instantes, el sentido práctico de la vida y el deber cívico asoman en medio de las fórmulas escolares, y se entrevé al político futuro bajo el niño precoz." p. 325

-El Doctor Antonio E. Malaver, por Eduardo L. Bidau, pp. 344-361.

-La pesquisa, pp. 362-380. En nota al pie: "El autor de este cuento ha querido guardar el anónimo -y tan sinceramente, que nosotros mismos ignoramos su nombre. La persona respetable que nos comunicó el manuscrito nos lo dio como el estreno literario de un joven argentino. Deseaba conocer nuestra opinión y la expresamos con publicar su ensayo, a pesar de revelar cierta inexperiencia y no corresponder del todo al principio la conclusión. No dudamos que $* * *$ reincida en la tentativa y que, con ocasión de otro trabajo, nos permita publicar su noticia biográfica." p. 362. El autor no es otro que el mismo Groussac.[El cuento apareció 
en dos antologías: Cuentos policiales, Buenos Aires, Calicanto, 1977, pp. 71-74; El cuento policial, Buenos Aires, CEdAL, 1981, pp. 7-22]

-La música el en arte de curar, por Diego T. R. Dávison, pp. 381-398.

-En la caverna de Mammoth, por Carlos A. Aldao, pp. 399-413.

-Poemas de América, por Rubén Darío, pp. 414-421. [un poema sin nombre y Tutecotzimi]

-Santiago de Liniers, por Paul Groussac, pp. 422-458.

-Documentos históricos:

"Carta del Alcalde de primer voto del cabildo de Buenos Aires, para S. M. Acompaña documentos que explican episodios anteriores a la toma de aquella ciudad y de Montevideo por los ingleses y en que intervinieron personas que se significaron más tarde en la independencia del virreynato" pp. 459-476.

-Boletín bibliográfico:

Dedicado a la Reseña histórico-descriptiva de antiguas y modernas supersticiones del Río de Plata, de D. Daniel Granada, pp. 477-481.

-Redactores de La Biblioteca, pp. 482-487.

Año II, Tomo IV, abril-junio, 1897. [Buenos Aires, Librería de Félix Lajouane, Editor, 85 de la calle Perú; se sigue imprimiendo por Coni]

Año II, Tomo IV, abril, 1897. (11)

-Asalto y toma de la ciudad de Santa Fe. Fragmento de las memorias inéditas del General Iriarte, pp. 5-27.

-Cabildos coloniales, por Miguel A. Montes de Oca, pp. 28-60.

-Letras americanas, por Bartolomé Mitre, pp. 61-77. El artículo comienza con un pequeño encabezado que resume su contenido: “¿Existe una literatura americana? - Examen de los antecedentes de la cuestión. - Lo que es una literatura de conjunto. -¿Es posible escribir un curso metódico de literatura americana, por razón de la geografía o de las lenguas. - Balance de la literatura hispanoamericana. - Corolarios crítico históricos y conclusiones." p. 61. Dice Mitre: "Una literatura, tal como la considera la crítica moderna, es una ciencia experimental, que se funda en hechos tales como la historia, o bien una ciencia positiva, que deduce de los hechos una teoría. Reducida a sus elementos, es un arte, o bien una exposición de reglas didácticas que de ella se deducen..

Puede la literatura no componerse sino de un solo libro como la Biblia (el libro) que comprende la cosmogonía, la religión, la historia, la poesía, la moral y la filosofía de un pueblo; pero esta es la excepción. En abstracto, es el producto sucesivo de la intelectualidad de una nación o de una raza en el transcurso del tiempo, simbolizado por una lengua común que le sirve de vehículo, que lo sintetiza y constituye una originalidad, o más bien dicho, una genialidad colectiva." pp. 63-64. La historia literaria es una parte de la historia general. "Los cursos de literatura deben tener, como razón de su unidad, o bien la lengua o el género, o bien los enlaces filosóficos que constituyen un cuerpo lógico y compacto de doctrina." p. 68. "En literatura, como en población, la América española está todavía en estado de colonización. Hay muchos vacíos que llenar, así en sus territorios como en sus cabezas (...) en su suelo fecundo, pero erial, donde se aclimatan y modifican productos importados bajo la acción de un nuevo medio, que a su tiempo asumirán su forma original y definitiva." p. 70. Analiza los distintos géneros y en cuanto a la novela señala: "Lo poquísimo que en este género puede presentar como muestra, carece en absoluto de invención, de observación, de originalidad y de interés, y sobre todo de aliento continuo. Se ha pretendido vestir esta indigencia con la María de Jorge Isaacs (deplorable poeta), que se ha comparado con Pablo y Virginia y Atala, que es una narración trivial en su estructura, sin argumento y sin interés, sin emoción ni psicología, de estilo empalagoso, en la que se ha querido pintar la vida campestre del ameno valle de Cauca, pero sin dibujo ni colorido, reemplazando los cuadros de su naturaleza tropical por la nomenclatura árida de los objetos, y que no resiste al fastidio enervante de su lectura. $\mathrm{Si}$ esta fuese la obra maestra de la literatura hispanoamericana, como se pretende, podría deducirse de ella el grado inferior de las de su especie; pero debe decirse, en justicia, que hay varias muy superiores a esa producción clorótica, sin sangre y sin color." Más adelante: "Y lo que digo que se llama literatura hispanoamericana, -que no tiene un drama, un poema, una novela, ni un ensayo filosófico de cuenta,- lo digo 
de lo que se llama literatura argentina, que recién se va formando, pero que todavía no forma un conjunto que merezca este nombre, ni aún para los simples efectos de la clasificación de los géneros.76-77.

-Higiene pública. Saneamiento de Mendoza, por Samuel Gache, pp. 78-87.

-El método histórico en las ciencias jurídicas, por Antonio Dellepiane, pp. 88-103.

Se trata de la lección inaugural de la cátedra Filosofía del Derecho.

-Manuel Gutiérrez Nájera, por Luis Berisso, pp. 104-118.

El artículo comienza con una cita del Prólogo a las Poesías de Gutiérrez Nájera de Justo Sierra.

En la retórica modernista Berisso traza una semblanza de Gutiérrez Nájera: "La vida del duque Job -era este su seudónimo,- podría concretarse así: una aspiración sin término a los cielos del Ideal. Diríase que no reconocía nada más alto después de Dios, que la divina Poesía" p. 105. Parafraseando a Rubén Darío, Berisso sostiene: "Su cuerpo era de Méjico y su alma de París. Impregnóse su espíritu de Parisina a punto de que su producción se confundiría con la de un escritor francés si no fuera el tema local. En prosa, lírico o ligero, un periodista boulevardier; en verso, un insigne banvillista, en su mejor período. En sus primeras poesías vese algo como una predilección por Alfredo de Musset" p. 106. Más adelante: "Y este exquisito soñador, que no había nacido para las 'plebeyerías republicanas', pagó también tributo a la política. Tuvo que andar del brazo de esa cortesana rica, caprichosa y voluble. El brillo de las armas y la oratoria tiene para las multitudes inconscientes mayor fulgor que el de las letras. Los entorchados del militar se reverencian más que un gajo de laurel simbólico." p. 107. Analiza su labor de periodista pero sobre todo se detiene en sus poesías: "Ondas muertas", "Mariposas" y otras.

-Santiago de Liniers, por Paul Groussac, pp. 119-162.

-Boletín bibliográfico:

Dedicado a Lecciones sobre historia argentina de José Manuel Estrada, pp. 163-164. El tomo compila las lecciones que Estrada pronunció en el Colegio nacional en 1868.

\section{Año II, Tomo IV, mayo de 1897. (12)}

-Rozas. Ensayo histórico-psicológico, por Lucio V. Mansilla, pp. 165-174. Estas páginas constituyen el Prólogo del libro de Mansilla.

-Constituciones y partidos, por Juan A. Argerich, pp. 175-205.

-La diplomacia de la Revolución, por Miguel Cané, pp. 206-221.

-Rivadavia, por Nicolás Avellaneda, pp. 222-240. En nota al pie: "Estas páginas inéditas (las últimas sin duda del eminente escritor) parecen trazadas rápidamente - muchas de ellas con lápiz en hojas volantes de varios formatos como en el primer arranque de la improvisación. Descifrado el manuscrito, se descubre que el supuesto borrador reviste forma acabada en su soltura oratoria, y que el firme pensamiento se desenvuelve sin hesitación, hasta completar, no sólo el retrato vivo del personaje, sino el resumen sinóptico de medio político y social: el esbozo resulta pintura. Fuera de su valor propio, tiene, pues, este escrito el de un documento psicológico. Demuestra que pertenecía Avellaneda a la familia de los escritores que llamaremos 'peripatéticos', -cuyo jefe es Rousseau,- los que tienen la facultad de componer mentalmente sus producciones antes de darlas a luz: de tal suerte que, llegada la hora, su primera redacción es definitiva. Breve o larga, la gestación es suficiente para que el organismo literario nazca completo. Así se explica cómo los manuscritos de Avellaneda, a pesar de sus escrúpulos de artista, no presentan más enmiendas ni borraduras que los de Sarmiento -improvisador genial, a lo Diderot. Estos últimos crean ex nihilo al escribir, y sus ideas nacen realmente al ritmo tumultuoso de la pluma que rebota sobre el papel. (Nota de la dirección)".p. 222.

-Lucía Miranda, por Damián Menéndez, pp. 241-246. El artículo lleva una 'Nota de la Dirección' en la se remite a otras fuentes que tratan sobre este personaje, a saber Siripo de Lavardén y Estudios biográficos y críticos de Juan María Gutiérrez- Es importante señalar el hecho de que incluso los trabajos no firmados por Groussac están sujetos a su inspección, si no ya para enturbiar la opinión de sus autores, sí para agregar información.

-El hombre de oro, por Rubén Darío, pp. 247-261.

-Esteban Echeverría. La Asociación de Mayo y el Dogma Socialista, por Paul Groussac, pp. 262-297. (octubre de 1882). En nota al pie Groussac aclara: "Estas páginas forman parte de una manuscrita, terminada y 
encuadernada desde 1882. Este solo hecho muestra al menos que el autor no cultiva ilusiones exageradas acerca de la eficacia de sus escritos y la urgencia de su publicación. En el presente, se notarán, junta a cierta exuberancia y verdor juvenil, muchas inexperiencias que preferimos no corregir: quod scripsi, scripsi. Es ocioso advertir que, sobre el fondo de la cuestión, nuestro criterio actual sería mucho menos afirmativo. Pero la juventud no duda; afirma o niega. ¡Dichosa juventud!” p. 262. Este escrito de Groussac fue duramente criticado por José Ingenieros en La Montaña, en el $\mathrm{n}^{\circ}$ 6, aparecido en el mes de junio de ese mismo año de 1897, un mes después de publicado el escrito de Groussac.

-Documentos históricos: pp. 298-316.

"Oficio del Comandante General de la Expedición Reconquistadora Don Santiago de Liniers, al excelentísimo Señor Príncipe de la Paz, Generalísimo de los reales Ejércitos y armadas", y otros documentos, entre los cuales se cuentan una "carta de Liniers a la princesa Carlota J. de Borbon", una "representación del Señor Liniers pidiendo al rey tenga a bien el no nombrarlo virrey".

-Boletín bibliográfico:

-Polémica de la Triple alianza entre el general Mitre y el doctor Juan Carlos Gómez, pp. 317-324.

-Escritos póstumos de Juan B. Alberdi, pp. 324-327. Groussac recuerda que antes de la publicación de este libro, su revista fue la que dio a conocer algunos de los manuscritos inéditos de Alberdi. Aclara también el criterio de selección del material publicado: "Es conocida nuestra elección: desechamos las obras de cólera y represalias, prefiriendo su estudio afectuoso y penetrante sobre Juan M. Gutiérrez; y al hacerlo, tuvimos la conciencia de servir igualmente los intereses del público y los de esa ilustre cuanto combatida memoria. En esos mismos días salía a luz un nuevo volumen póstumo sobre el Gobierno de Sud-América, extraña lucubración, inspirada al parecer por la deplorable aventura del imperio mexicano, -y poco digna del luminoso escritor de las Bases. Guardamos silencio, no teniendo bien alguno que decir." pp. 325-326. Groussac señala el criterio equivocado, pues no hace justicia al talento ni a la inteligencia de Alberdi, de publicar Belgrano y sus historiadores y Facundo y sus biógrafos.

Traducciones de Leopoldo Díaz, pp. 327-328. Groussac destruye el propósito que guía al libro de Díaz: "La traducción en verso, como todos los géneros literarios, tiene sus leyes propias: la primera de todas es que no se debe intentar." p. 327. Critica la forma en que traduce a Poe: "Al señor Díaz, que ha traducido el Cuervo de Poe, recomendámosle que medite las páginas curiosas - The Philosophy of Composition- en que dicho poeta analiza su propio poema, indicando las razones sutiles que tuviera para la elección del símbolo, del ritmo, de los consonantes reduplicados, por fin del sordo y lúgubre nevermore (de tono tan opuesto al sonoro y claro nunca más!) que termina cada estrofa como toque de agonía)" p. 328.

\section{Año II, Tomo IV, junio, 1897. (13)}

-Los Estados Unidos en Sud-América. La doctrina Monroe y su evolución, por Roque Sáenz Peña, pp. 329-346.

-Conquista del Río de La Plata (1535-1555), por Luis L. Domínguez, pp. 347-365. El texto es la introducción de Domínguez a la traducción del volumen homónimo del artículo, la fue escrita por encargo de la Sociedad Hakluyt de Londres. "Se publica por primera vez el texto original en castellano". p. 347.

-La propiedad raíz en Buenos Aires en el siglo XVII, por Juan A. García (hijo), pp. 366-383.

-El hombre de oro, por Rubén Darío, pp. 384-396.

-La diplomacia de la revolución. El director Pueyrredón y el emisario Le Moyne (Nuevos documentos), por Miguel Cané, pp. 397-425.

-Jesús, por Pedro B. Palacios, pp. 426-435.

-Santiago de Liniers. Digresión polémica, por Paul Groussac, pp. 436-480. "El señor Mitre, cuya Historia de Belgrano necesita consultar muy a menudo todo aquel que de estas materias argentinas se ocupe, ha dignádose prestar atención a ciertas críticas menudas que de pasada hemos creído útil apuntar. A decir verdad, hubiéramos preferido que el ilustre historiador se diese espera hasta la conclusión de este trabajo antes de salir, a la defensa de sus opiniones. A no haberse abierto el ingrato paréntesis, esta sería la hora en que, sin duda para solaz de nuestros lectores, terminaríamos nuestro bosquejo del virreynato de Liniers y el trágico alborear de la Independencia. Pero, iniciado el debate en la forma que más reproducimos, y dada la calidad excepcional 
de su autor, nadie extrañará que, nuestra costumbre de guardar silencio ante objeciones casi siempre superficiales y desinteresadas, interrumpamos el relato para acudir a la brecha.

La forma de esta réplica habrá de ser forzosamente minuciosa y pedestre, teniendo que seguir paso a paso el itinerario marcado por nuestro respetable impugnador. Para no acrecentar lo árido de la discusión, -y también evitar las citas truncas que sirven de pretexto para eternizar las polémicas, -juzgamos conveniente transcribir in extenso el interesante trabajo del Señor Mitre (el cual, digámoslo entre paréntesis, tenía en la Revista que se honra con tan valiosa y asidua colaboración). Así el lector tendrá a la vista todo el expediente y podrá sin esfuerzo escoger entre las dos versiones contradictorias." pp. 236-237. Es importante marcar la voluntad que asoma en esta cita por parte de Groussac de generar y poner en escena una polémica, más forzada que real, respecto del pasado argentino, sobre todo como estrategia de Groussac para mostrar la clase de lectores y colaboradores de su revista.

-Documentos históricos:

Información de testigos sobre la ocupación del Cañón tomado a la columna de enemigos ingleses el día cinco de julio enfrente de las casas de temporalidades, y al salir de la plazuela de la ranchería. pp. 481-490.

-Redactores de La Biblioteca, pp. 490-495.

Año II, Tomo V, julio-septiembre, 1897. [Administración de La Biblioteca, Perú, $\mathrm{n}^{\circ}$ 79; se sigue imprimiendo por Coni e hijos].

Año II, Tomo V, julio, 1897. (14)

-El estanco del alcohol, por Carlos Pellegrini, pp. 5-43.

-Los estados Unidos en Sud-América. La doctrina Monroe y su evolución, por Roque Sáenz Peña, pp. 65-53.

-Derecho constitucional. Se trata el tema de la posibilidad de acusación de funcionarios ante el Senado, por

José M. Guastavino, pp. 54-74.

-Primeros descubrimientos en el Nuevo Mundo, por Luis L. Domínguez, pp. 75-93.

-La diplomacia de la revolución. El director Pueyrredón y el emisario Moyne, por Miguel Cané, pp. 94-121.

-Marinas y paisajes americanos, por Paul Groussac, pp. 122-148.

-La musa colonial. Sonetos inéditos del siglo XVIII, por Juan Baltazar Maziel, pp. 149-154.

-Boletín Bibliográfico:

Tesis de la Facultad de Derecho y Ciencias Sociales (1897). Este artículo es importante por lo que en él observa Groussac la conformación y formación intelectual de la dirigencia política argentina. "El diploma doctoral no conduce solamente al ejercicio patentado de la abogacía: es un verdadero mandarinato que confiere a su feliz poseedor el botón de cristal, habilitándole sin otro título para todas las funciones políticas y administrativas, para todas las magistraturas de la inteligencia. El grupo forense constituye la clase dirigente, casi tan exclusiva y cerrada como una casta sacerdotal. Salvo contadas excepciones, que derivan su influencia personal de otro prestigio todavía predominante en Sud-América, han sido y son abogados -es decir doctores, que aquí ambas dignidades se confunden -casi todos los que hablan y escriben de materias generales, casi todos los que en la prensa, el parlamento, la administración, el libro y la cátedra, se presentan como pilotos de la nave argentina y asumen la dirección de sus destinos. En el presente y en el futuro próximo, tendrán que salir del cuerpo privilegiado de nuestros hombres de pensamiento y acción; y ya se trate de resolver los arduos problemas sociales, ya de enseñarnos historia, letras o filosofía, será título de suficiencia, -en todos los sentidos de la expresión-, el testimonio de ser doctor utriusque juris y haber oído en las lejanas mocedades la palabra de un maestro que acababa de ser discípulo." pp. 154-155. A partir de las más de 72 tesis que contiene el volumen Groussac realiza una serie de consideraciones acerca de "nuestra educación superior".

\section{Año II, Tomo V, agosto, 1897. (15)}

-Cartas al señor don Matías Romero, pp. 161-169. [ministro plenipotenciario de México en Washington, del cual se había publicado en diciembre de 1896 un trabajo sobre las revoluciones mexicanas] Son cartas que Sarmiento le escribió a Romero.

-Evolución de la democracia argentina, por Francisco Ramos Mejía, pp. 170-201. 
-La telegrafía sin hilos, por Jorge Duclout, pp. 202-226. Excitado por los logros de la ciencia, Duclout se asombra: “... nos vienen ahora los diarios de Europa llenos de otra maravilla: se sabe telegrafiar a 15 kilómetros sin hilos que liguen los aparatos, sin vinculación aparente alguna; se dice que, a la misma distancia, va a poderse hablar por teléfono sin hilos; sin que nunca se ponga mala la línea" pp. 202-203; luego exclama: "¡Nuevo triunfo de la ciencia pura y nueva derrota de los eternos prácticos, que confunden la seguridad con la rutina y temen perder el tiempo, dedicándolo al estudio de los fenómenos sólo interesantes bajo el punto de vista científico sin directa aplicación inmediata (...)". Finalmente, antes de explicar la teoría que funda estas aplicaciones prácticas dice: "Parece cuento de hadas, lo que es clara y potente verdad" p. 203.

-Problemas constitucionales, por José M. Guastavino, pp. 227-256.

-La diplomacia de la Revolución. El director Pueyrredón y el emisario Moyne, por Miguel Cané, pp. 257-276.

-La voz contra la roca, por Leopoldo Lugones, pp. 277-286.

-El Centenario, por Paul Groussac, pp. 287-305.**

-Documentos históricos, pp. 306-316, escritos por Santiago de Liniers.

-Boletín Bibliográfico:

Evoluciones navales y táctica de combate de Manuel José García, pp. 317-320.

Año II, Tomo V, septiembre, 1897. (16)

-Excursión al río Salado y al Chaco, por Amadeo Jacques, pp. 321-359.

-Estudios de Historia Argentina, por Ramón J. Cárcano, pp. 360-371.

-Los negocios en Buenos Aires durante el siglo XVII, por Juan A. García (hijo), pp. 372-394.

-Derecho constitucional, por J. A. Guastavino, pp. 395-408.

-La diplomacia de la Revolución, por Miguel Cané, pp. 409-432.

-El hombre de oro, por Rubén Darío, 433-442.

-Alcoholismo y suicidio en Buenos Aires, por Fermín Rodríguez (H) pp. 443-466.

-El drama romántico. Hernani, por Paul Groussac, pp. 467-474. Comienza con la crítica al libro de Pierre Nebout que también lleva el título Le Drame romantique que salió en París por la esa misma época en que Groussac escribió ese artículo. Luego introduce su propia versión del asunto, para lo cual transcribe una crónica que había escrito para La Nación el 8 de agosto de 1896. Simula un diálogo entre Procurante y Pangloss, personajes del Cándido.

-Redactores de La Biblioteca, pp. 475-483.

Año II, Tomo VI, octubre-diciembre, 1897. [Administración de La Biblioteca, Perú, $\mathrm{n}^{\mathrm{o}}$ 79; se sigue imprimiendo por Coni e hijos].

Año II, Tomo VI, octubre, 1897. (17)

-Cartas a Avellaneda, por Domingo F. Sarmiento, pp. 5-42. Están precedidas por una pequeña introducción, en la que como en las notas al pie y en otros textos de presentación, Groussac expone sus criterios. Señala esta noticia la importancia de las cartas como documentos históricos, y en tanto estrategia implementada por otras revistas de renombre, procedimiento por el cual $\mathrm{La}$ Biblioteca -que ha publicado anteriormente otras correspondencias- se acerca al prestigio de aquellas: "La correspondencia de los escritores célebres ha sido siempre leída con deleite, como una producción literaria; sólo en este siglo puede decirse que la carta real, espontánea, escrita únicamente para el destinatario, ha ascendido a su merecido rango de documento histórico y psicológico, superior a cualquier otro. Considérase hoy que de Cicerón y Voltaire, la obra más viva y subsistente es su correspondencia; Taine ha dicho que daría las Décadas de Tito Livio por las cartas y apuntes que le sirvieron para escribirlas; Carlyle ha dado a luz la mejor historia de Cromwell, publicando íntegra la correspondencia del Protector, con un comentario intercalado. Por fin, a nadie escapa, para tomar un solo ejemplo entre los periódicos contemporáneos, que la Revue de Paris ha debido su éxito más justificado y duradero a la publicación de algunas correspondencias inéditas. Saben nuestros lectores que La Biblioteca ha prestado, desde sus comienzos, atención preferentemente a tales documentos, dándolos a luz en su integridad, sin retoques ni atenuaciones, como que no se trata al fin de corregir ni afeitar una fisonomía literaria sino de 
allegar documentos inatacables al historiador futuro. caso se tenga para ello que vencer ciertas preocupaciones existentes, acerca de los derechos y deberes del biógrafo. Entretanto, proseguimos nuestra útil y bien intencionada tarea, contando para ello con el concurso de nuestros lectores ilustrados. Publicaremos próximamente algunas cartas inéditas de Avellaneda que corresponden en cierto modo a las presentes. No necesitamos poner de relieve el interés especial de algunas de éstas; nos limitamos a breves indicaciones para aclarar ciertas alusiones o conjeturar las fechas que faltan. Sabido es que las cartas siguientes se refieren a períodos importantes de la vida de Sarmiento; podrían formar cuatro grupos: $1^{\circ}$ el gobierno de San Juan; $2^{\circ}$ la misión de los Estados Unidos; $3^{\circ}$ la presidencia; $4^{\circ}$ la presidencia de Avellaneda." p. 5.

-Sanatorio en la Sierra de Córdoba, por Samuel Gache, pp. 43-54. Es importante señalar respecto del comienzo de este trabajo, algo que se repite también en otros, y que tiene que ver con la conciencia de la incidencia o la efectividad de publicar en la revista de Groussac. La revista se presenta como el espacio audible para la discusión de cuestiones de políticas estatales, en este caso, la necesidad de que el Congreso sancione el proyecto de construcción de un sanatorio para tuberculosos en Córdoba. Dice Gache: “(...) quiero proseguir hoy aquella iniciativa, a cuyo efecto ampliaré mi pensamiento, en la esperanza de que el Congreso se servirá considerar el asunto y resolverlo favorablemente" p. 43.

-Los Estados Unidos en Sud-América. La doctrina de Monroe y su evolución, por Roque Sáenz Peña, pp. 55-67.

-Sic transit..., por. Lucio V. Mansilla, pp. 68-74.

-El Brasil intelectual, por Martín García Mérou, pp. 75-95.

-El Hogar desierto, por Paul Groussac, pp. 96-126. [Había salido como folletín e el diario Sudamérica]

-Defensa y triunfo del Tucumán por el general Belgrano, por Ambrosio Morante, pp. 127-151. Es una obra de teatro -"pieza militar", como lo consigna su autor en el subtítulo- en dos actos. De tema histórico. Al lado del resumen de los nombres de los personajes se lee la lista de los actores que los representaron.

-Bibliografía retrospectiva. El actor Ambrosio Morante, por Paul Groussac, pp. 154-160. Groussac atribuye y fecha la obra, resume los episodios fundamentales de Morante como autor teatral y como actor.

\section{Año II, Tomo VI, noviembre, 1897. (18)}

-Un discurso y un artículo de Vélez Sarsfield, pp. 161-172. Se trata de dos escritos inéditos de Dalmacio Vélez Sarsfield: uno, un discurso pronunciado en el Congreso constituyente de 1826, el 256 de febrero; el otro, es un artículo ("Aislamiento de las Provincias argentinas") publicado en El Nacional, el 18 de mayo de 1852, al poco tiempo de haberlo fundado Vélez Sarsfield.

-El Doctor Vélez Sarsfield, por Nicolás Avellaneda, pp. 173-189.

-Acrecentamiento de los gastos nacionales en la República Argentina, por Alberto B. Martínez, pp. 190-217.

-El Brasil intelectual, por Martín García Mérou, pp. 218-242.

-La memoria de los muertos, por Diego T. Dávison, pp. 243-269.

-Parsifal en Bayreuth, por Francisco Seeber, pp. 270-285.

-El hogar desierto, por Paul Groussac, pp. 286-302.

-La educación por el folletín, por Paul Groussac, pp. 312-324.** En este escrito Groussac reflexiona sobre el lugar de la prensa como espacio de la pedagogía y de ejemplificación de valores, y como tal, su responsabilidad social. Critica la iniciativa del diario La Nación de publicar un folletín de Zola. Este artículo debe leerse en relación con la diferenciación entre dos circuitos o espacios culturales que se van diseñando en el espacio público. Estos circuitos presentan puntos de contacto, tensiones, etc., y el hecho de que un diario como La Nación publique un folletín naturalista.

Año II, Tomo VI, diciembre, 1897. (19)

-El censo y la constitución, por Agustín de Vedia , pp. 324-339.

-El Brasil intelectual, por Martín García Mérou, pp. 340-380.

-Lo que se ama, por Delio Miranda [seudónimo], pp. 381-407. Suponemos que el autor de este relato es el propio Groussac quien ya en ocasión de la publicación de otro relato suyo -"La pesquisa"- en marzo de 1897, había utilizado una forma equivalente a este sistema del seudónimo, la del anónimo. (cf. lo referente al tomo 3, marzo de 1897 en este mismo índice). Por lo demás ningún otro autor publica en la revista sin darse a conocer 
y sin aparecer con su verdadera noticia biográfica en la sección 'Los redactores'. En nota al pie se dice: “Con su firma seudónima, su título y epígrafe ultrarománticos, que casi equivalen a un estado civil, hemos aceptado esta novelita sin desconocer las inexperiencias de fondo y forma que deslustran su laudable sencillez - siquiera un poco anticuada. Creemos conocer a la persona que nos la remite por correo, pudiendo afirmar que no es escribano de número; pero respetaremos su incógnito, y, desde luego, prevenimos al lector que la 'noticia biográfica'. En 'Los redactores', dice Groussac de Delio Miranda: "Habremos de defraudar por resta vez la legítima curiosidad del lector. Después de conocer la nota de la página 381, que precede su trabajo, la persona que oculta su figuración literaria bajo este seudónimo nos ha hecho expresar, por un miembro respetable de su familia, las razones que tiene para conservar el incógnito. Aunque no convencidos respetamos esta resolución y retiramos la noticia conjetural que teníamos escrita. Deploramos tanto más la decisión de Delio Miranda cuanto que el mal ejemplo puede ser contagioso. Quién nos dice que tan exagerada modestia no tendrá imitadores, y que en adelante habremos de hacer violencia a nuestros colaboradores, para presentarlos en público,- a manera de esos maestros aclamados que, en la noche de estreno, aparecen en el 'palco escénico', arrastrados a tirones por el director de orquesta y el empresario? (p. 464)

-La casa del sol, por Damián Menéndez, pp. 408-414. Sobre el lugar llamado Inti Huasi en quichua, ubicado en las sierras de Córdoba.

-Jacinto Gallina, por Rómulo, E. Martini, pp. 415-427. [Jacinto Gallina, es un autor teatral italiano]

-Alphonse Daudet, por Paul Groussac, pp. 428-453.

-El monumento de Lucio V. López. [Al cumplirse el tercer año de la muerte de López, se erige un monumento en su memoria. Además de una introducción por parte de Groussac, se transcribe el discurso de Carlos Pellegrini para la ocasión], pp. 545-459.

-Documentos históricos:

Diario de la toma, por los ingleses, de esta ciudad y su reconquista, pp. 460-463.

-Redactores de La Biblioteca, pp. 464-467.

Año II, Tomo VII, enero-marzo, 1898. [Administración de La Biblioteca, Perú, $\mathrm{n}^{\circ}$ 79; se sigue imprimiendo por Coni e hijos]

Año II, Tomo VII, enero, 1898. (20)

-Mariano Moreno y San Martín. Discursos con comentarios inéditos, por Nicolás Avellaneda, pp. 5-31. Ambos discursos fueron pronunciados en ocasión de las inauguraciones de monumentos en honor de cada uno.

En Nota al pie, se aclara que estos discursos corresponden al segundo tomo de Discursos de Avellaneda.

-El Ministerio Nacional, por Adolfo F. Orma, pp. 32-51. En este artículo se defiende la letra del artículo 87 de la Constitución nacional vigente (en el que se establece la existencia de 5 ministros secretarios que ' tendrán a su cargo el despacho de los negocios de la Nación y refrendarán y legalizarán los actos del presidente'), ante la necesidad de reforma de ese artículo.

-Vida del soldado, por Francisco P. Súnico, pp. 52-62. Es un relato en el que se cuenta las experiencias de la vida de los soldados en el campamento.

-Gobernación del Tucumán, por Ramón J. Cárcano, pp. 63-82.

-Finanzas argentinas. Apuntes históricos, por José A. Terry, pp. 82-93.

-La herencia, por Paul Groussac, pp. 94-107. Este relato ficcionaliza el problema del suicidio y del homicidio en los términos en que lo hace la ciencia que le es contemporánea.

-Documentos históricos: pp. 108-129.

-Boletín Bibliográfico: pp. 130-144.

Dedicado a:

Practique Chirurgicale de A. F. Llobet, pp. 130-140. Groussac hace la crítica de este libro y de una nota que sobre el mismo apareció en los Anales del Círculo médico argentino, escrita por Diógenes Découd. Su crítica al libro de Llobet es positiva -aunque siempre con reparos- y el análisis minucioso de la nota deja muy mal parado a Découd. Es interesante señalar el registro de una contaminación del discurso de la crítica literaria respecto de la ciencia [la ciencia experimental]: "Han recrudecido en estos últimos tiempos los ensayos de "crítica científica" de las obras literarias y artísticas [aquí Groussac cita el Année Psychologique, Revue de 
Paris, Revue Scientifique]; sin murmurar de estas distracciones inocentes, es permitido pensar que no sería menos interesante y eficaz la tentativa inversa: es decir el examen literario de las producciones científicas" $p$. 130. "Todos los sabios geniales han sabido escribir, en el pleno sentido de la palabra (...) Sólo para nuestras inteligencias modestas son útiles las 'especializaciones' cantonales, a manera de cercos divisorios entre pequeñas heredades" p. 131.

Lecciones de economía política de Félix Martín y Herrera, pp. 140-144. Se trata de la transcripción que de las clases que Martín y Herrera diera en la Facultad de derecho hicieron dos de sus alumnos. La reseña es favorable.

Año II, Tomo VII, febrero, 1898. (21)

-Un incidente diplomático, por Manuel Moreno, pp. 145-161. En Nota al pie se calara "este documento inédito, cuyo original de puño y letra de don Manuel Moreno nos ha sido comunicado por el doctor Bernardo de Irigoyen, constituye un interesante comentario de la obra oficial que se publicó en Londres, en 1835, con el título siguiente: Reclamaciones examinadas y juzgadas por la Comisión mixta, etc.”

-Los historiadores de Rozas, por José María Ramos Mejía, p. 162-189. Este escrito es el capítulo 2 del libro en ese momento en preparación- Rozas y su tiempo. Ramos Mejía sostiene que: "puede afirmarse que Rozas no ha tenido aún el historiador filósofo, el psicólogo anatomista, porque es caso de anfiteatro y de laboratorio" p. 163. Respecto de los libros sobre Rosas publicados hasta el momento señala: "Casi todos se parecen, si no en el estilo, cuando menos en el procedimiento y más que todo en esas tendencias tan poco científicas de juzgar al gobernante exclusivamente, sin llegar hasta el hombre, animal superior, que posee en este caso en su mentalidad y en su temperamento moral casi todo el determinismo sensitivo y político de su gobierno personal" Cita en dos ocasiones a Groussac -en el $\mathrm{n}^{\circ} 10$ de La Biblioteca, con su ensayo sobre Liniers, y cuando usa la palabra sugestión odiada por Groussac. Señala una característica de los historiadores argentinos: "la afición al papel viejo, nada más que por su vejez" que para Ramos Mejía ha matado al historiador.

-Finanzas argentinas, por J. A. Terry, pp. 190-208.

-Gobernación del Tucumán, por Ramón J. Cárcano, pp. 209-231.

-La guerra gaucha [Un estreno], por Leopoldo Lugones, pp. 232-241.

-El mineral de Famatina, por Ulric Courtois, pp. 242-267.

-Escritos de Mariano Moreno, por Paul Groussac, pp. 268-318.

-Boletín Bibliográfico: pp. 319-320.

Dedicado a Reconocimiento de la región andina de Francisco P. Moreno (Museo de La Plata). Luego del breve comentario -que promete ser próximamente una verdadera 'noticia bibliográfica'-, se consigna el reemplazo temporario en la dirección de la revista de Groussac por Enrique Rodríguez Larreta: "Habiendo el director de La Biblioteca resuelto tomar algunas semanas de descanso, el doctor Enrique Rodríguez Larreta ha aceptado gentilmente la dirección interina de la revista." p. 320.

\section{Año II, Tomo VII, marzo, 1898. (22)}

-Discursos de Bernardo de Irigoyen, pp. 321-335.

-El Falstaff de Shakespeare, por Miguel Cané, pp. 336-354.

-Límites con Chile, por Eduardo L. Bidau, pp. 355-384.

-La paz armada, por Lucio V. López, pp. 385-391.

-Gobernación del Tucumán, por Ramón J. Cárcano, pp. 392-418.

-Botánica médica americana, por Pedro N. Arata, pp. 419-448.

-Los historiadores de Rozas. Réplica al Doctor José María Ramos Mejía, por Adolfo Saldías, pp. 449-459. Saldías le contesta a Ramos Mejía las acusaciones de parcialidad de su estudio sobre Rosas en función de la intención que preside, según Ramos Mejía, el trabajo de Saldías. Responde Saldías: "En su último trabajo, publicado en esta revista, el doctor Ramos Mejía se hace eco de cierta conciencia pública, y desde lo alto de una autoridad tomada probablemente a la misma, repite lo que otros han dicho respecto de mi Historia de la Confederación argentina, es, a saber, que me he inspirado en el propósito de vindicar a Rozas, y me moteja el que yo no haya estudiado es este gobernante un caso patológico, como él lo va a estudiar en un libro que prepara con las cartas que Rozas dirigió a don José M. Rojas, y otros papeles que dice haber compulsado, a 
pesar de su confesado horror a los papeles." (p. 449) Luego, justifica su intervención, en términos de una conveniencia o estrategia intelectual: Ramos Mejía tiene mayor prestigio que otros (los tradicionalistas) que han atacado su trabajo. Sostiene Saldías: "No he contestado antes de ahora a los tradicionalistas que me han supuesto el propósito de vindicar a Rozas, porque no era el libro, sino yo, el blanco de ataque, y yo no podía discutirme (...) y porque no he creído deber acreditar en mi país el odio a la tiranía y mucho menos por el medio empleado por los que me acusaban.

Pero ahora repite la acusación un contemporáneo que por su talento goza de justa reputación en nuestro pequeño mundo literario [las cursivas son nuestras], pretendiendo que en ese libro, casi agotado ya, y a cuyo autor no han dejado lonja sin sacarle, afirmo hechos que no compruebo; y quiero contestarle por el respeto que debo a la nueva generación, a quien lo dediqué, para que a la luz de la filosofía histórica de la época que media entre 1820 y 1860 pueda ver cómo la tiranía existe latente en medio de la licencia de la libertad y de la mistificación del sistema representativo, porque el tirano es entonces un poder ejecutivo absorbente, o un parlamento cómplice de éste o salido de quicio, o el primero que reasuma la entidad de un pueblo que no existe como fuerza cívica gobernante." p. 450.

Es importante señalar que esta es una de las polémicas que tienen lugar en la revista, junto con la de Mitre / Groussac (cf. este mismo índice), y la intervención de Groussac, al reseñar en el mismo Boletín bibliográfico, Los Raros y los Recuerdos de la tierra de Leguizamón [daremos cuenta de esta polémica en el cuerpo del trabajo puesto que se relaciona con la posibilidad de construcción de una literatura nacional en lengua culta, hecho que por momentos preocupa a Groussac]. Esta polémica es sobre todo una polémica de método. En ese sentido, refiriéndose a La locura en la historia de Ramos Mejía dice Saldías: "Este esfuerzo intelectual, que hace honor a nuestras letras, retrata de cuerpo entero al doctor Ramos Mejía y deja esperar cosas peores que lo de vindicador de tiranos [acusación de Ramos Mejía a Saldías]. Girando alrededor de una idea preconcebida, ve perturbaciones de la inteligencia en ciertos rasgos geniales de gobernantes $u$ hombres públicos y ay de los locos! Como se lo dije después de leer su hermoso libro, su neurosismo implacable le ha conducido a exagerar un principio en términos tales que hasta los lectores tiemblan ante la posibilidad de sentirse locos; y concluirían por creerlo si no reflexionasen que, si ciertos actos decidieran del estado patológico de los gobernantes, quizá se llegara al resultado que todos, desde Numa Pompilio, con su ninfa inspiradora, hasta Sarmiento, con su demonio útil, han sido más o menos insanos, y que por medio análogo al empleado por el doctor Ramos Mejía se llega a la consecuencia de que todas las personas tienen fiebre después de comer." p. 458.

Es asimismo destacable un pasaje que pone en cuestión el estatuto de los periódicos como documentación: “(...) prejuzga mi libro anotando tal o cual pasaje, donde, asevera, yo afirmo sin otra documentación que la Gaceta Mercantil o las cartas de Rozas.” p. 450.

-El presupuesto de recursos. Su duración, por Miguel Romero, pp. 460-474.

-Redactores de La Biblioteca, pp. 475-479.

Año II, Tomo VIII, abril-mayo, 1898. (23-24) [Administración de La Biblioteca, Perú, $\mathrm{n}^{\mathrm{o}}$ 79; se sigue imprimiendo por Coni e hijos]

-Reflexiones y fragmentos, por Julio A. Roca, pp. 5-10. Estos fragmentos fueron extraídos de la correspondencia de Roca con Mariano de Vedia. Los dos últimos pertenecen a una carta que Roca escribió desde Europa a Agustín de Vedia.

-Finanzas argentinas, por José A. Terry, pp. 11-26.

-Límites con Chile, por Eduardo L. Bidau, pp. 27-54.

-El rey Enrique IV, por Shakespeare, pp. 55-124. Traducción de Miguel Cané del primero y segundo actos de la obra de Shakespeare, única existente en esa época en castellano.

-La ley del año. Distribución de os ministerios, por Horacio Beccar Varela, pp. 125-138. El artículo señala la modificación del artículo 87 de la Constitución Nacional por la convención reformadora, por la que se establece que el número de ministros será elevado de cinco a ocho.

-Gobernación del Tucumán, por Ramón J. Cárcano, pp. 139-176.

-La guerra gaucha, por Leopoldo Lugones, pp. 179-184. [Táctica] 
-Botánica médica americana. Los herbarios de las misiones del Paraguay, por Pedro N. Arata, pp. 185-192. -Prosper Merimée, por Paul Groussac, pp. 193-212.

-Por España. Discursos pronunciados en el teatro Victoria el 2 de mayo de 1898, pp. 213-240. Incluye los discursos de Roque Sáenz Peña y de Paul Groussac con motivo de la intervención de EE.UU. en Cuba.

El discurso de Roque Saénz Peña realiza la crítica al intervencionismo "yankee" que funda la doctrina Monroe:

"La doctrina del presidente Monroe, contenida en el mensaje de diciembre, se pronunció contra la intervención; pero ese pronunciamiento hizo reservas mentales que vuelven dudosos sus propósitos y perniciosos sus efectos; condena en principio las intervenciones europeas, pero se reserva de hecho las americanas, lo que vale significar y decir que no es una doctrina universal y científica, con unidad de concepción y de principio, sino un hecho nacional y propio que se notifica a las naciones como la idiosincrasia de un gobierno fuerte y de un poder incontrastable, -porque es de recordar que las arrogancias de la Casa Blanca las sustentaban en el caso las escuadras británicas y el apoyo del ministerio de Canning.

Esa doctrina, en mi opinión, es la causa y el origen de las actuales desviaciones del derecho público. La doctrina de Mackinley es simplemente el epílogo de la de Monroe y de la de Polk; no son tres doctrinas, son tres actos consagrando

-Boletín bibliográfico: pp. 241-243

Dedicado a:

El régimen colonial de Juan A. García (hijo), p. 241-242.

El Banco argentino con los señores Unzué, por Manuel Quintana, pp. 242-243.

-La desaparición de La Biblioteca, por Paul Groussac, pp. 244-248.**

-Redactores de La Biblioteca, pp. 249-285. Se consignan los redactores correspondientes a los 8 tomos, que ya habían aparecido al final de cada uno de los mismos.

-Índice general. Corresponden a $\operatorname{los}$ tomos 1 a 8 ; es un índice de autores que indica tomo, título de la colaboración y página de inicio de la misma. Es el único tomo que tiene un índice de estas características. 
Alberdi, Juan B.

Aldao, Carlos A.

Alsina, Adolfo.

Arata, Pedro N.

Argerich, Juan A.

Avellaneda, Nicolás.

Beccar Varela, Horacio.

Berisso, Luis.

Beuf, Francisco.

Bidau, Eduardo L.

Calandrelli, Matías.

Cané, Miguel.

Cárcano, Ramón J.

Courtois, Ulric.

Darío, Rubén.

Dávison, Diego T. R.

Dellepiane, Antonio.

Domínguez, Luis L.

Doynel, Carlos.

Drago, Luis María.

Duclout, Jorge.

Fregeiro, Clemente L.

Gache, Samuel.

García, Juan A.

García Mérou, Martín.

González, Joaquín V.

Goyena, Pedro.

Groussac, Paul. [no tiene perfil en 'Redactores']

Guastavino, José M.

Gutiérrez, Ricardo.

Iriarte, Tomás.

Irigoyen, Bernardo.

Jacques, Amadeo.

Kubly, Enrique

Liniers, Santiago. [no tiene perfil en 'Redactores']

López, Vicente F.

López, Lucio V.

Lugones, Leopoldo.

Mansilla, Lucio V.

Martínez, Alberto B.

Maziel, Juan Baltasar.

Menéndez, Damián.

Miranda, Delio. [Groussac]

Mitre, Bartolomé.

Montes de Oca, Manuel A.

Morante, Ambrosio. [no tiene perfil en 'Redactores]

Moreno, Manuel.

Novaro, Bartolomé.

Obligado, Rafael.

Orma,. Adolfo F.

Palacios, Pedro B.

Pellegrini, Carlos.

Pérez, Abel. 
Quesada, Ernesto.

Ramos Mejía, Francisco.

Ramos Mejía, José M.

Rodríguez, Fermín.

Rodríguez Larreta, Carlos.

Rodríguez Larreta, Enrique.

Roca, Julio A.

Romero, Matías.

Romero, Miguel.

Saénz Peña, Roque.

Saldías, Adolfo.

Sarmiento, Domingo F.

Schiaffino, Eduardo.

Seeber, Francisco.

Súnico, Francisco P.

Terry, José A.

Vedia, Agustín de.

Vélez Sarsfield, Dalmacio.

Williams, Alberto. 
Texto de apertura de El Mercurio de América

Buenos Aires, 20 de julio de 1898 literaria.

Desaparecida La Biblioteca, creemos hacer una obra de bien dando á la luz una nueva publicación La biblioteca ha sido, hasta hace algunos días, el órgano artístico social que más se ha leído en Buenos Aires y en todas la provincias de la República.

No obstante, La biblioteca fue poco conocida en los países del Nuevo Mundo. EL MECURIO DE AMÉRICA en una esfera menos brillante y no tan estrecha, tendrá Dios y el tiempo mediante, la amenidad y la vibración juvenil de que carecía La Biblioteca. Nos diréis que estas son ilusiones y que nuestra Revista pasará como tantas otras, que en otras palabras han prometido lo mismo. Á esta pregunta responderemos: Si Buenos Aires es una ciudad culta, está en la obligación de sostener un periódico de la índole del nuestro. Aún más. Si en Buenos Aires hay seres que piensen, EL MERCURIO DE AMÉRICA viene a llenar esa necesidad.

Inútil seria agregar que daremos á nuestra Revista un carácter eminentemente americano. El título, por otra parte, así nos lo exige.

El aislamiento en que vivimos respecto de las naciones de América, no obstante la comunidad de pensamientos y de ideales y el poco ó ningún acuerdo que existe, desgraciadamente entre los pueblos que hablan lengua castellana en el mundo, va a romperse, aun que sea momentáneamente, merced á la aparición de esta Revista. Y en efecto: estamos decididos á luchar

Lejos de todo propósito utilitarista, sabremos mantener bien alto el pabellón artístico. Todas las tendencias y opiniones, bellamente vertidas hallarán abrigo en estas columnas. El arte es uno. La Belleza inmortal es la misma, sea cual fuere la época o la forma en que se encuentre representada. Homero y Dante, Shakespeare y Cervantes, Víctor Hugo y Goethe, Ibsen y Zola: he aquí ocho nombres que resumen todas las escuelas.

Estas como los individuos pasan, afortunadamente. Solo queda la obra formidable y sincera.

EL MERCURIO DE AMÉRICA no hará cuestión de firmas para la inserción de los trabajos que en adelante se le remitan. Á su mérito real e intrínseco, á lo atinado de la observación y lo galano de la forma, atenderá únicamente. El exclusivismo no cuadraría bien con nuestro espíritu amplio y liberal, aún siendo en arte individualistas. Nuestros propósitos como los de los fundadores de La revista de América (nota al pie: que dirigieron los señores Rubén Darío y Ricardo Jaimes Freyre), son: "Levantar oficialmente la bandera de la peregrinación estética, que hoy hace con visible esfuerzo la juventud de América Latina, á los Santo Lugares del Arte y á los desconocidos Orientes de ensueño; mantener al propio tiempo que el pensamiento de la innovación, el respeto a las tradiciones y la jerarquía de los Maestros;

Trabajar por el brillo de la lengua española en América, y al par que por el tesoro de sus riquezas antiguas, por el engrandecimiento de esas mismas riquezas en vocabulario, rítmica, plasticidad y matiz:

Luchar por que prevalezca el amor a la divina belleza, tan combatida hoy por invasoras tendencias utilitarias;

Servir en el Nuevo Mundo y en la ciudad más grande y práctica de América latina, á la aristocracia intelectual de las repúblicas en lengua española" 


\section{La Montaña. Periódico socialista revolucionario, abril 1897- septiembre 1897. Indice hecho con los sumarios de la edición facsimilar de la Editorial de la Universidad de Quilmes}

Colección completa: 12 números; frecuencia de publicación: quincenal -Redactores: José Ingegnieros Leopoldo Lugones

Secciones: Estudios sociológicos; Arte, Filosofía, Variedades; Actualidad, y dentro de ella: Bibliografía, Movimiento Socialista

$\mathrm{N}^{\mathrm{o}} 1$ :

Arte, Filosofía, Variedades

1 de abril de 1897

Metempsicosis (Rubén Darío)

El animismo (Gabriel Tarde)

Colonia socialista de artistas (redacción de La plume)

Actualidad: Los políticos de este país.

$\mathrm{N}^{\circ} 2$ :

15 de abril de 1897

Sonetos Jean Richepin

La enseñanza universitaria (G. Degreef)

Desenlace inesperado (B. Malon).

Semana dolorosa (Leopoldo Lugones)

Lo obediencia pasiva (E. Renan)*

La casa paterna (H. Suderman) -fragmento-

La quincena:

Crítica de Lugones a la crítica a La casa paterna (Suderman) de Enrique Freixas del diario La Nación.

Filantropía universitaria. Crítica a la UNLP (A.M.H)

Bibliografía: Constancia: "semanario espiritista con artículos que convencen fácilmente a todos los que ya están dispuestos a convencerse" (p.54), Luz Astral "con una síntesis pésima de la excelente obra del ocultista Alberto Rochas sobre la 'Exteriorización de la motricidad"' p.54, Revista Magnetológica

Ultima Hora: El primer número de La Montaña ha sido secuestrado en Concordia por la policía de acuerdo con el correo.

Se anuncia la lista de colaboradores del $\mathrm{n}^{\circ}$ siguiente: Macedonio Fernández.

Movimiento Socialista: Festejos del $1^{\circ}$ de Mayo. Los centros Socialistas acuerdan designar a Leopoldo Lugones como único orador para cerrar el meeting.

$\mathrm{N}^{\circ} 3$

$1^{\circ}$ de Mayo de 1897

Artículo de Leopoldo Lugones sobre la fiesta del trabajo "La fiesta del proletariado": Este artículo va antes del sumario.

Tiraje del $n^{\circ} 12000$ ejemplares.

Estudios Sociológicos:

Macedonio Fernández: "La desherencia". Problema de la delimitación entre arte y ciencia. Da un 'estado' del siglo XIX en relación con la ciencia, poemas de Lombroso. Se pregunta: i"por qué parece reinar tan poca luz sobre el problema de la diferencia esencial entre ciencia y arte?" p.68.

Arte Filosofía Variedades:

Je suis socialiste (Paul Verlaine)

La lavandera (L. Tolstoi)

La Paz (E. Ferri) -tratada en analogía con la biología-.

Las clases (Stuart Mill)

Fragmentos (José Santos Chocano; dos poemas: "Para todos" y "Desde la cumbre": los poetas) 
Creced y multiplicaos (Octavio Mirbeau)

Retrospección (José Ingegnieros)

La legión de los descamisados (E. Guay Cendre)

La Montaña en Chile. (Mario Centore). (Publica un fragmento del artículo, "Sobre arte y socialismo", aparecido en El pueblo del Valparaíso)

$\mathrm{N}^{\circ} 4$

15 de mayo de 1897.

Arte, Filosofía, Variedades

-Bautismo de Sangre ( José Ingegnieros)

-Arte y revolución. El noviazgo rojo (Jean Ajalbert).

Palabras de un maestro (G. Flaubert)

Triptique. Puor les fous (Theodore Jean).

Actualidad:

La Montaña antes los jueces (La Redacción)

Los políticos de este país (L. Lugones)

La quincena (los Redactores)

Actualidad:

Ante una acusación: según los redactores, la municipalidad considera Los reptiles burgueses de José Ingenieros. "Ofensivo para la moral burguesa y peligroso para el orden social presente"p.95.; el asesor municipal de Alcobendas debe dictaminar sobre ese asunto.

La intendencia municipal, La Montaña y la moral pública

Los mercaderes de la prostitución. Un documento. 20000 pesos por una ordenanza municipal

Última hora: informa sobre la negativa del asesor municipal a dictaminar sobre el asunto originado en el artículo "Los reptiles burgueses" de José Ingenieros y el paso a manos del fiscal nacional. "...nos condenará, sin duda, al maximum de la pena."p.97.

Los políticos de este país.

Lugones critica a la intelectualidad burguesa. Para hablar de la intelectualidad se refiere exclusivamente a los políticos del país: Uriburu, Sáenz Peña.

-La quincena

Travesuras: da cuenta de las opiniones de distintas publicaciones de "la prensa burguesa" sobre la acusación a La Montaña.

Bibliografía: Lettre a Monsieur Bertrand por Luis Lagarrigue (Chile)

Es interesante ver que en la misma página se comenta una publicación positivista (Apostolado positivista del Brasil) y un libro que "impugna las doctrinas positivistas de A. Comte contestando brillantemente un artículo del académico parisiense".p.101.

$\mathrm{N}^{\mathrm{0}} 5$

$1^{\circ}$ de junio de 1897

Estudios sociológicos:

El socialismo y la libertad (Adolfo Zerboglio)

La evolución del Estado (Augusto Bebel)

Por qué es egoísta el individuo (Sebastián Faure)

Arte, Filosofía, Variedades

El flagelo (Angel Silvio Novaro)

La moral del arte (L. Lugones).

La fiumana (Ada Negri) 
"La Critique" (Los Redactores)

Arte Social (Juan Hoeckfeld) falta

Actualidad

La condena de La Montaña (Los Redactores)

Los reptiles burgueses 2 (J. Ingegnieros)

-La Quincena (J.C.)

Actualidad:

La condena. Secuestro, multa y censura.

Se secuestra el $n^{0} 2$ de la revista, se impone una multa de 300 pesos a los redactores (pena máxima). Se establece la censura para todos los números siguientes que la policía considere atentan contra la moral burguesa. Piden solidaridad a los suscriptores y socialistas para el pago de la multa.

Bibliografía

La critique. Interesa también porque es una revista de literatura modernista

L'Humanité Integrale. Revista de estudios psicológicos, espiritista, caracterizada por su sentimentalismo científico. Letras de Perú ("en nuestras filas socialistas siempre hay un puesto para los jóvenes que aman el Arte"p.126).

$\mathrm{N}^{\circ} 6$

15 de junio de 1897

Estudios sociológicos

El socialismo y la enseñanza religiosa (J. Bonagiuso)

La concentración capitalista (Jean Jaurés)

Cuentas claras (Trad. de la Rev. Soc. por Carlos Malagarriga)

Internacionalismo (Napoleón Colajanni)

Arte, Filosofía, Variedades.

Soneto ditirámbico (L. Lugones) Satiriza a Alcobendas en su pudorosa y casta vida.

¡Hambriento! (Paula Mink)

Canaglia (Adone Nosari)

La educación en la conducta (Julio Molina)

La mujer en el movimiento socialista (Alina Valette)

[Los textos poéticos se publican en el idioma original, sin traducción al español. Muchas veces - la mayoría- son poemas 'sociales', generalmente italianos y franceses, también se publican otros en alemán].

Actualidad

Pablo Groussac y el Socialismo (José Ingegnieros)

La intendencia y "La Montaña" (Los Redactores) [Nuevo avatar del caso. Nuevo personaje: asesor Basvilbaso. Cambio de jurisdicción]

La quincena: Extravío o defraudación. A propósito de las cartas -en relación con la multa, 9 cartas que contenían listas de suscriptores- que no la redacción de la revista no recibió en su casilla de correo.

Congreso científico.

- Arte social: La lucha de la mujer. Se comenta el estreno de en Suiza de una obra teatral de Juan Hochfeldt. "Para la propaganda feminista ha sido más útil esta pintura real que todas las exposiciones de la doctrina. El Arte es tan revolucionario como la economía política"p.151.

Bibliografia:

Temístocles y Arístide. Por Carlos Romagosa -quien había hecho una carta de recomendación para el diario La Nación a Leopoldo Lugones-. "Un folleto de buena prosa inspirado en reminiscencias de la 
historia griega. Su aparición es oportuna en estos momentos de crisis filohelénica" p.154. (Podría pensarse en el anhelo de LL por tiempos más heroicos)

\section{$\mathrm{N}^{0} 7$}

$1^{\circ}$ de julio de 1897.

Estudios Sociológicos

Psicología de la bancarrota (Antonio Renda)

La cuestión social es una cuestión económica (Aquiles Loria9

Socialismo y Revolución (J. Ingegnieros)

Arte, Filosofía, Variedades

Gegenzatz (Kerl Henckell)

El derecho civil y el Socialismo (N. de Sarmiento)

Los republicanos (Felipe Turati)

El hombre libre (Louis Blanc)

La vida del obrero (Jules de Marthold)

Actualidad

A $100^{\circ}$ de la infamia (L. Lugones)

Movimiento gremial en China (Adrián Veber)

En la Cámara francesa (Grupo Socialista)

Suscripción pro-Montaña

Bibliografía

Movimiento Socialista. Reuniones, etc.

Suscripción de protesta y solidaridad para cubrir el importe de la multa impuesta a La Montaña. Se transcriben las entidades y personas que han colaborado para evitarle la cárcel a José Ingegnieros. Es muy divertido ver los nombres de la lista: Un fogoso incendiario, un sastre socialista, el farol de la noche triste, Gerochunff (Gerchunoff?), buen amigo, cristiano, ciclista, Chimisturry, uno que desea la revolución, etc..

Bibliografía:

Letras: revista literaria quincenal de Chile, en la que se señala la colaboración de Ricardo Jaimes Freyre. L'Humanité Integrale revista espiritista de París. Se consigna sumario algo que no se hace con las demás revistas. Les Temps Nouveaux órgano de intelectuales anarquistas franceses, con suplemento literario interesante según la Montaña.

\section{$\mathrm{N}^{\circ} 8$}

15 de julio de 1897

Estudios sociológicos

El ideal futuro (Ch. Letourneau)

La cuestión social (Aquiles Loria)

Inutilidad social de las cooperativas (Augusto Bebel)

Arte, Filosofía, Variedades

Idilio diabólico. El revolucionario (Ad. Retté)

Areópago del Dragón Rojo (V. E. de Rozas)

A l'Idèal (Theodore Jean)

Humanismo integral (J. Hudry-Menos)

Internacionalización (G. Tarde)

¡iHermosa Libertad!! (Pablo Lafargue)

Actualidad

Los reptiles burgueses III (José Ingegnieros)

Partido Socialista Brazilero (Programa mínimo) 
El Japón socialista (Louis Dubreuilh)

Socialistas y anarquistas (LA Montaña)

La huelga de la Grand-Combe (Orden del día)

A nuestros amigos y compañeros (Los Redactores) [Se refiere al "éxito moral" que ha alcanzado la revista. Luego señala los colaboradores con los que cuenta la revista en el país: R. Darío, Dr. C. Malagarriga, Dr. Macedonio Fernández, Julio Molina y Vedia, Dr. Arturo Iznardi, Nicanor de Sarmiento, Meyer González, C. Alfredo Becú, Alfredo L. Palacios, José Pardo, Enrique Dickman, Salvador Lamesa y "otros amigos". p.200]

Socialistas y anarquistas (La Montaña)

Definiéndose como socialistas ("Los anarquistas afirman que los socialistas somos 'autoritarios'") establecen sus discrepancias con los anarquistas e invitan a los que así lo desean a polemizar (con la condición de ser breves evitando la retórica y la metafísica).

\section{Bibliografía}

La escuela positiva (Corrientes)

Revista Nacional de Literatura y Ciencias Sociales n 50 : "Trae un selecto material literario siendo en este género de lo mejor que se publica en América; pero no aborda, o lo hace con deficiencia, las importantes cuestiones sociales que preocupan al mundo intelectual: Quien ama el Arte debe defender al Socialismo". p.201. A este mundo intelectual pertenece el arte, el cual debe está indisolublemente ligado al Socialismo.

Letras (Tacna): revista de literatura modernista.

Anuncios -sección nueva- en la que aparecen las revistas y sus lugares de ventas.

La plume: revista de Arte Modernista.

La Critique: Revista de Arte.

\section{$\mathrm{N}^{\circ} 9$}

$1^{\circ}$ de agosto de 1897.

Estudios Sociológicos

Defensa de los criminales (Edward Carpenter)

La lucha de clases en el Derecho (Carlos Malagarriga)

Proletariado intelectual (Sebastián Faure)

Arte, Filosofía, Variedades

Operaio (Ada Negri)

Idilio diabólico- El revolucionario (Ad. Retté) Manuel M. Oliver.

A los ricos (San Basilio)

Actualidad

Alcobendas ante La Montaña. Impotencia o estupidez (Los Redactores)

El individuo y la sociedad (José Ingegnieros)

Partido Socialista Brasilero (Programa mínimo -en portugués-; este programa había sido anunciado en el sumario del $\mathrm{n}^{\circ} 8$ pero no se publicó allí)

Anarquistas y socialistas (Tribuna Libre)

Alcobendas ante La Montaña. Cobardía o estupidez.

Se le ha extraviado a Alcobendas la tramitación de la multa contra La Montaña. "Parece que solamente se trató de intimidarnos con los cincuenta renglones estúpidos del asesor, la censura previa, el allanamiento de la casa editora, y sobre todo con el epíteto de inmorales, cuyo efecto sobre las casas de familia no puede ser más desastroso."p.220.

En relación con una cuestión de propaganda señalan los redactores: "ni en la revista de la prensa socialista, insertada por Roberto Payró en el Anuario de la Prensa Argentina aparece La Montaña." p.221 
Bibliografía: L'Humanité intégrale, junio de 1897. "Un notable estudio sobre el amor y la inmortalidad por J. C. Chaigneau, y otros materiales de interés para los espiritualistas" p.226.

\section{$\mathrm{N}^{\mathrm{o}} 10$}

15 de agosto de 1897

Toda moral es relativa. Defensa de los criminales (Edward Carpenter)

El prejuicio de la legalidad (Enrique Turot)

Miseria y mortalidad Trad. por E. Pérez Casal)

Arte, Filosofía, Variedades

La revolte des Lys (Adolphe Retté).

Arte social. Gabriel Borkmann (H. Vallor)

La juventud de América y La Montaña (Mario Centore y José María Barreto)

Correspondencia del perú (Emiliano Lebardol)

La enfermedad (Víctor Hugo).

Actualidad

Los reptiles burgueses IV (José Ingegnieros)

Tribuna Libre (Juan Creaghe y la Redacción)

El meeting de los desocupados (Los Redactores)

La juventud de América y La Montaña: se transcriben opiniones acerca del asunto de la multa y la censura a la revista. Muestras de solidaridad de América.

Se transcribe de la revista literaria Letras (Perú) la opinión de José M. Barreto, su director. Los redactores dicen: "transcribimos los siguientes párrafos que nos alientan por ser la expresión viril de un elevado sentimiento de solidaridad, y una profesión de fe socialista que nos estimula en la lucha" p.236.

De El Pueblo (Valparaíso) que reproduce en sus páginas el artículo del $\mathrm{n}^{\circ} 4$-Ante una acusación-, se transcribe el texto del que va precedido, "La Montaña procesada": "cedemos lugar a La Montaña, que protesta, en los siguientes varoniles párrafos" p.237.

$\mathrm{N}^{\circ} 111^{\circ}$ de septiembre de 1897.

Estudios sociológicos

Defensa de los criminales III (Edward Carpenter)

La fabricación de cadáveres en la sociedad burguesa (Desiré Deschamps)

Los sindicatos de resistencia y la huelga general (Emilio Joindy)

Arte, Filosofia, Variedades

Monsieur Proudhomme (Paul Verlaine)

Ideal (Andrés A. Matta)

Arte socialista (N. Bona)

El amor egoísta (Lacordaire)

Paternalismo gubernamental (G. Novicow)

Actualidad

Los políticos de este país (L. Lugones)

La Patria, Guido y Spano, Cánovas del Castillo y la prensa patriotera (José Ingegnieros)

La quincena (Los Redactores)

Bibliografía

La Patria, Guido y Spano, Cánovas del Castillo y la prensa patriotera (José Ingegnieros)

Defensa de Guido y Spano ante el ataque de la prensa de La Nación. "Toda la prensa burguesa argentina, toda esa prensa mercenaria (...) sin carácter y sin conciencia, esa misma que hasta ayer, por mercantilismo patriotero, proclamaba a Guido y Spano como venerable elegido de las musas argentinas, le ha cerrado hoy sus columnas, porque la defensa del poeta hacía posible un descenso en el termómetro de las suscripciones."p.268 
Como en la entrega III de "Los reptiles burgueses" se refiere a la utilización de la idea patria por la burguesía.

La Quincena.

La ciencia oficial y la Facultad de Ciencias Herméticas.

La redacción condena el monopolio de la ciencia por parte de la "clase capitalista" y lo iguala, para no perder de vista la doctrina materialista histórica, con el monopolio de medios de producción. p.269.

Los redactores se quejan del consenso burgués en materia científica: "Se ha convenido en negar de un manera apriorista todos aquellos conocimientos y fenómenos que no han sido descubiertos por individuos que no aceptan los métodos científicos vulgares, y se ha pretendido matar con el silencio y el ridículo todas aquellas ramas del saber humano que han evidenciado un error o una deficiencia de los conocimientos científicos ya considerados como verdaderos" p.269. Condena propia del sectarismo científico que es igual que el religioso y el político -los socialistas sectarios-. "lógico es también (...) que el sectarismo en ciencia perjudique la integridad de los conocimientos científicos" p.269.

Ciencia oficial vs ciencia revolucionaria. Esta ciencia revolucionaria está habitada por una "legión de sabios": Rochas, Blavatsky, Crookes, Shakou, Soyen, Wallace, Aksakoff. Señalan la importancia de los estudios de Teosofía y Ocultismo, que "nos han dado a conocer fenómenos de indiscutible realidad, que están en contradicción con las pretendidas leyes de los sabios oficiales"p.269.

Estas disciplinas son presentadas como aquellas cuyos conocimientos visionarios serán incorporados tarde o temprano al terreno científico. Hipnotismo, magnetismo animal, sugestión hipnótica en la terapéutica sugestiva. p.269.

Según dicen se ha fundado o se va a fundar una Facultad de Estudios Superiores. En ella se dictarán, entre otros, los siguientes cursos: Ocultismo en general, Kabbala, Ocultismo práctico, Terapéutica oculta y Magnetismo trascendental. "Notamos la ausencia de un curso de Hiperquímica y de una sección de trabajos experimentales. p. 270 .

Bibliografía:

Boletín de la prensa argentina n $^{\circ}$ : "Publica un macaneo de E. Lobos sobre 'La propiedad literaria y artística"'

Sophia, nº. "Organo oficial de la sociedad teosófica de España. Publica: 'El Génesis' por Arturo Soria y Mata; 'Cartas a una sacerdote católico' por Arthur A. Wells; "Estudios acerca del buddhismo' por A. P. Sinner.

L'Humanité intégrale $\mathrm{n}^{\circ} 7$. "Revista espiritualista. Contiene: 'La vida y los mundos' por Marius George; 'La fotografía del C. Tregard' por Camilo Chaigneau; etc. etc..

Suscripción de protesta y solidaridad destinada a cubrir el déficit del $2^{\circ}$ trimestre de La Montaña. Aunque la situación de la multa ya ha quedado en la nada, sigue la colecta de fondos para pagar el déficit. p.273.

Anuncios:

La plume

L'Humanité intégrale

La Critique

Neuland. Revista de Arte Revolucionario Berlín.

Arte y socialismo: la revista ha publicado la obra de Adolph Retté, Idilio diabólico. El Revolucionario. Lo vende a 0,20 (por adelantado).

No12 15 de septiembre de 1987.

Estudios sociológicos

Utilidad del robo y la prostitución (E. Carpenter)

El Socialismo y la familia (Adolfo Zerboglio)

Congreso Internacional de Sociología (René Worms)

Arte, Filosofía, Variedades 
Epítome de Psicología (L. Lugones)

El burgués (José Pardo)

Moral burguesa (H. de Balzac)

La niña pobre (Paulina Lombroso)

Soneto (E. de Amicis)

Actualidad

Paradoja del pan caro (J. Ingegnieros)

Atentado a Borda (Francisco C. Aratta)

Partido Socialista de Bulgaria (Adrián Weber)

Para los desterrados españoles (F. Cini)

La Quincena

Congreso feminista

Movimiento Socialista

Bibliografía.

Congreso Internacional de Sociología celebrado el 21 de julio de 1897 en París en La Sorbona. Ver los temas: Terapéutica de la degeneración; justicia criminal, cerebro social e individual, la ciencia como función social, la evolución de la idea monárquica, la evolución de la educación, la teoría orgánica de las sociedades, las leyes de la evolución política, etc. 


\section{ANEXOS CORRESPONDIENTES AL CAPÍTULO 2}


Revista Ideas - Índice realizado a partir de los sumarios de los 24 números que componen la colección completa de la revista.

\author{
Año I, Tomo 1, no 1, mayo, 1903 \\ Ricardo Olivera \\ Sinceridades p. 3-10 \\ Alberto del Solar................El doctor Morris (se publica el acto II, escena V) pp. 11-20 \\ Ángel de Estrada.............. Los Rubíes maravillosos pp. 21-26 \\ Martín Gil ..........................Velorio siniestro pp. 27 -32 \\ Eugenio Díaz Romero...... El sueño del Emperador pp. 33-37 \\ G. E. Leguizamón ............. Psicología del amor pp. 38-50 \\ Emilio Ortiz Grognet........ Un crepúsculo del génesis pp. 51-55 \\ Martín A. Malharro............ Pintura y Escultura pp. 56-63. \\ Julián Aguirre.....................Música pp. 64-67 \\ Juan Pablo Echagüe.......... Letras argentinas pp. 68-71. \\ Emilio Becher....................... Letras francesas pp. 72-85. \\ Manuel Gálvez (hijo) ....... Teatro pp. 86-95. \\ Redacción........................... Revista de revistas pp. 96-104.
}

Año I, Tomo 1, no 2, junio, 1903

Leopoldo Lugones ............ Intimidades pp. 105-107

Juan Ángel Martínez........... Finanzas pp. 108-120

David Peña......Fomento del Teatro Nacional pp. 121-128

Alberto Ghiraldo.......Música prohibida pp. 129-133

E. Alonso Criado ........ De lo bello pp. 134-147

Mario Sáenz .............. Juliana pp. 148-154

Martín Malharro ........ Pintura y Escultura pp. 155-168

Julián Aguirre...... Música pp. 169-171

Ricardo Rojas.......... Letras Hispanoamericanas pp. 169-179

Emilio Becher........... Letras Francesas pp. 182-188

Letras argentinas. LFD pp. 189-194

Manuel Gálvez (hijo) ....... Teatros pp. 195-199 [también hay una nota de Echagüe]

$* * * * * * * *$.............................. 200

Erratas........................pp. 209.

Año I, $n^{0}$ 3, Tomo 1, julio, 1903

La Dirección.................. Una palabra pp. 209 [se va Olivera e ingresa como redactor Emilio Ortiz Grognet]

Lorenzo Andón y Miguel Toro Gómez.............Problemas lingüísticos pp. 210-220

Osvaldo Saavedra.............Pro divorcio pp. 221-234

José H. Porciel................. Invernal p. 235

Ricardo Rojas............... Estudio sobre Echegaray pp. 236-249

Adolfo Vidal................... Tratamiento y corrección pp. 250-256

Horacio F. Rodríguez................... Flores marchitas p. 257

Galería de intelectuales contemporáneos........ Barrantes Abáscal [no está en el sumario; se incluyen las caricaturas sobre Mitre y Cané] pp. 258-261

Julián Aguirre Música pp. 262-265

Emilio Becher Letras Francesas pp. 266-275

Alberto Gerchunoff.............. Letras argentinas pp. 276-284

Manuel Gálvez (hijo) .............. Teatro pp. 285-291

Héctor F. Dellmonte .......... Varias pp. 292-296

Redacción .................. Revista de revistas pp. 297-304

Teatros [no forma parte de la numeración corrida de la revista. Se consignan las obras en cartel] Las propagandas que vienen después tampoco forman parte de la numeración corrida de la revista.

Año I, Tomo 1, $n^{\circ}$ 4, agosto, 1903 [Propaganda de cognac] 
Francisco Sicardi. El genio y la multitud pp. 305-307

José Cibils El ritmo nuevo pp. 308-311

José Ingegnieros ...........El médico ignorante pp. 312-318 [dedicado a J. P. Echagüe]

Rafael Barret Aguas fuertes pp. 319-322

Alberto Williams

El tuco pp. 323

Carlos de Soussens ..... El crimen de la calle Florida pp. 324-336 [para Eduardo Pinedo]

Benjamín García Torres Nocturnal pp. 337-338

E. Ángel de Estrada (h) pp. 339-341.[ viene con una breve nota biográfica]

De León Tolstoi, traducido por J. S. Jofre....Los dos ancianos, Páginas ajenas pp. 342-360

Julián Aguirre. Música pp. 361-365

Emilio Becher Letras Francesas pp. 366-371

Roberto J. Bunge Letras argentinas pp. 372-380.

Manuel Gálvez (hijo) Teatros pp. 381-391.

Héctor F. Dellmonte Varias pp. 392-394

Redacción Revista de revistas pp. 392-394.

A. G. $-\mathrm{X}$ Tesis y folletos p. 398

Abajo del sumario dice "Un dibujo de F. Barrantes Abáscal

Hay al final de la revista un índice general hecho con los sumarios y luego propagandas que no forman parte de revista, además de la consignación de las obras de teatro.

Año I, Tomo 2, $\mathbf{n}^{0}$ 5, septiembre, 1903 [tiene propagandas de cognac, licores, librerías, ropa, y además un espacio de media página que dice "disponible"]

Manuel Ugarte....... Nuevas tendencias literarias pp. 2-9

A. de Estrada (hijo)............. Las cigüeñas de Luxor. pp. 11-19

Eduardo L. Arengo ..............Soneto p. 20

Georges Doré [Manuel Gálvez........... El teatro libre pp. 21-27

A. Monteavaro ...........Un retrato al pastel pp. 28-33 [sobre F. Sánchez]

J. J. Lastra ............. ¡Poeta! pp. 34

M. Argerich ......... La Milonga pp. 35-37

F. Barrantes Abáscal..............Prosa sagrada pp. 38-41

E.............................José Ingegnieros pp. 42-44 [va acompañado por una caricatura de Abáscal]

José Ingegnieros .............. Nietzschismo pp. 45-50["Palabras a J. L. Pagano en el banquete de artistas"]

De León Tolstoi, traducido por J. S. Jofre....Los dos ancianos, Páginas ajenas pp. 51-53.

E. C. O Bunge pp. 54-55 [lleva caricatura de Abáscal]

J. L. Pagano............ Más allá de la vida pp. 56-136 [drama]

Ricardo Rojas.......... Letras Hispanoamericanas pp137-146

Julián Aguirre............... Música pp. 147-149.

Manuel Gálvez (hijo) ..............Teatros pp. 150-152

Teatros : consigna los estrenos

Propagandas de vino, Luzio's Resturant, afirmados, zapatos.

Año I, Tomo 2, $\mathbf{n}^{0}$ 6, octubre, 1903 [ tiene 5 páginas de propagandas de cognac, licores, librerías, ropa, papeles pintados] Desde el número 5 lleva un dibujo de una antorcha con un llama]

Ricardo Gutiérrez Fragmento de Lázaro pp. 1553-156.

Manuel Ugarte A Pierrot pp. 157-158

Julio A. Rojas Sarmiento pp. $159-173$

Pedro J. Naón...............Esmalte pp. 174-176

J. P. Echagüe............. Cané "vu du dehors" pp. 177-179

J. M. Rubianes............ Relaciones con el Paraguay pp. 180-190

Salvador Oría ............. Arma roja pp. 191-192

A. Zavalía Guzmán.......... Flores marchitas pp193-194.

Emilio Becher........... Letras francesas pp. 195-203

Ricardo Rojas ........... Letras Hispanoamericanas pp. 204-210

Alberto Gerchunoff ........... Letras argentinas pp. 211-217 
E. B. ...Letras argentinas pp. 217-225

Julián Aguirre. Música pp. 226-228

Manuel Gálvez (hijo) Teatros pp. 229-232

Aviso del Hierro-quina-bisleri, cognac, zapatos, restaurant, librería Menéndez de libros bien diversos]

Año I, Tomo 2, $\mathbf{n}^{0}$ 7, noviembre, 1903 [tiene propagandas de cognac, de librería a. García Santos, vino, sobre La victoria del hombre de R. Rojas anunciando su aparición, ropa, imprenta Tragant y cía] Carlos O. Bunge......San Atanasio (parte no publicada de Xarcas Silenciario) pp. 233-259

Antonino Lamberti No vayas más p. 260

H. Muñoz Amor de artista pp. 261-265 [para Osvaldo Saavedra]

Ricardo Rojas La victoria del hombre pp. 266-268

Joaquín M. Rubianes Relaciones con el Paraguay pp. 269-288

B. Hernández Pecadora p. 289

L. Tolstoi Los dos ancianos

Traducción de J. S. Jofre Páginas ajenas pp. 290-299

Alberto Gerchunoff . Letras argentinas pp. 300-305

Alfredo C. López . Letras argentinas pp. 306-308

Manuel Gálvez (h) Teatros pp. 309-312

Avisos varios. No aparecen los avisos de teatro

Año I, Tomo 2, ${ }^{0}$ 8, diciembre, 1903

Enrique Prins. Flores azules pp. 313-324

Manuel Ugarte. A una demi-modaine pp. 325-326

Carlos Ortiz .Vagando y divagando pp. 327-332 [dedicado a Gando]

José M. Porciel. Sonetos pp. 333-334

J. M. Rubianes Relaciones con el Paraguay pp. 335-351

Juan J. Lastra Cumbres Rojas pp. 354-357

Ernesto L O'dena. M'hijo el dotor pp. 358-363

L. Tolstoi Los dos ancianos

Traducción de J. S. Jofre Páginas ajenas pp. 364-371

Emilio Becher Letras argentinas pp. 372-384

Manuel Gálvez Teatros pp. 385-390

[Índice general del segundo Tomo septiembre-diciembre. 1903]

Año II, Tomo 3, nº 9, enero, 1904.

Carlos María Ocantos Nebulosa p. 3-21

Enrique Crosa ¡Ya soy viejo! p. 22-47

Alberto Williams Nocturno en la sierra p. 48

Emilio Alonso Criado Contrastes filosóficos pp. 49-52

José León Pagano Núñez de Arce pp. 53-67

Juan Julián Lastra Albas épicas pp. 68-69

Rafael Barret La última primavera pp. 70-71

Emilio Becher Letras francesas pp. 72-74

Manuel Gálvez (h) Letras argentinas p. $75-89$

Manuel Gálvez (h) Teatros pp. 90-96

Año II, Tomo 3, n⿳0 10, febrero, 1904.

José León Pagano Jerónimo Rovetta p. 97-127

Enrique Crosa ¡Ya soy viejo! p. 128-147

Alfredo Arteaga El verso p. $148-152$

Ricardo Olivera El regreso de Palermo p. 153-161

Ricardo Rojas Letras españolas p. 162-180

Manuel Gálvez Letras argentinas p. 181-186

Manuel Gálvez Teatros pp. 187-192. 


\author{
Año II, Tomo 3, n 11 y 12, marzo abril, 1904 \\ Roberto Payró \\ Sobre las ruinas p. 193-296 \\ Pedro B. Palacios \\ Evangélico p. 297-298 \\ Ricardo Olivera \\ La novela de la sangre p. 299-306 \\ Julio A. Rojas \\ El alma de una raza p. 307-309 \\ Eugenio Díaz Romero.... Aparición p. 310-313 \\ Alberto Rougés \\ ¡El gaucho se va! p. 314-316 \\ F. Barrantes Abáscal.. Exposiciones artísticas p. 317-323 \\ Manuel Gálvez (h),.... Letras argentinas p. 324-347 \\ Abel Cháneton \\ Letras argentinas pp. 348-353. \\ Emilio Becher.............Letras francesas pp. 354-361 \\ Manuel Gálvez (h) ........Teatros p. 362-372 \\ Manuel Gálvez (h) ...... Juicios de afuera p. 373 -382 \\ Manuel Gálvez (h) ..... Índice del Tomo 3 enero -abril 1904
}

Año II, Tomo 4, n 13, mayo, 1904.

Belisario Montero ...... De mi diario.... pp. 3-13

Carlos O. Bunge.......La novela de la sangre (cap. Inédito) pp. 14-42

José Ingegnieros........ Las enfermedades del lenguaje musical pp. 43-52

E. Díaz Romero..... El crimen del otro pp. 53-62

R. Rojas............. Letras hispanoamericanas pp. 63-65

A. Chiappori...... Letras argentinas pp. 66-77

Julián Aguirre .... Música pp. 78-81

Abel Cháneton ..........Teatros pp. 82-91

M. Gálvez ...Crónica del mes p. 92

Redacción........ \{ sobre La victoria del hombre p. 96

Redacción \{ Juicios de afuera p. 96

Año II, Tomo 4, no 14, junio, 1904

Paul Groussac ............... El alma francesa pp. 107-119

Carlos O. Bunge ............ Psicología de los españoles (?) pp. 120-170

Amado Nervo ................ Sobre los sueños que pasan p. 171

Emilio Becher ............... Letras francesas pp. 173-178

Atilio Chiappori .............. Letras argentinas pp. 179-193

Abel Cháneton .............. Teatros pp. 194-199

Manuel Gálvez (h) ......... Crónica del mes pp. 200-202

Redacción ..................... El aniversario de Ideas p. 203-210

Redacción ...................... Juicios de afuera p. 211-212

Año II, Tomo 4, no 15, julio, 1904 [número que se agotó en dos días]

Osvaldo Saavedra ............ Cuerpo y alma p. 211- 245 [comedia en un acto]

A. Reynal O'Connor ......... Los poetas argentinos p. 246-268

Marguerite ....................... La jeune fille d'aujourd'hui est-elle hereusse p. 269-297

Godofredo Daireaux ......... Zorro viejo p. 298-300

Atilio Chiappori ............... Letras argentinas pp. 301-311

Abel Cháneton ............... Teatros pp. 312-315

Manuel Gálvez (h) ......... Crónica del mes p. 316-320

Año II, Tomo 4, n 16, agosto, 1904

Eduardo Wilde .............. Carta al Dr. Lucio V. López p. 321-324

José León Pagano .......... Rusiñol-Guimará p. 325-379

José Ingegnieros............ Una visión de Zarathustra p. 380-386

Elvira R. Dellepiane ........ La mujer intelectual p. 387-396 
Antonio Lobo La tertulia de Ramada p. 397-404 (traducción de R. J. Payró)

Julián Aguirre Música p. 405-408

Ricardo Rojas Letras Hispanoamericanas p. 409-418

Atilio Chiappori ............. Letras argentinas pp. 419-423

Manuel Gálvez (h) ........ Crónica del mes p. 424-426

Redacción Juicios de afuera p. 427-428

*** Índice del Tomo 4 p. 429 Mayo -agosto 1904.

Año II, Tomo 5, no 17, septiembre, 1904

Oscar Wilde El rey joven pp. 3-25

Manuel Ugarte La prueba pp. 26-36

Godofredo Daireaux El general Roca pp. 37-68

Antonio Monteavaro Carlos de Soussens pp. 69-78

Roberto Bunge Libros del mes pp. 79-89

Alfredo C. López Impresiones artísticas pp. 90-96

Abel Cháneton Teatros pp. 97-100

Emilio A. Criado Revista de revistas pp. 101-116

Manuel Gálvez (h) Crónica del mes pp. 117-120

Año II, Tomo 5, no 18, octubre, 1904

Rachilde La caza del aparecido pp. 121-135

Ernesto Quesada ...... Un literato guatemalteco pp. 136-181

Armando de Viana (seudónimo de Mario Bravo) ..... Los himnos pp. 182-188

Víctor Mercante ......... Parker's Calk on teaching pp. 189-200

Luis M. Jordán ........... Una taza de té ["A Ángel de Estrada, artista y poeta”] pp. 201-205

Roberto J. Bunge......... Libros del mes pp. 206-214

A. Monteavaro ........... Otra obra de Payró pp. 215-219

Emilio A. Criado .......... Revistas de revistas pp. 220-233

Manuel Gálvez (h) ........ Crónica del mes pp. 234-237

Manuel Gálvez (h) ........ Juicios de afuera pp. 238-240

Año II, Tomo 5, $\mathbf{n}^{\mathbf{0}}$ 19, noviembre, 1904

Georges D'Esparbés La victoria de los locos pp. 241-251

Florencio Sánchez La gringa (acto segundo) pp. 252-271

José Ingegnieros Clasificación de las aptitudes musicales pp. 272-298

Justo Solsona Jofre Los juegos florales en Barcelona pp. 299-308

Luis M. Jordán Triboulet pp. 309-322

Roberto J. Bunge Libros del mes pp. 323-340

Emilio A. Criado Revista de revistas 343-352

M. El "Himno a la luna" pp. 363-355

Redacción Libros recibidos pp. 356-358

Año II, Tomo 5, no 20, diciembre, 1904

Georges D'Esparbés Los Viejos pp. 361-369

Martín García Mérou La diplomacia americana pp. 370-442.

**** $\quad$................. Mientras llega el silencio pp. 443-445

Emilio Ortiz Grognet..................En la sombra (comedia en un acto) pp. 446-469

Alberto Tena La juventud hispanoamericana en París pp. 470-476

E. Alonso Criado Revista de revistas pp. 477-481

Redacción Libros recibidos p. 482

Redacción Índice del Tomo V septiembre -diciembre de 1904

Año III, Tomo 6, no 21, enero, 1905

Domingo Faustino Sarmiento Carta a D. José Posse (inédito) pp. 3-12

Osvaldo Saavedra Escenas sociales pp. 13-30 
Julio Molina y Vedia El problema de la cultura personal pp. 31-37

Ricardo Olivera A propósito de El Gringo p. 38-44

$* * * * * *$ Algunas páginas pp. 45-47

Una víctima de Nietzsche Andrèiff pp. 48-78

Libros:

Abel Cháneton ................. Hacia el Oriente por E. Mario Barreda pp. 79-81

Manuel Gálvez (h) ........... Inocencia por Francisco de P. Rendón pp. 82-85

Revista de Revistas:

En tierras antárticas - Si los gatos son personas - Los caprichos del rayo - Cartas de un oficial chino El arte primitivo estudiado en las pipas de tabaco - Las variedades del anarquismo contemporáneo Porvenir del castellano pp. 86-109

Redacción- Juicios de afuera .pp. $110-112$

Año III, Tomo 6, n $^{\circ 2}$, febrero, 1905

Maurice Maeterlink La intrusa pp. 113-137

Augusto Belín Sarmiento La ancianidad de Sarmiento pp. 138-165

Manuel Ugarte La primer cana pp. 166-169

Mariano A. Barrenechea Máximo Gorki escritor p. 170-178

Gastón Laudarés La revolución rusa -Los Sterawersi - El Pope pp. 179-185

Andreieff. Una víctima de Nietzsche (fin) pp. 186-198

Revista de revistas

Una explicación nueva del soneto de las vocales de Rimbaud - Colonias penitenciarias para niños Los japoneses juzgados por un americano - Costumbres inglesas a fines del siglo XVIII y comienzos del siglo XIX pp. 199-216

Redacción - Juicios de afuera (Sobre el libro La España literaria de José León Pagano) pp. 217-228

Año III, Tomo 6, no 23-24, marzo-abril, 1905

Oscar Wilde El pescador y su alma pp. 229-287

José León Pagano Federico Nietzsche pp. 289-309

Martín Malharro La estética en la escuela pp. 310-327

José Ingegnieros Origen y esencia de la Shyringa pp. 328-329

Eugenio Díaz Romero Las pescadoras pp. $330-340$

Ricardo Rojas El país de las selvas pp. 341- 347

Mariano A. Barrenechea ............. Nietzsche, las mujeres y Rema de Gourmont pp. 348-365

Abel Cháneton Cosas de borrachos (cuento) pp. 366- 374

Mario Bravo. Los himnos pp. 375-377[ está con y]

Emilio Alonso Criado Entelecchia pp. 378-405

Juan B. Justo, Nicolás Repetto, Julio Arraga, Manuel Ugarte, Julio A. Rojas..... Sobre el proyecto de "Ley de Trabajo" pp. 406-426

Redacción:

Revista de Revistas pp. $427-445$

Libros recibidos pp. $446-448$

Dos palabras al lector p. 449

Índice del Tomo VI pp. $450-451$. 


\section{Letras argentinas}

La revista tiene una sección específica dedicada a la producción literaria nacional. A diferencia de otras secciones de 'letras' nacionales, que tienen un redactor fijo, en 'Letras argentinas' escriben varios críticos, como lo muestra la lista que abajo transcribimos. Se publicó en los números 1-4, 6-16. La sección desaparece en el $\mathrm{n}^{\mathrm{o}} 17$, y es sustituida por otra, 'Libros del mes', a cargo del Roberto J. Bunge; paralelamente aparece otra sección, 'Libros recibidos', de la que se ocupan Gálvez y Cháneton. De literatura argentina se trata también en artículos que no forman parte de ninguna de las secciones mencionadas. Entre ellos se cuentan, la colaboración de Ernesto L. O'dena ( $\mathrm{n}^{\mathrm{o}}$ 8) sobre Florencio Sánchez (uruguayo), el trabajo de Olivera sobre La novela de la sangre de Carlos O. Bunge $\left(\mathrm{n}^{\circ} 11\right.$ - 12), las notas de Antonio Monteavaro sobre Florencio Sánchez ( $\mathrm{n}^{\circ}$ 5), sobre Charles de Soussens $\left(\mathrm{n}^{\circ} 17\right)$ y Triunfador de Roberto Payró $\left(\mathrm{n}^{\mathrm{o}} 18\right)$. Como se señala en el cuerpo de la tesis, el índice de la revista hace visible un interés particular sobre la producción vernácula.

En lo que sigue nos detenemos en cada una de las entregas de 'Letras argentinas', 'Libros del mes' y 'Libros recibidos', reseñamos brevemente su contenido, apuntamos problemas y transcribimos los pasajes fundamentales en relación con la perspectiva de tales problemas, ${ }^{1}$ que constituyen los puntos centrales del desarrollo de la investigación: tematización del estado del mundo intelectual, construcción de tradiciones, evaluaciones sobre el público, las instituciones, vinculación de las prácticas intelectuales con la política, cuestiones relativas a la inflexión nacionalista que constituye una de las marcas de autodefinición de la revista, etc..

\section{Listado completo de las entregas de:}

\section{a) Letras argentinas}

*Juan Pablo Echagüe, Año I, Tomo 1, n 1, mayo, 1903, pp.68-71.

*LFD, Año I, Tomo 1, nº 2, junio, 1903, pp. 189-194.

*Alberto Gerchunoff, Año I, nº 3, Tomo 1, julio, 1903, pp.276-284.

*Roberto J. Bunge, Año I, Tomo 1, n ${ }^{\circ}$ 4, agosto, 1903, pp. 372-380.

*Alberto Gerchunoff, Año I, Tomo 2, no 6, octubre, 1903, pp. 211-217

*E. B. [Emilio Becher], Año I, Tomo 2, no 6, octubre, 1903, pp. 217-225

*Alberto Gerchunoff, Año I, Tomo 2, no 7, noviembre, 1903, pp. 300-305

*Alfredo C. López, Año I, Tomo 2, nº 7, noviembre, 1903, pp. 306-308

*Emilio Becher, Año I, Tomo 2, no 8, diciembre, 1903, pp. 372-384

*Manuel Gálvez, Año II, Tomo 3, no 9, enero, 1904, pp. 75-89

*Manuel Gálvez, Año II, Tomo 3, n 10, febrero, 1904, pp. 181-186

*Manuel Gálvez, Año II, Tomo 3, no 11 y 12, marzo-abril, 1904, pp.324-347

*Abel Cháneton, Año II, Tomo 3, n ${ }^{\circ} 11$ y 12, marzo-abril, 1904, pp.348-353

*Atilio Chiappori, Año II, Tomo 4, no 13, mayo, 1904, pp. 67-77

*Atilio Chiappori, Año II, Tomo 4, no 14, junio, 1904, pp. pp. 179-193

*Atilio Chiappori, Año II, Tomo 4, no 15, julio, 1904, pp. 301-311

*Atilio Chiappori, Año II, Tomo 4, n 16, agosto, 1904, pp. pp. 419-423

\section{b) Libros del mes}

*Roberto Bunge, Libros del mes, Año II, Tomo 5, no 17, septiembre, 1904, pp. 79-89.

*Roberto J. Bunge, Libros del mes, Año II, Tomo 5, n 18, octubre, 1904 pp. 206-214

*Roberto J. Bunge, Libros del mes, Año II, Tomo 5, n ${ }^{\circ} 19$, noviembre, 1904, pp. 323-340

\section{c) Libros recibidos}

*Redacción [Manuel Gálvez], Libros recibidos, Año II, Tomo 5, nº 19, noviembre, 1904, pp. 356-358.

*Redacción [Manuel Gálvez], Libros recibidos, Año II, Tomo 5, nº 20, diciembre, 1904, p. 482.

*Abel Cháneton, Hacia el Oriente por E. Mario Barreda Año, Año III, Tomo 6, nº 21, enero, 1905, pp. $79-81$

\footnotetext{
${ }^{1}$ Algunas de las notas que se considera fundamentales, como la de Gerchunoff del $n^{\circ} 7$, no se transcriben porque se da cuenta de ellas detalladamente en el desarrollo de la investigación.
} 
*Manuel Gálvez (h), Inocencia por Francisco de P. Rendón, Año III, Tomo 6, n 21, enero, 1905, pp. 82-85. [esta entrega se llama solamente 'Libros']

* Redacción [Manuel Gálvez] Libros recibidos, Año III, Tomo 6, nº 23-24, marzo-abril, 1905, pp. 446-448.

\section{Detalle de cada una de las entregas de las secciones a), b), c).}

\section{a) Letras argentinas}

\section{$\mathbf{N}^{\circ} 1$}

Juan Pablo Echagüe, Año I, Tomo 1, nº 1, mayo, 1903, pp.68-71

Como se dijo en el cuerpo del trabajo, se trata de una nota programática en la que interviene polemiza con

Transcribimos la nota completa:

"Impera en las letras argentinas cierta especie de caudillaje, resto atávico del político que antes aplastara al país bajo su bota. Ha erigido su autoridad sobre un pasivo concensus omnium deprimente para nuestra autonomía mental. E invocando la usurpada "consagración" que debe á manejos de chicana electoral aplicados á la literatura, pontifica de Sumo Artista distribuidor de indulgencias y anatemas inapelables, que la grey tolera, peor aún, acata sumisamente.

Esos tiranuelos -entre los cuales no faltan Anatoles Frances de caricatura, para uso doméstico, que reflejan el original exactamente como un espejo convexo- son los responsables de nuestro relativo atraso literario. Ellos han enseñado á la juventud que pueden levantarse cátedras de "maestro" sobre la base del indolente laisser faire criollo, utilizando recursos de orfeón carnavalesco: exhibición y ruido. Ellos han demostrado prácticamente que para vencer, requiérese más audacia y bambolla que meditación y estudio. Ellos han extraviado por sugestiones de ejemplo la buena orientación intelectual, torciéndosela hacia el éxito inmediato y fugaz, en vez de dirigirla al único fecundo: el que se alcanza al fin de recias bregas forjadoras de cerebros y de músculos. Ellos, en fin, son los que hacen triunfar esa escuela de papagayos donde tan admirablemente aprenden los discípulos de la ciencia de los preceptores: repetir en tono sentencioso, frases clichés y juicios elaborados.

Urge combatir este mal, del mismo modo que apremia extirpar los parásitos en la planta joven, facilitándole un libre y sano crecimiento. Precisamos reivindicar nuestra lesionada soberanía del espíritu, porque sin ella caeremos en el servilismo mental, la más humillante de las esclavitudes en razón de la pasividad del sometimiento. Y para ello, hay que rebelarse virilmente contra los supremos sacerdotes del viejo templo polvoriento sobre cuyos altares enguirnalados de telarañas, ofícianse a puerta cerrada glorificaciones al Éxito. Hay que 'romper los vidrios aunque sea á pedradas si las ventanas están muy altas, dando paso a la luz de un pensamiento nuevo'. Y hay que colocar después otro símbolo en el ara: el del trabajo lento y silencioso como la germinación de la semilla, cuyo fruto solo ha de cosecharse más tarde, cuando cumplido su natural proceso de desarrollo, la granada espiga se abra dorada por el sol....

He aquí la causa a la cual servirá esta sección de la revista luchando enérgicamente, de frente.

Es verdad que no hemos de exterminar ni acaso conmover ese fetichismo que esteriliza tantas juveniles inteligencias. Para voltear el gigantesco ídolo, fuera necesario un formidable batir de arietes. Pero acaso unos certeros golpes de piqueta, abran en le basamento una brecha que sirva de partida a la demolición futura... No olvidemos, entre tanto, que 'el coloso se derrumba al fin, roído por la persistencia del insecto"” pp.68-71

\section{$\mathbf{N}^{\circ} 2$}

LFD [Lorenzo Fernández Duque], Año I, Tomo 1, no 2, junio, 1903, pp. 189-194.

- El concurso histórico literario de La sin Bombo. Se trata de un concurso de novela, en el que se arma una poética que une el género a una temática. Son novelas históricas nacionales.

Fernández Duque alaba la iniciativa de Juan Canter de lanzar este concurso. Este elogio se tributa habitualmente a todo aquello que implique la promoción de las prácticas intelectuales-artísticas. El concurso no ha sido un éxito, pero, explica Fernández Duque, esto se debe a la restricción a lo histórico y a la composición del jurado, compuesto por "personas poco conocidas". Se ve entonces otra función de estos concursos: respaldar, legitimar a quienes participan y a la vez favorecer este tipo de instituciones, a partir del prestigio y la competencia necesarios de los que juzgan y deciden sobre el 
mérito de las producciones. Sostiene: "La distribución de los premios nos ha dado la razón y nos afirma en la creencia de que, con la mejor voluntad, se equivocaron en grande en cuanto al mérito de las novelas" p.189. Describe las novelas premiadas: a) Golpe en vago de José Antonio Pillado, segundo premio -el primer premio se declaró desierto. Para LFD es la peor de todas: mal escrita, falta de sentido común y de verdad histórica, con caracteres mal trazados. b) ¿Qué fue? de Juan A. Facio, tercer premio. Rescata que esté bien escrita. "El paisaje, así como las costumbres de la época y los relatos retrospectivos, están hechos con erudición y colorido" aunque está "descuidada la psicología" del personaje Castro. c) La Bandera de Martín Coronado, mención honrosa. En cuanto a la lengua, la califica de monótona porque "hace de su prosa castiza en la frase, una sinfonía de consonantes involuntarios"; según LFD es ingenuo en la forma en que muestra las situaciones y también anticuado.

\section{$\mathbf{N}^{\circ} 3$}

Alberto Gerchunoff, Año I, nº 3, Tomo 1, julio, 1903, pp.276-284.

Comienza la sección con una referencia a su propia práctica crítica, en términos similares a los de Olivera en la nota apertura, para ratificar los imperativos que guían sus intervenciones. Transcribimos todo ese primer parágrafo que abre la sección y en el que enuncia su programa.

"Es de lamentar que en la Argentina no exista un psicólogo de la talla de monsieur Bourget, pues tendría ocasión para inmortalizarse en una obra cuyo asunto le propondríamos nosotros...

El argumento, nuestro novedosísimo argumento, consiste en desarrollar la psicología de un solo personaje, miembro de la redacción de una revista literaria, que se consume de angustia al no poder elogiar - como honradamente quisiera- las obras cuya crítica está a su cargo.

Tal es el asunto que no debería desperdiciarse, o tal es, mejor dicho -personalizando el casola situación desagradable y violenta del redactor de esta sección.

Juzgar una obra mediocre o combatir un ídolo falso con la virulencia y la severidad que imponen las circunstancias, es cosa que no se practica frecuentemente entre nosotros, donde la crítica está prostituida por la hipocresía más desvergonzada. Diríase la república de las letras copiando la oligarquía fraudulenta de nuestro sistema gubernamental...

He ahí lo que podríamos llamar nuestro estado de conciencia al encargarnos de esta sección en la revista Ideas.

Bien sabemos que en el ambiente social en que vivimos, el prejuicio obstaculiza toda intención sincera, exigiendo patente de autoridad al que pretende hablar en voz alta.

$\mathrm{Y}$ desgraciadamente, contra este mal, toda protesta es prematura aún. Es menester resignarse un tanto. Son usos lógicos mientras presida todas las funciones de la vida ese venerable rinoceronte que se llama Burgués!

Y nosotros, por nuestra parte, jamás descenderemos al elogio impuro, guiados por una caridad mal interpretada, que como toda limosna, es cruelmente humilladora.

Y no cabe duda que para todo espíritu sincero es preferible ser acreedor a un odio franco, tributado cordialmente por parte de los autores criticados, antes de enmugrecer la conciencia con manchas de cobardía.

Tal es el programa que ha de guiarnos. Las notas con que nos iniciamos suplen todo detalle de explicación. En cuanto a la patente de autoridad, opondremos nuestros pulmones de hierro y el vehemente amor que profesamos por el Arte y la Justicia. Así sea ...”

En un segundo apartado se dedica a la crítica de libros, consignando las editoriales en que aparecen publicados. En cada caso es importante reparar en la figura que construye para los autores.

-Ensayos y notas por Juan Agustín García (hijo), Arnoldo Moen, editor.

Se refiere al autor como "un gran laborioso que descuella entre nuestros intelectuales por su sólida erudición y por sus cualidades de escritor"; como autor de la Ciudad indiana, Gerchunoff esperaba una obra mejor que ésta que se publica: "Su Ciudad indiana nos lo reveló como un fuerte argumentador, y sobre todo como un estudioso, consagrado a documentar con acertado criterio a veces, los acontecimientos históricos de una época compleja, cuya interpretación científica daría motivo a una obra importantísima de sociología argentina". Refiriéndose a Ensayos y notas sostiene: "Componen este volumen, primero, varios estudios, que podrían tolerarse como notas marginales, y, segundo, una serie de notas verdaderamente chocantes, dignas de figurar en una recopilación de obras 
póstumas de cualquier periodista rural..." p.279. De los ensayos comenta y critica el que García dedica a Paul Groussac, y "La formación de las ideas".

-Horas lejanas, por Darío Herrera, Arnoldo Moen, editor.

Gerchunoff compara el libro de este colombiano ("que desde hace varios años a esta parte, es un verdadero adorno en nuestra sociedad elegante" p. 280) con un cuento de Dostoievsky "en el que el gran escritor pinta a una romántica entumecida, ni bonita ni fea, inmensamente insulsa, que ni siquiera tenía la vulgarísima virtud de inspirar deseos, 'una insipidez viviente', dice el autor.” p.280.

- En vísperas, "por el general Lucio V. Mansilla", hermanos Garnier editores, París, 1903.

Se trata de la crítica negativa al "lujoso volumen" de Mansilla, al que califica de "pseudo-libro".

"El pseudo-libro se ocupa de las vísperas de la elección presidencial, asunto que da motivo al autor a llenar varios capítulos con digresiones de filosofía gelatinosa, cuajada de humorismos de cocina que en boca del insigne diplomático adquieren cierto matiz de lunfardismo elegante. El autor de estas líneas se permite opinar que el libro en cuestión influirá bien poco en la solución del problema" p. 382.

-Las sombras de Hellas, por Leopoldo Díaz. [no hay dato de editorial, aunque se supone alguna famosa de París]

Se trata de un libro más de poemas del "cónsul argentino en Suiza". Edición bilingüe francés-español, cuyo traductor al francés es Frédéric Raisin. Tiene prólogo de Rémy de Gourmont, en el que se observan, según Gerchunoff, los malabarismos del escritor francés por hablar lo menos posible de los poemas que prologa. Califica a estos sonetos de "servil imitación", aunque su autor maneje relativamente bien el idioma, son versos vacíos. Esta vaciedad aparece ligada a la función estatal que ocupa: "Misterios de los hombres de prebenda, diría Heine". p. 283.

-Tradiciones argentinas, por Pastor S. Obligado [no se consigna la editorial]

Comienza con la consabida imagen del autor de cuyo libro se ocupa: "D. Pastor S. Obligado es uno de esos ejemplares, desgraciadamente tan comunes que no sabiendo en qué ocupar su existencia, la emplean en las letras, para tormento de los críticos, pues son los únicos lectores que tiene probablemente D. Pastor, a excepción de uno que otro deudo generoso" p. 283 Lo único que rescata es cierta erudición, aunque en el medio de episodios ridículos.

-El cadete del año 13, por Rodolfo Díaz de Olazábal, Arnoldo Moen editor.

Monografía sobre la época patricia en la que Gerchunoff no encuentra ningún valor.

-Fantasías y leyendas, por G. A. Martínez Zuviría. [no se consignan datos de la edición]

Cuentos "bastante bien escritos" aunque en lenguaje pobre; tiene un prólogo de José M. de Pereda. Según Gerchunoff, se puede esperar algo (del futuro Hugo Wast), ya que su autor es joven.

\section{$\mathbf{N}^{0} 4$}

Roberto J. Bunge, Año I, Tomo 1, no 4, agosto, 1903, pp. 372-380.

Se trata de una larga crítica a Modos de ver de Martín Gil.

En el primer apartado anticipa la crítica: es un "pretendido libro" de un "pretendido escritor". En el segundo apartado repasa algunos de los cuentos, dando una visión general negativa. Los títulos que revisa son: "Pato hediondo", "Tipos que pasan", "Cinematógrafo campestre", "Cielo y tierra" (nombrado como primer capítulo), "Intermezzo", "Ashaveras", "Noche de perros". En el apartado III, Bunge describe el libro como una "sucesión de artículos sueltos, acerca de los temas más diversos, vaciados todos en el mismo molde antiestético, llenos de lugares comunes, figuras trasnochadas, errores de dicción, comparaciones a granel, para expresar ideas de una mediocridad abrumadora" $\mathrm{p}$. 375. Luego de criticarlo detalladamente, en el parágrafo IV se modera y cambia el eje de la cuestión: "No le faltan condiciones, sin embargo. Menos desprecio por 'S. M. la frase', menos empeño en aparecer irónico y original, menos abuso de las complicaciones imaginativas, tan difíciles como peligrosas, lo convertirían en un escritor sano y agradable, para ciertos temperamentos. (...)

Si se dedicara franca y decididamente a cultivar la literatura campestre, estaría en su puesto, y llegaría alguna vez, no lo dudo, a justificar su renombre de autor nacional. 
No llegará a escribir obras desbordantes de verdad y de bríos, de sentimientos y de pasiones como Pereda -a quien podría presentarle como su mejor modelo literario- pero llegará, en cambio, a merecer el aplauso de muchos lectores, ávidos de escenas campestres, y hartos de Moreiras y demás 'héroes' bandidos" pp. 379-380.

\section{$\mathbf{N}^{0} 6$}

Alberto Gerchunoff, Año I, Tomo 2, no 6, octubre, 1903, pp. 211-217

-La novela de las horas y de los días, por Manuel Ugarte, París, Hnos. Garnier, editores.

Se trata del diario de un pintor. Dice Gerchunoff: "Todas las 232 páginas que componen la novela del sentimental pintor, podrían sintetizarse, a manera de una definición, diciendo, que el diario de Juan Lapeña, es un lento desfile de cosas angustiosas; definición que a su vez puede aplicarse al conjunto de la obra de Manuel Ugarte" p.212. Gerchunoff valora "el inmenso amor a la Justicia y a la Verdad. En el fondo de toda esa recopilación de memorias de un temperamento afligido y analista, palpita una consoladora piedad por todos los tristes y pequeños, por todos los derrengados y caídos, sobre quienes la Sociedad ha escupido su desprecio. Eso reanima un poco al lector" pp. 212-213. Del estilo sostiene: "es sencillo y claro, cuajado de elegancias imprevistas, robusteces que admiran." p.214. Le interesa a Gerchunoff Ugarte como "ejemplo honroso":

“(...) El vivió en París, y allí vio algo más que a los bohemios de taberna, y a los decadentes de profesión, pobres martirizadores de impotencia, hoy relegados a un secreto olvido.

En ese gran museo vivo de cerebros, en esa gran Cosmópolis, donde la civilización preside los destinos del mundo y de las razas, Ugarte observó y estudió todos los movimientos que implican un adelanto. Comprendió que en este período de transición universal, deben olvidarse las orquídeas en los invernáculos o en el ojal de los idiotas y descender a la lucha franca y abierta en pro de un Ideal. Comprendiendo tal cosa Ugarte, al venir acá por tan corto tiempo, lo ha empleado en las conferencias, en centros obreros, para hablarles del Socialismo [en mayúscula en el original], idea de la cual es sincero y vibrante paladín.” p. 214.

-El crepúsculo de los gauchos, por Félix Basterra.

Gerchunoff critica a propósito de este libro la ley de residencia. Protesta contra la abstención de la crítica, motivada por "una evidente perversidad que ellos designan bajo el nombre de patriotismo". Gerchunoff explica que como la obra se ocupa de dar cuenta de "las calamidades que afligen a la República y de la bancarrota de la constitución, la prensa optó por no hablar de este libro, a fin de no tener que confesar que vivimos en un país de civilización retardataria" p. 215. Critica el método del libro, aunque apruebe su contenido, porque carece de plan y es desordenado. Libro "de polémica pura, que no obedece a más orden que los distintos asuntos que cooperaron en el paradisíaco advenimiento de la ley de residencia". Y agrega: "Libros de esta clase hacen falta a la Argentina, para adquirir el sentido de la siniestra realidad que nos abruma, a pesar de lo que al respecto opine un señor Gómez de Montevideo, afirmando que Kropotkine y sus discípulos son sustentadores del crimen” p. 217.

- La conferencia de Ugarte, reseñada por Emilio Becher.

Califica esta conferencia ['Las ideas del siglo'] como el acontecimiento literario más importante del mes anterior. Realizada en el salón Operi Italiani, versa sobre la situación social de la época y sobre la posibilidad del socialismo. Becher reseña las cuestiones principales. Se refiere a la Utopía del socialismo: una sociedad fundada en la armonía y la justicia, por lo tanto basada en la necesidad de reformas sociales. Al margen de la doctrina Becher designa esta conferencia como "una noble victoria": "Ha sido indudablemente algo más que un manifiesto de partido; ha venido a afirmar la función moderna de la literatura, la necesidad de que el escritor sea, delante de los pueblos humanos, una especie de columna de fuego. Ha clamado, sobre la estéril actitud argentina, sobre las miserables preocupaciones de la política, de la Bolsa y de los salones, la vocación del Ideal. En una ciudad donde el escritor es perseguido y despreciado, donde la literatura es un oficio infame, es de agradecerle que haya demostrado, contra la mediocracia imperante en los clubs, la superioridad social del artista" p. 221 Critica al público socialista al que iguala con el público aristocrático, por lo grosero y lo estúpido. Hace referencia a los disturbios que se generaron en la calle: "La indignación de los guardianes del orden contra un literato que no comparte la doctrina política de las comisarías, es concebible." p.222. 
E. B. [Emilio Becher], Año I, Tomo 2, nº 6, octubre, 1903, pp. 217-225

- Vibraciones fugaces de Carlos Romagosa, por Emilio Becher.

Becher critica la exagerada intimidad de los relatos, y observa que esto no puede atraer al un "público extraño". Afirma: "Leyendo ciertos capítulos - In memoriam, Felicitación, Hermosa generosidad, etc.,-- se pregunta uno cómo un hombre de tan visible talento, ha podido creerse en la necesidad de publicarlos. Cuando se trata de los Goncourt o de Hugo, estas trivialidades de la autobiografía, se transfiguran bajo el divino resplandor del genio. En cualquier otro caso, el escritor corre el riesgo, difícilmente evitable, de una postura ridícula; y el lastimoso que un hombre capaz de escribir una obra [cursivas de Becher], como es el Sr. Romagosa, haya sido inducido a esta tentación". Además, señala el error cuando habla de política, de otorgar a hechos locales una validez excesiva. Más adelante observa que: "es evidente que la literatura parlamentaria -género irremediablemente inferiorno es el más apto para el libro, y que el más elocuente de los discursos, pasado su momento de actualidad, carece, por lo general, de sentido". A pesar de estas críticas, rescata a Romagosa por sus ensayos (El simbolismo y el prefacio a Joyas literarias), y fundamentalmente por haber recomendado al joven Lugones en carta dirigida a Mariano de Vedia en 1896, en la que vaticinaba el futuro del cordobés cuando recién se iniciaba, y escribía con el seudónimo de Gil Paz. Romagosa, es finalmente, para Becher, un "temperamento de batallador y de creyente", un "espíritu en ebullición".

-Se anuncia la reseña del libro recién publicado por Ángel de Estrada, La voz del Nilo, de la cual Gerchunoff se ocupa en el siguiente número.

\section{$\mathbf{N}^{0} 7$}

Alberto Gerchunoff, Año I, Tomo 2, no 7, noviembre, 1903, pp. 300-305

- La voz del Nilo, de Ángel de Estrada (hijo)

Desde una perspectiva que repara en las formas en que los escritores jóvenes intentan recortarse y diferenciarse de sus antecesores, aunque sea imaginariamente, esta nota es significativa "Ángel de Estrada es uno de nuestros escritores más laboriosos. Cada año aparece un libro suyo, fenómeno bien raro entre nosotros, donde la producción mental es tan escasa, y donde, por otra parte, basta para adquirir renombre, uno que otro volumen de prosas ligeras, apenas tolerables o las más de las veces intolerables del todo, o bien, para merecer patente de poeta, suficiente dar a luz un opúsculo de versos para tarjetas postales.

Estrada no se atuvo a esa tradición. Empezó hace tiempo a dedicarse a la literatura a pesar de ser rico. data su iniciación de la época en que recién nacían aquí las modernas corrientes literarias y comenzaba a tener más boga el cenáculo de los raros, encabezado por Rubén Darío y Leopoldo Lugones, en oposición al histórico Ateneo, cuyas ruinas aún existentes, acaudillado por el distinguido Dr. Calixto Oyuela, autor de la célebre Oda a España...

De aquel grupo de raros (hay que subrayar siempre esta palabra), entonces simples arlequines de frases, forjadores de originalidades absurdas, según el criterio general, resultaron algunas cabezas que hoy resplandecen en toda América; -Rubén Darío, el decadente de los 'aires suaves y pausados giros', se erigió una estatua en sus Prosas profanas; Leopoldo Lugones, el tempestuoso gigante de Las montañas del oro, es ahora el más original y profundo escritor de Sudamérica; José Ingegnieros, el eterno humorista que entre ocurrencia y ocurrencia se ha hecho célebre en todo el mundo científico, y por último, Ángel de Estrada, que es un literato exquisito, cuya labor representa un esfuerzo audaz y considerable. Y el círculo de los clásicos y sus adeptos espirituales zozobraron -ioh destino cruel!- en su propia solemnidad. El eminente Oyuela ya tiene canas y aún sigue medrando a la sombra de Fray Luis de León y Francisco Cobanyes, y asombrando de tiempo en tiempo a la gente desprevenida con sonetos filosóficos, dedicados a caballos que se debocan, o bien elegías, llenas de cristiana inocencia, en el homenaje al cadáver de León XIII... Miguel Cané, el más solemne de todos, ateneísta, si no de hecho, por lo menos de espíritu, grande y resonante como una bordaleza (sic) vacía, olímpicamente cubierto por la gloria de su literatura almaceneril... y otros muchos fracasados ilustres que no sigo nombrando por pura higiene artística...

De toda esa odisea interesante, como antes dije, resultaron del grupo filoneísta, esas pocas bellas cabezas que cité más arriba, figurando entre ellos el autor de La voz del Nilo. Es este libro, a mi manera de ver, uno de los mejores de este escritor, ya por lo vigoroso de sus pinturas, por la forma elegante y sugestiva y por esa sobriedad de imágenes y detalles que revelan al descripcionista por esencia" pp. 300-302 


\section{- La creación ante la pseudo-ciencia de Gustavo Martínez Zuviría}

Gerchunoff le aconseja a este joven que no malgaste su tiempo en "tan arduos trabajos sin la necesaria competencia en la materia". Lo nombra como "nuevo y pequeño libro", "inofensivo librito" que ha sido publicado con "la licencia de las autoridades eclesiásticas". p.305.

\section{- La simulación de la locura, de José Ingegnieros, por Alfredo C. López}

La nota empieza con una diatriba contra la mediocridad del mundo cultural argentino. Ingegnieros aparece como sabio y artista. La retórica que emplea evidencia la oposición entre lo verdadero y lo falso, típica del vocabulario de Olivera en "Sinceridades" y de otras intervenciones de la revista.

"Pueblo de pequeñeces el nuestro, con reducidos núcleos de falsa cultura, y estos mismos casi ahogados por la mediocracia imperante, no tuvo motivos ni ocasión de pesar en la balanza intelectual del mundo. Larva de un gran pueblo, existente más como verdad esquemática que sensible, todo en él fue hasta hoy motivo de reflejo. Sus leyes, decoración pura, su sistema institucional un andar a ciegas deformando la herradura a fuerza de marrar el clavo, su democracia y su libertad, un continuo volver al punto de partida, cuando no el cómodo laisser faire...." p.306 [cursivas en el original] Estas condiciones aparecen como las causas del estado de desarrollo cultural argentino que conduce al "naufragio' de las "altas inteligencias" en "este mar de ignorancias que nos aísla" p. 306. Ingegnieros con sus obras viene a representar, según López, la "nueva savia" que marca el comienzo de una etapa nueva. Es importante observar que López dice reservarse el estudio crítico de esta obra, de manera que la reseña insiste en el hecho mismo de la publicación de un libro como ése, más que en dar cuenta de su contenido o sus ideas: "En este libro -cuyo estudio crítico nos reservamos- hay tal profusión de conocimientos que solo una paciencia evangélica y un infinito amor al estudio son capaces de explicar. es la confluencia de una extensísima ilustración, contraída a la delineación de una teoría, confirmada sino descubierta- por el autor, con todo el peso del talento" p.308.

\section{$\mathbf{N}^{0} 8$}

Emilio Becher, Año I, Tomo 2, no 8, diciembre, 1903, pp. 372-384

- La victoria del hombre, de Ricardo Rojas.

La nota se abre con la afirmación de la "eficacia de la revolución simbolista", a partir del cual se ha producido la renovación que superó la retórica pseudo romántica y las imitaciones del clasicismo. Esta renovación en la Argentina ha chocado con el "grosero espíritu criollo". Becher ubica el poema de Rojas en esa línea abierta por la renovación simbolista.

"Tan ridiculizado ha sido por el grosero espíritu criollo el movimiento simbolista, que se hace necesario explicarlo. La tentativa de crear un arte menos lastimoso que las odas de los juegos florales y las décimas del pobre señor Domínguez pareció sin duda despreciable a los analfabetos de la política y a la élite irrisoria de las universidades. En un público que no lee, los juicios hechos alcanzan una fortuna rápida y la caricatura del modernismo, vulgarizada por la enemistad de los escritores rivales, sirvió de documento a los derrengadores de Verlaine..... Entre tanto, esos decadentes, a quienes se acusaba de todos los extravíos dieron, por primera vez, a nuestro arte, una conciencia [en cursiva en original]. Ellos refutaron la idea, tan errónea como inmoral, proclamada por los escritores de la generación anterior, de que la literatura era una tarea agradable y frívola, buena para el cuarto de hora del aburrimiento; y demostraron la ignominia de esta conducta que ponía el Ideal al nivel de las más bajas profesiones y reservaba para el alma excelsa de Beatriz la posición subalterna y equívoca de una concubina. Establecieron también una jerarquía más noble, y Los Raros propusieron a la admiración de la juventud, en vez del arte precario de las Academias, la sólida y poderosa escultura de Leconte de Lisle y la resplandeciente maravilla de Villiers. En suma, la obra de los llamados decadentes consistió en aplicar a la literatura española las doctrinas parnasianas y simbolistas, por la reforma de la técnica y la renovación de los pensamientos."pp.373-374

Quienes han realizado esta tarea de renovación en América son: primero Darío, luego Lugones, y ahora con esta obra, Ricardo Rojas

Becher analiza la obra en términos formales [apartados II, III] y luego pasa a la cuestión política que aparece en el texto. Aquí insiste en una imagen de intelectual cuya distancia con la práctica política se presenta casi como su cualidad diferencial y necesaria. Define a Rojas como un idealista. Sostiene además que si la obra de Rojas se lee como revolucionaria, esto se debe no a la una profesión de fe 
política (anarquista o socialista) sino al deseo de Rojas de "sintetizar las grandes ideas modernas" en las que están incluidos el anarquismo y el socialismo.

"Libro de asunto moderno, nada impedirá que se le atribuya una determinada intención política, y no faltará quien vea una profesión de fe anarquista en La epifanía del sueño o anticlerical en La vuelta de Cristo. Rojas no ha justificado tales suposiciones. Escritor, no hace más que constatar con imparcialidad. Poeta, tiene demasiado respeto por su arte para degradarle hasta las bajas tareas de la propaganda. Intelectual, el proyecto de juntarse con otros hombres en partido político, a fin de pensar en común, no le seduce. La idea de que el idioma divino del verso pueda servir anunciar opiniones de comités de facinerosos, le parece, con razón, la más siniestra de las profanaciones.

Imposible es, sin embargo, es que el escritor se aísle en sí mismo hasta el punto de estar como cerrado a las cosas de Afuera. La angustia del momento es demasiado honda para que se la ignore. Todo anuncia la proximidad de una vasta catástrofe. El sufrimiento de los pueblos se ha hecho ya intolerable, la época se estremece y da gritos. El poeta que ha defendido, contra el duro dogma de Nietzsche, la doctrina búdica y socialista del Héroe misericordioso y civilizador, no podía permanecer indiferente a tales dolores. La obra resulta así revolucionaria por el desarrollo lógico de su pensamiento, no por partidismo; y en sus composiciones socialistas el autor ha sido fiel a su programa de sintetizar las grandes ideas modernas.

A despecho de estas simpatías por la ciencia positiva, Rojas es un espíritu netamente religioso, en la acepción más noble y menos usada de la palabra. Lo es, ante todo, por su misma manera literaria, que prefiere las ideas abstractas y los símbolos a las narraciones y los paisajes; y en un sentido más elevado por la amplitud y la decisión de su fe y el fervor profundo de su idealismo. La obra entera es la demostración lírica de esta tesis: la superioridad del espíritu sobre la materia, su triunfo final. (...)

Y yo presentaría el ejemplo de Ricardo Rojas como una útil y noble enseñanza. He aquí un joven que ha tenido el valor de preferir, a las dulzuras de la mediocridad satisfecha y las recompensas deshonrosas del éxito, el arduo camino del Ideal. Haber proclamado contra el utilitarismo imperante, el amor a la belleza y la devoción a la Idea, en una ciudad donde se mira toda tentativa de arte como un atentado contra el orden público y la moral común, revela, por lo menos, una voluntad." pp.382-384.

\section{$\mathbf{N}^{\circ} 9$}

Manuel Gálvez, Año II, Tomo 3, nº 9, enero, 1904, pp. 75-89

-La novela de la sangre, de Carlos O. Bunge

La nota está estructurada en cuatro parágrafos. El primero hace un resumen en el que interpreta la época de Rosas desde una perspectiva antirrosista y anticaudillista, lo que luego le valdrá una contestación Ricardo Olivera en el número 11-12 de la revista: "Las constituciones y las leyes, habían caído pisoteadas por la bota del gaucho. En cada provincia, un amo semisalvaje y odioso, imponía sus caprichos despóticos a un pueblo aletargado por el terror, que se doblegaba ante el poder del caudillo, en la degradación del abyecto y la conformidad de su egoísmo." p.75. Se refiere a la época de Rosas como un momento en que se realiza "la unión de los pueblos, bajo el sable ensangrentado de la tiranía" p.75. En el segundo, resume el argumento. En el tercero se refiere al trabajo de Bunge como escritor de esta obra: "Sin pretensión de pintar la totalidad de una época, ha trazado Bunge diversos cuadros, característicos y exclusivamente propios de ese tiempo, de un colorido intenso, donde la gama del rojo difundida en la vasta extensión del libro, da la sensación completa de esas escenas sangrientas, cuyo principio, es, a veces, una grosera farsa y cuyo fin, un desenlace trágico".

Destaca como un logro el poder de transmitir "la impresión de lo trágico" y señala el error en el 'trazado' de los personajes principales, que aparecen con poco relieve. Así por ejemplo, sostiene que:

"Blanca solo adquiere relieve en la segunda mitad del libro, cuando va agostándose entre sus delirios histéricos y alucinaciones de mística. No se revela claramente el alma de Pantucci. En cuanto a Regis puede decirse que no ha sido definido.

Así como Wagner, según Nordau, recurre al leit motiv, para caracterizar un personaje, de un modo análogo y con objeto idéntico, Bunge afecta a los suyos con una tara o con una obsesión." p.81.

En cuanto al estilo, marca un desconocimiento "exacto de la técnica del idioma", cuyos efectos se ven la redacción imperfecta de algunos párrafos, frases sin sentido, repeticiones. Se pone de manifiesto el consenso en la valoración de nueva de la novela: "Si decir que un libro es entretenido ahora que la novela ha evolucionado hacia una arte más noble-, vale un elogio, no he de escatimarlo a 
La novela de la sangre cuyas páginas se devoran con la ansiedad de experimentar fuertes sensaciones" p.82. En relación esto y trazando una diferencia necesaria para la alta cultura, Gálvez observa: "Nótase sin mayor examen, la tendencia del autor a salvar su obra, de la abrumadora y despreciativa calificación de "novela por entregas" a que el argumento le hubiera, irremediablemente, llevado. Bunge ha salvado su obra sin dificultad visible, con su amplio saber, su conciencia del arte, la pureza de su intención, alejada de todo propósito industrial" p.82

En el último de los apartados, Gálvez enfatiza el valor de la obra de Bunge en el marco de un contexto adverso para la actividad intelectual, algo que ya es tópico y típico de la revista. Lo expone en los siguientes términos:

"Faltos en absoluto de todo ideal, incapaces de una labor continuada, absorbidos en las luchas de una política de chisme, fraguando revoluciones o acometiendo presupuestos, los escritores argentinos, en su mayoría, no han hecho obra, y apenas si los más constantes pueden presentar al cabo de años, uno que otro libro de viaje o algún opúsculo de comentarios sobre cualquier artículo -probablemente el $5^{\circ}$ o el $6^{\circ}$ de la Constitución Nacional.

Las nuevas generaciones que llevan una fe como lema y la lucha por un ideal como bandera, fueron desoídas y hasta vilipendiadas por el montón predominante e ineducado de los que habían recibido consagraciones como firmas indiscutibles.

Darío, Lugones, Jaimes Freyre, Ingegnieros y otros más -el grupo de El Mercurio de América si es lícito clasificarlos bajo esa denominación- no encontraron eco, y sus voces predicando nobles principios perdiéronse, como hambrientas de desierto y se hizo alrededor de sus obras, un desolador vacío.

Son raros los que, no aleccionados por los fracasos anteriores, arremeten con la indiferencia en una furiosa lucha a muerte.

Lo que en otra parte es un hecho diario -la aparición de un libro- aquí es un fenómeno, y sospechando el resultado, nadie quiere exhibirse en derrota.

Con Estrada, Ugarte y algún otro, Bunge ha seguido a letra, aquel sabio consejo el maestro Darío, que siempre ha de citarse porque es eterna memoria:

'Y la primera ley creador, crear. Bufe el eunuco; cuando una musa te dé un hijo, queden las otras ocho en cinta'

Y Bunge, cuya obra representa una labor enorme de estudioso, merece respeto y admiración, es aquí uno de los pocos convencidos que han opuesto al utilitarismo político e industrial de la masa, las fuerzas de sus ideales, que han de triunfar de la indiferencia, e imponerse a la muchedumbre de los necios haciéndole escuchar hasta del sordo, como el turbión que desciende de la montañas, e invade la llanura, trayendo en su ancho seno, salvajes rumores de huracán" pp.83-85.

\section{-Espigas sueltas por Leopoldo Basa pp.85-87}

Se trata de un libro que recopila trabajos "breves y ligeros" de distinta clase, cuentos y narraciones, en su mayor parte. En esta intervención Gálvez plantea la distinción entre lengua literaria y lengua de prensa. Es interesante observar cómo se insiste en un deber ser naturalista-realista de los textos. De ese modo se rescata la capacidad de reflejar y evocar las costumbres y tipos de una zona determinada (Galicia). Importa además porque Gálvez insiste en construir la imagen de la revista y la suya propia como la de "el grupo elegido de los pocos, entre nosotros, que conciben y realizan" p.87.

"Quizá algunos de ellos [cuentos, narraciones] se resientan de falta de observación, y varias veces, se hallará la causa de esto, en un conocimiento no del todo exacto del ambiente, cuando se trata por ejemplo de reflejar el más aristocrático medio social argentino -o bien en apresuramientos, resabios de periodismo, muy explicables en un libro de ensayo, escrito indudablemente con las inseguridades del inexperto y el nervioso anhelar del triunfo.

Basa es un descriptor. $\mathrm{Y}$ a veces su pluma es pincel que traza en breves rasgos una marina risueña (Bolaquente) o el cuadro pintoresco de un corso en carnaval ("Un manojo de jazmines").

De estilo, español, ya se sabe con esto lo que quiero decir, no es su idioma un instrumento que pueda expresar la vida moderna en toda su amplitud. Carece de concisión y elegancia, dos elementos indispensables en un libro contemporáneo, que debe llenar gustos refinados y vertir el pensamiento sin derroche de palabras" p.86. 


\section{- Alma de niña e Irresponsable de Manuel T. Podestá}

Esta nota es central porque en ella Gálvez comienza su militancia a favor de la novela. Es por eso que no se ocupa de los textos, que, además son reediciones, sino de construir una tradición de novela nacional, apelando a los juicios vertidos por Libros y autores por Martín García Mérou, crítico central de la obra de los escritores del 80 . Transcribimos la nota completa.

"Toda la historia de la novela argentina cabe en los últimos 30 años del pasado siglo. Los primeros períodos de esa época fueron bullentes en tal sentido. A las novelas policiales de Gutiérrez, nuestro exacto equivalente de Fernández y González, sucedió una serie de obras, ya olvidadas por desgracia, que vinieron a fundar, si es que esta palabra puede usarse, la verdadera novela nacional. El talento observador de Groussac había dado un bello fruto; una novela argentina "inspirada por nuestra naturaleza, nuestras costumbres, nuestra vida política y social, novela sana en el fondo" según la frase de García Mérou, y cuyo título, era Fruto vedado. López hacía el proceso de la sociedad en La gran aldea, con su fina ironía y sus rasgos de Dickens, Cambaceres, después de Silbidos de un vago y Música sentimental, publicaba Sin rumbo, un éxito grandioso como los anteriores y que causaría indignaciones y aplausos.

Luego hubo una paralización casi absoluta, sólo interrumpida por algunas obras de Ocantos, hasta que, en la última década, el poderoso Sicardi, vino a encerrar definitivamente en sus cinco tomos del Libro extraño, toda la sociabilidad argentina en sus fases más diversas; la política, el hogar, el suburbio. En aquella época anterior fue cuando Podestá dio a conocer sus novelas Alma de niña e Irresponsable, dos libros olvidados, y que tal vez, pasaran desapercibidos, en ese tiempo de incertidumbres y politiquerías.

Es verdad que aquí no suele apreciarse los libros según sus méritos ¿Se conoce acaso a Sicardi? No por cierto, a pesar de lo genial de su obra entera y de la presentación de Ingegnieros.

No haré un juicio a los libros de Podestá, que La Nación en un tomo de su biblioteca popular, ha publicado recientemente.

Y si escribo estas líneas es para hacer constar, movido por el espíritu de justicia, que hay un escritor más de talento, que en un estilo vigoroso y con una espontaneidad que asombra, describe a lo vivo cuadros diversos, y analiza el alma de los personajes -el hombre, los imanes, por ejemplo, con la visión exacta de un profundo psicólogo.

Es innegable que La Nación ha hecho obra meritoria, sacando del olvido libros como este que debieron ser inolvidables, no solamente por su valor actual, sino porque marcaron el comienzo de la novela argentina.

Hoy día, con más pretensiones, no se escriben casi libros, como los que entonces triunfaban.

En aquella época Fruto vedado y las obras de Cambaceres, constituían el exponente de nuestra intelectualidad.

Ahora no pasa lo mismo. Será quizá porque entonces Cané no era pontifice y ni había soñado con escribir Martín Gil” pp. 87-89.

\section{$\mathbf{N}^{\circ} \mathbf{1 0}$}

Manuel Gálvez, Año II, Tomo 3, nº 10, febrero, 1904, pp. 181-186

-Ideales y caracteres por Joaquín V. González

Esta reseña importa porque se ocupa justamente de la obra un literato, de un político (ministro de Roca), no de un escritor, y sirve para contrastar lo explicitado en la entrega de $n^{\circ} 9$, para mostrar el valor estratégico de aquellas afirmaciones, que ahora pasan a segundo término, porque es necesario construir las figuras de "maestros". Joaquín V. González es elegido junto con Groussac, Wilde, Sicardi, Almafuerte, Darío y Lugones, para insistir en el pasado literario nacional, que ya había esbozado para la novela en el número anterior. El libro de González es, además, una recopilación de artículos, no hecha por el autor, publicada a fines del año anterior. Este último dato es importante porque muestra la decisión de Gálvez - quien habitualmente no publica en 'Letras argentinas' sino en 'Teatros'- de dar cuenta de este libro, del que los columnistas de la sección no se ocuparon en su momento. Mientras que en otros artículos -y no solo de Gálvez- la revista se opone a este tipo de obras, en éste leemos: "Esperemos alguna nueva obra de este laborioso escritor. Pero ¿acaso no vale más que muchos volúmenes, ese inspirado artículo "La visión del lago"? p. 185. 
La nota es muy elogiosa. Gálvez valora la relación del autor con la naturaleza que el libro muestra, y esa relación se plantea en términos de una experiencia tanto material como afectiva:

"González ha sentido la naturaleza, ha respirado a pleno pulmón el aire de las cumbres, su oído ha escuchado los rumores todos de la soledad, la montaña le fue familiar, y el Famatina, que no tuvo para él secretos, le deslumbró más de una vez con sus mudos espectáculos" p.182.

Además, rescata en González, un punto de coincidencia futura respecto del interior como lugar de la espiritualidad nacional, como aparecerá en La maestra normal: "Los relatos, las descripciones, las frases mismas, están hablando de los encantos de "sus montañas", esas montañas que él venera, y son u pedazo de nuestra tierra, porque en toda la extensión de su grandeza, vaga, en silencio, el alma nacional" p. 182.

Se refiere al trabajo con la lengua, mostrándolo en contraste con lo nuevo:

"Tiene el arte de manejar su idioma con elegancia, concisamente, difícil técnica que nunca se realiza en absoluto ni se aprende en libro alguno. El buen gusto, exponente de un temperamento artístico, solo da ese aprendizaje. Y así nunca se llegará saber el modo de construir una frase, sin ese sedimento de ilustración, sin esa capacidad de sentir la belleza.

La prosa de González produce a veces cierto cansancio. Su frase, debido quizá a esa misma sencillez de que antes hablé, es demasiado extensa. Los períodos se unen yuxtaponiéndose, y el párrafo de esta manera, resulta interminable. La prosa moderna es muy breve, los períodos se dividen, las conjunciones y los gerundios casi desaparecen sustituidos por puntos que al cortar la frase danle concisión y elegancia".pp. 183-184.

Hacia el final de la nota Gálvez se ocupa de precisar, como siempre lo hace, algunas cuestiones vinculadas con lo programático, que en este caso incluye la distinción entre dos circuitos culturales. Así, mientras que la alta cultura tiene un pasado intelectual prestigioso, que aparece en la nómina de los autores escogidos, la cultura impresa de los semanarios se asocia -recurriendo a la oposición entre arte y mundo burgués- con la repetición, la falta de originalidad.

"Muchas veces se ha dicho que la juventud literaria argentina no tiene rumbos, ni guías que le señalen el camino a seguirse.

En primer lugar creo que los jóvenes escritores argentinos, no necesitamos que alguien nos fije rumbos, o nos trace un camino. ¿Hay rumbo más seguro que la fe y camino más amplio que el ideal?

Y si se entiende por guías los maestros del idioma, los talentos que crean una obra vasta, ¿no podríamos dar ese calificativo a González, Sicardi, Wilde, Groussac, Almafuerte, Darío y Lugones?

Pero ya comprendo. Seguramente al decir que la juventud necesita rumbos y maestros, se habla de esos escritores soñolientos y que y quejumbrosos de las revistas semanales, eunucos del pensamiento, burgueses de la frase, o sus colegas de los teatros, dramaturgos por instinto e ignorantes por profesión. Esos sí que necesitan maestros. Pero maestros de primeras letras.

$\mathrm{Y}$ no he de concluir esta breve nota, sin hacer constar mi profundo respeto y mi franca admiración, hacia este trabajador silencioso y constante, que, aún en su alta posición política, rinde culto a las letras, oponiendo su fe y su amor por la belleza, al desprecio de este ambiente, donde priman los mediocres de las facultades, que desdeñan al escritor y al artista porque pierden su tiempo en bagatelas y no trabajan, como si lo único provechoso y práctico para la vida, fuese explicar un entereolismo o borrajear una expresión de agravios".

\section{$\mathbf{N}^{0} 11$-12}

Manuel Gálvez, Año II, Tomo 3, nº 11 y 12, marzo-abril, 1904, pp.324-347

Este número doble de la revista se concentra en la producción nacional, y la sección 'Letras argentinas' es más extensa que en otras entregas. En él se publica Sobre las ruinas de Payró. [Cf. el índice hecho con los sumarios que presentamos en este informe]

- Nebulosa, por Carlos María Ocantos

En el primer apartado de los tres que componen la nota, la figura de Ocantos aparece recortada y caracterizada por su despreocupación por el éxito, algo que Gálvez dice no compartir. Como en muchas de las intervenciones de la revista se acuñan imágenes de los escritores tratados. Opina Gálvez sobre Ocantos:

"Hay una constancia encomiable en la labor de Ocantos. Su último libro, Nebulosa, tomo IX de las Novelas argentinas, es el tributo reciente -como continuación de una obra vasta- que, desde Madrid, su residencia, da a las patrias letras, este fecundo y tenaz escritor. 
Con una insistencia digna de aplauso - grafomanía o fe, no importa la causa- sus novelas han sucedídose con breves lapsos de tiempo, casi anuales, nutridas de lectura, de asunto argentino siempre.

Venían sin réclame, sin ruido, como revelando una total despreocupación del éxito. No aplaudo tal sistema. Simplemente lo constato.

Por eso, Ocantos no ha triunfado? Por eso solamente? No, hay algo más. Causas más poderosas han influido en ello: luego lo diré" p.324.

En el segundo apartado se resume el argumento, algo que no se hace con las obras de teatro, que supone Gálvez son más conocidos a través de la prensa periódica. La acción transcurre en Mar del Plata [Marplatina en el texto] y la novela cuenta las desventuras de Flora, una mujer no tan joven ya, que se ve obligada a aparentar para realizar un matrimonio por conveniencia. Este matrimonio nunca llega y Flora, harta de la farsa entra en crisis, y finalmente muere ahogada en la playa. "Los ataques nerviosos, reveladores de su anormalidad sucédense continuados, desesperantes, con ideas extrañas" p. 328. Además se consignan todos los tipos: "calaveras, jugadores, borrachos, haraganes, esposas infieles, maridos cornudos, señoritas sin escrúpulos" p. 326.

En el tercer apartado rescata la "maestría de novelista" en el manejo de la acción aunque critica el carácter extraño de algunos de los personajes, y eso se debe, según Gálvez, a la una segunda naturaleza, peninsular, de Ocantos. Lo mismo se observa en la lengua literaria empleada. En función de estos rasgos califica la obra de Ocantos de "literatura anodina". A pesar del mérito que le reconoce como novelista, no es exitoso. Explica Gálvez ese fracaso criticando cierta institucionalización de la crítica, que ya había sido motivo de queja en la sección 'Teatros' y también en las intervenciones Gerchunoff de esta misma sección: las librerías.

“ (...) Quizá su exagerada forma de españolismo sea la causa conducente de su ostracismo en

Pero no, no es eso. Es que le han faltado las cartas consagradoras de los pontífices y la venia de los maestros árbitros de la crítica.

De otra manera, Ocantos habría sentido en su propia tierra -como tanto aborigen tarambanala huraña realización del éxito.

Y luego, no estaría lejos de la popularidad -supremo anhelo de los mediocres- que confunde entre las glorias del momento, el triunfo del intérprete genial en la obra de arte, y el aplauso populachero a los discursos de párrafos editoriales que pronuncian como energúmenos, en las asambleas tumultuosas de nuestra política facciosa, los tribunos improvisados del comité parroquial". pp. 332-333

-Xarcas Silenciario por Carlos O. Bunge.

La nota comienza con una mención elogiosa del autor, que polemiza con cierta crítica que ha llamado "grafómano" a Bunge: "Carlos O. Bunge ha asombrado a nuestra escaso ambiente intelectual, incapaz de comprender el trabajo, hasta llamar grafómanos a estos laboriosos, que conciben sin descanso y realizan con fe" p. 334. Se hace referencia a la utilización de teorías en la novela: "He aquí lo más interesante del libro, tema del prólogo y del epílogo, donde Bunge recurre a diversas teorías, más o menos científicas para explicar el caso y que dan una base meritoria a la obra, por la originalidad del asunto, su apariencia psicopatológica, el fino humorismo que en sus páginas vive" p. 334 . Es la historia del manuscrito que escribió Bocelli, posteriormente internado en el Hospital de Alienados, referida por Juan López, un procurador y amigo de Bocelli. La historia narrada en el manuscrito ("Recuerdos de ultratumba de Xarcas silentiarius") transcurre en el siglo IV. Según Gálvez "en este libro, la reconstrucción de la época, es tan solo un pretexto para dar base al desarrollo de una teoría científica. Lo principal aquí es el caso Bocelli.

¿Qué explicación daríase al fenómeno? Se exponen muy claramente diversas opiniones, cuyo análisis no podría en esta mera nota bibliográfica, emprender; metempsicosis, la herencia, los recuerdos de raza, algo como los 'quistes dermoides'.” p. 337.

Finalmente, Gálvez remarca la importancia del prólogo y del epílogo, escritos por Bunge, en los que se revela "un profundo saber sobre psicología" p. 337.

Bunge hace una reconstrucción histórica en relación con la cual Gálvez explica y critica:

"No basta, para una reconstrucción histórica, del siglo IV escribir con soltura y haber leído a Flaubert y a France. El sistema, aunque muy cómodo, no es serio. De esa manera sucedería lo que con el teatro 
nacional. Se ha representado algunos dramas gauchescos, cuyos autores -puedo asegurarlo- solo han visto el campo en pinturas de telones.

Requiérese un conocimiento exacto de la época, de tal modo que no pueda confundirse con otra alguna, por la total delineación de sus caracteres propios y esenciales.

¿Qué vemos en Xarcas silenciario? Una época de imitación, calcada sobre Thais” pp. 338-339.

La noticia de Gálvez combina el elogio con la crítica, y termina con el reproche a la indiferencia de la crítica que no se ha ocupado de esta novela: "Las plumas de los literatos de afición, no han encontrado materia para sus desahogos inofensivos, -censura o elogio-. Y sin embargo, más de una vez he leído artículos ignominiosos en la impudicia del elogio, sobre libros, que son el producto más acabado de la mediocridad" pp. 340-341.

\section{-Ciencia y fe por Raúl L. Villarroel}

"Opúsculo" de noventa páginas, formado por una recopilación de artículos publicados en diarios de Santa Fe, donde vive y escribe el autor. El tema es la incompatibilidad entre la verdad de la ciencia y la doctrina católica. Se menciona la polémica (formada por numerosos artículos) entre este libro y el de Martínez Zuviría, La creación ante la pseudo-ciencia. Gálvez desestima el libro tanto por su forma como por su contenido. Critica el lenguaje "de periodismo. Pero de periodismo de aldea". No obstante, rescata la "sinceridad" y el "heroísmo" de este "trabajador modesto, que con actividad digna del mayor aplauso, trata, en su esfera, de propagar lo que su conciencia cree verdadero" p. 342. Destaca al autor como educador.

\section{- La conferencia de Almafuerte}

Gálvez explica que se referirá a la conferencia "reasumiendo las ideas capitales allí vertidas". Más allá de que la palabra "reasumiendo" sea un error de tipeado, y en realidad Gálvez haya querido escribir resumiendo, lo que se observa en el tono general de la nota es la coincidencia plena con Almafuerte. Gálvez introduce su resumen con un texto que así lo confirma, y que vuelve a mostrar a Almafuerte como otro maestro, tal como Gálvez lo consignara en la nota sobre Ideales y caracteres de Joaquín V. González. Dice Gálvez:

"Con palabra vibrante, reveladora de sinceridad, y en frases cáusticas, -llenas de vigor, certeras como la puñalada del gaucho-, Almafuerte hablaba de política.

No de política, solamente, no. De otras también, de muchas cosas. Y de todo hablaba genialmente, con la fuerza poderosa de su estilo único y macizo.

Lo que ha observado por los estercoleros de la sociedad argentina, en tantos años de vida provechosa, todo, salió de su boca, con vibraciones apocalípticas de apostolado y formidables ecos de profecía.

Era como el brazo de la justicia, arrojando venganzas en los lodos de una moderna Cartago, faz a faz de la impudicia; o un profeta austero y rabiosamente inspirado, que en actitud bíblica proclamase el exterminio del vicio.

No era aquí el poeta, era el hombre. Sí, un hombre, raro ejemplar de una casi extinguida especie. Extinguida, no porque nos hayamos elevado a superhombres, sino porque hemos degenerado en subhombres.

No hablaré aquí de Almafuerte, luchador y poeta. Ello es materia de un volumen. Algún día emprenderá la obra, pero mientras tanto, solo he de referirme a su conferencia, resumiendo capitales allí vertidas" pp.342-343.

En el segundo apartado de los tres que componen el artículo, Gálvez reseña los temas de la conferencia: la situación del extranjero en Buenos Aires, la política corrupta, el predominio de la moral práctica, los literatos decadentes ("enfermos de modernismo y admiradores de Ibsen, Tolstoi etc. porque es la moda"). El último párrafo de este segundo parágrafo muestra la interpelación directa de Almafuerte, como intelectual, al presidente de la república: "Y Almafuerte cree que el presidente de la república en lo futuro, debe responder a esa necesidad de higienización moral y ser un hombre sincero y honrado capaz de continuar en el Gobierno, la tradición de nuestros abuelos". p. 316.

- Literatura argentina, apuntes por Emilio Alonso Criado [redactor de la sección Revista de revistas] Elogia a su colaborador y señala la orientación pedagógica del libro. 
"Emilio Alonso Criado es uno de los laboriosos incesantes, raros ejemplares, en este ambiente improductivo y fácil para el arraigo de pereza -nuestra encomiable enfermedad.

Estos apuntes - para servir de texto en los colegios nacionales y escuelas normalesconfeccionados quizá en los paréntesis del descanso, que alguna obra robusta le permite, no pueden resistir a la disección implacable y fría de una crítica severa. La crítica es definida como "disección".

El propio autor reconoce la modestia de su trabajo. Y para demostrar sus faltas de pretensiones -que serían inexplicables en un libro de colegios- hace una lista de los escritores no estudiados, ausencias inevitables en trabajos de esa índole. En esa lista figuran en abigarrada mezcla, la mayoría de los escritores argentinos. Sicardi alterna con Quesada; Lugones se codea con Naón y Nemesio Trejo parece sustituir a Wilde, que falta.

Por lo demás, en todos los juicios, se advierte un excelente criterio y una erudición que para los 20 años es vastísima pero sobre todo es una obrita útil para los estudiantes de los colegios.

Y esta condición -el mejor mérito en la obra didáctica- le recomienda muy eficazmente al aplauso imparcial y sincero del estudioso" pp. 346-347.

\section{Abel Cháneton, Año II, Tomo 3, nº 11 y 12, marzo-abril, 1904, pp. 348-353}

-Trepando los Andes por Clemente Onelli.

El redactor hace una crítica totalmente adversa al libro del director del Jardín zoológico de la ciudad de Buenos Aires. Se trata de un libro malo cuya factura costosa (papel satinado y numerosas fotografías de los Andes) se opone a la calidad de las composiciones que lo forman. Es interesante ver cómo se insiste en la construcción de falsas reputaciones por parte del periodismo.

"Un mal libro no es, después de todo, una cosa extraordinaria. Al menos entre nosotros. No habría entonces motivo de alarma, porque el Sr. Clemente Onelli haya publicado un libro malo. Pero es el caso, que dicho Sr. Es un funcionario público. Y nada menos que director del Jardín Zoológico de Buenos Aires. Cómo no lamentar que en el puesto ilustrado por Holmberg, haya ahora una tan mediocre inteligencia. Siquiera por respeto a su antecesor, debió el Sr. Onelli evitar ese mal paso. Por su antecesor y por el intendente municipal, que para ocupar ese puesto lo designara.

Nos explicamos los móviles que sin duda le indujeron a publicar este volumen. Quiso tal vez justificar su personalidad impuesta a fuerza de bombo periodístico. Pero le ha pasado lo que a esos gauchos que, improvisados malos por las mentas de algunos paisanos, se autosugestionan, llegando ellos mismos a creer en su valor legendario hasta que en una ocasión cualquiera, las circunstancias descubren la verdad echando por el suelo su fama. Y es sensible, con sinceridad lo decimos. Hasta la publicación de su libro el señor Onelli era geógrafo distinguido, escritor notable, hombre de ciencia y de asombrosa erudición. Por lo menos así lo aseguraban a diario los órganos más característicos de la prensa. Y además era extranjero, no había por qué dudar. ¿Acaso no reposa sobre idénticas bases la reputación de todas nuestras eminencias? ¿Por qué solo en este caso habría de ser una mistificación?

¡Y pensar que todo eso se ha derrumbado!

Lástima grande ¿verdad? Tan fácil que le hubiera sido al nuevo director del jardín Zoológico conservar su reputación! Con solo no abrir la boca.

Pero la fábula cuenta: el cuervo, halagado por los elogios zorrescos quiso dejar oír su voz y graznó" pp. 348-349.

-El crimen del otro por Horacio Quiroga

La nota de Cháneton consiste en la discusión de los conceptos vertidos por Leopoldo Lugones sobre Quiroga, aparecidos en una nota de El Diario. Tal discusión apunta a la devaluación de la autoridad de Lugones como crítico, esto es, como miembro de la vida intelectual argentina, en función de su condición de político - funcionario. Este hecho muestra la distancia que la revista -o desde ella-, muestra imprescindible entre literatura y política.

Transcribimos la nota completa

"En un volumen de 235 páginas, presenta el Sr. Horacio Quiroga (h) doce cuentos. Y en un artículo que El Diario publicó, Leopoldo Lugones presenta al Sr. Quiroga. Y lo presenta como el primer prosista del Plata, por ahora. Para más tarde, lo vaticina "uno de los primeros estilos del habla española.

Consentimos en esta segunda afirmación. Pero de ningún modo en la primera. Y por si algún catecúmeno juzga audaz nuestra independencia de criterio, ahí van algunas líneas que la justifican. 
Hubo una época en la que el autor de Las montañas del oro se armó en la crítica. No hay que decir si supo romper bien sus lanzas. Por entonces no era más que literato. Hoy es también político y esto naturalmente, ha perjudicado aquello. Su autoridad se ha resentido después de aquel panegírico famoso ¿recordáis? y de aquella no menos famosa elección en la cual un simple abogado le derrotó.

Él mismo lo comprende así. Y por si alguien extraña ver a aquel hombre conocido en los comités, al pie de una crítica, comienza por advertir que desde hace tres años, otra alguna ha escrito.

Dijimos que pasábamos porque el Sr. Quiroga llegará a ser con el tiempo, uno de los primeros estilos de habla española. Pero en manera alguna, que sea ya entre nosotros lo que dice Lugones. El crimen del otro es apenas la obra de un principiante, que como tal carece de individualidad propia. Su inteligencia está aún en el período asimilativo. La influencia de sus lecturas es tan notoria, tan dominante, que llega a absorber por completo los rasgos originales. Poe, especialmente, ha labrado un hondo surco en su alma. Darío asoma también a veces; pero resulta exótica su figura en aquellas páginas.

De los doce cuentos que componen el volumen, son en mi sentir los mejores: 'Estilicón' y ‘El crimen del otro'. Es en este último donde están las cuatro mejores páginas del libro, que son asimismo las últimas cerrándolo con magnífico broche. Valen ciertamente por todo el volumen y constituyen, fuera de duda, 'la más intensa descripción de locura que yo conozca en letras americanas'.

'Estilicón' es también un cuento hermoso. El proceso de bestialización de aquellos dos sujetos, está admirablemente hecho.

'El corto poema de María Angélica' es una larga insulsez, apenas sazonada por la perversión amorosa del protagonista.

'La muerte del canario' es un asunto de Darío estropeado por Gonzalo Ochoa.

Este libro constituye con todo una seria tentativa. Hay en su estilo páginas de sencilla belleza. Si bien hay otras en que ese mismo afán de sencillez lo hace rebuscado y monótono. Es pues desigual. Y al lado de un párrafo tan hermosamente concluido como éste: 'De repente levantamos la cabeza; el foco de un crucero azotó el cielo, barrió el mar, la bahía se puso clara con una lívida luz de tormenta, sacudió el horizonte de nuevo, y puso de manifiesto a lo lejos, sobre el agua ardiente de estaño, la fila inmóvil de los acorazados'; hay renglones construidos con tan mal gusto como los que siguen:

'En una hermosa de verano se abrió a mi su alma en esta nueva faz. Estábamos en la azotea, sentados en sendos sillones de tela"” pp. 351-352

La novela de la sangre de Carlos O. Bunge por Ricardo Olivera. [No forma parte de 'Letras argentinas'] no 11-12, marzo-abril, 1904.

Esta nota discute la crítica que Gálvez realizara en $\mathrm{n}^{0} 9$ de 'Letras argentinas' Olivera le reprocha su antirrosismo, en la acusación de parcialidad; también señala errores en los que "El 'fondo' histórico tratado con criolla despreocupación abunda en yerros y anacronismos" p.303. Es importante porque se plantea el problema de la edición de libros en la Argentina.

Afirma: "Carlos Octavio Bunge ha publicado durante el año Principios de Psicología Individual y Colectiva, Nuestra América y La Novela de la Sangre, tres volúmenes nutridos. Recordad su colaboración constante en diarios y revistas y la última edición, considerablemente ampliada, de $L a$ Educación - su empresa de mayor aliento- y complacidos saludadlo trabajador fecundo, inmunizado por altas y nobles ambiciones contra el contagio de estos medios, favorables al desarrollo de perezas atávicas.

Los Principios de Psicología han sido incorporados a la colección Félix Alcan, vertidos al francés por Augusto Dietrich, traductor de Nietzsche y Max Nordau... Antes cuando La Educación, transformada en un respetable infolio, ingresara a la Biblioteca de La España Moderna -vulgarizadora peninsular de Spencer, Taine y Stuart Mill- fue Unamuno, el accesible rector salmantino prologuista linajudo y bondadoso. Rafael Altamira, catedrático de cierta notoriedad, ha sido solícito padrino de Nuestra América y la prensa extranjera no escatima espacio al examen de la obra bungeana.

'Nadie es profeta en su tierra', y el doctor Bunge, por compensación feliz, empieza a serlo en la extraña. La novela de la Sangre ha sido impresa también allá, en los hospitalarios países consagradores: Daniel Jorro, Madrid, leeréis en el pie de imprenta, libres -una vez siquiera- del inevitable Moen, pseudoeditor de eminencias caseras. Todo muestra al joven metafísico, sociólogo, novelista, psicólogo, magistrado y catedrático -maravilla de actividad poliforme- en habilidosa 
procura de la repercusión europea, desdeñada por Sarmiento, López, Alberdi ... condenados a perdurar ignorados, fuera del pequeño rincón nativo, por haber despreciado las artes sonoras de Barnum.

$\mathrm{Y}$ ha conseguido ya la atención de los intelectuales españoles, valiosa aproximación de la amable acogida de París, -un tanto arisco y lejano" pp. 299-300.

Olivera advierte de los peligros de abordar una época demasiado cercana por el novelista " $L a$ novela de la sangre transcurre bajo Rosas. Tiempos climatéricos de luchas enconadas, las pasiones en paroxismo y la diaria peripecia, deben atraer al artista: la preferencia de Bunge se explica. Pero es el suyo empeño atrevido. La Historia debe ser auxiliar indispensable de la novela histórica. Y la historia del gobierno de Rosas, demasiado cercano para encontrar imparcialidad, todavía no está escrita" pp. 300-301.

\section{$\mathbf{N}^{0} 13$}

Atilio Chiappori, Año II, Tomo 4, no 13, mayo, 1904, pp. 67-77

Nota de Chiappori en la que explica que continuará con el programa planteado por Gálvez para la sección y sobre todo, dar una impresión sintética, de conjunto.

- Anales de la Biblioteca, Tomo III, colección dirigida por Paul Groussac, pp.67-71.

Este tercer tomo incluye: Una refutación inédita de Moreno, Biografía de Santiago de Liniers, Cartas y documentos históricos, Diario de D. Diego de Alvear, Tres cartas inéditas de Bolívar. El trabajo que más le interesa es el de Groussac sobre Liniers. Se dice admirador de Groussac. Transcribe el cuadro de Buenos Aires colonial, el día de la llegada de Sassenay.

-Mis cuentos, por Carlos María Ocantos, Madrid, 1904, pp.72-74

"Se ha dicho [Gálvez en Ideas], y con verdad, que Carlos María Ocantos, a pesar de los esfuerzos hechos en sus 'once tomos de la serie de Novelas, en que estudia y describe la vida argentina contemporánea bajo sus diversas manifestaciones', no ha hecho obra argentina in siquiera americana. Es un reproche justo. Solo que no debe fundarse en la forma literaria, sino en la falta de sinceridad que ella acusa. Le perdonaríamos, aunque a regañadientes, su vocabulario rancio y hasta el tono zumbón de sus relatos, propios del 'género chico', si, a lo menos, fuera un forjador de caracteres

Pero no, sus personajes 'nacionales' son de una risueña inverosimilitud.

Así, en el tomito de cuentos que nos ocupa, entre varios apólogos y parábolas doctrinarias, hallamos un solo cuento de fábula nacional. Por lo menos el título: 'La viuda', así lo hace presumir. Como comprenderéis, se trata de la vieja leyenda de nuestros campos. El fantasma de la eterna viuda que, de creación supersticiosa de la mente infantil del gaucho, transformóse luego en aprovechado recurso de matreros y salteadores.

Bien. A pesar de la nomenclatura criolla de que en él se hace gala (fogón, mate, ensartado cordero, acabadito de desollar, etc.), y de los nombres de distintos personajes: ño Usebio, ña Torcuata, no encontraríamos, en toda nuestra inmensa campaña, una sola estancia que pudiera servir de escenario de semejante relato." En el retrato de los personajes de otro cuento "Miss Alice", Chiappori critica que "haya preferido lo llamativo de la caricatura a la justeza de la realidad" p.73

En cuanto a las fábulas que calificara de parábolas doctrinarias, Chiappori, sostiene que son las peores y que algunas "reeditan" las ideas de otros escritores [las tres esmeraldas reedita a Brunetiére con sus ideas sobre la bancarrota de la ciencia, Revue des deux Mondes, $n^{\circ}$ 1, p. 97, 1895.] Critica la forma en que presenta a los anarquistas para hacerlos "más odiosos": invertidos sexuales.

-Negociaciones internacionales, por José Bianco. pp.74-75

250 páginas de estudios sobre este tema, sobre todo en relación con la figura de Irigoyen. Bien recibida en los círculos políticos.

-Rimas de Amor, por G. A Martínez Zuviría, p.75.

Según el crítico, se trata de poesía que tiene un valor puramente personal no merece análisis detallado. Estereotipado. “(...) si el señor Martínez Zuviría cincela sus estrofas y abandona definitivamente esa tendencia subjetiva, se hallará en condiciones de realizar las muchas esperanzas de su juventud." p. 75 -El idilio del valle, por Carlos Leumann, pp.75-76

No tiene nada nuevo: "Es siempre el mismo idilio trágico, narrado con los versos de siempre" p. 76 -Albores, por Mercedes Pujato Crespo [santafesina] p. 76

Le previene del "peligro que corre editando composiciones destinadas al álbum de una amiga cariñosa, o para los efectos de una declamación" p. 76

-El ejército de los Andes, por Adán Quiroga 
Se trata de una composición patriótica que ha sido premiada en el "certamen hispanoamericano que la Academia del Plata celebró el 30 de agosto de 1903" (...) "de todos sus trozos hemos preferido, por su justo color local y su fuerza descriptiva, el que relata la llegada a Mendoza de los hijos de las diferentes provincias, para engrosar el ejército de San Martín” p. 77.

\section{$\mathbf{N}^{0} 14$}

Atilio Chiappori, Año II, Tomo 4, nº 14, junio, 1904, pp. 179-193

- Hacia la vida intensa, por Julio Molina y Vedia

Chiappori manifiesta su decepción respecto del libro, por el desprecio con que se dirige a sus lectores, el sectarismo ideológico, por la falta de demostración de sus proposiciones. Chiappori explica que Molina y Vedia no es ni anarquista ni socialista porque "estas dos sectas son, para él, ideales de la décadénce” p.181. Chiappori ironiza: “¿Cuál es, entonces, su reino? Escuchad: 'Pues bien, mi idea es que el punto de partida de la nueva sociedad está donde nadie lo ha buscado, donde estuvo en la prehistoria, en la familia'. Una especie de patriarcado donde 'el individuo fuera a la vez padre, familia y sociedad por la transfusión de su sangre y de su espíritu, que ese individuo coexista en sus hijos y los nietos, que no esté limitado por la superficie de su cuerpo y pase así a la inmortalidad"” pp.181-182.

-Visiones de España, por Manuel Ugarte

Se trata de una colección de artículos -algunos de ellos ya aparecidos en La Nación- y entrevistas a hombres de letras y políticos. La crítica es elogiosa: se evalúa el estilo como claro y sencillo.

\section{-A la independencia de América, por Adán Quiroga}

Es una "extensa" oda patriótica, "leída y premiada en el certamen continental celebrado por la Biblioteca de La Plata el 25 de mayo" de 1904. Se trata de una nota irónica sobre el género y la estética elegida. Chiappori critica la imperfección de algunos de sus versos; se burla de Adán Quiroga y lo presenta como un estudioso pero no como escritor.

"Si a ello [al colorido de la adjetivación que Chiappori aprueba] uniera el Sr. Quiroga una estricta policía para sus metáforas (emplea algunas de marcado sabor andradiano, por ejemplo: 'tronar de escarmiento') desarmaría la más meticulosa crítica.

Teniendo las mejores referencias de este autor, he creído sin embargo un deber observarle esas pequeñas incorrecciones de detalle, para salvar el criterio de honradez que sugiere estas líneas.

El Sr. Quiroga es un trabajador incansable. En el índice que tengo a la vista cuento 47 obras suyas, sobre arqueología americana, derecho, y literatura" p.191. [cursivas nuestras]

\section{- La propiedad intelectual en el derecho argentino, por Ernesto Quesada}

La edición de la obra corresponde a J. Menéndez. Se trata de documentos jurídicos y bibliográficos en que se basó Quesada para sentenciar en casos de propiedad intelectual. De esos documentos se suprimieron los datos del contenido, según aclaración del mismo Quesada en la introducción de su trabajo. Evaluando su propio libro, Quesada añade que: "este libro será indispensable en todas las bibliotecas de hombres de la magistratura, del foro, de letras y de teatro: los problemas dilucidados interesan por igual a todos ellos, y, por vez primera, se tendrán reunidos en un solo volumen todos los elementos de juicios indispensables para conocer el estado actual de [la] propiedad intelectual en la República Argentina" pp. 192-193.

\section{$\mathbf{N}^{0} 15$}

Atilio Chiappori, Año II, Tomo 4, no 15, julio, 1904, pp. 301-311

-El viaje intelectual, por Paul Groussac

Este al que se refiere Chiappori, es el primer tomo de la obra. Define a Groussac como "escritor fuerte y original" p.302. El libro está formado casi en su totalidad por artículos publicados en Argentina y en el extranjero, pertenecientes a épocas reconocibles en la textura de los trabajos y en el cambio de opiniones sobre una misma materia tratada. Chiappori explica que no se detendrá en el análisis por cuestiones de espacio que son también, de honestidad intelectual. 
-Sensualismo, por Leonardo A. Bazzano

En función de la reseña argumental de Chiáppori, Sensualismo aparece como una novela de corte naturalista. Su protagonista, Julián del Carril, antes adinerado, " tiene por costumbre ir a charlar con las locas de Casino para hacer un poco de psicología intuitiva”. En la escena, ambientada en París, le parece a Chiappori obvia la alusión a Buenos Aires. Una noche del Carril va un café concert y, deslumbrado por mademoiselle Mevrille, arma un plan para conquistarla. El personaje se transforma repentinamente de "gozador" en socialista. La prostituta resulta finalmente una ex modista que él había seducido años antes en París, y de la que ahora se enamora. Al comienzo ella le propone que sean solo amigos, aunque luego "se le entrega". El $1^{\circ}$ de mayo "se produce el desorden obrero", escena con la cual termina el relato. Explica Chiappori:

"Este rápido bosquejo del asunto deja entrever la naturaleza de 'los trozos de vida bonaerense' que el autor retrata. No soy de los que me persigno ante una descripción 'verista', ni por mojigatería ni por tendencia libertaria, pero estimo en mucho la probidad intelectual y, por lo tanto, repudio todos los excesos adrede...

El señor Bazzano se deleita a trasladar a su libro, escenas que serán todo lo corrientes y naturales que quiera, pero como no constituyen peripecias imprescindibles de la novela, chocan con su excesiva crudeza.

No, nadie habrá llegado a mayores audacias de realismo que Zola; pero sus escenas más crudas tienen una explicación en el argumento, concurren a un fin de moralidad. La violencia brutal de Ragú con Fernanda en el fétido guardarropía del Abismo, es el no más allá de la descripción naturalista, pero representa una peripecia de la novela que sirve al autor para deducir una reflexión sociológica que cimenta la tesis desarrollada" p. 308.

\section{- Feminismo - Sintéticas, por Luis Bonaparte}

Se trata de dos "folletos" en los que se da cuenta de la actuación de las intelectuales argentinas. Es importante reparar en este género "folletos" como otra de las formas de publicación intermedia entre el artículo periodístico y el libro, característica para textos no 'literarios' (en sentido estricto).

-Ratos de ocio, por Manuel Escuder

Se hace mención a la opinión del presunto prologuista, un tal Sr. Brague al que se le ocurre comparar al ignoto Escuder con Cervantes.

- Recuerdos de mi vida diplomática, por Vicente Quesada

Es el primer tomo de las Memorias.

\section{$\mathrm{N}^{0} 16$}

Atilio Chiappori, Año II, Tomo 4, nº 16, agosto, 1904, pp. pp. 419-423

-Música prohibida, por Alberto Ghiraldo

Chiáppori rescata las ideas que Ghiraldo vierte en es sus poemas, más que la calidad estética. "la música de sus versos - por algo la llama prohibida- se debe extraer de sus ideas. (...) Es necesario aceptarle como es, no como quisiéramos que fuese. Y si bien, la forma es parte esencial de la expresión poética, téngase en cuenta que una cosa es cantar, asediado de hostilidades, guiando "hacia el sol las muchedumbres pálidas', y otra consumir sus vigilias puliendo ensueños de estilo" p.420 El crítico sostiene que la obra de un poeta no puede separarse de su vida ni de su temperamento, y a partir de allí se detiene en el ideal político que lo guía y que hace de él un apóstol.

-Mis memorias, por Lucio V. Mansilla

Chiappori consigna la editorial: Garnier. Lo que se publica es el primer tomo de las Memorias, que corresponden a la infancia y adolescencia, respecto de las cuales opina Chiappori:

"Indudablemente, esta primera parte debe carecer de interés para la mayoría de los lectores. Salvo las anécdotas chispeantes de tal o cual personaje sonado, y que como no todas pertenecen a la infancia o adolescencia del general pudieron incluirse en cualquiera de ellas, los recuerdos exclusivamente familiares de este volumen, solo pueden gustarlos un reducido círculo: el que deriva del núcleo social en el que el autor se actuara. El general Mansilla parece que ha olvidado que escribe para una ciudad transformada, cosmopolita y de casi un millón de habitantes a cuya enorme mayoría no puede llamarle 
la atención, por ejemplo, que su tía Hermenegilda permaneciese soltera o que tuviese la cara deformada, circunstancias las dos que, por otra parte, no influyen en la leyenda ni pueden rectificar la historia. Por eso, en mi entender, en vez de citar tanto nombre propio y particularidades de personas que no tuvieron más actuación que la familiar, algunas de las cuales no han dejado, siquiera, descendencia, pudo el autor extenderse en pinturas de cuadros sociales, de escenas de la época, de barrios de la ciudad antigua, los únicos susceptibles de participar de la verdadera tradición."

Aquí debe destacarse el pacto de lectura que el crítico imagina para la literatura moderna, en función del cual L. V. Mansilla, aparece como un sujeto anacrónico. [nos detenemos más extensamente Capítulo II, parágrafo 2]

\section{b) Libros del mes}

\section{$\mathbf{N}^{0} 17$}

Roberto Bunge, Libros del mes, Año II, Tomo 5, nº 17, septiembre, 1904, pp. 79-89.

- El imperio jesuítico, por Leopoldo Lugones

Bunge señala la poca o nula atención que para con este libro ha tenido la crítica.

"Con El imperio jesuítico ha alcanzado Lugones un hermoso triunfo de impopularidad. Alrededor de este libro, efectivamente, hase hecho la conspiración del silencio.

Habituados al desborde de los elogios incondicionales que a diario tributan los panegiristas de profesión, a cuanto libro mediocre publica tal [o] cual almacenero de Letras, pudiera extrañarnos esa indiferencia. Ella paréceme bien lógica, sin embargo.

Pequeño esfuerzo representa, en verdad, remedar un artículo, a base de adjetivos de sonoridad más o menos legítima, y de frases hechas -simples lugares comunes- cuando se quiere ensalzar novelitas, cuentos y poemas cortos, donde los 'Vizcondes de abanico', las 'Princesas azules', 'el leve peinador blanco' y 'la alcoba perfumada', forman escena, decoraciones y personajes de idilios azucarados o tragedias de broma...

El caso es sugerente tratándose de Lugones, víctima favorita antes de ahora de los incensadores de oficio. Esta vez, el real mérito de su obra, sírveles de escudo para repeler agresiones de ese género. Pero debe felicitarse, porque es siempre preferible el discreto vacío, a la avalancha de notas encomiásticas de crueldad espeluznante con que tantas veces se le ha asediado.

Ello es prueba de la bondad del libro. La acometida crítica se torna difícil, porque, de cualquier modo, sean cuales fueren sus defectos, estamos en presencia de una de las obras más dignas de análisis publicadas en esta última década." pp.79-80

Bunge resume los contenidos explorados por Lugones. Critica el método de este libro que deja algunos problemas meramente esbozados y no profundiza en ellos, como por ejemplo, lo que se refiere a la obra de los jesuitas. Con respecto al "Epílogo" Bunge ataca la lengua literaria: "Necesita el lector del hacha demoledora para abrirse camino en esa selva enmarañada, pletórica de vegetación; y no es sin esfuerzo que consigue penetrar hasta el fin sus atrevidas conclusiones. Ese era el momento de sacrificar la intención literaria, en obsequio a la claridad didáctica, descartando incidencias de puro lujo externo...." p. 85.

A continuación transcribimos algunos pasajes del último apartado (de los tres que forman la nota):

"Por su carácter y tendencias, es El imperio jesuítico una obra de pensamiento. Obra llena de observaciones ingeniosas, revela total comprensión del vasto tema desarrollado, a la vez que una ilustración poco común. Pero es preciso convenir, sin embargo, que ni lo uno ni lo otro constituye su virtud más descollante.

La exposición se resiente de falta de método. Y en términos generales, es más un libro de 'impresiones', que un 'Ensayo histórico'. Su erudición, de buena ley es cierto, resulta a las veces un tanto forzada: en el abultado índice bibliográfico, huelgan quizás varios nombres...

Lugones no ha podido desligarse de su propia tradición. Y Lugones es ante todo, hombre de letras. Íntegramente, página por página, línea por línea, está sellado el libro con el cuño de su estilo personalísimo.

Y he ahí como una obra sociológica, viene a ser, substancialmente, una obra literaria. (...)

La inmoderada pasión por los giros y las expresiones novedosas, trae como consecuencia inmediata, el amaneramiento. Y séame permitido observar que ese anhelo de originalidad, frecuente en los escritores de la moderna escuela simbolista, es el defecto capital del estilo de Lugones. Pero si tal 
defecto existe, se le perdona de buen grado, en obsequio a la riqueza sorprendente del idioma, a la precisión del concepto, y para decirlo todo de una vez, a la elegancia escultural de la forma." pp.85-87. En lo que resta del apartado continúa analizando la lengua literaria de Lugones en los términos que siguen: "amor a las rarezas", amontonamiento de calificativos, abuso del diccionario de sinónimos, falta de sobriedad. p. 87

-La enseñanza del dibujo, por Martín Malharro.

"Con el propósito de demostrar las ventajas de la enseñanza de esta materia en los colegios nacionales, ha publicado, el Sr. Martín Malharro un pequeño folleto, dedicado al Sr. Ministro del ramo y el Presidente del Consejo Nacional de Educación" p. 88

Bunge aclara que en número siguiente se ocupará de Los simuladores de talento, Los poetas argentinos, El caudillismo y la anarquía argentina.

\section{$N^{0} 18$}

Roberto J. Bunge, Libros del mes, Año II, Tomo 5, nº 18, octubre, 1904 pp. 206-214

- El caudillismo y la anarquía argentina, estudio psicológico de los orígenes nacionales, hasta el año $X X I X$, por Lucas Ayarragaray.

La nota comienza con una constatación que muestra el vacío que existe, más allá de las obras de Mitre, López y Paz, en los estudios historiográficos. "Se ha dicho con razón, que nuestra historia no ha sido escrita todavía. De los libros de Mitre, López y el General Paz, se ha dicho también, que servirán de cimientos al futuro edificio de la historia argentina..." La obra de Ayarragaray se inscribiría en ese camino a realizar. Bunge se levanta contra el análisis de "los lugares comunes de la mitología política nacional" que realiza el autor, desde su perspectiva sociológica, porque de él resulta que:

“(...) le leyenda nacional se derrumba estruendosamente, produciendo al caer, crujidos de ídolos despedazados. Estadistas y guerreros, leyes y constituciones, todo se empequeñece." p.207.

Interesa este pasaje porque Bunge comprende la necesidad para el Estado de la ficción nacional: "Sin duda, poco influirá en el hombre de cultura superior, la verdad descarnada sobre los acontecimientos históricos de su patria.

Para el pueblo, en cambio, la necesidad del culto del héroe es imperiosa" p.207.

Bunge define este libro como "obra de ideas", "trabajo serio, de tesis científica, desarrollada con claridad y método" p. 208.

-Los poetas argentinos, por Arturo Reynal O'Connor

Esta crítica es relevante porque en ella se distingue a quienes escriben poemas de ocasión de los verdaderos poetas.

"Una antología de poetas argentinos, fuera, en verdad, empresa harto escabrosa. Nombres hay, consagrados por el culto popular, que no podrían resistir el más generoso análisis. No es prudente, entonces, golpear las tumbas donde descansan tales héroes -algunos consulares de las letras argentinas- exhibiendo sus adorables ingenuidades, porque horrorizaría el sacrilegio.

Protejamos su féretros con el amable azul y blanco de la bandera nacional, y dejemos que sus estrofas, llenas de anhelo patriótico, se reciten en las escuelas del Estado, solemnizando por bocas infantiles, fechas gloriosas... La propia educación reemplazará en el hombre, los gustos del niño o del adolescente.

Llevados de un mal entendido respeto por las tradiciones nativas, seríamos indiscretos. Evitemos la tentación de presentar al examen frío del lector del siglo XX, los sencillos cantos que inflamaban la fibra patriótica de nuestros antepasados, y consolémonos con santa resignación, del pecado de no tener literatura patria...

Bajo este punto de vista, es censurable la misión que se ha impuesto el Dr. Arturo Reynal O'Connor, al iniciar una serie de estudios acerca de Los poetas argentinos.

El resultado es contraproducente. Impulsado por nobles propósitos, aspira a poner relieve las cualidades de estos precursores de la poesía nacional. Y sin embargo, únicamente consigue hacer resaltar la insoportable inferioridad de las composiciones exhumadas." Califica el trabajo de O’Connor de "tarea estéril, si no perjudicial" para el país. p.214.

\section{$\mathbf{N}^{0} 19$}

Roberto J. Bunge, Libros del mes, Año II, Tomo 5, n ${ }^{\circ} 19$, noviembre, 1904, pp. 323-340

-Los simuladores de talento, por José María Ramos Mejía 
Es según Bunge, "una aplicación original de una tesis conocida. Y este solo enunciado, envuelve ya un elogio", aunque más adelante agrega: "Diríase un libro desigual, concebido a retazos reveladores de estados de ánimo contradictorios" p.325 Luego se detiene en discutir las opiniones de la crítica amable "que han ungido al autor de Las multitudes en estilista eximio. Tratándose de Ramos Mejía, tal aseveración es sencillamente calumniosa.

A cada paso, resalta su marcadísimo empeño en 'hacer estilo'. Y su estilo es mediocre" p.327. La crítica se centra en el "desconocimiento del léxico", la construcción sin lógica de los neologismos, la repetición de palabras, la ortografía "estrafalaria", la falta de criterio en el uso de las comas, errores de concordancia, abuso de ques, epítetos vulgares, etc..

- Estudios sociales, por Belisario Montero

"Obra de un diplomático [cónsul general en Bélgica]... No hay que alarmarse, sin embargo, pues no se trata esta vez de las inofensivas 'novelas argentinas' del estimable Sr. Ocantos, ni siquiera de los impecables sonetos del parnasiano Leopoldo Díaz.

A los libros serios publicados por nuestros representantes en el exterior, agregamos hoy Estudios sociales (...)” pp. 330-331.

El libro trata de distintos temas, "Educación política y comercial", "industria de la lechería en Bélgica", "Industria del azúcar", "Lucha contra la tuberculosis", "La regeneración de mendigos y vagabundos". Bunge se detiene el capítulo dedicado a la "Enseñanza estética en la escuela primaria", y piensa en el caso de la Argentina, como problemático ya que quienes están a cargo de enseñar estos temas son las maestras. Aquí es interesante ver la visión despreciativa que sobre "la maestra", tiene Bunge, y a la que convierte en un tipo social nuevo:

"....Ya llega la maestra [cursivas del crítico]. Su gusto detestable se advierte al primer golpe de vista. Muy de mañana, sorprende con su indumentaria inapropiada. El traje de colores chillones y formas pretenciosas, raído a fuerza de uso, ostenta un lujo peculiar, lujo de mendigo. Mal; disimulada pobreza bajo esos harapos de relumbrón, a su paso se percibe, amortiguado por obra del tiempo, el leve crujido de las sedas. Su andar garboso, demasiado garboso, recuerda a la modistilla inmodesta. Y la frescura de su piel, que acaricia rudamente el aire matinal, se oculta bajo espesa nube de polvos de arroz, artículo de precio módico, y tal cual huella de pomada, que lo mismo se adquiere en la botica que en la mercería...

$\mathrm{Su}$ voz ordena con imperio. Es una voz seca, sin modulaciones insinuantes y femeniles, apropiada para explicar graves cosas a los pequeños educandos: astronomía, física, química, probablemente también lingüística y arqueología... Todo cabe en los programas primarios!

Los maestros elementales llevan por su parte a la aldea mediterránea, su prosopopeya ministerial, su gesto adorable de omniscientes.

Por eso apena observar grupos de colegiales de vuelta al hogar. Ah! Ellos repiten como un eco caricaturesco, con manera violentas, cuanto aprenden en clase. Y aprenden, a fe, harto más de los que les enseñan!" pp.332-333

Bunge se detiene luego en dos artículos particularmente actuales para 1904: "La Argentina como país de inmigración" y "Legislación belga referente a la residencia, policía y expulsión de los extranjeros". Respecto de este último critica la ligereza con que intenta aplicar la ley belga (inspirada en la legislación francesa) a la Argentina, y la extrañeza que le causan las protestas que aquí ha provocado la ley de residencia. Sin embargo, no debe pensarse que Bunge defienda a los anarquistas, ya que lo que critica es la incoherencia en el propósito de Montero, quien no piensa en que " (...) no puede ser excepción [al tratamiento de por la justicia federal], el delito público de profesar doctrinas subversivas del orden social existente" p.335.

- Don Juan de Garay, por José Luis Cantilo

Es una "monografía". Libro "ameno" e "instructivo", escrito por un "diarista de abolengo y cultísimo literato".

\section{c) Libros recibidos}

\section{$\mathbf{N}^{0} 19$}

Redacción [Manuel Gálvez], Libros recibidos, Año II, Tomo 5, nº 19, noviembre, 1904, pp. 356-358.

-Recuerdos de mi vida diplomática, por Vicente G. Quesada 
Chiappori ya se había referido a este libro en 'Letras argentinas' del $\mathrm{n}^{\circ} 15$. Gálvez explica que se refiere a la Misión de EE. UU. Finalmente hace una observación que parece copiar lo que dijera Chiappori del primer tomo de las memorias de Mansilla: "Quizá el Dr. Quesada dé excesiva importancia a detalles que al lector no interesan; pero eso es un defecto insignificante que el mérito total del libro hace perdonable" p.356.

-Accidentes histéricos, por José Ingegnieros

Gálvez comienza el breve comentario remarcando la condición de colaborador de Ingenieros en su revista. Se trate del estudio de gran cantidad de casos, bien escritos.

-El problema de la inmortalidad. Teoría basada en el materialismo y la lógica, por Luis Vigil.

De este libro dice: "Es un folleto reducido conducente a demostrar la no existencia del alma" p.357

- Por el niño pobre, por Alberto Meyer Arana

- Cantos augurales, por Armand Vasseur

Gálvez explica: "Aquel Américo Llanos que imitaba a Lugones con tan excelentes resultados, nos envía bajo su nuevo nombre, este tomo de poesías delicuescentes, escritas en un idioma incomprensible, pero reveladoras de una fuerte inteligencia. Se nota demasiado la imitación de los grandes poetas americanos.

-El eterno poema, por Leopoldo Velazco.

Versos sobre tema amoroso, vulgar y anodino.

$\mathbf{N}^{\mathbf{0}} 20$

Redacción [Manuel Gálvez], Libros recibidos, Año II, Tomo 5, nº 20, diciembre, 1904, p. 482]

-Canciones de la vida, por Juan Mas y Pi.

Crítica negativa. Considera al libro unan amalgama de las ideas de moda.

-Conferencia sobre feminismo, por Luis Bonaparte

\section{$\mathbf{N}^{0} 21$}

Abel Cháneton, Hacia el Oriente por E. Mario Barreda Año III, Tomo 6, nº 21, enero, 1905, pp. 79-81 Es un libro de poemas editado por Arnoldo Moen. La amistad que tiene con el autor lo obliga a la sinceridad; de ese modo introduce los juicios no demasiado elogiosos sobre la obra. La figura del autor queda preservada por el futuro que les promisorio: "Porque no me cabe duda: Ernesto Barreda llegará. Hay en Hacia el Oriente semilla que germinará, con la ayuda del estudio y del trabajo, una cosecha sana y abundante. Critica sobre todo la marca visible de otros poetas en sus versos (Darío, Lugones).

Manuel Gálvez (h), Inocencia por Francisco de P. Rendón, Año III, Tomo 6, nº 21, enero, 1905, pp. $82-85$

Es una novela colombiana, que Gálvez califica de "deliciosa". Esta nota sirve para caracterizar las preferencias estéticas de Gálvez en relación con la novela. Dice Gálvez: "En esta novelita figuran una gran cantidad de personajes, todos a cual mejor caracterizados. Aunque el autor no los nombrara, se les reconocería por la manera de hablar y pensar. El autor ha llegado a la perfección, en punto a esa impersonalidad que exigía Flambert (sic) [Flaubert] en el novelista.

Todo el plan del libro, la manera de dialogar, la elección de las escenas, el dominio de la técnica y la belleza del idioma, certifica un escritor consciente de su arte". p.83.

\section{$\mathbf{N}^{0}$ 23-24}

-Historia de la diplomacia americana, por Martín García Mérou García Mérou es definido como "laborioso y fecundo publicista"

-Sarmiento anecdótico, por Augusto Belín Sarmiento

-Fábulas argentinas, por Godofredo Daireaux. Se consigna que el libro ha sido publicado en La Nación, con prólogo de Roberto J. Payró. 
Actuación parlamentaria del diputado socialista Alfredo L. Palacios, publicado por el Partido Socialista.

La nota -algunos de cuyos fragmentos transcribimos a continuación- apareció en el n ${ }^{\circ} 13$ de Ideas.

Eugenio Díaz Romero..... El crimen del otro pp. 53-62

"El espectáculo no tenía en verdad, ninguna seducción atrayente. Era uno de esos sainetes abigarrados y hueros a que nos tienen habituados las compañías locales" p. 54. Díaz Romero hace un retrato de Quiroga, de su figura como escritor, de la forma, escasa en que se relaciona con los demás. Dice: "Quiroga atravesaba sin duda por un mal momento o era de una reserva impertinente" p.55 Opuesto a la sociabilidad mundana, lo imagina en una biblioteca. respecto del libro, critica que los cuentos sean breves.

"Cada una de estas historias certifican en el autor especiales dotes de descriptor y un poder de observación poco común. Esta es una de las raras veces, en que se nos ofrece un libro donde la belleza del estilo y del fondo marchan de perfecto acuerdo. En las distintas piezas, trabajadas con pulcritud, con riqueza de detalles y una seguridad de cincel digna de todo elogio, hay una elegancia impecable en el conjunto, reveladora de la intención que las ha precedido al tallarlas, y de los bocetos preliminares de que el orfebre se ha servido a fin de darles la construcción definitiva. No son, como alguien podría creer, figuras o caracteres fijados en el papel con un rasgo inusitado de inspiración. Los elementos que contribuyen a dar al cuento su expresión palpitante, han sido aquí fijado previamente, eliminados y pesados con la una conciencia plena de la obra artística. Las proporciones debidamente observadas, reflejan sobre el trabajo total, un resplandor de piedra preciosa, pues vese a simple vista, la solidez con que éste acaba al fin por destacarse, sin perder una sola de sus bellezas constitutivas. El argumento ha sufrido en la mente del novelista, una metamorfosis semejante a la del feto en el vientre de la madre." (...) p.57-58

"No es únicamente por la similitud de los temas, por el modo original de calcular las emociones, por la elevación, en ciertas partes aladas del lenguaje, por lo que el nombre de Edgardo Poe, flotó más de una vez sobre el libro del señor Quiroga. He profesado siempre por el profundo y triste poeta norteamericano una admiración religiosa. Pues bien, no tengo pudor ninguno en confesar que mientras leía ciertos capítulos de esta obra, me he sentido embargado de un sentimiento parecido al experimentado en presencia de las Historias extraordinarias." p.58

"Es posible que Horacio Quiroga, sienta la naturaleza como la sentía el visionario de El Cuervo. Si así sucede en efecto, sus producciones se asemejarán forzosamente, aunque con las naturales diferencias establecidas por el medio y las leyes atávicas". p. 59

Califica estas historias de "extrañas fantasías, impregnadas de un intenso interés y de soplo conmovedor de misterio" Retruca a Lugones que lo ha llamado "primer artista de América": "No cometeré pues la exageración de decirle al señor Quiroga que es el primer artista de América. América es grande y cuenta actualmente con escritores de primer orden. Están Rubén Darío, cuya prosa magnífica resbala como un manto de seda, Manuel Díaz Rodríguez, delicado y flexible, como el cuello de un cisne; están la sonora trompeta y los dulces violines de Vargas Vila, mezclando sus armonías a los acentos graves de Rodó, los sollozantes ritmos de Ángel de Estrada, la pomposa orquestación de Lugones y el épico clarinear de Sicardi. Hay otros más todavía, ante los cuales el señor Quiroga no se hallaría incómodo, preocupados de pulir sus joyeles, con el amor y la fe con que todo noble artista satisface este sueño". p.60

Como se ve Díaz Romero utiliza un repertorio modernista en su crítica, y las referencias [Musset, Regnier, Vigny, Hugo,] muestran o acentúan la influencia francesa. 
No lo enmascara su rostro ásperamente cavado por las intemperies, como el de una roca- cuyas duras prominencias dicen lealtad y huraña altivez, al par que enuncian indiferencia de montaña para las tempestades. La negra espesura de una barba, refuerza esa viril entonación de su semblante.

Sus miradas perforan las distancias, es morena su tez, su voz un jirón de trueno, y como un marcial penacho una melena opulenta remacha su estampa de león.

Su melancolía proverbial - pálida sonámbula que surge de la tiniebla- diluye crepusculares vidalitas en el alma de las noches lunares, cuando huyendo de una gran inundación de luz, en islas de sombras se refugian los misterios, para balbucear sus revelaciones estupendas.

Siempre a caballo es centauro en América, que rapta en sus ancas ninfas atrigueñadas por soles internos, -y es fama que cerca de los abismos negros de sus ojos siente vértigo el gaucho.

Magnífico debió ser, verlos pasar -cuando la ciudadela- revueltos en nubarrones de tierra, como galope frenético de huracán por los desiertos, cuando por saludar a la vecina gloria de los combates encabritándose los corazones, batiendo a martillazos los atléticos tórax, como relojes afanados por marcar la huella de aquellos momentos solemnes.

Terrible debió ser, cuando por el aire enturbiado pasaba silbando las boleadoras, como brazos descarnados de la muerte, que iban a estrangular las gargantas con infernales abrazos y oír el inmenso trueno de los guardamontes que ahuyentaba al enemigo.

Heroico debió ser, verlos volver haciendo galopar un cañón en el extremo de su lazo, un cañón como fiera subyugada y al caer mortalmente heridos, verlos levantarse por un instante y solo para ofrendar a su patria el último resto de su vida, en un certero lanzazo...

Esfuerzos inútiles ha hecho el payador por encerrar en estrofas aquellas Ilíadas americanas; para conseguirlo debieron ser pesadas aquellas cárceles de estrofas, hechas con hierro fundido en la inspiración, en la llama abrasadora que da un cerebro genial y gloriosamente incendiado. Por eso lleva su heroica historia el gaucho que se va. Ya sin vuelta, a desembocar en el olvido, dejando solo leves rastros de su paso.

Con el alma errante de los pamperos vivió en la tierra; hoy se va por no escuchar el crujido espantoso que, martirizadas en las máquinas, dan sus hermanas de crianza, las fuerzas antes rayos, tempestades ... antes salvajemente libres, hoy esclavas, hoy torturadas. pp.314-316 


\section{Letras francesas}

Esta sección siempre estuvo a cargo de Emilio Becher, quien colaboró además en Letras Argentinas. El corpus está formado por 8 entregas compuestas por 13 notas sobre obras literarias de distintos géneros. En estos escritos y según Rojas en su "Evocación", ${ }^{1}$ Becher realiza una labor importantísima, que en cierta medida, cubre la ausencia de una cátedra de Literatura Francesa en la Facultad de Letras.

-Año I, Tomo 1, $\mathrm{n}^{\mathrm{o}} 1$, mayo, 1903, pp. 72-85

-Año I, Tomo 1, n 2 , junio, 1903, pp. 182-188

-Año I, Tomo $1, n^{\circ} 3$, julio, 1903, pp. 266-275

-Año I, Tomo 1, no 4, agosto, 1903, pp. 366-371

-Año I, Tomo 2, no 6, octubre, 1903, pp. 195-203

-Año II, Tomo 3, nº 9, enero, 1904, pp. 72-74

-Año II, Tomo 3, no 11 y 12, marzo abril, 1904, pp. 354-361

-Año II, Tomo 4, nº 14, junio, 1904, pp. 173-178

-Año I, Tomo 1, nº 1, mayo, 1903, pp. 72-85.

Se trata de dos textos uno de Zola, Verité y otro de Huysmans, L'Oblat. Las notas interesan porque a partir de ellas Becher arma su posición respecto del problema del positivismo. Se refiere a "una profunda corriente de ideas hacia el catolicismo" a la que liga directamente con la declinación del positivismo y señala la necesidad de una "fe superior".

-Verité, por Émile Zola.

Se trata de una crítica que rescata sobre todo la dimensión ética presente en esta obra de Zola. Además, es importante observar que el mercado aparece bajo la forma de una política editorial que Becher critica. La obra de Zola ha sido mal traducida por "periodistas inferiores" para El Diario. El mercado aparece asociado a un emprendimiento editorial que descuida la calidad de las traducciones que divulga, una tarea que según puede inferirse debería estar a cargo de escritores o periodistas mejor formados -como podría ser el caso de Payró, quien además ha traducido a Zola. Transcribimos la nota completa.

"Hace tres meses, terminamos la lectura del último evangelio de Zola en la desagradable versión que, ilustrada magníficamente por Malharro, divulgó entre nosotros El Diario. La carencia de unidad, la innominable penuria del estilo, la absoluta ignorancia de todo idioma, son cualidades que no nos han sorprendido; pero hemos de deplorar la falta de respeto evidente, el espíritu de chacota y de blague con que periodistas inferiores se han permitido traducir esta obra, que la proximidad de la Muerte había hecho doblemente sagrada.

Digno, sin embargo, de adquirir la simpatía de un intelectual verdadero era este libro, no tanto por su virtud literaria, como por la amplitud de su significado y la profunda honradez de pensamiento. No hay en la literatura contemporánea una obra comparable a esos Cuatro Evangelios, que, por primera vez, han alcanzado a fijar en un mito definitivo, el poderoso esfuerzo moderno hacia la república venidera. En ellos Zola aspiró a personificar en cuatro héroes esta inmensa tentativa, revelando por medio de grandes parábolas el misterio de la Renovación. Mateo proclama la ley del amor, Lucas la ley de justicia, Marcos la ley de verdad: el primero es el creador, el segundo es el organizador, el tercero es el iluminador. Cada uno de ellos describe un aspecto de ese ideal revolucionario, que Pedro Froment ya había presentido obscuramente. De aquí la unidad del poema y la semejanza de las aventuras; pues, a pesar de la diferencia de ambientes, todos se proponen, en realidad, una obra única, y estos tres temperamentos, tan parecidos por la claridad de su fe, su indomable bravura, -debía sentir, bajo formas diversas, el mismo conflicto del porvenir contra el pasado.

En esta obra, la tarea intelectual está encomendada a Marcos. Para convencerse de ello basta observar el tipo del héroe, la cabeza firme, en que la frente característica de los Froment, "la alta frente

\footnotetext{
${ }^{1}$ Rojas edita póstumamente un volumen en que compila textos diversos de Becher. Esos textos están precedidos de la "Evocación". El título de la compilación es Diálogo de las sombras y otras páginas de Emilio Becher, Buenos Aires, Facultad de Filosofía y Letras, Instituto de Literatura Argentina, 1938. Recordemos que tampoco había cátedra de Literatura Argentina, hecho que no sucede sino hasta 1913, inaugurada por el mismo Rojas.
} 
en forma de torre" haya crecido todavía más. La psicología, someramente indicada, confirma, no obstante, el diagnóstico. Se trata de un temperamento de cerebral, en que la inteligencia prima. No es un amoroso como Mateo, y en cierto modo tampoco es un apasionado como Lucas, siendo intelectual su pasión. De aquí que vea las cosas desde un punto de vista personal y especial, "a través de su temperamento", si todavía puede hablarse así. La injusticia, los problemas sociales, todo el conflicto moderno se presenta a sus ojos como una lucha de ideas. La opresión no es para él, más que ignorancia, y el secreto de las emancipaciones está en la ciencia y en la verdad.

Así, después de Trabajo, la pasión ha subido un grado, y después del Activo aparece el Pensador. Pero apresurémonos a hacer notar que la diferencia entre los caracteres de Lucas y de Marcos es menos profunda de lo que podría creerse. Ciertos rasgos morales han cambiado, pero lo interior del alma está intacto, y la obra sigue siendo la misma. Lo que Beauclair se llamaba Injusticia, en Maillebois se llama Mentira: nada más. En el fondo, hay el mismo amor por los pequeños y los doloridos, por la humanidad pululante de los miserables. Tienen altura de Evangelio, las páginas en que Zola, con una mal contenida emoción, nos ha narrado la obra escolar de Marcos, sus quince años de lucha y fatiga, contra la dura y pesada hostilidad de la ignorancia.

Como se ve, la obra de Marcos es netamente intelectual. No vamos a repetir ahora el argumento harto conocido. En las peripecias de su drama, Verité reproduce la historia de Dreyfus. Pero, por un movimiento feliz, Zola ha hecho del presidiario inocente, no un militar sino un maestro, separando así los detalles inútiles para no conservar del Asunto más que lo general y lo esencial.

Así también ha dado a la historia un estilo más vasto y solemne, presentándola como un verdadero conflicto de civilizaciones. Después de habernos descripto la lucha de los proletarios contra la burguesía, Zola ha intentado presentar en este libro la batalla de la escuela laica contra la religiosa o, un aspecto más alto, del positivismo contra la Iglesia, del método científico contra la fe. Se puede adoptar una u otra opinión, pero nadie podrá desconocer la gravedad del problema, de cuya solución depende todo nuestro futuro mental.

Acaso la realidad o, si se quiere, la actualidad de este problema, es lo que ha dado a Verité una emoción más acentuada, un soplo de vida más poderoso. En tales párrafos, la frase misma late con un ritmo tan humano, que se diría que hay allí un corazón vivo. Las lágrimas son aquí más sinceras, la tristeza más natural, el esfuerzo más doloroso y visible, y hay en las alternativas de ese sufrimiento y en el progreso de esa esperanza, algo de vulgar y de miserable, es decir, algo de nuestro verdaderamente. No conozco episodio de heroísmo semejante a aquel en que Marcos, por amor a su empresa de verdad, renuncia a la caricia y el beso de Genoveva.

Diríase que el cansancio de ese sufrimiento ha alcanzado también al escritor. En la primera parte de encuentran todavía páginas admirables, y la historia del proceso es un admirable estudio de psicología social; pero a medida que se avanza, se constata una torpeza en la construcción, una penuria del idioma, una fatiga y desaliento crecientes. Las últimas páginas desmayan. La visión del futuro es turbia; y la aventura de la nieta de Marcos, -tan laudable por su nota de pesimismo humano,- no es más que un efecto buscado, que choca como una interrupción. Ciertamente, la obra es todavía grandiosa, pero ¡qué distante de los poemas, de la serenidad búdihca de Travail, o de la gracia ingenua y versicular, el canto de biblia de Fecondité!...

Como obra de pensamiento, Verdad debe ser simpática a los que creen que la victoria de la Iglesia, nos llevaría, hoy, a un estado de civilización inferior. Constatemos, también, que este libro, a pesar de su violencia, es sincero. Pero no por eso la visión del problema es menos incompleta.

Al lado de la reacción social, motivada por la ignorancia de la mujer y el terror de las aristocracias, hay una profunda corriente de ideas hacia el catolicismo, provocada por la bancarrota de la filosofía positiva y el anhelo de una fe superior. Zola no querido o no ha podido ver esta faz del problema, estudiada, aunque muy imperfectamente en París.

Estas cosas hay que decirlas, sin embargo, en voz muy baja. No hace mucho tiempo que hemos asistido al espectáculo, ridículo si no fuera tan triste, de una conspiración de todas las cobardías y todas las infamias, contra un espíritu que ya había puesto entre su gloria y ese lodo, la distancia sagrada de la Muerte. Y es obligación de todos nosotros defender el honor de Aquel que permanecerá como el más grande y puro escritor de su época, y que fue en medio de los hombres, por la nobleza de su pensamiento y el heroísmo de su caridad, un hermano de Mateo, de Marcos, de Lucas y de Juan. 
En esta nota Becher focaliza en el problema del artista, y construye una figura caracterizada por una relación negativa con el mundo exterior, el repliegue en el pasado, la fe: el artista como creyente. Becher ironiza sobre el naturalismo y en ello debe leerse nuevamente un juicio negativo tanto del positivismo como del socialismo.

"Para que este libro sea inteligible, hay que leer los volúmenes anteriores, Là-Bas, En Route, la Cathédrale. Un estudio completo no cabe, ciertamente, en esta simple noticia bibliográfica; pero más tarde, es posible que nuestra revista emprenda la obra necesaria de dar a conocer esta admirable figura de Durtal, en que Huysmans ha presentado a la vez que un experto y penetrante análisis del movimiento católico, toda la psicología del artista contemporáneo.

En el fondo, Durtal no es más que un hiperestésico, como De Esseintes, que querido por las sensaciones demasiado brutales de la realidad, se refugia en su mundo interior. Exasperado por la grosería y la mediocridad de la época, 'la inmundicia americana del siglo', se vuelve hacia la Edad Media que le ofrece el espectáculo de una emoción profunda, una fe total, un estado permanente de heroísmo, y sobre todo de un arte maravilloso, ingenuo y puro. La impresión de ese arte es tan intensa que su conversión no es, en realidad, más que una manera de identificarse, de comunicar más profundamente con los creadores de la pintura primitiva, del cántico gregoriano y de las catedrales góticas. Lo demás le interesa poco, o nada. 'La prueba del catolicismo es su suerte'. Poco importa, entonces, que su fe sufra agresiones terrible, la lujuria primero, después el orgullo, después la desorientación, 'la languidez y la anemia del alma'. A través de toda esta tempestad su conversión no cesa de afirmarse. En Route no nos presenta más que un fatigado, excedido por la sensualidad y la melancolía. En La Cathédrale aparece ya el artista conducido a la fe por la contemplación de las armonías y el sentido de la belleza. En L'Oblat, el creyente predomina.

Tan sencillo, por otra parte, es el argumento del libro que se explica en una palabra. Todo se reduce a la historia, minuciosa como en los volúmenes anteriores, de un año de estudio y de meditación que termina con el ingreso de Durtal, en calidad de oblato, en la orden de los Benedictinos. Dentro de este cuadro tan simple vienen a colocarse descripciones de la vida del convento, retratos, explicaciones de historia, y de liturgia; y periódicamente, en páginas inflamadas de lírica, escenas evangélicas o monásticas, visiones de cuadros antiguos, y el drama de las grandes ceremonias abaciales, con su pompa de leyenda, sus altares llenos de oro, sus bordados y sus joyas, el pueblo medioeval de los monjes, bajo una nube pesada de incienso, que atraviesan las llamas rectas de los cirios y el gran clamor de los salmos...

Paralela a esta biografía de Durtal, se desarrolla la historia de la expulsión de las congregaciones. Como se ve, el mismo problema ha preocupado, simultáneamente, a dos de los más grandes escritores actuales; y es curioso ver como influye la perspectiva de las cosas humanas este cambio de posición del espectador. Es Verité vista del otro lado. Es probable que la visión de Zola sea más justa como más conforme con la esperanza humana, con el anhelo vehemente de las revoluciones. Pero sería de desear que los lectores de Verité corrigieran su impresión leyendo este otro libro. Es el punto de mira opuesto, el catolicismo observado a través de la mística, como antes lo fue a través del socialismo. ¡Quién sabe! tal vez la verdad esté, aquí también, en el medio, como explica la vieja frase latina.

De todos modos, la inmensa sinceridad de esta obra la recomienda suficientemente. Hay a través de sus páginas un soplo de tristeza y de cólera tan verdaderas, tanto dolor de hombre, que uno se siente, a pesar suyo, arrastrado. Las páginas políticas con su violencia de periodismo no convencen ciertamente a nadie, pero en los últimos capítulos, en toda la historia del destierro, la cólera es tan furiosa, la emoción tan profunda, que uno concluye por amar, contra toda voluntad, a esos monjes.

$\mathrm{Y}$ esto, no solo por ese catolicismo profundo que hay en el interior de todo latino, no solo por espontánea simpatía hacia los perseguidos y los que sufren, sino por todo lo que ese hecho significa. Debajo de esta simple expulsión de conventuales se siente algo más grave, la desaparición de todo un mundo, la muerte de la Edad Media. 'La Iglesia, constata melancólicamente Durtal, está en un estado de abandono y de anemia, después que se ha despreocupado del arte, y que el arte se ha separado de ella. El toque de muerte de las Órdenes suena, los claustros van a desaparecer. El Val de Saints ha muerto; he asistido al entierro de la abadía y he sido sepulturero de sus oficios'. Sobre esta impresión de tristeza se cierra el libro.

Como ha podido observarse, a pesar de su fe, Huysmans es, en el fondo, un hombre libre. Ninguno ha proclamado con más valor la decadencia del catolicismo moderno como filosofía y como arte. En su 
ternura exclusiva por la Edad Media, no perdona a la Iglesia haber transigido con el 'americanismo de la época'. Las páginas en que estudia el 'estilo oleaginoso' de la literatura católica o de la 'abyecta estatuaria' de los templos son de una verba regocijada y furiosa. Su venga es terrible cuando se trata de los sacerdotes liberales, de los párrocos en amistad con las municipalidades socialistas, y sobre todo de la burguesía clerical, cuya alma de vanidad, de ignorancia y de devoción se simboliza en el barón de Atours, el cantor de couplets piadosos, a quien describe cruelmente con su cráneo liso, su bigote de cepillo de dientes, su voz ascética, pasando su rosario de plata, con el ruido de un caballo que sacude su freno.

Je blague dice, en cierta ocasión, Durtal. Toda el alma del héroe está en estas palabras. Llegado a la Iglesia en la plenitud de su talento, -el caso es tan feliz como raro,- Huysmans conserva toda su vivacidad y su vigor de artista moderno. En suma, su obra más importante es la de haber aplicado a la sociedad religiosa el método de observación naturalista. Entre los que se imaginan a los monjes 'según un fotograbado que conocéis, mofletudos y rechonchos, teniendo en una mano un pastel y apretando con la otra, sobre su corazón, una botella revestida de mimbre', y los que se les figura 'angélicos, cerniéndose sobre el mundo', él los ve en su realidad de hombres vivos. El ardor de su devoción no amortigua en nada su poderoso sentido cómico. Hay que leer, por ejemplo, en La Cathédrale ese simple croquis de los eclesiásticos en marcha bajo la lluvia, para comprender toda la maliciosa alegría, la perspicaz comprensión del ridículo, la tendencia caricatural del novelista. En toda su obra, debajo del puro lirismo religioso, se siente palpitar la vieja alma gauloise, una especie de risa ahogada y profunda.

Esta alegría se transmite a los personajes del libro. No queda nada aquí de esa figura clásica del monje, de ojos bajos y manos juntas, aterrado y fanático. Son locuaces, sonrientes, benévolos, llenos de un gozo grave y discreto. Algunos tienen un aspecto humano, una gracia de imperfección y de humildad que emociona: el hermano Gédre, huérfano recogido por una escuela congregacionista y pasado de allí a la abadía, que a veces se pregunta si no peca al ser tan feliz, y de un alma delicada y simple que llora de aflicción, cuando para herirle en su vanidad le quitan su cargo de ceremoniario; -Don de Fonneuve, 'la abuelita del monasterio', de una bondad ardiente y brusca, tan indignado con los religiosos que no observaban el reglamento 'que les reniega furiosamente, golpeando con el puño la mesa, y después, cuando el culpable había partido, corría, le abrazaba, le rogaba que le perdonara su vehemencia; y su ternura, su deseo de reparar el vejamen eran tales que el delincuente no podía faltar, entonces, con impunidad, a las reglas'; el padre Miné, 'el alquimista', idiota a consecuencia de un golpe, sordo, sin palabra, sin memoria, incapaz de ver nada, ni siquiera la farmacia, en que ha pasado toda su vida, y sin embargo de una exactitud tan escrupulosa para las horas de los oficios, de una inteligencia tan completa en lo que atañe a las cosas divinas, y que cuando penosamente consigue articular algunas palabras, es para alabar a Nuestro Señor y a la Santa Virgen.

Y entre los laicos, aún dejando a un lado a Mme. Bavoil, tan espléndidamente presentada, qué admirables figuras, la de Mlle. Garambois, por ejemplo, la vieja solterona, 'que tenía 17 años cuando sonreía', caritativa y alegre, con su alma de chicuela traviesa, sin más pasiones que la liturgia y los buenos platos; o la de M. Lampre, 'benévolo y rabioso', siempre indignado contra los monjes, exasperado por sus imperfecciones humanas, diciendo enormidades de los benedictinos, y sacrificándose por ellos, entregándose en cuerpo y alma, a cada instante. Como éstos, cuántos otros!

Sería interesante conocer la impresión que conservan de esta literatura, los católicos, 'Très raide, très raide!' opina el confesor del Journal d'une femme de chambre. La frase es a un tiempo vaga y precisa. Los mismos benedictinos protestan a veces, exasperados por la exorbitancia de su vocabulario y la travesura de sus símiles. 'Tiene Ud. una manera naturalista de encarar las cosas, más que singular'. - 'Me chanceo', explica inmediatamente Durtal. Pero no los tranquiliza. Desde Barbey d'Aurevilly la Iglesia mira con terror a estos revoltosos defensores. Son verdaderamente los oblatos, los afiliados legos, mitad monjes, mitad profanos, adictos a la Iglesia sin renunciar al siglo, que consienten pagar la contribución de su talento, siempre que no se trabe su libertad de artistas. Este es, por otra parte, el concepto de la oblatura, defendido en todo el libro por Huysmans.

A pesar de todo, la Iglesia tiene interés en conservar este grupo de escritores, por el cual comunica con el pensamiento del siglo y con todos los que, simpatizando con una filosofía humana y una moral laica, admiran en el catolicismo la gloria de los símbolos y el esplendor de las tradiciones. En un tiempo en que ya no quedan en la Iglesia más que fariseos de ropas largas, analfabetos de mecánicas devociones o sacristanes llegado a obispos, por astucia, es un verdadero milagro la 
aparición de este espíritu en que sobrevive, exhausta y doliente, el alma misma de la Edad Media. Si su dolor intelectual, la agudeza de sus sensaciones, su inquietud, el estilo martirizado y retorcido, denuncian un artista moderno, es todo medioeval por la amplitud de la fe, la bravura de las alegorías, su total caridad; y diríase un contemporáneo de la ventana ojival, del canto llano, de los Primitivos, y de aquel Jean Le Texier, llamado Jean de Beauce, que levantó, a principios del siglo XVI, en la Catedral de Nuestra Señora de Chartres, un campanario nuevo" pp.72-84.

-Año I, Tomo 1, nº 2, junio, 1903, pp. 182-188

-Les prophétes, por Adolphe Brisson

Se trata de una serie de entrevistas narradas -no taquigráficas- a distintas figuras contemporáneas de la cultura francesa. Becher señala el valor de renovación y transformación del periodismo contemporáneo que hay en Brisson, y esa valoración se concentra en una operación que podemos llamar estética, que singulariza esas producciones escritas, y realza la figura del periodista como escritor, no meramente como informador/comunicador. Explica:

"En lugar de las antiguas interviews fonográficas, la prensa tiende a establecer un reportaje más espiritual que prefiere las ideas a las palabras, que se preocupa por comprender más bien que de oír, y que permite, al lado del esfuerzo puramente mecánico de la retentiva, un trabajo de distribución racional y de creación artística. La superioridad de este procedimiento solo podría ser puesta en duda, por aquel ciudadano de los Estados Unidos que consideraba un progreso del siglo la sustitución de la pintura por la fotografía. Gracias a él, Brisson nos ha dado páginas de verdadero arte" pp.180-181.

La reseña interesa también por construcción de las figuras de los escritores como "videntes" o profetas: "Debajo de todos estos videntes, el alma vasta y confusa del pueblo crea el destino futuro, la humanidad de mañana. Nadie, hasta ahora, ha sido capaz de penetrar ese profundo secreto; pero es indudable que algo está por venir, algo que se oye, vagamente, crecer en la sombra. El espíritu sopla, la obra se realiza hasta por la virtud de los vaticinios hostiles (...)" p. 183.

\section{-L'inutile éffort, por Edouard Rod}

Es una novela, cuyo autor que aparece mencionado como discípulo de Zola. Se trata de una "novela de observación psicológica" p.186. Becher opina sobre el naturalismo como algo ya superado; importa por este juicio al naturalismo porque muestra la preferencia de Gálvez y otros escritores de la revistas por estéticas ya probadas, a la hora de construir una tradición literaria nacional.

"El armamento no es nuevo. Ciertos novelistas ingleses lo han utilizado más de una vez para provocar el llanto de las niñas aficionadas a la lectura. Pero (...) sobre la misma trama que sirviera para la confección de inofensivos romances, ha sabido erigir una novela de observación psicológica"p.186

Más adelante observa: "En cada página se manifiesta el mismo desprecio de la forma, la misma aspiración a la sencillez. Este procedimiento no carece de ventajas; es quizá el único medio de expresar la vida tal como es, vulgar y simple."pp. 186-7. Se pierde en amplitud pero se gana en intensidad: "observación exacta y sobria". "Me he detenido en esta noticia, porque Edouard Rod es todo un ejemplo. Discípulo de Zola en sus primeros años, separado luego violentamente de la escuela, resume en su aspecto más general la evolución de la literatura moderna. Su preferencia por los problemas del alma, es una protesta contra el naturalismo, la reivindicación del mundo interior, desdeñado por una retórica demasiado estrecha. Esto solo hace de la obra de M. Rod un fenómeno importante, digno de ser señalado. Ha introducido en la novela las inquietudes de la vida mental, y en el análisis psicológico una vibración de simpatía, hecha de caridad y pesimismo. Pero su literatura no es de las que van a quedar. Dentro de la reacción idealista, su obra no puede ser comparada a la de J. K. Huysmans o la de los hermanos Rosny. Le falta la robustez de la creación y el prestigio del arte, la suma originalidad y la perfección por la que una tentativa literaria se prolonga en los tiempos. Mañana, la obra de Zola y la de Hugo, que Rod ataca por la mediocridad del pensamiento, aparecerán colosales, no por las ideas que hayan expresado, sino por las que suscitarán, en las generaciones sucesivas, estos dos cuadros totales de la vida moderna" pp.187-188.

-Año I, nº 3, Tomo 1, julio, 1903, pp. 266-275

-Visions de l'Inde por Jules Bois 
Esta nota es significativa porque Becher señala la influencia de la prensa en la el conocimiento de la figura de Bois. Contraponiendo los artículos aparecidos en periódicos a la obra de Bois publicada en libro, y por lo tanto distinguiendo bien una zona de la producción de la otra, Becher explica:

"Pasa con Jules Bois, una cosa curiosa. Hace unos dos años era un autor poco menos que desconocido, en Buenos Aires. No solo sus obras, sino aún su nombre mismo eran corrientemente ignorados. Hoy es casi un autor de moda. Los diarios le citan. Sus artículos, traducidos o extractados, dan la vuelta a la prensa. (...) Sin embargo, su obra no es más conocida que antes, y el grande y puro artista de L'Eve nouvelle y Contre le satanisme et la magie no es todavía, para muchos, más que un reporter avisado y sagaz" p. 266

\section{-La Ruse por Paul Adam (novela)}

Resalta la calidad y la originalidad del estilo, que lo distinguen de todos los escritores franceses jóvenes.

\section{-Histoire comique por Anatole France}

Elogia la forma de narrar los hechos espantosos con "una sonriente tranquilidad". France aparece como una de las imágenes fuertes para pensar a los escritores e intelectuales desde la perspectiva de Becher, quien lo caracteriza en los siguientes términos: "La gloria de France consiste, en efecto, en haber conservado, frente al espectáculo de los hombres en actividad, un escepticismo sin desesperación y una ironía sin acritud" p. 273.

-Año I, Tomo 1, n 4, agosto, 1903, pp. 366-371

- Sanguines, por Pierre Louÿs

Es un conjunto de cuentos ya aparecidos en ediciones Lotus. Es una reseña elogiosa desde el punto de vista estético, aunque no ideológico: “(...) la doctrina sobre la cual se funda esta literatura es detestable. Hace diez años que Pierre Louÿs trata de demostrar esta insostenible paradoja: que la obra de las ciudades griegas supera el esfuerzo acumulado de la humanidad durante todos los siglos, y que después de la desaparición de Alejandría la civilización ha ido en continuo descenso" p.368. A esto responde Becher: "Pero la idea de la evolución humana a través de las épocas sucesivas, concepto positivo que ha reemplazado la noción metafísica de progreso - es hoy una verdad demasiado evidente, para que la literatura pretenda desconocerla. Paul Adam ha fundado sobre ella su amplia síntesis de $\mathrm{Le}$ temps et la vie."p.369

-Año I, Tomo 2, no 6, octubre, 1903, pp. 195-203

-L'imitation de la mort, por Rachilde. La reseña es importante porque, como otras de Becher, muestra el decadentismo como la estética del siglo XX [que siguió al naturalismo], y en ese sentido confirma una evaluación sobre el naturalismo como algo ya superado o al menos cuestionado.

"Fue Jean Lorrain, creo, uno de los primeros que hablaron de Rachilde. Pocos, en efecto, podían comprender mejor que el turbio y acre poeta de la decadencia lo que decía esta extraordinaria evocatriz de Sodoma y Gomorra. En el vasto clamor de nuestro siglo -el más ruidoso de todos, porque en él cada pensamiento ha tenido la forma de un grito- la Rachilde ha sido el chambelán del Pecado, el heraldo de las ciudades malditas" p.195

Chez les Russes de Émile Delage, periodista francés. Se trata de un libro para viajeros.

-Año II, Tomo 3, nº 9, enero, 1904, pp. 72-74

- L'eau profonde, por Paul Bourget. Esta reseña es muy importante porque señala la hegemonía de la novela como género literario. Sobre Zola, sostiene: "Zola, y antes que él, los naturalistas rusos, estudiaron [cursivas nuestras] las más importantes cuestiones sociales" p.72. La novela es entonces una forma del estudio de la sociedad, aquella especie de protosociología de la que hablaba el mismo Zola en La novela experimental .

Transcribimos la nota completa. 
"Durante el siglo XIX, la novela creció en importancia, aspiró a condensar la suma de las actividades, a ser la expresión de toda la vida, como lo fue en los tiempos heroicos, con Walnicky, después, con Homero, y entre los bárbaros, la epopeya. Al antiguo romance de aventuras, sucedió un nuevo género, que había recuperado en profundidad lo perdido en interés superficial, y que, brillante y ligero, resultaba por ello mismo más denso. En realidad, la novela ha dejado de ser en nuestros días un género, pues ha invadido y ocupado toda la literatura. Con Flaubert y Villiers de L'Isle Adam adquirió la plenitud y el resplandor de los grandes poemas. Zola, y antes que él, los naturalistas rusos, estudiaron las más importantes cuestiones sociales. Con Pierre Loti, el relato de viajes se ennobleció. Paul Adam se aplicó a fijar en los argumentos los grandes símbolos, las tradiciones. Los Rosny introdujeron la ciencia, definitivamente. Corresponde a M. Paul Bourget el honor de haber hecho entrar la novela en la psicología moderna.

Puso en ello una capacidad de observación nada común, el don de adivinar, una minuciosa paciencia, una inducción rápida y segura, talento. Diéronle crédito de psicólogo sus Ensayos, después sus Estudios y Retratos, la Fisiología del amor moderno, en tanto que sus primeras novelas permitirían designarle como el fundador de un género nuevo que opondría al exagerado objetivismo de los naturalistas, una fórmula basada sobre una concepción más amplia de la vida.

Creyóse que podría ser el vidente de las cosas íntimas, el hombre capaz de mirar, debajo de las apariencias, el alma.

Hélas! M. Bourget ha defraudado todas las esperanzas. El éxito -mal consejero-, le perdió, como perdió, antes a Raoul Vigny. El analista sutil y hondo no desdeñó relajarse a una literatura de alcoba. Nada le pareció más noble que continuar la tradición de M. Octave Feuillet, miembro de la Academia.

Descubierta la receta, bastaba ceñirse a sus prescripciones, alterando solo los detalles de la manipulación y las dosis de los ingredientes. Todas sus novelas se parecieron. El drama del adulterio sentimental le proporcionó episodios innumerables. En todos sus libros se encontrará la misma duquesa ingeniosa y delicada; el mismo marido honorable y confiado; el mismo amante escrupuloso y fogoso. Tantos años después de Mme. Bovary abogó -todavía- por la "omnipotencia del autor".

Inconsolablemente se apiadó de sus heroínas, obligadas a la infamia, por la presión de circunstancias fatales. Fue el pintor curioso y enternecido del pecado elegante. La gracia superficial y fina de las aristocracias, gracia inútil y frágil de bibelot, le pareció una excusa suficiente para las abyecciones del adulterio.

Sería injusto atacarle demasiado por ello, (Mirbeau tuvo su injusticia). La decadencia burguesa necesitaba un historiador, que quisiera narrar, para la posteridad, sus dolores mediocres y sus ambiciones sin grandeza. Las obras de Bourget son la confesión de toda una casta . Ellas explicarán más tarde, mejor que todas las historias, el estado del alma de toda una sociedad.

L'eau profonde no difiere sensiblemente de los libros anteriores. Los mismos personajes, los mismos ambientes, los mismos episodios, la misma vida. Y siempre el adulterio, la gracia aristocrática, la nobleza nativa, la mujer sensible, la elegancia, el buen gusto, las banquetes, $d u$ Bourget, quoi!"

-Año II, Tomo 3, nº 11 y 12, marzo abril, 1904, pp. 354-361

René Dys: Ernest Renan en Bretagne, importa por la figura que se construye, cargada de espiritualidad, no por la cuestión estética; sirve para caracterizar a Becher y al tipo de intelectual que propone.

-Año II, Tomo 4, nº 14, junio, 1904, pp. 173-178 
Sobre Crainquebille, Putois et plusieurs autres récits profitables, Paris, Calmann Lévy, éd., 1904, y referencias también a Opinions Sociales y los volúmenes de la Historia contemporánea de Anatole France. Sirve para ver la diferenciación entre arte y política, que es central en Becher para construir la figura del intelectual: "Que mi amigo Manuel Ugarte me lo perdone, -pero cuando supe que Anatole France se había hecho socialista, sentí una gran tristeza. Primero porque todo partido es estrecho, injusto e ilógico; y también porque estos revolucionarios no tienen ya la gloria de ser, como antes, los anunciadores de futuras verdades y los campeones de la justicia perseguida. Nadie puede ser al mismo tiempo mártir y miembro de un gabinete, y los socialistas han tenido que elegir" p.173.] 


\section{Letras hispanoamericanas y Letras españolas}

Estas secciones están a cargo de Ricardo Rojas, quien comienza a colaborar desde el segundo número. 'Letras españolas' aparece una sola vez. Sin embargo en 'Letras hispanoamericanas' se hace crítica de autores y libros españoles, de manera que es dable pensar que la denominación 'Letras hispanoamericanas' como perspectiva desde la que se mira y se establece una continuidad con España. Por último hay un caso -el de el "Estudio sobre Echegaray"- que no aparece bajo el nombre de ninguna de estas dos secciones, al que incluimos dentro de 'Letras españolas', porque Rojas se ocupa solo de ese libro español.

\section{Letras hispanoamericanas:}

-Año I, Tomo 1, $\mathrm{n}^{\mathrm{0}}$ 2, junio, 1903, Letras Hispanoamericanas, pp. 169-179

-Año I, Tomo 2, n ${ }^{\circ}$ 5, septiembre, 1903, Letras Hispanoamericanas pp137-146

-Año I, Tomo 2, no 6, octubre, 1903, Letras Hispanoamericanas pp. 204-210

-A ño II, Tomo 4, no 13, mayo, 1904, Letras hispanoamericanas, pp. 63-65

-Año II, Tomo 4, n 16, agosto, 1904, Letras Hispanoamericanas pp. 409-418

\section{Letras españolas}

-Año I, no 3, Tomo 1, julio, 1903, Estudio sobre Echegaray, pp. 236-249 [no aparece bajo el nombre de 'Letras españolas']

-Año II, Tomo 3, n 10, febrero, 1904, Letras españolas pp. 162-180

\section{Letras hispanoamericanas}

-Año I, Tomo 1, nº 2, junio, 1903, Letras Hispanoamericanas, pp. 169-179

- El Superhombre de Juan Valera

El libro es una recopilación de artículos críticos sobre temas variados. Rojas elogia la figura de Valera. Explica más allá de la variedad temática en el libro se reconoce un factor común: "que los temas son españoles y que a todos ha sabido darle su sana espiritualidad" pp. 172-173.

Los dos primeros artículos, a partir de los cuales Valera desarrolla la cuestión del superhombre, tienen como punto de partida dos libros de Pompeyo Gener: Amigos y maestros e Inducciones, a los que Rojas se refiere como conocidos en el medio intelectual argentino. El resto de los artículos versan sobre las últimas novelas en España ya sea nuevas o reediciones. Es interesante ver la preocupación de Rojas por los proyectos editoriales españoles. En este caso, es importante que señale la existencia misma de los proyectos de reedición del pasado literario. Critica los últimos artículos por su carácter de "gacetilla": "algunos apenas si parecen páginas de gacetilla, debido ya a la trivialidad de los asuntos, ya a la brevedad con que los trata, ya a la propia vejez del autor" [que además aclara Rojas en el comienzo de la nota, está paralítico] p.174.

En la imagen que construye de Valera, propone una relación deseada entre "generaciones" intelectuales. Por otra parte se refiere en términos bien concretos y mercantiles a la posibilidad de vivir ("lucrar") de las letras, de la cual distingue el anhelo de consagración que aparece siempre como algo lejano, y no necesariamente vinculado al éxito. Explica:

"[el lector de las notas] descubre en sus [de Valera] pensamientos, como formando su generosa esencia, la bondad paternal con que el ilustre anciano saluda regocijado la aparición de nuevas inteligencias en su país, confundiéndose acaso en una sola claridad [cursivas nuestras], los primeros destellos de la aurora con los últimos rayos de un sol poniente. Oh!, semejante espectáculo nos ha sido vedado hasta hoy a los jóvenes de América, aunque vivamos en 'la Atenas del Plata'... aquí la juventud intelectual entra en la vida, sola, vacilante, y librada a sus propias fuerzas. Los que la precedieron en la jornada, no le ofrecen ejemplos, ni le señalan rumbos. La mitad de la vida se va en el reve (sic) y en el ensayo, y casi siempre abandona la senda y cae vencida, falta de estímulos de todo género, pues la imagen lejana de la gloria es aquí miserable y el lucro, apenas una quimera" pp. $174-$ 175. Es importante además ver cómo se repite esta imagen de la quimera asociada a la idea del mercado. Recordemos que en "Sinceridades", Olivera se refería en estos términos al Teatro Popular que comenzaba en Francia. Finalmente Valera aparece como un "ejemplo de altruismo intelectual" para "los viejos embriagados en las orgías criollas de la política o indiferentes en la petulancia que 
oculta la mediocridad" p. 175. Como se puede observar, el lamento es propiedad de casi todos los miembros de Ideas.

- Los modernistas, por Víctor Pérez Petit -uruguayo.

Rojas refiere la forma en que supo del autor del libro, y esa explicación marca un aspecto de la sociabilidad entre escritores y afirmar la continuidad con la revista de Díaz Romero. Lo conoció por un artículo sobre D'Annunzio publicado en el primer número de El Mercurio de América. El libro es parte de un proyecto del autor en el que se encargará después de "los idealistas", y en tercer lugar de "los realistas". En el tomo que reseña Rojas se publican trabajos sobre "La lírica en Francia", y estudios sobre Tolstoi, Hauptmaen, Eugenio de Castro, Verlaine, Strindberg, Darío, etc.. Rojas explica, inmediatamente luego de la enumeración de autores, que "el vocablo modernistas [cursivas de Rojas], no ha sido tomado en cuanto afecta a los escritores que en Francia o en extraños países, iniciaron o siguieron la última evolución literaria", sino que el término es utilizado por Pérez Petit "en su acepción ideológica, comprendiendo (...) figuras características del pensamiento contemporáneo" p.176. Rojas señala además que el autor no es un crítico sino solo un "brillante impresionista", y considera este método (de presentar "sus visiones interiores") híbrido para la crítica "por su falta de precisión objetiva"; aclara que la abundancia de imágenes va contra "la claridad" y "el buen gusto". Rojas reitera su preocupación por el "comercio" intelectual en una observación centrada en el estilo de Pérez Petit: "Estilo semejante ofrece el doble inconveniente de que la traducción, hoy tan necesaria para el comercio universal de las ideas [cursivas nuestras], se hace difícil, y de que la concepción cae fácilmente en formas tan sonoras como vacías" p. 177. El juicio concluye indicando que sobra imaginación y falta análisis, por lo que confía Rojas que el autor "será más aceptable en la novela $U n$ amor cuya publicación anuncia" p.178. Agrega a esto el carácter escasamente didáctico de los artículos y su incapacidad para sintetizar sin distorsionar. Como se puede observar, esta nota sirve para identificar los postulados (y valores) de la poética crítica de Rojas. Afirma: "Quien no conozca a esos personajes por estudios directos o exposiciones que las (sic) sustituyan, difícilmente podría sacar de este libro una noción definida y completa sobre el espíritu de aquellos. Su crítica, pues, está muy lejos de ser didáctica y muy lejos también de aquellas magistrales síntesis de Saint Victor, que dan la idea comprensiva de un hombre o de un hecho, sin dañar la belleza e la forma, haciendo de ellas una creación de mármol, sólida y harmoniosa." (cf. p. 178)

-Año I, nº 3, Tomo 1, julio, 1903, Estudio sobre Echegaray, pp. 236-249 [no aparece bajo el nombre de 'Letras españolas']

"Echegaray (Ensayo de crítica, a propósito de El loco dios y Malas herencias")

Esta reseña importa porque naturalismo aparece señalado para la construcción de una poética de la novela nacional. Es importante reparar en la elección de los géneros, que coincide con lo que la revista propone desde el principio: novela y teatro.

Rojas trata cuestiones relativas al público pensado como "multitud" apelando a las perspectivas de distintos teóricos. Se manifiesta contrario a la lógica en que se complace al público, para mejor someterlo. Afirma que aunque el autor no se concentre en la creación de caracteres "los episodios que las [obras] forman ofrecen elevadas bellezas de detalle. A esto de el éxito de sus obras, pues aparte del lenguaje siempre galano, -aunque por ello no siempre oportuno-, suele ofrecer al público, no pocas situaciones emocionantes, coronadas por desenlaces fortísimos y talvez (sic) brutales. El público, hoy como ayer, va al teatro en busca de esas fuertes impresiones, pues quizá haya en esto algo de lo que llevaba al circo antiguo, donde vio correr sangre de gladiadores, de bestias y de vírgenes." p. 242.

Realiza una suerte de sociología del público de Buenos Aires:

"Bien sabemos lo que Larra decía de la opinión pública con tan amarga verdad y lo que observadores recientes han anotado acerca de la psicología colectiva [Max Nordau Psicofisiología del genio y del talento, y V. Sighele: La folla delinquente]. Las multitudes en la historia, en el delito, en el aplauso, dondequiera que están, son siempre ilógicas, inconscientes, fácilmente sugestionables. Su mentalidad es más baja cuanto más heterogénea su composición. No creo que en el presente caso pueda argumentarse con 'lo selecto de los públicos', pues todos los días vemos cuál es el ambiente de nuestros 'teatros elegantes'; y una opinión autorizada reveló no ha mucho, a propósito de Wagner, qué gente va a las temporadas líricas de Bayreuth. En tal concepto, dispenso tan poco respeto intelectual, con relación a los elementos que lo componen, a la multitud que gasta frac y seda en las 
salas decoradas, como a la otra, vestida de andrajo, de los tumultos callejeros". En la nota al pie de la página 243 se dan tres ejemplos del comportamiento del público en el teatro, en los conciertos y en las conferencias de Groussac sobre Bizet. Transcribimos la nota completa:

"Dentro de este orden ideas, puedo invocar en mi favor dos hechos reveladores: -Los abonados de la Opera habían asistido más de una vez a las representaciones de Iris, sin escandalizarse de la obra, -acaso porque no la comprendieron, - hasta que cierto pontífice [Cané] denunció la inmoralidad del libreto y anunció la perdición de las almas...Las damas desesperaron entonces de contricción (sic), boicotearon la pieza y, desde aquel día, no asistir a las audiciones de Iris fue un acto de buen tono [cursivas de Rojas], según aquel celoso director espiritual... El otro hecho no es menos desconocido: -Los conciertos de la Biblioteca han degenerado también en reuniones sociales. La gente va allí, como a la Opera, a ver, no a oír ...[cursivas de Rojas] Pues, a tales 'guarangos' he visto cuchichear con el vecino, mientras la orquesta ejecutaba una sinfonía de Beethoven; y mientras Groussac pronunciaba su magistral conferencia sobre Bizet, he visto irritado, a hombres y mujeres, bostezar y suspirar de aburrimiento impaciente! La denuncia es cruel, pero la debo a la verdad, y ella deprime al auditorio tanto cuanto levanta al eminente escritor" pp. 243- 244.

El "teatro de ideas" es presentado como la opción estética y ética elegida y reafirmada en la revista: "Se había dicho que Echegaray entraba con sus últimas obras en las sanas tendencias del teatro de ideas" p. 244. Se menciona en el apartado V a Taine:

"El lenguaje es todo en la obra literaria; la forma fija el estilo y la originalidad, y no de otra cosa que de las palabras depende la noción que nos da el autor, ya de un paisaje, ya de un temperamento. Debemos al lenguaje el conocimiento de las ideas y sentimientos de un personaje real o imaginario; y de la porción de estados anímicos que transmite, el que recibe la creación extraña hace una síntesis y constituye esa abstracción que se llama 'carácter'. Así es cómo la forma y el espíritu son inseparables y cómo la crítica literaria, lo mismo que la historia, se ha convertido en 'un problema de psicología', a partir de Taine, que hizo de estas ideas su filosofía del arte." p.247

"Ampuloso y oratorio [el lenguaje], en ciertas ocasiones delata la mente del autor olvidada de la realidad en la fiebre de su fantasía. Fijada así la psicología de Malas herencias, resultan dos que aman (...), dos que odian (...) sin que unos ni otros, odien o amen por transmisión hereditaria, sino por simples fenómenos adquiridos, no habiendo, desde luego, herencias malas ni buenas"p.248 Se mencionan los trabajos de Ribot sobre la herencia psicológica.

Rojas plantea un deber ser de la obra de neto corte naturalista: "Así como la obra literaria debiera ser la revelación de los caracteres del mundo y de la vida, así la crítica debe tender a desentrañar los caracteres de aquella, fijándolos por la observación, como base de la emoción estética que cada uno siente a su modo. (...) la verdad es constante y única, porque es una identificación objetiva. Por eso a fijar esta última, siquiera aproximadamente, ha debido aplicarse el presente ensayo, dejando librada aquella a la apreciación individual" pp. 248-249.

-Año I, Tomo 2, no 5, septiembre, 1903, Letras Hispanoamericanas pp. 137-146

Sobre Cosas de España de Pompeyo Gener. La nota es relevante por lo que dice acerca del método del libro: "Todo el libro es la aplicación a España de la teoría de las razas (...) En la capacidad de cada uno de estos grupos [los distintos que conforman su país] para realizar el progreso y la civilización, busca el autor la clave de todo al proceso histórico de España (...) Los argumentos están presentados con serenidad científica y esto, unido a la intervención preponderante que en la explicación de los fenómenos se da al factor antropológico y al ambiente físico, no bastan a ocultarnos las simpatías y las pasiones del autor." Se hace referencia al carácter científico de los estudios sociales, a la lucha por la vida, a la herencia y el medio como factores determinantes. Así, por ejemplo, observa: "tal vez se podría objetar a Pompeyo Gener el valor exclusivo que da a la raza en la historia de su país. La comunidad de suelo y las guerras seculares acaso terminaron por modificar las entidades específicas de los distintos grupos étnicos y por nivelar sus temperamentos, sin borrar las diferencias que la herencia mantiene y que determina el ambiente geográfico. Por otra parte, muchos caracteres fueron adquiridos del medio social, de las costumbres bélicas, de la tiranía política y religiosa que por tantos años se ejerció, fenómeno que él mismo reconoce" p.141.

"Todo tiene su razón de ser en el determinismo de la historia, y tal vez, la causa en este caso, sea que cada grupo social cumple una misión distinta en la evolución de la especie, favorecido o contrariado por las ideas siempre variables del espíritu humano.” p.142. 
Formula criterios modernos de legitimación intelectual. Explica: "El ideal contemporáneo tiende a fundar en el pensamiento la única aristocracia legítima, y todo bienestar en el trabajo, en la naturaleza, en la vida, en el esfuerzo propio"p.143 Habla de la "energía fecunda" de los intelectuales de la Barcelona, que se irradia al resto de la península y "es lo que deberá regenerarla". De ese modo se muestra el carácter curativo-médico de la labor de los intelectuales en relación con la nación.

Rojas señala las ideas de Gener como tributarias de las de Darwin, Spencer, Renan, Taine, Bernard, Comte, Littré. "Todas sus ideas convergen a este ideal supremo: enaltecer e intensificar la VIDA [en mayúscula en el original] a hacerla agradable deben converger todas las fuerzas sociales. Lo que no sirve a ese fin está demás y debe desaparecer. Este noble ideal inspira todas sus obras."p.144. Critica el estilo inelegante.

En relación con el problema del mercado editorial, es importante que consigne los datos de la edición del libro [Llordachs, Barcelona], puesto que como se explicó en el desarrollo del apartado referido a la novela, la edición es uno de los problemas con que se enfrentan los escritores. Rojas describe: "y el volumen presenta el mismo cachet arcaico de otros libros de Gener: capítulos exornados de guardas emblemáticas e iniciales de misal, signos y monogramas, todo bajo cubiertas arcaicas".

“(...) Gener, que como hemos dicho, pertenece a la reducida legión de los que aspiran a la resurrección española. Esa resurrección vendrá por la verdad, por eso empiezan a revelársela los que tienen educación netamente francesa, como Pompeyo Gener, y otros que siendo antigalos como Unamuno, son también sacerdotes del nuevo Ideal."p.146. La palabra ideal, como para los intelectuales de Ideas, remite también en este caso a la preocupación por lo nacional.

-Año I, Tomo 2, $n^{\circ}$ 6, octubre, 1903, Letras Hispanoamericanas pp. 204-210

Odio por Alfonso Danvilla. Se trata de un conjunto de cuentos. Rojas conoce a este escritor a través de Juan Valera. Cuando aclara esto, consigna los datos de la edición del libro de Valera [la casa Fernando $\mathrm{Fe}$ ] Alfonso Danvilla es autor de numerosas obras, aunque no es conocido en América. La causa de esto se halla, según Rojas, en el "aislamiento en que nos encontramos con respecto a la vida intelectual de la península" o lo que en su argumentación es equivalente, la importación hegemónica de la cultura francesa. Y prosigue: "El espíritu de América, no contento con haber proclamado la independencia política, rompiendo los vínculos que nos ligaban a la España materna, ha cumplido también, en cuanto a esta nación se refiere, la independencia mental, mientras el aluvión inmigratorio va realizando la diferenciación de la raza. El siglo XIX comenzó para nosotros con el reinado de la enciclopedia francesa, y hemos asistido a sus postrimerías al florecimiento de una literatura francesa también. Así, en vez de haber completado aquella rebelión, con nuestra soberanía intelectual, hemos caído en otra servidumbre (...)". p.205. Rojas explica esta hegemonía de la cultura francesa desde los revolucionarios de Mayo hasta los "simbolistas y decadentes de la cosmópolis capitalizada", en función de una ausencia de una "literatura directiva" en España, la cual según su opinión brinda motivos que le hacen creer en su "resurrección". Esta será obra de las nuevas generaciones a las que Danvilla pertenece. p.206.

Entre los argumentos que para defender y elogiar los relatos del autor se cuentan la presencia de psicología, su "mucha observación", la "fina crítica social que constituye su mérito [del cuento "A la puerta de la Iglesia"].

El crítico apunta más adelante el pasaje de los personajes de un medio a otro, que puede pensarse en relación con la impronta naturalista: "Debemos apuntar que Danvilla ha preferido para componer sus cuentos, asuntos y tipos de la vida elegante, ya moviéndose estos últimos o desarrollándose aquellos en su propia esfera, ya complicándose en escenario más modesto, como suele con tanta frecuencia suceder en la realidad". Y, más adelante: "En cuanto a su temperamento y escuela como novelista [aquí el término interesa porque es Rojas quien está pensando en la novela y en Zola como modelo deseable, ya que lo reseña son cuentos], sería difícil clasificarle. Tiene facultades de observación y sabe dar interés a sus relatos. Prefiere el movimiento, la acción, los estados de ánimo, los diálogos, para sugerir al lector la emoción novelesca; pero faltan casi por completo las descripciones del ambiente, sobre todo las descripciones de cosas inanimadas, que son tan frecuentes en Zola, por ejemplo". p. 208. Danvilla no evita los vocablos extranjeros y eso manifiesta, según Rojas, un espíritu más universal. Considera además que "la vez la novela es uno de los géneros literarios en que las 
costumbres se reflejan más fielmente". Como se ve, Rojas vuelve a insistir en la novela y subsume en ella las demás formas narrativas [al menos al cuento].

El párrafo final está dedicado a favorecer los vínculos culturales entre España y América. (p.210)

Año II, Tomo 3, $n^{\circ}$ 10, febrero, 1904, Letras españolas p. 162-180

Se trata de la crítica sobre La catedral de Vicente Blasco Ibáñez, cuyo comienzo informa sobre cuestiones editoriales: "La casa valenciana de Sempere, ha prestado a los pueblos de habla española, el beneficio inapreciable de popularizar, el exiguo precio de sus ediciones económicas, el pensamiento renovador del Siglo XIX". Alterna la edición de este tipo de libro con las de novelas, entre las que se cuentan dos de Blasco Ibáñez [Flor de Mayo y La Barraca] a la que se agrega La catedral.

En esta reseña se enuncian una serie de predicados relativos a la figura del intelectual / novelista y a la estética y al género elegidos por la revista para llevar a cabo su labor cultural de constituir una identidad nacional. Se pone en escena una poética (una teoría específica) fechada sobre el género novela, que aparece como un género condensador de todos los demás, y a la vez, el lugar de registro de las innovaciones tanto estéticas como del pensamiento científico, filosófico, histórico, médico. Se ve además la preferencia por el modelo del naturalismo francés.

"No obstante, entre la polvareda de las torres que caen, un nuevo ideal ha surgido, pasando de la ciencia al arte, como esos vientos que, nacidos de la tempestad, llevan a las distintas flores, gérmenes de vida. El drama y la novela estaban destinados a ser, dado su carácter, el más proficuo surco de la nueva cosecha, y en él ha nacido La catedral, último libro de esa casa de Sempere y la obra más reciente de Blasco Ibáñez. He conducido su lectura, y ella revela en su autor, por la valentía de su pensamiento y la firmeza de su estilo, a uno de los escritores de talla de la España moderna y a uno de esos hombres que desde ha medio siglo, están lanzando al mundo la profecía generosa de una época mejor." p.163

La novela de Ibáñez se organiza alrededor de un hecho político: la revolución de Septiembre, y muestra el cambio (evolución psicológica) que va de la mano de la educación nueva a la que el personaje accede en París. "Vencida su causa, pasó a París, y el nuevo medio contaminó su pensamiento". Se hace anarquista, vuelve a Claverías donde concientiza a los obreros del pueblo. Se trata en este caso de una novela que responde a los postulados del naturalismo. Así, Rojas sostiene que Los cuatro evangelios de Zola son el molde sobre el cual se vacía la novela de Blasco Ibáñez: "Vaciada esta novela en el molde de los Evangelios de Zola, se diferencia de ellos por su desenlace. Falta la visión épica de Mateo en Fecondité, de Lucas en Travail. Esto es en mi sentir lo que le quita su carácter de novela de tesis. (...) Vencido Gabriel [el protagonista], no pierde por ello el libro su carácter de obra y novela de pensamiento, nutrida de sanas observaciones. La narración, en sí misma, es ya un hecho elocuente: la evolución paulatina y recóndita del espíritu de Gabriel, por influencia de la educación y del medio."p.168. Así se explica entonces, a la luz de la adscripción al naturalismo, la determinación del medio:

"A primera vista, la obra parecería sustentar la tesis de que es inútil pretender regenerar a tan abyecta chusma [los obreros de Claverías que profanan la catedral]. Pero no: el que el ideal, como todas las fuerzas de la naturaleza, tiene su razón de desarrollo y eficacia en determinadas condiciones de tiempo y lugar. Antes habrá que renovar las conciencias progresivamente, como el labrador prepara la tierra en donde ha de arrojar la semilla" p.169

"Es este valor [el del libre examen y la independencia mental] el que necesitan los pueblos en lo presente, el valor de la sinceridad que desafía las iras de la plebe para regenerarla por la verdad que ella misma se obstinó en resistir. He constatado, antes de ahora, una actitud análoga, por parte de otros escritores españoles, que parecen convencidos de los altos deberes que les impone esta ola de crisis en su país. Es claro que resulta más propicia para su destino inmediato, la actitud de quienes prefieren halagar las miserias del chauvinisme, agravado en España por las miserias de la superstición. Pero no importa; puesto de sacrificio es el de las avanzadas de la verdad. El Ideal nuevo para España tendrá que ser la negación de su pasado, sin que esto importe renunciar al culto de sus legítimas glorias, pues la tradición ilustre torna más fuerte a los pueblos cuando realmente lo son. Corresponde este novísimo apostolado a los escritores, dentro o fuera de los géneros literarios clásicos. El talento ha demostrado ya qué tendencia semejante es, en la novela, por lo menos, compatible con la más pura belleza del arte [podemos suponer que se refiere al naturalismo/realismo]. Toca, pues la tarea a este nuevo tipo de 
predicador laico, toda vez que la Iglesia ha probado que ya no puede servir al progreso, siendo incapaz de adaptarse a los nuevos tiempos, en razón de lo inmutable de su propia naturaleza" pp.170-171. "Pero el problema es complejo y, tal vez, en lugar de atribuir la decadencia del catolicismo por el abandono del arte (que según D. Luis la Iglesia no comprendió jamás) fuera más lógico buscar una causa filosófica en los espíritus, económica en la sociedad, para reconocer en aquel una simple repercusión de otros fenómenos.pp.172-3.

Rojas reconoce en el carácter ideal de los personajes Blasco Ibáñez la misma limitación que en los personajes de Zola. Afirma: resultan "más naturales los personajes secundarios". p.174. "Los que hayan leído Travail reconocerán en estos [de Gabriel y Sagrario] los amores de Lucas y Josina" p.175 Hay además un parentesco ideológico con Zola que se da, según Rojas, en la adscripción a la fórmula ética de Zola: "el bienestar de los demás será la condición de nuestro propio bienestar" p.176. Zola aparece como el maestro; se transcribe una entrevista que Blasco Ibáñez tuvo con Zola cuyas palabras -se dice- aparecen como una verdadera "cerebración inconsciente" en el escritor español. p.180.

Año II, Tomo 4, nº 13, mayo, 1904, pp. 63-65

-Letanías simbólicas, por César Miranda

Se trata de la crítica negativa a un libro estéticamente anacrónico. Explica Rojas: "Bajo la cubierta que pugna por ser simbólica y solo consigue ser vulgar, nos llega desde Montevideo el endeble opúsculo en que César Miranda ha coleccionado menguadas prosas y poesías delicuescentes, flores tardías del ya caduco modernismo. El oportuno epígrafe, Letanías simbólicas, sintetiza en su propia incoherencia, lo más íntimo de tan exigua y abigarrada colección. Letanías son, acaso, por su monótono son; y simbólicas sin duda porque acompasando el paso al ritmo personalísimo de Rubén Darío, pasan Bacantes y Phaunesas, Ninfas y Centauros, entrevistos, por entre los decadentes sudamericanos, en la desconocida selva helénica.

En el prólogo, que se parece al de las Prosas profanas por la distribución topográfica, el autor dice:

'Y Pan aparece.

Pan, el dios que amo.

Pan el de la amarilla flauta,

Pan el del femenil llanto.'

Y se ha de decir después que no solo de pan vive el hombre!... El señor Miranda vive de eso, que en griego quiere decir todo; y a pesar de se tan antigua la materia de su folleto, agrega con cierto énfasis: 'Este libro es para los nuevos' pp. 63-64 Señala el libro como un "síntoma alarmante y anacrónico y regresivo" "y conviene aconsejar a muchos de los que se presumen discípulos de Verlaine, la lectura de los versos dolientes de ese Pauvre Lelián, que solo tuvo de extravagante, lo que tuvo de enfermo, es decir, la décima parte de su exquisito genio artístico" p.65

Año II, Tomo 4, no 16, agosto, 1904, Letras Hispanoamericanas pp. 409-418

- Quelques petites ames d'ici et dáilleurs..., por Enrique Gómez Carrillo

El libro ha sido publicado (en francés) por la Biblioteca Internacional de Sansot y Ce. (cía). Se consignan también los datos del traductor: Ch. Barthez. Gómez Carrillo aparece como el "croniqueur, amable, fácil, ligero" p. 414. La reseña es relevante porque el de Gómez Carrillo se presenta como el itinerario de la juventud hispanoamericana, que parte hacia París, a vivir en algunos casos la bohemia, en otros a estudiar. Rojas reprocha a quienes se embarcan en ese rumbo, desde una posición nacionalista:

"Una edición europea, una colaboración en revistas extranjeras, son poderosas fuerzas de sugestión en estas tierras fetichistas. Dada la pobre mentalidad de la multitud, se vuelve del extranjero rodeado de un prestigio exótico y superior. Pero perseguir en nuestra lengua la gloria europea, me parece una ilusión. (...) ¿A qué arrancarse al puesto civilizador, -aunque un tanto apostólico por ser de sacrificio, que en estas tierras vírgenes les corresponde? ¿A qué trocar una simple simulación de la fama (...) por el beneficio y la gloria positivos de un Rubén Darío, creando aquí, parmi les sauvages, y con su propio verbo, una conciencia en la élite literaria que le acompañó en Buenos Aires? p.411 Por supuesto, el caso de Gómez Carrillo es una excepción a esto, según el propio Rojas.

- El intruso otra novela de Blasco Ibáñez p.418

Rojas explica que no se detendrá en esta novela porque incurriría en repeticiones de sus propios juicios. Solo observa que "El intruso continúa la serie de las novelas sociales que su autor viene 
publicando; se estudia en ella con realismo ingenuo y animado, el trabajo y la miseria de los obreros en las minas de Bilbao"p.418. 


\section{Teatro/s ${ }^{1}$}

La sección aparece desde el comienzo de la revista. Las notas sobre teatro que aparecen bajo el título de la sección corresponden a los números 1 a 17. Gálvez se ocupa de esta sección durante los trece primeros números; a partir del número 14 y hasta el 17, se ocupa de "Teatro" Abel Chaneton. En el $\mathrm{n}^{\mathrm{o}} 3$ se publica el primer cuadro de la comedia Pro divorcio de Osvaldo Saavedra, cuyo cuadro tercero -Escenas sociales-, es publicado en el $n^{\circ} 21$. En el $n^{\circ} 5$, además de la nota firmada, Gálvez publica, con el seudónimo de Georges Doré, un artículo a favor del teatro libre, y el drama Más allá de la vida de José León Pagano. En los últimos siete números desaparece la sección pero la revista mantiene su interés por del tema. En el $\mathrm{n}^{\circ} 15$ se publica Cuerpo y alma, comedia en un acto de Osvaldo Saavedra; en el $\mathrm{n}^{\circ} 17$ se da a conocer una parte de La prueba, drama de Manuel Ugarte; en el $\mathrm{n}^{\circ} 18$ Antonio Monteavaro escribe sobre Triunfador de Roberto Payró, en el 19 aparece el segundo acto de La gringa de Florencio Sánchez; en el 20 se publica la comedia en un acto de Emilio Ortiz Grognet, En la sombra; en el 22 La intrusa de Maurice Maeterlink. Debemos agregar que además de las notas mencionadas, hay otras referidas a teatro: la de Antonio Monteavaro sobre Florencio Sánchez $\left(\mathrm{n}^{\circ}\right.$ 5), la de Ernesto E. L'Ódena ( $\left.{ }^{\circ} 8\right)$ sobre M'hijo el dotor, la de Alfredo C. López del número sobre Ibsen (n $\left.{ }^{\circ} 17\right)$, la de Olivera sobre El Gringo de Otto Miguel Cione $\left(\mathrm{n}^{\circ} 21\right)$, y escritos pertenecientes otras secciones, como por ejemplo el de Rojas, "Echegaray (Ensayo de crítica, a propósito de El loco dios y Malas herencias" ( $\left.\mathrm{n}^{\mathrm{o}} 3\right)$. En lo que sigue reseñamos exclusivamente las notas de la sección.

- Manuel Gálvez, Año 1, nº1, mayo, 1903, pp. 86-95.

- Manuel Gálvez (hijo), Año 1, n², mayo, 1903, pp. 195-199

- Juan Pablo Echagüe, Año 1, nº 2, junio, 1903, pp. 197-199 [no se anuncia en el sumario]

- Manuel Gálvez, Año 1, no 3, julio, 1903, pp. 285-291

- Manuel Gálvez, Año 1, no 4, agosto, 1903, pp. 381-391

- Manuel Gálvez, Año 1, no 5, septiembre, 1903, pp. 150-152

- Manuel Gálvez, Año 1, no 6, octubre, 1903, pp. 229-232

- Manuel Gálvez, Año 1, no 7, noviembre, 1903, pp. 309-312

- Manuel Gálvez, Año 2, nº 9, febrero, 1904, pp. 90-96

- Manuel Gálvez, Año 2, nº 10, febrero, 1904, pp. 187-192

- Manuel Gálvez, Año 2, no 11-12, marzo-abril, 1904, pp. 362-372

- Abel Chaneton, Año 2, no 13, mayo, 1904, pp. 194-199

- Abel Chaneton, Año 2, no 14, junio, 1904, pp. 82-91

- Abel Chaneton, Año 2, no 15, julio, 1904, pp. 312-315

- Abel Chaneton, Año 2, no 17, septiembre, 1904, pp. 97-100

- Ricardo Olivera, Año 2, nº 21, enero, 1905, pp. 38-44 NO VA

\section{$\mathrm{N}^{0} 1$}

Manuel Gálvez, Año 1, nº1, mayo, 1903, pp. 86-95.

Como toda nota de comienzo, ésta puede leerse como declaración de principios o como programa que guiará la sección. El objetivo que persigue Gálvez en el marco de la operación crítica que la revista se propone, es "decir la verdad" p.86. En este escrito incluye su propia figura en el grupo de aquellos que no ejercen una crítica adulona, que tienen un juicio independiente. Gálvez enjuicia los distintos pactos que subyacen en las diversas formas en que la crítica se practica, que ocasionan la opinión interesada del crítico:

"El crítico, en primer lugar, obligado por la exigencias del noticierismo [cursivas nuestras] escribe su artículo en el más breve tiempo posible después de la representación, pues a las pocas horas debe aparecer impreso. Con rapidez semejante, no será el artículo, a buen seguro, ni muy pensado, ni bien escrito. No creáis sin embargo que esta causa es la más importante en la manera de hacer crítica. Hay otras más hondas, más graves, más perturbadoras. (...)” p.86 Así lo que se critica es la forma de producción inherente a la prensa.

\footnotetext{
${ }^{1}$ La sección se denomina alternativamente teatro o teatros.
} 
Inmediatamente agrega: "Un crítico reputado exige de las empresas el pago de sus artículos [cursivas nuestras]. Y yo os advierto que no es exigente: con poca cosa queda satisfecho. Otro hay, que juzga del mérito de las obras según la nacionalidad del autor. Otro hay, que es incapaz. Otro hay, que cuando se trata de elogiar al amigo o de adular, agota el diccionario. Otro hay, .... iba a decir mal: ahora es una empresa periodística que recibe varios miles de pesos, por sostener el interés de una temporada, cuyo resultado era dudoso en extremo. Otro..... pero es bastante. (...) Elogia el articulista para conseguir diversos fines: localidades para su familia y sus amigos, los favores de alguna actriz, o la subvención de la empresa [cursivas nuestras].p. 87

Para Gálvez el problema está en que la crítica que forma el gusto, se subordina a los beneficios económicos en las distintas formas del mercado teatral. Así la crítica no es un medio cuyos fines siempre la apartan del tratamiento de su objeto.

El teatro aparece como un espacio de cruce en el que confluyen distintos tipos de consumidores culturales y sociales. Gálvez se refiere al teatro como de un fenómeno que interesa a "la opinión general", "el público, el buen público, al que engañan". Muestra de esta forma su convencimiento de que es la crítica la que educa el gusto teatral y su deseo de intervenir en ese sentido. En la nota, Gálvez diferencia claramente a los intelectuales del público ["los inteligentes" y "el público"].

Gálvez realiza un deslinde de los orígenes del teatro nacional, para discutir la importancia de las compañías provenientes del circo criollo. Así, dice Gálvez que no puede atribuirse al trabajo de una compañía la fundación del teatro nacional. Gálvez critica el tipo de obra con que se inició la compañía.: dramas primitivos cuyo argumento es el del gaucho perseguido. Para Gálvez un teatro se forma no se funda: "En la formación [cursivas de Gálvez] de un teatro influyen múltiples elementos, algunos de los cuales, como la cultura general y principalmente el mérito y buen éxito de las obras que se representan, deben mencionarse. (...) En todo caso, el papel de una compañía podría consistir en apoyar la formación del teatro, protegiendo a los jóvenes que se inician, representando solamente obras originales y de éstas las mejores, y valiéndose de muchos otros medios conducentes a ese fin."p.89 Propone una política de selección de obras de autores dramáticos nacionales, en contra de las obras traducidas. [Cf. en el capítulo dedicado a la revista el apartado 5.2. En contra del criollismo: el gaucho se va, en el analizamos esta intervención de Gálvez]

Obras a las que se refiere:

- Caín de Enrique García Velloso en el Rivadavia. Critica y elogia más o menos por igual. Dice que "no siempre lleva sello de realidad".

-La de San Quintín de Benito Pérez Galdós por la cía. Cobeña. Gálvez se pone del lado de la "idea revolucionaria" que encierra la obra. Dice "es obra de ideas". [ teatro Politeama.]

-Lo irreparable de Héctor Quesada (arreglador), en el Apolo. Es una obra exitosa. Pablo Podestá representa a don Camilo, lo mejor de la obra, según Gálvez.

\section{$\mathbf{N}^{\circ} 2$}

- Manuel Gálvez (hijo), Año 1, nº 2, mayo, 1903, pp. 195-199 [Teatros]

La nota comienza con la crítica al mal gusto del público. Es por eso que la comedia de Capus, $L a$ Veine, no ha tenido éxito. En continuidad con el escrito de Peña "Fomento del teatro nacional" publicado en este mismo número, en relación con la hegemonía de las representaciones criollistas, Gálvez discute el juicio condensado acerca del carácter central de este tipo de obras en la escena nacional (porteña):

"El público de Buenos Aires, se ha dicho en diarios, revistas y conversaciones privadas, posee preparación, inteligencia, y reconocido buen gusto. Pero permitid. Queremos dudarlo. Y queremos dudarlo, porque hemos visto glorificar mistificaciones y denigrar genialidades. Y también, porque hemos visto sonreír indiferencias, ante reputaciones hechas a fuerza de arte. (...) Las emociones artísticas, porque no son manjar para imbéciles, requieren si han de ser saboreadas, paladares sanos, no corroídos aún por la gangrena del mal gusto. "El público de Buenos Aires, no siente las obras maravillosas de Ibsen. Y por el contrario, goza y ríe las inmundicias de un vaudeville o el can-can de una opereta. La moda y lo sucio; he ahí los dos principales objetivos, que llevan al teatro a ese público considerado inteligente" p.195 
La discusión con el criollismo importa porque sirve para delimitar los puntos de la polémica: el primero, la parcialidad de la representación respecto de lo argentino, y luego, el lenguaje inverosímil, que está plagado de modismos, al que se opone la corrección de un español estándar al servicio de la representación de nuevos temas, consumible por un público imaginado como relativamente homogéneo, ya que como argumenta después: "Porque el arte -si es la transmisión de sentimiento, debe ser para todos". De este modo, en ese anhelo de un carácter potencialmente compartible/consumible, se lee la ambición de un público más amplio, al que se imagina relativamente homogéneo.

Elogia la actuación de Carmen Cobeña en La dama de las camelias

Juan Pablo Echagüe, Año 1, nº 2, junio, 1903, pp. 197-199.

Da cuenta de la actuación en el Odeón de la compañía Pino, proveniente del teatro de la Comedia de Madrid, con la obra de Tirso Don Gil de las calzas verdes.

Elogia el trabajo de la sra. Pino y lo hace en términos de una estética: "La moderna escuela realista, tiene en ella una sobresaliente discípula. Procede por 'naturalidad', diremos. Fisonomía móvil e intensamente expresiva; grandes ojos, verdaderos espejos del alma -o del 'estado del alma', si gustáis; voz suave, de timbre neto que su dueña sabe, en cada caso, templar al diapasón de llanto, de carcajada o de sonrisa. Y por sobre todo ello, una ausencia de artificiales poses [en cursiva en el original], una amplia desenvoltura de movimientos que resultan de exacto y ponderado realismo".

- El doctor Morris de Alberto del Solar, cuyo primer acto había sido publicado en el no 1 de la revista. Señala su éxito relativo:

"Un éxito de complacencia (íbamos a decir negativo) benévolamente tolerado por la crítica.

La crítica...!" p. 199.

\section{$\mathbf{N}^{0} 3$}

Manuel Gálvez, Año 1, no 3, julio, 1903, pp. 285-291 [Teatro]

Comienza con la repetida queja sobre la crítica prostituida: aquí lo que se impugna es la relación servil con el mercado de las empresas teatrales; esta relación muchas veces está gestada desde los periódicos, no individualmente. Equipara la suya con la tarea del censor. "Es desagradable tarea la de censurar eternamente, y que los elogios prodigados en los diarios, patentizando nuestra imparcialidad, han hecho doblemente antipática. Siendo práctica vieja saludar con aplauso toda obra nueva, es doloroso para un crítico imparcial, tener que referirse en cada caso, a esa amabilidad de la crítica prostituida"p.285.

La sección se organiza a partir de los teatros en que se representan las obras

-Crítica negativa sobre Faro de Alberto del Solar, representado en la Comedia. Faro es una puesta en escena basada en la novela de Del Solar. Comenta que al leer la novela encontró un párrafo casi calcado de El doctor Morris también de Del Solar y que la revista publicara en su no 1 . Sin embargo, agrega un elogio, que debe tomarse como parte del programa de Gálvez tanto para novela como para el teatro: "Por lo demás, la belleza del asunto, la propiedad del lenguaje, un conocimiento exacto del medio, todo en una prosa robusta y castiza, son cualidades que han impresionado agradablemente" p.287.

- Teatro Apolo: se hace referencia al concurso que este teatro lleva a cabo. Se representan las obras y se las juzga. El turno es de El Trofeo de Nicolás Granada (autor de Al campo). Se crítica "La vulgaridad chocante del asunto, la inverosimilitud y pobreza del diálogo, la pesadez de ciertas escenas, son lamentables condiciones indignas de la pluma de quien escribió Al campo" p.289.

- Teatro Odéon. Allí actúa la compañía de la Comedia de Madrid, cuyo trabajo es elogiado. Es según Gálvez la mejor de todas las compañías extranjeras. Ha representado Las flores de los hermanos Álvarez Quinteros (comedia en dos actos).

Se consignan futuras llegadas de actores a teatros de Buenos Aires: Antoine (Odeón), Jane Harding (Argentino), Carmen Cobeña (teatro a designar).

En otro orden de cosas, defiende El hombrecito de Jacinto Benavente e informa de la muerte de Gaspar Núñez de Arce. 
En "Varias" (pp.292-296), Héctor J. Delmonte informa sobre Iris de Mascagni, y nuevamente [ver la nota al pie de letras hispanoamericanas de Rojas] se hace referencia a la crítica moral de Cané del año anterior. También se refiere a la censura teatral de Demi-Vierges de Marcel Prévost.

Aparece inmediatamente después de la nota de Gálvez y con el título 'Teatros', una pequeña sección que no forma parte de la numeración corrida de la revista, en la cual se consignan las obras en cartel.

\section{$\mathbf{N}^{\circ} 4$}

Manuel Gálvez, Año 1, nº 4, agosto, 1903, pp. 381-391. [Teatros]

Sobre Ezequiel Soria, autor de Cristián que se representa en la Comedia. Se reconoce la habilidad de Soria como dramaturgo, en el manejo de las escenas, pero se le critica que la emplee en "tremendos melodramas, hechos para un público maleducado, sin propósito artístico verdadero" [p.381]. Y agrega la falta de originalidad en los argumentos de sus obras: "Y es sensible también que pudiendo producir originalidades, en un amplio sentido, forme sus argumentos con aventuras y peripecias exentas de toda novedad, muy vulgares, muy conocidas.

La cuestión de los géneros "malsanos" a los que se identifica con los géneros populares aparece como una cuestión central en la reseña y forma parte de la campaña a favor del teatro nacional que lleva adelante la publicación. Dice Gálvez: "Cristian, un éxito franco que noche a noche arranca aplausos entusiastas, pertenece a ese género malsano y burdo del melodrama, tan aplaudido del público, tan tentador para los autores, en ese anhelo de aplauso que sacrifica la independencia del artista, y muchas veces, toda una probable gestación de bellas ideas, la obra encomiable, quizá ahogada por la visión turbia de un estruendoso batir de palmas en la noche fiebrosa del estreno. (...) Se prefiere la compadrada, la frase patriotera o el efecto grosero, a una observación atinada, o a un pensamiento elevado.

Por eso el teatro de ideas, no tendrá jamás arraigo entre nosotros" p.382 Y más adelante: "De cualquier manera, los autores deberían modificar los gustos, produciendo obras en que el progreso lento y constante, llevara hacia un perfeccionamiento relativo, el teatro universal moderno, tan lleno de enseñanzas proficuas, tan hondamente intenso.

No se ha seguido esta opinión. Se escribe, ahora como hace un año. Los mismos vicios, las mismas pocas virtudes, un género amorfo, llorón, cuando no inmundo, cultivado por todos tenazmente" p.383.

La nota sin embargo suaviza la crítica, volviendo a elogiar a Soria en su técnica. En cuanto al estilo Gálvez lo califica de "vulgar en grado extremo", "ampuloso, lírico", "monótono", caracterizado por la "pobreza en su idioma". p.385.

El primer apartado de la reseña culmina señalando las faltas: "No es Cristian obra de pensamiento. Ni ha sido la psicología de los personajes debidamente estudiada. Hay ausencia de caracteres, en el más estricto sentido. Aquellos personajes, son figuras de marionetas que el titiritero mueve con suma habilidad. La pintura de costumbres tampoco apunta" p. 386

La descalificación de la obra vuelve a recaer en el género: "Hemos dicho anteriormente que es un melodrama. eso basta. Un trabajo más del todo inútil, que irá a confundirse en el fárrago de tanteos más o menos aceptables, de que ha vivido hasta ahora nuestra inocente y anémica literatura dramática" En otro apartado se critica nuevamente un género teatral, en este caso el sainete: "El arte dramático arrojado del Odeón (...) se refugió en el Apolo y en la Comedia donde el llamado teatro nacional se cultiva.// Maltrecho salió de allí. En cierto sainete especialmente. Es innoble, verdaderamente, que el cinismo, la desvergüenza y el chiste inmundo, que popularizó el teatro chico y murieron con él, hayan vuelto a resurgir con su corolario de carcajadas soeces y ruborizaciones femeniles. Se impone la protesta, mayormente cuando se trata de una pieza, que opta al premio de un concurso" p.387

Se consignan las futuras actuaciones de Jane Harding en el teatro Argentino y de Antoine en el Odeón. Se detallan los repertorios. Los datos son importantes por las evaluaciones de Gálvez. Sobre Los aparecidos se dice: "aquella tragedia estupenda, ese estudio de la herencia, magistral y grandioso por su terribilidad"; El cochero de Henschel de Hauptman es calificado como un "drama en el que la realidad vive en la escena"; entre otros títulos figura La terre de Zola [tomada por el autor de su romance] de la cual Gálvez imagina "algo enorme". Interesa, además, ver lo que se espera de Antoine en su interpretación de $A u$ téléphone: "Antoine nos hará ver en su rostro las torturas crueles, las desesperaciones nacidas ante la muerte y la desgracia, las pasiones más humanas, y la rabia y la 
impotencia que turban el alma del protagonista, oyendo por el teléfono todas las catástrofes que agobian la felicidad de su hogar"p. 388

Se hace saber que en la primera función del abono especial a obras de tesis se representó La fille Elise, tomada de la novela

En el tercer apartado se reseña la situación de los autores dramáticos respecto del mercado de las compañías teatrales. Sabemos que se trata de Payró y su obra Sobre las ruinas aunque no se lo explicite. Se vuelve a señalar la cuestión del género al que deben adecuarse las obras según las compañías teatrales.

Resabios de Mariano Bosch, representada en el concurso del Apolo. Según Gálvez carece de argumento, las escenas son interminables, los personajes son inverosímiles, "no existen ni han existido en parte alguna del mundo. Son tipos de vaudeville. Nos recuerdan los que intervienen en esas malas traducciones de las piezas francesas, representadas en los teatros nacionales" p.390. Se rescata la actuación de Pablo Podestá al que se le recomienda que no haga tantas payasadas ni exageraciones. p.391

\section{$\mathbf{N}^{0} 5$}

Manuel Gálvez, Año 1, nº 5, septiembre, 1903, pp. 150-152 [Teatros]

Gálvez repasa las actuaciones de algunos actores: Jane Harding, Angelina Pagano, Ferrucio Garavaglia. Se comentan los estrenos por la compañía Pagano de Il dominatore de Pagano y Vittina de Pachierotti. De Il dominatore se señala su relación con el pensamiento de Nietzsche; Vittina cuyo tema es el divorcio es presentado como un drama de tesis, en función de la cual se elogia la propiedad del caso elegido y su desarrollo. Se hace referencia al éxito de la comedia M'hijo el dotor de Sánchez y se critica la falta de coherencia del personaje de Julio: "El personaje que encarna una tendencia, debe no solo estar bien trazado, sino ser consecuente con sus opiniones." p.151 Niega la trascendencia que "algunos" otorgaron a la obra. Dice Gálvez: "Simplemente es una buena obra, donde se retratan costumbres y tipos, como en el acto primero y en el tercero lo que a la negra se refiere, todo muy bien llevado, muy bien pensado, en un diálogo lleno de observaciones, delicado a veces, y siempre humano y verdadero" p. 152. Este hecho es interesante porque más tarde cuando Sánchez ha sido unánimemente consagrado, Gálvez se acopla a los elogios.

Se menciona como una obra intrascendente Culpas ajenas de Martín Coronado (representada en el Apolo). Se anuncia la próxima actuación de la compañía de Clara della Guardia en el Politeama.

Aparece en el final aquella breve sección teatros, que además de propagandizar las obras informa sobre los precios de las entradas.

\section{$N^{0} 6$}

- Manuel Gálvez, Año 1, nº 6, octubre, 1903, pp. 229-232

Gálvez se refiere a Próspera de David Peña: "David Peña quiere regenerar [cursivas mías] el país. Es ahora un apóstol del civismo y la moral política, que ha combatido desde las columnas de los periódicos, y satiriza luego desde el escenario de un teatro.

Por su carácter político, la comedia Próspera, que estrenara en el teatro San Martín la compañía Cobeña, debe ser juzgada bajo su doble faz de obra de propaganda y de obra literaria" p.229. Alaba la obra como propaganda: “(...) David Peña se atreve a decir al público todas las vergüenzas y las hipocresías de que vive esta aristocrática sociedad criolla."p.229 La adaptación de la obra no es buena según Gálvez. Se refiere al diálogo de la obra como "sencillo" y "verdadero".

Sobre Puertas que se abren de Manuel Argerich sostiene que comparativamente, es menos mala que otras obras.

Vuelve a insistir en el éxito de público de M'hijo el dotor de Sánchez, y ahora, empieza a cambiar de opinión y se refiere a la obra en los siguientes términos: " $M$ 'hijo el dotor continúa triunfando. El público parece no ser tan imbécil como muchos creen, pues ha comprendido las bellezas de la obra de Sánchez, aplaudiendo con entusiasmo y llenando el teatro noche a noche" p. 232

\section{$\mathbf{N}^{0} 7$}

- Manuel Gálvez, Año 1, nº 7, noviembre, 1903, pp. 309-312 
En este número Gálvez destaca los concursos de teatro, poniendo énfasis en la importancia que tienen en sí mismos, institucionalmente, más allá de los resultados. Los concursos son el del teatro Apolo y el del teatro Podestá. En el primero participaban obras en un acto [se lo declara desierto] y en tres actos [sale elegida la obra culpas ajenas de Coronado, se habían presentado además Alma débil cuyos autores no se consigna-, Resabios de Mariano G. Bosch, El trofeo de Granada]. Del concurso Podestá, Gálvez dice que "no ha sido un éxito, pero el esfuerzo, muy meritorio, muy loable, es obra virtuosa que debiera imitarse" p.310.

Se consigna el estreno de Sacrificio de Méndez Caldeira, cuya crítica pasa al no 8.

El comentario sobre Lázaro [no se dice el autor] es importante porque a partir de él Gálvez marca una vez más la diferencia entre el teatro que Ideas impulsa y el que desestima. Afirma: "Lázaro es, sin duda alguna, el último gaucho cantor que pasa por nuestros escenarios. La Pampa, que evocó tantas veces nuestro espíritu, el sonido doliente de las cuerdas de la guitarra, se va con sus gauchos para siempre, a refugiarse en el olvido de las cosas viejas. Y ese Lázaro, el protagonista de un drama salvaje pero evocador de un mundo nuestro, se aleja del escenario donde vivieron sus hermanos de leyenda, -Martín Fierro, Santos Vega, Calandria,- entre flores, en plena pampa, al gemido de un triste inmensamente poético. Y antes de irse, amargamente, nos dice con los versos del más exquisito poeta en lengua española:

Yo soy el postrer gaucho que parte para siempre/ De nuestra vieja patria llevando el corazón" pp.310-311.

Flor en el fango de Héctor G. Muñoz, colaborador de la revista, se representa en el teatro Nacional. Salvo por el final al que Gálvez califica de inverosímil, por melodramático, la obra merece un juicio favorable.

-Oltre la vita, publicado por Ideas en el número 5, a cargo de la compañía de Angelina Pagano. Ha sido, según Gálvez, ignorado y censurado por la crítica. Lo define como una "obra de grandes cualidades, donde se traza un carácter magistral y único en la literatura de todos los tiempos. Hay toques de maestro, todo está dialogado con verismo [cursivas de Gálvez] ibseniano y la acción conducida sencillamente, con desprecio absoluto del aplauso conquistado a golpes de efecto. Es además una obra filosófica donde se habla de problemas trascendentales y un caso patológico [cursivas de Gálvez] interesante y bien observado.

Antoine aparece nombrado como quien da a conocer en Buenos Aires la escuela ultra verista.

\section{$\mathbf{N}^{0} 8$}

Manuel Gálvez, Año 1, no 8, diciembre, 1903, pp. 385-390

-Sacrificio, por Méndez Caldeira, que se presenta en el Apolo.

Según Gálvez la obra ha sido un éxito, "solamente atenuado por las reservas de la crítica, que no tuvo para esta pieza los elogios que dispensa a los amigos o a los consagrados [cursivas de Gálvez]" p.385. La cuestión del medio aparece en el argumento: "Una familia de provincia -quizá demasiado rara en provincia por lo poco rural, se dispone a partir a Buenos Aires, donde el jefe de ella ocupará una banca (...) En Buenos Aires -como irrupción de plagas- una serie de calamidades invaden el hogar de Joaquín: la esposa que traba relaciones amorosas con un ministro protector del diputado, el lujo, con su corolario de deudas y apuros, y la muerte de Aurora [personaje principal], que va agotándose poco a poco, entre sus delirios de amorosa y una incurable enfermedad" p.387 Interesan las observaciones con respecto a la lengua literaria de la pieza porque son también parte del programa de la revista: "El diálogo es correctísimo. Escrito en español puro, un tanto académico quizá. Es por cierto muy dificultoso describir un medio genuinamente nuestro, sin recurrir al criollismo soez y repugnante y que a fuerza de usársele ha conseguido aburrir a todo el mundo. Méndez Caldeira ha triunfado de esa dificultad; el ambiente de su comedia es argentino, y todos los personajes hablan con corrección" p.389. Explica Gálvez que esta obra no es moderna porque no se encuadra en "ninguna de las dos tendencias que hoy predominan en el teatro universal; la idea revolucionaria y el drama psicopatológico. Pertenece más bien al género que se cultivaba hace un cuarto de siglo, por los escritores franceses e italianos."p.389

\section{$\mathbf{N}^{\circ} 9$}

Manuel Gálvez, Año 2, nº 9, enero, 1904, pp. 90-96 
Alborada de Enrique García Velloso. Es elogiada por Gálvez. Se trata de un drama en el que una familia va a la quiebra [dêbacle es la palabra que usa] y cambia de "ambiente". Aquí se hace presente la cuestión del medio: "Y es innegable que todos ellos en el nuevo ambiente, sufrirían modificaciones en el carácter, ya en forma de depresiones para unos o de redenciones para otros". Esto dice Gálvez, no sucede, y con ello se corta el desarrollo del drama. La explicación que da Gálvez para no reseñar el argumento es curiosa, o al menos muestra cómo imagina la relación del público del teatro con la prensa: "No he de referir el argumento. El espacio me apremia y los diarios, por otra parte, se han complacido, ya en relatarlo minuciosamente. Debo, pues, suponer enterado del asunto al lector" p.90.

Cuando se refiere a Girón de vida de Florencio Fernández Gómez, Gálvez sostiene que lo importante a la hora de juzgar una obra de teatro es "la intención del autor" p. 93. En ese sentido, la obra de Fernández Gómez, tiene algún valor.

Elogia, aunque no asistió a su representación, La Gaviota de Nicolás Granada.

\section{$\mathbf{N}^{0} 10$}

Manuel Gálvez, Año 2, no 10, febrero, 1904, pp. 187-192

¡Ya soy viejo! de Enrique Crosa. Si bien Gálvez sostiene que "la concepción es de una belleza innegable", critica negativamente los dos primeros actos. Respecto del último acto observa:

"Esta parte del drama, sin embargo, no ha sido convenientemente realizada. Hay palabras que no encuadran en la índole del asunto. Se repite demasiado las mismas frases. Da cierta apariencia de ingenuidad a la obra, el criollismo de Muñoz, cuyo vocabulario exactamente verídico, quiebra el efecto total de la escena última, donde la situación de tragedia que allí se observa, exige palabras menos criollas y exclamaciones no tan contraproducentes como aquel ¡Jesucristo! que suelta Muñoz al enterarse de los amores de su sobrino y Laura.

La comedia de Crosa está dialogada con verdad indiscutible, tal vez como no se ha visto en los teatros nacionales. Y esto que es su virtud, es también su defecto. Es una virtud, porque muestra la honradez encomiable del autor para no adular los gustos pésimos del público y porque revela la existencia de un ideal, de una tendencia artística, traducible en un naturalismo ferviente. y es un defecto porque esa realidad, esos diálogos tan vulgares, no llegan a constituir un mérito si no se los adorna de gracia o de ironía, de observaciones o espiritualidades." p.189 Verdadero pero vulgar. Siempre oscilante, para poder introducir su crítica al público, Gálvez rescata la obra, contradiciéndose: "Obra culta, bien escrita (...), muy exacta como traslado de la realidad a la escena, era creedora más que otras piezas aplaudidas, al favor del público.

Pero ya está visto que esta 'bestia enorme' como le llama D'Anunnzio, prefiere lo que adula sus groseros gustos, esos absurdos melodramas, donde se mezcla la dramaticidad más ridícula a la gracia ordinaria del sainete." p.190

Por otro lado, Gálvez se refiere a "la fiebre de las traducciones" por parte de las compañías teatrales. "Lo que las compañías criollas no es ciertamente favorecer el desarrollo del teatro nacional. Por el contrario, le perjudican, matando la emulación, en su preferencia por las traducciones.

Se explica. Una obra original se paga más y no atrae sin embargo más público" p.191

Se hace referencia al estreno de Gallo ciego de Otto Miguel Cione y La querida de A. Soler del Valle. De la obra de Cione dice Gálvez: "Gallo ciego es un drama en un acto, dividido en cuadros, de argumento interesante, pero que no llega jamás a conmover. Quizás en esto haya influido algo la deficiente interpretación"

\section{$\mathbf{N}^{0}$ 11-12}

Manuel Gálvez, Año 2, nº 11-12, marzo-abril, 1904, pp. 362-372

-La querida, por A. Soler del Valle.

Gálvez se refiere a ésta como una obra plagada de lugares comunes, "deshilvanada e insulsa" p.362. Es importante reparar en los términos con que Gálvez la descalifica: "Allí el lugar común tiene preferente sitio. Es una literatura -ique debamos darle esa denominación!- de crónica policial.

Las frases huecas, altisonantes, plagadas de incorrecciones, solo inspiran lástima hacia los artistas y el público, las víctimas inevitables de esa fastidiosa pirotecnia de majaderías" p.362

Se critica la política del teatro Apolo en el que La querida se representa, la mezcla de sus elecciones estéticas, la convivencia, que hace posible el mercado, entre lo alto y lo bajo: 
"Jamás en teatro alguno, como en el Apolo, hase visto mayor diversidad de tendencias, entre las obras que allí se representan.

Lo ordinario y guarango alterna con la pochade francesa, espiritual y fina; y a los pocos días de un estreno con música y quebradas [cursivas de Gálvez] no es improbable ver el anuncio de un drama de tesis" p.363

Gálvez rescata Inútil de David Peña, a la que distingue de las obras de García Velloso y M'hijo el dotor de Sánchez en las que según Gálvez "la tendencia a conseguir el aplauso prima sobre cualquiera otra". p363. Se aprueba el asunto de la obra, la creación del carácter de su protagonista, Angelina, por su "realismo de forma". El tono de las frases de la obra es el de la tragedia. Sin embargo sostiene que su idioma carece de "colorido" [aquí el colorido es equivalente del color local]: "En su idioma, falta colorido. No sabe pintar costumbres y sus descripciones carecen de detalle. Su pluma no da las medias tintas, los tonos apagados, falta el gris en su paleta. (...) Tampoco tiene vigor. (...) No refleja la verdadera realidad, ni la reflejará jamás" pp.364-365. Critica la influencia negativa del periodismo en la escritura de Peña, que se observa en los lugares comunes, y el hecho de nombrar a autores teatrales en la obra. Respecto de esto último se queja:

"Todos los dramaturgos nacionales (oh! perdón!) desfilan evocados por los artistas criollos [cursivas de Gálvez] los que tienen talento, pero no son fecundos -Sánchez, Payró, Pagano- y los fecundos, -Trejo, Soria, García Velloso, etc. Como veis la lista era abundante. Sin embargo debo confesar que la hubiese preferido menos completa" p. 366. Gálvez recurre a la autoridad de Groussac, para construir su figura de crítico, pero sus ironías y su estilo distan mucho de los del francés. Lo mismo que Groussac da consejos.

Anuncia la próxima actuación de Zacconi en el teatro San Martín y transcribe todas obras que se estrenarán en ese teatro representadas por Zacconi. La lista muestra variedad genérica (dramas, tragedias, comedias) y de autores (Rovetta, Ibsen, Hauptmann, Tolstoi, Turgeniev, Curel, Daudet, Strindberg, Maeterlink, Goldoni, Sardou, Augier, Henriot, Dumas, Benville, Bracco, Beaumarchais, etc.). Entre los títulos no figura uno muy famoso Maschere de Bracco, y Gálvez que no pierde oportunidad para criticar a los actores criollos, se pregunta: “¿Por qué entonces no ha sido anunciado? No será seguramente por temor de que se le compare con Podestá. Maschere no ha sido aquí, nunca, representada [cursivas de Gálvez]. Es decir hubo de serlo. Pero en lugar de interpretarse el dramita de Bracco, vimos una caricatura imperdonable. Bienvenido sea Zacconi si ha de borrarnos el mal recuerdo de Máscaras y Caretas." p.369. Confía en el éxito de Zacconi en función del éxito de la venta del abono.

Refiere la llegada de otra compañía teatral, la española del teatro Lara de Madrid, y encomia la tarea del empresario Faustino Da Rosa, quien ha traído a Antoine a Buenos Aires y ahora trae a este elenco. Los autores que llevará a escena esta compañía son Benavente, Carrión, Ramos, Echegaray, que según Gálvez garantizan la calidad.

Gálvez deja la sección que desde el número siguiente estará a cargo de Abel Cháneton. De él dice Gálvez: crítico, colaborador en diarios y revistas, publicó en La Nación el primer capítulo de una novela. Explica que deja la sección porque lo han acusado de ser demasiado severo.

\section{$\mathbf{N}^{0} 13$}

- Abel Cháneton, Año 2, nº 13, mayo, 1904, pp. 194-199

Se trata de un balance de la escena nacional que hace a pedido de Gálvez.

"Quiere la dirección de Ideas que, en este primer artículo y a modo de introducción, haga un balance de nuestra literatura dramática.

Si me lo permitís, no hablaré del pasado. Sería proporcionarse, voluntariamente, una desconsoladora impresión. Es tan estéril la jornada! ¿Para qué constatar una vez más, después de tres años, la perpetuación triunfante en la escena del gaucho y del compadrito?

Vengamos al presente. Creed que, con poco trabajo escribiría acerca de él, largas páginas. Pero dificulto alcanzaran la elocuencia que, en sí mismos, tienen los hechos. y opto entonces por presentarlos en su desnudez entristecedora.

Ante todo: el desprestigio del teatro (No se olvide hablamos siempre desde un punto de vista nacional, o mejor aún, local). El arte dramático, es hoy entre nosotros res nullius. El primer advenedizo, ininteligente pero audaz. se cree con derecho a poner en él sus manos. Individuos que tendrían escrúpulos para redactar una noticia de policía, en cualquier hoja diaria, atacan, sin 
remordimientos de conciencia, la comedia y el drama. Así hemos asistido a una verdadera invasión de escribidores noveles.

Es tentador el estudio psicológico de estos personajes. Llegan de quien sabe qué remotas regiones - la trastienda de un almacén o el taller de una sombrerería- y vienen, colones de una nueva América, a describrirnos el arte. Tenían aficiones literarias: Ohnet, Escrich, Montepin y Ponson du Terrail deleitaban sus ocios. Y eran sin duda felices viviendo entre sus telas o sus sombreros . Pero, el destino se complace a veces en estas sangrientas ironías. Y un buen día, resultante de todas aquellas lecturas mal; digeridas, en el magín estrecho de cualquiera de ellos, se hilvana una trama. Es vulgar; tanto como podría serlo una novela de Ponson du Terrail, Montepin, Perez Escrich y Ohnet, escrita en colaboración. Sin embargo a nuestro autor, en su crasa ignorancia, antójasele original. Y resuelve hacer un drama. Previa lectura de esos o tres precursores más o menos clásicos (Fontanella, Trejo, etc.) pone manos a la obra, con un entusiasmo loco y una fe ciega en que, por fin, tendrá una verdadera producción..

Hasta aquí nada hay de malo. Lo serio es la complicidad desvergonzada con que las empresas protegen estos atentados. No son otra cosa algunas obras puestas en escena de un tiempo a esta parte. y atentados contra el sentido común. No concretamos, para evitar se crea, que guían nuestra crítica, personales inquinas.

No extrañéis, conociendo estos antecedentes, lo acaecido con Sobre las ruinas -una producción que honraría la literatura dramática de cualquier país-, en el Apolo y la Comedia. Ni os asuste tampoco, saber que Un cuerpo, última obra de David Peña, ha corrido, en el primero de dichos teatros, la misma suerte. ¿Por qué es esto? preguntádlo a los empresarios que usufructúan el derecho de hacer arte nacional. Ellos tendrán para satisfaceros, agachadas de gaucho ladino. Os dirán que esas son obras buenas... muy buenas; pero... no gustan al público. No hay en ellas efectos, (vele decir tiro, puñaladas, escenas de pugilato, tentativas de violación, etc.) ¡iCaín!!

Desconfiáis del porvenir, ¿verdad? mal hecho. El porvenir está preñado de gratas esperanzas. Hay ya un conjunto de artistas capaces de constituir una buena compañía. Hay un núcleo de autores que, prescindiendo del éxito inmediato, trabajan con los ojos puestos en el futuro. Y hay sobre todo, en los espíritus que siguen de cerca estos acontecimientos, la conciencia hecha de que una revolución se impone.

Hasta ahora, los Podestá detentaron, como capital propio, el título de fundadores del Teatro Nacional. Y, en honor a la verdad sea dicho, han sabido llenar su misión.

Pero, en mitad de la jornada, han cruzado los brazos. Se sienten incapaces de avanzar. Embarcados en un globo cautivo. Llegaron ya al máximo desarrollo del cable. Presiente más arriba un horizonte inmenso. Y fácil les fuera, en un solo momento de decisión, cortar como inútiles trabas, todo lo que les ata aún a su pasado. Pero les espanta el más allá. Y como el que se detiene, retrocede, se han quedado atrás. No les extrañe entonces que mañana, recoja alguien la bandera, pasando a la vanguardia. Y serán para él los honores y el provecho definitivo en la jornada...

Dije de Sobre las ruinas, que honraría la literatura dramática de cualquier país. tal es, en efecto, mi opinión. Por lo pronto, entre nosotros tiene conquistado el primer puesto. Ni como factura, ni como concepción, se había hecho hasta ahora, nada semejante. Sobre todo, como concepción. El drama de Payró es la síntesis completa de un momento histórico. Con fina psicología y envidiable criterio sociológico, ha sorprendido un minuto de esta "hora evolutiva que vivimos" según una acertada expresión ajena. Y ha sabido volcarlo en su drama como un viejo autor para quien la escena no tuviera secretos.

Se nos anuncia el estreno de Sobre las ruinas dentro de breve tiempo. Reservemos para entonces el juicio crítico in extenso que merece.

Permitidme saludar a Martín Coronado, el obrero más entusiasta y fecundo del incipiente teatro argentino. En nuestro medio, 'favorable al desarrollo de las perezas atávicas', es un caso. Y no extrañéis si, por un momento, olvido mi severidad crítica. Cuando como él se han consagrado veinte años al servicio de una idea, predicando con el ejemplo y malgré la falta de solicitaciones de un ambiente hostil, se tiene derecho a una admiración respetuosa. Por mi parte declaro que me encuentro desarmado ante el poeta. Jamás haré crítica -tal como yo la entiendo- a una obra suya. Otros encontrarán en ellas, todos los defectos inherentes a la escuela del autor, la buena escuela romántica. Y tendrán razón. Yo os pido, únicamente, me deis otro dramaturgo que conozca como él, la técnica 
teatral y que, con fidelidad por él empleada en los dos primeros actos de Flor del Tambo, sepa pintaros el ambiente y los personajes. Dame ese autor y arrimo el hombro para hacer a un lado, como cosa vieja, toda esa obra entusiasta y sincera que comprende desde Rosa Blanca a la producción estrenada recientemente en el Apolo, en el cual Pablo Podestá, creando el tipo de viejo vasco, ha obtenido uno de sus triunfos más grandes y legítimos.

El señor Mariano Bosch, es un paciente y laborioso investigador de nuestros archivos. Desde hace diez años, con ejemplar contracción, pesquisa entre manuscritos apolillados y viejos periódicos, los orígenes del teatro nacional. Los que sabemos de su labor ímproba, aguardamos con interés el fruto de estas tareas: un libro acerca de nuestros primeros escénicos sería por demás interesante. Ya nos ha anticipado un volumen, con cuyas inducciones sociológicas y de psicología colectiva, disiento en absoluto.

Inclinaciones naturales lo han llevado a escribir para el teatro. Es el autor de Resabios. 'Y después de un fracaso lamentable -La herencia de Palmieri- acaba de obtener un triunfo más lamentable aún. Porque sabedlo, el estreno de Misericordia fue un triunfo: la mayoría del público lo aplaudió. La crítica, en cambio, ha enmudecido con imperdonable cobardía. En vano se esperó la nota melosa de Frexas o el puazo firme de Jean Paul [Juan Pablo Echagüe]. Y en ninguna ocasión, con tanta justicia como en esta, pudieron fulminarse acerbas recriminaciones. Porque Misericordia, es la obra más deshonesta, desde el punto de vista de los procedimientos, que haya subido a la escena. Nunca el abuso de groseros efectismos fue llevado a tal punto entre nosotros. Por otra parte, el drama se diría de un principiante. Donde quiera, el más profundo desconocimiento del teatro se revela. Ese final del tercer acto, que es asimismo final de la obra, no es admisible ni en pantomimas para Gignol.

Hasta hora, a nadie se le había ocurrido hacer que dos vigilantes se crucen de brazos ante el asesino de su jefe, para que éste pueda despachar a su gusto un largo parlamento, salpicado de frases, dignas por su profundidad de figurar en la 'Máximas y pensamientos', infolio de muchas páginas, atribuido a Pero Grullo.

Con todo y como afirmábamos al principio, Misericordia ha sido un triunfo. En el vestíbulo del Apolo, he oído comparar las condiciones de dramaturgo del Sr Bosch con las del Sr Fontanella. Para mí es superior este último. El autor de Federación, ha adquirido, en su frecuente trato con dramaturgos extranjeros, italianos especialmente, un profundo conocimiento de los recursos escénicos. Véase si no, su drama Justicia o El cuchillo como creo que se llamaba antes.

Copia textual desde pp.82-88

-El noventa, estrenado el 13 de mayo en la Comedia. "Su autor- Mario Sáenz- merece desde luego un aplauso, por la exquisita discreción y recomendable honradez con que ha escrito la obra. La nota patriotera, difícil de evitar en producciones como ésta y de efecto seguro, por lo demás, sobre cierta parte del público, no asoma en ningún momento. Intencionadamente, el autor ha orillado el terreno político. Toda referencia que a él se hace, está en una sátira, escrita con intención y bien recitada por la niña Podestá. La pintura del medio, en que la trama se desenvuelve, es asimismo incompleta. Y estos son defectos capitales para una obra así."p. 89

-Mosca de Oro de García Velloso. Es vista como un "tropiezo" en la carrera del autor.

-Para eso paga, de Pedro E. Pico. Rescata el episodio por el que la Comedia se arrepiente de haber rechazado la obra y finalmente la lleva a escena. Se trata de un acto único.

\section{$\mathrm{N}^{\circ} 14$}

Abel Chaneton, Año 2, no 14, junio, 1904, pp. 194-199

-Jettatore, por Gregorio de Laferrere. Es un éxito de público pero para Chaneton no pasa de una pochade. Se pregunta entonces por las causas del éxito: "la estúpida vanidad femenina" p.195. "Nuestras damas juzgan el mérito artístico de una producción dramática, por las familias que asisten al espectáculo. De ahí la influencia casi omnipresente de la crónica social en los éxitos teatrales" p.195. Se describe el la forma en que se construye socialmente ese tipo de éxitos: "Por camaradería política, o personales vinculaciones, los periódicos noticiaron en la sección respectiva, entre un suelto necrológico y el anuncio de un enlace próximo, el éxito estruendoso de la obra. Y a continuación la 
lista de familias presentes [cursivas de Chaneton] (...) De ellas casi ninguna había asistido. Pero a la noche siguiente, para no desmentir al cronista, concurrieron. Las demás, para no ser menos, fueron también"p.195. Rescata de la obra la interpretación, a cargo de la compañía de Gerónimo Podestá.

En otro apartado se refiere al genio de Zacconi en su actuación en Espectros de Ibsen, al que prefiere no describir por inabarcable. La nota parece ridícula. Nombra otras obras interpretadas por Zacconi, El moro de Venecia, I dionesti, Morte civile, Otello. Describe el público de Espectros: "Aquella noche un público escogido llenó la amplia sala del San Martín. Ante un buen número de médicos, estudiantes y estudiosos, se desarrolló la espeluznante tragedia ibseniana. En el ambiente, parecía flotar una atmósfera de clínica".

- En este mismo número se conmemora el primer aniversario de la revista y para festejarlo la revista realiza una encuesta, cuyos mentores han sido Juan Pablo Echagüe y Antonio Monteavaro. Este banquete que los organizadores califican como "fiesta de arte" es una reunión autocelebratoria que junto con otras como las reuniones en los cafés literarios, se constituyen en prácticas específicas en las que se ejercita la hermandad intelectual, la sociabilidad literaria entre intelectuales y escritores. Es importante ya que puede leerse como un momento central de la campaña que la revista realiza en pro de un teatro de ideas. La encuesta tiene su origen en la negativa de los empresarios teatrales Pepe y Pablo Podestá a representar Sobre las ruinas de Roberto Payró, obra que se había publicado en Ideas en el $n^{\circ} 11-12$ de marzo-abril de 1904. Los resultados de la encuesta son publicados en este $\mathrm{n}^{\mathrm{o}} 14$.

A continuación transcribimos los nombres de los asistentes y reseñamos las opiniones de los encuestados.

"Asistieron los Señores:

José Ingegnieros, David Peña, Osvaldo Saavedra, Carlos Octavio Bunge, Félix Lima, Lorenzo Fernández Duque, Ricardo Rojas, Julián Aguirre, Abel Cháneton, Atilio M. Chiappori, José Ojeda, Antonio Monteavaro, Manuel Gálvez (hijo), Roberto J. Payró, Alberto Gerchunoff, Emilio Becher, Juan Pablo Echagüe, Justo Solsona Jofre, Alfredo Arteaga, Salvador Oria y Angel M. Novillo Linares.

Excusaron su asistencia los señores:

Francisco Sicardi, Alberto Williams, Mario Saénz, Ricardo Olivera, Roberto J. Bunge, Carlos Vega Belgrano, Eugenio Díaz Romero, Héctor Muñoz, Carlos de Soussens, Julio A. Rojas." Ideas, Año II, nº 14, junio, 1904, p.203.

Las preguntas que constituían la encuesta eran:

1. ¿Qué opinión le merece la obra de Payró, rechazada por las empresas teatrales: Sobre las ruinas? Oposición autores / empresas

2. ¿Cree usted que debe ser representada?

3. En caso afirmativo ¿qué medio cree oportuno para conseguir su representación? p.204 Se ve la intención de favorecer la puesta en escena de este tipo de obras, al preguntar por los medios.

El análisis de las respuestas arroja los siguientes datos:

David Peña: marca la calidad de la obra, su relación fluida -en tanto autor- con las compañías teatrales-, la poca aptitud del público de compañías como la de José. J. Podestá para un tipo de teatro como el que la obra de Payró representa: “- Hablé más tarde con José. J. Podestá porque requirió mi consejo. Todo fue inútil. Me demostró que el público de su teatro no era apto para esa clase de obras." (pp. 204-205)

Carlos Octavio Bunge: la obra es buena, representable, y para ello hay que formar una "compañía seleccionada de artistas argentinos" p.205

Antonio Monteavaro: la califica de "obra de enjundia (criolla de veras) y muy poco teatral" p.205. La representación sería la forma de juzgarla más plenamente. Propone el fomento de "un teatro de artistas con protección del Estado, más o menos a la manera de la Comédie Française, a fin de que el juicio de las empresas particulares no sentencie sobre obras que el público debe conocer" p.205. Es interesante la preocupación por el público y su relación necesaria entre obras de ideas (enjundia).

Juan Pablo Echagüe: sostiene que aunque carente de "plasticidad escénica", es la "mejor obra dramática nacional" p.205; el público es el que tiene en sus manos el fallo sobre el mérito de la obra. 
Para representarla propone: "Aunar el esfuerzo -siquiera moral- de los círculos pensantes, para hacer presión sobre las empresas" (p.205)

Justo Solsona Jofre: las palabras que usa para caracterizarla son "finura", "tesis", "trascendencia". No solo es representable sino que piensa que será exitosa. Para demostrar la equivocación que supone no representarla, opina que si ninguna compañía se atreve, se debería "dar una audición aunque sea privada". (p.206)

José Ingegnieros: la obra es buena y debe ser representada; no especifica qué se puede hacer para ello. (p. 206)

L. Fernández Duque: la califica como la "más completa de las obras hechas para el teatro nacional"; sostiene que tiene "todas las condiciones para obtener un éxito"; el medio para representarla es constituir una compañía "que bien podría tener el apoyo del público" ya que no hay "intérpretes conscientes". (p. 206)

Salvador Oria: sostiene que es la mejor obra del teatro nacional porque "es un estudio sociológico oportuno del ambiente 'nacional' hecho con amor y, en cierto modo, con arte dramático". Esta opinión interesa porque pone el acento no en lo estético sino en el valor interpretativo, explicativo, respecto de lo social. El arte aparece así como una sociología. Debe ser representada porque es representable, pero además por un interés relativo a la sociabilidad como forma de promover este tipo de prácticas culturales en sí mismas, "para hacer conocer una producción que tiene como formar ambiente literario, sobre todo entre nuestros autores dramáticos, y como hacer 'medio' en nuestra sociedad". El medio de conseguir que se represente es "publicar una adhesión general de los hombres de pensamiento". Como se ve, se insiste en hacer efectivo el capital simbólico de los nombres de quienes participan del mundo cultural, a través de una acción conjunta. (pp.206-207)

Abel Chaneton: considera la obra como la mejor a nivel nacional. "Payró, con admirable criterio sociológico, ha sorprendido un momento de nuestra evolución y con habilidad de maestro ha concebido y ejecutado su obra". La forma de lograr su representación apunta contra los actores de las compañías y contra las obras representadas: "Convencer a los que hacen teatro nacional, de que la bondad cabe en obras sin escenas de pugilato y sin tiros". (p.207)

Atilio Chiappori: afirma más allá de su representación, la proyección futura de la obra en la historia del teatro nacional: "constituirá siempre una de las piedras angulares sobre la que deberá cimentarse nuestro verdadero teatro nacional" [cursivas nuestras]. En cuanto al medio: "No prescindiendo de las compañías nacionales (?) existentes, ninguno" [con signo en el original] (p.207)

Julián Aguirre: la obra de Payró es un su opinión un "drama excelente", es representable, pero explica que no sabe " por qué medio se podría compeler a una compañía en forma eficaz". (p.207)

Ricardo Rojas: no leyó la obra, aunque como teatro es representable. Recomienda "Aguardar que actores más inteligentes aparezcan en la escena nacional". (p. 208)

Alberto Gerchunoff: sostiene que el drama de Payró honraría a cualquier teatro extranjero. "Suderman podría firmarlo". Para Gerchunoff debe ser representada como modo de protesta contra la injusticia que con esta obra se ha cometido. Los medios pueden ser cualesquiera. Apela a los "inteligentes". (p. 208)

Emilio Becher: "La obra de Payró representó en nuestro teatro, esta cosa inesperada y propia para aterrar a la plebe de los mediocres: una obra de 'ideas'. Que los hombres de la Comedia se hayan rehusado a representar para el público, un drama de indiscutible belleza, parece lógico". Debe ser representada, y desconoce los medios por los cuales se puede llevar a cabo. (p. 208)

Alfredo Arteaga: señala que la obra es "uno de los poquísimos dramas argentinos dignos de tal nombre" y "perfectamente representable por una compañía inteligente" que debe ser formada. (pp. 208-209)

Osvaldo Saavedra considera la obra como "un progreso artístico e intelectual en el teatro nacional". El rechazo de los empresario se interpreta como un desconocimiento. La obra debe representarse "porque envuelve una idea sociológica que satiriza la barbarie campesina". Lo que debe hacerse es: "repetir por la prensa, hasta el convencimiento del público y de las empresas, que los cómicos no son artistas sino intérpretes del artista que es el autor" ( p. 209)

A. Novillo Linares: no conoce la obra, pero sostiene que en Buenos Aires "solo se representa por negocio; pregúntese a los del ramo"; sostiene que la forma de representarla es formar "una compañía especial para los principiantes". (p. 209) 
Manuel Gálvez (hijo): es una obra que no tiene comparación en Argentina. debe ser representada porque con ella se inicia, según Gálvez, una nueva forma de teatro. En cuanto a los medios coincide en que lo único que se puede hacer es esperar que se forme la compañía teatral de la que se habla tanto.

Roberto J. Payró: explica que una obra en la que ha puesto mucho trabajo, esfuerzo, voluntad; que "debe representarse, como un homenaje al trabajo", y que lo único que se puede hacer es esperar.

\section{$\mathbf{N}^{\mathbf{0}} \mathbf{1 5}$}

Abel Chaneton, Año 2, nº 15, julio, 1904, pp. 312-315

Chaneton organiza la sección con apartados numerados, que aparecen mencionados en lo que denomina sumario, inmediatamente después del título: I. La compañía de Lara; II. Magnaud en el Victoria; III Un rival del Dr. de la Plaza.

I. Se refiere en especial a dos actrices de la compañía de Lara: Clotilde Domus y Conchita Ruiz. Elogia a ambas. También da cuenta de la llegada próxima de Matilde Rodríguez, Balvina Balverde y José Santiago. Básicamente este apartado tiene el carácter de crónica teatral.

II. Comenta el estreno el mes anterior (junio de 1904) de Magnaud de David Peña, a la que califica de infantil, inesperada y decepcionante en función de la experiencia que el autor ya tiene.

III. Critica a Atilio Zanetta, autor de un drama cuyo nombre no se consigna, estrenado en el teatro Apolo el unes 18 de julio de 1904. Se burla del aspecto físico de este hombre ("hubiérase creído un fervoroso anacoreta que, exhausto tras largas abstinencias, volvía del desierto para predicar un credo nuevo"), que por su apellido bien se conoce que es italiano o descendiente de italianos. Se burla también de su verborragia. El escrito muestra la alianza criticada previamente por Gálvez en otras entregas de la sección, entre autores extranjeros/ traducciones y las compañías de los Podestá.

\section{$\mathbf{N}^{0} 17$}

Abel Chaneton, Año 2, $\mathrm{n}^{\mathrm{o}}$ 17, septiembre, 1904, pp. 97-100

Chaneton organiza la sección en dos apartados.

I. Angelina Pagano en el San Martín: alienta a la actriz y directora de una compañía luego una serie de fracasos (Vocación de Méndez Caldeira y Revolución en Chulampo) Aclara que en el caso de Vocación, la palabra "tropiezo", que usó para referirse a ella, significa que no fue un éxito de público II. Sobre las ruinas: se refiere a la representación de la obra de Payró. Importa porque se hace explícita una interpretación con la que acordarían los firmantes de la encuesta del no 14. "El triunfo de Sobre las ruinas... es un triunfo colectivo. Los honores de la jornada corresponden por igual a Payró, glorioso autor, a Ideas y a toda la intelectualidad argentina. Como que importa la primera batalla ganada contra el mercantilismo miope y tiránico de los empresarios torpes" p.98. Insiste en los juicios vertidos anteriormente en la encuesta, y reivindica la obra por su capacidad de sintetizar un momento histórico: "Con fina psicología y envidiable criterio sociológico, ha sorprendido un minuto de esta "hora evolutiva que vivimos" p.99. Elogia a Blanca Podestá en el papel de Leonor, y a Muiño, que representa a Juan.

- Ricardo Olivera, Año 2, no 21, enero, 1905, pp. 38-44

A propósito de El gringo de Otto Miguel Cione. [se trata de un fragmento de una carta dirigida Cione] Olivera hace un repaso de la obra del autor y lo ubica entre los que contribuyen la creación del teatro nacional. La nota es relevante porque en ella Olivera vuelve sobre las que considera las causas de la situación del teatro nacional. Asimismo se toca otro punto central que muestra la forma en que es pensada la relación de las clases altas porteñas con la inmigración extranjera. Este vínculo deseable, que la obra de Cione contradice -puesto que una jeune fille porteña se casa con Nicolotti, un ferretero italiano, que se hace cargo de una hipoteca-, se asemeja al diseñado en la última novela de Cambaceres En la sangre. Olivera lo ataca por considerarlo inverosímil y por lo tanto no válido como objeto de estudio. Los argumentos son en realidad argumentos de clase.

Transcribimos algunos pasajes de la nota:

"El gringo hace méritos mayores [que Maula y Paja Brava]. En tema trascendental de sociología contemporánea todas sus cualidades de pensador y estudioso encontraron aplicación digna de ellas y quizás superior, pues aborda con valentía simpática -heroísmo quijotesco antojársele a más de un 
fabricante de remuneradores dramones- pretendidas peculiaridades de la heteróclita sociabilidad argentina. Esta elección de argumento vales como reveladora de una tendencia fecunda. (...) p.39

Se resiente la obra de una falla orgánica. La 'comedia de salón' es prematura en nuestro teatro. Y las causas son varias. Fáltanle, público suficiente, artistas adecuados, empresarios, hasta autores capaces de ubicarla con exactitudes de detalle. La propiedad de la mise en scéne significa gastos ruinosos dado el exiguo precio de las localidades. El diálogo fino, de tenues matices, malabar juego de la frase, no es para gritado (sic) por voces gruesas de bastos actores ni para escuchado (sic) por frecuentadores de espectáculos baratos, inmunizados por el sainete habitual contra la ironía velada y la gracia amable. (...) pp. 39-40

Falta verdad en su drama: en el ambiente, en las situaciones, en los caracteres. La escabrosa entrevista de la señorita de Carreño y Avila con Nicolotti, aparte de estar dialogada atrevidamente, desarróllase en un jardín, en total aislamiento, mientras avanzan las sombras de un crepúsculo sugerente: citaría otras análogamente irreales. (...) p.40

Obra de 'costumbres nacionales', El gringo no resiste una crítica imparcial. En la sociedad de Buenos Aires el caso de Nicolotti saltando de su acreditada ferretería a palacios patricios por hechizo de una hipoteca oportuna, es demasiado raro para merecer estudio en la escena. Es la nuestra, aristocracia azás nueva par admitir insuflaciones de sangra extranjera innecesarias a organismos en vigorosa juventud. Quien quiera operar el milagro de tamaño franqueamiento fíe antes en la dudosa legitimidad de un título pontificio o lusitano, que en la eficacia incontrovertible de un millón de nacionales, pacientemente amontonados de tras de un mostrador. La jeune fille porteña, si por extremos de miseria dorada, llega al cálculo, irá heroicamente a los brazos de cualquier criollo, encanecido en veinte años de campo, pero estanciero -equivalencia autóctona del noble desde los tranquilos siglos coloniales- nunca tendero de modos hacia el zurdos y pintoresco vestir, cuyo cortejar inopinado, dibujará irónicos mohines en la carita adorable, sino subleva en la insistencia, todas sus altiveces ancestrales. p.41

El conflicto de su drama es ampliamente europeo, propio de pueblos con respetadas tradiciones y graves armoriales, guardadores de apellidos repetidos por la Historia. En ese carácter general el argumento es humano y solo así argentino. La familia aristocrática arruinada, llevando por difundido arte de simulación, el tren fastuoso de la perdida opulencia y el hombre rudo, surgido por tenaz impulsión de la fortuna, son factores de desorden social fatalmente destinados a la fusión aparente y a la repulsión efectiva e inmediata. Si la improvisación de la riqueza puede resultar de la consagración de una vida sin vejez, el desplazamiento del medio, aun en estas heterogéneas sociabilidades democráticas, no se opera sin el concurso de segundas generaciones -excepción salvada del advenedizo genial. p.42

Tales uniones - permutas fundamentalmente- proporcionan asuntos excelentes para novelistas y dramaturgos, siendo como son permanentes estados de discordia. El adulterio es en ellos, incidente irremisible y simpático: el desquite del Amor. (...) Para mi modo de ver nada más natural que la falta de su protagonista, explicable, sentimental y hasta fisiológicamente: heredera de oidores virreinales y de generales de la independencia, bella flor de selecciones seculares (...) habrá sido recién, dándose al hombre de su extirpe, cuando la carne gozosa conoció el placer. pp.42-43.

El matrimonio requiere para cimentar establemente su felicidad de varias identidades: identidades de origen, de posición, de cultura, de fe." p.43. 
Texto de apertura de la revista

"Sinceridades", Año I, Tomo 1, n¹, mayo, 1903, pp.3-10.

Buenos Aires -expresión sintética de la república- nunca ha tenido esa morosa predilección por las cosas del espíritu que es exquisito exponente de las civilizaciones superiores. Llamarlo Atenas ha sido siempre mejor sarcasmo que elogio. Tal vez en cortos períodos, por veleidad caprichosa, ha apaciguado el ruido de sus fábricas ó el gritar de su plebe politiquera, para gustar mejor algún raro sonido que no tenía vibraciones de metal: un ático artículo de Goyena, la oratoria tribunicia de Del Valle, el período armonioso de Estrada, un verso de Andrade o una ironía de López. Era atención de breves instantes y en seguida las energías volvían a tenderse en constante ansia de fortuna y placer.

Hoy mismo no hace vida intelectual aunque entre en sus pretensiones, figure la de repetir el caso de París: ser para con esta América de los caudillos y los motines lo que es aquel para Europa y el Mundo: Ciudad -Luz que absorbe todo el pensamiento continental para irradiar civilización. En la gran ciudad que continúa gran aldea esta convicción es mágico efecto de espejismos. La realidad, que ignora los codos galantes que disfrazan de Cortesano á la Mentira, muestra argentinos que tienen más bien rasgos de fenicios que perfiles de atenienses.

Es cierto que por nuestros escenarios desfilan todos los inviernos las mejores compañías. Pero considerado aisladamente, el Teatro no es exponente de la cultura de una sociedad y por el contrario en el verdadero índice -resultante de factores muy complejos- su influencia es secundaria. No llevan á la sala de la Gran Ópera los mismos impulsos que encaminan hacia las aulas de la Sorbona: se asiste á una lección cediendo únicamente a imperativos de la Idea y se concurre á una representación por lujo, por vanidad, porque lo exige la moda ó porque conviene á un flirt. Hay todavía otras razones. El teatro y el buen teatro sobre todo, es caro y como consecuencia privilegio de la minoría; en todas partes está aun lejano el advenimiento del Teatro Popular y lo que en París es solo esperanza, en Buenos Aires es quimera. En el pequeño núcleo pudiente que frecuenta los espectáculos por tantas cosas ajenas al Arte, es raro encontrar delicados temperamentos de sensitivos que comulguen con la Belleza en una nota de Tamagno ó en un gesto de Sarah.

Con todo, el teatro es la manifestación más intelectual de esta metrópoli y casi la única, porque estudiar el desarrollo argentino de los demás factores que hacen las culturas nacionales es descubrirlos es estado primitivo. Si alguien publica libros nadie los lee pero todos los critican; si en el artículo del diario se prodigan uniformemente elogios tan enormes y repetidos que ya no hay quien los presuma sinceros, en la conversación se afilan ironías como estiletos y se esgrimen carcajadas como mazas. La crítica se ha prostituido y es difamación. El chisme está en alma colectiva de todas las aldeas y Buenos Aires no es sino un aldea colosal.

Así se explica el éxodo del Talento. No hay ambiente para el arte y para las Letras; es siempre el mismo gesto de indiferencia ó burla, salvo las veces demasiado frecuentes que hay simpatías y entusiasmos para algún mediocre que con alma de arriviste no ha sentido la repugnancia del atajo; y estas falsas consagraciones, son un desaliento más para los verdaderos cerebrales, -eternos postergados de la atención que sería el triunfo.

Los pintores, los músicos, los escultores, todos los artistas, emigran y no siempre vuelven, -no suscitan nostalgias invencibles las tierras ingratas. Tienen la certidumbre que será más fácil obtener la consagración de París que ama los talentos como su espíritu mismo, que la de este Buenos Aires que abusa del ridículo y ha construido con sus sonrisas irónicas un inmenso esterilizador.

No hay universidades ni universitarios. La grave y solemne escolástica desterrada de todas las escuelas europeas, hace vid en nuestros claustros todavía coloniales. Las facultades son siempre escuelas profesionales donde todos corren detrás del diploma, sin querer saber si fuera de los textos que proporcionan las nociones necesarias para balbucear exámenes y aprobar cursos, hay algo digno de ser leído y meditado. Y los ya graduados no estudian porque ignoran lo suficiente para creer que saben demasiado. ¿Es acaso necesario saber de Taine para curar un enfermo ó de Claude Bernard para ganar un pleito? Los doctores no son sino médicos o abogados, y constatados estos modos de ver como criterios invariables de conducta, no es paradoja afirmar que un universitario argentino y un minero de Alaska tiene estados de alma muy semejantes.

Todas las manifestaciones de refinada cultura que hacen perdonar á París la orgía cosmopolita que pasea sus bulevares, no se advierten en Buenos aires. ateneos, Sociedades de artistas y de literatos, Escuelas de bellas artes, exposiciones Pintura y Escultura, Universidades Populares, cuando logran 
nacer de las abnegaciones de algún pequeño grupo, arrastran vida precaria y casi siempre efímera, sin lograr nunca echar raíces hondas en esta tierra todavía impermeable. Son instituciones exóticas que nuestras clases dirigentes miran y no protegen y el pueblo en su total ignorancia de analfabeto contempla y no comprende.

Es así cómo la Argentina se encamina con paso tardío y vacilante por las rutas del progreso y próxima á su primer centenario no es aún capaz de la hegemonía continental á que nació predestinada, porque su aristocracia repugna las severas disciplinas y sus multitudes no saben de la fuerza maravillosa del libro. Todos olvidan que es factor esencial de la potencia de una nación, la robustez de pensamiento y su verdadera riqueza, producto del cultivo simultáneo de campos y cerebros. Y la civilización argentina habrá de cristalizarse en un inmenso prisma, hecho de una piedra preciosa colosalmente valiosa y grande, si se cumplen las más caras ambiciones de la masa anónima que con esfuerzos dolorosos hace la vida y la hace mal.

Siempre han existido cerebrales vigorosos que han anhelado la reacción. El ambiente opaco de factoría encontrado inadaptables. Ellos quisieron aprovechar varias ocasiones para efectuar la operación salvadora de inocular ideal, en este organismo nuestro que no necesita de nada más, para recorrer triunfal el ciclo de su evolución.

Fracasaron. Eran muchos pero nunca constituyeron un grupo: constantemente faltó el vínculo que solidarizándolos en la batalla, les hubiera asegurado la victoria. Lucharon aislados, solos, hasta enemigos. Y la vieja parábola del viejo, los niños y las ramas continúa siendo verdad: la unión es requisito del triunfo.

La nueva generación tiene también un pequeño núcleo de estudiosos, capaz de colaborar en la gran tarea, pero como los anteriores que tuvieron la aptitud y por no saber forzar la oportunidad, declinan estériles, posee el fermento disolvente, secreto de todas las derrotas. Hay necesidad suprema de impedir que imitando ejemplos próximos y nocivos se anarquice y se disperse. Las vanidades, las impaciencias, los rencores,- la arcilla humana- puja por encerrar á cada uno, en las torres de marfil que construyen los egoísmos. Es preciso que los Maestros prediquen la nobleza de la solidaridad, y la evidencien otro factor de triunfo, mostrando cómo la sangre mezclada en las batallas, se han compuesto los mágicos elixires que han hecho batallones invencibles.

...Es dolorosa esta exhibición de la cultura argentina en estado rudimentario. Pero San Agustín habla de la utilidad de los sufrimientos "perdidistis utilitatem calamitatis et miserrima facta estis". Si la desunión que multiplica las dificultades, y la carencia de estímulos que genera los desalientos, han sido causas del triste estado actual, si la indiferencia ha triunfado de las vocaciones y si la ausencia de fe ha traído la esterilidad, el remedio está señalado. Debemos trabajar, creer y confiar y lo demás nos será dado por añadidura. Es necesidad nacional que grita su urgencia, reunir el esfuerzo de la juventud al de las generaciones anteriores y de polarizar todas las energías hacia la gestación de un ideal para el pueblo argentino. El pequeño grupo que funda estas páginas no quiere demorar su aporte á la gran obra. Su iniciativa es un llamado a la acción sin exclusiones. No se le ocultan las múltiples dificultades; sabe de indiferencia de los analfabetos y del snobismo e los que no leen sino impresos extranjeros; sabe de rivalidades, de envidias, hasta de odios; sabe de las carcajadas que lastiman y de las ironías que hieren. Pero sabe de los deberes de la juventud fundando una revista mensual, donde la obra acabada de los maestros se reúna á los bocetos de los aprendices, con el provecho recíproco que el docent diximus ya enunciaba.

IDEAS porque es de la Juventud será entera para verdad. No es una revista conservadora ni es tampoco una revista revolucionaria: no pertenece á ninguna escuela. En sus páginas recibirán hospitalidad afectuosa, todos nuestros verdaderos intelectuales, de los ya consagrados los pocos que deben su fama al propio mérito, de lo inéditos todos los que sean dignos de surgir. Porque hay en nuestros reducidos círculos intelectuales muchas mistificaciones. Los diarios generalmente han sido complacientes con exceso; la verdadera crítica ha contado muy escasos representantes, y en el público existe la atávica pereza intelectual que hace aceptar sin examen la opiniones ajenas ..... Todo ha contribuido -la herencia y el ambiente- a que la audacia encontrara medio propicio y auxiliada por la camaradería sin escrúpulos, pudiera otorgar reputaciones incontrovertidas a mediocres insignificantes. Es así cómo tenemos oradores tartamudos, historiadores que no alcanzan a cronistas, sociólogos que no sospechan a Comte, novelistas incapaces de comprender la vida; pseudo-críticos, pseudofilósofos ... ¿Quién dijo que la mentira es vicio nacional? 
Estas páginas modestas serán inaccesibles para esos incansables mistificadores que persiguen á las Gracias sin amarlas, ignorando tal vez que no las poseerán jamás en el abrazo fecundo de donde nace la obra maestra, porque Ellas, las Bellas Inspiradoras, son únicamente de quienes saben quererlas. En cambio los veréis desfilar por nuestras revistas críticas desnudados de todos sus postizos de plagiarios, sin el menor respeto por sus poses de falsos maestros. Como en el Martín Pescador de los juegos infantiles, pasará, pasará, hasta quedar reducidos á sus verdaderas proporciones, -la insignificancia. En nuestras secciones permanentes, donde se hará crítica verdadera, no soplarán venticelos cortesanos; será un pampero agreste y rudo. Y a su menor amago, el público percibirá crujidos de ídolos rotos.

Montaigne escribió en la portada de un libro célebre "ceci un livre de bonne foi; lecteur" la frase es hoy un vulgar cliché que todos repiten y ninguno realiza. Nuestra mayor ambición se cifra, en que cuando esta obra haya de ser juzgada, los críticos imparciales puedan reconocerla, "obra de buena fe". -Porque es raro mérito ser sincero en tiempos de hipocresía.

Ricardo Olivera 


\section{ANEXOS CORRESPONDIENTES AL CAPÍTULO 3}




\section{Nosotros. Revista mensual de literatura, historia, arte, filosofía ${ }^{1}$ [agosto 1907- diciembre 1913]}

\section{Indice y resúmenes razonados}

Si bien la revista cuenta con un excelente índice publicado por el Fondo Nacional de las Artes, a cargo de Elena Ardissone, ${ }^{2}$ el que aquí realizamos difiere de aquél puesto que nuestro criterio de organización privilegia el diseño de los números particulares y el orden cronológico de publicación. Esta perspectiva nos permite más fácilmente realzar la revista en sí misma -no ya como material de referencia-, exhibir sus cambios, dar cuenta de las polémicas que en ella se producen, de las temáticas que la recorren, el tipo de obras publicadas, de la relación de algunas de sus secciones con su contexto de enunciación políticoideológico. Nuestro trabajo recorta la revista según la orientación que propone el plan de tesis, intentando precisar la forma particular en que se pone en escena la emergencia del campo literariointelectual y los problemas vinculados con este proceso. De este modo reseñamos casi exclusivamente aquellos trabajos que son relevantes para las hipótesis planteadas. Del resto de los escritos solo consignamos número de páginas o referencias breves sobre su contenido. Cuando nos ocupamos de la sección libros recibidos transcribimos todos los datos de publicación que allí se consignan, y entre [ ], los que agregamos.

En el interior del primer número se anunciaban como secciones "permanentes":

Opiniones por Emilio Becher [nunca aparece como sección; Becher colabora sólo en el primer número]

Crónica extranjera por Joaquín de Vedia [nunca aparece como sección]

Bellas Artes por Emilio Ortiz Grognet

Música por Miguel Mastrogianni

Cuestiones pedagógicas por Benjamín García Torres

Letras Francesas por A. Chiappori

Letras Italianas por Leopoldo Longhi

Letras Españolas por Alberto Gerchunoff

Letras Portuguesas y Brasileñas por Juan Más y Pí

Letras Hispanoamericanas por José M. Rizzi

Letras Argentinas por Roberto Giusti

Teatro Nacional por Roberto Giusti [desde el segundo número hasta el $n^{\circ} 9$, Bianchi se ocupa de la sección]

Revista de revistas por Alfredo A. Bianchi

Notas y comentarios por Nosotros

Administrador: Alfredo Costa Rubert

Dirección y administración: Buen Orden 357

También se consignan las formas de venta de la revista:

Ciudad y Provincias Exterior

Trimestre …..... \$ 2,50 Trimestre .................\$ oro 1.50

Semestre ............ " 5.00 Semestre...................." 2.50

Año...................." 10.00 Año........................." 5.00

Número suelto..." 1.00 Número suelto.........." 0.50

Atrasado........... " 1.50 Atrasado..................." 0.80

En el $n^{0} 45$ de enero de 1913 se informaba sobre los agentes de venta de la revista y sobre la conformación del primer directorio de la Sociedad Cooperativa Nosotros

Agentes de la Revista Nosotros

Interior

La Plata: Sr. Erasto Nogueira, 48, entre 8 y 9.

Rosario: Señora Flora, viuda de Vidaurreta, Córdoba 1254

Mendoza: Sr. José Sitjar, San Martín 1477.

${ }^{1}$ El título fue después Nosotros. Revista mensual de literatura, historia, arte, filosofia y ciencias sociales.

2 Ardissone (comp.), 1971. 
San Nicolás: Sr. Gabriel A. Bomón

Tucumán: Señores Guzmán y Sánchez, 25 de Mayo 213/17.

Mar del Plata: Sr. Antonio H. Varela.

Córdoba: Sr. A. Petrel Torres.

Azul: Sr. Juan Carlos Bosh.

Catamarca: Sr. Domingo Minghetti, Librería.

Exterior:

Montevideo: Sr. José Serrano, Andes 178.

México: Sr. J. L. Méndez.

Medellín (Colombia): Sr. Antonio J. Uribe.

Sociedad Cooperativa Limitada

"NOSOTROS"

Primer directorio

Presidente: Dr. Rafael Obligado; Vice-presidente $1^{\mathrm{o}}$ : Sr. Alberto Gerchunoff; Vice-presidente $2^{\mathrm{o}}$ : Dr.

Mario Bravo; Secretario: Dr. Emilio Ravignani; Pro-secretario: Sr. Coriolano Alberini; Tesorero: Sr.

Alfredo A. Bianchi; Síndico: Dr. Joaquín Rubianes

Vocales: Sr. Enrique Bancha, Sr. José M. bustillo (hijo), Sr. Eloy fariña Núñez, Dr. Manuel Gálvez

(hijo), Dr. Martiniano Leguizamón, Sr. Roberto Levillier, Sr. Juan Mas y Pi, Sr. Alvaro Mellán

Lafinur, Sr. Carlos Obligado.

Directores de la revista "NOSOTROS": Alfredo A. Bianchi, Roberto F. Giusti

Administrador - gerente: José Blanco Caprile

Año I, tomo 1, no 1, agosto, 1907 (Editada bajo el sello de Arnoldo Moen y hermano)

-Presentación................ La dirección de la revista, pp. 5-6.

-Introducción a Nosotros de Roberto J. Payró ............. R. Darío pp. 7-12.

-Nosotros (primer capítulo de un libro en preparación) .............Roberto Payró pp. 13-19.

-Historiografía romana........... Francisco Capello pp. 20-25

-Beltrán y Faustino (Fragmento de una crónica del siglo VI)........ Emilio Becher pp. 26-28

-Cuatro bocetos por E. Banchs ("El café", "Rincón de patio", "El Cristo del juzgado", "Bajo la lluvia") pp. 29-31 Se trata de poemas sobre espacios urbanos; espacios y personajes que coinciden, en parte, con los de Carriego)

-El sacristán ...........Luis María Jordán pp. 32-34

-La interlocutora...........A. Chiáppori pp. 35-36 (de Borderland)

-Verlaine............ A. Arteaga pp.-37-38

-Almafuerte (Primer capítulo de un ensayo crítico en preparación).......... Juan Más y Pí pp. 39-44.

-Divagaciones irreverentes............ Hans Friedrich [Giusti], pp. 45-50.

-Bajo el rey sol ......... Evar Méndez pp. 51-52 (Tríptico a la manera Watteau)

-Letras argentinas............ Roberto Giusti pp. 53-57

-Teatro nacional............ Roberto Giusti, pp. 58-62

- Notas y comentarios .............Nosotros pp. 63-64

-Presentación................ La dirección de la revista, pp. 5-6.

Transcribimos el texto completo:

"La revista ya lleva en su título una rotunda afirmación de sí misma. Acaso ese título, como toda altivez juvenil, aún pueda parecer algo petulante. Porque es en efecto Nosotros una revista de jóvenes, y como tal se presenta armada de aquel ardimiento que una esperanza todavía no decepcionada presupone.

No sabemos si ella viene o no a llenar un vacío. El éxito que obtenga lo dirá. Pero, de todos modos, siempre ha de marcar alguna huella. Lo espera, aún más, lo pretende, pues que, cumpliendo rectamente su programa, que es el de tenerse apartada de todo lo burdo, lo vulgar, de todo lo manoseado, no ha de ser ineficaz la contribución que aporte, por poca que sea, al adelanto de las altas actividades del espíritu entre nosotros. Bueno es arrojar simiente. Ya fructificará algún día. 
Sus aspiraciones no tienen límite prefijado. Ellas tomarán si duda mayor amplitud, a medida que la revista avance en su camino. Más alto sube, más el horizonte de uno se ensancha.

Esta revista no será excluyente. No desdeñará las firmas desconocidas. Si lo hiciere, renegaría de este su origen, humilde, como el lector ve. Todo aquello que bien pensado y galanamente escrito a sus puertas se presentare, recibirá una afable acogida. Ningún otro anhelo anima a sus directores que el de poner en comunión en sus páginas, las viejas firmas ya consagradas con las nuevas ya conocidas y con aquellas de los que surgen y han de surgir. Siempre que lograra revelar a algún joven, ya podría esta revista vanagloriarse de su eficacia. Y si estas aspiraciones pudiesen salvar las fronteras de la patria y extenderse a toda América latina [en minúscula en el original], mejor aún. Nada de más urgente necesidad que la creación de sólidos vínculos entre los aislados centros intelectuales sudamericanos.

Sonrían los descreídos. Salmodien una vez más su repetida pregunta: “para qué sirve éso?” El arte, en toda su aparente inutilidad, pasa sencillo, sonriente, en marcha hacia el cumplimiento de los altos fines que persigue, sin cuidarse de aquellos que desde las tinieblas le arrojan piedras.

La Dirección"

-Introducción a Nosotros de Roberto J. Payró por R. Darío pp. 7-12. Tiene una nota el pie de la Dirección en la que se explican los motivos de la publicación del texto de Payró, y se aclara que el artículo de Darío ya ha sido publicado como en La Nación en 1896. Esto es importante porque se señala la propia continuidad con la crítica que se pretende construir, cuyo modelo es el de la especialización. [analizamos este texto en el apartado "Nosotros en el comienzo: inconclusión y continuidad" del capítulo correspondiente a Nosotros]

-Historiografía romana, por Francisco Capello pp. 20-25

Pasa revista a los distintos autores italianos y del resto del Europa que se han ocupado de la historia de Roma en diferentes épocas. La obra más monumental es la de G. de Sanctis: "Si de Sanctis alcanza a poner fin a su obra, Italia tendrá una historia romana a la altura de los estudios contemporáneos" p. 25.

-Beltrán y Faustino. Se refiere al problema de la ausencia de fe, en una historia que funciona como exemplum del castigo divino sobre Faustino (no ve y luego se ahoga, por consultar la ciencia)

-Cuatro bocetos por E. Banchs ("El café", "Rincón de patio", "El Cristo del juzgado", "Bajo la lluvia") pp. 29-31 Se trata de poemas sobre espacios urbanos; espacios y personajes que coinciden, en parte, con los de Carriego; son tres sonetos

-Almafuerte, por Juan Más y Pí, pp. 39-44

Se trata de un ensayo novelado. Se refiere a la "leyenda" de ogro que circula sobre Almafuerte, al que denomina Maestro. "Enseñar es aliviar. El que sabe y comprende hállase a cubierto de males: pero el que comprendiendo y sabiendo los padece por asimilación apostólica es un héroe. Ese heroísmo, empero, es locura dentro del equilibrio anormal de la sociedad contemporánea. Por eso el poeta es 'el loco' para los hijos degenerados de los imbéciles que veían en Jesús 'el bandido'. Ese heroísmo nervioso, desequilibrado en el raquítico medio ambiente donde todo lo grande es anormal, es el de Almafuerte: gesto amplio en los brazos abiertos para recibir al desgraciado y al miserable" p. 41. Hombre cuyas acciones demuestran una firme voluntad, fe inquebrantable, "espíritu único". "Lo demás, todo lo demás, era accidental, fugitivo, vano. El salón donde se tejen los perfumados triunfos mundanos; el pasillo del palacio legislativo, el despacho ministerial, donde se trepa y asciende en 1 dominio de los hombres; el proscenio deslumbrante donde se conquista el corazón y el sentimiento de los auditorios; todo eso es lo accidental, lo inútil, lo pasajero, dentro de la vida genial de los héroes del amor humano. Lo esencial es la escuela primitiva, en pleno campo; la dura lucha con el ambiente salvaje; la obstinada labor, casi manual de sembrar abecedario en los cerebros incultos, más vírgenes que la dura tierra nunca herida por la reja; lo indispensable es la permanente lucha en el suburbio, frente a frente de las pasiones malsanas que irrumpen como vahos fétidos de una falseada civilización; es la inmensa gesta de un ejemplo noble, de una vida intachable, de un sacrificio prolongado hasta la propia aniquilación cerebral" p. 41. "Job se lamenta, Cristo lanza un grito de desesperación y perdona; nuestro Misionero, nuestro Poeta, que comprende y por comprender duda, no hace más que entregarse, darse todo en su vida de apostolismo excepcional." p. 42 La sinceridad aparece en este escrito como "la base del heroísmo" p. 43. 
Almafuerte aparece como el maestro, el héroe, el apóstol. Es posible pensar una genealogía del magisterio espiritual en Nosotros, que incluya a Almafuerte, Rodó, etc. La hipótesis del magisterio intelectual ha sido trabajada por Leticia Prislei en "Itinerario intelectual y político de los Maestrosciudadanos. (Del fin del siglo a la década del '20)", Entrepasados, Año II, nº 2, comienzos de 1992, pp. 41-59.

-Divagaciones irreverentes, por Hans Friedrich (Giusti), pp. 45-50. Lleva una nota de la dirección. Es importante porque para hablar de filosofía en tono relativamente leve, Giusti apela a un seudónimo, que más allá de la nacionalidad declarada del autor, suena a alemán. Transcribimos la nota:

"La índole especial de este artículo requiere dos palabras preliminares.

Quien lo firma es un desconocido para el público argentino. Poco hace, en efecto, que llegó de su patria, Dinamarca, donde ejerció durante muchos años el profesorado. El señor Hans Friedrich es un solitario. Habita, completamente retirado, en su pueblecito de los alrededores, sin otro cuidado que el de su jardín, que constituye su única pasión. Adora las plantas. También se ocupa de la filosofía, pero tiene sobre ella opiniones radicalísimas. No ama a los filósofos, a los modernos sobre todo. Alimenta a su respecto ideas muy raras, que, si bien expuestas con escasa gravedad, encierran a menudo hondas verdades. Complacida esta revista da hoy cabida y la dará en los números siguientes a algunas de esas ideas, que tienen por lo menos el mérito de romper con la solemne uniformidad del pensar común, sugiriéndole al espíritu nuevos puntos de vista para considerar las cosas.” p. 45

-Bajo el rey sol por E. Méndez pp. 51-52 (Tríptico a la manera Watteau) Contrasta con la poesía de Banchs por los temas de estos sonetos. Los personajes son las hijas de unas marquesas del siglo XVIII francés.

Letras argentinas [En esta sección se reseñan distintos tipos obras, no exclusivamente literarias]

-Voz del desierto de Eduardo J. Talero, por Roberto Giusti. [Si bien Talero es colombiano, Giusti ha sostenido -en Visto y vivido- que "hizo de la Argentina su segunda patria" p. 76]

Es según el crítico, un libro que pretende sumarse a la literatura nacional a la manera de "aquellas obras que deben su justa fama a su característica de ser el reflejo del ambiente físico y social en que nacieron, y a ese sabor inconfundible del terruño que sus autores supieron infundirles." p. 53 La crítica se refiere principalmente a la "afectación": "la obra se ha impregnado de un tono general de afectación. La falta de naturalidad es el principal defecto de ese libro destinado a cantar a la Naturaleza. Se siente en él el tiempo empleado en buscar la imagen rara, en labrar la frase intensa, en hallar el rasgo brillante (...) Por eso, por aquel amaneramiento de que adolecer las mejores descripciones de Voz del desierto, se les prefiere aquellos otros capítulos más sencillos, más familiares, -verbigracia 'Los colonos', 'Dura lex', 'Balazos patriarcales'- en los que el autor nos muestra algunos de los más interesantes aspectos de la vida de esos lejanos pobladores del territorio argentino. (...)

En un rapto de lirismo campestre juróle sin duda antipatía eterna ala ciudad y a la civilización, y por cierto que esa antipatía no le abandona ya en las páginas de su obra. Para expresarla encuentra acentos verdaderamente sinceros; mas, con frecuencia, se excede en su expresión, recibiendo entonces ese odio, en su mismo exceso, el merecido castigo, pues resulta completamente risueño" p. 54

La crítica de Giusti muestra la ambivalencia que caracteriza muchas de las notas. El mecanismo es el de criticar negativamente y luego atenuar esa crítica con un valor positivo, generalmente de la personalidad del autor.

-Thespis de Carlos Octavio Bunge editado por la Biblioteca de La Nación, por Roberto Giusti.

Presenta y alaba a Bunge como un sujeto polifacético: "Extremadamente múltiple ha sido hasta la fecha la producción del señor Bunge. Múltiple y variada. A la pedagogía, a las ciencias jurídicas, a la psicología, al teatro (ay!), y a la novela, les ha rendido culto con mayor o menor fervor. Esta misma adaptabilidad de su mente, sin embargo, esta misma sorprendente variabilidad de sus aptitudes, más han redundado en su perjuicio que en su provecho. Sobre todo en perjuicio de su reputación como hombre de ciencia. Y ello es natural. El público generalmente resístese a creer en la profundidad de conocimientos de quien aborda con invariable entusiasmo temas diversos." p. 55 La ciencia o los hombres de ciencia 
cuyo capital simbólico es elevado, se desmerecen ante la vista del público, aquí tratado despectivamente, que desconfía del ejercicio de varias disciplinas a la vez.

Se trata de cuentos. Dice Giusti respecto del género al que califica de "harto difícil":

"El género presenta, en efecto, mayores dificultades de las que comúnmente suélese atribuirle. Sin mencionar las inherentes a la ejecución, otra dificultad supone más insalvable: la de lograr ser originales en campo tan trillado. Hecho éste en el que debe irse a buscar la explicación de esa excesiva eflorescencia de cuentos fantásticos que en nuestras playas, para no ir más lejos, se ha dado en escribir, en libros y en revistas."p. 55

La crítica es positiva: Thespis es un buen libro de cuentos, de estilo fluido, sencillo, asuntos diversos (cómicos, groseros, trágicos, delicados, más menos originales e interesantes)

- Estudios de filosofía jurídica y social de A. Dellepiane, por Alfredo Bianchi.

Bianchi señala un vacío disciplinar: "Redactado en estilo sobrio y llano, viene este libro a acrecer nuestra aun limitada producción sociológica". El libro presenta dos partes: una orientada al programa de Filosofía del Derecho, de la que Dellepiane es profesor en la universidad de Buenos Aires. La segunda presenta, a diferencia de la primera, un interés más general. Le interesa a Bianchi la consideración de la faz científica de la obra de Zola -al que Bianchi se refiere como Maestro-, en el artículo "Zola y la herencia". Las conclusiones a las que llega Dellepiane coinciden con "las que más tarde formulara Max Nordau en su harto zarandeada Degeneración." Finalmente califica la obra de "Libro concienzudo y honesto" p. 57.

Teatro nacional, por Roberto Giusti, pp. 58-62

Giusti organiza la sección según los teatros en los que se representan las obras

En el Nacional:

-Para vencer de Leopoldo Longhi

Cuenta la historia de un escritor -Raimundo- a quien su mujer abandona, por un amigo del escritor

-Leonardo-, porque Raimundo vive solo preocupado por su ansia de gloria. Se trata según Giusti de un drama "defectuoso" (sobre todo el final, en que Elisa, la mujer de Raimundo se suicida)

"El señor Longhi ha demostrado en este drama no conocer aún a fondo todos los resorte de la técnica teatral. Falta en él movimiento, falta vida, falta habilidad en el manejo de los personajes. (...)

Fluido el diálogo, aunque retórico y abundante en imágenes, no siempre de buena ley.

Pero son todos esos defectos que el autor irá fácilmente corrigiendo a medida que vaya acumulando mayor experiencia en estas lides, razón que hace mayormente resaltar la injusticia de ciertos criticastros que sin compasión atacaron el drama, errado hasta cierto punto, pero acusador de un fresco talento juvenil." pp. 61-62. Blanca Podestá interpreta el papel de Elisa.

-El mejor tesoro de Emilio Ortiz Grognet

Critica la falta de compenetración de los actores en sus papeles. Giusti sentencia y reclama: "El señor Ortiz Grognet ha acreditado su fino talento dramático en dos estimables ensayos. Hecha ya la mano a las dificultades de la escena, ha llegado el momento en que se empeñe en una obra de proporciones mayores. Indudablemente lo acompañará el éxito más completo.

-Otras músicas de Alberto de Zabalía (estrenada el 2 de agosto de 1907, "con éxito franco, la graciosa comedia en un acto")

Giusti consigna que en el teatro Marconi "viene actuando con éxito la compañía de Pablo Podestá, que acaba de estrenar el drama Parientes pobres por don Martín Coronado. Nos ocuparemos de él en el próximo número.”p. 62

Notas y comentarios

-Las conferencias de Guillermo Ferrero [en el Odeón]. La opinión es regular: Ferrero no tiene "vuelos de águila".

"Guillermo Ferrero ha terminado la serie de sus conferencias del Odeón. Ocho veces en el mes esa aristocrática sala se ha llenado de selecta y numerosa concurrencia de damas, políticos, periodistas, literatos, intelectuales de todo género y de todas las condiciones, acudidos, los unos por verdadero interés, los otros por simple snobismo, a escuchar durante dos horas consecutivas al distinguido historiador. 
Y Ferrero, con su voz monótona y plañidera, desagradable en principio hasta hacerse simpática por la fuerza de la costumbre, ha rememorado ante el auditorio respetuosamente recogido, la pasada grandeza de Roma, acompañando su fácil elocución con amplios ademanes de sus brazos largos y huesudos.

Sin temor de errar puede asegurarse que la impresión dejada en el auditorio por ese ciclo de conferencias, ha sido inferior a la expectativa" p. 63 Inmediatamente después se refieren las preferencias del público: "El público no gusta tan fácilmente de abandonar ciertas arraigadas creencias. A la sequedad de una prosaica demostración científica, prefiere la fe ciega en una poética leyenda, magüer fuese falsa." - Tallaví en Los espectros. Se comenta la actuación de Tallaví en el teatro Argentino en la obra de Ibsen como una revelación. La revista se queja de los motivos que llevan al público al teatro: "A ver ese drama de Ibsen no se va hoy en día sino para contemplar en cual forma desenvuelve el actor el proceso de la espantosa enfermedad de Osvaldo. El público no va al teatro sino para ver cómo sufre y cómo muere el protagonista, y si lo hace tal como en las clínicas se ve. Reflexionándolo bien eso es simplemente horrible. En definitiva no es algo más elevado que el truculento folletín que place a la gente menuda" p. 64

\section{Libros recibidos}

Esta sección es importante porque aquí se ven las alianzas que se construyen entre editoriales, temas, géneros, autores.

- A. Dellepiane, Estudios de filosofia jurídica y social, Valerio Abeledo, editor

- Eduardo Talero, Voz del desierto Edición de la "Sociedad de escritores de Buenos Aires"

- Carlos O. Bunge, Thespis de, Biblioteca de La Nación

- C. Iglesias Paz, El problema social, Arnoldo Moen y hermano,

- Juan Más y Pí, Cuentos extraños, La Plata. [no se consigna editorial]

- Manuel Ugarte, Vendimias juveniles, Garnier hermanos (París).

\section{Año I, tomo 1, n 2, septiembre, 1907 (editada bajo el sello de Arnoldo Moen y hermano)}

-Nosotros (primer capítulo de un libro en preparación)........ Roberto J. Payró, pp. 65-71

-Ética del cristianismo (de un libro en prensa) ........... Carlos. O. Bunge, pp. 72-77

-"La dama del jardín"............ Eugenio Díaz Romero, pp. 78-80 [poema amoroso de matriz modernista: cuello de marfil]

-"Los orientales"........... Víctor Arreguine, pp. 81-90 [historia de la independencia uruguaya]

-Página vieja......... E. Banchs [escrita en castellano antiguo, galaico portugués; es la historia de un caballero, Mossen Diego de Valera, ambientada en 1481]

-Los ancianos..........Raimundo Manigot, pp. 95-97.

-El buen viejo..........Salvador Oria, pp. 98-100 [diálogo entre un poeta y Saturno]

-Letras francesas......... Atilio Chiappori, pp. 101-107

-Letras españolas.......... Alberto Gerchunoff, pp. 108-111.

-Letras Brasileñas..........Juan Mas y Pí, pp. 112-114.

-Letras Argentinas........ Roberto Giusti, pp. 115-120

-Sociología....... José H. Rosendi, pp. 121-124

-Bellas Artes (sección) ........E. Ortiz Grognet, pp. 125-128

-Música (sección) .......... Miguel Mastrogianni. Comenta los estrenos. pp. 129-133

-Teatro nacional ......... Alfredo Bianchi, pp. 134-136

-Notas y comentarios aparece como hoja suelta -color verde- en la que se incluye 'Libros recibidos'

-"Nosotros" (primer capítulo de un libro en preparación) por Roberto J. Payró, pp. 65-71

Segunda entrega del primer capítulo de la novela de Payró. Cf. El apartado "Nosotros en el comienzo: inconclusión y continuidad" del capítulo correspondiente a Nosotros.

-Ética del cristianismo (de un libro en prensa) por Carlos O. Bunge, pp. 72-77

En el párrafo final sintetiza: "De la virtud suprema, vale decir, de la Caridad, se desprenden, para el cristianismo puro, una serie de virtudes secundarias y concomitantes: Castidad, Resignación, Pureza del 
alma, Fe, Esperanza, etc. Y todas ellas giran alrededor del principio de la igualdad humana y de la plena seguridad de una compensación justiciera para después de la muerte" p. 77

-Los ancianos, por Raimundo Manigot, pp. 95-97. Habla de la RAZA, palabra que sirve para oponerse al cosmopolitismo más anónimo, contra el poseur "de esta época enfermiza y enervada que pica la tarántula del exhibicionismo à outrance" p. 96. En contra del materialismo y del progreso. A favor de los "jóvenes ancianos" que poseen ideales.

"Yo, escucho esas requisitorias, esas catilinarias, esas diatribas condenatorias de innovaciones mórbidas que riñen con la hidalguía nativa y el buen sentido; 'modernismos' que las convenciones sociales imponen sin previo examen porque son el disfraz que mejor oculta las vilezas del siglo presente. p. 96. (...)

Son escasos, sí, esos 'jóvenes ancianos' que persiguen el anonadamiento de sus tristezas en el culto de 'lo que ha sido y no volverá a ser'. Esos descreídos que anhelarán cruzar la vida, de la cuna al sepulcro, con la despreocupación risueña de la infancia, sin mancharse en el lodo del camino ni rasgar su carne en las espinas del abrupto sendero entre las zarzas.

Pero la comunión de sus espíritus con los de los ancianos ya renunciantes a las exuberancias ilusionadas de la vida, inspira más simpatía que las empresas egoístas de sus contrarios, faltos de ideales, desalmados, impostores, que sólo buscan en el mundo la satisfacción de sus sentidos a base de engaño mutuo, como si complaciéranse a [sic] demoler el edificio de las tradiciones para reinar un día sobre sus ruinas con la ilusoria majestad de déspotas de melodrama." p. 97.

-Letras francesas pp. 101-107.

Paul Verlaine por Edmond Lepelletier, reseñado por A. Chiappori.

El crítico no acuerda con el entusiasmo con que Darío ha recomendado este libro. "Que Rubén Darío me perdone, pero no llego a compartir su entusiasmo. No me duele saber que Verlaine era hombre de ideales burgueses, ni me desilusiono comprobando que el asunto Rimbaud está lejos de ser lo que la perspicacia de mesa redonda suponía. Jamás hice literatura de 'soucoupe', con gran detrimento de mi prestigio intelectual, y mi gusto literario siente por la 'bonne pourriture' el mismo asco invencible que mi inadecuado paladar criollo por las aves 'faisandées'. Al contrario, pienso que hay muchas vidas raras cuyas reputaciones deben reverse, siendo que, casi siempre, este panegírico y aquel denuesto no tienen otro origen que el inmediato arrobamiento de camaradas o la invariable difamación de la última querida" p. 102.

Letras españolas, por Alberto Gerchunoff, pp. 108-111.

-Carmen un poema en cantares de Francisco Villaespesa. Crítica que elogia el tono no académico de los versos. "Francisco Villaespesa es una de las personalidades literarias más interesantes de la España actual. es con Machado, Antonio de Zayas y Diez Canedo, uno de los que anuncian en el esfuerzo generoso de su labor devolver a su literatura el brillo de los días extinguidos e independizar el arte restituyéndole a la virtud del ensueño, que es regenerador sin propósitos y educador sin programas, a la inversa de lo que pensaba don Gaspar Núñez de Arce, al atribuir a la poesía funciones docentes y políticas" p. 110 [cursivas nuestras]

(...)

Es variado en su aparente monotonía y es robusto en la forma liviana y humilde. Sus libros dan la idea de una antología de canciones populares, tan ajeno es a todo artificio y eso prueba la presencia de un poeta auténtico, depurado de academicismos y decadentismo [cursivas nuestras], atenido a la fuerza misteriosa de lo bello y de lo fuerte, que es amor y dolor, base de todo arte verdadero" p. 111.

-Letras Brasileñas, por Juan Más y Pí, pp. 112-114

Las modernas corrientes estéticas en la literatura brasileña (en portugués) de Elysio de Carvalho. Coedición brasileña-francesa. Está presente la vocación del americanismo: "Desconocer Brasil y conocer en cambio lo ruso y lo japonés, por obra y gracia de la tiránica ley de importación, es algo absurdo que muy poco dice en favor del espíritu de crítica y de investigación en nuestro medio"p.113. Esta obra interesa por "atenerse con preferencia al estudio de las nuevas generaciones, tan fuertes como las anteriores, aunque, tal vez, más originales" p. 113. Menciona la traducción de Canáan de Graça de Aranha, realizada por Roberto Payró. 
La reseña termina expresando el deseo de conformación de una hermandad intelectual americana:

"Mucho sería de desear que el libro de Carvalho se leyera entre nuestros intelectuales, realizando la verdadera y la más digna obra de confraternización americana" p. 114.

Letras argentinas, por Roberto Giusti, pp. 115-120

-Las Barcas por E. Banchs pp. 115-117 Crítica elogiosísima.

Banchs aparece para Giusti como el caso anómalo del poeta joven que no imita. Destaca la robustez de su pensamiento difícilmente etiquetable. Sostiene que es más fino que sentimental, posee un talento superior, una imaginación desbordante, una potente inspiración. Por su calidad es parangonable con Almafuerte y Lugones, a quienes Giusti califica de los dos más grandes poetas. Transcribimos la nota completa.

"He de necesitar de la mayor serenidad para abordar el análisis de este libro, que más me arrastra al ditirambo entusiasta que a la crítica mesurada. Y con todo, ditirámbica será esta crítica, pues otra cosa no es posible frente a un libro como Las Barcas, que es al mismo tiempo una revelación y una promesa: la revelación de un talento en flor y la promesa de un gran poeta. (Y conste que no arrojo los epítetos al caso)

Este libro, obra de un joven que no ha llegado aún a los veinte años, encierra en sí, sin embargo, méritos suficientes para formar la reputación de cualquier escritor.

Condición primera de Banchs es la de ser a la edad en que se comienza invariablemente por imitar, un poeta esencialmente propio, personal. Vana tarea fuera la de quien pretendiese buscar las fuentes de su poesía. Banchs no es de aquellos susceptibles de ser marcados con una dada etiqueta. Otra característica de su mentalidad es la robustez. Banchs concibe y siente y rima con vigor, pero ello sin menoscabo de una especial delicadeza con que toca todos los temas. Es fino más que sentimental. No hace sentir hondo, pero transporta al lector en un mundo suave, espiritual, de ensueño. su poesía es más intelectual que afectiva, más de la cabeza que del corazón. Es una poesía complicada, sutil: nada concede a la pereza intelectual del lector. Obliga a pensar, a desentrañar la imagen preciosa, conceptuosa, rica de significación. Lástima que la mayoría no ame estas cosas, y descargue sobre el poeta la culpa de su incomprensión del primer momento.

Los temas que aborda son siempre novedosos: variados los metros que emplea, y ricos en sonoridades o en matices. No es dudoso que un Calandrelli cualquiera ( $j a$ qué citar siempre a Valbuena?) podría hallar en eso versos ancho campo para sus más o menos hábiles acrobatismos, pero ciertas minucias no han de detener al lector inteligente, que advierte que se halla ante un talento superior. Caídas, versos rudos, algunas expresiones dudosas, sí tiene; pero son todos defectos que más que a su impotencia débense a su juvenil desdén por el pulimento excesivo. Al contrario asombra verle salvar, al parecer sin esfuerzo, tantas y tantas dificultades. Y ya nótanse en él, además, condiciones de otra clase que las simplemente inherentes a su rica mentalidad: nótanse ya en él condiciones de disciplina mental que mucho prometen para el porvenir, tal por ejemplo su serio dominio del lenguaje y un cierto cuidado en la elección del epíteto, que trata de hacer preciso y sugeridor.

$\mathrm{Si}$ a su imaginación desbordante, a su potente inspiración, comparables con las de los más grandes poetas, une, como parece que está en camino de hacerlo, el estudio, un arte refinado, la nitidez en todo, sin concesión alguna al desgano intelectual, Banchs no tardará en ser un poeta completo. Cualidades le sobran para serlo.

He hablado de su delicadeza. El es sin embargo multiforme, y sabe también, cuando quiere, ser enérgico y rudo. No es raro encontrar en Las Barcas una composición de ternura exquisita al lado de otra de violento empuje, resonante de ideas grandes y de altos sentimientos. La lira que apostrofa tañe con igual maestría que la que acaricia.

A los labios vienen involuntariamente las comparaciones. $Y$ en verdad no puedo abstenerme de observar, -pese a quien pretenda tacharme de exagerado- que abundan estrofas y aun enteras composiciones en Banchs, que bien pueden sostener el parangón, alta la frente, con las mejores de nuestros dos más grandes poetas: Almafuerte y Lugones.

Pero dejemos a la opinión que diga su última palabra sobre este nuevo poeta que entra en la liza, por cierto bien armado.

'Gloria al esfuerzo virgen, paso a la barca nueva' 
Es probable que ella nos diga que de la generación que surge, Banchs es sin duda el talento más robusto." pp. 115-117

-Vendimias juveniles por Manuel Ugarte. , pp. 117-118

Elogia al autor en los siguientes términos: "Ugarte no es un poeta complicado. Es sencillo y claro. Su imagen, siempre precisa, aunque envuelta en ligerísima bruma, sugiere al lector todo un mundo"; caracteriza al autor como un "alma de soñador y de artista". pp. 117-118.

-Cuentos extraños, por Juan Más y Pí, pp. 118. Según el crítico, en ellos se escucha la voz de un profeta con algo de Zarathustra, pero también de Cristo, que predica una filosofía áspera y saludable: "Predica la ruptura con todo lo pasado y la esperanza en el ideal, la caída de los añejos prejuicios y la creencia en las futuras realizaciones; la nivelación social y el amor universal; el odio a la canalla y la confianza en la humanidad del provenir; el cultivo de la voluntad, la seguridad en sí mismo y la marcha hacia la vida intensa." p. 118.

-El enigma interior por Manuel Gálvez, pp. 119-120.

Crítica negativa que ataca fundamentalmente el trasvasamiento del metro francés al castellano. El defecto fundamental de El enigma interior es su carencia de originalidad. Respecto del verso libre, señala que en el caso de Gálvez y de otros poetas nacionales y extranjeros, no se lo resuelve bien, y sólo se trata de prosa sencilla, a pesar de los artilugios tipográficos. Aquí se menciona a Lugones con su Los crepúsculos del jardín como una estimable aplicación del verso libre.

Transcribimos la nota completa:

"Versos, versos, versos... Opima va a ser este año la cosecha poética. Otro libro más, El enigma interior, impregnado todo él de una indefinible melancolía. Diríase llegado del boulevard. Podrá haber en ello un motivo de censura, pero esta no ha de ser sino relativa. Cierto es que esos versos suenan extrañamente en nuestro idioma, porque, en verdad, a pesar de toda nuestra buena voluntad por imitar a los demás -a los noruegos, a los rusos, a los japoneses, ¡qué sé yo!- y por dejar de ser americanos, aún no hemos logrado acostumbrarnos a ese parisienismo excesivo. Sin embargo, se debe separar lo accidental de lo esencial, y hacer una honda distinción entre ciertos rasgos que se dan de pescozones con nuestro modo de ser, y otros que son universales e igualmente propios de París como de Buenos Aires, pues que son la real, la íntima expresión de nuestra sensibilidad dolorosamente afinada de hipercivilizados.

El defecto fundamental de El enigma interior es su carencia de originalidad. Verlaine sobre todo -dejo de lado otras visibles influencias- pesa sobre este libro. Pero Gálvez es sincero consigo mismo. El siente a sus poetas predilectos, con ellos se ha compenetrado y como ellos se expresa. En sus versos se advierte la sinceridad de los sentimientos que canta. No es, pues, un vulgar imitador.

Mas, dejo ya de hacer hincapié en este lamentable defecto de El enigma interior, para pasar a considerarlo desde otros puntos de vista más interesantes.

Es un libro delicado y a ratos intenso. rasgos hay en él que revelan toda un alma de artista. Pero es un libro desigual. Felices expresiones, bellos versos, codéanse en él con tropiezos verdaderamente lastimosos.

Una cuestión que este libro levanta es la del verso libre, cuestión que ya desde el prólogo el poeta se apresura a plantear y discutir brevemente.

No es éste el lugar para volver sobre tan debatido asunto, cuya discusión requeriría una amplitud que no puedo darle aquí. Pero es el caso de observar, muy a la ligera, muy dogmáticamente si se quiere, puesto que a continuación va sin pruebas, que hay composiciones en verso libre en El enigma interior y en otros libros, nuestros y extranjeros, que, a pesar de todos los artificios tipográficos no pasan de estar en prosa, en sencillísima prosa. Esa cuestión del ritmo interno es cosa muy delicada y que nos se resuelve con meras palabras preliminares.

Lo dicho va sin desconocer el mérito de la innovación de Khan (a quien se hiciera notar que descubrir el verso libre después de La Fontaine y de Corneille era algo difícil), y sin desconocer tampoco que entre nosotros, donde por fortuna no ha arraigado muy hondo, se han hecho de ella estimables aplicaciones, en Los crepúsculos del jardín principalmente.

De todos modos, dando un corte al asunto, opino que Gálvez ha abusado un poco de tan peligrosa innovación. 
Pero los defectos, los errores, se contrabalancean en este libro con las buenas cualidades. Y si hay en él versos falsos, ingenuidades, chocantes imitaciones, hay también sensibilidad, frescura, delicadeza, y todo un temperamento de artista que si se independiza de las influencias que sobre él gravitan, podrá dar, desarrollando sus modalidades, obras poéticas de verdadero aliento" pp. 119-120.

-Pétalos marchitos, por Luis Juan Alfonso

Giusti define este libro como un "Tomito de versos olientes a juventud y a inexperiencia." p. 120

Sociología (sección), por J. H. Rosendi, pp. 121-124.

-El problema social, por César Iglesias Paz.

La nota es importante porque Rosendi reseña el estado de la discusión acerca de estos problemas. Rosendi explica el carácter de "modismos corrientes" que tienen palabras tales como el socialismo, la cuestión obrera, los problemas sociales, en función del momento histórico político y de un argumento racial: "estamos en la gestación de una democracia, tenemos que ser la continuación de Europa bajo muchos conceptos y representamos como país una necesidad de espacio y económica de la parte civilizada del antigua continente: somos un país de inmigración de raza blanca, raza en la cual se ha engendrado el socialismo y sus problemas tienen que presentarse aquí aunque no deben plantearse idénticamente." p. 121.

-El problema nacional obrero y la ciencia económica, La cuestión obrera y su estudio universitario, Herbert Spencer y sus doctrinas sociológicas, por E. Quesada. Reseña Giusti, pp. 123-124.

Giusti define a Quesada como trabajador infatigable, distinguido publicista.

Bellas Artes (sección) por E. Ortiz Grognet, pp. 125-128.

Este escrito es importante porque señala la alianza entre los miembros de la esfera de la cultura. Constata el crecimiento de la cultura artística de Buenos Aires.

"De seis años a esta parte, la cultura artística de Buenos Aires ha acrecido considerablemente, efectuando el proceso de su evolución a grandes saltos.

Este fenómeno es de sencilla explicación; en arte como en todas las manifestaciones de la moderna actividad, vivimos del reflejo de los grandes focos europeos y pocas cosas más rápidas en la propagación que la luz, pero esa luz se apropia el color del cristal que se le interpone. El estudio pues de la tamización de las luces de España, de Italia y de Francia -que son las que más directas y en más profusión nos llegan-, a través del cristal de nuestro propio temperamento, será objeto primordial, sino exclusivo de estos artículos.

De las aisladas exposiciones que con explicable rubor, dado el medio, se organizaban en los años pasados, queda sólo la tradición; hoy las exposiciones se suceden unas a otras y algunas, las malas especialmente, se propagan por generación espontánea. El snobismo rumboso hizo medrar a los mercaderes, la fama de nuestra largueza y minuficencia, limó de telarañas la infinidad de cuadros, grandes brochazos de barniz rejuvenecedor se extendieron sobre la pátina de olvido de muchas telas de valor subalterno que han sido negociadas aquí a precios altos y hoy gozamos la justa fama de constituir uno de los mercados artísticos más importantes del mundo.

Más importantes sí, pero menos considerados; somos excelentes pagadores y apreciadores de una gran deficiencia; esto es lo lamentable y esto dará también tema continuo a nuestra propaganda" pp. 125-126 Sostiene que privilegiará el análisis de lo propio por sobre lo extranjero. Se lee aquí el intento de construcción -también- de un arte nacional.

Más adelante:

"Transcribimos un párrafo de Malharro que sintetiza nuestro pensamiento: Creemos, dice, en un arte nacional, en un arte original como nuestra naturaleza; en un arte con carácter propio, netamente definido, sincero, con medios de expresión nuestro [s], en un arte lozano, valiente y original como original es el Facundo de Sarmiento.

La razón primera y fundamental de la originalidad de Facundo es la independencia y originalidad del espíritu del autor.

Alentar a nuestros artistas, predicarles fe para la lucha y el cultivo de la propia personalidad; hacerles conocer del público, sacarles de la sombra, donde la incuria nacional injustamente les ha reglado hacerles apreciar en lo que realmente valen y prometen valer, será el alto y patriótico fin que con todo tesón perseguiremos" p. 128. 
Música (sección) por Miguel Mastrogianni. Comenta los estrenos de la temporada lírica. Se refiere al público que va a la ópera por razones no artísticas sino de moda.

Sostiene: "Hoy nadie discute la superioridad del drama lírico sobre la ópera a la antigua usanza. Es menester, pues, que no sigamos ajenos a una evolución reconocida legítima y necesaria” p. 133.

Teatro nacional, por Alfredo Bianchi, pp. 134-136

Nacional:

El buen dolor por Félix Alberto de Zabalía. Según Bianchi, las únicas obras de importancia que se han estrenado en agosto en este teatro son las comedias dramáticas El mejor tesoro de E. Ortiz Grognet, La suerte negra de José de Maturana, y El buen dolor. A pesar de su calidad ninguna ha obtenido éxito considerable entre el público. Según Bianchi esta cuestión es relevante porque Bianchi encuentra en ella la razón por la cual los autores teatrales no practican más que géneros menores: "Y lo peor es que, cuando como en el caso actual [El buen dolor] no se premia con justicia una tentativa seria, se niega el derecho del desaliento al autor y que en vista de la inutilidad del esfuerzo, se entregue éste a la composición de sainetes cómico-líricos, más al alcance del gusto del público. De este gran error, son culpables y responsables, ante todo, los auditores inteligentes".

-Se consigna la reprise de la obra de Payró Marco Severi, con éxito en las seis noches en las que se representó.

Marconi:

La eterna ciega de Otto Miguel Cione.

"Obra de tendencia sana, pues con ella el autor se propone corregir un defecto de nuestra ley penal, poniendo de manifiesto las injusticias a que se presta la imprecisión de un artículo; bien construida y de caracteres particulares perfectamente individualizados, es en verdad merecedora del aplauso caluroso con que fue recibida" p. 135

Bianchi señala una serie de incongruencias en lo relativo al tiempo que resultan en inverosimilitudes. Finalmente se refiere al público y a los actores: "La interpretación, bastante buena. Únicamente sería de desear que el señor Pablo Podestá contuviera un poco sus ímpetus rugidores que, si bien pueden agradar al público de las galerías altas, solo consiguen, ante el público culto, hacer antipático y hasta odioso al personaje que precisamente debiera serlo menos" p. 136.

En hoja suelta: Notas y comentarios y Libros recibidos

Libros recibidos

-Maximiliano Avilés, Fuerza de acción, Nueva York [no se consigna editorial]

-Emilio Ortiz Grognet, El mejor tesoro, drama en un acto. [no se consigna editorial]

- Luis Juan Alonso, Pétalos marchitos [no se consigna editorial]

- Francisco Capello, Pinus Mendociae [no se consigna editorial]

-Ernesto Quesada. El problema nacional obrero y la ciencia económica, La cuestión obrera y su estudio universitario, Herbert Spencer y sus doctrinas sociológicas. [no se consigna editorial]

-Manuel Gálvez, El enigma interior, Librería América -Casa editora

-A. Castilla Aguiar Hogar sin fuego, novela social, (Biblioteca Nacional 'Nec plus ultra')

-Ramón Oliver La corona del bosque, poema (Biblioteca Nacional 'Nec plus ultra')

Año I, tomo 1, no 3, octubre, 1907 ((Editada bajo el sello de Arnoldo Moen y hermano)

-Nosotros (primer capítulo de una libro en preparación)....... R. J. Payró, pp. 137-142.

-Un anónimo más....... F. Sicardi, pp. 143-144

-Oda a Rubén Darío........A. Arteaga, pp. 145-148

-Don Miguel de Unamuno (Breves apuntes. Acerca de D. Miguel de Unamuno y de su influencia en las letras hispanoamericanas)....... Max Grillo, pp. 149-161.

-Su sonrisa........ A. Monteavaro, pp. 162-163

-Cosas de Andresillo....... E. Carriego, pp. 164-167.

-Presente griego (Fantasía trágica en un acto, original de Otto Miguel Cione) Primer premio del concurso dramático del teatro Nacional, pp. 168-178

-La ermita.........Leopoldo Longhi, pp. 179-181.

-Sonetos.........José de Maturana (del libro Jardines salvajes, "Las dos primaveras", "Carne florida", "Los ojos de la esperanza), pp. 182-184 
-Descartes y el criterio de verdad....... Hans Friedrich [Giusti], pp. 185-190.

-Escepticismo....... Luis Ipiña, pp. 191-193.

-Bellas artes ......... E. Ortiz Grognet, pp. 194-200.

-Letras argentinas........ Roberto Giusti, pp. 200-203

-Teatro Nacional........Alfredo Bianchi, pp. 204-206

-Notas y comentarios...... pp. 207-208

-Nosotros (primer capítulo de una libro en preparación) por R. J. Payró, pp. 137-142. Tercera entrega del primer capítulo de la novela de Payró. Cf. el apartado "Nosotros en el comienzo: inconclusión y continuidad" del capítulo correspondiente a Nosotros.

-Un anónimo más, por F. Sicardi, pp. 143-144

Es el relato de la vida miserable de un hombre, que como tantos otros, padece la miseria y los males asociados a ella, como el alcoholismo. Muere de frío y su cuerpo es sepultado en una fosa común.

-Oda a Rubén Darío, por A. Arteaga, pp. 145-148 Darío es apostrofado como Maestro que desdeñas los tumultos de las turbas triviales/ y cincelas joyeles o engarzas claras gemas/ en tus magníficos poemas/ maravilloso artífice del verbo" p. 146

-Don Miguel de Unamuno (Breves apuntes. Acerca de D. Miguel de Unamuno y de su influencia en las letras hispanoamericanas), por Max Grillo, pp. 149-161.

Grillo afirma que "La personalidad literaria y científica de Unamuno adquiere cada día mayor relieve". Sostiene que "La tarea que se ha impuesto el profesor salmantino al dar a conocer en las revistas madrileñas el movimiento literario de la América hispana tiene laudables consecuencias" Transcribe algunos párrafos de la nota de Unamuno publica en La Lectura, "Algunas consideraciones sobre literatura hispanoamericana", de septiembre-octubre de 1906: "La necia y torpe política metropolitana nos hizo perder las colonias, y una no menos necia ni menos torpe conducta en cuestión de lengua y de literatura podría hacernos perder -si estas cosas se rigieran por procedimientos de escritores y literatos la hermandad espiritual. Tenemos que acabar de perder los españoles todo lo que encierra en eso de madre patria, y comprender que para salvar la cultura hispánica nos es preciso entrar a trabajarla de par con los pueblos americanos, recibiendo de ellos, no solo dándoles". Grillo destaca el reconocimiento por parte de Unamuno de la influencia del modernismo hispanoamericano en las letras españolas y recalca el carácter no sectario del escritor español.

-Su sonrisa, por A. Monteavaro, pp. 162-163

Relato cuyo tema es la sonrisa enigmática de Enriqueta, de quien se enamora Aníbal, su primo.

-Cosas de Andresillo, por E. Carriego, pp. 164-167. Ficcionaliza el destino del joven que Don Quijote salva de los palos de su amo, en la novela de Cervantes Andresillo se ha transformado en un Quijote y está en un manicomio.

-Presente griego (Fantasía trágica en un acto, original de Otto Miguel Cione) Primer premio del concurso dramático del teatro Nacional, pp. 168-178

Personajes: Doctor Guerra (Guillermo Battaglia), Blanca , hija del doctor Guerra (Blanca Podestá), Julio, novio de Blanca (Julio Escarsela), Tristán, asistente de laboratorio (Arturo Podestá), Doña Josefa, vieja criada (Josefa Lanaro). Blanca muere picada por una víbora que, para impedir su casamiento con Julio ocultó Tristán (que siempre la ha amado) en un canasto, al que ella ha ido a buscar su retrato de comunión, para dárselo a Julio. Tristán se suicida arrojándose a la jaula de unas víboras, que lo devoran rápidamente.

-Descartes y el criterio de verdad, por Hans Friedrich, pp. 185-190. Giusti, discute el criterio de verdad cartesiano y opone a la razón, la experiencia: "El criterio de la verdad es el que fue indicado por Leonardo. 'Solo la experiencia es madre de la ciencia, del saber verdadero. Lo que no cae bajo la experiencia nunca podrá afirmarse con seguridad" p. 190. 
Bellas artes, por E. Ortiz Grognet, pp. 194-200.

Tercera exposición de aficionados

En el Salón Costa se inaugura y clausura el tercer certamen artístico organizado por la "Sociedad de aficionados". Exponen 76 pintores . Se distinguen en pintura Cupertino del Campo, Carlos de la Torre, Francisco de Elizalde; también Enrique Prins; en escultura Pardo de Tavera y Guillermo Rojo. Es interesante remarcar el criterio de actualidad que organiza la sección, que se hace presente en último párrafo que le dedica Ortiz Grognet: "No hacemos más crónica por haber perdido esa exposición su actualidad y cerramos esta nota con un aplauso de estímulo para todos los que contribuyeron a su éxito" p. 195 .

Grognet se ocupa especialmente al grupo NEXUS, y a su antecesor integrado en 1901 por Sivori, Schiaffino, Della Valle, Ballerini, Rodríguez Etchart y Caraffa. p. 195. La nota es importante porque refiere los comienzos del grupo Nexus, al que califica como guardia joven, y apoya decididamente este tipo de iniciativa juvenil. Transcribimos parte de esa nota :

"Fue también en septiembre, en los primeros días primaverales del año 1901, que en el antiguo salón Freitas y Castillo, un grupo de pintores argentinos, Sivori, Schiaffino, Della Valle, Ballerini, Rodríguez Etchart y Caraffa, respondiendo a un mismo ideal, dispuestos a la defensa y a la lucha, abrieron su primera exposición. Tuvo ésta un gran éxito y se repitió en julio del año siguiente, enriquecida la falange inicial con los nombres de Malharro, De la Cárcova, García, Maggiolo, Marcelino Barneche, Correa Morales y Mateo Alonso.

Después dejaron de vivir Ballerini, Rodríguez Etchart y Della Valle; los demás, asolados por la rudeza del doloroso golpe que suprimía a los más valientes y tesoneros de la fila, ahogados en el enrarecimiento del ambiente, menos propicios que ahora a la floración autóctona, se dispersaron, perdida la fe y el brío del primer momento.

Ahora, después de seis años de la primera tentativa, un grupo de la joven generación, bajo el lema Nexus, se vincula en estrecho compañerismo, en esfuerzo y fe común y en una franca exposición en el Salón Costa nos da clara muestra de sus gallardas condiciones.

La aparición de esta guardia joven [en cursiva en el original] del arte nuestro implica una diferenciación con la guardia vieja [en cursiva en el original], discrepancia en la particular tendencia, técnica distinta, ideal diverso. Esta diferencia nos dará en lo sucesivo interesantes puntos de comparación.

Fernando Fader, personal siempre, amplio y rudo, presenta siete telas ricas de color y más ricas de promesa, que le individualizan entre sus compañeros. Tiene un defecto - gala de su juventud- la impremeditación y la fogosidad, y una alta virtud, la conciencia absoluta de su propio valer. Con más concienzudo reposo, con más respeto por las leyes fundamentales de la técnica, sus obras venideras serán definitivas.

El óleo "Contando ropa" que probablemente el autor propone a los demás, es para mí, entre las suyas, su nota más valiosa.

Pio Collivadino es el que expone en mayor número, óleos, dibujos y aguafuertes, realizados aquí y en Europa" pp. 195-196. Agrega a otros integrantes del grupo Nexus: Irurtia y Quirós que no ha participado de la exposición.

Más adelante da cuenta de las "Manifestaciones extranjeras" entre las que se repasan las obras presentadas en los salones Witcomb y L'Aiglon.

Hay un apartado dedicado a "El desnudo en el arte", en el que Ortiz Grognet se muestra a favor. En esta misma sección con e nombre 'Notas', se dan a conocer noticias varias: la colocación de dos esculturas de Meunier (El sembrador y el Segador, en la Av. Alvear); la compra por parte de la municipalidad del grupo escultórico "El triunfo del trabajo" de Irurtia; el encargo de un monumento a Sarmiento, al escultor Víctor de Pol, para ser colocado en Rosario; la inauguración del monumento a Echeverría realizado por Torcuatto Tasso.

Bajo el título ' Confirmación' Ortiz Grognet da cuenta de su propósito de construir un crítica que no se rija por el criterio de "no herir susceptibilidades" y "ser galantes", que se da por ejemplo en la crítica teatral, y que tiene como resultado el extraviar el criterio del público. Como se ve, la crítica reafirma su ideal de guiar y construir el gusto.

Letras argentinas, por Roberto Giusti, pp. 200-203

-Estudios históricos y políticos, de Lucas Ayarragaray, por Roberto Giusti, pp. 200-201 
Giusti critica la forma en que se organizan los libros, de la cual éste es un ejemplo: se trata de una serie de discursos, artículos, que no conforman un libro con unidad propia. Dice Giusti: "Usase entre nosotros de un procedimiento harto conocido para la formación de los libros. Se escriben artículos en cualquier diario, se envían cartas abiertas, se pronuncian discursos; luego, al cabo de algún tiempo se reúne la producción, sin método, sin crítica, sin una previa selección, y héte el libro formado. Este adolecerá como es natural, de todos los defectos inherentes a una producción ocasional (...)" p. 201.

-Los vencidos, de Marcelo del Mazo, por Roberto Giusti, pp. 202-203. Se trata de un libro de cuentos. La crítica es positiva en relación con la factura y con los argumentos, y también con respecto a las cualidades de psicólogo de su autor, completadas con su delicadeza y su sagacidad.

Teatro Nacional, por Alfredo Bianchi, pp. 204-206

Nacional: Las dos fuerzas por Julio Sánchez Gardel, La rondalla por V. Pérez Petit, La tía Brígida por Alberto Novión

-Las dos fuerzas: “(...) es una comedia en tres actos, de argumento trivial, de construcción débil, caracteres poco precisos, de diálogos faltos de ingenio y de factura literaria mediocre, pues la forma en los pasajes 'cuidados' es justamente aquella que puede mejor dar a los iletrados la ilusión de la 'literatura'.

-La rondalla: “(...) del distinguido escritor uruguayo Víctor Pérez Petit, es un drama en tres actos, de trama sencilla y conmovedora. El interior de un hogar humilde, con todos los diarios incidentes de la vida de familia, está pintado, especialmente en el segundo acto, de una manera verdaderamente sabrosa. Escrito en una prosa firme, nítida, y toda llena de sinceridad La rondalla es una obra robusta y sana, un excelente estudio de costumbres. Los caracteres tienen un relieve bastante marcado, de un análisis un poco sumario, pero bien vivos y dramáticos.

$\mathrm{Su}$ defecto capital lo constituye el tercer acto, pesado, mortalmente aburridor y demasiado cargado en tintes melodramáticos. Es un acto inútil y atentatorio al (sic) buen éxito de la obra" p. 205.

-La tía Brígida: “(...) es una comedia de costumbres camperas llena de frescura, sencillez e ingenuidad. Los diálogos fáciles, chisporroteantes de ingenio, hicieron pasar al público ratos deliciosos. La acción es tan natural, que a ratos resulta muy lenta. Los caracteres, bien precisos, especialmente el de la tía Brígida, admirablemente interpretado por la señora Orfilia Rico. Doña Rosario, La gaucha y las otras obras del señor Novión han demostrado que es un maestro en el género. Si bien en le eje central son todas demasiado similares, siempre encierran detalles interesantes y novedosos que las diferencian unas de otras. Sobresalieron además en la interpretación la señorita Ángela Tesada y el señor Elías Alippi” p. 205

Marconi: Juan Facundo Quiroga por Alejandro Gancedo -Hijo.

Según Bianchi, a pesar de que la obra había estado precedida de una gran réclame, y pretendía refutar una obra de David Peña sobre el mismo tema, el público no la favoreció. Bianchi la considera al menos como una pieza "estimable".

Reprises del Marconi: Los Muertos de Florencio Sánchez ("nuestro Bracco por la potencia y por la audacia" p. 206.); El Arlequín de Otto Miguel Cione (a la que considera buena, más allá de notársele "ciertos toques artificiosos y novelescos")

Notas y comentarios

-Muerte de Sully Proudhomme. La revista quiere dejar también su homenaje al poeta.

-El viaje de Roberto J. Payró.

"Uno más que se marcha a visitar otras tierras.

Forman legión ya los artistas y estudiosos de este país idos a Europa a cosechar experiencia y conocimientos. Payró es uno más de la útil falange. Y él lleva consigo al partir condiciones de las que acaso la mayoría de los viajeros hállase desprovista; lleva consigo una amplia experiencia adquirida en sus largos año de brega en el periodismo; un profundo conocimiento de la vida, de los hombres y 
sobre todo el país, y a más un vivo deseo de aprender y de hacerse nuevos puntos de vista, nuevos criterios en esos nuevos horizontes que se le abrirán.

A través del mar la revista le envía su saludo a este fuerte e incansable trabajador.” p. 208.

-Presente griego. Incidentes y discusiones a propósito de esta obra, que fue la ganadora del concurso del teatro Nacional y que la revista publica en este mismo número.

Libros recibidos

Marcelo del Mazo, Los vencidos

Francisco Capello, Petrarca

F. Enrique D. Sisson, Grisailles el Vitraux

Año I, tomo 1, no 4, noviembre, 1907.

-Leonardo de Vinci........Francisco Capello, pp. 209-225.

-El viejo Tucumán (fragmentos)....... Salvador Debenedetti, pp. 226-229

-Recuerdos del Pío Latino....... Federico Tobal, pp. 230-237.

-Tarde.............Marcelo del Mazo, pp. 238-239. Relato del un espíritu decepcionado del amor.

-Lirios............ Juan Julián Lastra, pp. 240-241 [cuartetos octosílabos]

-Menudencias filológicas ( firmado por Leptir), pp. 242-246.

-Melancólicamente...........Leopoldo Velasco, pp. 247. . [Soneto de tema amoroso. Hay una "pálida doncella" de "ojos pensativos" frente a cuyo paso se queda extasiado el yo lírico]

-Las dos fuerzas......... R D. Carbia, pp. 248-254. Cuento científico.

-En mi estancia........ Arturo Pinto Escalier, pp. 255-256. Tema amoroso.

-Seducción (escena de un drama)..........Gastón F. Tobal, 257-259.

-Letras españolas...............A. Gerchunoff pp. 260-263

-Letras argentinas.............. Roberto Giusti, pp. 264-267.

-Teatro nacional............Alfredo Bianchi, pp. 268-270

-Notas y comentarios.............. pp. 271-272

-El viejo Tucumán (fragmentos), por Salvador Debenedetti, pp. 226-229 En estos versos se narra la historia anterior a la conquista y se caracteriza a "aquella raza que pobló la tierra" p. 226.-

-Recuerdos del Pío Latino, por Federico Tobal, pp. 230-237. En nota al pie de la dirección se explica: "constituye un epílogo a los Recuerdos del Colegio Nacional, que con motivo del 8. aniversario de su fallecimiento, comenzó a publicar en Diciembre del año pasado el Diario" p. 230. Tobal cuenta cómo no llega a ser clérigo. Condena la disciplina militar de los jesuitas. Lo echan del colegio, y vuelve a Buenos Aires, para educarse en la Universidad. Cuenta los viajes que hizo con fray Pedro Durand.

-Menudencias filológicas ( firmado por Leptir), pp. 242-246. Sobre la importancia del latín en la segunda enseñanza y en la universidad. Coincidencias y discrepancias con Unamuno, cuya atención ha llamado con un artículo publicado en La Nación sobre la enseñanza del latín. Quien escribe bajo el pseudónimo de Leptir, aparece como alguien con una formación clásica fuerte, políglota. Concluye abogando por la apertura, en la universidad argentina, de estudios "glotológicos y filológicos" . p. 246.

-Las dos fuerzas, por R D. Carbia, pp. 248-254. Relato que cuenta la historia de un médico latinoamericano, que desairado por una traición amorosa se venga en una paciente, dejándola morir. $\mathrm{Al}$ hacerlo experimenta dolor y placer. El narrador en primera persona no juzga a Inchausti sino que lo comprende.

-Seducción (escena de un drama), por Gastón F. Tobal, 257-259. Tema amoroso. Una joven se enamora del novio de su amiga. El fragmento que se transcribe es el monólogo del arrepentimiento de María Elena. 
Letras españolas por A. Gerchunoff pp. 260-263

-Poesías de Manuel Machado (Museo y Cantares; prologadas por M. de Unamuno).

Se trata de estrofas y sonetos antiguos. Gerchunoff retoma, en el comienzo de su nota, los juicios de Unamuno para coincidir con él y rescata, la frescura no artificiosa del libro: "El rector de Salamanca elogia a Machado. Lo halla jugoso y lleno de gracia y al hacer el análisis de su obra, afirma que, siendo por fórmula modernista e influido por la escuela francesa, está más cerca de los clásicos, como lo estaba de Esquilo, Víctor Hugo a través de Dante y Shakespeare. Considera también el señor Unamuno que Machado, como todo poeta auténtico, es una fuerza de la naturaleza pues su frescura, fuera de artificios pomposos, le da un aspecto de verdad profunda" p. 260.

Considera a Machado en el grupo de los que como Villaespesa, Zayas y Diez Canedo han renovado la poesía española, "arrancándola de la vaciedad de los académicos" p. 261. Explica: "Pertenece Machado al grupo joven que ha roto los moldes añejos que sirvieron a Núñez de Arce para construir sus poemas somnolientos y al desventurado señor Emilio Ferrari sus estrofas sin vida a la sombra de las cuales floreciera el buen Federico Balart" p. 261. Gerchunoff reconoce el mérito de "haber contribuido a la evolución iniciada en América por Rubén Darío" y, en ese marco, lo reconoce como el más castizo de los poetas. p. 261. Y más adelante: “Es Machado el poeta noble de ese tiempo [el de los castillos y los conquistadores] que sabe condensar en el ritmo de sus versos preciosos el ama del rancio pasado y el espíritu de la Andalucía actual, -las dos bellezas de España, la extinguida y la viva.” p. 262

Señala la aprobación de Darío frente a la ceguera de la Academia española: "A Manuel Machado lo criticó sin mesura un grave académico. Rubén Darío le ha elogiado con entusiasmo" p. 262.

-Estrofas de Ricardo Catarineu, p. 263. Se trata de la obra de un escritor que viene del periodismo. Más preocupado por las ideas que por la forma.

Letras argentinas, por Roberto Giusti, pp. 264-267

La sección comienza con un pasaje programático, antes de dedicarse específicamente a los libros. En ese pasaje se pone de manifiesto el estado precario de la literatura argentina, las obligaciones que la crítica debe asumir en ese marco, y se delinea una tradición de literatura nacional. Se transcribe completo.

"Por más que el mérito de tal o cual libro sólo sea escaso, sin embargo se impone en estas notas bibliográficas el elogio, la frase de aliento para su autor, si es que el libro, en su valor meramente relativo, revela un digno esfuerzo o una sana aspiración de arte. Y la razón es obvia.

Nuestra literatura -si es que existe- no tiene sino un valor relativo. Por lo tanto no se puede usar a su respecto el mismo criterio que se emplearía al juzgar la literatura europea. Es de desear, naturalmente, que la producción artística argentina sea de verdadero mérito, mas no han de exigirse imposibles. Por algo hay que empezar. Al lado de un Obligado, de un Groussac, de un Lugones, de un Ramos Mejía y de algunos otros hombres de letras que honrarían a cualquier país ¿cuántos, entre nosotros, cuya labor, que es considerada y es justo considerar con respeto, quedaría borrosa en otro medio?

En estas cosas como en todas, no puede haber criterios absolutos. Con ellos, verbigracia, debiera empezarse por excomulgar desde ya nuestro naciente teatro que, ni vale la pena decirlo, no resiste por cierto el parangón con ningún teatro europeo. Apenas si Sánchez, en algunas de sus obras, se acerca al tipo. Y sin embargo no es cosa de desdeñar la labor de los demás.

¿Y qué decir de nuestra entera literatura? Si a su respecto no se hicieran valer los mismos argumentos, a qué quedarían reducidos Echeverría, Mármol, Andrade o Gutiérrez, al lado de Hugo, de Byron, de Zorrilla. Valuaciones distintas han de regir, no hay duda. Con criterios absolutos no se llega a ninguna parte.

Eso sí, guerra a la mediocridad, a la pereza, a la falta de honradez artística, en una palabra, a la grafomanía" p. 264-265

-Joyeles por Juan Aymerich, pp. 265-266. [sonetos]

Giusti comienza su reseña con una referencia a la cuestión del soneto -que manifiesta conocer-, lo cual señala su figura como crítico especializado. En directa relación esto se lee la vocación por la precisión y el detalle, que la nota pone en primer plano, y que se corrobora en la frase que consignamos: "Sus 
sonetos, endecasílabos y alejandrinos, (salvo dos de versos de dieciséis sílabas)" p. 265. Son cien sonetos parnasianos, según Giusti, pues dominan la línea, el color, por sobre el sentimiento. Se crítica la trivialidad de la rima y los epítetos poco novedosos.

-Cavalcanti, por Luis María Jordán. [cuentos]

Contrariamente a lo que había hecho esperar su primer libro, La túnica del sol, este libro de Jordán defrauda. "En este último libro se ve al autor luchar con la falta de tema." Asunto pobre. El libro se salva por el estilo. "El señor Jordán es un artista y un poeta. Su lengua es fácil, su imaginación rica. Y abundan en delicadezas de expresión dignas de todo elogio" pp. 266-267.

-Vértigos de sol, por Rafael A. Arrieta.

Seis cuentos breves, que componen lo que Giusti define como "Un prometedor librito". Califica los cuentos de ingenuos e interesantes.

Teatro Nacional, por Alfredo Bianchi, pp. 268-270

Nacional: En el cepo por Félix Alberto Zabalía; Jaula de locos por José de Maturana

-En el cepo: comedia en tres actos, de un autor cuya fama hacía esperar una obra mejor. "Obra artificial en absoluto, En el cepo es falsa como una pintura de costumbres, endeble en la descripción de caracteres, al punto de no haber uno solo que se destaque nítidamente en ese conjunto de tipos chirles y mediocres que circulan en la comedia.

Tan absurda va siendo la obra a medida que avanza en su desarrollo, que hubo momentos en llegamos a creer que el señor Zabalía se hubiera propuesto, a sabiendas, especular sobre la vulgaridad intelectual de nuestro público. Pero si tal fue su objeto, éste le salió errado, pues la indiferencia más aplastadora acogió esta tentativa fracasada. Y lo más lamentable del caso, es que parece que el autor se propuso hacer con esta obra, una obra de tesis. ¿Defensa del divorcio? Por ningún lado vemos que los matrimonios que nos presenta en la comedia, prueben algo en favor de la ley." p. 268.

Jaula de locos. Bianchi se refiere a Maturana como un "autor apreciado". Aunque se trate de una obra que solo pretende "divertir al auditorio" a juicio de Bianchi debería "su grano de buen sentido" p. 269.

Apolo: La conferencia de La Haya por Nicolás Granada

El comentario de la obra está precedido por una queja sobre el momento de crisis que atraviesa el teatro nacional: "Nuestro teatro se halla indudablemente en un período de crisis. Surgió vigorosamente hará unos cinco años, casi como en movimiento de reacción contra el malhadado género chico que tan estragado tenía nuestro gusto. A pesar de que en el transcurso de estos años, se dieron muchas obras malas, casi todas eran tentativas más o menos serias y por lo tanto dignas de estima. Pero, de un tiempo a esta parte, se nota en nuestros autores una evolución alarmante. La mayoría tiende a la fácil composición de sainetes y zarzuelas de fácil aplauso, pero con el agravante de ser estas piezas lo más antiartísticas y groseras. Siquiera, en aquel género chico tan combatido, se encontraba, de vez en cuando, una buena letras y una buena música.

Estas reflexiones nos surgen con motivo del estreno en el teatro Apolo de una revista humorística cómico-lírica [en cursiva en el original] titulada La conferencia de La Haya, cuyo autor es el conocido escritor don Nicolás Granada.

En absoluto desaprobamos este género de producciones teatrales. $\mathrm{Ni}$ el vaudeville [en cursiva en el original], ni la zarzuela, están dentro de la literatura. Y no se crea que estas observaciones son inaplicables a la obra que las origina.

La conferencia de La Haya, es una sátira grosera e inconveniente, en la que se ponen en la picota del ridículo a naciones, que ahora menos que nunca nos conviene ridiculizar, si no queremos perder nuestra secular tradición de cultura.

Lo único bueno de La conferencia de La Haya, fueron las decoraciones. Estas merecen una felicitación.

Aparte de esto, la interpretación de la revista fue bastante buena. Demasiado buena, como alguien dijo, dado el escaso valor de la última producción del señor Granada, quien debe volver a tentativas sanas y serias como Al campo y La gaviota, si desea ser aplaudido sin reticencias." pp. $269-270$

Marconi 


\section{Dice Bianchi:}

"En este teatro no habido ningún estreno. Quizás sea mejor.

En cambio, con motivo del beneficio del estimable actor Pedro Gialdroni, volvió nuevamente al cartel en familia, esa sencilla, sobria y hermosa comedia de Florencio Sánchez. En el rol de Eduardo, renovó el señor Gialdroni sus triunfos de hace dos años.

Verdaderamente, el asistir a la representación de una obra de Florencio Sánchez, constituye un merecido reposo para el espíritu conturbado por tanta obra mediocre. Sin género alguno de duda, el señor Sánchez es el primero de los autores dramáticos argentinos" p. 270.

Notas y comentarios

Se transcribe una carta (respuesta) de Unamuno a Giusti. Esta carta es importante porque en ella el escritor español insiste en una política de integración, con la cual la revista coincide. Transcribimos el texto completo, que además aparece citado, en parte, en el cuerpo del trabajo.

"Don Miguel de Unamuno - El ilustre rector de la Universidad de Salamanca, ha contestado, a nuestro pedido de colaboración con la carta que, gustosos, a continuación insertamos:

Señor, don Roberto Giusti. - Mi estimado señor: llegó su carta a esta mi casa estando yo ausente de ella, de veraneo en mi país vasco, y hoy me llega el segundo número de Nosotros -el primero no lo he visto. El número este que tengo delante me agrada; es de fisonomía simpática. Veo el esfuerzo a darle variedad y a conjuntar la amenidad con la seriedad. Porque las revistas o suelen pecar de superficiales o de inamenas.

Encuentro un trabajo de Carlos Octavio Bunge, mi buen amigo, y siento una punzada de reconvención porque aún no he dedicado el trabajo que debía a exponer los méritos de ese trabajador infatigable que tanto hace por elevar el nivel de la cultura de su patria. Lo que más me gusta en Bunge es su ahínco por tratar las cosas en hondo y en vasto, la tendencia genuinamente filosófica de su pensamiento.

Algún otro conocido encuentro en el número.

Quisiera poder gozar pronto de un respiro en mis crecientes tareas para enviarles algo a Nosotros, incluyéndome así -y muy honrado con ello- en ese pronombre titular de la revista.

Creo que ahí, en la Argentina, lo mismo que aquí, en España, es de necesidad crear un núcleo de jóvenes atentos a las formas más elevadas, más puras, menos pragmáticas -aunque no por eso menos hondamente prácticas- de la cultura, a todo lo que siendo hoy un nuevo lujo espiritual para la colectividad en conjunto, llegará a ser mañana sustancia de la patria. Una nación necesita alma y alma duradera y fuerte, y ésta no puede encontrar ni duración ni fuerza sino en la visión de una elevada finalidad, que trascienda del bienestar y la riqueza de las generaciones actuales. La labor de ustedes tiene que ser dar personalidad espiritual a la patria argentina, y que tenga un signo y sello y un valor para los demás pueblos. Y esto es más necesario donde las continuas avenidas de gentes extrañas, de emigrantes, tienden a romper la unidad de carácter espiritual. La unidad de ustedes deberá ser unidad de integración, no de homogeneidad, y por eso es más difícil.

Y basta de divagaciones.

Con ustedes, con Nosotros, estoy en espíritu y en anhelos, y ojalá su labor sirva a la vez para enriquecer la cultura de esa tierra, para hermanarle más con los demás pueblos de lengua castellana.

Los saludo su affmo.- Miguel de Unamuno. Salamanca, octubre 10 de 1907." pp. 271-272.

-Comentario sobre El Tiempo en su aniversario $14^{\circ}$ y saludo a Carlos Vega Belgrano, su director. El diario aparece como un ejemplo de "integridad y civismo" por haber mantenido la "bandera de los más sanos principios, en medio del turbulento embate de las pasiones políticas"; "protector" para los que en él han publicado sus primeros trabajos.

-Comentario sobre la nota en La Cultura española en la que se elogia la conferencia de Francisco Capello, profesor de literatura griega en la Facultad de Filosofia y Letras y colaborador de Nosotros, sobre Josué Carducci.

\section{Año I, tomo 1, n 5, diciembre, 1907 (Editada bajo el sello de Arnoldo Moen y hermano)}

- Azorín ...........Juan Mas y Pí. pp. 273-84.

-"La mesa" (del libro La casa de la primavera que aparecería en breve) G. Martínez Sierra -fechado en noviembre de 1907 en Madrid. pp. 284-289. 
-Una historia inmoral........ H. Quiroga. pp. 290-297.

-"La poesía del progreso". Alberto Insúa. pp. 298-300

-"La copla en el camino"......... E. Banchs. 301-307 [cuartetas eneasílabas, consonantes. abab]

-"Eucaristía"........ Antonio de Hoyos y Vinent, -Madrid, nov. 1907- 308-311.

[Dedicado a Carlos Octavio Bunge]

-"Prosas para Margot" José Pardo, pp. 312-14. Tema amoroso.

-"Bajo la angustia", "Al pasar"......... E. Carriego pp. 315-16.

-"La corte de los milagros".........Juan Luis Ferrarotti, 317-321.

- El canto errante, de R. Darío.......... Eduardo Talero, pp. 322-326.

- Letras argentinas........ Roberto Giusti, pp. 327- 336

-Teatro nacional....... Alfredo Bianchi, pp. 335-338. Situación de plena barbarie del teatro nacional.

-Notas y comentarios.........pp. 339-341

-Índice del tomo........ pp. 342-344

- Azorín por Juan Más y Pí. pp. 273-84. Ensayo en que el crítico promueve al escritor como "la personalidad más interesante de la literatura española”. p. 283.

-"La poesía del progreso", por Alberto Insúa. Relato del paseo a pie del narrador y un poeta por Alcalá. Descripción del progreso. Se señala la relación entre la poesía y la época. Así se hace necesario cantar al progreso. pp. 298-300. Remarca la inevitabilidad del cambio en la temática de la poesía.

-"Bajo la angustia", "Al pasar", por E. Carriego pp. 315-16. En "Bajo la angustia" el personaje es hermana tísica; en "Al pasar", la costurera/ trabajadora decente.

-"La corte de los milagros", por Juan Luis Ferrarotti, pp. 317-321.

Es la narración de la bohemia de un grupo de café literario. "Cuando aparezca mi obra, donde se hermanarán sin obstruirse Verlaine, Ibsen, Sade y Mallarmé nadie se atreverá a discutir la existencia de la literatura nacional" p. 319. "Morir desconocido es muy triste". "es preciso que formemos el auditorio". Se citan revistas nacionales e internacionales reconocidas: Caras y Caretas, Pulgarcito, el Mercure; se señala el camino o itinerario del reconocimiento: la prensa, caricatura en Caras y caretas, luego, París. "Sí, che. Lugones y Rubén Darío se repiten. Hay que renovarlo todo. Nuevas formas, nuevas escuelas. Es la ley fatal, los nuevos deben luchar contra los viejos. En literatura, un año da patente de vejez. Creo que debíamos empezar por una revista..." p. 320. Este texto es importante porque en él se ven las diferentes evaluaciones sobre las instituciones, los artistas, las formas de consagración, tipos de subjetividad, expectativas, circuitos culturales prestigiados, etc. Se habla de las revistas y de la necesidad como grupo de publicar una revista. "Su obra era él": frase que condensa la idea central de la bohemia.

- El canto errante, de R. Darío, por Eduardo Talero, pp. 322-326.

Talero señala el carácter antiacadémico del libro de Darío y lo nombre como "nueva obra maestra". Se refiere al prólogo del libro, y cita varios pasajes. Es importante destacar que uno de ellos se refiere a: la necesidad de independencia de la literatura, en la que Darío cifra el sentido de la palabra "aristos"; a la atención de Darío a la cultura clásica, pero fundamentalmente a la que le es contemporánea; a la oposición del culto exclusivo de la palabra, resaltando la vinculación de la palabra con la idea. Talero dice que las frases que transcribe del prólogo de Darío vienen "de perillas para la literatura sudamericana, donde el prejuicio aún ocupa reductos coloniales". Y sigue: "El estado de nuestras letras puede partirse en dos bandos: los que siguen al clasicismo español inconsciente y servilmente; y los que siguen a los innovadores sin comprenderlos, y también servilmente. (...) Gran culpa de esto la tienen los profesores de literatura, quienes enseñan a sus discípulos a pensar según que se le ocurrió al señor don José Mamerto Gómez Hermosilla, y no más. (...)

Felizmente, en Sudamérica hay un buen núcleo de renegados que no llevan en paciencia dictaduras y se han resuelto a tener el valor de tener talento y pensar con la cabeza que llevan sobre los hombros" [en cursiva en el original]. Reconoce en Darío al iniciador de tales "audacias" pp. 324-325

En el final de la nota remarca el carácter inevitablemente cosmopolita de los pueblos sudamericanos: "Soy un gran convencido de que los sudamericanos, como pueblos que habrán de ser 
cosmopolitas, tenemos que estudiar muy a fondo las literaturas extranjeras, y en especial la clásica española: pero creo también que nunca haremos letras propias siguiendo escuelas importadas ni aborígenes, sino perseverando en el tesón de hacer y respetar la obra individual” p. 326.

Letras argentinas, por Roberto Giusti, pp. 327- 336

-El derecho, por Carlos O. Bunge. Giusti presenta a Bunge como "un infatigable escritor" al que rinde homenaje por su labor intelectual. la obra es de índole didáctica. Es importante la aclaración de Giusti puesto que recorta la sección como 'Letras argentinas' como un espacio de discusión específica: "Mi propósito no obstante al trazar estas breves notas no es sino el de ocuparme de un único capítulo que más que ningún otro ha despertado mi interés. La índole especial de esta sección, consagrada exclusivamente a las letras me excusa de que no me detenga en un examen minucioso de la obra entera". Se ocupa de la ética y critica la teoría de la ética de Bunge ('sistema positivo de ética') pp. 327-331. Esta ética está sustentada en principios sin apoyatura real.

-Borderland, por A. Chiappori. pp. 331-333. Crítica elogiosa. [cuentos] Sus personajes son según Giusti 'tipos', "almas trágicas o anormales". "El señor Chiappori ha arrancado sus tipos a los libros de psiquiatría" Señala una relación con Poe. Para Giusti esta literatura no es nueva pero sí lo es la forma en que la realiza Chiappori, sobre todo su estilo "trabajado, sutil y preciso"

"El señor Chiappori, inquiridor curioso de hechos mórbidos, ha puesto en alguno de sus mejores cuentos todo un caso científico, ocultando su triste aridez con el ropaje elegante de su fino arte. 'Un libro imposible' por más que finalice con una inconvincente escena de finalización de cuento fantástico -ipero tan hermosa, tan original!- a ella llega empero por un ingenioso razonamiento lógico. Esa última escena remata el curioso desarrollo de una teoría en boga, sabiamente aprovechada, la teoría somática de las emociones, que, con una claridad en que el arte no daña a la exactitud científica, expone el señor Chiappori en unos pocos párrafos de un tecnicismo riguroso. Abundan además en el libro y en esa primer novela [la había definido como novela corta] principalmente, mil peregrinas teorías, mil observaciones psicológicas de no escaso valor, que acreditan en el señor Chiappori es un espíritu penetrante y reflexivo." p. 332

En el final de la reseña, Giusti le aconseja dejar de lado ese tipo de literatura: "El señor Chiappori se ha estrenado con una obra aristocrática y refinada, por consiguiente poco accesible al vulgo, pero que ha de darle entre nuestros escritores la posición que bien merece. Este Bordeland es una flor extraña: es un libro demasiado doloroso. Sobre sus páginas se cierne una atmósfera malsana. Por eso, expresando una opinión puramente personal, sin pretensiones de despacharla como receta, gustaríame que el señor Chiappori se apartara desde ya de esta literatura anormal, y nos diera con su estilo tan propio, tan inconfundible, algún otro libro, -cómo decirlo?- más sano, más humano.......” p. 333.

-Almafuerte por Juan Más y Pí. Giusti festeja la aparición de este libro, sobre todo porque en la Argentina no abundan los estudios de crítica. Además, se trata de un autor cuya obra, en su mayor parte, no se ha editado.

"Siempre han sido descuidados en el país los estudios de aliento sobre tal o cual escritor, sobre éste o aquel aspecto de nuestras letras. Bien sé que en general ellas valen muy poco, mas no a tal punto de no presentar lados interesantes para la curiosa mirada de los que a tales estudios gustan de aplicarse." p. 333. Más y Pí es presentado como discípulo de Almafuerte. En una nota al pie consigna la lista de los críticos que realizan una tarea sostenida: "Los que han enriquecido nuestra bibliografía crítica, pueden contarse con los dedos de la mano: Mitre, Groussac, García Mérou, Quesada, fray Otero, Saldías, Urien, Gez, Reynall O'Connor...Prescindo de la crítica militante de cualquier época y confieso que a alguno sólo lo he citado a título de curiosidad" p. 333.

-Intención y voluntad por Mario A. Carranza. Crítica negativa, luego matizada.

Para Giusti es un libro desconcertador, poco uniforme, que toca materias diversas. Luego de haber criticado el hecho de defraudar las expectativas del título (se esperaba algo de mayor envergadura filosófica, ya que se citaba, en francés, un lema de Nietzsche), Giusti señala: "A pesar de esto [declararse admirador de A. France] el señor Carranza tiene convicciones, sólidas convicciones de las que carece el Maestro, o mejor dicho, el France de la primera hora, que más tarde él hubo de adquirirlas. Son fuertes y saludables las convicciones del señor Carranza. Tampoco fáltale audacia para pensar y criticar, y eso es bueno. En este sentido el libro merece un aplauso. Repito no obstante que no me entusiasma, aunque veo 
en él un millón de cosas de que generalmente carece nuestra producción. Creo por consiguiente que, sin necesidad de entonar prematuramente fanfarrias triunfales por este libro común, bien intencionado y mal compuesto, aún desde el punto de vista estilístico, puede esperarse de su autor alguna otra obra más uniforme a la que sin duda ni le faltará nervio ni utilidad. 'Es tan triste convencerse inútil'. Sí, tiene razón el señor Carranza, pero para alcanzar a ser útil no deben ahorrarse esfuerzos, se debe escribir y pensar con el sudor de la frente, y si es posible con la propia sangre" p. 336.

Teatro nacional, por Alfredo Bianchi, pp. 337-338.

Se despacha acerca de lo que considera una situación de plena barbarie del teatro nacional. Transcribimos la nota completa.

"Nuestro teatro se halla en un período de plena barbarie. ¡Barbarie! la palabra puede parecer un poco dura, pero, sin embargo, es la única verdaderamente justa.

Un mal humillante, un mal contagioso ha invadido los escenarios. La inmoralidad y la grosería.

Al salir, después de haber asistido a la representación de algunas de las obras que hoy se estrenan, me preguntaba qué singular extravío podía haber guiado la mente del autor a concebir tal asunto y a entregarlo en manos de una compañía. ¡Porque hemos visto cada obra! ..... ¡ah!, ¡cada obra!!

Hoy en día ¿dónde poder conducir [a] una hija o [a] una hermana. Verdaderamente no se sabe. De vez en cuando, se ven en los carteles algunas de las buenas obras de épocas anteriores, pero, con todo, no hay un buen teatro, un teatro donde, después de nobles emociones, después de sanas alegrías, se está al abrigo de alguna pieza grosera presentada brutalmente.

No pido como remedio esa cosa torpe, equívoca y sobre todo impotente, que se llama la censura. No, ése no es un remedio, pues nunca ha curado nada. La censura debe partir del mismo público, el cual, es necesario se decida de una vez por todas, a no tolerar la representación de obras que, poco a poco, van efectuando un lento trabajo de embrutecimiento popular. No debemos olvidar que teatro influye singularmente sobre la marcha y la calidad de los hechos ambientes.

Hay que reaccionar. Lo menos que podemos exigirle a una obra es que sea moral. Llamo pieza moral, simplemente [a] aquella que no daña las costumbres. El bien está en el arte natural. El arte es el bien mismo. Desembaracémosle de la concurrencia que el mal le hace por todos lados, y veremos cómo se afirmará.

¿Conocéis La piedra de escándalo? El suceso prodigios de esta obra es un síntoma considerable. En pleno medio popular ha triunfado, tanto por los golpes escénicos que en ella se hallan, cuanto por ser una obra sana y moral. A pesar de sus defectos, tiene La piedra de escándalo un sello de distinción artística que puede presentarse como modelo a esta generación de escritores que acostumbran sonreír de los triunfos del poeta Martín Coronado, y nos dan en cambio productos incalificables.

Entre nosotros, se dice que hay como cien autores. Constituye la enfermedad del momento actual, esta necesidad infantil de producir y aparecer como autor. Seguramente la mediocridad vanidosa es vieja como el mundo, pero hasta poco era, por lo menos, una planta de jardín, mientras que ahora se cultiva por todos lados. Cada actor, músico o portero de teatro, se considera en el deber de escribir su obra. Yo no sé si esto es progreso.

Ante tal bancarrota de inventiva, aconsejaríamos a nuestros autores, se dedicaran a la traducción de las obras de mérito de los repertorios extranjeros. Así hemos visto, con satisfacción, que el señor Nicolás Granada, antes que reeditar su Conferencia de La Haya ha preferido traducir un intenso drama de Ugo Ojetti. Este es un ejemplo que debiera ser imitado" pp. 337-338.

\section{Notas y comentarios}

- 'Palabras de aliento': se refiere la carta que José E. Rodó envía a la redacción de Nosotros

"Desde el primer momento la dirección de esta revista pensó en extender su acción más allá de las fronteras de la patria, con el sano propósito de que ella fuera un medio más, acaso insignificante pero de todos modos eficaz, para robustecer los débiles lazos intelectuales que unen esta república con las restantes de América Latina y con la madre patria." p. 339. Transcribimos completa la carta de Rodó:

"Señores directores de Nosotros -. Gracias, de corazón, por el amable envío de Nosotros.

Desde el primer día de su aparición estoy con ustedes y tengo hecho el propósito de corresponder al pedido de colaboración. Ello será en breve. Entretanto, quiero que sepan con cuánto íntimo placer veo desplegarse, gallardamente, en nuestro mar de indiferencia y de tedio, las velas de la valerosa revista, para una nueva expedición de arte, de idealidad, de belleza. Para estas aventuras, para 
estas búsquedas de fabulosos vellocinos, siento mi entusiasmo intacto y mi fe tan candorosa y eficaz como siempre. ¿Sobre qué versará mi colaboración? No son temas los que faltan. Recuerdo, por ejemplo, que ha tiempo tengo contraído conmigo mismo el compromiso, muy grato, de escribir sobre las últimas obras de Ángel de estrada, ese espíritu de selección, de estudio y de arte que tanto realza al nuevo pensamiento argentino.

Entre los nombres que presenta el periódico de ustedes, reconozco con afecto a muchos de quienes de antiguo son mis amigos, y veo, con interés y simpatía, nombres nuevos que desde ahora, son para mí nombres de amigos también. Para todos, mis más cordiales sentimientos; y para ustedes, que llevan la mano en el timón, mis mejores aplausos y mis mejores votos. -José Enrique Rodó. Montevideo, 30 de noviembre de 1907" pp. 339-340.

-Se menciona la incorporación, como colaborador y a cargo de 'Letras brasileñas', de Elysio de Carvalho. Juan Más y Pi -anterior encargado de 'Letras brasileñas'- se ocupará en delante de 'Letras catalanas'.

-Relata el caso del artista José A. Merediz, pintor en formación, que se dedica completamente -y en París- a estudiar "con ambición, obstinación y fe en sí mismo", virtudes por las que la dirección de la revista le augura un "lugar grande y honroso en el arte pictórico nacional" p. 341.

Libros últimamente recibidos: con este título, bajo el que se repiten los títulos de libros ya citados en números anteriores, se informa sobre los pocos libros nuevos del mes. La lista es la siguiente:

Joyeles por Juan Aymercih

Cavalcanti por Luis María Jordán

Vestigios de sol por Rafael A. Arrieta

Liminares por Enrique Pellegatta

El derecho por Carlos O. Bunge

Borderland por Atilio M. Chiappori

Corazón por Ricardo Levene

Almafuerte por Juan Más y Pi

Intención y voluntad por Mario A. Carranza

El país de la selva por Ricardo Rojas, del que dicen se ocuparán en el número siguiente de la revista.

Algunas críticas por José H. Rosendi, del que se ocuparán en el número siguiente

Bartolomé Mitre, discurso conmemorativo, por el prof. Giov. B. Sivori

Corona fúnebre por Luis F. Suárez

Biblioteca Nacional "Non [Nec] plus ultra"

Pensamientos por Martín Bernal

\section{Año II, tomo 2, ${ }^{\circ}{ }^{6}$ y 7 , enero-febrero de 1908}

Dedicado a Florencio Sánchez. Se publica Los derechos de la salud, que ha sido representada en Montevideo.

Explicación La Dirección pp. 5-6

Los derechos de la salud Florencio Sánchez, pp. 7-58[

Bravo Sánchez Juan Cancio pp. 59-60 [seudónimo de Mariano de Vedia]

Charlas de un montevideano Samuel Blixen, pp. 61-64

En la frontera V. di Napoli Vita pp. 65-68

Florencio Sánchez ................ Joaquín de Vedia pp. 69-70

Florencio Sánchez................. Carlos Octavio Bunge, pp. 71-73

La obra de Florencio Sánchez, Raúl Montero Bustamante, pp. 74-75

El hermano Florencio ................Antonio Monteavaro, pp. 76-78

Florencio Sánchez Arturo Giménez Pastor pp. 79-80

Florencio Sánchez .................... Luis Doello Jurado p. 81

La labor de Sánchez Ambrosio Pardal pp. 82-86

Los derechos de la salud. Alfredo A. Bianchi pp. 87-90

Revista de revistas. Alfredo Costa Rubert pp. 91-93

Notas y comentarios. Nosotros pp. 94-96 
Esta nota de la Dirección de la revista es programática en cuanto a la camaradería intelectual y el pacto de sociabilidad que son modelos de conducta entre intelectuales. pp. 5-6

Transcribimos la nota completa, de la que nos ocupamos en el cuerpo del trabajo, a propósito de la relación Giusti-Lugones.

"La dirección de la revista ha resuelto dedicar el número de la fecha a Florencio Sánchez.

Justifica este homenaje el éxito completo de su última obra Los derechos de la salud, estrenada en Montevideo y en Buenos Aires, casi simultáneamente.

El homenaje es sencillo: no supone una trascendencia de ninguna especie, ni pretende ser una consagración. Sólo es una forma discreta de dejar sentados públicamente el aprecio y la admiración que Sánchez ha sabido conquistarse con su obra ya vasta y multiforme, aprecio y admiración que abonan en este número las firmas de insospechables escritores.

Los puritanos de la literatura suelen clamar sobre estos impulsos sinceros que califican de "mutuo elogio". Bien sea: mutuo elogio, sí; pero ¿acaso fuera preferible un ideal de vida literaria en el que cada escritor se encastillase en sí mismo, envolviendo en profundo desprecio a los demás? ¿cómo han de surgir las buenas, las nobles, las fecundas ideas; cómo han de formarse las sólidas reputaciones sino al calor de los círculos literarios, sino mediante el mutuo apoyo, el mutuo estímulo, exteriorizados por el artículo, la carta, el consejo?

No, no son por cierto de despreciar aquellos que se alientan, que se defienden, que se unen para afirmarse y combatir de este modo la indiferencia del medio. Y no se diga que, merced a la misma receta, unos poco tontos logran a menudo levantarse, pues se debe pensar que ese endiosamiento de este o aquel mal escritor por medio de los elogios de sus colegas, a más de ser efímero nunca engaña a los que en verdad han hecho un culto del arte.

Sí, hay que unirse y afirmarse, en este país principalmente, donde, cuando el indiferentismo de los más, no ahoga las verdaderas manifestaciones literarias, surgen el esnobismo corriente, la carencia de un justo criterio artístico, a achicar todo lo nuestro en odiosos paralelos con lo europeo. No se trata por cierto de ensalzarnos más de lo que valemos; pero también es justo resistir el convencimiento ya aceptado, general, de que existe un abismo infranqueable entre los escritores europeos y los americanos. Imposible fuera actualmente hacer entrar en muchos cerebros que júzganse despiertos, la idea de que tal o cual obra argentina bien vale tal otra europea, si es que no la supera.

Estas razones y más que por lo extensas o lo sabidas no se exponen, han movido a la dirección de la revista a tributarle este modesto homenaje a Sánchez, quien es sin duda en estos momentos, a juicio de la mayoría de los que se ocupan de arte, un pilar necesario, indispensable, de los más indispensables, de nuestro naciente teatro." pp. 5-6.

Bravo Sánchez, por Juan Cancio pp. 59-60

La nota se refiere a la ausencia de los hombres de letras, críticos y aficionados en la última representación de Los derechos de la salud que ha sido un éxito, y se pregunta: "¿con qué derecho se pretenden tales [críticos, aficionados, hombres de letras], cuando no son capaces de ir a rendirse frente a un triunfo indiscutible del talento, frente a la primera prueba real de gran teatro verdadero, concebido y ejecutado amplia y definitivamente por una inteligencia bien nuestra". p. 60 Y sigue: "Es que no hay solidaridad intelectual, o es que cuesta mucho admirar y aplaudir todavía en Buenos Aires? Lo primero podría ser consecuencia de lo segundo; pero también podría ser explicación y causa" p. 60. (...) "Era muy común considerar a Sánchez como un feliz autor de primeros actos (...) Era igualmente muy común la idea d que Sánchez se desprendería con dificultad de su teatro primero, del ambiente asfixiante y del medio bajo o torpe de sus producciones anteriores; pero en éstas ha levantado todo por igual -nivel y lenguaje- sin incurrir en una sola vulgaridad, en una sola disonancia, en una sola falta de gusto". Esto es producto según el crítico del "talento" y del "trabajo" de Sánchez.

Charlas de un montevideano, por Samuel Blixen pp. 61-64.

En el marco del elogio rotundo de esta obra de Sánchez, Blixen va dando, como todos los que escriben en este número de la revista dedicado al autor, una poética para el teatro nacional más o menos compartida - no acordada, pero sí compartida. Señala los defectos de las obras anteriores a la luz de su corrección en Los derechos de la salud: "En todas [las obras previas del autor] encontraba que reprochar la índole crítica de mis aficiones teatrales, y sin desconocer en el joven y valiente autor, 
excepcionales condiciones para la escena, al constatar la seguridad de su instinto en materia de efectos y de recursos, muchas veces tuve que limitar el elogio, deplorando la evidente falsedad o la exagerada audacia de ciertas 'tesis', por él sostenidas, con un inmenso talento digno de ponerse al servicio de ideas menos pueriles. (...) en todas las obras anteriores , notaba fallas, lagunas, puntos débiles, y, sobre todo, advertía un evidente artificio en la manera de solucionar los problemas sociales o psicológicos, abordados, siempre, eso sí, con una laudable valentía. El pensamiento de la obra era franco y honrado, pero los procedimientos escénicos, por medio de los cuales se desarrollaba ante el público, carecían muchas veces de esa honesta sinceridad...." p. 61

(...) "Idea fundamental novedosa, clara y exacta; argumento sobrio y lleno de interés; originalidad en las situaciones; riqueza de observación psicológica; caracteres lógicos y bien trazados; acción rápida y segura; diálogo admirable por la naturalidad, el colorido, y la elocuencia... todo eso hay en Los derechos de la salud. Producción modernísima por su tendencia doctrinaria, casi clásica, resulta por la sencillez de sus recursos y la sobriedad de su belleza. está impregnada de ese optimismo sano y cruel que Nietzsche ha inculcado en las almas contemporáneas, y que da razón hasta a las mismas perversidades de la vida" p. 62

\section{En la frontera, por V. Di Napoli- Vita}

Es quien traduce al italiano M'hijo el dotor, que es representada por la compañía que en el teatro Argentino arman Antonio Bolognesi y Ema Pirovano.

"Con sus últimas obras Sánchez dejando de reflejar el ambiente campesino, demasiado local, que daba a su teatro un carácter del todo semejante al de las obras dialectales del viejo mundo latino, ha levantado la expresión de los tipos y de las costumbres regionales a la dignidad de tipo general: el arte rústico, con el drama Los derechos de la salud se ha vuelto arte nacional, orgullo de una base de teatro sudamericano, del que el autor bien puede, cual representante, presentarse en la frontera, alta la frente, yendo a reclamar el lauro que le espera" p. 67.

"Descubrámonos, y agitemos en señal de aplauso estimulante nuestro sombrero, saludándolo, mientras él se encamina por el ancho sendero que conduce al Templo!" p. 68

Florencio Sánchez, por Joaquín de Vedia

Rescata de Sánchez la indiferencia frente al éxito, su talento y su originalidad: "No conozco ningún comediógrafo -verdad es que conozco muy pocos- más indiferente al éxito inmediato de las propias creaciones." p. 69 "No e obsede la preocupación de plantar bandera más alta que las banderas de los demás; ni corre la carrera de los carteles, que es en sustancia la carrera de la vulgaridad. Hace teatro, simple, espontánea, insensiblemente, porque comenzó a hacerlo, porque ha de seguir haciéndolo (...)" p. 70

Florencio Sánchez, por Carlos O. Bunge

Considera que "El autor posee un indiscutible genio dramático" comparable al de "un diamante en bruto", a la vez que nota "cierta falta de pulimiento y de ideal. No quiero decir con ello que el teatro de Sánchez sea una vulgar fotografía de la vida, sin ideas ni personalidad" p. 71. Agrega: "En cuanto al fondo, Sánchez hace siempre primar en sus personajes los apetitos y pasiones sensuales, sobre estímulos y móviles más bellos... ¿Puede hacérsele un cargo por eso? ... En manera alguna, pienso, puesto que Sánchez ve así [cursivas en el original] la vida. 'El arte, como dice genialmente el menos artista de los grandes escritores, Zola, es la Naturaleza vista a través de un temperamento'. (...) Sánchez es Sánchez." p. 72 La única crítica que le hace se refiere a la artificiosidad que, por momentos tiene el lenguaje de los personajes.

"El teatro de Sánchez, en general el teatro criollo, es lo que algún crítico francés, refiriéndose a Berstein llama 'teatro frenético'. El diálogo se presenta escueto y desnudo en una violenta trama pasional e ideológica. No hay matices, no hay paréntesis, no hay absolutamente serenidad. Desde la exposición al desenlace la acción va rápida y segura como una puñalada.”p.73 Según Bunge, Sánchez hace "arte verdadero" y por eso mismo, "hace moral". p. 73

La obra de Florencio Sánchez, por Rómulo Bustamante

"Fuera de estos dos elementos esencialísimos y fundamentales [intensidad y eficacia], hay en la obra del dramaturgo oriental una honrada tendencia hacia la simplicidad y el realismo, que a menudo crea 
escena[s] de tan cruda verdad que la idealidad desaparece frente a la vida transportada sumariamente al teatro. Pero estas caídas que suelen angustiar por lo crueles, están admirablemente engarzadas en la obra, donde una concepción general de la vida, un poco romántica, la mantiene constantemente ajustada al diapasón de una discreta idealidad.

Por lo demás, Sánchez modela con maestría los elementos psicológicos del drama: espíritus, pasiones, sentimientos, emociones, en sus manos cobran animación y vida, forman personalidad, constituyen acción y chocan, se funden o rechazan" pp. 74-75.

El hermano de Florencio Sánchez, por Antonio Monteavaro

Se refiere el talento del hermano -Alberto- de Sánchez y a la admiración que mutuamente se profesan.

Florencio Sánchez, por Arturo Giménez Pastor

Remarca las "extraordinarias facultades de interpretación artística de la realidad, que le permiten llevar la vida la escena sin que pierda nada de su intensidad al pasar por el crisol donde el arte la depura de cuanto en ella obsta ala armonía estética, y, sobre todo, por el precioso don de la espontaneidad que caracteriza en Sánchez el sentimiento del teatro, gracias al cual realiza sin esfuerzo ni artificio, con certera visión y justa medida, la obra ideal, a un tiempo mismo creación y verdad" p. 79.

Florencio Sánchez, por Luis Doello Jurado

Declara su admiración por Sánchez y su preferencia por algunos personajes - el haragán de En familia- y algunas obras -La gringa.

La labor de Sánchez, por Ambrosio Pardal

Destaca, lo mismo que Joaquín de Vedia, la actitud de Sánchez "ajena a toda concesión al público". Aclara que se refiere a las obras no escritas "pane lucrando".

"Se reveló con M'hijo el dotor. (...) Allí Sánchez se reveló realista verdadero: el campo que nos dio era el campo que todos conocemos; sus tipos, esos tipos con quienes todos hemos hablado. La psicología del viejo estaba presentada de mano maestra.

Luego, una a una, vinieron las demás obras. Inmediatamente Pobre gente, de un realismo idéntico al de M'hijo el dotor, aunque en un escenario distinto. Y después, La gringa, obra maestra que desconcertó por su salvaje robustez. La gringa se me hace que representa en el teatro de Sánchez lo que La tierra en la obra de Zola. No me refiero naturalmente al contenido sino al valor representativo de ambas obras como notas discordantes por su aspereza, en le concierto de otras obras de una crudeza menos enérgica. En La gringa Sánchez derramó la lengua de sus tipos camperos, esa jerga multiforme que ora es el cocoliche en boca de este gringo, ora es el criollo en labios del paisano, ora el lenguaje de la ciudad, español adulterado en boca de aquel pueblero.

La gringa es un drama lleno de vida y de pujanza, disgustante a ratos por su desnudo naturalismo, pero siempre humano, siempre verdadero, siempre sincero. E además una obra saludable. Entraña un símbolo: significa la lucha entre el progreso y la rutina, entre al inmigración fecunda y triunfante, y la raza del suelo, noble raza, pero estacionaria y vencida. La gringa encarna de un modo más vívido, más vigoroso, más concreto lo que otro poeta nuestro, Rafael Obligado, ha cantado en una hermosa leyenda: la lucha entre Juan sin Ropa el forastero y santos Vega el Payador. (...)

Barranca abajo era (...) una obra dolorosa y sentida, una obra de observación y análisis. Y el campo aparecía en ella una vez más, maravillosamente reflejado.

Del campo pasaríamos a la ciudad y allí presenciaríamos otro derrumbe moral. En familia (...) era la pintura fiel de un asunto real: el desequilibrio existente en tantos y tantos hogares." pp. 82-83

"Negar los evidentes méritos de Sánchez, cual observador de medios sociales inferiores no era ya posible; pero se suponía que solo en ese terreno habría de encontrarse a sus anchas. Se le relegaba a pintor del campo, del conventillo, del café concierto, de la calle, de los hogares modestos" El crítico señala que con El pasado esos prejuicios se desvanecen en que incursiona en "ambientes más cultos".

\section{Los derechos de la salud, por Alfredo Bianchi}

La nota comienza con un comentario sobre una polémica teatral en París, que Bianchi toma para sentar su poética sobre el teatro, enrolado en las filas del naturalismo, y porque viene a cuento de la crítica que ha recibido la obra de Sánchez, señalando su falta de "bondad, de misericordia, de amor" 
"Con motivo de una crítica del señor Adolphe Brisson a propósito de una obra del señor Pierre Wolff, suscitóse últimamente en París una polémica, en la que intervinieron, entre otros, el aludido señor Brisson, Henri Berstein, Albert Guinon y Henri Bataille.

El señor Brisson reprochaba a la generación nueva de autores dramáticos su inmoralidad, su indiferencia ante el vicio o la virtud. Contraponía a ese teatro, el Augier y Dumas, ya hasta el de Meliac y Halevy, Sardou y Henri Becque. Y concluía diciendo que el teatro no debía proponerse un estudio impasible de la vida, considerar el animal humano como el sabio observa putrefacciones en el campo del microscopio, indiferente a todo otro cuidado que el de anotar fenómenos, sino que tenía un rol menos humilde que cumplir: retratar los individuos, seguramente; pero, al mismo tiempo, despertar la conciencia del público, remover las fuentes de la emoción que brotan de su corazón cuando se sabe golpearle en buen sitio, proponerle ejemplos, inspirarle el odio por la villanía y el egoísmo, el gusto de la honestidad, la idea justa y sana de que todo no es podredumbre acá abajo, que existen otras alegrías más delicadas que la feroz satisfacción de nuestros apetitos y que es bello alguna vez inmolarse a una idea, a un principio, a un escrúpulo....

Henri Berstein, el notable autor de Rafale y La griffe, interpretando los sentimientos de sus colegas atacados, decía: 'Sí, querido señor, vicio o virtud... Yo no odio el vicio. No escribiré jamás una pieza que glorifique la virtud o que ataque un artículo del Código, ni tampoco que ataque o glorifique cualquier cosa. La vanidad de esos sermones laicos me hace sonreír; se me crispan los nervios ante el ruido bien conocido de las puertas desde largo tiempo abiertas y que se pretende aún abrir; honro el hecho raro, obscuro, ese momento de la vida, ese nudo de la cadena, ese minuto brutal, pero que es necesario tomar con todo lo que le rodea de existencias perturbadas y de almas puestas al desnudo." pp. $87-88$

"A su vez el señor Guinon decía:

'Vemos en el teatro la consecuencia de una evolución de las costumbres... Una tendencia general de la educación y un movimiento general de las ideas, nos llevan a disminuir, a atenuar la responsabilidad humana. (...) Ahora bien, nosotros como dramaturgos, somos el reflejo de nuestra época. educados, crecidos en esta atmósfera de escepticismo y de indulgencia, es natural y lógico que escribamos obras inspirándose menos en la moralidad que las obras de épocas más disciplinadas y más rigurosas. y por la misma razón esencial y profunda, el público no siente casi la necesidad de una sanción moral agregada a su placer intelectual" p. 88

Bianchi sostiene que Sánchez es "el más poderoso removedor de ideas con que cuenta nuestro teatro" p. 89.

Más adelante: "Creemos que, como todo buen autor naturalista, el señor Sánchez piensa que en el teatro, el autor debe abstenerse de toda intervención. Por lo tanto, no desea que tal o cual personaje de sus obras resulte simpático. Tomados de la vida real, con sus teorías, con sus sentimientos, su estilo propio, su acento y sus tics, los traslada a la escena y allí los hace actuar, indiferente a todo cuidado que el de anotar los hechos. [cursivas de Bianchi]. Pero para arribar a esta exactitud, que es la perfección, a la desaparición completa del autor detrás de sus creaciones, es necesario conocerlas a fondo, identificarse con ellas, entrar, como se dice, en su piel: en fin, es preciso un riguroso análisis psicológico." p. 90

"Los derechos de la salud, escrito en francés y estrenado en París, hubiera obtenido uno de esos éxitos que consagran [a] un autor y hacen que su obra dé triunfalmente la vuelta al mundo. Entre nosotros, se ha dado solo diez noches, y ocho de ellas estaba el teatro vacío." p. 90.

Revista de revistas

Revista de la Facultad de Letras y Ciencias (Habana); Archivos de Psiquiatría y Criminología (Buenos Aires); en el número siguiente prometen ocuparse de: La Lectura (Madrid), Revista de Letras y Ciencias social (Tucumán); El Fígaro (La Habana), La Verdad (Buenos Aires), La Revista Artística y Teatral (Buenos Aires), otras más cuyos nombres no se consignan.

Notas y comentarios

-Las caricaturas de Pelele. Se alaba a este "artista". Nota escrita por Gerchunoff

-Advertencia: se refiere al atraso con que se ha publicado el número de la revista

-José León Pagano reemplaza a Leopoldo Longhi en 'Letras italianas' 
-Sociedad de autores dramáticos. Se consigna la constitución de una sociedad de autores dramáticos, a principios de ese mes. La 'mesa directiva' está formada por: Otto Miguel Cione (presidente), V. di Napoli Vita (vicepresidente), Félix Alberto de Zabalía (secretario); Raúl Casariego (secretario de Actas); Alberto Ghiraldo (tesorero); Enrique García Velloso, José de Maturana, Vicente Nicolau Roig, Fernando Navarrete (vocales).

-Círculo de Prensa. Se refiere al logro que significa haber conseguido un centimetraje de 20 de propaganda para la esta institución, en casi todos los diarios del país.

Libros recibidos

-Gregorio Martínez Sierra, La casa de la primavera, Madrid, Librería del Pueblo, 1907.

-Rafael Padilla, Leonor, (drama en dos actos y en prosa; prólogo de José santos Chocano, Madrid, 1907)

Luis Eduardo Molina, Estudios sobre política aduanera más conveniente a la Argentina, Córdoba, 1907.

Alejandro L. Bouquet, Apellidos blasonados, (sátira filosófica en tres actos), Buenos Aires, 1907.

Rodolfo Rivarola, Solidaridad universitaria (dos discursos universitarios en Córdoba), Buenos Aires, 1907.

Juan B. Sivori, Los métodos científicos (Estudio crítico filosófico), Buenos Aires, 1907.

\section{Año II, tomo 2, n $^{0}$ 8, marzo de 1908.}

-La Nave......... Hans Friedrich (a propósito de la obra homónima de D’Annunzio), pp. 97-107

-Cantique des Cantiques......... Carlos de Soussens A Lily C. pp. 108-109

-Los que ignoran que están muertos........ Amado Nervo, pp. 110-112

-Los versos de Fray Candil.......... M. Márquez Sterling pp. 113- 117

-Esta noche de noviembre......... Manuel S. Pichardo, (Cuba), p. 118

-El amoralismo subjetivo........... Coroliano Alberini, pp. 119-132

-Sonetos.......Juan Aymerich, pp. 133-134

-Prosas para Margot relato....... José Pardo, pp. 135-137

-Canto a María........ Pablo Della Costa (h), pp. 138- 141

-Letras españolas .La casa de la primavera.........Alberto Gerchunoff, pp. 142-144

-Juan Maragall...........Juan Más y Pí, pp. 145-149

-Letras argentinas......... Roberto Giusti, pp. 150- 154

-Revista de revistas......... Alfredo Costa Rubert, pp. 155-158

-Notas y comentarios.......... pp. 159-160

En este número las secciones propuestas son

Opiniones por Emilio Becher [nunca aparece como sección; Becher colabora sólo en el primer número]

Crónica extranjera por Joaquín de Vedia

Letras Francesas por A. Chiappori

Letras Italianas por Leopoldo Longhi

Letras Españolas por Alberto Gerchunoff

Letras catalanas por Juan Mas y Pi

Letras Portuguesas y Brasileñas por Juan Más y Pí

Letras Hispanoamericanas por José M. Rizzi

Letras Argentinas por Roberto Giusti

Educación- Criminología por Benjamín García Torres

Bellas Artes por Emilio Ortiz Grognet

Música por Miguel Mastrogianni

Teatro Nacional por Alfredo Bianchi

Revista de Revistas por Alfredo Costa Rubert

Notas y comentarios por Nosotros

-Los que ignoran que están muertos pp. 110 -112 
Es un relato de argumento fantástico, entre la ciencia y la literatura. El argumento fantástico está apoyado en ejemplos de casos de clínica médica. Se trata de una sesión de espiritismo. Es interesante observar que el narrador muestra que eso es ficción en la utilización de paréntesis que explican al lector: “(Uds saben que hay mediums, auditivos, videntes, materializadores, etc.)"p.110 REVISAR

\section{Letras españolas}

La casa de la primavera por G. Martínez Sierra reseñado por Gerchunoff

En el final hay un parágrafo que carácter general sobre la vuelta al pasado por los poetas de España: "Después de las aventuras filosóficas, los poetas de la España actual retornan al pasado y, lejos de las peregrinaciones a los Falansterios, tratan de vivir vida interna y prefieren loar las cosas muertas a las cosas por venir. Esta tendencia tiene todas las desventajas de una reacción, tan extremada ahora como anteriormente. Ella no perderá, pero de ella se obtendrá uno que otro poeta de fuerza. Las ciudades románicas muestran a Martínez Sierra en viaje ideal por las calles de los lugares remotos: Brujas, Toledo, Ávila, Colonia, lugares sobre los cuales el cielo parece una telaraña extendida sobre un objeto agobiado de vejez. Mas la evocación de los sitios vetustos, el paseo por lo antiguo, no es enfermizo en él. La muerte no le impresiona sino de un modo superficial y tras los versos melancólicos ala dama "en el amor doctora y en el decir estrella", vibra el alma llena de sol, de vida plena y activa. Es esta la característica del autor. Sin advertirlo pomposamente, a la manera de Salvador Rueda, Martínez Sierra canta, en prosa y en verso, a la existencia robusta, a las mujeres hermosas, a los cielos y a las flores y su canción resuena, aturde, embriaga. Mejor aún sus prosas que sus versos. Sus cuentos y sus novelas denuncian la presencia de un cerebro sólido y un alto corazón. Su estilo es pletórico, vibrante de color y de música y su obra toda es un espectáculo de primavera." pp. 144.

Este pasaje insiste en la construcción de un tipo de subjetividad que reniega de la del decadente poseur, y en ello debe verse un rasgo común a muchos de los críticos y escritores de la revistas. Este rasgo se lee en consonancia con los autores y la estética elegida por Nosotros como 'más correcta': el realismo a la manera Payró.

Letras argentinas pp. 150-154

El país de la selva de Ricardo Rojas

Giusti se refiere a una concepción dominante sobre la literatura que la asocia con una forma de conquista imaginaria vinculada con la nación moderna: "Hasta la saciedad se ha escrito sobre la conveniencia que existe para todo el país, de que, palmo a palmo, región por región, vayan sus hijos conquistándolo para las letras. Al nuestro, desde tal punto de vista, le ha cabido buena suerte. Aceptado es ya y general que Echeverría conquistó la pampa. Cierto es que la pampa de nuestro inmortal romántico, como observaba acertadamente hace ya algunos años un crítico "no es tan pampa como yo quisiera"; pero no son más los que creen lo mismo, por lo que, y en tren de concesiones, quiero admitir la mencionada conquista. Obligado y Leguizamón -en verso y prosa, respectivamentehan clavado sus estandartes victoriosos en esa riente tierra de Entre Río cuyo Paraná se ha vuelto el río proverbial del poeta de "El hogar paterno". González ha unido para siempre su nombre a sus montañas, con aquella clásica obra de una arquitectura maciza como la de esas mismas montañas. Por allá Lugones se ha apoderado con La guerra gaucha de las mesetas salteñas y jujeñas, convirtiéndolas en materia de arte en su prosa ruda, abrupta, que bien condice con la épica lucha que "canta". p. 150. Se nombra también a Eduardo Talero, como representante de esa poética; Rojas que viene a cartografiar Santiago del Estero, se suma a esa tradición.

"El libro se desliza con el tono de una narración, casi siempre sencilla, llana, que nos pone en contacto directo con las cosas y seres que el autor se propone pintar. Por eso repruebo el primer capítulo, en el que un cierto aparato épico -propio, comprendo, de la materia tratada- y algunas formas estilísticas lugonianas que el asunto involuntariamente sugiere, le hurtan al relato sencillez y naturalidad" p. 151. En otro pasaje: "Pero, además de estos elementos artísticos, otros hay en El país de la selva de índole distinta y de mérito no menor, cuales son esas reflexiones sesudas, esas serias consideraciones que Rojas va derramando en cada página"p.151

-Museo Histórico Nacional: El clero argentino desde 1810 a1830

Crítica negativa por lo descuidado de la edición como por el lenguaje también descuidado del prólogo, escrito por Adolfo p. Carranza, director del Museo Histórico Nacional. 
Por los caminos del mundo de Guido A. Cartey

Giusti define el volumen como "ramillete de poesías, frescas y humildes". Luego: "Tal es la musa del señor Cartey, sincera, sin complicaciones, sin audacias de forma de ningún género". El libro, en loa perspectiva de una futura carrera, es visto como anticipo de lo que vendrá.

Revista de revistas Alfredo Costa Rubert

La Lectura. Revista española. Se glosa un artículo de Pedro Dorado, “¿Viva el pecado?”.

El Cuento Semanal: es una revista española. Se trata de la edición especial para Argentina cuyo objeto es "hermanar lo más posible la literatura hispana y la bonaerense, ofreciendo a sus representantes una tribuna selecta y propicia a todas las inquietudes del espíritu moderno" p. 158 estas palabras entre "“" son las de la misma revista.

Notas y comentarios

-Da cuenta de un premio otorgado por la revista ilustrada veneciana La Bauta a Miecio, del que se la Dirección de Nosotros se entera por una carta que el propio Miecio envía, y, en la que incluye su retrato.

-"Vicente Medina - Un saludo cariñoso para el poeta. Que Nosotros le diga una vez más, en estos primeros momentos de su estadía en nuestra tierra, que aquí, si ya desde tiempo atrás se le estimaba a la distancia, en adelante se le querrá no solo como poeta, más también como compañero en esa lucha por el ideal -y por el pan, ay!- en la que la pluma es la única arma. p. 159. Medina es un poeta joven español.

Aquí la dirección vuelve a defender una poética en la que dominan los valores de la bondad y de la ternura, los afectos sencillos del alma.

-Enrique Banchs se incorpora como secretario de redacción de la revista. "A ella puede sin embargo decirse que ya la acompañaba espiritualmente desde su aparición, tantos fueron sus desvelos, tanto su afectuoso interés por su marcha sin tropiezos, habiendo honrado sus páginas, con bellas, raras composiciones en prosa y verso, que causaron la admiración de los entendidos.

El señor Banchs es ventajosamente conocido en nuestro mundo literario. Su primer libro de versos, Las barcas, aparecido en Setiembre próximo pasado, constituyó el mejor éxito poético del año. Es joven y tiene mucho talento." p. 160

-Libros recibidos

-Amado Nervo, Almas que pasan Ultimas prosas, Madrid, 1906. [no se consigna editorial]

-Paul Groussac, Santiago de Liniers conde de Buenos Aires 1753-1810, con un retrato al aguafuerte y un plano de Buenos Aires en 1807, Buenos Aires, Arnoldo Moen y hermano, editores, 1907

Rudyard Kipling, El libro de las tierras vírgenes, traducido del inglés con la autorización del autor realizada por Ramón D. Perés, ilustraciones de José Triadó, segunda edición, Barcelona, Gustavo Gilli editor, 1908.

Rubén Darío, El canto errante, Madrid, Biblioteca nueva de escritores españoles, M. Pérez Villavicencio editor, 1907

-Guido Antonio Cartey, El dilema (drama), 1907, Por los caminos del mundo (poemas), 1908, Buenos Aires [no se informa editorial]

-Carlos Shaefer, Lucha. Tragedia de almas, Buenos Aires, Biblioteca Nacional Non Plus Ultra, 1907.

Aurelio del Hebrón, Domus Aurea, Montevideo, 1908 [no se consigna editorial]

-Juan A. García, Memorias de un sacristán, dibujos de Carlos Clérice, París, A. Donnamette, 1908.

-Félix Basterra, Asuntos contemporáneos, Buenos Aires, F. R. Miller, editor, 1908.

- Adolfo P. Carranza (compilador), El clero argentino de 1810-1830 -oraciones patrióticas-, dos tomos, Buenos Aires, Museo Histórico Nacional, 1907.

Año II, tomo 2, $n^{0}$ 9, abril de 1908

Reacciones. Carlos Vaz Ferreira, pp. 161-165 
Poesía española (Idilios, por Fernando Fortún, Tarde de sol y fatiga, por Leonardo Shérif), pp. 166-168

Hoyos, novelista español........ Carlos O. Bunge, pp. 169-173

Cuando la mujer escribe.......... Ida Baroffio Bertolotti, pp. 174-177

El regreso............Mario Bravo, pp. 178-183

El diario de Lucy Ocampo........... Gastón F. Tobal, pp. 184-192 (relato con entradas de diario íntimo)

La dama inefable.......... Arturo Pinto Escalier, pp. 193-194

El amoralismo subjetivo.......... Coriolano Alberini, pp. 195- 206

Mandolinata....... Julio S. Canata, pp. 207-209

De Amicis......... Ambrosio Pardal, pp. 210 -213

Santiago de Liniers (sobre el libro de p. Groussac)......... Rómulo de Carbia, pp. 214-218

Letras argentinas............. Roberto Giusti, pp. 219-225

Concurso Labardén...............Alfredo A. Bianchi, pp. 226-229

Notas y comentarios.......... pp. 230-232

Antes del primer artículo hay un suelto/recuadro titulado "A los suscriptores", en el que se lee: "Desde el presente mes, la Administración de Nosotros, mediante un arreglo hecho con la Administración de La Nación, ofrece, como regalo a los suscriptores que abonen un SEMESTRE o AÑO adelantado, uno y dos volúmenes respectivamente de la biblioteca de La Nación, los que podrán elegirse de la lista adjunta (edición a la rústica). [no aparece tal lista]

El envío de los referidos volúmenes se hará por cuenta de la Administración de Nosotros"

\section{- Reacciones, por Carlos Vaz Ferreyra}

Se trata de las opiniones breves del autor con respecto a toda una serie de autores. Spencer, Víctor Hugo, Comte, Goethe, Spinoza, Taine, Verlaine, Renan, y un libro: el Eclesiastés. Este artículo es importante porque en él se evalúa a estos autores y esta evaluación puede ser tomada como indicativa de algunas de las opiniones que la misma revista sostiene, considerada en tanto representativa de un cambio o de un momento, el de la construcción de una identidad cultural ya sea argentina o americana, para lo cual hay que reparar en estas opiniones y en estas lecturas, más inclinadas a recoger las lecciones extranjeras que tienen el signo de lo nacional.

-Hoyos, novelista español por Carlos Octavio Bunge p. 169-173.

Luego de la publicación de Cuestión de ambiente, Hoyos publica otra novela de costumbres: A flor de piel, de la cual se ocupa Bunge. Hoyos es, según Bunge, una voz autorizada para hablar de la aristocracia española puesto que es uno de ellos: "El caso es que este joven y talentoso escritor, hijo del distinguido diplomático español, marqués de Hoyos y hermano del actual marqués, pertenece a la grandeza de España y lleva una activísima vida social. Está vinculado a la más alta aristocracia y posee uno de los salones más selectos de Madrid.” p. 169.

En la nota se ve la poética con la que se critica: el epígrafe de la novela es de Stendhal, los personajes son tipos: "Los tipos de mujeres (...) son todos realísimos"; Bunge lee en lo desparejo del estilo una falta de unidad que no es buena ni deseable, porque para Bunge lo que importa es la marca de estilo del sujeto autor, que debe ser una sola. Y además ese sujeto no es un autor a la manera en que lo pretenden los jóvenes. La caracterización que de él hace Bunge muestra claramente cómo se recorta al autor como subjetividad social no literaria.

"Hoyos es un hombre moderno, esencialmente moderno. Se ve que ha nacido y vive en los tiempos del telégrafo sin hilos y del automóvil. No es un escritor naturalista lleno de fuerza y salud a la manera de la señora Pardo Bazán, ni un arcaico caballero a la moderna como Valle Inclán, ni un resucitado del Renacimiento al modo de Valera, ni un alma rancia y grandiosamente castiza a lo Pereda y Pérez Galdós.... Es algo distinto de todo eso, que casi raya en la literatura mórbida de nuestros días, y que resulta un tanto nuevo y exótico en España.... Es, en una palabra, con sus condiciones y sus defectos, quizá más por sus defectos que por sus condiciones, un hijo genuino del siglo XX"p. 173.

El regreso, por Mario Bravo (versos) 
$\mathrm{S}$ trata de un poema y está dedicado a A. Chiappori. [Tomado del libro en preparación: Poemas del campo y de la montaña]

De Amicis, por Ambrosio Pardal pp. 210-213.

Este artículo construye y asigna a la novela un lugar opuesto al estudio relegándola al ocio. Quien escribe la reseña recuerda su propia experiencia de lectura de ficción, Cuore de De Amicis: "Aún recuerdo con melancolía aquellas tardes en que, en la escuela humilde en donde cursé mis primeras letras, nuestro maestro, para procurarnos un rato de esparcimiento en la última hora de clase, de ciertos nublados días invernales, tan pesada, tan larga, abría al acaso Cuore, y nos leía algún capítulo. Bastaba que nos dijese: "Voy a leerles Cuore" para que cambiara súbitamente el aspecto de la clase. Al instante desaparecía el desorden propio de la hora, todos, cruzando los brazos -significativo ademán que en nuestro lenguaje expresaba obediencia,- nos disponíamos a escucharle atentos y de antemano conmovidos." p. 210.

Santiago de Liniers por Paul Groussac. Reseña de Rómulo D. Carbia pp. 214-218

Comienza con un juicio negativo hacia Groussac: "Fuera de toda duda, el estro del señor Groussac está en ocaso. En su espíritu la tarde ha comenzado a caer, invadiéndolo todo de cansancio. Tal, por lo menos, nos lo revela su último libro: Santiago de Liniers, editado recientemente por la casa Moen". Se comienza a criticar a Groussac de modo más irreverente del acostumbrado: se critica el método (no usa el modo deductivo y por eso incurre en errores), la erudición inútil, la parcialidad de los juicios, el entusiasmo desmedido por su héroe, en lo cual Carbia ve una cuestión nacional, y la juzga también desde una perspectiva argentina nacionalista: “(...) nos hace ver demasiado brillantes las acciones de nuestros compatriotas, cuando ellas se han llevado a cabo bajo un cielo y bajo una bandera que no son los que cobijaron nuestra cuna" p. 217

Rescata la calidad, "el valor literario", que no es otra cosa que el estilo de la prosa de Groussac a la que reconoce como la mejor América. p. 217

Letras argentinas pp. 219-225

Memorias de un sacristán, por Juan A. García

Reseña con motivo de la segunda edición - Ilustrada por Carlos Clérice- a dos años de la primera que ha sido efectivamente exitosa: "saludada con general aplauso por la crítica" Se hacen referencias al género novela, del cual esta obra no es, según Giusti, un ejemplo. p. 219

-El alma española, por Ricardo Rojas pp. 223-224

Transcribimos la nota:

"Rojas va afirmando paulatinamente y sin tropiezos su reputación literaria sobre una sólida base. Su obra, ya bastante vasta y sin nada de deleznable, acusa además todo un temperamento. No hay en ella discontinuidad como en la de otros escritores: ciertas características comunes de los tres libros que las constituyen, son testimonio de la unidad del pensamiento de su autor. El último de esos libros, recientemente llegado, es El Alma española, publicada por la biblioteca de Sempere.

Es una recopilación de artículos críticos, que datan de diferentes fechas, sólidamente pensados, escritos con galanura, que dan muestras de la seriedad del pensamiento de Rojas y de su educación literaria poco común por aquí. Son artículos que no justifican tal vez a primera vista el título demasiado amplio y significativo del libro, pero que, bien considerados, lo explican suficientemente. Ellos, en efecto, no son unas simples crónicas más o menos superficiales, de aquellas que -como todas estas que se escriben al día- viven una hora y mueren, cumpliendo su misión del momento. No. Algo alienta en ellas de más positivo y más serio: es el sentimiento profundo del alma española que Rojas posee y que en todas ellas ha puesto; es la comprensión de esa alma, tan compleja y tan rica, de la que, yo creo que por desgracia, estamos nosotros, los argentinos, demasiado divorciados. Pero a Rojas no le falta el sentimiento de la tradición de la raza, de la que se siente el eco en todos sus libros; su lenguaje conserva algo de lo grave y lujoso de la buena prosa castellana; y, todo ello, adviértase, lo remoza con su cultura bien moderna y su conocimiento de las cosas de Francia.

Doblemente elogiable, pues, lo considero: no solo por el talento que en todas sus obras demuestra, sino también por el espíritu de esas obras, que tiene mucho de castizo que me sabe a bien. Pues, ciertamente, ninguna cosa más provechosa para nuestras letras que esa influencia francesa, solo reprobable por los rancios pedante, que ha venido a airearlas, que les ha abierto horizontes, que las ha 
puesto en el buen camino; únanse a el enhorabuena, si es posible, otras influencias, sobre todo la italiana; pero manténgase en nuestras letras el espíritu español, que si la literatura francesa les ha aportado los elementos que les faltaban, ese espíritu que es su lastre, les da el nervio, el colorido, el modo de ser propios del sentir de la raza, de la cual, -jvamos!- no estamos aún tan desvinculados. Téngase efectivamente en cuenta que es el castellano nuestro idioma y que, si algo nos conviene, es ahondarlo y espurgarlo y conocerlo mejor, para usarlo con provecho, más bien que dar a nuestra lengua un colorido gris que va adquiriendo por el calco que de ella hacemos sobre la francesa. Léase si no El imperio jesuitico de Lugones -justamente me refiero a un libro de actualidad- y dígase si no vale más esa prosa gallarda que sabe a castizo, que esa jerga mestiza e incolora en la que todos solemos nadar. Mas el tema es largo y no como para desarrollarlo en una breve nota bibliográfica. me felicito, sin embargo, que a estas consideraciones me haya llevado el libro de Rojas, en el que me he sentido durante unas horas en medio de un atmósfera sana."

\section{-Burbujas de vida, por Manuel Ugarte pp. 224-225}

Giusti reconoce su prevención respecto de los libros producidos en base a la recopilación: "Tengo, en efecto, opiniones radicales sobre esas obras heterogéneas, formadas con los más opuestos artículos, obras sin espíritu y sin unidad, contra las que ya he tenido ocasión de arremeter varias veces. Y creí por un instante que la de Ugarte entrara en el número. Pero su lectura me conquistó y me mostró mi engaño.

Ugarte no ha necesitado esforzarse para reunir el material de ese libro. Cronista fecundo, brillante, poco ha debido costarle hallar entre su producción dispersa. Y como libro de crónica, todas sabrosas en su superficialidad genérica, merece con justicia el elogio.” pp. 224-225

-Cantos de juventud, por Ángel Diez de Medina p. 225

Versos, algo vulgares, de un joven "distinguido" escritor boliviano.

Concurso Labardén por Bianchi

Se trata del concurso iniciado por el conservatorio Labardén. Bianchi comenta las obras representadas en el marco de ese concurso. No consigna los nombres de los autores.

Fruto sano: "es una comedia de positivo mérito, que coloca a su autor al lado de nuestros mejores dramaturgos"; "La exposición [del primer acto] es clara y rápida. Los caracteres bien perfilados, se destacan nítidamente desde la primer palabra (...)". p. 227

La soberbia: "mala comedia, sin caracteres, de asunto pobre y de factura mediocre". p 228

Divina: "Con un argumento simple, que se desarrolla lentamente, sin choques violentos ni trucs de ningún género, ha sabido el autor mantener durante tres actos pendiente al auditorio de la música arrulladora de las frases que brotaban espontáneas de labios de los personajes. (...) hoy en día, después de haber pasado el movimiento naturalista por la novela y por la escena, no es ya posible hacer la misma afirmación. Los naturalistas pensaban, y con razón, que cuanto más se daba la sensación de la vida, más se hacía obra de artista" p. 229

Los novios de Julio Castellanos [único autor consignado], conocido ya en el medio artístico. "En efecto la pieza, graciosa y bien tramada, llena de rasgos felices, mantiene despierta la atención de los espectadores durante todo su desarrollo. Y no es del caso pasar por alto sobre estas obras teatrales de escasa importancia, pues, si pretendemos crea un teatro nacional, nos solo hemos de atender a las obras de aliento sino también a las de menor cuantía,[aunque] solo sean simples entremeses, para desterrar una vez de la escena esos burdos sainetes, ofensivos del buen gusto y de las buenas costumbres" p. 229

Notas y comentarios pp. 230-232

-Muerte de Enrique A. S. Delachaux, geógrafo francés.

-Ida Barofio Bertolotti se incorpora a la redacción de la revista; se ocupará de estudios "de vida y psicología femeniles"

-Advertencia sobre la responsabilidad de los autores y no de la revista respecto de los juicios vertidos en los trabajos publicados, principalmente en aquellos de crítica literaria.

Libros recibidos [dentro de Notas y comentarios] 
Enrique Gómez Carrillo, Langueurs d'Alger, traducido al francés por Ch. Barthez, París, Sansot y Cie., 1908.

Manuel Ugarte, Burbujas de vida, París, Paul Ollendorf, 1908.

Ricardo Rojas, El alma española, Valencia, F. Sempere y Cía, editores, 1908

Leopoldo Lugones, El imperio jesuítico. Ensayo histórico. Segunda edición, corregida y aumentada, Buenos Aires, Arnoldo Moen y hermano, 1908 [el agregado "Nos ocuparemos de él en el próximo número" muestra la importancia que se le otorga a Lugones]

Miguel de Unamuno, Recuerdos de niñez y de mocedad, Madrid, Fernando Fe y Victoriano Suárez editores, 1908. [se ocuparán de él en el número siguiente]

Ángel Diez de Medina, Cantos de juventud, Buenos Aires, 1908 [no se consigna editorial]

José Eneas Riú, Yerba mala. Cuadro dramático en un acto, Buenos Aires, 1908 [no se consigna editorial]

Revistas recibidas p. 232

Anales del Círculo de la Prensa, Buenos Aires

Anales del Ateneo de Panamá, Panamá

Archivos de Psiquiatría y criminología, Buenos Aires

Archivos de Pedagogía y ciencias afines, La Plata

Colección Ariel, San José, Costa Rica

Cultura Española, Madrid

El Fígaro, La Habana

El Cuento Semanal, Madrid-Buenos Aires

España y América, Madrid

La Revista Artística Teatral, Buenos Aires

La Verdad, Buenos Aires

La Rassenga Nazionale, Firenze

La Lectura, Madrid

Lineas, Cartagena, Colombia

Mes literario, Coro, Venezuela

Nuevos Ritos, Panamá

Páginas ilustradas, San José de Costa Rica

Revista de la Facultad de Letras y Ciencias Sociales, Tucumán

Revista Histórica, Montevideo

Revista Jurídica y de Ciencias Sociales, Buenos Aires

Vida intelectual, San Salvador

Año II, tomo 2, mayo-junio, $n^{0}$ 10-11, 1908

Los colegas................. Alfredo Bianchi, pp. 233-234

La filosofía jurídica en la formación del jurista.............. Antonio Dellepiane pp. 235-245

Los colegas Thespis, pp. 246-297

Claro de luna.................. Manuel Ugarte, p. 298 [escrito en Zurich]

La hoja de parra. A propósito del desnudo en el arte............. Ricardo Rojas, pp. 300-305 [escrito en Pompeya, Italia]

Poniente trágico................. Eugenio Díaz Romero, pp. 306-308

Información filosófica.................. Em. Duprat, pp. 309-311.

De mi vida .................. Federico Mertens, pp. 312-315

Semblanzas de la tierra.................... Leopoldo Velasco, pp. 316-319

Recuerdos de niñez y de mocedad............. Luis Ipiña, pp. 320-321

De mi villorio................. Enrique Banchs, pp. 322-326 [crítica sobre el colombiano Luis C. López]

El imperio jesuítico................ Roberto F. Giusti, pp. 327-332 [con motivo de la segunda edición; nos ocupamos de ella en apartado "Lugones, ese simpático enemigo de Giusti" del capítulo correspondiente a Nosotros]

Notas y comentarios.

Nosotros pp. 333-335 


\section{Libros recibidos}

\section{Los colegas por Alfredo Bianchi pp. 233-234}

Bianchi anuncia la publicación de esta obra en la revista para que pueda ser juzgada como es, no mutilada y alterada como se la representó en el Teatro Moderno.

"Los colegas, quinta obra de[1] Concurso Labardén, (¿y aun se habla del Concurso Labardén?) estrenada hace apenas dos meses, es presentada hoy por la Dirección de Nosotros al veredicto de sus lectores.

De las cinco obras conocidas hasta ahora de éste, por muchas causas, célebre Concurso, Los colegas es, indudablemente, sino la mejor, por lo menos la única que, junto con El fruto sano, resiste a una crítica un poco severa.

El éxito obtenido por esta pieza la noche de su primera representación, es muy digno de tenerse en cuenta dadas las deplorables condiciones en las que se la presentara. En efecto, desconfiando de teatralidad, la compañía del Teatro Moderno, parece que se hubiera puesto de acuerdo para hacerla fracasar. Siendo, de todas las obras que ella ha puesto en escena, la que más necesitaba de un primer actor, fue la única en que no trabajó el primer actor de la compañía. No se ensayó, nos consta, más que dos veces. Ninguno de los artistas se sabía su papel. Substituyóse el texto con palabras improvisadas, a veces incorrectas y hasta absurdas. Por otra parte, se efectuaron en el original, sin derecho ni criterio alguno, innumerables cortes. Escenas íntegras fueron suprimidas. Nosotros la ofrece hoy, tal cual la escribiera su autor para que pueda evidenciarse la sinrazón de tales supresiones.

Y si a pesar de todas estas circunstancias desfavorables, la pieza triunfó, hay que convenir en que ello se debió al mérito intrínseco de la obra.

Los colegas es un drama intenso y sencillo, escrito con elegancia y vigor. Todo en él abunda en efectos dramáticos de buena ley, presentando además, desde le principio al fin, una perfecta unidad en los caracteres.

El público sintió y pensó desde los primeros momentos con el autor, compenetrándose de la original idea, nervio de la obra, que aparte sus méritos artísticos, es también de una encomiable eficacia ética, lo que constatamos sin que esto importe una especial inclinación nuestra por las piezas moralizadoras.

Y ahora, juzgue el lector" pp. 233-234

Los colegas por Thespis pp. 246-297 [Thespis: pseudónimo de C. O. Bunge, nombre de un volumen de cuentos de Bunge que aparece reseñado en el número 1 de Nosotros. Los colegas es editada y vendida por la revista]

Información filosófica, por E. Duprat, pp 309-311.

-Vingtcinq années de Vie Littéraire de M. Barrés, de la Academia Francesa, con una introducción de Henri Brémond, editado por Blond, París, 1908]

Esta reseña es importante porque se refiere al nacionalismo del Barrés como teoría literaria no ya solo política: "Su nacionalismo, en fin, no es solamente una doctrina política de la cual nosotros no debemos ocuparnos aquí, sino una teoría literaria, presentada bajo un aspecto sumamente seductor, con sorprendentes recursos de dialéctica. Pero lo que sobre todo es menester alabar en Barrés, lo que está por encima de sus teorías sociales o literarias, es su arte." p. 309 Recordemos que Barrés y sobre todo Renan son autores de referencia para algunos de los miembros de Ideas.

-Morale des Idées-Forces, de Alfred Fouillé. Bibliothéque de Philosophie contemporaine, F. Alena, éditeur, Paris, 1908.

Notas y comentarios

-Se explica que este número de la revista es doble por dificultades imprevistas y por la voluntad de publicar "un drama completo de algún autor nacional".

-Se anuncia la próxima llegada de Ricardo Rojas de su gira por Europa, y se señalan sus "éxitos" en el Ateneo de Madrid, con la lectura de una conferencia sobre Olegario V. Andrade. Rojas ha dado cuenta de su gira como corresponsal de La Nación.

-Max Grillo [colombiano] escribe una carta de la que se transcriben algunos párrafos en los que alienta a Nosotros a "proseguir en la tarea emprendida" [estrechar vínculos intelectuales entre "las naciones 
hispanoamericanas"]. Grillo define la revista como "palestra para los jóvenes ingenios", "lugar de cita de los escritores sudamericanos donde se den a conocer unos a otros", "lazo de confraternidad" entre los pueblos, y se refiere al liderazgo futuro de la Argentina en la América hispana.

-Émile Duprat se incorpora como colaborador extranjero. Dará cuenta de las novedades filosóficas y religiosas de Francia, tal como lo hace, en la revista Cultura española.

- Miecio Horzowski. Se consigan la muerte de la madre del concertista polaco.

Libros recibidos [dentro de Notas y comentarios]

-Max Grillo, Raza vencida. Tragedia en un acto, con prefacio del autor, Bogotá, Colombia, 1905

-Luis C. López, De mi villorio, con prólogo de Juan Manuel Cervera, Madrid, 1908 [no se consigna editorial]

-Carlos Olivera, Mujeres de Ibsen, La Plata, 1908 [no se consigna editorial]

-Francisco Ramos Mejía, Rosas y su tiempo, segunda edición corregida (tres tomos), Buenos Aires, Félix Lajouane y cia., editores, 1907.

-Juan B. Ambrosetti, Exploraciones arqueológicas en la ciudad prehistórica de 'La Paya'(valle Calchaqui - Provincia de Salta), Facultad de Filosofía y Letras, Publicaciones de la sección Antropológica, $\mathrm{n}^{\circ} 3,1^{\mathrm{a}}$ parte, Buenos Aires, 1907.

-Justo González Hervás, Vértigo en altura, [novela], con prólogo de José Francés, Madrid, Librería de Gregorio Pueyo, 1908.

-Informan que Los derechos de la salud, en el número 6 de Nosotros, ha sido objeto de crítica en la revista italiana Rassegna Nazionale, en la que además se elogian las críticas de Bianchi y Bunge sobre el texto de Sánchez. Recuerdan que en breve Nuestros hijos de Sánchez será representada en el teatro Urquiza de Montevideo, en su versión italiana.

\section{Año II, tomo 2, julio, $n^{0}$ 12, 1908}

Los colegas. Thespis, pp. 335-378 Acto III y IV

La góndola de María Antonieta............... Ángel de Estrada (hijo), pp. 379-383

Sobre el amor ...... José Ingenieros, pp. 384-389

Versos de este otoño............. Enrique Banchs, pp. 390-397 [El elogio de los niños, "Hombre de la plaza", "Epístola", “Al porvenir", "Hacen señas", "Nosotros"]

La ciencia y el arte................ Clotilde Guillén, pp. 398-404

Ven ligero y olvida.

Nerio A. Rojas, p. 405

Notas y comentarios .............. Nosotros, pp. 406-410

Indice del tomo, pp. 411-414

Clotilde Guillén.

La ciencia y el arte pp. 398-404

Se trata de las relaciones entre el arte la ciencia. Se reconoce la ampliación que significó para el arte su contacto con la ciencia, y también se critica este vínculo, negativo sobre todo para el arte: "La consecuencia de este consorcio íntimo de la ciencia con el arte tiene por resultado hacerlo cada vez más abstracto, más elevado, más difícil de entender, más sutil y menos accesible a todas las inteligencias. El arte no se socializa, por el contrario, tiende a una aristocratización cada vez más evidente y creo que llegará un momento en que la influencia de la ciencia sobre él será tan fuerte y extensa que el arte será el privilegio de la aristocracia intelectual" p. 404

Notas y comentarios

-El atentado contra Salomé de Ricardo Strauss. Se critica la iniciativa de un "grupo de damas de nuestra lata sociedad" que presentó una nota a la empresa teatral para que no se representara, por inmoral, la obra de Strauss. Se recuerda una episodio famoso, -y comentado varias veces en Ideas- en el que Cané censurara Iris: "Después del caso de la pobre Iris, que, por una desdichada ocurrencia de Miguel Cané, se vio puesta en el índice, le hemos dado el vergonzoso espectáculo a Eleonora Duse de prohibirle la representación de La abadesa de Jouarre" p. 407.

- La visita de Enrique Ferri

Su presencia es prueba, según la redacción de la revista, de "que Buenos Aires ya no sea solo el bienquisto mercado de cueros y cereales de estas lejanas regiones -lejanas para Europa- de SouthAmerica, sino también la gran ciudad latina que despliega sus alas como para remontar el vuelo siempre más alto, y que es ya considerada por las más preclaras intelectualidades europeas, como 
merecedora de una visita. Pero... Completo sería nuestro regocijo si Ferri hubiera venido espontáneamente, llevado por un natural deseo de visitar este interesante rincón del mundo, y no contratado a semejanza de un artista, para una tournée que en este caso es de conferencias, pero a la que no falta, y es natural que no falte, la réclame. Y si, bien predispuestos admitimos que las condiciones de nuestra sociedad actual que todo lo mercantiliza, hacen naturales estos viajes bien remunerados, no por ello dejan de ser menos simpáticos.

¡Cuánto más grata fue para nosotros aquella visita que años atrás nos hiciera De Amicis, con aquella su familiar bonhomía!....” p. 407.

Oponen al utilitarismo el fin político de la palabra: "En definitiva, más podría interesarnos oír de sus labios un discurso partidista en cualquier reunión obrera que una conferencia distinguida ante un auditorio de guante blanco" p. 408

- Nosotros en Madrid

Se refiere a la intermediación del director de La Lectura de Madrid, Fernando Acebal, para "colocar esta revista [Nosotros] en el mercado de libros

- Nosotros en Cuba. Se refiere a las "palabras de aliento" de Julio Laurent Pagés, escritor cubano, director de la revista América, aparecidas en El Diario Español de La Habana, el 4 de mayo de 1908.

- Ernesto Mario Barreda. Se aplaude el triunfo de Barreda quien leyó en el Ateneo de Madrid.

- Dificultades para que la revista saliera en la fecha fijada.

Año II, tomo 3, agosto-septiembre, $n^{0}$ 13-14, 1908

La dirección.............Un año de vida pp. 5-6

Ferri conferencista........Ernesto Quesada pp. 7-29

El viaje a las Indias....... José Santos Chocano pp. 30-31

Mazzini y su pensamiento filosófico............José León Pagano pp. 32-43

(capítulo del libro en prensa Bárbaros y europeos)

Presagio triste........... Vicente Medina pp. 44-45.

Discurso...............Eduardo Talero pp. 46-53

El jardín del convento..........Juan Aymerich pp. 54-55

El arlequín............... Otto Miguel Cione (tragedia moderna en tres actos) pp. 56-80

Recógete a soñar.......... Arturo Pinto Escalier pp. 81-82

Hilandera mocetona......... Arturo Pinto Escalier pp. 83-84

Alberto Insua.............Juan Más y Pí pp. 85-93

Oficios...............Juan Julián Lastra pp. 95-97 (A Manuel Ugarte)

El espíritu de la historia........ Ricardo Levene pp. 98-107(Al Dr. Manuel Derqui)

París...............Antonio de Tomaso p. 108

Sangre y Arena.............Eloy Fariña Núñez pp. 108-113

Letras Argentinas..........Roberto Giusti pp. 114-121

La demostración a Ricardo Rojas, pp. 122-127

Notas y comentarios, pp. 128-134

Un año de vida

"Nosotros entra en su segundo año de vida. El momento es propicio para detenerse un instante a calcular el camino recorrido y cobrar alientos para proseguir la marcha. Pocas palabras sinceras al respecto dirán más que cualquier tirada lírica en tono de himno.

El sendero no era libre de obstáculos y la desesperanza con frecuencia nos afligió al andarlo. Sin embargo, el benévolo apoyo de todos - público, escritores y prensa- y la favorable acogida que en América entera y en las naciones latinas de Europa se nos ha dispensado, nos ayudó a superar los obstáculos y a levantarnos en los desmayos, infundiéndonos la alegre confianza en el arribo feliz. Aún hemos de andar mucho, empero, para llegar. Nos enorgullece afirmar que apenas hemos adelantado un trecho muy breve. Bien pobres serían nuestras aspiraciones si así no fuera.

Nunca ha desmentido Nosotros el programa que se trazó, que va desarrollando lenta pero certeramente. En sus páginas, como sus directores lo advirtieron en el primer número, se han hallado en comunión las viejas firmas consagradas con las nuevas ya conocidas y las de los que surgen o han 
de surgir. No ha podido reunir, es verdad, ni tampoco cabía que lo hiciera, una serie incontrastada de firmas ilustres. Nosotros con alcanzar a la meta de sus aspiraciones jamás pasará de ser la expresión de nuestro ambiente intelectual, y el ambiente, aún más elevado - no es del caso engañarse a sabiendasno rivaliza por cierto con el de los grandes centros europeos. Por ahora apenas se empieza.

Nosotros no se ha adscripto a ninguna tendencia literaria, política o filosófica. El momento es de indecisión y sus directores han preferido la tolerancia por todas las opiniones a un exclusivismo sin sólidas bases.

Un espíritu definido la animó, sin embargo, desde sus primeros pasos: su espíritu francamente americano, fundado sobre un amplio y bien entendido nacionalismo. Toda su propaganda ha tenido por objeto estrechar vínculos entre las diferentes naciones latinas de América y entre estas y la madre patria. Más vale marchar en la ruta de la tradición con la mirada fija hacia adelante, que desviarse de ella, extraviándose. Conocida ya la revista en todo el continente y en España, rápido sin duda prosperará el ideal de americanismo que lleva por bandera.

Y vaya ahora, al entrar en el segundo año de vida, nuestro saludo afectuoso y nuestro agradecimiento conmovido a todos aquellos colegas, los diarios y las revistas de la República, América y los países latinos de Europa, que a través del primer año nos han continuamente expresado simpatía, alentándonos a perseverar en la labor emprendida." pp. 5-6

-Ferri conferencista........... Ernesto Quesada pp. 7-29

Conferencias dictadas en el Odeón. El empresario de ese teatro, Da Rosa, lo ha tratado, según Quesada como a un divo: "Ferri se ha sometido a este papel de tenor en gira artística, como si viniera vulgarmente a 'far l'America', para usar la jerga cocoliche de marras"p.9; los temas elegidos son para un público intelectualmente superior. Su reputación científica se ve afectada, según Quesada. Lo define como un tribuno, y como tal merece elogio. Es importante porque los intelectuales participan de este negocio que iniciaron los empresarios teatrales, y para ser tan masivo como las representaciones teatrales, debe adecuar la temática, esto es en términos de Quesada bajar el nivel intelectual.

-Mazzini y su pensamiento filosófico............José León Pagano, pp. 32-43 (Conferencia leída en el Centro republicano Español, en ocasión del centenario de Mazzini). Es un capítulo de un libro en prensa Bárbaros europeos.

-Presagio triste, por Vicente Medina, pp. 44-45. Adaptación del libro La canción de la muerte del mismo autor.

-Discurso pronunciado por Eduardo Talero (con motivo de la peregrinación de exalumnos a celebrar el $59^{\circ}$ aniversario del colegio nacional de Concepción del Uruguay) Visión positiva del progreso: hay una poesía del progreso. pp. $46-55$

-El jardín del convento (dedicado a Rosendo Villalobos en Bolivia), por Juan Aymerich. pp. 54-55 - Alberto Insúa, por Juan Más y Pí, pp. 85-93.

Se refiere a un ensayo y a dos novelas del autor: Don Quijote en los Alpes y En tierra de santos y La hora trágica. En los tres casos se trata de una crítica positiva. En el primero es central la figura de Amiel. Es importante el artículo de Más y Pí puesto que se refiere al diario de Amiel, que contiene algunos de los motivos propios o apropiados para pensar la operación cultural con el nacionalismo en la revista, pero también, y fuera de ella, en 1910, para dar cuenta de un texto como El diario de Gabriel Quiroga de Manuel Gálvez. En el sentido de esa aflicción ideológica debe leerse el pasaje que transcribimos: "La vida sentimental del maestro [Amiel], pura y sin tacha, lejos de la tentación mundana, como un anacoreta; su timidez frente ala masa de indiferentes que lo observaban y analizaban, (...) su temor del público; su tristeza poética; su patriotismo, su amor a Ginebra, a sus paisajes, al Saléve sobre todo...."

En cuanto a la novela En tierra de santos. Su protagonista Sangil es un escéptico, figura con la que no acuerda Más y Pí. "El escepticismo está de moda por la sencilla razón de que es un patrimonio de las clases bien acomodadas; ser escéptico esa casi afirmar que se poseen medio de fortuna. No puede ser escéptico el trabajador manual a quienes la rudeza de la vida lleva a combatir sin tregua" Pero, sobre todo, la crítica de Más y Pí se relaciona con las consecuencias que esto tiene tanto en lo social como 
para la literatura. "No es le escepticismo la cualidad de los hombres fuertes, pletóricos de vida, rebosantes de energía; en lo social y en lo literario es patrimonio de viejos y jóvenes (....) Los fuertes, los que viven por amor a un ideal en el que la vida se concreta, ignoran el escepticismo, forma de la duda, máscara de la negación, símbolo de la cobardía moral y de la impotencia física”.

La hora trágica, que es la continuación de En tierra de santos, en la que critica Más y Pí ciertos "errores cometidos en la descripción psicológica de Sangil", lo cual no le impide ubicarlo entre los primeros novelistas españoles.

- El espíritu de la historia (al Dr. Manuel Derqui) por Ricardo Levene, pp. 98-107. Se transcribe la conferencia de apertura del curso de ese año de Revista de la historia Moderna y Contemporánea de la Facultad de Derecho y Ciencias Sociales. Hace una historia de los métodos de investigación histórica y sociológica. Registra el cambio del sujeto por la colectividad, la masa. En contra del estudio de los detalles, señala: "Las grandes causas históricas y sociales, gestadoras de los grandes acontecimientos hacen su obra silenciosa y lentamente, pero sólida y definitiva, como la obra de la estalactita sobre las rocas. A veces, por momentos parece como si esos factores desaparecieran, y es que se han sumergido en el fondo mismo del alma social y allí continúan actuando, ocultos por los pequeños factores que hacen ruido sonoro en la superficie.

La historia entera se compone así de lentas transformaciones, de continuas adaptaciones." p. 102.

-Sangre y arena, por Eloy Fariña Núñez, pp. 109-113.

Es importante porque rescata en Blasco Ibáñez el realismo como poética a seguir.

"Es la novela más simbólica, es decir, más representativa de Vicente Blasco Ibáñez. España toda vive en ese libro en una de sus fiestas nacionales más características: la corrida de toros. (...)

Vigoroso y admirable documento de la sociedad española (...)" p. 109

Rescata la "manera de novelar" que da cuenta de "una vida"[la de "El Gallardo"], es decir de una totalidad (la novela es "la evocación de una España pintoresca y dramática"), no de un fragmento; asimismo elogia la exactitud de la descripción (el texto es un "lienzo multicolor"), el carácter real de las figuras, el trabajo de la psicología de los personajes.

Letras argentinas, por Roberto Giusti, pp. 114-121

-Misas herejes por E. Carriego pp. 114-116

Como en otras notas, Giusti ve las obras de los escritores como promesas, más que como realizaciones. Señala que este libro de Carriego "no es una obra vulgar", y prosigue: "Es de aquellas que, en nuestro circunscrito ambiente intelectual donde los vuelos de gallina son la regla, marcan algo, siquiera una no ficticia promesa de una perdurable producción futura" p. 114 Carriego es presentado como un escritor que ha abierto una senda personal. En sus versos según el crítico "alienta el espíritu de su tierra entrerriana". "No es, pues, monocorde su lira. Si debe arrancar la nota vibrante del heroísmo o la áspera del desaliento, si la acariciadora o la tierna, también da una que le es propia, exclusiva: la sensación del suburbio. 'El alma del suburbio'.... este tuvo un descriptor en el inolvidable Fray Mocho: ahora Carriego ha recogido esa alma y la ha volcado en sus estrofas. Allí aparece el poeta de cuerpo entero, colorista y psicólogo audaz en la pincelada estridente o cuando pone manchones de miseria en su cuadro; sentimental al siluetar [a] la pobre costurerita que está por caer o [a] la prostituta que cayera hace tiempo" p. 115. Marca después algunos de los defectos que define como "rastros de mal decadentismo". Hacia el final de la nota Giusti aboga por una función de la poesía de la que se deriva una poética respecto del lenguaje y que se lee en relación con los defectos observados: "Nuestro poetas de América deben proponerse el apostolado de una poesía sencilla, honda y sana, no de enfermizos credos, flores de un día regadas con ajenjo. Lo cual no significa que hayan de cantar eternamente la patria, la bandera, los Andes o Manco-Capac" p. 116. Resumida esta poética se condensa en: "salud", "serenidad", "sincera emoción", "resplandeciente belleza", "reflexión".

-Cartas de Europa de Rojas

Giusti vuelve a insistir en la conexión de Rojas con España, en este caso, a partir del parecido con Francisco Navarro Ledesma, del cual Rojas es admirador. "A mi ver existe un cierto parentesco espiritual entre el malogrado escritor español, cuya fama ha de ir acreciéndose con el tiempo, y nuestro compatriota. Ambos son frutos jugosos del espíritu de la raza: eminentemente castizo el español, cual árbol robusto que arraigó profundamente en las entrañas de la tradición de su pueblo; castizo también 
el argentino, en quien empero en el viejo tronco de la tradición se han insertado los ramajes vírgenes y audaces de sus selvas de América." pp. 117-118.

-Al margen de la ciencia por J. Ingenieros pp. 117-118 (elogio de Ingenieros como sujeto, hombre de ciencia, hombre de arte, poseedor de un estilo)

-Cómo estrenan los autores por José León Pagano p. 119 (crónicas teatrales que ya salieron en La Nación)

-Mujeres de Ibsen por Carlos Olivera p. 119 Elogio.

-Enrique Ferri y el positivismo, por el Dr. Horacio Areco, La mala vida en Buenos Aires por el Dr. Eusebio Gómez. pp. 120-121. Se trata de dos libros cuyos autores pertenecen al Instituto de Criminología: "Ambos marchando en el derrotero seguro abierto en los estudios penales por la escuela positiva italiana, son valerosos trabajadores del pensamiento que aportan desde hace algunos años su contribución a las investigaciones iniciadas con tanto éxito en este país en el mencionado terreno y que han de preparar el material y los criterios necesarios para constituir la futura ciencia criminológica argentina." p. 120.

Transcribimos el siguiente pasaje que importa porque muestra a la novela como el lugar de las adquisiciones del pensamiento científico:

"La mala vida en Buenos Aires, es una revista general de las múltiples formas que asumen las actividades antisociales en este gran centro urbano. Me ha resultado interesantísimo este libro. Lo he leído con idéntica curiosidad con que leería una novela. Varias veces se me ha ocurrido que, mientras el doctor Gómez ha acumulado toda esa vasta documentación de patología social con un propósito puramente científico, un artista podría hallar en muchas de esas páginas inspiración para una obra de realidad y dolor." p. 120.

La demostración a Ricardo Rojas, pp. 122-127

Es importante el discurso con que la revista presenta la figura de Rojas y por lo que el homenaje en sí mismo significa: "Los diarios han adelantado ya la crónica del banquete que fuera inoficioso repetir y que como es sabido resultó una demostración tan significativa por el número como por la representación intelectual y social adherentes. Ella merece, con todo, que se la señale como un signo de que acaso se acerca el tiempo de una reacción en el sentido de respetar el esfuerzo de la inteligencia productiva y la obra desinteresada del espíritu.

Homenaje que importa ya solo por eso, un ejemplo saludable para la multitud, resulta en este caso particular doblemente plausible, por cuanto sanciona la excelencia de una obra literaria, cuyo conjunto atestigua un talento de primer orden. No es este el momento de definir la personalidad de Rojas, que a través de una obra múltiple y todavía dispersa en parte, ha proclamado en un estilo magnífico, en un idioma a la vez plástico y musical, extraordinario de fuerza y de colorido, el culto del ideal y la belleza de la vida.

Como lo hacía notar el Sr. Chiappori, hay en el fondo de este poeta exaltado un combatiente y su discurso fue un voto en favor del advenimiento de una era nacionalista que fortalezca la unidad espiritual del pueblo argentino, amenazada por las fuerzas destructoras del cosmopolitismo. Tal palabra es siempre oportuna en una ciudad como la nuestra y en un momento como el de ahora, y era Ricardo Rojas el más indicado para pronunciarla. El esfuerzo por esa reintegración del alma nacional corresponde en efecto a los jóvenes, de quienes puede esperarse una reacción contra lo existente. No tratándose además de un movimiento susceptible de traducirse en una agrupación cerrada ni de constituir el programa de una acción personal, sino de una obra colectiva, incumbe desde luego a toda una generación.

Hubiera debido temerse que esta palabra de 'nacionalismo', la cual por otra parte solo significa la convicción de que es necesario conservar la integridad moral de la patria, sorprendiese el sentimentalismo cosmopolizante que se enternece en confraternidades internacionales y desdeña lo que constituye nuestro verdadero patrimonio. Pero esa palabra responde a ideas y sentimientos por suerte más difundidos de lo que se cree. Por ese este banquete ha sido significativo por más de un concepto. Ha sido una afirmación elocuente en favor del culto desinteresado del arte y de la patria. Ha sido al mismo tiempo una manifestación de simpatía sincera por la obra de una de las personalidades más representativas de nuestra juventud." pp. 122-123.

El discurso de Chiappori interesa porque allí Rojas es presentado como un "gran político" p. 123: "En efecto; de los hombres de nuestra generación que se preocupan del porvenir espiritual de la raza, 
Ricardo Rojas es el mejor dotado para agitar ideas y congregar almas afines en un inminente movimiento de regeneración. A la solidez de su cultura, a su gesto categórico y su probidad antigua une la más ardiente fe en los destinos de la Patria, entusiasmo que le hace esperar, en oposición al pesimismo ambiente, un supremo resurgimiento del alma nacional." pp. 123-124.

-Discurso de Ricardo Rojas pp. 124-127

Rojas insiste en la necesidad de un ideal nacional heroico en relación con el cual la cultura desempeña un papel fundamental.

"Glorifiquemos, por el contrario [el término de oposición es el triunfo], lo que encierra de grande esfuerzo silencioso y heroico: la labor cotidiana aplicada al anhelo de la perfección espiritual. Proclamemos el desinterés a la sabiduría; mostremos a los hombres la belleza mística y militar que hay en ciertos renunciamientos. Tengamos todos algo de monjes en nuestra condición de soldados. Y nosotros necesitamos tenerlo para crear en medio de la moral utilitaria que hoy impera en el país, resortes permanentes de cultura, pues si no reaccionamos en el sentido de un categórico idealismo que restaure la idea de continuidad en la obra de las generaciones, y de sistemático nacionalismo que restablezca la conexión sentimental de la raza, vamos en cambio de fundar una de las civilizaciones más mediocres y efímeras que hayan aparecido en ele mundo" p. 125.

Ensaya luego una legitimación del arte en relación con un proyecto nacional: "Nosotros hemos tomado de la civilización europea la envoltura política, sin cuidarnos de transplantar o de crear para ponerlo en ella el contenido estético y ético indispensable a toda civilización. Así hemos formado esta ciudad que se precia de tener cuantos vehículos ha inventado el progreso, pero donde los espíritus carecen de todo género de disciplinas, desde las sociales y cívicas hasta las religiosas e intelectuales. Hemos hecho lo que los negros de África o de las islas de Oriente, que toman de la religión que les llevan los misioneros cristianos las baratijas del culto para adorarlas como a sus viejos fetiches y de la política que les llevan sus colonizadores militares, el alcohol y las armas con que se vuelven contra ellos. Así pues puede decirse que en nuestro país la antigua lucha entre la civilización y la barbarie no ha terminado: ha cambiado simplemente de escenario y de forma: su teatro es la ciudad ya no es el campo, y los montoneros ya no emplean el caballo sino la electricidad: Facundo viaja en tranvía. (...)

(...) he pensado si acaso no será que no es dable realizar íntegramente el transplante de una civilización.

(...) he pensado que la civilización brota sustancialmente del suelo cuando un pueblo dotado de autonomía y homogeneidad espiritual se identifica con su territorio. (...) mientras el desarrollo externo del progreso no sea resultante del desarrollo interno de la cultura; mientras no demos disciplinas morales a la conciencia; mientras no creemos el sentimiento de solidaridad social y el de perpetuidad histórica que emana de la tradición histórica; mientras no rehagamos la escala de nuestras jerarquías sociales de acuerdo con una moral idealista. La realización de tan vasto plan, que será la condición de una democracia más sana, de una economía más estable, y de un arte duradero y original, no podrá realizarse sino con el concurso de todos los hombres de pensamiento, persuadidos de que si hace cincuenta años pudo ser el ideal de la nación que surgía una política de cosmopolitismo, ésta al realizarse ha comportado nuevos problemas que nos obligan a modificar la fórmula originaria y adoptar otra de sistemático nacionalismo. Entre un pueblo heterogéneo de diez millones de habitantes, y otro de cinco, pero dotado de cohesión espiritual e ideales nacionales, éste será el que venza en la guerra y el que prospere en la paz" pp. 125-127.

- A Ricardo Rojas, por Charles de Soussens [Poéte], p. 127.

-Notas y comentarios, pp. 128- 134

Se refiere a El Arlequín, obra de teatro publicada por la revista en este mismo número, y se transcriben los pasajes de la crítica que la elogian.

"Continuando en su propósito de ir dando paulatinamente a la publicidad las obras teatrales de nuestros autores nacionales que más éxito han logrado en estos últimos años, Nosotros inserta en este número la tragedia en tres actos El Arlequín del señor Otto Miguel Cione.

El público y la crítica acogieron con todo favor la nueva producción del señor Cione, confirmándose luego su éxito de los primeros momentos con el número de representaciones a que ya ha alcanzado de aquí en lo dos años transcurridos desde su estreno" p. 128

Consignamos un fragmento del pasaje de la nota de Echagüe (de El País) que se transcribe en esta sección: 
"El arlequín es a nuestro juicio, un trabajo fuerte, serio, bueno. Revela estudio y sanos propósitos artísticos en su autor. Tiende hacia un fin de moral social combatiendo esa plaga terrible del alcoholismo que carcome y envenena colectividades e individuos. No le falta nobleza en la concepción ni destreza en la factura. Debe ser aplaudido como un esfuerzo fecundo y nada vulgar, entre el fárrago de las chateces que están inundando la escena nacional y que a diario vemos entusiastamente celebradas por la inepta turbamulta" p. 129

Los fragmentos de la nota de Tribuna alaban la originalidad de la obra y la señalan como el momento consagratorio de Cione.

-Semblanzas de la tierra por Leopoldo Velasco. El autor y su obra han sido bien recibidos en Córdoba, su lugar natal. Velasco es un joven escritor cuya obra se presenta "henchida de promesas para el futuro" p. 130.

-Se consigna la incorporación como redactores de Nosotros de Alfredo C. López y Coriolano Alberini, que se encargarán de las secciones de 'Política' y 'Filosofía' respectivamente.

Es interesante ver cómo es presentado López: "El ama todo lo noble y lo elevado y es, sin embargo, de los pocos de nuestros intelectuales que aún conservan el sentido de la realidad. Sobre ella basa sólidamente sus ideales. (...) Patriota hasta lo íntimo de su ser, sufre con el olvido de nuestra tradición o con la falta de ideales para el futuro. Nuestro momento presente vergonzosamente chato, tiene en él un convencido adversario.

-Instituto de Enseñanza y General

"Esta asociación, constituida a mediados del año último por un grupo de jóvenes animosos, estudiantes de nuestra universidad, con el propósito de difundir la educación en todas las clases sociales y estimular y facilitar entre los estudiosos el trabajo intelectual, en todas sus formas, ya ha entrado de lleno en la labor con una seriedad de miras que raras veces se halla en las instituciones de la índole que se esterilizan en un huero patrioterismo, cuyo único objeto esencial es el de halagar la vanidad de sus componentes. Nada de concursos poéticos con los seculares y ñoños temas A América o Al 25 de mayo" p. 132 Las actividades realizadas por el Instituto son conferencias y cursos públicos y gratuitos; posee además una Biblioteca social.

-La demostración a Evaristo Carriego, con motivo de la aparición de Misas herejes.

Libros recibidos

-Carlos Goyena, Mi corazón no sabía... (Diario de una niña), Buenos Aires, 1908 [no se consigna editorial]

-José León Pagano, Como estrenan los autores (Crónicas de teatro), Biblioteca de Autores Americanos, F. Granada y Cía., editores, Barcelona.

-Ernesto Quesada, La teoría y la práctica de la cuestión obrera, Biblioteca del Instituto de Enseñanza General, Arnoldo Moen y hermano, editores, Buenos Aires, 1908.

-Dr. Horacio P. Areco, Enrique Ferri y el positivismo penal, Buenos Aires, J. Lajouane y cía, editores, 1908

-Eusebio Gómez, La mala vida en Buenos Aires (con prólogo de José Ingenieros), Buenos Aires, Luis Roldán, editor, 1908

-Evaristo Carriego, Misas herejes, Buenos Aires, 1908. [no se consigna editorial]

-Roberto Levillier, Alienados delincuentes y delincuentes alienados, Buenos Aires, 1908 [no se consigna editorial]

-Francisco Capello, Virgilio, Biblioteca del Instituto de Enseñanza General, Arnoldo Moen y hermano, editores, Buenos Aires, 1908.

-Ricardo Rojas, Cartas de Europa, segunda edición, Buenos Aires, Rodríguez Giles, editor, 1908.

-Domingo Fernández, Preludios, París, Garnier hermanos, 1908.

-José Manuel Carbonell, La visión del águila (Canto a la patria), La Habana, Imprenta de Rambla y Bouza, Obispo 35, 1908.

-Federico Urbach, Amor de ensueño y de romanticismo (versos premiados en los juegos florales celebrados por el Ateneo y Círculo de La Habana, en el gran Teatro Nacional, la noche del 14 de mayo de 1908), Habana, 1908.

-Martiniano Leguizamón, El colegio del Uruguay, Buenos Aires, 1908 [no se consigna editorial] 
-Luis M. Cora, Arpegios crepusculares, Buenos Aires, Biblioteca Non plus ultra, 1908.

-Dr. Leopoldo Longhi, El pecado de Ovidio -traducción clásica, Buenos Aires, Emp. Gustavo Patrioli, 1908.

José María Vélez, Perlas rotas, Buenos Aires, Casa Jacobo Peuser, 1908.

Año II, Tomo III, $n^{0}$ 15, octubre, 1908.

-José Enrique Rodó Antonio Gómez Restrepo, pp. 137-147 [colombiano]

-Un americano ilustre. José Luis Cantilo [sobre el general Guzmán Blanco], pp. 148-150.

-Fragmento del "Poema del otoño". Rubén Darío, pp. 151-155. Tomado de El Fígaro de la Habana.

-La filosofía francesa en 1907 Em. Duprat, pp. 156-160 [sobre Evolución creadora de H. Bergson y Los elementos principales de la representación de O. Hamelin]

-Del dietario de un pobre hombre Emiliano Ramírez Angeles (Madrid), pp. 161-166. [fragmentos de un diario de un sujeto mundano, que ya hastiado prefiere la soledad del campo al ruido y la gente de las ciudades]

-Canciones de niño "El Galán". Vicente Medina (Rosario), p. 167

-Fantasía lunar........E. Banchs, pp. 168-171 [fábula sobre la condición del poeta Lelián]. -Wagner.......... Ximeno, pp. 172-177.

-Rapsodia póstuma............ Ricardo Rojas, p. 178 [en el poema hay un héroe: "varón en rostro y alma formidable/ (rostro de tigre y alma de león)-”; "épico y lírico varón”] -Janua Caeli (dedicado a Lucio Salas Oroño)...............Gastón Federico Tobal, pp. 179-188.

-Poesías: "Tus manos" por Álvaro Melián Lafinur, "Llanto y rocío" por M. Esther Rehga Molina, "Como el pelícano" Salvador M. Boucau, "Viejos perfumes" por Armando R y Salazar, pp. 189-191.

-Vicente Medina......... Jorge Walter Perkins, pp. 192-196. [Elogia al poeta ]

-De crítica..........Arturo Carricarte, pp. 197-200. [sobre Nosotros]

-Letras argentinas............ Roberto Giusti, pp. 201-206

-La demostración a Evaristo Carriego, pp. 207-213

-Notas y comentarios, pp. 214-215

-Libros recibidos, p. 216.

-José Enrique Rodó por Antonio Gómez Restrepo, pp. 137-147 [colombiano]

Defiende a Rodó de la crítica de Manuel Ugarte (a propósito del artículo de Rodó en La Nación sobre La joven literatura hispanoamericana de Ugarte), más allá de no compartir lo central de la doctrina de Rodó. Destaca "criterio amplio y hospitalarios, su odio a la política jacobina que tantos males ha causado en nuestra América; su entusiasmo por las más desinteresadas manifestaciones del arte y su aversión a esa especie de filosofía utilitaria que quiere medir todas las cosas por el grado de satisfacciones materiales que proporcionan" p. 137 Le interesa como ensayista y en particular el punto de vista sociológico desde el que considera el arte. AMPLIAR COPIA LALE LO SUBARAYADO

-De crítica por Arturo Carricarte

Elogia la revista por su tarea de difusión de las novedades del arte, y la cultura en general. Sostiene: "Además de eso -gran factor de cultura- alientan y estimulan la labor nacional (...) exponiendo el error de tendencias malsanas, ora aplaudiendo aciertos y despertando la atención de reacia de nuestros públicos sobre la posibilidad de crear y mantener un arte propio, noble y grande en cada porción de nuestra América.

He aquí el verdadero patriotismo" p. 198

"Ofrécese el porvenir abierto, y el 'arte nacional', el arte realista de forma y argumento, se sobrepone al arte enfermizo de nuestro añejo y prestado exquisitismo. Pero aun cuando existe firme decisión de enmienda, a veces, como los frutos no se palpan al instante, sino que es preciso aguardar para que maduren, algunos creen yermos los campos que guardan la simiente, y entonces ocurre el pánico en los grupos donde los más débiles abundan. Ese instante es la crisis peligrosa y es la ocasión de exhibirse el chauviniste. 
Pero, en definitiva, las almas de firme temple se orientan hacia espacios de luz; conmuévelas cuanto ayer contemplaron indiferentes y aun hostiles: el patrio escenario, sus bellezas físicas, sus problemas sociales -que antes nos rodeaban sin saberlo, como el lenguaje que hablaba el personaje de Molière,todo eso ha venido a ser presa del arte, y 'en estos tiempos reales les está naciendo a América el hombre real' que anunció José Martí. "El vino de plátano, si sale agrio, !es nuestro vino!" Ya no desdeñamos la acidez de nuestro vino, sino que tratamos de endulzarlo; y el sociólogo estudia "Nuestra América", y el dramaturgo escribe "Sobre las ruinas", y el poeta canta "Mis Montañas". El crítico ve todo eso y lo estudia y lo fomenta; pero aún el ideal definitivo apenas se esboza." p. 199 "Esa obra es la obra que Nosotros realiza. La tendencia a la realidad, el retorno a la fuente primitiva de verdad y "humanismo", es su credo, practicado virilmente. Y gran revista culta, escrita para pueblo culto -¿por qué murió "El Mercurio de América"? !Paradoja irritante!, -no limita su esfuerzo al patrio solar donde tan fecunda es su obra, sino que tiende la vista y recoge cuanto las varias tierras continentales aportan a la evolución intelectual” p. 199

Letras argentinas, Roberto Giusti, pp. 201-206

El libro de los elogios por E. Banchs. Elogioso pp. 201-204.

Giusti se regocija de haber señalado a Banchs como "el talento más fuerte de la generación que surge", en ocasión de la publicación de Las barcas. Reconoce en el poeta "el alma de un niño" y como tal "ingenuo y sincero". Su poesía emana de ese espíritu infantil, y se caracteriza por la "sencillez" que Giusti entiende como "una protesta contra la afectación, contra la retórica". E insiste en aquellos valores ya enunciados: "Su verso respira salud, frescura, alegría". p. 202.

-La eterna angustia de Chiappori p. 205-206 Se trata de una crítica elogiosa.

-La demostración a Evaristo Carriego [con motivo de la publicación de Misas herejes]

Se transcriben el discurso de Juan Más y Pí -en el que Carriego aparece como un luchador que descubre "las llagas y de investigar los males que infestan el alma del pueblo"- y partes de Misas herejes seleccionado y leído por Marcelo del Mazo], pp. 207-213.

Notas y comentarios, pp. 214-215 [Machado de Assis, a propósito de su muerte; se transcribe un poema suyo sobre Camoes]

Libros recibidos, p. 216.

\section{Año II, T3, n⿳0 16-17, noviembre-diciembre, 1908}

-Homero. La civilización de Creta......... F. Capello, pp. 217-228

-Tres sonetos inéditos: "Cabellos blancos", "El madrigal de las rosas", "Vida y arte"....... J. Santos Chocano, pp. 229-230.

-Con mi sombra...........E. Talero, pp. 231-232

-El hombre a quien le dolía el pensamiento.......... A. Nervo, pp. 233-235

-Sardou........... Joaquín de Vedia [en recuerdo del dramaturgo recién fallecido. Artículo publicado con fecha 9/11/1908 en La Nación], pp. 236-240.

-Pour un inconnue.......... Carlos de Soussens, p. 241.

-En la paz campesina......... Fernando Fortun (Madrid), pp. 242-244.

-Del lloro de los abedules por la muerte del hijo del rey............ Carlos A. Leumann, de El libro de la duda y los cantos ingenuos, recientemente aparecido, pp. 245-246.

-De crítica. Alrededor de Alma nativa.......... Arturo Carricarte, pp. 247-251

-En el mundo de los fantoches............Eloy Fariña Núñez, pp. 252-259 [relato sobre la mujer moderna, los bohemios, etc.]

-Cisnes y estrellas............Arturo Muscari, pp. 260-261

-Etapas del camino............Juan Aymerich [dedicado a Arturo Carricarte], pp. 262-265

-El demiurgo de Francisco Soto y Calvo.......... Juan Chiabra, pp. 266-268. [editado en París]

-El alma nuestra............. Rómulo D. Carbia pp. 269-273

- Sedientas............ Marcelo del Mazo, pp. 274-275 [del libro Los vencidos en preparación]

-Sobre Une nuit de Scheherezade de Carlos Pedrell...........José André, pp. 276-283 [crítica musical]

-Crepuscular.............. Salvador Debenedetti, pp. 284-285 
-Liras Federico

S. Mertens, pp. 286-288 [relato sobre el único "amor inmaculado" de

Augusto: su madre]

-Remembranzas de la última semana de pasión

S. Perkins Fragueyro, pp. 289-293

-Enrique Banchs El libro de los elogios Juan Más y Pí, pp. 294-307.

-Letras argentinas Roberto Giusti, pp. 308-318

-Notas y comentarios pp. 319-324

-Libros recibidos pp. 324.

-Indice del tomo III, Año II.

- De crítica. Alrededor de Alma nativa, por Arturo de Carricarte, pp. 247-251

Carricarte señala un proceso histórico en relación con el cual lee lo que llama "amor por el pasado". Ese proceso tiene su punto de inflexión en la inmigración.

"Adviértese en la literatura argentina del día, en la obra de los poetas, de los novelistas y de los dramaturgos un sello de común amor al pasado; no por cierto en sentido regresivo o reaccionario, sino en el más brillante y amable de curiosidad e interés por una época extinta, llena de poesía y de encanto; un sano amor hacia aquellos tiempos pintorescos y adorables en los cuales el gaucho iniciado escasamente en recursos de la civilización- mostraba al desnudo su alma varonil, tiempos de rudeza si se quiere, pero en los cuales brillaba como un sol (bajo las nubes sombrías de Rosas después del eclipse colonial ) el sentimiento de la libertad y el anhelo de independencia (...)” p. 247

Más adelante: "En menos de tres lustros, el gaucho, que no podía evolucionar si quería adaptarse, se transformó en algo mítico o legendario y los artistas, enamorados siempre de todo lo poético y de todo lo heroico, se sintieron atraídos hacia aquella resistencia estoica y ante el peligro de la extinción rápida se apresuraron a llevar aquel mundo singular que huye vertiginosamente hacia el pasado hacia las páginas de la novela, a las escenas del drama, a las estrofas del poema.

Recientemente publicó Manuel Ugarte una encantadora 'nouvelle' en la cual encarnó de mano maestra al tipo de Martín Fierro, de Juan Moreira, de Santos Vega, del gaucho, en suma, que se aleja y hubo de colocarlo en oposición al argentino que "se perfila", del argentino que cada un día [sic] muestra más definida y propia su personalidad, ostentando el sello de la nación nueva, la de la argentina de Buenos Aires, no la de las pampas de Entre Ríos. La leyenda del gaucho intitula Ugarte su cuento y en él como en el drama de Payró Sobre las ruinas y en no pocos cuentos de Bunge (...) se advierte el mismo sentimiento melancólico. Igual nostalgia y tierna añoranza de aquellos días de los piales, de los rastreadores, de las pechadas..."

Carricarte polemiza con quienes sostienen que esta tendencia ["amor al pasado"] no puede ser considerada el carácter definitivo de la literatura argentina y sostiene que se trata solo de un "momento de la evolución literaria de ese gran país, firmemente orientado en la obra 'nacionalista'que da tono y color a la moderna literatura y que señala, además, los rumbos del futuro porque la novela, a plazo corto, será nacional o no será" p. 248

En ese contexto, Alma nativa de Leguizamón ofrece una descripción bien contrastada entre el pasado y el futuro, y declara la -en palabras de Leguizamón- "urgencia de salvar los rasgos originarios del tipo que agoniza". "Como Ocantos en su Misia Jeromita y tantas otras gallardas novelas, como Florencio Sánchez en sus dramas, Joaquín V. González en sus cuentos, Lugones en La guerra gaucha, Ricardo Rojas en El país de la selva, han transcripto la vida contemporánea argentina, su fisonomía social, sus bellezas naturales; así Leguizamón ha mostrado el encanto de la campaña, los hábitos de ayer, la melancolía de los viejos pamperos que ven huir todo "su mundo"” p. 249. La estética en la que se inscribe es el realismo.

-El alma nuestra, por Rómulo D. Carbia pp. 269-273

Esta es otra de las intervenciones que debe leerse vinculada con el nacionalismo en Nosotros. Transcribimos algunos fragmentos:

"Generalmente se cree entre nosotros que el patriotismo consiste en sostener a capa y espada la grandeza de Buenos Aires, en invocar a menudo los nombres de San Martín y de Belgrano, en cantar las glorias de la bandera celeste y blanca, y en hacer derroches de elocuencia alambicada en panegíricos de nuestro pasado remoto. 
Para los patrioteros -es decir, para la mayoría de nosotros- los prohombres de Mayo son el sumum de todo lo bueno. El que así no lo piense, el que trate de desvirtuar el fetichismo con que se rodea al héroe de la gran epopeya, es un antipatriota, un monstruo social.

Por eso no tenemos Historia, El patrioterismo está reñido con la verdad, y no cree, con Carlos XII, que la Historia es un testigo y no un adulador.

Queda fuera de duda, pues, que no tenemos aún una idea exacta de la patria, y que estamos muy lejos de tenerla.

Lo que nosotros llamamos patriotismo no es más que un amor, un poco petulante, de nuestra grandeza material; pero un amor desprovisto de todas las características que determinan al verdadero patriotismo.

Y como no tenemos casi ni el concepto de la nacionalidad, pues la apatía por aquello que no tenga atingencia con nuestra tan mentada grandeza económica todo lo ha invadido, es muy difícil que podamos en poco tiempo, como sería necesario, crear nuestro patriotismo, del que hoy más que nunca necesitamos con urgencia. p. 272.

(...)

¿Y cuándo y cómo tendremos patriotismo? Altamira [en Psicología del pueblo español]dice que lo esencial del patriotismo es el elemento espiritual, y que habrá sentimiento patriótico en los pueblos que se hayan afirmado en el proceso del tiempo y por la acumulación de intereses, riesgos, sensaciones, ideas, etc., con cierta unidad y solidaridad sociales, cristalizados en un carácter común y una idealidad colectiva.

Por su parte Legrand en la obra L'idée de Patrie, afirma que en la actualidad el patriotismo no tiene por base las afinidades de raza, desde que éstas no producen la patria sino que son una consecuencia de ella.

El criterio moderno no admite que la lengua, la religión ni la cultura hagan la patria, sino el clima, el suelo y ciertos otros factores." p. 272

-Enrique Banchs El libro de los elogios por Juan Más y Pí . Crítica muy elogiosa de Banchs, en la que también se valora a otro poeta, Carriego, por su "nota vibrante, altiva, digna de aprecio" con Misas herejes.

-Letras argentinas, por Roberto Giusti, pp. 308-318

-De cepa criolla, de Martiniano Leguizamón, pp. 308-310

El comienzo de la nota en que se transcribe un fragmento del discurso de Rojas en el homenaje que la revista tributara en honor de Rojas, publicado en el $\mathrm{n}^{\circ}$ 13-14, exhibe el acuerdo general de Giusti respecto del programa nacionalista de Rojas. Transcribimos los pasajes centrales del texto de Giusti que precisan el diagnóstico de Rojas y proponen la necesidad de una intervención cultural que desde la literatura se traduzca o concrete en la enseñanza de la literatura argentina en los colegios nacionales.

“ '...Si no reaccionamos en el sentido de un categórico idealismo que restaure la idea de continuidad en la obra de las generaciones y de un sistemático nacionalismo que restablezca la cohesión sentimental de la raza, vamos en camino de fundar una de las civilizaciones más mediocres y efímeras que hayan aparecido en el mundo'.

Así decía Ricardo Rojas últimamente -iy con cuánta razón!- en el banquete que sus amigos le ofrecimos a su vuelta de Europa. Mucho me temo, sin embargo, que el condicional reaccionar que Rojas establecía como necesidad imprescindible para la restauración de la cohesión sentimental de la raza, no se produzca; mucho me temo que ya estemos en el triste camino que sus palabras señalaban. Aquí no tenemos nada. Falta un ideal colectivo, falta el sentimiento de la tradición, faltan aspiraciones para el futuro. Vagamente pensamos que la patria irá haciéndose siempre más rica, y nada más. Apenas si alcanzamos a ver triplicados los millones de cabezas de ganado que hay actualmente sobre el territorio argentino; apenas si se nos ocurre pensar que en vez de cinco millones de habitantes bien pronto habrá diez y que las cifras de importación y exportación aumentarán a la par.

Extranjerizarnos hasta la saturación; irnos a París (París es Europa) apenas podamos; ubicarnos lo mejor posible en el presupuesto; reírnos de la política como de cosa que hay que tomar en broma para no hacerse mala sangre, es todo aquello de que somos capaces. Conservar una característica nacional mantener una tradición, cultivar una interesante peculiaridad de nuestras costumbres, ni por sueño! Todo eso el cosmopolitismo lo ha borrado. 
Yo no sé cuales remedios pueda haber para esto, y ni siquiera si admite remedio; pero me espanto de la disolución del espíritu nacional y comprendo la inmensa verdad que contentan las palabras de Rojas, que fueron, sin embargo, como un fustazo que despertó a muchos de su modorra.

Ciertamente, como en ese banquete se convino, es menester trabajar en pro de una franca reacción. ¿Cómo? El particular requeriría mayor detenimiento del que en esta rápida crónica puedo prestarle; pero se me ocurre que no son los artistas -sobre todo los literatos- quienes menor contribución pueden aportar a la obra. Estudiar con amor el pasado argentino; revivir las tradiciones, las costumbres, los tipos de antaño; poner en plena luz la historia nacional sin piadosas mentiras ni apasionamientos ya fuera hora: levantar en nuestros libros otros tantos monumentos a nuestros grandes hombres, inundar en una palabra, el país de estudios sobre lo que fue, o lo que aun conserva sabor criollo, no con absurdas ambiciones de crear un híbrido idioma argentino, sino al contrario valiéndose de la fresca, bella, robusta lengua castellana, remozándola de acuerdo con nuestras necesidades, tal ha de ser el punto de mira de todos, arqueólogos, historiadores, críticos, novelistas, hombres de teatro.

No es esta de ningún modo una indicación de limitar nuestros horizontes al gaucho, como algunos lo pretenden, con un cerrado criollismo. La República Argentina tiene su campaña y sus ciudades; su pasado y su porvenir; no es por lo tanto solo con la mirada puesta en el campo y en el pasado que ha de estar el artista; pero sí ha de dirigirse a ellos con frecuencia, y no, como ahora, rimar versos en que nieva en Diciembre, porque así sucede en París. Si el alma de las ciudades argentinas es semejante a la de los grandes centros europeos, surjan en buen hora entre nosotros los libros que traduzcan tal hecho, análogos a los que se escriben allá; mas no nos limitemos a ello, y dejen de extasiarse nuestros poetas exclusivamente ante el minueto cuando en el gato o el pericón podrían hallar tema para admirables poemas de color.

(...)

¿Cuándo haremos conocer de verdad la literatura argentina en los colegios nacionales, poniendo a los alumnos en contacto con las mejores páginas de nuestros prosistas y poetas, vivos o muertos, y no como ahora, haciéndoles aprender de memoria una lista de veinte o treinta nombres, como apéndice a un curso que se iniciara con el Ramayana y El libro de Job? ¿Cuándo será obligatoria la lectura de Facundo en las escuelas como lo es la de I promessi sposi en Italia?

(...)

Leguizamón es algo más que un escritor; es también un estudioso que con cariño filial gusta de escudriñar las cosas de nuestro pasado; y así como en el campo de nuestras letras ocupa un lugar preeminente, merecidísimo tiene el que la Junta de historia y numismática americana le ha cedido, incorporándolo a su seno.

De cepa criolla con ser una recopilación de artículos ya aparecidos, me ha cautivado. El cariñoso interés que Leguizamón tiene por las cosas de la tierra y el sentimiento sincero que le guía de contribuir con su granito de arena a la obra de constituir una compacta nacionalidad, tienen en el libro tan sincero acento de verdad que conquistan en el acto y son acicate para que el cerebro del lector se ponga inmediatamente al unísono con las ideas que inspiran a su autor.

(...)

Leguizamón debe perseverar en la tarea que con tanto ahínco ha emprendido de mantener encendido el fuego en el hogar de la tradición nacional; la tarea no puede ser más necesaria en el momento presente ni más útil la participación que él toma en ella, por ser cada uno de sus artículos o libros chisporreante haz de leña, que aviva la llama y retarda su extinción.” pp. 308-310

- Talismanes, por Ernesto Mario Barreda, p. 311

Crítica favorable al autor y su obra de la que dice Giusti: "se impone(n) inmediatamente a la atención del lector como seguras expresiones de personalidades literarias ya hechas" p. 310

- Prosa de combate, por Juan Pablo Echagüe, pp. 312-313.

La reseña es, en realidad, la transcripción de algunos pasajes de la nota de El País, del 14 de diciembre. Empieza con la referencia a la publicación del libro por el sello español Sempere, a la que se califica como "la biblioteca popular de mayor difusión en España y en los países de habla española". Se trata de un libro armado con algunos de los artículos que Echagüe ha publicado en diarios como El País, La Nación. El autor es presentado como una especie de guerrero que lucha 
contra las "falsas reputaciones", "los malos autores, los pésimos cómicos, los públicos incultos", especialmente como crítico teatral.

-Ánima, por Ernesto Turini

Se refiere a este y Líricas otro libro del autor, en los que puede verse "un poeta tierno y sencillo, adorador de las mujeres tristes, de los crepúsculos lentos, de las noches de luna tranquilas, de los parques solitarios", "un poeta sediento de ideal y contento de sentirse bueno: me [Giusti] bastaba" p. 313 Anima representa un progreso para el autor.

\section{- Historia de un amor turbio, por Horacio Quiroga}

Dice Giusti: "Horacio Quiroga es considerado con razón uno de nuestros mejores cuentistas. Sabe hallar argumento para sus relatos, describe con seguridad, es agudo psicólogo y tiene una curiosa visión de vida que da un carácter inconfundible a cualquiera de sus páginas" p. 315 Señala el humor y el tono burlón presentes en los relatos del autor. Elogia la historia por lo sencilla que Quiroga "desarrolla con sólida lógica y sana naturalidad". En el volumen se incluye el cuento "Los perseguidos", al que Giusti caracteriza "de índole patológica, sobre la cual Quiroga tiene especial dominio" p. 316 Termina con un párrafo que va en el sentido de la poética que Giusti promueve: "Y si al terminar me permitiera hacerle a Quiroga una indicación (siempre es conveniente dar consejos para mantener alto el prestigio de la crítica) le diría que, ya que se ha revelado maestro en ambas psicologías [la de la primera historia, más sana, dirá Giusti, y la patológica, de "Los perseguidos"], la normal y la mórbida, resultarían sin duda más simpáticos sus libros si se inclinara con preferencia por la primera..." p. 316.

-Perlas rotas, por José María Vélez

Giusti celebra este libro y menciona los anteriores: Cumbres y quebradas, Cantos rodados, Montes maravillas. En los tres "se reveló el vigoroso colorista, el inspirado poeta que es". p. 316

Notas y comentarios pp. 319-324

-Carta de Menéndez y Pelayo a Francisco Capello, colaborador de Nosotros, que es usada como respuesta de Capello a las injurias de un crítico a su poema "Pinus Mendocinae"

- Juan Chiabra [italiano] se incorpora como colaborador de la sección "Letras italianas"

-A nuestros lectores: se explica el atraso en la publicación de este número doble de la revista.

-Nosotros en el interior: tiene representantes en el interior (La Quiaca, Jujuy, Tucumán, Córdoba, Rosario). De su viaje a Bolivia, Bianchi logra tener allí un representante para la revista.

-Nuestro administrador: deja la administración Alfredo Costa Rubert.

-Salón Sud-Americano: se transcribe la carta que Luis Mandrés, envía a la revista explicando los objetivos de este salón recientemente instalado en Barcelona "cuyo objeto primordial es el de facilitar con todos los medios posibles las comunicaciones de la América del Sur con España a favor de los transeúntes y residentes, y cooperar al desarrollo general de toda iniciativa plausible entre los países Sudamericanos y la Península” p. 322. El salón, instalado en la Rambla de las Canaletas nº 2, ha sido abierto por Luis Mandrés.

\section{Libros recibidos}

-Carlos Ibarguren (profesor de la Universidad de Buenos Aires), Una proscripción bajo la dictadura de Syla, Buenos Aires, Arnoldo Moen y hermano, editores, 1908 (Publicación del Instituto de Enseñanza General)

-Martiniano Leguizamón, De cepa criolla, La Plata, Talleres gráficos Sesé, 1908.

-Ernesto p. Turini, Anima, Buenos Aires, Garre y Zorzópulos editores, 1908.

-Juan José Vélez, Manila, Córdoba, Imprenta y casa editora de F. Domenici y cia., 1908.

-Enrique Gómez Carrillo, Grecia (con prólogo de Jean Moréas), Madrid [no se consigna editorial]

-Carlos Alberto Leumann, El libro de la duda y los cantos ingenuos, Buenos Aires, Arnoldo Moen y hermano editores, 1908.

-Samuel López G., El anillo de Polícrates, Bogotá, 1908. [no se consigna editorial]

-Severo Amador, Confesión, Sorpresa, Palabras póstumas, Aguas calientes, México, 1905 [no se consigan editorial] 


\section{Año II, T4, no 18-19, enero-febrero, 1909}

-Ecce Homo (cómo se llega a ser lo que se es)

Federico Nietzsche, pp. 5-21 (En nota dice: "Esta traducción es de Henri Albert y corresponde a la traducción francesa de Ecce Homo que este distinguido traductor de la obra entera de Nietzsche, ha comenzado a publicar en el Mercure de France, en la segunda quincena de noviembre del año próximo pasado" [1908])

-La resurrección de Lázaro Carlos Octavio Bunge pp. 22-26 [tiene como intertexto una historia narrada en El viaje entretenido de Agustín de Rojas, del siglo XII]

-Sonetos (La vejez del sátiro, Pentámetros al Hermes trismegisto, Sub-Umbra, Glyere)....... L. Díaz, pp. 27-29

-El espíritu de Goethe. José Enrique Rodó, pp. 30-32

-Aclaración Martiniano Leguizamón, pp. 33-35

-Fragmento de crónica. Enrique Banchs, pp. 36-41

-Leyendas viejas. Leopoldo Velasco, p. 42 [soneto]

-Los fragmentarios (Prólogo)............Pedro Sonderéguer pp. 43-44 [libro editado bajo el sello de Nosotros; los artículos aparecieron antes en La Nación]

-La música en Francia............Mariano Antonio Barrenechea pp. 45-62

-Poemas del campo y de la montaña.

Mario Bravo pp. 63-64 ["Invitación a los héroes de la vida", "Los recuerdos", "La montaña inmortal", sonetos]

-Conversaciones de actualidad. Elogio de la democracia (A Joaquín de Vedia).......... Alberto Gerchunoff pp. 65-73

-El artista.............Samuel López G. p. 74 [traducción del poema de Oscar Wilde]

-Opiniones de un sanjuanino sobre Anatole France Roberto Levillier pp 75-79 (carta a la dirección de la revista)

-Crónica de arte (La doute).

Juan Grijalba pp. 80-83. [sobre esculturas de Henri Cordier; especialmente sobre "La doute", que ha sido adquirida por la comuna de Buenos Aires]

-Sonetos.............Nerio A. Rojas (La agonía, Dreamland, La aldea, La voz del viento) pp. 84-85

-Estado actual de la literatura en Venezuela............Rufino Blanco Fombona pp. 86-97 CRITICA [se trata de la segunda parte de un artículo publicado por su autor en la Revue des Revues]

-La duda.

Domingo Robatto pp. 98-99

-Tu homenaje, bebe. Julio S. Canata pp. 100-101

-La tragedia de las almas.............Julio L. Noé pp. 102-105

-Les ans...........Raimundo Manigot (escrito en francés) p. 106

-Magdalena....... Antonio De Tomaso p. 107

-Los cruzados de la causa (Valle Inclán)

E. Suárez Calimano pp. 108-109

-Grecia (Enrique Gómez Carrillo)............Jorge Walter Perkins pp. 110-116

-Letras Italianas.............Juan Chiabra pp. 117-120 [Es la segunda entrega de la sección]

-Letras Argentinas...........Roberto F. Giusti pp. 121-135

-La demostración a Juan Más y Pí............ pp. 136-139

-Notas y comentarios........ Nosotros pp. 140-144 Ravignani es el nuevo administrador de la revista Libros recibidos [dentro de Notas y comentarios] ..... p. 144

El espíritu de Goethe José Enrique Rodó pp. 30-32

Este trabajo que forma parte de Motivos de Proteo es importante porque el tipo de figura que Rodó arma en relación con Goethe y algunos de cuyos rasgos la revista promueve en las figuras de los jóvenes. Así Goethe aparece como: "El más alto, perfecto y típico ejemplar de vida progresiva, gobernada por un principio de constante renovación y de aprendizaje infatigable, [cursivas nuestras] que nos ofrezca, en lo moderno, la historia natural de los espíritus, es, sin duda, el de Goethe" (p. 30)y más adelante: "Su afán infinito de saber, difundido por cuanto abarcan la naturaleza y el espíritu". (p. $31)$.

- Aclaración, por Martiniano Leguizamón. 
Leguizamón responde a un comentario de Arturo Carricarte sobre el parecido entre el argumento de un relato de A. Nervo, uno de Boisgobey y uno suyo [de Leguizamón].

-Fragmento de crónica, por Enrique Banchs

Se trata de un texto en que el autor, en nota al pie, explica que ha querido lograr un "poco del sabor de otra edad", que incurre en anacronismos y recrea una historia entre Salomé y Salomón.

-Conversaciones de actualidad. Elogio de la democracia (A Joaquín de Vedia), por Alberto Gerchunoff, pp. 65-73.

Este escrito reviste una importancia central para pensar la posición política de la revista, que en general es bastante reacia a explicitar estas cuestiones abiertamente. Uno de los personajes se pronuncia a favor de la democracia. Cf. el apartado de "Una lección de socialismo: el buen nacionalismo", en este mismo capítulo, en el que nos detenemos en el trabajo de Gerchunoff.

- Opiniones de un sanjuanino sobre Anatole France, por Roberto Levillier pp. 75-79 (carta a la dirección de la revista)

Si bien en el artículo se reconocen las cualidades artísticas de France y su preocupación "por las cosas humanas" Levillier ensaya una comparación con su padre, que representa, frente al francés hipercivilizado e irónico, la "robusta salud de 'carácter' del primitivo", "imagen del antiguo 'Gaulois"”.

- Estado actual de la literatura en Venezuela, por Rufino Blanco Fombona, pp. 86-97

Pasa revista a las letras venezolanas, lo cual incluye la producción relativa a la historia, novela cuento, lírica, y crítica.

- Grecia (Enrique Gómez Carrillo), por Jorge Walter Perkins, pp. 110-116

Perkins elogia la labor de Gómez Carrillo, y señala el gusto que despiertan sus crónicas en la más diversa clases de lectores. Carrillo aparece como un sujeto atento a todas las novedades: "No ha de encontrarse en estos últimos tiempos ningún acontecimiento literario de trascendencia de que Carrillo no se haya ocupado". Más adelante se lo define como un "alma rara", un "raro sujeto".

- Letras Italianas Juan Chiabra pp. 117-120

El contagio nietzscheano en Italia

Se refiere a los ecos de la obra de Nietzsche y a su valor en la historia de la filosofía.

"No es de maravillarse que un pensador y un estilista tan nuevo y tan subjetivo como Federico Nietzsche, haya conquistado una popularidad tan ruidosa también en Italia. Los más de sus lectores y de sus secuaces se encuentran, no entre los estudiosos y los doctos, o entre los hombres de ciencia, sino entre los artistas y los literatos puros (...)

Individualistas, aristócratas, intelectualistas, y todos los "refinados" del reino, han expresado en los círculos literarios y artísticos, con conferencias y en los diarios, su viva simpatía por el gran partidario de una doctrina diametralmente opuesta a todas las teorías democráticas, sociales, ecualitarias" p. 117

Más adelante concluye: "Considerando a ésta [la obra de Nietzsche], no como un sucederse desordenado de teorías, pero como un desarrollo progresivo, en el cual, en conjunto, una determinada teoría es el perfeccionamiento de la que le precede, y el germen de la que le sigue, la filosofía de Nietzsche representa, para nosotros, una vigorosa y eficaz reacción contra la filosofía de la humildad, contra el humanitarismo excesivo" p. 118.

- Últimos libros

Se refiere al último libro (de poemas) de Olindo Malagodi, publicado por la Sociedad Tipográficoeditora Nacional de Turín, a Albo carducciano publicado por Zanichelli de Bologna (edición lujosa), editor que ha publicado además la obra de (18 volúmenes) y sobre Carducci.

Letras Argentinas, por Roberto F. Giusti pp. 121-135

-La gloria de don Ramiro, por Enrique Larreta, pp. 121-125 
El crítico compara a Larreta por la dedicación - cinco años tardó en escribir la novela- con Flaubert. "En una prosa admirable, que reúne condiciones sobresalientes de sabor y color, de noble severidad en el giro amplio, rotundo, o de ligereza graciosa en el empleo de la imagen; de precisión, vigorosa o suave, según los casos, en la notación del detalle, y de castiza propiedad en todo momento, ha escrito Larreta su novela, en la cual concíliase la esbeltez de cada una de sus páginas, de sus descripciones, de sus episodios, con la maciza aunque elegante contextura del conjunto.

Esta sí que es prosa sana y robusta, abundante en el léxico, suelta en el giro, finamente poética sin languidecimientos innecesarios, siempre exacta sin haber menester de tortura, y que posee además el don superior de continuar en la buena tradición de la lengua castellana." pp. 121-122.

Califica a Larreta de "novelista impersonal" en tanto "contempla las cosas de este mundo (...) con mirada serena e imparcial" y sostiene que esta novela es hasta el momento la mejor novela argentina. "Ni por la materia ni por el idioma, La gloria de don Ramiro nos es ajena. No lo es por la materia, porque tiene para nosotros un interés histórico y sociológico enorme todo aquello que atañe a la grandeza ya la decadencia de la madre patria, con cuya vida nos han unido en todo tiempo los vínculos de la sangre, dependiendo del conocimiento del alma de su pueblo la aclaración de muchos de nuestros fenómenos sociales; y no lo es por la lengua, pues fuera locura admitir que ha de renegarse de un libro escrito con libertad en buena prosa castiza, malgrado no sea dicha prosa la más familiar a la mayoría de nuestros escritores" p. 124.

Giusti transcribe el juicio ("vaticinio") de Groussac de 1896 sobre Larreta, en las páginas de la sección 'Los redactores' de La Biblioteca, en el que Groussac lo calificaba como "Príncipe de la generación entrante con Estrada y algún otro, ¿tendrá esa energía persistente del esfuerzo, que retribuye y valoriza el gratuito del talento?" p.124 [la transcripción es más extensa

-El viaje a través de la estirpe y otras narraciones, por Carlos O. Bunge pp 125-126

Lo califica de "buena obra en el género". Se trata de relatos de distinto tipo (fantásticos, científicos, psicológicos, algunos más humorísticos).

-El libro de la duda y otros cantos ingenuos, por Carlos A. Leumann pp. 126-130

Se trata de un libro de versos en que se advierte la falta de dominio sobre la el lenguaje y la forma.

-Ideaciones por Juan Más y Pí, pp. 130-132

Se refiere al acontecimiento que implica la publicación de un libro de crítica, como defensa de la una práctica que Giusti juzga denigrada por la opinión.

"Bello libro a fe mía, Ideaciones! [tal el original] No es finísimo, sino modesto, el papel en que está impreso; no lo han editado los hermanos Moen, y se vende baratísimo; pero es un muy buen libro.

En él ha reunido Más y Pí una parte de su enorme producción, dispersa en periódicos y revistas. Enorme sin exageración pues Más y Pí es de los pocos que han hecho entre nosotros de las letras y del periodismo una profesión al par que una misión noble y útil. El periodismo es el plato en que, con mayores o menores ganas, nos desayunamos diariamente todos aquellos a quienes nos dio $\mathrm{u}$ buen día por echarnos a escribir; sin embargo, ¿cuántos son los que lo ejercen con independencia y elevación tales, que no tuerzan su criterio ni por la esperanza de prebendas, en pago o a cuenta de elogios pasados o futuros, ni porque así lo exige la dirección del diario, en el cual es menester decir blanco lo que se cree negro?. Entre ellos, a mi juicio, figura con derecho Más y Pí.” p. 131.

El libro tiene dos partes: una sobre hombres y libros argentinos y americanos, otra sobre letras y pensamiento europeos. Giusti se refiere a Más y Pí como biógrafo de Almafuerte y como su discípulo. [Sobre Almafuerte Más y Pí publicó un estudio en el no 1 de la revista, del que se ha ocupado Giusti en el $\left.n^{\circ} 5\right]$

-Las nuevas tendencias literarias, por Manuel Ugarte, pp. 132-135

Opinión contraria a los criterios de valor literario que organizan el libro de Ugarte.

Sostiene Giusti: "En Las nuevas tendencias literarias ha reunido Manuel Ugarte una serie de crónicas ya publicadas en diarios y revistas, y algunos prólogos, en todos los cuales con entusiasmo comunicativo expone sus teorías sobre la literatura manifestándose como siempre decidido partidario del arte social. 
Aceptables o no sus opiniones, tienen, sin embargo, esas páginas, los méritos de la generalidad de las del brillante cronista, a saber, la fecunda efusión, el delicado espíritu poético, la elevación de ideales y seductora elocuencia.

Pero no es sobre estas cualidades de la prosa de Ugarte sobre las que hoy quiero detenerme una vez más, sino sobre la errada inclinación de muchas de las mencionadas crónicas que el autor ha convertido en catálogos de nombres y en índices bibliográficos que acusan su falta de espíritu y su aparente capacidad para distinguir lo bueno de los mediocre y éste de lo rematadamente malo." p. 133 Giusti prosigue: "Pero Ugarte es demócrata también en literatura, y como tal tiende a nivelarlo todo. en su libro Darío o Valencia, Sánchez o Fortoul, entremézclanse fraternalmente interminables y heterogéneas retahílas de nombres, muchos de ellos tullidos, con los más vacíos, tontos y despreciados grafómanos de América. (...)

La culpa de esto reside en el descamisado concepto del arte que se comienza a tener. El socialismo también va entrando ene ese terreno, que debiera quedarle cerrado. En las páginas de Ugarte parecen ya escucharse los gritos de los proletarios de la literatura, pidiendo también ellos igualdad sobre la pauta de su miseria intelectual. es la confusión de las ideas seculares, el derrumbe de las cumbres, la muerte del ideal, el enseñoreamiento de lo plebeyo" p. 134

Hacia final vuelve a condenar a Ugarte -como lo había hecho en el comienzo de la nota- por sus comentarios adversos a Rodó, a quien junto con Blanco Fombona y Juan Más y Pí, Ugarte ha calificado de "gacetilleros". p. 135

La demostración a Juan Más y Pí, pp. 136-139

No es en rigor una demostración, según explica la nota de la dirección, sino que en la reunión mensual en lo de Ferrari (el "almorzáculo"), se celebra la aparición de Ideaciones de Más y Pí.

Asistieron: Juan Más y Pí, Salvador M. Bocau, Florencio Sánchez, Carlos de Soussens, Enrique Banchs, Marcelo del Mazo, Federico S. Mertens, Evaristo Carriego, Guarro Vilarnaur, Rafael Arrieta, Alvaro Melián Lafinur, Emilio Ravignani, Alfredo Costa Rubert, Jorge G. Borges [¿?], Macedonio Fernández, Josué A. Quesada, Carlos Schafer, Salvador Diez Mori, N. Larrea, Alfredo A. Bianchi y Roberto Giusti. "La franca cordialidad animó la comida". p. 136

Discurso de Marcelo del Mazo

Da cuenta de la situación de la crítica dominada por personas que acceden a sus puestos en los diarios de formas "condenables". Más y Pí se cuenta entre los que pocos que "han contribuido a alentar la producción literaria". Entre los que se han esforzado en ese y otros sentidos se nombra a Payró y especialmente se refiere a El Triunfo de los otros y a la "Sociedad de escritores" que impulsó; a Carlos Vega Belgrano, quien en las columnas de El Tiempo dio lugar a "las más nobles ideas" y fue "medio para exteriorizar las formas literarias igualmente nobles"; a Juan Pablo Echagüe; Charles de Soussens ("el cisne helvético"); Bianchi y Giusti.

Notas y comentarios

-El congreso internacional de filosofía de Heidelberg

Se transcribe la nota de E. Duprat, colaborador de Nosotros.

-Nuestro nuevo administrador

Se va Alfredo Costa Rubert y asume el cargo Emilio Ravignani, quien es presentado como "estudiante próximo a doctorarse", "espíritu selecto". Participa del directorio del Instituto de Enseñanza General.

-Revista de Scienza (Scientia)

Se informa sobre la aparición de esta revista que va en contra de la especializaciones científicas excesivas.

-Ecce Homo. Se comienza la publicación del libro de Nietzsche en este número de la revista. Se consigna que Ecce homo "ha sido publicado por primera vez en los países latinos por el Mercure de France en sus últimos números, vertido al francés por Henri Albert, el traductor de la obra completa" de Nietzsche. Nosotros publica por primera vez la obra en su traducción española.

-Un incidente de los juegos de Bogotá. El ganador del concurso, Ángel María Céspedes es premiado por el gobierno con el cargo de Canciller del consulado de Colombia en EE. UU, con la intención de ampliar sus estudios

Libros recibidos 
-Alfredo Parodié Montero, Rimas selváticas, Poesías, Buenos Aires, Biblioteca Nacional Non plus Ultra, 1908.

-Manuel Ugarte, Las nuevas tendencias literarias, [Valencia], F. Sempére y cía. editores, [1909]

-Anales de instrucción primaria, Tomo V, $\mathrm{n}^{\mathrm{o}}$ 6, Montevideo, 1908 [no se consigna editorial]

-Juan Más y Pí, Ideaciones, Barcelona, F. Granada y cía. editores, [1909]

-Carlos Sigúrez y Acha, En la Pampa, N. Tommasi editor

- Leopoldo Lugones, Lunario sentimental, Buenos Aires, Arnoldo Moen y hermano editores, 1909.

- Ernesto León O’Dena, Enseñanza de la moral cívica (conferencia patrocinada por la Sociedad

Fomento de la Educación Común del Concejo Escolar 5º, Buenos Aires, 1909.

-Juan Álvarez, Orígenes de la música argentina, 1908 [no se consigna editorial]

\section{Año III, tomo IV, no 20-21, mayo-junio, 1909}

Ecce Homo (cómo se llega a ser lo que se es; por qué soy tan maligno)......... Federico Nietzsche pp145-159

Elegía Perla, Gólgota, Penitente. Manuel Cervera pp. 160-161 [colombiano]

José Asunción Silva..............Guillermo Valencia (Juan Lanas) pp. 162 - 176 [dedicado a José Ignacio

Cuellar]

Obsesión del esplin.............Eugenio Díaz Romero pp. 177-178

Un lírico catalán. Emilio Guanyabéns........Juan Más y Pí pp. 179-190

Vuelve. Enrique Banchs p. 191

Chopin, estudio 12, Op. 10

.Pablo Della Costa (hijo) pp. 192-193

La evolución orgánica de la música..........Mariano Antonio Barrenechea pp. 194- 207

Romances sentimentales ...........Arturo Pinto Escalier pp. 208-211 ["Mi alma está herida", "Vive contenta, resignada", "Soy como un nido vacío"]

Los fragmentarios (Pedro Sonderéguer) ......... pp. 212- 216 ACL [¿¿?] CRITICA

Walt Whitman............Alvaro Melián Lafinur pp. 217-218 [Whitman aparece como el profeta del futuro]

Las viejas murallas........... Roberto Levillier pp. 219-221 [relato de la dinámica del progreso; lo nuevo se hace con los escombros del pasado]

La Abuela, La intrusa, La Aldea......... Gustavo Caraballo pp. 222-223

Los primarios del verso. Base de una nueva poética........ Edmundo Montagne pp. 224-230

Arpalina................Hugo Achával pp. 231-232

Pellegrini..........Julio A. Rojas [discurso con motivo de la primera estatua del país, en Chivilcoy] pp. 233-236.

Homenaje de la escuela a don Juan Cruz Varela pp. 237-242 [introduce G.T ¿? las palabras de

Alberto Julián Martínez, secretario del Consejo Superior de enseñanza primaria]

Crónica musical..........Mariano Antonio Barrenechea pp. 243-248

Letras italianas.............Juan Chiabra pp. 249-255 [a propósito de la estética de Croce]

Libros.......... S pp. 256- 260

Notas y comentarios..............pp. 264.

-Pellegrini, por Julio A. Rojas

El discurso tiene un tono marcadamente nacionalista. Dice Rojas: "Al pie de las estatuas, desde la más remota antigüedad, hubo siempre una conjunción de ideales colectivos: Grecia, dando forma plástica a las divinidades olímpicas, inmortalizaba en el pentélico famoso las fuerza directrices del organismo social y entregaba al culto severo de las generaciones futuras las cosas inmateriales de su tradición, como si quisiera refrenar el curso de las horas fugaces y darles perennidad terrena." p. 233.

La muerte de Pellegrini "tiene para todos una misma sugestión: la de la orfandad (...)". "El país atraviesa por uno de los momentos más difíciles de su historia; no peligra por cuestiones internacionales ni por la violencia de sus luchas internas; peligra porque se ha disuelto el espíritu nacional, porque nadie apasiona a la opinión pública, porque comienza a perderse la fe en los partidos y a tenerse fe en círculos y antesalas (...) El habría podido encauzar las corrientes de la opinión pública hacia destinos más altos y horizontes más poéticos que el mercantilismo subalterno infiltrado en la vida cívica de los tiempos actuales.”p. 234 
Habla de "cosmopolitismo sentimental" e "hibridismo político", como factores negativos que sustituyeron "las costumbres nativas, las fuerzas inmanentes de la tradición hispánica, desequilibrando el contenido étnico de la sociedad argentina. Todo eso compromete nuestro destino manifiesto en el mundo. El Nilo, cuando baja de las regiones abruptas, trae en sus aguas las semillas fecundantes de las diversas tierras, los gérmenes nocivos de diferentes climas, y cuando deposita su humus sobre el suelo de Egipto, lo entrega como una masa homogénea, susceptible de todos los cultivos y unificada por la obra obscura de la Naturaleza [en mayúscula en el original]. De igual manera, cuando vienen a nuestro territorio, mezclados en la corriente inmigratoria, los hombres buenos y malos de lejanos países, es necesario que nos despojemos de ese culto del becerro de oro, que nos convierte en factoría y de este hibridismo político que nos convierte en remedo; de ese cosmopolitismo sentimental que nos convierte en una Babel, para que todo ello se unifique y sedimente sobre la tierra común en un ambiente de argentinismo vigoroso, como a su turno lo hizo Roma con las sucesivas inmigraciones." pp. 234-235.

Homenaje de la escuela a don Juan Cruz Varela, pp. 237-242

Esta nota participa del espíritu nacionalista que se observa en la revista. "Un soplo vivificante de noble patriotismo parece estremecer de nuevo el alma de la escuela. Algunas disposiciones recientemente tomadas por e Consejo Nacional de Educación lo evidencian plenamente, pues se dirigen todas con encomiable acierto, a neutralizar y a extinguir en la niñez teorías ambientes de cosmopolitismo suicida, y a robustecer en los ciudadanos de mañana el concepto egoísta pero grande de la patria propia. Así la institución de la semana de Mayo, y el juramento a la bandera; así el bautismo de las escuelas con los nombres de nuestros más ilustres antepasados; así la celebración del día de los caídos para siempre en las luchas la nacionalidad; y así por último, entre muchas otras, la medida que suprime libros extranjeros de lectura, si dignos como concepción si dignos como concepción y factura literaria, exentos por su finalidad de los propósitos a que debe tender esta enseñanza en un país tan rico de heroicas tradiciones.

Parte de este vasto programa y de cuyas exteriorizaciones nos hemos de ocupar detenidamente en breve, ha sido el homenaje tributado por niños en la tumba de D. Juan Cruz Varela ” p. 237.

\section{Libros, por I. L. N y P.S pp. 256- 260}

-Se refiere a las colecciones de la casa editorial parisina Bloud y cie., que publica textos de orientación religiosa y también otras colecciones como obras maestras de la literatura y la dedicada a filósofos y pensadores. Esto es importante porque muestra el interés de la revista por propagandizar este tipo de iniciativa editorial. I.L.N

-Los tres últimos libros de Martínez Sierra (El agua dormida -cuentos-, Aventura -novela corta-, La sombra del padre-comedia-). I. L. N

-Bajo el sol del valle, por Alberto Carvajal p. S

Versos de un joven poeta colombiano al que se presenta como una promesa literaria, que aún no ha encontrado su estilo.

\section{Notas y comentarios}

-Anatole France

Sobre la visita del escritor a la Buenos Aires.

"Milagro nos parece que Anatole France haya venido a esta tierra 'eminentemente agrícola y ganadera'. esto último, sobre todo, el Maestro habrá podido, sin duda, comprobarlo. Su llegada no ha dado lugar a entusiasmos ruidosos. Debía de ser y conviene, que haya sido así. Tampoco se ha visto agruparse a su alrededor [a] la reducida intelectualidad argentina. Esto, aunque algo más extraño, es también explicable. La crónica social ha tomado demasiada participación en la estadía de Anatole France entre otros, para no redundar en prejuicio de la meramente intelectual. Las conferencias que el Maestro ha dado en el Odeón sobre Rabelais han sido seguidas con discreto interés por una selecta concurrencia, que ha sabido reconocer las cualidades que dan lustre a su prosa alada, en la exposición habilísima que él ha hecho de la obra del célebre cura de Meudon” p. 261.

-Vicente Blasco Ibáñez

Está también Buenos Aires dando un ciclo de conferencias en el Odeón. "Saludémosle con respeto, si no como a la más elevada representación intelectual de la España contemporánea, tal algunos han 
dicho, cual a uno de los más robustos novelistas de la hora actual, que ha cavado hondo en el surco abierto por el Maestro de Médan” p. 262.

- Renacimiento

Se refiere a la aparición del número 1 de la revista y discute con ella para señalar su propio lugar en el campo intelectual.

"Es una nueva revista mensual de 'ciencias geográficas, sociales, filosóficas, letras y bibliografía' que viene a aumentar con ventaja el número de nuestras escasas publicaciones periódicas. Los hombres que la redactan, la lista de sus colaboradores y este primer número, cuya bondad acreditan excelentes artículos y conocidas firmas, son segura promesa para el colega de un porvenir brillante.

Sinceros, como somos, sin embargo, sin cobardías estériles, sin falsa modestia, sentimos la necesidad de someter a una benévola crítica la presentación de la nueva revista, algunos de cuyos conceptos se prestan a la discusión.

Dice el artículo inicial de Renacimiento, titulado 'En la arena', que 'la especialización de otras publicaciones periódicas -importantes dentro de la órbita que se han trazado- ha limitado hasta ahora la realización de un programa tan amplio como el que se propone nuestra revista'. Lamentamos disentir al respecto. El programa que Renacimiento se propone, ya lo tienen por bandera actualmente en Buenos Aires dos revistas más: La Revista de Derecho, Historia y Letras y Nosotros. El programa que Nosotros se ha trazado no admite limitaciones: en sus páginas los escritos filosóficos se han codeado con los históricos, los geográficos, los literarios y hasta los jurídicos. Una simple revisión del índice de los varios tomos hasta la fecha aparecidos puede atestiguarlo. En cuanto a la acreditada revista del doctor Zeballos, su índole es demasiado conocida y su título ya la indica con suficiente amplitud, como para no detenernos en demostrar que constituye asimismo una refutación a lo anteriormente citado. No es cierto, pues, 'hoy, como ayer, un grande núcleo de la intelectualidad de nuestro país carece del medio fácil para difundir sus conocimientos'. Hoy, como, tanto como ayer (¿olvida Renacimiento acaso la La Biblioteca, la mejor revista aparecida?) existen órganos, aunque escasos, suficientes para la difusión de las ideas de los que piensan bien. Y decimos escasos, pero suficientes, porque lo que aquí falta no son tanto los órganos de difusión cuanto la misma función. Lo que hay de verdad es que aquí se escribe poco sobre cosas serias y se piensa menos. Falta de remuneración, se argumenta. Probablemente; pero el hecho es que no dan el ejemplo, aquellos pocos que, hallándose en situación holgada, podrían por su ilustración y prestigio, sembrar a manos llenas y fecundar el terreno. Aclaremos, pues: para los que saben pensar y escribir, medios para difusión de sus ideas existían ya antes de la aparición de Renacimiento: Nosotros sin vanidad ni modestia, se cuenta entre ellos.

¡Bienvenida ahora la hermana que hace más numerosa la familia! Para ella nuestro afectuoso saludo" pp. 263-264

-Un libro sobre Lugones

Se refiere a la próxima aparición de Leopoldo Lugones y su obra de Juan Más y Pí.

\section{Año III, t. 4, no 22-23, julio-agosto, 1909}

Nuestro segundo aniversario

La Dirección pp. 265-266

Ecce Homo. Por qué escribo tan buenos libros, ................. Federico Nietzsche pp. 267-286

El moribundo.

Enrique Banchs pp. 287-289

Leopoldo Lugones (A propósito de Lunario Sentimental),

Roberto F. Giusti pp. 290-306

La sombra de un gran rey............. Amado Nervo pp. 307-309 [sobre Alfonso el Sabio, a partir de la publicación por la Nueva Biblioteca de autores españoles, y al cuidado de Menéndez Pidal, de la Primera Crónica General o estoria de España, que mandó componer Alfonso X.]

Aires murcianos. Vicente Medina p. 310

Nocturno No. 7............... José Santos Chocano, pp. 311-312

Eduardo Marquina.............. Juan Más y Pí, pp. 313-323

La filosofía francesa en 1908............. EM. Duprat, pp. 324-328

Salutation, por Carlos Alberto Leumann [escrito en francés] pp. 329-330

Sonetos (El matrero, El ombú, en las colinas Hércules)................. Ernesto Mario Barreda, pp. 331-332

Los gauchos judíos............. Alberto Gerchunoff, pp. 333-335 [fragmento del libro próximo a aparecer] 
Beethoven y Horszowski. Juan Chiabra, pp. 336-342

Poesía interior Pedro Sonderéguer, pp. 343-345

Cumbres y abismos...............Germán García Hamilton, pp. 346-348

Triste veladas. Adolfo Elías (hijo), pp. 349-350

Motivos de Proteo...........Alvaro Melián Lafinur, pp. 351-356 CRITICA

Libros últimos, pp. 357-365

La demostración de Nosotros a Blasco Ibáñez, pp. 366-371.

Notas y comentarios, pp. 372-376

Nuestro segundo aniversario

Transcribimos el texto completo

"Hemos llegado al segundo aniversario. Oportunas son por lo tanto unas pocas palabras sinceras, que, como en ocasión del primero, comenten esta fecha, para nosotros tan grata. Lo que entonces decíamos lo hemos mantenido. Siempre persiguiendo los mismos fines que nos trazáramos en nuestro programa inicial, hemos continuado nuestra marcha con entusiasmo, sabiendo sacar fuerzas para proseguirla aun de los desmayos inherentes al fatigoso andar.

Los progresos por Nosotros realizados los atestiguan plenamente los últimos números, en que la abundancia y selección del material le han ganado así los elogios repetidos de la prensa argentina y extranjera como el favor unánime del público lector.

Entendámonos: del público lector de estas cosas, que, por desgracia, es bien escaso. Algunos centenares de personas y pare Ud. de contar. No nos engañemos: los estudios serios y extensos, si tienen entre nosotros pocos cultivadores, encuentran igualmente pocos lectores. Se les prefiere a (sic) las poesías ligeras y los cuentos breves.

De ahí deriva la falta de medios con que comúnmente deben luchar las publicaciones de esta índole, cuando como Nosotros han sido lanzadas sin capital, contando con el solo esfuerzo de sus directores y la buena voluntad de los simpatizantes con ellas. Falta de medios que en el caso presente hubiera podido ser subsanada por los poderes públicos -aquí donde el dinero se despilfarra a manos llenas estérilmente- si una indiferencia deplorable, menos por lo que nos toca que por lo que significa, no hubiera siempre contestado con silencio a nuestros modestos pedidos de ayuda.

Seguiremos luchando, sin embargo, con la confianza en el triunfo. Nuestro anhelo es noble: se vería satisfecho si lográramos incorporar definitivamente al periodismo del Plata, una revista seria, con base estable, órgano del pensamiento de las jóvenes generaciones. Esperémoslo. Dos años de vida son ya un fundamento para ello.

$\mathrm{Y}$ ahora, al entrar en el tercer año, al agradecer de nuevo a nuestros amigos -colaboradores y lectoresy al periodismo que unánime e invariablemente nos dispensó la acogida más benévola a la aparición de cada fascículo, queremos hacer pública también nuestra viva gratitud al doctor Juan Antonio Argerich, quien simpatizando con nuestra humilde empresa, pidió para ella al Congreso Nacional a principios de este año, un pequeño subsidio, cuya negación no aminora el sentimiento expresado" pp. 265-266.

En el apartado "Nosotros y la posta intelectual: la forma de construcción de la autonomía" damos cuenta de los problemas tratados en este texto.

-Leopoldo Lugones (A propósito de Lunario Sentimental), por Roberto F. Giusti pp. 290-306

Para la discusión que plantea Giusti en esta reseña, cf. el apartado "Giusti crítico de Lugones" del capítulo correspondiente a Nosotros.

-Motivos de Proteo, por Alvaro Melián Lafinur, pp. 351-356

Crítica en la que se destaca la figura de Rodó como ensayista y lo aproxima a las figuras de Ralph Waldo Emerson y Juan Montalvo. Lafinur sostiene: "Belleza de estilo, profundidad de concepto, pasmosa erudición, únense en este gran libro para formar un imponderable conjunto. - Añádase a ello la generosa sinceridad, el desinterés y el optimismo sano y fecundo del autor que como un perfume se desprende de sus palabras para embriagar de fe y de confianza el espíritu del lector.

De mí sé decir que después de leer cada uno de sus capítulos me he sentido fortalecido por la tonificante doctrina de este maestro de la voluntad." p. 352 
Contrapone la filosofía de Rodó al escepticismo y al pesimismo: "Rodó da a la vida toda la importancia que la vida tiene, desciende hasta las más mínimas manifestaciones humanas para demostrar su trascendencia y preconiza el posible mejoramiento individual por medio del esfuerzo persistente y bien orientado de la voluntad.

Así brota de este magnífico libro uno de los más robustos himnos que se haya entonado jamás en loor de la voluntad humana. -Himnos que no está formado por épicas declamaciones ni por apologías directas sino que fluye naturalmente de la enunciación clara y precisa (...)” p. 352

El crítico, quien acuerda con el individualismo de Rodó, destaca la "persistencia de la educación" a la que se refiere Rodó para llegar a una vejez gloriosa.

Libros últimos, pp. 357-365

-Poemas del campo y la montaña, de Mario Bravo, por Claudio Diniz

Destaca Diniz: "No hay en la obra rebuscamientos ni efectos de modernismo malsano. Bravo se muestra como es en lo hondo de su temperamento americano, lleno de amor hacia la naturaleza, lleno de cariño a la vida, sin complicaciones sin filosofías trascendentales que a la postre solo sirven para entristecer la existencia" p. 357.

-Sursum, por Domingo A. Robatto, por Giusti

Versos precedidos de un prólogo de Raimundo Manigot. "Es un pequeño volumen de versos, muy simpático, más quizá por lo que anuncia que por lo que contiene"p.358

-Cosmópolis, por Ricardo Rojas, por Giusti

"Como El alma española, como Cartas de Europa, Cosmópolis es otra de aquellas compilaciones de artículos que Rojas sabe formar con alto criterio de selección aplicado a su labor dispersa en periódicos y revistas.

Todos ellos densos de pensamiento, son además vivificantes evangelios de virilidad, de sana belleza, de levada moral, medios excelentes para la propaganda nacionalista de que Rojas se ha hecho esforzado paladín. Nobles y coherentes opiniones políticas, morales y estéticas constituyen la trama de estos artículos, no despreciables granos de arena aportados a la obra de preparación de la civilización superior e idealista, espiritualmente homogénea, que el poeta sueña para el porvenir de la patria.

El prólogo de Cosmópolis es todo un programa que vale la pena comentar y discutir detenidamente. Propicia me será para ello la ocasión de comentar y discutir detenidamente. Propicia me será para ello la ocasión cuando haya de ocuparme en el próximo número de La restauración nacionalista, la obra recientemente aparecida, en que Rojas, como fruto de las observaciones hechas por su viaje a Europa, ha encarado de lleno y expuesto con amplitud sus patrióticos ideales" p. 359

-Ecos de ausencia, por E. Talero, por Giusti

Giusti se refiere a la edición del libro “(...) fuerte libro sobre el Neuquén, [Talero] acaba de publicar una nueva obra, editada por al casa española Sempére en uno de esos elegantes y económicos volúmenes de su biblioteca blanca, que tanta difusión alcanzan en España y América.” p. 359 Es un volumen de cuentos con buenos argumentos.

-Sendero de humildad, de Manuel Gálvez, por Giusti

La crítica es hostil tanto al libro como al autor:

"Manuel Gálvez ha creído que bastaba escribir versos con bondad y sencillez de alma para hacer un buen libro. Grave error. Esa no es ciertamente una receta infalible. Con ella pueden hacerse buenos libros, tan indistintamente como mediocres o malos. Por lo pronto el de Gálvez no es de los primeros. (...)

Gálvez ha confundido la simplicidad con el desaliño: de esta suerte no cree oportuno medir o acentuar correctamente sus versos, que así más que tales resultan por lo general renglones de prosa. Que hay cosas bonitas y sentidos por aquí y por allá en Sendero de humildad es posible; pero con rasgos felices y dispersos y raros no se hace un buen libro. Que su autor es sincero, también es cierto, peor la sinceridad no constituye por sí sola una virtud artística. Si así fuera, las cartas de amor de los horteras a las modistas deberían considerarse como monumentos literarios." p. 360

-Versos de una juventud, de Edmundo Montagne, por Giusti

Crítica elogiosa y benévola. 
Luego, Giusti consigna los libros no reseñados aunque leídos:

Almas de crepúsculo de Ricardo Sáenz Hayes

La escoria de Guido Anatolio Cartey

Las naves de oro de Arturo Vázquez

Cosas de la vida de Federico Mertens

La heroína del sud de Aníbal Latino

Hecatombes a Minerva de Fernando Márquez

La vieja senda de Julio R. Barcos

Chispas azules de Federico Curlando

-La literatura y las artes gráficas: El alma de los perros, de Juan José de Soiza Reilly, por A. G. [Alberto Gerchunoff, seguramente]

Dice A. G.: "Sería muy difícil precisar la filiación literaria del señor Soiza Reilly. Se diferencia de los demás periodistas por su estilo y éste ofrece tan solo novedades apreciable desde un punto de vista exclusivamente físico. El señor Soiza Reilly pertenece al espíritu de una época fenecida, en que se trataba de espantar al burgués. (...)

Publica un libro de entrevistas en las que nos facilita los detalles y las fotografía que se encuentran en las vistas de todos los reporters, anteponiéndoles un prólogo en el cual declara odiar a la multitud. Para ella, sin embargo, han sido escritas esas páginas, pues solo la masa puede atribuirles algún interés. Ahora nos ofrece un volumen de cuentos con el inevitable prefacio de Manuel Ugarte" p. 363.

-Un libro español: El triunfo de Alberto Insúa, por Más y Pí.

Destaca la calidad de la novela aunque no acuerda del todo con el tipo de personaje que representa Sangil (un escéptico), protagonista de la novela de Insúa.

La demostración de Nosotros a Blasco Ibáñez

Transcribimos las palabras con que la dirección de la revista reseña el encuentro en el restaurante Ferrari. Es importante destacar la contraposición que se plantea entre las dos figuras en cuanto a los modos de intervención intelectual que representan Anatole France y Blasco Ibáñez, respectivamente.

"Nosotros hubiera deseado asociarse en alguna forma a los muchos homenajes de simpatía tributados a Anatole France, el ilustre escritor, hasta ha poco nuestro huésped; pero aquella falta que hubo -y que comentáramos- de comunicación entre él y nuestra juventud intelectual, y la misma índole espiritual del Maestro, amigo más bien de la quietud meditativa que de la agitación y el bullicio, hizo que la revista limitara su homenaje a la bienvenida cordial dada en sus mismas páginas, y al respeto silencioso.

Distinta cosa debía naturalmente suceder con Don Vicente Blasco Ibáñez, el vigoroso novelista español, todavía nuestro huésped. Blasco Ibáñez siempre ha vivido en medio de la Vida [en mayúscula en el original], habiéndolo solicitado de continuo la propaganda, la agitación, la lucha política o literaria; un banquete fraterno en que nuestra juventud le expresara la simpatía que su obra le merece, no era, pues inoportuno, antes bien, llenaba un general anhelo, y por ello fue que Nosotros se encargó humildemente de realizarlo.

El banquete congregó alrededor de una mesa modestísima a más de sesenta comensales. La cordialidad con que transcurrió la comida, y la franca alegría que en ella dominó durante tres horas consecutivas, las damos por supuestas: referirnos a ellas fuera incurrir en las acostumbradas redundancias de las crónicas sociales en ocasiones semejantes.

Ofreció la demostración a nombre de Nosotros en un sobrio e intenso discurso, el caracterizado miembro de nuestra redacción, D. Carlos Octavio Bunge, y a continuación leyó unos originalísimos versos ciranescos, también a nombre de la revista, el distinguido escritor D. Eduardo Talero, contestando a ambos Blasco Ibáñez, en una brillante improvisación, cuyos términos no recordar, pero en la cual manifestó la satisfacción inmensa que el banquete le había reportado por su significado especial, y abundó en sanos conceptos sobre el Arte y su valor en la Vida [así en el original]

Los tres fueron calurosamente aplaudidos.

Numerosos comensales les siguieron en el uso de la palabra, quienes, como Edmundo Montagne y Pedro Sonderéguer, leyendo conceptuosas páginas; quien, como Alfredo Palacios, estudiando en una 
elocuente improvisación la obra de Blasco Ibáñez, y quienes, como Carlos de Soussens, Carlos M. Pacheco y algunos más, poniendo la nota amena en la reunión con jocosas declamaciones, ruidosamente festejadas por todos.

En resumen, una fiesta de arte y de confraternidad intelectual, sencilla y sincera, y la poesía de D. Eduardo talero, ya publicados en la prensa diaria" pp. 366- 367

-Discurso de C. O. Bunge: se refiere a Blasco Ibáñez en términos de referente para la juventud, "artista", "luchador". Esa lucha es una defensa de la justicia, la democracia y el progreso, el interés por las "cosas colectivas". Define el arte de Ibáñez como "el de guiar a las multitudes". p. 368

-Discurso de Pedro Sonderéguer: define al escritor como "eterno".

-Presentación: poema de Talero, tramado en motivos mitológicos griegos. Así el escritor español aparece como "Apolo" y la juventud argentina, como cadetes, de ese "capitán".

Notas y comentarios, pp. 372-376

-Rafael Altamira

Interesa esta reseña porque Altamira aparece como una figura intelectual a seguir, como ejemplo: “(...) es por otra parte el tipo del maestro, por su gran nobleza, por su enorme honradez intelectual. Espíritu generoso, logra comunicar su generosidad al auditorio, que ve en él, no al seco investigador endurecido en el cultivo excluyente de una especialidad, sino al hombre lleno de bellos ideales y bellos sueños. Es un sabio a la manera de los sabios españoles" p. 372.

-Florencio Sánchez

Se informa el viaje a Europa de Sánchez, para buscar su "nombradía europea". En una nota al pie se lee un detalle risueño: "Sánchez fue despedido con un fraternal banquete que sus amigos le ofrecimos en París Hotel. Camilo Villagra le dijo una sentida despedida, y Ricardo Rojas en un soneto pidió a Talatta, la deidad marina, propicias aguas para el viajero" p. 373.

-Miecio Horszowski

Se refieren las audiciones del pianista en Buenos Aires, a las que no han asistido demasiadas personas. Esto se relaciona con la situación que señala la desproporción entre crecimiento material y crecimiento cultural, de la que se queja intermitentemente la revista.

-Los gauchos judíos

Se anuncia la reunión en volumen y con el título de Los gauchos judios, de los cuentos conocidos como Cuadritos de la colonia. El prólogo es de M. Leguizamón.

-Un plagio

Guido Anatolio Cartey informa a la revista del plagio de su novela Cadenas rotas, que, publicada en 1906 por la "Biblioteca del Progreso de la Boca" "ha sido reimpresa descaradamente este año en Madrid por un señor Dr. Domiciano Estrada con el título de Libertad y el subtítulo: Novela argentina. Libertad pertenece a la Colección Ánfora de la Librería de Pueyo, editor cuya buena fe ha sido indudablemente sorprendida por el plagiario" p. 375

-Los fragmentarios

Se transcribe la carta de Max Nordau, en la que le agradece el libro y lo elogia. Dice haber leído parte del libro en La Nación.

Nuestra administración

La revista tiene un nuevo administrador -que reemplaza a Alfredo Costa Rubert-: C. Alberto Guida, "librero establecido en la calle florida 512, que atenderá todos los asuntos a ella referentes" p. 376. El mensaje está destinado a los suscriptores.

Erratas importantes; consigna los errores de tipeado en el artículo de Giusti sobre Lugones. En p. 292 líneas 20-21 debe decir "verterá" y no "en préstito"; en p. 299 en antepenúltimo renglón debe decir "fresia" en lugar de "poesía". 


\section{Año III, tomo 4, n 24, noviembre, 1909}

Ecce Homo. Por qué escribo tan buenos libros. Humano, demasiado humano............. Federico Nietzsche, pp. 378-393

A Maura (versos).............. Calixto Oyuela, pp. 394-395 [en contra de los libertarios; "furor libertario", "turbas viles"]

Urquiza y la casa del Acuerdo (advertencia preliminar)

Martiniano Leguizamón, pp. 396-400

Las Erinnias (tragedia), traducción en verso de E. Banchs (primera parte: Clitemnestra).

Leconte de Lisle, pp. 401-423

El padre Gerardo

Guido A. Cartey, pp. 424-431

Teoría y práctica de la Historia. Juan Chiabra, pp. 432-437

Sonetos.......... Felipe Valderrama, Domingo A. Robatto, Carlos A. Sanguinetti, Ataliva Herrera, pp. 438-440

La revolución olímpica

José M. Bustillo, pp. 441-444

Motivos de Proteo Alvaro Melián Lafinur, pp. 445-454

Zupay Poema sinfónico de Pascual Rogatis. José Ojeda, pp. 455-459

La demostración a Nosotros.......... La Dirección, pp. 460- 464

La demostración a Nosotros .............Roberto F. Giusti

La demostración a Nosotros ............Florencio C. González

Notas y comentarios.

Nosotros, pp. 465-467

-Urquiza y la casa del Acuerdo por M. Leguizamón, pp. 396-400

Se transcribe la advertencia preliminar del libro homónimo, escrita también por Leguizamón. En ella se explican los motivos de la publicación de una serie de documentos que según el autor sirven para aclarar un debate suscitado respecto de la figura de Urquiza. Comienza así: "La presentación de un proyecto a la legislatura de Buenos Aires, -bien inspirado, sin duda,- y por el cual se declara de utilidad pública la modesta casa donde se reunieron los gobernadores pactantes del acuerdo se San Nicolás, para convertirla en una biblioteca popular con el nombre del general Urquiza, autor del pacto memorable, inspiró nuestro primer artículo publicado en La Argentina el 30 del mes de Agosto" p. 396. Leguizamón pretende contribuir en esta "hora presente en que tan poco interés se presta a las cosas que hablan de nuestro pasado. Empero estimo que no ha de resultar estéril mi esfuerzo y por eso recojo las breves páginas siguientes -ampliadas con algunos documentos importantes para darles autoridad de que carecen- confiando que acaso tengan utilidad para la juventud estudiosa, siquiera sea como simples referencias de las fuentes de buena información a que puede acudir para estudiar uno de los períodos más interesantes y oscuros de nuestra organización institucional "p.397. Debe hacerse la historia de esa época "tormentosa": "La historia de esa época tormentosa no está escrita todavía" p. 397.

Cf. el apartado: "Martiniano Leguizamón: hacia la construcción de la historia nacional" en el capítulo correspondiente a Nosotros para ver la forma en que la revista participa del debate de la identidad nacional.

-Teoría y práctica de la historia de Juan B. Justo, reseñado por Juan Chiabra pp. 432-437.

"Pero este ponderado y poderoso [negritas de Chiabra] libro es también una obra científica, y desde tal punto de vista puede ser considerado, notando que muy raramente encontramos una condensación tan feliz y tan oportuna de la pura intención de la ciencia fecunda con el amor inquebrantable que vigoriza y levanta el concepto de la vida en sus más grandes y nobles aspiraciones"p.432-433.

Chiabra destaca el método del libro: "La obra del señor Justo, por su método y la ausencia de una única tesis unilateral y fija desde el principio, se levanta por encima de todas esas historias, grandes y pequeñas, particulares y generales, en las cuales el alma del historiador o de sus lectores es como el teatro, la escena, desde cuyo punto de vista se halla representado el drama de las cosas y los hechos narrados en la producción histórica" p. 434.

-Sonetos pp. 438-440:

"Rayo de luna" por Felipe Valderrama 
"El deseo muerto" por Domingo A. Robatto

"Entre colores" por Carlos A. Sanguinetti

"Las golondrinas", "Bajo las parras", "La flor del aire" por Ataliva Herrera.

-Motivos de Proteo por Alvaro Melián Lafinur pp. 445-454.

Rodó sigue siendo presentado como Maestro. Transcribimos algunos párrafos en los que se leen los puntos básicos del acuerdo entre Lafinur y Rodó.

"Rodó es pues y en alto grado un moralista. Sus doctrinas idealistas, no pueden dejar de ser benéficas para todos los espíritus y principalmente para los jóvenes que han menester de esas lecciones de voluntad y energía.

Pienso que Motivos de Proteo debería ser difundido entre la juventud, para que la propagación de las nobles ideas que contiene, contribuyen a robustecer voluntades enfermizas, a sugerir ideales y a despetar vocaciones y aptitudes dormidas en el fondo de muchas almas.

Motivos de Proteo es 'un libro de bien' que diría Rubén Darío.

(...)

Rodó posee como pocos pensadores la facultad esencial según él de exponer y 'enseñar con gracia' facultad que tuvieron entre otros, Renan y Guyau a quienes parece considerar sus maestros" $\mathrm{p}$. 453

Hacia el final Melián Lafinur llama a Rodó "sacerdote" del que siempre esperar "su nuevo sentir", "nueva verdad", "nueva palabra". p. 454

Zupay. Poema sinfónico de Pascual Rogatis. Crítica de J. Ojeda.

"Zupay es el primer poema sinfónico realmente argentino que haya tomado carta de ciudadanía en el arte y esto no es poco para agregar a su verdadera importancia musical.

$\mathrm{Su}$ asunto tiene hondas raíces en la leyenda popular de las provincias del norte y su temas son genuinos autóctonos de la misma región tomados sin mezcla en los lugares propios. Su estilo es original y rico de las cadencias rigurosamente indígenas de los yaravís y huanitos -negrita de Ojedaquichuas y la exactitud del folklore ha sido llevada hasta los ruidos de la naturaleza y los cantos de los pájaros.

El asunto es último capítulo de El país de la selva, de Ricardo Rojas, libro pletórico de savia tropical, frondoso y vasto como el bosque, tierno y fuerte como el gaucho." p. 456.

-La demostración a Nosotros

La dirección comenta la reunión realizada en el restaurant Luzio por los amigos de la revista. Es interesante ver cómo se construye un nosotros basado en la camaradería, la amistad y la igualdad: "Huelga decir que transcurrió [la comida] en medio de la más viva alegría y franca cordialidad: sobrados vínculos unían a los concurrentes y demasiado familiar era el ambiente a todos, para que por un solo momento pudiese pesar sobre la reunión la fría solemnidad de las fiestas 'distinguidas' ". p. 460

La dirección da una lista de los asistentes y de quienes enviaron cartas de felicitaciones. De los primeros y en ese orden: Martiniano Leguizamón, Atilio M. Chiappori (quien habla sobre la situación del mundo cultural y de la tarea de la revista), Ricardo Rojas, Alfredo Palacios, Emilio Becher, Eduardo Talero, Ignacio Orzali, Mario Bravo, Vicente Segovia, Ricardo Levene, Salvador Boucau, José Ojeda, Carlos de Soussens, Benjamín García Torres, Roberto Levillier, Florencio César González, Hugo Achával, Marcelo del Mazo, Luis Ipiña, Pascual de Rogatis, Salvador Debenedetti, Francisco Chelia, Julio L. Noé, Francisco Paolantonio, Emilio Ravignani, José A. Merediz, Carlos A. Leumann, Gastón Federico Tobal, Coriolano Alberini, Joaquín Rubianes, Domingo A. Robatto, Elio del Giglio, Emilio Suárez Calimano, Alfredo A. Bianchi y Roberto Giusti. Las cartas fueron enviadas por: José Enrique Rodó, M. Maurtúa, Antonio Dellepiane, Juan Antonio Argerich, Osvaldo Magnasco, Ernesto Quesada, Francisco Capello, Francisco Sicardi, Carlos O. Bunge, José Luis Cantilo, Mariano de Vedia, Francisco Uriburu, Camilo Morel, Calixto Oyuela, Emilio Ortiz Grognet, Alberto Ghiraldo, Juan José Colombo Berra, Juan Aymerich, Alberto Tena, Juan Chiabra, Gustavo Caraballo, Arturo Pinto Escalier, Carlos F. Múscari, Francisco Villamil y Arnoldo y Balder Moen.

En el festejo hablaron: Atilio Chiappori, Florencio César González, Alfredo L. Palacios y Carlos de Soussens (los dos últimos, a pedido de los presentes) 
Discurso de Giusti en el festejo:

"La simiente por lo demás caía en terreno propicio. Un órgano de la índole de Nosotros era necesario para continuar la serie de aquellas gallardas, entusiastas y juveniles revistas, puntos de concentración de energías espirituales dispersas, cuyos dos últimos exponentes fueran El Mercurio de América e Ideas, que todos conocéis bien y recordáis con afecto, pues las circundasteis entonces con la misma efusiva simpatía con que ahora circundáis a Nosotros. Órganos de jóvenes sí, pero de jóvenes que no olvidan a quienes les han precedido, sin servidumbre espiritual por cierto, mas tampoco sin y razonadas rebeldías, por el exclusivo placer de rebelarse. Órganos, en suma, en los cuales, como tuve ocasión de escribirlo hace dos años en la presentación de la revista, se encontraran en comunión con sus páginas las viejas firmas consagradas con las nuevas ya conocidas y con aquellas de los que surgen o han de surgir." p. 462.

"He hablado de las simpatías de todos. Quiero decir de todos vosotros - ¡Nosotros en una palabra!presentes y ausentes, poco importa, que Nosotros somos todos los que llevamos en el alma un poquito de ideal, todos los que creemos que se colabora para la grandeza futura de la patria tanto con el trabajo del cerebro como con el del músculo.

Ya sé que nos ha faltado la estimación de los que no son de nuestro mundo, ya sé que el Congreso Nacional nos ha negado una pequeña subvención que para la revista hubiera sido un gran auxilio... Conviene lamentarlo, pero debemos explicárnoslo y darnos cuenta de que es lógico que para la mayoría de nuestros congresales un órgano que es exponente del pensamiento joven argentino no merezca la pena de ser ayudado, mientras sí se han ganado con justicia una pensión las revistas para uso de los bufetes de abogados.

Hay que considerar que ciertamente el público intelectual aquí es escaso, pero que del mismo modo lo es, donde más, donde menos, en todas partes. También en Atenas las sutiles disputas de Protágoras con Sócrates tenían sin cuidado al portero de la casa. Naturalmente esta ciudad no es Atenas. Solo una desmedida vanidad patriótica pudo hacerlo creer a alguien por un instante. Pero si no es Atenas, tampoco creo que sea Cartago, como yo alguna vez he oído decirlo. Ni tanto ni tan poco. Roma, si os place, la Roma republicana, manteniéndonos en el campo intelectual, saltando por encima de todas las enormes diferencias, y no dándole al paralelo más valor que el de un símil literario." p. 462-463.

-Discurso de Florencio César González: es el vocero de la revista Renacimiento, a cuyos redactores define como "hermanos en propósitos" y "esforzados soñadores, que lleva como divisa el sano optimismo de los cerebros fuertes y la euforia de las vidas juveniles". Ellos "saben que es la [la palabra de aliento] única recompensa que merecen hoy los que disuenan en esta vida argentina, cuya orientación única dijérase encarnada en enriquecer la médula para hacerla inagotable fuente de laceres, olvidando que los ricos tejidos del cerebro están vecinos a la atrofia por inacción del órgano.

Y vosotros, señores de Nosotros, disonáis en este concierto de la materialidad, porque tenéis en el cerebro una llama que ilumina con intensos resplandores el horizonte siempre azul de vuestros ideales." p. 464.

\section{Notas y comentarios}

-A la prensa

Agradecimiento a la prensa por las muestras de estimación hacia la revista en su segundo aniversario. Se nombra como "revistas hermanas" a Renacimiento y La Vida Moderna

- El asunto Ferrer - La muerte del coronel Falcón

Explican por qué hacen referencia a hechos que como éstos exceden los límites trazados por la misma revista. "Bien que cuestiones estas sobre las cuales Nosotros por su índole de revista alejada del campo de la lucha activa, política o social, podría rehuir de tratar sin faltar a su programa, constituyen, sin embargo, dos páginas de historia contemporánea, general la una, argentina la otra, que por presentar ancho margen al comentario sereno y fecundo, valdrá la pena recordar" Señalan que no coinciden con el poema de Oyuela "A Maura", en el que se vierten conceptos contrarios a los "libertarios". Con respecto al asesinato de Falcón, la revista había preparado un comentario que, bajo el estado de sitio no puede publicarse. 
Se excusan por no haber reseñado algunos de los libros recibidos en la redacción.

"Abundante ha sido en estos meses la producción de índole histórica: así lo dicen la obra del señor Clemente Ricci, La historia de Europa y la segunda Roma. La significación histórica del cristianismo- voluminoso trabajo cuyo autor querré disculpar la demora en ocuparnos de él, explicable por la larga lectura que exige-; la contribución histórica Urquiza y la casa del Acuerdo del distinguido escritor Martiniano Leguizamón, del cual publicamos el prólogo en este mismo número; y las extensas monografías El Deán Funes en la historia argentina de D. Mariano de Vedia y Mitre, y Don Cornelio Saavedra por el señor Zimmermann Saavedra, obras todas que trataremos como se merecen en el número siguiente.

A esta producción de índole histórica puede agregarse el notable informe sobre educación, $L a$ restauración nacionalista, presentado al Ministerio de Instrucción Pública por el conocido hombre de letras D. Ricardo Rojas, respecto del cual debemos postergar la publicación del artículo que le dedicábamos, por ser incompatible, debido a los puntos que en él se tocan, con la situación anormal que a la prensa ha creado el estado de sitio últimamente dictado." p. 465. [en la nota del no 26 en que finalmente se publica el artículo de Giusti, se hace referencia a esta situación]

También se ocuparán en el número siguiente de : La Nave de D’Annunzio, de Moral Cívica y Política de Ernesto León O’Dena, y de Comenzar el camino de Gastón F. Tobal. p. 466

Como casi siempre, al final de esta sección la redacción se excusa por el atraso en la publicación de la revista, recuerda a los suscriptores "dejar el importe de suscripción en sus casas, a fin de facilitar el cobro" p. 467.

\section{Año IV, tomo $V, n^{0} 25$, enero, 1910}

-Ecce Homo Federico Nietzsche, pp. 5-16

-Las Erinnias (tragedia), traducción en verso de E. Banchs. Leconte de Lisle, pp. 17-42

-Dos "Cantos" de Oyuela Francisco Capello, pp. 43-51 ["Estrofas" y "Oda a España"]

-Primavera sentimental (versos) Juan Aymerich, pp. 52-54 [dedicado a Giusti]

-Grandezas muertas (versos)... Pedro J. Naón, pp. 55-56 [dedicado a Rómulo Carbia]

-Un Maestro . Motivos de Proteo. Alberto Gerchunoff, pp. 57-62 [a E. Becher]

-Sonetos Max Grillo, Baudilio Vázquez Ludueña pp. 63-65

-Letras argentinas Roberto Giusti y HA, pp. 65-77

-Notas y comentarios Nosotros, pp. 78-80

Un maestro. Motivos de Proteo, por Alberto Gerchunoff, pp. 57-62

Gerchunoff dedica a Becher este artículo. Se queja de la ausencia de crítica para un libro tan importante. La crítica es muy elogiosa. Rodó aparece bajo distintas figuras: "docto varón", "maestro docto", que habla de cosas bellas con palabras bellas, "predicador de una suave religión de belleza y verdad" o "ministro" religioso, "alma(s) repleta(s) de idealidad. (p.60). Según Gerchunoff no es fácil determinar la tesis del libro, que intenta sintetizar como: el optimismo o la falta de "razones para entristecerse ante el espectáculo de la vida. Los hechos humanos revelan en sí, a los ojos del filósofo, motivos para alabarlos" p. 59.

"Posiblemente pasaría ante el observador por un burgués lleno de vulgar indiferencia y es, sin embargo, el que llena el Mirador de Próspero con el vuelo de las sagradas abejas que poblaban con la música de sus alas, el jardín Academus. Es él quien nos habla inspirando rumbos floridos a los jóvenes anhelosos de ideal e imprime direcciones certeras a las manos impacientes de accionar al impulso de la sangre bullente. Es el suyo un destino sacerdotal (...) Predica. Erguido en un alto púlpito, se dirige a los feligreses que acuden a su templo para oír sus pacíficos sermones. ¿Crees, lector amigo, que estoy exagerando? Es así. Considero a Rodó predicador de una suave religión de belleza y de verdad. ¿Qué era Renan? ¿Qué era Guyau, tan dulce, tan bueno?

En otro pasaje: "Rodó se les [a Renan, a Guyau] parece. Tiene del primero el amor a la verdad y al bien, la sabiduría minuciosa y el don del arte. Tiene del segundo esa hondura llena de claridad latina y la fecundidad de lo nuevo.” p. 60 
"Si ha podido florecer un D. Juan María Gutiérrez en época de sangrientas luchas, y elaborase después en pleno fundente étnico, tipos como Payró y Lugones, después del esfuerzo de nuestros primitivos, que dejaron labor de epopeya -Sarmiento y Hernández- Rodó, digo, confirma la razón de los que esperan frutos opulentos de las generaciones mezcladas bajo el cielo americano. Su obra, repito, anuncia la cultura perfeccionada, la simetría y el brillo, que se alcanza tras prolijos refinamientos de crisol." pp. 60-61

Finalmente: "Hoy día, en que las ideas sufren extraño desvío, las personas de talento se orientan hacia el pasado en ilógico afán de retroceso; hoy día en que las aspiraciones de mejora social son admiradas con desprecio, hoy que los poetas se acercan a Paul Deroulede, acabada encarnación de lo vacuo (si es que lo vacuo puede tener encarnación) y olvidan a los esplendorosos sembradores, a los obstinados renovadores de la sociedad, Rodó aparece como indicando el verdadero camino. Agradezcámosle tan generosa tarea, hagamos votos para que continúe trabajando siempre con tan armoniosa energía por el bien y la verdad" p. 62 .

Letras argentinas

Giusti se ocupa de reseñar todos los libros que no fueron comentados en el número anterior, salvo el de Tobal que es reseñado por H.A. ( ?)

-Urquiza y la casa del Acuerdo por M. Leguizamón. [Cf. el apartado "Martiniano Leguizamón: hacia la construcción de la historia nacional" en el capítulo correspondiente a Nosotros]

Giusti reseña el libro pegado a la perspectiva del autor. Es un comentario elogioso.

-Don Cornelio Saavedra, por Alberto Zimmermann Saavedra, pp. 69-70 Se trata de un libro de "vindicación". Destaca la oportunidad del libro en vísperas del Centenario. No es la obra de un historiador.

-El deán Funes en la historia argentina, por Mariano de Vedia y Mitre, pp. 71-72. Se trata de una conferencia que el autor dio meses antes en la Facultad de Filosofía Letras, y publicada por la Biblioteca del Instituto de Enseñanza General, "agrupación de jóvenes universitarios que está cumpliendo una verdadera obra de cultura". Fácil de leer, "Carece este estudio, eso sí, como el anterior libro del señor Zimmermann, de las condiciones esenciales para que una obra histórica resista a la acción del tiempo": "vigor y sutileza en la argumentación" p. 71.

-La Nave de D'Annunzio, pp. 72-73. Informa sobre la traducción al castellano de Andrés A. Demarchi de la obra de D'Annunzio, publicada en La Revista Artística de Buenos Aires, dirigida por Vicente Di Napoli Vita. Según Giusti se trata de una buena traducción.

-Trovas breves, por Pedro J. Naón, pp. 73-75

Sostiene que el autor tiene "alma de poeta" aunque "inspiración limitada" y "fantasía demasiado unilateral" p. 73.

En el final de las reseñas de Giusti hay una nota al pie que se refiere a la continuidad del estado de sitio y la cómo éste afecta su libertad de expresión:

"Como quiero decir a mi gusto una infinidad de cosas vedadas, esperaré a que concluya el estado de sitio para ocuparme de La restauración nacionalista, el bello trabajo de Ricardo Rojas. Hay que respetar las leyes....

Acaba también de aparecer el tercer libro de versos de Enrique Banchs, titulado El cascabel del Halcón. Libro a mi juicio admirable, no me atrevo a tratarlo apresuradamente en dos o tres páginas. Lo dejo para el número próximo." p. 75.

-Comenzar de un camino, de Gastón Federico Tobal, por H. A. [¿?]

Señala la filiación con Valle Inclán. "Bello el estilo y mala su prosa".

Notas y comentarios

-Nota a los lectores en la que se explica cómo aparecerá la revista, nuevamente en números simples y entre el $1^{\circ}$ y el 15 de cada mes. p. 78 Da precisiones a los suscriptores.

-Consigna la partida a Europa de Carlos O. Bunge para ocuparse de la traducción de su libro El Derecho. En el final de la nota aparece el elogio al tipo de figura que Bunge representa: "El doctor Bunge, que antes partir ha dejado concluida una original y útil antología para las escuelas, es un 
trabajador infatigable que sabrá sin duda convertir en oro intelectual de la mejor ley, el tiempo que pase en Europa en aparente viaje de placer" p. 79

-El número poético de Caras y Caretas. Sirve para distinguir tipos de publicación y de lectores. Se dice:

"Anotémoslo espontáneamente: el número extraordinario de primero de año, enteramente poético, que Caras y Caretas ha dado a luz, representa en nuestro ambiente no sólo un notable esfuerzo de la Dirección y Administración de la popular revista, sino también, un rasgo de audacia, viniendo como viene de una publicación cuyos millares de lectores, sólo, en su mayoría, exigen de ella literatura amena y superficial, y abundante información gráfica" p. 79.

Termina el comentario alabando a Caras y Caretas: "La difundida revista se hecho acrededora, sin duda, a un aplauso bien ganado" p. 79.

-Se refiere el concurso que organiza el Centro patriótico Estudiantil. Se trata de un certamen literario, para conmemorar el primer Centenario de la revolución de mayo. p. 79.

Es importante porque los temas muestran lo que se considera patriótico a la hora de celebrar el centenario de mayo, y exhiben su incoherencia y eclecticismo. Transcribimos dichos temas: " 1 " Opiniones acerca del primer Centenario de la Revolución de Mayo . Maneras de verlo. $2^{\circ}$ Canto a la Independencia. $3^{\circ}$ América y su porvenir. $4^{\circ}$ Influencia de la inmigración en el desarrollo social e intelectual de la R. Argentina. $5^{\circ}$ Poemas en prosa: tema libre. $6^{\circ}$ el periodismo en el Centenario: su influencia en el desarrollo de la cultura argentina. $7^{\circ}$ Canto al Amor: verso y metro libres. $8^{\circ}$ estudio psicológico del gaucho $9^{\circ}$ Las Universidades de América Latina: su rol en la cultura Americana $10^{\circ}$ Las revistas ilustradas: su objeto e influencia en la sociabilidad. $11^{\circ}$ Soneto: tema "El Gaucho". $12^{\circ} \mathrm{La}$ juventud americana: estudio psicológico. $13^{\circ}$ Canto a España. $14^{\circ}$ Rivadavia, Sarmiento y la educación. $15^{\circ}$ Economía del país y la tierra pública. $16^{\circ}$ Madrigal: tema libre. $17^{\circ}$ estudios sobre el caudillismo en la América Latina: medios para procurar su extinción. $18^{\circ}$ Estudio sobre la Belleza. $19^{\circ}$ El arte en América: sus diversas fases y tendencias; sus hombres; influencia europea en el arte americano. $20^{\circ}$ Una décima" pp. 79-80.

Los trabajos podrán ser publicados por el Centro en folletos de distribución gratuita, diarios o revistas.

\section{Año IV, tomo 5, no 26, febrero, 1910}

Ecce Homo.............. Federico Nietzsche. Cómo se llega a ser lo que se es. Por qué soy una fatalidad, pp. 81-89

A Francis Jammes............Juan Más y Pí pp. 90-91

Una lección sobre Víctor Hugo......... Arturo Giménez Pastor pp. 92-105

Crepuscular Salvador Debenedetti pp. 106-107

La estatua del Maestro.......... Vicente Medina pp. 108-110 [sobre el uso y significado de las estatuas. Rescata la tributada a un Maestro de primeras letras en Archena -Murcia.]

Discurso de Eduardo Talero como mantenedor en los juegos florales de Lomas de Zamora, celebrados el 8 de diciembre .........pp. 111-122

Sonetos.............Gustavo Caraballo [El llanto interior, La carta enemiga, El violín, El viaje romántico] pp. $123-125$

Política espiritual [sobre los discursos de Joaquín V. González] Juan Cancio [seudónimo de Mariano de Vedia] pp. 126-130

La estafa del indiano............ Silverio Lanza [lleva una nota aclaratoria de Juan Más y Pí, en la que consigna la calidad de "literato de excepción" de Lanza y el paralelo desconocimiento por parte de sus contemporáneos españoles; alabado por Darío, Baroja, Azorín, por el crítico] pp. 131-133. CUENTO [con moraleja] ¿A quién culpar?. Gisberta S. de Kurth pp. 134-138 [sobre la necesidad de educación de la mujer]

La restauración nacionalista de Ricardo Rojas. Roberto F. Giusti pp. 139-154

Comenzar de un camino.... Ángel de Estrada pp. 155-156 [sobre los "cuentos aristocráticos" de Gastón Federico Tobal, al que augura un futuro novelístico]

Letras Argentinas Roberto Giusti pp. 157-159

Notas y comentarios p. 160 
-Una lección sobre Víctor Hugo......... Arturo Giménez Pastor pp. 92-105

Este artículo es relevante desde el punto de vista de su género. Se trata de una lección a partir de la cual los alumnos puedan formarse una idea "lo más completa posible del escritor y de su obra". Que sea una lección es importante porque muestra la vocación pedagógico-democrática de la revista.

-Discurso de Eduardo Talero como mantenedor en los juegos florales de Lomas de Zamora, celebrados el 8 de diciembre, pp. 111-122

Se trata de un discurso que impugna el progreso ("esa deidad sin alma que pomposamente llaman civilización moderna" p. 113 Patria, Amor y Fe [con mayúsculas] son los tres conceptos en que se basa para Talero la "dignidad humana". Considera la poesía como elemento central para la formación del sentimiento patriótico, al que liga directamente con la geografía: "Cunde como aceptable eso de que los títulos de la patria reposan en las cancillerías, y de que el sentimiento patriótico se decreta y se regimenta. No, señores. La patria más corresponde a la jurisdicción de los poetas que a los Ministerios de Relaciones Exteriores, a cuya untuosa cortesía de protocolo rara vez llegan esas estrofas bravas, en cuyos resortes se condensan de tarde en tarde las emociones de un pueblo.

La patria no se transmite de generación en generación cuando el maestro la señala al discípulo sobre los trapos del mapa, sino cuando por los tiernos nervios de la infancia pasa de improviso la onda vibratoria de la emoción tradicional, o cuando el paisaje espiritualizado ya por los artistas, asombra las pupilas del niño con visiones del ideal, y le arropa el alma virgen en el vaho de las grandezas por venir.

Pero si los artistas nacionales se aposentan en torrecillas de bambú, para garrulear amores falsos con princesitas japonesas; si creyendo conquistarse renombre universal van a saquear en Europa los kioscos cosmopolitas; (...) si no acordan su corazón a los ritmos profundos de su tierra; entonces llegará un día en que a las generaciones nacientes no haya como entregarles ni tradición, ni cielos, ni paisajes, ni nada, fuera de un territorio sin alma y de una muchedumbre sin conciencia, todo lo cual no es patria." pp. 114-116.

El texto finaliza con un una serie de llamados de atención a los políticos, a los 'cándidos sociólogos', y a todos los que "se niegan a aceptar la influencia de los poetas en los destinos de la patria", de la que Talero da ejemplos históricos.

-Política espiritual [sobre los discursos de Joaquín V. González], por Juan Cancio pp. 126-130

El texto es relevante y se suma a muchos otros en los que se privilegia la participación de los intelectuales como necesaria en relación con la construcción de la nación. Se trata de una carta que le escribe Cancio a González en la que recuerda el comienzo de la amistad. Se refiere a González como estudioso y poseedor de la obra "más vasta y fecunda que un argentino haya llenado a su edad". En González, coinciden, según Cancio, obra intelectual y acción pública: "Es cierto que su labor intelectual representa en mucha parte su misma acción pública y tiene el doble mérito de la ciencia aprendida en los libros y de la ciencia practicada en la vida" p. 128 (...)

Cuando Cancio se ocupa de Política espiritual sostiene: "Política espiritual, dedicada a la patria. Es lo que corresponde. La patria le ha arrancado a usted sus mejores acentos, sus inspiraciones más altas, sus pensamientos más hondos. Usted es el escritor que haya pronunciado mayor número de veces el santo vocablo. Patria se llama un libro suyo. Los pusilánimes de las letras no dicen Patria, ni Amor, ni Ideal [en mayúscula en el original]. Son palabras anticuadas, expresiones románticas, sensiblerías impropias de la época. La Patria de ellos, iya lo creo! La de usted es la que hay que invocar eternamente" p. 128. Cancio transcribe un pasaje completo de González de Patria en el que se define la nación del estado liberal guiado por el progreso, la inclusión, la igualdad, y la comunión de los ciudadanos.

De Política espiritual destaca el estilo elegante, sobrio, sin excesos.

-La restauración nacionalista de Ricardo Rojas, por Roberto F. Giusti pp. 139-154 
Para los detalles de esta reseña cf. el apartado "La discusión con los pares: con el idealismo de Rojas y a favor del cosmopolitismo" en el capítulo sobre Nosotros. Como se trata de un texto bien conocido no nos extendemos en la transcripción.

\section{Letras Argentinas}

-Nuestra patria por Carlos O. Bunge pp. 157-158

Dice Giusti: "Carlos Octavio Bunge, siempre infatigable, solicitado por sus tendencias de pedagogo ha querido compilar una antología para el $5^{\circ}$ y el $6^{\circ}$ grado[s] de las escuelas primarias, que fuese un libro de lectura de espíritu netamente nacional.

Una antología sin lunares es casi un imposible, y más todavía lo es una antología para las escuelas. Afirmar por tanto que esta del doctor Bunge no es obra perfecta, a nadie ha de sorprender, y menos, me supongo, a su autor, quien, más que otro cualquiera debe conocer las dificultades de la empresa.

La oportunidad y utilidad de la obra tampoco nadie ha de desconocerlas, e igual cosa dígase en el caso presente de su originalidad." Transcribe el índice de la antología: "Esta [antología] se divide en cuatro partes: trata la primera de 'La tradición y la historia del pueblo argentino'; la segunda de 'La poesía argentina'; de 'El país argentino' la tercera, y de los 'Cuadros y fases de la vida argentina' la cuarta y última" p. 157

Alberto Ghiraldo, de Juan Más y Pí

Giusti discute el valor literario de Ghiraldo, no así su propaganda anarquista. Discute también con ciertas afirmaciones no probadas de Más y Pí respecto de "la inferioridad de aquel ambiente del primer lustro que siguió al 90" durante el cual estuvo Darío en Buenos Aires. Se opone a las consagraciones inmerecidas, como lo es, en este caso, la que realiza Más y Pí de Ghiraldo.

Notas y comentarios

-Se consigna el regreso de Europa de Juan Pablo Echagüe, luego de dos años de permanencia. Lo recuerda como crítico de teatral de El país

-Saludan a Atilio Chiappori que parte a Europa.

\section{Año IV, tomo 5, no 27, abril, 1911}

A nuestros lectores. la dirección pp. 161-162

El teatro de Florencio Sánchez. Ricardo Rojas pp. 163-180

Vario decir. Enrique Banchs pp. 181- 183 [tema amoroso; cinco estrofas de 14 versos endecasílabos]

Martín Goycoechea Menéndez. Antonio Monteavaro pp. 184-191

Titta Ruffo Mariano Antonio Barrenechea pp. 192-200

Sé alegre y bueno Arturo Pinto Escalier pp. 201-202

La sabiduría de Salomón. Fragmentos de una crítica Pedro Sonderéguer pp. 203-207

Julio Herrera y Reissig (En el primer aniversario de su muerte)......... Vicente Martínez Cuitiño pp. 208 $-210$

Sonetos..............Alvaro Melián Lafinur [El nocturno, La plegaria, Yo coroné tu frente] pp. 211-212

Dios en la historia y un profeta en el pasado................Coriolano Alberini [sobre la obra de Clemente Ricci] pp. $213-225$

Leopoldo Lugones y su obra............ Roberto F. Giusti [respuesta al autor del libro, Juan Más y Pí] pp. 226- 231.

Notas y comentarios. pp. 234 - 254 REVISAR LOS NÜMEROS DE P EN BIB.

A nuestros lectores [luego de un año de ausencia -el último número está fechado en febrero de 1910empieza a publicarse nuevamente]

"Al año de habernos retirado del combate, para reparar las armas, volvemos a la palestra. Lo del combate no es imagen enfática e impropia: cabe emplearla, aquí, donde sostener una revista literaria, seria e independiente, es empresa en que se choca contra la hostilidad de los más, sin otro apoyo que el de muy pocos.

Al reaparecer lo haremos con la misma enseña y el mismo cartel. Con la misma enseña: Nosotros, que si la malignidad de alguien pudo atribuir absurdamente a una desenfrenada megalomanía de los dos directores, no puede significar otra cosa, ante el buen sentido, que tales somos 
todos quienes creemos que a la patria se la sirve tanto con la labor intelectual como con el esfuerzo material. Y con el mismo cartel; revista de arte, letras, historia, filosofía, esencialmente argentina, y más que argentina, americana, abierta a todos los vientos del espíritu y desvinculada de cualquiera círculos y prejuicios.

No muchos pero buenos fueron los que nos acompañaron en la anterior cruzada: a todos ellos, lectores, colaboradores y amigos acudimos de nuevo en demanda de la ayuda material y moral que entonces nos dieran generosamente. Ya lo hemos dicho: Nosotros es revista de todos y para todos.

En el campo están ya algunas aguerridas compañeras, entre ellas las dos más semejantes por su carácter: Renacimiento, que daba los primeros aletazos cuando Nosotros estaba por llamarse a silencio, y tiene ahora cimentada sólidamente su vida; Atlántida, que nacida en la segunda centuria de nuestra vida libre, parece destinada a continuar la tradición ilustre de nuestras grandes revistas de otro tiempo.

No pretendemos, pues, venir a llenar un vacío. No lo pretendimos cuando salimos a luz en 1907, en momentos en que la metrópoli carecía de publicaciones de la índole, y menos podríamos hacerlo ahora. Solo reclamamos un sitio en las filas, el sitio libre y bien ganado que ya ocupábamos, para hacer algo también, en fraternal acuerdo, por el pensamiento y el arte.

Nuestra aspiración no es la de dormir gloriosamente en las bibliotecas del futuro; es la de vivir, y muy despiertos, la vida del día, con todos sus afanes, sus contratiempos, sus satisfacciones morales. Y espacialmente, vivir con entusiasmo. Que sea Nosotros una revista ágil, briosa, juvenil, en que se den y reciban golpes si es necesario, pero cuyas páginas vivan al menos... ¿Será posible? Ello no depende sino a medias de sus directores: que digan su palabra ahora los que aquí piensan y escriben. Los directores no pueden hacer otra cosa por el momento que esperar y agradecer las ya abundantes e inequívocas muestras de simpatía que les han sido dadas, sobre todo por la prensa, con notable unanimidad, que les ha llegado hasta lo más hondo del alma." pp. 162-162

-El teatro de Florencio Sánchez, por Ricardo Rojas pp. 163-180

Conferencia dada en el teatro Odeón en homenaje a Sánchez, recientemente fallecido. En nota, la dirección explica que publicará las demás conferencias que en el mismo marco dieron, también en el Odeón, Joaquín de Vedia, Enrique García Velloso y Vicente Martínez Cuitiño.

Rojas se autocaracteriza como "pregonero de una argentinidad más intensa, y heraldo ilusionado de un arte propio" (p. 164) y como crítico pionero en el reconocimiento y apoyo a la obra dramática de Sánchez. Para Rojas la obra de Sánchez, a quien reconoce una "poderosa capacidad representativa de los hechos actuales" y en ese sentido son realistas (p.169), "permanecen en los límites del particularismo y la realidad" ya que no realizan generalizaciones filosóficas. (p. 169)

Entre todos los rasgos que señala como característicos del autor ("la simpatía humana", "la prodigiosa capacidad auditiva y visual", "las memorias específicas que son subsiguientes a toda sensación de gestos y sonidos", que dan a su teatro "el acento espontáneo de la vida y el matiz pintoresco del color local) destaca la inclusión de personajes e historias nuevos en el teatro culto: "Fábulas desconocidas y sin prestigio, tipos de gauchos, de gringos, de compadres; lenguaje de orilleros y gurisas, de canillitas y lunfardos; escenarios de leonera de conventillo y de galpón, he ahí lo que Sánchez nos ofrecía en su teatro, desafiando la tradición culterana y el snobismo rioplatense; (...) Su victoria es la victoria del Teatro Nacional [en mayúscula en el original] en el Río de la Plata, y recíprocamente. Sus tipos, sus lenguajes, sus escenas, venían elaborándose desde muchos años atrás, y ha contribuido a realizarla, esa pléyade numerosa constituida en Sociedad Argentina de Autores dramáticos que con sobrados títulos patrocina también esta ceremonia" p. 173

Y sigue: "Raro es el tipo de Sánchez cuyo antepasado no esté en los sainetes de hace veinte años o en la literatura criolla del siglo anterior. La escena del matadero descripta por Echeverría le preludia, el argumento gaucho contado por Hernández le anuncia, los tipos criollos creados por Gutiérrez le hacen presentir, los diálogos cosmopolitas referidos por Fray Mocho le dan el instrumento elaborado -todo esto sin contar a todos sus predecesores del teatro-, de tal modo que escenas, argumentos, tipos y coloquios, vienen a confluir en él, cristalizándose en una obra cíclica y un talento sintético que a todos los resume." p. 173

Sánchez aparece en la mirada de Rojas como una especie de sociólogo nacional: "Había elaborado ya las escenas de nuestra clase media y de nuestras clases rurales, donde sus antecesores y colaboradores son tan numerosos, y preparábase a obrar con nuestra burguesía, donde su labor hubiera sido tan 
personal, que habría dado a nuestro teatro una nueva era, a nuestra literatura una nueva conquista; y puesto que nos solo el gaucho es argentino, a nuestra conciencia cívica una nueva revelación.” p. 173

Para Rojas La Gringa es la obra más importante del autor, "un drama representativo y duradero" (p.175), y contiene todo lo meritorio de las anteriores obras de Sánchez. Destaca de ella el hecho de "ser cosa aborigen y no parecerse a ninguna obra de teatro europeo: La Gringa ha brotado nuestro suelo, de nuestra historia, de nuestra idealidad; fija un momento de la conciencia argentina y se engrandece hasta los límites de la patria misma; continúa, por fin, las corrientes iniciales de nuestro teatro, a tal punto que sus personajes y su argumento son el avatar más avanzado de espíritus que ya habían aparecido en nuestras letras bajo formas inferiores, parciales o larvadas" (p.176).

La última parte de la conferencia Rojas la dedica a discutir y precisar su concepto de nacionalismo, ya que según refiere, ha sido mal interpretado: "Yo no he proclama nunca como maliciosamente se me ha atribuido, la hostilidad a los extranjeros; antes por el contrario, los deseo a todos argentinos de pensamiento y de corazón. No pudiendo organizarnos aún según la fórmula humanitaria y abstracta de las ciudades futuras, he propuesto que nos cohesionemos según la emoción patriótica y concreta del territorio que ocupamos. Es nuestro nacionalismo una doctrina racional, democrática y progresiva, a pesar de los que por ignorancia o mala fe, han pretendido deformarla. (...) No ha dicho al espíritu criollo, en presencia de las fuerzas exóticas que lo anonadan, combatid lo inmigrante, sino conocéos, fortalecéos y convertid el hibridismo en argentinidad y en idealidad el mercantilismo. Siendo la patria una obra de solidaridad espiritual, la solución propuesta ha sido el arte, y la enseñanza, como condición democrática del arte" p. 179. La obra de Sánchez sirve para este propósito y por eso Rojas la destaca.

Martín Goycoechea Menéndez, por Antonio Monteavaro pp. 184-191

Se trata de un artículo que hace siete años ha sido publicado en un periódico de Buenos Aires, y que los directores de Nosotros, "sagaces hurones del periodismo" -tal como los califica Monteavaro en una nota al pie- han desempolvado. Es un relato de una de las reuniones en la redacción de El País, de las que participaban Juan Pablo Echagüe, Camilo Villagra, Ricardo Rojas, Charles de Soussens, Joaquín de Vedia. Goycoechea aparece como un aventurero, básicamente como narrador de esas aventuras, es decir, como una charlista, causeur. "Un día narra de cómo vivió misteriosamente entre una sociedad de ladrones y asesino con su sede en el Paseo de Julio; otro, sus hazañas de pirata en los mares del sur; más tarde su evasión maravillosa de una cárcel de Paraguay donde fue encerrado por sus ideas políticas, y luego su actuación de caudillo, levantando bandera de rebeldía, derrotando ejércitos, acampando en cementerios, en una de cuyas tumbas tuvo que guarecerse, revolcado con los huesos de un difunto dentro de un estrecho ataúd”. p. 186.

Leopoldo Lugones y su obra de Juan Más y Pí, por Roberto F. Giusti, pp. 226-231.

Es la respuesta de Giusti, en forma de carta a Juan Más y Pí, al que se dirige como "estimado amigo". Se disculpa de antemano por lo que va escribir, aunque lo cree necesario, porque afirma "No estoy dispuesto, mi estimado amigo, a soportar que me vapuleen, sin siquiera poner el grito en el cielo, aquí me tiene en son de protesta. Me apresuro, para que su sentencia no pase en cosa juzgada" p. $226 \mathrm{La}$ disputa se centra en dos aspectos. El primero referido a la crítica sobre la obra Lugones, que en palabras de Más y Pí "no ha merecido hasta hoy la atención reposada, profunda, de la crítica serena y equilibrada. Giusti le recuerda al crítico los artículos por él mismo citados en el libro. El segundo aspecto se refiere a la discusión de las afirmaciones de Giusti como crítico de Lugones sobre $L a$ guerra gaucha, Lunario sentimental. Califica el libro de Más y Pí de "panegírico de Lugones". p. 230 El párrafo que transcribimos a continuación muestra desde qué perspectiva Giusti lee a Lugones y en función de ello, realiza una selección de las obras, que otras intervenciones críticas posteriores mostrarían como desacertadas.

“¿Recuerda Ud.? Yo me preguntaba: ‘¿Quedará algo en pié de la obra lugoniana?’ Y me contestaba: ‘! Quién sabe! Tal vez su prosa, aunque éste no es elemento suficiente para encomendarse a la aprobación de la posteridad, cuando no se le ha empleado en obras serias y consistentes. Y en cuanto a su poesía, el artificio continuado que es su alma, es también un germen de muerte'. Y bien; me ratifico en tales palabras, escritas en Agosto de 1909. Pero advierta Ud. que desde entonces Lugones con su infatigable laboriosidad y su enorme talento ha publicado cinco obras más —icinco! - y acaso, después de ellas, yo rectificara mi juicio. No sé si podría modificarlo sobre los versos, porque sólo he 
ojeado las Odas Seculares; pero en cuanto a la prosa, puedo confesarle que la Historia de Sarmiento me parece un gran libro, y así lo declararé ampliamente en el próximo número, y Prometeo me interesa sobre manera, como ya lo he manifestado en un artículo anónimo aparecido en El Monitor de la Educación Común. Respecto de este último libro sólo pude formarme idea de la parte discursiva, porque sobre la explicativa de los mitos no soy autoridad para opinar. De mitos griegos no se más que lo que me basta para leer a mis clásicos. Dejo la palabra en semejantes asuntos a mi gran amigo Hugo de Achával, quien me asegura que los conoce, y, en efecto, como Ud. sabe, en la revista que Ud. tan dignamente dirige, dijo cosas muy interesantes sobre Prometeo." p. 230

Notas y comentarios

-Muerte del novelista italiano Antonio Fogazzaro

-Nueva edición de los clásicos castellanos. "Le lectura, la más literaria de las revistas españolas, ha dado comienzo desde hace unos meses a la empresa de editar nuevamente los clásicos castellanos, en ediciones que están al alcance de todos." Se hace referencia a la oportunidad de la empresa que ya han realizado otros países europeos; se nombra también otra colección ya existente: la biblioteca Rivadaneyra, que tienen el problema de su alto costo, además de "sus muchos defectos excusables por el tiempo en fue compilada: su poca manuabilidad, su mala presentación tipográfica y sus frecuente inseguridad filológica" p. 255 Habla de la "necesidad de una edición a la vez económica y científica, y que la obra de La lectura sea merecedora del reconocimiento de todos los que deseamos una siempre mayor difusión de las letras españolas para honor de nuestra raza y de nuestra habla" p. 255.

-Letras americanas. Un artículo del Mercure. La sección 'Letras hispanoamericanas' de la revista francesa está a cargo de un chileno, Francisco Contreras. Se transcriben pasajes de la nota de Contreras referida al modernismo.

-Se queja del cambio de nombre la calle Cuyo por Sarmiento, porque creer que el primer nombre que "recordaba una provincia histórica debía haberse conservado"

-Viajeros: regreso de A. Chiappori luego de un año en Europa; partida de Lugones a Europa -se va por cuatro años- ; regreso de Europa de Jaimes Freyre quien en breve publicará La república de Tucumán.

-Archivo de investigaciones históricas: se trata de una revista madrileña, de la que transcriben el sumario de ese primer número.

-Las obras teatrales del año - Los premios municipales

Se transcribe un aparte del decreto municipal que declara desierto el concurso de 1910 . Y a continuación la dirección opina sobre el estado del teatro nacional: "Nuestro teatro atraviesa en estos momentos por un lastimosos estado de esterilidad, y casi diríamos de decadencia, pensando en sus buenas épocas recientes, si no nos detuviera la consideración de que aún está en sus comienzos y conviene por tanto no desesperar de su porvenir. Esto depende todos: de los autores, de la crítica, de los empresarios, de los actores y del público, de éste último, sin embargo, menos que de los demás citados, pues ni todo él es tan subalterno como algunos quieren dar a entenderlo, porque así les conviene, ni es recio a ser educado. El mismo que ahora se aviene con los monstruosos engendros que suelen presentarse en nuestros escenarios, es el que supo comprender y apreciar el teatro de Sánchez, el de Payró, el de Giménez Pastor, el de Méndez Caldeira y el de algunos otros de nuestros autores que han dado obras dignas de un teatro culto, sin rebajarse nunca a producciones inferiores. La responsabilidad mayor incumbe a los autores y a la crítica. En sus manos está el obligar empresarios y el educar actores y público" p. 237

-Nuestras secciones permanentes: se agregan dos nuevas, una sobre teatro, y otra de crítica bibliográfica. para esta última se pide a editores y autores que envíen a la redacción los libros publicados. Prometen una sección de crítica de arte.

-Joaquín de Vedia es nombrado director de la Biblioteca del Congreso; se comenta la próxima aparición de la Revista latina, una publicación de jóvenes; consignan el cierre de la Escuela Normal Superior y de la Facultad de Ciencias comerciales; se refiere el estreno exitoso en Italia de Los muertos de Florencio Sánchez (Turín, teatro Politeama); se comenta la noticia del retiro de Roca de la vida política.

-Libros últimamente recibidos:

Leopoldo Lugones, Historia de Sarmiento, Buenos Aires, 1911. [no se consigna editorial] Juan Más y Pí, Leopoldo Lugones y su obra, Buenos Aires, editorial de la revista Renacimiento,. 
Manuel Ugarte, El porvenir de la América Latina, Valencia, 1911 [no se consigna editorial]

Juan José de Soiza Reilly, El gran ciudadano. Juicio crítico sobre la personalidad de José Batlle y Ordóñez, Buenos Aires, 1911.

Fray Mocho, Tierra de matreros, La Plata, Joaquín Sesé editor, [no se consigna año]

José M. Salaverría, Las sombras de Loyola [sin año ni editorial]

Rafael Barret, El dolor paraguayo, Montevideo, O. M. Bertani editor.[no se consigna año]

César Félix, El libro de los poemas, Corrientes, 1911 [sin editorial]

Juan P. Ramos, Historia de la instrucción primaria en la República Argentina, tomos I y II, Buenos Aires [sin año ni editorial]

Año IV, tomo 5, nº 28, mayo, 1911

Centenario paraguayo........... Eloy Fariña Núñez pp. 241-249

En el surco.............. Mario Bravo [fragmento del tercer capítulo de una novela próxima a aparecer]

pp. 250-253. [el protagonista es Fortunato Montoya, hombre que vive 200 años y que ha participado

de la guerra civil argentina]

Emoción de ayer........ Juan Aymerich pp. 251-252 [ de La vida sentimental]

Una lección sobre Víctor Hugo......... Arturo Giménez Pastor pp. 253-269

La casa del obispo............Luis María Jordán pp. 254- 277 [cuento fantástico]

Estancias ..............Rafael Alberto Arrieta pp. 278 -280

Florencio Sánchez (Conferencia leída en el teatro Nacional Norte)........Joaquín de Vedia pp. 281-286

Despedida familiar a la filosofía Hans Friedrich pp. 287- 288

Dios en la historia y un profeta en el pasado.................Coriolano Alberini pp. 289-296

Poesías.................Edmundo Montagne, D. A. Robatto, A. Z. López Penha pp. 297-298

Bibliografía.............pp. Roberto F. Giusti pp. 299-306

Crónica musical.............. T. A. Y [¿?]pp. 307-311

Notas y comentarios..............Nosotros pp. 312-319

-Florencio Sánchez (Conferencia leída en el teatro Nacional Norte)........Joaquín de Vedia pp. 281-286 Ofrece una perspectiva diferente de la Rojas. Habla como amigo. Se refiere al éxito de M'hijo el dotor y, fundamentalmente a la forma de producción de Sánchez: nunca corrige, escribe de un tirón en el bar, la sala de un diario, en "el cuarto de un camarada", en su casa, estimulado por la emoción. "Es que su talento no entraba en actividad, no despertaba, si no en el choque con una emoción interna o externa, pero definida y vigorosa" p. 284. Se refiere a las dos actividades predilectas del dramaturgo: caminar por los suburbios pobres y leer diarios minuciosamente. Dice de Vedia: "Y lo admiro, sobre todo, en su sinceridad profunda, en su sencillez absoluta, en el amor de que está lleno, por la tierra, por la humanidad, por las cosas. Todo lo que su talento poderosamente objetivo calla sobre sus propios fondos tiene compensación más que suficiente en la intensidad con que reprodujo la vida colectiva de nuestras campañas, de nuestros suburbios, y de nuestra clase media, y en las felices síntesis que nos deja de algunos caracteres significativos de esos ambientes, el viejo gaucho don Cantalicio, el moderno D. Nicola, Moneda Falsa, Canillita, La tigra, el honrado holgazán de En familia y tantos y tantos más" pp. 285-286.

Bibliografía

-Historia de Sarmiento, de Leopoldo Lugones, por Roberto Giusti

"Yo no sé si de sus páginas surge el verdadero Sarmiento, tal como fue: surge sí el Sarmiento que nosotros vemos, el de la posteridad, el que nos representamos en ademán de hachear [sic] la selva con su brazo formidable para abrir picadas de civilización.

¿No es una historia? Tal vez. Es decir: no sé. Veamos. ¿ Qué es lo que ha querido hacer Lugones? contarnos a Sarmiento, hacer su filosofía. Para eso se tiene a mano su vasta y heterogénea obra escrita, su nutricio anecdotario, los recuerdos de quienes lo conocieron, que son todavía tantos, su abundante iconografía, y luego la literatura política y administrativa del tiempo: diarios, decretos, mensajes, cartas, discursos, qué sé yo... Bien; el biógrafo dispone de este material informativo. Lo lee todo, escucha a todos, se entera de todo. Y cuando todo lo haya leído y escuchado y sabido, ¿se hallará en condiciones de presentar la figura real, la exacta, la fotografía moral del hombre?" p. 299. Giusti 
sostiene que no se puede pretender objetividad absoluta, sino veracidad en los datos que se manejan. Y prosigue:

"Perfectamente bien ha hecho pues Lugones en dejarse llevar por el entusiasmo, que caldea su prosa robusta y castiza, rica en léxico y elegante en los giros, su mejor prosa, solo machacada de vez en cuando demasiado en el yunque de la elocuencia hasta el extremo de despedir una que otra chispa de retórica. Y ese mismo comienzo de capítulo "El hombre": 'La naturaleza hizo grande a Sarmiento'.... con todo lo que sigue; ese mismo comienzo a lo Hugo, y tan de Lugones, que al principio me chocara con su cargazón excesiva de varia ciencia, he acabado por explicármelo cual expresión literaria, psicológicamente excusable, de la visión monstruosa de la antítesis -luz y sombras, simas y cumbres-, de ciclópea grandeza que el biógrafo tuvo del coloso. Fragorosa y desordenada orquestación con que se quiere producir un efecto de conjunto: por tal entiendo yo ese comienzo.

Tengo para mí que hasta ahora éste es el libro [cursivas de Giusti]. Vez pasada empeñárame en la molesta tarea de intentar probar lo deleznable de la deslumbradora obra lugoniana. Vi en ella mucho talento, sí pero poca vida, pocas condiciones para durar. Quienes me interpretaron en el sentido de que yo lo juzgaba a Lugones inferior a cualquier fulano de tantos que raquíticamente vegetan en estos arenales de las letras, no me entendieron o yo no me expliqué. Negarlo a Lugones so es factible desde un punto de vista superior, solo con esta pregunta: ¿qué quedará de él? Su fuerte y complejo talento se debe al Tiempo, a la historia literaria de nuestra lengua: yo planteé la cuestión de si había respondido a esa esperanza y la resolví negativamente. Y bien; permítaseme ahora volver sobre aquel severo juicio, lo que hago muy gustoso. Pienso ahora que cuando La guerra gaucha esté arrumbada como un malogrado esfuerzo retórico, y El imperio jesuítico haya sido arrastrado por la corriente del olvido, junto a la nula producción histórica, que nada agrega y nada quita a lo sabio, y en cambio estorba; cuando Las fuerzas extrañas se recuerde como brillante dechado de una moda que pasó; cuando todos esos títulos ya no sean sino restos flotantes de un gran naufragio $-\mathrm{y}$, por consiguiente, restos muy dignos de respeto-, probablemente la Historia de Sarmiento seguirá leyéndose todavía.

El escritor al fin ha encontrado su tema." pp. 300-301.

-Historia de la América latina de Manuel Ugarte, por A. L. P. [¿̨?]

La pregunta por el destino ("porvenir") de la Argentina, es según A. L. P, el "tema predilecto de los viajeros ilustres" que visitan el país, predilección que ha tenido sus resultados; entre ellos, este libro de Ugarte, libro que aparece en un momento oportuno.

El crítico rescata la "preocupación por la patria" de Ugarte y lo coloca junto a Rojas: "Heraldo de verdad o error, su autor [Ugarte] es, sin duda ninguna, ciudadano de altos merecimientos y argentino de la primera hora. Su preocupación por la patria lo coloca cerca de los hombres que, como Ricardo Rojas, integran los anhelos del genial Echeverría." p. 302.

A. L. P. discute la posición de Ugarte que piensa básicamente en términos latinoamericanos y no nacionales. "Pero la defensa argentina reside más en una organización interior que en la solidaridad latinoamericana, no inútil tampoco en absoluto. es mejor que cada palo aguante su vela, sin perjuicio que el mayor evite la rotura del trinquete y de la mesana." p. 304.

-El gran ciudadano. de Juan José de Soiza Reilly, por R. Giusti

Se trata de un libro en el que su autor defiende, en el estilo de un cronista amable, al presidente de Uruguay José Batlle y Ordóñez. Para Giusti Soiza Reilly no convence a sus lectores porque su estilo se lo impide: "Si se hubiera dejado arrastrar por sus convicciones excesivas, diciendo sus entusiasmos en un lenguaje llano y espontáneo; si se hubiera preocupado menos por la extensión de las frases y más en la profundidad de los conceptos, el folleto podría ser una verdadera pieza de combate, quizá más agradable, tal vez más eficaz" p. 305.

-La hora que pasa, de F. García Godoy, por R. Giusti

Reconoce en el autor de Santo Domingo a una figura destacada del "animoso grupo de los que luchan por las cosas del arte en aquellas regiones de América", y alaba su hispanoamericanismo. p. 305 El libro en cuestión es un conjunto de estudios breves sobre literatos americanos y estudios filosóficos.

-El alma uruguaya, Estirpe e idioma, de Carmelo Bonet, por R. Giusti 
Señala a Bonet como una de las figuras de la nueva generación. Remarca también en él -como lo ha hecho con el Lugones que le interesa, con Rojas y otros- el lenguaje "claro y seguro" que se presenta en la forma de una "prosa elegante y castiza". "(...) lengua ágil y varia, no aprendida en La Prensa ni en las traducciones Maucci de D’Annunzio, sino en Cervantes, para citar un ejemplo, o en Rodó, para no quedarnos tan lejos; lengua propia, de buena cepa, hasta oliendo añejo, pero no a rancio, nos asegura que estamos en presencia de un escritor en formación, de dotes poco comunes" p. 306

Notas y comentarios

-Centenario de Sarmiento. Además de alabar inmensamente la figura de Sarmiento ("Forma parte de nuestra religión de ciudadanos") destaca dos actos públicos realizados en su honor: el de la Sorbona, presidido por Enrique Rodríguez Larreta, y la de la Universidad de Buenos Aires (en todas las facultades simultáneamente)

-Agradecen "las expresiones de simpatía con que la prensa ha acogido con unánime compañerismo la reaparición de la Nosotros" p. 313

-Se informa de dos nuevas secciones permanentes: Bibliografía y Crónica musical, de las que se encargarán colaboradores variados; Letras italianas, a cargo de Francisco Albasio, al que se refieren como "nuestro más eficaz colaborador en el resurgimiento de Nosotros"

-La Facultad de Filosofía y Letras

Se defiende a la institución universitaria en su posibilidad de dar clases en las escuelas medias, funciones que cumplían con exclusividad los egresados del Instituto del Profesorado, "una institución inferior" a la facultad. Se consigna la demanda que en ese sentido ha presentado el Centro de Estudiantes de filosofía y Letras al ministro de Instrucción Pública Dr. Garro.

-Celebran la aparición de La Revista Argentina de Ciencias Políticas, dirigida por Rodolfo Rivarola y por Horacio Rivarola.

-Sociedad de psicología. Se da cuenta de la primera reunión anual de la misma, en la que se conmemoró el centenario de Sarmiento. Hablaron Rojas y Rodríguez Etchart. La comisión directiva quedó integrada por: José Ingenieros (presidente), Carlos Rodríguez Etchart (vice), Rodolfo Senet (secretario general), Víctor Mercante (secretario de Actas), Antonio Vidal (tesorero), Nicolás Roveda (director de publicaciones).

-Regresa Juan Pablo Echagüe de París, que había ido por encargo del gobierno con "una misión de propaganda". Se espera que haya publicado en Garnier su libro Cartera de un salvaje.

-Se consigna el estreno de la última obra de Mascagni (que está en Buenos Aires), Isabeau.

-Se repasan los concursos, congresos y actividades de las Asociaciones internacionales.

-Se anuncia la reaparición de la sección Música en el número siguiente a cargo de Mariano Antonio Barrenechea.

Libros últimamente recibidos

Carmelo M. Bonet, El alma uruguaya, Estirpe e idioma, Buenos Aires, 1911 [no se consigna editorial]

Horacio C. Rivarola, Las transformaciones de la sociedad argentinas y sus consecuencias institucionales (1853-1910). Ensayo Histórico, Buenos Aires, 1911 [no se consigna editorial]

Guillermo Stock, Fragmentos de una vida (segunda edición), Buenos Aires, E. Lantes editor, Biblioteca Azul, 1991.

Cornelio Hispano, El jardín de las Hespérides, Bogotá, 1909 [no se consigna editorial]

Vicente Rossi, Teatro Nacional Rioplatense. Contribución a su análisis y a su historia, Río de la Plata, 1910. [no se consigna editorial]

\section{Año IV, tomo 5, n⿳0 29, junio, 1911}

Nuestros orígenes literarios............... Martiniano Leguizamón pp. 321- 329

El agua en las arenas............. Juan Antonio Argerich pp. 332-336 [sobre la poesía de Gabriel y Galán]

Presencias.............Eduardo Talero pp. 337-338 [cuartetas octosílabas, se canta al paisaje del Limay; opone al paisaje apacible el progreso encarnado en un tren: "Al hipido zalamero/ de un cabro allá entre la zampa,/ contesta el grito altanero/ de un tren violando la pampa" p. 338.

Por cuatro garabatos (comedia en un acto de A. Duhau, estrenada el 11 de mayo de 1911 en el teatro Nacional Norte)........... pp. 339-362

Poesías............. Ernesto Mario Barreda pp. 363-366 
A propósito del Dr. Trigo, novelista erótico ...........Juan Más y Pí pp. 367-372

La necesidad del arte. José Ojeda pp. 373-376

Letras italianas Francisco Albasio pp. 377-392 [sobre Alma poesis de Francisco Cazzamini Mussi]

Bibliografía. A. de L. pp. 393-398

Notas y comentarios........ Nosotros pp. 399-400

Nuestros orígenes literarios, por Martiniano Leguizamón pp. 321- 329

La nota es una respuesta polémica a la obra de Mas y Pi Leopoldo Lugones y su obra. Leguizamón se ve en la obligación de "rectificar algunas de sus rotundas conclusiones, porque revelan, o un desconocimiento completo de nuestros orígenes literarios, o un injustificado menosprecio hacia otros escritores de esta tierra, iniciadores cabalmente de esa reacción con tendencia nacionalista que el crítico pretende atribuir a las obras del autor elogiado." (p. 321) Se ocupará del capítulo X dedicado a La guerra gaucha, en el que su nombre es aludido, para corregir el lugar que le corresponde en la tendencia literaria nacional: "Modesto obrero en esa empresa literaria, en que el sentimiento argentino fue norte y esperanza para muchos que arrostraron los desdenes de los que aún piensan que es tarea baladí el preocuparse en rastrear la vean oculta de las cosas nuestras, necesito reivindicar para ellos la prioridad en la iniciativa que hoy se les desconoce". (p.321). Critica la lengua literaria de La guerra gaucha, aunque no la materia tratada. Sostiene que: "mi obra, que con todos sus defectos, que soy el primero en reconocer pero con una acusada característica del sentimiento nacional no ha surgido después de la obra de Lugones como se afirma." (p.323) y para ello, agrega, basta comparar las fechas de las ediciones. Y continúa: "No he sido, pues, un paladín de las huestes lugonianas; no renuncio a mi humilde papel de montonero en la brega para abrir una picada en la selva densa de las cosas nuestras, y no necesito recordar aquí que, ese afán siempre alerta para salvar del olvido el rico acervo de las tradiciones y costumbres nativas, fue el tema predilecto que orientó mi producción (...) p. 323 Cita en ese mismo camino a Rafael Obligado y a Joaquín V. González: "Y con más brillo y con más éxito en la empresa, había presentado ya Joaquín V. González, en Mis Montañas y Cuentos (1893-94) páginas rebosantes de sabor de la tierra; como lo hiciera mucho antes aun Rafael Obligado, cantando episodios de la guerra de la independencia y la leyenda del payador argentino en décimas fluentes y armoniosas, con colorido y rumores de Pampa." pp. 323-324.

También le recuerda a Mas y Pi la tarea de Eduardo Acevedo Díaz, autor uruguayo que escribió Ismael (1888, que inicia la trilogía de romances históricos) en la que el "gaucho, el caballo y el escenario agreste fueron los elementos primordiales con que se pinta esa porfiada y soberbia resistencia de las masas campesinas contra el invasor y por la emancipación del suelo" p. 324.

En la tradición que organiza están presentes Sarmiento, López, Ricardo Gutiérrez, Pedro Goyena, Lucio Mansilla y Paul Groussac quienes "no han olvidado esa gran fuerza que, en su hora fue la encarnación más original de las fuerzas intrínsecas de nuestro pueblo (...)” p. 325.

“Tampoco puede calificarse 'teatro bajo' el meritísimo esfuerzo de los escritores que como el malogrado Florencio Sánchez en Barranca abajo y La gringa y Roberto J. Payró con Sobre las ruinas, llevaron a la escena estudios serios y bien interesantes del problema social planteado por la inmigración que va desalojando al antiguo morador de nuestros campos. El medio resultará tosco, pero el cuadro de ambiente y la pintura de los personajes es de sugerente poder evocativo; en cuanto al lenguaje ni es falso, ni rastrero al ajustarse a las hablas regionales para darles el aire familiar, sin degenerar por eso en la jerga cocolichesca de que otros abusaron, hasta convertir en caricatura grotesca ese misterio humano que se encarna en la noble figura del gaucho.

De ahí que también resulte errónea y gratuita la afirmación de que el autor de La guerra gaucha más que ningún otro escritor, sea el que haya "hecho más patria", destruyendo la falsa leyenda del gaucho, de la montonera, de las luchas civiles y el que recogió el espíritu ingenuo, sentimental y heroico del Martín Fierro para fundirlo en el tipo de sus luchadores anónimos.

Háse visto ya que el tipo de esos bravos luchadores anónimos en la guerra de la montonera rioplatense ha quedado indeleble en las páginas de otros libros que precedieron la pujante obra de Lugones, como el Ismael que tiene figuras de gauchos guerreros soberbios y descripciones que parecen escritas bajo la honda impresión del fragor y la sangre de la pelea. ¿Cuál es pues, la falsa leyenda destruida? En qué razones étnicas o históricas se apoya el crítico para suponer que ese gaucho montañés es el auténtico y que son falsos los del llano y el monte que pintó Sarmiento. Acevedo Díaz, Hernández y Viana, por 
ejemplo? ¿No sabe acaso, que el morador de cada región de nuestro territorio tiene modalidades típicas que lo diferencian fundamentalmente, por la mezcla de la sangre aborigen y por el medio físico que imprime en el alma del nativo su rasgo prominente?...p.325-326 Para Leguizamón Martín Fierro es "el primer y único poema nacional surgido de esta tierra" p. 328.

-Por cuatro garabatos (comedia en un acto de A. Duhau, estrenada el 11 de mayo de 1911 en el teatro Nacional Norte), pp. 339-362

Personajes: Manuel Heredia 35 años (Sr. Battaglia); Gerardo Marín, 38 años (Sr. Guitérrez); Rodolfo Montero, 26 años (Sr. Aranaz); Eva Marín, 28 años (Sra. Gamez); Pepita Heredia, 25 años (Sra. Blas). La acción transcurre contemporáneamente -1911- en Buenos Aires, en el estudio de Manuel Heredia, un abogado, quien decide hacerle saber a un íntimo amigo suyo, Gerardo Marín (médico), que su mujer (Eva), lo engaña.

La necesidad del arte, por José Ojeda pp. 373-376

La nota es importante porque muestra lo que institucionalmente sucede también en las artes plásticas y exige el fomento y protección por parte del Estado, siguiendo los ejemplos de los países centrales europeos. La transcribimos completa.

"Nuestra civilización agrícola no ha dado todavía el fruto de su plenitud y madurez. No es posible negar la relativa falta del arte entre los abundantes productos de la ubérrima tierra argentina y sería inútil jactancia citar los ensayos y balbuceos aparecidos durante el primer siglo de vida libre en apoyo de una afirmación que por sí misma se destruye.

La enumeración seca que a guisa de una historia ausente hizo don Eduardo Schiaffino en el número de La Nación del centenario, basta a probarlo, y si esto no fuera suficiente, sobraría una visita al Museo de Bellas Artes, donde no existe o se guarda con piadosa vergüenza la obra nacional.

Pero si esto es cierto en forma general, si el árbol no ha ofrecido aún su floración completa, si la infancia del pueblo no ha permitido el desarrollo de esa última expresión de la raza, habría de ser injusto el rechazo de toda posibilidad para el futuro. Es corta la existencia de cien años para una nación que se forma y exiguo el término para una conciencia nacional recién surgida.

El terreno preparado sin mucho plan ni gran trabajo, lo debemos a la obscura tarea de unos cuantos maestros extranjeros arrojados en nuestro suelo por los desbordes de las mareas sociales del viejo mundo, a la fecundación espontánea de una progresiva elevación intelectual, al riego de las ideas y de los ejemplos europeos de los que no pueden defenderse los rudos agricultores en sus ostentosos viajes a París.

La preparación del suelo es evidente. Un anhelo constante de arte se nota a cada paso en las manifestaciones individuales o colectivas del pueblo, y aunque todavía no caben tres pintores en Buenos Aires, se nota sin embargo el deseo de conseguirlos, con tal que sean baratos.

Porque nos encontramos en la situación, ridícula si no enternecedora, del comerciante enriquecido y deseoso de engalanar su casa, que reputa caro un cuadro si no ha visto la firma en letras de molde, o la no menos graciosa del ricachón que compra estatuas a tanto la docena. Pero esto mismo es digno, puesto que ocupa la feliz ansia de ennoblecer el dinero, y no obstante las cicaterías de un pasado villano que revive, demuestra el obscuro propósito de procurarse un ambiente para el porvenir.

A mayor abundamiento los señores extranjeros que han venido a descubrirnos durante estos últimos años, Ferrero, France, Ferri, Huret, Clémenceau, volvieron a su patria a ponderar nuestra riqueza material admirados hasta la estupefacción de nuestra pobreza artística. Alguno de ellos sólo encontró mérito intelectual en las obras de un compatriota, pero es sabido que en todo francés vive un chauviniste. Esa unanimidad nos ha herido, - fácil es notarlo, —en lo más íntimo de nuestra vanidad. ¡No hay arte! ¡y el arte es caro! ¿cómo hacer? ¿cómo introducirlo económicamente?

Desde el año 80, enviamos jóvenes aventajados a Italia, a Francia, a Alemania, en busca de un talento que en seis lustros no ha llegado todavía. Bien que contadas excepciones hayan remunerado los sacrificios fiscales en una medida estrictamente comercial, la gran mayoría, la que hace ley y debe tomarse de base para los cálculos, no ha pasado de una situación de diletantismo y medio de vida, cuando no ha sido en suma un pretexto de socorro para giras, de bohemio inútil.

No hace más de un mes que por laudable iniciativa del señor Ernesto de la Cárcova, inspector de becados en Europa, se está poniendo orden en esa rama de la administración. La Escuela de Bellas 
Artes de París ha prestado su concurso para el examen de los postulantes argentinos. En una semana de pruebas entre quince estudiantes de los diez y ocho enviados por el gobierno, han sido admitidos cinco, y los diez restantes se verán en la obligación de retornar a sus hogares del Río de la Plata para dedicarse a un oficio menos divertido y más a su alcance.

¡Cuánto tiempo habríamos ahorrado si se hubiera procedido de igual modo desde un principio! ¡Qué de admiración y de entusiasmos almacenados y que ahora nos faltan por su derroche en pura pérdida!

Otro ensayo fue la exposición internacional de Bellas Artes del Centenario; hermosa demostración, a fe, de nuestra insignificancia, pues nos valió la gentileza de Chile y del Uruguay para no ser los últimos; pero al mismo tiempo, la más eficaz y completa de las enseñanzas, la lección más oportuna y poderosa que pudo proporcionarse a la masa, la más espléndida de las demostraciones prácticas del valor efectivo del arte.

A través de sus salones, formados por la mezcla algo heterogénea y precipitada de los espíritus y tendencias de cada país, sin representación verdadera del estado de cada nación, excepto Suecia y los Estados Unidos, el visitante argentino pudo discernir en una vaga mirada de conjunto la magnificencia posible y las delicadezas hacederas, en comparación con las obras de aficionados de la sección argentina, sin vuelo, sin concepto y sin hondura.

Esa nueva comprobación evidencia una vez más que el suelo estará pronto a dar su fruto, por poco que se le siembre. Falta sólo la simiente y el cultivo racional, y estos únicamente pueden esperarse de una acción conjunta del estado y del pueblo.

En Francia, en Inglaterra, en Italia, donde el arte es un ser vivo de fuerte y exuberante existencia, los poderes públicos fomentan con singular cuidado sus manifestaciones por medio de becas, subsidios, premios, concursos, encargos, exposiciones y toda clase de apoyos, sin contar con las condecoraciones y títulos que se otorgan a sus más célebres cultores como sanción social de sus méritos, y entre nosotros cada artista tiene que batirse sólo, desarmado, desamparado, contra la vida y contra la indiferencia ambiente. La exigua ayuda de un sueldo apenas bastante en el único establecimiento nacional de enseñanza del arte, las miserables cátedras de dibujo en las escuelas y colegios, más atrofian y traban la libre imaginación del artista con sus deberes a término fijo, que sustentan su espíritu en la noble aspiración de la belleza.

Es necesario, pues, imprescindible sin duda alguna, que los hombres de estado entiendan ese anhelo y pongan en su pro el empeño usado en favor de la raza caballar o de la cría de ganados, puesto que a esta altura de la civilización argentina tanto vale la riqueza material como la artística.

Los concursos y las exposiciones oficiales deben comenzar cuanto antes, y más que todo, la organización de una división de bellas artes en el Ministerio de Instrucción Pública, encargada del estudio y proposición de las medidas conducentes a ese fin, es tan urgente que cada día que pasa se pierden considerables promesas para un futuro que se aleja a su proporción.

Aunque una revista no es el lugar propicio para echar a rodar estas observaciones, a Nosotros que se interesa por cuanto hay de justo y elevado, me he tenido que atener a ello"

\section{Bibliografía}

Teatro Nacional rioplatense, de Vicente Rossi, por R. Giusti todo pp. 393-394

Transcribimos completa la reseña del libro de Rossi

"Establezcamos eso ante todo: no es una historia de nuestro teatro, ni pretende serlo. Su autor ha querido 'contribuir' a su historia; no hacerla. Aceptado lo cual, ya no hay caso de quedar decepcionado porque el libro no hable de lo que no quiso hablar su autor.

Pregúntese, entonces, si vale como contribución, y habrá llegado la oportunidad de responder categóricamente que sí. Sí vale, y mucho. En una detestable prosa, a veces apenas periodística, mechada además de una cantidad incalculable de criollismos, buscados con empeño, diríase, más que hallados por ignorancia, el señor Rossi nos ha contado una serie de cosas interesantísimas sobre los orígenes de nuestro teatro popular.

Cierto es que no son cosas que pertenezcan al campo de la literatura propiamente dicha; pero ¿los orígenes de cual teatro han pertenecido nunca a ella? Más exclusivo aún, participo de la opinión de Brunetiére en cuanto veía en el teatro de todo tiempo una manifestación espiritual, sólo relativa a la historia literaria por accidente, en determinados casos. Vale, por tanto, el libro del señor Rossi, aparte sus divagaciones doctrinarias, más o menos discutibles - más bien menos - sobre cuestiones de arte, de crítica o de idioma, como contribución al estudio de nuestro folklore. Y cuando 
se lo lee acercando — v.gr. - con la mente esa pantomima de Juan Moreira, origen escénico del famoso dramón popular, al mimo de los latinos; o los títeres de los viejos barracones montevideanos - el negro Pancho o Teresito - a los tipos de la antigua Atelana, o a las máscaras de la moderna Comedia del Arte, uno se siente dispuesto a suavizar su desprecio por ese infantil y torpe comienzo de nuestro teatro, y a esperar para él los buenos tiempos futuros.

Alguien me ha señalado con enojo que el señor Rossi deja en silencio la mayor parte de los autores y obras que hemos aplaudido en los últimos años, inclusa la producción vasta y robusta del malogrado Sánchez. Le contestaré con las propias palabras del censurado: 'No siendo este trabajo una crítica de arte, sino una noticia más o menos comentada o razonada, que pueda dar idea de la fundación, formación y factores de nuestro teatro, no es posible darle más amplitud, hay que ser tan breve como lo fue él mismo en su aparición y desenvolvimiento. Además, un estudio crítico sería algo difícil y contraproducente; el repertorio ha sido en su mayoría de discutible mérito, visto al lente de una crítica honrada, pero de gran valor intrínseco en su misión de hacer Teatro, para el pueblo, que no lee críticas y no discute detalles de ningún calibre, "le agrada" o "no le agrada' dándose el caso ya común de que fracasa la crítica y triunfa la obra, especialmente en esta empresa de un arte que ese pueblo tiene por suyo'.

El autor cree en un futuro teatro criollo, expresión del alma de nuestra raza y escrito en el soñado Idioma nacional de los argentinos... Yo no quito ni pongo. Le agradezco, sí, la suma de ideas que su mal compuesto libro me ha sugerido, con sus noticias curiosas y sus observaciones no pocas veces certeras" pp. 393-934

Las sendas del Arquero, de Gustavo Carcaballo, por A. de L. [i?]

Intervalos, de Federico Mertens, por J. N. [Julio Noé]

Antología paraguaya, de José Rodríguez Alcalá, por A. de L.

\section{Notas y comentarios}

- El señor Roldán en las provincias

-Plagio descubierto

- Premios de la Academia francesa. Se difunde el concurso sobre pragmatismo(historia y significación de esta filosofía), y otro cuyo tema es "Educación cívica y moral en una democracia". Se dan los montos de los premios

-Libros en preparación: Gesta bárbara (novela sobre la época de Urquiza) y De paso por Tucumán de Gerchunoff.

-Correo abierto

Responden a A. p. no poder publicar un artículo que enviara a la revista por su intolerancia ideológica.

\section{Año IV, tomo VI, n 30, julio, 1911}

El diario de mi amigo ..............E. Herrero Ducloux pp. 5-9

Rosa................... Rafael Obligado pp. 10-13. [Poema de tema argentino: los gauchos en sus faenas,

Rosa, que reparte mieles a todos, etc.]

Los lises del blasón A. Gerchunoff pp. 14-22

Sobre unas críticas. Juan Más y Pí pp. 23-27

A Martiniano Leguizamón....... Eduardo Acevedo Díaz pp. 28-29

La Oda a los Padres de la Patria ........... E Banchs pp. 30-42

Las sendas del arquero. Juan Julián Lastra pp. 43-50

Un libro de Julio Piquet. Mirror (i) pp. 51-56

Isabeau.........................Enrique Giordano junior pp. 57-61 Sobre la obra de Mascagni.

Teatro nacional..............Nicolás Barros pp. 62-66

Bellas Artes. José Ojeda pp. 67-69

Bibliografía. pp. 70-80 [se explica por qué no sale en este número 'Notas y comentarios']

-Los lises del Blasón, de Ricardo Rojas, por Alberto Gerchunoff, pp. 14-22

Se trata de la crítica negativa de Gerchunoff a la obra poética de Rojas. La crítica se basa en la falta de continuidad entre lo declarado como propósito general de la obra de Rojas y este libro. No guarda relación con la prédica idealista que es lo prometido por Rojas. "el libro carece de tendencia espiritual 
y carece de ideas, revelando una esfuerzo exclusivamente artístico". Esto asombra a Gerchunoff ya que Rojas había definido la literatura en Cosmópolis como "cosa abominable". La crítica se concentra en lo reaccionario de cierta poesía, (como la española ya citada de Martínez Sierra) que da la espalda al presente.

Transcribimos la nota completa

Los Lises del Blasón

'...la literatura es cosa abominable. El arte que se universaliza es el que vive por el aliento de la tradición y por la emoción del paisaje nativo, como los poemas homéricos ó el romancero del Cid.'

(Ricardo Rojas, COSMÓPOLIS, pág. X.)

Cuando hace meses, algunos amigos me anunciaron el libro de don Ricardo Rojas, creí que aquél sería una continuación de su obra que él mismo ha calificado con el rótulo de 'prédica idealista'. De ahí, quizás, que sus poesías recientes me hayan causado, una impresión de sorpresa. No guardan, por cierto, relación con los propósitos enunciados por el escritor en distintas oportunidades y, para decirlo de una vez, el libro carece de tendencia espiritual y carece de ideas, revelando un esfuerzo exclusivamente artístico. Es para definirlo en otros términos, un resultado literario y esto asombra un poco, después de haber declarado el señor Rojas, en el prólogo de Cosmópolis que 'la literatura es cosa abominable'. Lo es, en efecto, y esa convicción hacía esperar que su temperamento se manifestase de un modo más espontáneo y sincero. Como no lo informa una tesis filosófica, sospechaba trabajos de índole emotiva y lírica. Ya que la propaganda de ideas no inspira más a los poetas, en viviente contradicción con el siglo cuya belleza robusta encuentran prosaica, hay el derecho de pedirles la exteriorización de su intimidad, la historia de su vida visionaria y abstraída del mundo. No pediremos a las almas a quienes repugna la realidad que consagren a sus minucias los cánticos que nos prometen, pero sí que no reduzcan las magnificencias con que sueñan, a un valor puramente verbal. Es como no lograrán dejar huella alguna en las generaciones a que hablan. Afirmarán tal vez, que anticipan una fórmula desconocida de arte, pero eso quedará incomprendido, para nosotros, que además contamos con un argumento definitivo: Jamás han existido los incomprendidos. Los reformadores encontraban obstáculos de género diverso, más su pensamiento fue siempre penetrable. Se hostilizaba su escuela por lo que comportaba de audaz y no por la obscuridad. Y el último movimiento francés, es una prueba decisiva: Verlaine es claro como el agua en lo substancial de su obra y los representantes mas eximios de esa orientación evolucionaron hacia el clasicismo aportando cada uno las originalidades que los definen. La experiencia es terminante y el más ligero análisis demuestra que esos ensayos deben servir para aprovechar una deducción rudimentaria: la manera exterior es efímera y la labor artística perdura por su fondo humano y general.

El señor Rojas, insiste en las exageraciones en que incurrieron esos reformadores en su comienzo. Da a su poesía un sentido aisladamente musical. Fuera de los números melódicos, la tarea no tiene destino. Emoción y paisaje, idealidad o pensamiento desaparecen sacrificados a la apariencia de una forma rara, que con serlo, tampoco ofrece la virtud de una novedad absoluta, puesto que explota lo realizado por nuestros artistas, mas grandes, Darío, Lugones y Jaime Freyre. Además, hay esta desventaja: hemos pasado la época de las recias batallas en que los cultores de uno y otro principio necesitaban hasta de la aberración para imponer su método. Hoy no suscita discordias la reaparición de un clásico ni provoca polémicas un continuador de los revolucionarios. ¿Tiene talento? Basta esa condición, y para el buen sentido es una ley que el talento halla inevitablemente, el nivel de lo verdadero y el medio de expresar sus sentimientos de un modo inconfundible y personal. El caso del señor Rojas, es, por lo tanto, desconcertante. El rico talento que he probado en obras intensas y en concepciones sólidas, si bien discutibles como hipótesis, se encubre ahora como si fuera su intención desorientar al público. Confieso que no lo comprendo. Él nos ha dicho con loable persistencia que es necesario vivir de la tradición, por cuyo aliento, subsiste y se universaliza el arte, según asegura en el prólogo citado. Aconseja amar los paisajes nativos y saturarse con el humus de la tierra materna. Es sin duda el credo artístico que nos conviene y es el que debemos pregonar si aspiramos a que la literatura participe en la civilización de la república. Acompaño al señor Rojas en este punto de su prédica y creo que un cuento de Leguizamón vale para nosotros más que una tragedia helénica. Y es precisamente el señor Rojas quien desvirtúa su doctrina con un volumen de versos inusitados. Ignoro 
qué se ha propuesto y abandono todo razonamiento sobre tendencias para circunscribirme a la impresión escueta de sus poesías.

No estamos con ellas cerca de ninguna tradición estética. Forman una originalidad, pero una originalidad censurable, cosa que es honrado afirmar, pues tratándose de un autor considerado, a quien nadie disputa aptitudes, sería poco fingir el elogio habitual, que en Buenos Aires va erigiéndose en norma dominante. La crítica desinteresada no existe y cada uno se conforma con una tímida o estruendosa alabanza sin ir a lo hondo de la producción, sin profundizar el examen, sustituido metódicamente por el aplauso fácil y la camaradería pronta a la ovación. Soy de los que más estiman al señor Rojas, pero no lo hago en el globo. Mi viaje simpatía hacia él no excluye la serenidad del juicio y su obra me obliga a estudios prolijos, como todas las obras que respeto. Estudiando "Los Lises del Blasón", he llegado a convencerme que don Ricardo Rojas, atribuye a la poesía un fin demasiado superfluo. En suma, no es posible decir que esto sea poesía. No impresiona por el atrevimiento de las imágenes o por la pujante novedad con que asombraron Darío, Lugones y Jaimes, después de cuya labor removedora, nada sorprende. Es el fondo de esas composiciones que no logran conducir a nuestro espíritu la menor emoción.. Diríase que ha perseguido tan sólo el afán de combinar palabras poco familiares y su cuidado ha consistido en evitar que se le comprenda. Una selección de vocablos adornan las precarias rimas y las estrofas no realizan otro papel que aglomerar esos vocablos. Si preguntáis por la idea que se propone desenvolver os quedaréis sin respuesta y si buscáis su sentimiento, un síntoma de sensibilidad poética os estrellaréis contra ese muro de fríos adjetivos y de epítetos infranqueables. Las ideas y los sentimientos elementales se funden en esa dialéctica sin vida y sin calor. Dijérase que el poeta cultiva un extraño aljamiado, ante la probabilidad de que su texto sea accesible a la multitud, y origine las denuncias que morismas y juderías evitaban en la edad media recurriendo al disfraz de los caracteres semíticos. Es hermético e inexpugnable. Es este un sistema que determina por fuerza la hostilidad del lector, que no puede comunicarse con el pensamiento ignoto del artista, sujeto a su anhelo de explotar recursos reñidos por su naturaleza con la verdadera poesía.

No sé si esa fórmula traduce un temperamento o prueba simplemente una afectación desdeñosa. En cualquiera de las circunstancias, atestigua la falta de nervio poético, y podemos afirmar, invocando este libro, que la poesía no es el camino del señor Rojas. La brillante retórica de su prosa, la opulencia lírica de los períodos, que he alabado en El país de la selva, desaparecen en el verso. La claridad que se notaba en La victoria del hombre, ha cedido su lugar a complicaciones atormentadas y a retorcimientos que nunca describirán una pasión o un eco profundo. Y si la poesía no es ya un instrumento de ideas, tampoco es un pretexto de equilibrismo. Los críticos académicos fulminaban a Darío asegurando que su arte es un juego malabar. Esa aseveración no se aplica al incomparable maestro pero sí a don Ricardo Rojas. Malabarismo puro, ni siquiera tiene el mérito de una musicalidad cuya dulzura nos entretenga como pasa con determinadas páginas de Verlaine. "La forma, dice Heine, es de por sí pensamiento": Heine lo ha comprobado en su obra inmortal y Darío repite esa prueba. "Los Lises del Blasón" en cambio, nos alejan de la sentencia del ruiseñor alemán y sólo nos presenta el trabajo perdido de un hombre que se dedica a tareas inferiores de coleccionista. Si la idea de la muerte sugiere a Byron, por ejemplo, estrofas penetrantes que ahondan nuestro ser, y con aquel su lenguaje simple en su misma forma declamatoria, nos conmueve, el señor Rojas necesita extraer de la cábala y de los tratados ocultistas un compendio de signos impenetrables, que alinea en la medida del verso. Con esto la muerte se torna lema tan frígido como la expresión confusa y antojadiza con que la viste. El esqueleto de la Danza Macabra, cuyo espectro se agita en los versos eternos de Sem Tov se trueca en el idioma torturado del señor Rojas en una receta de exorcismo, sin el peligro espantable de la brujería. Dígalo este pasaje:

¡La muerte! Mala palabra...

Llamemos, lector, la obscura

Potencia que la conjura:

Sator-dí- y Abracadabra,

Arepo, Keter, Jesod,

Tenet, Tipheret, Bináh,

Opera, Yah, Geduláh,

Rotas, Abédenego, Hod! 
Y sin embargo el autor pretenderá seguramente, hallarse en la corriente moderna y exigirá la tolerancia para la expansión de su índole individual que los cronistas literarios pedían para Darío. Darío es nítido, accesible y espontáneo. Su pensamiento está al alcance de cada uno y su novedad no es sino la manifestación de su genio. Él también nos habla de la muerte en El Coloquio de los Centauros. Los que la pintan obscura y siniestra, los que la exhiben tranquila, son siempre poetas, grandes poetas que consiguen elevarse sin ocultar su concepto. Shakespeare, Hugo y Goethe, el viejo rabino de las coplas, Heine, Baudelaire, y Rubén Darío son comprensibles. El señor Rojas encuentra recursos para no serlo. ¿Lo debemos a un exceso de profundidad? Lo dudo. Schopenhauer, nos enseña desconfiar de los filósofos alemanes cuyas teorías aparecen cerradas para la gente y tal vez el excelente Hegel sería mucho menos de lo que es, si sus libros estuvieran escritos en un estilo distinto. Lo mismo debe aplicarse a los poetas herméticos. Si no se les comprende es porque nada tienen que decirnos. Hemos visto cómo la visión de la muerte se reviste de términos nigrománticos en Los Lises del Blasón. Para comprender a Darío en lo que posee en Coloquio de los Centauros de legendario, de clásico, se requiere conocimientos comunes de mitología; para entender al señor Rojas se necesita estudiar una especie de criptografía. Compárese el trozo anterior con el fragmento que cito de Prosas Profanas:

\section{Medón}

¡La muerte! Yo la he visto. No es demacrada y mustia

$\mathrm{Ni}$ ase curva guadaña, ni tiene faz de angustia.

Es semejante a Diana, casta y virgen como ella;

En su rostro hay la gracia de la nubil doncella

Y lleva una guirnalda de rosas siderales.

En su siniestra tiene verdes palmas triunfales,

$\mathrm{Y}$ en su diestra una copa con agua de olvido.

A sus pies, como un perro, yace un amor dormido.

Amico

Los mismos Dioses buscan la dulce paz que vierte.

Quirón

La pena de los dioses es no alcanzar la Muerte.

Eureto

Si el hombre - Prometeo - pudo robar la vida,

La clave de la muerte serále concedida.

Quirón

La virgen de las vírgenes es inviolable y pura.

Nadie su casto cuerpo tendrá en la alcoba obscura,

Ni beberá en sus labios el grito de victoria,

Ni arrancará a su frente las rosas de la gloria.

Si expongo al señor Rojas a careo tan desigual, no es con el deseo de hacer comparaciones, pues soy de los que lo aplauden por su esfuerzo literario y sé lo que significa su personalidad en nuestra literatura. Lo hago para evidenciar con un ejemplo las observaciones de mi crónica. Hemos llegado a una época en que se debe imponer a los cultores de las letras, un rumbo y un ideal. En esto el señor Rojas estará de acuerdo conmigo pues mi tendencia al formular estos apuntes está dentro de la suya que dejó esbozada en su comienzo. Si La Victoria del hombre, discutible como poema juvenil, no es sino una promesa, El País de la Selva es un bello libro argentino, que tiene su vida y su emoción, y sus volúmenes restantes lo confirman en ese terreno y citaré La restauración nacionalista como documento incontestable en este sentido. En desacuerdo con la tesis central de la obra, encuentro en ella un objetivo, un camino, del cual no debió salir, pues las poesías, que a mi modo de ver, desconceptúan su propia finalidad de literato, equivalen a una sugestión de ociosidad artística y forman tan sólo un ejercicio paciente de voluntad. Pero convendremos que, si pasa como gimnasia intelectual, buena para no salir del gabinete a guisa de anotaciones marginales, no es posible ofrecerlo 
en el aspecto definitivo del libro. Me he particularizado con la idea de la muerte, que en el señor Rojas adquiere expresiones tan curiosas y pasaré a sentimientos y nociones igualmente primarias para demostrar idéntica inhabilidad en el autor para transmitirlas al verso. Para mí es una cuestión fundamental: el señor Rojas no siente la emoción de la poesía. Admitamos que sea un gran versificador, pero no es un poeta. Y la versificación es una aptitud mecánica, que se adquiere en la práctica. Simple sabiduría, se despoja de toda cualidad superior sino contiene la fuerza substancial de la belleza, que no es la mera euritmia de las palabras. La correlación de éstas implica inevitablemente el eje inevitable de una idea y por lo tanto se justifica el aforismo heineano: mas Los Lises del Blasón nos dan únicamente vocablos aislados que no responden a un vínculo visible; tal vez exista; no lo advierte el lector más experto. Hay imágenes pero sus series no se ligan por un sistema que exprese algo y en conjunto sólo tiene un valor material de sonido. El mismo resultado se obtienen con el amontonamiento de sílabas sin sujetarse a principios de lógica idiomática sino a las reglas comunes de la métrica. Con ello se aparta el señor Rojas, del carácter esencial de la poesía que se diferencia de la música por su capacidad determinativa. Es la fusión entre el sentido verbal y melódico, cuya separación no fue sino una vaga protesta de los innovadores contra los rituales fríos del clasicismo.

Este libro es tanto más extraño, por tener el autor un talento demasiado consistente para dilapidarlo en pruebas de tal género. Hay el derecho de esperar de él obras distintas, que no sean la consecuencia de sugestiones literarias. Y esta sugestión es evidente en el prefacio del volumen. La composición, de tipo verlainiano, descubre el modelo sin dificultad, si bien dista mucho de aquella ligereza aérea y de aquella frescura divina que constituían el encanto del excelso maestro. He ahí una muestra:

Ella va a cogerla, pero,

De antuvión, el gnomo arisco

Roba de afuera su disco

Par aun maligno hechicero...

La Musa torna empusí,

Con su alegre boca fresca,

Y ríe, funambulesca,

Río: - ¡Hi-hi-hi-hi-hi!

El exterior es efectivamente verlainiano, pero nada dicen sus versos. No son ni sentimentales ni irónicos, ni profundos, ni filosóficos. Son tan sólo musicales, de una musicalidad común, fruto de la metrificación corriente y notoria. Estrofas adelante, dice:

Espinela, cor, discor,

Balada, lay, virolay,

Villanela para el Gay-

Saber de su trovador...

Pregunto yo: ¿Qué se propone el autor?

Ninguno de los trozos transcriptos tienen en realidad una significación ideal. Es pura combinación rítmica, que nos explica en otro lugar de la composición:

Y ella responde: - Mi voz

Por l'Arte Poética va,

De aquél que dice: De la

Musique avant toute chose.

Los fragmentos indicados definen la categoría del poeta y de la índole de su poesía. Si es más metódico en el desarrollo de otras composiciones y a veces menos obscuro, no arriba a la adorable nitidez de los artistas espontáneos. Se complace en ensombrecer su discurso y donde es menos hostil a la claridad no por eso vence la gelidez que es el tono dominante de su labor. Esa observación se comprueba en "La Respuesta de Loxias", poema helénico que es, sin duda, lo mejor del libro. Mas, de su lectura tampoco nace emoción alguna. La frialdad de los versos revela el trabajo del cincel sin que haya intervenido otro factor poético. Falto de imaginación, de calor y de vida, nos brinda lo que extrae 
de su paciencia. Las composiciones menores y más inteligibles, denuncias la influencia ejercida en Rojas por Lugones. Consúltese, por ejemplo, "Divagación Otoñal" cuya impresión recuerda la de "La Romántica", de Lugones, así como no pocos sonetos de "Los Lises del Blasón", evocan a otros de "Los crepúsculos del Jardín". No sería éste un defecto grave si no se tratara de una personalidad como Rojas, a quién, insisto se debe exigir obra propia y grande, pues la producción sin sello vigorosamente individual, que da para los subalternos. En suma, un libro libresco, erudito, paciente e incoloro. Aparte de la técnica, que nunca puede ser motivo de alabanza, ya que sin ella no es imaginable la tarea poética. Me contestará con "La Sonata del tiempo pasado" a manera de signo evidente de originalidad. La posee pero ésta no es sino un signo de extravagancia. Véase:

A, B, C...

La cartilla se me fue...

V. a, n: van...

Los días se van...

Letras ingenuas, letras que

Sabéis la historia, dónde están

Las alegrías que se van?

Tán!... Tán!... Tán!...

Idéntica frialdad encontramos en las poesías patrióticas. La misma frialdad predomina en los ásperos hexámetros de la "Oda Latina" y en el "Canto a la mañana de Mayo". No hay un soplo sentimental en los escasos versos amorosos y tampoco hay un impulso épico en las canciones patrias. Igual uniformidad gris cubre sus horizontes y diríase, que la musa, cuyas virtudes describe de un modo tan prolijo y vario, no pertenece al núcleo ágil y radiante del Parnaso. Es una musa de biblioteca, amojamada y frígida. La patria, la amistad, el amor y la muerte, los paisajes natales, que preconiza en sus obras anteriores, que con justicia la colocan bien alto, no le inspiran arranques, ni gemidos, ni acentos. Se diluye en hielo.

Yo esperaba, repito, otro libro, el fruto de un arte más sincero, más vivo, más argentino, Es una supervivencia del período tormentoso del decadentismo, es decir, una labor anacrónica. Claro es, que el autor no piensa tal cosa y mi obligación de lector es confesarlo y contribuir en lo posible a convencerlo del error. Son escasos los literatos de quienes se espera producción seria y si éstos se extravían en aberraciones, es necesario señalarlo y combatirlo. Estoy seguro que Rojas, no dejará de encontrar razonable mi actitud, cuya honradez aprobará, pues él ha sido siempre crítico severo y justo, que es el método único que debe seguir un escritor que atribuya valor a su palabra. Tales cosas, decía yo a propósito de Los Lises del Blasón. Una camarada me observó que el rigor no cuadra con un nombre de tanta valía intelectual. Es por esto que consideré útil fijar mi opinión, para no amenguar con un silencio displicente o cómplice la amistad que le profeso y que le debe ante todo el homenaje de la lealtad, buena siempre aunque a veces sea ruda y fiera" (Buenos Aires, junio de 1911)

Sobre unas críticas pp. 23-27

Respuesta de Más y Pí a Leguizamón en relación con la periodización de la literatura nacional que Más y Pí hace en Leopoldo Lugones y su obra. Es una respuesta también a Giusti. Más y Pí señala lo que debe ser la crítica : "La crítica argentina, mal que pese a Giusti (...) ha sido por mucho tiempo el elogio o la censura, sin términos medios, y aunque esta verdad, como casi todas las verdades, "huela a rancio", es menester repetirla cada vez que, con plena sinceridad, un crítico pasa a comentar la obra de un literato como Lugones, ensalzado por unos y atacado por otros, brutalmente en los casos, sin comentarios ni explicaciones."p.24.

En otro pasaje: "En las tumultuosas luchas que durante tres cuartos de siglo agitaron el alma argentina, no había sosiego ni descanso para la obra literaria, para la verdadera obra literaria, casi profesional, como se la entiende en Europa. Había políticos y militares y médicos que escribían libro sobre libro; pero no había literatos." p. 25

"El literato profesional, tal como lo entiendo yo, -y conmigo otros muchos,- no existió en la República Argentina hasta el movimiento iniciado por Rubén Darío. Leopoldo Lugones fue el más grande de todos. Leopoldo Lugones ha sido un verdadero literato, trabajando día a día, publicando obra tras obra, 
fiando más en el esfuerzo intelectual que en lo demás, (aunque en este demás comprendamos aquello que le aseguraba la materialidad de la vida).

Discute la afirmación de Más y Pí que sostiene que ha sido L. Lugones el que con su Guerra Gaucha ha abierto el camino para un camino, el del nacionalismo, y habla de "las tendencias nacionalistas que después se impusieron".p.26

Para finalizar: "Ancho es el campo y todos caben. Por otras parte esa diversidad de criterio es tal vez lo que forma las armonías. Y hasta ahora no había existido más armonía que la de la indiferencia." p. 27.

Uno de los reproches de Leguizamón es la ausencia en el libro de Más y Pí de Eduardo Acevedo Díaz (uruguayo). Más y Pí responde que como no se trata de la novela rioplatense en su libro, no lo ha consignado. En la nota que sigue el mismo Acevedo Díaz aparece agradeciendo a Leguizamón.

-A Martiniano Leguizamón por Eduardo Acevedo Díaz. Transcribimos el texto completo.

"Señor doctor don Martiniano Leguizamón:

He leído sus libros y sus críticas, pienso como usted. Su estética nativa, habla al corazón y al pensamiento.

El bramar de pampero entre los ramajes del ombú solitario, más imponente al cruzar el Plata, como si la libertad de su zona diese mayor brío a la onda sonora; y más violento ante las barreras de 'sombras de toro' cuyos gajos rompe y dispersa en el espacio para abrirse camino bajo las bóvedas de la selva hasta perderse en remotas fronteras en medio de intensos rumores, como últimos gritos de un combate de gigantes, todo eso es nuestro, todo eso es indígena.

Tales fueron el instinto y el ímpetu de nuestro hombre intermediario.

El gaucho -que fue- bramó así, luchó, venció y depuró el ambiente hispano colonial.

Merece entonces prolongado examen y detenido estudio.

Para convencerse de que una nacionalidad es tal, y no fruto y artificio del convencionalismo de los más fuertes que por una u otra causa hayan influido en sus destinos, es necesario investigarla en sus orígenes, en sus medios primitivos de formación y desenvolvimiento espontáneo, en sus costumbres más rudas, en sus instintos libres de freno, en su lenguaje tosco bordado de modismos como un calzoncillo de criba, y en su aspiración constante hacia una finalidad determinada.

Es como podrán darse cuenta los pósteros de cuál era la idiosincrasia de su país nativo y cuál su verdadera historia, así que los apellidos de un tronco realmente originario se hayan extinguido por la conmixtión continua con otros extraños y recién venidos de todas partes del mundo, y así que el empuje irruyente de otros hábitos y tendencias económicas y sociales se hayan modificado y diluido como cuerpos simples en combinaciones químicas, los que fueron propios, personalísimos, singulares de una sociabilidad incipiente

Cuando el tronco originario haya perdido sus raíces, como cualquier ñandubay, y ya no exista ni el rastro de la raza criolla, el campeón errante que se impuso en los primordios de la lucha será sombra legendaria, menos fantástica que la de muchos paladines realzados por la poesía épica, y más real, más verosímil y más humano que las sombras blancas del oro de Homero.

Las muy solemnes de Vercingetorix, de Arminio, de Pelayo surgidas de la barbarie virgen, en sus encarnaciones del patriotismo solo fueron pasión y valor, y estas dos grandes energías juntas los arrastraron a las batallas gloriosas, y los convirtieron en símbolos augustos. Hoy se veneran.

¿Por qué razón negar su lugar prominente en el espacio y en el tiempo a los gauchos extraordinarios que hicieron en su medio lo mismo, con proyecciones más fecundas, en favor de la libertad y de la democracia -extremo ideal de la civilización moderna?

Pienso como usted.

Por eso precedo con esta dedicatoria el libro que me complazco en brindarle. E sus páginas históricas se encierran las virtudes de aquellas generaciones que usted, con robusto talento ha sabido rememorar y enaltecer en obras literarias que yo considero es con boleto de paso al porvenir y noble blasón de supervivencia.

Dígnese usted aceptar mi homenaje y mi honda simpatía” pp. 28-29

Las sendas del arquero por Juan Julián Lastra pp. 43-50

El pasaje que transcribimos se vincula con el aspecto institucional de la literatura: 
“ ‘La Agonía de Euphorión’ y 'Los Poemas de la Primavera', vendrán a aumentar modestamente para la próxima primavera, la vendimia de versos del año que han incido algunos poetas felices. Versos todavía? Sí... "Mientras exista una mujer hermosa!" No parece, sin embargo, que la crítica y el medio ambiente se interesen demasiado por el porvenir de las letras en América. Hay, es indudable, una tácita conspiración de silencio alrededor de los escritores. Sus obras aparecen, brillan como constelaciones efímeras y pasan al olvido de las Bibliotecas, al depósito de las librerías, y muy felices, si después de algún tiempo, alguna alma lírica y llena de azul, las recuerda. El mercado intelectual no existe entre nosotros, dicen los señores libreros ... la gente no quiere leer versos. Cosa tan baladí en la literatura, contrapuesta al boato y al dolor de la vida en prosa! Pudiérase pensar así que asistiéramos en la Ciudad romántica a la agonía del espíritu del verso, que no sé si, discretamente, simbolizo en el mito helénico de Euphorion.

Tal la opinión de la burocracia, de la burguesía, del bizantinismo social y político y de los corredores de Bolsa. Viene bien aquí la pregunta que se le hiciera a un literato amigo de alta reputación, después de felicitársele por su última obra... “AAdemás de esto, usted se ocupa de alguna cosa práctica?"”p.43 Luego viene un pasaje en que se recrea la oposición entre el arte y el dinero y la consideración más general respecto del arte como algo que, lo mismo que las cosas prácticas, requiere un esfuerzo. "Al par que el esplendor material del comercio, de las industrias, de la riqueza pública, el destino de los pueblos y de las sociedades exige el esplendor intelectual, la constante renovación de las ideas que son su génesis" p. 44

La nota termina con palabras que alaban a los escritores que como Caraballo contribuyen a la cultura nacional: "Bienvenidos pues, los escritores y los poetas, si como Caraballo nos indican el éxodo hacia las Castalias del camino, en cuyas aguas sean vigorizadas la sangre y el alma de nuestra nacionalidad tal como apostoliza Ricardo Rojas- o canta en sus advocaciones a la República Mario Bravo.” p. 50.

-Un libro de Julio Piquet por Mirror (sobre Tiros al aire, cosas pensadas, sentidas, vistas oídas o soñadas)

Julio Piquet es para Mirror (creo que Rojas) un espiritualista: "Si la ciencia no ofrece a Piquet ni la posibilidad del descubrimiento de la verdad, en cuanto al origen y fin de la vida, la solución metafísica, que hace poco considerara tan ineficaz al respecto como la científica, le resulta menos repugnante. "Ábralo [el libro] por donde quiera, con la absoluta seguridad de que en todas las páginas ha de encontrar médula, motivo para pensar o para sentir, y en todo caso, para deleitarse con la conversación de tan excelente compañero espiritual [cursivas mías].p.56. Anota la filiación anarquista del libro. Califica al autor como un epicúreo amable que más allá de su pesimismo ama la vida. Destaca la delicadez y sobriedad del lenguaje, y el "don de evocación" que tienen las anécdotas narradas en el libro.

Teatro nacional, por Nicolás Barros

-El dolor del rosal de Alejandro Marcó

Según Nicolás Barros, esta obra, más allá de sus deficiencias ya señaladas por la crónica diaria, vale como tendencia en el teatro argentino y colabora en refinamiento del gusto del público.

"El haber del repertorio nacional, no es, ciertamente, de lo más ampliamente dotados en materia de comedia. Cuando nuestros autores han decidido abandonar el colorido regional -cursivas mías- en sus obras lo han hecho para pasar bruscamente a la pieza de enredo que, con técnica deficiente de gente poco experta, ha[n] vacilado hasta ahora, entre la "pochade" libre, y la "farsa" grotesca.". En cuanto al autor sostiene: "Abandonando el colorismo, y la situación grotesca, ha hecho una comedia espiritual que contraste vivamente con todo lo que hasta hoy se ha hecho entre nosotros. Abandonada la 'acción escénica' hasta un punto casi perjudicial, el doctor Marcó ha logrado sostener sin embargo, en la psicología sutil del diálogo, el interés del auditorio.

Desde luego el intento es enteramente plausible. No me halagaría que el género "psicológico" -que ha dado en llamarse así últimamente- y que ha usado el doctor Marcó en su comedia, fuera la tendencia definitiva de nuestro teatro. Acaso no sea ese el género que resulte de nuestro enigmático cosmopolitismo; sin embargo, como experiencia, como ejercicio, como moda fugaz en nuestra literatura entiendo que la comedia psicológica tiene en el teatro argentino una doble misión; refinar el gusto público, asaz desorientado en el último tiempo, y acostumbrar a nuestros a autores en el manejo 
espiritual de los tipos, reducidos hasta hoy, generalmente, a un procedimiento de pura mecánica y efectismo teatral." p. 63

-La última noche de Héctor C. Quesada y Nemesio Trejo. Crítica negativa. Se trata del teatro entendido como representación y por lo tanto como constructor de un público específico, esto es, no lector. Sucede que aquí se produce un conflicto de incumbencias entre la alta cultura y la cultura popular. Nemesio Trejo es un "sainetero" p. 64.

Barros señala que no para hacer una obra teatral no bastan la buena intención y el entusiasmo, y en función de ello, explica el fracaso de la obra que comenta. En cuanto a Nemesio Trejo sostiene que el error que esta obra constituye es menos explicable que para H. Quesada (político puesto a autor teatral) dado que es un hombre de teatro: "No exigiríamos que al señor Trejo que reparara en las mil vulgaridades de la pieza - que para ello ha demostrado sus cortas aptitudes en cincuenta sainetes bailables- pero al menos era de esperar que él, hombre de entre bastidores, supiera medir los efectos y disciplinar la técnica de una obra encomendada a su revisión". p. 63

"A raíz del estreno, la crítica comentó el fracaso. El señor Trejo, volviendo por sus fueros de autor siempre aplaudido, recibió tales comentarios con el gesto airado que correspondía a tamaña irreverencia. A raíz del estreno, y de no haber sido nunca un autor teatral, envió valientemente su renuncia de miembro y vocal de la Comisión, a la Sociedad Argentina de Autores Dramáticos. Naturalmente, el popularizado sainetero dejó en el silencio de su convicción las verdaderas causas de resolución tan inaudita." [cursivas nuestras]. p. 64

-Un loco de David Peña [en el teatro Buenos Aires, por la compañía Villagomez]

Crítica negativa. El personaje no cuadra con el género ya que es un loco puesto en un escenario de comedia. Además señala la decepción respecto de la obra representada, puesto que leída prometía mucho más. Se esperaba algo mejor "leída en diversas oportunidades y con aprobación general en diversos círculos intelectuales y de amigos del autor." p. 64. Se ataca la artificiosidad.

Bellas artes, por José Ojeda Las exposiciones particulares - Las aguadas de Cassier

Se consigna el progreso del gusto artístico del público de Buenos Aires, desde la exposición de arte del Centenario.

Bibliografía

-Las transformaciones de la sociedad argentina de Horacio G. Rivarola, por Coroliano Alberini.

Es la tesis con que el autor alcanza el título de doctor en filosofía y Letras. Alberini discute las implicancias metodológicas del concepto transformación, central para el trabajo de Rivarola. Al margen de esto, la crítica es positiva. Se valoran la documentación y el método. "Mucho pudiera agregarse sobre este trabajo. Por ejemplo, que reboza de patriotismo severo, inmune de nacionalismo endémico, que no es sino la tumefacción literaria de aquél." Así, resalta la "sencillez agradable de la forma" y afirma que "no se calza el coturno retórico para hablar de la patria". p. 72.

-Los lises del blasón de Ricardo Rojas, por Alfonso de Laferrére

Coincide con el juicio negativo de Gerchunoff sobre esta obra de Rojas. Coincide también en el reconocimiento del talento en toda su obra previa, pero, señala: " no ha menester, por cierto, de esfuerzos ineficaces por lo artificiales como el que acaba de ofrecernos con Los lises del Blasón." p. 72 Parece casi copiar a Gerchunoff. Según el crítico, Rojas no es poeta; se ataca el rebuscamiento inútil en la forma, la falta de sentimiento, el carácter puramente intelectual de la obra. "Sospechamos las torturas mentales a que se habrá sometido para rimar cosas como la siguientes:

Arepo, Keter, Jesod

Tenet, Tipheret, Bináh,

Opera, Yah, Geduláh,

Rotas, Abédenego, Hod!" p. 73

"Si Rojas no fuera el artista de tantas prosas de mérito, bien podríamos creer que su deseo ha sido espantar a los burgueses." p. 73. 
-Los jardines galantes, de Luis María Jordán, por Alfonso de Laferrere

Juicio positivo sobre el libro y su autor. Se corrige de los juicios previos y apresurados sobre Jordán a partir de dos libros de cuentos y algunos artículos discretos "que hablaban de una personalidad tan insignificante que ni siquiera lograría destacarse en nuestro chato medio intelectual.

Los Jardines Galantes vienen a demostrarnos lo apresurado del juicio." p. 74

-Odas singulares, de Arnoldo Fregones, por Alfonso de Laferrere

"La virtud de la risa es algo que no se discute. Han coincidido en proclamarla, pensadores de todas las épocas; entre los que se cuentan Rabelais, Nietzsche e Ingegnieros. El buen reír superioriza. Así lo ha comprendido el autor de este libro, dedicándose a reírse de Lugones, temible sujeto para tales experimentos. No estamos de acuerdo con A. F. en su manera, un tanto atrevida, de tratar con el autor de Prometeo, a quien admiramos y veneramos; pero sí estamos de acuerdo en su forma alegre e irónica de encarar las cosas." p. 75

“(...) Forma el volumen una colección de parodias de las principales composiciones lugonianas. Los fuegos artificiales se llama aquí Los cohetes; el Himno a la luna, Himno al Sol; Los burritos, Las mulitas, etc., etc. Indudablemente los títulos están bien imitados. No ocurre lo propio, sin embargo, con lo demás. Si el autor hubiera llegado a penetrar el verdadero sentido y el mérito real de la obra del maestro, no se arriesgara tal vez en empresa semejante. Sus sátiras contra Lugones fracasan siempre en forma lamentable" p. 75

-Perfume de belleza por José Fabio Garnier

“(...) amable libro de crítica literaria y artística, editado por la casa valenciana de Sempere. De crítica decimos y decimos mal, pues el señor Garnier no es precisamente un crítico. Es más bien un impresionista." p. 76

-Bibliografía de Sarmiento con prólogo de Ricardo Rojas (UNLP, trabajo realizado por alumnos de letras), por Julio Noé.

"La germánica afición de emprender obras trabajosas, no concuerda con nuestra clásica despreocupación y con su "repentinismo" consecuente. Los pocos casos en los cuales la voluntad argentina ha deseado imitar el ejemplo alemán, han constituido una peregrina mezcla de propósitos encomiables con fatales improvisaciones. La accidentada acción a que obliga la necesidad imperiosa de constituir la nacionalidad,[cursivas nuestras] no es ajena al laboratorio científico ni al estudio razonador. De aquí la máxima de Sarmiento, acaso la más argentina de cuantas han sido lanzadas: las cosas hay que hacerlas; aunque sea mal, pero hacerlas. Esta ha sido, en definitiva, la norma de todo esfuerzo, bajo la cual se amparaban los que en este país se preocupan por hacer algo, aunque ese algo signifique nada.

Don Ricardo Rojas, acaso el más representativo de la joven intelectualidad argentina, propúsose, como labor de seminario a cumplirse en su curso de letras de la Universidad de La Plata, hacer por la ayuda de sus discípulos, la Bibliografía de Sarmiento. La obra era, en realidad, difícultosa, pero, dividido el trabajo, creyó terminar en un año escaso la síntesis de los 52 volúmenes de la edición oficial." p. 78

La crítica es negativa y se dice que el libro es por momentos de una gran pobreza porque los alumnos sintetizan libros que ni siquiera conocen. Sin embargo, se reconoce el valor de la iniciativa. Se elogia el prólogo de Rojas: "Rojas afirma con estas páginas su conocimiento del idioma, y la fama de activo ciudadano que en propicia hora señaló los peligros que amenazaban la conciencia argentina. Acaso lo más discutible de este mismo prólogo sea la curiosa definición del genio; pero, no deseamos cruzar el otro cercado." p. 78-79

-Letras españolas de Juan Más y Pí, por Julio Noé

"De los pocos críticos que en nuestro país han ejercido su alto ministerio con mayor inteligencia, Juan Más y Pí ocupa un lugar preferente.” p. 79 "Más y Pí parece escribir para que su prosa combata la opinión contraria; no es fría y razonadora, es brusca, como el moderno periodismo lo exige. No olvida nunca que s escribe para todos, para el público que lee diarios o para el dilettante que hojea revistas. 
-Épocas militares de los países del Plata de Eduardo Acevedo Díaz, por Julio Noé.

Noé define el libro en relación con los modos de practicar la historia: "La antigua manera de hacer historia, dando mayor importancia a la crónica de los sucesos que a las consecuencias institucionales de los mismos, ha hallado en el señor Acevedo Díaz un último adicto, fiel en todo a los principios que ella sustentara. Al apuntar este hecho, no pretendemos señalar defectos que tal vez no existan, sino caracterizar la índole del libro." p. 80 Los trabajos abarcan el período 1806-1832. "El libro en general, como el autor reconoce, carece de unidad y de método, peor ello se explica por origen de los capítulos que lo constituyen. En cuanto al escritor que lo compuso, bien se percibe la ágil pluma del autor de Nativa, obra que tanta importancia tiene en los orígenes de la literatura nacional" p. 80.

"Nota: por falta absoluta de espacio, nos vemos en la precisión de postergar la publicación de varios artículos, ya compuestos y compaginados. Igual suerte han corrido diversas Notas y comentarios" p. 80

Año V, tomo 6, n⿳ 31, agosto, 1911.

Pájaros fritos Amado Nervo pp. 81-84.[de un libro próximo Filosofando]

Coplas de la Tierra Martiniano Leguizamón pp. 85-95

Poesías.......... Carriego (El camino de nuestra casa); Debenedetti (Era...!); Raymundo Manigot (La epopeya de amor), Guido A. Cartey (Vallis Moeroris) pp. 96-101

Alejandro Marcó ........... El dolor del rosal (comedia) pp. 102-144 Acto único.

El poema silencioso ......... R. Francisco Mazzoni pp. 145-150.

Daniel Elías................Las alegrías del sol pp. 151-152

La fanciulla del West ..................... Enrique Giordano Junior, sobre la ópera de Puccini pp. 153-156

Teatro nacional .................... Nicolás Barros pp. 157-160

Bibliografía ................. Julio Noé pp. 161-167

Notas y comentarios ........... Nosotros pp. 168-176

\section{-Coplas de la tierra por M. Leguizamón}

Leguizamón, siempre en la misma línea de las cosas de la tierra, y con una mirada de etnógrafo como la de sus Recuerdos de la tierra, propone una forma de apropiación de la cultura popular (en este caso la música popular y especialmente las vidalitas) por la alta cultura registrándola en su forma escrita. El modelo es J. V. González con Mis montañas.

Leguizamón cuestiona al autor del libro que reseña Tras los mares. Interpela a Juan Antonio Cavestany en tanto miembro de la Real Academia española "que según el viejo mote de la venerable institución limpia, fija y da esplendor a la lengua. Con esa honrosa credencial viene precedido su libro; de manera que las voces, los usos y las costumbres de estos pueblos que el poeta ha reflejado en sus impresiones americanas llevan el pasaporte de recogido in situ como auténticos, y serán incorporados mañana tal vez, al léxico para enriquecerlo".p.86 La forma en que lo interpela refuerza las atribuciones que se asignan a las instituciones en el cuidado, que en este caso es visto como enriquecimiento, de la lengua española.

Como ya señalamos en el apartado "Martiniano Leguizamón: hacia la construcción de la historia nacional", Leguizamón objeta la tesis generalizada que considera el folklore argentino como herencia de los conquistadores. En función de esto, para Cavestany petenera y vidalita son "hermanas". Leguizamón sostiene: “(...) son completamente diferentes por su origen, la estructura del verso y la cadencia melódica, no teniendo más aire familiar que el idioma aunque bastardeado por el típico ceceo flamenco y las rudas hablas del lenguaje gaucho" p. 89

"La vidalita, es por el contrario, triste siempre; su música sencilla, su letra casi sin variantes le imprimen un acento sentido de melancolía profunda y resignada [cursivas nuestras], en que parecen flotar los sufrimientos de la raza indígena y los anhelos del alma gaucha que reflejó en aquellas toscas canciones las amarguras de su mortal desamparo." p. 89 La vidalita no es de La Pampa. A La Pampa corresponde los cielitos "con que Hidalgo enardecía a las masas criollas contra el godo" y los tristes de Santos Vega vertidos en la décima castellana. El origen de la vidalita es incásico. Sin embargo se resalta la funcionalidad política de la vidalita -lo mismo que de los cielitos. "Un rimador anónimo condensó las palpitaciones del alma de las muchedumbres que interrogaban anhelosas, en esta copla 
popular" y cita aquí una copla alusiva ala muerte de Lavalle. Habla de "vidalitas como los sollozos de una raza" p. 93.

"El distinguido poeta ha cometido un grave error al creer que algunos meses de residencia en Buenos Aires le habilitaban para conocer su medio ambiente y penetrar los arcanos del pasado argentino. De ahí las fallas de sus juicios erróneos como se ha visto.

Pero este es el punto donde claudican invariablemente todos los escritores extranjeros en su afán de encontrarnos pintoresco y exóticos, que lo lleva a decir cosas muy divertidas, como las que nos contó recientemente Clemenceau, a propósito de nuestras costumbres campestres desde las columnas de La Prensa.

(..)

Ah! La Pampa y el gaucho continúan siendo el filón inexhausto para ciertos escritores costumbristas de allende el mar. Y sin duda, resultarían una antología risueña si se seleccionaran las cosas de bulto que dijeron con tanto desenfado como ignorancia de la geografía y hasta del sentido común sobre esta tierra incógnita.

Pero no es de extrañar que los extranjeros incurran en semejantes desbarros, cuando algunos escritores de la tierra los cometen por falta de observación (...)" p. 94

Para terminar: "Y con la misma pasión con que él exalta el inconfundible abolengo de la copla de su nativa tierra sevillana, ha de concederme que defienda yo el origen americano de la vidalita; y, que empleando una voz del tosco lenguaje aborigen que aún la entona allá bajo la sombra de nuestros bosques mediterráneos, le diga: -Kayca noccapa,- esto es mío.” p. 95.

El dolor del rosal (comedia), por Alejandro Marcó, pp. 102-144 Acto único. La obra se estrenó el 19 de junio de 1911 en el teatro Nacional. La acción transcurre en Buenos Aires, en la época del estreno. Elenco y personajes: Sabina Vittone (Doña Laura, 42 años), Anita Podestá (Angélica, 24 años), Olinda Bozán (Leonor, 21 años), Blanca Podestá (Marta, 18 años), José Gómez (Marcos, 22 años), Salvador Rosich (Raúl, 29 años); aparece un mucamo como personaje secundario.

En la primera escena, en la sala de la casa de doña Laura, Leonor toca el piano, Marta lee a Maupasant, Angélica pinta un cuadro en base al modelo vivo de un loro que está en la salita, también. Raúl, enamorado de Marta, decide viajar a Estados Unidos, para olvidar. Decide despedirse de Marta, de la madre de Marta y sus hermanas y hermano. En esa despedida hay una confesión apresurada de Marta, la revelación del amor de Leonor por Raúl, quien finalmente no va a quedarse ni con Marta ni con Leonor, sino con Angélica.

Teatro nacional

-Los mirasoles de Julio Sánchez Gardel. Se comenta el estreno exitoso de esta obra en un nuevo teatro criollo, El Moderno, inaugurado ese mes por Pablo Podestá, con gran éxito. Dice Barros "Sánchez Gardel, ha tocado en Los Mirasoles la misma cuerda provinciana que tan buenos éxitos le ha proporcionado en las obras anteriores (...)" p. 137. Azucena, una joven provinciana se enamora de un joven de ciudad que va al interior en misión política. Azucena le adjudica una posición social que no tiene y su novio no se anima a hablarle francamente, hasta que lo hace y la obra termina con la "modestísima apoteosis al amor burgués y sencillo de los protagonistas" (p. 138), solución que agrada al público pero no al crítico.

-La eterna prosa de Cayol. Estrenada en el Apolo por la compañía Podestá; se critica la actuación y la obra misma respecto de su significación en la obra del autor. Se dice tiene "las desventajas de la frondosidad excesiva", poca acción

¿Hizo Bien?

Elogio a Juan José de Soiza Reilly, por esta obra, cuyo estreno fue accidentado. Se lo conocía como periodista: "reporter de revistas gráficas" p. 159.

Bibliografía por Alfonso de Laferrere y Julio Noé

-Jardines solos por A. Capdevila. Poesías. Córdoba

Laferrere se burla de la dedicatoria que escribe Capdevila a Estanislao Zeballos. Luego alaba las cualidades de Capdevila. Para finalizar: "Es un poeta menor, un buen muchacho sentimental que ha cantado sus íntimos poemas en una manera simple, agradable y harmoniosa" p. 162.

-El libro de Horas de Fernán Félix de Amador. París 
"toda la inspiración delicada, exquisita, y enfermiza de los simbolistas" es la frase que según el crítico sintetiza el libro. Imitación de los modernistas. Se refiere en estos términos: "las exageraciones modernistas, tan deplorables y desgraciadamente tan comunes" p. 162 Rescata algunos poemas, y algunos aspectos del libro.

\section{-Colección Ariel San José de Costa Rica}

Se reciben los 8 primeros volúmenes de esta colección dirigida por Joaquín García Monje.

"La obra de cultura en que se halla empeñado este escritor, merece el más decidido aplauso los pequeños folletos de la Colección Ariel difunden entre el pueblo una cantidad de conocimiento útiles y sencillos que a la larga tienen que producir naturales beneficios, y al mismo tiempo ponen al alcance de la mayoría las grandes obras de todos los tiempos. Así vemos que el primer volumen nos ofrece fragmentos del Diario de Amiel, el segundo prosas escogidas de Manuel Gutiérrez Nájera, y los restantes una buena traducción de Tolstoi intime de Sergio Persky, una selección poética del inolvidable Isaías Gamboa, El hombre y la tierra de Reclus y El canto de las Horas, obra inédita de Roberto Brenes Mesén, psicólogo y poeta bien conocido entre nosotros” p. 164.

-Visión de Paz y Calidoscopio por A. de Estrada hijo. Elogio. Último representante del arte por el arte. - Los emigrantes por Eduardo Zamacois.

Se trata de una novela sobre Argentina "El señor Zamacois, como la mayoría de los europeos que nos visitaran en gira de conferencias, ha dedicado un libro a la Argentina" p. 166. Novela más o menos naturalista.

-Desde las aulas por Luis Méndez Calzada

Prologado por Zeballos. Toma temas estudiantiles y jurídicos.

Folletos:

- El problema nacional por Clodomiro Cordero

"La propaganda anti-argentina que emprendieron últimamente diversos publicistas y hombres de estado eminentes, sugirieron a don Clodomiro Cordero los artículos que constituyen este folleto.

Cuatro tópicos estudia el autor: la psicología del inmigrante, la conciencia nacional, la justicia y la instrucción pública, y la nacionalización de los extranjeros. En cada artículo protesta con acalorado nacionalismo de las afirmaciones vertidas sobre nuestro país, y pretende demostrar cómo el actual cosmopolitismo es causa antes bien que de incalculables ventajas, de muchos de los vicios institucionales que nos roen." p. 167

- Monólogos por Vicente Nicolau Roig

Notas y comentarios

-Miecio Horszowski. Nota sobre su posible locura.

-Franz von Vecsey. Presentación del violinista en el teatro Coliseo.

-M. Victor Margueritte: la suya se suma a las conferencias de otros intelectuales franceses en Buenos Aires -France, Clemenceau. A lista se agregará en breve la de "Jean Jaurés, el gran poeta del proletariado, apóstol valeroso de la justicia social" p. 171.

-El Mercure de France

Aparece como un ejemplo de "juvenil constancia, en una ardua empresa de arte" p. 171. Se transcriben algunos pasajes de las palabras de Rémi de Gourmont en su artículo de Le Temps:

“ 'El Mercure, surgió a fines de 1889, por iniciativa de un grupo de jóvenes sin relaciones, sin notoriedad, sin dinero. Los primeros números, que no pasaban de treinta y dos páginas, traían, en la cubierta de atrás, estas palabras: La Pleiade, $2^{\circ}$ année. Una primera Pléiade, cuya cubierta violeta la enlaza evidentemente al Mercure de France, así como a su redacción que permaneció más o menos la misma, había sido ya fundada en 1886 por Rodolfo Dargens. En esta primera Pléiade fue donde René Ghill publicó su Traité du verbe. La entrega de Mayo trae el nombre de un escritor que deberá luego, conquistar gran fama en el mundo literario: el de Mauricio Maeterlinck. Pero, ¡cuántos son los que leyeron, en la Pléiade de 1886, el Massacre des innocents!'.

El Mercure sólo volvióse simbolista hacia 1895. Hasta entonces, de todas las tendencias artísticas que acogió y defendió, la simbolista es la que peor está representada. Respecto a la fundación escribe el articulista:

'En el mes de Diciembre de 1889, uno de mis amigos me preguntó ex-abrupto si quisiera asociarme a algunos jóvenes que habían decidido fundar una pequeña revista titulada Le Mercure de France. Consintió De Gourmont. Tanto más cuanto que habían hallado un buen director en Vallette. "Vallete, 
— decíale el amigo a De Gourmont —es un espíritu sólido, sin vuelos líricos, de visión neta, y que sabe estimar las cosas y los hombres según su valor. Con él no nos perderemos en las nubes, sino que permaneceremos siempre en contacto con la realidad". Las previsiones pronto se realizaron. El Mercure surgía sobre muy frágiles bases financieras y lanzábase a la conquista del mundo literario con un puñado de fuerzas intelectuales bastantes inciertas. Cómo recoger el dinero para fundar la revista? Haciéndose todos accionistas y pagando cinco francos por mes! Mayor cantidad no podían gastar, si se exceptúa al más rico, que pudo permitirse el lujo de subscribirse a cuatro acciones. La sostuvieron de esta suerte algunos años. Cubriendo a duras penas, con las escasas entradas de la subscripción y de la venta menuda, los serios deficits del presupuesto. Pero fueron tales el orden y la regularidad, tanto en la administración como en la dirección, que ya en su segundo año la revista pudo transformarse y mejorar notablemente. A ello contribuyó muchísimo también la obra de sus redactores y colaboradores: la de Laurent Tailhade en primer término, quien publicó en ella baladas de tal belleza, que le adquirieron al Mercure en el acto las simpatías del público; y luego la de Jules Renard, cuyas novelitas y bocetos pintorescos, fueron también un importante factor de éxito.

De aquella primera redacción del Mercure un sólo escritor era conocido: Rachilde, la autora de Monsieur Venus, novela de la cual Mauricio Barres acababa de alabar, con toda su precoz gravedad, la moral misteriosa... Pero, a medida que las entregas del Mercure aumentaban en volumen, también la fisonomía de la revista iba modificándose. Lentamente, pero con seguridad, se infiltraba en ella el simbolismo. Hacia 1895, después de cinco años de vida, entre cincuenta revistas o periódicos más, el Mercure, ya es la concentración, si no la síntesis, de la nueva literatura... Al año siguiente con la publicación de Aphrodite de Pierre Louys, el Mercure levanta el vuelo definitivo. "Con esta fecha, 1896, — dice Remy de Gourmont - puede cerrarse el primero y más glorioso capítulo de su historia'.

Los restantes capítulos que De Gourmont no ha escrito, nuestros lectores no los ignoran: El Mercure de France es hoy día no sólo una gran revista, sino también una importante casa editora, que cuenta en su haber la publicación de varios centenares de volúmenes, entre ellos la traducción de las obras completas de Nietzsche" pp. 171-173.

-Exposición Nacional de Arte

La Comisión Nacional de Bellas Artes resuelve realizar una exposición de pintura y escultura, arquitectura, artes decorativas. Se transcribe el reglamento de participación en el concurso. Las obras serán seleccionadas por un jurado. Los premios son en dinero.

-Máscaras

Es el nombre de la revista de Carlos Alberto Leumann: "revista ilustrada de gran circulación callejera, que constituye toda una novedad entre nosotros, en su género" p. 174. Revista dedicada especialmente al teatro "pero inspirada por un alto criterio, no sólo hace suyos los asuntos que tienen por marco el reducido de la escena, sino todos aquellos que so vida vivida, vida pasional, dramática por tanto." p. 174.

-Florentino Ameghino

Se anuncia la publicación en el número siguiente de la revista de un trabajo de Salvador Debenedetti sobre "el ilustre sabio".

-Concierto Collin reseña [C. S. L ¿̨?

Emilio Collin, concertista y profesor de piano, realiza una muestra de sus alumnos en el salón del Operai Italiani. Se transcribe el programa de obras ejecutadas.

\section{Año V, Tomo VI, $n^{0}$ 32, septiembre, 1911}

Los dos peligros de América .... Jesús Castellanos pp. 177-186. [a propósito de dos libros: El porvenir de la América Latina de Manuel Ugarte y La Reconquista de América del cubano Fernando Ortiz] Dios sea loado ........... Ricardo Jaimes Freyre pp. 187-189

Ganador y Placé..............comedia en un acto de Arturo Giménez Pastor pp. 190-212

Versos para Rosina que se casa .............. Alfredo Arvelo Larriva pp. 213-216 (con una introducción de R. Giusti) 
Ameghino. Una faz de su obra

Salvador Debenedetti pp. 217-222

Las veladas del Brazil

Juan Manuel Méndez pp. 223-227

Sonetos

Pablo Della Costa y E. Lazcano Tegui pp. 228-230

Bellas artes Martín Malharro. José Ojeda pp. 231-232

Teatro Nacional pp. 233-235 por Nicolás Barros

Crónica Musical - Conciertos pp. 236-238 por Miguel Mastrogiani

Bibliografía pp. 239-249

La demostración a Nosotros, pp. 250-256

Notas y comentarios.

La dirección, pp. 257-260

Ganador y Placé.

comedia en un acto de Arturo Giménez Pastor pp. 190-212

Personajes: María (20 años), Alicia (18 años), Romualda (45 años), Doña Elvira (45 años), mucama (28 años), Aurelio (26 años), Germán (28 años), Don Rafael, Don Antonio (55 años ambos), Horacio (25 años), Jorge (24 años), Carlitos (20 años), un chico de 10 años, un mucamo. La acción transcurre en un patio de "casa de familia" desde el que se ven la puerta cancel, puertas de habitaciones, elegante chalet vecino. Se trata de los problemas que enfrenta un autor teatral para escribir sobre el tema que le tocó en suerte en el concurso, del que no sabe nada. El título a partir del cual debe imaginar su obra es Ganador y placé. Todos en su casa -a excepción de Don Rafael que se opone- saben de carreras de caballos, menos Aurelio, el autor teatral. En nota del autor el pie se aclara : "Esta comedia fue la consecuencia de una humorada de autores dramáticos que se convirtió en concurso o certamen público sometido a las condiciones que se enuncian en el diálogo [se refiere al diálogo entre Aurelio y su mujer en el que Aurelio explica su desgracia por haberle tocado tal título] esto explica la naturaleza de la obra, y el apasionado interés que esa justa despertó y el favor que hasta ahora otorga el público a Ganador y placé explican su publicación" p. 191.

Las veladas del Brazil, Juan Manuel Méndez pp. 223-227 [en ese momento, el lugar ha cambiado de nombre y se llamaba 'Café de los Inmortales']

Este texto está dedicado a Mario Bravo. Es relevante porque relata el tipo de sociabilidad que se desarrolla en los bares a principios de siglo en Buenos Aires. Se caracteriza a un nosotros juvenilista, idealista.

Transcribimos algunos pasajes:

"Las Veladas del "Brazil"

Apuntes

A Mario Bravo.

Todos teníamos veinte años, menos Rosa María que no cumplió los diez y nueve. Unos habíamos llegado el día antes de lejanas aldeas, con la mirada fija en la luna; otros volvían ya de la primera aventura, con un gran estupor en el azul lavado de los ojos: nosotros presentíamos algún mal obscuro alrededor, ellos ya sabían... Cada cual ennoblecía a su manera el ideal común, el mismo afán había orientado hacia el mismo punto la labor de su juventud; Emilio, Alfredo, yo, cualquiera, éramos la conciencia del grupo. La obra aislada establecía las variantes de intensidad, carácter y amplitud en aquella extraña igualdad de temperamentos. Una analogía más rara aún ha descubierto el tiempo transcurrido, una ponderación intelectual diferenciada apenas por los matices, sea ó no resultado de la idéntica naturaleza y extensión del estudio ó influencia general del contacto diario y emulación unánime en la esperanza de avenir a una humanidad superior en mentes y corazones. Pues había allí corazones también, anhelosos algunos de perfecta cultura y nobles rasgos de interés anecdótico que acaso la emoción del recuerdo nos haga parecer mayores.

(...)

¡En verdad que eran chuscos con sus aires de mesurado asentimiento ó descortés atención!

Tal vez, igual desconfianza inspirábamos a varios otros colegas que hubiesen ocupado un lugar deferente en nuestro círculo y nuestro afecto. Hubo quienes se nos incorporaron a última hora y quienes nos flecharon inocentemente con chistes ó nos respetaron desde lejos. Un defecto considerable, quizás, podía empequeñecernos a su ojos; ya uno de nosotros lo había expresado 
claramente en forma de un amenazante reproche: - "!Ay, muchachos! Toda nuestra actividad se reduce a estas conversaciones. Vamos a tener que interrumpirlas radicalmente si no nos corregimos". Pero en el silencio de los retiros no todo era esterilidad e indolencia. Debe decirse, algunos trabajábamos. Basta hacer el inventario de las publicaciones aparecidas algo después, cuando el pudor de los más bellos días y el deseo maduro de la manifestación, se despedían en nuestras almas. En ellas aparecen elaborados los gérmenes manifiestos en aquellas reuniones: motivos generales de novelas, narradas distraídamente como episodios incidentales de libros desconocidos; ideas; observaciones del momento, magnificadas con amor y paciencia de lapidario; dramas, cuadros, poemas, largamente pensados, sentidos y vividos, perfeccionados con la voluptuosa lentitud de una exquisita inteligencia.

(...)

Almas, sensitivas, inteligencias bien organizadas, unos volvieron a las aldeas natales, a la soledad dolorosa de las casas paternas; otros lograron una mediana conformidad en los boulevares estruendosos, en una alcohólica indiferencia; algunos cumplieron una vaga misión en las redacciones de los diarios, crearon al fin alguna belleza anónima, y todos, todos sin excepción, en las horas memorables, se acercaron a sonreírnos con una tristeza infinitamente delicada.

Por parecernos más íntima para el carácter de nuestras entrevistas, concurrimos algunos meses antes de la disolución definitiva, a una categoría del barrio de la Opera, atendida por un sólo mozo y tan original que hubiese parecido muy antigua, sin sus muebles blancos y su brillo de joya. En el "Brazil" transcurrió el mejor período de nuestras relaciones; allí nos unimos indisolublemente en el amor del arte verdadero, el menosprecio de los triunfos fugaces y el odio al dilettantismo brillante, la literatura barata y las flores de papel pintado de las capillas empolvadas, de las capillas en cuyas puertas se han escrito como una profecía, los asombrosos versículos de una leyenda antigua:

"El templo está cerrado,

La llave se ha perdido,

La pluma se ha embotado".

(...)

Ignorábamos y algunos seguíamos con disgusto esta norma de intimidad puramente cerebral, quiénes eran nuestras familias, quiénes nuestras novias, quiénes nosotros mismos, fuera de las aptitudes que nos mediamos con severa justeza y de las impresiones sumarias que producían nuestros actos. De otro modo, no éramos amigos, pero entre todos nosotros había, sin embargo, una cosa muy dulce que no queríamos definir"

Teatro Nacional por Nicolás Barros

Moderno: Los invisibles, pieza en cuatro actos de D. Gregorio de Laferrére. Transcribimos algunos pasajes de la nota.

"El estreno de Los invisibles, de Laferrére, ha asumido las proporciones de un doble acontecimiento social y teatral; lo primero por las vinculaciones del autor, que lograron formar una mayoría anticipadamente dispuesta a todas las amabilidades, y lo segundo por los prestigios de este comediógrafo, que sin ser un profesional del teatro ha tenido momentos tan felices -nos referimos a Las de Barranco- que bien valdrían el empeño de un autor consciente y completo.

Autor a ratos perdido, comediógrafo por 'sport', el señor Laferrére es un buen hombre alegre e inteligente que exterioriza en sus comedias momentos de su fino buen humor a pretexto de ridiculizar conocidas chifladuras populares, o costumbres típicas del ambiente. Sin ser un observador de cosas profundas, percibe y retiene la trivialidad de las cosas exteriores. De ahí que nadie sepa dar como él brillo tan singular a sus comedias, a base de pequeñas observaciones.

Pero en su espontaneidad de mero 'dilettante', Laferrére ha abandonado todo sistema, toda tendencia de arte, toda disciplina en su producción. A raíz de Las de Barranco pudo verse en él el primer comediógrafo porteño, por la 'trouvaille' del tema, y la habilidad del desarrollo. Pudo confiarse en el advenimiento de un fiel cronista de la ciudad -dentro del teatro- con la suficiente talla den folklorista requerida para tal empresa. Pudo esperarse a través del éxito de esta [pieza, de exacta evocación local, de fino espíritu criollo, que el autor perseverara en esa tendencia e hiciera de ella su especialidad. de ahí que el estreno de Los invisibles resultara una decepción. Laferrére vuelve -por ahora al menos- al género de Jettatore, con todos sus halagos de aplauso y todos sus inconvenientes de vulgarización. La tontería de la 'guigne' que llegó a hacerse en Buenos Aires una manía colectiva a 
raíz del estreno de Jettatore, será substituida ahora por la manía del espiritismo. De nada valen en este género de obras las moralejas finales; el efecto de ellas se asemeja al de las obras de bajo fondo, que a pretexto de un desenlace moral instruyen al público en los manejos funestamente tentadores de la mala vida..." pp. 233-234

La nota concluye con la consabida atenuación de las críticas, argumentando que si ha sido pensada como obra de mero entretenimiento, el objetivo está cumplido.

Bibliografía pp. 239-249

-Rosario de sonetos líricos de Unamuno, por Roberto Giusti. La crítica es negativa, pp. 239-240.

-Tras los mares de Juan Antonio Cavestany, por Roberto Giusti, pp. 241-244

Leguizamón ya se ha ocupado de este libro en la revista y ahora lo hace Giusti, quien en su crítica cita a Leguizamón.

“PPara qué volver a escribir La Argentina y sus grandezas, si ya se le había adelantado el Sr. Blasco Ibáñez? Además. como dice el refrán criollo, cada cual se agarra con las uñas que tiene.” p. 241.

Y prosigue: "Si el señor Eduardo Rossi, autor de Arpa de gloria, tomo de poesías con las cuales ha ganado más medallas en los certámenes literarios que comparsa en carnaval, hubiese escrito Tras los mares, yo, poseído del más frenético entusiasmo, empinándome sobre la punta de los pies le habría arrojado todas las flores de mi jardín de benévolo cronista. Pero el señor Cavestany es miembro de la Real Academia Española y pretende o pretenden que representa, con los Ferrari y los Grilo, la ilustre tradición poética hispana, que encarnaban no ha mucho todavía un Núñez de Arce y un Campoamor. Supongo, entonces, que en estas condiciones puede juzgársele según un criterio algo mas severo del que se aplicaría a cualquier premiado en los juegos florales de Macachín. Ahora bien, es el caso que el señor Cavestany no pasa nunca de ser un primer premio de concurso patriótico-literario.

Versifica con facilidad: ¿qué menos se le puede pedir? Pero si lo sacan ustedes de ahí, ya no les dará otra cosa que ingenuidades y lugares comunes, juntados con una averiada argamasa de ripios. Gastadas las ideas, deslucidas las imágenes, ausente la emoción, paupérrima la rima: no hallaréis en sus versos un sólo mérito; sí advertiréis a la primera ojeada la deleznable obra de albañilería poética que ha resultado de la reunión de todos ese material de deshecho" p. 242

Más adelante: “(...) sea como sea, Tras los mares no tiene perdón, porque es malo como poesía y malo por la intención con que ha sido lanzado al mercado" p. 243.

-Poesías completas de Carlos Guido Spano, por Roberto Giusti. p. 244.

Es importante porque se hace referencia a la edición: "La casa Maucci acaba de publicar una nueva edición de las Poesías completas de Guido Spano. Ello debe ser motivo de satisfacción para todos los amantes de las letras" p. 244. Elogio completo al poeta.

-La canción de un hombre que pasa de E. Mario Barreda editada por Nosotros, por Alfonso De Laferrére..

"Los temas que requieren su atención resultan siempre nobles y elevado. Cuando ellos no surgen naturalmente en medio a las inquietudes cotidianas, va a buscarlos en los paisajes nativos, observa las nobilísimas fatigas del Agro, se inspira en la solemne majestad de la llanura pampeana, y canta entonces las cosas de la tierra en estrofas llenas de sentimientos y de color. Muy pocos son los poetas argentinos que hayan logrado tanta fuerza de expresión cual la obtiene Barreda en hermosos sonetos como "El matrero", "Cuadro familiar", "El ombú", los inolvidables de "Talismanes" y ese otro que comienza: "Yo soy uno de aquellos de la llanura"”. p. 245. Elogio.

Varios a varios de Manuel Cervera, Luis C. López y Abraham Z. López Penha, con un "prólogo arbitrario" de F. Ramos González. Madrid, por Alfonso De Laferrére.

-Documentos relativos a la Organización Constitucional de la República Argentina publica la Facultad de Filosofía y Letras a partir del relevamiento de los archivos de Paraná, Santa Fe y Tucumán. Reseña Julio Noé.

- Titta Ruffo (Notas de psicología artística) por Mariano Antonio Barrenechea. pp. 248-249. Reseña Julio Noé.

- El egoísmo de los intelectuales. Reseña Julio Noé. p. 249 
La demostración a Nosotros a propósito del cuarto aniversario de la revista. pp. 252-256

Discursos de Gerchunoff, Giusti, F. Albasio (editor).

Los siguientes pasajes muestran una vez más la forma en que la revista autoevalúa su intervención intelectual y los recursos a que apela para seguir subsistiendo. En este caso, se trata de un colaborador de la revista quien aparece como figura central del resurgimiento Nosotros [cf. Notas y comentarios del $\left.n^{\circ} 28\right]$

Extracto del discurso de Gerchunoff

"Reduzcámonos tan sólo a comprobar la acción benéfica de la revista. Ella realiza una tarea de cultura y representa con honor la intelectualidad de Buenos Aires. Alabemos el esfuerzo de sus directores que han sabido inspirar a la revista un rumbo tan certero y una amplitud tan hermosa. No funda ninguna tendencia, no es el órgano de cenáculo alguno. Acoge con generosidad tentativas juveniles y fomenta la labor mental con invariable energía. Su programa consiste en no tenerlo, lo cual hay que elogiar, pues esto excluye todo límite perjudicial y toda estrechez, todo prejuicio equívoco"

Discurso del Sr. Roberto Giusti [completo]

¿Es ésta, señores, fiesta de natalicio o de resurrección?

¡Rara cosa Nosotros! Parecía muerta y bien muerta — ¿quién lo hubiera dudado? - y no estaba más que alertada. Durmió un largo invierno - puramente metafórico, porque para invierno fue demasiado tiempo- y despertó a nueva vida más sana y fuerte que nunca. Confieso, sin embargo, que vacilo sobre si lo sucedido fue un fenómeno natural, inherente en estas tierras a todas las publicaciones literarias, o un milagro hecho y derecho. Y pensándolo mejor, me inclino al milagro. Sí, hubo muerte y resurrección, ni más ni menos. Me permitiréis que os nombre al Cristo de este Lázaro: fue un hombre modesto y laborioso, amante de las letras; es mi viejo amigo Francisco Albasio. Agregaré también, para poner todas las cosas en su punto, que quien le movió a resucitar al muerto fue Alfredo Bianchi, cuya infatigable dedicación a la revista, celebré ya en una circunstancia semejante a la actual, como acaso algunos recordaréis.

La reconocisteis en el acto: os lo agradezco en su nombre. ¡Qué amigable, qué benévola fue la acogida que le dispensasteis! No me extraña: Nosotros había sido una buena compañera de todos, y con todos tuvo siempre la misma afectuosa vinculación. A veces habló mal de alguno; es su costumbre y no sé si decir su mejor cualidad. Los malsines cuando no ponen venenosa hiel ni pasión personal en sus palabras, son tan interesantes! Y tan útiles, para sacudir el fastidio, allí donde se ha establecido la uniformidad monótona del mutuo elogio, blando e insincero!... Excusa a Nosotros además, la fatalidad de su maledicencia. ¡Si es muy capaz de hablar mal hasta de sus mismos padres!

Pero para alegoría me parece que sobra. Dejemos el cómo y el porqué se produjo la resurrección y pasemos a lo importante, a cómo conviene vivir la nueva existencia.

No esperéis de mi que os reproduzca los inevitables denuestos contra el ambiente apegado a lo material, desviado de lo espiritual. Es un hecho social que tiene sus causas y que no hemos de corregir aquí entre dos platos, aunque nos enojemos ante el regocijado champaña. Más tarde, mañana si queréis, habrá llegado el caso de trabajar por la eclosión de la flor del espíritu en estos campos entregados a la agricultura. El esfuerzo, lo sabéis, ha de ser conjunto para que dé resultado: yo os ofrezco a Nosotros como muy útil instrumento de remoción. Bien empleado, os aseguro que surtiría efecto...

Una revista joven, amigos, abierta a todos, en la cual la dirección conserva la más estricta neutralidad acerca de lo que en ella se piensa y se dice, por quienes saben pensar y decir ¿no creéis que es un factor de cultura envidiado y anhelado en muchas partes?

¡Sacudamos, eso sí, la pereza que nos hace rehuir la labor; el temor de que el esfuerzo resulta estéril; la vanidad de no querer colaborar en la obra común, con trabajadores más humildes!

Os repetiré a este propósito el anhelo que formulé con motivo de la reaparición de la revista: "Nuestra aspiración no es la de dormir gloriosamente en las bibliotecas del futuro; es la de vivir, y muy despiertos, la vida del día, con todos sus afanes, sus contratiempos, sus satisfacciones morales. Y especialmente, vivir con entusiasmo. Que sea Nosotros una revista ágil, briosa, juvenil, en que se den y reciban golpes si es necesario, pero cuyas páginas vivan al menos... ¿Será posible? Ello no depende sino a medias de sus directores; que digan su palabra ahora los que aquí piensan y escriben". 
Pero advierto que para trazarnos severos planes de campaña no es la más apropiada ocasión la presente, en que sobre el pensamiento prepondera la emoción. Abandonémonos a ésta, pues! Que habla mi corazón y diga cómo lo han tocado las buenas y bellas palabras de aliento que acaba de pronunciar Alberto Gerchunoff; que declare su reconocimiento vivísimo por la fraternal presencia entre nosotros del director de la revista, compañera en la brega, la laboriosa Renacimiento, cuyo ininterrumpido progreso ha de darnos La Revue argentina; que diga por fin, cuán grata la es la cordial simpatía que todos os habéis apresurado a manifestar por nuestra obra humildísima.

Y para concluir, os pido que me acompañéis en levantar la copa a la salud de un maestro mío, el ilustre poeta Rafael Obligado, que ha querido traernos el saludo de aquella brillante generación que entre el 80 y el 90 honró para siempre las letras argentinas" pp. 252-254

Transcribimos algunos pasajes del discurso del nuevo editor, F. Albasio.

“(...) pero puedo asegurar que en sostenerla estamos empeñados los que la queremos, los que en su éxito tenemos comprometido nuestro amor propio, los que anhelamos mantenerla como la representación genuina, como la interpretación palpitante de lo que se agita en el cerebro hispanoamericano; alto exponente de cultura, palestra de toda pluma, órgano de difusión de enseñanza, y sobre todo, obra patriótica sincera."p. 255

Sostiene, como es obvio, que las dificultades que afronta la revista son de orden financiero, y cuenta que todos los colaboradores -algunos de ellos quejándose- debían pagar el monto de la suscripción.

Más adelante: "Hoy por hoy, no está demás repetirlo, es una quimera pretender una utilidad, ni siquiera irrisoria, sobre una publicación como la nuestra, confeccionada materialmente a todo costo, y esto es lo principal, sin recurrir a la réclame que es la piedra de base de todas ellas. (...) pero espero que nunca se verá en la nuestra ningún aviso recomendando al consumo cualquier excelente aceite de oliva, frente por frente a alguna sesuda disquisición pragmática de Alberini, por ejemplo, como les pasa a acreditadas revistas del viejo mundo." p. 256 [como veremos, la revista incluirá más adelante Luego: “(...) a Nosotros le toca el mérito de haber rasgado las tiniebla de la indiferencia pública, desafiándola, al luchar por elevar el espíritu en poco más allá de los cálculos ganaderos, por hacer palpitar con más fuerza el sentimiento de que la grandeza material de un pueblo está en relación directa de su grandeza moral, de la entereza de su personalidad, de su grado de instrucción, de la amplitud de sus miras intelectuales, de la solidez de su criterio" p. 256.

Notas y comentarios pp. 257-260

"Jean Jaurés"

Un acontecimiento: Jaurés está en Buenos Aires. El gran orador se presentó ente Buenos Aires, tal como lo habíamos imaginado: simple, ingenuo, ardoroso de fe. Le admiramos por su talento y nos complace ver cómo el más ilustre de los apóstoles de la reforma permanece íntegro en sus afirmaciones, sin variar en su conducta. Es el gran combatiente de siempre, el infatigable propagandista de un ideal.” p. 257. aparece como pensador prestigioso y como profeta.

-Renacimiento: revista dirigida por Florencio César González y Juan Más y Pí. Aparición: julio de 1909. Primero mensual, luego quincenal. Se hace referencia a su segundo aniversario.

-Comidas literarias

Homenaje a Ferruccio Garavaglia por sus ex alumnos del conservatorio Labardén, que consistió en la representación de El alcalde de Zalamea, y una cena el Aue's Keller por el actor Nicolás J. Grosso.

-Miecio Horzowski: se desmiente un rumor sobre su posible locura.

-Mariano Antonio Barrenechea

Cronista musical de La Nación parte hacia Europa específicamente a Bayreuth "meca obligada del culto wagneriano" p. 260.

-Mundial

Se consigna el envío del número 4 de la revista Mundial de Rubén Darío -editada en París-, por parte de sus representantes en Argentina, García y Dasso.

Año V, Tomo VI, nº 33, octubre, 1911 
-La obra literaria de Rafael Obligado

Gregorio Uriarte pp. 261-277 [La crítica es importante porque puede leerse en relación con la el problema del nacionalismo en Nosotros ya que lee en la obra de Obligado un versión de literatura nacional en lengua culta que no se opone al cosmopolitismo]

-Poesías. Rafael Antonio Arrieta pp. 278-282

-Breve elogio de Buenos Aires José María Salaverría pp. 283-287

-Los que quieren irse "de esta estrella" Amado Nervo pp. 288- 290 [del libro Filosofando de próxima aparición]

-El teatro de Ibsen ante el público latino Luis de Villalobos pp. 291-292 [dedicado a David Peña]

-Almas gemelas. Raúl F. Oyhanarte pp. 293-295

-Dos poetas. Roberto Giusti pp. 296-312 [sobre Banchs y Barreda]

-Sonetos. Alvaro Melián Lafinur pp. 313-314 [dedicados a Hugo Achával]

-Decadencia de la mentira. Una protesta. Oscar Wilde pp. 315-325 [traducido por Luisa S. de Barreda]

-Bellas Artes. José Ojeda pp. 326-329 LEER

-Teatro Nacional Nicolás Barros pp. 330-335

-Crónica musical. Conciertos. .Miguel Mastrogianni pp. 336-338

-Notas y comentarios .pp. 339-340

Teatro Nacional, por Nicolás Barros

Nacional Norte: Las soñadoras comedia entres actos de Felipe Sassone -peruano

Apolo: a propósito de Tucumán

Nacional: Pájaros de presa, sainete en tres actos de Carlos M. Pacheco

Nuevo: El Otro, drama en dos cuadros de Otto Miguel Cione

Nacional Norte: Las soñadoras comedia entres actos de Felipe Sassone -peruano

Del autor se dice que "se ha incorporado desde un tiempo a esta parte a la bohemia de nuestros teatros criollos" p. 332.

Más allá de ser una obra que carece de originalidad en el tema -[todas las escenas remiten o hacen pensar en otras ya vistas-, está bien escrita: "escrita en un castellano que sin pecar de regionalismo, concilia las expresiones puras con la necesidad ineludible del recitado destinado a los cómicos criollos. (...) es, pues, la obra de un hombre culto, inteligente, vivaz, pero no- y este es mi pero fundamental- la producción de un autor muy celoso de su individualidad literaria" pp. 330-331. La obra ha tenido éxito como obra de entretenimiento.

El apartado siguiente se inicia con una diatriba en contra del mercantilismo como marca dominante de la producción teatral: "Si solo de gente idealista viviera nuestro teatro nacional, la frecuente mala ortografía de los autores quedaría compensada con su intención honesta. Habría en suma un aliento para los que piensan y escriben, persiguiendo -dentro de la relatividad de sus fuerzas- un ideal de arte o de cultura.

Pero es el caso que ahora como antes, el mercantilismo de las empresas -y lo que es más grave aún- el mercantilismo de los pseudoautores, va convirtiendo el teatro nuestro en modus vivendi, vulgar y fácil, para los que se hallan vinculados por alguna circunstancia personal a las empresas.

Se da el caso en nuestro incipiente ambiente teatral criollo, de que un 'director artístico', válido de su posición de tal, estrene con facilidad asombrosa cuanta obra indigna de un escenario le inspira el afán de percibir emolumentos extraordinarios; se da el caso de los secretarios teatrales que incapaces de escribir siquiera sea con gramática, hacen representar bajo su firma y percibiendo por mitades los derechos, piezas de autores desconocidos, de esos que sin tenerse suficiente fe, consienten en cualquier humillación, para llegar al momento soñado del estreno; se da, en fin, el caso de empleados administrativos de teatro que ejerciendo una especie de superintendencia literaria (sic), aceptan y rechazan obras con una puntual y meticulosa ignorancia, para dar lugar a la representación de la producción propia, inspirada no en esas ambiciones -a veces descabelladas- de los jóvenes soñadores, sino en una idea más burguesa y positiva de la vida: la eterna razón del estómago" pp. 331-332

Más adelante interpela a la crítica y al público: "Es tiempo de que el público reaccione y analice antes de aplaudir, y es tiempo de que la crítica periodística cumpla con su verdadera misión de control [cursivas nuestras], no prolongando por más tiempo esa suavidad desesperante que es su sistema y que 
a pretexto de alentar la producción meritoria, se complica con sus consideraciones o con su silencio, en cuanto pecado artístico cumple la mediocridad y el mercantilismo que monopoliza el cartel de los teatros criollos" p. 332

El resto de la nota está dedicado a denostar a Carlos M. Pacheco y al género que representa: "En el señor Pacheco, sainetero, hay algo. No sabemos qué, pero podríamos rotundamente afirmar que hay algo. Y si no, ¿cómo hubiera llegado el señor Pacheco a tanta notoriedad dentro de nuestros círculos teatrales criollos?

(...)

El señor Pacheco no ha hecho muchos sainetes; ha hecho uno que con modificaciones de forma le ha servido para hacerse una plataforma de producción que, según todas las apariencias, le tiene francamente orgulloso. (...)

Pájaros de presa, es una reproducción de sus obras anteriores, y un paso -por fortuna poco feliz- en los progresos del sainetismo que ha enfermado nuestra producción teatral.

La obra, sin desagradar de una manera ruidosa, no gusta al público. Los tipos de efecto seguro con que este autor cuenta para sus éxitos, a fuerza de repetidos no llegan a satisfacer de manera plena. El 'cocoliche' -que tan significativos triunfos personales le ha proporcionado al autor- no llena ya las exigencias del público. Este pide algo nuevo, algo que el señor Pacheco no podrá darle con sus conocidos procedimientos.

Se ve, sin embargo, en el autor de Pájaros de presa, el propósito de hacer más honestos sus medios escénicos, y de refinar su técnica (dicen por ahí que el señor Pacheco habla a menudo de 'su técnica'). El final de la nueva pieza, parece insinuarlo, al omitir el infaltable pugilato rojo, y sustituirlo por una escena de comedia, afrontando la frialdad del público.

También es una muestra de este propósito el hecho de que el señor Pacheco no utilice en su obra esa filosofía 'trascendentaloide' con que expresó antes sus reflexiones personales, en presencia de las situaciones por él mismo creadas" p. 333

Cuando Barros se ocupa de la obra Cione El otro la considera, por su falta de técnica y por la mala interpretación, un "nuevo error teatral que deberá lamentar el autor de El arlequín". p. 335.

Notas y comentarios pp. 339-340

-Viajeros

Se consignan los regresos de Rogelio Irurtia y Roberto Payró, en primer término, y luego el de Manuel Gálvez y su esposa Delfina Bunge.

Partirán el 17 de octubre José Ingenieros y José André.

-Las conferencias del profesor Martinenche (erudito hispanista profesor de la Sorbona), realizadas en la Facultad de Filosofía y Letras

-Acertado nombramiento

Se refiere al nombramiento de Marcos M. Blanco Caprile -colaborador de la revista- como jefe de redacción de la Revista de Educación de la Provincia.

Advertencias

Piden disculpas y explican el hecho de que la revista se haya impreso con un papel de calidad inferior. Fe erratas. Por falta de espacio el comentario de libros y folletos pasa al número siguiente.

\section{Año V, Tomo VI, $n^{\circ}$ 34, noviembre, 1911}

Recuerdos de Wiesbaden. Ernesto Quesada, pp. 314-351 [las cartas son de 1906, pero en argentina no habían sido publicadas]

El canto de las horas...............José Fabio Garnier [costarricense, sobre la obra El canto de las horas de Roberto Menes Breséns]

Fuego Fatuo. Drama en un acto y en prosa ................. Enrique García Velloso, pp. 357-380

Poesías....... Luis María Jordán [del libro próximo a aparecer Las canciones de la noche]; Manuel Lizondo Borda pp. 381-385

La obra de Florencio Sánchez............. Joaquín de Vedia, pp. 386-393.

Régimen Municipal de la Ciudad de Buenos Aires, por José María Sáenz Valiente.......... A. Beccar Varela pp. 394-397 [se trata de una tesis universitaria de la facultad de Derecho]

Párrafos a un joven filósofo. Jorge Walter Perkins [dedicado a X. X...] pp. 398-399 
Sonetos.............Edmundo Montagne ["Atardecer urbano", "Silencio", “A esa ternura extraña”], D. A. Robatto ["Tierras incultas"] pp. 400-402.

Apreciaciones musicales............ Oscar Spinetto pp. 403-406

Bibliografía............ Julio Noé, Alfonso de Laferrere y X pp. 407-416

La demostración a Roberto J. Payró...........Nosotros pp. 417-419

Notas y comentarios. p. 420.

Fuego Fatuo. Drama en un acto y en prosa , por Enrique García Velloso, pp. 357-380

La obra fue premiada en el concurso del teatro Nacional de 1906. En ese sentido es interesante observar que el gesto de la revista en publicar supone una selección que va más allá de la mera actualidad teatral. Los personajes son: Eloisa, Lucero, Gloria, Argüello, Álvaro, Juana, La Chena, Perosca, Félix y Anselmo. La obra trata de un artista (Lucero) a quien su mujer -Eloisa, que ha renunciado a un mejor pasar por estar con él- no comprende. Lucero es el artista que se niega a seguir los imperativos del mercado. Argüello es un amigo que también es artista y a su regreso de Europa decide dedicarse a la industria agropecuaria. Argüello dice: "Basta de talleres artísticos, donde no se realiza, ni la existencia ni el ideal...Basta de estos antros donde la voluntad se pudre y donde no sale más que el fuego fatuo que brilla instantáneamente... En esta lucha de egoísmos que forman la vida moderna, solo triunfa la fuerza. (...) allá afuera... en la Pampa.... el carácter vuela... A la Pampa... sí.... que esa es la ubre..." p. 377 Y luego prosigue: "Vive [nuestro pueblo], se ensancha... se hace fuerte sin exigir a sus hijos un arte que vendrá... que viene... pero no por estos vericuetos de bohemia inmunda... El arte es Sorolla... pintando al salir el sol en la ribera valenciana, el arte es Zola, engulléndose el famosos sapo de todas las mañanas; el arte es la fuerza de la naturaleza y lo mismo surge aquí y se llama Sarmiento (...) y se llama Ibsen” p. 378.

-La obra de Florencio Sánchez, por Joaquín de Vedia, pp. 386-393

Es el discurso que pronuncia de Vedia en el homenaje que le tributa a Florencio Sánchez la compañía teatral de Pablo Podestá, con motivo del primer año del fallecimiento del autor. En nota, la dirección aclara: "Nosotros, que considera uno de sus más legítimos títulos de honor el haber estado siempre al lado de Sánchez, en la amistad y en la admiración, entrega ahora a sus lectores este nuevo trabajo crítico sobre aquel inolvidable creador, como un elemento más para el juicio definitivo y para recuerdo de la triste fecha" p. 386.

El escrito es importante porque es una versión sobre el teatro nacional que la revista confirma en la parte de la nota que transcribimos antes [cf. supra]. Extractamos sus pasajes más significativos:

"Dios me libre de incurrir en reproches, sin autoridad en mis labios, y amén de injustos, pueriles, a los que siguiendo la indicación de sus gustos o siquiera las corrientes del snobismo, cultivan entre nosotros plantas literarias exóticas, según varios, muy capaces de repetir, a renglón seguido de esta clasificación agresiva, aquello de que el arte no tiene patria. Sin embargo, considero plausible, benéfica, la denunciada limitación de medios del teatro local, que le obliga a circunscribir al campo de los estrictamente nativo los dominios de su observación y el alcance de sus tendencias. si por algo resulta chocante el adjetivo que lo persigue, es porque un teatro, al nacer o morir, es nacional por definición. La escena, humana ante todo, vive de la semejanza entre el hombre que en ella está y el hombre que enfrente de ella escucha y mira, y tanto más corta sea, vale decir, tanto más nacional será la distancia que media entre esos dos hombres tanto más grande será la eficacia artística y social de aquélla. No hay teatros universales. Fuera del mundo de los eruditos y del internacional intelectualismo, los pueblos ignoran recíproca y escrupulosamente, las obras maestras de sus autores dramáticos.(...)

Nace éste [el teatro argentino] con Juan Moreira, pantomima primero, alternada con diálogos después y convertida por último en drama; es un poco el proceso del formación de lo que ha venido a llamarse en Francia la ópera cómica. Su escenario es en un comienzo la pista del circo, que se complica más tarde con un escenario verdadero. Es original y bárbaro, aquel producto de la ciudad que vive en íntimo consorcio con la vida y las costumbres del campo, pero es tan propio del medio, que nadie, aún en las clases sociales que ya empiezan a sacudir sus vínculos tradicionales y a vivir en la nación fuera de la nación; nadie, ni los remilgados, ni los que dan principio a la tarabilla parisién, dejan de ir a verlo, y no una, sino muchas veces. Muy pronto, la ciudad, multiplicados sus elementos 
de comunicación con el exterior, al tiempo que se aflojan los vínculos con el interior, relega aquel teatro al público constituido por factores ajenos al interés que congrega a los favorecidos del rango y la fortuna en esas salas donde grandes actrices y actores extranjeros evocan, con lo precipitado y desmantelado de sus representaciones, reminiscencias de la misa en el campamento. Esa abandonada escena criolla quiere seguir la transformación, rompe para siempre con la pista, su cuna, y renunciando a su nombre de bautismo, se hace llamar nacional. Al perder su personalidad, sufre la crisis determinada por las nuevas orientaciones generales, cae en la imitación servil, imitación de la barbarie originaria por un lado, imitación del populacherismo de la zarzuela española por otro, imitación, en fin, de las pretensiones filosofistas de cierto drama moderno. La retahíla inagotable de las metáforas gauchas, el accidental 'cocoliche', y el episódico 'lunfardo, proveen su lenguaje, sus asuntos o sus caracteres, y cuando sale de ahí, es para caer en tal lecho de lirios y crisantemos de contrabando que se envenena el aire de las salas miserablemente sórdidas. Todo es falso, el gringo y el compadre, el paisano inculto y el pueblero hipócrita y cruel.

Entonces aparece Florencio Sánchez, que tiene el instinto, una genial preciencia del teatro, y, sin volver al punto de partida, porque ya no es necesario, trae a la escena, con la misma ingenua sinceridad que dio vigor al primitivo género criollo, los hombres del país, con los cuales ha vivido y ha peleado también, y hace esa serie de dramas y comedias, como Barranca Abajo, como La gringa, rápidos en la forma que los sintetiza, lentos en el fondo que desarrollan, donde el estallido solo viene con el hartazgo del sufrimiento, donde la lucha no es tumultuosa, donde no hay abismos, sino declives, donde se siente la monótona tranquilidad de la naturaleza, donde el amor o el odio hacen pausadamente su camino a través de largas distancias, el teatro de la pampa argentina y de las cuchillas uruguayas, que saltando sobre el gaucho del folletín va a buscarlo en la leyenda para unirlo con su última realidad viviente en tipos tan bellos, tan nobles, tan consoladores, como don Zoilo, don Cantalicio, o el viejo de M'hijo el dotor. Así como encuentra un público que, a pesar de su cosmopolitismo, le comprenda, le estimule, le aplauda, encuentra actores que le interpreten. Hay teatro, donde el intérprete se siente ancho en su papel, y donde el pueblo ve reflejarse las costumbres, el temperamento, el espíritu de la raza.(...) Dentro de la campaña misma , realiza la conjunción de ese crepúsculo con la nueva aurora, y entre don Nicola el colono y don Cantalicio el criollo despojado, que plantean el conflicto, está Próspero, el tipo joven en quien se suma el esfuerzo positivo del trabajo y el idealismo altanero de la aventura; y entre el paisano don Zoilo y el pueblero Juan Luis, está el pobre Aniceto, que desaparece, más apto y más libre que aquél, mejor y más bueno que éste, con rumbo a quién sabe qué desquites o venganzas. $\mathrm{Y}$ no se crea tampoco que es unilateralmente campesina la visión del autor: así como supo ver y sobre todo sentir ese aspecto principalísimo de la existencia nacional, supo considerar y comprender, en sus calles en sus casas, en sus tugurios, en las salas de los palacios y en los patios de los conventillos, en las guaridas del crimen y en el honesto hogar obrero, en todas sus fases, la metrópoli frenética de opulencia y miseria, de ansias y dolores, de virtud y vicio." pp. 387-390.

Sánchez es un "iniciador" p. 390

Apreciaciones musicales, Oscar Spinetto pp. 403-406

A propósito de las obras de los rusos Sibelius, Rimsky-Korsakow y Borodin, interpretadas en los conciertos de Pallemaerts, establece la necesidad de un arte argentino: "Queremos un Arte Argentino, con mayúscula se entiende, y para eso hay que comenzar con minúscula. No tenemos fe en los becados en el extranjero -el verdadero artista se cría e su suelo nativo. Panizza ha vuelto disfrazado de Puccini y eso es lo pero que le podía haber sucedido. Nuestro pintores vuelven con imitaciones de Monet, Manet, Whistler y Cía.. Nuestros jóvenes poetas se perfuman con esencias extraídas de Las flores del mal o reflejan las sensaciones que han recibido de literaturas extranjeras. Solo se considera arte nacional drama compadre y al tango. Tienen éstos también interés y aún cierta belleza, pero es una faz de la joya que tiene millares" p. 404. Ve en Joaquín V. González -cuya obra Mis Montañas cita en el final del artículo- una fuente de inspiración patria.

Bibliografía, por Julio Noé, Alfonso de Laferrére y X pp. 407-420

-Divertidas aventuras del nieto de Juan Moreira, de Roberto J. Payró por Julio Noé pp. 407-410

Transcribimos la nota completa. 
"Este libro es toda la historia argentina desde el año 53 hasta la fecha. Su acción comienza con la organización definitiva del país y acaso concluye en nuestros días.

Suponiendo que fuera exclusivamente una novela, si debiera yo indicar una palabra que significara su género, me vería en difícil trance. Las expresiones suponen siempre un concepto anterior más o menos definido y necesario de calificar, a fin de no confundir sus más insignificantes características. Todo apelativo que apliquéis a este libro no alcanzará a caracterizarlo. Es algo más que una novela de costumbres, mucho más que un relato entretenido, muy otra cosa que una novela psicológica: es una novela 'argentina'. Argentina por la trama, por los personajes, por el ambiente y hasta por el idioma. Todo en ella huele a nuestro [en cursiva en el original], desde Juan Moreira, el abuelo legendario que recuerda el título del libro, hasta la más inadvertida acción de sus nietos; todo en ella lo reconocemos, todo nos es familiar: es nuestra historia.

En esto consiste el primer mérito de Roberto Payró. El ha creado nuestra novela, puesto que no pueden reputarse tal los ensayos anteriores, más o menos afortunados, que si iniciaron la tendencia, no acentuaron sus características. Los precursores, entre los cuales hay nombres de verdadero mérito, habían observado bien, pero fragmentariamente. la situación del hombre, frente a la inmensidad del territorio que le había dado las cualidades y los defectos más fundamentales, dio, desde un principio, base y motivo a sendas descripciones. El gaucho, soñador y altivo, pendenciero o rebelde, fue un primer instante, el elemento único sobre el que se hizo literatura nacional. De aquí que, con este falso concepto, más de uno renegó de ella, prefiriendo superficiales imitaciones sin valor y sin vida.

Sin embargo, el ambiente sufría modificaciones. Junto a la campaña estaba la pequeña población, donde se respetaba la propiedad y la justicia, donde existía una autoridad constituida y un vínculo social. Este núcleo y esta gente ofrecía mayor campo de observación que la vida errante del gaucho, sujeto a su cabalgadura y sin principio moral alguno. Pero por ser aquél de más fácil análisis, fue tenido en segundo lugar por los escritores que iniciaron la tendencia de nacionalización. Era ese pequeño núcleo, empero, el que constituiría el espíritu nacional.

Sus habitantes tenían en común con el gaucho andariego, la virtud del coraje y la puntiaguda [sic] susceptibilidad. No eran Juan Moreira, sino sus parientes que debieron, desde luego, tener otro escenario para sus hazañas.

Frente a la campaña larga y vacía también estaba Buenos Aires, demasiado importante y seductora. Por ella entraba la civilización europea, en ella comenzaba a transformase el espíritu criollo y era ella quien dirigía los destinos del inmenso territorio. Esta diversidad fundamental dentro de los mismos límites nacionales, este antagonismo entre los catorce estados que la constitución declara independientes y la ciudad máxima, motivó una época fuera de duda más interesante que dio nacimiento a la revolución misma.

Aquella época es la que ha elegido Payró para su obra: es éste su segundo acierto. Fue en ella que nuestro espíritu se ha perfilado en las líneas inconfundibles sin que más tarde se ofrecieran variantes trascendentales. Es desde entonces que el criollo se ha dado a la política, la cual vocación, de puro vivaracho, sentíala de nacimiento y que cultivó siempre como el más agradable de los sports, ante el cual fracasaban todos los humanismos y todas las democracias.

Mauricio Gómez Herrera, el protagonista del libro de Payró, es una figura tan representativa de nuestro medio, como Don Quijote lo es en todo el universo. Su actuación en su provincia y en Buenos Aires nos sugiere mucho más que el mejor comentario constitucional. Es el propio ideal del criollo muy cuidadoso de su reputación, incapaz de fechorías indignas, pero cuya moral no se ofende ante el 'negocio' que denota su diablura y su 'savoir vivre'. Todos le reconocemos y seríamos capaces de sustituir su nombre por muchos otros bien conocidos, pero nadie hasta ahora nos lo había presentado con tanta crudeza como Roberto Payró. Tiene tres aspiraciones que le obseden de continuo: hacerse rico, ser diputado y por lo tanto figurar y hundir a su enemigo que milita en la oposición. El arrivismo es su credo, la venganza su entretenimiento. Conoce la escasez de su ingenio, pero esto no le inquieta. ¡Acaso sea su primera virtud! En las cuestiones privadas, varias seducciones y algunos engaños, le darán mayor prestigio; además, algún duelo le consagrará su arrojo, sin el cual inútil le sería toda tentativa por ser 'algo'.

Payró se ha ensañado con este personaje. Nos lo ha presentado en todos los momentos de su existencia, desde su infancia turbulenta y rebelde, hasta la plenipotencia en el extranjero. No ha omitido tampoco el juicio que Mauricio Rivas -su hijo natural- hubo de escribir sobre su padre desconocido. la página es concluyente, y no resisto a la tentación de reproducirla: 


\section{Divertidas aventuras del nieto de Juan Moreira}

'Tan importante y tan dominador como el abuelo, nació en un rincón de provincia, y creció en él sin aprender otra cosa que el amor de su persona y la adoración de sus propios vicios. Nunca entendió ni aceptó cosa alguna de ley, sino cuando le convino para sus intereses y sus pasiones. Es la síntesis de la respetable generación que nos gobierna; y media sociedad, si se viera en el espejo, se diría cuando pasa: 'Yo soy ése'. Tuvo de su abuelo el atavismo al revés, y así como aquél peleó contra la partida, muchas veces sin razón, éste pelea siempre sin razón con la partida, contra todo lo demás. Suprime sin ruido, hasta gobernadores, como el otro 'compadremente', facón en mano... Heredó de su padre el caudillaje, y vistiendo la ropa del civilizado, fue, desde criatura, la esencia del gaucho y del compadrito, despojado con el chiripá y el poncho de todas las que pudieran parecer virtudes, conservando solo cierto valor personal y un desprendimiento que no es sino la jactancia del ente que se cree superior, y que se ensoberbece más cuanto más grandes son las personas a quienes pueda o trate de humillar'.

El nieto de Juan Moreira había descripto sin quererlo la figura de su padre: Payró tampoco ha olvidado el simbolismo de este juicio.

Los demás personajes de la novela son menos interesantes. ¿Qué decir del gobernador Camino, qué del gobernador Correa, de los Rivas, de De la Espada?

Este libro es demasiado amargo, demasiado cruel, pero muy nuestro. La obra en sí, es la más representativa de su escuela. Payró ha demostrado ser el mejor y más vigoroso costumbristas de Sud América: Pago Chico le anunció, y este libro le consagra. El nos indica la tendencia que debe seguirse y el ejemplo que debe imitarse: Mauricio Gómez Herrera no es el único tipo curioso que vive en estas tierras. Otros muy ilustres personajes han tenido descendencia en la República. Conocidos todos y representados como este buen nieto de Juan Moreira, servirán estos libros de inmejorables documentos para escribir la historia nacional. Al fin, ya es algo...” pp. 407-410.

-Páginas argentinas de Martiniano Leguizamón, por Julio Noé

"La campaña iniciada hace ya varios años a favor del nacionalismo literario, ha tenido en Martiniano Leguizamón el más constante y convencido de sus defensores. Si la semilla no ha fructificado como era deseable esperar, no es culpa de quienes la ofrecieron. París sigue siendo para los escritores americanos la Meca de sus mejores sueños, y los volúmenes a 3,50 francos la fuente de sus inspiraciones y sabidurías. No es este el momento de señalar las causas del 'francesismo' literario de Hispano-América -sobre le que volveremos algún día- pero es ciertamente doloroso que nos hayamos esclavizado a sus preciosuras y a sus juegos de artificio. Por fortuna, la ansiada reacción ha comenzado, y ella nos promete los mejores resultados, a pesar de la insistencia enfermiza con que muchos de nuestros escritores, nacidos en la última aldea provinciana, lloran su Versalles y su duquesita de blanca peluca.

Contra esta tendencia ha luchado siempre Martiniano Leguizamón. Escritor de sangre y por vocación, ha sentido la belleza seductora de su tierra nativa, ha admirado el gesto del hombre argentino perdido en la inmensidad de su territorio interminable, ha palpitado ente la epopeya organizadora y constituyente, y ha lamentado a la vaga y dolorosa vidalita que luego se trocaría en canto de esperanza.

Su predicación idealista no es menos estimable. su ansia por la literatura verdaderamente argentina, le llevó a veces al elogio de obras medianas, pero 'olientes a patria'. 'El éxito de toda profesión de fe -ha escrito- depende de la constancia de su reiteración, por el comentario que renueva y por los nuevos adeptos que conquista'

Siente que el cosmopolitismo invasor nos está llevando todo y se dice con angustia: 'es urgente salvarlo antes de que desaparezca para siempre'. El mismo deseo, la misma aspiración hubo de manifestarla anteriormente en su libro De cepa criolla, y Páginas Argentinas en su misma fragmentariedad, es un credo que nuestros escritores jóvenes no deberían desoír.

Al fin y al cabo, Leguizamón completa la obra que iniciara Sarmiento, que continuaran Gutiérrez, González, Groussac, Obligado, y que Ricardo Rojas propiciara últimamente en dos libros de envidiable fortuna.

Cuando en nuestros colegios y facultades se enseñe a las generaciones nuevas el valor de nuestra escasa literatura, cuando se estimule el amor por nuestras cosas y se haga conocer la fuente 
inagotable de sano esteticismo que ellas contienen, la obra de Martiniano Leguizamón será considerada en toda la importancia que actualmente no se alcanza a reconocer.

Entretanto, esperemos que el autor de Calandria y Alma nativa no desmaye en sus entusiasmos. Ellos nos llevarán a la buena época que los actuales momentos parecen augurar" pp. $410-411$

-Mis filosofias de Amado Nervo, por Julio Noé

- Primavera de Luciano González Calderón, por Alfonso de Laferrére

- La hora primaveral de Segundo Moreno, Por Alfonso de Laferrére. El crítico constata la abundancia de poetas den Buenos Aires, cantidad que es inversamente proporcional a la calidad de las obras producidas. El libro es sobre todo un esfuerzo retórico.

-El libro de las incoherencias de Abraham Z. Lopez Penha, por Alfonso de Laferrére

-Horas fugaces de Felipe Valderrama, por Alfonso de Laferrére. El autor es mencionado como director de Mes literario de Venezuela. Valderrama publica en ella sus poemas Horas fugaces.

-Urquiza. Su vida, su personalidad y su obra de Juan A. González Calderón y Florencio C. González, por X

Se trata de dos monografías prologadas por Benjamín Victorica.

- La caridad en Buenos Aires de Alberto Meyer Arana, por X.

Se trata de dos volúmenes en los que se reúnen "noticias" de distinta procedencia a partir de las cuales se muestra lo que han hecho en Buenos Aires "el estado" y "las clases pudientes en pro de los desheredados y los enfermos"

La demostración a Roberto J. Payró

El 21 de octubre un grupo de "escritores, artistas y periodistas" festejan el regreso a la Argentina de Payró. Organizan el evento Nosotros y Renacimiento. Martiniano Leguizamón es el encargado del discurso, en el que "sostuvo con valiente decisión el ideal literario americanista" p. 417. También habló Charles de Soussens.

Asistentes: Martiniano Leguizamón, José Murature, Eduardo Talero, Luis Mitre, Ernesto Mario Barreda, Enrique Hurtado y Arias, Manuel Gálvez (hijo), Jorge A. Mitre, Alfredo C. Torcelli, José Pardo, Florencio César González, Alfredo Bianchi, Ignacio Orzali, Ricardo Rojas, Roberto Giusti, Enrique García Velloso, Alfredo B. Palacios, Atilio M. Chiappori, M. Martínez Castro, Nicolás J. Grosso, D. González Ramírez, A. Abeledo, Mario Bravo, Alfredo C. López, Julio Rinaldini, Marcos M. Blanco, Joaquín de Vedia, José Ojeda, Jorge Drago Mitre, Pedro Angelici, Pedro E. Pico, Emilio Becher, Fernando Peña, Carlos de Soussens.

-Discurso de Martiniano Leguizamón

Transcribimos algunos de los pasajes centrales.

"Para sus hermanos en letras, para sus compañeros de común ilusión y entusiasmo, y ¿por qué no decirlo? De comunes triunfos también, - si triunfos fueron aunque modestos los de nuestro gremio, - esta fiesta no es de agasajo trivial, sino de confirmación del credo espiritualista de los escritores que piensan como Roberto Payró, que es una noble tarea el cultivar los veneros de belleza y emoción que nos brindan los asuntos de la tierra.

De los que piensan y demuestran, que esa es la "escondida senda" que los artistas argentinos debieran seguir, en vez de esterilizar su inspiración persiguiendo bajo extraños cielos la quimera de interpretar asuntos que no conocen más que a través de la lectura de algunos escritores extranjeros, que no pueden sentir por tanto, ni pintar con verdad, y cuyas producciones llevan oculto el estigma letal de todo lo falso y efímero, porque no son fruto de serena meditación de las cosas vívidas, ni reflejo del ambiente y el paisaje nativo que nos satura el alma con los dulces cariños de la añoranza.

Espíritu de poesía retrógrada, regresiones sentimentales, apegos lugareños, yo sé que contestarán los escritores jóvenes, que persiguen la renovación de la nueva forma estética y de los nuevos ritmos líricos, en la obra de los poetas de la vieja España, en los versos de Berceo, de Góngora y de Quevedo; en el sentimentalismo enfermizo de Verlaine o en las obscuridades simbolistas de Mallarmé y los novadores franceses, sin apercibirse que con esa tarea subalterna de simples imitadores pierden el sello de su personalidad y malogran la frescura virgen de los temas originales que nuestra tierra está brindando al artífice animoso, desde que el autor de "La Cautiva", descubrió los tesoros de armonías emociones líricas que duermen escondidos entre los pajonales de la Pampa; desde que las páginas 
henchidas de sabor y de vida del "Facundo", nos enseñaron el rumbo para rastrear el filón del oro nativo y la substancia nacional. ¿Qué promesas pueden traer para el arte americano, que por su naturaleza no puede ser, no debe ser sino la expresión palpitante y vivaz del mundo virgen, las imitaciones y reflejos ajenos, sin un solo soplo del espíritu territorial, sin un eco de esa vaga flor de leyenda con que cada país ha tejido la urdimbre de su tradición?...

Pero no necesito esforzarme en demostrar lo que es convicción profunda para los que se sientan a la mesa tendida en honor de un escritor argentino, que ha labrado su reputación escribiendo tantas páginas hermosas como médula y sentimiento de la tierra en que inició los donaires de su estilo rico y cambiante, desde las escenas emocionantes del drama a la sonrisa fina y picaresca de la novela de psicología popular, como si hubiera querido responder así al espíritu snobista que desdeña estas cosas del terruño, que serán siempre manantial nutritivo de ensueño y de inspiración para las creaciones del arte..."pp. 418-419

Notas y comentarios

-La enseñanza de la historia en las universidades alemanas. Se comunica que el libro de Quesada ha sido condecorado por el emperador Guillermo con la orden de la corona.

-Advertencias: se aclara que por razones de espacio se dejan para el número siguiente algunos artículos y por lo mismo no aparecen las secciones Bellas Artes y Teatro nacional. Se contesta el reclamo de los poetas cuyas composiciones abundan que se las publicará aunque en el orden en que se reciban.

Año V, Tomo VI, $n^{0} 35$, diciembre, 1911

El ojo maravilloso. Amado Nervo pp. 421-424 [sobre una lente de un observatorio de Pasadena, EEUU]

Pequeño comentario de ideas sobre la pasión.......... Luis Ipiña pp. 425-436

De la ciudad............. Juan Aymercih pp. 437-438

El escudo de armas de Buenos Aires.......... Martiniano Leguizamón pp. 439-441

La decadencia de la mentira. Una protesta (Conclusión)....... Oscar Wilde pp. 442-460

Canciones colectivas, Canciones personales............. Mario Bravo pp. 461-467

El perro.........Juan de Afuera pp. 468-470

El cultivo de la iniciativa individual....................Jorge Leyro Díaz pp. 471-477 [discurso leído en el teatro municipal de San Nicolás para recaudar fondos para los alumnos pobres de la escuela 'complementaria'; propone favorecer y desarrollar la facultad de independencia, útil sobre todo en lo económico y que ve con no demasiado buenos ojos en los extranjeros que han labrado una fortuna y poseen casi todas las "fuentes de riqueza" del país]

Sonetos......... José Lucas Penna, Marcelo F. Manigot pp. 478-479

Bibliografía........ J. L. Ferrarotti, pp. 480-486 [sobre Casos de derecho penal de Carlos O. Bunge, que han sido publicados en La Nación previamente. Interesa porque construye una galería de escritores e intelectuales argentinos: Lugones, Sicardi, R. Rojas, R. Payró, E. Larreta, Ameghino] RELEER

Teatro nacional..............Nicolás Barros, pp. 487-488

Compositores argentinos........ Oscar Spinetto, pp. 489-492

Crónica musical..........Juan Pedro Calou pp. 493-496

Indice del tomo...........pp. 497-500

Teatro nacional..............Nicolás Barros, pp. 487-488

Barros se queja de la crítica periodística: "La propaganda periodística - en su constante empeño informativo- ha inflado un tanto la importancia del concurso organizado por la empresa del teatro Nacional.

A público y periodistas se les ha ocurrido lo que a los fantásticos habitantes de Tarascón que nos describe Daudet; por efecto del 'miraje', todos han llamado concurso, y han asignado valores artísticos, a una mera reclame de la empresa, de cuyas conclusiones no podrá sacarse en consecuencia, ni la pobreza intelectual de nuestros autores inéditos, ni el desinterés de los organizadores. Una persona seria, solo por un error que luego debe forzosamente lamentar, presenta sus obras a estos concursos de verano, organizados en tan precarias condiciones artísticas. 
Errores d esta índole hemos debido presenciar sin embargo, en lo que va de este torneo. Desde luego Resaca es uno de ellos. Su autor, un señor Waisembach, persona desconocida -o casi desconocida hasta ahora en estas veleidades teatrales- ha demostrado poseer, dentro de un discretísimo dominio de los recursos escénicos, una aptitud artística poco vulgar. Sorprende necesariamente, dentro de la vaciedad común en el género, que un autor desconocido sepa ganar público y crítica desde la primera hora, presentando con rigor de lógica, con verdad - maravillosa en ciertos instantes- un tipo de exacta psicología, un tipo vivo y común en nuestro ambiente, que no había sido llevado hasta ahora al teatro" p. 487

Aire de afuera de José Rafes es otra de las obras que se presentan en este concurso, y que pertenece según Barros al género "comedia de hogar que inició Laferrére y que ha continuado Mertens". Otra obra que consigna es La hora del balcón.

Año VI, tomo 7, nº 36, enero, 1912

El crepúsculo de un dios. Anatole France.............. Paul Glassier pp. 5-16 [no se consigna traductor; tal vez no lo haya] CRITICA

En los libros............. Enrique Banchs pp. 17-18

La obra de Payró. Divertidas aventuras del nieto de Juan Moreira.......... Alberto Gerchunoff pp. 19-25 CRITICA

La matanza de los inocentes...........Maurice Maeterlink [se aclara "traducido expresamente para Nosotros, el texto de 1886 y apareció en una "revista de jóvenes" La Pléiade]

Sobre la Psicologia musicale de Mario Pilo............ Alfonso Corti pp. 35-42

La filosofía de los sanos...........Hans Friedrich [Giusti] pp. 43-48.

Día gris (Salvador M. Boucau) El buen camino (Juan Manuel Méndez) pp. 49-50.

La cuestión previa.............uis de Villalobos pp. 50-55 [contra el progreso: "El progreso son las máquinas, es el arte refinado de la simplificación, es el terrible agente de las terribles síntesis, el eliminador por excelencia, pseudofactor de libertad" p. 54-55, contra el utilitarismo]

La enseñanza de la historia en las universidades alemanas..........Coriolano Alberini pp. 56-64 [sobre el libro de Ernesto Quesada]

Bibliografía............pp. 65-73

Notas y comentarios........pp 74-80

-La obra de Payró. Divertidas aventuras del nieto de Juan Moreira, por Alberto Gerchunoff pp. 19-25 La nota es importante porque en ella se afirma la preferencia por la figura de Payró y por su estética realista. Transcribimos algunos pasajes centrales:

"Roberto Payró revela siempre una visión amarga del país. Ciertamente, la amargura no se refleja en su obra sino a través de un tono amable y de un buen humor que es el aspecto de su filosofía, o si se quiere, de su esperanza. Esa dualidad debe buscarse en la formación mis[ma] de su espíritu, que ha influido en su índole de escritor, y en su carácter de novelista: Payró se ha plasmado sobre los modelos clásicos de la literatura española. No importa que desde joven se haya nutrido en mentalidad francesa y se haya penetrado de las concepciones que constituyen hoy el rumbo de todos. Ello le sirve de base. sus escritos contienen el ácido crítico y la doctrina que denuncia a un pensador a quien ocupan los problemas de la sociedad. pero, esa doctrina y esas concepciones son el fondo de la obra cuyo linaje es castellano, a pesar de la orientación de sus hipótesis. Laucha o Gómez Herrera, los figurantes y protagonistas de Pago Chico, reconocen por antecesores ilustres a los héroes de la picaresca. (...) Es [Payró] brote puro de la observación y la crueldad que de ella se deduce es el documento de su verosimilitud.

Visión amarga del país. Payró no construye sus personajes con la preocupación exclusiva del novelista que confina su laboratorio al medio en que se desenvuelve la acción. Laucha es un ser vivo y andante, andante y vivo es Gómez Herrera en la ficción de la autobiografía. Mas éste y aquél asumen a medida que progresa el relato la proporción representativa del estado social que definen con su conducta. la novela pierde así, en su trágico desarrollo, el subterfugio de la fábula y se convierte en la historia de la república" pp. 19-20

Más adelante y en el mismo sentido prosigue: "Es el espíritu, el desenvolvimiento del alma colectiva el que le interesa y conmueve y esto solo puede revelar el cuadro político. De ahí que la novela sea exacta como documentación." p. 21. Gerchunoff sostiene: "El carácter de Gómez Herrera como el de 
su época, se explica, pero no se logrará justificarlo. Payró ha observado la sobriedad que es su índole misma de escritor. Es psicólogo y ahonda el tema con enérgica honradez. Es artista y su arte resulta del conjunto de la verdad, de la belleza viva, e interior, que anima las páginas. Crea almas, construye existencias que distinguimos después den la multitud, que reconocemos en el diario comercio con la gente. A esa virtud primordial, se une la perfección del dibujo: la novela se desenvuelve dentro de la más rigurosa proporción y el análisis denuncia un investigador humano, el panorama revela a un maestro en la novela, el arte literario por excelencia. Y novelas como éstas llenarían con su eco un país de tradición civilizada. Entre nosotros, la vida esta en manos de los Gómez Herrera, que desprecian como su símbolo genuino, a los que pudiendo ocuparse en los oficios productivos y pingües, se dedican a las letras y al cultivo de las cosas espirituales. Ello no ha de impedir que el futuro dignifique la era actual, no por los montos de la riqueza ni por la acción monopolizadora de los mediocres, sino por obras como ésta de Payró, que bastan para hacer respetable la literatura de un pueblo. Sirva eso de magro consuelo al gran escritor.

La nota culmina con una valoración de Payró en la literatura nacional y la defensa de su figura como la de un escritor y periodista esforzado, en un retrato semejante al que traza Zola del escritor moderno, en "El dinero en la literatura" (recordemos que la comparación de Payró con Zola estaba ya presente en el artículo de Rubén Darío "Introducción a Nosotros de Roberto J. Payró" del primer número de la revista):

"Y Payró ha de consolarse. En el fondo, es optimista puesto que confía en tiempos mejores y al hacer la historia de un tipo o de un período, la comenta con una sonrisa. Durante su larga labor ha visto muchos para asombrarse y ha conocido demasiado cerca el mundo, para no abandonarse a la dulzura de la esperanza que lo ha confortado en su jornada sin término del periodismo y en la lucha de artista, hostilizado por el medio, formado sobre un fundamento exclusivo de éxito. Es cierto que la esperanza es el don de los fuertes. Sólo Payró ha logrado concretar obra no obstante su ruda y enorme ocupación de diarista en cuyo desenvolvimiento moderno ha sido factor y señal. Solo los que han trabajado en un diario en forma disciplinada y metódica pueden apreciar la suma de sacrificio y de vocación que comporta el libro, sustraído a la dolorosa fatiga de la diaria parición, hecha a costa del sueño. Y Payró no se ha reducido así sea en la tarea periodística, a la producción corriente: ha creado obra como la afirma su "Australia Argentina", que siendo periodismo es literatura fundamental y documento de estudio en cuyo fondo palpita la eterna compasión y su eterno ideal de ciudadano para quien la patria no termina en la escarapela de las fiestas conmemorativas. Y parte de eso, que basta para plasmar una personalidad, Roberto Payró es de los que fundan con su nombre el prestigio artístico de un país. Autor dramático, inclinó al teatro a una evolución de cultura e hizo obras como Sobre las ruinas, en la que abarca un momento de transición social, el choque entre lo legendario, lo arcaico, con el avance de la vida robusta y nueva del progreso y en ese episodio cuyo enunciado parece una cuestión técnica casi, se revuelve un hondo conflicto humano, con sus amarguras, con sus incertidumbres. En Marco Severi aboga un pensamiento de piadosa justicia y nos refirió en El triunfo de los otros, la existencia trágica del escritor, la historia lúgubre de los periodistas. Ha creado a Laucha, que es una obra maestra, ha escrito sus cuentos de Pago Chico y haciendo conquistado un insuperable alcance como cuentista se perfila hoy como constructor de novelas.

Jamás se abatió su energía. Me parece verlo junto a la mesa de redacción, en la cual encontraban consejo y ayuda los principiantes: por más de veinte años nos e apartó de esa mesa y pudo demostrar que la faena formidable del diario no anula fácilmente una mentalidad de su consistencia. Pero, entre nosotros son desconocidos las intimidades de la vida intelectual. Rosny habría hallado en Payró un tipo glorioso para su novela de costumbres literarias. Aquí, la gloria y el provecho no es para almas de su temple. La gloria no conoce sino al militar, al industrial y al político y esperemos-ya que nos enseña amar el provenir que en días menos incompletos, la labor artística tendrá también su sanción. Ya tenemos grandes escritores puesto que tenemos libros como este de Las divertidas aventuras de un nieto de Juan Moreira. En el futuro la gloria no será esquiva con los literatos cuya aureola augusta es el silencio actual. Trabajemos, pues" pp. 23-24.

-La enseñanza de la historia en las universidades alemanas, por Coriolano Alberini pp. 56-64 [sobre el libro de Ernesto Quesada]

La reseña es importante porque es una disputa con el nacionalismo que Rojas propone en $L a$ restauración nacionalista, y en segundo término porque muestra la necesidad de construir la historia 
como disciplina y como ciencia (se pretende la búsqueda de la verdad) no ya como relato interesado y faccioso sobre el pasado. VER SI ES ASI LO DE ROJAS

A propósito de la cuestión del nacionalismo en los países europeos, Alberini interviene y discute con Rojas, al que no menciona: "Ahora bien: si la historia gloriosa fundamenta el nacionalismo [el de Alemania, por ejemplo], ¿en qué habrán de fundar el suyo las naciones hispanoamericanas? No cumple resolver aquí el problema; pero conviene observar que la cuestión nacionalista en países sudamericanos presenta caracteres tan peculiares que absurdo y garrafal fuera aplicarle soluciones tudescas, como alguien entre nosotros intentara. Alemania, por ejemplo, era ya una gran patria antes de que asomara la fanfarria nacionalista. Poco importa que políticamente no existiese pero existía psicológica, idiomática, literaria y filosóficamente. La soberanía no fue sino la coronación de una obra secular. Fichte, con sus Discursos a la Nación alemana, no creó el patriotismo alemán: lo despertó simplemente. Sus Reden no son sino una campanada de alarma frente al napoleonismo (...) Aquellos discursos, rebosantes de metafísica vidente, jamás cabrían en chirumen latino, y mucho menos en el criollo" p. 63. Y más adelante: "La teoría del patriotismo de Moreno -muy moderna por ciertoconcibe el sentimiento de la patria como una forma del sentimiento de la libertad. Allí no se habla de tal o cual quimérica voz de la raza y demás elementos de la mise en scène nacionalista" p. 64. Inmediatamente después polemiza: "Arrendajo antifilosófico será, pues, resolver el problema inoculándonos soluciones galaico-tudescas. Y por otra parte, cabría preguntarse, después de lo mentado, si no sería absurdo piramidal hablar de pedagogía nacionalista a base de historia sudamericana, cuando harto notorio resulta que ella todavía ostenta marcado continente de cronicón sectario. Cualquiera que no esté obnubilado por importados sedentarismos nacionalistas, habrá de convenir que en nuestro país la historia antes merece ser escrita que adulada. Y escrita de veras, no ya a manera de alegato o requisitoria, sino con absoluto desinterés, tendente [sic] solo a dar la sensación exacta de la realidad pretérita" p. 64.

Bibliografía pp. 65-73

-La lámpara encendida de Eugenio Díaz Romero por F. J.

Reconoce los méritos del autor pero critica "la manera poética, que por lo general es la decadente, ya bastante pasada de moda" p. 66

- Musa errante Francisco Aníbal Riú por F. J.

Se trata de un conjunto de décimas que cantan a las cosas de la tierra. "Conceptuamos equivocada la tendencia. No es por ese camino que el señor Riú llegará a la poesía. Versos sonoros, llenos de imágenes destinadas a provocar el aplauso fácil de las asambleas políticas, nunca podrán ser consideradas como obras de arte. Es una literatura inferior y primitiva, como que su único objeto ha sido halagar los sentimientos de la masa" p. 66

-Canto secular de Eloy Fariña Núñez por Roberto Giusti

A la manera de Lugones en su "Oda a los ganados y a las mieses", canta el poeta paraguayo el centenario de su patria.

- Bajo los astros de Arturo Marasso Roca por Roberto Giusti

"Excelente" como libro de comienzo, "librito modesto, nutrido de composiciones de diverso carácter y escuela" p. 68.

-La asistencia social en la República Argentina de José Ed. Coll, por Roberto Giusti

- Folletos: Sarmiento evocado ante la juventud universitaria de La Plata de Ricardo Rojas; El deán Funes de David Peña ambos reseñados por Roberto Giusti.

Cuando se refiere elogiosamente a la conferencia de Rojas no puede dejar de anotar su disidencia respecto del nacionalismo que promueve: "Yo que siento la más viva estimación por la bella inteligencia de Rojas, me complazco en poderle tributar mi aplauso entusiasta en esta circunstancia en que me encuentro con él en el amor a Sarmiento, ya que no me es dado seguirlo en su personal prédica nacionalista" p. 71.

- La juventud intelectual hispanoamericana de Alejandro Sux, por Julio Noé

Noé se queja del carácter bondadoso de la crítica y las valoraciones equivocadas a las que conlleva este criterio.

- Los nietos de Icaro de Francisco Camba por Julio Noé 
- Napoleón íntimo. Memorias de su secretario particular Fauvelet de Bourrienne, por Julio Noé. Editadas por la editorial Hispanoamericana, traducidas por Antonio Muñoz Pérez e ilustrada con 29 grabados.

Notas y comentarios

La redacción de la revista se enoja con la falta de registro de la prensa respecto de las muertes de intelectuales sudamericanos en detrimento del que se hace de la muerte de algún "diputado francés o capitalista austríaco o profesor alemán". Acto seguido se dedica a homenajear a Enrique Piñeyro, Rufino José Cuervo y Carlos Arturo Torres. Después se consigna la muerte del poeta siciliano Mario Rapisardi.

-La Facultad de Filosofía y Letras. Se ataca el último decreto del ministro de Instrucción Pública, Garro que restringe las incumbencias de la enseñanza en los colegios secundarios a los títulos expedidos por el Instituto Nacional del Profesorado y la sección pedagógica de la Universidad Nacional de La Plata. Advierten sobre la posibilidad de que se entregue el monopolio de la educación a la Universidad Católica.

-La Biblioteca Nacional. El diario La Nación publica una estadística en la que la Biblioteca Nacional tiene un movimiento inferior al de "cualquier biblioteca municipal de una ciudad de segundo orden de estados Unidos". Entre otras cosas, se debe a los horarios: verano 12 a 17, invierno 12 a 16 y 20 a 22 -Por el derecho de reunión

La redacción considera necesario opinar directamente sobre política, algo que no hace habitualmente. En este caso se trata de manifestarse -tal como lo han hecho otros medios- en contra de la prohibición del Ministerio del Interior del mitin socialista en contra de la ley social. Señalan como reaccionarios este hecho y la amenaza de aplicación de la ley 7029 a un diario [La Nación? La Prensa?] que ha opinado sobre la actitud del gobierno en la "gran huelga ferroviaria". Frente a este tipo de regresiones la revista interviene.

\section{Año VI, tomo 7, no 37, febrero 1912}

Alejandro Sawa. A propósito de Iluminaciones en la sombra. Alvaro Melián Lafinur, pp. 81-91 Prólogo.......... Enrique Banchs pp. 92-93 [de un libro en preparación]

Algunas páginas de Rafael Barret...........pp. 94-104 [1leva una nota introductoria de Giusti; "Mi hijo", "el perro", "En la estancia", "Alberdi"]

La sofística moderna.............Hans Friedrich [Giusti] pp. 105-108

Poesías .............. Juan Aymercih [dedicadas a Alfredo Bianchi, "La tristeza del agua", "La tristeza del jardín", "Estampas", "Un lienzo de Richard"] pp. 109-112

El conscripto. Drama en un acto de Francisco Mazzoni.............pp. 113-134

Aristarco y ellos............Roberto Giusti pp. 135-149

La reforma de la enseñanza secundaria.......... la dirección pp. 150-153

Letras italianas.............. Francisco Albasio, pp. 154-156

Notas y comentarios.............pp. 157-160 VER

La reforma de la enseñanza secundaria, pp. 150-153

"Cuando menos lo sospechábamos, el ministro de instrucción pública nos ha sorprendido con una reforma fundamental del plan de estudios de los colegios nacionales. El decreto es mucho más revolucionario de lo que podía esperarse de la apatía de este ministerio que hasta ahora solamente había sabido desprenderse de los institutos que entorpecían su bienaventurada existencia en el desembarazado cielo de la abstracción, el recogimiento y la pereza. Las variaciones de mayor bulto introducidas en el sistema de enseñanza son dos: el cambio de frente en cuanto al criterio anterior que hacía de los estudios secundarios unos meros estudios preparatorios de los universitarios, y la subdivisión de los colegios nacionales en dos categorías elementales y superiores; los primeros, destinados a los pueblos de más de 15.000 habitantes, con un plan de estudios de cuatro años, y los segundos, para las ciudades de más de 30.000 habitantes, las capitales de provincia y la capital federal, con un plan de seis años. 
El decreto que la prensa diaria ha dado a conocer ampliamente, contiene muchas excelentes disposiciones; en conjunto da, sin embargo, la impresión de algo sin consistencia ni estabilidad, que ni ha sido cimentado sólidamente después de una profunda remoción del terreno en que ha de levantarse, ni es posible que dure mucho más que las precedentes construcciones de Magnasco, Serú, Fernández, González, Pinedo y Naón, todas caídas bajo la piqueta del ministerio siguiente. Comenzará a regir sólo para los alumnos que ingresen este año y se concede la vida a si mismo hasta que el congreso haga uso de la facultad que le acuerda el artículo 67, inciso 16 de la constitución. Esto acusa en el doctor Garro un envidiable optimismo, que él basa, fuera de duda, en las siguiente convicciones: $1^{\circ}$, Que su ministerio se prolongará pacíficamente durante incalculables años, y acaso sea vitalicio; $2^{\circ}$, que el congreso no hará jamás uso de la facultad constitucional; $3^{\circ}$, que en caso de que se le ocurriera acordarse de ella, la ley orgánica que dictará no será otra cosa que el presente decreto, demostrado a los diputados por el p. E., el mejor de los decretos en el mejor de los mundos posibles.

¿Quiere decir nuestro escepticismo que consideramos inoportuna una reforma de la enseñanza secundaria y conveniente dejar las cosas como están per saecula sacculorum —y perdónenos el señor Garro este latín eclesiástico?- De ningún modo. Creemos que la organización definitiva de la enseñanza secundaria se impone de una vez, para honor de la cultura del país; pero, como no estamos tan seguros como el doctor Garro de su longevidad ministerial, encontramos vana la reforma presente, y grave, además, por cuanto es revolucionaria, pues no ha de pasar de ser un espasmo más, de los tantos que venimos presenciando desde tantos años a esta parte. ¿Y entonces? Entonces, este p. E. que ha conseguido hacer aprobar por el Congreso su ley electoral, debía o debiera acometer una reforma no menos trascendental que la precedente, consiguiendo la sanción por las cámaras de la por muchos anhelada Ley Orgánica de Enseñanza Secundaria, que acaba una vez por todas con esta frenética ronda de planes y más planes, a cual más precipitado. pp. 150-151

(...)

Nosotros nos declaramos decididos partidarios de la enseñanza clásica, y por consiguiente en esto nos colocamos del lado del reciente decreto, contra la mayoría, naturalmente.”p. 152

Notas y comentarios

-Centenario de Dickens

-Comentario a la muerte del barón de Río Branco, canciller brasileño

-Se anuncia la próxima aparición de El Mirador de Próspero de Rodó, de la que Nosotros publicará algún capítulo. Editado por Serrano y Cía.

-Se transcriben los comentarios de Max Nordau (en francés) y de Salvador Rueda al libro de Ernesto Mario Barreda, La canción del hombre que pasa, editado por la revista.

-Se comentan las reformas a los planes de estudio de las escuelas normales, tendiente a eliminar el enciclopedismo

-Bajo el título irónico "Voces de aliento" se transcribe una cita de Javier de Viana en Crónica, en la que califica de "petulantes" a los miembros de la revista, aparentemente por opiniones vertidas sobre teatro.

Libros recibidos últimamente [dentro de Notas y comentarios]

-Clásicos castellanos. Ediciones de La Lectura de Madrid, 1911. Cervantes: Don Quijote de la Mancha, I, II. Edición y notas de Francisco Rodríguez Marín, de la Real Academia Española

-Orestes Araujo, Historia de los charrúas y demás tribus indígenas del Uruguay, primera parte, Montevideo, José María Serrano editor, 1911

-Shakespeare, Obras completas, traducidas por Jacinto Benavente, edición de la La Lectura, Madrid, tomo I, El rey Lear.

-Camilo de Cousandier, El poema interior, Buenos Aires, Biblioteca América, 1911.

-Enrique de Muoliá, La primer etapa, Buenos Aires, 1912 [no se consigna editorial]

-Los grandes pintores [H. y J. van Eyck, Velázquez, Ticiano], París, Casa editorial Hispanoamericana. -María Concepción Flores, Lírica, Buenos Aires, 1911. [no se consigna editorial]

\section{Año VI, tomo 7, no 38, marzo 1912}

Parini o de la gloria..........Giacomo Leopardi, pp. 161-175 [traducido por Roberto Giusti]

La cita........... Ernesto Mario Barreda pp. 176-178 [en forma de diálogo rimado] 
Las otras vidas. Comentarios sobre Mauricio Maeterlink y su obra.............Juan Mas y Pí pp. 179-183 CRITICA

La literatura y el carácter.......Pedro César Dominici [prólogo a Ensueños y emociones de Felipe Valderrama] pp. 184-187

Versos .......... Rafael de Diego, D. A. Robatto, Luis C. López, pp. 188-192

Comedia de pequeños burgueses.............Alberto Gerchunoff pp. 193-206 [primer acto]

Cuando vela Pierrot............Pablo Della Costa (hijo) pp. 207-209

Marcos, amador de la belleza..........Alberto Nin Frías pp. 210-215

La siesta........... Carmelo Bonet pp. 216-217

El manifiesto presidencial..........La dirección pp. 218-220

Teatro Nacional .............. Nicolás Barros, pp. 221-226

Bibliografía...... pp. 227-234

Notas y comentarios.... pp. 235-240

El manifiesto presidencial. pp. 218-220

Se trancribe el texto completo

Los espíritus candorosos y honestos están siempre dispuestos a creer en la buena fe de los gobernantes, y a este respecto es candorosa y honesta la gran mayoría de los hombres. Debe ser así, por otra parte. Cuando un ciudadano, exaltado a la más alta magistratura de un país, promete a su pueblo no proponerse anhelo superior al de cuidar los intereses del estado, y de procurar la realización del mayor bienestar colectivo posible, y lo jura sobre la constitución, y lo repite de continuo en mensajes y decretos, repugna a la conciencia admitir que todo eso que sus labios dicen y su pluma escribe es falso, que su propósito no es otro que el de enriquecerse, que el sudor y el dolor de sus compatriotas, a cuya felicidad él podría propender si quisiera, no le interesan, que no cree ni en la verdad, ni en la pureza de las instituciones y de los hombres, que no le preocupa siquiera legal su nombre a la posteridad, limpio de reprocho o de infamia. Y esto es sin embargo, lo corriente, sobre todo en estos pobres países de América, víctimas seculares del caudillismo ávido y despótico.

El doctor Roque Sáenz Peña, primero en su programa de candidato a la presidencia, luego en sus documentos públicos de primer magistrado, viene haciendo desde hace algunos años a su pueblo las mismas promesas. Los espíritus desconfiados o decepcionados han podido legítimamente dudar de la sinceridad de tales promesas. Les daban derecho a ello, las desilusiones, los engaños sufridos anteriormente. Pero la hora de la incredulidad ya ha pasado. La presidencia Sáenz Peña podrá haber dado muestras repetidas de debilidad y de vacilación; podrá haberse equivocado más de una vez; pero es evidentemente una presidencia honesta y sincera. Se ha propuesto como programa fundamental la reforma de nuestras costumbres electorales, la purificación del sufragio, la devolución al pueblo de la soberanía que le corresponde de derecho y que de hecho nunca poseyó durante nuestra vida independiente, y contra viento y manera lo está cumpliendo con una constancia y una tenacidad que verdaderamente admiran.

En el reciente manifiesto el Presidente ha expresado al pueblo sus temores, sus anhelos y sus esperanzas acerca de la elevada acción política que ha resuelto firmemente desarrollar: su palabra ha sonado con acentos de sencilla franqueza, raras veces oídos aquí, Se diría que ese manifiesto, antes que una voz de estímulo para la lucha, es el testamento político de uno que abandona la batalla, diciendo con el supremo desinterés de los que abdican espontáneamente: "ahí queda eso; es mi obra; proseguidla".

La acción de arriba ha surtido su efecto. Mucho habrá que hacer todavía en las provincias, para desmontar la "máquina" que desde tantos decenios funciona; algo ya se ha conseguido en algunas; lo demás lo harán el tiempo y la firme constancia del ejecutivo; pero en la capital la "máquina" ya ha sido desmontada. Las próximas elecciones serán libres, absolutamente libres, y limpias o casi porque el delito es eterno como el mundo - de todo fraude. Los traficantes de libretas, que en otras épocas, y no lejanas, dispusieron a mansalva de todos los empleos públicos, aflojaron todos los resortes de la administración nacional, corrompieron todas las instituciones, y palmearon a los presidentes y ministros a quienes servían, con la misma familiaridad que a los rufianes y ladrones de quienes se servían, van a ser muy pronto una vergüenza del pasado. El mismo voto venal ha sido certeramente herido, aunque — iay! — no de muerte. Los partidos que el 7 de abril se presenten a la 
lucha, podrán tener la seguridad del triunfo, sean cualesquiera que sean, con tal que la tengan en sus fuerzas propias. Ya no cabe duda en que se está produciendo un resurgimiento cívico. Los radicales han salido por fin de su antigua y hosca abstención, para jugarse en los próximos comicios; los socialistas abrigan fundadas esperanzas de éxito; las candidaturas independientes de todo partido se multiplican sobre la base de la imparcialidad de las urnas y de la popularidad mayor o menor de los candidatos; los partidos mayores, la Unión Nacional y la Unión Cívica, se aprestan a reñirse las diputaciones vacantes con armas leales y con igual confianza: todo ese fermentar de aspiraciones y de entusiasmos, propio de la verdadera vida republicana, no tiene otro origen que la palabra empeñada por el presidente, y corroborada por sus actos, de que los comicios próximos y todos los comicios argentinos, serán escenarios de luchas francas y libres, de ideales y de partidos.

Aun no existen, sin embargo, los grandes partidos, que sean algo más, como dice el mismo manifiesto, que "agrupaciones eventuales, vinculadas por pactos transitorios". Por ahora no hay más que dos partidos de ideas, y no son los mayores: el socialista y el radical, y acaso lo es sólo el primero, pues el Presidente ha venido a sustituir al Radical en la persecución de sus fines. Probablemente, después de este primer ensayo de libre vida electoral, se inicie la concentración de las fuerzas todavía dispersas en grandes ejércitos, para librar las grandes batallas republicanas del futuro. Esperémoslo.

Por todo ello, por lo que presencia en la hora actual, y por lo que espera de los años venideros, Nosotros, absolutamente insospechable de partidismo político, aplaude al Presidente de la República, único padre de esta consoladora regeneración cívica de nuestro país.

La Dirección."

Teatro Nacional

Nicolás Barros, pp. 221-226

Apolo:

La cruz pieza de Alberto Ghiraldo basada en una obra previa de Florencio Fernández Gómez

Se pregunta Barros por el propósito de la obra (¿crítica social?, ¿crítica a los prejuicios cristianos?, /representar una faz amarga de la vida y mostrarla en su carácter irremediable?). La obra es un fracaso porque "han querido, y no han podido [los autores] llegar a la nota independiente, personal, prefiriendo en cambio, a mitad de camino abandonar el azar de un posible atrevimiento, para transigir con la solución burguesa de atribuirlo todo a la fatalidad" p. 221 Para Barros, el fin del teatro es pedagógico. Así sostiene: "No vale la pena llevar al teatro una emoción, cuando no tenga por objeto educar una fibra noble de nuestro espíritu. (...) Y entiéndase que no estamos arguyendo a favor de un teatro de ideas. Nos es indiferente el pensamiento expresado en ideas, olas pasiones expresadas en hechos lógicos; estamos arguyendo a favor de una docencia de las obras teatrales, que los autores inteligentes han seguido inconscientemente, y que los melodramaturgos han olvidados a menudo en sus empeños efectistas. estamos reclamando para la obra teatral, en suma, el espíritu de arte y de humanidad que ha de darle aliento" p. 222 La obra de Ghiraldo y Fernández González no responde a estos principios y por lo tanto Barros no encuentra otro valor en ella que el del buen gusto literario de sus autores, la sobriedad, y "cualidades de observación muy apreciables" p. 223.

-El festín de los lobos de Roberto Cayol [tres actos]

Barros señala a Cayol como autor de comedias y observa en la introducción de "moldes" diversos que realiza en sus sucesivas obras, un rasgo de indecisión estética. Entre sus modelos está la comedia ligera de los hermanos Quintero, y con El festín de los lobos aparece ahora Benavente. Rescata los diálogos que evitan "las vulgaridades de la conversación verdadera" y critica la falta de optimismo, tratándose de un autor joven. el argumento no tiene nada nuevo. Se trata de la "novela de todos los días que pasa indiferente ante los ojos de la mayoría, la novela amarga de la muchacha pobre, que es mucho para amante y poco para esposa" p. 224

El malón blanco, pieza en tres actos de Vicente Martínez Cuitiño.

Se inscribe y confirma la orientación realista que se observaba en la obra anterior del autor, Mate dulce. Según Barros el "afán de crítica social" es perjudicial para el sentido estético. La obra ha gustado al público pero no a base de vulgaridades. Sin embargo Barros no reconoce talento en esta pieza. 
Año VI, tomo 7, no 39, abril, 1912

Parini o de la gloria........... Giacomo Leopardi (conclusión) pp. 241-255 [traducido por Roberto Giusti] Faltaba una..........Eduardo Talero p. 256

Por las tierras de Castilla............ Amado Nervo pp. 257-263

Al margen del caso paraguayo......... Eloy Fariña Núñez, pp. 264-270

La España latina. Barcelona................ Manuel Gálvez pp. 271-276 [de El solar de la raza]

Brujas..........Fernán Félix de Amador p. 277

Comedia de pequeños burgueses.............Alberto Gerchunoff pp. 278-295 [segundo acto]

Política nueva...........La dirección pp. 296-298

Bellas artes..........José Ojeda pp. 299-300 LEER

Crónica musical.......pp. 301-305 [no se consigna el nombre del crítico]

Teatro nacional........... Samuel Linnig pp. 306-314

Notas y comentarios..........pp. 315-318.

Indice del tomo........pp. 319-320

Política nueva, pp. 296-298

Se transcribe el texto completo:

"Este año será histórico en los fastos argentinos. Será histórico, con tal que no padezca ningún contraste la nueva orientación política, cuyos comienzos marca. El país ha surgido a la vida verdaderamente democrática, por una transformación tan total y sorprendente de sus costumbres cívicas, que no registra otra parecida nuestra historia. Las elecciones libres auguradas por la larga serie de actos gubernativos que se han sucedido en el transcurso de más de un año, y que el manifiesto presidencial coronó bellamente, se han efectuado, al menos en la capital y en algunas provincias, poniendo de manifiesto la existencia efectiva del pueblo, tantas veces negada por los de arriba.

La elocuente significación de las elecciones provinciales del 31 de marzo en Santa Fe, la magnífica sorpresa del escrutinio de las elecciones del 7 de abril en la capital, y la magnitud superior a toda esperanza del mitin contra el voto venal del 14, han sido las tres expresiones características de este despertar cívico, que ni los más optimistas se hubiesen atrevido a esperar un mes atrás.

En nuestro número anterior, al comprobar los entusiastas preparativos de las elecciones del 7 de abril, lamentábamos que el voto venal no hubiese podido ser herido de muerte. Y nos equivocábamos, como se equivocaron todos. Ha habido un partido, que negándose a aceptar las abiertas y equitativas condiciones de lucha que el presidente de la nación ofrecía a todos, creyó poder perpetuar el viejo sistema de la compra del voto, atribuyéndose por medio de él jactanciosamente el triunfo de antemano. Y ha sido vencido y burlado, y la gran mayoría lo ha visto con regocijo hundirse, pues su actitud había sido desleal y antipatriótica en la hora suprema de la prueba, en que el país jugaba su porvenir político. Desde ahora no será ya posible fundar en los millones de pesos las probabilidades del éxito: los pocos votos venales arrojados en el platillo de la balanza no alcanzarán jamás a contrarrestar el peso de la verdadera voluntad popular.

Quisiéramos que se comprendiese que no escribimos triviales frases de editorial. Existe en efecto una voluntad popular. Los que han triunfado son los partidos que están más cerca del corazón del pueblo, y es el pueblo que ha querido que triunfasen; y de los hombres, han concentrado a su alrededor el mayor número de simpatías, los de verdadero prestigio moral, no los politiqueros ni los charlatanes. El escrutinio lo ha declarado elocuentemente. Los primeros días fueron de estupor. Los radicales y los socialistas se imponían en una forma abrumadora. Es el suburbio que se vuelca sobre la ciudad, dijeron con desprecio los decentes. Las cosas cambiarán cuanto entremos en el asfalto. Y se entró en el asfalto, y las cosas no cambiaron. Persistió el triunfo de los radicales, persistió el de los dos socialistas más caracterizados; y si en la lista definitiva entraron dos hombres de otros partidos, fue porque su figura personalmente prestigiosa los impuso sobre sus momentáneos compañeros de bandera a la atención de todos los electores conscientes de su voto. Salvo esas excepciones, los principios derrotaron a los hombres, hecho de indiscutible significado moral, que merece ser meditado por las futuras grandes agrupaciones que hayan de formarse. En cuanto a los politiqueros de profesión, fueron en los partidos mayores los que generalmente obtuvieron menor número de votos, $\mathrm{y}$ es ése otro consolador resultado de la jornada. La época de los caudillos de barrio parece pasar, y los propietarios de casas oscilantes entre el comité y el prostíbulo pueden dar por concluidos sus turbios oficios. 
La victoria del partido radical es algo más que una victoria de hombres: representa la protesta de 30.000 ciudadanos contra un régimen político que ya había hecho su tiempo y sólo era una vergüenza para el país. También en Santa Fe, en Córdoba y en otras provincias el pueblo ha querido llevarlos al Congreso: en estos momentos el porvenir político del país está en sus manos. Tienen por tanto una grave misión que cumplir: les faltan hombres y un programa. Es de esperar que sabrán resolver felizmente ambos problemas: formando los primeros, con un amplio y sereno criterio que escoja los mejores donde quiera los encuentre, abandonando las intransigencias inútiles ya, o, peor, perjudiciales; e inspirándose para el segundo en las reales condiciones y necesidades del país, como se sabe, étnicamente cosmopolita, espiritualmente liberal, y económicamente agropecuario en su gran extensión, en industrial en la metrópoli. Se ha dicho con razón que una oposición se hace con gestos, pero un gobierno con ideas. Esperemos que los radicales prueben tenerlas, y buenas.

Un soplo de juventud y de entusiasmo va a ventilar en breve la viciada atmósfera del congreso. Las unanimidades obsequiosas, o las tibias oposiciones nacidas del despecho personal, se acabarán también. Confiamos en que este año se oirá gritar un poco en esta cámara, donde todos hablan en voz baja porque todos se entienden sin hablar. Todo lo que hagan los nuevos representantes de la capital y del interior, por mover esa quietud de capilla, será bien venido. El pueblo argentino ha entrado con pasión en la vida política; Buenos Aires ha votado como un solo hombre, y durante dos semanas ha estado febrilmente pendiente del lento escrutinio que había de manifestar su veredicto: es necesario no dejar debilitar esas energías cívicas, felizmente despertadas. Que los nuevos entrantes hagan el proceso de las oligarquías que no han advertido la enorme revolución pacífica que acaba de realizarse; que la intervención federal restituya a cada provincia argentina, como a Santa $\mathrm{Fe}$, sus derechos ciudadanos; y que se forme, como ya se anuncia, la concentración, de las fuerzas conservadoras. Esto último es lo que necesita el país y lo que el presidente reclama desde hace tiempo: los grandes partidos, con programas definidos, que establezcan en el gobierno la rotación política que es necesaria a toda verdadera democracia.

La Dirección."

Teatro nacional.......... Samuel Linnig pp. 306-314

Nuevo

- Mas allá de la ley, drama en cuatro actos de Camilo Muniagurria

Linnig señala la imposibilidad de producir emoción estética de la obra: “Alrededor de un caso clínico, factor único del drama, acumula una observación psicológica de gran riqueza, pero que no justifica la falta de emoción estética, ni puede ser tolerada dentro del teatro, aun cuando el propósito, la sátira, el desarrollo, el pensamiento noble y gallardo que anima los cuatro actos le hagan acreedor de todos nuestros respetos" p. 308

-La Mancha, drama en cuatro actos de Arturo Giménez Pastor

Se refiere a la obra como comedia o comedia dramática, que "exige una solución de continuidad en el desarrollo, que toda digresión o incidencia que no corresponda directamente a la esencia de la obra la malogra". Inmediatamente censura: "Arrastrado por el afán de hacer crítica social sin revelar en ningún instante el conocimiento del ambiente que critica, el señor Giménez Pastor no logra su propósito. Su sátira es endeble y su moralismo tanto más endeble que su sátira" p. 309. Señala la falta de conocimiento del medio [alta sociedad] que describe, al que conoce no directamente sino por las crónicas sociales.

Apolo

-Canción de primavera, "poema rústico en tres actos" de José Maturana

Se trata de una crítica positiva: "Canción de primavera es la mejor obra poética que se ha escrito en el teatro argentino" p. 311 La califica de "égloga moderna", y destaca su "sinceridad, sencillez y frescura" p. 312

Odeón

Un cuerpo de David Peña. 
Critica la falta de visión escénica del autor y la ausencia de emoción: "obra eminentemente cerebral, de positivo mérito como propósito artístico, escrita con un lenguaje propio para la escena, pero falta en absoluto de emoción, carece de interés debido a la pobreza de la técnica, directo resultado de la falta de visión escénica en el autor" p. 313.

\section{Año VI, tomo 8, no 40, mayo 1912}

El progreso y su fórmula....... Antonio Dellepiane pp. 5-34 [se trata del resumen de las LECCIONES que dictó Dellepiane en la Sorbona sobre la Teoría del progreso. Este dato es importante porque muestra el interés y el vínculo privilegiado con el sistema de enseñanza universitario. La institución francesa le confirió el título de profesor agrée]

De El espejo de la fuente..........Rafael A. Arrieta pp. 35-36

Giovanni Pascoli...... Francisco Capello pp. 37-51 CONFERENCIA

La misa de oro........ Giovanni Pascoli pp. 52-64 [traducido por Giusti] Discurso de Pascoli sobre la cuestión ciencia vs fe.

Bellas Artes....... José Ojeda pp. 65- 66

Teatro Nacional......Samuel Linnig pp. 67-70

Bibliografía.........pp. 71-81

Notas y comentarios..... pp. 82-88

Bellas Artes....... José Ojea pp. 65-66

La nota señala las causas del gran número de exposiciones, conferencias, audiciones, esculturas que se registra en Buenos Aires. Estas se vinculan fundamentalmente con la rentabilidad que adquieren este tipo de productos culturales, más que por la consideración del público como un conocedor y poseedor de un gusto, por su riqueza. "Como todo el mundo sabe, los negocios son los negocios. Quienes se dedican al transporte y venta de obras de arte no pueden perder su dinero por prurito de educarnos y harían mal en traernos un Whistler o un Monet, como harían mal en enviar a las provincias percal sin grandes flores de color" p. 65.

Teatro Nacional Samuel Linnig pp. 67-70

Los equilibristas, "comedia dramática en tres actos del Señor Carlos M. Pacheco"

Esta reseña es importante porque señala una polémica que se viene dando en el espacio de la alta cultura letrada respecto de la dirección que debe tomar el teatro nacional, y porque se reconocen algunos intentos de autores que, inscriptos en otros géneros menores, intentan abordar, por ejemplo, la comedia dramática.

"Por tercera vez, Carlos María Pacheco, intenta la realización de un género de teatro superior a aquel con el cual consiguiera buenos éxitos de galería. Comenzó con el drama La vida inútil, al cual siguió Las mariposas y finalmente intenta la comedia dramática Los equilibristas.

En el autor de sainetes se ha operado una evolución artística de todo punto necesaria, y a la que como propósito no se le debe escatimar aplauso, ya que como realización escénica, ideológica y sentimental, es la última producción de Pacheco, en extremo defectuosa y difusa.

El autor dramático, que dentro de un orden elemental triunfa fácilmente sobre las asperezas que le crean los conflictos dramáticos por él planteados, se ve vencido y anulado, cuando, dentro de un género escénico superior, con personajes, ambientes y factores más complicados o en relación a su anterior producción, más sutiles, plantea o determina situaciones que no sabe desarrollar, $\mathrm{y}$, en consecuencia, a las cuales no se halla solución de continuidad en la evolución de las ideas y de los sentimientos a través de la acción. Esto que le ocurre al señor Pacheco, es un mal endémico en la casi totalidad de los autores nacionales" p. 67

Lennig reitera lo que ya ha dicho de otras obras: falta emoción, sin acción dramática (los personajes "desarrollan la comedia dramática a base del comentario de sus propios conflictos" p. 69), y también, falta de ideas. Si de teatro de ideas se trata, el modelo que cita Lennig es Pérez Galdós quien construye "sentimientos en torno de ideas" p. 68. 
Bibliografía, pp. 71-81

Metodología de la enseñanza de la historia de Victorio M. Delfino

La nota comienza alabando el interés de este autor y de otros "estudiosos" por las cuestiones educativas. El libro lleva un prólogo de Víctor Mercante. Quien reseña destaca un aspecto del libro relacionado con "la formación del carácter nacional" y transcribe varios pasajes en que Delfino se refiere a la cuestión: 'De esta manera se irá formando formando el carácter nacional en el crisol de la historia patria. Pero pensamos que nada se obtendrá cuando se trate de infundir el espíritu nacional hablando de él mismo a sus alumnos (como se hace comúnmente) (...) Enseñemos la historia patria como aconseja la moderna metodología y contribuiremos a la formación de grandes cualidades: la conciencia nacional y el carácter; la primera por las enseñanzas concienzudas de la historia del país y el segundo por la verdad con que enseñamos'. Quien redacta la nota agrega: "Muy sana opinión que contrasta radicalmente con la de los nacionalistas a pura bandera y puro himno, como con la de los pedagogos descarriado que en un país libre como el nuestro siguen exaltando las ventajas de la mentira patriótica [en cursiva en el original] como medio educativo" p. 73

Documentos relativos a los antecedentes de la Independencia de la R. A., Documentos para la historia del Virreinato del Río de la Plata.

El escrito empieza con una defensa de la Facultad de Filosofía y Letras a la que el ministro de Instrucción Pública, doctor Garro, ha cuestionado públicamente, y muestra el lugar privilegiado que se confiere a la universidad en relación con la cultura nacional:

"La Facultad de Filosofía y Letras, a pesar del empeño que el doctor Garro ha puesto en desconocerla y desdeñarla, acaso por ser ella un centro de trabajo y de estudio y como tal blanco natural de la ojeriza de un ministro ocioso e inepto, continúa prestando al país con seria tenacidad inapreciables servicios de orden superior.

A las muchas iniciativas que sus autoridades han tenido hasta la fecha para fomentar la cultura de la República, elevar el nivel intelectual de nuestros estudiantes, dar una sólida base a ciencia arqueológica argentina y preparar, en general, el advenimiento del verdadero espíritu científico en las materias históricas y literarias, espíritu que entre nosotros apenas ha apuntado, debe agregarse la no menos importante de haber puesto mano a la empresa de ir publicando todos los documentos referentes a nuestra historia, así la colonial como la independiente, que duermen en esos archivos" p. 73 Los tomos que se han publicado hasta la fecha (seis) son "preciosos elementos para el historiador y el sociólogo" p. 73.

Desde La Falda. Poesías por R. Monner Sanz

Crítica burlona del libro. El autor aparece como un profesor de gramática que escribe versos. La nota se cierra con el siguiente párrafo: "Gracias a Dios la literatura poética de las niñas argentinas aumenta constantemente. Al lado de Tras los mares que, suponemos, habrán hecho encuadernar coquetonamente con cantos celeste, pueden sin temor colocar en su biblioteca, Desde La Falda, para cuya encuadernación les aconsejamos el color caramelo. Ni su maestra de gramática, ni la de moral se han de oponer, pueden estar seguras" p. 73

\section{Cariños de Julio Cruz Ghío}

Se trata de un volumen de relatos de tema "de la tierra".

"A través de todas las páginas de Cariños se lee el alma del poeta rústico, fiera, impulsiva, idealista (...) Lástima , eso sí, que el poeta gaucho se transforme a veces demasiado en poeta urbano. Ghío siente y sabe describir con fuerza y con frescura el campo y sus tipos; pero a veces se le atraviesa por medio la literatura[en cursiva en el original], la mala literatura, y da entonces en rebuscar su léxico, con perjuicio para el efecto de vigoroso realismo, de evidencia inmediata que se ha propuesto producir" p. 76 califica al autor como un escritor "con muy felices aptitudes para la literatura de la tierra"p.76

Versos de una juventud por Edmundo Montagne [segunda edición del libro, del que ya se ocupó Nosotros en su momento] El autor es presentado como "uno de los más hondos y sinceros líricos de la joven generación poética" p. 77 
Jerusalén y la Tierra Santa de Enrique Gómez Carrillo

Es la compilación en volumen de las crónicas de Gómez Carrillo en La Nación. “(...) delicioso croniqueuer, exquisita flor de bulevar, ciertamente, pero a la vez legítimo orgullo del periodismo hispanoamericano" p. 77

La Propia y otros tipos y escenas costarricenses de Magón [seudónimo de Manuel González Zeledón]

Miscelánea de Manuel Ugarte

La "Colección Ariel" de Costa Rica da a conocer en antología la obra de Ugarte, privilegiando los temas latinoamericanos y por lo tanto seleccionando fragmentos que principalmente provienen de $E l$ porvenir de la América latina. El libro lleva como prólogo unas páginas escritas en 1902 por Darío.

Ensayos críticos: I. Gastón F. Deligne de Manuel F. Cestero

Es la obra de un poeta y "joven crítico dominicano". Vale más como el intento ("estudiar la personalidad de los literatos más conspicuos de su patria") que como resultado. Se señala que "se inspira en la fórmula de Ugarte que manda que la crítica se erija en conciencia colectiva y marque rumbos" p. 79.

Vida de Torres Villarroel

Se trata de la reedición que hace del libro La Lectura de Madrid en "sus intachables ediciones de los 'Clásicos castellanos', con lo cual ha prestado indudablemente un nuevo servicio a la causa de las letras y de la cultura españolas”. Edición anotada por Federico de Onís.

Memorias secretas de la Corte de Rusia [M. C. p. Masson], La Corte de Luis XV [memorias varias de la época] , Napoleón Emperador [segunda parte de las memorias de Fauvelet de Bourrienne]

Se destaca el emprendimiento de la Casa Editorial Hispanoamericana. En el elogio se evidencia el acuerdo de Nosotros con este tipo de empresas culturales que apuntan a un público más amplio. De esta editorial se destaca el "esmero tipográfico" y la "interesante" colección de la Serie histórica en que se publican estas tres obras, de las cuales se dice: "Trátase, como puede adivinarse, de obras de fácil e interesante lectura, de carácter entre histórico y novelesco -al menos las dos primerasdestinadas atener difusión, no solo entre quienes se interesan de las cosas del pasado, sino entre todos los que buscan un rato de esparcimiento en la lectura de los hechos grandes y peregrinos, así sean verídicos, así sean fantásticos" La traducción de las tres obras es de Mariano Ramón Martínez; el director de la editorial es José Muñoz Escámez; los libros tienen ilustraciones “documentales". p 81

Notas y comentarios

- Muerte de Marcelino Menéndez y Pelayo

-Muerte de Ferrucio Garavaglia [actor italiano] Por medio de un "manifiesto" escrito por David Peña y que la revista transcribe, se llama a cooperar con la familia del actor que queda económicamente arruinada. Se pide al público que asista a los espectáculos organizados a tal fin.

-Banquete a Martínez Cuitiño

La redacción de Nosotros señala que a raíz de ese banquete que celebraba los éxitos y la graduación universitaria del autor, quedaron ala vista "el ambiente de pequeñas miserias en que nos agitamos. Entre sesenta o más comensales que rodeaban al obsequiado, solo podía verse tres o cuatro autores teatrales conocidos. Esa falta absoluta de compañerismo en un gremio tan numeroso -casi no se tropieza en los cafés con un individuo limpio del pecado teatral- ya la hicimos notas a propósito de la comida que meses atrás se realizara en honor de uno de nuestros más serios dramaturgos: Julio Sánchez Gardel" p. 85.

Hablan en el banquete Gerchunoff, el periodista de Tribuna Enrique Villarreal y el homenajeado.

- Viajeros

Regreso de Juan Pablo Echagüe

La redacción sostiene que "Su viaje ha sido útil para nuestro teatro, por cuanto Echagüe ha sido eficaz intermediario entre la Sociedad de Autores Franceses y la de los autores argentinos, con objeto de llegar a un provechos acuerdo entre ambas".

partida de Hugo Achával 
José Blanco Caprile es el nuevo administrador que tendrá desde el mes de abril la revista, que ve en su persona "el mejor seguro de vida para la publicación"

\author{
Año VI, tomo 8, $n^{0}$ 41, junio 1912 \\ Del lado de afuera........ Roberto J. Payró pp. 89-94 [sobre la cuestión de la razón y la fe. Diálogo \\ entre dios y el diablo] \\ Rosal viejo........ Juan Aymerich pp. 95-96 \\ La enseñanza de la historia en las universidades alemanas.... Coriolano Alberini pp. 97-121 \\ Elogio del verso español........ Carlos Obligado pp. 122-123 \\ El Retorno. Drama en un acto y en prosa original de José Fabio Garnier [Costa Rica] pp. 125-144 \\ Un novelista del criollismo brasileño. Alcides Maya........Juan Más y Pí pp. 145-152 CRITICA \\ Letras argentinas....... Álvaro Melián Lafinur pp. 153-161 \\ Crónica musical.... Juan Pedro Calou pp. 162-165 \\ Notas y comentarios....... pp. 166-168 \\ Letras argentinas....... Álvaro Melián Lafinur pp. 153-161 \\ Se hace cargo de la sección. Transcribimos el discurso previo a las críticas. \\ "Un excellent critique serait un artiste qui aurait beaucoup de science et de gout, sans prejugés et sans \\ envie". \\ Voltaire.
}

La Dirección de Nosotros me ha hecho el honor de encomendarme la crítica de literatura argentina en esta sección bibliográfica. La he aceptado consecuente con mi propósito de servir en cuanto me sea posible el ideal de cultura y difusión literaria y artística que esta revista importa. No he de negar mi sencilla contribución a empresa tan elevada y de tanta necesidad en nuestro medio.

Lamento el primero, que esta tarea dejo de estar en manos de quien hasta ahora supo cumplirla con ecuanimidad y competencia, y procuraré sustituirle dignamente. Si no estoy seguro de dar gran lucimiento a mis crónicas, puedo en cambio estarlo en lo que respecta a la serenidad, amplitud y tolerancia de mis juicios, jamás turbados por el apasionamiento que conduce a la injusticia, ni regidos por fórmulas estrechas. La crítica requiere para ser ejercida con nobleza, esa virtud de simpatía y facultad de admirar, que capacitan a quien la realiza para compenetrarse con la obra examinada y desentrañar su significación moral y su valor estético. Como dice Renan, 'el progreso de la crítica no es posible sino a condición de una rigurosa buena fe'. Con razón se ha afirmado, en efecto, que las obras más perfectas pueden tornarse ridículas por la malignidad del intérprete. Un verso sublime resulta absurdo si se le declama afectando un tono de necedad.

Confieso mi predilección por los estudios amplios, profundamente analíticos, completos y prolijos, de que tan preclaro ejemplo son entre los franceses, - maestros insuperables en este arte, - los debidos a Sainte Beuve, Taine, Scherer, Brunetiere, Faguet, France y tantos otros, pero no cabiendo en los límites de esta sección trabajos de esa naturaleza, y no pudiendo ser, por otra parte, la mayoría de los libros que aquí se publican, objeto de esa clase de comentarios, la crítica a hacerse estará, salvo una que otra excepción, estrictamente ceñida a la obra juzgada, y exenta en lo posible de esas digresiones tan tentadoras para el crítico, pero que no tendrían, como digo, lugar en estas páginas.

La eficacia virtual de la crítica, en cuanto a su finalidad inmediata, ha sido muy discutida. Creo no obstante que un dictamen sincero, en que la sinceridad se transparente, juicioso en sus observaciones y expresado con altura y buena fe, no puede menos de operar en los autores una acción saludable a la vez que concurre a formar el gusto y encaminar el criterio de los que leen.

El concepto de tolerancia antes enunciado, no implica desde luego una benevolencia incompatible con la dignidad del arte, hacia obras falsas y deleznables. No implica sino la vastedad de espíritu necesaria para reconocer en todos los modos de concebir el arte y en todas las formas de realizarlo, —aún en aquellos que están fuera de la tendencia u orientación predilecta del crítico por razones de temperamento,- lo que ellas atesoren de verdadero, de bello y de bueno. Toda labor desprovista por completo de algún atributo que la dignifique, debe ser juzgada con severidad implacable.

Tal es el ánimo con que asumo esta tarea, cuya seriedad mido y cuya responsabilidad bien se me alcanza. He de tratar de que ninguna circunstancia me aparte ni aún involuntariamente de la línea 
trazada y de estar lo menos lejos posible (siquiera sea en lo que toca a su última cláusula), de la definición del filósofo que sirve de epígrafe a estas palabras preliminares. A.M.L."

-Las chicas de mamá Pacholí. Narración de costumbres por Federico Mertens []. "Espíritu [el del libro] de sátira social" y novela en la que "se confirman las cualidades de observador y colorista" del autor. Se describen "las modalidades de una familia de la clase media y el ambiente en que ella se agita". Reconoce una "intención burlesca" y un "propósito correctivo". p. 155.

-El árbol que canta. Poemas de Emilio Lazcano Tegui

La reseña interesa porque insiste en la legibilidad como parámetro de juicio de las obras: "La mayor parte de esta poesía resulta poco o nada accesible. Puede decirse que el señor Lazcano Tegui cultiva brillantemente la oscuridad literaria. Dice cosas con tan abstrusa combinación de imágenes y vocablos incongruentes y hasta contradictorios, que sus poesías deben quedar casi siempre solo comprensibles para él. Pero de cuando en cuando la visión se aclara, el instrumento se afina y surgen hermosos versos que atestiguan la existencia en el autor de un temperamento de poeta, oculto por su propia extravagancia como bajo un disfraz arlequinesco" p. 157. Lo considera ingenuo en su propósito de asombrar a los burgueses.

En nota al pie se comenta que, al cierre de la edición, la aparición de Blasón de plata de Ricardo Rojas, que será criticada en el número siguiente.

\section{FALTA TRANSCRINIR NOTAS Y COMENTARIOS}

\section{Año VI, tomo VIII, nº 42, julio 1912}

Prólogo al Nerón de Agote...... Osvaldo Magnasco pp. 169-186 [seguido de una ilustración p. 187-188]

Otoño de Albert Samain.......... Edmundo Montagne p. 189 [no se sabe si es una traducción]

El mito de Narciso......... Paul Adam pp. 190-201 Teatro [traducción de Juan Más y Pí]

El momento heroico...... Julio Noé pp. 202-208.

Versos....... Armando Ibarlucía pp. 209-210 [La pobre abuela, De luto, Alegría exterior]

El crepúsculo...........Carmelo A. Bonet [dedicado a Carlos Obligado]pp. 211-214

Los orígenes argentinos........ Mariano Antonio Barrenechea [sobre la obra de R. Levillier] pp. 215-220 En secreto.........Pío Pandolfo pp. 221-222

El asceta del teatro. Ferruccio Garavaglia............ Angelo Rigghianti pp. 223-227 [con motivo de la muerte del actor italiano, se reproduce, traducido, el artículo de la revista Rassegna Nazionale]

Letras argentinas...... Alvaro Melián Lafinur pp. 228-237

Crónica musical.......Juan Pedro Calou pp. 239-241.

Pepito Arriola........ A. A. B pp. 242-244

Nosotros.......... La dirección pp. 245-246

Indice del tomo ...........pp. 247-248

El momento heroico, Julio Noé, pp. 202-208

Este artículo es importante porque insiste en el carácter hegemónico del debate acerca de la nacionalidad, cuya construcción es considerada por Noé como indispensable. Italia aparece como caso ejemplar. Dice Noé: "El ejemplo que nos da la campaña italiana de ultramar no puede ser más admirable, ni significativo. El nos confirma una nacionalidad, una política y una aspiración: la nacionalidad que se formará al calor del más alto patriotismo, la política mesurada e inteligente que siguiera a aquella unidad y la aspiración imperialista de un pueblo que, seguro de su voluntad de potencia, quiere templar en una guerra fácil su espíritu heroico.

Tal movimiento no puede ser observado con escepticismo. El pasado de Italia significa algo más que vulgar sucesión de acontecimientos históricos; en cuanto a su futuro, fuera empresa vana e injusta el no constatar su inteligente preparación. (...) 
Ahora la [a Italia] observamos en su momento heroico, definitivo en su vida política. Se está formando una nueva conciencia nacional, latina en el fondo, racionalista en sus manifestaciones exteriores, que se cristaliza uniformemente y da los resultados más admirables" p. 202.

Señala, en ejemplos concretos de intelectuales, la posibilidad de conciliar nacionalismo y socialismo. Los teóricos son Rossi -Doria, Ferri y Antonio Labriola.

Letras Argentinas, por Álvaro Melián Lafinur, pp. 228-235

Blasón de Plata. Meditaciones y Evocaciones sobre el Abolengo de los argentinos, de Ricardo Rojas, Transcribimos algunos de los pasajes del escrito. Melián coincide con un aspecto de la semblanza que años más tarde hará Giusti sobre el autor, respecto de la postura vatídica que adopta en sus afirmaciones. Este texto de Rojas, como observa Melián, constituye una intervención respecto de la construcción de la identidad nacional que se agrega a las otras previas del autor.

"El señor Ricardo Rojas aparece a través de su ya copiosa obra literaria como un pensador a quien preocupan los problemas de su raza y de su patria.

La naturaleza le ha dotado de un temperamento vigoroso como el quebracho de su selva santiagueña. Una fuerte voluntad anima su ser. La vitalidad de su espíritu expándese en enérgicas vibraciones. Solidario con lo humano y con lo más íntimamente ligado a sí como es la tierra en que ha nacido y los hombres nacidos en esa misma tierra, el escritor Rojas ha consagrado su esfuerzo a una determinada prédica idealista y patriótica, que él conceptúa con razón la más noble tarea para un intelectual de este país en la época presente.

(...)

Desde luego, la orientación del señor Rojas presupone un espíritu tan lejano de todo escepticismo, que casi raya en el extremo opuesto, o sea el fanatismo de sus ideas directrices, del que lo preservan, no obstante, el ejercicio mental que implican sus hábitos de estudioso y la solidez y variedad de su cultura.

Desde La Victoria del Hombre mostró el autor el fondo de su alma optimista y creyente, en el sentido que debe tener esta palabra sin referirse a determinada religión. Poseído de un sentimiento vagamente panteísta, heliólatra fervoroso que ama a la naturaleza y a la vida y confía en ellas, su fe en la humanidad y en la patria, comunica a su ritmo y a su estilo, que en él 'es todo el hombre', el ardimiento entusiasta de convencido y de apóstol que late en los períodos armoniosos y rotundos de su prosa. Ya la penetración simpática de ese gran espíritu que se llama Emilio Becher, supo calificar al de Rojas, a propósito del poema citado, de 'netamente religioso en la aceptación más noble y menos usada de la palabra'. Y yo creo ver en él, ante todo y más que todo, a un poeta con algo de visionario y de místico, en quien la inquietud del misterio pone a veces un toque de superstición.

(...)

Una confianza ilimitada en sí mismo, lleva al señor Rojas a exagerar la seguridad en su palabra y en su gesto que resultan a veces demasiado categóricos. Su manera de afirmar es una característica defectuosa en un talento que precisamente por su educación, debiera reconocer que hay cosas que no pueden ser objeto de aserciones rotundas, y que es conveniente dudar un poco a veces de nuestras representaciones. Mi verdad es la verdad, parece ser el postulado que fluye de la obra y la persona de Rojas. Suele asumir en sus libros posturas vatídicas y ademanes de hierofante y todo ello es producto de su individualidad apasionada, impetuosa y llena de fe en sus creencias y en su esfuerzo.

(...)

Blasón de Plata continúa la corriente de ideas iniciada, por La Restauración Nacionalista en cuanto su objetivo es suscitar el sentimiento de conciencia nacional por la contemplación de la tradición, la solidaridad íntima con el pasado y el conocimiento de la tierra natal. Pero la primera, siendo su base un informe sobre educación, tenía un carácter más circunscripto y concreto: se trataba de restaurar el sentido nacionalista por la enseñanza de la historia. Esbozaba ella en consecuencia un plan, un programa. En Blasón de Plata henchido del mismo sentimiento y persiguiendo idéntica finalidad, el pensamiento del autor tórnase empero más complejo y de proyecciones más vastas. El señor Rojas se propone realizar aquí la intrahistoria, la historia espiritual de la patria, desde los orígenes de la nacionalidad, que en su sentir nació, propiciada su emergencia y desarrollo por una fuerza misteriosa y tutelar, como quien dice 'por un decreto especial de la Providencia' si es dado emplear con respecto a una nación las palabras de Renan a propósito de Hugo. El Sr. Rojas ve en el mito argénteo del estuario 
epónimo una revelación del destino de nuestra patria. 'Tal ha sido, dice, la leyenda heráldica del solar donde se generó nuestra estirpe; las aguas del gran río la bautizaron con su nombre argentino, [resaltado en el original] ellas fecundaron su pampa o ritmaron su historia, y desde la génesis del destino, todo fue presidido por el auspicio de la generosa quimera fluvial'. 'El encanto de la leyenda originaria, continúa, se ha desvanecido para el propio pueblo que recibió de ella su nombre. Restaurar nuestro Blasón de Plata con el testimonio de los viejos cronistas, en el momento en que ese pueblo afirma su conciencia colectiva, e interroga su porvenir, es obra de verdadero indianismo, ya que tuvo la suerte de reunir cuna, bautismo y augurio en cosa tan estable como este occidente de su propio territorio'.

Lo que hace interesante y significativa la obra del señor Rojas no es precisamente el elemento histórico o científico que pueda haber en ella, aunque su autor la haya disciplinado y haya buscado su documentación 'por cierto escrupulosa' — según manifiesta el prólogo, - en la historia, la ética, la sociología o la política. Fincan en todo caso ese interés y esa significación en la original visión global o sincrética del autor, en su interpretación mística de los acontecimientos y de las leyendas que los deforman o magnifican. La recapitulación histórica en sí misma, es cuestión de erudición al respecto, que prueba, eso sí, prolijos estudios americanistas.

(...)

Así pues el valor y la belleza de Blasón de Plata está en la concepción poemática que los mitos, y la 'contemplación de los paisajes natales', han tenido la virtud de suscitar en el poeta, infundiéndole el arrebato y la emoción lírica que cantan en su libro.

(...)

No podría encararse así, por cierto, una obra exclusiva y científicamente histórica, pero sí una de esta naturaleza que el autor mismo considera ni conceptual, ni doctrinaria, ni didáctica, sino 'un libro de pura emoción que como los libros heráldicos, reavivase por la leyenda o la historia, el orgullo y la fe de la casta'.

(...)

La volición social que impulsa al señor Rojas en su apostolado, tiende, pues, acertadamente a actuar sobre el sentimiento. Busca producir y afianzar la solidaridad racial, la conciencia territorial que dé a los argentinos la cohesión y comunidad de ideales necesarios para constituir la verdadera patria."

-Versos de amor, por Arturo Giménez Pastor

El autor es presentado como un autor dramático que "no ha dedicado especialmente ni siquiera regularmente su actividad literaria a la poesía" y por lo tanto la obra no es la de un poeta.

\section{Nosotros}

"Con este número termina una etapa más de la vida de Nosotros. Perseverante en la empresa de dar al país una revista a la vez ágil y seria, en que todas las variadas manifestaciones de nuestro mundo intelectual tengan un eco y un comentario, y aleccionados por una experiencia de estas cosas que ya comienza a ser larga, hemos resuelto inaugurar el sexto año de existencia con una completa transformación de la revista" p. 245 Se continuará la serie de modificaciones proyectadas a saber: la "mayor estabilidad y amplitud" de las secciones permanentes de letras argentinas, españolas, americanas, bellas artes, música y teatro nacional, a partir de la presencia de críticos de renombre; la creación de nuevas secciones que tenderán a "hacer de Nosotros el fiel espejo de todos los múltiples aspectos de la vida argentina"; incrementar la variedad y la amenidad en la publicación de novelas, cuentos, y dramas nacionales. Se aumentará en número de páginas a 120, papel más delgado, letra más chica, pero a igual precio. Todo esto tiene que ver con la reestructuración de la revista que deja de ser administrada por la casa Francisco Albasio y cía., para constituirse en una sociedad anónima.

Año VI, tomo 9, n $^{0}$ 43, noviembre, 1912 [La revista sale después de tres meses de ausencia] A nuestros lectores......... La dirección pp. 5-7 Inglaterra y Francia juzgadas por un inglés.............. Eça de Queiroz pp. 8-18 [traducido por R. Giusti] Protesta......... Rafael Obligado pp. 20-21

Goya o el pintor exasperado......... José María Salaverría pp. 22-24

La Nena. Boceto dramático en un acto.......... Clelia della Costa pp. 26-44 
Huracán patagónico............. Eduardo Talero pp. 45-46

Una vida como muchas............ Adán C. Diehl pp. 47-49

Evaristo Carriego............. pp. 51-57 [discursos con motivo de la muerte de E. C] p. 50 Dibujo de E. C

Poesías inéditas Evaristo Carriego pp. 58-59

Primera encuesta de Nosotros...............pp. 60-61 [¿Es más culta la mujer que el hombre en nuestra sociedad?]

Letras argentinas .......... Álvaro Melián Lafinur pp. 62-73

Letras españolas............ Juan Más y Pí pp. 74-77

Pintura y escultura......... Manuel Gálvez 78- 95

Crónica musical............ Juan Pedro Calou pp. 96-102

La demostración a Roberto Levillier.........pp. 103-110

Notas y comentarios.

pp. 111-112

\section{A nuestros lectores pp. 5-7}

En agosto de 1907 fundamos Nosotros. Fue bien acogida por el público, los escritores y la prensa. Encontró valiosos colaboradores en la República, en América, en España; no le faltó nunca la atención del núcleo reducido pero alentador de lectores, y la prensa le prestó generosamente todo su apoyo. Son conocidas, sin embargo, las dificultades con que en nuestro ambiente debe luchar una revista exclusivamente literaria: después de combatirlas bravamente durante tres años, Nosotros tuvo que ceder. Al poco tiempo volvió a aparecer y a empeñar la lucha con renovados bríos, y tuvo que rendirse una vez más ante la tenaz oposición de la realidad, con todos sus compromisos materiales. Ante este segundo fracaso de una iniciativa desinteresada si las hay, hemos visto claro en la cuestión. hemos comprendido que a nada estable se llegaría, si antes de resolver el problema espiritual de la revista, como órgano de cultura y de hermanamiento intelectual, no se resolvía en una forma enérgica y decisiva, el problema de sus sostenimiento material.

Creemos haberlo resuelto. A tal objeto se ha fundado la Sociedad Anónima Cooperativa Nosotros, destinada a asegurarle a la revista una existencia duradera. El entero directorio de la Sociedad, y el nombre de su presidente, Rafael Obligado, es la mejor garantía de la seriedad de la empresa, única por su carácter, creemos, en los anales del periodismo argentino, empresa de poetas que se han dado cuenta de que también para realizar una obra idealista conviene proceder con el código en una mano y un fajo de billetes de banco en la otra.

Nosotros vuelve a parecer con un nuevo formato, que la hace más elegante y manuable, y aumentada en sus páginas y en su texto. Su programa es el mismo de siempre. Seguirá teniendo por invariable norma de conducta la imparcialidad. Ello quiere decir que la revista continuará abierta a todas las opiniones, literarias, artísticas políticas, filosóficas, religiosas. Nosotros no conoce enemigos, y tampoco -declarémoslo valerosamente- conoce amigos, si por tales han de entenderse protegidos y apadrinados. Que cada cual, si desea criticar, si necesita defender o defenderse, lo haga con su pluma y bajo su firma, caballerescamente, que la revista no ha de cerrarse a ninguna opinión.

Respecto a lo que daremos a nuestros lectores, no queremos adelantar promesas, porque no queremos fijarle límites al incesante progreso de la revista. Sin salirnos de las líneas que su carácter netamente literario le determina; sin olvidar que Nosotros, de acuerdo con su programa inicial, ha sido fundada para todos, no solo para los escritores ilustres, sino también para los principiantes oscuros, que sepan manejar gentilmente su pluma, trataremos de dar a sus páginas el mayor interés y la mayor amenidad posibles, aligerándolas de toda carga pesada, y haciéndolas vivas, ágiles, movidas. Prestaremos especial atención a la producción dramática y novelesca; mantendremos al corriente a nuestros lectores, mediante las respectivas secciones que serán puntualmente atendidas por distinguidos críticos, de cuanto suceda en la República en el orden social, artístico y literario, sin descuidar a América y a España; amenizaremos cada número con concursos, encuestas, noticias y anécdotas referentes a nuestro pequeño mundo intelectual, hasta lograr que ninguna nota del pensamiento nacional deje de hallar en Nosotros su eco y su comentario.

Pero, lo repetimos: no queremos prometer; queremos hacer. Confiamos en no defraudar las esperanzas de nadie. ¿Podemos a nuestra vez esperar que no ha de faltarnos el apoyo de quienes hasta ahora nos han acompañado?

Para todos, nuestro saludo afectuoso; para la prensa nuestro agradecimiento profundo: sin su amistosa ayuda no habríamos podido jamás hacer ni una mínima parte de cuanto hemos hecho." 
Evaristo Carriego, pp. 51-57

La dirección destaca que Carriego es un escritor ampliamente leído. "¿Quién no había leído a Carriego? Nadie, entre nuestros poetas cultos, artistas, le superaba en popularidad. Sus versos sencillos y henchidos de sentimiento habían entrado con Caras y Caretas en todos los hogares" p. 51.

El discurso de Juan Más y Pí lo señala como el que ha encontrado "la unidad moral del bajo fondo argentino".

Las poesías reproducidas son: "Has vuelto..."; "A Carcavallo".

Letras argentinas

Álvaro Melián Lafinur pp. 62-73

-Nerón. Los suyos y su época, por el doctor Luis Agote

-El espejo de la fuente, por Rafael Alberto Arrieta

La obra es elogiada en los siguientes términos: "Una pureza de expresión, exenta de toda frondosidad artificiosa, una emotividad serena, un sentimiento hondo del paisaje, una admiración ingenua ante las cosas, y de cuando en cuando una melancolía dulce y resignada, tales son las modalidades que definen la poesía de este autor, quien por la sinceridad y belleza de su obra, cuenta entre los mejores poetas de la última generación" p. 64 .

-Melpémone por Arturo Capdevilla, Córdoba.

Se trata de poemas "trágicos" en los que según Melián Lafinur "pasa como un soplo el pathos griego" p. 68

-Las barcas del ensueño, por Arturo Orgaz, Córdoba

El crítico señala que se trata de un libro que no debió publicarse porque el autor "no domina el verso" y su gusto no está todavía formado. libro "desigual, impersonal, baladí" p. 70 Rescata algunos poemas como "Alma mía", "Al alma latina".

-Palmas y yedra, por Arturo Samuel Drew, editado por Honorio Leguizamón y Atilio Enrique Caronno, amigos del poeta ya muerto. Caronno es el autor del prólogo.

-El Arca de Noé. Libros de lectura para segundo y tercer grado, por Julia y Delfina Bunge

- Al ras de los ensueños por Raúl Oyhanarte, La Plata. Señala Melián que "El autor de este libro de versos parece creer aún en las excelencias de la declamación y de la hipérbole, como asimismo que formar verbos y pluralizar ciertas palabras es siempre una virtud literaria" p. 72 .

Letras españolas pp. 74-77

-El mundo es ansí, por Pío Baroja. Rescata la vuelta a la picaresca, al relato de aventuras, como camino alternativo "del ciencicismo a la moda", "sin preocupaciones sabias", tiene el "encanto de lo vivido" Conjuga lo nacional con lo universal.

-Soliloquios y conversaciones, Contra esto y aquello, por Miguel de Unamuno. La primera obra ha sido editada por la universidad de Salamanca. Ambos libros son recopilaciones de artículos publicados en La Nación.

-El deseo, cuentos, por Alberto Insúa

-Cánovas, por Benito Pérez Galdós [episodio nacional]

La demostración a Roberto Levillier, a su regreso de Europa y con motivo de la edición casi simultánea de su Los orígenes argentinos en Francia y en Buenos Aires.

Discursos de Marco Avellaneda y del autor

Avellaneda remarca la oportunidad del libro de Levillier y destaca "la probidad y el método científico usado". Sostiene: "Señores: el libro de Roberto Levillier no puede llegar en hora más propicia. En este momento en que el arado y la res productiva nos abren los mercados del mundo y atrae[n] sobre nosotros la curiosidad que inspiran los advenedizos, los recién llegados, es oportuno referir gallardamente, en idioma de asegurada difusión, suave como la seda, flexible como una cota de malla, referir la formación de un pueblo, de un gran pueblo que no ha imitado a los héroes de Homero que entraban al combate proclamando su genealogía y alabando su valor, sino como aquellos paladines de la Edad Media que luchaban con la visera del casco calada y solo después de la victoria, recién mostraban sus blasones

El momento es, pues, oportuno no solo para cambiar no solo productos del suelo y de la industria, sino también la flor de virtudes nacionales y la esencia de pensamientos propios; para 
establecer la filiación de nuestras costumbres y riquezas, reconstruir el pasado, examinando orígenes, condiciones de ambiente y la evolución del espíritu argentino habituado a respirar la atmósfera de las cumbres." p. 105.

Notas y comentarios

-Muerte de Diego Fernández Espiro [poeta] 21/10/1912

-Viajeros: regresan de Europa Julio Noé [No ha hecho el pedantesco 'viaje de estudio'] y Florencio César González, director de la revista Renacimiento que luego de una breve interrupción reaparecerá en París, desde 1913, editada por la casa Ollendorf

-Consignan haber recibido el manifiesto de una revista de próxima aparición en París, titulada Ariel, bajo la dirección de Alejandro Sux.

Año VI, tomo 9, n $^{\circ}$ 44, diciembre, 1912

La evolución de la música. Carta al doctor Miguel Cané ....... Mariano Antonio Barrenechea pp. 113-334

El hallazgo de sí........... Enrique Banchs p. 135

Dibujo de Juan Pablo Echagüe por Ríos p. 136

Los cubistas y arte nuevo...... Juan Pablo Echagüe pp. 137-141

Mariano Moreno........... Enrique García Velloso pp. 142-163

Mi novia............... Carlos Obligado pp. 164-165

Un problema eterno. Un capítulo de El pensador... Pedro Sonderéguer pp. 166-170

La parábola del hombre que poseyó la lámpara............ Víctor Juan Guillot pp. 171-174

La conquista. Comedia en tres actos de César Iglesias Paz............ Carmelo Bonet pp. 175-178

El "croniqueur" poeta........ Antonio Burich pp. 179-181 [Sobre Gómez Carrillo]

El medallón....... Luis Matharán Aguerre p. 182

Alejandro Bustillo (primer premio del salón Nacional) [caricatura]....... Cancalón p. 183

Nuestra encuesta........... pp. 184-198

Letras argentinas....... Álvaro Melián Lafinur pp. 199-203

Letras americanas.........Álvaro Melián Lafinur pp. 204-210

Letras españolas...... Juan Más y Pí pp. 211-213

Teatro Nacional........ Manuel Lugones pp. 214-216

Notas y comentarios........pp. 217-224

La conquista. Comedia en tres actos de César Iglesias Paz, por Carmelo Bonet pp. 175-178

Es importante destacar la diferencia social que hace entre "un éxito de público inteligente" y "un éxito de público arrabalero"; el de la obra de Iglesias Paz corresponde al primero, y va acompañada de un elogio "esquivo y desganado" de parte de la crítica. Es la historia de infidelidad en un matrimonio, en la que finalmente la mujer recupera a su esposo. El autor de la reseña explica lo que cree es el pensamiento del autor: "Las mujeres se casan y creen que el vínculo del matrimonio les garantiza la perpetuidad del amor. Y no se curan de fortificarlo, de mantenerlo vibrante, y se abandonan corporalmente y espiritualmente" p. 176

Letras argentinas....... Álvaro Melián Lafinur pp. 199-203

La voz de la roca, por Arturo H. Vázquez [poemas]

-La lámpara de arcilla. Nuevos poemas de Fernán Félix de Amador

Este poeta reside en París, se dice, como Ugarte. Autor de El libro de Horas

-Libro sentimental, por A. Fernández García. Libro desparejo

- La Pirunga. Novela romántica de Enrique Mouliá, con prólogo de Víctor Juan Guillot.

- Argentina y la conquista del río de La Plata, por Martín del Barco Centenera. Editado por Ángel de Estrada y cía. se trata de una edición facsimilar.

-Papeles viejos. Librería "La Facultad". La revista ha recibido como regalo una colección de facsímiles de todos los periódicos publicados en Argentina desde 1801 hasta 1872. Son 98 grabados que reproducen la primera página de cada publicación y el libro tiene un estudio de J. a Pillado "la imprenta y los diarios antiguos en la Argentina". p. 203. 
Letras americanas

- Por la vida abajo, por Jorge Mateus. Versos. [colombiano y amigo de Pedro Sonderéguer]

- Vidas y obras (estudios de crítica), por Amadeo Almada (Montevideo)

Reunión de artículos sobre distintos autores entre los que se cuentan rodó, Sánchez, Ángel Falco, Manuel Ugarte. Se plantea un desacuerdo con el programa crítico de Almada, quien sigue a Sainte Beuve, Taine y sus sucesores, lo cual lo obliga a hablar sobre el medio, la psicología del hombre, su biografía antes de llegar a la obra.

-Alucinaciones de belleza, por Emilio Oribe, Montevideo. Poemas.

-El pájaro azul, por Maurice Maeterlink. Versión castellana de Roberto Brenes Mesén (tomo 20 de la colección Ariel)

-Poesías escogidas, por Ismael Enrique Arciniegas (tomo 21 de la colección Ariel)

-Los libros de producción latinoamericana.

Ensayo de Antonio Miguel Alcover, jefe del Archivo Nacional de La Habana, sobre la expansión comercial de tales libros dentro del continente.

-La casa abandonada, por Pedro Prado, Santiago de Chile

Parábolas y ensayos.

Teatro Nacional........ Manuel Lugones pp. 214-216

Nacional

La echarpe de miss Silvia, comedia en tres actos de Camilo Muniagurria

Se trata de un tipo de comedia poco cultivado en Buenos Aires: "A la inversa de su [del autor] procedimiento habitual, no es ya la magnitud del argumento buscado lo que dará fuerza a esta obra, sino las observaciones que el ingenio del autor sepa sacar a la trivialidad de los acontecimientos vulgares. Género difícil, indudablemente" p. 214. Se sigue observando la crítica a los géneros menores, y en este caso tal crítica se centra en los actores: "Agréguese a ello [a la dificultad del género] el peligro de confiar comedias 'habladas' a actores que, como los nuestros, no han aprendido a estarse quietos en escena. Recuérdese que los éxitos del año, El malón blanco y El minué federal, han sido lo que en la jerga teatral llaman obras de gran movimiento" p. 214

Y continúa Linnig en un ataque a la originalidad de la obra: "El propio autor confiesa que la obra es tomada de un cuento extranjero, que no conocemos. Su argumento es trivial y socorrido. La menos perspicaz de las lectoras de la biblioteca de La Nación podría citarnos inmediatamente muchos argumentos similares, pero, justo es reconocerlo, si el autor recurrió a un tema pobre y que poco da de sí, lo ha hecho con una gran honestidad de recursos. Cualquier profesional de la teatralidad hubiera en su caso 'movido' un vaudeville despampanante. (...) Equivocóse desde un principio su autor al pretender nacionalizar un argumento que no se aviene con nuestra psicología, merced a un cambio de nombres geográficos que choca desde el primer momento" p. 215

\section{-Los que pasan, de Evaristo Carriego}

Define las poesías de Carriego posteriores a Misas herejes como la tristeza de lo trágico cotidiano, al que vincula con Maeterlink [La trilogía de la muerte] y con Ibsen [Solness]. Destaca los personajes y situaciones de Carriego: "la costurerita que dio aquel mal paso; la mirada furtiva hacia la vieja silla, la silla que ahora nadie ocupa, es la mujer otoñal que, contempla la caída de las hojas, evoca su lejana juventud perdida...” pp. 215-216

Lo que más interesa al crítico es la tragedia que asoma entre las palabras de los personajes que hablan "para ocultar lo que pasa en el interior de sus almas" p. 216.

Notas y comentarios

-Encuesta literaria realizada por Juan Más y Pí cuyos resultados se publican en La Razón de Montevideo. La revista publica el texto de la encuesta y la extensa respuesta de Banchs a las preguntas.

"¿Cree usted en la existencia de una literatura verdaderamente nacional?

¿Qué tendencia guía a la generación actual y qué perspectivas ve usted a su actividad artística"

¿Cuál es su opinión sobre la novela y el teatro en el Río de La Plata?

¿Qué concepto le merecen los esfuerzos realizados hasta hoy?"

Reproducimos algunos de los fragmentos de la respuesta de Banchs: 
Banchs sostiene que no existe una literatura nacional, si es que como él piensa, la literatura es el "arte que tiene que expresar bellamente las pasiones humanas" p. 217

"A esta concepción de la literatura como espejo del alma, sucede otra de muy flaco vigor lógico, a mi ver: la que caracteriza a la literatura nacional por la abundancia de los términos criollos. Es esta muy deleznable ilusión con que se confunde la sustancia con la vestidura. (...) Oh! no es posible podar la universalidad de una literatura, ni clavarle las raíces en una limitada tierra con nombre de nación, porque diga 'che', cuando afuera dicen 'tú, o 'misia' en lugar de 'madame'. No hay arte literario construido con arquitectura de palabras solamente (...) Las palabras no coloran en diversos tonos al espíritu íntimo de un arte, ni nacionalizan su profunda armonía, tanto menos nacionalizable cuanto más profunda y pura. Por lo demás, una literatura con tanto engaste de términos locales, es momentánea. Hace setenta años se desconocían en esta tierra la mayor parte de los criollismo que en el momento de hoy hacen cierta literatura criolla. Y es curioso observar que si un novelista quisiera describir una escena sabrosamente local, la del corral de las carreras, por ejemplo, para ser exacto tendría que recurrir a quién sabe cuantos vocablos extranjeros: 'handicap', 'outsider', 'pouliniére', 'flyer', 'écurie'...

¿Y nuestros tipos? ¿y nuestras costumbres? Nuestros tipos y nuestras costumbres no tienen la adultez y la firmeza precisa para dar vigor al roble de la literatura nacional. (...) En ninguna virtud nos hemos distinguido más que otros pueblos para tener el derecho de cantarnos con un himno distinto, un himno de 'literatura nacional'. Ni es aquí la vida tan miserable o degenerada que ofrezca 'ejemplares valiosos' de intensa, de pura, de hermosa fealdad moral. Hay en el ambiente nuestro una mediocridad insípida tan sin carácter que el arte no encuentra interés en sus tipos. Nuestro avaro no tiene el perfil tallado a tremendos golpes del sanguinario judío de la leyenda; nuestro político no tiene la inteligencia ni la perversidad maquiavélicas. ese político es precisamente el prototipo de todos los personajes que encontraría aquí la literatura nacional: un pobre diablo que se busca la vida. (...)

Por fin, señor, cada día que pasa se hace más difícil la formación de una literatura nacional. El mundo se achica, quiero decir, el mundo se comprende, acercando los fragmentos de su espíritu. Las comunicaciones, el progreso las comodidades de la civilización, se penetran mutuamente en todas las regiones formando una sola comunión (...)

Si he dicho que no podría existir una literatura nacional artística, no dejo de reconocer una literatura nacional científica. Es ésta una distinción que pocas veces se hace al hablar de este asunto. (...)

Las tentativas muchas veces esforzadas para fomentar una literatura nacional han concluido entre lamentaciones y anatemas contra este 'infame ambiente', este 'odioso medio', esta 'ciudad mercantilista, sorda u hostil a las manifestaciones literarias'. Como este infame ambiente ha tenido la gentileza de callarse la boca son ya muchos los escritores que se encargan de declarar a sus conocidos que aquí no se puede hacer nada. Este ambiente perro....

Y sin embargo, la proporción del elemento canino en el ambiente es muy discreta y legítima. Aquí se lee mucho, pero el público lee lo que le conviene y no manifiesta un interés muy pronunciado por el triunfo de la literatura nacional. Lee lo que le agrada y en este punto nunca sacrifica sus placeres. El dinero, el tiempo, las convicciones, todo eso sacrificará, pero el placer no. Continuará agotando las ediciones de Maeterlink, Rostand y D'Annunzio y dejará de lado las obras cuyo principal mérito es el de ser argentinas. Cuando nosotros podamos ofrecerle libros de un valor artístico parecido a los de los autores citados y que le causen una emoción tan noble como ellos, ¡ay, del público!, si entonces no favorece a la literatura nacional: tendremos derecho de cruzarle la cara con el látigo de Juvenal... Pero por ahora el público no tiene más culpa que la de querer ser inteligente a ratos y la de ser sincero en sus gustos

-Se anuncia la inauguración en el año siguiente de la primera cátedra de Literatura Argentina en la facultad de Filosofía y Letras, que estará a cargo de Ricardo Rojas.

-Concurso literario para los países hispanoamericanos de Mundial Magazine y Elegancias, revistas editadas en París por Alfredo y Armando Guido, bajo la dirección literaria de Rubén Darío. Géneros del concurso: poesía, novela, teatro, cuentos.

-Se pide a los autores argentinos que remitan los libros publicados a Francisco Contreras, encargado chileno de la sección Letras hispanoamericanas del Mercure de France 
-Julio Noé es el nuevo secretario de redacción de Nosotros y es presentado como "uno de los buenos representantes de la generación universitaria del momento actual" p. 223

-Homenaje al senador Láinez

-Errata correspondiente a Protesta de Rafael Obligado debe decir silbido en lugar de silbo

-Por falta de espacio pasa al número siguiente "Pintura y escultura" (Gálvez)

\author{
Año VII, tomo 9, n 45, enero, 1913 FALTA RESENAR TODO EL NÚMERO \\ La obra de Rodó \\ Pedro Henríquez Ureña pp. 225-238 \\ Poemas \\ José Martínez Jerez, pp. 239-243 \\ Dibujo de Juan Más y Pí \\ Ríos p. 244
}

La muerte de Jesús Eça de Queiroz pp. 245-259

Avenida de Mayo...... Adolfo Korn Villafañe pp. 260-261 [versos sobre los personajes elegantes de Av. de Mayo]

El amor a la verdad. Hans Friedrich [R. Giusti] pp. 262-269

Lavalle y Rosas......... Clodomiro Cordero pp. 270-276 [Carta al dr. Carlos A. Carranza en la que se discute el método y se aboga por la teoría del héroe de Carlyle y por la utilización del método positivo]

El nardo....... José Muzzilli p. 277

Nuestra encuesta............pp. 278-287

Alberto Lagos..............Cancalón p. 288

Pintura y escultura....... Manuel Gálvez pp. 289-294

El año literario........... Álvaro Melián Lafinur pp. 295-297

Teatro Nacional......... Manuel Lugones pp. 298-302

Crónica musical........... Juan Pedro Calou pp. 303-306

El año político............ Roberto Giusti pp. 307-311

La literatura sociológica hispanoamericana........Emilio Ravignani pp. 312-330

Crónica femenina. Niñas de hoy..........Fanny Pouchan pp. 331-336

Notas y comentarios. pp. $337-344$

El año literario Álvaro Melián Lafinur pp. 295-297

Para el crítico se trata de un período satisfactorio pero no brillante. Destaca como obras importante a las que encuadra dentro de la sociología y la historia argentina Blasón de Plata (Rojas), Los orígenes argentinos (Levillier), Los orígenes de la democracia argentina (conferencias de Ricardo Levene), y Documentos relativos a los antecedentes de la independencia de la República Argentina, editados por la Facultad de Filosofía y Letras. Como reedición, se consigna Las multitudes argentinas de José María Ramos Mejía.

El año político............. Roberto Giusti pp. 307-311

Teatro Nacional......... Manuel Lugones pp. 298-302

El subtítulo de la nota es "El año teatral" y comienza con una queja sobre el "momento sociológico actual" que se caracteriza según Lugones por "el afán agropecuario, una afligente pobreza de ideas, fácil de advertir en todas las actividades de la vida nacional" p. 298 Y más adelante insiste: "La intelectualidad se reduce a una deformación estética de la vestimenta corriente, tanto en la ropa como en lo demás"p. 298

Lugones establece una correspondencia entre lo que caracteriza a ese "momento sociológico" y el teatro nacional:

"Nuestro teatro nacional es un fiel reflejo de esa pobreza espiritual de nuestro tiempo.

Habiendo alcanzado mayor desarrollo que los demás géneros literarios, por su más fácil difusión y su resultado práctico inmediato, es quizás el que más nítidamente refleja esa característica argentina..

Era por lo demás un género que estaba llamado a tener entre nosotros la difusión que ha alcanzado hoy. nada más accesible a las mediocridades que el teatro y el verso. Para ambos es fácil hallar moldes mentales, que evitan pensar y que no son dificultosos de llenar. La gente de teatro ha 
monopolizado desde hace años nuestro mercado literario y, sin embargo, no ha dado hasta ahora otro nombre prestigioso que el de Florencio Sánchez, un precursor.

Mucho se esperaba para el año 1912. El gran número compañías nacionales, las direcciones artísticas confiadas a personas de nombre en los círculos teatrales, la excesiva demanda de obras, todo hacía prever un año laborioso y fructífero. Sin embargo el balance no le es por cierto favorable." p. $299(\ldots)$

"Con todo, sería injusto negar a nuestro teatro la selección alcanzada dentro de su propia mediocridad. Una evolución progresiva, aunque lenta, va dignificando su medio ambiente al mismo tiempo que permutando falsos valores inflados a base de una crítica complaciente y de camaradería. Nada ha sido más pernicioso para nuestro teatro que esa crítica parcial que, apoderada de los grandes diarios, impone dictatorialmente desde sus columnas el éxito de las mediocridades, negando el pan y el agua a todo aquel que pretende surgir sin haber ingresado antes al círculo predilecto de los elegidos. (...)

La pobreza de ideas ha caracterizado a nuestro teatro en el año pasado. Sobre todo de ideas que respondan a nuestra alma nacional. Los autores han buscado temas generales, como la trata de blancas, que tanto ha seducido a nuestros autores, o bien han ido francamente a problemas aislados anotados ya al margen de las crónicas de policía, ya en las entrelíneas de los estudios clínicos. Los más han reeditado! y quién sabe hasta cuándo! el eterno argumento de La gringa

Una reacción saludable contra este estado de cosas se ha iniciado ya, tratando de llevar el regionalismo a nuestro teatro, es decir, procurando buscar otro ambiente que el cosmopolita de esta capital.

Sánchez Gardel, que lo iniciara antes, ha insistido en esa brecha y es de anotar también el ensayo de Weisbach. Desviada así la corriente de nuestro teatro hacia un escenario más vasto, es de esperar una mayor nacionalización y acaso también una mayor potencialidad ideológica.

La obra del año ha sido sin duda ensayo de tragedia de Sánchez Gardel La montaña de las brujas, primera parte de una trilogía regional. (...)

La comedia y el drama nos han dado también obras de mérito. El malón blanco, de Martínez Cuitiño, cuyo éxito mímico es innegable y en el que la influencia de Bracco es indiscutible, no nos convence. En cambio, no podemos dejar de aplaudir la fina labor de la obra de Iglesias Paz, La conquista, así como también El festín de los lobos, de Roberto Cayol. En la comedia y en la comedia dramática la influencia de Benavente y los Quinteros se precisa. En las dos comedias citadas se dibuja netamente la manera del autor de La noche del sábado. Escenas de los Quinteros se advierten hasta en los sainetes lunfardos... Sin contar con esa fiebre de poemitas sentimentales a la manera del de Amores y Amorios..." pp. 300-301

Lugones se refiere al escasamente cultivado género de "las reconstrucciones históricas" al que califica de productivo: "El triunfo de El minuet federal debe tentar muchas ambiciones. Lástima que nos exponga a obras como La loca de la guardia" p. 301

Inmediatamente después se ocupa de lo que incluye en el que bautiza como "género ínfimo". Este incluye, según Lugones, "zarzuelas en un acto, sainetes, revistas", y es definido como "hijo directo del género chico español" con sus mismos "vicios". Y así los enuncia: "Guarango, soez, disparatado, es un género que no puede durar. Por lo demás, da poco de sí. Obras tan disparatadas como Fresco el andarín, el éxito de la compañía Podestá Vittone, no hacen por cierto honor a ningún teatro. Creemos justo, sin embargo, librar del merecido olvido en que han caído la mayoría de esas obras a la revista Los ilustres gatos, ensayo meritorio que no tuvo por cierto el éxito que le hubiera correspondido dada 1 inferioridad de las obras con que alternaba en el cartel.

Curiosa repetición. Después de más de un siglo, el sainete, nuestro primer género nacional desde los tiempos de la colonia, incurre en la misma característica: la guaranguearía. Cambiando en italiano el vilipendiado portugués de nuestros abuelos, sirve de base a los consabidos disparates escritos en lunfardos inverosímiles, ya ensayados en aquellos tiempos... Y es de lamentar que género tan inferior lleve al fracaso a trabajadores tan asiduos como Pacheco, que inútilmente trata de alcanzar trata de alcanzar la comedia, monopolizado por su manera característica, y Alberto Novión, que parece haber abandonado el sainete en pos de obras de mayor aliento.

La zarzuela no tiene mayor arraigo entre nosotros, quizá por falta de elementos que la representen. Es fácil advertir en la urdimbre de las pocas con que contamos, el número musical de 
quita y pon, que no atañe mayormente a la obra. La opereta tan, en boga, tuvo también su muestra en Espuma de mar, una linda opereta del maestro Obiglio.

Tal es el resumen del año. Para completarlo nos faltaría agregar una palabra de condenación para los obscenos arreglos de vaudevilles franceses que cultiva la compañía de don Florencio Parravicini, pero preferimos omitirla, ya que ese género dudoso mal puede considerarse nacional.

Nuestras compañías -harto numerosas para la eficacia de sus conjuntos,- han dado de sí cuanto ha sido posible para la presentación escénica de las obras, no así en cuanto a interpretación. En el fondo de cada artista nacional hay un alma de primer actor que lo imposibilita para educarse progresivamente. Viven aún bajo el imperio de la intuición. ¿Y los directores artísticos?...

No obstante las observaciones apuntadas y lo adverso de nuestra opinión, creemos realmente en el progreso de nuestro teatro y abrigamos la esperanza de verlo respetable y floreciente antes de mucho. Yodo es cuestión de tiempo y de trabajo" pp. 301-302

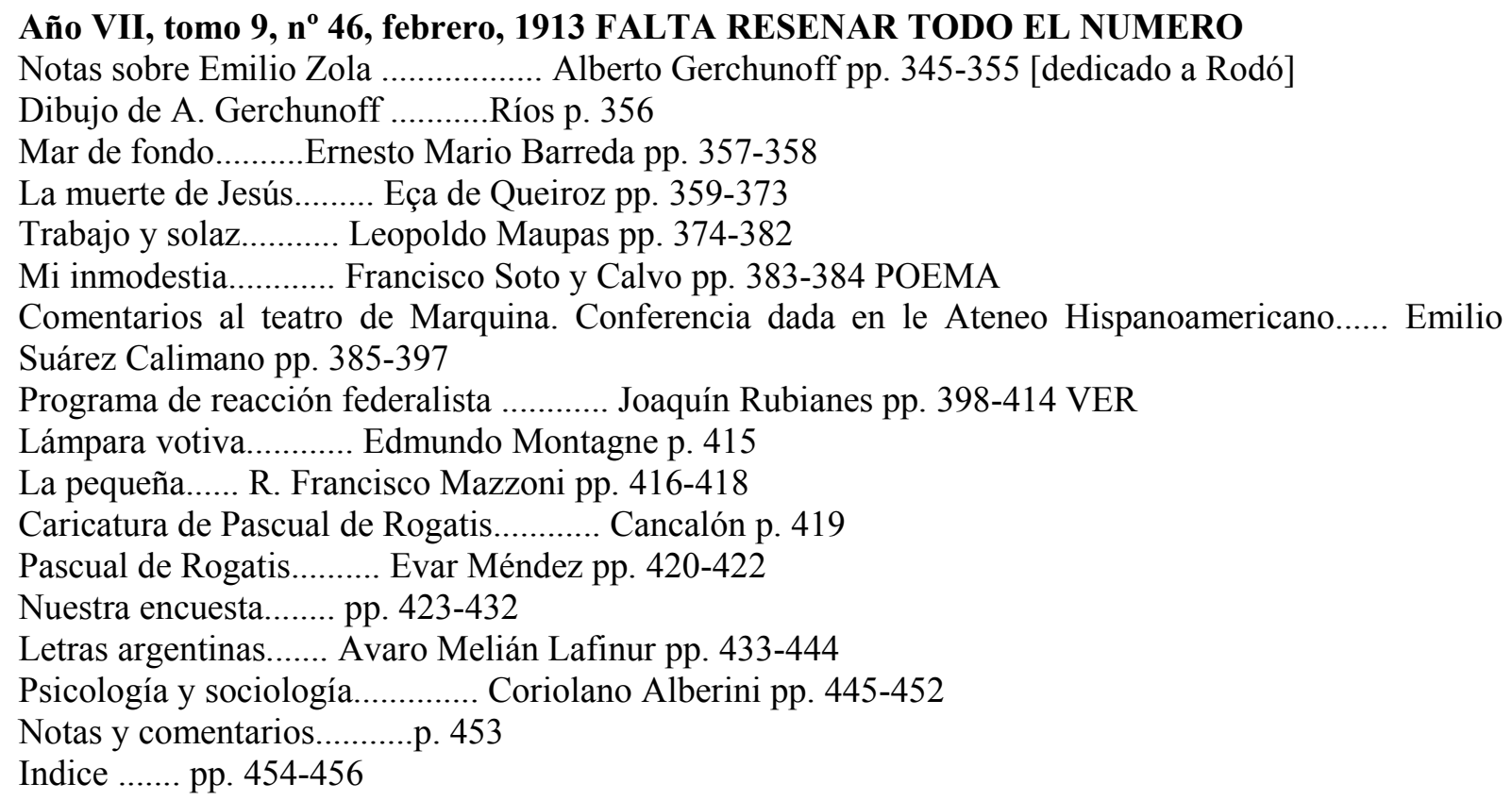

Comentarios al teatro de Marquina. Conferencia dada en le Ateneo Hispanoamericano...... por Emilio Suárez Climano, pp. 385-397

La nota importa porque insiste en una perspectiva "nacionalista", que en este caso se manifiesta en lo que se señala como positivo del teatro de Marquina. Así se valora la voluntad de construir un ideal nacional por medio del arte: "Hace diez años, Marquina confesaba al notable escritor argentino José León Pagano la falta de un ideal nacional en España, tras el que pudiera encauzarse y levantarse la poesía española, doliéndose al mismo tiempo de que el florecimiento romántico nada dejara de consistente y persistente, por inspirarse en la tendencia retrógrada y haberse gastado en fuegos de artificio.

En los años transcurridos, Marquina ha puesto remedio a ello, y por mi fe que lo hiciera con gallardía. El ha levantado en la escena voces que han dicho como en los buenos tiempos, porque de ellos son, del honor y la justicia y la patria y el amor, comenzando así a crear ese estado de alma nacional determinante de aquel ideal nacional que el poeta echara de menos y sobre el cual ha de levantarse la necesidad de nuevas empresas, como se levanta en los campos tras la borrasca que los abatiera, trinar de pájaros y perfume de flores, asegurando la eternidad de la gestación y de los partos... Surgen sus evocaciones con potencialidad de realidades y las viejas figuras que encarnaron toda la grandeza de momentos históricos culminantes, así redivivas, vienen a infundir la emulación y a marcar el derrotero." p. 393 
Año VII, tomo 10, $n^{\circ} 47$, marzo, 1913

Introducción al estudio de Juan Montalvo. José Enrique Rodó pp. 5-19 [p. 19 es un dibujo de Rodó hecho por Ríos; capítulo de El mirador de Próspero] CRITICA

Balada. En elogio del poeta Eugenio Díaz Romero. Rubén Darío pp. 20-21

La muerte de Jesús

Eça de Queiroz pp. 22-35

Un saludo. Enrique Banchs p. 22

Heráclito Jorge Cabral pp. 23-53

Recuerdos del tiempo viejo. Los entierros en Buenos Aires Baltasar Moreno pp. 54-58 [se consigna el pseudónimo del autor: Mefistófeles]

Poesías Juan Aymerich pp. 59-61 [dedicadas a Alberto Arrieta]

Rhodopis (primer capítulo de una novela). Eloy Fariña Núñez pp. 62-71

Palingenesia.................. W.W [¿?; sobre un libro de versos de Ricardo Gutiérrez] pp. $72-76$ [contra la "pose parisiense, decadente, montmartrista" que se imita en las composiciones]

Sala antigua..............Pedro Miguel Obligado pp. 77-78

Letras argentinas.............Álvaro Melián Lafinur pp. 79-87

Letras americanas........... Álvaro Melián Lafinur pp. 88-91

Sociología.............. E. Duprat pp. 92-96

Teatro nacional..........Evar Méndez pp. 97-104 [incluye dos caricaturas de Ríos, una del autor Felipe Sassone y los principales actores de su obra El miedo de los felices, otra de Arturo Giménez Pastor]

Notas y comentarios. pp. $105-112$

Letras argentinas Álvaro Melián Lafinur pp. 79-87

-El libro fiel de Leopoldo Lugones

A excepción de algunas composiciones, el libro es considerado "poco interesante y casi siempre inferior de lo que esperábamos" p. 79. Y prosigue: "El conjunto ofrece, por lo demás, las mismas cualidades y defectos que caracterizan la poseía de Lugones: sugestivo poder de evocación, riqueza de léxico y de imágenes, estructura musical, sorprendentes hallazgos de analogías imprevistas de donde surge la metáfora insólita tan feliz casi siempre, y por la otra parte, obscuridad, extravagancia y prosaísmo" p. 79.

-La leyenda del sol, de Rómulo D. Carbia

Libro que se funda en lo helénico

-Ritmos de Enrique Rivarola

Libro de versos escrito a la manera de Núñez de Arce.

-Ataúdes, de Miguel di Carlo

Libro de versos con prólogo de Juan José de Soiza Reilly. Se habla de él en términos de "ingenua espontaneidad"

-The crime of the war, by his Excellency John Baptist Alberdi, London, 1913

Letras americanas, por Álvaro Melián Lafinur, pp. 88-91

-La hermana agua, por Amado Nervo [poema]

- La vida humilde, por Vicente Salaverri [español] Libro de cuentos breves "que denotan un temperamento artístico de recia contextura, depurado en el estudio de la vida y afinado en la sutil observación psicológica. Vibra en ellos la realidad y sangra el dolor (...) Sobrio en la narración, suele sorprender su aptitud para encerrar en dos páginas tan sólo (...) toda una tragedia punzante de verdad" p. 89 Lleva prólogo de Juan José de Soiza y Reilly.

- Vida criolla (la novela de la ciudad) por Alcides Arguedas [boliviano]

- Colección Ariel (tomos 22, 23, 24 y 25), dirigida en Cota rica por Brenes Mesen. Uno de los objetivos de la colección es reproducir "trabajos breves de autores americanos". Uno de los tomos está dedicado a Lugones y en él se publican La voz contra la roca, La política y los pueblos, y trabajos extraídos de Las fuerzas extrañas y de Los crepúsculos del jardín.

Letras americanas FALTA TRANSCRIBIR

Sociología por E. Duprat 
Se ocupa de Gaston Richard, específicamente La sociologie géneral et les lois sociologiques, editado en París por O. Doin e hijos, en 1912. [volumen de la Bibliothèque de Sociologie]

Teatro nacional..........Evar Méndez pp. 97-104 [incluye dos caricaturas de Ríos, una del autor Felipe Sassone y los principales actores de su obra El miedo de los felices, otra de Arturo Giménez Pastor]

Se repasan las obras estrenadas

-El miedo de los felices [drama en tres actos] de Felipe Sassone[teatro Nuevo]

-La cantera de Alberto T. Weisbach [teatro Nacional]

-La comedia de hoy, de Roberto Cayol [teatro Nuevo]

- La chusma de Alberto Novión [teatro Nuevo]

-Como se olvida de Luis Bayón Herrera [teatro Nuevo]

-La moral ajena de Enrique Villarreal [teatro Nacional]

- Luz de sombra de Arturo Giménez Pastor [teatro Nuevo]

En el comienzo de la nota Méndez explica que se referirá a "los teatros de género nacional" Nacional y Nuevo.

"Mientras el Nuevo se ha asegurado -con un inteligente director artístico y una conocida actriz al frente de la compañía- la abundancia de obras mediante el establecimiento premios en dinero, el Nacional sigue confiando en sus propias fuerzas, que reposan en los nombres de un grupo de actores estimados por el público, y afronta decididamente la lucha." p. 97

Con respecto a El miedo de los felices de Felipe Sassone, a la que reconoce cierto interés, señala la evidente intención de satisfacer los gustos del público del teatro Nuevo por sobre las propias tendencias del autor. La obra ha sido interpretada "con alguna corrección" por parte de Angelina Pagano, Pablo Podestá, Julio Escarcella y Elías Alippi. El argumento es el engaño de una coqueta a su marido, un hombre de negocios rico, que termina con el asesinato de la mujer.

La cantera de Alberto T. Weisbach, no colma las expectativas fundadas en sus obras anteriores, Resaca y El guaso. Es una especie de zarzuela con música de Arturo Bassi. El asunto es "poco original, sumario y estirado de modo excesivo". No agrega nada, "una obrilla de género chico nacional que se agrega a las del repertorio y no es mejor ni peor que otras muchas" p. 100

-La comedia de hoy, de Roberto Cayol. Consta de un prólogo y escenas. Califica el trabajo de novedoso y divertido.

-La chusma de Alberto Novión. "El autor transporta a escena, una vez más, sus personajes de siempre, una serie de tipos suburbanos miserable, amorales, crápulas bien observados, bien copiados, y los hace vivir sus existencias lamentables en sus propio medios (...) Ha querido esta vez construir una especie de poema trágico del arrabal, y son su héroes una muchacha nacida de una familia de pillos y haraganes, y un sujeto de la misma índole, aunque inclinado a regenerarse". El crítico expresa su disgusto por la sensiblería presente en el segundo y en el tercer acto. "Es una pieza romántica que tiende a enaltecer [a] la canalla" p. 101

- Como se olvida de Luis Bayón Herrera que acompaña la obra de Novión. Viajan en un transatlántico un joven y una joven. La relación entre ambos hará que él olvide un amor anterior. Según el crítico está bien pensada y bien escrita.

-La moral ajena de Enrique Villarreal. autor joven en el que el crítico reconoce algunos progresos. Se trata de un marido engañado por su esposa, cuyo amante es un antiguo protegido del engañado. El marido al ver que la mujer ama al otro, emprende un viaje al extranjero dejando en libertad a su mujer. -Luz de sombra de Arturo Giménez Pastor. Crítica muy elogiosa. Destaca al autor y Rosich, uno de los intérpretes.

Historia trágica de un hombre que padece alucinaciones luego del suicidio de su esposa adúltera.

Notas y comentarios

-Una carta de Maupas

-Renuncia de Ingenieros por la mención de Roque Sáenz Peña en su El hombre mediocre

-Se insiste en la necesidad de que "los poderes públicos se preocupen por la suerte" de la Biblioteca

Nacional, que carece del personal y los fondos apropiados. 
-Gálvez es convocado como colaborador de Museum -revista artística de Barcelona- en la sección de arte argentino.

-Regreso temporario de Lugones, quien en abril dará sus conferencias en el Odeón sobre Martín Fierro.

-Se consigna la futura aparición de El mirador de Próspero de Rodó

-Representación de Los muertos de Sánchez en Barcelona, a cargo de Tallaví.

-Salvador Rueda en Buenos Aires

-Enrique Giordano, amigo y colaborador de Nosotros ha escrito un tango, cuyo autor se diferencia de la "trivialidad habitual de los compositores" p. 112

\section{Año VII, tomo 10, $n^{\circ} 48$, abril, 1913}

La amistad de Federico Nietzsche y Ricardo Wagner........Mariano Antonio Barrenechea pp. 113-122 [112 es la caricatura de Barrenechea por Ríos]

Poesías........... Amado Nervo pp. 126-127 [del libro Serenidad]

Pitunga. Leyenda de 'Abra vieja'..... Alberto Meyer Arana pp. 128-132

Dos libros y una elección. Diálogo..........Roberto Giusti pp. 133-146

Momentos......... Jorge Borges pp. 147-148

La comedia de hoy. Farsa en un acto. Original de Roberto L. Cayol.....pp. 149-166

La magia bienhechora.....Luis Reyna Almandos pp. 167-170

Rosas........Dardo Corvalán Mendilaharzu pp. 171-189 [incluye fotos del archivo personal del autor]

Una vida simple...... Ernesto Turini pp. 190-192

Crónica femenina. Las mujeres y la vida.

Fanny Pouchan pp. 193-197

Mimí Aguglia en Salomé

S. Judica pp. 198-201

Pintura y escultura..........Manuel Gálvez pp. 202-208

Crónica musical.........Juan Pedro Calou pp. 209-213

Teatro nacional......... Manuel G. Lugones pp. 214-219

Notas y comentarios. pp. $220-224$

La comedia de hoy. Farsa en un acto. Original de Roberto L. Cayol.....pp. 149-166

Se trata de la relación de un matrimonio de "casa de familia", que posan de modernos pero en realidad no lo son. La visita de un amigo da pie para que el marido se muestre celoso. Personajes: Germán, Marta y Fidel -el amigo mujeriego-, un criado. La acción transcurre en una tarde lluviosa en un "suntuoso despacho" p. 152.

Teatro nacional......... Manuel G. Lugones pp. 214-219

Nuevo:

El Espanto [drama en tres actos] de Faustino Trongé

La Santa [drama en tres actos] de Eugenio Gerardo López

Nacional

La muerta de aquella noche [drama en tres actos] de Roberto Cayol

El Espanto [drama en tres actos] de Faustino Trongé

Respecto del autor, Lugones observa: "No es preciso ser muy observador para adivinar en él al diletante que (...) concibe y ejecuta una obra opuesta a su temperamento" De esto se siguen los que son evaluados como defectos de la obra: "artificialidad", "rebuscamiento", "falta de sinceridad", "afán de efectismo melodramático, gestero, y secundario, que trabaja a la mayoría de nuestros más pulidos autores" p. 215 En contra de la figura del diletante que se dedica al teatro como podría haber hecho cualquier otra cosa. Explica: "El diletante es, por lo general, una persona de cierto rango. Su firma viene precedida de un nombre adquirido en la política, en la cátedra, en el foro, en el agiotismo, cuando no se trata de uno de esos talentos debidos a la tácita condescendencia anónima” p. 216.

La Santa [drama en tres actos] de Eugenio Gerardo López

Encuadra al autor entre aquellos que adquirido cierta experiencia en la mecánica teatral pero cuyas obras carecen de una sólida concepción. Los defectos más evidentes son la falta de "dotes de observación necesarias no solo para realizar una obra nacional, sino también para desarrollar en forma 
verídica la urdimbre psicológica de sus personajes". La última crítica se vincula con la elección del gaucho como personaje: "En cuanto a lo que se refiere al ambiente nacional de la obra, por más que el autor ha ido a buscar como protagonista al gaucho ya poco a poco desterrado de la escena, pensando sin duda en el efecto indudable del facón inherente, es inútil buscarlo. Nada, pues, justifica la obra del señor López" p. 218

La muerta de aquella noche [drama en tres actos] de Roberto Cayol

Considera la obra una reedición de El festín de los lobos en cuanto a su fábula. El crítico se opone a los personajes y al ambiente que Cayol recrea en su obra, y observa que el autor reincide ya que se encuentra "seducido por esa filosofía modesta y untuosa, inspirada en la caída de las modistillas engañadas". Se opone al tono melodramático de algunas escenas, al lirismo inapropiado con que hablan algunos personajes, y a la inclusión de personajes ajenos a "nuestro ambiente", tributarios de ciertos autores españoles como Quinteros.

Notas y comentarios

-Muerte de Pedro J. Naón

-Visita Salvador Rueda a quien Nosotros saluda

-Regresa a Europa Roberto Levillier, a quien la facultad de Derecho ha encargado escribir una obra sobre el régimen económico de la época colonial y a quien la Municipalidad de Buenos Aires le encomendó escribir otro libro sobre la historia de la administración municipal también durante la colonia. En París publicará un libro "sobre nuestra psicología y nuestras costumbres" El alma argentina.

-Sobre la disputa de Enrique Larreta con quien escribiera un libro en contra de La gloria de don Ramiro. Nosotros critica que Larreta, utilizando su condición de diplomático haya movilizado a la policía francesa para encontrar al autor de El caso de la gloria de don Ramiro.

-El Ateneo Hispanoamericano festeja el tercer centenario de la muerte de Cervantes. Conferencia de Gerchunoff sobre Don Quijote

-Se transcribe el jurado Concurso literario de Mundial Magazine y Elegancias revistas francesas, entre quienes se cuentan Rubén Darío (presidente) y Gómez Carrillo.

\section{Año VII, tomo 10, nº 49, mayo, 1913}

A campo y cielo............. Leopoldo Lugones pp. 225-236 [p.236 la caricatura de Lugones por Ríos] El incensario...........Salvador Rueda pp. 237

La decadencia del tipo femenino..........Carlos Baires pp. 238-248

El libro de Lamberti.......... E. C pp. 249-251 [incluye un poema del libro de Lamberti]

La muerte del protagonista......... Arturo Giménez Pastor pp. 257-262

Wagner y el misticismo.............Juan Chiabra pp. 263-278 [se trata de una conferencia que Chiabra dio en el teatro Argentino de La Plata]

Carta desde el mar...........Absalón Rojas pp. 279-281 [octavas endecasílabas]

Tríptico...........E. Suárez Calimano pp. 282-285

Las palabras, Líneas....... A. Terzaga (hijo) pp. 286-292 [cordobés; se trata de un conjunto de reflexiones y consejos de vida]

El ciego.............. Lola Salinas Bergara de Bourguet pp. 293-296 [dedicado a Alberto Meyer Arana]

Homenaje a Salvador Rueda................ pp. 297-307 [realizado en el colegio Nacional Bernardino

Rivadavia; discursos de Mariano de Vedia y Mitre y de Rafael Obligado]

Carlos Pedrell.................. Juan Pedro Calou pp. 308-312 [p. 308 es el dibujo de Pedrell por Ríos]

Letras argentinas............Álvaro Melián Lafinur pp. 313-317

Pintura y escultura.......... Manuel Gálvez pp. 318-323 [incluye foto firmada por Anselmi]

Teatro nacional............ Manuel G. Lugones pp. 324-326

Notas y comentarios ..........pp. 327-336 
La muerte del protagonista......... Arturo Giménez Pastor pp. 257-262

Se trata de un joven escritor dedicado a finalizar su obra, una novela, cuyo protagonista muere de una enfermedad cardíaca ("asistolia"). El joven autor para hacer su novela, estudia. En las paredes de su habitación hay, colgados, retratos de Zola, Daudet, Hugo. Los personajes son Juan Carlos (escritor), su madre, doña Mercedes, y Briseño, amigo de Juan Carlos. Entre los dos jóvenes se realiza la oposición entre la gran ciudad (Buenos Aires), y la pequeña ciudad de provincia (Quinales), y todas las que de esa primera oposición puedan derivarse.

Lo que Nosotros publica es la versión escrita (según su autor el "texto primitivo") de la obra representada en el teatro Victoria, no se dice cuándo.

Letras argentinas...........Álvaro Melián Lafinur pp. 313-317

-La senda encantada de Belisario Roldán. Libro de poemas que "representa el producto quintaesenciado de su espíritu sentimental y romántico y es una afirmación de idealismo" p. 313. Poesía amatoria y galante. El poema cíclico "Ante-raza", compuesto por cien estrofas, se dedica a narrar "la epopeya del gaucho".

-Solar guaraní, por J. L. Fernández de la Puente Libro de sonetos dedicados a cantar la tierra natal del autor.

Teatro nacional

Lugones consigna las obras de teatro representadas en el teatro Nuevo y en el Nacional

Nuevo:

Mala semilla [drama en tres actos] de Carlos Ravier

Nobleza obliga [comedia en un acto] de Mario Oliver Acosta

La columna de fuego [drama en tres actos] de Alberto Ghiraldo

Los cardales [drama en tres actos] de Alberto Vacareza

Suerte y azar [drama en un acto] de Mariano G. Bosch

Nacional

El atentado de Nur [drama en cuatro actos] de Ruy de Lugo Viña

Máscara negra o el sueño de Tim, "obra policial de don Ricardo Cappemberg"

A diferencia de otras críticas de Lugones ésta no analiza en detalle ninguna de las obras mencionadas sino que las subordina al objetivo central de la nota, que es el de advertir los peligros que para la escena nacional tiene la hegemonía de Pablo Podestá en la escena nacional. Explica:

"Hoy por hoy, y esto es lo que nos obliga a señalar el peligro con ruda franqueza, el teatro nacional está a punto de sucumbir para transformarse en el teatro de Pablo Podestá.

Pasado ya el buen tiempo, que también lo tuvimos, de los que trabajaban solo por la gloria, nuestros autores se ha dejado seducir por el codiciado éxito de la taquilla y plantean sus obras teniendo en vista las predilecciones de ese actor, que ha sabido acapararse la mayor parte de la producción del año con el hábil artificio de un concurso. Todas las obras estrenadas hasta ahora, y las citamos para que no se crea que hacemos una afirmación gratuita, El miedo de los felices, La chusma, El espanto, La Santa, Mala semilla, La columna de fuego, Los cobardes y Suerte y azar, reproducen más o menos el mismo tipo favorito de Pablo Podestá, mustio, cabizbajo, perseguido, engañado, que termina siempre en escenas de pugilatos, con tiros, puñaladas y estrangulamientos. Es un actor unilateral y secundario, incapaz de abordar otros géneros, y su influencia será funesta si nuestros autores, aunque más no sea por pudor artístico, no reaccionan contra esa tendencia impuesta por este 'genio local' engrandecido por la reclame". p. 325

Notas y comentarios

Esta entrega de la sección está marcada por lo nacional

-Centenario del Himno nacional

-Las lecturas de Lugones

La redacción señala la asistencia del público a las conferencias de Lugones en las Tardes del Odeón representa "un adelanto indiscutible": "El público selecto, que va del político y del clubman al 
literario y al curioso de las cosas espirituales, llenaba el teatro y oía con recogimiento y con inteligencia".

"Digamos desde ya que Lugones no hizo concesión alguna a su público, tan heterogéneo en su misma uniformidad de selección. Ese fuerte no se amenguó en instante alguno. Tal como es siempre, corajudo sin jactancia y recio sin deformidades, estudió la formación de la raza gaucha, cuya filiación analizó concretando en síntesis históricas, pensamientos nuevos relacionados con nuestros orígenes y con nuestro desenvolvimiento nacional. Examen erudito y sólidamente construido de la línea del gaucho, como entidad étnica y moral a través de la existencia argentina, esa obra reúne el doble carácter de la crítica literaria e histórica. Lugones involucra así, en la exégesis de la poesía autóctona la exégesis de la nacionalidad toda. $\mathrm{Y}$ esa labor constructiva, que en otros autores tendría fatalmente la aridez de una investigación monográfica, tiene en Lugones la brillantez característica de su literatura, esa riqueza de idioma tan típicamente suya, que bastaría, aparte ya de sus méritos cardinales de pensador, para convertirlo en maestro y elevarlo a la indisputable categoría que ocupa como figura universal en las letras americanas.

El público habrá notado, desde luego, la índole docente de ese trabajo. Esa glorificación del poeta popular que se inmortalizó con su rústica epopeya del gaucho, es una enseñanza de la cual sacamos saludables ejemplos de civismo, que es el alto buen sentido patriótico, fundado en la cohesión del espíritu nacional hacia la voluntad de afirmarse en beneficios positivos de libertad, de bienestar, de justicia, pues ello y no las parodias chauvinistas, es lo que define la grandeza de un país. No dudamos que el público, al aclamar a nuestro escritor, daba muestras de identificarse con su pensamiento elevado de ciudadano y con su noble comprensión de la belleza. Lugones, que se va a Europa, se despidió del auditorio con una nota sentida que conmovió profundamente. Después de imponerse a la admiración, se impuso al afecto. Se ha trabado entre el artista y el pueblo la necesaria amistad, que es la calificación, la consagración, mejor dicho, de la obra de todo pensador y de todo literato.

Accediendo a nuestro pedido, Lugones ofrece en este número a los lectores de Nosotros una primicia: la publicación íntegra de una de sus conferencias, de la segunda. Como es sabido, las lecturas del ilustre escritor, hasta ahora no han aparecido sino en forma fragmentaria en La Nación." p. 330

-Centenario del combate de San Lorenzo. La revista transcribe el discurso de Jorge Walter Perkins. Consignamos algunos pasajes:

"Vive la patria, como la religión, del fanatismo ciego de los que la quieren. Siendo una prolongación del hogar, los sentimientos que la caracterizan no pueden ser otros que los de la familia. Como todos los grandes cariños es irreflexivo y no admite discusión. Teniendo sus entrañas en la naturaleza, donde el amor de los hombres no obedece a otras leyes que las del azar, es contradecirla, el querer explicarnos lo que no puede ser otra cosa que una gran emoción. Paralela a las grandes emociones, eternas o inmutables, participa a la vez de la poesía de la noche estrellada, de la religiosidad de las montañas, del abierto horizonte, de las extensiones marinas.

No trato de definir la patria, sino fortalecer el sentimiento que inspira, al buscarle como a las razas o al árbol de la selva, su raíz secular.

Son momentos los que atravesamos en que todos los instantes son propicios y todas las tribunas necesarias para darle el significado ideal que le corresponde y el sentimiento histórico que representa." p. 333

-Regreso de José León Pagano y Martínez Cuitiño.

- Cuarto aniversario de la revista Renacimiento de Florencio C. González.

\section{Año VII, tomo X, $\mathbf{n}^{0}$ 50, junio, 1913}

La literatura argentina.........Ricardo Rojas pp. 337-365 [conferencia leída el 7/6/13 con motivo de la inauguración de la cátedra de Literatura argentina en la Facultad de Filosofía y Letras; p. 365 dibujo de Rojas por Ríos]

Páginas de álbum...........Manuel Ugarte (Mi excusa, La mujer cubana, Ofrenda, Voto) pp. 366-369

El secreto de meser Nicolao.......... Mariano Antonio Barrenechea pp. 370-375[a Irmus Lovy]

Spleen...............Clodomiro Cordero pp. 336-384

Epifanía............Julio S. Canata pp. 385-386

La novia de Zupay. Leyenda regional en dos actos y un intermedio poético.............Carlos Schaefer Gallo pp. 389-424 
Segunda encuesta de Nosotros ¿Cuál es el valor del Martín Fierro?..........pp 425-433

Letras argentinas....... Álvaro Melián Lafinur pp. 434-439

Ernesto Drangosch [pianista]............ La dirección pp. 440-441 [p.440 dibujo de Drangosch por Ríos]

Teatro nacional.............. Manuel G. Lugones pp. 442-446

Notas y comentarios. pp. $447-453$

Indice 454-456

La literatura argentina........Ricardo Rojas pp. 337-365 [conferencia leída el 7/6/13 con motivo de la inauguración de la cátedra de Literatura argentina en la Facultad de Filosofía y Letras; p. 365 dibujo de Rojas por Ríos

La novia de Zupay. Leyenda regional en dos actos y un intermedio poético Carlos Schaefer Gallo pp. 389-424

La acción transcurre en 1898 en Santiago del Estero (Villa de Guasayán). Personajes: Margarita, Manuel, Ricardo, Protasio, Gualberta, Juan, Michi, tres peones, paisanos y devotas. Se trata de la leyenda del diablo que encarnado en don Ricardo se interpone entre Manuel y Margarita, a la que domina con sus poderes. Los personajes hablan en estilo campero. Ej: -Te va quedar lejos pa dirte a vos, Michi, si te agarra l'aguacero..."p. 421

El intermedio poético es la leyenda de Zupay en verso. pp. 407-408.

Segunda Encuesta de Nosotros, pp. 425-433

Transcribimos el texto de la encuesta

"¿Cuál es el valor del Martín Fierro?

A mediados del mes en curso la dirección de Nosotros dirigió a nuestros más distinguidos hombres de letras una circular, cuyo contenido es el siguiente:

Las lecturas de Leopoldo Lugones han puesto de actualidad el Martín Fierro. Lo que ya algunos pensaban y unos pocos habían publicado por escrito con audacia de paradoja, Lugones lo ha sostenido sin ambages con todo el prestigio de su talento: el Martín Fierro es nuestro poema nacional por excelencia, la piedra angular de la literatura argentina. Ricardo Rojas lo ha repetido con personal convicción en su conferencia inaugural del curso de literatura que dicta en la Facultad de Filosofia y Letras: el Martín Fierro es nuestra Chanson de Roland, nuestra Gesta de Mio Cid.

El problema literario que plantean estas rotundas afirmaciones es de una importancia que nadie puede desconocer. ¿Poseemos en efecto un poema nacional, en cuyas estrofas resuena la voz de la raza? El acercamiento establecido por los críticos entre los varios poemas gauchescos, recogido oficialmente en los programas de literatura de los estudios secundarios, ¿importa acaso un enorme error de apreciación sobre el diverso valor estético de aquellos poemas? ¿Es el poema de Hernández una obra genial, de las que desafían los siglos, o estamos por ventura creando una bella ficción, para satisfacción de nuestro patriotismo?

La opinión a este respecto de todos los escritores argentinos es valiosísima, y puede contribuir grandemente a determinar las verdaderas proporciones del Martín Fierro.

Teniendo esto en cuenta, Nosotros ha resuelto abrir una encuesta, en la cual puedan aparecer todas las formas de su opinión, que es de suponerlo, será varia y contradictoria. A tal objeto una circular igual a la presente ha sido pasada a un distinguido núcleo de hombres de letras, con la seguridad de que ninguno de ellos ha de negar su palabra sobre el tema en debate. Las respuestas, que podrán tener la amplitud que sus autores juzguen oportuna, irán apareciendo sucesivamente en Nosotros, a medida que vayan recibiéndose.

La dirección de la revista se permite solicitar de usted, quiera contribuir con su autorizado juicio, a la solución de esta importante cuestión literaria.

Algunos conocidos intelectuales ya han respondido a la encuesta, y no dudamos que a estas primeras contestaciones han de seguir otras muchas, no menos oportunas para la dilucidación del problema en debate. Problema decimos, por más que un ilustre escritor, poeta y crítico de larga nombradía, nos haya negado en carta particular que tenemos a la vista, la existencia del mismo. "Confundir al Martín Fierro — nos escribe - con las epopeyas primitivas y genuinas; asimilarlo a la Chanson de Roland y a 
la Gesta de Mio Cid; atribuir carácter de verdadera poesía popular, que sólo puede ser la surgida espontánea e impersonalmente del pueblo con lenguaje y todo, a una obra de mera interpretación gauchesca con reflexivo remedo del lenguaje gaucho), nacida de un concepto personal y culto, con tendencias de reforma social sustentada en su alegato implícito; ver en él un pleno poema nacional, en vez de la representación, admirable, sí, de un estado y tipo locales y transitorios; hinchar la declamatoria crítica hasta hombrear a su autor en incoherente mezcolanza con Homero, Ovidio, Dante... y el Tasso! Es, simplemente, no saber lo que se dice". La respuesta es dura, pero expresa una fundada opinión sobre el tema, que hemos juzgado necesario dar a conocer en su pensamiento central." pp. 425-426.

Teatro nacional.............. Manuel G. Lugones pp. 442-446

Nuevo:

La novia de Zupay, leyenda regional en dos actos y un intermedio, por Carlos Schaefer Gallo Santos Vega, evocación poética en tres actos y dos cuadros, de Luis Bayón Herrera

"El ambiente subalterno de delictuosidad morbosa y pasional que venía caracterizando la producción nacional del año, ha tenido un breve paréntesis. A dos poetas jóvenes se debe esta reacción, y era precisamente de ellos de quienes debía venir. Poco o nada puede esperarse ya de la falange harto numerosa de autores teatrales que periódicamente llevan a nuestro escenario la eterna farsa, hábil en recursos de técnica, inmejorable para el lucimiento de tales o cuales actores, pero que en la que inútilmente se buscaría la obra de artes o de pensamiento. Bienvenidos, pues, los poetas, tan escasos en nuestros teatros, ya que solo de ellos puede esperarse su necesaria renovación. (...)

Despreciando el incidente policial de los suburbios o la campaña, repetidos ya hasta la saciedad, el señor Schaefer Gallo ha buscado para su obra el ambiente regional, llevando a la escena - como Sánchez Gardel en La montaña de las brujas -, el espíritu supersticioso de los campesinos" pp. 443-444

Cuando se refiere a Santos Vega de Bayón Herrera, rescata su propósito de evocar al payador, pero critica la presencia de resabios del drama de circo como lo son las escenas típicas de la payada, la pelea con la partida y el baile campestre (p.445). Así la figura de Santos Vega, tal como aparece en esta obra, recuerda más a Moreira y Julián Jiménez que al legendario payador de Obligado, que aparece como la referencia positiva para Lugones.

Notas y comentarios

-Una exposición de arte antiguo. se señala la paradoja que Buenos Aires, quiera tener ya una exposición como ésta.

- Regreso de Ugarte a Buenos Aires, luego de una gira por América. "Ha dicho en los países de la América latina la palabra sincera y elocuente de confraternidad y de unión espiritual de todas las naciones de descendencia hispánica; ha repetido por todas partes su ideal, que es también el ideal argentino. Ugarte ha ampliado, sin embargo, el criterio histórico de nuestra diplomacia. Señala los peligros que pueden poner en trance difícil a Hispanoamérica, recuerda la historia de los diversos ataques a su independencia absoluta y, por fin, llama a la unión espiritual del continente para la defensa común" p. 449.

-Conferencias en la Facultad de Filosofía y Letras. Se comenta la inauguración de la cátedra de Literatura Argentina por Ricardo Rojas y se transcribe el discurso de Rafael Obligado, presidente de la Academia de la Facultad. Copiamos el discurso de Obligado.

"Señor Decano; señoras; señores:

No sé hasta qué punto puede darse por investigada y escrita nuestra historia política y militar, ni si la respetabilidad de los nombres de Bartolomé Mitre y Vicente Fidel López, citando sólo sus artífices mayores, basta para que demos por realizada aquella tarea, al menos en cuanto se refiere a las épocas de la colonia y la independencia.

No se falta al respeto que especialmente en esta casa se debe a nuestros dos ilustres historiadores, afirmando que nuevas investigaciones, con metodología más racional, más científica, y por eso más verdadera y humana, pueden hacernos dudar de la exactitud de sus conclusiones en los hechos o de la verdad de la pincelada fisonómica en sus héroes. Esto no los menoscabará, sin embargo, porque Clío, su inspiradora, es la musa de la justicia distributiva, y sabe bien que ni Curtius, el admirable vidente de 
los orígenes y los hechos griegos, ni Mommsen, el concienzudo investigador del Lacio y reconstructor de su historia, pueden escapar a la ley fatal de ir quedando rezagados, porque no se progresa sin dejar atrás aún a los mejores.

Puede, pues, dudarse de que nuestra historia en las épocas indicadas esté definitivamente escrita, pero sería incierto negar que ha sido trazada en sus grandes líneas dentro del lienzo continental y que sus primeros actores han irradiado sin coloración falsa la luz que les fue propia. Sin vacilación alguna podemos afirmar que Moreno, Belgrano, San Martín y Rivadavia, esto es, el pensamiento, el corazón, la espada y la clarovidencia de Mayo, imponen su ya invariable y magnífica verdad desde las páginas de Mitre y López.

He invocado esta innegable conquista de nuestra ciencia histórica, preciosamente para hacer resaltar un doloroso contraste. Mientras los hombres de acción externa ocupan con relieve el primer término, asaltan cumbres y baten enseñas, los otros, los de la labor oculta, los pulidores del diamante humano, los que encienden la chispa nacional, no aparecen en escenario alguno. La historia, achatada bajo su birrete académico y tradicional, no escucha más que clarinadas de victoria o triunfos de políticos audaces; ni una página para el vaquero y el labrador, que son como la raíz de la nación; ni una página para el primer industrial, que fue entre nosotros el fabricante de escobas y velas de sebo, es decir, de la limpieza y la luz; ni una página para el que curtió la primer carona, creó la blandicia del primer recado y refractó en la plata del tirador, del estribo o del regatón de la lanza las luces del alma gaucha.

En la estrechez del horizonte histórico de entonces, no cabía más que el relámpago de las tormentas políticas o del sablazo hecho rayo. El pensamiento era un infeliz que deslizaba por ahí su vida oscura. Por suerte, hemos ampliado nuestra visión, y las modernas investigaciones van del conjunto al detalle, y se interesan lo mismo por toda humana labor.

De la acción de los próceres de Mayo, de sus primeras asambleas, de sus grandes capitanes y victorias, todo lo sabemos; podríamos escalonar con justicia, de arriba abajo, los méritos de cada uno; pero... ¿y los otros? ¿los que les acompañaban y acaso les dirigían desde el gabinete o el periódico y el libro en la primera mitad del siglo pasado? De ellos conocemos muchos nombres, podríamos citar algunas obras, pero si alguien nos pidiera que fijáramos su colocación respectiva entre sus contemporáneos, seguramente la honradez nos sellaría los labios. Tribuna, púlpito, periodismo, cátedra, poesía, novela, teatro, elocuencia popular, tuvieron su verbo encendido, apagado ya por la acción del tiempo y la indiferencia harto dolorosa de los países de aluvión.

A reparar esa injusticia, a dispersar esa tiniebla, viene la luz de la cátedra de literatura argentina que el Consejo de esta Facultad abre hoy en su casa, incluyéndola en su nuevo plan de estudios.

Es antorcha difícil de encender y conducir, precisamente porque intenta iluminar lo más íntimo de la vida de la nación: sus pensares y sentires; es cátedra no sólo de investigación bibliográfica y documentaria, sino también de emoción artística, de sensibilidad exquisita, para recoger notas dispersas y acordarlas en la sonoridad de nuestro primer siglo.

Por todo ello, el Consejo de la Facultad de Filosofía y Letras no ha podido confiar tal tribuna sin exigir condiciones especiales a quien debiera ocuparla. Ha designado a don Ricardo Rojas, al autor de la Restauración Nacionalista, precisamente porque se trata de restaurar el alma argentina en su amplia vibración; al evocador del Blasón de Plata, que así descendió a las tumbas del Inca, conmovidas por el himno patrio, como vio resurgir la vida trasvasada del conquistador a "las carnes terreñas de las madres indias"; y también al poeta de los Lises del Blasón, porque el dominio de la rima y el ritmo prueba la microfonía del oído para todas las audiciones, inclusive la delicadísima del latir de los pueblos.

Señor Rojas: En representación del decano de la Facultad, quien gentilmente me ha encargado presidir este acto, invocando mi puesto en la Academia de Filosofía y Letras, rengo el agrado y la honra de invitarle a ocupar su cátedra." pp. 450-451

-Se consigna la fundación del "hogar universitario" por parte de la Asociación cristiana de jóvenes de la universidad de Buenos Aires y la formación de un Centro de egresados por parte de un grupo de alumnos del Colegio Nacional, alrededor de un docente, Francisco Chelía.

-Regreso de Europa de Hugo de Achával

Año VII, tomo 11, $n^{0}$ 51, julio, 1913

El misticismo de Ávila............ Manuel Gálvez pp. 5-12 [capítulo de El solar de la raza en prensa]

Foto de Gálvez ..........p. 13 
La transformación social

Francisco García Calderón pp. 14-20 [contra el socialismo y el anarquismo; a favor del nacionalismo y del radicalismo como vías o "direcciones necesarias en la vida republicana" p. 20]

Como un león tendido........... Enrique Banchs p. 21

El último mármol............... Alberto Meyer Arana pp. 22-31

Fragmento inédito del De profundis........... Oscar Wilde pp. 32-48 [traducción de Alfredo Bianchi]

Sonetos........Luis María Díaz pp. 49-51

Sobre Lavalle y Rosas (carta abierta)........ Osvaldo Saavedra [a Clodomiro Cordero] pp. 52-55

Los ojos raros (cuento fantástico)...........Eduardo Acevedo Díaz (hijo) 56-65

La Argentiada........... Manuel G. Chueco pp. 66-73 [escrita por el 'Solitario de América']

Nuestra segunda encuesta............pp. 74-89.

Pintura y escultura..............Manuel Gálvez pp. 90-95

Crónica musical............ Juan Pedro Calou pp. 96-104

Notas y comentarios.......... pp. 105-112

Notas y comentarios

-Se comenta el descargo de Arturo Capdevila que sostiene que una obra suya, Melpémone, es anterior a la muy semejante (plagio) de Carlos Schaefer Gallo, La novia de Zupay.

-Enrique Loncán escribe sobre el actor Guillermo Battaglia recientemente fallecido.

- Se comenta la fundación del Ateneo Nacional presidido por David Peña

-Bajo el título "Viajeros" se consigna:

* el regreso de Europa de "nuestro aplaudido comediógrafo" Enrique García Velloso. Sus éxitos en Madrid son conocidos por "telégrafo"; se mencionan las crónicas de García Velloso en La Nación sobre algunas personalidades de la "España actual"

* la vuelta de Europa de José de Maturana, quien también ha sido cronista para La Nación (desde Portugal)

* Próximo viaje de Leopoldo Lugones a Europa. "El muchacho que algo más de tres lustros atrás llegó de su provincia a conquistar Buenos Aires con la sola aptitud de su gran talento, ha realizado por fin su ambición. Buenos Aires es suyo, y con Buenos Aires toda América. Ahí están como testimonio sus conferencias del Odeón sobre Martín Fierro que congregaron el aristocrático teatro [a] todas las clases sociales, espectáculo nuevo para nosotros: un público argentino consagrando en forma definitiva, y no ya en la fugaz del entusiasmo de un momento, a un letrado argentino que habla de cosas exclusivamente argentinas iy tran poco prácticas!

Su triunfo será sellado uno de estos días en un magno banquete que le ofrecerán sus muchos amigos y admiradores" p. 112.

Año VII, tomo 11, no 52, agosto, 1913

Nuestro sexto aniversario pp. 113-114

Impresiones de Sevilla.............Ernesto Mario Barreda pp. 115-126 LEER

Lujuria..........Alberto Samain pp. 127-131 [traducción de Manuel Lugones]

Velivolo ideal..... Eduardo Acevedo Díaz pp. 132-138

Por el idioma (carta abierta)........... Roberto Giusti pp. 139-146 [dirigida a Carlos Ibarguren, ministro de Instrucción Pública]

Tus manos............Juan Julián Lastra pp. 147-149

María Barrientos y el arte del 'bel canto'

Mariano Antonio Barrenechea pp. 150-169

Dos historias de amor. Comedia erótica en tres actos. Escena final del acto primero......Carmelo M.

Bonet pp. 170-179

Siluetas......... Lilia Lacoste pp. 180-183

Siempre .......... A Marasso Rocca pp. 184-185

Segunda encuesta de Nosotros........... pp. 186-190 [responden Carlos Baires, Antonio de Tomaso]

Letras argentinas. Alvaro Melián Lafinur pp. 191-195

Bibliografía psicológica ......... Enrique Mouchet pp. 196-205 [sección que aparece por primera. vez]

Arte argentino........ Manuel Gálvez pp. 206-210

Teatro nacional..........Manuel Lugones pp. 212-214 
Crónica musical.......... Juan Pedro Calou pp. 215-218

Notas y comentarios. pp. 219-224

Nuestro sexto aniversario

Ha cumplido Nosotros su sexto aniversario. Mejor que sus directores podrá el público lector apreciar la eficacia de su acción y los resultados de su esfuerzo.

Nació la revista como todo gesto de juventud, espontáneamente. Si en principio se tuvo confianza en el trabajo, no se tuvo, en cambio, en la durabilidad de su publicación. Apareció Nosotros en época no muy propicia, y prueba de ello fueron las dificultades con que se tropezó en el camino. Llegó un momento en que sus directores perdieron toda esperanza, parecióles difícil la lucha contra un medio indiferente y la revista dejó de aparecer un año. Vinieron después mejores tiempos, se luchó con la misma fe con igual entusiasmo y así hemos llegado, contra todos los inconvenientes, a nuestro sexto aniversario.

Congratulémonos. No es posible aún evaluar nuestra labor, modesta si se quiere, pero persistente y tranquila. Esto es acaso de lo que más nos enorgullecemos. Publicación redactada y dirigida por toda una juventud, Nosotros podría haber sido una de las tantas revistas demoledoras e irreverentes que desean fundar la fortuna de su círculo en el desprestigio de los viejos maestros. No lo hemos querido. En su primer número determinamos un programa de tolerancia y de amplia discusión, y lejos de desvirtuarlo posteriormente, lo hemos ratificado y mantenido en los hechos. Si algunos no lo han comprendido todavía, cúlpenlo a su incomprensión. Hubiera sido pernicioso e injusto para nuestra naciente literatura, en un momento como el actual, de desorientación estética, y en un ambiente como el nuestro, escaso en escritores genuinos, que Nosotros se hubiese vuelto el eco de la venenosa fatuidad de cualquier camarilla. Alguna página amarga ha publicado, alguna valiente, alguna discutible. Le ampara, sin embargo, la sinceridad de su voz y la independencia de sus directores.

Al entrar en el año séptimo, con animosa confianza en el futuro, debemos una palabra de agradecimiento al grande poeta don Rafael Obligado, que después de haber dado a nuestra literatura sus mejores páginas de emoción argentina, sabe estimular con su consejo y su ayuda a la nueva generación de escritores que le admira y respeta.

La Dirección.” pp. 113-114.

\section{Letras argentinas FALTA TRANSCRIBIR}

Teatro nacional..........Manuel Lugones pp. 212-214

Nuevo: La Zaina de Federico Moreno; La trepadora de Carlos Schaefer

Argentino: Los provincianos de Alberto Novión [pochade en tres actos]

La Zaina de Federico Moreno [comedia en tres actos]

La crítica comienza con una referencia al tema que organiza la obra.

"Una pretendida resistencia de los elementos nativos al progreso ha sido explotada con singular preferencia por nuestros hombres de letras. Nada, sin embargo, más falso que esa tesis. La marcha evolutiva de nuestra sociedad no ha encontrado tropiezo alguno en su avance y si lo ha habido, estuvo antes en la presurosa facilidad con que nuestros hombres trataron de amoldarse, en una aventurada precipitación de ganarle tiempo al tiempo, que en la pretendida resistencia de los nativos. Loca aventura que ha caracterizado nuestra idiosincrasia emprendedora en más de una calamitosa crisis de progreso, fenómeno tan nuestro.

Hay en toda sociabilidad que se pierde transformándose una poesía nostálgica, frecuente a todo lo que muere, de la que es difícil sustraerse. Elemento poético meramente intelectual, sensible tan solo a las generaciones posteriores a la transformación que la produce, objetiva en la oportunidad esa tristeza de lo transitorio que vive latente en el hombre civilizado como resto indeleble de la melancolía cristiana. No debe extrañarnos, pues, que nuestros poetas del verso y de la prosa calumnien, tergiversándolo, nuestro afán de progreso, para brindarnos una bella y añorante fábula con sabor de lágrimas y de imposibles, ya que fue siempre su norma sacrificar un mundo para pulir un verso, según la bastante usada cita. 
En nuestro teatro nacional el tema no es, por cierto, nuevo."

Notas y comentarios FALTA TRANSCRIBIR

Año VII, tomo 11, no 53, septiembre, 1913

Puyrredón y la diplomacia de su tiempo............. Mariano de Vedia y Mitre, pp. 225-242

Caricatura de M, de Vedia y Mitre............Ríos, p. 243

César Borgia............. Juan Aymerich, p. 244 POESÏA

Poetas y locos................Nerio A. Rojas, pp. 245-255

Las tres damas quiméricas..............Eduardo Acevedo Díaz (hijo), pp. 256-265

El canto de las estaciones.......... Pablo Della Cota (hijo), pp. 267-268

Azahares.................Idilio en un acto de Roberto Bracco [versión castellana de Alejandro Secchi], pp.

268-282

Crónica femenina.................Fanny Pouchan, pp. 283-288 [se reproducen cartas de "Inés" a su flirt, a su amiga doña Felisa y a su amigo Ricardo] Realmente llama la atención que la revista publique este tipo de colaboración. Una de las cartas está escrita en francés.

Letras argentinas...............Alvaro Melián Lafinur, pp. 289-294

Letras españolas..............Juan Mas y Pí, pp. 295-298

Bibliografía psicológica.........Enrique mouchet, pp. 299-304

Ciencias sociales......... Luis Reyna Almandos, Roberto Giusti [R.G.], pp. 305-310

Arte argentino......... Manuel Gálvez, pp. 311-316

Dibujo de José A. Merediz............ Ríos, p. 317

Teatro nacional............ Manuel Lugones, pp. 318-321

Crónica musical.............Juan Pedro Calou, pp. 322-325

Notas y comentarios...........Nosotros, pp. 326-333.

Año VII, tomo 12, n $^{0}$ 54, octubre, 1913

El salón Nacional de 1913...............Manuel Gálvez, pp. 5-17

De "Estelas...".......................Carrasquilla Mallariño, pp. 18-22 POESÏA

Sawa. Iluminaciones en la sombra................ Alberto tena, pp. 23-27 [dedicado a Mario Bravo]

Romance de un varón triste...............Víctor Juan Guillot, pp. 28-32 [tema amoroso]

Mensaje de lágrimas................uis M. Díaz, pp. 33-34 POSEÏA

Orugen y evolución de la crítica literaria..............Victorio M. Delfino, pp. 35-47 [no toma la crítica argentina sino europea]

Dibujo de Zonza Briano............. Ríos, p. 48.

El arte de Zonza Briano...............Samuel Linnig, pp. 49-56 [dedicado a Emilio Giménez Zapiola, que

lo "condujo" a Taine]

Sonetos..............Pedro González Castellú, pp. 57-58.

Nuestra segunda encuesta.................Emilio Alonso Criado, pp. 59-74.

Huiñaj (leyenda de tierra adentro)............ Carlos Schaefer Gallo, pp. 75-77

Sonetos..........José Muzzilli [Galantería, La flor de lis, Como agua del mar, Elogio de tu voz, Noche de azur, Canción de plata], pp. 78-81

El solar de la raza .................Julio Noé, pp. 82-89

Psicología argentina.............Enrique Mouchet, pp. 90-98

Teatro Nacional...................Manuel Lugones, pp. 99-100

Un actor argentino............. Alvaro Melián Lafinur, pp. 101-105 [sobre Nicolás J. Grosso]

Notas y comentarios..............Nosotros, pp. 106-112.

Año VII, tomo 12, $n^{\circ}$ 55, noviembre, 1913

La evolución de la música [segunda parte]

Mensaje de primavera............José Martínez Jerez, pp. 143-149

Rabindranath Tagore (dibujo).........p. 150 [no se consigna autor]

Gitanjali ...............Rabindranath Tagore, pp. 151-155 [ el autor había recibido en ese momento el Premio Nobel de literatura; se trata de las traducciones que hizo Nosotros de la versión en inglés hecha por Tagore, de algunos de los poemas del libro Gitanjali] 
Teatro Sobrehumano

Eloy Fariña Núñez, pp. 156-166.

Tus manos.......... Cayo Lenis [pseudónimo de "un distinguido hombre de estudio y talentos publicista"], pp. 167-168

$\mathrm{Su}$ romance incontable. ..Gastón Federico Tobal, pp. 169-186 [dedicado a Clara Figueroa

Alcorta]

Lazaro............... [dedicado al Dr. Carlos Ibarguren], Arturo Marasso Rocca, pp. 187-191.

Letras americanas Alvaro Melián Lafinur, y J.M.J, pp. 192-201

El solar de la raza Alvaro Melián Lafinur, pp.202-204 TRANSCRIBIR

El salón nacional Manuel Gálvez, pp. 205-214

Crónica musical. Juan Pedro Calou, pp. 215-220

Notas y comentarios Nosotros, pp. 221-224.

Año VII, tomo 12, n $^{0}$ 56, diciembre, 1913

Salomé. Tragedia de Oscar Wilde. Drama musical de Ricardo Strauss Alfredo López Prieto, pp. 225-239.

Dibujo de Alfredo López Prieto Ríos p. 240

Poesías......... Calixto Oyuela [Campesina, Reciprocidad], pp.241-242

El retrato de Baudelaire........... Juan Mas y Pi [dedicado a Víctor Pérez Petit], pp. 243-252

Marcos Sastre. Martiniano Leguizamón, pp. 253-258

Luna de la patria. Francisco Contreras, pp. 259-263 POEMAS

La evolución de la música (tercera parte) Mariano Antonio Barrenechea, pp. 264-287

A pesar de todo Eduardo Talero, pp.288-289 [sobre el cóndor] poema

Foto de Gregorio de Laferrere. p. 290

Poesía inédita de Gregorio de Laferrere.............pp. 291-292

Teddy W. W., pp. 293-294

El perro Enrique Murena, pp. 295-301

Crónica femenina. Del diario de mi amiga............Fanny Pouchan, pp.302-307.

Sonetos y canciones por Luis María Díaz. Roberto Giusti, pp. 308-312

El salón nacional Manuel Gálvez, pp. 313-323

Crónica musical......... Juan Pedro Calou, pp. 324-326

La demostración a Manuel Gálvez.............Nosotros, pp. 327-331

Necrología...........Nosotros, pp. 332-333. 
Presencia de colaboraciones y datos relativos a los vínculos culturales entre Argentina y España. Listado confeccionado a partir de los números 2 a 22-23 en los que dichos vínculos surgen y se consolidan.

\section{$\mathrm{n}^{\mathrm{o}} 2$}

-En 'Letras españolas', Alberto Gerchunoff, escribe sobre Carmen, un poema en cantares de Francisco Villaespesa.

$\mathrm{n}^{\mathrm{o}} 3$

-Max Grillo colabora con "Don Miguel de Unamuno (Breves apuntes. Acerca de D. Miguel de Unamuno y de su influencia en las letras hispanoamericanas)"

$\mathrm{n}^{\mathrm{o}} 4$

-En "Menudencias filológicas", firmado por Leptir, Unamuno aparece como interlocutor en un debate sobre la enseñanza del latín en la segunda enseñanza.

-En 'Letras españolas', Alberto Gerchunoff se ocupa de Museo y Cantares de Manuel Machado; prologadas por M. de Unamuno.

-En 'Notas y comentarios' se transcribe una carta de Unamuno.

$\mathrm{n}^{\mathrm{o}} 5$

-Juan Mas y Pí se ocupa de la obra de Azorín.

-Se publican "La mesa" (poema de Gregorio Martínez Sierra perteneciente a La casa de la primavera), "Eucaristía", relato de Antonio de Hoyos y Vinent (dedicado a Carlos Octavio Bunge), "La poesía del progreso" de Alberto Insúa. En 'Notas y comentarios' se aclara que estas colaboraciones fueron solicitadas por la dirección de la revista.

-Eduardo Talero escribe sobre El canto errante de Darío que ha sido recientemente publicado en España, donde por ese tiempo reside Darío. Alberto Insúa es amigo personal de Darío.

-En 'Notas y comentarios' se recuerda bajo el título 'Palabras de aliento' la carta de Unamuno del número anterior y se explica la función que pretende cumplir Nosotros: "un medio más, acaso insignificante pero de todos modos eficaz, para robustecer los débiles lazos intelectuales que unen esta república con las restantes de América Latina y con la madre patria." p. 339.

-Se anuncia como sección nueva 'Letras catalanas'

$\mathrm{n}^{\circ} 8$

-Gerchunoff escribe sobre La casa de la primavera, Juan Más y Pí pública un artículo sobre Juan Maragall

-En 'Revista de revistas' se glosa un artículo de Pedro Dorado de La Lectura. (“¿Viva el pecado?”); se informa sobre la edición especial para Argentina de la revista española El Cuento Semanal, en la que se expresa el objetivo de "hermanar lo más posible la literatura hispana y la bonaerense, ofreciendo a sus representantes una tribuna selecta y propicia a todas las inquietudes del espíritu moderno" p. 158

- En 'Notas y comentarios' se saluda la presencia del joven poeta español Vicente Medina. $n^{\circ} 9$

-Se publican poesías de Leonardo Shérif y Fernando Fortún

-Carlos Octavio Bunge dedica un ensayo a Manuel de Hoyos y Vinent ("Hoyos, novelista español”)

-En 'Letras argentinas' Giusti critica El alma española de Ricardo Rojas

-Entre los 'Libros recibidos' se cuenta Recuerdos de niñez y mocedad de Unamuno y aclaran, como lo hacen con los materiales que consideran importantes, que se ocuparán de él en el número siguiente.

-En 'Revistas recibidas' se mencionan Cultura Española (Madrid), El Cuento Semanal (MadridBuenos Aires), España y América (Madrid), La Lectura (Madrid)

$\mathrm{n}^{\mathrm{o}} 10-11$

-Luis Ipiña reseña Recuerdos de niñez y mocedad de Unamuno

-En Notas y comentarios:

Se comentan los éxitos de Ricardo Rojas (que ha leído una conferencia sobre Olegario V. Andrade) y de Ernesto Mario Barreda en el Ateneo de Madrid; se hace referencia al comentario elogioso aparecido en La Cultura española sobre la conferencia sobre Carducci de Francisco Capello, profesor de literatura griega en la Facultad de Filosofía y Letras y colaborador de Nosotros; se informa que E. Duprat, colaborador de Cultura Española, lo hará también en Nosotros, encargándose de los mismos temas (novedades filosóficas y religiosas de Francia); se consiga la edición en Madrid de De mi villorrio de Luis C. López, con prólogo de Manuel Cervera; se informa sobre la aparición de la novela Vértigo en 
altura de Julio González Hervás, editado en Madrid (librería de Gregorio Pueyo), con prólogo de José Francés.

$\mathrm{n}^{\mathrm{o}} 12$

-En 'Notas y comentarios' y bajo el título "Nosotros en Madrid", Nosotros comunica las gestiones de Fernando Acebal, director de La Lectura de Madrid, para "colocar este revista [Nosotros] en el mercado de libros"

$\mathrm{n}^{\circ} 13-14$

En la lista de 'Libros recibidos' aparece Cómo estrenan los autores (Crónicas de teatro) de José León Pagano, Biblioteca de Autores Americanos, F. Granada y Cía., editores, Barcelona.

$\mathrm{n}^{\circ} 16-17$

-En 'Notas y comentarios', aparece una carta de Menéndez y Pelayo a Francisco Capello, colaborador de Nosotros, que es usada como respuesta de Capello a las injurias de un crítico a su poema "Pinus Mendocinae"

-Se transcribe la carta que Luis Mandrés envía a la revista explicando la finalidad del recientemente constituido Salón Sud-Americano de Barcelona "facilitar con todos los medios posibles las comunicaciones de la América del Sur con España a favor de los transeúntes y residentes, y cooperar al desarrollo general de toda iniciativa plausible entre los países Sudamericanos y la Península" p. 322. $\mathrm{n}^{\circ} 18-19$

Entre los 'Libros recibidos' está el de Manuel Ugarte, Las nuevas tendencias literarias, [Valencia], F. Sempére y cía. editores, [1909]

$\mathrm{n}^{\mathrm{o}} 20-21$

Se refiere la visita de Vicente Blasco Ibáñez a Buenos Aires

$\mathrm{n}^{\mathrm{o}} 22-23$

Homenaje de Nosotros a Blasco Ibáñez.

Además, en las reseñas de Giusti de 'Letras argentinas' se va construyendo una posición en relación con la lengua deseable que es el castellano, que los escritores deben conocer a fondo, enriquecer, etc.. 
Lo que llama la atención es la contradicción entre la imagen de Rodó que construye G. (más allá de la participación real de Rodó en la política uruguaya, es una imagen que se construye a partir de su obra) que está siempre alejada de lo público y más cercana a lo religioso en tanto oposición de lo público, un sujeto que habla desde arriba, esa armonía, la belleza como ideal, la forma de bella de hablar, las comparaciones con el ciudadano griego de la polis, para hablar de una prédica que tiene pretendidamente un valor presente. Además está la terminología de la espiritualidad incontaminada, alejada de la materialidad de la vida real. Ahí creo está la impronta de la lectura interesada de Gerchunoff que necesita adjudicar un valor presente y actual a un discurso como éste del desinterés, de las altas especulaciones intelectuales, y marcadamente individualista. 